\title{
A disrupted balance? Prevention of terrorism and compliance with fundamental legal rights and principles of law - The Dutch anti-terrorism legislation
}

Citation for published version (APA):

Veegens, K. (2011). A disrupted balance? Prevention of terrorism and compliance with fundamental legal rights and principles of law - The Dutch anti-terrorism legislation. [Doctoral Thesis, Maastricht University]. Intersentia. https://doi.org/10.26481/dis.20111220kv

Document status and date:

Published: 01/01/2011

DOI:

10.26481/dis.20111220kv

Document Version:

Publisher's PDF, also known as Version of record

Please check the document version of this publication:

- A submitted manuscript is the version of the article upon submission and before peer-review. There can be important differences between the submitted version and the official published version of record.

People interested in the research are advised to contact the author for the final version of the publication, or visit the DOI to the publisher's website.

- The final author version and the galley proof are versions of the publication after peer review.

- The final published version features the final layout of the paper including the volume, issue and page numbers.

Link to publication

\footnotetext{
General rights rights.

- You may freely distribute the URL identifying the publication in the public portal. please follow below link for the End User Agreement:

www.umlib.nl/taverne-license

Take down policy

If you believe that this document breaches copyright please contact us at:

repository@maastrichtuniversity.nl

providing details and we will investigate your claim.
}

Copyright and moral rights for the publications made accessible in the public portal are retained by the authors and/or other copyright owners and it is a condition of accessing publications that users recognise and abide by the legal requirements associated with these

- Users may download and print one copy of any publication from the public portal for the purpose of private study or research.

- You may not further distribute the material or use it for any profit-making activity or commercial gain

If the publication is distributed under the terms of Article $25 \mathrm{fa}$ of the Dutch Copyright Act, indicated by the "Taverne" license above, 
A Disrupted Balance? 
School of Human Rights Research Series, Volume 48.

The titles published in this series are listed at the end of this volume. 


\begin{abstract}
A Disrupted Balance?
Prevention of terrorism and compliance with fundamental legal rights and principles of law The Dutch anti-terrorism legislation
\end{abstract}

Karin Veegens

intersentia

Cambridge - Antwerp - Portland 
Intersentia Ltd

Trinity House | Cambridge Business Park | Cowley Road

Cambridge | CB4 0WZ | United Kingdom

mail@intersentia.co.uk

Karin Veegens

A Disrupted Balance? Prevention of terrorism and compliance with fundamental legal rights and principles of law - The Dutch anti-terrorism legislation

(C) 2012 Intersentia

Cambridge - Antwerp - Portland

www.intersentia.com | www.intersentia.co.uk

Cover image: (c) Fokko Veegens

ISBN 978-1-78068-042-2

NUR 828

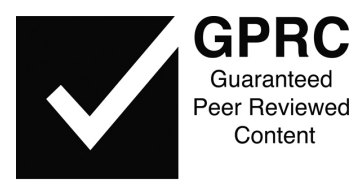

British Library Cataloguing in Publication Data. A catalogue record for this book is available from the British Library.

No part of this book may be reproduced in any form, by print, photoprint, microfilm or any other means, without written permission from the publisher. 
I dedicate this book to my dear mother, without whom I would not be where I am now. 



\section{ACKNOWLEDGEMENTS}

Writing this book, has been a valuable experience in every possible way. It has taught me what I am capable of, and what I am not capable of doing. It has taught me to have patience with myself and with others and has caused me to experience all sorts of emotions. It has proven to me that perseverance, drive and discipline are the most important prerequisites for finishing a dissertation, or any long-term project for that matter. Most importantly, perhaps, it has showed me how many people are willing to help you, in various, sometimes quite unexpected ways, if only you let them.

The impact of writing a $\mathrm{PhD}$ on your frame of mind is difficult to put into words and to explain to those who you want to understand it the most. It is a lonely job, but to actually finish it alone is almost impossible. During the last 3 years, especially, there have been several people who have helped me to finish this dissertation, in many different ways. Finding the right words to thank those people has sometimes proven to be more difficult than finishing this book.

First of all, I would like to thank Taru Spronken, Gerard Mols, Michele Panzavolta, Martin Kuijer and Stijn Franken for having read my work at such short notice. Your comments amply demonstrated how thoroughly and critically you have read my work.

Jan Fermon and Paul Frielink, you helped me to accentuate specific chapters as regards content. Thank you for giving me valuable insight into the practical side of law, and for challenging me to consider the legal system in more than one way.

Gerard de Jonge, almost 10 years ago I wrote my Master's thesis under your supervision. Your prediction as regards my future 'career plans' came true. Your enthusiasm, your vigorous mind, your incredible knowledge, and your capability of finding connections between different aspects of law have inspired me to start and to continue writing.

In the first few years of my appointment at Maastricht University I participated in the activities of the School of Human Rights Research and in the activities of the Maastricht Centre for Human Rights. During those years I enjoyed working with Fons Coomans, Menno Kamminga, Fred Grünfeld, Chantal Kuijpers and Martine Boersma. Your enthusiasm for human rights related matters has always been a source of encouragement for me, as well as your sincere interest in and compassion with others. Thank you! 
Johannes Keiler and Dorris de Vocht, I would like to thank you for encouraging me so many times, for very pleasantly distracting me when necessary, and for just being there and caring. You proved to me that the adagium 'Out of sight, out of mind', does not always hold true.

David Roef and Ria Wolleswinkel, thank you so much for having been there for me, especially after Peter died. All three of us experienced a great loss when he died. Being able to share my sorrow with you, to cry together, to laugh together, and to talk about Peter, who we all loved in our very own way, has helped me to continue writing, without Peter.

Peter, we were going to finish this book together, we were going to do 'closereading', we were going to laugh, to eat, to drink together during that work, and to party long into the night when the book was finished. Then all of a sudden you died.

I was stricken by grief. I never had the chance to tell you once again how fond I was of you, how I enjoyed working with you, talking seriously, but also making jokes and mocking things we were indignant about. How you surprised me with your creative insights, with your ability to really cooperate, with your knowledge of such a broad spectrum of subjects, and with your everlasting desire for new ideas and new challenges. I was amazed by your resilience, your energy, and by your ability to sincerely see and treat everyone as equals. You were one of a kind.

During the first years of writing this book when I was stressed about finishing things on time and rightly - which was quite often - you always told me 'Don't worry, it will all be okay'. I have missed those soothing words so much. You were right, it is okay now. Only, I will never have the chance to show you and to share these feelings of intense relief and happiness with you. Hopefully you will be around on the $20^{\text {th }}$, because I need you there standing next to me, whispering to me 'Don't worry, it will all be okay'...

André, when, in 2004, you offered me a PhD position I promised you I would not disappoint you. Well, with this book, I hope, I have adequately honoured that promise to you. During these years you have been incredibly patient, reliable, steady and understanding. You have taught me to get over my 'rhetorical-emotional writing style' (and insights!) and to start thinking and writing as a lawyer: well-defined, concise and open-minded. You have, moreover, successfully challenged me to look into, and get enthusiastic about, new fields of law. I needed a push in that (right) direction and you sensed that perfectly!

Since Peter died, you have done a tremendous job of filling in that gap. I'm sure that has not at all been easy for you. You have been there for me ever since, in many ways, and I'm incredibly thankful for that. I'm touched by your genuine empathy and thoughtfulness. Your trust in me, in particular during these last 2 years, has given me the confidence to conclude this dissertation. 
My dear uncle Harm, you have taught me the actual metier of writing. The difference between my pre-Harm era writing and my post-Harm era writing is incredible. You forced me to reason perspicuous, concise, and in diverse ways. You taught me to sort out the chaos, in my reasoning and in my writing. Your wit, your endless knowledge of the most diverse subjects, and your swift and high-level ability to reason, made it very inspiring and challenging to work with you. Even though we started working together in 2005 , during the past 1.5 years in particular, you have been there for me continuously, with infinite patience, encouraging me and convincing me that this book was worth publishing. You made me realise what I'm capable of, without telling me in so many words. That is what I needed to finish this book in a way that would make even me satisfied.

Peet and Kees, the evenings we spent together - especially while eating pizza at Quattro Mori (!) - showed me why I have such a fascination for criminal law. To me, you are the perfect voices of a just, moderate and conscious criminal justice system. I have learned a lot from your open-mindedness, your endless knowledge, and your playful way of discussing serious matters. Dear Peet, ever since we met at Scorp many years ago, you have been a dear and very loyal friend - thank you for that! Kees, you showed me the practical side of the criminal justice system with so much patience, enthusiasm and knowledge; various chapters of this book have undoubtedly gained quite a bit of reality thanks to your help!

Dear Maartje, in 2005 we went to Bella Sicilia together for 2 weeks, for a specialisation course in International Criminal Law. During those weeks, our 'friendly colleagues relationship' developed to a steady friendship. One way or the other I always had the feeling that we are a 'perfect match' - paradoxically, because we are quite different in some respects. Our adventure in Sicilia confirmed that feeling. Your wisdom, your ability to observe without passing judgement, your sincere truthfulness, your peace of mind and, of course, your incredible sense of humour, have made me take you to my heart. These last years you have helped me to overcome many hurdles, and you consoled me with such patience when Peter died. I am very grateful for our friendship and will cherish it.

Also, I would like to take the opportunity to thank Dr. van den Neucker, Valentina's physician. If only all physicians would be like you! You have given me the peace of mind and confidence regarding Valentina's health, which I needed to finish this book. Your understanding, expertise and incredible sympathy towards Valentina, Ama, Bart and me continue to be invaluable!

Niek, for the past 3 years I have called you desperately time and again, even in the middle of the night, when something was wrong with Valentina. From the first day on, you have been an incredible support to me - giving advice, listening, reassuring, 
but most of all caring. Thank you so much for having taken such incredibly good care of Valentina, Bart and me.

Dear Mieneke and Berend, your love, understanding, warmth and compassion have given me the energy to keep on seeing and enjoying the beautiful, often little, things in life, even though it has been very difficult from time to time: Valentina feeding the chickens, playing with Berend with the doll's house, walking Duko with Mieneke, and playing the 'ballonenspel' together. My gratitude cannot be adequately expressed in words. I love you both, very, very much.

My dear Fokko and Floor, thank you for having been there for me, for having helped me with practical computer related problems (Fokko!), for having understood the obstacles I had to overcome to finish this book, and thank you for not blaming me for my absence on many (important) occasions during the past few years.

Jules, my dear 'almost father', your philosophical calm has quieted me down so many times that I have lost track. You have 'counterbalanced' me by asking questions instead of passing judgement and by waiting instead of acting at once. Steady as a rock, you have been there for Valentina, Bart and me all these years. No effort was too much for you, even as a busy 'pensionado'. Your thoughtfulness and gentle way touched me many times. You have continued to take a sincere interest in the progress of this book, even reading pieces once and a while. Never during these years you have lost the profound belief that I would and could finish it. Trusting my abilities to such an extent has prompted me to do my best even more. Thank you for just being you, always, no matter what the circumstances.

Dear Bart, we have had some rough years; difficult years, for both of us. Valentina's health problems, added to writing this book, have made it difficult for me to still sufficiently see and appreciate the many things that we share. There have been many lonely evenings for both of us - me working, you dealing with things at home. That has been hard for you, especially during these past few months. Your patience with me while finishing this book has been admirable. Practical as you are, you must have felt powerless to not being able to do anything about so many things that are incomprehensible to you. I hope that on the $20^{\text {th }}$ December, you will understand why things have gone the way they went. I hope more than anything that you will be proud of me, and of yourself, and of us together!

Dear Mammie, these, almost last words are for the one person without whom this book would never have been finished. You have - literally - done everything possible to help me during all these years, as if it was the most natural thing in the world. You took care of Valentina as if she was your own daughter, with so much dedication, patience and love. You showed me that there is always reason for hope, 
if not now, surely in the near future. You convinced me over and over again, without actually saying it, to go on, in the broadest sense of the word.

These past three years have been both beautiful and very difficult for me, and for you. To me, we experienced these extreme feelings together. You have been capable of making me feel that I was not alone in these feelings, simply by being there unconditionally, by showing understanding without using words, by seeing me as I am, and by making me feel loved. There are no ways to adequately put my love and gratitude for you into words, but, that, you know...

Valentina, mijn lieve kleine dappere nenà, jouw ongelofelijke moed, oneindige veerkracht en niet te stuiten vrolijkheid hebben mij eindeloos geïnspireerd om dit 'boekje' af te maken...

Reijmerstok, October 2011 



\section{Contents}

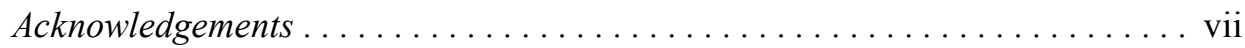

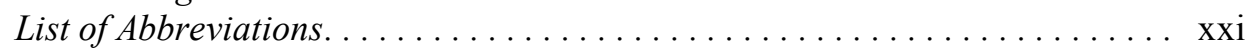

Chapter I

Terrorism as Timeless Trend: An Introduction $\ldots \ldots \ldots \ldots \ldots \ldots \ldots \ldots$

1. Terrorism in the Netherlands . . . . . . . . . . . . . . . . . . . 1

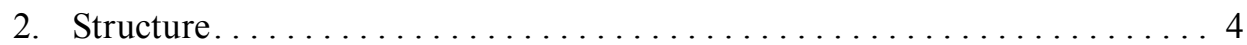

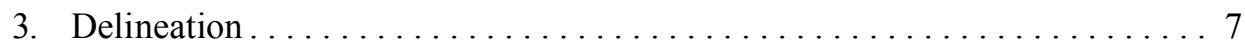

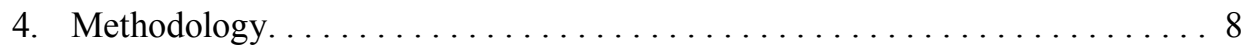

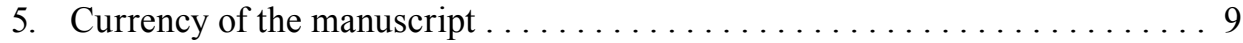

Chapter II

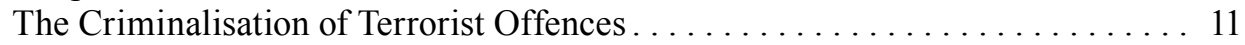

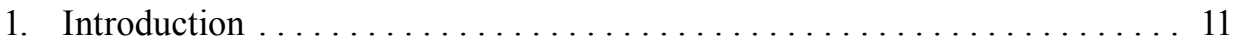

2. The European Framework Decision on Combating Terrorism . . . . . . . . 13

3. The Dutch reaction to $9 / 11$ and the implementation of FD 2002/475 . . . . . 15

4. Terrorism as defined in the Dutch criminal justice system . . . . . . . . . . 18

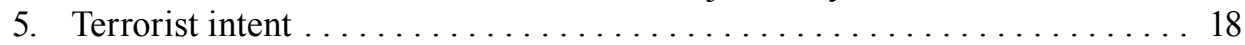

5.1 Mohammed B: Murder or terrorist murder? . . . . . . . . . . 22

5.2 Preparation of a terrorist attack and terrorist intent. . . . . . . 25

5.3 Illegal possession and/or use of weapons with or without terrorist intent? .............................. 28

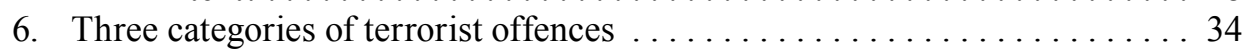

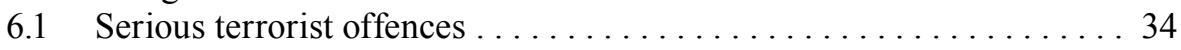

6.1.1 An example: Conspiracy to commit a terrorist offence. . . . . 36

6.2 Terrorist offences with increased penalties . . . . . . . . . . . 44

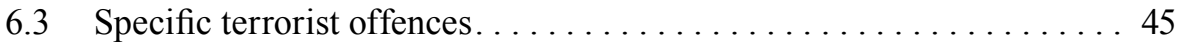

6.3.1 An example: Membership of a criminal/terrorist

organisation ...................... 46

6.3.1.1 The first requirement: Organisation. . . . . . . . . 48

6.3.1.2 The second requirement: The organisation's purpose................... 57

6.3.1.3 The third requirement: Participatory behaviour . . . 66

6.4 Training for terrorism and preparation for a terrorist offence . . . . . . 74

7. The principle of legality within the Dutch legal system . . . . . . . . 76

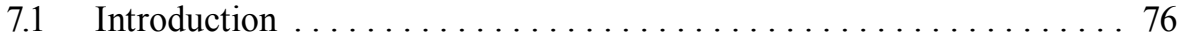

7.2 The lex certa prerequisite $\ldots \ldots \ldots \ldots \ldots \ldots \ldots \ldots \ldots \ldots \ldots \ldots$ 
Contents

7.3 The prohibition of applying criminal law by analogy . . . . . . 86

7.4 The prohibition of using customary law and the prohibition of

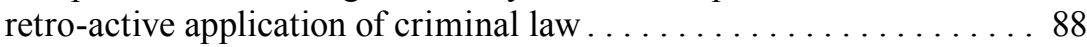

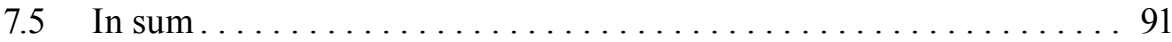

8. The principle of legality pursuant to Article 7 of the ECHR . . . . . . . 92

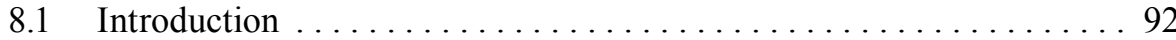

8.2 Only law can define a crime and prescribe a penalty . . . . . . 93

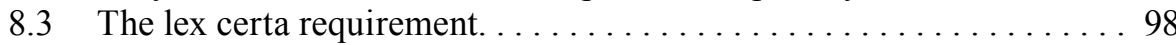

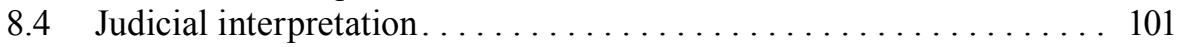

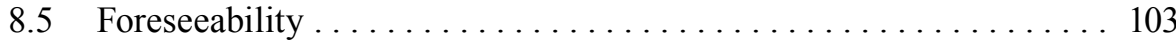

8.6 Law and state practice . . . . . . . . . . . . . . . 110

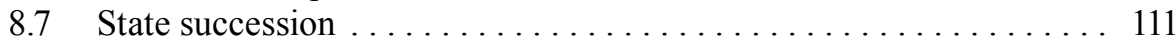

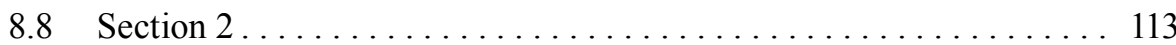

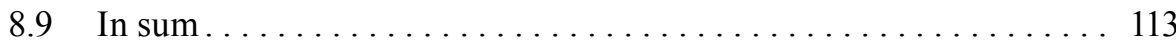

Chapter III

Allegedly Involved in Terrorist Activities . . . . . . . . . . . . . 117

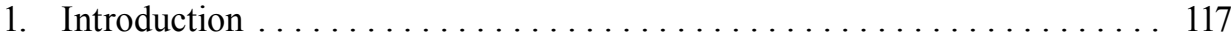

2. Alleged involvement in terrorist activities. . . . . . . . . . . . . . 119

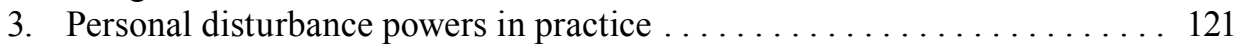

4. Personal disturbance powers and the DCCP . . . . . . . . . . . . 124

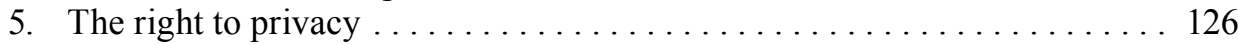

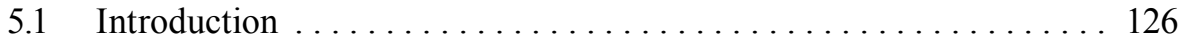

5.2 An adequate legal basis for personal disturbance powers: The first

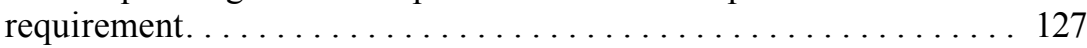

5.3 The necessity requirement in light of personal disturbance . . . . . 130

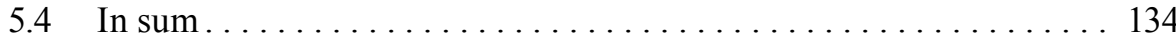

Chapter IV

Assumed Connections with Terrorism . . . . . . . . . . . . . . . 137

1. Introduction . . . . . . . . . . . . . . . . . . . . . . . 137

2. Assumed connections with (the support of) terrorist activities. . . . . . . . 139

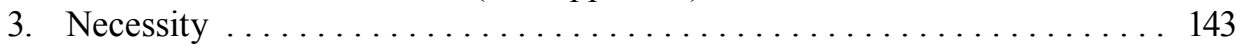

4. The administrative measures, statutory remedies and further details . . . . 144

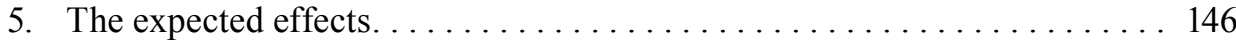

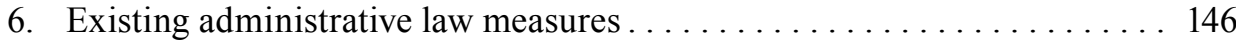

7. Criticism and recommendations from experts. . . . . . . . . . . 148

8. Recommendations of the Council of State. . . . . . . . . . . . . . . 150

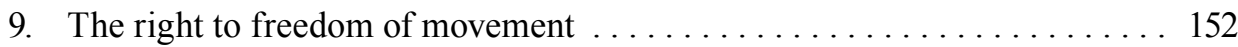

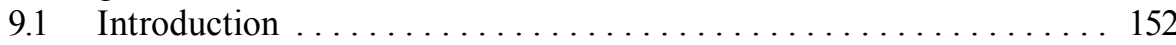

9.2 Restrictions on liberty of movement versus deprivation of liberty . . 152 
9.3 The scope of the right to liberty of movement . . . . . . . . . . 155

9.4 Lawful restrictions on the right to liberty of movement . . . . . . . 156

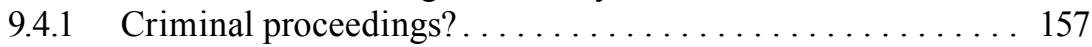

9.4.2 Level of suspicion and evidence ............... 159

9.4.3 Automatic continuation and prior warning .......... 161

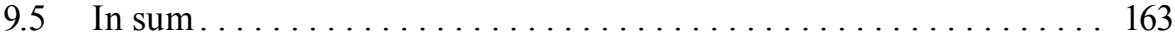

\section{Chapter V}

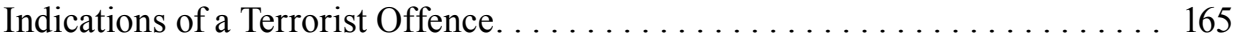

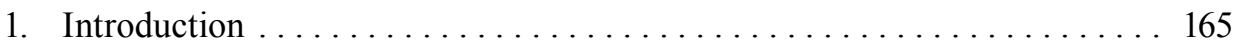

2. Indications of a terrorist offence $\ldots \ldots \ldots \ldots \ldots \ldots \ldots \ldots \ldots \ldots \ldots$

3. Powers on the basis of indications of a terrorist offence . . . . . . . . 173

4. The exploratory inquiry into terrorist offences . . . . . . . . . . . . . 174

4.1 Exploratory inquiry into common offences: Article 126gg of the

DCCP ................................ 175

4.2 Exploratory inquiry into terrorist offences: Articles $126 \mathrm{hh}$ and

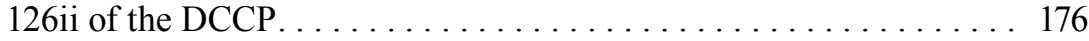

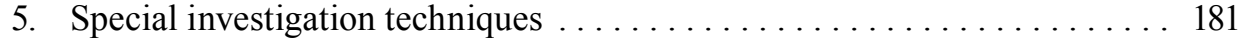

$5.1 \quad$ General provisions . . . . . . . . . . . . . . . . . . . 182

5.2 Systematic surveillance, pseudo purchases and the provision of services, undercover systematic gathering of information,

powers to enter enclosed places, and infiltration . . . . . . . . . 183

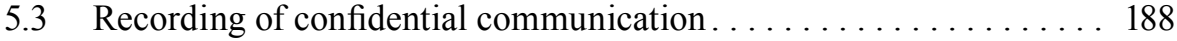

5.4 Requisition of data . . . . . . . . . . . . . . . . . . . . . 192

6. Investigative powers in security risk areas . . . . . . . . . . 196

6.1 Indications of a terrorist offence and security risk areas . . . . . . . . . 197

6.2 Powers of investigation. . . . . . . . . . . . . . . . . . . 199

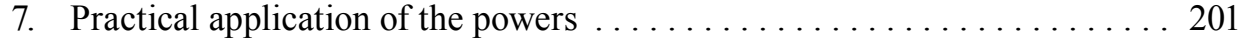

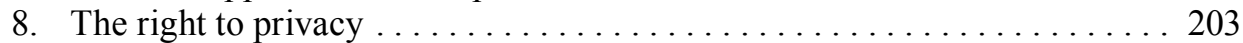

8.1 In accordance with the law? . . . . . . . . . . . . . . . 204

8.1.1 Qualitative requirements for legal provisions . . . . . . . . . 204

8.1.2 Investigative powers within security risk areas and the law . 216

8.1 .3 The exploratory inquiry and the law ........... 221

8.1.4 Effective and adequate safeguards.............. 226

8.2 Necessary in a democratic society . . . . . . . . . . . . . 238

Chapter VI

A Reasonable Suspicion . . . . . . . . . . . . . . . . . . . . . 251

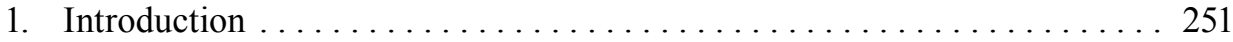

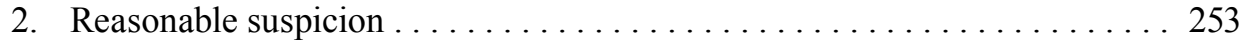

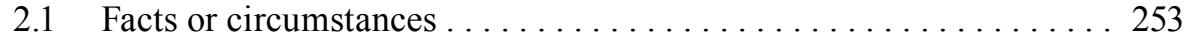


Contents

$2.2 \quad$ Reasonable .......................................... 269

2.3 Guilty of a criminal offence..................... 271

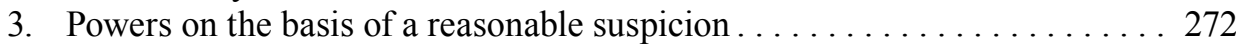

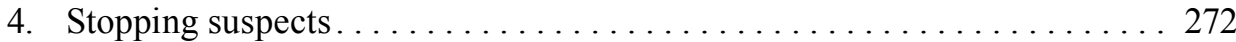

5. Arrest and police arrest for interrogative purposes . . . . . . . . . . . 273

6. Police custody . . . . . . . . . . . . . . . . . . . . . . . . . . . . . . 277

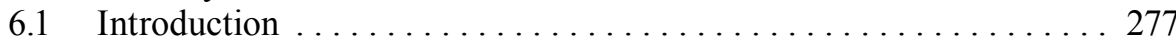

6.2 Rules and formalities ............................. 278

6.3 Terms regarding police custody . . . . . . . . . . . . . . . . 279

6.4 Supportive coercive measures . . . . . . . . . . . . . . . . . . 281

6.5 Police custody and judicial control. . . . . . . . . . . . . . . 282

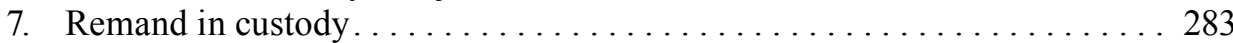

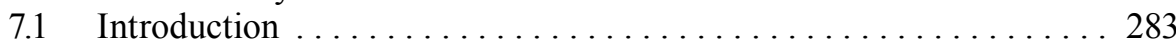

$7.2 \quad$ Rules and formalities ............................ 284

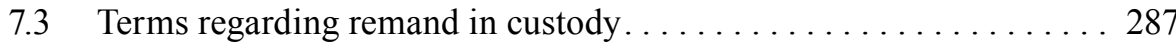

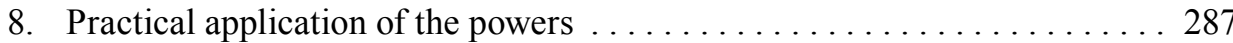

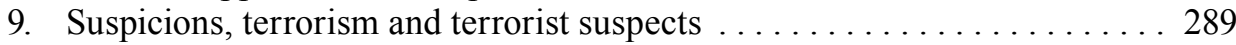

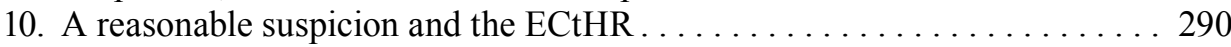

10.1 Introduction . . . . . . . . . . . . . . . . . . . . . . . 290

10.2 The 'UK cases' . . . . . . . . . . . . . . . . . . . . . . . . . . 291

10.3 Case law based on the UK judgements . . . . . . . . . . . . . . 297

10.4 In sum . . . . . . . . . . . . . . . . . . . . . . . . . . . . . . . . 299

11. The right to liberty and security of person $\ldots \ldots \ldots \ldots \ldots \ldots \ldots \ldots \ldots$

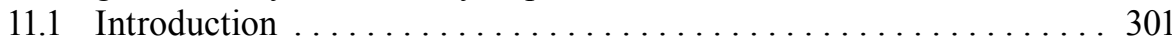

11.2 The concept of 'Liberty and security of Person' . . . . . . . . 302

11.3 Arrest period............................... 306

11.3.1 The scope of and the reasons for deprivation of liberty . . . 307

11.3.2 A procedure prescribed by law and lawful: A tripartite structure .......................... 315

11.3.3 Judicial control during the arrest period . . . . . . . . . 322

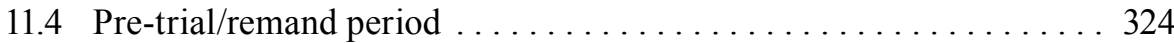

11.4.1 Introduction . . . . . . . . . . . . . . . . . . . . . . . . 324

11.4.2 Danger of absconding . . . . . . . . . . . . . . . . 328

11.4.3 The risk of an interference with the course of justice . . . . . 331

11.4.4 The need to prevent crime . . . . . . . . . . . . . . . . . 333

11.4.5 The need to preserve public order . . . . . . . . . . . . . . 334

11.4.6 Alternative measures . . . . . . . . . . . . . . . . . . . . . . 337

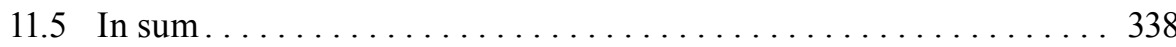

Chapter VII

Serious Objections ................................... 341

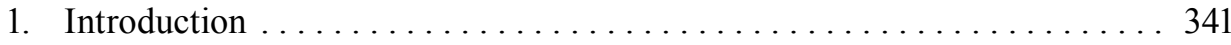




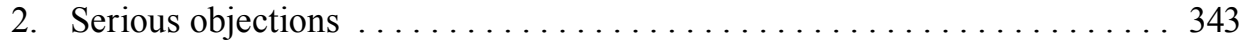

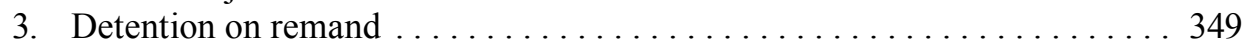

4. Non-disclosure of the case file . . . . . . . . . . . . . . . . . 353

5. The reasonableness of pre-trial detention and special diligence . . . . . . . 359

$5.1 \quad$ Introduction . . . . . . . . . . . . . . . . . . . . . . . . 359

5.2 Criteria to determine compliance with the special diligence requirement. ............................ 363

5.3 Special diligence: The type of criminal behaviour .......... 365

5.4 Special diligence: Inactivity of domestic authorities .......... 368

5.5 Special diligence: The complexity of the case and investigative

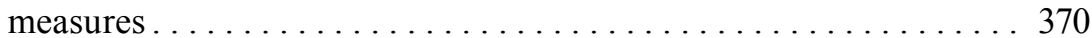

5.6 Special diligence: The suspect's attitude . . . . . . . . . . . . . . 373

5.7 In sum . . . . . . . . . . . . . . . . . . . . . . . . . . . . . . 373

6. Habeas corpus proceedings . ........................ 375

6.1 The right to lodge a habeas corpus complaint ............. 377

6.2 Applicability of Article 5, section 4 of the ECHR ........... 378

6.3 The competent authority. ...................... 380

6.4 The nature of habeas corpus proceedings $\ldots \ldots \ldots \ldots \ldots \ldots \ldots 383$

6.5 Habeas corpus proceedings in case of terrorism: Exceptions? . . . . 395

6.6 Lawfulness of pre-trial detention . . . . . . . . . . . . . . . 403



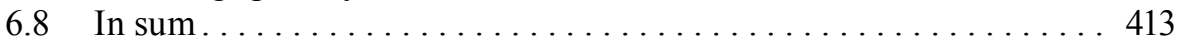

\section{Chapter VIII}

Blacklisted as Terrorist................................. 417

1. Introduction . ................................ 417

2. Origin of the European Union blacklisting system: The United Nations blacklisting. . . . . . . . . . . . . . . . . . . . . . . . . . . . . . 419

3. The European Union blacklisting system . . . . . . . . . . . . 420

3.1 Council Common Position 930/2001/CFSP . . . . . . . . . . . . . 421

3.2 Council Common Position 931/2001/CFSP . . . . . . . . . . . . . 422

3.3 Council Regulation (EC) No $2580 / 2001 \ldots \ldots \ldots \ldots \ldots \ldots \ldots 425$

4. Safeguarding fundamental rights and freedoms throughout blacklisting

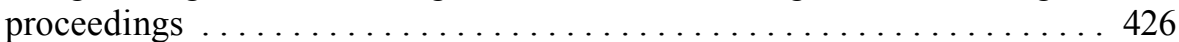

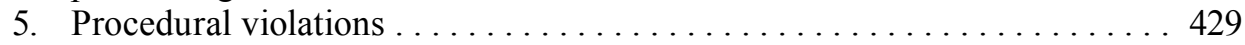

5.1 Competence of the Union regarding blacklisting. . . . . . . . . . 429

5.2 Defence rights............................ 431

$5.2 .1 \quad$ The right to a fair hearing $\ldots \ldots \ldots \ldots \ldots \ldots \ldots \ldots 432$

5.2.2 The right to be informed of the reasons for inclusion on the blacklist ......................... 434

5.2.3 The right to an effective legal remedy . . . . . . . . . . 436

5.2.4 The interdependence of defence rights . . . . . . . . . 437 
Contents

5.3 Effective judicial review and essential procedural requirements ... 443

5.3.1 The scope of judicial review . . . . . . . . . . . . . . . . 444

5.3.2 Judicial review for Category 1 terrorists . . . . . . . . . . 446

5.3.3 Judicial review for Category 3 terrorists . . . . . . . . . . . 448

5.3.4 The burden of proof in (de)-listing procedures . . . . . . . . . 449

5.3.5 Safeguarding essential procedural requirements and the nature of fund-freezing measures . .............. 451

5.4 Infringement on the right to be presumed innocent. . . . . . . . 453

6. Substantive violations. . . . . . . . . . . . . . . . . . . . 460

6.1 Non-compliance with substantive prerequisites of the Regulation

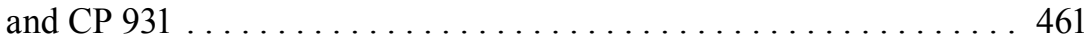

6.2 Infringement on the right to property $\ldots \ldots \ldots \ldots \ldots \ldots \ldots . \ldots 68$

6.3 Infringement on the principles of subsidiarity, proportionality and legal certainty ......................... 471

6.4 Infringement on the right to assembly, association, expression and privacy ................................. 473

7. In sum........................................ 474

Chapter IX

Conclusions and Recommendations........................... 479

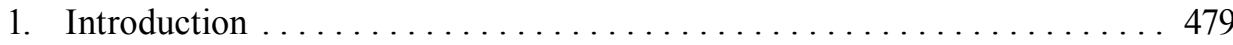

2. Characteristics of Dutch anti-terrorism legislation .............. 480

2.1 Substantive anti-terrorism legislation. . . . . . . . . . . . . . . 480

2.2 Procedural anti-terrorism legislation .................. 493

3. Anti-terrorism legislation and fundamental rights and principles of law . . 503

3.1 The principle of legality and the DTA ............... 503

3.2 The right to privacy and Dutch anti-terrorism legislation........ 505

3.2.1 'In accordance with the law' for the sake of preventing terrorism? . . . . . . . . . ................ 506

3.2.2 Necessary for the sake of preventing terrorism? . . . . . 513

3.2.3 The error rate and the risks of Rasterfahndung. . . . . . . . 521

3.4 The right to liberty and Dutch anti-terrorism legislation. . . . . . . 522

3.4.1 The arrest period and Article 5 of the ECHR . . . . . . . . . 523

3.4.2 The remand period and Article 5 of the ECHR ......... 528

3.4.3 Non-disclosure of part of the case file, habeas corpus proceedings and Articles 5 and 6 of the ECHR........ 532

3.5 The right to freedom of movement and Dutch anti-terrorism legislation ..................................... 537

3.6 Blacklisting and fundamental rights and principles of law ....... 539

4. Counterbalancing interferences with fundamental rights and principles

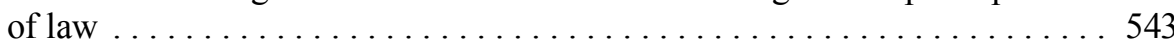

$4.1 \quad$ Terrorist offences ................................ 544 
4.2 Special investigation techniques . . . . . . . . . . . . . . 545

4.3 Investigative powers in security risk areas . . . . . . . . . . 547

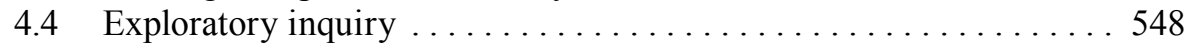

4.5 Deprivation of liberty . . . . . . . . . . . . . . . . . 548

4.6 Non-disclosure of information comprised in the case file . . . . . . 549

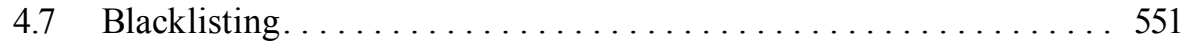

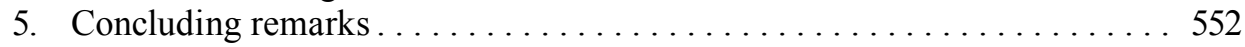

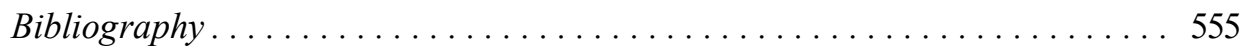

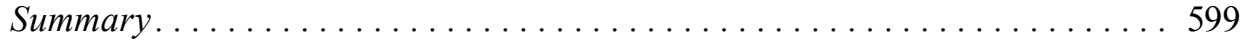

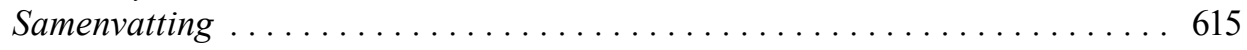

Curriculum Vitae ............................. 633 



\section{List of Abbreviations}

$\begin{array}{ll}\text { AA } & \text { Aliens Act [Vreemdelingenwet] } \\ \text { AEO } & \text { Act on Economical Offences [Wet economische misdrijven] } \\ \text { AIVD } & \text { Algemene Inlichtingen en Veiligheidsdiensten } \\ \text { CFI } & \text { Court of First Instance of the European Union } \\ \text { CIE } & \text { Criminele Inlichtingen Eenheid } \\ \text { DCC } & \text { Dutch Criminal Code [Wetboek van Strafrecht] } \\ \text { DCCP } & \text { Dutch Code of Criminal Procedure [Wetboek van Strafvordering] } \\ \text { DPTA } & \text { Dutch Procedural Terrorism Act } \\ \text { DTA } & \text { Dutch Terrorism Act [Wet Terroristische Misdrijven] } \\ \text { ECHR } & \text { European Convention for the Protection of Human Rights and } \\ & \text { Fundamental Freedoms } \\ \text { ECJ } & \text { European Court of Justice } \\ \text { ECtHR } & \text { European Court of Human Rights } \\ \text { EU } & \text { European Union } \\ \text { MIVD } & \text { Militaire Inlichtingen en Veiligheidsdiensten } \\ \text { NJ } & \text { Nederlandse Jurisprudentie } \\ \text { NJB } & \text { Nederlands Juristenblad } \\ \text { NJCM } & \text { Nederlands Juristencomité voor de mensenrechten } \\ \text { OA } & \text { Opium Act [Opiumwet] } \\ \text { PA } & \text { Police Act [Politiewet] } \\ \text { RCIE } & \text { Regionale Criminele Inlichtingen Eenheid } \\ \text { TEC } & \text { Treaty establishing the European Community } \\ \text { TEU } & \text { Treaty on the European Union } \\ \text { TFEU } & \text { Treaty on the Functioning of the European Union } \\ \text { UK } & \text { The United Kingdom } \\ \text { UN } & \text { The United Nations } \\ \text { UNSC } & \text { United Nations Security Council } \\ \text { USA } & \text { United States of America } \\ \text { WAA } & \text { Weapons and Ammunition Act [Wet Wapens en munitie] } \\ \text { WODC } & \text { Wetenschappelijk Onderzoeks- en Documentatie Centrum } \\ & \end{array}$





\title{
Chapter I Terrorism as Timeless Trend: An Introduction
}

\author{
1. Terrorism in the Netherlands
}

Preamble

On 24 December 2010 the Dutch public prosecution service received a memo from the secret intelligence services alleging that the Netherlands faced a potential terrorist attack. The attack, it was alleged, would be committed by four Somalis. The target was unknown. ${ }^{1}$ That evening, a mobile phone shop in Rotterdam was raided. Twelve Somalis were arrested and taken into police custody. ${ }^{2}$ During the subsequent house searches, no explosives or weapons were found. ${ }^{3}$

Five suspects were released on 27 December, another six on 28 December and the last suspect was released on 30 December. Three Somalis remained under suspicion in respect of the alleged preparation of a terrorist attack. In the media, acquaintances of the twelve Somalis repeatedly uttered their disbelief regarding these allegations. They argued that the arrested Somalis were anything but Muslim fundamentalists citing, for example, that they drank alcohol and occasionally used drugs. $^{4}$

On 29 December the National Anti-terrorism Coordinator [Nationaal Coördinator Terrorismebestrijding] stated that four of the arrested Somalis were 'listed as alleged terrorists'. Who listed them as alleged terrorists, on what account, on which list, and on the basis of what information, is unclear. The other eight Somalis were considered 'collateral damage'. 5 The prevention of terrorism is a top priority, and according to the National Anti-terrorism Coordinator, this implies that innocent persons may be arrested during operations. In the case of the Somalis, this meant that when the shop was raided, the special squads arrested everyone they suspected of 'being involved in terrorism', and according to the Coordinator, they had to be absolutely sure they indeed 'had everyone'.

In the government's view, arrests being made on the basis of insufficient evidence or no evidence at all is inevitable where terrorism is concerned, that is all in the game. According to the National Anti-terrorism Coordinator, even though criminal proceedings and the course of justice are important, in cases of counter

\footnotetext{
J. Mat, 'Nog veel onduidelijk na arrestaties', in NRC Handelsblad 27 December 2010.

B. Hinke, 'In de belwinkel is iedereen verbaasd', in NRC Handelsblad 27 December 2010.

Volkskrant 25 December 2010, 'Somaliërs opgepakt wegens terrorismedreiging'.

B. Hinke, 'In de belwinkel is iedereen verbaasd', in NRC Handelsblad 27 December 2010.

ANP, 'Meer Somaliërs opgepakt door OM dan AIVD wilde', in Volkskrant, 28 December 2010.
} 
Chapter I

terrorism these are unequivocally of secondary importance. ${ }^{6}$ Preventing potential acts of terrorism is deemed more important than prosecuting and convicting supposed terrorists. This is also the public prosecution service's view. ${ }^{7}$

\section{DUTCH ANTI-TERRORISM POLICY}

I have not chosen to discuss the 'Somali case' in the preamble at random. First of all, this case raises several questions. Secondly, the 'Somali case' is particularly characteristic of Dutch counter terrorism policy and its practical implementation by the Executive. This policy explicitly aims at preventing terrorism, primarily by means of the criminal justice system. ${ }^{8}$ Let us start with the questions raised by this case.

The first question is whether the Executive would have acted the same way if there had been a suspicion of a common criminal offence? Regarding unlawful arrests as 'inherent to preventing terrorism' raises the question of the extent to which the legal system is currently used, in cases of terrorism, to serve purposes beyond those statutorily defined purposes in the Dutch Code of Criminal Procedure (DCCP). In other words: to what extent is the law, substantive as well as regarding procedure, still decisive in determining the scope of state powers to prevent

6 B. Rijlaarsdam, 'Het moest heel snel. En je kunt niet een beetje ingrijpen', in NRC Handelsblad 29 December 2010. Compare, also, with J.P.H. Donner, 'Beter tien schuldigen vrijgesproken dan één onschuldige veroordeeld?' in Rechtsgeleerd magazijn Themis 2004-1, pp. 14-15 and Th. A. de Roos, Strafrechtelijke terrorismebesttijding: een vraagteken bij een vraagteken, in Rechtsgeleerd Magazijn Themis 2004-1, pp. 15-16, and see J. Oranje, Schuldig tot het tegendeel is bewezen, in NRC Handelsblad 12 February 2005, where M. Verhagen (politician) underlines, in Parliament, that in the case of terrorism, the fundamental principle that it is 'better setting 10 guilty persons free than depriving 1 innocent person of his liberty' does not apply, and E. Kalse and J. Verlaan, Ik moet primair terreur bestrijden. Donner over kritiek rechters, in NRC Handelsblad 18 February 2005.

$7 \quad$ M. Leijendekker, 'Somalische terreurverdachten Elf verdachten zijn alweer vrij. De arrestaties passen in een europese trend', in NRC Handelsblad 28 December 2010; M. Leijendekker, 'Snel arresteren is ook in andere landen strategie', in NRC Handelsblad 28 December 2010; B. de Graaf and W. Schinkel, 'Het recht op veiligheid schept een permanente noodtoestand', in NRC Handelsblad 31 December 2010; M. Thie, 'Justitie: AIVD zinspeelde op acute dreiging', in NRC Handelsblad 27 December 2010. Empirical evidence demonstrates that persons suspected of a terrorist offence are not often convicted on account of such offences (27 of the 113 suspects compared to more than $50 \%$ suspects of the 260.000 common suspects).

8 This aim applies to all of the Dutch anti-terrorism legislation. See, in this respect, P.J.A. de Hert, 'Balancing security and liberty within the European human rights framework', in A.M. Hol \& J.A.E. Vervaele (eds.), Security and Civil Liberties: The Case of Terrorism, Yearbook Utrecht Law Review 2005, Intersentia Antwerpen-Oxford, pp. 37-38; M.J. Borgers, De vlucht naar voren, Den Haag, Boom Juridische Uitgevers, 2007; A.A. Franken, Strafrechtwetenschappen en terrorismebestrijding, in Delikt en Delinkwent 2006, 1 and Y. Buruma, 'Grenzen aan de strafrechtelijke aansprakelijkheid', in M.S. Groenhuijsen \& J.B.H.M. Simmelink (red.), in Glijdende Schalen, Nijmegen Wolf Legal Publishers 2003, pp. 71-93; Kamerstukken II 20012002, 27 925, nr. 10, pp. 8-14; Kamerstukken II 2002-2003, 28 649, nr. 3; Handelingen II 2003 2004, p 2338. 
terrorism? Another question is to what extent such state action, which undeniably interferes with fundamental legal rights such as the right to privacy and liberty, can be justified on the basis of such thinly corroborated information? How does the justified goal of preventing terrorism relate to mandatory compliance with fundamental legal rights and principles of law as enshrined in the European Convention on Human Rights (ECHR)? I hope to answer all of these questions throughout this book.

As discussed above, Dutch counter-terrorism policy primarily focuses on prevention. This dissertation discusses one aspect of that policy: the scope of the preventiveoriented anti-terrorism legislation within and beyond criminal law and its impact on the principles of (criminal) law and on fundamental legal rights as enshrined in the ECHR, which in case of the Netherlands, is higher law.

Anti-terrorism legislation is a new phenomenon within the Netherlands, even though terrorism is not. ${ }^{9}$ Since the 9/11 terrorist attacks in the United States of America (USA) and the terrorist attacks in Bali, Madrid, London and Mumbai, combating terrorism has become a top priority in Dutch politics. This has led to extensive anti-terrorism legislation, primarily in the field of substantive criminal law and criminal procedure. However, existing public order law and private law are also used to counter terrorism. In the field of administrative law also, legislative initiatives to better prevent terrorism have been undertaken. Last, but certainly not least, the European Union has also adopted a firm anti-terrorism policy which has also led to national legislative activity to better counter terrorism.

This means that every field of law is employed in preventing terrorism. In the Netherlands, the prevention of terrorism by means of the criminal justice system is strived for by (1) creating far-reaching criminal liability, especially in respect of inchoate offences, and by (2) providing for corresponding extensive state powers that can be mobilised on the basis of low criteria for application. State action to counter terrorism by means of the administrative law system and by means of public order law follows the same trend..$^{10}$

It goes without saying that preventing terrorism, as such, is not only a legitimate endeavour, but it is even an obligation under the ECHR. ${ }^{11}$ However, is the outcome

9 See for a description of the history of terrorism in the Netherlands E.R. Muller, 'De geschiedenis van terrorisme in Nederland', in Terrorisme. Studies over terrorisme en terrorismebestrijding, E.R. Muller, U. Rosenthal, R. de Wijk (eds.), Kluwer Deventer, 2008, pp. 217-235. See, also, A.P. Schmid, J.F.A. de Graaf, F. Bovenkerk, L.M. Bovenkerk-Teerink, L. Bunt, Zuidmoluks terrorisme, de media en de publieke opinie. Twee studies van het Centrum voor Onderzoek van Maatschappelijke Tegenstellingen (Rijksuniversiteit Leiden), Uitgeverij Intermediair Amsterdam 1982.

10 See Chapters III and IV on public order law and administrative law measures to prevent terrorism, respectively.

11 See the Preamble and Article 1 of the Guidelines of the Council of Europe on human rights and the fight against terrorism. See, also, M. Kuijer, Van Lawless naar een rechtmatige bestrijding 
of part of that endeavour - the current anti-terrorism legislation - justifiable in light of mandatory respect for fundamental legal rights and principles of law as enshrined in treaties?

The legislative implementation of the Dutch preventive-oriented anti-terrorism policy and its effects on compliance with fundamental legal rights and principles of law as treaty obligations form the central pillars of this book and have led to the following key research question:

To what extent do the statutory criteria for the application of pre-trial anti-terrorism powers and measures and their practical implementation, especially as regards the required level of suspicion, within the criminal justice system, public order law, administrative law and European union law, comply with the relevant fundamental legal rights and principles of law, as enshrined in the applicable European treaties?

To answer this question several sub-questions are raised and discussed throughout the following chapters, of which these are the most important three:

I. What constitutes an act of terrorism as the law stands in the Dutch criminal justice system, and how and to what extent has the criminalisation of terrorism affected criminal liability, particularly during the pro-active phase?

II. What level of suspicion is required to apply which powers and/or measures situated in what area of law to prevent terrorism?

III. How does the application of these state powers, particularly in light of the criteria for application, affect which fundamental legal rights and principles of law?

\section{Structure}

\section{SUB-QUESTION I}

The above research questions lead to a tripartite structure in this dissertation. First of all, Chapter II relates to the first sub-question and serves to examine the scope of criminal liability in respect of terrorist offences in terms of mens rea and actus reus. What distinguishes terrorist offences from common offences and with respect to what offences is this most visible? How has the judiciary interpreted the scope of terrorist offences thus far?

van terrorisme, Wolf Legal Publishers 2005, pp. 8-9, who considers a state's imperative duty to protect its people as a fundamental right. Therefore, this right should be balanced against interference with other non-absolute (derogable) rights. 
The Dutch Terrorism Act [Wet terroristische misdrijven, DTA] entered into force in 2004. This means that case law on terrorist offences is still rather limited, which itself has been shown an impediment to the clear ascertainment of the scope of criminal liability in respect of terrorist offences. Case law mostly concerns several specific terrorist offences, including participation in a terrorist organisation and preparation for the commission of terrorist offences. The difference regarding the scope of criminal liability between common offences and terrorist offences is primarily visible with respect to such inchoate offences. Chapter II will therefore chiefly explore the scope of inchoate terrorist offences.

\section{SUB-QUESTION II}

Chapters III to VIII concern themselves with the second sub-question, and therefore discuss several specific pre-trial measures and powers available to the Executive, in the field of public order law, administrative law, criminal procedure and European Union law, to prevent terrorism. Which criteria have to be fulfilled so these powers and measures can be applied? What information is used to demonstrate the 'suspicion' of terrorism, and to what extent does such information need to be indicative for specific terrorist offences? What is the scope of the powers and measures available to counter terrorism, and how do they relate to existing common powers and measures in the respective fields of law?

The measures and powers are categorised on the basis of the required level of suspicion. In this respect, the notion of 'the required level of suspicion' is considered as a criterion for application of the respective measures and powers. Chapter III starts with the lowest level of suspicion, that of 'involvement in terrorist activities', and chapter VII ends with the most demanding level of suspicion, that of 'serious objections'. This rising continuum approach implies that Chapter III concerns public order law, Chapter IV concerns administrative law and Chapters V to VII concern criminal procedure.

Chapter VIII relates to the European Union's system of blacklisting terrorists. As this system factually does not rely on a suspicion criterion, as prerequisite for applying anti-terrorism measures, it cannot be arranged along the rising continuum approach. The discussion of the European Union's system of blacklisting terrorists in Chapter VIII is therefore primarily inspired by the intrusive character of this system, specifically in terms of its compliance with fundamental legal rights and principles of law as incorporated in the Charter of Fundamental Rights of the European Union ('the Charter') and in the ECHR.

The goal of the rising continuum approach is to not only examine the scope of the respective powers and measures separately, but also to consider the connection between these powers and measures in the various fields of law. That will enable us to determine on what legal basis the Executive is allowed to exert which powers and 
measures on civilians to prevent terrorism, and what the criteria of application are, corroborated by what type and amount of information.

Chapters III to VII are comparable in structure because they are all built around a (statutorily) defined suspicion criterion. Chapter VIII, regarding the European Union's terrorism blacklisting system concerns the Union's measures to prevent (the financing of) terrorism. As mentioned above, this system does not, in practice, rely on suspicion criteria as justification for blacklisting and the imposition of fundfreezing measures. Therefore, a slightly different approach and structure is called for: In Chapter VIII the emphasis will be placed on discussing the system of blacklisting, the powers available within that system, and on European Union case law regarding the practical effects of this system on, inter alia, compliance with defence rights. This latter aspect brings us to the last sub-question: the impact of anti-terrorism measures and powers on the fundamental legal rights and principles of law, as enshrined in the ECHR and - in respect of Chapter VIII - in the Charter.

\section{Sub-QUESTION III}

The third sub-question is the leading thread throughout all of the chapters: which fundamental legal rights and principles of law are affected by the discussed Dutch anti-terrorism legislation, and what is the scope of these effects? The phrasing of this question demonstrates the chosen methodology as regards sub-question three. The powers and measures discussed in Chapters III to VIII determine what fundamental legal rights and principles of law are scrutinised rather than the other way around. ${ }^{12}$ Following that approach, the following legal rights and principles are elaborated on: the right to privacy pursuant to Article 8 of the ECHR, the right to liberty and security in accordance with Article 5 of the ECHR, the right to freedom of movement under Article 2 of the $4^{\text {th }}$ Protocol with the ECHR and the principle of legality as interpreted in Dutch case law and as interpreted by the ECtHR under Article 7 of the ECHR. Chapter VIII on the blacklisting system is, again, a bit different in this respect, and deals with more (specific) legal rights and principles dealt with by the European Union's judiciary in its case law, including defence rights, the right to property, the principles of legal certainty, proportionality andsubsidiarity, and the presumption of innocence.

Each chapter will end with an analysis of the scope of the fundamental legal right(s) and/or principles that is/are affected by the respective powers and measures. These analyses aim to disclose the issues that may arise under the legal rights and principles mentioned above, in light of the required criteria for application of the respective powers and measures.

\footnotetext{
12 Aksu for example takes as starting point various fundamental rights enshrined in the ECHR. See M. Aksu, Straatsburgse kaders voor terrorismebestrijding. EVRM, strafrecht en terrorisme, dissertatie Wolf Legal Publishers 2007.
} 
The question of whether the powers and measures discussed in Chapters III to VIII may be deemed compatible with the relevant fundamental legal rights and principles of law, as guaranteed by the ECHR and the Charter, respectively, is discussed in the concluding Chapter IX. This latter chapter also elaborates on possible statutory solutions to ensure the compatibility of the preventive-oriented anti-terrorism powers and measures with fundamental legal rights and principles of law.

\section{Delineation}

Terrorism, anti-terrorism legislation and fundamental legal rights and principles of law are all very broad research areas. Many books, articles and reports are, and have been, written on these subjects. Limiting the scope of this dissertation has therefore proven to be quite a difficult task. It also means that it is impossible to examine and discuss in-depth all the relevant anti-terrorism legislation and all fundamental legal rights and principles of law, as enshrined in the ECHR and the Charter that are affected by the present legislation. The scope of this dissertation has therefore been limited by several factors.

First of all, the examination of criminal liability in respect of terrorist offences is primarily confined to three specific inchoate terrorist offences: conspiracy to commit a terrorist offence, preparation for the commission of terrorist offences and participation in a terrorist organisation. ${ }^{13}$ The changed criminal liability caused by the enactment of the DTA is most discernible with respect to these three terrorist offences. In addition, domestic case law regarding terrorist offences primarily concerns prosecution in respect of these three inchoate terrorist offences.

Secondly, I have only scrutinised the powers and measures to prevent terrorism that apply during the pre-trial phase. This means, for example, that the Act on using evidence from (partly) anonymous witnesses during criminal proceedings [Wet Afgeschermde Getuigen] will not be examined. ${ }^{14}$ Limiting this research to the pretrial phase is primarily inspired by the fact that the - effects of - the Dutch preventive-oriented anti-terrorism legislation are most visible during this phase, firstly, because most of the anti-terrorism measures and powers enacted since 2004 apply during the pre-trial phase, and secondly, because criminal investigations into terrorist offences do not often lead to criminal proceedings in respect of terrorist offences.

13 See, for a broad discussion of the DTA J.M. Lintz, De plaats van de Wet terroristische misdrijven in het materiële strafrecht. Een onderzoek naar de wederzijdse beïnvloeding door de Wet terroristische misdrijven en het Wetboek van Strafrecht en enkele bijzondere wetten, dissertatie EUR, Wolf Legal Publishers, Nijmegen, 2007, pp. 54-60; P.J.H.M. Brouns, Opzet in het Wetboek van Strafrecht, dissertatie, Gouda Quint, Arnhem, 1988.

14 Staatsblad 2006, 460 and Staatsblad 2006, 461. 
Thirdly, the elaboration of the third sub-question is confined to discussing the most apparent interferences with fundamental legal rights and principles of law, guaranteed by the ECHR and, to a lesser extent, by the European Charter, the interferences which are moreover, specifically caused by the enactment of the anti-terrorism legislation. For example, extended powers to deprive persons suspected of a terrorist offence of their liberty, as will be discussed in Chapters VI and VII, interfere primarily with the right to liberty of persons but they may, generally speaking, also interfere with the right to privacy. However, in this case the direct impact of the amendments brought forth by the DPTA is most visible with regard to compliance with the right to liberty of persons. These amendments do not comprise powers or measures to further curtail a terrorist suspect's right to privacy during pre-trial detention.

\section{Methodology}

This dissertation primarily discusses legislation that comprises powers and measures to counter terrorism, as well as domestic and European case law on that legislation and on the scope of the relevant fundamental legal rights and principles of law.

Chapter II, The criminalisation of terrorist offences, examines the DTA primarily by analysing the law itself, the corresponding parliamentary memoranda and case law on terrorist offences in the period 2004-2011. The principle of legality, which is relevant to this chapter, is scrutinised by means of domestic case law on this principle and on the basis of the case law of the European Court of Human Rights (ECtHR) on Article 7 of the ECHR.

Chapter III, Allegedly involved in terrorist activities, looks at the scope of so-called 'personal disturbance', an anti-terrorism measure based on existing public order law. The scope of this chapter is very limited, given the fact that there is no explicitly drafted legal basis for this measure. Also, there are only two cases relating to it. The relevant Strasbourg perspective - case law on the right to privacy pursuant to Article 8 of the ECHR - is also limited since there is no explicit case law relating to comparable state powers.

Chapter IV, Assumed connections with terrorism, scrutinises the Bill on administrative law measures to safeguard national security. This bill has not entered into force, which means that there is no case law available on the practical implementation of these measures. To better understand the scope of the Bill, this chapter explicitly elaborates on parliamentary memoranda and on criticism uttered by expert organisations regarding the measures comprised in the Bill. These measures would primarily have interfered with the right to freedom of movement and are therefore examined on compatibility with Article 2 of the $4^{\text {th }}$ Protocol with the ECHR, as interpreted in Strasbourg case law.

Chapters V to VII all discuss amendments brought forth by the Dutch Procedural Terrorist Act (DPTA). These amendments will be discussed extensively on the basis 
of legislation and parliamentary memoranda. They are categorised depending on the required level of suspicion. As there is no case law on the practical application of the extended powers to counter terrorism brought forth by the DPTA, three reports published by the Dutch Scientific Research and Documentation Centre [Wetenschappelijk Onderzoek- en Documentatiecentrum, WODC] on the DPTA will be scrutinised broadly in order to gain better insight in the scope of the DPTA.

Chapter V, Indications of a terrorist offence, discusses Strasbourg case law on Article 8 of the ECHR that specifically relates to the impact of secret measures of surveillance on the respect of the right to privacy. In this respect I have not differentiated between case law that specifically relates to anti-terrorism measures and case law that relates to common criminal law measures that interfere with the right to privacy.

The legislation discussed in Chapter VI, A reasonable suspicion and Chapter VII, Serious objections, includes state powers that primarily interfere with the right to liberty and security of person pursuant to Article 5 of the ECHR. The amount of case law on this provision is huge. On a case-by-case basis I have examined which judgements concern issues that may also rise in the case of the pre-trial deprivation of liberty of a terrorist suspect in the Netherlands. To gain a better understanding of the system of pre-trial deprivation of liberty and, more specifically, of the practical implementation of the criteria for application of measures implying deprivation of liberty, I undertook a work placement with Mr. K. van der Meijde, who, at that time, was working as investigative judge at the Roermond District Court.

Chapter VIII, Blacklisted as terrorist, first of all discusses the basic European Union legislative documents for the blacklisting system. Secondly, I have examined all case law of the European Union judiciary regarding actions filed by blacklisted parties to be delisted. That case law is ordered on the basis of the fundamental legal rights or principle of law that were invoked by the blacklisted party and scrutinised by the judiciary of the European Union, respectively.

Finally, in Chapter IX, Conclusions and recommendations, I have tried to provide an overall picture of the characteristics of Dutch anti-terrorism legislation and its impact on fundamental legal rights and principles of law as enshrined in the relevant treaties. Finally, I present some possible statutory solutions to ensure that these legal rights and principles are fully complied with throughout the state's endeavour to effectively counter terrorism.

\section{Currency of The Manuscript}

The relevant developments with regard to Dutch anti-terrorism legislation and the fundamental legal rights and principles of law have been systematically analysed up to 1 January 2011. Later developments of major importance have also, in part, been included in this dissertation. 



\section{Chapter II The Criminalisation of Terrorist Offences}

\section{INTRODUCTION}

Dutch anti-terrorism legislation in the field of substantive criminal law is based on two main starting points. The first is legislation aimed at preventing terrorism rather than at responding to it. ${ }^{15}$ In other words, persons who presumably intend to commit a terrorist offence should be stopped prior to committing it. The second point is that anyone suspected of being involved in or linked to 'terrorist activities' in any way should also be stopped. ${ }^{16}$ Assisting in terrorist crimes, attempts or conspiracy to commit such crimes, and being part of a terrorist organisation, all lead to criminal responsibility. In order to attain these two goals, criminal liability has been broadened considerably with regard to terrorism. The extent of this criminal liability and its relation to the principle of legality will be discussed in this chapter.

It is important to understand that terrorist offences, as currently codified in the Dutch Criminal Code (DCC), are considered to be a specific type of criminal behaviour that needs to be dealt with accordingly. ${ }^{17}$ That holds for both substantive criminal law and criminal procedure, as will be set out in Chapters V to VII. Not only have terrorist offences been codified as a separate category of crimes within the DCC, but special procedures to investigate such offences have also been established. For example, the criteria used to apply special investigation techniques are different for terrorist offences and for common offences. Furthermore, secret intelligence information is used to arrest presumed terrorists and as evidence against terrorist suspects during a trial. Investigative measures, specifically designed to trace terrorist crimes have been expanded. All of these measures within the Dutch substantive and procedural criminal justice system, serve to prevent acts of terrorism and to investigate anyone involved in the commission of such crimes.

The main issue that will be discussed in this chapter is the scope of terrorist offences pursuant to Articles 83 and $83 \mathrm{a}$ of the DCC. The emphasis will be on inchoate

15 This aim goes for all of the Dutch anti-terrorism legislation. See in this respect P.J.A. de Hert, 'Balancing security and liberty within the European human rights framework', in A.M. Hol \& J.A.E. Vervaele (eds.), Security and Civil Liberties: The Case of Terrorism, Yearbook Utrecht Law Review 2005, Intersentia Antwerpen-Oxford, pp. 37-38; M.J. Borgers, De vlucht naar voren, Den Haag, Boom Juridische Uitgevers, 2007; A.A. Franken, 'Strafrechtwetenschappen en terrorismebestrijding', in Delikt en Delinkwent 2006, 1 and Y. Buruma, 'Grenzen aan de strafrechtelijke aansprakelijkheid', in M.S. Groenhuijsen \& J.B.H.M. Simmelink (red.), Glijdende Schalen, Nijmegen Wolf Legal Publishers 2003, pp. 71-93.

16 See, for example, Handelingen II 2003-2004, nr. 33, p. 2350.

17 See, for example, Handelingen II 2003-2004, nr. 33, p. 2338. 
terrorist offences. Case law on these provisions primarily concerns terrorist offences that took place during the pro-active phase, the phase in which a terrorist offence is being prepared, conspired, attempted, or planned (possibly within a terrorist organisation). For example, persons are frequently arrested while planning, conspiring, or preparing to commit a terrorist murder, rather than after they have committed the murder. Almost all Dutch 'terrorists' are currently in jail for inchoate terrorist crimes and were hence arrested during the pro-active phase. One exception is Mohammed B., who was sentenced to life imprisonment for having murdered Theo van Gogh with terrorist intent.

The purpose of this chapter is to demonstrate what state of mind (mens rea or 'guilty mind') and what factual conduct (actus reus or 'guilty act') is required for it to be considered as 'terrorist' in accordance with Articles 83 and Article 83a of the DCC. In addition, the question of whether criminal liability with regard to terrorist offences has been expanded with the enactment of the Dutch Terrorist Act (DTA 2004) is addressed and, if so, to what extent. To adequately answer these questions, the following subjects will be discussed.

Firstly, the EU Framework Decision on Combating Terrorism (FD 2002/475) will be scrutinised. The FD 2002/475 was the direct reason for drafting the DTA. In this respect it is important to realise that prior to the enactment of the DTA, the Dutch Criminal Code (DCC) did not contain any provisions which criminalised terrorist offences, as such. The notion of a 'terrorist offence' did not exist in the DCC. In that light, the DTA may already be considered as rather revolutionary within the Dutch legal system. Some notes will also be made regarding the Dutch reaction to the events of $9 / 11$ in the USA.

Next, the DTA is discussed on main points in order to clarify the meaning of the terms 'terrorism', 'terrorist' and 'terrorist intent', according to the Dutch criminal justice system. When does one stop being a common criminal who commits a common murder and become a terrorist who commits a terrorist murder? What is the difference between a 'regular' murder and killing with terrorist intent? What distinguishes a criminal organisation from a terrorist organisation?

Lastly, the principle of legality, as interpreted in the Netherlands and the Strasbourg context, is discussed. How does the definition of terrorist intent, as a conditio sine qua non for an offence to be considered a terrorist offence, affect the principles of legality?

Within the context of the DTA three specific inchoate terrorist offences will be analysed: preparation for the commission of a terrorist offence, conspiracy to commit a terrorist offence, and participation in a terrorist organisation. Though legally speaking these three offences are 'complete crimes' for which a person may be given long sentences, factually speaking the behaviour is incomplete, in the sense that the perpetrator's ultimate goal has not yet been reached and no harm needs to have occurred. 
For example, in respect of an attempted murder (Article 45 of the DCC in conjunction with Article 289 of the DCC), the victim has not yet been killed and the suspect has not yet succeeded in fully realising his ultimate goal - that of killing someone. In legal terms, both situations constitute a criminal offence with high penalty clauses. However, factually speaking there is a difference between an attempted murder and actual murder, in terms of the threat posed to the protection of the legal order. In the first situation, the victim does not necessarily need to be touched/hurt, whereas in the second situation the victim dies.

Since the government's aim is to prevent terrorist crimes and, thus, to apprehend suspects during the preparatory or conspiring phase, the importance of inchoate offences has increased considerably. Most cases related to terrorism deal with perpetrators who have not yet succeeded in achieving their goals. As will later become evident, this often leads to a situation in which both the judiciary and the prosecution have to guess precisely what a perpetrator's 'ultimate goal' was and how his behaviour to that point should be valued in legal terms.

\section{The European Framework Decision on Combating Terrorism}

After the 9/11 terrorist attacks in the USA, the European Union felt a strong need to jointly act against terrorism within the European framework. Therefore, the European Commission came up with the FD 2002/475. . $^{18}$ The FD 2002/475 aimed at harmonising existing anti-terrorism legislation among all Member States. For some Member States, such as the Netherlands, the FD 2002/475 introduced an obligation to supplement the domestic substantive criminal justice system with terrorist offences as such offences did not exist prior to the FD 2002/475. ${ }^{19}$ For other states, such as the United Kingdom and Spain, the FD 2002/475 did not call for significant supplements or amendments to their substantive criminal justice systems for they already had anti-terrorism legislation in force prior to the FD 2002/475.

Although Europe already had some international legal precedents in the field of combating terrorism, a joint conclusive definition of a terrorist offence had never officially been agreed upon. ${ }^{20}$ Academics from various disciplines have had considerable difficulty defining terrorism. Different points of view, political views

18 Council Framework Decision 2002/475/JHA of 13 June 2002 on Combating Terrorism (OJ L 164, 22.6.2002, p. 3-7) and Council Framework Decision 2008/919/JHA of 28 November 2008 amending Framework Decision 2002/475/JHA on combating terrorism (OJ L 330, 9.12.2008, p. 21-23).

19 A survey from the Commission of the European Union demonstrates that prior to 2001, only 7 of the then 15 Union Member States had explicit anti-terrorism legislation.

20 The European Convention on The Suppression of Terrorism (1977), the Treaty on Cooperation among the States Member of Commonwealth of Independent States in Combating Terrorism (1999), the International Convention for the Suppression of Terrorist Bombings (1997), and the International Convention for the Suppression of the Financing of Terrorism (1999). 
as well as differences in academic discipline and religious background, have resulted in different definitions. ${ }^{21}$

The Union has defined terrorism in the FD 2002/475 as an 'intentional act' from the enumerative list of offences comprised in Article 2. Moreover, such an act must be committed with one of the three alternative terrorist intents. ${ }^{22}$ The list of offences (factual conduct) is limitative and includes crimes against a person's life or physical integrity, kidnapping or hostage taking, crimes infringing on property rights and, in addition, any threat of committing one of the listed offences.

Terrorist intent (state of mind) is required for the offence to be actually denoted as a terrorist offence. The FD 2002/475 comprises three alternatives:

- The aim of seriously intimidating a population; or

- Unduly compelling a government or international organisation to perform or abstain from performing any act; or

- Seriously destabilising or destroying the fundamental political, constitutional, economic or social structures of a country or of an international organisation. ${ }^{23}$

The Preamble of the FD 2002/475 obliges Member States to enact the definition of a terrorist offence in the implementing documents at the national level, in accordance with Article 1 of the FD 2002/475. Offences relating to terrorist groups also have to be criminalised. Furthermore, sanctions reflecting the seriousness of terrorist offences have to be implemented, as prescribed in the FD 2002/475. ${ }^{24}$

The FD 2002/475 additionally includes an obligation for Member States to criminalise membership of a terrorist organisation pursuant to Article 3 of the FD. A final point of attention of the FD 2002/475 is that inciting, aiding or abetting and attempting to commit a terrorist offence, as referred to in Article 1, section 1 also ought to be criminalised at the domestic level. Further explanation of how inciting, aiding, abetting and attempting should be interpreted is, however, missing, and is consequently left to the discretion of the Member States.

These obligations have determined the way in which terrorism is defined as a crime within the DCC. The following sections will further elaborate on this issue. Although the DTA is quite similar to the FD 2002/475, there are some aspects in which the Dutch implementation goes further, i.e., attributing more criminal responsibility than the FD 2002/475.

In the following sections, some general remarks will first be made regarding the DTA, they will focus primarily on the parliamentary discussions leading to the enactment of the DTA. Then, the scope of terrorist intent, terrorist offence,

21 J.R. Thackrah, Dictionary of Terrorism, Second edition, London: Routledge, Taylor \& Francis Group, 2004.

22 Article 1, section 1 of the FD 2002/475.

23 Article 1, section 1, under a to $i$ of the FD 2002/475.

24 See the Preamble, recital 6 and Article 2 of the FD 2002/475. 
preparing for the commission of a terrorist offence, conspiracy to commit terrorist offences, and participation in a terrorist organisation, will be analysed. As stated, the main goal is to examine what is needed, both in terms of factual behaviour (actus rea) and state of mind (mens rea), for a person to be held liable for these terrorist offences.

\section{The Dutch Reaction to 9/11 AND the implementation OF FD 2002/475}

The Netherlands does not, aside from the Moluccan train hijackings in the 1970s and 1980s, have a broad history of large-scale organised terrorist violence comparable to other countries such as the United Kingdom, Germany, Spain or Italy. ${ }^{25}$ Terrorism has always been dealt with by the common criminal justice system. The Netherlands did not have any specific domestic anti-terrorism legislation prior to $9 / 11 .{ }^{26}$ Nor did it have any experience in drafting and applying such legislation. ${ }^{27}$ This makes the Dutch reaction to $9 / 11$, in general, and the implementation of the FD 2002/475, in particular, interesting to examine. Various questions arise. How did the Dutch government react to the events of 9/11? In what area of the legal system was that reaction most predominant? What consequences did this reaction have for the substantive criminal justice system in terms of broadened criminal liability?

Approximately three weeks after 9/11, the Dutch government devised an 'action plan' to counter terrorism. ${ }^{28}$ This action plan was, to a degree, inspired by comparable initiatives in the United Nations and the European Union. The plan was

25 A.P. Schmid, J.F.A. de Graaf, F. Bovenkerk, L.M. Bovenkerk-Teerink, L. Bunt, Zuidmoluks terrorisme, de media en de publieke opinie. Twee studies van het Centrum voor Onderzoek van Maatschappelijke Tegenstellingen (Rijksuniversiteit Leiden), Uitgeverij Intermediair Amsterdam 1982; E.R. Muller, 'De geschiedenis van Terrorisme in Nederland', in E.R. Muller, U. Rosenthal, R. de Wijk (redactie), Terrorisme. Studies over terrorisme en terrorismebestrijding, Kluwer Deventer, 2008, pp. 217-243. The Netherlands has, contrary to other countries, extradited terrorist suspects, see A.H. Klip and A.H.J. Swart, 'International Criminal Law in the Netherlands', in Beiträge und Materialien aus dem Max-Planck-Institut für internationales und ausländisches Strafrecht, Band S 66, Freiburg im Breisgau 1997, pp. 104-105.

26 The Netherlands has ratified all international Conventions on terrorism, but these Conventions did not lead to specific domestic anti-terrorism legislation.

27 See for a historical overview on policies and legislation in the field of countering terrorism in the Netherlands, among others, M.M. Dolman (red.), Terrorisme, Europa en Strafrecht, Amsterdam: Vossiuspers UvA, 2003; P. Klerks, Terreurbestrijding in Nederland 1970-1988, Amsterdam: Ravijn Uitgever, 1989; N. Keijzer, Het Europees Vedrag tot Bestrijding van Terrorisme, Amsterdam: Kluwer-Deventer, 1979; E.R. Muller, Gijzelingen, aanslagen en ontvoeringen in Nederland. Terrorisme en politieke verantwoordelijkheid, Leiden: Gouda Quint, 1994.

Kamerstukken II 2001-2002, 27 925, nr. 10. 
divided into eight spearheads that formed the initial policy framework within which counter-terrorism legislation was drafted in the Netherlands.

The first spearhead is the prevention of terrorism. To realise this goal, the intelligence services were reconstituted completely. In addition, a new law allowing for the extension of powers to collect, analyse, share and disseminate information was enacted in 2002. ${ }^{29}$

Prevention is not merely seen from a national perspective, but also from an international/Union perspective, and improved and extended cooperation with foreign intelligence services, Eurojust and Europol, but also with individual states, form part of this policy. A safer Union visa-policy and improved Union border control are also needed to contribute to the prevention of terrorism.

Thus, the prevention of terrorism is not to be achieved merely by broadening criminal liability, especially during the pro-active phase, and by a corresponding extension of investigative powers during this phase, but also by extending the powers of the intelligence services and by improved international judicial cooperation.

A second spearhead in Dutch anti-terrorism policy is extended security surveillance of certain political persons and of potential target locations, such as airports and governmental buildings. One way in which this spearhead has been realised is through the enactment of the Dutch Procedural Terrorism Act (DPTA), which makes it possible for investigative authorities to frisk persons, to search vehicles and to inspect objects present in permanent or temporary security risk areas without prior (reasonable) suspicion. ${ }^{30}$

Schiphol Airport is an example of a permanent security risk area in which any person may be frisked, all objects inspected, and each vehicle present on Schiphol property searched at any time. ${ }^{31}$

The improvement of general public security, together with the maintenance of public order, form a third spearhead. Manpower within the responsible organisations has been, and will continue to be, enlarged. Financial budgets for departments, such as that for Defence, Justice and the Interior, have increased considerably since the 9/11 terrorist attacks. ${ }^{32}$ Another measure taken to support this spearhead, is increased CCTV surveillance in various large cities. A number of measures have also been taken at the local level to increase public security.

29 Kamerstukken II 2001-2002, 27 925, nr. 10, pp. 8-14; Kamerstukken II 2002-2003, 28 649, nr. 3.

30 See Chapters V to VII for a discussion of the DPTA.

31 Staatsblad 2006, 730.

32 Kamerstukken II 2002-2003, 27 925, nr. 96. 
The fourth spearhead is of more interest and importance within the criminal law context. In the Dutch government's opinion, the investigative authorities need additional investigative powers to counter, and preferably prevent, terrorism. The consequences for the common criminal justice system have been far-reaching and controversial. This will be demonstrated in Chapters V to VII.

In the early stages of this new anti-terrorism policy, the focus was primarily on organisational aspects of the responsible executive bodies. However, together with the eighth spearhead, this spearhead has since increasingly developed into the creation of an entirely new criminal justice system, specifically designed to better counter terrorist offences. ${ }^{33}$ The above-mentioned extension of powers of the intelligence services (2002), for the police and for the prosecuting authorities (2007) forms part of this new anti-terrorism criminal justice system within the Netherlands.

The following two spearheads of the action plan involve proposals to improve the integrity of the financial sector and the Ministry of Defence's position in combating terrorism. While these aspects of Dutch anti-terrorism policy are not discussed further, they are, however, illustrative of the all-encompassing policy that the Dutch government has developed to counter terrorism. In the field of private law and administrative law, but also within the Dutch educational system, the organisation of economic and social services and the cultural sector, various measures have been taken to enhance the scope and effectiveness of the anti-terrorism policy.

Spearhead eight, titled 'remaining legislative aspects', is, together with spearheads two and three, the most important for this dissertation. The scope of the new antiterrorism legislation and its effect on yet existing legislation in particular, may be called revolutionary. The initial goal of the anti-terrorism legislation was to realise the ratification of the two most important UN terrorism treaties ${ }^{34}$, to finalise and implement the FD 2002/475, and to implement the EU Framework Decision regarding the Arrest Warrant. ${ }^{35}$ However, this spearhead swiftly developed into: (1) a 'licence' to extend possibilities for improved cooperation between Union Member States for the purpose of information sharing and exchange, and (2) an incentive for more far-reaching domestic legislation in the field of procedural and substantive criminal law.

The following sections discuss the implementation of the FD 2002/475 within the Dutch legal order, the main aspects of which have already been mentioned briefly.

\footnotetext{
33 Kamerstukken II 2001-2002, 27 925, nr. 10, p. 6-7.

34 The International Convention for the Suppression of Terrorist Bombings (1997) and the International Convention for the Suppression of the Financing of Terrorism (1999).

35 Council Framework Decision 2002/584/JHA of 13 June 2002 on the European arrest warrant and the surrender procedures between Member States (OJ L 190, 18.7.2002, pp. 1-18). See, in this respect, J.M. Reijntjes, 'Europees aanhoudingsbevel', in NJB/14, 2002, pp. 712-713.
} 
At this point, the FD 2002/475 is not scrutinised further, because it does not clearly indicate the extent of criminal liability for terrorist offences within the Dutch criminal justice system. Discussion of the DTA will focus on two aspects: (1) the meaning of terrorist intent as defined in Article 83a of the DCC, and (2) the three categories of terrorist offences in accordance with Article 83 of the DCC. Attention then turns to the actual question of how far criminal liability extends to the pro-active phase with regard to the three specific inchoate terrorist offences already mentioned: conspiracy to commit a terrorist offence, preparation for the commission of a terrorist offence and participation in a terrorist organisation.

\section{Terrorism as defined in the DutCh CRiminal JUSTICE SYSTeM}

The Act that implements the FD 2002/475 in the Netherlands is the Dutch Terrorism Act (DTA) of August 2004 [Wet Terroristische Misdrijven]. ${ }^{36}$ For an offence to be considered as a terrorist offence, two cumulative conditions must be met. First, it must appear in the limitative list of offences included in Article 83 of the DCC. Second, it must be committed with terrorist intent as defined in Article 83a of the DCC. This latter provision introduces 'terrorist intent', as a required state of mind for criminal liability in the common criminal justice system. In other words, if such intent can be proven, common criminal offences become terrorist offences simply due to the perpetrator's state of mind. ${ }^{37}$ For instance, murder, manslaughter, assault or kidnapping may be committed with or without terrorist intent. Only when committed with terrorist intent are these offences considered as terrorist offences rather than as common offences. The scope of terrorist intent will be discussed first. The limitative list of offences that may be considered as terrorist offences, pursuant to Article 83 of the DCC, will then be analysed briefly and further clarified by means of some examples.

\section{Terrorist INTENT}

Various concepts included in the DTA are broadly defined, leading to lively debates among academics, members of the Judiciary and the Executive, members of society 
and politicians. These debates focus primarily on the meaning of terrorist intent, as defined in Article 83a of the DCC. ${ }^{38}$ Terrorist intent may occur in three forms ${ }^{39}$ :

1. In the case that the perpetrator(s) act(s) with the purpose of frightening a country's population or part of it; or

2. In the case that the perpetrator(s) act(s) with the purpose of unlawfully compelling a government or international organisation to do, omit or tolerate something; or

3. In the case that the perpetrator(s) act(s) with the purpose of disrupting or destroying a country's fundamental political, constitutional, economical or social structures.

Terrorist intent, if linked with an offence that falls into one of the three categories mentioned in Article 83 of the DCC, constitutes a terrorist offence. However, the scope and meaning of terrorist intent is broad. The much-debated criminal liability of animal rights activists in respect of terrorist offences is a clear illustration of the ambiguity of Article 83 a of the DCC. ${ }^{40}$ Even in the explanatory memorandum of the DTA, a clear interpretation of the notion of terrorist intent is lacking. ${ }^{41}$ The Minister of Justice attempted to delineate the scope of terrorist intent by arguing that: 'to be denoted as a terrorist offence, a crime must actually have as its purpose to seriously frighten (part of) a population - or to achieve one of the two other possibilities. $^{\text {,42 }}$

38 See for example: E. Myer, 'Minder vrijheid voor veiligheid: over voorgestelde maatregelen tot een doeltreffender terrorismebestrijding', in Nieuwsbrief Strafrecht/10 (2004); Y. Buruma, E.R. Muller, 'Wet Terroristische Misdrijven in perspectief', in NJB/41 (2003), pp. 2138-2144; H.G. van der Wilt, 'Het terroristisch oogmerk', in M.M. Dolman (red.), Terrorisme, Europa en Strafrecht, Amsterdam: Vossiuspers UvA, 2003, pp. 55-81; Y. Buruma, 'Terrorisme en de weerbare rechtsstaat', in Delikt en Delinkwent 2001, pp. 1025-1033.

39 At this point I will only elaborate on the notion of terrorist intent. See, for further discussion of the notion of special intent [oogmerk] considered within the Dutch criminal justice system H.G. van der Wilt, 'Het terroristisch oogmerk', in M.M. Dolman (red.), Terrorisme, Europa en Strafrecht, Amsterdam: Vossiuspers UvA, 2003, pp. 55-81; J.M. Lintz, De plaats van de Wet terroristische misdrijven in het materiële strafrecht. Een onderzoek naar de wederzijdse beïnvloeding door de Wet terroristische misdrijven en het Wetboek van Strafrecht en enkele bijzondere wetten, dissertatie EUR, Wolf Legal Publishers, Nijmegen, 2007, pp. 54-60; P.J.H.M. Brouns, Opzet in het Wetboek van Strafrecht, dissertatie RUG, Gouda Quint, Arnhem, 1988, pp. 169-175.

40 See, in this respect, J.M. Lintz, De plaats van de Wet terroristische misdrijven in het materiële strafrecht. Een onderzoek naar de wederzijdse beïnvloeding door de Wet terroristische misdrijven en het Wetboek van Strafrecht en enkele bijzondere wetten, dissertatie EUR, Wolf Legal Publishers, Nijmegen, 2007, pp. 76-77. Lintz disputes that the DTA succeeded in clearly distinguishing between 'terrorists' on the one hand and animal rights activists or protestors, on the other.

41 Kamerstukken II 2001-2002, 28 463, nr. 3, p. 2-4.

42 Kamerstukken II 2002-2003, 28 463, nr. 6, p. 5. 
Several questions then arise. What is needed to frighten a population or part of it? What is 'part of a population'? Does that mean the population of one province or of one city? Does it merely need to be an alleged terrorist's aspiration, or does this aspiration actually need to be fulfilled in the sense that the population or part of it is indeed frightened as a consequence of the terrorist's factual conduct? Moreover, what is meant by the phrase 'disrupting a country's political structures'? Does this include politically inspired demonstrations that have gotten out of hand, accompanied by acts of violence committed 'in the heat of the moment'? The parliamentary memoranda answer these questions only to a limited extent.

The Dutch government has responded to the question of why it has chosen to use the criterion of 'frightening' a country's population/part of the population, instead of the UN's use of 'intimidating' a country's population. ${ }^{43}$ This has been done in order to assure that the terrorist's intent - i.e. to frighten - does not necessarily have to be achieved to fulfil this requirement. The government argues that 'intimidation' implies successful frightening, whereas for the broader criterion of 'frightening' to be fulfilled, a population does not necessarily have to be intimidated. ${ }^{44}$ Therefore, in the government's view, a person's intent when committing a terrorist offence is more important than whether or not he actually succeeds in achieving this intention. As long as this terrorist intent of wanting to frighten a population/part of a population can be proven, the factual result of the terrorist offence on the population is irrelevant.

The government has also dealt with the question of whether the broadness of the definition of terrorist intent will lead to unwanted results, such as animal rights crusaders and other similar peaceful activists being labelled as 'terrorists'. The Dutch government has repeatedly asserted that this is not the case. It argues that the activists' acts do not result in people being frightened. ${ }^{45}$ This appears inconsistent with what was argued in the previous section where it is clearly stated that (part of) the population do not necessarily have to be frightened by the terrorist's behaviour as long as frightening was the perpetrator's intent. ${ }^{46}$ Thus, according to the earlier interpretation of Article 83a of the DCC, terrorist intent may be proven if an activist

43 Kamerstukken II 2002-2003, 28 463, nr. 6, p. 2-4.

44 See, in this respect, E. Prakken, 'Regelgeving en rechtspraak: terrorisme en het strafproces', in Strafblad, 2/4, 2004, pp. 228-237. Prakken argues that the Netherlands' implementation of the FD 2002/475 is considerably more far-reaching than necessary according to the literal text of the FD 2002/475. Not only is this reflected in the chosen phrasing of terrorist intent in Article 83a of the DCC, but the criminalisation of recruitment for armed conflict and conspiracy also go beyond the scope of the FD 2002/475. The government holds, in the explanatory memorandum to the DTA, that it has chosen for a wide implementation of the FD 2002/475. See Kamerstukken II 2001-2002, 28463 , nr. 3, p. 1.

45 Kamerstukken II 2001-2002, 28 463, nr. 3, p. 3.

46 In further debates the government has evaded giving clear-cut answers to questions regarding the potential application of Article $83 \mathrm{a}$ of the DCC to activists. See, for example, Kamerstukken 2002-2003, 28 463, nr. 5; Kamerstukken 2002-2003, 28 463, nr. 6. 
group's intent is to frighten, for example, a political party or the factory farming industry, without actually succeeding in its intent.

The explanatory memoranda try to resolve this inconsistency by explaining that these activists most likely do not intend to frighten a population/ part of a population, but that their actions may, nevertheless, result in people being frightened. ${ }^{47}$ This argument appears evasive and is not, in fact, a satisfactory explanation for the government's inconsistent argumentation. Moreover, one may question the true intent of activists. In some, if not all, cases frightening part of the population may, in fact, be their intent. Parliamentary memoranda show that various politicians have posed the same sort of questions to the Minister of Justice. ${ }^{48}$ In the mean time, the third WODC report demonstrates that animal rights activists are in practice indeed considered as 'terrorists' and hence as falling within the scope of Article $83 \mathrm{a}$ of the DCCP. ${ }^{49}$

In short, making the definition of terrorist intent as broad as possible, for the sake of assuring successful prevention, prosecution and/or conviction of presumed terrorist suspects is not without risk. This will be further elaborated below.

The only seemingly unambiguous aspect of the explanatory memoranda regarding the scope of terrorist intent is the following: Terrorist intent is considered to be a component of a criminal law provision that increases the penalty [strafverzwarende omstandigheid]. Therefore, terrorist intent has to be proven, as do all the remaining (more objective) components of the criminal law provision. ${ }^{50}$

To prosecute a suspect for a terrorist offence successfully, a public prosecutor must prove that the suspect acted deliberately, and in addition, he must prove that the suspect acted with terrorist intent. Aside from the practical problems that a public prosecutor may encounter when proving these aspects, there is the challenge of proving, beyond reasonable doubt, a concept that is anything but clear. One may also question whether, and if so, in what sense, the common 'purpose requirement' has any added value next to the condition of terrorist intent. Lastly, it remains to be seen how a person's intentions can be proven objectively when that person refuses to disclose any information about his state of mind prior to, and during the commission of, an offence.

In contrast to the explanatory memoranda of the DTA, the Judiciary has, in the past few years, provided some clarification regarding the meaning of terrorist intent. The

\footnotetext{
$47 \quad$ Kamerstukken 2001-2002, 28 463, nr. 3, p. 3.

48 Kamerstukken 2002-2003, 28 463, nr. 5, p. 3; Handelingen II 2003-2004, nr. 31, p. 2201 and pp. 2192-2193; Handelingen EK 2003-2004, nr. 32, p. 1699; Kamerstukken II 2003-2004, 28 463 , nr. 29, pp. 11-12.

49 B. van Gestel, C.J. de Poot and R.F. Kouwenberg, De Wet opsporing terroristische misdrijven drie jaar in werking, WODC, Cahier 2010-3, p. 11-12.

50 Kamerstukken 2002-2003, 28 463, nr. 6, p. 5.
} 
most important judgements will now be analysed in order to better understand the scope of Article 83a of the DCC.

It is important to mention that since the entering into force of the DTA in 2004, only a dozen cases regarding the interpretation of terrorist offences - and thus of terrorist intent - have been heard. Drawing general conclusions on the basis of such a limited number of cases is difficult. Another difficulty in interpreting case law regarding terrorism is the fact that information used during such trials is sometimes kept secret in the interest of national security, and is hence not fully disclosed in the judgements.

Lastly, for example, in the Hofstadgroep case, the court explicitly underlined that not all of the documents found at the suspects' houses had been examined, let alone translated. These factors make it difficult to fully understand and interpret case law relating to terrorism, and specifically, to get a better understanding of the scope of terrorist intent under Article 83a of the DCC.

\subsection{Mohammed B: Murder or terrorist murder?}

In order to scrutinise the scope of Article 83a of the DCC, it is imperative to review the criminal proceedings against Mohammed B. with regard to his role in the murder of Theo van Gogh. ${ }^{51}$ In particular, the connection between Mohammed B.'s factual conduct and his intent prior to and during the murder has been thoroughly elaborated on by the Rotterdam District Court. ${ }^{52}$

Mohammed B. murdered van Gogh by shooting him seven times. Subsequently, he cut van Gogh's throat and stabbed him several times in his stomach. He also left a threatening letter on van Gogh's chest after the murder. This letter contained among others threats against Ayaan Hirsi Ali, a rather controversial politician at the time. As a result of these threats, Hirsi Ali was unable to freely perform her work as Member of the Dutch Parliament. Van Gogh died immediately. Two bystanders were also hit in the gun attack, though were not fatally wounded. Mohammed B. reloaded his gun and walked in the direction of a nearby park, where he took part in a fire fight with some policemen who were trying to arrest him. He allegedly attempted to kill eight police officers and he threatened an additional three. The police eventually succeeded in overpowering him by shooting him in the leg.

During the criminal proceedings, Mohammed B. confessed to the above-mentioned crimes and he forbade his lawyer to defend him. The Court found him guilty of

\footnotetext{
51 Mohammed B. has also been prosecuted for membership of the Hofstadgroep, see Rotterdam District Court 10 March 2006, LJN: AV5108, 10/000322-04, 10/000328-04, 10/000396-04, 10/000393-04, 10/000325-04, 10/000323-04, 10/000395-04. See for the complete indictment in this case, www.recht.nl/proxycache.html?cid=38928. 
first-degree murder ${ }^{53}$ [moord], eight counts of attempted murder ${ }^{54}$ [8 keer poging tot moord], illegal possession of a gun ${ }^{55}$ [wapenbezit], threatening three policemen ${ }^{56}$ [bedreiging], and threatening a Member of Parliament, which made proper functioning as a Member of Parliament impossible. ${ }^{57}$ The crucial question for the Court was whether all of these crimes were committed with terrorist intent.

The public prosecutor argued that Mohammed B. intended to disrupt fundamental political, constitutional, economical and/or social structures by killing Theo van Gogh. The fact that he knew, or ought to have known, that he would not achieve his aims by committing one murder, did not alter this intent, according to the public prosecutor. Furthermore, the prosecutor held that Mohammed B. had committed all of the above-mentioned offences with terrorist intent, thus, not only the killing of Theo van Gogh, but also the shooting of the other policemen, the illegal weapons possession, etc.

According to the Court, the murder of van Gogh aroused feelings of fear and insecurity in Dutch society. Several factual factors caused the Court to decide that Mohammed B. acted with terrorist intent when he killed Theo van Gogh and threatened Hirsi Ali. These included the fact that the murder took place on a busy street, it was rush hour at the time of the killing, ${ }^{58}$ the victim was a Dutch filmproducer, and the murder was committed in a horrible way. The murder had a destabilising effect on public order. ${ }^{59}$ Mohammed B. himself declared that he had committed the murder out of religious conviction, but the Court responded by stating that this conviction did not necessarily exclude terrorist intent. The threats towards Hirsi Ali were not only committed with the intent to scare her, ${ }^{60}$ but also to scare the Dutch population, and to disrupt or even destroy the constitutional and political structures of the Netherlands.

In sum, the Court concluded that van Gogh's murder and the threats towards Hirsi Ali were both committed with terrorist intent of frightening part of the population and could therefore be defined as terrorist offences in compliance with Articles 83 and 83a of the DCC.

What is striking in this judgement is that the Court largely based its reasoning on the factual circumstances of the case post facto, rather than on Mohammed B.'s

\footnotetext{
53 Article 289 of the DCC.

54 Article 289 of the DCC in conjunction with Article 45 of the DCC.

55 Article 26 of the WAA.

56 Article 285 of the DCC.

57 Article 285 of the DCC in conjunction with Article 121 of the DCC.

58 More than 50 witnesses testified that they had seen Mohammed B. killing Theo van Gogh.

59 Several Mosques and Islamic schools were attacked during the days following the murder of van Gogh.

60 After the threats had been made, Hirsi Ali was subject to maximum security measures and had to go into hiding for a considerable period of time.
} 
statements regarding his intentions prior to committing the offences. Mohammed B. claimed that he had committed the murder based on his religious beliefs. This contention was factually substantiated by various documents found at his home, some written by himself, some translated. He did not declare that he had committed the murder to frighten the Dutch population or to disrupt, for instance, fundamental constitutional structures. As has been set out above, terrorist intent is determined by a suspect's intentions prior to the actual criminal offence and not by the factual effect an offence has on society.

These two viewpoints may differ considerably. What the Court did, was to focus significant attention on the result of Theo van Gogh's murder: part of the Dutch population was frightened by the murder and bystanders were also frightened. These circumstances were all quite factual in nature and were determined retroactively. Whether Mohammed B.'s primary goal was to frighten bystanders or to disrupt or destabilise political structures was not directly demonstrated by his statements.

On the other hand, there are indeed two facts that clearly justify the Court's decision that Mohammed B. murdered Theo van Gogh with terrorist intent. Firstly, the fact that the letter that Mohammed B. left on Theo van Gogh's body was not only directed at Hirsi Ali, but also at the Dutch population. Secondly, there were some bystanders who said to Mohammed B.: 'This cannot be, you can't do this', whereupon Mohammed B. replied: 'I can do this and now you know what is awaiting you.'

The first fact in particular may convincingly sustain the assumption that Mohammed B. killed Theo van Gogh with the intention of disrupting social, constitutional and political structures. Also, it is not illusory that Mohammed B. intended to frighten (part of) the Dutch population by directing his treats towards 'the Dutch (non-Islamic) people'. All the other circumstances were post facto used to demonstrate terrorist intent while they do not necessarily say something about Mohammed B.'s intention prior to the murder.

Furthermore, it is important to note that the Court did not directly use Mohammed B.'s ideology to conclude that he murdered van Gogh with terrorist intent. So, in this case the fact that Mohammed B. evidently adhered to an ideology that promotes the use of (deadly) violence against non-believers does not automatically imply that he committed all offences with terrorist intent. To prove such intent, there must be additional - more factual - evidence aside from a person's ideas regarding the 'justified' use of violence. The rest of the charges, i.e. the attempted murder of several policemen and two bystanders, as well as the threats issued to three policemen, were not considered as terrorist offences. The Court argued that these crimes were committed with the mere intent to kill and to be killed. Mohammed B. wanted the policemen to shoot and kill him in order for him to die as a martyr, 
instead of killing them with the intent to frighten the Dutch population (or at least a part thereof). ${ }^{61}$

Consequently, the Court did not consider it proven that Mohammed B. shot and threatened the policemen and bystanders respectively with the intent of frightening (part of) the Dutch population. On account of all the charges, Mohammed B. was sentenced to life imprisonment. He did not lodge an appeal.

Hence, in this judgement the Court demonstrated terrorist intent by (1) referring to the post facto interpretation of the factual circumstances of the case, and (2) to a lesser extent, by referring to Mohammed B.'s thoughts, as expressed in the letter that was pinned on van Gogh's chest.

\subsection{Preparation of a terrorist attack and terrorist intent}

In a judgement of the Middelburg District Court, a suspect was prosecuted on three charges of terrorist offences: (1) preparation for the commission of a terrorist attack, (2) (preparation of) threatening a person publicly with a terrorist offence (multiple times) and (3) publicly inciting people to commit offences against the public authorities (among others, Articles 46, 83, 83a, 131, 157, 176a and 285 of the DCC). ${ }^{62}$

The suspect was apprehended while carrying various street maps of the Hague city centre, addresses of foreign embassies and governmental buildings, as well as a description of a bomb. Moreover, it emerged later during the trial that the suspect had been experimenting with explosives.

Although the Dutch Forensic Institute (DFI) reported that these explosives were indeed capable of causing explosions, the Court ruled that the suspect's preparations for such an explosion were not yet adequate to cause an explosion of a substantial nature. Nevertheless, the fact that this suspect (1) had already gathered a considerable amount of crucial information regarding the target of the intended explosions, (2) made the material preparations for an explosion, and (3) carried a floppy disk containing a valedictory letter, was sufficient proof for the Court to convict him of the charge of preparing to commit a terrorist attack.

In the valedictory letter the suspect provided a 'justification' for the terrorist attack he intended to commit. It also contained a detailed description of how he was going to commit the intended attack. Furthermore, the letter clearly reflected the suspect's intention of becoming a martyr during the attack. The Middelburg District

\footnotetext{
61 One of the policemen who escorted Mohammed B. to the hospital after he was shot in the leg told him: 'You were lucky that we didn't shoot you dead!', to which Mohammed B. answered: 'It was exactly my intention to get killed by you.'

62 Middelburg District Court 14 February 2005, LJN: AS5730, 12/000211-04.
} 
Court considered all of these documents and objects to be evidently intended to prepare to commit a terrorist attack..$^{63}$

The Court demonstrated the suspect's terrorist intent by referring to several public online discussions that the suspect had had, during which he proclaimed that a worldwide Islamic caliphate would be established through the use of violence. These thoughts/wishes had - at least partly - been transformed into deeds: the gathering of documents, the construction of explosives, and his writing of a farewell letter on floppy disk. The suspect made all these preparations with a clear intent to disrupt political and constitutional structures pursuant to Article 83a of the DCC. Such behaviour validated in the Court's opinion, the accusations of preparing a terrorist attack instead of a common attack/offence.

Specifically with respect to preparatory conduct, it must be underlined that the DPTA amended Article 46 of the DCC. ${ }^{64}$ Objects that serve to prepare for a (terrorist) offence no longer need to serve evidently [kennelijk] to prepare for such an offence. The notion of 'evidently' served to guarantee an objective approach regarding criminal liability for preparatory behaviour: objects had to be manifestly for the purpose of committing a crime. This meant that to the general bystander it must be abundantly clear that the objects have a criminal purpose. ${ }^{65}$

Due to the amendment of Article 46 of the DCC, even more weight is attached to the suspect's intention itself, than to objectively verifiable facts and circumstances. ${ }^{66}$ Even possessing objects that are, in themselves, completely harmless, such as a racing bike, may be construed as incriminating evidence of the preparation of a (terrorist) offence or of the intention to commit such an offence. ${ }^{67}$ Strijards defines a suspect's intention as a steady orientation of the suspect's will, which may be objectified in law and might result in his criminal responsibility. ${ }^{68}$ Hence, from somehow objectified circumstances one has to elicit the suspect's (criminal or terrorist) intention. Case law demonstrates that these intentions are often deduced from documents found at a suspect's house, witness statements, or evidence from recorded telephone conversations. ${ }^{69}$

For criminal liability pursuant to Article 46 of the DCC, the moment at which objects found in a suspect's possession are evaluated, may be of importance. In the

63 Middelburg District Court 14 February 2005, LJN: AS573012, 000211-04. The suspect was prosecuted on account of Articles 46, section 1, 83 and 83a of the DCC in conjunction with Article 9, section 1 of the WAA. The District Court convicted the suspect pursuant to Article 46 of the DCC in conjunction with Articles 157 and 176a of the DCC.

Staatsblad 2006, 580.

Kamerstukken II 1990-1991, 22 268, nr. 3, p. 18.

Kamerstukken II 2004-2005, 30164, nr. 3, p. 49.

Kamerstukken II 2005-2006, 30 164, nr. 12, p. 2.

G.A.M. Strijards, Strafbare voorbereidingshandelingen, Tjeenk Willink Zwolle 1995, p. 19.

Kamerstukken II 2005/06, 30 164, nr. 7, p. 11. 
case of Samir A., the District Court and the Court of Appeal evaluated his possessions ex post..$^{70}$ At the trial, an expert declared that the explosives that Samir A. had manufactured would never have worked. ${ }^{71}$ In light of that finding, the judges concluded that despite Samir A.'s intentions, the explosives and other objects ${ }^{72}$ found at his house could not be considered as evidently intended to prepare for murder, arson and/or causing an explosion. ${ }^{73}$

The Supreme Court considered this interpretation of Article 46 of the DCC too narrow. The Court of Appeal should have examined (ex ante) whether the explosives and other objects, separately or collectively, by their outward manifestation at the time of the material conduct could have been suitable for the criminal purpose that the suspect had in using them. ${ }^{74}$ Hence, the Supreme Court abstracted from the question of whether Samir A.'s behaviour threatened the legal order, or could ever do so with the explosives and objects he possessed. It seems that the Supreme Court considered Samir A.'s subjective intentions, which became clear from several documents demonstrating his adherence to a form of Islamic fundamentalism, more important than the question of whether he actually posed an objective danger to society due to his preparatory acts.

The Amsterdam Court of Appeal, after referral, followed this line of reasoning, and considered the explosives and the objects, collectively and in light of Samir A.'s

70 It is important to note that Samir A. was prosecuted under the old Article 46 of the DCC, which still required objects to be evidently intended to commit an offence. Furthermore, the fact that Samir A. was not prosecuted on account of a terrorist offence is of importance. The DTA had not yet entered into force when he committed the preparatory acts. He was therefore charged with the illegal preparation of murder and the illegal preparation of arson and/or causing an explosion.

71 Rotterdam District Court 6 April 2005, LJN: AT3315, 10/030075-04; the Hague Court of Appeal 18 November 2005, LJN: AU6181, 10-00075-04, NJ 2006/96.

72 During a house search at Samir A.'s apartment, the police found several items, which, according to the prosecution, undoubtedly served to prepare for an attack. They found, among others, a bullet-proof vest, a pair of vision goggles, hydrochloric acid, ammonia, several documents inciting Jihad and the killing of Americans, Jews and non-Islamic people, manuals for using guns and explosives, various street maps and drawings of government buildings, and documents about items required to commit an attack.

73 The line of reasoning of the District Court and the Court of Appeal was slightly different, but both Courts concluded that Samir A. could not be convicted of illegal preparation of murder, arson and/or causing an explosion. The District Court primarily referred to the fact that attempts by absolutely impossible means are not eligible for punishment. The Court of Appeal focused on the question of whether there was indeed dangerous conduct.

74 Three aspects are thus important: (1) the outer appearance of the objects found; (2) the criminal intent of the suspect, and (3) the intended application of the objects [voorwerpen afzonderlijk dan wel gezamenlijk, naar hun uiterlijke verschijningsvorm ten tijde van het handelen dienstig kunnen zijn voor het misdadige doel dat de verdachte met het gebruik van de voorwerpen voor ogen had]. Case law demonstrates that the second and (to a lesser extent) the first are decisive. See, in this respect, E. Gritter, E. Sikkema, 'Bestemming onbekend. Strafbare voorbereiding (artikel 46 Sr) en wetsvoorstel 30 164', in Delikt en Delinkwent 2006, afl. 3, p. 277-302. Gritter and Sikkema emphasise that for criminal liability to exist the intended crime must actually have been prepared. 
intentions, as evidently intended to prepare for a murder and deliberate arson and/or to cause an explosion (Article 157 of the DCC). ${ }^{75}$ This means that the Court of Appeal emphasised the intended use of the 'explosives' and abstracted that from the fact that the means of materialising the intention were unsuitable. ${ }^{76}$ The Court of Appeal took into account that Samir A. had expressed sympathy for violence and Islamic fundamentalism in the past. Furthermore, the fact that he chose to remain silent during trial, and his failure to explain the objects found, was taken into account.

This judgement, which was hence handed down before the amendment to Article 46 of the DCC and did not consider prosecution on charges of terrorist offences, demonstrates that criminal liability for preparatory behaviour tends to rest heavily on a suspect's (subjective) intentions rather than on factual conduct that threatens the legal values/order.

\subsection{Illegal possession and/or use of weapons with or without terrorist intent?}

The first judgement under this heading concerns a suspect who was arrested on charges of illegal possession of homemade explosives and of threatening a politician with a terrorist offence. ${ }^{77}$ The explosives were of such quality that they could actually have caused an explosion. The suspect threatened Wilders (a politician) by e-mail, referring to the destiny of all unbelievers' as interpreted in Islam. It was clear that Wilders was the suspect's intended target.

The Amsterdam District Court (and the prosecution) held that the illegal possession of explosives was not committed with terrorist intent, however, without further explanation. Apparently, the possession of working explosives (though of limited reach) in combination with threats made against a politician through the internet, is not sufficient to demonstrate terrorist intent with respect to the possession of illegal weapons.

In the Piranha I judgement (which will be further discussed below) conversely, the Rotterdam District Court considered the possession of illegal weapons by the suspect to be committed with terrorist intent. ${ }^{78}$ The suspect made a private videotaped will in which he made threats against the Dutch population (all unbelievers), while holding a weapon and dressed in traditional Muslim attire. The Court considered the combination of these facts and the way in which he uttered the threats, to justify the conclusion that the suspect possessed the weapons with

Amsterdam Court of Appeal 17 September 2007, LJN: BB3756, 23-001907-07.

Amsterdam Court of Appeal 17 September 2007, LJN: BB3756, 23-001907-07.

Amsterdam District Court 7 November 2005, LJN: AU5675, 13/997079-05.

Rotterdam District Court 1 December 2006, LJN: AZ3589, 10/600052-05, 10/600108-05, 10/600134-05, 10/600109-05, 10/600122-05, 10/600023-06, 10/600100-06. 
terrorist intent, i.e. the intent to frighten (part of) the Dutch population. The Court interpreted the notion of terrorist intent exactly as intended by legislation: from the suspect's perspective (intentions) prior to, or during, the perpetration of the offence.

The second case concerns the Hofstadgroep judgement. ${ }^{79}$ Several members of this alleged terrorist organisation were charged with illegal possession and use of explosives and/or weapons. The suspects, Ismail and Jason, were charged with WAA offences committed with terrorist intent. The facts of the case were as follows.

The police arrested Ismail and Jason. When a team of police men succeeded in entering the suspects' house, they were met with violent resistance. The suspects possessed four hand grenades, of which they threw one in the direction of the policemen. Although the policemen were not killed, they were severely injured.

After they had thrown the hand grenade, Ismail and Jason started yelling that they wanted to be killed by the policemen so that they could become martyrs. Additionally, they proclaimed that they would decapitate all non-Islamic people, that they would go to paradise and that all non-Islamic people would go to hell. One of the suspects even claimed to possess 20 kilos of explosives with which they could blow up the whole street. Several witnesses testified that the suspects held up a newspaper article featuring the headline 'war', while they made gestures to suggest the cutting of throats. Throughout all of this they repeatedly invoked Allah. ${ }^{80}$

The public prosecutor charged Jason and Ismail with being the accessories to ${ }^{81}$ five counts of attempted murder/manslaughter [vijfvoudige moord/doodslag] by throwing a hand grenade in the policemen's direction, and with the illegal possession of four hand grenades. All of these offences were committed with terrorist intent, according to the public prosecutor. ${ }^{82}$

The suspects declared that they had thrown the hand grenade without premeditation; they claimed they were seized by panic caused by the police siege. ${ }^{83}$

As the suspects' phones were still being tapped during the siege, the investigative authorities listened to several phone calls that the suspects made prior to, and during, the siege. From these calls it followed that the suspects were well aware of

79 Rotterdam District Court 10 March 2006, LJN: AV5108, 10/000322-04, 10/000328-04, 10/000396-04, 10/000393-04, 10/000325-04, 10/000323-04, 10/000395-04.

80 Rotterdam District Court 10 March 2006, LJN: AV5108, 10/000322-04, 10/000328-04, 10/000396-04, 10/000393-04, 10/000325-04, 10/000323-04, 10/000395-04, paragraph 81.

81 Rotterdam District Court 10 March 2006, LJN: AV5108, 10/000322-04, 10/000328-04, 10/000396-04, 10/000393-04, 10/000325-04, 10/000323-04, 10/000395-04, paragraphs 89-91.

82 Rotterdam District Court 10 March 2006, LJN: AV5108, 10/000322-04, 10/000328-04, 10/000396-04, 10/000393-04, 10/000325-04, 10/000323-04, 10/000395-04, paragraph 79. See Article 289 and 289a in conjunction with Article 45 of the DCC and Article 26 of the WWM in conjunction with Article 55 of the WWM in conjunction with Articles 83 and 83a of the DCC.

83 Rotterdam District Court 10 March 2006, LJN: AV5108, 10/000322-04, 10/000328-04, 10/000396-04, 10/000393-04, 10/000325-04, 10/000323-04, 10/000395-04, paragraph 82. 
police plans to arrest them by raiding their house. Moreover, it emerged from the conversations that, in that case, the suspects intended to kill the policemen by throwing hand grenades.

According to the Rotterdam District Court, these phone calls were sufficient evidence that the throwing of the hand grenade was premeditated. ${ }^{84}$ The Court therefore found the suspects guilty of the possession of four hand grenades and a five counts of the attempted murder of policemen. The question, at this point, was whether the illegal possession of the four hand grenades was committed with terrorist intent, as contended by the prosecution.

No information was available regarding the suspects' intentions in respect of the possession of the hand grenades, aside from the above-mentioned tapped phone calls. From these phone calls, no explicit plan/intention to frighten the Dutch population by throwing the grenades could be sustained. Only during the siege of their house and after they had thrown the hand grenade, did Ismail and Jason start to behave in a certain way (see above) which may have demonstrated their alleged intention to frighten the Dutch population. Furthermore, they did not involve the hand grenades in that intimidating conduct by, for example, showing bystanders the hand grenade while proclaiming that all non-Islamic people should be killed. Nor did they make any plans to use the hand grenades to terrorise bystanders.

In sum, the Court concluded that the mere simultaneity of terrorist intent and the illegal possession of hand grenades did not justify the automatic conclusion that the illegal possession was committed with terrorist intent. The Court did not find the suspects guilty of illegal possession of hand grenades with terrorist intent.

The Court followed the same line of reasoning in respect of the five counts of attempted murder. The fact that the suspects proclaimed, during their telephone conversations, that they hated the Dutch police and that they hoped to be killed by the SWAT team in order for them to become martyrs, does not imply that they threw the hand grenade with the intent of, for example, frightening (part of) the Dutch population. Although part of the Dutch population might have felt frightened by the incident for some hours after the explosion took place, due to the extensive mediacoverage, that had not been the intention of the suspects prior to the incident. The actual throwing of the hand grenade was not accompanied by a concurrent clear threat directed at the Dutch population or part of it, neither were there any other circumstances, during the moment of throwing the grenade, which indicated that this action was meant or suited to terrorise part of the population or disrupt State structures. Therefore, the suspects were acquitted of committing the attempted murders with terrorist intent. ${ }^{85}$

\footnotetext{
84 Rotterdam District Court, 10 March 2006, LJN: AV5108, 10/000322-04, 10/000328-04 10/000396-04, 10/000393-04, 10/000325-04, 10/000323-04, 10/000395-04, paragraph 87.

85 Rotterdam District Court 10 March 2006, LJN: AV5108, 10/000322-04, 10/000328-04, 10/000396-04, 10/000393-04, 10/000325-04, 10/000323-04, 10/000395-04, paragraph 92.
} 
The Court's reasoning is in line with the intended scope of Article 83a of the DCC.

On appeal, the Hague Court of Appeal explicitly discussed the scope of terrorist intent. ${ }^{86}$ The Court underlined that terrorist intent does not refer to what consequences a suspect's conduct may have or has had (objectively), but it refers to what consequences the suspect aspired through his conduct (subjectively). Even though Article 83a of the DCC accordingly comes down to a purely subjective criterion, it is proven by objective circumstances. To demonstrate a suspect's presumed intent of unlawfully forcing a government to do or to omit something, the suspect must, for example, have threatened the authorities that he will commit an offence if certain demands are not met. In the case against Jason and Ismail, there were no objective circumstances to demonstrate that they acted with such premeditation when they threw the hand grenades.

The Court of Appeal also elaborated on what the phrase 'frightening (part of) the population' means. This presupposes that the perpetrator aims, by committing an offence, at causing (part of) the population to feel frightened that something bad will happen to them. Accordingly, the perpetrator wants to cause (part of) the population to feel like 'they may be the next victims'. It is important to see that the perpetrator does not need to have succeeded in achieving his aims. The Court of Appeal furthermore clarified that 'part of the population' means a sufficiently substantial part of the population. In short: as long as there is proof that the perpetrator committed the offence with the intent of frightening (part of) the population in the aforesaid way, it is irrelevant whether (part of) the population indeed felt frightened. ${ }^{87}$

In line with the above considerations, the Court of Appeal argued that the fact that Ismail and Jason shouted, after having thrown the hand grenades, that they possessed 20 kilos of explosives with which they could bomb the whole street, did not prove that they intended to frighten (part of) the population by throwing these hand grenades. If the suspects had shown the hand grenades to the people in the street while shouting 'we have 20 kilos explosives and we will blow up all of you', such intent might have been present, but that was not the case. Hence, the mere simultaneity of (1) adhering to beliefs that preach the justified use of (deadly) violence against non-believers, and (2) illegally possessing explosives, was held to be insufficient to prove that the hand grenades were illegally possessed with the intent to prepare/commit a terrorist offence. In respect to the five counts of attempted murder also, the Court of Appeal reached the same conclusion as the District Court.

\footnotetext{
86 The Hague Court of Appeal 23 January 2008, LJN: BC2576, 22001897-06 (Jason W.); the Hague Court of Appeal 23 January 2008, LJN: BC4129, 22001886-06 (Ismail).

87 See also Kamerstukken II 2002-2003, 28 463, no. 6, p. 4.
} 
This judgement shows the same line of reasoning as the District Court's reasoning in the case against Mohammed B.: objective circumstances are required to determine whether or not the suspect intended to frighten (part of) the population prior to committing the offence. If there are no objective circumstances to sustain the alleged terrorist intent, Article 83a of the DCC does not apply, even if (part of) the population was frightened as result of the offence.

The last member of the Hofstadgroep who was individually charged with a weapons-related offence was Nouriddin el F. He was arrested while carrying a loaded machine gun in his backpack. The crucial question was obviously whether he possessed the weapon with terrorist intent. ${ }^{88}$ The explanatory memorandum of the DTA asserts that possession of a weapon with terrorist intent is possible when the weapon is possessed with the intent to use it to commit a future terrorist offence. The terrorist intent of the intended offence is hence retrospectively applied to the preceding illegal weapon possession. ${ }^{89}$ Mohammed B. was therefore convicted of possession of an illegal weapon with the intent to prepare or facilitate a terrorist offence pursuant to Articles, 26, section 1 and Article 55, section 5 of the WAA and Articles 83 and $83 \mathrm{a}$ of the DCC. The Amsterdam District Court held that Mohammed B. illegally possessed a weapon in preparation for the terrorist murder of van Gogh. ${ }^{90}$

To prosecute a suspect caught illegally possessing weapons for a terrorist offence pursuant to Article 55, section 5 of the WAA, the prosecution must prove (1) what the suspect's intent was with the arms he possessed, and (2) what he aspired to accomplish with the intended crime. This means that the prosecution must prove exactly which terrorist offence the suspect intents to commit with the weapon he possesses.

In this case against Nouriddin el F., it could not be proven beyond reasonable doubt that Nouriddin was actually on his way to commit the terrorist murder of Hirsi Ali or Wilders with the loaded machine gun on the day he was arrested. ${ }^{91}$ The Court did not doubt that Nouriddin intended to commit a 'common' attack or murder with the gun sooner or later. However, it could not be determined whether that attack or murder would be committed with the intention of frightening (part

Article 26 of the WAA in conjunction with Article 55 of the WAA in conjunction with Article 83a of the DCC.

89 Rotterdam District Court 10 March 2006, LJN: AV5108, 10/000322-04, 10/000328-04, $10 / 000396-04,10 / 000393-04,10 / 000325-04,10 / 000323-04,10 / 000395-04$, paragraph 63 . The District Court asserted moreover that the sole possession of a weapon is generally not frightening to (part of) a population because of its secrecy. Therefore, requirements of terrorist intent with respect to frightening (part of) a population will not be fulfilled with respect to the forbidden possession of a weapon.

90 Amsterdam District Court 26 July 2005, LJN: AU0025.

91 Rotterdam District Court 10 March 2006, LJN: AV5108, 10/000322-04, 10/000328-04, 10/000396-04, 10/000393-04, 10/000325-04, 10/000323-04, 10/000395-04, 64-67. 
of) the Dutch population or to disrupt constitutional and/or democratic structures. ${ }^{92}$ Therefore, the Court found Nouriddin guilty of common possession of an illegal weapon and sentenced him to 5 years imprisonment.

The fact that Nouriddin belonged to the Hofstadgroep, ${ }^{93}$ an organisation the District Court considered to be a terrorist organisation, did not justify the conclusion that that organisation's intent to commit terrorist offences could be used as proof of Nouriddin's terrorist intent with respect to the possession of the illegal weapon. Hence, the organisation's intent to frighten the Dutch population by committing terrorist offences could not be used to determine Nouriddin's individual intentions. Apparently, proof of Nouriddin's intent in relation to the possession of the illegal weapon should, rather, have been sought from his own individual conduct. The mere fact that he adhered to extreme forms of Islam, wore long robes, frequented Mosques and belonged to a terrorist organisation did not justify the conclusion that all of his behaviour was per se inspired by, determined by and ultimately committed with terrorist intent.

In the Piranha I judgement (first instance and appeal) and in the Piranha II judgement (first instance), the Rotterdam District Court and the Hague Court of Appeal held that the suspects possessed weapons with the intention of preparing or facilitating a terrorist offence (Article 26, section 1 and Article 55, section 5 of the WAA, and Articles 83, 83a and 96, section 2 of the DCC). ${ }^{94}$ The Courts based their conclusions on the following circumstances: the suspects possessed and transported weapons, they went together to a forest near Amsterdam to practice shooting, they continuously carried weapons, some of them were allegedly on their way to a Dutch politician with a weapon, the suspects possessed and exchanged a (coded) list with names and addresses of Dutch politicians, and the contact among the suspects was intense.

These circumstances were explicitly considered in light of the suspects' support of the violent Jihad, and their hatred of Western countries and their belief that all unbelievers should be killed, especially several politicians who had explicitly expressed their opinions with regard to Muslims and Islam. The suspects adhered to an extreme interpretation of Islam, preaching complete and strict obedience to Allah and the Koran, and rejecting and regarding every divergent polity, authority,

92 Compare with Rotterdam District Court 19 October 2005, LJN: AU4531, 10/600046-05.

93 Nouriddin was convicted for belonging both to a criminal and to a terrorist organisation pursuant to Articles 140 and 140a of the DCC. Rotterdam District Court 10 March 2006, LJN: AV5108, 10/000322-04, 10/000328-04, 10/000396-04, 10/000393-04, 10/000325-04, 10/000323-04, 10/000395-04, paragraph 223.

94 Rotterdam District Court 1 December 2006, LJN: AZ3589, 10/600052-05, 10/600108-05, 10/600134-05, 10/600109-05, 10/600122-05, 10/600023-06, 10/600100-06; Rotterdam District Court 25 March 2008, LJN: BC7539, 10/600112-05; Rotterdam District Court 25 March 2008, LJN: BC7531, 10/600111-05; the Hague Court of Appeal 2 October 2008, LJN: BF4814, 22-007351-06. 
regulation, way of living or behaviour, as abhorrent. The suspects' adherence to these beliefs led the Court of Appeal to the conclusion that at least some of the suspects intended to disrupt or destroy fundamental political structures and to frighten (part of) the population. To that effect it did not need to be certain exactly what the suspects sought to attain by committing the offences. The fact that there was no unequivocal answer to the question of how the suspects intended to realise their terrorist intentions did not hinder the Courts in concluding that the suspects acted with such intent while they illegally possessed weapons.

The notion of terrorist intent has been discussed in the foregoing sections. Article 83 and $83 \mathrm{a}$ of the DCC are intertwined to such an extent that it is almost impossible to discuss the scope of terrorist intent as a separate issue from the factual conduct required pursuant to Article 83 of the DCC. Therefore, in the upcoming sections the notion of terrorist intent will be examined in light of the factual conduct required to constitute criminal liability with regard to terrorist offences.

\section{THREE CATEGORIES OF TERRORIST OFFENCES}

This section sets out which offences can actually be denoted as terrorist offences pursuant to Article 83 of the DCC. Basically this provision distinguishes between three categories of terrorist offences. Firstly, Article 83, section 1 of the DCC concerns various common criminal offences, which, in combination with the required terrorist intent, render, for example, a 'common murder' a 'terrorist murder'. Secondly, section 2 lists crimes that, in case they are committed with terrorist intent, carry an increased penalty. For example, serious assault, pursuant to Article 302 of the DCC, carries a maximum penalty of 8 years imprisonment, but when committed with terrorist intent, the penalty is 12 years imprisonment. Thirdly, Article 83, section 3 of the DCC includes several special terrorist offences such as belonging to a terrorist organisation pursuant to Article $140 \mathrm{a}$ of the DCC. ${ }^{95}$ In the following sections these three categories of terrorist offences will be discussed with reference to the relevant case law.

\subsection{Serious terrorist offences}

The first category of terrorist offences includes, to begin with, offences punishable with imprisonment of 20 years to life-imprisonment. Examples are first-degree murder and premeditated attempted murder of the Queen or the head of a state of an ally. ${ }^{96}$ Several offences that comprise an element of (threatening with) assault

$95 \quad$ Kamerstukken II 2001-2002, 28 463, nr. 3, p. 4.

96 The Articles enumerated in Article 83, section 1 of the DCC are: Article 92-96, Article 108, section 2, Article 115, section 2, Article 117, section 2, Article 121, 122, 157, section 2 Article 161quater, section 2, Article 164, section 2, Article 166, section 3, Article 168, section 2, 
endangering public safety, people or goods, also form part of the first category of terrorist offences. An example is Article 95 of the DCC whose provision entails an attack on the Council of State leaving the Council no longer able to function properly. The use of violence (or threatening with the use of violence) against Dutch Parliament is a terrorist offence under Article 83, subsection 1 of the DCC as well. ${ }^{97}$ Furthermore, conspiracy to attempt ${ }^{98}$ the murder [samenspanning tot een aanslag] on, among others, the head of the state as well as preparative acts to do so pursuant to Article 96 of the DCC, also belong to the first category of terrorist offences. Lastly, offences that endanger society as a whole, such as destroying buildings, ships or water supplies, which, moreover carry a penalty of 20 years to life imprisonment, are also mentioned as terrorist offences under Article 83, section 1 of the DCC.

All of these offences, which are existing common criminal offences, become terrorist offences when committed with terrorist intent.

Important to note is that Article 83, section 1 of the DCC does not increase the penalties for the enumerated criminal offences when they are committed with terrorist intent. This implies that a common murder and a terrorist murder carry exactly the same penalty - i.e. life imprisonment. With regard to murder, this is hardly surprising, as a sentence of life imprisonment can obviously not be increased. Nevertheless, conspiracy to commit an attack on the reigning Queen, pursuant to Article 96 of the DCC, carries a penalty of 10 years, which could very well be increased if the offence is committed with terrorist intent.

What then, if not raising the penalty, is the reason for denoting existing serious common criminal offences as terrorist offences? Besides the fact that the FD 2002/475 had to be implemented, rendering common offences terrorist offences facilitates easier application of (investigative) powers for the competent authorities. For example, special investigation techniques may be used on the basis of a less demanding suspicion criterion when it concerns terrorist offences rather than common offences. This issue will be further discussed in Chapters V to VII, but at this point it is important to note that this may be one of the main reasons for the Dutch government categorising certain common criminal offences as terrorist offences, without changing the penalty.

The reason the government provided for categorising the above-discussed offences as terrorist offences is obvious. In the explanatory memorandum, the government argued that the FD 2002/475 obliges Member States to regard an attack

Article 170, section 3, Article 174, section 2 and Article 289 of the DCC, and Article 80, section 2 of the Dutch Nuclear Power Act.

97 See Article 121 of the DCC.

98 Articles 92 to 95 a of the DCC refer to 'attempt/attack' [aanslag] which is further defined in Article 79 of the DCC. This latter Article refers to Article 45 of the DCC regarding attempts to commit a criminal offence. Hence, Articles 92 to 95a of the DCC all concern attempts to commit various serious offences that pose a threat to state related persons/goods/issues. 
on a person's life, if committed with terrorist intent, as a terrorist offence. Furthermore, the FD 2002/475 prescribes that damaging another person's physical integrity and uttering threats with terrorist intent are to be deemed as terrorist offences too.

However, these two reasons are not incompatible. Surely, the government aimed to adequately implement the FD 2002/475, but a second agenda, i.e. broadening the scope of procedural powers in the case of terrorist offences, cannot be excluded as additional reason for the broad implementation of the FD 2002/475.

\subsubsection{An example: Conspiracy to commit a terrorist offence}

Criminal liability with regard to conspiracy already existed prior to the entering into force of the DTA. Article 96 of the DCC criminalised conspiracy with respect to a limited list of 'serious offences'. These offences all related to the continuation and (good) functioning of (fundamental parts) of the state. Accordingly, conspiracy only constituted a crime when combined with criminal offences that threatened the internal and external safety of the State. ${ }^{99}$

The DTA broadened the scope of Article 96 of the DCC with almost 30 terrorist conspiracy offences. ${ }^{100}$ Terrorist conspiracy offences include conspiracy to murder/ manslaughter with terrorist intent, conspiracy to commit arson with terrorist intent, conspiracy to deprive someone of his liberty with terrorist intent, and conspiracy to inflict grievous bodily harm with terrorist intent.

The Minister of Justice gave three main reasons for broadening the scope of conspiracy. To begin with, it was argued that terrorist offences pose a serious threat to the state, society, democracy and individual freedom. Therefore, as conspiracy covers behaviour that threatens the good functioning of the state, there is an obvious need to criminalise conspiracy to commit the most serious terrorist offences.

Secondly, the Minister of Justice referred to the goal of preventing and punishing acts of terrorism at the earliest possible moment. As will be demonstrated below, the broadened criminalisation of conspiracy serves as safety net in case Article 46 of the DCC (preparatory acts) or Article 140a of the DCC (participation in a terrorist

See Articles 92a to 95 of the DCC.

See C.M. Pelser, 'Preparation to commit a crime. The Dutch approach to inchoate offences', in Utrecht Law Review, volume 4, issue 3, 2008, pp. 75-78; H.G. van der Wilt, 'Ontwikkeling van nieuwe deelnemingsvormen', in Delikt en Delinkwent 2007, 10; M.J. Borgers, 'Strafbaarstellingen in de strijd tegen het terrorisme; Werving ten behoeve van de gewapende strijd en samenspanning tot terroristische misdrijven', in A.H.E.C. Jordaans, P.A.M. Mevis \& J. Wöretshofer (red.), Praktisch strafrecht (Reijntjes-bundel), Nijmegen: Wolf Legal Publishers 2005, p. 26-28; J. Lintz, 'Samenspanning in de Wet terroristische misdrijven', in Delikt en Delinkwent 2005, p. 1133-1139; C.M. Pelser, 'Samenspanning: over overt act en uiterlijke verschijningsvorm', in M. Boone e.a. (red.), Discretie in het strafrecht, Den Haag: Boom Juridische uitgevers 2004; A.E.M. Röttgering \& L.M.J. Backx, 'Terrorismebestrijding: strafrecht tegen jihad?', in Strafblad 2004 , p. 264-254. 
organisation) fail to provide the investigative authorities with a legal ground to investigate and possibly prosecute persons involved in terrorist activities. ${ }^{101}$ Thirdly, it was asserted that the broadened scope of conspiracy better facilitated mutual legal assistance. $^{102}$

With respect to the parliamentary process of expanding the conspiracy offences the following should be kept in mind. The Dutch government did not deem it necessary to consult the Council of State, or the advisory bodies of the Judiciary, the prosecution service, the police and the Bar Association, as is customary, regarding the amendments to Article 96 of the DCC. In the government's view, 'it concerned only a minor amendment to the criminal justice system', for which it could bypass the Council of State. Furthermore, the government argued that 'the criminalisation of terrorist conspiracy offences was desirable because of their gravity.' ${ }^{103}$

Besides the fact that these amendments cannot be said to be minor, it is important to keep in mind that Article 96 (and Article 205) of the DCC is (are) not a requested implementation of the FD 2002/475. The FD 2002/475 does not oblige Member States to criminalise conspiracy to commit a terrorist offence or to criminalise recruitment for the armed struggle. Hence, the broadening of this exceptional criminalisation within the Dutch criminal justice system has not been imposed by the Union, but has been an initiative of the Dutch government to broaden criminal liability on the basis of Article 96 of the DCC, which has been categorised under the heading of 'countering terrorism'. ${ }^{104}$ In light of this latter consideration, the recommendations by the Council of State would have been all the more important.

Article 83 of the DCC distinguishes between (1) conspiracy to commit the offences codified in Articles 92 to Article 95a of the DCC with terrorist intent, and (2) conspiracy to commit a whole range of other, specific, terrorist offences, such as conspiracy to commit murder with terrorist intent. The first category of terrorist conspiracy offences ${ }^{105}$ is criminalised under Article 83, section 1 of the DCC, whereas the second category ${ }^{106}$ is criminalised under Article 83, section 2 of the DCC. In further discussing the scope of conspiracy to commit terrorist offences, I will not, however, differentiate between these two categories.

101 See Kamerstukken II 2003-2004, no. 28 463, no. 10, p. 27; Handelingen II 2003-2004, p. 2348. See, with regard to the connection between Article 140(a) of the DCC and Article 96 of the DCC, M.J.H.J. de Vries-Leemans, Art. 140 Wetboek van Strafrecht, Arnhem: Gouda Quint 1995, p. $137-153$.

102 Kamerstukken II 2002-2003, 28 463, nr. 8, p. 4-5.

103 Kamerstukken II 2002-2003, 28 463, nr. 8, p. 5.

104 See Kamerstukken II 2001-2002, 28 463, no. 3, pp. 13-17.

105 Articles 92 to 95 a in conjunction with Article 83 of the DCC.

106 Articles 114b, 120b, 176b, 282c, 289a, 304b, 415b, in conjunction with Article 83 of the DCC. 
Article 96, SeCtion 1 of the DCC

For criminal liability in relation to conspiracy, three criteria have to be fulfilled: (1) there must be an agreement between at least two parties, (2) to commit a terrorist/ common offence and (3) the parties must have a twofold special intent - the agreement to commit, as well as the intention of, committing the terrorist/criminal offence. ${ }^{107}$ For a successful prosecution, a public prosecutor needs to know the kind of offence the perpetrators agreed to commit, the place at which the crime was to be committed and the estimated time at which the intended offence was to be committed. ${ }^{108}$ Concrete plans or a precise schedule for how, exactly, the perpetrators are going to commit the intended crime are not required for criminal liability. ${ }^{109}$ The question of who is finally going to commit the crime is of no importance in terms of the criminal liability of the conspirator.

Thus, the most important aspect of criminal liability in respect of conspiracy is the agreement between 2 or more persons to commit a (criminal or terrorist) offence. ${ }^{110}$ Basically, with regard to substance, criminal liability is exclusively based on such an agreement. The criminalisation of conspiracy to commit certain crimes is primarily based on the threat that emanates from the fact that two or more persons agree to commit a (terrorist) crime. This means that one person with such intentions is not liable to be punished, whereas two or more persons who jointly have such intentions are committing conspiracy pursuant to Article 96 of the DCC. The danger lies primarily in the agreement. This is considered to be the discerning element of having a gesinnungsstrafrecht: the mere intention of one person is not criminalised but the openly expressed and shared intention of two or more persons is required to be held criminally liable under article 96 of the DCC. ${ }^{111}$ Mols poses, in this respect, the following important question: '[...] But what is an agreement other than the intention and the collective thought to commit a criminal offence without any further action/behaviour to factually realise that intention?'112

So, although, formally speaking, the agreement serves as an objective element next to the mere intention, factually, the agreement does not really add substantively to that intention. To constitute criminal liability, it is not, for example, required that

107 C.M. Pelser, 'Preparation to commit a crime. The Dutch approach to inchoate offences', in Utrecht Law Review, volume 4, issue 3, 2008, p. 76.

108 Kamerstukken II 2003-2004, 28 463, no. 10, p. 19; Kamerstukken I 2003-2004, 28 463, C, p. 10.

109 Kamerstukken II 2002-2003, 28 463, no. 8, p. 6; Kamerstukken II 2003-2004, 28463, no. 10, pp. 23, 35; Kamerstukken I 2003-2004, 28 463, C, p. 8, 10 and 11; Kamerstukken I 2003-2004, 28 463, E, p. 3. See, as well, A.A.M. Orie \& J.J.I. Verburg, 'De Koningin bedreigd', in Delikt en Delinkwent 1975, p. 477-478.

110 Article 80 of the DCC.

111 Handelingen II 2003-2004, p. 2350; Kamerstukken I 2003-2004, 28 463, C, pp. 8-9.

112 G.P.M.F. Mols, Strafbare samenspanning: Een rechtshistorisch en rechtsvergelijkend onderzoek, Gouda Quint Arnhem 1982, pp. 154-155. 
the suspect has the intention of factually contributing to the commission of the offence(s) to which they are conspiring. ${ }^{13}$ However, others argue that the agreement forces persons to contribute to the factual commission of the intended criminal/ terrorist offence, even if these persons may change their minds along the way. Following this line of reasoning, it may indeed be in the agreement in which the threat to the legal value lies.

Whatever line of reasoning one follows, it is essential to see that conspiracy constitutes a striking exception to the general rule within the Dutch criminal justice system that criminal liability only arises upon a 'factual and deliberate muscular movement'. Intentions should not, as such, give rise to criminal liability. However Article 96, section 1 of the DCC criminalises agreements regarding a future intended (terrorist) offence. An agreement may, theoretically, be considered 'more' than intentions only, but it is certainly less than a factual and deliberate muscular movement. Pelser is right in arguing that in this respect 'in the traditional Dutch approach to inchoate crime, the focus is on the penalisation of acts or behaviour. This position leaves no place for a broad concept of conspiracy, as these offences have no direct relationship between acts and the intended substantive offence'. ${ }^{114}$

\section{Article 96, SeCtion 2 OF the DCC}

Article 96, section 2 of the DCC introduces criminal liability for behaviour committed with the intent of preparing or advancing criminal/terrorist offences. This provision is considered to be a lex specialis of the general criminalisation of preparatory acts pursuant to Article 46 of the DCC. The behaviour that leads to criminal liability under section 2 is specified in subsection 1 to 5 .

Under subsection 1, a person may be held criminally liable for attempts to incite another person to commit a (terrorist) crime, attempts to make others commit a (terrorist) crime, attempts to cooperate in committing a (terrorist) crime, attempts to assist in the perpetration of a (terrorist) crime, and attempts to provide the opportunity, means and/or information to commit a (terrorist) crime. Subsection 2 continues with attempts to equip others or oneself with information, means or opportunity to commit an (terrorist) offence. Then, subsection 3 criminalises the possession of objects, which the suspect knows are intended for the commission of an (terrorist) offence. Subsection 4 concerns the possession or preparation of plans for the execution of a (terrorist) crime, plans which are, moreover, intended to be made known to others. Lastly, subsection 5 makes people who try to stop, obstruct

113 Arnhem District Court 8 July 1975, NJ 1975/418; Supreme Court 22 June 1976, NJ 1976/563.

114 C.M. Pelser, 'Preparation to commit a crime. The Dutch approach to inchoate offences', in Utrecht Law Review, volume 4, issue 3, 2008, p. 75. 
or frustrate governmental measures intended to prevent or suppress (terrorist) crime, liable to punishment. ${ }^{115}$

The DTA has expanded the scope of Article 96, section 2 of the DCC considerably. In addition to Articles 92 to 95a of the DCC, Article 96, section 2 of the DCC can currently also be linked to the offences mentioned in Articles 114b, ${ }^{116} 120 b,{ }^{117}$ $122,{ }^{118} 176 b,{ }^{119} 282 c,{ }^{120} 289 a,{ }^{121} 304 b,{ }^{122}$ and $415 b^{123}$ of the DCC.

Let me give some examples: a person who attempts to assist/cooperate in a terrorist murder may be punished with 10 years imprisonment, even if he did not actually assist/cooperate in the factual murder. Moreover, the terrorist murder does not even need to have taken place. This person is then punished for the mere fact that he strived to assist in committing a terrorist murder. Another example: a person who attempts to incite another person, though does not succeed in his attempt, to kidnap a person with terrorist intent, is also liable for 10 years imprisonment. The fact that he changed his mind during his attempts does not free him from criminal liability.

A different example: someone who writes an e-mail with plans regarding the terrorist murder of a politician is liable to serve 10 years imprisonment, even without yet having sent the e-mail. This example may even go further than conspiracy to commit a terrorist murder, as no agreement has yet to exist for criminal liability to ensue. If, in the end, the person decides not to send the e-mail, he will not be released from his criminal responsibility. A last example: a person who attempts to cooperate with others in the preparation of premeditated severe harassment is also liable to punishment.

All of these examples come down to criminalisation of behaviour that takes place long before the intended (final) terrorist offence occurs. The behaviour defined in Article 96, section 2, subsection 1 to 5 of the DCC is liable to punishment, irrespective of the consequences/result. There is, hence, no direct relationship between what a person strives to realise on the one hand, and any form of behaviour that directly threatens or may come to threaten the legal order/values, on the other.

115 See, for further elaboration on these sections, Wetboek van Strafrecht - Noyon/Langemeijer \& Remmelink, artikel 96 Wetboek van Strafrecht, aantekeningen 1-8 (Prof. mr. J. W. Fokkens); B.F. Keulen, 'Over voetbal, voorbereiding en samenspanning', in NJB 2009/1481. 
With regard to Article 96, section 1 and 2 of the DCC, is it furthermore important to note that voluntary withdrawal [vrijwillige terugtred], as defined in Article 46b of the DCC, does not cancel out criminal liability. In the case of section 1, this may be due to the fact that once the agreement is made, it is considered more difficult to withdraw, due to the potential group pressure to carry on with the materialisation of the intention. ${ }^{124}$ That does not however apply in the case of section 2 . This means that once the conspiracy agreement is made, or behaviour mentioned in section 2 is displayed, there is no way back in terms of criminal liability. This applies, hence, also when the (terrorist) offence conspired to or strived to being prepared does not take place in the end. That is surprising if one takes into account that common preparatory acts to commit a (terrorist) offence, ${ }^{125}$ or an attempt to commit a (terrorist) offence, ${ }^{126}$ are no longer liable to punishment when the perpetrator voluntarily changes his mind and withdraws from the (incomplete) preparation/ attempt pursuant to Article $46 \mathrm{~b}$ of the DCC. 127

So, criminal liability for conspiracy to commit an (terrorist) offence or attempts to prepare/advance such crimes does not dissapear when the perpetrator changes his mind and abstains from his criminal behaviour. This situation is, in terms of the legal system and rationale, inconsistent when taking into account that behaviour, as codified in Article 96 of the DCC, may take place before preparatory acts pursuant to Article 46 of the DCC, or attempts to commit a (terrorist) offence as defined in Article 45 of the DCC. If one placed all these inchoate criminal offences on a continuum, stage 1 would be Article 96 of the DCC (furthest away from a 'complete offence'), followed by stage 2 , the preparation of an offence in accordance with Article 46 of the DCC, stage 3, Article 45 of the DCC, and stage 4 would be the perpetration of a 'complete' offence. Currently, an alleged perpetrator may evade criminal liability during stages 2 and 3, but not during stage 1. This, I find completely incomprehensible. The government does not provide any explanation for this inconsistency.

Lastly, it is important to bear in mind that preparation of conspiracy is, theoretically speaking, a criminal offence at present. An amendment seeking to preclude criminal liability for attempted conspiracy and preparation of conspiracy was rejected during parliamentary discussions. ${ }^{128}$ The Minister of Justice argued, in this respect, that, for example, the first conversation before the actual agreement is made can be

\footnotetext{
124 H.G. van der Wilt, 'Ontwikkeling van nieuwe deelnemingsvormen', in Delikt en Delinkwent 2007, 10, p. 138.

125 See Article 46 of the DCC.

126 See Article 45 of the DCC.

127 See Article 46b, in conjunction with Articles 45 and 46 of the DCC. See Supreme Court 15 February 1977, NJ 1978/6; Kamerstukken II 2003-2004, 28 463, nr. 10, p. 24. See, also, C.P.M. Cleiren, J.F. Nijboer (red.), Strafrecht Tekst \& Commentaar, 7de druk, Kluwer Deventer 2008, pp. 387-417.

128 Kamerstukken II 2003-2004, 28 463, nr. 24.
} 
considered as preparation of/attempted conspiracy. ${ }^{129}$ This clearly extends criminal liability far into the pro-active phase. In this respect, it should be kept in mind that once something is categorised as a terrorist offence, the investigative authorities are allowed to use all of the procedural (investigation) powers to investigate terrorist offences. This issue will be discussed further in Chapters V to VII.

\section{Case law with Regard to Category 1: The Piranha Case}

In the Piranha I judgement, ${ }^{130}$ the suspects were prosecuted on the basis of Article 96, section 2 of the DCC. In addition, the public prosecutor indicted the suspects on the charge of participating in a terrorist organisation pursuant to Article 140a of the DCC. The Rotterdam District Court argued that the suspects did not sufficiently cooperate in a more or less enduring and structured way so as to be categorised as a terrorist organisation in compliance with Article 140a of the DCC.

Article 96, section 2 of the DCC does not require there to be an organisation, nor does it call for preparatory acts, as required under Article 46 of the DCC. In such situations, Article 96, section 2 of the DCC serves as a 'safety net' against Articles 140a and 46 of the DCC. As discussed above, the only condition for criminal liability under Article 96, section 2 of the DCC is that the suspect must have displayed behaviour, as enumerated under subsections 1 until 5, with the intent of preparing or advancing a limitative list of serious (terrorist) offences.

This judgement has already been briefly discussed in the previous section. At this point I will only elaborate on the question of on which of the alternatives comprised in Article 96, section 2 subsections 1 to 5 of the DCC the suspects were convicted. To start with, the Rotterdam District Court considered that several members of the Piranha group acted in clear violation of the DTA. This followed foremost from the confiscated digital documents, but also from established meetings between several members and from other evidence. For example, during a house search at one suspect's house (Samir A.), a video-taped will was found and confiscated, in which the suspect concerned spoke of committing offences intended to frighten the population and to destroy the Dutch legal order.

The Court contended in this respect that the video-taped will was meant to be made public to the Dutch population after the commission of a terrorist offence, such as the bombing of the intelligence services' office or the murder on (a) politician(s). In addition, the Court argued that the video-taped will, as such, already

129 Handelingen II 2003-2004, 33, p. 2352. See, in this respect, also C.M. Pelser, 'Preparation to commit a crime. The Dutch approach to inchoate offences', in Utrecht Law Review, volume 4, issue 3, 2008, p. 78. 
sufficed to make spectators feel frightened. Furthermore, all of the suspects (among whom was Samir A.) possessed illegal weapons, saw weapons, or were otherwise involved in the possession of illegal weapons.

Next, there was one suspect who tried to illicit information from her sister - who worked in a pharmacy - regarding several politicians' addresses. The police also found a document with the names and addresses of 4 politicians at one suspect's house. Furthermore, on a computer of one of the suspects, the investigative authorities discovered documents describing how to drive by truck, with a homemade bomb, into the intelligence services' office, after which, the perpetrator, it was claimed, would go to paradise.

Taking into account these circumstances, the Court concluded that the suspects were willing to commit terrorist offences against non-believers, the intelligence services and/or politicians. ${ }^{131}$ In light of Article 96, section 2 DCC, the Rotterdam District Court and the Hague Court of Appeal held that several - but not all ${ }^{132}$ - of the suspects did not merely have (joint) plans to commit terrorist offences, but also committed one, or more, of the preparatory acts, as enumerated in subsections 2,3 and 4 , with the intent to prepare and advance the commission of terrorist offences. ${ }^{133}$

Another case that led to a conviction under Article 96, section 2 of the DCC regarded a suspect convicted of the preparation of the following offences: terrorist murder/manslaughter, causing an explosion, ${ }^{134}$ and threatening politicians with terrorist offences. ${ }^{135}$ During his prison sentence, he asked fellow detainees where he could find explosives (semtex) and weapons (hand grenades). Moreover, he offered his fellow detainees money in return for the required information. Furthermore, the suspect informed his fellow detainees that he wanted to die a holy death by blowing himself in a crowd of people, or near a government building, preferably the headquarters of the intelligence services'. He also expressed his intention of killing various politicians in front of the mass media.

Upon his release from prison, the suspect possessed (digital) information on how to commit a terrorist attack and information on Islamic fundamentalism. He also possessed practical, step-by-step and sophisticated systematic information on how to make explosives and poisons.

131 Articles $157,176 \mathrm{~b}$ and/or $289 \mathrm{a}$ of the DCC.

132 One suspect was acquitted, the other six were convicted of the preparation of terrorist offences in accordance with Article 96, section 2 of the DCC.

133 Rotterdam District Court 1 December 2006, LJN: AZ3589, 10/600052-05, 10/600108-05, $10 / 600134-05,10 / 600109-05,10 / 600122-05,10 / 600023-06,10 / 600100-06$; the Hague Court of Appeal 2 October 2008, LJN: BF4814, 22-007351-06.

134 Articles 176b and 289a of the DCC.

135 Rotterdam District Court 14 February 2006, LJN: AV1652, 10-600017-05. The suspect was convicted on the basis of Article 96, section 2, subsections 1, 2 and 3 of the DCC, in conjunction with Articles 176b and 289a of the DCC, and on the basis of Article 205 of the DCC. 
On the basis of these facts and circumstances, the Rotterdam District Court concluded that the suspect intended to prepare and advance the commission of several terrorist offences pursuant to Article 96, section 2 under sub 1, 2 and 3 of the DCC. The Court held it was the intention of the suspect to prepare/advance terrorist offences, rather than common offences, as it was clear from his statements and the documents he possessed that he intended to frighten (part of) the Dutch population and to disrupt constitutional and/or political structures by means of the planned offences.

These two judgements quite clearly illustrate the practical meaning of Article 96, section 2 of the DCC. This provision does not explicitly require evidence such as a bomb, weapons, or other objects that directly endanger or may come to endanger the legal order. The prosecution needs to demonstrate the suspect's intention to prepare or advance a (serious) terrorist offence through conduct, as described in subsection 1 to 5. Furthermore, these subsections do not require preparatory acts as under Article 46 of the DCC.

\subsection{Terrorist offences with increased penalties}

The FD 2002/475 states in its preamble: 'Terrorism constitutes one of the most serious violations of principles of democracy, respect for human rights and the rule of law. This must be expressed in the imposed penalties'.

Article 83, section 2 of the DCC therefore provides for increased penalties when a selection of common criminal offences is committed with terrorist intent. ${ }^{136}$ All of the offences mentioned in Article 83, section 2 of the DCC, when committed with terrorist intent, carry a penalty one and a half times higher than such offences committed without such intent.

The terrorist offences of Article 83, section 2 of the DCC are all offences that endanger general safety, persons or goods. Firstly, there is a category of offences that all comprise an element of violence or the threat of violence. For example, committing or conspiring to assault life or freedom of members of the Royal Family, of the head of a state of an ally, or of internationally protected persons, or of lower state officials, without resulting in death, however, pursuant to Article 114a, 114b, 120a, 120b, 130a DCC.

Secondly, Article 83, section 2, in conjunction with Article 176a of the DCC includes several offences that endanger public safety, such as deliberately committing arson, causing an explosion (Article 157 of the DCC), deliberately contaminating air, water, soil, goods, plants, animals or people with radiation (among others Article 161quater of the DCC), or deliberately destroying a building or a piece of carpentry, the destruction of which, it is feared, could endanger persons 
or goods (Article 170 of the DCC). ${ }^{137}$ This means that the mere fear of danger to life or goods combined with terrorist intent, suffices to justify the imposition of at least 18 years imprisonment. ${ }^{138}$ Other terrorist offences of this kind are listed in Article 161, 161bis, 162, 162a, 164, 166 and Article 168 of the DCC.

Lastly, Article 83, section 2 of the DCC includes the following terrorist offences: conspiracy to false imprisonment/kidnapping (Article 282c of the DCC), conspiracy to commit murder or manslaughter (Article 289a of the DCC), serious assault (Article 304a of the DCC) or conspiracy thereto (Article 304b of the DCC), hijacking of a plane (Article 385a of the DCC), assaulting those onboard a plane (Article 385b of the DCC), the passing on of false flight information (Article 385c of the DCC), and assault with dangerous substances/objects at an airport (Article $385 \mathrm{~d}$ of the DCC). ${ }^{139}$ Obviously, all of these offences must be committed with terrorist intent to be deemed terrorist offences.

\subsection{Specific terrorist offences}

The last category of terrorist offences consists of specific terrorist offences. These are not composed of an existing common criminal law provision combined with Article $83 \mathrm{a}$ of the DCC, but are separately defined terrorist offences. ${ }^{140}$

To begin with, Article 140a of the DCC criminalises participation in a terrorist organisation and leading, directing or managing such an organisation. This provision prescribes maximum penalties of 15 and 30 years imprisonment, respectively, and considerable fines. The taking of hostages with terrorist intent is also penalised under Article 83, section 3 of the DCC (see Article 282b of the DCC). Threatening to commit a terrorist offence is defined as a terrorist offence, and carries a maximum penalty of 6 years imprisonment pursuant to Article 285, section 3 of the DCC. ${ }^{141}$ Furthermore, manslaughter committed with terrorist intent is a special terrorist offence under Article 288a of the DCC. ${ }^{142}$

Article 83 of the DCC also amended the Weapons and Ammunition Act (WAA) [Wet Wapens en Munitie]. Several WAA crimes that carry a penalty of eight years imprisonment are, when committed with terrorist intent, considered as terrorist offences. Basically, when a common WAA crime ${ }^{143}$ is committed with terrorist

\footnotetext{
137 Kamerstukken II 2001-2002, 28 463, nr. 3, p. 5.

138 Kamerstukken II 2001-2002, 28 463, nr. 3, p. 5.

139 See, in this respect, also, Articles 415a and 415b of the DCC and Article 80 of the Nuclear Power Act [Kernenergiewet].

140 Article 83, section 3 of the DCC.

141 Kamerstukken II 2001-2002, 28 463, nr. 3, p. 10.

142 Article 83, section 3, in conjunction with Article 288a of the DCC.

143 Article 9, section 1; Article 13, section 1; Article 14, section 1; Article 26, section 1 and Article 31, section 1 in conjunction with Article 55, section 5 of the WAA.
} 
intent or with the intent of facilitating or preparing a terrorist offence, that WAA offence becomes a terrorist offence. ${ }^{144}$ Furthermore, violation of the Dutch implementing statutes of the UN Convention on Biological Weapons ${ }^{145}$ and the UN Convention on Chemical Weapons ${ }^{146}$ is a terrorist offence pursuant to Article 83, section 3 of the DCC. ${ }^{147}$ The last two amendments made by the DTA concern the Nuclear Energy Act (Kernenergiewet) and the Civil use of Explosives Act (Wet explosieven voor civiel gebruik). ${ }^{148}$ Amendments to these two Acts include increased penalties for violating existing injunctions with terrorist intent.

One specific terrorist offence under Article 83, section 3 of the DCC will now be examined in depth, that of participation in a terrorist organisation pursuant to Article 140a of the DCC. The criminal proceedings in the Hofstadgroep and the Piranha $I$ and $I I$ cases all concerned the scope of criminal liability in respect of participation in a terrorist organisation. These judgements will therefore be discussed extensively.

\subsubsection{An example: Membership of a criminal/terrorist organisation}

The criminal proceedings regarding the Hofstadgroep resulted in the first Dutch mass terrorist trial, during which 14 persons were prosecuted for membership of a 'terrorist organisation' as defined in Article 140a of the DCC. ${ }^{149}$ The Hofstadgroep

144 Article 55, section 5 of the WAA.

145 Convention on the Prohibition of the Development, Production and Stockpiling of Bacteriological (Biological) and Toxin Weapons and on their Destruction, signed in Washington, Moscow and London 26 March 1975.

146 Convention on the Prohibition of the Development, Production and Stockpiling of Chemical Weapons and on Their Destruction, signed in Washington, Moscow and London, 29 April 1997.

147 To that effect, an extra section has been added to Article 6 of the Act on Economic Offences [Wet op de economische delicten]. The maximum penalty is 8 years imprisonment.

148 See Article 33a of the Civil Use of Explosives Act [Wet explosieven civiel gebruik] and Articles 79 and 80 of the Nuclear Energy Act [Kernenergiewet].

149 Rotterdam District Court 10 March 2006, LJN: AV5108, 10/000322-04; 10/000328-04; 10/000396-04; 10/000393-04; 100000325-04; 10/000323-04; 10/000395-04, (Compilation Hofstadgroepproces/Arles-groep). Article 2 of the FD 2002/475 obliges Member-States to criminalise offences relating to terrorist groups. The provision prescribes that: (1) For the purposes of this Framework Decision, 'terrorist group' shall mean: a structured group of more than two persons, established over a period of time, and acting in concert to commit terrorist offences. 'Structured group' shall mean a group that is not randomly formed for the immediate commission of an offence and does not need to have formally defined roles for its members, continuity of its membership or a developed structure. (2) Each Member State shall take the necessary measures to ensure that the following intentional acts are punishable: (a) directing a terrorist group, (b) participating in the activities of a terrorist group, including by supplying information or material resources, or by funding its activities in any way, with knowledge of the fact that such participation will contribute to the criminal activities of the terrorist group. 
has been included on the European Union blacklist since June 2007, after conviction by the Rotterdam District Court. ${ }^{150}$

In 2003, the secret intelligence services began to map out this group of (young) persons. All members of the group ${ }^{151}$ adhered to extreme forms of Islam supporting, among others, the violent Jihad against all non-Islamic people ('unbelievers'). The secret intelligence services alerted the police to the fact that this network of young radical Muslims was involved in the preparation of 'a terrorist attack'. ${ }^{152}$ This information led to the arrest of 14 suspects, to house searches, to pre-trial detention and to extensive interrogations. The information that was subsequently gathered revealed that the suspects adhered to radical forms of Islam, that two of them went to a training camp in Pakistan and subsequently recruited others to join them and that they sympathised with people who commit terrorist attacks. ${ }^{153}$

To better understand the scope of these criminal proceedings, the course of proceedings must be kept in mind. The Rotterdam District Court handled the case as the Court of First Instance. Both the prosecution and the accused filed an appeal, resulting in a judgement by the Hague Court of Appeal. Subsequently, the Supreme Court ruled on the case, and lastly, the Amsterdam Court of Appeal passed judgement (after referral).

All of the alleged members of the Hofstadgroep were charged with participation in a criminal and a terrorist organisation pursuant to Articles 140 and 140a of the DCC. The explanatory memorandum of the DTA underlines that Article 140a of the DCC (terrorist organisation) should be interpreted and applied in a similar way to Article 140 of the DCC (criminal organisation). ${ }^{154}$ Nevertheless, there is one additional requirement included in Article 140a of the DCC: participating in a terrorist organisation implies a twofold special intent namely the organisation's intent to commit offences with a terrorist intent. Hence, in order to be held criminally liable under Article 140a of the DCC, the prosecution must prove that the organisation in which a person participates aims at committing offences with terrorist intent as defined in Articles 83 and 83 a of the DCC. ${ }^{155}$

150 Council Common Position 2007/448/CFSP of 28 June 2007 (OJ L 169, 29.06.2007, pp. 69-74) and see, for the most recent blacklist, Council Decision 2011/430/CFSP of 18 July 2011 (OJ L 188, 19.07.2011, pp. 47-49).

151 The non-legal word 'group' is used at this point instead of the legal word 'organisation' because one of the main questions throughout these criminal proceedings was whether or not the Hofstadgroep could be denoted as criminal and terrorist organisation pursuant to Article 140(a) of the DCC.

152 Rotterdam District Court, 10 March 2006, LJN: AV5108, 10/000322-04, 10/000328-04, 10/000396-04, 10/000393-04, 10/000325-04, 10/000323-04, 10/000395-04, paragraph 125.

153 At the time (2003) when the suspects actually recruited other members of the group for the visit to a training camp in Pakistan, that behaviour did not constitute a criminal offence. Article 205 of the DCC, which criminalises recruitment for the armed struggle, entered into force in August 2004 with enactment of the DTA. Therefore, the suspects were not prosecuted in that respect.

154 Kamerstukken II 2001-2002, 28 463, nr. 3, p. 9.

155 Kamerstukken II 2001-2002, 28 463, no. 3, p. 8-9. 
The main question in the following sections is when a person is, in fact, participating in a terrorist organisation. What is needed in terms of factual behaviour and state of mind to prove that a person is liable for punishment under Article 140a of the DCC, and what role does Article 83a of the DCC play in that respect?

Prior to scrutinising whether or not a suspect has indeed participated in a terrorist organisation, two other requirements need to be fulfilled. Firstly, the suspects must form an 'organisation' in the legal sense of the word. Secondly, it must be ascertained that the organisation's purpose is the perpetration of terrorist offences. Case law on Article 140 of the DCC shows that these three cumulative requirements need to be convincingly proven in order for criminal liability to be established. The following sections will extensively discuss these three requirements in light of the criminal proceedings against the Hofstadgroep and in light of the Piranha I and Piranha II judgements. This will serve to establish how, exactly, the judiciary has interpreted the scope of criminal liability pursuant to Article 140a of the DCC. The facts and circumstances of these cases will therefore be scrutinised comprehensively.

\subsubsection{The first requirement: Organisation}

\section{The Hofstadgroep Judgements}

The first requirement for criminal liability under Article 140a of the DCC is that there must actually be an 'organisation'. Obviously, this needs to be established prior to elaborating on the organisation's purpose and on the participatory behaviour of its alleged members. How does the judiciary interpret the notion of 'organisation'? When does a 'group' in lay-language become an 'organisation' in the legal sense?

Case law regarding Article 140 of the DCC reveals that every more or less wellstructured and enduring factual cooperation between two or more persons falls under the heading of 'an organisation'. ${ }^{156}$ Furthermore, that cooperation must serve a common goal and the persons involved must be active in fulfilling this common goal. ${ }^{157}$ A more or less fortuitous cooperation is insufficient to comply with Article 140(a) of the DCC. Also, the organisation must endure in time. ${ }^{158}$ The

156 Supreme Court 8 October 2002, NJ 2003/64; Supreme Court 16 October 1990, NJ 1991/442; Supreme Court 18 November 1997, NJ 1998/225; Supreme Court 5 September 2006, NJ 2007/336; Almelo District Court 29 April 2008, LJN: BD 0835, 08/710423-07; H.G. van der Wilt, 'Ontwikkeling van nieuwe deelnemingsvormen. Ben ik mijn broeders hoeder?', in Delikt en Delinkwent 2007, 10.

157 J. de Hullu, Materieel Strafrecht: Over algemene leerstukken van strafrechtelijke aansprakelijkheid naar Nederlands recht, vierde druk, Kluwer Deventer 2009, pp. 434-435. See Supreme Court 16 Ocotber 1990, NJ 1991/442 (Mariënburcht); Supreme Court 18 November 1997, NJ 1998/225.

158 's-Hertogenbosch District Court 15 April 2008, LJN: BC 9370, 01/889067-05; M.S. Groenhuijsen, 'Mariënburcht, annotatie bij Hoge Raad 16 oktober 1990', in Ars Aequi XL 1991, p. 421 . 
cooperation does not, however, continually need to consist of the same persons, even though a hard core appears to be required, nor do all persons involved actually need to know each other. ${ }^{159}$ Continual cooperation among the same persons is not required.

Whether the alleged group members indeed cooperate in this sense is examined on the basis of one or more of the following aspects: (1) the extent to which the organisation has a common set of rules, by means of which, moreover, certain pressure can be exerted on the organisation's members; (2) the question of whether the members consult each other regularly and take joint decisions; and (3) the extent to which the organisation has a certain hierarchy or a certain division of tasks.

These aspects are not constituent elements, but they serve as criteria to answer the question of whether the members of a group cooperate in such a way that one can speak of an organisation in accordance with Article 140(a) of the DCC.

How were these aspects applied throughout the criminal proceedings against the Hofstadgroep?

The Rotterdam District Court underlined that all of the suspects ${ }^{160}$ regularly assembled in Mohammed B.'s house to discuss religious and political issues. The gatherings took place recurrently, in a fixed location, there was a regular host Mohammed B. - and the group of attendees was more or less fixed in respect of its structure. In addition, the group as a whole exerted pressure on each individual member to live strictly according to the Islamic regimen. ${ }^{161}$ During some of the gatherings, an Islamic 'teacher' (Abu Khaled) ${ }^{162}$ was hired to set out his ideas regarding Islam and to educate the suspects further in the Islamic faith. The investigative authorities found, during house searches carried out in the suspects' houses, several educational texts and notes that were obviously provided, and made, during these 'lessons'. ${ }^{163}$ Among the members, several radical texts were exchanged in which the democratic rule of law was rejected and the violent Jihad and martyrdom glorified. Justified use of violence against all unbelievers was prescribed.

159 Supreme Court 29 January 1991, NJB 1991/50; Supreme Court 22 January 2008, NJ 2008/72; the Hague Court of Appeal 8 February 2008, LJN: BC 3872, 2200454506.

160 The suspects are: Jason Walters. Zine Labidine A., Mohammed B., Youssef E., Mohamed Fahmi B., Nouriddin el F., Ahmed H., Mohammed el M., Nadir Adarraf, Rachid Belcacem. Mohammed el B., Zakaria T., Jermaine Walters, and Ismail A. See Rotterdam District Court, 10 March 2006, LJN: AV5108, 10/000322-04, 10/000328-04, 10/000396-04, 10/000393-04, 10/000325-04, $10 / 000323-04,10 / 000395-04$. See, in this respect, Th.A. de Roos, 'Kroniek van het straf(process)recht', in NJB 2006/31, p. 7384 e.v.

161 Rotterdam District Court, 10 March 2006, LJN: AV5108, 10/000322-04, 10/000328-04, 10/000396-04, 10/000393-04, 10/000325-04, 10/000323-04, 10/000395-04, paragraph 111-112.

162 This man is considered as 'religious leader/inspiration' for the Hofstadgroep.

163 Rotterdam District Court, 10 March 2006, LJN: AV5108, 10/000322-04, 10/000328-04, 10/000396-04, 10/000393-04, 10/000325-04, 10/000323-04, 10/000395-04, paragraphs 109-110. 
The District Court held that the suspects were joined by these common religious (extreme) beliefs. All of the Hofstadgroep members were educated systematically, which basically left no room for deviating opinions or behaviour. Joint activities, such as hiring teachers and gathering extremist information, were also undertaken to further strengthen their beliefs and to ripen their spirits for participation in the violent Jihad. The suspects, furthermore, collectively provided the wife of one of their 'colleagues', who was imprisoned at that time, with financial aid. Another indication of the cooperation among the alleged members of the Hofstadgroep was found in a letter that Mohammed B. had sent to the other suspects just before he murdered van Gogh. In that letter, Mohammed B. addressed the other members of the group as 'brothers'.

In sum, the structured exchange of texts and tapes containing information about extremist forms of the violent Jihad and the group's common hatred of the rule of law as an 'ideological binding aspect', were according to the District Court, clear indications of the existence of structured cooperation among the group members. ${ }^{164}$ They were accordingly considered as forming an organisation pursuant to Articles 140/140a of the DCC. ${ }^{165}$

In January 2008, the Hague Court of Appeal quashed the Rotterdam District Court's judgement with regard to the Hofstadgroep members' conviction for membership of a criminal and terrorist organisation. ${ }^{166}$ All of the members who were convicted by the District Court on the basis of Articles 140 and 140a of the DCC, were acquitted on appeal. The key question is on the basis of which considerations the Court of Appeal acquitted these members.

The Court of Appeal focused on two main questions: (1) whether the Hofstadgroep could actually be considered a criminal and terrorist organisation in the sense of a well-structured and enduring organisation and (2) whether this organisation - if characterised as such - had as a(n) (immediate) goal, ${ }^{167}$ the perpetration of violent criminal acts and eventually the establishment of an Islamic State? At this point, the first question will be discussed.

164 Rotterdam District Court, 10 March 2006, LJN: AV5108, 10/000322-04, 10/000328-04, 10/00039604, 10/000393-04, 10/000325-04, 10/000323-04, 10/000395-04, paragraph 113 and 121.

165 These aspects will be discussed in the following two subparagraphs.

166 The Hague Court of Appeal 23 January 2008, LJN: BC4171, 22001871-06; the Hague Court of Appeal 23 January 2008, LJN: BC2576, 22001897-06 and the Hague Court of Appeal 23 January 2008, LJN: BC4129, 22001886-06; the Hague Court of Appeal 23 January 2008, LJN: BC4177, 22001864-06; the Hague Court of Appeal 23 January 2008, LNJ: BC4182, 22001863-06; the Hague Court of Appeal 23 January 2008, LJN: BC4178, 23 January 2008, 22001862-06; the Hague Court of Appeal 23 January 2008, LJN: BC4183, 22001866-06. See, with respect to this judgement,: E. Prakken, 'Wilders: verbieden of toestaan', in NJB 2009, p. 270 e.v.; J.H. Gerards, J.P. Loof, H.C.K Senden, 'Kroniek van de grondrechten', in NJB 2008/34, p. 1737 e.v.; T. Spronken, 'Kroniek van het Straf-proces)recht', in NJB 2008/16, p. 800 e.v.

167 According to the public prosecutor's office, the group aimed to commit criminal and terrorist offences pursuant to Articles 131, 132, 137d and 285 of the DCC. 
The Court of Appeal first and foremost scrutinised if the Hofstadgroep did indeed have a commonly shared ideology, and if so, to what extent. This was an important issue, taking into account that it was partly used as foundation for the Hofstadgroep's conviction by the District Court. The Court of Appeal deemed the religious documents that had been found and confiscated during several house searches, as insufficient to prove that there existed in the Hofstadgroep a commonly shared ideology among its members. In that respect, the Court of Appeal underlined that the documents revealed that there is no coherence in the Islamic world regarding the interpretation of various religious texts. Therefore, to factually answer the question of whether the Hofstadgroep shared a common ideology, the Court of Appeal scrutinised Mohammed B.'s beliefs and examined to what extent these beliefs were shared by other alleged members of the Hofstadgroep. Mohammed B. adhered to an extreme interpretation of Islam that implied that the democratic rule of law, and, in general any other way of living, or any deviating society or culture, was rejected and considered abhorrent, and against whom justified violence may be used. ${ }^{168}$

According to the Court of Appeal, evidence presented during trial did not unequivocally reveal that all of the alleged members of the Hofstadgroep shared Mohammed B.'s extreme beliefs. The members were obviously all Muslims, but there was a great variety among the members when it came to the interpretation of the Koran, ranging from the extreme beliefs of Mohamed B. to the non-violent beliefs of other members. This also implied that it could not be proven beyond reasonable doubt that the shared nearby purpose of the Hofstadgroep was the committing of violent offences on the basis of a commonly shared ideology. In this respect, the Court of Appeal emphasised that for criminal liability under Article 140(a) of the DCC to apply, it must have been possible to exert a certain pressure on the members of the alleged organisation on the basis of a common shared purpose. This was lacking, as none of the alleged members of the Hofstadgroep were obliged to attend the meetings at Mohammed B.'s house. Everybody was free to decide whether or not they had time and/or the inclination to attend the gatherings.

In sum, even though the Hofstadgroep endured in time, the group was not as wellstructured as required to be deemed a criminal or terrorist organisation pursuant to Article 140(a) of the DCC. ${ }^{169}$ The written documents, the data and the computers of the alleged members of the Hofstadgroep did not contain sufficient evidence to

168 Mohammed B. held, during trial, that this was the theoretical basis of his beliefs. Nevertheless, there was no unequivocal opinion as to how this theory needed to be put into practice. He gave an example: if an 'unbeliever' would be killed in court right in front of everyone with reference to the Koran, he would consider that to be justified. However, the question of whether he, himself, as a Muslim, would have been obliged to kill the unbeliever, is not unequivocally answered in the affirmative. Mohammed B.'s reasoning should be considered in light of an expert-witness on Islam who argued that Mohamed B.'s beliefs would not necessarily and automatically lead to the future commitment of acts of violence.

See for a comparable judgement Supreme Court 10 July 2001, NJ 2001/ 687. 
adequately demonstrate the existence of a coherent and structured cooperative organisation. The alleged members did not share a common ideology or a common goal, and no pressure could be exerted on these members. ${ }^{170}$ An online discussion group, as was formed by several members of the Hofstadgroep, could not, as such contribute to proving the existence of an organisation.

Basically, the only aspect that was demonstrated during criminal proceedings was that the members regularly gathered at Mohammed B.'s house to talk about religious matters and to be taught the Islamic faith. However, these gatherings were not always attended by the same people and, one never knew, in advance, who would actually come. Information or documents were exchanged during these gatherings but serious arrangements to further distribute the documents - without the group - were not made.

In 2010 the Supreme Court quashed the Hague Court of Appeal's judgement and declared the latter's ruling with respect to the notion of organisation, too restrictive. The Supreme Court left the question of the precise scope of 'organisation' in accordance with Article 140 a of the DCC unanswered. ${ }^{171}$ It only considered the Court of Appeal's criterion regarding the required structured nature of the group and the durability of cooperation within the group to be too demanding.

After referral, the Amsterdam Court of Appeal concluded that the Hofstadgroep was an organisation pursuant to Article 140/140a of the DCC. The members of the group were held as feeling tied to one another due to their common religious beliefs. All members were systematically taught in those beliefs, and structured activities were organised to further convince one another of those beliefs and 'to mature their spirits' for participation in the Jihad. The Court of Appeal emphasised that all members shared a common interest in those beliefs. The fact that the members differed regarding: (1) the extent to which they accepted and were involved in those shared radical fundamentalist religious beliefs, and (2) the intensity of the contacts they maintained with other group members, did not matter in this respect. ${ }^{172}$

170 See also Rotterdam District Court 1 December 2006, LJN: AZ3589, 10/600052-05, 10/600108_ 05, 10/600134-05, 10/600109-05, 10/600122-05, 10/600023-06, 10/600100-06 (Piranha case). The Rotterdam District Court did not consider it proven that the suspects formed an enduring and structured cooperative organisation as required by Article 140a of the DCC. Therefore, the suspects were acquitted of the charges of membership of a terrorist organisation. BK5182/BK5172，08/00721，08/00695，08/04955，08/00721，08/00740，09/01625，09/01626， 08/00623, paragraph 4.

172 Amsterdam Court of Appeal 17 December 2010, LJN: BO9017, 23-000746-10, paragraph 3.1; Amsterdam Court of Appeal 17 December 2010, LJN: BO9015, 23-000750; Amsterdam Court of Appeal 17 December 2010, LJN: BO9014, 23-000749-10; Amsterdam Court of Appeal 17 December 2010, LJN: BO8032, 23-000747-10; Amsterdam Court of Appeal 17 December 2010, LJN: BO7690, 23-000751-10; Amsterdam Court of Appeal 17 December 2010, LJN: BO9018, 23-000748-10; Amsterdam Court of Appeal 17 December 2010, LJN: BO9016, 23-000745-10. The Court of Appeal explicitly underlined that it took as a starting point for its 
In reaching this conclusion, the Court of Appeal explicitly referred to the fact that the suspects all possessed more or less the same: (1) educational texts, (2) documents illustrating a very narrow interpretation of the Tahweed which preaches the violent Jihad, (3) cassette tapes containing appeals to join the violent Jihad, (4) computer documents containing sound and images data on the suppression of Muslims and on the violent Jihad, and (5) notes taken during 'lessons' on extreme interpretations of Islam. In the Court of Appeal's view all of this pointed to a mutual and coordinated exchange of such information. Jointly becoming member of the above-mentioned online discussion group and jointly providing financial benefits to one suspect's wife were also evidence of the group's shared loyalty and the structured and coordinated nature of the group.

\section{The Piranha I Judgements}

The Piranha I judgements (Court of first instance and Court of Appeal) were briefly discussed in the previous section as regards to preparatory acts pursuant to Article 96, section 2 of the DCC. This section goes into the suspects' alleged criminal liability in respect of Article 140a of the DCC.

The Rotterdam District Court ruled in its Piranha I judgement, contrary to its judgement in the Hofstadgroep case, that the suspects did not form an organisation pursuant to Articles 140/140a of the DCC. ${ }^{173}$ Even though the suspects, or at least two of them, shared a common extremist interpretation of Islam, not all members actively justified these beliefs, spread documents glorifying such beliefs, tried to convert people to radical Islam, incited others to commit violent terrorist offences, or threatened others with terrorist offences. There was no common and openly 'practiced' religion among all of the group members. They did not, for example, exchange ideas regarding their religious beliefs on a regular basis. Furthermore, only two members could be deemed to be 'active' members according to the District Court. In light of these considerations, the group members were considered to cooperate insufficiently - qualitatively as well as quantitatively - to be considered as an organisation under Article 140/140a of the DCC.

Also, there was no proof that the suspects shared a common (violent) purpose that might have connected them. In that respect, the District Court underlined that the meetings during which the suspects talked about religious matters were not always frequented by the same persons. ${ }^{174}$ There was no pressure exerted on

considerations, the Supreme Court's considerations, as formulated in Supreme Court 22 January 2008, LJN: BB7134, 01263/07.

173 Rotterdam District Court 1 December 2006, LJN: AZ3589, 10/600052-05, 10/600108-05, 10/600134-05, 10/600109-05, 10/600122-05, 10/600023-06, 10/600100-06 (Piranha case). The accused are: Samir A., Mohammed C., Nouriddin al F., Mohammed H., Brahim H., and Soumaya S.

174 Compare with Supreme Court 22 January 2008, LJN: BB7134, 01263/07; Supreme Court 29 January 1991, NJB 1991/50. 
'members' to make an active contribution to the group, as such, or to a joint purpose. This also demonstrated a lack of structure and coherence among the group members.

In sum, the District Court held that the suspects did not cooperate in such a structured and enduring way as to be deemed to be an organisation under Articles 140/140a of the DCC. In this respect, the judgement is comparable to the first Court of Appeal's judgement in the Hofstadgroep case.

On appeal, the Hague Court of Appeal answered the question of whether the suspects of the Piranha I group formed an organisation in great detail. ${ }^{175}$ Quite contrary to the District Court's opinion, the Court of Appeal did consider the Piranha group as an organisation. The Court of Appeal based its opinion on the following arguments.

First of all, the group members clearly shared the same extreme interpretation of the Koran. This was proven by several documents found at the suspects' houses. Meetings, during which this extreme interpretation of the Koran/Islam was preached, were held in private places and group members received an actual invitation for such meetings. All suspects spoke/lectured during the meetings and played therefore an active and clearly defined (leading) role. The group members also used the internet (MSN) to broadcast extreme ideas and illustrations, such as films depicting the decapitation of unbelievers. Moreover, they incited others to disseminate these extreme ideas and illustrations. Also, several group members possessed and exhibited digital instruction films on how to use an explosives belt. Often, such films were accompanied by a request for the necessary materials to make such a belt. Many group members possessed, and further communicated, information such as names, phone numbers and addresses of Dutch politicians. They furthermore possessed, transported and looked at firearms, balaclavas and gas masks. The group named itself 'The Lions of Thaweed' [De Leeuwen van Tahwied] and a logo was even used on several documents/letters that were made public through the internet. Documents signed 'Lions of Thaweed' accompanied by the logo were found on the suspects' computers. Also, the group jointly held 'shooting exercises' in a forest near Amsterdam.

In addition, there were certain rules that existed among the group members, for example, regarding the way in which women should be dressed, which had to be adhered to. By means of such rules, the leaders of the group also tried to pressure members to remain members. According to the Court of Appeal, such working methods demonstrated a coordinated, cooperative group, which, moreover, aimed to distribute documents designed to incite extreme ideas to the 'general public'.

175 The Hague Court of Appeal 2 October 2008, LJN: BF4814, 22-007351-06; the Hague Court of Appeal 2 October 2008, LJN: BF5180, 22-007384-06; the Hague Court of Appeal 2 October 2008, LJN: BF5225, 22-007350-06; the Hague Court of Appeal 2 October 2008, LJN: BF 3987, 2200734906. See, in this respect, T. Spronken, 'Kroniek van het straf(proces)recht', in $N J B$ 2007/13, p. 682 e.v. 
The group also had a certain durability as the suspects cooperated over a considerable period of time. A last important conclusion was that the Court of Appeal deemed the input of the various suspects within the group to be proof of a certain work- or task division with regard to: the transfer of persons, lecturing, maintaining contact with each other and with other persons, transporting and hiding weapon(s), intellectually expressing and upholding an extreme interpretation of the Koran and other religious documents, providing lodgings for the co-accused and other participants during group meetings, and offering accommodation and looking for legal representation for the co-accused who had been arrested and/or detained on remand.

What further struck the Court of Appeal was the cunning and covert manner in which the group members kept in touch with each other, exchanged information and documents, made appointments, and further published and proclaimed their ideas. They made it very hard for the investigative authorities to trace them and to discover their modus operandi. There was proof that the suspects exchanged information on how to evade being observed by the police and how to behave when apprehended. This information was found at several suspects' houses, and the Court of Appeal stressed that the suspects had also behaved as the information had instructed, so as to evade being caught while contacting other members and exchanging information, as described above.

The Court of Appeal clearly judged this case to be quite different from the Hofstadgroep. Members of the Piranha group did share an ideology; invitations for meetings were send to all members, such meetings were, moreover, held in closed, non public, places. Furthermore, members of the group played an active role and all group members disseminated the shared extremist ideas. Further joint activities were the shooting exercises. The group had a logo and a common name that was made public through the internet. Contrary to the Hofstadgroep, moreover, they had shared rules that all members obeyed, and through which group members were put under pressure. In sum, the Court of Appeal considered the Piranha group to form a coherent, enduring and structured group with active members, which could be deemed to be an organisation under Articles 140/140a of the DCC.

\section{The Piranha II Judgement}

Lastly there is the Piranha II judgement of the Rotterdam District Court. ${ }^{176}$ It is unclear what the precise difference was between the first and the second Piranha case, but it is most likely that the group of suspects was slightly different. ${ }^{177}$ The

\footnotetext{
176 Rotterdam District Court 25 March 2008, LJN: BC7539, 10/600112-05.

177 In the Piranha I case the group consisted of seven person, in the Piranha II case the group consisted of six persons.
} 
prosecution may have gained a better insight into the structure of the group, and thus better understood which members formed an organisation according to Article 140/140a of the DCC, and which members only formed a 'group, without legal value/relevance.'178 The period during which the Piranha I suspects allegedly formed a criminal/terrorist organisation partly overlapped with the period in the Piranha II case. ${ }^{179}$

The criminal offences in respect of which the suspects were prosecuted in this case were similar to the ones in the Piranha I case: participation in a criminal/terrorist organisation (Articles 140/140a of the DCC), the preparation of terrorist murder/ manslaughter (Article 96, section 2 and Article 46 of the DCC) and illegal possession and use of various weapons with the intent of preparing a terrorist offence. At this point, the question of whether the suspects did indeed form an organisation pursuant to Articles 140/140a of the DCC, will be discussed.

In this case the District Court concluded, without much deliberation there was sufficient cooperation between the suspects for them to be deemed to be an organisation. This was grounded on the following facts: the suspects jointly drove back and forth to Belgium, they jointly rented an apartment in Belgium where all group-members could stay, they jointly possessed weapons, there were joint shooting exercises near Amsterdam, group members transported one another to Utrecht, they exchanged the addresses of Dutch politicians, they welcomed group members with weapons, and many joint conversations had taken place. With regard to the required structure and enduring nature of the group, the District Court argued that two of the six suspects were clearly 'leaders', whereas the other four suspects were ordinary members. The organisation existed during a time period of seven months.

In sum, the above joint activities that the suspects carried out, justified, in the District Court's view, the conclusion that there was sufficient cooperation among the suspects to be considered as an organisation under Articles 140/140a of the DCC.

If one compares this judgement with the foregoing judgements, it is striking how unsubstantiated the District Court's conclusion is. ${ }^{180}$ The District Court did not elaborate extensively on the group members' shared ideology, their beliefs, or way of life. This is surprising taking into account that such considerations form the most

178 The Piranha I case took place in 2006, the Piranha II case in 2008.

179 In the Piranha $I$ case, the suspects allegedly formed a criminal/terrorist organisation from 11 November 2004 until 22 October 2005. In the Piranha II case, that period was considerably shorter: from 7 April 2005 until 14 October 2005.

180 See C.P.M. Cleiren and J.F. Nijboer, Strafrecht Tekst \& Commentaar, 7de druk, Kluwer Deventer 2008, p. 810. Ten Voorde argues that the Rotterdam District Court was less strict in determining whether or not the suspects in this case formed an organisation pursuant to Article 140(a) of the DCC than in the Hofstadgroep case. 
important part of the deliberation in the Hofstadgroep and the Piranha I judgements. In these judgements, the suspects' beliefs played a major role in determining whether or not they formed an organisation. In the Piranha II judgement, the Rotterdam District Court focused primarily on joint, rather factual, activities carried out by the suspects, instead of on more fundamental issues, such as what it was that 'mentally' joined them as an organisation.

\subsubsection{The second requirement: The organisation's purpose}

\section{The Hofstadgroep JUdgements}

Once a group of suspects is considered to be an organisation, it must be determined whether the organisation has, as a nearby purpose, the intent of committing criminal/ terrorist offences. These offences may be of any nature and character. The organisation may also have other - legitimate - purposes besides committing offences. A criminal/terrorist organisation's aim of committing offences does not, hence, need to be the organisation's sole objective. ${ }^{181}$

Purpose refers primarily to the organisation's purpose, and not to that of the individual members. Practically speaking, however, the organisation's purpose is inferred from that which the individual members, alone or together, do or omit to do. On the other hand, not every single piece of conduct of individual members can always be attributed to the organisation. Members may also commit offences on their own initiative, separately from their participation in offences perpetrated by the organisation. ${ }^{182}$

To determine whether the Hofstadgroep had, as nearby purpose, the perpetration of terrorist offences, the Rotterdam District Court focused on two main questions: Firstly, the question of whether (criminal) behaviour was displayed by individual group members that could contribute to and/or determine the purpose of the group as a whole; and secondly, the question of whether the group did, accordingly, aspire to commit criminal/terrorist offences. The Court examined these questions concurrently in the judgement.

First, the Court examined the question of whether the illegal possession of weapons by some members, the preparatory behaviour of Samir A., ${ }^{183}$ and the murder of Theo van Gogh by Mohammed B., could determine the organisation's intent of committing terrorist offences. In the case against Samir A., the police found, during a house search, a silencer, two cartridge clips, numerous items and materials

\footnotetext{
181 Supreme Court 26 June 1984, NJ 1985/92; Supreme Court 26 February 1991, NJ 1991/499.

182 Rotterdam District Court, 10 March 2006, LJN: AV5108, 10/000322-04, 10/000328-04, 10/000396-04, 10/000393-04, 10/000325-04, 10/000323-04, 10/000395-04, paragraphs 122-125.

183 Although Samir A. was not an accused during this trial, he was questioned as a witness concerning explosives that were found in his house during a house search.
} 
designated to manufacture explosives, and several drawings and maps of alleged targets for a terrorist attack. Samir A. was eventually convicted of the illegal possession of weapons, and of preparing a murder and preparing to carry out a deliberate arson attack and/or to cause an explosion. ${ }^{184}$ The District Court asserted that these findings could not contribute to proving the Hofstadgroep's alleged intent of committing terrorist offences, because there was no proof that Samir A.'s behaviour was more than a one-man operation.

For a member's individual behaviour to contribute to proving the organisation's alleged intent to commit criminal/terrorist offences, there must be some factual evidence demonstrating that the individual behaviour forms part of the organisation's intention. The District Court might have come to a different conclusion if other members had been involved in the manufacturing of the explosives, or when taped telephone conversations had revealed that other members were well-acquainted with, and approved of, the possession of weapons, and helped to, for example, gather the street-maps.

The same reasoning applied to Mohammed B.'s murder of van Gogh. Even though the Amsterdam District Court considered that there were some indications that Mohammed B. had been helped by other members in preparing for the murder, that allegation could not sufficiently be sustained by lawful evidence during the proceedings against the Hofstadgroep. ${ }^{185}$ There was no direct evidence to demonstrate that van Gogh's murder was jointly prepared by, or even discussed among, the members of the Hofstadgroep. ${ }^{186}$ In sum, neither Samir A.'s, nor Mohammed B.'s individual (terrorist) offences could contribute to proving the alleged intent of the Hofstadgroep's to commit criminal and/or terrorist offences.

The next question was whether the group, thus jointly, displayed behaviour that could serve as evidence of its presumed intent to commit criminal and/or terrorist offences. In answering this question, the District Court primarily focused on the Hofstadgroep's radical-extremist religious conviction. Mohammed B., for example, murdered Theo van Gogh on religious grounds. ${ }^{187}$ Samir A. testified about the Tahweed, his hatred of the democratic rule of law, the political undertone of 'his Islam', and the beauty of the violent Jihad. Ismail A. and Jason W. committed attempted murders on several police officers while exclaiming religious phrases.

\footnotetext{
184 Samir A. was not prosecuted in relation to terrorist offences as, at the time he committed these offences, the DTA had not yet entered into force. Rotterdam District Court 6 April 2005, LJN: AT3315, 10/030075-04; the Hague Court of Appeal 18 November 2005, 10-00075-04, NJ 2006/96; Supreme Court 20 February 2007, LJN: AZ0213, 00447/06; Amsterdam Court of Appeal 17 September 2007, LJN: BB3756, 23-001907-07.

185 Amsterdam District Court 26 July 2005, LJN: AU00025, 13/129227-04.

186 Rotterdam District Court 10 March 2006, LJN: AV5108, 10/000322-04; 10/000328-04; 10/00039604; 10/000393-04; 100000325-04; 10/000323-04; 10/000395-04, paragraphs 138-145.

187 See the previous paragraph for a discussion of the murder of Theo van Gogh.
} 
They testified that they found themselves in a state of religious euphoria. Nouriddin el F. testified that he bought his machine gun for religious reasons. ${ }^{188}$

In view of these statements, the District Court accepted as a fact that this group unequivocally associated its religious beliefs with obligatory practical consequences that implied, in their view, the legitimate use of violence.

During the criminal proceedings, the public prosecutor contended that each member of the Hofstadgroep adhered to this Islamic fundamentalism, and that therefore each member would ultimately commit violent offences. This line of reasoning served to demonstrate the alleged intent of the organisation to commit criminal and, foremost, terrorist offences: the Hofstadgroep-members needed to commit violent crimes in order to put into effect their religious conviction. ${ }^{189}$

The District Court agreed with the prosecutor that the organisation's joint religious beliefs, theoretically, legitimised the use of violence. That use of violence may, accordingly, have been the group's ultimate goal. However, the District Court did not agree with the argument that it could automatically be concluded that the group's common and, especially, its nearby purpose, was to prepare or commit such violent offences. To prove that, the District Court required concrete behaviour which pointed at actual preparation, or other evidence to show that the group agreed to commit these violent offences.

So, even though the District Court accepted as a fact that the group members were preparing one another for the violent Jihad, due to a lack of concrete and common preparatory acts - the planning of, for example, the murders of Hirsi Ali or Wilders - the District Court did not consider it proven, beyond reasonable doubt, that the organisation's joint purpose was to commit violent terrorist offences. ${ }^{190}$

This does not mean that the organisation was not considered to have any criminal intentions. Even though there was no evidence of the Hofstadgroep's intent to commit violent offences, the District Court concluded that the organisation's common purpose was: incitement, ${ }^{191}$ the possession and/or the distribution of inciting documents, ${ }^{192}$ inciting hatred, ${ }^{193}$ and threatening persons with terrorist

188 Rotterdam District Court, 10 March 2006, LJN: AV5108, 10/000322-04, 10/000328-04, 10/000396-04, 10/000393-04, 10/000325-04, 10/000323-04, 10/000395-04, paragraph 149.

189 Rotterdam District Court, 10 March 2006, LJN: AV5108, 10/000322-04, 10/000328-04, 10/000396-04, 10/000393-04, 10/000325-04, 10/000323-04, 10/000395-04, paragraph 154.

190 Rotterdam District Court, 10 March 2006, LJN: AV5108, 10/000322-04, 10/000328-04, 10/00039604, 10/000393-04, 10/000325-04, 10/000323-04, 10/000395-04, paragraph 155 and 156.

191 Article 131 of the DCC. Inciting is publicly provoking, stirring up or urging someone to commit any criminal offence or to act violently against the government.

192 Article 132 DCC. To constitute criminal liability it is sufficient when someone possesses these documents with the intention to distribute them outside a private circle.

193 Article 137d of the DCC. The notion of 'hate' is interpreted as a sense of deep aversion together with the desire to see a person go down with or without hurting that person. 
offences. ${ }^{194}$ The District Court cited extensively from several of these inciting documents, that had been found during house searches, on the internet, and through intercepted phone calls, and online discussion groups. ${ }^{195}$ All of these texts contained appeals to overthrow the democratic rule of law in the Netherlands, insulting language in respect of several politicians, and glorifying proclamations concerning the violent Jihad.

Furthermore, the suspects aimed at making the documents public, one of the requirements of all the above-mentioned offences, by disseminating them through the internet and marking some of the texts as 'open letters'. Also, the documents encouraged the reader to further distribute the documents to fellow believers. ${ }^{196}$ On the basis of these facts, the District Court concluded that the organisation indeed had as nearby and joint purpose, the perpetration of criminal and terrorist offences, though no serious violent offences. The organisation intended to commit the criminal and terrorist offences codified in Articles 131, 132, 137d and 285, section 3 of the DCC. Threatening with a terrorist offence, as defined under Article 285, section 3 of the DCC is - as opposed to the other enumerated offences - a terrorist offence. According to the District Court, the documents that were found demonstrated that the organisation intended to publicly threaten several politicians, with the purpose of disrupting political and constitutional structures in the Netherlands. ${ }^{197}$

In sum, the District Court required specific and concrete 'action' from within the organisation to adequately demonstrate the organisation's intentions. Those intentions could not be inferred exclusively from members' individual (terrorist) offences. Proclaiming threatening words and distributing corresponding texts about certain politicians was not indicative for a nearby terrorist murder, but it was sufficient to prove that the organisation aspired to threaten these politicians with terrorist offences, even though the threats were not issued directly, in person, against them. Clearly, the organisation's religious beliefs played a role in coming to this conclusion.

As discussed above, the Hague Court of Appeal concluded that the Hofstadgroep could not be regarded as organisation. ${ }^{198}$ This meant that the two remaining

194 Article 285, section 3 of the DCC.

195 Rotterdam District Court, 10 March 2006, LJN: AV5108, 10/000322-04, 10/000328-04, 10/000396-04, 10/000393-04, 10/000325-04, 10/000323-04, 10/000395-04, paragraphs 170-178.

196 Rotterdam District Court, 10 March 2006, LJN: AV5108, 10/000322-04, 10/000328-04, 10/000396-04, 10/000393-04, 10/000325-04, 10/000323-04, 10/000395-04, paragraph 178-187.

197 The threats that members of the Hofstadgroep issued in the written documents spoke of an intent to overthrow the democratic legal order. Rotterdam District Court, 10 March 2006, LJN: AV5108, 10/000322-04, 10/000328-04, 10/000396-04, 10/000393-04, 10/000325-04, 10/000323-04, 10/000395-04, paragraph 189 and 190.

The Hague Court of Appeal 23 January 2008, LJN: BC4171, 22001871-06; the Hague Court of Appeal 23 January 2008, LJN: BC2576, 22001897-06; the Hague Court of Appeal 23 January 
prerequisites of Articles 140/140a of the DCC, the organisation's purpose and the participatory behaviour, did not need to be discussed. 199 The Court of Appeal, however, elaborated extensively on the question of whether the group had a shared ideology. This served not only to examine whether the Hofstadgroep could be considered as organisation, but also to scrutinise whether the group had a joint purpose/intent. ${ }^{200}$

As demonstrated above, the Court of Appeal ruled that the suspects did not all adhere to the same extremist interpretation of Islam. As there was no joint adherence to this extreme form of Islam, the Court of Appeal held that there was, consequently, no joint intent of committing offences such as terrorist murder/manslaughter. In that respect, though on the basis of different reasoning, the Court of Appeal agreed with the Rotterdam District Court.

Next question was then if - despite the lack of a joint ideology - the Hofstadgroep could be considered to aspire to the perpetration of the offences, as comprised in Articles 131,132, 137d and 285 of the DCC.

On the basis of the documents found and the opinions expressed therein, the group could not be said to aspire to the perpetration of offences according to Articles 131, $132,137 \mathrm{~d}$ and 285 of the DCC. However, Mohammed B. did come within the scope of the criminal justice system when he called on his fellow believers to wage a violent and armed war against all non-believers, to kill all non-believers, and even to kill persons who merely insult Islam. Such opinions no longer fall under the protection of the right to freedom of religion/opinion, and the Court of Appeal considered such opinions. in principle, as incitement and as threatening with terrorist offences pursuant to the above mentioned provisions. However, one important prerequisite under Articles 131, 132 and 137d of the DCC is that the inciting opinions must have been voiced in public or must have been addressed to a bigger audience than merely one's fellow believers. That was not the case with respect to the opinions (written and oral) voiced by Mohammed B. He expressed his opinions mostly during gatherings with his fellow believers. Only two documents

2008, LJN: BC4129, 22001886-06; the Hague Court of Appeal 23 January 2008, LJN: BC4177, 22001864-06; the Hague Court of Appeal 23 January 2008, LNJ: BC4182, 22001863-06; the Hague Court of Appeal 23 January 2008, LJN: BC4178, 23 January 2008, 22001862-06; the Hague Court of Appeal 23 January 2008, LJN: BC4183, 22001866-06.

199 The Hague Court of Appeal explicitly balanced the need to protect public order and the democratic legal order against 'powers' which could destabilise or even destroy these values, against the protection of the right to freedom of opinion and the right to freedom of religion (Articles 9 and 19 of the ECHR), which contribute to the development of democracy and can be considered as the cornerstones of the rule of law. In the Court of Appeal's opinion, the Rotterdam District Court and the prosecution did not sufficiently balance these two (opposing) interests against each other.

200 This demonstrates that the three constituting elements of Articles 140/140a of the DCC (organisation, purpose and participatory behaviour) are closely interrelated. 
were distributed beyond the Hofstadgroep: the 'open letter' that Mohammed B. published on the internet, and the letter he left on the dead body of Theo van Gogh.

In the end this was irrelevant for two reasons: first, these were offences committed by Mohammed B., and as discussed above, offences committed by one group member cannot automatically contribute to proving the group's (terrorist/ criminal) intent. Second, following this consideration, the Court of Appeal concluded that the Hofstadgroep did not form an organisation, which made further discussion of the question of whether Mohammed B. could be prosecuted individually under Articles 131, 132 and/or 137d of the DCC irrelevant.

After the Supreme Court's judgement, the Amsterdam Court of Appeal decided that the Hofstadgroep's purpose was indeed the perpetration of several terrorist offences. ${ }^{201}$ However, there were no violent terrorist offences, such as terrorist murder, among these terrorist offences. It is important to see that the Court of Appeal explicitly emphasised - in line with the judgements of the District Court and the Court of Appeal - that extreme beliefs, as adhered to by members of the Hofstadgroep, that justify the use of violence, are not sufficient to assume that the organisation's purpose is to commit violent (terrorist) offences. To assume such a purpose, concrete steps in realising that purpose must have been taken. ${ }^{202}$

Nonetheless, the organisation did intent to commit the offences as defined in Articles 131, 132, section 1, 137d and 285 of the DCC. ${ }^{203}$

201 Amsterdam Court of Appeal 17 December 2010, LJN: BO9017, 23-000746-10, paragraph 3.2; Amsterdam Court of Appeal 17 December 2010, LJN: BO9015, 23-000750-10; Amsterdam Court of Appeal 17 December 2010, LJN: BO9014, 23-000749-10; Amsterdam Court of Appeal 17 December 2010, LJN: BO8032, 23-000747-10; Amsterdam Court of Appeal 17 December 2010, LJN: BO7690, 23-000751-10; Amsterdam Court of Appeal 17 December 2010, LJN: BO9018, 23-000748-10; Amsterdam Court of Appeal 17 December 2010, LJN: BO9016, 23-000745-10.

202 Amsterdam Court of Appeal 17 December 2010, LJN: BO9017, 23-000746-10, paragraph 3.2.1; Amsterdam Court of Appeal 17 December 2010, LJN: BO9015, 23-000750-10; Amsterdam Court of Appeal 17 December 2010, LJN: BO9014, 23-000749-10; Amsterdam Court of Appeal 17 December 2010, LJN: BO8032, 23-000747-10; Amsterdam Court of Appeal 17 December 2010, LJN: BO7690, 23-000751-10; Amsterdam Court of Appeal 17 December 2010, LJN: BO9018, 23-000748-10; Amsterdam Court of Appeal 17 December 2010, LJN: BO9016, 23-000745-10. The alleged purpose of the organisation would then be the perpetration of the offences pursuant to Articles 46, 96, 121, 122, 157, 205, 287, 289 of the DCC and Article 26 of the WAA.

203 Amsterdam Court of Appeal 17 December 2010, LJN: BO9017, 23-000746-10, paragraph 3.2.2 and 3.2.3; Amsterdam Court of Appeal 17 December 2010, LJN: BO9015, 23-000750-10; Amsterdam Court of Appeal 17 December 2010, LJN: BO9014, 23-000749-10; Amsterdam Court of Appeal 17 December 2010, LJN: BO8032, 23-000747-10; Amsterdam Court of Appeal 17 December 2010, LJN: BO7690, 23-000751-10; Amsterdam Court of Appeal 17 December 2010, LJN: BO9018, 23-000748-10; Amsterdam Court of Appeal 17 December 2010, LJN: BO9016, 23-000745-10. 
With respect to Articles 131, 132 and 137d of the DCC, the Court of Appeal argued that the organisation's purpose to commit such offences with respect to oral utterance or illustrations could only be proven if it could be determined that certain inciting statements (oral or by means of illustration) had been made in public, or were meant to be made in public, or had been possessed with the intent to distribute these further. There was no evidence that the members of the Hofstadgroep made these inciting statements public, that they were about to make them public, or intended to make them public. They were only distributed and made to members of the organisation and to some other specific individuals, not to an undefined, unrestricted mass of people. ${ }^{204}$

Nevertheless, Articles 131, 132 section 1, 137d and 285 of the DCC also apply to the inciting documents that had been found at the suspects' houses. ${ }^{205}$ The Court of Appeal considered the documents found in the possession of members of the Hofstadgroep to be threatening (with terrorist offences), as inciting the use of violence, as inciting hatred and as inciting violence. With respect to these documents, the Court of Appeal judged that they had already been partly made public/distributed beyond the organisation, and that the organisation's intention was to increasingly do so. Members of the organisation possessed these documents with the intent to further distribute them.

For Article 285, sections 2 and 3 of the DCC to be applicable, the Court of Appeal required that the threats must have been (1) sufficiently concrete and clear, (2) that the threatened persons must actually have been aware of the threats, and (3) that the threats were of such calibre that the threatened person reasonably feared that the threats would be realised, or at least that the organisation's intent was making sure that the threats would be realised. These criteria were all complied with. The threats made by the organisation's members were sufficiently concrete, and following their publication on the internet and distribution in paper form, the threatened persons actually became aware of the threats. ${ }^{206}$ These threats were,

204 Amsterdam Court of Appeal 17 December 2010, LJN: BO9017, 23-000746-10, paragraph 3.2.2.1; Amsterdam Court of Appeal 17 December 2010, LJN: BO9015, 23-000750-10; Amsterdam Court of Appeal 17 December 2010, LJN: BO9014, 23-000749-10; Amsterdam Court of Appeal 17 December 2010, LJN: BO8032, 23-000747-10; Amsterdam Court of Appeal 17 December 2010, LJN: BO7690, 23-000751-10; Amsterdam Court of Appeal 17 December 2010, LJN: BO9018, 23-000748-10; Amsterdam Court of Appeal 17 December 2010, LJN: BO9016, 23-000745-10.

205 Amsterdam Court of Appeal 17 December 2010, LJN: BO9017, 23-000746-10, paragraphs 3.2.2.2. and 3.2.2.3; Amsterdam Court of Appeal 17 December 2010, LJN: BO9015, 23-00075010; Amsterdam Court of Appeal 17 December 2010, LJN: BO9014, 23-000749-10; Amsterdam Court of Appeal 17 December 2010, LJN: BO8032, 23-000747-10; Amsterdam Court of Appeal 17 December 2010, LJN: BO7690, 23-000751-10; Amsterdam Court of Appeal 17 December 2010, LJN: BO9018, 23-000748-10; Amsterdam Court of Appeal 17 December 2010, LJN: BO9016, 23-000745-10.

206 In particular two specific documents named 'To catch a wolf' and 'Open brief aan het Nederlandse volk'. 
moreover, of such calibre that the threatened persons had reasonable feared that the threats would be realised. ${ }^{207}$

This meant that the Court of Appeal did consider the Hofstadgroep to have, as a joint and nearby purpose, the perpetration of criminal and terrorist offences.

\section{The Piranha I Judgements}

In the Piranha I case, the Rotterdam District Court did not elaborate extensively on the alleged common purpose of the group, simply because the District Court held that the group did not form an organisation. ${ }^{208}$

The Court argued that there was no proof to assume that the members of the group, jointly and in a cooperative way, aimed at inciting others to join the violent Jihad, to wage war against all unbelievers, and, in general, to act according to extreme Islam. Even though huge quantities of written documents on the violent Jihad had been found, these documents had not been exchanged, on a large scale, among members of the group, let alone without the group. The required public element was therefore lacking. The group members merely incited one another, rather than going beyond the group to convert others to join them.

On appeal, the Hague Court of Appeal elaborated considerably on the question of what the purpose was of the organisation. ${ }^{209}$ Several witnesses testified that the members of the Piranha organisation adhered to an extreme form of Islam in which there is only one possible and acceptable way of living: strict obedience to the Koran and Allah and everything associated with it. ${ }^{210}$ Any other - non-Islamic way of living, polity, authority, regulation or behaviour is automatically rejected,

207 Amsterdam Court of Appeal, 17 December 2010, LJN: BO9017, 23-000746-10, paragraphs 3.2.2.2. and 3.2.2.4; Amsterdam Court of Appeal 17 December 2010, LJN: BO9015, 23-00075010; Amsterdam Court of Appeal 17 December 2010, LJN: BO9014, 23-000749-10; Amsterdam Court of Appeal 17 December 2010, LJN: BO8032, 23-000747-10; Amsterdam Court of Appeal 17 December 2010, LJN: BO7690, 23-000751-10; Amsterdam Court of Appeal 17 December 2010, LJN: BO9018, 23-000748-10; Amsterdam Court of Appeal 17 December 2010, LJN: BO9016, 23-000745-10.

208 Rotterdam District Court 1 December 2006, LJN: AZ3589, 10/600052-05, 10/600108-05, 10/600134-05, 10/600109-05, 10/600122-05, 10/600023-06, 10/600100-06 (Piranha I case). The Hague Court of Appeal 2 October 2008, LJN: BF4814, 22-007351-06; the Hague Court of Appeal 2 October 2008, LJN: BF5180, 22-007384-06; the Hague Court of Appeal 2 October 2008, LJN: BF5225, 22-007350-06; the Hague Court of Appeal 2 October 2008, LJN: BF 3987, 2200734906. The Court of Appeal considered three of the organisation's members to be leaders (among which were probably Samir A. and Nouredin el F.). This was mainly due to the important role they played with regard to the weapon possession, the shooting practices in Amsterdam, the dissemination/promotion of the violent Jihad, and the production of a video message that was intended to be published after the murders of one or more politicians.

210 Digital documents and files and digital images were also found at the suspects' houses, demonstrating the suspects' adherence to this extreme interpretation of Islam. 
and any person who does not adhere to, and live in accordance with, this extreme interpretation of the Koran and Allah, is considered an 'unbeliever' and consequently, an enemy against whom violence may be used, and who may even be killed. No compassion is allowed with such 'unbelievers'. The Court of Appeal linked the organisation's adherence to this extreme interpretation of Islam to the shooting exercises and the possession of illegal weapons, ${ }^{211}$ and concluded that the suspects partly acted on their ideas on using violence against unbelievers. Essentially, the Court of Appeal adduced factual evidence to maintain the assumption that the organisation was using, and would increasingly use, violence to put their beliefs into practice.

The mere fact that the organisation shared a common ideology that preaches the use of violence against non-believers appeared insufficient to ascertain the organisation's purpose. Extra practical evidence was required to demonstrate that the suspects started to put these beliefs into practice. In this respect, the Court of Appeal used the following practical evidence: the suspects possessed lists containing the names of Dutch politicians, and at one suspect's house the investigative authorities found a video-taped will, in which the suspect discussed the fact that the only language between 'us' - i.e. people who adhere to extreme Islam - and 'you'i.e. unbelievers - is the 'language of weapons'. The suspect also talked about 'this deed'. In the Court of Appeal's opinion, the goal of such proclamations could not be mistaken. Furthermore, at several of the suspects' houses, documents were found demonstrating that they had as 'nearby goal' the use of violence against one or more Dutch politicians.

The Court of Appeal considered it proven beyond reasonable doubt that the organisation's members jointly aimed to prepare or to support the terrorist murder (murder/manslaughter) on one or more Dutch politicians (Article 96, section 2 of the DCC). This meant that the Piranha group had as nearby purpose the use of violence against politicians, with murder as the ultimate goal. Consequently, the organisation aspired, by means of violence against politicians who work in democratic institutions, to at least frighten part of the Dutch population and to destabilise or destroy fundamental political, economical, constitutional or social structures pursuant to Article 83a of the DCC. The Court of Appeal did not believe that the organisation aimed to cause an explosion with terrorist intent.

\section{The Piranha II Judgement}

Lastly, we look at the Piranha II judgement. ${ }^{212}$ The Rotterdam District Court underlined that seriously engaging oneself with the Koran, discussing Jihad, and

211 This was proven by the fact that weapons were circulated between suspects and in one suspect's house, the investigative authorities found a glove on which bullet remains were discovered.

212 Rotterdam District Court 25 March 2008, LJN: BC7539, 10/600112-05 and Rotterdam District Court 25 March 2008, LJN: BC7531, 10/600111-05. 
rejecting democracy and any law that does not come from Allah, is allowed within the framework of the right to freedom of expression and the right to freedom of opinion. This even goes for persons who adhere to beliefs that affect the fundament of our society - democracy and the rule of law. These freedoms are however not unlimited, the perpetration of criminal/terrorist offences - even if committed with political and/or religious motives - goes beyond the boundaries of these freedoms. The District Court considered these boundaries to be overstepped in this case.

The suspects not only adhered to these extreme beliefs, but, moreover, they purchased and transported weapons, they fired shots using one of these weapons in a forest near Amsterdam, they were continuously armed, one suspect might have been on his way to attack a politician with a loaded weapon, they possessed a (coded) list containing the names of Dutch politicians, they maintained intense contact with each other and spoke regularly about the violent Jihad, they went on trips to Tsjetsjenia to fight there, and they intended to kill several Dutch politicians.

The District Court judged all of these activities in light of the organisation's extreme beliefs, and held that the organisation's purpose was the perpetration of offences which aimed at frightening at least part of the Dutch population and destabilising or destroying fundamental political structures.

This judgement is comparable to the Piranha I judgement on appeal. Just as the Court of Appeal had done, the District Court linked the organisation's beliefs to the actual (criminal) conduct of members of the organisation. This conduct was considered as the first step taken by the organisation to put their (violent) beliefs into practice and was therefore used to determine the organisation's intent. In this respect, it was not required that all of the organisation's members adhered to the same extreme interpretation of Islam.

\subsubsection{The third requirement: Participatory behaviour}

\section{The Hofstadgroep JUdgements}

The last requirement pursuant to Article 140/140a of the DCC, is that the suspect must have factually participated in the organisation. When exactly does a person participate in a terrorist or criminal organisation? What individual behaviour is required to be held criminally liable? In this respect, it is important to note that for criminal liability under these provisions, it is completely irrelevant whether the crimes the organisation aimed to commit have already been committed, or attempts have been made, or whether only preparation or plans have been made. ${ }^{213}$

213 Rotterdam District Court 10 March 2006, LJN: AV5108, 10/000322-04, 10/000328-04, 10/000396-04, 10/000393-04, 10/000325-04, 10/000323-04, 10/000395-04, paragraph 101. See, also, Supreme Court 18 November 1997, NJ 1998/225 m.nt. JdH; Supreme Court 5 September 2006, LJN: AV4122, 01422/05. 
To be held criminally liable for participation in a criminal/terrorist organisation, two cumulative criteria need to be fulfilled: (1) the suspect must factually belong to the organisation, the so-called 'membership requirement', and (2) the suspect must participate in, or support, behaviour which serves, or is directly associated with, the purpose of committing (terrorist) offences, the so-called 'behaviour requirement' of the participant. In order to be convicted on the basis of Articles 140/140a of the DCC, the organisation's members must, as factual members, have taken part in the materialisation of the criminal/terrorist purpose of the organisation. ${ }^{214}$

Participation in a criminal/terrorist organisation presupposes an active and factual contribution to the organisation. Such a contribution does not need to be criminal in nature itself, ${ }^{215}$ but the fact that it supports the organisation in the perpetration of criminal/terrorist offences makes the group member liable for prosecution under Article 140 of the DCC. Generally, such a contribution does presuppose deliberate behaviour in the sense of 'willingly and knowingly' [onvoorwaardelijk opzet] doing something, instead of the more lenient form of dolus eventualis [voorwaardelijk opzet]. This means that for criminal liability to exist, a member of a criminal organisation must, in general, have known about the organisation's intent to commit criminal offences, which, moreover did not withhold him from, for example, financing, or otherwise actively supporting, the organisation. ${ }^{216}$

The Rotterdam District Court elaborated on the phrase 'in general have known' in the Hofstadgroep case in order to examine whether participating in a criminal organisation automatically implies participating in a terrorist organisation. In other words: Must a Hofstadgroep member, in order to be convicted for both participating in a criminal and in a terrorist organisation, have known about all the specific criminal and terrorist offences the organisation intended to commit? Or is it sufficient if that member must have known, in general, about the organisation's intent to commit criminal offences, without explicitly having known about the organisation's intent to commit terrorist offences?

The District Court followed the second interpretation. It was held to be sufficient if the organisation's member realised that there was a considerable chance that the organisation would, as well as committing common criminal offences, also move in the direction of committing terrorist offences. Members of the organisation took that chance by becoming or remaining a member of the organisation in spite of this

214 Supreme Court 16 October 1991, NJ 1991/442 m.nt. Corstens; Supreme Court 18 November 1997, NJ 1998/225; Supreme Court 5 June 2001, NJ 2001/518; Supreme Court 18 November 1997, NJ 1998/225.

215 Article 140a, section 3 of the DCC, in conjunction with Article 140, section 4 of the DCC, which criminalises the financial support of criminal/terrorist organisations.

216 Rotterdam District Court 10 March 2006, LJN: AV5108, 10/000322-04, 10/000328-04, 10/000396-04, 10/000393-04, 10/000325-04, 10/000323-04, 10/000395-04, paragraphs 191 and 195 . 
knowledge [voorwaardelijk opzet]. ${ }^{217}$ This means that the member of the organisation must know/have known about the Hofstadgroep's general intent to commit criminal offences [onvoorwaardelijk opzet], but need not have known all the specific (terrorist) offences the organisation intended to commit to be held liable under Articles 140 and 140a of the DCC. ${ }^{218}$

With regard to the members of the Hofstadgroep, the District Court assumed, without much deliberation, that all the suspects must have known about the intent to commit criminal and terrorist offences. ${ }^{219}$

The last aspect that the District Court had to examine was whether all of the suspects equally actively supported and, hence, participated, in achieving the organisation's purpose? To that effect, the District Court scrutinised each individual suspect's behaviour to examine whether it could be seen as participatory behaviour [deelnemingshandeling]. .20 $^{220}$

To begin with, the District Court distinguished between three sorts of members within the Hofstadgroep. The first kind, although they formed part of the organisation, merely attended gatherings, during which other members incited hatred and issued threats. Even though these 'passive members' belonged to the criminal and terrorist organisation, they did not actively participate in the organisation. Therefore, these members were not held to be criminally liable under Articles 140 and 140a of the DCC. For example, reading or listening to inciting and threatening texts, or possessing these texts without the intention of disseminating them, is judged as such passive behaviour, and hence, as non-participatory behaviour.

In the District Court's view, these 'passive' members did not, directly or indirectly, contribute actively to the realisation of the organisation's purpose, and were therefore 'hangers on' [meeloper] rather than participants. Suspects regarded as 'passive' members were acquitted of participation in a criminal and terrorist organisation. ${ }^{221}$

217 Rotterdam District Court 10 March 2006, LJN: AV5108, 10/000322-04, 10/000328-04, 10/000396-04, 10/000393-04, 10/000325-04, 10/000323-04, 10/000395-04, paragraph 195.

218 Rotterdam District Court 10 March 2006, LJN: AV5108, 10/000322-04, 10/000328-04, 10/000396-04, 10/000393-04, 10/000325-04, 10/000323-04, 10/000395-04, paragraph 196; Amsterdam Court of Appeal, 17 December 2010, LJN: BO9017, 23-000746-10, paragraph 3.3.2.

219 Rotterdam District Court 10 March 2006, LJN: AV5108, 10/000322-04, 10/000328-04, 10/000396-04, 10/000393-04, 10/000325-04, 10/000323-04, 10/000395-04, paragraph 198. The Amsterdam Court of Appeal based this assumption on the fact that all of the suspects possessed documents including threatening texts and texts inciting violence and hatred. Amsterdam Court of Appeal 17 December 2010, LJN: BO9017, 23-000746-10, paragraph 3.3.3. Rotterdam District Court 10 March 2006, LJN: AV5108, 10/000322-04, 10/000328-04, 10/000396-04, 10/000393-04, 10/000325-04, 10/000323-04, 10/000395-04, paragraph 199.

221 Rotterdam District Court 10 March 2006, LJN: AV5108, 10/000322-04, 10/000328-04, 10/000396-04, 10/000393-04, 10/000325-04, 10/000323-04, 10/000395-04, paragraph 200. 
The second category of members was slightly more active, but their behaviour was still too distant from actively contributing to the organisation's purpose to be held criminally liable under Articles 140/140a of the DCC. Examples of such behaviour are: occasionally driving another group member to gatherings or other locations, and letting a group member lodge in one's home, without that support being evidently linked to the organisation's intent. ${ }^{222}$

The last category of members consisted of 'active members'. These members had indeed actively contributed to the realisation of the organisation's purpose - that of committing criminal and/or terrorist offences. Active members, for example, organised gatherings during which the organisation incited hatred or issued threats; they lectured or acted as 'panel chairmen' during these gatherings; they actively proclaimed the organisation's ideology outside the organisation; they recruited people for the violent Jihad; they incited to martyrdom; they wrote, distributed and/ or translated inciting or threatening documents within and beyond the organisation through written texts or via the internet, and/or facilitated digital distribution of threatening/inciting documents by making someone member of a MSN group within which these documents were exchanged. ${ }^{223}$ All of these acts were considered to contribute directly to the perpetration of criminal and terrorist offences. ${ }^{224}$

The Hague Court of Appeal did not deem the Hofstadgroep to be an organisation (see above), which explains why the Court of Appeal did not explicitly elaborate on specific forms of participatory behaviour of the group members. ${ }^{225}$ The Court of Appeal did, however, elaborate on the role of individual group members within the group, as such, in order to provide some insight into the structure of the group.

The suspects were regarded as forming a network rather than a 'group' or 'organisation'. This network had, as a central meeting place, Mohammed B.'s house.

222 Rotterdam District Court 10 March 2006, LJN: AV5108, 10/000322-04, 10/000328-04, 10/000396-04, 10/000393-04, 10/000325-04, 10/000323-04, 10/000395-04, paragraph 202.

223 Rotterdam District Court 10 March 2006, LJN: AV5108, 10/000322-04, 10/000328-04, 10/000396-04, 10/000393-04, 10/000325-04, 10/000323-04, 10/000395-04, paragraph 203. See for an enumeration of the conduct that the District Court considered to fall within the first, second or third category of members, paragraphs 205-218.

224 Four of the suspects were deemed to be 'passive members', and were consequently acquitted; the rest were convicted of actively participating in the organisation and were sentenced to various terms of imprisonment, depending on the kind of preparatory acts they performed and the duration of their membership. See Rotterdam District Court 10 March 2006, LJN: AV5108, 10/000322-04, 10/000328-04, 10/000396-04, 10/000393-04, 10/000325-04, 10/000323-04, 10/000395-04, paragraphs 208-218.

225 The Hague Court of Appeal 23 January 2008, LJN: BC4171, 22001871-06; the Hague Court of Appeal 23 January 2008, LJN: BC2576, 22001897-06; the Hague Court of Appeal 23 January 2008, LJN: BC4129, 22001886-06; the Hague Court of Appeal 23 January 2008, LJN: BC4177, 22001864-06; the Hague Court of Appeal 23 January 2008, LNJ: BC4182, 22001863-06; the Hague Court of Appeal 23 January 2008, LJN: BC4178, 23 January 2008, 22001862-06; the Hague Court of Appeal 23 January 2008, LJN: BC4183, 22001866-06. 
It was never known in advance who would be present at the meetings and what was going on. Everybody just came when they liked, depending on time commitments and preference. Such behaviour could - in line with the Rotterdam District Court's judgement - be regarded as 'passive participatory' behaviour. It was important that nobody was obliged, in any way, to be present at meetings or on regular fixed days or times. Some members went to Mohammed B.'s house just for fun, to hang around with friends, some went there in order to discuss political or religious matters, and others went for both. During such gatherings, the members spoke about religion, about politics and about everyday things. Sometimes, members took notes on what was being said, and on some occasions written documents were exchanged. There was no intention, however, to disseminate these documents publicly.

These considerations led the Court of Appeal (as extensively discussed above) to conclude that the Hofstadgroep could not be regarded as an organisation. However, if the Court of Appeal had considered the suspects as forming an organisation, their individual behaviour would most likely have been defined as mere passive/hanger on behaviour rather than active. Important, in that respect, was that individual criminal responsibility for specific criminal/terrorist offences of group members (as of Mohammed B. and Nouriddin el F.), was not used as a foundation for considering them as active group members within the group. What was required was an active contribution to the materialisation of the organisation's common purpose rather than merely committing individual criminal/terrorist offences that did not necessarily contribute to this.

After the Supreme Court's judgement, the Amsterdam Court of Appeal dealt extensively with the individual behaviour of each of the suspects. ${ }^{226}$ First of all, the Court of Appeal emphasised that participatory behaviour included behaviour, which, as such, did not consist of criminal acts. This meant that, for example, inciting others, through online discussion groups, to join the armed conflict, glorifying or inciting others to join the violent Jihad or to become martyrs, or disseminating audio data/footage comprising threats or images of terrorist suicide bombings, all constituted behaviour that was important in answering the question of whether a suspect actually participated in a terrorist/criminal organisation. ${ }^{227}$

226 Amsterdam Court of Appeal 17 December 2010, LJN: BO9017, 23-000746-10; Amsterdam Court of Appeal 17 December 2010, LJN: BO9015, 23-000750-10; Amsterdam Court of Appeal 17 December 2010, LJN: BO9014, 23-000749-10, Amsterdam Court of Appeal 17 December 2010, LJN: BO8032, 23-000747-10, Amsterdam Court of Appeal 17 December 2010, LJN: BO7690, 23-000751-10, Amsterdam Court of Appeal 17 December 2010, LJN: BO9018, 23-000748-10, Amsterdam Court of Appeal 17 December 2010, LJN: BO9016, 23-000745-10.

Amsterdam Court of Appeal 17 December 2010, LJN: BO9017, 23-000746-10, paragraph 3.3.4; Amsterdam Court of Appeal 17 December 2010, LJN: BO9015, 23-000750-10; Amsterdam Court of Appeal 17 December 2010, LJN: BO9014, 23-000749-10; Amsterdam Court of Appeal 17 December 2010, LJN: BO8032, 23-000747-10; Amsterdam Court of Appeal 17 December 2010, LJN: BO7690, 23-000751-10; Amsterdam Court of Appeal 17 December 2010, LJN: 
Provided that the suspect formed part of the organisation and knew, in general, about the organisation's intent of committing criminal/terrorist offences, the Court of Appeal considered the following as constituting participatory behaviour:

1. Repeatedly attending gatherings of the organisation;

2. Organising or facilitating such gatherings;

3. Acting as a leader/panel chairman during gatherings;

4. Writing/drafting/translating/editing inciting or threatening texts/documents/data or texts/documents/data that incites hatred or violence;

5. Distributing within or beyond the organisation such texts/documents/data, or planning to do so;

6. Facilitating the digital distribution or other use of such texts/documents/data, including making other members of the organisation members of an MSN group or repairing their computers;

7. Receiving and saving or storing the abovementioned texts/documents/data, in combination with attending gatherings;

8. Recruiting others for the armed struggle, glorifying or inciting others to join the violent Jihad or to become martyrs or broadcasting audio material including such summons;

9. Showing footage that is linked to the violent Jihad, and which shows how people have been killed/carry out suicide attacks. ${ }^{228}$

All of the suspects were judged to have participated in the organisation by means of one or more of the above described behaviours. This interpretation of participatory behaviour is considerably broader than the one developed by the Rotterdam District Court. In particular the conduct defined under 1, 5, 6 and 7 does not necessarily and directly contribute to the organisation's purpose of committing terrorist/criminal offences. Such conduct undeniably resembles the preparatory conduct criminalised in Article 96, section 2 of the DCC. It is most likely that the Rotterdam District Court and the Hague Court of Appeal would have considered such behaviour to be insufficiently 'active' to actually contribute to the fulfilment of the organisation's purpose.

BO9018, 23-000748-10; Amsterdam Court of Appeal 17 December 2010, LJN: BO9016, 23-000745-10.

228 Amsterdam Court of Appeal 17 December 2010, LJN: BO9017, 23-000746-10, paragraph 3.3.4; Amsterdam Court of Appeal 17 December 2010, LJN: BO9015, 23-000750-10; Amsterdam Court of Appeal 17 December 2010, LJN: BO9014, 23-000749-10; Amsterdam Court of Appeal 17 December 2010, LJN: BO8032, 23-000747-10; Amsterdam Court of Appeal 17 December 2010, LJN: BO7690, 23-000751-10; Amsterdam Court of Appeal 17 December 2010, LJN: BO9018, 23-000748-10; Amsterdam Court of Appeal 17 December 2010, LJN: BO9016, 23-000745-10. 


\section{The Piranha I Judgements}

In the Piranha I case, the Rotterdam District Court ruled that the Piranha group did not to form an organisation pursuant to Article 140/140a of the DCC. ${ }^{229}$ Nevertheless, the District Court did elaborate on the different roles, hence the potential participatory behaviour, of the group members. If the group had been deemed to be an organisation, two of the seven suspects would have been considered as 'leaders', and consequently, as active members.

These two suspects not only glorified the violent Jihad against all unbelievers ${ }^{230}$ and aimed to completely implement the Thaweed, but they also put their beliefs into practice by distributing written documents that called for others to join them. In addition, these written documents were used to insult and to threaten others (unbelievers) with terrorist offences. One of these two leaders was, moreover, the 'director' of the 'Lions of the Thaweed' website, which was considered as insulting, threatening and inciting. The District Court did not further elaborate on the specific role of other members of the Piranha group. These other members were, however, convicted of preparatory behaviour pursuant to Article 96, section 2 of the DCC. ${ }^{231}$

The Hague Court of Appeal, who did consider the suspects as forming an organisation, examined in great detail, the various activities of the seven suspects. ${ }^{232}$ Like the judgement of the Rotterdam District Court in the Hofstadgroep case, a distinction was made between members who committed participatory acts and members who merely 'hung on' or had passively joined the organisation. The Hague Court of Appeal emphasised that criminal liability under Articles 140/140a of the DCC required some form - even though of minor factual importance - of active conduct. This included convincing others to join the organisation, possessing and/or using weapons, possessing or distributing inciting, threatening or insulting written documents, or, in any other active way, contributing to realisation of the organisation's purpose.

\footnotetext{
229 Rotterdam District Court 1 December 2006, LJN: AZ3589, 10/600052-05, 10/600108-05, 10/600134-05, 10/600109-05, 10/600122-05, 10/600023-06, 10/600100-06 (Piranha I case).

230 Unbelievers are those who do not adhere to the extreme Jihadistisch-salafistisch beliefs. These persons should be converted or, if that does not work, 'prosecuted' or killed.

231 See section 6.1.1 on conspiracy pursuant to Article 96 of the DCC. This judgement demonstrates clearly how Article 96, section 2 of the DCC serves as 'safety net' under Articles 46 of the DCC and Articles 140/140a of the DCC. The burden of proof, in respect of the latter two provisions, is more demanding than in respect of preparatory behaviour under Article 96, section 2 of the DCC.

232 The Hague Court of Appeal 2 October 2008, LJN: BF4814, 22-007351-06; the Hague Court of Appeal 2 October 2008, LJN: BF5180, 22-007384-06; the Hague Court of Appeal 2 October 2008, LJN: BF5225, 22-007350-06; the Hague Court of Appeal 2 October 2008, LJN: BF 3987, 2200734906.
} 
The Court of Appeal considered the leading members of the organisation as 'active' members: they lectured others on the violent Jihad and the implementation of the Tahweed and they held private inciting conversations with others over the internet. These leaders also tried to convince others to join the violent Jihad through the use of films depicting, among others, the decapitation of unbelievers and by showing them weapons. In addition, they convinced others to join them in the shooting exercise and to assist them with more practical matters (transport, searching an apartment in Belgium and the transporting weapons). As mentioned above, one of the leaders made a video-taped will.

Another member of the organisation was considered as active member due to the fact that she had asked her sister - who worked in a pharmacy - to provide her with the names, addresses and phone numbers of several Dutch politicians. While doing so, she was well aware of the fact that the organisation possessed weapons, and she adhered to the same extreme religious beliefs. In the latter respect, she even functioned as a mediator between the men of the organisation and the women who also formed, albeit passively, part of the organisation. Furthermore, this suspect participated in the shooting exercises, repeatedly transported weapons to and from Belgium, and drove back and forth to Belgium with other members, among who the two leading members. The Court of Appeal held these activities as directly contributing to the realisation of the organisation's purpose - that of committing criminal/terrorist offences.

Another member was deemed to be an active member because he pressured two persons - witnesses - to provide factual services to the organisation that were of key-importance to the successful functioning of the organisation. In addition, this member had hidden weapons in the basement of his apartment.

\section{The Piranha II Judgement}

Lastly, the Piranha II judgement. ${ }^{233}$ The considerations regarding the participatory behaviour of the suspects in this judgement are comparable to the judgement of the Hague Court of Appeal in the Piranha I case. The Rotterdam District Court considered the combination of; (1) adhering to, or at least knowing about the adherence of other members, to an extremely radical interpretation of the Koran; and (2) specific conduct contributing to the realisation or facilitation of the organisation's purpose, as sufficient to be regarded as participatory behaviour. This conduct included participating in shooting exercises, possessing and transporting weapons, and possessing weapons while allegedly being en route to Dutch politicians.

233 Rotterdam District Court 25 March 2008, LJN: BC7539, 10/600112-05; Rotterdam District Court 25 March 2008, LJN: BC7531, 10/600111-05. 


\subsection{Training for terrorism and preparation for a terrorist offence}

In 2010 the Act on the Penalisation of Participation in a Terrorism Training Camp and Collaboration in Training for Terrorism entered into force ('the Act') [Wet tot strafbaarstelling van het deelnemen en meewerken aan training voor terrorisme]. This act introduced Articles $83 \mathrm{~b}$ and $134 \mathrm{a}$ into the DCC, provisions which primarily serve to reinforce the ways of preventing terrorism. ${ }^{234}$ The criminalisation of collaboration in training for terrorism is an implementation of Article 7 of the 2005 European Convention for the Prevention of Terrorism ('the Convention'), and of Article 1 of the Council Framework Decision of 2008 amending Framework Decision 2002/475 on combating terrorism ('FD 2008'). ${ }^{235}$ The criminalisation of participation in a terrorism training camp serves to adopt a motion proposed by a Member of Prliament in 2005. ${ }^{236}$

Because this act only entered into force in 2010, there is no case law on the above-mentioned provisions. Therefore this section will merely describe the scope of, and rationale behind, Articles $83 \mathrm{~b}$ and 134a of the DCC.

In the explanatory memorandum of the Act, the government argued that the scope of Articles 96, 140a and 46 of the DCC was still insufficient to adequately prevent terrorism. This was specifically the case with regard to persons who (intend to) participate in a terrorist training camp, within the framework of an intended terrorist attack, but who do not form part of an organisation. Such persons would not, in the Minister of Justice's opinion, unequivocally and/or sufficiently clearly be criminally liable pursuant to the above-mentioned provisions. To fill in this gap and to provide more clarification in this respect, the government included Articles 134a and Article $83 \mathrm{a}$ in the DCC. ${ }^{237}$ In that respect, these provisions are - aside from a mandatory implementation of the Convention and the FD 2008 - a clear illustration

234 Staatsblad 2009, 245 and Staatsblad 2010, 139. See, also, Kamerstukken II 2007/08, 31386 , no. 3, p. 4. The Act also includes several other amendments to the DCC and to the DCCP. These amendements will not, however, be discussed. See Noyon/Langemeijer/Remmelink Strafrecht, commentaar op artikel 134a Wetboek van Strafrecht, aantekening 1 tot en met 5 (prof. mr. J.W. Fokkens).

235 Tractatenblad 2006, 34. Article 7 of the Convention specifies that 'for the purposes of this Convention, 'training for terrorism' means to provide instruction in the making or use of explosives, firearms or other weapons or noxious or hazardous substances, or in other specific methods or techniques, for the purpose of carrying out or contributing to the commission of a terrorist offence, knowing that the skills provided are intended to be used for this purpose.' The Council Framework Decision 2008/919/JHA of 28 November 2008 amending Framework Decision 2002/475/JHA on combating terrorism (OJ L 330, 9.12.2008, pp. 21-23). Article 1, under c specifies that 'training for terrorism' shall mean providing instruction in the making or use of explosives, firearms or other weapons or noxious or hazardous substances, or in other specific methods or techniques, for the purpose of committing one of the offences listed in Article 1(1)(a) to (h), knowing that the skills provided are intended to be used for this purpose.' Kamerstukken II 2004/05, 29 754, nr. 13; Kamerstukken II 2005/06, 29 754, nr. 60.

237 Kamerstukken II 2007/08, 31 386, no. 3, p. 5-6. 
of the tendency within the Dutch criminal justice system to criminalise behaviour early on in the pro-active phase, specifically when it regards terrorism.

Article $83 \mathrm{~b}$ of the DCC enumerates the offences that serve to prepare or facilitate terrorist offences. ${ }^{238}$ It is important to note that these offences are not terrorist offences, but common criminal offences committed with the intent to prepare or facilitate terrorist offences - not being preparation pursuant to Article 46 of the DCC. If a person commits a common offence, such as forgery or fraud, with the intent of preparing or facilitating a terrorist offence, that intent increases the penalty of the common offence. For example, common theft carries a penalty of 4 years imprisonment under Article 310 of the DCC. Theft committed with the intent of preparing or facilitating a terrorist offence pursuant to Article 311, section 1 under 6 of the DCC carries a penalty of six years imprisonment.

Some of the offences included in Article 83b of the DCC were introduced in the DCC by means of the DTA. ${ }^{239}$ However, the Act expanded this list considerably, and collected together all of the offences that may be committed with the intent of preparing or facilitating a terrorist offence in Article 83b of the DCC.

Article 134a of the DCC criminalises participation in a terrorism 'training camp and collaboration in training for terrorism'. However, the notion of 'training camp' and that of 'training' have not been included literally in the provision. ${ }^{240}$ The scope of Article 134a of the DCC is therefore considerably broader than it appears at first sight.

It criminalises (1) anyone who deliberately provides or attempts to provide himself or someone else the opportunity, means or information to (a) commit a terrorist offence, or (b) to commit an offence to prepare or facilitate a terrorist offence; or (2) anyone who obtains or imparts to someone else knowledge or skills to that effect. The penalty for this offence is eight years imprisonment. This penalty was not chosen randomly, as the use of extensive special investigation techniques, such as the one codified in Article 1261 of the DCCP, is only allowed to investigate offences that carry a penalty of at least eight years imprisonment.

238 The following Articles comprise offences that serve to prepare or facilitate terrorist offences: Articles 131, section 2, 132, section 3, 205, section 3, 225, section 3, 285, section 4, 311, section 1 under 6,312 , section 2 under 5, 317, section 3 in conjunction with 312, section 2 under 5, 318, section 2, 322a, 326, section 2 and 354a of the DCC.

239 Articles 312, section 2 under 5, Article 317 and Article 225 of the DCC and several special offences comprised in among others the AEO.

240 The elements of Article 134a of the DCC are to make all conduct that may fall under the heading of 'training-camp' or 'training' liable to punishment. The government accordingly chose to provide for a broad implementation of the above-mentioned international obligations to criminalise collaboration and participation in training for terrorism. See Kamerstukken II 2008/09, 31 386, nr. 8, p. 4. 
It is important to underline that Article 134a of the DCC relates to: (1) the terrorist offences comprised in Article 83 of the DCC, and (2) to the common criminal offences committed with the intent to prepare or facilitate terrorist offences pursuant to Article $83 \mathrm{~b}$ of the DCC. ${ }^{241}$ According to the government, the suspect's intentions may be demonstrated by means of his background, including, for example his hatred of the Western world, his fascination with terrorist violence or the radicalisation process he underwent, or by means of the nature or the character of the 'training.' ${ }^{242}$ The parliamentary memoranda furthermore demonstrate that training may include taking shooting or flying lessons or learning martial arts, but may also comprise the acquisition of specific language skills. ${ }^{243}$ Article $134 \mathrm{a}$ of the DCC also includes acquiring knowledge or skills through the internet. The period during which a person has participated in a terrorism 'training camp' or collaborated in 'training for terrorism', is irrelevant. ${ }^{244}$

The scope of the concept of training for terrorism as defined in the DCC, is considerably broader than as prescribed by the abovementioned Convention and the FD 2008. This means that in that respect, criminal liability may go beyond what has been imposed by Article 7 of the Convention and by Article 1 of the FD 2008 . As to the practical scope of Article 134a and Article 83b of the DCC, it remains to be seen how the investigative authorities will apply these provisions and how the judiciary will judge on that application. It may however be accepted as a fact that these provisions considerably expand the scope of inchoate common offences which relate to terrorism. In this respect it is important to note that the government considers that a person's intent of preparing/facilitating a terrorist offence can be deduced from his adherence to an extreme mental legacy only. Factual evidence does not seem to be required to that effect.

\section{The PRINCIPLE OF LEgALiTY WITHIN THE DUTCH LEGAl SYSTEM}

\subsection{Introduction}

During the preparatory work for the DTA, the Minister of Justice at the time, Donner, expressed the following point of view:

'The more precise and restrictive penal clauses are, the less suited they will appear at the moment they are needed. 245

241 Kamerstukken II 2007/08, 31 386, nr. 3, p. 8.

242 Kamerstukken II 2008/09, 31 386, nr. 8, p. 6

243 Kamerstukken II 2008/09, 31 386, nr. 12, p. 4.

244 Kamerstukken II 2008/09, 31 386, nr. 8, p. 5; Kamerstukken II 2007/08, 31 386, nr. 3, p. 5-6.

245 Handelingen II 2003-2004, p. 2338. 
The Minister expressed this opinion during a public discussion about Dutch preventive anti-terrorism policy. Prior to this, he had underlined that prevention is the central goal of Dutch anti-terrorism policy. Therefore, as he asserted, one cannot act with restraint during a criminal investigation into terrorism. ${ }^{246}$ In his opinion, this means: (1) that the (investigative) authorities must have sufficient powers at their disposal, powers which should, moreover, be used following less (convincing) information, and (2) that criminal law provisions should not be too precise, and hence restrictive. In the foregoing, the broad definition of terrorist offences pursuant to Articles 83 and $83 \mathrm{a}$ of the DCC has been discussed. Extended powers for the investigative authorities in the case of criminal investigations into terrorism will be discussed in Chapters V to VII. At this point it is important to realise that one of the government's reasons for not further clarifying the notion of terrorist offence was to make sure that the investigative authorities have, at their disposal, all powers they need during a criminal investigation to prevent alleged terrorism. Hence, when it regards terrorism, broadening (substantive) criminal law provisions partly serve to extend the scope of procedural powers.

This chapter elaborates on the principle of legality. Vaguely edited criminal law provisions may interfere with, or even violate, the principle of legality. This cornerstone principle of any democratic society states, in general terms, that no person may be punished for an act that was not a criminal offence at the time of its commission: nullum crimen, nulla poena sine praevia lege poenali (no crime can be committed, nor punishment imposed without a pre-existing penal law). ${ }^{247}$ The maxim is sometimes split into three parts: (1) nulla poena sine praevia lege, (2) nulla poena sine crimine and (3) nullum crimen sine poena legali. ${ }^{248}$ Regardless of how exactly the principle is phrased or summarised, it all comes down to the dictum that nobody may be implicated in a criminal investigation, prosecuted or punished, for behaviour that was not criminalised in law, prior to the commission thereof.

Fletcher formulates several functions attached to the principle of legality that underline its importance within the criminal justice system. First, he mentions the protective function: citizens are protected against an aggressive state that will invariably seek to impose its (arbitrary) will on its subjects. The procedures for decentralised power contribute to the security of citizens against the state. The other side of this argument is then, obviously, that the criminal justice system serves as legal basis for the government to prosecute, convict and punish perpetrators. In this latter sense, the principle of legality serves as instrument for the state to enforce criminal law. Third, in a world of moral disagreement, citizens must be told, in

\footnotetext{
246 Handelingen II 2003-2004, p 2338.

247 See Paul Johan Anselm Ritter von Feuerbach, Lehrbuch des gemeinen in Deutschland gültigen peinliches Rechts, 1801.

248 See Paul Johan Anselm Ritter von Feuerbach, Lehrbuch des gemeinen in Deutschland gültigen peinliches Rechts, 1801.
} 
advance, whether particular forms of conduct will trigger criminal sanctions or not. This function refers to the prevention of criminal behaviour: people must know which behaviour leads to criminal liability in order to behave in accordance with norms and standards comprised in the substantive criminal justice system. And last, the rule of advanced legislative warning serves to bind the judges against zealous decision-making. Fletcher argues that if judges must justify their decisions in the language of enacted rules, shared by the community as a whole, they are less likely to act in 'idiosyncratic ways'. 249

Cleiren distinguishes between an instrumental function and a protective function attached to the principle of legality. The first enables the state to investigate, prosecute and punish persons who commit criminal offences. The second assures that civilians are protected against (arbitrary) state intervention: the principle guarantees that civilians will not be prosecuted or punished for behaviour which was not criminalised at the time of its commission. ${ }^{250}$

Kelk distinguishes between three 'dimensions' attached to the principle of legality: (1) the constitutional dimension, (2) the protective [rechtsbescherming] dimension, and (3) the general-preventive dimension. ${ }^{251}$ The first dimension implies that the principle of legality attributes power to the state, and authority to the Executive, to be used without overstepping the balance of powers [trias politica], all in order to implement/apply criminal law. ${ }^{252}$ This is also considered as the instrumental character of the (any) criminal justice system. In that perspective, criminal law is simply seen as a system to trace, prosecute, convict and punish persons who do not behave in accordance with norms/standards comprised in the substantive criminal law system. The protective dimension assures legal certainty and equality for citizens. The principle of legality requires that all state powers are clearly laid down in laws. These laws prescribe exactly when, under which circumstances, and how, the Executive may interfere with citizens' rights in order to enforce the criminal law. This dimension is naturally closely linked to the constitutional dimension, only the perspective differs. In that view, the principle of legality provides 'tools' for states to enforce the criminal law on the one hand, and on the other, it ensures that citizens are protected against arbitrariness and legal uncertainty. So, powers for the

249 See G.P. Fletcher, Basic Concepts of Criminal Law, New York Oxford University Press 1998, p. 207. See, for a elaborate discussion of the principle of legality in the field of criminal law, E. Claes, Legaliteit en rechtsvinding in het strafrecht. Een grondslagentheoretische benadering, Universitaire Pers Leuven, 2003.

250 See C.P.M. Cleiren, 'Het legaliteitsbeginsel', in C.P.M. Cleiren, Th. A. de Roos, M.A.H. van der Woude, Jurisprudentie Strafrecht Select, Sdu Uitgevers Den Haag 2006, p. 236; C.P.M. Cleiren J.F. Nijboer, Tekst en Commentaar Strafrecht, Kluwer Deventer 2008, pp. 5-12.

251 C. Kelk, Studieboek Materieel Strafrecht, Kluwer Deventer 2005, $3^{\text {rd }}$ edition, pp. 77 and further.

252 Compare with Supreme Court 18 September 2001, LJN: AB1471, 00749/01 CW 2323, paragraph 16. 
state presuppose, at the very same time, protection for citizens against arbitrary application of these powers. ${ }^{253}$

The general preventive dimension connects the first and second dimension. It aims to keep potential perpetrators from committing criminal acts through the deterrent function of the criminal justice system. From this perspective, the principle of legality also serves to prevent people from taking matters into their own hands [eigenrichting] which, in the sense of legal doctrine, refers to individuals enforcing their rights without resorting to legal writ or consultation with a higher authority. Specifically concerning terrorist offences, one has to keep in mind that it is highly unlikely that terrorists will be kept from committing terrorist offences due to the criminalisation of these offences. Other (common) crimes committed with, for example, emotional motives, such as a crime of passion, are equally hard to prevent through codification of criminal behaviour. The general preventive dimension will therefore not be further discussed in this writing.

Both the protective function and the instrumental function of the principle of legality are, however, very important. As mentioned before, the Dutch government primarily shows an interest in the instrumental function when it comes to countering terrorism. The question is, however, whether the principle of legality also still offers protection to citizens during the state's endeavour to prevent terrorism - among others - through the extension of criminal liability for terrorist offences.

In the upcoming sections, the principle of legality, as interpreted within the Dutch legal system,will be discussed. The principle of legality is comprised in Article 1 of the DCC and Article 16 of the Dutch Constitution. The case law that is discussed in the following sections will demonstrate that even though the principle of legality has been codified, in practice this principle does not appear to have an actual purport in the context of the criminal justice system. ${ }^{254}$

Within the Dutch legal system, the principle of legality is supposed to comprise the following aspects: (1) the prohibition of vague and unclear (local) criminal law provisions [lex certa, bepaaldheidsgebod], (2) the prohibition of applying customary law, (3) the prohibition of applying criminal law by analogy and (4) the prohibition

253 See R. Foqué and A.C. 't Hart, Instrumentaliteit en rechtsbescherming, Gouda Quint, 1990; A.A.G. Peters, Het rechtskarakter van het strafrecht, inaugurele rede Utrecht, Deventer Kluwer 1972.

254 See, in this respect, the annotation of J.M. Reijntjes (paragraph1 and 2) with Supreme Court 18 September 2001, LJN: AB1471, 00749/01 (Bouterse); W.J.M. Voermans, M.J. Borgers, C.H. Sieburgh, Controverses rondom legaliteit en legitimatie, Handelingen Nederlandse JuristenVereniging 141e jaargang/2011-1, p. 156; T. Spronken, 'De communicatieve strafrechter', in NJB 2011/1128; T. Spronken, 'De politierechtbank of: waar blijft de rechter?', in NJB 2011/1126; A.A. Franken, 'Casuïstiek en legaliteit in het materieel strafrecht', in Delikt en Delinkwent 2006, 67. 
of applying criminal law retrospectively to the detriment of the suspect. ${ }^{255}$ These four aspects will now be discussed in greater detail.

In the next section (8), the principle of legality is discussed on the basis of the ECtHR's case law regarding Article 7 of the ECHR.

\subsection{The lex certa prerequisite}

The lex certa prerequisite [bepaaldheidsgebod] requires criminal law provisions to be sufficiently clear in order for citizens to behave in accordance with the norms and standards underlying these provisions. Behaviour for which one may be held criminally liable should be defined as unambiguously as possible in criminal law provisions.

In practice, this aspect of the principle of legality appears to be difficult to comply with. Many criminal law provisions are broad, due to the open and ambiguous norms and notions they comprise. Let me give some examples: terrorist intent (Article 83a of the DCC), indecent assault (Article 239/246 of the DCC), behaving in contravention to public decency, behaving offensively, rape (Article 242 of the DCC), theft (Article 310 of the DCC) or guilt (Article 307 of the DCC). These notions often constitute the principal part of a criminal law provision. Further explanation and interpretation (primarily by the Judiciary) is required to clarify the scope of the criminalised behaviour. Even after judicial clarification, the scope of many criminal law provisions remains unclear and is dependent on the specific circumstances of the case and on the societal, technical, political or cultural state of affairs.

Obviously, these latter aspects also play an important role with respect to antiterrorism legislation. The more fuss there is about terrorism, the more keener the prosecution will be to interpret and apply the DTA as broadly as possible. In addition, substantive anti-terrorism legislation is complex because it comprises and refers to various different laws/regulations. Consequently, the precise scope of the criminalised behaviour becomes uncertain. ${ }^{256}$ Furthermore, the broad spectrum of inchoate terrorist offences and inchoate common criminal offences that serve to prepare or facilitate terrorist offences may undermine the lex certa prerequisite. An example is the above-mentioned possibility of criminal liability in respect of the preparation of conspiracy to commit a terrorist offence. ${ }^{257}$ I will further elaborate on this issue below.

255 C.P.M. Cleiren and J.F. Nijboer, Strafrecht Tekst \& Commentaar, Kluwer Deventer 2008, 7de druk, pp. 5-12.

256 See J. de Hullu, Materieel Strafrecht: Over algemene leerstukken van strafrechtelijke aansprakelijkheid naar Nederlands recht, vierde druk, Kluwer Deventer 2009, p. 101-103. See, Supreme Court 1 July 1996, DD 96, 364.

257 See the preceding sections regarding the meaning of 'terrorist intent' and the scope of the conspiracy provisions. 
To clarify ambiguous criminal law provisions, the Judiciary may use (a combination of) five different methods of interpretation: interpretation according to the grammatical/linguistic method, interpretation using the (legal) history of a criminal law provision, interpretation taking into account the (legal) system, interpretation in consonance with the societal function of the provision, or interpretation in accordance with the goal/purport of the provision. ${ }^{258}$ At this point I will not elaborate further on these four methods of interpretation. ${ }^{259}$

\section{CASE LAW ON THE LEX CERTA REQUiREMENT}

Most judgements regarding the principle of legality concern the lex certa prerequisite. Accused complain about excessively vague and ambiguous criminal law provisions on the basis of which they are nevertheless convicted and sentenced.

Several recent judgements regarding the lex certa prerequisite concern a local regulation/ordinance which prohibits certain - explicitly identified - youngsters from gathering in public in groups of more than 5 persons [samenscholingsverbod]. ${ }^{260}$

Two requirements must be fulfilled in order to be convicted and punished on the basis of these regulations: (1) a person must gather in public in a group of more than five persons, and (2) the group must display conduct which poses a threat to public order, or which directly disrupts public order.

Even though the concept of 'gathering in public' is not unequivocal in respect of its possible interpretation, the Judiciary does not consider it, in principle, to be in conflict with the principle of legality. According to the Utrecht District Court, the phrase must be explained and interpreted according to its use in lay language and in accordance with the purport of the underlying norm. ${ }^{261}$

258 See C. Kelk, Studieboek Materieel Strafrecht, Kluwer Deventer 2005, $3^{\text {rd }}$ edition, p. 87; Losbladige Melai, aantekeningen bij artikel 1 Wetboek van Strafrecht - Supplement 143 (August 2008), pp. 1-20-24 until 1-31. See, also, Supreme Court 21 January 1929, NJ 1929, p. 709; Supreme Court 27 June 1898, W 7146; Supreme Court 28 February 1956, NJ 1956/204; Supreme Court 10 May 1955, VR 1955/69; Supreme Court 22 June 1954, NJ 1954/477; Supreme Court 15 November 1843, NJ 1944/186; Supreme Court 31 March 1953, NJ 1953/493; Supreme Court 18 February 1969, NJ 1970/31; Supreme Court 1 March 1955, NJ 1956/2.

259 For more information regarding methods of interpretation within the Dutch criminal justice system see losbladige Melai, aantekening en bij artikel 1 Wetboek van Strafrecht - Supplement 121 (februari 2003)/Supplement 143 (August 2008), pp. 1-20-24-1-38-42.

260 Utrecht District Court 13 February 2008, LJN: BC4202, 16/436625-07; Utrecht District Court 13 February 2008, LJN: BC4162, 16/436623-07; Utrecht District Court 13 February 2008, LJN: BC4161, 16/436624-07; Utrecht District Court 13 February 2008, LJN: BC4155, 16/436713-07; Utrecht District Court 13 February 2008, LJN: BC4156, 16/436459-07; Utrecht District Court 13 February 2008, LJN: BC4158, 16/436458-07; Utrecht District Court 13 February 2008, LJN: BC4152, 16/436712-07.

261 Utrecht District Court 13 February 2008, LJN: BC4202, 16/436625-07; Utrecht District Court 13 February 2008, LJN: BC4162, 16/436623-07; Utrecht District Court 13 February 2008, LJN: BC4161, 16/436624-07; Utrecht District Court 13 February 2008, LJN: BC4155, 
Nevertheless, in several of these cases the Burgomaster did not require the youngsters to pose a threat to public order or to disrupt public order to be held criminally liable. Hence, these youngsters were then merely convicted for gathering in public, regardless of their (threatening) behaviour. According to the Judiciary, such an application of the material provision was too broad and violated the right to freedom of movement without sufficient justification. The judiciary did not, however, explicitly judge the provision to be in violation of the principle of legality.

Hence, the provision regarding samenscholing was not considered contrary to the principle of legality per se, but the Burgomaster's extensive application of the provision was considered to go beyond the norm underlying the provision, and subsequently violated the youngsters' right to freedom of movement. Even though the Burgomaster applied the material criminal law provision broadly, the conduct the youngsters had displayed in these cases was considered to fall under the heading of samenscholing.

The Arnhem Court of Appeal has asserted in this respect, that disruption of public order is an open norm/notion and may occur in different forms. ${ }^{262}$ Various types of behaviour may be considered as disrupting/disturbing public order. This inevitably implies that samenscholing is a vague concept that requires further clarification in case law. The Arnhem Court of Appeal does not consider that vagueness to be in violation of the principle of legality. To that effect, the Court of Appeal underlined that the suspect had been informed of the fact that it was prohibited for him to gather with more than four other people in a certain area of Utrecht. Therefore, it must have been unmistakably clear to him how to avoid criminal liability, even though the local regulation comprised a broadly defined criterion. ${ }^{263}$

The Supreme Court also considers the notion of samenscholing to comply with the lex certa prerequisite. ${ }^{264}$ Just as with the Arnhem Court of Appeal, the Supreme Court has ruled that samenscholing may occur in so many different forms that a certain vagueness in the wording of the criminal law provision is inevitable. Furthermore, the Supreme Court emphasised that it was sufficiently explained to the suspect, among others in the memorandum with the law, what precise behaviour would lead to prosecution.

16/436713-07; Utrecht District Court 13 February 2008, LJN: BC4156, 16/436459-07; Utrecht District Court 13 February 2008, LJN: BC4158, 16/436458-07; Utrecht District Court 13 February 2008, LJN: BC4152, 16/436712-07.

Arnhem Court of Appeal 1 October 2008, LJN: BF3946, 21-001061-08. See, for a judgement in which this was not the case, the Hague District Court 19 February, Nieuwsbrief Strafrecht 2004/139.

Supreme Court 28 May 2002, LJN: AE1511, 01569/01; Supreme Court 28 May 2002, LJN: AE1490, 01549/01; Supreme Court 28 May 2002, LJN: AE1494, 01552/01. 
Vagueness in criminal law provisions, in order to effectively counter certain criminal behaviour, is quite openly accepted in the Dutch criminal justice system. ${ }^{265}$ According to the Judiciary, various criminal law provisions have to be phrased in somewhat vague terms, for otherwise, the prosecution and punishment of perpetrators would become impossible. On the other hand, the Judiciary does require the norm/standard underlying the criminal law provisions to be sufficiently clear for citizens to avoid prosecution and subsequent criminal liability.

So, on the one hand the Judiciary acknowledges that criminal behaviour cannot always be criminalised without using vague/ambiguous standards, ${ }^{266}$ but on the other hand, this lenient attitude vis-à-vis the lex certa requirement is confined by the requirement that it must remain reasonably possible for citizens to behave in accordance with the norms underlying the criminal justice system. With respect to professionals, the Judiciary furthermore introduced a duty to make an effort to elucidate the scope of legal provisions by seeking legal advice in order to comply with relevant criminal law provisions. ${ }^{267}$

The scope of Article 240b of the DCC, which criminalises, among others, the possession of child pornography [bezit van kinderporno], has been discussed in various judgements concerning the lex certa prerequisite. ${ }^{268}$ In one of these judgements, the Hague Court of Appeal reasoned that possessing child pornography implies having a stock of child pornography. The defence lawyer stated that such an interpretation amounted to application of law by analogy. The Hague Court of Appeal disagreed and held that the gradual development of law in case law shows that 'having a stock' falls within the scope of 'possessing' child pornography under Article $240 \mathrm{~b}$ of the DCC. ${ }^{269}$

This is a plain example of how criminal law provisions are clarified and developed further with regard to their scope by means of judicial interpretation and application. This judgement also demonstrates the relative value of the prohibition of applying criminal law by analogy. I will further elaborate on this issue in the next section.

\footnotetext{
265 The Hague District Court 6 May 2004, LJN: AO8977, 09/757708-03.

266 Supreme Court 30 June 2009, LJN: BG4822, 07/10742 (NJ 2009, 481, van Anraat), paragraph 5.3.

267 Supreme Court 30 June 2009, LJN: BG4822, 07/10742 (NJ 2009, 481, van Anraat), paragraph 6.13; Supreme Court 18 January 2005, LJN: AR6579, 01142/04 E; Utrecht District Court 21 December 2007, LJN: BC0843, 16/600941-07; Supreme Court 29 March 2005, LJN: AS5435, 01289/04 E; Zwolle District Court 13 February 2002, LJN: AD9245, 07/40081-01.

268 Article $240 \mathrm{~b}$ of the DCC also criminalises dissemination, public exhibition, production, import, export and the conveyance of child pornography, but this judgement regarded the scope of possession of child pornography.

269 The Hague Court of Appeal 11 July 2008, LJN: BF3925, 22-000473-08 A; the Hague Court of Appeal 11 July 2008, LJN: BD7009, 22-000473-08.
} 
Another judgement regarding the lex-certa prerequisite concerned a local regulation which forbids people: (1) to sit or lie in a window frame or on the pavement/doorstep of buildings situated on a (public) road; (2) to lean against a window or door of a building situated on a (public) road; and (3) to stay/loiter, without a reasonable purpose, around a gate or porch situated on a (public) road. ${ }^{270}$

The suspect sat, allegedly without 'reasonable purpose', on the doorstep of a building. He was arrested and sentenced to a fine (60 Euros). Before the Court of Appeal and the Supreme Court, he asserted that this criminal law provision was insufficiently clear, and therefore violated the principle of legality. The Supreme Court did not agree, and ruled that the suspect could have, from the wording of the provision, adequately foreseen when he would, or would not act, in violation of the provision.

This conclusion is hardly surprising taking into account other case law that prescribes that whenever the place and/or the forbidden behaviour is adequately clearly stipulated, such legislation is not in violation of the principle of legality. ${ }^{271}$ Again, the Supreme Court underlined that (some) criminal law provisions are inevitably couched in terms which are vague, and whose interpretation and application are to be clarified further in case law. ${ }^{272}$

Two other judgements regard local regulations concerning public order disturbances in 'red-light districts' in Utrecht and Groningen. In both cities, prostitution causes problems for the inhabitants of several areas. Therefore, both cities drafted local regulations prohibiting persons, prostitutes and pimps from hanging around in certain areas of the city at specified times of the day.

The suspects asserted that these provisions limited their right to freedom of movement disproportionately, without legitimate goal and on the basis of too excessively edited criminal law provisions.

Even though the provisions were not examined on their compliance with the principle of legality, the Supreme Court did go into the question of whether these were sufficiently clearly edited provisions. The Utrecht criminal law provision comprised a prohibition of anyone being present on certain (parts of) roads - which were publicly appointed by the local government - after a police officer had given an order, aimed at preserving public order, for the area to be cleared. According to the Utrecht District Court and the Supreme Court, this provision was too broadly edited in order to justify interference with citizens' right to freedom of movement. ${ }^{273}$

Supreme Court 28 March 2006, NJ 2006/237.

Supreme Court 1 September 1998, NJ 1999/61; Supreme Court 2 April 1985, NJ 1985/796.

Supreme Court 2 April 1985, NJ 1985/796. The local criminal law provision prescribed that it was forbidden to start fights, to behave indecently, to light fireworks, to call other persons names or to otherwise misbehave at railway stations or on trains. The Supreme Court did not consider such a provision to be incompatible with the principle of legality.

273 Supreme Court 7 February 1984, NJ 1984/740. See, also, Supreme Court 6 November 1990, NJ $1991 / 218$ 
Consequently, the restriction on the right to freedom of movement under these conditions was deemed disproportionate and unjustified.

The Groningen local regulation was slightly more precise, and prohibited persons who, as reasonably appeared, were party to prostitution or any other form of indecent behaviour, or were involved in furthering/providing such behaviour, from loitering in certain, publicly designated, areas at certain times of the day. The Groningen District Court judged this regulation to be too broad, and thus in violation of citizens' right to freedom of movement.

However, the Supreme Court did not agree, and held that the provision was sufficiently clear. ${ }^{274}$ This was primarily due to the fact that the provision specified precisely which conduct was prohibited, performed by whom, in which area, and at what time(s) of the day.

Lastly, there are several judgements concerning the Tobacco Act [Tabakswet]. ${ }^{275}$ This Act prohibits the advertising and sponsoring of tobacco, save for several exceptions, of which Article 5 of the Act gives an exhaustive account. One of these exceptions regards the 'common presentation of tobacco', i.e. in a closed packaging, in front of a normal background, normally priced, in a regular tobacco outlet.

The defendant in this case sold and presented tobacco during Koninginnenacht, a national holiday. On her stand, she piled numerous packages of tobacco and displayed them with lots of lights. Moreover, the packages she sold came from under the counter and, the displayed packages remained in place. The defendant argued that she had presented the tobacco in a 'common' way, hence, in accordance with the Tobacco Act. Furthermore, she argued that the exception comprised in Article 5 of the Act violated the lex certa requirement anyway, as no one could infer from the wording of the law what the notion of 'common presentation of tobacco' implied.

The Rotterdam District Court reasoned that the way in which the defendant presented the tobacco obviously did not fall within the scope of this exception. She therefore violated the Tobacco Act. Nevertheless, the District Court subsequently concluded, without much deliberation, that the exception, as mentioned in Article 5 of the Tobacco Act, was in violation of the lex certa prerequisite, as such. The District Court reasoned that the provision was too ambiguous to comply with the principle of legality, and declared it invalid. ${ }^{276}$

In sum, case law demonstrates that the Judiciary rarely considers a criminal law provision to be inapplicable due to a violation of the lex certa prerequisite

\footnotetext{
274 Supreme Court 23 October 1990, NJ 1991/542.

275 Rotterdam District Court 18 December 2006, LJN: AZ6087, 05/6174. See, also, Rotterdam District Court 25 April 2006, LJN: AW 5519, 05/2647. These are both administrative law judgements.

276 See, for another judgement regarding the interpretation of the Tobacco Act, Supreme Court 23 February 2010, Nieuwsbrief Strafrecht 2010/101.
} 
(bepaaldheidsgebod). Mostly, the Judiciary acknowledges that criminal law provisions must, inevitably, be couched in somehow vague notions in order to assure that a whole (potential) range of different perpetrators/forms of behaviour may be convicted or criminalised on the basis of a criminal law provision. ${ }^{277}$ Criminal law provisions must, to a certain extent, be 'time less' in order to remain applicable in the face of changing societal, technical, political or cultural circumstances. ${ }^{278}$ Therefore, the substantive criminal justice system comprises many notions that may undermine the lex certa requirement. ${ }^{279}$ Nevertheless, the Judiciary tends to accept these infringements on the principle of legality, generally without much deliberation, as long as the 'essence' - i.e. the underlying norm/standard - of the criminalised behaviour is sufficiently clear. ${ }^{280}$

When it comes to local regulations, the judiciary is satisfied once broad notions are narrowed down through, for example, specifying a time and/or place when or where certain behaviour is prohibited. If (local) criminal law provisions are, nonetheless, deemed too broad, this usually leads to a violation of, for example, the right to freedom of movement, rather than to an explicit violation of the principle of legality.

\subsection{The prohibition of applying criminal law by analogy}

If criminal law provisions are not sufficiently clear, application by analogy lies in wait. This means that a criminal law provision, which is meant to criminalise a specific type of behaviour, is also used for other types of behaviour which are almost the same, but for which the provision was originally not intended. ${ }^{281}$ So, analogy implies that criminal law provisions are applied to circumstances for which they are not intended, even though the circumstances are very much the same as the ones for which the provision is intended. The scope of a criminal law provision is thus extended beyond its legally set boundaries.

277 See, for example, Supreme Court 20 October 1998, NJ 1998/48. This judgement dealt with the alleged unclear editing of Article 197a, section 1 of the DCC. The Supreme Court rejected the appeal and held: (1) that the norm comprised in Article 197a of the DCC is inevitably phrased in somewhat vague notions, and (2) that the norm was sufficiently clearly codified in order for people to behave in accordance with the provision. See, also, Supreme Court 4 October 2005, Nieuwsbrief Strafrecht 2005/412 and Supreme Court 18 January 2005, Nieuwsbrief Strafrecht 2005/54 
Application of criminal law by analogy is unequivocally prohibited in the Dutch criminal justice system. However, criminal law provisions always need interpretation. Even extensive interpretation and application of criminal law provisions is allowed. The difficulty is determining when a provision is interpreted extensively, which is allowed, and when it is interpreted by analogy, which is not allowed. Sometimes, one can hardly distinguish between mere extensive interpretation/application on the one hand, and analogy, on the other.

Some authors argue that the principle of legality will be violated, due to application by analogy, if the meaning of the criminal law provision is no longer predominant in the passing of judgement. ${ }^{282}$ While interpreting criminal law provisions, the Judiciary should thus stick as close as possible to the wording of the provision in order to avoid application by analogy. The prohibition of analogy serves to prevent dicastokratie 283 and, indirectly, to maintain the balance of powers in order to avoid arbitrariness in the implementation of criminal law.

A notorious, though old, judgement regarding the alleged application of a criminal law provision by analogy concerned the theft of electricity. The suspect had put a peg in the electricity meter that enabled him to take electricity without the meter showing it, and thus, without paying for it. He was thereupon prosecuted for theft pursuant to Article 310 of the DCC. The judgement dealt with the questions: (1) of whether electricity can be considered as a 'good', and (2) of whether electricity can be 'taken away', pursuant to Article 310 of the DCC.

The Supreme Court eventually interpreted Article 310 of the DCC extensively, and convicted the suspect of the theft of electricity. ${ }^{284}$ Various authors, however, considered this interpretation to amount to analogy. The judgement clearly

282 See Losbladige Melai, antekening en bij artikel 1 Wetboek van Strafrecht - Supplement 143 (August 2008), pp. 1-12.

283 See J. Remmelink, 'Actuele stromingen in het Nederlands strafrecht', in V.H. Davelaar-van Tongeren e.a. (red.), Strafrecht in perspectief, Arnhem: Gouda Quint 1980, p. 346.

284 Supreme Court 23 May 1921, NJ 1921/564. See, for a recent judgement in which the judiciary interpreted Article 310 of the DCC as comprising 'virtual theft', Leeuwarden Court of Appeal 10 November 2009, LJN: BK2773, 24-002668-08 (met noot M.J. Borgers). Compare with Arnhem Court of Appeal 27 October 1983, NJ 1984/80; Supreme Court 3 December 1996, NJ 1997/574, regarding the theft of digital documents. See, also, Supreme Court 7 January 1997, NJ 1997/361, regarding the interpretation of Article 249 of the DCC; Supreme Court 21 November 1892, W 6282; Supreme Court 1 May 1903, W 7919; Supreme Court 30 January 1959, NJ 1959/584; Supreme Court 23 January 1928, NJ 1928/363; Supreme Court 11 October 1983, NJ 1984/111; Supreme Court 12 September 1995, DD 96.009; Supreme Court 7 May 1996, NJ 1996/585; Supreme Court 31 October 2000, NJ 2001/14; Supreme Court 29 February 1972, NJ 1972, 347; Supreme Court 20 July 1950, NJ 1950/646; Supreme Court 19 October 1971, NJ 1971/490; Supreme Court 6 February 2001, NJ 2001/498; Supreme Court 29 November 1966, NJ 1967/116; Supreme Court 7 January 1997, NJB 1997, 18, p 220; Supreme Court 2 February 1971, NJ 1971/385; Supreme Court 16 November 1971, NJ 1972/61. See Losbladige Melai, aantekening en bij artikel 1 Wetboek van Strafrecht - Supplement 121 (August 2008), pp. 1-12 until 1-20-24. 
demonstrates that extensive interpretation of a criminal law provision and interpretation by analogy often overlap.

Another, more recent, judgement regarding the prohibition of applying criminal law provisions by analogy concerned the interpretation of Article 278 of the DCC. ${ }^{285}$ This provision criminalises the abduction of children from within the boundaries of the Netherlands to another European State. That is the literal text of the criminal law provision. However, the facts of the case were exactly the other way around: a child was brought from Brazil to the Netherlands. The suspect was convicted on the basis of Article 278 of the DCC.

The question was then, of course, whether Article 278 of the DCC was applied by analogy. The Supreme Court held that, taking into account the current legal and societal reality, Article 278 of the DCC should be considered as comprising both situations, even if the literal text of the provision only refers to abduction from the Netherlands to another European State. This judgement has been the subject of some criticism. ${ }^{286}$ Even the procureur-generaal argued that the Supreme Court's interpretation of Article 278 of the DCC was too broad/extensive. He asserted that this was more a task for Parliament than for the Judiciary.

Other examples of accepted, though extensive, interpretation of criminal law provisions include: him implies her, written implies in braille, pencil implies typewriter, writing implies document, disturbingly following someone implies disturbingly going ahead of someone, a brand implies a chassis number and a key implies an electric devise with which one can manipulate the meter of a gambling machine. ${ }^{287}$

\subsection{The prohibition of using customary law and the prohibition of retro- active application of criminal law}

The prohibition of using customary (unwritten) law to prosecute, convict and punish persons is unequivocal. People may only be punished on the basis of a written law, entered into force in accordance with constitutional and legislative requirements. ${ }^{288}$

285 Supreme Court 20 November 2001, NJ 2003/632, LJN AB2809.

286 See C.P.M. Cleiren, 'Het legaliteitsbeginsel', in C.P.M. Cleiren, Th. A. de Roos, M.A.H. van der Woude, Jurisprudentie Strafrecht Select, Sdu Uitgevers Den Haag 2006, pp. 227-251; annotation of P. Mevis and R. de Lange and M.M. Dolman, 'Actus regit locum? Over legaliteit, rechtsmacht en 'prospectieve overruling", in Delikt en Delinkwent, 2004, afl. 2/15, p. 231 and further; M.J. Borgers, 'De grenzen van het Rijk in Europa en de grenzen van interpretatievrijheid van de strafrechter', in Delikt en Delinkwent 2004, afl. 6/44, p. 590 and further. 
Criminal law provisions may legally enter into force following both local and national law-making processes. ${ }^{289}$ Just as the preceding sub-rule, this rule also serves to prevent arbitrariness.

Nevertheless, to interpret certain legal notions used in criminal law provisions, such as the notion of 'guilt' in Article 307 of the DCC, the Judiciary does take into account 'customs'. ${ }^{290}$ Another example is the notion of 'immoral pictures', as comprised in Article 240 of the DCC, which is interpreted and applied according to the prevailing (societal) view. ${ }^{291}$ The same obviously goes for the notion of 'terrorist intent' pursuant to Article 83a of the DCC.

A clear example under this heading is a judgement concerning a criminal law provision that did not include a penalty. ${ }^{292}$ The (local) provision criminalises youngsters who play truant [spijbelen]. It prescribes that youngsters of 12 years and older, or youngsters who only have to go to school part-time, may be punished with a fine when they regularly failed to attend school. Even though the provision did not specify the maximum fine that may be imposed on perpetrators, the public prosecutor required the suspect to be punished with a fine of $f 750$.

The Judiciary considered the provision to be incomplete and in violation of the principle of legality, due to the lack of an explicit penalty clause. Such a judgement is obviously an exception, but it is nevertheless interesting to see that incomplete criminal law provisions may also lead to a violation of the principle of legality.

Another striking judgement concerned an Afghan refugee who worked as high ranking military officer in the secret intelligence services in Afghanistan. ${ }^{293} \mathrm{He}$ was suspected of ordering/committing torture and/or inhuman or degrading treatment. The suspect claimed that the principle of legality was violated because the prosecution founded his alleged criminal liability (in part) on the common Article 3 of the Geneva Conventions, rather than on a specific national criminal law provision. According to the defence this provision is to begin with a mere instruction norm, rather than a criminal law provision on which criminal liability may be based. Secondly, it was argued the provision is not sufficiently foreseeable and accessible for the suspect to be able to adapt his behaviour accordingly.

289 See Article 81 and further of the Dutch Constitution. See further: Losbladige Melai, aantekening en bij artikel 1 Wetboek van Strafrecht - Supplement 121 (February 2003), p. 1-10 and 1-11.

290 Supreme Court 19 February 1963, NJ 1963/512.

291 Supreme Court 19 November 1968, NJ 1969/360 and Supreme Court 28 November 1978, NJ $1979 / 93$.

292 Rotterdam District Court 26 October 2000, LJN: AA8004, 10/433648-99.

293 The Hague District Court 25 June 2007, LJN: BA7877, 09/750001-06. See, in this respect, also the Hague District Court 14 October 2005, LJN: AU4373, 09/751005-04; the Hague Court of Appeal 29 January 2007, LJN: AZ4173, 2200613105; Supreme Court 8 July 2008, LJN: BC7418, 07/10063 (with annotation of A.H. Klip) Nieuwsbrief Strafrecht 2008/300. In this latter case, the Judiciary elaborated more on questions of jurisdiction than on the scope of the principle of legality. 
With respect to the first argument, the Hague District Court underlined that Article 8 of the Dutch War Crimes Act [Wet Oorlogsstrafrecht] contains the criminal law provision on which the suspect's prosecution was based, and common Article 3 of the Geneva Conventions comprised the substantive criteria. Hence, there was an actual criminal law provision on which the prosecution founded the suspect's prosecution. Regarding the second argument, the Hague District Court asserted that Afghanistan ratified the ICCPR in 1983. This Convention prohibits the use of torture or inhuman or degrading treatment. According to the District Court, the suspect must have known that torture and inhuman or degrading treatment are prohibited under (inter)national law. In addition, the District Court ruled that the Afghan criminal code must also comprise a criminal law provision prohibiting the infliction of torture/inhuman or degrading treatments.

In sum, the Hague District Court concluded that the suspect must have known that torture and inhuman or degrading treatment are violations of international humanitarian law, and are, as such, regarded and known as criminal offences. Article 7 of the ECHR, and Article 1 of the DCC, respectively, were therefore not held to be violated. ${ }^{294}$

At this point it is important to note that Article 7 of the ECHR differs from Article 1 of the DCC. Article 7 of the ECHR refers to any criminal offence on account of any act or omission which did not constitute a criminal offence under national or international law at the time it was committed, whereas Article 1 of the DCC refers exclusively to criminal acts under national law. Hence, Article 7 of the ECHR does not need to be violated when a person is convicted for an act which is exclusively criminalised at international level, and which hence, does not necessarily constitute a crime according to domestic criminal law.

The prohibition of the retroactive application of criminal law to a suspect's detriment is the last aspect of the principle of legality as comprised in Article 1 of the DCC. ${ }^{295}$ This aspect serves to ensure legal certainty, and is also considered to have a general preventive effect. ${ }^{296}$ Section 2 lists one exception to this prohibition: any modification to the legal system, which entered into force after the commission

294 See, also, the Hague District Court 14 October 2005, LJN: AU4373, 09/751005-04; the Hague Court of Appeal 29 January 2007, LJN: AZ4173, 2200613105; Supreme Court 8 July 2008, LJN: BC7418, 07/10063 (with annotation of A.H. Klip) Nieuwsbrief Strafrecht 2008/300. In these comparable judgements, the Judiciary did not consider the principle of legality violated in the case of a suspect prosecuted for acts of torture committed in Afghanistan. However, in this latter case, the Judiciary elaborated more on questions of jurisdiction than on the scope of the principle of legality. See, also, Supreme Court 18 September 2001, LJN: AB1471, 00749/01 (Bouterse), where the Supreme Court ruled that criminal liability must be based on (written) national legislation that was in force when the suspect committed the alleged criminal offence. Supreme Court 2 December 1997, NJ 1998, 290; Supreme Court 28 November 1995, NJ 1996, 383. 
of the act, and which is more favourable to the suspect, must be applied. ${ }^{297}$ Nevertheless, the modification to the legal system must concern a changed view on the criminal liability [strafwaardigheid] of certain behaviour. ${ }^{298}$ So, in order for section 2 to be applicable, it must be ascertained: (1) that the new law is more favourable for the suspect than the old law, and (2) that the modification to the law concerns the criminal liability of the material behaviour. At this point I will not elaborate on this issue further. ${ }^{299}$

\subsection{In sum}

Case law concerning Article 1 of the DCC shows that the judiciary considers Dutch criminal law provisions generally to be in consonance with the principle of legality. Most judgements concern alleged unclear criminal law provisions, and hence, alleged interferences with the lex certa requirement [bepaaldheidsgebod].

Broadly defined criminal law provisions need interpretation, which is sometimes said to be too extensive - i.e. leading to analogy. Nevertheless, if the Judiciary interprets a criminal law provision extensively, this is mostly regarded as consistent, and a logical consequence of the development of law. By and large, criminal law provisions and their subsequent application are judged to be sufficiently clear and unambiguous for people to adapt their behaviour accordingly, if needed, with professional advice.

In various judgements regarding complaints about unclear criminal law provisions, the Judiciary has considered the underlying norm of the provision to make it impossible to define the forbidden behaviour more precisely. As long as the core of the forbidden conduct is clear, there will be no violation of the principle of legality. In some cases, the conduct itself is not defined with great precision, but the - mostly local - provision stipulates, for example, specifically where the material behaviour takes place. If the Judiciary concludes that - mostly local - criminal law provisions are unclearly edited, this leads to violation of, for example, the right to freedom of movement, rather than to a violation of the principle of legality.

Taking into account the above-demonstrated limited practical importance of the principle of legality in the criminal justice system, it is unlikely that Article 83 and

297 Kelk mentions some exceptions, see C. Kelk, Studieboek Materieel Strafrecht, Kluwer Deventer 2005, $3^{\text {rd }}$ edition, pp. 107 and further. See, also, Losbladige Melai, aantekeningen bij artikel 1 Wetboek van Strafrecht - Supplement 121 (February 2003), p. 1-31 and further.

298 See Losbladige Melai, aantekeningen bij artikel 1 Wetboek van Strafrecht - Supplement 121 (February 2003), p. 1-38-42; see Supreme Court 28 October 1940, NJ 1940/192; Supreme Court 21 March 1995, NJ 1995/440; Supreme Court 29 November 2005, NJ 2006/177.

299 For more information regarding the prohibition of the retroactive application of criminal law in the Netherlands, see Losbladige Melai, aantekeningen bij artikel 1 Wetboek van Strafrecht Supplement 121 (February 2003)/supplement 143 (augustus 2008), pp. 1-38-42-1-68-72. 
83a of the DCC will, in this respect, cause any fundamental problems. This issue will further be elaborated on in Chapter IX.

\section{The Principle of legality pursuant to Article 7 of the ECHR}

\subsection{Introduction}

Article 7 of the ECHR sets out that no one shall be held guilty of any criminal offence on account of any act or omission which did not constitute a criminal offence under national or international law at the time when it was committed. ${ }^{300}$ Also, this provision requires that no heavier penalty shall be imposed than the one that was applicable at the time the criminal offence was committed. Retrospective application of criminal law to the detriment of the suspect is prohibited. ${ }^{301}$ Since Scoppola v. Italy (No. 2), the principle of retrospectiveness of the more lenient criminal law has been added to the scope of Article 7 of the ECHR. ${ }^{302}$

The principle of legality is regarded as the general principle of (international) criminal law that serves to prevent arbitrariness in the application of criminal law. ${ }^{303}$ Legal certainty in the field of criminal law is of major importance to counterbalance the unequal relation between state and civilians, among others, during criminal proceedings. Besides, clearly defined, and hence foreseeable, offences serve the general and special prevention of criminal behaviour: persons are able to regulate their conduct in such a way so as to avoid criminal liability.

The guarantees enshrined in Article 7 of the ECHR, as essential element of the rule of law, occupy a prominent place in the ECHR system of protection. This is underlined by the fact that no derogation from Article 7 of the ECHR is permissible under Article 15 of the ECHR in the time of war or any other public emergency. ${ }^{304}$

300 See also Article 49 of the Charter of Fundamental Rights of the European Union. The Judiciary of the European Union interprets the principle of legality no differently than how the ECtHR interprets Article 7 of the ECHR. Compare with judgements of the Court (Grand Chamber) of 3 May 2005 in the cases of Silvio Berlusconi, Sergio Adelchi and Marcello Dell'Utri and Others (Joined Cases C-387/02, C-391/02 and C-403/02).

301 Article 7 of the ECHR does not oppose to retroactive application of a criminal law provision in the accused's favour. See Jamil v. France, appl. no. 15917/89, 8 June 1995, §25 and further; Veeber v. Estonia (no. 2), appl. no. 45771/99, 21 January 2003, §30 and further; Puhk v. Estonia, appl. no. 55103/00, 10 February 2004, §24 and further; Kokkinakis v. Greece, appl. no. 14307/88, 25 May 1993, §52; G. V. France, appl. no. 29/1994/476/557, 31 August 1995, §24; affaire Gurguchiani c. Espagne, requête n ${ }^{\circ}$ 16012/06, 15 décembre 2009, §28-44; M. v. Germany, appl. no. 19359/04, 17 December 2009, §117-138. 
In the view of the ECtHR, Article 7 of the ECHR should be construed and applied, as follows from its object and purpose, in such a way as to provide effective safeguards against arbitrary prosecution, conviction and punishment. ${ }^{305}$

In Kononov v. Latvia, the ECtHR (chamber) summarised the seven sub-rules that have been developed under Article 7 of the ECHR. These sub-rules form, as a whole, the ECtHR's interpretation of the principle of legality. In its case law, the ECtHR applies these rules rather leniently, leaving a wide margin of appreciation to the domestic Courts in interpreting and applying national criminal law provisions.

The following sections will discuss the ECtHR's sub-rules pursuant to Article 7 of the ECHR. As many Strasbourg judgements regarding the princple of legality do not merely deal with one sub-rule, choices are sometimes random and may be equally illustrative of other sub-rules.

\subsection{Only law can define a crime and prescribe a penalty}

First there is the core rule that only law can define a crime and prescribe a penalty (nullum crimen, nulla poena sine lege). ${ }^{306}$ By the same token, Article 7 of the ECHR prohibits: (1) the extension of the scope of existing offences to acts which previously were not criminal offences (retro-active application of criminal law), and (2) an extensive construction of the criminal law to the detriment of the accused, for instance by analogy. ${ }^{307}$ These rules aim to preserve legal certainty (lex certa) and prevent arbitrariness. Civilians must be protected against excessive state intervention.

While examining a complaint under Article 7 of the ECHR, the ECtHR first verifies whether at the time when an accused person performed the act which led to his being prosecuted and convicted, a provision of national or international law which made that act punishable was in force.

305 Kononov v. Latvia, appl. no. 36376/04, 24 July 2008, §113; S.W. v. The United Kingdom, appl. no. 47/1994/494/576, 22 November 1995, §41; C.R. v. The United Kingdom, appl. no. 48/1994/495/577, 22 November 1995, §68; Kononov v. Latvia (Grand Chamber), appl. no. 36376/04, 17 May 2010, §185; Scoppola v. Italy (No. 2) (Grand Chamber), appl. no. 10249/03, 17 September $2009, \S 92$.

306 G. v. France, appl. no. 15312/89, 27 September 1995, §24; Kokkinakis v. Greece, appl. no. 14307/88, 25 May 1993, §52; Custers, Deveaux and Turk v. Danmark, appl. no. 11843/03, 11847/03 and 11849/03, 3 May 2007, §76; Jorgic v. Germany, appl. no. 74613/01, 12 July 2007, $\S 100$; Kafkaris v. Cyprus, appl. no. 21906/04, 12 February 2008, §137; Protopapa v. Turkey, appl. no. 16084/90, 24 February 2009, §90; Moiseyev v. Russia, appl. no. 62936/00, 9 October 2008, §233; Korberly v. Hungaria (Grand Chamber), appl. no. 9174/02, 19 September 2008, §68; Kononov v. Latvia, appl. no. 36376/04, 24 July 2008, §114; Ünsal Öztürk v. Turkey, appl. no. 29365/95, 4 October 2005, §44; Scoppola v. Italy (No. 2) (Grand Chamber), appl. no. 10249/03, 17 September 2009, $\$ 93$.

307 See, among others, affaire Dragotoniu et Militaru-Pidhorni c. Roumanie, requête no. 77193/01 et 77196/01, 24 May 2007, $\S 33$ and further. 
The case of Kononov v. Latvia is illustrative of this first sub-rule. ${ }^{308}$ After the Chamber's judgement, this case was referred to the Grand Chamber. The Chamber found a violation of Article 7 of the ECHR whereas the Grand chamber did not. This section primarily discusses the Grand Chamber's judgement.

The applicant in this case led a unit which carried out a punitive mission on 27 May 1944 on a village governed by the German Wehrmacht. The impugned operation was carried out against six specific, identified men, who were strongly suspected of having collaborated with the Nazi occupying forces. These men were all killed. With the exception of three women, the remaining villagers were spared. It could not be proven that the applicant himself killed, or tortured, the inhabitants of the village, but domestic authorities did consider it proven that he had led the unit who committed these atrocities, and the Judiciary therefore convicted Kononov and sentenced him to several years imprisonment. ${ }^{309}$

The applicant complained that he had been the victim of retrospective application of a criminal law provision. He submitted that the acts of which he was accused did not, at the time of their commission, constitute offences, under either domestic or international law. He furthermore argued that the exception set out in Article 7, section 2 of the ECHR could not apply in his case, because the alleged offences manifestly did not come within its scope.

The ECtHR had to determine whether the operation which the applicant led could, in itself, reasonably be regarded as having contravened the laws and customs of war as codified by the Hague Convention of 1907,310 or if the operation was in violation of domestic law. More specifically, it had to be examined objectively whether a

308 This judgement is illustrative of practically all the sub-rules developed under Article 7 of the ECHR.

309 By a law passed on 6 April 1993, the Latvian Supreme Council inserted into the special section of the former Criminal Code, then in force, a new Chapter 1-a, which contained provisions criminalising acts such as genocide, crimes against humanity or peace, war crimes and racial discrimination. A new Article 68-3 dealt with war crimes, which were punishable with sentences of between three and fifteen years imprisonment or life imprisonment. The same law also inserted an Article 6-1 into the Code, permitting the retrospective application of criminal law with respect to crimes against humanity and war crimes, and an Article $45-1$, which exempted such offences from statutory limitation. Although that provision contained a summary list of the outlawed acts - such as murder, torture and pillage - it referred directly to the 'relevant legal conventions' for a precise definition of such acts. The impugned conviction was, therefore, based on international rather than domestic law, and had to be examined primarily from that perspective, in the ECtHR's view.

310 The Judiciary characterised the applicant's acts by reference to three international instruments: the Hague Convention of 1907 concerning the law and customs of war on land (or, more precisely, the Regulations appended thereto), the Geneva Convention of 1949 relative to the Protection of Civilian Persons in Time of War and, lastly, the Additional Protocol to that Convention, which was adopted in 1977. Of these three instruments, only the Hague Convention existed and was in force at the time the alleged offences were committed in 1944. The other two came into being at a later date and did not contain any provisions affording them any retrospective effect. 
plausible legal basis existed on which to convict the applicant of a war crime and, subjectively, whether, at the material time, the applicant could reasonably have foreseen $^{311}$ that his conduct would make him guilty of such an offence.

In the Chamber's view, there was no sufficiently foreseeable and clear (inter)national legal basis for the applicant's conviction, or a corresponding penalty clause on which his sentence could be based. ${ }^{312}$ This led the Chamber to rule that a violation of Article 7 of the ECHR had occured.

The Grand Chamber decided differently. ${ }^{313}$ First of all, quite contrary to the Chamber, the Grand Chamber considered it relevant that even though arms and munitions supplied by the German military administration were found in the deceased villagers' homes, none of those villagers were carrying them. None of the villagers killed had attempted to escape or had shown any form of resistance to the partisans so that, prior to being killed, they were all unarmed, not resisting, and under the control of the applicant's unit. ${ }^{314}$

The question of whether the villagers were to be considered as civilians or combatants was of importance in examining the applicability of the relevant international humanitarian law on the applicant's conduct. The Grand Chamber analysed the facts of the case on the basis of a hypothesis most favourable to the applicant: that the deceased villagers fell into the category of 'civilians who had participated in hostilities' (by passing on information to the German administration as alleged - an act that could be defined as 'war treason'), or that they had the legal status of 'combatants' (on the basis of one of the alleged auxiliary roles). ${ }^{315}$

The Grand Chamber underlined that with regard to the rights attaching to combatant status, it was unlawful under jus in bello in 1944 to ill-treat or summarily execute a prisoner of war. The use of arms was permitted if, for example, prisoners of war attempted to escape or to attack their captors. ${ }^{316}$

In respect of the protection attaching to "civilians having participated in hostilities', the other hypothesis made as regards the deceased villagers, the Grand

311 The Chamber held, with regard to the accessibility of Hague Conventions to the applicant, that although the USSR had not ratified it, the Hague Convention merely reproduced the fundamental customary rules that were firmly recognised by the community of nations at the time. The Chamber therefore presumed that the applicant, as a serviceman, must have been aware of these rules.

312 Kononov v. Latvia, appl. no. 36376/04, 24 July 2008, §131-148.

313 Kononov v. Latvia (Grand Chamber), appl. no. 36376/04, 17 May 2010. See in this respect T. Mertens, 'Rechtspraak of geschiedschrijving? Geen schending van Artikel 7', in NJCM-Bulletin, jrg. 35, 2010, nr. 8, pp. 1076-1088.

314 Kononov v. Latvia (Grand Chamber), appl. no. 36376/04, 17 May 2010, §191.

315 Kononov v. Latvia (Grand Chamber), appl. no. 36376/04, 17 May 2010, §195.

316 Kononov v. Latvia (Grand Chamber), appl. no. 36376/04, 17 May 2010, §202. 
Chamber noted that civilians could only be attacked for as long as they took a direct part in hostilities. ${ }^{317}$

If it was suspected that the civilians who had participated in hostilities had committed violations of jus in bello in doing so (for example, war treason for passing on information to the German military administration), then they remained subject to arrest, fair trial and punishment by military or civilian tribunals for such acts, and their summary execution without that trial would be contrary to the laws and customs of war. ${ }^{318}$

Next, the Grand Chamber underlined the fact that by May 1944 war crimes were defined as acts contrary to the laws and customs of war, and that international law had defined the basic principles underlying, and an extensive range of acts constituting, those crimes. States were at least permitted (if not required) to take steps to punish individuals for such crimes, including on the basis of command responsibility. Consequently, during and after the Second World War, international and national tribunals prosecuted soldiers for war crimes committed during the Second World War. ${ }^{319}$

With regard to the applicant's behaviour, the Grand Chamber held that, having regard notably to Article 23, under b and c of the Hague Regulations 1907 and Article 16 of the Geneva Convention (IV) 1949, even if the deceased villagers were considered combatants or civilians who had participated in hostilities, jus in bello in 1944 considered the circumstances of their murder and ill-treatment to be a war crime since those acts violated a fundamental rule of the laws and customs of war protecting an enemy rendered hors de combat. The villagers would have been entitled to protection as prisoners of war under the control of the applicant and his unit, and their subsequent ill-treatment and summary execution would have been contrary to the numerous rules and customs of war protecting prisoners of war. Accordingly, the ill-treatment, wounding and killing of the villagers, and the burning of the farm buildings, constituted a war crime. ${ }^{320}$

In conclusion, even assuming that the deceased villagers could be considered to have been 'civilians who had participated in hostilities' or 'combatants', there was a sufficiently clear legal basis, having regard to the state of international law in 1944, for the applicant's conviction and punishment for war crimes as the commander of the unit responsible for the attack on Mazie Bati on 27 May 1944. If the villagers had been considered 'civilians', a fortiori they would have been entitled to even greater protection. ${ }^{321}$ 
Lastly, the Grand Chamber had to rule on the question of whether the applicant could have foreseen that the relevant acts constituted war crimes and that he would be prosecuted. In this respect, the Grand Chamber recalled that it had previously held that the individual criminal responsibility of a private soldier was defined with sufficient accessibility and foreseeability by, inter alia, a requirement to comply with international fundamental human rights instruments. ${ }^{322}$ In this case, the Grand Chamber considered that even a private soldier could not show total, blind obedience to orders which flagrantly infringed not only domestic law, but internationally recognised human rights, in particular the right to life, a supreme value in the international hierarchy of human rights. ${ }^{323}$

The Grand Chamber did not consider the fact that (1) the Latvian Criminal Code did not contain a reference to the international laws and customs of war, or the fact that (2) the relevant international laws and customs were not formally published in the USSR or in the Latvian SSR, to be decisive in ruling on the foreseeability/ accessibility requirement. International laws and customs of war were sufficient in 1944, of themselves, to found individual criminal responsibility. ${ }^{324}$

Moreover, the Grand Chamber noted that in 1944 those laws constituted detailed lex specialis regulations fixing the parameters of criminal conduct in a time of war, primarily addressed to armed forces, and, especially, commanders. The present applicant was a Sergeant in the Soviet Army assigned to the reserve regiment of the Latvian Division: at the material time, he was a member of a commando unit and in command of a platoon whose primary activities were military sabotage and propaganda.

Given his position as a commanding military officer, the Grand Chamber was of the view that the applicant could have been reasonably expected to take such special care in assessing the risks that the operation in Mazie Bati entailed. Having regard to the 'flagrantly unlawful nature' of the ill-treatment and killing of the nine villagers in the established circumstances of the operation on 27 May 1944, 'even the most cursory reflection by the applicant, would have indicated that, at the very least, the impugned acts risked being counter to the laws and customs of war as understood at that time and, notably, risked constituting war crimes for which, as commander, he could be held individually and criminally accountable'.

For these reasons, the Grand Chamber deemed it reasonable to find that the applicant could have foreseen, in 1944, that the impugned acts qualify as war crimes. Therefore, the applicant's conviction for war crimes did not constitute a violation of Article 7, section 1 of the ECHR. ${ }^{325}$

\footnotetext{
322 Kononov v. Latvia (Grand Chamber), appl. no. 36376/04, 17 May 2010, §236. See, for further notes on the requirement of foreseeability, section 8.5. The case to which the Grand Chamber referred was K.-H.W. v. Germany, appl. no. 37201/97, 22 March 2001.

323 K.-H.W. v. Germany, appl. no. 37201/97, 22 March 2001, §75.

324 Kononov v. Latvia (Grand Chamber), appl. no. 36376/04, 17 May 2010, §237.

325 Kononov v. Latvia (Grand Chamber), appl. no. 36376/04, 17 May 2010, §238-245.
} 


\subsection{The lex certa requirement}

Criminal law provisions and the relevant penalties must be clearly defined by law. ${ }^{326}$ This lex certa requirement is the second sub-rule under Article 7 of the ECHR. Civilians must be able to determine, from the wording of criminal law provisions, and, if need be, with the assistance of the (domestic) Courts' interpretation of it, what acts and omissions will make them criminally liable. ${ }^{327}$ When speaking of 'law', Article 7 of the ECHR alludes to the very same concept as that to which the ECHR refers elsewhere when using that term. This means that the concept of 'law' comprises statute law as well as case law, and implies qualitative requirements, including those of accessibility and foreseeability. ${ }^{328}$

The case of Kokkinakis v. Greece explicitly concerned vaguely edited criminal law provisions and the potential arbitrariness that may result in. ${ }^{329}$ The applicant in this case was convicted for proselytism. In his application to the ECtHR, he criticised the absence of any description of the objective substance of the offence of proselytism in Greek law. Moreover, he claimed the vagueness to be deliberate, so as to make it possible for any kind of religious conversation or communication to be caught by the provision. ${ }^{330}$

The ECtHR first of all underlined that the wording of many national criminal law provisions is not absolutely precise. These provisions do not always need to be clear-cut at first sight. Excessive rigidity in that respect should be avoided. Pace needs to be kept with changing circumstances. ${ }^{331}$ This is solely possible when criminal behaviour is, to some extent, broadly defined in criminal law provisions. ${ }^{332}$ This implies that many laws are inevitably phrased in terms, which, to a certain extent, are vague.

See, among others, Achour v. France, appl. no. 67335/01, 29 March 2006, §41.

See, among others, Cantoni v. France, appl. no. 17862/91, 15 November 1996, §29; Scoppola v. Italy (No. 2) (Grand Chamber), appl. no. 10249/03, 17 September 2009, §94-95.

See Coёme et Autres c. Belgique, appl. nos. 32492/96, 32547/96, 32548/96, 33209/96 et 33210/96, 22 June 2002, §142 and further; Yaşar Kemal Gökçelĭ c. Turquie, appl. no. 27215/95 et 36194/97, 4 March 2003, §51; Grigoriades c. Grecque, appl. no. 121/1996/740/939, 25 November 1997; Kononov v. Latvia (Grand Chamber), appl. no. 36376/04, 17 May 2010, §185; Scoppola v. Italy (No. 2) (Grand Chamber), appl. no. 10249/03, 17 September 2009, §99.

Kokkinakis v. Greece, appl. no. 14307/88, 25 May 1993.

Kokkinakis v. Greece, appl. no. 14307/88, 25 May 1993, §16 for the criminal law provision prohibiting proselytism.

Kokkinakis v. Greece, appl. no. 14307/88, 25 May 1993, §40; Scoppola v. Italy (No. 2) (Grand Chamber), appl. no. 10249/03, 17 September 2009, §99-100.

See, also, M. Shahabuddeen, 'Does the Principle of Legality Stand in the Way of Progressive Development of Law', in Journal of International Criminal Justice 2 (2004) Oxford University Press, pp 1007-1017. M. Shahabuddeen concludes, in his article, that the principle of nullem crimen sine lege does not bar progressive development of the law (in case law), provided that the development law retains the very essence of the original crime, even though not corresponding to every detail of it. 
In the ECtHR's opinion, criminal law provisions concerning proselytism were a clear example of an offence that cannot be defined with great precision, but which has to be developed and clarified further in (domestic) case law. In Greece, there was indeed a huge quantity of published, and thus accessible, case law interpreting and clarifying the offence of proselytism. Therefore, the ECtHR did not find a violation of Article 7 of the ECHR. ${ }^{333}$

In Sud Fondi srl et autres contre Italie, the ECtHR did find a violation of Article 7 of the ECHR. ${ }^{334}$ The applicants built several apartments and other buildings in an area that was (later) appointed as a protected area where nothing was to be built. Due to inconsistencies between local by-laws and national legislation regarding construction permits, it was completely unclear when, where and under what circumstances, buildings could legally be constructed. Nevertheless, the prosecution instituted criminal proceedings in respect of illegal construction works and the buildings concerned were confiscated. The Italian Judiciary acquitted the applicants, while the confiscation continued. According to the applicants, the confiscation was not (clearly) prescribed by law, and thus, they could never have foreseen that such penalties could be imposed on them. The Italian Supreme Court concluded that the legislation was too ambiguous on this point, which made it impossible for persons to foresee when exactly they were violating the material law. Also, the Supreme Court underlined that because the law was unclear at this point, the applicants had never had the intention of violating the material criminal law provisions.

The ECtHR asserted in this respect that there cannot be any criminal responsibility without being 'guilty'. In the ECtHR's view, being guilty presupposes responsibility for certain (illegal) conduct. A person must have had the intention of violating criminal law in order to be held criminally liable. If that intention, and hence criminal responsibility, is lacking, then the imposition of criminal sanctions is not allowed under Article 7 of the ECHR. In this case, the applicants could not be deemed to be responsible for the illegal construction works because the Italian legislation was too unclear on this point. Any sentence imposed was therefore considered arbitrary, and thus in violation of Article 7 of the ECHR. The ECtHR interpreted Article 7 of the ECHR to such extent here, that it also included the adagium: no punishment without (legal) guilt. 335

333 Kokkinakis v. Greece, appl. no. 14307/88, 25 May 1993, §36-42. See, as well, Kalin c. Turquie, appl. no. 31236/96, 10 November 2004, §34-35, in which the ECtHR underlined '(...) que la notion de droit (“law”) utilisée à l'article 7 correspond à celle de "loi” qui figure dans d'autres articles de la Convention (...)'.

334 Affaire Sud Fondi srl et autres contre Italie, appl. no. 75909/01, 20 January 2009.

335 See also G.P.M.F. Mols, Annotation with affaire Sud Fondi srl et autres contre Italie, in EHRC 2009, no. 48 . 
Another case concerning the lex certa requirement is Cantoni v. France. ${ }^{336}$ The applicant was an owner of a supermarket. In France, supermarkets are not allowed to sell pharmaceutical products. Cantoni however, sold several products that the Pharmacists' Association regarded as pharmaceutical. He asserted that the definition of medicinal products in French law was very imprecise and left a significant discretion to the Courts. Even the Court of Cassation's case law in this field was marked by arbitrariness and a lack of certainty. Legislation, as well as case law, thus, failed to afford the required foreseeability and accessibility of law. ${ }^{337}$

The ECtHR underlined that case law has to provide some elucidation where the wording of a legal provision lacks clarity. ${ }^{338}$ It was acknowledged that when the legislative technique of categorisation is used, there will often be grey areas at the fringes of the definition. This uncertainty in relation to borderline facts does not, it was argued, in itself make a provision incompatible with Article 7 of the ECHR, as long as it proves to be sufficiently clear in the large majority of cases. The role of adjudication vested in (domestic) Courts, it was asserted, is precisely to dissolve such interpretational doubts, taking into account the changes in everyday practice. $^{339}$

This means that criminal behaviour cannot always be defined precisely enough to enable persons to infer instantly, from the wording of a criminal law provision, when they will be criminally liable. In order to avoid excessive rigidity and to keep pace with changing circumstances, criminal law provisions will generally be defined in, more or less, unspecified and vague terms. This practice is not, as such, contrary to Article 7 of the ECHR, as it is impossible and counter effective to require excessively specified (criminal) law provisions. It is precisely this ambiguity that needs to be clarified by national Courts in order to make the 'law' satisfactorily foreseeable in the large majority of the cases to comply with Article 7 ECHR. ${ }^{340}$ Depending on the knowledge of the legal system, a person who gets into trouble with the law has - he may even be obliged - to invoke legal advice to assist him in clarifying certain provisions.

A criminal law provision may thus still satisfy the lex certa requirement, even if the person concerned has to take appropriate legal advice to assess, to a degree that is reasonable in the circumstances, the consequences which a given action may entail. ${ }^{341}$ One important aspect in this respect, which also played a key role in

336 Cantoni v. France, appl. no. 17862/91, 15 November 1996.

337 See, for facts of the case and relevant law, Cantoni v. France, appl. no. 17862/91, 15 November 1996, §7-22.

339 Cantoni v. France, appl. no. 17862/91, 15 November 1996, §32. See, also, Kononov v. Latvia (Grand Chamber), appl. no. 36376/04, 17 May 2010, §185.

340 Cantoni v. France, appl. no. 17862/91, 15 November 1996, §32.

341 See, as well, Grigoriadus v. Greece, appl. no. 121/1996/740/939, 25 November 1997, §37 and 38. 
Cantoni v. France, is the professional activities of a person. ${ }^{342}$ The ECtHR argued that Cantoni, who was the manager of a supermarket, could be expected to take special care in assessing the risks that such activity entailed. With the benefit of appropriate legal advice, Mr Cantoni, should have taken into account that, in view of case law stemming from the French Court of Cassation and from some of the lower Courts, he ran a real risk of prosecution for the unlawful sale of medicinal products. ${ }^{343}$ In light of these considerations, the ECtHR considered the criminal law provisions concerning the prohibition to sell pharmaceutical products in a supermarket to be sufficiently clear.

\subsection{Judicial interpretation}

In its case law, the ECtHR has repeatedly underlined that however clearly drafted a legal provision may be, in any system of law - including criminal law - there is an inevitable element of judicial interpretation. ${ }^{344}$ Whilst certainty is highly desirable, it may bring with it excessive rigidity, and the law must be able to keep pace with changing circumstances. ${ }^{345}$ There will always be a need for elucidation of ambiguous points and for the adaptation to changing circumstances. The role of adjudication vested in domestic Courts is precisely to dissipate such interpretational doubts as remain. Moreover, it is a firmly established part of the legal tradition of the states party to the ECHR that case law, as one of the sources of the law, necessarily contributes to the gradual development of criminal law. ${ }^{346}$ Article 7 of the ECHR does not, hence, prohibit the gradual clarification of the rules of criminal liability through judicial interpretation from case to case, provided that the resultant development is consistent with the essence of the offence and could reasonably be foreseen. ${ }^{347}$

342 See, also, the decision regarding the admissibility in Van Anraat $v$. the Netherlands, appl. no. 65389/09, 6 July 2010, $\S 81$, where the ECtHR held that 'A law may still satisfy the requirement of foreseeability even if the person concerned has to take appropriate legal advice to assess, to a degree that is reasonable in the circumstances, the consequences which a given action may entail. This is particularly true in relation to persons carrying on a professional activity, who are used to having to proceed with a high degree of caution when pursuing their occupation. They can on this account be expected to take special care in assessing the risks that such activity entails.'

Cantoni v. France, appl. no. 17862/91, 15 November 1996, $\$ 35$.

See, in this respect also, G.P. Fletcher, Basic Concepts of Criminal Law, New York Oxford University Press 1998, p. 208. And see the decision regarding the admissibility in Van Anraat $v$. the Netherlands, appl. no. 65389/09, 6 July 2010, §81-83.

345 Liivik v. Estonia, appl. no. 12157/05, 25 June 2009, §94.

346 Scoppola v. Italy (No. 2) (Grand Chamber), appl. no. 10249/03, 17 September 2009, §101.

347 See C.R. v. the United Kingdom, appl. no. 20190/92, 22 November 1995, §40; Jorgic v. Germany, appl. no. 74613/01, 12 July 2007, §100 and further; Kononov v. Latvia (Grand Chamber), appl. no. 36376/04, 17 May 2010, §185; Korbely v. Hungary (Grand Chamber), appl. no. 9174/02, 19 September 2008, \$69-71. The latter case concerned the interpretation of genocide as comprised in the German Penal Code (the crime was codified in Germany in 1955). The German 
In C.R. v. the United Kingdom, domestic case law determined the substantive meaning of the material criminal law provision - as is usual in the UK. ${ }^{348}$ The applicant had sexually assaulted/raped his wife after she had previously announced that she wanted a divorce. The applicant claimed that, according to United Kingdom (case-)law 'it is clear, well-settled and ancient law that a man cannot, as actor, be guilty of rape upon his wife. ${ }^{349}$ In response to this supposition, his (ex-)wife asserted that this exception was out-of-date, given recent judicial interpretation of law, and had thus been superseded. The ECtHR agreed with her by referring to the fact that Article 7 of the ECHR cannot be read as outlawing the gradual clarification of the rules of criminal liability through judicial interpretation from case-to-case. In this case the resultant development was consistent with the essence of the offence, and could reasonably have been foreseen. ${ }^{350}$ This line of reasoning was also applied in K.A. et A.D. c. Belgique. ${ }^{351}$ The ECtHR did not per se prohibit a new, broader, interpretation of a criminal law provision, without any precedents:

'Les pratiques en question étaient tellement violentes - et donc sans doute tellement rares - que l'absence de jurisprudence pertinente ne saurait guère étonner. L'absence de précédents ne pouvait être une circonstance empêchant les autorités nationales d'intervenir. Dans le cas contraire, on aboutirait à ce paradoxe que plus une pratique (sadomasochiste ou autre) est violente et donc rare, quelles que soient ses conséquences, plus elle a des chances d'échapper à l'application de la loi pénale.'352

In addition, the ECtHR emphasised that it is, in the first place, for the national authorities, notably the Courts, to interpret and apply national law. ${ }^{353}$ This restricts

Courts gave a rather wide interpretation of the notion of genocide (also entailing intent to destroy a group as social unit) and the ECtHR did not consider that interpretation to amount to analogy. See, also, Moiseyev v. Russia, appl. no. 62936/00, 9 October 2008, §226; Streletz, Kessler and Krenz v. Germany, appl. no. 34044/96, 35532/97 and 44801/98, 22 March 2001§50.

348 C.R. v. the United Kingdom, appl. no. 20190/92, 22 November 1995. See, also, M. Shahabuddeen, 'Does the Principle of Legality Stand in the Way of Progressive Development of Law?', in Journal of International Criminal Justice 2 (2004) Oxford University Press, pp 1013-1015. Shahabuddeen argues that in strict theory, the principle of nullum crimen sine lege was breached in C.R. v. the United Kingdom, because at the time of the alleged act, there was solely a judicial tendency in the direction of interpreting the law as giving rise to the crime for which the accused was charged (rape). There was only a tendency, that had not been brought to a 'climax' at the time at which the act was committed. The author argues that one is not charged on the basis of a tendency, however persistent it may be, or however foreseeable its final destination.

See C.R. v. the United Kingdom, appl. no. 20190/92, 22 November 1995, §16-26 for a broad elaboration on the United Kingdom law regarding rape and the exception applicable to married men.

350 C.R. v. the United Kingdom, appl. no. 20190/92, 22 November 1995, §34.

351 K.A. et A.D. c. Belgique, appl. nos. $42758 / 98$ et $45558 / 99,17$ February 2005, $\S 9-33$.

352 K.A. et A.D. c. Belgique, appl. nos. $42758 / 98$ et $45558 / 99,17$ February 2005, §55. Compare with Streletz, Kessler and Krenz v. Germany, appl. no. 34044/96, 35532/97 and 44801/98, 22 March 2001; K.-H.W. v. Germany, appl. no. 37201/97, 22 March 2001.

353 Kemmache v. France, appl. no. 17621/91, 24 November 1994, §37. 
the possibilities for the ECtHR to find violations of Article 7 of the ECHR, simply because, to a certain extent, it does not consider itself authorised to value and/or judge on the interpretation of national law by domestic Courts.

Another argument restricting the scope of Article 7 of the ECHR appeared in C.R. $v$. the United Kingdom. The ECtHR held that 'it [the broadened interpretation of rape] cannot be said to be at variance with the object and purpose of Article 7 of the ECHR, namely to ensure that no one should be subjected to arbitrary prosecution, conviction or punishment. What is more, the abandonment of the unacceptable idea of a husband being immune against prosecution for rape of his wife was in conformity not only with a civilised concept of marriage but also, and above all, with the fundamental objectives of the Convention, the very essence of which is respect for human dignity and human freedom'. ${ }^{354}$

This consideration is comparable to the line of reasoning in Streletz, Kessler and Krenz v. Germany and in K.A. et A.D. c. Belgique. Apparently, the ECtHR accepts that some acts are so repugnant that criminal liability should not be absent, even if that liability does not unequivocally follow from the precise wording of a criminal law provision, from state practice or from interpretation in case law. ${ }^{355}$ People are held responsible for their actions because they should have known that their behaviour would be intolerable under criminal law, even if that could not be easily and unambiguously derived literally from the applicable 'law' itself or its interpretation and development in case law. In C.R. v. the United Kingdom the fact that it concerned a common law country undeniably played a role in this respect.

\subsection{Foreseeability}

The fourth sub-rule of the Strasbourg principle of legality prescribes that criminal law provisions must be foreseeable. The scope of the concept of foreseeability depends, to a considerable extent, on: (1) the content of the instrument at issue, (2) the field it is designed to cover, and (3) the number and status of those to whom it is addressed. ${ }^{356}$

\footnotetext{
354 C.R. v. the United Kingdom, appl. no. 20190/92, 22 November 1995, $\$ 42$.
}

355 See, also, Jorgic v. Germany, appl. no. 74613/01, 12 July 2007, $\$ 100$ and further. This case concerned a rather broad interpretation of the notion of genocide by the German Judiciary.

356 Kononov v. Latvia (Grand Chamber), appl. no. 36376/04, 17 May 2010, §235; Scoppola v. Italy (No. 2) (Grand Chamber), appl. no. 10249/03, 17 September 2009, §102; decision regarding the admissibility in Van Anraat v. the Netherlands, appl. no. 65389/09, 6 July 2010, §81. A law may still satisfy the requirement of foreseeability even if the person concerned has to take appropriate legal advice to assess, to a degree that is reasonable in the circumstances, the consequences that a given action may entail. This is particularly true in relation to persons carrying on a professional activity, who are used to having to proceed with a high degree of caution when pursuing their occupation. They can in this respect be expected to take special care in assessing the risks that such activity entails. See Pessino v. France, appl. no. 40403/02, 10 October 2006, $\S 33$. In this case, the applicant had indeed taken appropriate legal advice. Nevertheless, that was 
The case of Streletz, Kessler and Krenz v. Germany is relevant with respect to the question of foreseeability. ${ }^{357}$ Before the reunification of the GDR and the FRG, the GDR's border policing regime entailed a rather strict blocking method to prevent people fleeing from East to West Germany. The border between West and East was secured by the Berlin Wall, landmines, and heavily armed East German border guards. This border policy cost many fugitives their lives during their attempts to get to West Germany.

The applicants in Streletz, Kessler and Krenz v. Germany occupied senior positions in the GDR state apparatus, and were convicted, after the reunification of Germany, of incitement to commit intentional homicide. Their convictions were based on the grounds that they had participated in high-level decision-makings on the GDR's border policing regime, and hence, shared direct responsibility for the deaths of a number of young people. ${ }^{358}$ The applicants asserted that their behaviour had not been criminal according to the law and practice of the GDR. Their convictions after the reunification were therefore not foreseeable. The ex post facto interpretation of the GDR's criminal law by the Courts of reunified Germany was not based on any case law of the GDR's Courts, and would hence have been impossible for the applicants to foresee at the time of the events that gave rise to the charges. ${ }^{359}$ Nevertheless, the government contended that the applicants could have foreseen that the killing of unarmed fugitives, who were not a threat to anyone, might give rise to criminal prosecution under the relevant legal provisions of the GDR, notwithstanding the contrary practice followed by the GDR regime. ${ }^{360}$ The government based this claim on national, as well as international law, from which followed unequivocally the fundamental character of the right to life and hence the prohibition to violate that right, especially when there is no legitimate justification for the infringement. ${ }^{361}$

The question with which the ECtHR was confronted was whether the German Courts interpreted the GDR law in such a way that the potential legal consequences for the applicants remained sufficiently foreseeable. From the relevant criminal law provisions and the GDR Constitution in force at the time, the ECtHR concluded that

still insufficient to behave in accordance with the criminal justice system. Therefore, the ECtHR found a violation of Article 7 of the ECHR because it judged the material criminal law provisions as not foreseeable for the applicant. 
the victims' attempts to cross the border - although prohibited by GDR law - could not be classified as a 'serious crime' against which the proportional use of firearms by the applicants would have been allowed. ${ }^{362}$

The applicants were not prosecuted under GDR law before the reunification, so how should this state practice be dealt with? And could the practice serve as a(n) (unwritten) law that would supersede the GDR criminal law provisions and the relevant Constitutional principles of the GDR? The ECtHR ruled that this state practice was not only in breach of the Constitution and the GDR law itself, but it was also in breach of the obligation to respect human rights and the other international obligations of the GDR. The GDR had ratified the International Covenant on Civil and Political Rights, expressly recognising the right to life. Basically, the ECtHR weighed up the criminal (written) law provisions against the deviant (unwritten) state practices, and concluded that the state practice could not supersede the written laws, even if that written law was not obeyed de facto at the material time. ${ }^{363}$

With regard to the question of whether the applicants could have foreseen, at the material time, that their acts would lead to criminal responsibility, the ECtHR argued that the broad divide between the GDR's legislation and its practice was, to a great extent, the work of the applicants themselves. Because of the very senior positions they occupied in the state apparatus, they evidently could not have been ignorant of the GDR's Constitution and legislation, or of its international obligations and the international criticism of its border policing regime. Also, they themselves had implemented or maintained that regime, by superimposing on the statutory provisions, published in the GDR's Official Gazette, secret orders and service instructions on the consolidation and improvement of the border protection installations and the use of firearms. ${ }^{364}$

The ECtHR furthermore balanced Article 7 of the ECHR against states' positive obligation under Article 2 of the ECHR - to protect the right to life of all citizens and concluded that state practice, such as the GDR's border policing policy, 'which flagrantly infringes human rights and above all the right to life, the supreme value in the international hierarchy of human rights ${ }^{365}$, cannot be covered by the protection of Article 7, section 1 of the ECHR. 366

362 See, for an extensive discussion on the relevant criminal law provisions and the Constitution, Streletz, Kessler and Krenz v. Germany, appl. no. 34044/96, 35532/97 and 44801/98, 22 March 2001, \$56-67.

363 Streletz, Kessler and Krenz v. Germany, appl. no. 34044/96, 35532/97 and 44801/98, 22 March 2001, §73-76.

364 Streletz, Kessler and Krenz v. Germany, appl. no. 34044/96, 35532/97 and 44801/98, 22 March 2001, \$78.

365 See, for further considerations regarding the status of the right to life in international human rights law, Streletz, Kessler and Krenz v. Germany, appl. no. 34044/96, 35532/97 and 44801/98, 22 March 2001, §90-102.

366 Streletz, Kessler and Krenz v. Germany, appl. no. 34044/96, 35532/97 and 44801/98, 22 March 2001, $\S 87$ and 88 . 
To sum up, the ECtHR considers that the application of (written) criminal law, which was factually not lived up to at the material time, does not imply, that a conviction later, on the basis of that law, was not foreseeable. Although states may factually abstain from prosecuting certain behaviour, contrary to the written law, this does not mean that such practice supersedes the written law, especially when the behaviour infringes fundamental rights, such as the right to life. ${ }^{367}$ Criminal law provisions that are not factually implemented nevertheless remain foreseeable in terms of the principle of legality if, at once, they are put into practice through criminal proceedings.

The ECtHR has repeatedly held that the development, through case law, of criminal law provisions has to remain foreseeable to the accused. ${ }^{368}$ The meaning of a criminal law provision and its interpretation in case law may change over time, or at least may develop by means of that case law. This may (potentially) conflict with the principle of legality as entailed in Article 7 of the ECHR. Where however, should one draw the line between acceptable and unacceptable interpretation/ development? When is a criminal law provision explained, interpreted or developed in compliance with Article 7 of the ECHR?

The general consideration of the ECtHR in this matter is that extensively construed or applied criminal law to the detriment of the accused, i.e. by analogy, is forbidden and in breach of Article 7 of the ECHR ${ }^{369}$ A series of cases against Turkey ${ }^{370}$ illustrates this. Part of Turkish anti-terrorism legislation prohibits the dissemination of separatist propaganda by means of periodicals. The owners or directors of a publishing house can - in addition to the authors - also be sentenced under this law. At first sight, this part of Turkey's anti-terrorism legislation does not conflict with Article 7 of the ECHR. Nevertheless, the authorities tend to apply the legislation by analogy to book writers or to the authors of non-periodical articles even though these persons are not explicitly mentioned in the aforesaid criminal law provision.

367 See J. Cameron (ed.), Trial of Heinz Eck et al. (the Peleus Trial), London 1948, p. 132, where it is stated that it may well be that no particular concrete law can be pointed to as having been broken, but the principle of 'no punishment without pre-existing law' cannot limit punishment of persons who have outraged human decency in their conduct. See, also, A. Cassese, International Criminal Law, Oxford University Press 2003, p. 138-141. Cassese points out the difference between national systems that ground their criminal law in either the doctrine of substantive justice or that of strict legality. Under the former doctrine, the legal order must primarily aim to prohibit and punish any conduct that is socially harmful or causes danger to society, whether or not that conduct has already been legally criminalised at the moment it is carried out. The doctrine of strict legality, however, prescribes that a person may only be held criminally liable and punished if, at the moment when he performed a certain act, the act was regarded as a criminal offence by the relevant legal order. 
In several cases, the ECtHR considered this practice to be in violation of Article 7 of the ECHR. For example, in E.K. c. Turquie 371 the applicant had published two articles concerning the human rights conditions for Kurds in Turkey in a non-periodical publication. The applicant was subsequently, contrary to the applicable law, convicted and sentenced for being an editor of a periodical publication when she was not. This method of extensive interpretation and application of a criminal law provisions, in order to impose a higher penalty, is judged to be in violation of Article 7 of the ECHR as it boils down to an application of criminal law by analogy. 372

In Başkaya and Okçuoğlu v. Turkey, one applicant was a journalist and the other an owner of a publishing house. The second applicant published a book - written by the first applicant - criticising Turkey's ideology. Both, the publisher and the author were prosecuted, on the basis of the same article, for the dissemination of separatist propaganda. ${ }^{373}$ The applicants held that, since the book in question was solely an academic study, their convictions under the Terrorist Act had been unlawful. In view of the lack of clarity of the wording of the Act and the vagueness of the notion of 'dissemination of propaganda against the indivisibility of the State', it had not been foreseeable at the material time that the publication at issue constituted an offence.

The ECtHR first acknowledged that criminal law provisions meant to prohibit dissemination of separatist propaganda may be difficult to draft with absolute precision. A certain degree of flexibility may thus be called for to enable the national courts to assess whether a publication should be regarded as separatist propaganda against the indivisibility of the state or a permitted academic publication. More generally, the ECtHR underlined that legal provisions, however clearly drafted always need 'elucidation of doubtful points and adaptation to changing circumstances'. ${ }^{374}$ Considered in that light, the Terrorist Act - read in conjunction with the accompanying case law - was held to be sufficiently clear. A conviction had therefore been foreseeable in respect of the first applicant. The question of whether a specific law is sufficiently clear is thus merely valued by examining qualitative requirements for legislation in general. When legislation is sufficiently foreseeable and accessible it will most probably also be in compliance with Article 7 of the ECHR. As mentioned above, the wording of a legal provision is not the sole indicator for deciding on these matters. Persons are expected to combine the text of the substantive (criminal) law provision with the relevant case law concerning that provision and - if necessary - seek legal assistance. These conditions make a violation of Article 7 of the ECHR due to 'unclear' legal provisions rather unlikely.

371 E.K. c. Turquie, requête $\mathrm{n}^{\circ} 28496 / 95,7$ février 2002.

372 E.K. c. Turquie, requête $\mathrm{n}^{\circ} 28496 / 95,7$ février 2002, §51.

373 Başkaya and Okçuoğlu v. Turkey, appl. nos. 23536/94 and 24408/94, 8 July 1999, §9-25.

374 Başkaya and Okçuoğlu v. Turkey, appl. nos. 23536/94 and 24408/94, 8 July 1999, §36 and 39. 
The second applicant in Başkaya and Okçuoğlu v. Turkey, the owner of the publishing house, had also been convicted and sentenced to imprisonment on the basis of the Terrorist Act, as editor. The law prescribed considerably lower penalties for publishers (merely a fine) than for editors (imprisonment). Such an application of the law was, according to the ECtHR, in the present case based on an extensive construction, by analogy, which was incompatible with the principle nulla poena sine lege as enshrined in Article 7 of the ECHR. ${ }^{375}$

In sum, extensive interpretation of criminal law provisions by way of analogy will be contrary to Article 7 of the ECHR when sentencing provisions are applied to persons other than those explicitly mentioned in the provision. This prohibition obviously does not apply when a more favourable sentence is applied contrary to the criminal law provision.

In Liivik v. Estonia, the ECtHR also found a violation of Article 7 of the ECHR in respect of insufficiently foreseeable criminal law provisions. The applicant was the acting Director General of the Estonian Privatisation Agency ('the Agency') at the material time. ${ }^{376}$ The Estonian Parliament decided that AS Eesti Raudtee ('ER'), a public limited company in possession of the Estonian railways, was to be privatised in accordance with the Privatisation Act. The privatisation process was accompanied by considerable political debate, as well as by pressure from various stakeholders on the persons conducting the privatisation. Under the Privatisation Act, it was the responsibility of the Agency to carry out the privatisation of state assets. The applicant, as the acting Director General of the Agency, signed the privatisation agreement. At the time when the application to the ECtHR was lodged, ER was, in the applicant's submission, a successful company through which the state earned ten times more for its $34 \%$ shareholding than it had previously done with a $100 \%$ stake. ${ }^{377}$

At domestic level, the applicant was charged with abuse of his official position in making the representations and warranties in the privatisation agreement. According to the charges, he had created a situation whereby the preservation of the state's assets might have been jeopardised. This could be considered to have caused significant damage to national interests. Moreover, by repeatedly assuming unlawful obligations for the state, the applicant had cast doubt on the legitimacy and reliability of the activity of the Agency as a state institution, thus materially impairing the authority of the state in society, and had also damaged the reputation of the Republic of Estonia as a contractual partner at an international level; those acts, in aggregate, had to be considered to have caused significant (moral) damage to the state. 
Accordingly, he had committed an offence under Article 161 of the Criminal Code. 378

The applicant argued that the law on the basis of which he had been convicted was not clear and comprehensible. He pointed out that even the most qualified lawyers, like the Prosecutor General and the Head of the Prosecution Department of the Public Prosecutor's Office, had found his activities lawful. ${ }^{379}$

The ECtHR underlined that the penal law provision in respect of which the applicant had been prosecuted, and its interpretation, were inherited from the former Soviet legal system. Thus, the domestic authorities were confronted with the 'difficult task of applying these legal norms and notions in the completely new context of a market economy.' 380

The ECtHR observed that the applicant was charged with, and convicted of, creating a situation whereby the preservation of the state's assets might have been jeopardised, and that this was regarded as significant damage, despite the fact that the risks had not materialised. Furthermore, he was found to have caused significant moral damage to the interests of the state. According to the competent domestic Court of Appeal, the applicant's acts had not been in compliance with 'the general sense of justice'; as a high-ranking state official he had cast doubt on the lawfulness and reliability of the activities of the Agency as a state institution, thus materially impairing the authority of the state in society, and also damaging the reputation of the Republic of Estonia as an international contractual partner. ${ }^{381}$

According to the wording of Article 161 of the Estonian Criminal Code, 'causing of significant damage', is a necessary element of the offence of the abuse of an official position. The text of this provision does not mention the mere creation of a risk as comprising such damage. The Estonian Supreme Court's case law demonstrates that importance is attached to the creation of danger as damage. However, the ECtHR underlined that no criteria had been developed for assessing such a risk. Moreover, the applicant actually acted under an obligation to conduct the privatisation of ER, having to balance risks relating to the proceeding with the privatisation against those relating to withdrawal from the agreement. In light of these considerations, the ECtHR held that the applicant could not reasonably foresee that his acts would be deemed to amount to causing significant damage - in respect

378 Liivik v. Estonia, appl. no. 12157/05, 25 June 2009, §29. This criminal law provision regarding abuse of an official position provided: 'Intentional misuse by an official of his or her official position, if it causes significant damage to the rights or interests of a person, enterprise, agency or organisation protected by law or to national interests, shall be punished by a fine or up to three years' imprisonment'.

379 Liivik v. Estonia, appl. no. 12157/05, 25 June 2009, §88-89.

380 Liivik v. Estonia, appl. no. 12157/05, 25 June 2009, \$97.

381 Liivik v. Estonia, appl. no. 12157/05, 25 June 2009, §97-98. 
of the alleged creation of a risk of damage - within the meaning of Article 161 of the Estonian Criminal Code. ${ }^{382}$

In respect of the alleged causing of significant moral damage to the interests of the state, the ECtHR ruled that the assessment was made by the domestic Courts retroactively on the basis of their discretionary judgement and it was not susceptible of proof. The applicant's attempt to adduce evidence showing that the reputation of the state had not been damaged was turned down by the courts. It appears that an alleged violation of law by the applicant in itself served as an irrebuttable presumption that the applicant had caused moral damage to the interests of the State. According to the ECtHR, so broad an interpretation could, in principle, render any breach of law a criminal offence within the meaning of Article 161 of the Estonian Criminal Code. Moreover, any such moral damage would have to be qualified as 'significant'. The ECtHR noted, in this context, the attempts in the Supreme Court's case law to lay down criteria for an assessment of whether there existed, in a given case, any non-pecuniary damage, and whether this damage was 'ordinary, significant or large-scale'. However, the criteria used by the domestic courts to establish that the applicant had caused 'significant' non-pecuniary damage - that he had been a high-ranking state official who had been working in a field attracting great public interest, and that his acts had been incompatible with 'the general sense of justice' - were too vague. The ECtHR was therefore not satisfied that the applicant could reasonably have foreseen that he risked being charged with, and convicted of, causing significant moral damage to the interests of the state on account of his conduct. 383

In sum, the interpretation and application of Article 161 of the Estonian Criminal Code in the present case involved the use of such broad notions and such vague criteria that the criminal provision in question was not of the quality required under the ECHR in terms of its clarity and the foreseeability of its effects. ${ }^{384}$

\subsection{Law and state practice}

According to the general principles of law, defendants are not entitled to justify the conduct that has given rise to their conviction, simply by showing that such conduct did, in fact, take place, and formed a practice. The state practice of tolerating or encouraging certain acts that have been deemed to be criminal offences under national or international legal instruments, and the sense of impunity that such a

382 Liivik v. Estonia, appl. no. 12157/05, 25 June 2009, §99.

383 Liivik v. Estonia, appl. no. 12157/05, 25 June 2009, $\$ 100$.

384 Liivik v. Estonia, appl. no. 12157/05, 25 June 2009, \$101 and 104. 
practice instils in the perpetrators of such acts, does not prevent their being brought to justice and punished..$^{385}$

At this point, I will merely refer to the above-discussed case of Streletz, Kessler and Krenz v. Germany, in which the ECtHR unequivocally concluded that state practice, which was contrary to criminal law and showed complete disregard of the right to life, could not supersede the written law. ${ }^{386}$

\subsection{State succession}

The sixth sub-rule relates to problems that arise following state succession and the (changed) application of criminal law provisions. According to the ECtHR, in the event of state succession or a change of political regime in the national territory, it is entirely legitimate for a state governed by the rule of law to bring criminal proceedings against persons who have committed crimes under a former regime. Similarly, the courts of such a state, having taken the place of those which existed previously, cannot be criticised for applying and interpreting the legal provisions in force at the material time in the light of the principles governing a state subject to the rule of law. ${ }^{387}$ This sub-rule is, so far, only applied in judgements regarding prosecutions after the German reunification.

The case of K.-H.W. v. Germany is illustrative, in this respect. Comparable to the facts in Streletz, Kessler and Krenz v. Germany, the applicant committed intentional homicide as a border guard in the GDR. ${ }^{388}$ The applicant had fired five (deadly) shots at a person trying to flee from East Berlin by swimming. Important to note is that the victim had been unarmed and did not pose a threat to anyone; his one aim had been to leave the GDR, as it was almost impossible at that time for ordinary citizens, apart from pensioners and a few privileged persons, to leave the GDR legally. ${ }^{389}$ His attempt to cross the border, although prohibited by GDR law, could therefore not be classified as a 'serious crime' since he did not mean any harm nor did he pose a threat to anyone.

\footnotetext{
385 See Streletz, Kessler and Krenz v. Germany, appl. no. 34044/96, 35532/97 and 44801/98, 22 March 2001, §74, 77-79 and 87-88.

386 See section 8.5.

387 K.-H.W. v. Germany, appl. no. 37201/97, 22 March 2001, §84.

388 K.-H.W. v. Germany, appl. no. 37201/97, 22 March 2001, §47. The applicant in this case was, however, considerably younger than the ones in Streletz, Kessler and Krenz v. Germany. Furthermore, the applicant was a low-ranking officer who 'merely executed orders' of senior/ high ranking officers. The ECtHR underlined however, that 'even a private soldier could not show total, blind obedience to orders which flagrantly infringed not only the GDR's own legal principles but also internationally recognised human rights, in particular the right to life, which is the supreme value in the hierarchy of human rights'. See K.-H.W. v. Germany, appl. no. 37201/97, 22 March $2001 \S 42$ and 75.

389 K.-H.W. v. Germany, appl. no. 37201/97, 22 March 2001, §11-16.
} 
According to the applicant, his prosecution violated the principle of legality as he could not have foreseen, at the time of the commission of the acts, that he would be prosecuted (after the German reunification - considered as state succession). At the moment of the commission of the offence, perpetrators of such offences were not prosecuted in the GDR - even though murder/homicide was criminalised under the Criminal Code in force. ${ }^{390}$ His pleas ${ }^{391}$ were of no avail, the domestic judiciary sentenced him to 1 year and 10 months imprisonment based on the criminal law of the GDR applicable at the material time.

The ECtHR held that the fact that the applicant had not been prosecuted in the GDR, and was not prosecuted and convicted by the German Courts until after the reunification, on the basis of the legal provisions applicable in the GDR at the material time, did not, in any way, mean that his act was not an offence according to the law of the GDR. This reasoning is similar to the one developed in Streletz, Kessler and Krenz v. Germany. Nevertheless, in this case, the ECtHR specifically discussed the impact that state succession may have on Convention conform application of criminal law provisions by the new regime. The ECtHR reiterated that for the purposes of Article 7, section 1 of the ECHR, however clearly drafted a provision of criminal law may be, in any legal system, there is an inevitable element of judicial interpretation. There will always be a need for elucidation of ambiguous points and for the adaptation to changing circumstances. In this judgement, the ECtHR regarded state succession as falling within the scope of 'changing circumstances'. Normally, development in case law - as result of changing circumstances - refers to the gradual development of case law in a given state subject to the rule of law and under a democratic regime. However, this also remains valid where, as in the present case, one state has abruptly succeeded another. ${ }^{392}$

This means that state succession may result in a completely different (opposite) application of the (provisions comprised in the) existing criminal law, contrary to the interpretation to date, and, without violating the principle of legality as comprised in Article 7 of the ECHR.

In this particular judgement, this line of reasoning was further reinforced by the pre-eminence of the right to life in all international instruments on the protection of human rights, including the ECHR itself. The ECtHR therefore considered the German courts' strict interpretation of the GDR's legislation in the present case to be compatible with Article 7, section 1 of the ECHR. ${ }^{393}$

390 At the material time, the applicant was not prosecuted for the offence in the GDR. This was because of the contradiction between the principles laid down in the GDR's Constitution and its legislation, on the one hand, which were very similar to those of a state governed by the rule of law, and the repressive and factually accepted state practice of the border policing regime in the GDR and the orders issued to protect the border, on the other.

391 The applicant put forward several pleas. He claimed, among others, to be 'innocent' as he merely acted on the orders of his superiors.

392 K.-H.W. v. Germany, appl. no. 37201/97, 22 March 2001, §85.

393 K.-H.W. v. Germany, appl. no. 37201/97, 22 March 2001, §58, 59, 88 and 105. 


\subsection{Section 2}

The ECtHR considers Article 7, section 2 of the ECHR to constitute an exceptional derogation, from the general principle laid down in the first section, in the case of the trial and punishment of an act or omission, which, at the time it was (c)omitted, was a criminal offence, according to general principles of law.

The two paragraphs of Article 7 of the ECHR are intertwined and must be interpreted in a concordant manner. ${ }^{394}$ The preparatory works to the ECHR show that the purpose of the second section is, even though it is formulated in a general way, to specify that this provision does not affect laws which, in the wholly exceptional circumstances at the end of the Second World War, were passed in order to punish war crimes, treason and collaboration with the enemy. Accordingly, this section does not, in any way, aim to pass legal or moral judgement on those laws. The reasoning also applies to crimes against humanity committed during this period. ${ }^{395}$

Article 7, section 2 of the ECHR may still be of importance for those contracting states where the limitation in respect of war crimes has been suspended. In the opinion of van Dijk and van Hoof, it may also have effect with respect to other cases, such as cases where the violation of ' general principles of law recognised by civilised nations' can be qualified as a crime against humanity or a war crime. At this point I will not elaborate further on this issue. ${ }^{396}$

\subsection{In sum}

Article 7 of the ECHR prescribes that persons can be exclusively convicted and sentenced on the basis of a criminal law provision that was in force at the time of the commission of the offence. The above-discussed sub-rules serve to specify the scope of the Strasbourg principle of legality. This principle seems to convey the impression of an unambiguous and strict character, but the ECtHR's case law undermines that impression in several ways.

To start with, the ECtHR affords states a large margin of appreciation and does not, moreover, consider itself as a kind of 'European Court of Appeal' which reviews the correctness of the interpretation followed by the national courts. National states determine what behaviour is criminalised and the ECtHR merely reviews, marginally, whether the editing of a criminal law provision complies with Article 7 of the ECHR in specific cases. The ECtHR's role is confined to ascertaining whether the effects of an interpretation of a domestic criminal law provision are compatible

\footnotetext{
394 Tess v. Latvia, appl. no. 34854/02, 12 December 2002.

395 Papon v. France, appl. no. 54210/00, 25 July 2002.

396 P. van Dijk, F. van Hoof, A. van Rijn and L. Zwaak (eds.), Theory and Practice of the European Convention on Human Rights, fourth edition, Intersentia, Antwerpen-Oxford, 2006, p. 660-662.
} 
with the ECHR. Case law demonstrates that mostly pure procedural aspects of the principle of legality, i.e. clear retroactive application of criminal law to the detriment of the accused, lead to a (procedural) violation of that Article. Also, blunt application of criminal law by analogy will lead to a violation of the principle of legality. These are nonetheless all more or less 'procedural' breaches of the principle of legality.

So far, the ECtHR has rarely condemned Member States for the application of excessively vaguely drafted criminal law provisions. And if the ECtHR has found a 'substantive' violation of Article 7 of the ECHR, that violation has mostly been due to application of vague criminal law provisions by analogy. So, instead of bluntly stating that a criminal law provision is edited too vaguely, the ECtHR rather concludes that the provision has been applied too extensively, amounted to analogy. This was, for example, the case in the judgement of Sud Fondo Srl et autres contre Italie.

The dissemination of separatist propaganda, the notion of proselytism, insulting someone, offending someone, and the notion of pharmaceutical products, are all sufficiently clear to comply with Article 7 of the ECHR, even though these notions can be interpreted in many ways. According to the ECtHR, judges should be left to interpret and develop criminal law provisions according to changing societal circumstances. Excessively clearly defined offences would obstruct that.

The ECtHR acknowledges that criminal law provisions must be applicable in various situations and to all potential (future) perpetrators. This implies that such provisions must, to a certain extent, be edited in somewhat broad terms whereas the principle of legality, theoretically, requires criminal behaviour to be edited as clearly as possible. There is, consequently, a constant inherent tension in drafting, as clearly as possible, criminal law provisions, which at the same time, also cover all (future) behaviour that is to be considered criminal in nature. ${ }^{397}$

Domestic case law must clarify ambiguous facets of criminal law. If needed, civilians should seek further legal assistance to foresee, to a reasonable degree, when and under what circumstances conduct might lead to criminal liability. Clarification of ambiguous criminal law provisions through case law is though conditional on some criteria. Firstly, the development of law should always be in accordance with rules of criminal liability relating to the basic offence, more specifically, with the rules defining 'the essence of the offence'. Secondly, the interpretation of an existing criminal law provision must respect fundamental principles of criminal law, or at least the general principles of law. Often, a court's interpretation will implement and further develop an already existing trend in case law or in society. Thirdly, the development has to be reasonably foreseeable by the accused. Therefore, the application of a criminal law provision should have been

397 A.C. 't Hart, Strafrecht en beleid, 1984, p. 189-231; C.P.M. Cleiren, 'Het legaliteitsbeginsel', in C.P.M. Cleiren, Th. A. de Roos, M.A.H. van der Woude, Jurisprudentie Strafrecht Select, Sdu Uitgevers Den Haag 2006, pp. 227-251. 
reasonably anticipated by the accused as complying with general principles of criminal law.

Requirements on clearly defined, and hence, foreseeable, criminal law provisions are generally satisfied when the requirements for '(prescribed by) law' regarding, for example, Article 9 of the ECHR have been met. This low standard is to be regretted, particularly taking into account that 'prescribed by law' involves an assessment of the law in general whereas 'law' in Article 7 of the ECHR exclusively refers to criminal law. It seems as if it is only when the legal uncertainty of a person is almost total that the ECtHR will rule that there has been a violation of Article 7 of the ECHR - due to non-compliance with the lex certa requirement. The ECtHR deems an extensive interpretation of criminal law provisions, which is in line with (gradual) changing (societal) circumstances, not to be in violation of the principle of legality, as long as the interpretation remains in accordance with the essence of the provision and, to a certain extent, foreseeable. Nevertheless, several judgements have shown that even a completely different (broader) interpretation of a criminal law provision regarding serious offences - hence without gradual preceding development - does not automatically imply a violation of Article 7 of the ECHR. Faced with such a dilemma, the ECtHR deems the punishment of serious criminal behaviour, even if not obviously falling within the scope of a criminal law provision, to be more important than the strict application of the principle of legality.

In conclusion, in the field of clearly drafted criminal law provisions, Article 7 of the ECHR will not be of great service. Fortunately, the ECtHR does examine substantive aspects of criminal law in cases concerning, for example, the right to privacy, while scrutinising compliance with the lawfulness requirement and the necessity requirement. ${ }^{398}$ This issue will further be discussed in Chapters III, IV and $\mathrm{V}$.

398 See the Guidelines on Human Rights and the Fight Against Terrorism adopted by the Committee of Ministers on 11 July 2002, Council of Europe Publishing, September 2002, rule 3, section 2: 'When a measure restricts human rights, restrictions must be defined as precisely as possible and be necessary and proportionate to the aim pursued'. 



\section{Chapter III \\ Allegedly Involved in Terrorist Activities}

\section{INTRODUCTION}

In this chapter the anti-terrorism measure referred to as 'personal disturbance' [persoonlijke verstoring], and the underlying suspicion criterion, are discussed. During the period 2004-2007 the police, acting under authority of the Mayor, used a range of surveillance powers (personal disturbance powers) on persons allegedly involved in terrorist activities/persons posing a terrorist threat. The powers are comparable to consistent observation, as defined in the DCCP, and included tailing a person, making inquiries about his whereabouts, and/or asking his acquaintances for an identity card. ${ }^{399}$

The government invoked Articles 2 and 12 of the Police Act (PA), and Article 172 of the Municipality Act [Gemeentewet], as a legal basis for personal disturbance. These provisions describe the general task description of the Mayor and the police, that of safeguarding public order. Articles 2 and 12 of the PA define the police's task as factually preserving the legal order and providing help to those who require it. This task must be performed in subordination to the Mayor, and in accordance with the applicable legal rules. Article 172 of the Municipality Act comprises a general duty of the Mayor to safeguard public order. To that effect, he is allowed to prevent or to stop violations of legal provisions that concern public order.

However, none of these provisions include specific criteria of application for personal disturbance powers. The criteria of 'persons allegedly involved in terrorist activities' or 'persons who pose a terrorist threat', are not codified, just mentioned in parliamentary memoranda. ${ }^{400}$

The above-mentioned provisions provide an adequate legal basis for various police powers that infringe upon fundamental rights, though only to a limited extent. For instance, observing a person by means of a camera that is placed on a public road, is considered as a minor interference with the right to privacy. ${ }^{401}$ Other examples are: briefly tailing a person because he behaves in a way which makes involvement in a recently reported criminal offence likely, superficially observing a group of youngsters, or systematically observing certain objects such as a shed, a vessel, or a vehicle. Powers that interfere to a more far-reaching extent with persons' privacy

399 See J.G. Brouwer, Van nachtbrakers tot terroristen, over persoonsgericht verstoren, inaugural lecture delivered at 13 June 2006, Groningen, $\mathrm{p} 1$.

400 Kamerstukken II 2006-2007, 30 977, no. 104, p. 1.

401 Supreme Court 12 February 2002, NJ 2002/301. See also Supreme Court 19 March 1996, NJ 1997/85 and Supreme Court 25 January 2000, NJ 2000/279; Supreme Court 30 March 2004, NJ 2004/377; Supreme Court 18 January 2005, NJ 2006/12. 
must be based on more explicit legal provisions. The more far-reaching an interference with fundamental rights is, the greater the need for a separate explicit legal basis to legitimise the application of (police) powers. ${ }^{402}$

Academics and various specialised organisations have criticised the use of personal disturbance, and have labelled it as police stalking. ${ }^{403}$ This criticism is primarily directed at the lack of an adequate legal basis for personal disturbance. ${ }^{404}$ The Judiciary has been asked twice to rule on the lawfulness of specific cases of personal disturbance. ${ }^{405}$ These two judgements will be discussed below. The government issued a parliamentary memorandum on personal disturbance in $2007 .{ }^{406}$ In this memorandum the government argued that: (1) the intrusiveness of personal disturbance powers was considerably less than assumed, and (2) those powers had no longer been applied since the beginning of 2007. Basically, the government has trivialised the practical importance of personal disturbance and has accordingly brushed aside criticism of this measure.

The government's conclusion with regard to the period after 2007 may be considered justified. As far as publicly known, no persons have been subject to personal disturbance powers since 2007. This is not surprising, considering that was the year

402 Permanent camera observation within the public domain used to be based on Articles 2 and 12 of the PA as well. Finally, the government decided to enact a separate legal basis for this measure in order to legitimise the consequent interferences with the right to privacy.

403 See J.G. Brouwer, Van nachtbrakers tot terroristen, over persoonsgericht verstoren, inaugural lecture delivered at 13 June 2006, Groningen; L.J.J. Rogier, M.A.D.W. de Jong, C.M. Bitter and F.W. Bleichrodt, Bestuursrechtelijke aanpak van criminaliteit en terrorisme. Preadviezen Vereniging voor Bestuursrecht, Boom Juridische Uitgevers 2007 Den Haag. The supervisory body for the Dutch secret intelligence service also argued that personal disturbance will most likely be judged in violation of Article 8 of the ECHR. See, further J.P. Loof, 'Politie-inmenging in de persoonlijke levenssfeer zonder wettelijke basis: terrorismebestrijding en constitutioneelrechtelijk experimenteergedrag', in Rechtsgeleerd Magazijn Themis 2007-3, pp. 112-115; E.R. Muller, L.J.J. Rogier, H.R.B.M. Kummeling, R.P. Bron, A.J. Th. Woltjer and V.C. Kalkhoven, Bestuur, recht en veiligheid. Bestuursrechtelijke bevoegdheden voor openbare ordehandhaving en terrorismebestrijding, COT Instituut voor Veiligheids en Crisismanagment, Erasmus Universiteit Rotterdam en Universiteit Utrecht, 1 October 2007, pp. 1-195; J.J.H. Suyver, M.J. Borgers, C.P.M. Cleiren and P.J. van Zunderd (Commissie Suyver), Rapport van de Commissie evaluatie anti-terrorismebeleid, Naar een integrale evaluatie van antiterrorismemaatregelen, mei 2009, pp. 40-42 and 49-50 and 57; S. Ouchan and L. Talsma, 'Persoonsgericht verstoren: een disproportionele maatregel in de strijd tegen het terrorisme', in NJCM-Bulletin jrg 32, 2007, no. 7, pp. 984-998.

See L.J.J. Rogier, M.A.D.W. de Jong, C.M. Bitter and F.W. Bleichrodt, Bestuursrechtelijke aanpak van criminaliteit en terrorisme. Preadviezen Vereniging voor Bestuursrecht, Boom Juridische Uitgevers 2007 Den Haag.

406 Kamerstukken II 2006-2007, 30 977, no. 104. See, also, Kamerstukken II 2006-2007, 29 754, no. 100 
the DPTA entered into force. ${ }^{407}$ This Act provides the investigative authorities with powers comparable to personal disturbance powers, which may, moreover, be used on the basis of low suspicion criteria. Personal disturbance then, has become redundant. However, it remains to be seen if the government's conclusion regarding the period 2004-2006 is tenable, in particular, with respect to the most intrusive forms of personal disturbance. Was the intrusiveness of personal disturbance powers applied during that period in light of the applicable (not statutorily defined) 'suspicion criterion' as minor as the government asserted in the above-mentioned memorandum?

Even though the practical importance of personal disturbance has diminished since 2007, the highly instrumental character of this measure remains worth discussing. This is a characteristic of all measures that aim to prevent terrorism in Dutch antiterrorism policy.

In the coming sections the following issues will be discussed. Section 2 elaborates on the notion of 'alleged involvement in terrorist activities/posing a terrorist threat'. Then the practical scope of personal disturbance-powers and their resemblance to special investigative techniques, as comprised in the DCCP, is considered in Sections 3 and 4. Thirdly, the Strasbourg right to privacy pursuant to Article 8 of the ECHR, will be discussed in light of the application of personal disturbance powers in Section 5. To this effect, two issues will be discussed: (1) the requirement that interferences with the right to privacy must be in accordance with the law, and (2) the necessity requirement.

\section{Alleged inVolvement in terrorist aCtivities}

Personal disturbance powers are applied to persons who allegedly pose a terrorist threat to society. ${ }^{408}$ Connections with presumed terrorists or involvement in terrorist activities may lead to being labelled as such a threat. The government refers to 'strong indications' which are, however, still insufficient to initiate criminal proceedings. ${ }^{409}$ The government did not further specify when exactly a person is considered as posing a terrorist threat because of his alleged involvement in terrorist activities. Generally, investigative authorities need to substantiate a (reasonable) suspicion on account of a specific offence in order to lawfully apply state power(s) that interfere with fundamental rights. However, actual involvement in a specific terrorist offence is not a precondition for the application of personal disturbance

\footnotetext{
407 See for a discussion of the DPTA, Chapters V, VI and VII.

408 Kamerstukken II 2006-2007, 30 977, no. 104, p. 1-2. See, also, Kamerstukken II 2006-2007, 29 754, no. 100.

409 See J.P.H. Donner and J.W. Remkes, 'Kritiek op persoonsgerichte aanpak onjuist', in Binnenlands Bestuur 21 July 2006.
} 
powers. ${ }^{410}$ The prevention of terrorism by means of personal disturbance does not require a concrete suspicion in respect of a specific terrorist offence comparable to the criminal justice system. ${ }^{411}$

The Mayor is the competent authority to order the application of personal disturbance powers. It is supposed to fall within the remit of his task, that of maintaining public order. His decision to apply personal disturbance powers in a specific case is based on information stemming from the CT-Infobox. ${ }^{412}$ Mere unsubstantiated secret intelligence information has often led to the application of personal disturbance powers. The two judgements regarding personal disturbance that will be discussed in Section 3 only provide some clarification on the question of what and how much information may lead to personal disturbance. These judgements demonstrate that very superficially knowing a member of an alleged terrorist organisation, and conversion from a reformed background to a strict Islamic lifestyle, may be sufficient to be regarded as posing a terrorist threat to society. It remains to be seen, in light of Article 8, section 2 of the ECHR, whether such information can be considered as sufficient information to justify interferences with the right to privacy.

According to the government, personal disturbance powers serve to make persons incapable of further developing joint terrorist activities. As personal disturbance is openly applied and inevitably implies the surveillance of acquaintances, the person to whom personal disturbance powers are applied will be avoided by his 'terrorist friends' and will cease to pose a threat to society. This means that the application of personal disturbance powers does not merely lead to interferences with the right to privacy of the person regarded as posing a threat to society, but potentially also to interferences with other persons' privacy.

The scope of personal disturbance powers varies from intense and combined application of several of these powers, to less intrusive personal disturbance, which consists of mere superficial observation. This chapter primarily focuses on the more far-reaching form of personal disturbance, which includes observing a person for several days around the clock, calling them regularly on their home and/or mobile phone, asking acquaintances for their identity cards, staring at the person concerned and visiting him (unannounced) regularly at home. Personal disturbance may also comprise the police inviting the person concerned (repeatedly) to come to the police

\footnotetext{
410 Kamerstukken II 2006-2007, 30 977, no. 104, p. 4.

411 Amsterdam District Court 1 December 2005, LJN: AU7314, 328230/KG 05-2159 AB, legal ground 10 .

412 The CT-Infobox is a cooperative information network consisting of the secret (military) intelligence services, the immigration and naturalisation services [IND], the national police headquarters [KLPD] and the public prosecution service. See for further discussion of the CT-Infobox Chapter IV on the administrative measures as comprised in the Bill.
} 
station, visiting places he frequents and distributing leaflets regarding the possibility of anonymously reporting a crime in the neighbourhood of the person concerned [Meld Misdaad Anoniem]. ${ }^{413}$

\section{Personal disturbance powers in practice}

So far, the Judiciary has only been asked to rule on the lawfulness of personal disturbance twice. The first case concerned a (Muslim) woman (claimant) who was arrested during a house-search. ${ }^{414}$ The search was performed on the basis of her conversion from a Christian reformed background to a strict Islamic lifestyle. She also started wearing a long gown, a headscarf, and she refused to shake hands with men. ${ }^{415}$ Lastly, she kept in touch with one member of the Hofstadgroep. The neighbourhood-watch sent the information to the prosecutor's office. The subsequent house search did not yield any incriminating evidence. Therefore, the claimant was released shortly afterwards. ${ }^{416}$

As she was still considered a threat to public order, the police started to apply personal disturbance powers. These powers included driving noticeably by her house and stopping outside for several minutes with motor running, both day and night; following her by (police) car when she went out; stopping visitors and asking for their identity card; calling her when she was not at home; and observing her house on a regular basis. ${ }^{417}$

413 See J.P.H. Donner and J.W. Remkes, 'Kritiek op persoonsgerichte aanpak onjuist', in Binnenlands Bestuur 21 July 2006.

414 Amsterdam District Court 1 December 2005, LJN: AU7314, 328230/KG 05-2159 AB, legal ground 1. Or: NJF 2006-57, 1 December 2005, nr. 328230 / KG 05-2159 AB.

415 During the lawsuit, it appeared that prior to the house search the regional Amsterdam criminal secret service had passed a memo to the police, which read that explosives were being produced in a house 'somewhere in Amsterdam-North in the vicinity of the Meeuwenlaan between the roundabout and the bridge over the IJ', thereupon the police started a criminal investigation. They discovered that the woman's children were brought to school by a member of the Hofstadgroep, an alleged terrorist organisation. Additionally, during the subsequent house search two tapes were found containing Arabic texts on how to cut someone's throat. Also, the woman recently married a man who adhered to Islam. It is important to note, however, that the two last-mentioned facts only came to light as a result of the house search, and were hence not known to the police prior to the search. Furthermore, the tapes that were allegedly found were not confiscated by the police, and as the woman denied the existence of the tapes, the Amsterdam District Court concluded that the existence of the tapes had not been proven, and could therefore not play a part in the proceedings.

416 See Article 49 of the Weapons and Ammunition Act.

417 The regional police-cooperation of Amsterdam-Amstelland [crisis en terrorisme overleg van de Regiopolitie Amsterdam-Amstelland] advised the Mayor of Amsterdam to apply personal disturbance powers to the woman concerned. At no point did the police inform her any further of the reasons for her being subjected to such powers. The secret nature of the information that led to the personal disturbance made it impossible for her to rebut the allegations. 
The Amsterdam District Court underlined that there is no other legal basis for personal disturbance powers aside from the generally defined Article 12 of the PA. Furthermore, prior approval by an independent supervisory authority is not required. The sole judicial (post) control mechanism to assess the lawfulness of the application of personal disturbance powers consists, therefore, of summary proceedings. The District Court considered it questionable whether this system is 'in accordance with the law', as required by Article 8 of the ECHR. Adequate and effective procedural safeguards are required in the case of infringements, especially when state authorities have a certain discretion in applying powers which interfere with the right to privacy. With regard to the legal basis for personal disturbance, the Amsterdam District Court argued merely that it was highly unlikely that the infringement on the claimant's right to privacy was sufficiently provided for by law, in accordance with Article 8, section two of the ECHR. ${ }^{418}$

Interferences with the right to privacy must be necessary in a democratic society. This implies that the aims pursued must be relevant and sufficient, and that the interference must be proportional to the aims pursued. In this respect, the Amsterdam District Court underlined that several of the initially existing concerns against the claimant had expired: she did no longer have any contact with the alleged member of the Hofstadgroep, tapes with Arabic texts on how to cut someone's throat could not play a part in the proceedings, and no explosives had been found during the house search.

The claimant's adherence to the Islam was the only justification for the continued application of personal disturbance-powers. According to the Amsterdam District Court, this fact, as such, could not lead to, and justify application of, personal disturbance powers. Consequently, the District Court judged the application of personal disturbance powers to be disproportionel to the aims pursued, and therefore unlawful. 419

The Amsterdam District Court judged otherwise in the second case. This time, it concerned a man (claimant) who kept in close touch with several members of the Hofstadgroep. During a house search the police found (electronic and video) documents regarding the murder of Theo van Gogh, and a floppy disk containing documents in which threats were issued against prominent Dutch politicians. Also, the police found a member of the Hofstadgroep residing in the claimant's basement.

The claimant was kept in police custody and in remand custody, after which time he was released. There was insufficient evidence to initiate a prosecution on account of membership of the Hofstadgroep but the public prosecutor did consider

\footnotetext{
418 Amsterdam District Court 1 December 2005, LJN: AU7314, 328230/KG 05-2159 AB, legal ground 7.

419 Amsterdam District Court 1 December 2005, LJN: AU7314, 328230/KG 05-2159 AB, legal grounds $14-18$.
} 
him to be a suspect, based on Article 205 of the DCC (recruitment for the armed struggle).

At the time of the summary proceedings, the personal disturbance powers applied to the claimant consisted of driving by his house and staying there three times a day for 10 minutes (also during the night), 'staring' at the claimant whenever he left his house, and regularly calling him to make appointments without apparent cause.

As the application of these powers amounted to a certain pressure being exerted on the claimant, the District Court held that the personal disturbance powers interfered with his right to privacy. ${ }^{420}$ The question was whether this interference could be justified, in accordance with Article 8, section 2 of the ECHR.

Quite contrary to the first case, this time the District Court considered Article 12 of the PA explicitly as an adequate legal basis, primarily in light of the limited nature and scope of the powers applied to the claimant. Furthermore, the District Court judged the powers to be proportional to the aim(s) pursued - i.e, to hinder the claimant in developing any (further) terrorist activities.

In sum, the fact that the claimant kept in close touch with several members of the Hofstadgroep, the limited nature of the personal disturbance powers applied, and the fact that he was still considered a suspect in respect of Article 205 of the DCC, were decisive in the District Court concluding that the measures did not amount to a violation of Article 8 of the ECHR. ${ }^{421}$

IN SUM

In both cases, the Amsterdam District Court did not, as such, explicitly prohibit the application of personal disturbance powers, when based on Article 12 of the PA. No decisive answer was given to the question of whether this general provision was adequate. The District Court merely expressed doubts in this respect. The Court only judged explicitly on the question of whether the personal disturbance powers were proportional to the aims pursued. The answer to that question depended on the specific circumstances of the case. In the first case, the personal disturbance powers were more intrusive and based on less convincing evidence whereas in the second case the evidence was more compelling and the personal disturbance powers less intrusive. Hence, the more incriminating the evidence against a person is, and the less intrusive the personal disturbance powers are, the more inclined the Judiciary is to allow such powers to be exerted on the basis of Article 12 of the PA.

\footnotetext{
420 Amsterdam District Court 9 March 2006, LJN: AV4173, 335612 / KG 06-282 SR, legal ground 7.

421 Amsterdam District Court 9 March 2006, LJN: AV4173, 335612 / KG 06-282 SR, legal grounds $12-17$.
} 
It is, furthermore, striking to see that the District Court aligned national security with public order in the case of the application of personal disturbance powers. Article 12 of the PA refers to public order. In the two above-discussed judgements, the notions of public order and national security were used as interchangeable concepts. Alleged involvement or future (potential) involvement in terrorist activities was considered as threat against public order and as threat to national security. It is questionable whether involvement in terrorist activities, as interpreted with respect to personal disturbance powers, always equally, and moreover, directly, endangers public order, let alone national security.

Both judgements demonstrate that when it regards alleged involvement in terrorist activities, even if there may not be a (direct) threat against the legal order, all potential powers are mobilised to prevent the further development of such activities. When there is insufficient evidence to justify the application of powers within the criminal justice system, let alone to prosecute a person, the state nevertheless considers itself authorised to apply state powers which interfere with persons' fundamental rights on a generally formulated legal basis.

\section{Personal disturbance powers and the DCCP}

Personal disturbance can best be compared to consistent observation pursuant to Articles $126 \mathrm{~g}, 126 \mathrm{o}$ and $126 \mathrm{zd}$ of the DCCP. ${ }^{422}$ However, the DCCP requires a reasonable suspicion or indications of a terrorist offence to lawfully apply such powers. The application of personal disturbance powers does not require any formalised level of suspicion. Nevertheless, the information that leads to personal disturbance can best be compared to the information underlying indications of a terrorist offence pursuant to Article 126zd of the DCCP.

Personal disturbance was primarily used prior to the enactment of the DPTA. Since this Act entered into force, personal disturbance has no longer been applied. ${ }^{423}$ Can Article 126zd of the DCCP be considered as the 'codification' of the most intrusive form of personal disturbance? If that appears to be the case, personal disturbance may have been applied unlawfully during the period 2004-2007.

Although personal disturbance powers are, with regard to their scope, comparable to special investigation techniques ${ }^{424}$ like consistent observation, there are some

422 See Chapter VI for an elaborate discussion of special investigative techniques (to investigate terrorism) as comprised in the DCCP.

423 Kamerstukken II 2006-2007, 30 977, no. 104. See, also, Kamerstukken II 2006-2007, 29 754, no. 100 C.J. de Poot, R.J. Bokhorst, W.H. Smeenk, R.F. Kouwenberg, De Opsporing verruimd? De Wet opsporing terroristische misdrijven een jaar in werking, WODC, Cahier 2008-9.

424 The Dutch government deems the investigative techniques mentioned in Articles 126g until 126aa of the DCCP to be special investigative techniques because they are considered to be very risky to the integrity and the controllability of criminal investigations, and because the 
differences, of which I will mention a few. Firstly, as mentioned above, consistent observation requires a reasonable suspicion or indications of a terrorist offence while personal disturbance powers do not require a legally defined suspicion. Secondly, personal disturbance powers serve to maintain public order and/or national security. These powers are also applied to persons who have been acquitted of charges of (the preparation of) a terrorist offence, but who, nevertheless, are alleged to have terrorist intentions. ${ }^{425}$ Special investigation techniques are used during a criminal investigation and serve to initiate criminal proceedings. ${ }^{426}$

Thirdly, with regard to consistent observation, the public prosecutor is the competent authority, while the Mayor is competent to order the application of personal disturbance powers. An order for consistent observation is, furthermore, furnished with various formal safeguards, such as a time limit. Personal disturbance is not, in any way, formally limited in scope or duration.

The last important difference is that consistent observation takes place secretly, while personal disturbance is performed openly, and hence, with full knowledge of the person concerned. ${ }^{427}$

Despite these differences, personal disturbance powers, when applied in the most intrusive form, are very similar to consistent observation. Personal disturbance, as applied in the first above-discussed case, may very well amount to the same interference with the right to privacy as in case of consistent observation pursuant to Article 126zd of the DCCP. Further, the fact that the claimant knew that she was being 'watched', even though not 24 hours a day, sustains this conclusion. The pressure that such knowledge may put on the person concerned intensifies the interference with his privacy.

Keeping in mind the close resemblance of the most intrusive form of personal disturbance with consistent observation, pursuant to Article 126zd of the DCCP, we will now turn to the Strasbourg perspective. The above-discussion demonstrates that personal disturbance primarily raises issues regarding: (1) the legal basis for interferences with the right to privacy due to the application of personal disturbance

techniques infringe upon civil rights. See Kamerstukken II 1996-1997, 25 403, no. 3. $M v T$ Wijziging Wetboek van Strafvordering in verband met bijzondere opsporingsmethoden, p. 9. 2005, LJN: AT3315, 10/030075-04; the Hague Court of Appeal 18 November 2005, 10-00075-04, NJ 2006/96; see J.P.H. Donner and J.W. Remkes, 'Kritiek op persoonsgerichte aanpak onjuist', in Binnenlands Bestuur 21 July 2006.

426 See N. Tahir, 'Ook ik had een martelaar voor Allah kunnen worden', in NRC-Handelsblad 26 and 27 August 2006.

427 The Dutch government argues that openly applying personal disturbance powers will make the person concerned useless within a terrorist network. See: www.nctb.nl/Images/21-07-2006\%20 Artikel\%20Binnenlands\%20Bestuur\%20persoonsgericht\%20verstoren_tcm111-125870.pdf. 
powers, and (2) the necessity of these interferences. What criteria does the ECtHR provide, within the framework of Article 8 of the ECHR, in this respect?

\section{The RIGHT TO PRIVACY}

\subsection{Introduction}

The application of the most far-reaching form of personal disturbance powers may lead to infringements of the right to privacy of, primarily, the person who is allegedly involved in terrorist activities/who poses a terrorist threat. ${ }^{428}$ In its case law, the ECtHR prescribes that state authorities are obliged to thoroughly balance respect for the right to privacy against the interest of protecting national security, public safety or the economic well-being of the country, for the prevention of disorder or crime, for the protection of health or morals, or for the protection of the rights and freedoms of others. ${ }^{429}$ Interferences with the right to privacy must be in accordance with the law. Furthermore, these interferences must be necessary in a democratic society. ${ }^{430}$

The following sections elaborate on the question of which specific problems will come up, in terms of these two prerequisites, when the Mayor decides to apply personal disturbance powers on a person. Has the ECtHR passed judgement in comparable cases, and if so, under what circumstances does the ECtHR consider the application of such comparable powers to be in accordance with the law and to be necessary in a democratic society? What role does the fact that it concerns the prevention of further alleged involvement in terrorist activities play in this respect? And how does the ECtHR judge on interferences with the right to privacy that are justified at domestic level on such thinly substantiated information?

Before going into the above-mentioned questions it is important to keep in mind three general remarks regarding the scope of Article 8 of the ECHR. Firstly, the ECtHR allocates Member States a rather broad margin of appreciation ${ }^{431}$ in deciding whether there is an adequate legal basis in domestic law to legitimise interferences with the right to privacy. Secondly, Strasbourg case law is obviously very casuistic. Therefore, it is difficult to draw general conclusions as to the admissibility of

428 Other rights, such as the right to freedom of movement, may also be interfered with. However, I will exclusively focus on interferences with the right to privacy.

429 See for a balancing of the state's duty to safeguard public order against the state's duty to safeguard respect for the right to privacy, Radovanovic v. Russia, appl. no. 42703/98, 22 July 2004, §31: '(..) The Court reiterates that it is for the Contracting States to maintain public order (...). However, their decisions in this field must, in so far as they may interfere with a right protected under paragraph 1 of Article 8, be necessary in a democratic society, that is to say justified by a pressing social need and, in particular, proportionate to the legitimate aim pursued (...)'.

431 Soini and Others v. Finland, appl. no. 36404/97, 17 January 2006, §45. 
interferences with the privacy caused by domestic legislation. Thirdly, as will be demonstrated henceforth, there is, to my knowledge, no Strasbourg case law that examines powers comparable to personal disturbance powers, hence, beyond the criminal law context, on compatibility with Article 8 of the ECHR. The only Strasbourg judgement that may be useful in examining personal disturbance on compatibility with Article 8 of the ECHR is the case of Klass and others $v$. Germany. ${ }^{432}$ That judgement will be discussed below.

\subsection{An adequate legal basis for personal disturbance powers: The first requirement ${ }^{433}$}

When state authorities interfere with fundamental rights, an adequate legal basis is required to legitimise these interferences. Article 8, section 2 of the ECHR prescribes that interferences with the right to privacy must be in accordance with the law. Firstly, this implies that there must at least be some legal basis in domestic law to legitimise state powers. ${ }^{434}$ Secondly, the law must be accessible: persons must be able to have an indication that is adequate in the circumstances, of the legal rules applicable to a given case. ${ }^{435}$ Thirdly, a legal provision must be formulated with sufficient precision to enable citizens to regulate their conduct. They must be able, if need be, with appropriate advice, to foresee, to a degree that is reasonable in the circumstances, the consequences that a given action may entail. ${ }^{436}$

A law that confers a power upon state authorities involving a certain discretion must indicate the scope of that discretion. The ECtHR recognises the impossibility of attaining absolute certainty in the framing of laws, and acknowledges the risk that the search for such certainty may lead to excessive rigidity. Formulating a law to cover every eventuality is barely possible. Nevertheless, although many laws are inevitably couched in terms, which, to a greater or lesser extent are vague, their interpretation and application should be sufficiently clarified by practice.

432 Klass and Others v. Germany, appl. no. 5029/71, 6 September 1978, $\$ 25$ and 40.

433 See, for a more elaborate discussion of this requirement, Chapter V.

434 Silver and Others $v$. the United Kingdom, appl. nos. 5947/72; 6205/73; 7052/75; 7061/75; 7107/75; 7113/75; 7136/75, 25 March 1983, §86; Sunday Times v. the United Kingdom, appl. no. 6538/74, 26 April 1979, §47; McLeod v. the United Kingdom, appl. no. 24755/94, 23 September 1998; Taylor-Sabori v. the United Kingdom, appl. no. 47114/99, 22 October 2003, §18-19; PiskPiskowski v. Poland, appl. no. 29/03, 14 June 2005, §28-29.

435 Silver and Others $v$. the United Kingdom, appl. nos. 5947/72; 6205/73; 7052/75; 7061/75; 7107/75; 7113/75; 7136/75, 25 March 1983, §87. See, as well, Poltorastskiy v. the Ukraine, appl. no. 38812/97, 29 April 2003, §155; Kuznetsov v. the Ukraine, appl. no. 39042/97, 29 April 2003, $\S 134-135$.

436 Silver and Others $v$. the United Kingdom, appl. nos. 5947/72; 6205/73; 7052/75; 7061/75; 7107/75; 7113/75; 7136/75, 25 March 1983, §88; Radaj v. Poland, appl. nos. 29537/95 and 35453/97, 28 November 2002, §21 and 22; Narinen v. Finland, appl. no. 45027/98, 1 June 2004, §34-39; Bykov v. Russia, appl. no. 4378/02, 10 March 2009, §69-83. 
So, a law that confers a discretion on state authorities is not, in itself, inconsistent with the requirement of 'in accordance with the law'. As long as that law and its practical interpretation sufficiently indicate the scope of the discretion and the manner of its exercise, it is considered as conforming with Strasbourg guidelines in that respect. ${ }^{437}$ However, the unequivocal lack of a legal basis in domestic law to legitimise powers that interfere with the right to privacy is, in itself, a violation of the right to privacy.

States must, moreover, make available to the individual whose privacy is interfered with, the effective possibility of challenging the power that led to this infringement. There must be an appropriate domestic forum that offers adequate guarantees of independence, impartiality and procedural safeguards, to examine the relevant issues. ${ }^{438}$ This requirement is partly examined within the scope of the question of whether the interference with someone's privacy is necessary in a democratic society. 439

It is important to note that not every power that interferes with the right to privacy always needs an equally high-qualitative legal basis. The less intrusive an the interference with a person's privacy is, the more generally defined the legal basis may be that defines the impugned power. ${ }^{440}$ Within the Dutch legal system, Articles 2 and 12 of the PA are considered to be sufficient to legitimise minor interferences with the right to privacy. For intrusive interferences with the right to privacy, there must be a more detailed and specific legal basis. ${ }^{441}$ The dividing line between minor interferences, which can be justified by Articles 2 or 12 of the PA, and intrusive interferences which need an explicit basis, depends on the question of whether the observation was systematically exerted [stelselmatig]. When a person is observed systematically, the competent authority needs a legal basis to legitimise the consequent interference with the right to privacy that is more specific than Articles 2 and 12 of the PA.

437 See, as well, Gillow v. the United Kingdom, appl. no. 9063/80, 24 November 1986, §51; Segerstedt-Wiberg and Others v. Sweden, appl. no. 62332/00, 6 June 2006, §76; Drozdowski v. Poland, appl. no. 20841/02, 6 March 2006, §25. This issue will further be discussed in the following section. In Bykov v. Russia this issue was examined as part of the question of whether the interference was in accordance with the law. See Bykov v. Russia, appl. no. 4378/02, 10 March 2009, §69-83.

440 See Malone v. the United Kingdom, appl. no. 8691/79, 2 August 1984; Niemietz v. Switzerland, appl. no. 13710/88, 16 December 1992; Murray and Others v. the United Kingdom, appl. no. 14310/88, 29 October 1994; P.G. and J.H. v. the United Kingdom, appl. no. 44787/98, 25 September 2001.

441 Kamerstukken II 1996-1997, 25 403, no. 3, p 110. See, also, Supreme Court 14 October 1986, NJ 1987, 564; Supreme Court 14 October 1986, NJ 1988, 511; Supreme Court 13 October 1992, NJ 1993, 223; Supreme Court 19 December 1995, NJ 1996, 249 (Zwolsman); Supreme Court 11 November 1994, NJ 1995, 400; Supreme Court 13 October 1998, Amsterdam Court of Appeal, 3 June 1999. 
The legal history of Articles $126 \mathrm{~g}, 126 \mathrm{o}$ and $126 \mathrm{zd}$ of the DCCP and the relevant case law demonstrate that consistent observation comes down to acquiring a more or less complete picture of certain aspects of a person's life. ${ }^{442}$ Such aspects may include a person's social contacts or his whereabouts. Several criteria have been developed to determine whether observation is consistent or not, such as the length of the observation, the place where a person is observed, the intensity or frequency of the observation and the question of whether technical equipment which offers more than just reinforcement of the senses, has been used. When a person is observed for a long period, in a rather intimate place, on a relatively frequent basis and in an intense way or by means of technical equipment, this may be considered consistent. ${ }^{443}$

Parliamentary memoranda demonstrate that regular police surveillance and the superficial observation of a group of youngsters do not qualify as consistent observation, and may be based on Articles 2 and 12 of the PA. However, frequently or intensively tailing a person does amount to consistent observation, and requires, consequently, a more explicit and specific legal basis. Furthermore, public as well as secret observation may be defined as consistent. ${ }^{444}$ Obviously, this is an important consideration with respect to the application of personal disturbance powers as these powers are publicly applied, unlike observation pursuant to the DCCP. Case law also shows that a brief, though deliberate, observation may be just as intrusive as a lengthy period of observation during which a person is observed less frequently. Both forms of observation are considered consistent, and, hence, require a legal basis to legitimise the consequent interference with someone's privacy.

Observing someone several times at home during the day and night, tailing him whenever he leaves the house and phoning him to inquire where he is, enables the police to get a more or less complete picture of the whereabouts of that person. ${ }^{445}$ As the two above-discussed judgements show, the intensity and the frequency of the most intrusive form of personal disturbance powers may be considerable. Generally, various powers are cumulatively applied, day and night, for a period of at least 1.5 months. If applied in such a way, personal disturbance can hardly be considered superficial, or merely as regular police surveillance pursuant to Article 2

442 See, in this respect, Melai, Strafvordering, commentaar op artikel $126 \mathrm{~g}$ wetboek van strafvordering, aantekening 2, 3 en 5 (Prof. mr. Y Buruma).

443 In the explanatory memorandum of the law on special investigative techniques, the government asserted that the intensity of the observation is the most important aspect in deciding whether observation may be defined as consistent. See Kamerstukken II vergaderjaar 1996-1997, 25403 , no. 3 , pp. $26-27$ and 70.

444 Kamerstukken II 1996-1997, 25 403, no. 3, p 70.

445 Kamerstukken II 1996-1997, 25 403, no. 3, p. 47. This memorandum underlines that the question of whether observation is, in fact, consistent, does not depend on the actual result thereof, but on the result that may reasonably be expected. 
of the PA. The fact that personal disturbance powers are applied in the surroundings of a person's home is also of importance in this respect. ${ }^{446}$

In sum, personal disturbance powers, as applied in the above-discussed judgements, may amount to consistent observation pursuant to Articles 126g, 126o and 126zd of the DCCP. It makes it questionable whether the application of this anti-terrorism measure in the above-discussed way would satisfy the Strasbourg criterion that interferences with the right to privacy must be in accordance with the law. This primarily concerns the most intrusive forms of personal disturbance. Less intrusive forms of personal disturbance, like the mere incidental observation of a person, can, without doubt, be based on Articles 2 and 12 of the PA and Article 172, section 2 of the Municipality Act. ${ }^{447}$

\subsection{The necessity requirement in light of personal disturbance ${ }^{448}$}

Interferences with the right to privacy must serve a legitimate aim and be necessary in a democratic society to be compatible with Article 8 of the ECHR. ${ }^{449}$ Let us assume for a moment that personal disturbance would have been furnished with an adequate legal basis. Can the application of personal disturbance powers then be considered necessary in a democratic society? This question will be answered as though the DPTA had not entered into force. If personal disturbance powers were currently applied, thus, next to the special investigation techniques to investigate terrorism as comprised in the DCCP, it would be highly unlikely that the consequent interferences with the right to privacy would be deemed necessary in a democratic society. easily be considered as safeguarding national security, public safety and preventing disorder and
crime. Violations of Article 8 of the ECHR are, to my knowledge, never due to the lack of one of
the legitimate aims comprised in the second section of that provision. The ECtHR often accepts
that measures that interfere with civilians' privacy do serve at least one of the legitimate aims
even without examining the reasons adduced by the Member State to substantiate the existence
of such an aim. See, for example, Yildiz v. Austria, appl. no. $37295 / 97,31$ October $2002, \S 40$;
Moustaquim v. Belgium, appl. no. 12313/86, 18 February 1991, $\$ 39$ and 40 ; Haase v. Germany,
appl. no. $11057 / 02,8$ July $2004, \S 87$.

See Halford v. the United Kingdom, appl. no. 20605/92, 25 June 1997, §44-46.

In this writing I will, aside from mentioning the article not further elaborate on Article 172, section 2 of the Municipality Act as a legal basis for personal disturbance-powers. For a thorough examination of the question of whether the Municipality Act may serve as adequate legal basis for personal disturbance, see: J.G. Brouwer, Persoonsgericht verstoren potentiële terrorismeverdachten op last van burgemeester ongrondwettig, pp. 11-22, at: www.rug.nl/ Corporate/nieuws/opinie/opinie_20. Brouwer concludes that Article 172, section 2 of the Municipality Act cannot serve as an adequate legal basis for personal disturbance, nor can any other article in the Municipality Act.

See for an elaborate discussion of the necessity requirement, Chapter V. Generally, the ECtHR's standards are all but demanding with respect to the question of whether
interferences with the right to privacy serve a legitimate aim. Personal disturbance will without 
The necessity requirement prescribes that interferences with the right to privacy must correspond to a pressing social need and must be proportionate to the legitimate aim(s) pursued. ${ }^{450}$ Does the ECtHR consider interferences resulting from the application of powers that specifically serve to prevent terrorism 'more necessary' than when it would regard interferences caused by powers meant to counter common crimes?

The judgement Klass and Others v. Germany ${ }^{451}$ is important in this respect. The applicants in this case (Klass) complained about German legislation that granted the investigative authorities far-reaching surveillance powers beyond the criminal law system. Klass did not dispute that the state had the right to use surveillance measures but he challenged this legislation in that it, among other things, excluded the possibility of any remedy before the domestic courts against the ordering and the execution of such measures. ${ }^{452}$

The German legislation set a series of limitative conditions that had to be fulfilled before a surveillance measure could actually be imposed. Also, the measures were confined to cases in which there were factual indications for suspecting a person of planning, committing, or having committed, certain serious criminal acts. Additionally, the measures could exclusively be ordered if the establishment of the facts by another method was without prospects of success or considerably more difficult. Even then, the surveillance could cover only the specific suspect. Hence, so-called exploratory or general surveillance was not permitted by the contested legislation.

Even though the powers comprised in the German legislation were considerably more far-reaching than personal disturbance, the ECtHR also commented in general on the necessity of surveillance measures to combat crime and/or terrorism.

The ECtHR held that powers of (secret) surveillance are tolerable under the ECHR only in so far as strictly necessary for safeguarding the democratic institutions and in exceptional circumstances. ${ }^{453}$ States are not allowed to adopt whatever measures

450 Klass and Others v. Germany, appl. no. 5029/71, 6 September 1978, §42; Keegan v. the United Kingdom, appl. no. 28867/03, 18 July 2006, §30 and 31; Ploski v. Poland, appl. no. 26761/95, 12 November 2002, §31 and 35; El Boujaïdi v. France, appl. no. 123/1996/742/941, 26 September 1997, §39 and 40; Hoffmann v. Germany, appl. no. 34045/96, 11 October 2001, §40-42. The ECtHR held that in respect of the question of whether the necessity requirement has been fulfilled, states have a wide margin of appreciation: '(..) the margin of appreciation to be accorded to the competent national authorities will vary in accordance with the nature of the issues and the importance of the interests at stake. Thus, the Court recognises that the authorities enjoy a wide margin of appreciation (...)'. See, also, Görgülü v. Germany, appl. no. 74969/01, 26 May 2004, §41-44.

$451 \quad$ Klass and Others v. Germany, appl. no. 5029/71, 6 September 1978.

452 Klass and Others v. Germany, appl. no. 5029/71, 6 September 1978, $\$ 10$.

453 Klass and Others v. Germany, appl. no. 5029/71, 6 September 1978, §42 and 48. See, as well, Lupsa v. Romania, appl. no. 10337/04, 8 June 2006, \$34 in which the ECtHR likewise asserted that: '(...) the existence of adequate and effective safeguards against abuse, including in particular procedures for effective scrutiny by the courts, is all the more important since a system of secret surveillance designed to protect national security entails the risk of undermining 
they deem appropriate in the name of the struggle against terrorism. ${ }^{454}$ The assessment of what is necessary is, however, highly casuistic in character, and may be dependent on one or more of the following aspects: the nature, scope and duration of the possible measures; the prerequisites for ordering such measures; the authorities competent to permit, carry out and supervise such measures; and the kind of remedy provided by the national law. ${ }^{455}$ How do those aspects relate to the application of personal disturbance powers?

The nature of personal disturbance powers is considerably intruding on a person's privacy, taking into account the fact that the police follow a person's daily routine, stop and check his acquaintances, ask neighbours about his habits and whereabouts, and phone the person concerned on his home and mobile phone. However, contrary to, for instance, intercepting phone calls by means of secret surveillance, the police cannot monitor private conversations under the guise of personal disturbance. The duration of personal disturbance may amount to several months, such as in the case of alleged members of the Hofstadgroep.

The prerequisites for ordering personal disturbance are not established in law. The only guidelines as to the question of when a person may be subjected to personal disturbance are comprised in a parliamentary memorandum dated 2007.456 With regard to the question of which authorities are competent to permit, carry out and supervise the application of personal disturbance powers, it is important to underline that it is the Mayor, rather than a public prosecutor let alone a court. The fact, as such, that the Mayor - instead of a judicial authority - is the competent authority to order personal disturbance, without any requirement to adduce an objectively verifiable cause, let alone a reasonable suspicion, may make compliance with the ECtHR's interpretation of Article 8 of the ECHR problematic.

A key issue, pursuant to Article 8, section 2 of the ECHR is the duty of the state to provide sufficient and effective safeguards against arbitrary application or even abuse of state powers that interfere with civilians' privacy. ${ }^{457}$ The ECtHR attaches great importance to this issue. The rule of law implies that an interference by the executive authorities with an individual's rights should be subject to effective control which should normally be assured by the Judiciary, at least in the last resort; judicial control offering the best guarantees of independence, impartiality and proper procedure. The ECtHR explicitly underlines that 'in a field where abuse is

or even destroying democracy on the ground of defending it (...)'. See, as well, Rotaru v. Romania, appl. no. 28341/95, 4 May 2000, §55 and 59.

Klass and Others v. Germany, appl. no. 5029/71, 6 September 1978, §49.

Klass and Others v. Germany, appl. no. 5029/71, 6 September 1978, §50.

Kamerstukken II 2006-2007, 30 977, no. 104. See, also, Kamerstukken II 2006-2007, 29 754, no. 100 .

See, in a criminal law context, Bykov v. Russia, appl. no. 4378/02, 10 March 2009, §69-83. 
potentially so easy in individual cases and could have such harmful consequences for democratic society as a whole, it is in principle desirable to entrust supervisory control to a judge'. ${ }^{458}$ In Klass and Others v. Germany, the ECtHR concluded that the surveillance measures applied to Klass were necessary in a democratic society but the ECtHR explicitly took into account the comprehensive safeguards enacted in the German surveillance system.

The importance of adequate procedural safeguards increases when the level of suspicion upon which state powers may be applied is low. The less demanding the statutorily required level of suspicion is, the stricter counterbalancing procedural safeguards must be. Also, the more groundless a suspicion against someone is, the more disproportionate, and therefore inadmissible, interferences with his right to privacy may become. This means that a reasonable suspicion, as a prerequisite for the application of state powers, allows for more far-reaching interferences with the right to privacy then in the case of just requiring potential involvement in terrorist activities to apply such powers. If there is no explicit level of reasonable suspicion required to apply state powers that interfere with the right to privacy, there must be effective counterbalancing procedural safeguards to prevent arbitrariness, provided that such a practice is in compliance with the ECHR.

Personal disturbance does not provide for a mandatory, legally embedded, supervision of the progress and results of the application of personal disturbance powers. This introduces the risk that the application of those powers may continue while the underlying causes have ceased to exist - as was clearly the case with respect to the first above discussed judgement of the Amsterdam District Court. The only post facto judicial examination of the lawfulness of personal disturbance takes place when a person subjected to personal disturbance powers decides to instigate summary proceedings. Such proceedings do not lead to a final decision regarding the lawfulness of personal disturbance powers, nor do such proceedings enable the competent judge to examine compliance with Article 8 of the ECHR and the fundamental principles of law comprised therein as such. Furthermore, there is no prior judicial approval required for personal disturbance, and the level of suspicion for personal disturbance is clearly all but demanding, and in any case, not formalised.

Lastly, it is important to note that the case law of the ECtHR's and the Council of Europe Guidelines on human rights and the fight against terrorism explicitly refer to the fundamental principles of proportionality, subsidiarity, lawfulness and legal certainty in respect of anti-terrorism legislation that interferes with the right to

458 Klass and Others v. Germany, appl. no. 5029/71, 6 September 1978, §55. 
privacy. ${ }^{459}$ These principles may be undermined due to the application of personal disturbance-powers.

Is observation of a person who is allegedly involved in terrorist activities, on the basis of, often unverified information, not a disproportionate infringement of his privacy? Moreover, not only is the privacy of the person who is subjected to personal disturbance powers interfered with, but his acquaintances and family members are also hindered in freely enjoying their privacy. Legal certainty can hardly be safeguarded when persons are subject to intrusive personal disturbance powers on the basis of the police's general task of safeguarding public order. The principle of subsidiarity primarily plays a role when taking into account consistent observation, as defined in Articles 126g, 1260 and 126zd of the DCCP.

All things considered, it is highly questionable that the ECtHR would have deemed personal disturbance compatible with the necessity requirement. Although the ECtHR does recognise that measures of (secret) surveillance are necessary to avert terrorist threats, it nevertheless limits that necessity by asserting that it does not imply a carte blanche for Member States to limitlessly interfere with civilians' rights to privacy, all in the name of safeguarding national security. ${ }^{460}$ Adequate procedural safeguards are considered essential to counterbalance poorly defined legal provisions that provide for far-reaching state powers.

\subsection{In sum}

During the period 2004-2006, the most far-reaching forms of personal disturbance considerably interfered with the right to privacy. The application of personal disturbance powers, furthermore, undermined principles of law, such as the principles of legal certainty, proportionality and subsidiarity. Personal disturbance implies a large discretionary power for the Mayor, whose power, moreover, is not counterbalanced by automatic and effective procedural safeguards like mandatory judicial control. As personal disturbance is not situated within the criminal justice system the general procedural protective safeguards that are part of that system, do not apply. Whether the application of personal disturbance powers is in compliance with Article 8 of the ECHR and with the abovementioned fundamental principles of law can only partly be examined post facto by summary proceedings lodged by the person subjected to personal disturbance.

The lack of a specific and explicit legal basis for these powers and the doubtful necessity of these powers makes compliance with Article 8 of the ECHR

Council of Europe, Guidelines on human rights and the fight against terrorism, adopted by the Committee of Ministers on July 2002 at the $804^{\text {th }}$ meeting of the Ministers' Deputies See foremost guidelines 2, 3 and 6 .

460 Klass and Others v. Germany, appl. no. 5029/71, 6 September 1978, §49. See, also, Gillan and Quinton v. the United Kingdom, appl. no. 4158/05, 12 January 2010, §57-87. 
questionable. ${ }^{461}$ However, it must be underlined that there is no Strasbourg case law available dealing with matters comparable to the application of personal disturbance powers. This explains the rather limited examination of these powers in respect of the right to privacy.

What can, however, be assumed is that with the entering into force of the DPTA, the application of the most intrusive forms of personal disturbance have become redundant. Article 126zd of the DCCP provides for an explicit legal basis to consistently observe a person on the basis of indications of a terrorist offence. ${ }^{462}$

In this respect, it is important to take into account the main reason for the codification of the existing special investigation techniques. In 1994 a parliamentary inquiry ${ }^{463}$ was instigated when it came to light that the police were using various farreaching investigative methods without a specific legal basis. That inquiry forced the Dutch government to codify those investigative techniques that infringe extensively upon fundamental rights. ${ }^{464}$ The codification of special investigation techniques and, currently, of surveillance powers in clearly edited legal provisions, is an essential safeguard against illegitimate and arbitrary use of such powers. ${ }^{465}$ In light of these considerations, one may assume that far-reaching forms of personal disturbance, if still considered necessary, demand unequivocally formulated legal provisions.

461 See, in this respect, Anti-terrorismemaatregelen in Nederland in het eerste decennium van de 2le eeuw. Over totstandkoming, toepassing, beoordeling en aanpassing van antiterrorismemaatregelen in Nederland 2001-2010, January 2011, Nationaal Coördinator Terrorismebestrijding, bijlage H: P.H.P.H.M.C. van Kempen, J. van de Voort, Nederlandse antiterrorism-regelgeving getoetst aan fundamentele rechten. Een analyse met meer bijzonder aandacht voor het EVRM, Radboud Universiteit Nijmegen 1 December 2010, paragraph 5.2.

462 See Chapter $\mathrm{V}$ for a discussion of special investigation techniques to investigate terrorist offences.

463 The parliamentary inquiry was named de Van Traa-commissie after the chairman of the commission (Maarten van Traa). See for more information: A.B. Hoogenboom, Schaduwen over Van Traa, Koninklijke Vermande 2000, Lelystad; R.J. Bokhorst, Evaluatie van de wet BOB: Fase 1, de eerste praktijkervaring met de Wet bijzondere opsporingsbevoegdheden, WODC 2002 Boom Juridische Uitgevers, Meppel; A. Bijer, R.J. Bokhorst, M. Boone, C.H. Brants, J.M.W. Lindeman, De Wet bijzondere opsporingsmethoden-eindevaluatie, WODC 2004 Boom Juridische Uitgevers, Meppel.

464 This whole affair is known as the IRT-affaire. See, for more information, www.irt-affaire.nl and see for the report which was drafted under de Van Traa parliamentary inquiry: www.burojansen.nl/traa/e.htm.

465 Kamerstukken II 1996-1997, 25 403, no. 3, p. 10. Some authors do regard the codification of special investigative methods after the IRT-affaire as an imminent safeguard in light of legal certainty but at the same time they doubt whether the codification of special investigative techniques will be adequate to prevent abuse of such procedural powers. See W. Wedzinga, 'Bijzondere opsporingsbevoegdheden in wetsontwerp 25 403', in Delikt en Delinkwent 1999, afl. 4, pp. 235-248; F.D. van Asbeck en M. Jongeneel-van Amerongen, 'Uitgangspunten van het Wetsvoorstel bijzondere opsporingsbevoegdheden', in P.J.P. Tak (red.), Bespiegelingen omtrent de Wet Bijzondere Opsporingsbevoegdheden, Gouda Quint, Deventer 1998; M.S. Groenhuijsen, 'De crisis in de opsporing en het wetsontwerp bijzondere opsporingsbevoegdheden. Enkele inleidende aantekeningen', in Delikt en Delinkwent 1997, p. 859. 



\section{Chapter IV Assumed Connections with Terrorism}

\section{INTRODUCTION}

In this chapter the bill on administrative law measures to safeguard national security is discussed [Wet bestuurlijke maatregelen nationale veiligheid, 'the Bill']. The government introduced the Bill in Parliament in 2006. The Lower House adopted the Bill, but further discussion by the Upper House was postponed. This was due to the elaborate parliamentary discussions and the recommendations formulated in the Suyver Report (2009). This report evaluated all Dutch anti-terrorism legislation and its joint effects on respect for fundamental rights and principles. ${ }^{466}$ It called for attention to be paid, in particular, to the fact that both administrative and criminal law measures that interfere with fundamental rights and principles, had been taken concurrently. ${ }^{467}$ This was said to result in overlapping powers, and it undermined the principles of proportionality, subsidiarity, necessity and legitimacy. Furthermore, suspicion criteria concerning terrorist offences - as used within the criminal justice system - had been lowered to such an extent that it was deemed questionable whether there was, in fact, a difference between the field of application of the Bill and the criminal law system. On 10 June 2011, the Bill was withdrawn. ${ }^{468}$

Even though the Bill was recently withdrawn, it should, nevertheless, be discussed within the framework of this dissertation. Firstly, because this bill is yet another clear illustration of the government's pursuit of the prevention of terrorism by all possible means, preferably, early in the pro-active phase. Boundaries between the various fields of law become blurred when it concerns terrorism. Secondly, this bill demonstrates how quite controversial anti-terrorism measures are piloted through Parliament, while being justified with reference to the treat terrorism poses to national security.

The Bill was the first legal anti-terrorism measure situated in the administrative law system. The principal aim of the Bill was to act when the criminal justice system could not yet, or could no longer, be applied to avert presumed terrorist

466 Kamerstukken II 2005-2006, 30 566, nr. 3.

467 J.J.H. Suyver, M.J. Borgers, C.P.M. Cleiren and P.J. van Zunderd (Commissie Suyver), Rapport van de Commissie evaluatie antiterrorismebeleid, Naar een integrale evaluatie van antiterrorismemaatregelen, May 2009, pp. 34-38, 47-51 and 90.

468 Kamerstukken I 2010-2011, 30 566, E. In January 2011 the government had already announced its intention to withdraw the Bill in light of the amendments brought forth by the DPTA. See the governmental press release on www.nctb.n1/Actueel/persberichten/2011/persbericht-110128. aspx?cp $=91 \& \mathrm{cs}=25472$. See, also, the report Antiterrorisme-maatregelen in Nederland in het eerste decennium van de 2le eeuw. Over totstandkoming, toepassing, beoordeling en aanpassing van antiterrorismemaatregelen in Nederland 2001-2010, January 2011, p. 99. 
activities. Hence, the Bill served to prevent terrorism by means of administrative state intervention early in, and even before, the pro-active phase. The government underlined its intention of 'completing the set of anti-terrorism measures', also beyond the criminal law system. ${ }^{469}$

Persons who were alleged to be connected with terrorist activities or the support thereof could be subjected to a restraining order and/or to a duty to report periodically to the police ('the administrative measures'). A reasonable suspicion of a specific terrorist offence was no prerequisite for the application of the administrative measures. This was the principal difference with the criminal justice system, in which some level of suspicion is always required for the lawful application of state powers.

When state authorities would impose one or more of the administrative measures comprised in the Bill, the person concerned would have been restricted in his freedom to choose where to go and who to meet. The administrative measures therefore would have interfered with the right to freedom of movement pursuant to Article 2 of the $4^{\text {th }}$ Protocol with the ECHR ('the Protocol'). ${ }^{470}$

Several questions arise. For instance, what is the scope of the right to freedom of movement as interpreted by the ECtHR, and to what extent would the administrative measures actually have interfered with this right? Under what circumstances are interferences with the right to freedom of movement allowed pursuant to Article 2 of the Protocol? What role does the fact that it concerns the prevention of terrorism play? In this respect, it is important to consider the administrative measures in light of the anti-terrorism legislation within the criminal justice system. ${ }^{471}$ Was the Bill really necessary in addition to personal disturbance, broadened criminal liability for terrorist offences, and the expanded scope of state powers to investigate terrorist offences?

The following sections will discuss: (1) the level of 'suspicion' and other criteria for application of the administrative measures; (2) the scope of the administrative measures comprised in the Bill, also in light of other (comparable) state powers to prevent terrorism; and (3) the scope of the right to freedom of movement and the potential impact that the administrative measures would have had on this right. Discussion of the Bill and its implications in terms of respect for fundamental rights is limited due to: (1) the fact that the Bill has never entered into force, and (2) a dearth of case law on Article 2 of the Protocol.

\footnotetext{
469 Kamerstukken II 2006-2007, 30 566, nr. 6, p. 3.

470 In the explanatory memorandum to the Bill, the right to freedom of movement was interpreted as the right to move freely without governmental interferences. See Kamerstukken II 20052006, 30 566, no. 3, p. 10.

471 See Chapters V, VI, VII for a discussion of the anti-terrorism legislation in the field of criminal procedure.
} 


\section{ASSUMED CONNECTIONS WITH (THE SUPPORT OF) TERRORIST ACTIVITIES}

Two cumulative prerequisites were to be fulfilled to lawfully impose one or more of the administrative measures comprised in the Bill. ${ }^{472}$ Firstly, there had to be assumed connections with (the support of) terrorist activities, based on conduct displayed by the person on whom these administrative measures were to be imposed. ${ }^{473}$ Secondly, imposing the administrative measure had to be strictly necessary to protect national security. These two prerequisites raise several questions.

When would a person be supposed to be connected with terrorist activities? Is the notion of 'terrorist activities' the same as (complicity in a) 'terrorist offence' pursuant to the DTA? What behaviour would have been deemed to be an indication of alleged connections with terrorist activities? These questions will be discussed in light of the parliamentary memoranda. The following section discusses the second prerequisite.

In the parliamentary memoranda, the government argued that the notion of 'terrorist activities' pursuant to Article 2 of the Bill, was to be interpreted and applied in line with Articles 83 and 83 a of the DCC. ${ }^{474}$ However, 'terrorist activities' is a broader concept than terrorist offence, as interpreted within the criminal justice system. The notion of 'terrorist activities' was to include behaviour that could not yet be qualified as a terrorist offence pursuant to the DCC. In other words, 'terrorist activities' would include conduct which was not liable to punishment in the criminal justice system, but which was 'committed' with terrorist intent. ${ }^{475}$ Also, the notion of 'terrorist activities' did not relate to a specific terrorist offence, whereas criminal liability does relate to a particular (terrorist) offence. ${ }^{476}$

For instance, conduct indicative of the preparation of a terrorist offence - though without preparatory acts as required for criminal liability under Article 46 of the DCC - would have been considered as terrorist activity under Article 2 of the Bill. This means that terrorist intentions, as defined in Article 83a of the DCC, would have formed the basis for imposing the administrative measures. Being connected with terrorist activities therefore included behaviour that took place prior to the preparation of a terrorist offence pursuant to Article 46 of the DCC. 477 The parliamentary memoranda specified that such behaviour could consist of providing a person with the information, means or opportunity to further develop terrorist

\footnotetext{
472 The scope of these administrative measures will be discussed in Section 4.

473 Kamerstukken II 2005-2006, 30 566, nr. 3, p. 17-19.

474 Kamerstukken II 2002-2003, 28 463, nr. 3, pp. 2-4 and nr. 6, pp. 5-7.

475 Kamerstukken I 2007-2008, 30 566, C, p. 12.

476 Kamersukken I 2007-2008, 30 566, C, p. 12.

477 Kamerstukken I 2007-2008, 30 566, C, p. 7.
} 
activities. ${ }^{478}$ Hence, the notion of 'terrorist activities', if considered within the criminal justice system, may very well have implied the criminalisation of terrorist intentions.

The notion of 'certain conduct' pursuant to Article 2 of the Bill, was meant to serve as a guarantee of objective verifiability. ${ }^{479}$ The parliamentary memoranda prescribed that one single act of conduct was insufficient. There needed to be a certain behavioural pattern to speak of 'conduct'. That conduct had to, moreover, demonstrate that the person concerned posesd an actual and serious threat to national security, but it did not need to concern one or more specific terrorist offences. ${ }^{480}$ The memoranda described three examples of a 'behavioural pattern' legitimising the imposition of the administrative measures.

The first example concerned a person who adhered to a radical Islamic legacy, and who had just returned from a long stay in Pakistan, during which he joined a training camp. In addition, he regularly visited violent websites. Lastly, he and his friends were frequently seen in the vicinity of government buildings.

The second example regarded a person who adhered to radical Islam, and who proclaimed that he was willing to force that belief, if needed, with violence, on others. Also, he possessed and distributed literature regarding extreme Islam. Furthermore, he invited people to attend meetings about theses extreme beliefs.

The third example concerned a person who gathered information on violent religious beliefs, terrorist offences and politicians on the internet and saved it. Additionally, he was frequently spotted near government buildings.

It is important to note that these 'behavioural patterns' could currently all lead to criminal liability pursuant to, for example, Article 134a of the DCC (first example); Article 131, section 2 of the DCC (example 2); or Article 96, section 2 of the DCC (third example). ${ }^{481}$ When the Bill was drafted, the DPTA had not yet been introduced into Parliament. This meant that, for example, the application of special investigation techniques on the basis of indications of a terrorist offence was not yet possible. Also, Article 134a of the DCC had obviously not yet been introduced into the DCC. Criminal liability on account of Example 1 in particular might therefore have been slightly more difficult. However, as discussed in Part II, criminal liability for terrorist offences has become almost unlimited within the joint system of Articles 140a, 46, 96 and (now) 134a of the DCC.

478 Compare with Article 46 of the DCC, which criminalises preparation of serious criminal/ terrorist offences. See Kamerstukken I 2007-2008, 30 566, C, p. 7.

479 In the original Bill, Article 2 did not refer to 'behaviour', but to 'facts or information'. The government replaced the notion of facts or information - due to its vagueness - with (active) 'behaviour' in response to several of the recommendations that were published regarding the Bill. See, for instance, the recommendations of the NVvR.

480 Kamerstukken I 2007-2008, 30 566, C, pp. 1-2 and Kamerstukken II 2006-2007, 30 566, nr. 6, p. 4.

481 See, for a discussion of criminal liability on account of terrorist offences, Chapter II. 
At present - hence after enactment of the DPTA and the entering into force of Article 134a of the DCC - the application of investigative powers, as comprised in the DCCP, is possible with respect to all three examples. In that light, the necessity of the Bill had become questionable, and the administrative measures comprised in the Bill were in fact superseded. This issue will further be discussed in Sections 7 and 8 .

\section{INFORMATION TO DEMONSTRATE ASSUMED CONNECTIONS WITH TERRORIST ACTIVITIES}

Primarily the secret intelligence services - national and regional - were to provide the Minister of Interior (the competent authority) with the information required to impose the administrative measures. ${ }^{482}$ Information exchange between the secret intelligence services and local government institutions takes place within the Contra-Terrorism Infobox (CT Infobox). ${ }^{483}$ The CT Infobox serves to expand information exchange between several state authorities and institutions. That must enhance a more effective anti-terrorism policy.

Basically, the CT Infobox is an assembly point for all the information available regarding terrorism. The participating authorities are: the secret intelligence services, the public prosecution service $[O M]$, the National Royal Police Services $[K L P D]$, and the Immigration and Naturalisation Service [IND]. These authorities all have access to the information available in the CT Infobox. Not only do these authorities exchange information, but they also actively cooperate in the prevention of terrorism. After analysing and comparing available information, a joint decision is taken regarding which authority is to act within which forum - criminal law, administrative law, law regarding aliens, secret intelligence services, or otherwise. ${ }^{484}$

The CT Infobox is based on several statutes. To start with, the central role of the secret intelligence services in countering terrorism is primarily based on their responsibility for safeguarding national security pursuant to Article 6, section 2 under a of the statute regarding the secret intelligence services [Wet op de inlichtingen en veiligheidsdiensten, WIV $].{ }^{485}$ The secret intelligence services are

482 See Vaste verbindingen: Een advies aan de Minister van Binnenlandse Zaken en Koninkrijksrelaties over de verstrekking van gegevens op het terrein van veiligheid door landelijke diensten aan burgemeesters, Rapport van de Werkgroep gegevensverstrekking burgemeesters, november 2005, at: www.aivd.nl/contents/pages/55138/vasteverbindingen.pdf; Kamerstukken II 2005-2006, 29 876, nr. 9; Kamerstukken II 2005-2006, 30 566, nr. 3, p. 19; Kamerstukken I 2007-2008, 30 566, C, pp. 1-2.

483 See L.J.J. Rogier, M.A.D.W. de Jong, C.M. Bitter, F.W. Bleichrodt, Bestuursrechtelijke aanpak van criminaliteit en terrorisme, Vereniging voor Bestuursrecht Preadviezen, Boom Juridische Uitgevers Den Haag 2007, p. 156-157.

484 Kamerstukken II 2004-2005, 29754 and 27 925, nr. 21; Kamerstukken II 2005-2006, 30 566, nr. 3, p. 19.

485 See Article 6, section 2 under a of the WIV. 
allowed to send information regarding national security issues - in an AIVD communication - directly to the competent administrative/criminal law authority and/or to the CT Infobox. ${ }^{486}$

The public prosecution service is authorised, as long as it serves a substantial general interest, to pass information on to the Minister of Justice and the Minister of the Interior, pursuant to Article $39 \mathrm{f}$ of the statute concerning information on judicial and procedural criminal law [Wet justitiële en strafvorderlijke gegevens]. Subsequently, such information can be used to impose, for instance, the administrative measures.

The police are empowered to pass information on to administrative authorities when public interests demand so, in accordance with Article 2 of the PA, in conjunction with Article 18, section 3 of the Law concerning police records (Wet politieregisters en Besluit politieregisters). This will doubtlessly be the case when it concerns terrorism.

Besides the public prosecution service, the police and the secret intelligence services, and also the IND, the Royal Military Police [Koninklijke Marechaussee], the Tax authorities [Belastingdienst, FIOD-ECD] and the National Coordinator responsible for countering terrorism [Nationaal Coördinator Terrorismebestrijding, $N C T b]$, are, in compliance with the laws concerning the respective services, authorised to provide the administrative authorities with information concerning persons connected with terrorist activities.

Lastly, in light of Chapter VIII on the Union blacklists, it is important to see that the Union and UN blacklists could also have served as a source of information for the application of the administrative measures. A person's inclusion on a blacklist could have been an indication to consider whether that person also needed to be subjected to the administrative measures. ${ }^{487}$ Even more, if a person formed part of a blacklisted organisation, without himself having been included on a blacklist, that would have been sufficient cause to impose the administrative measures on him.

486 See Articles 36 and 40 of the WIV. Kamerstukken II 2005-2006, 30 566, nr. 3, p. 27. The (sources of the) secret intelligence information would not always have been disclosed to the person who would be subject to the administrative measures. If the person concerned had decided to lodge an appeal against an injunction, only the administrative judge would have been allowed to view (part of) the information. Thus, even if the person concerned had lodged an appeal, he would not have been allowed access to the information leading to the imposition of the administrative measure when the measure was based on secret intelligence information. See, also, Article 8:29 of the General Statute concerning Administrative Law (Algemene Wet Bestuursrecht, $A W B$ ). 


\section{NeCESSITY}

The second prerequisite for the lawful imposition of the administrative measures the necessity - implied compliance with the principles of proportionality, subsidiarity and necessity. This prerequisite found its rationale in the fact that interferences with the right to freedom of movement had to be balanced against the interest of protecting national security. The scope and the duration of the administrative measures were to be proportionate to the alleged threat to national security. To that effect, Article 3 of the Bill obliged the Minister of Interior to regularly examine - i.e. every three months - if there were new facts or circumstances that required the discontinuation of the administrative measure(s) in a specific case.

Before the Minister could decide to impose one or more of the administrative measures, he was to scrutinise whether there were less intrusive means of preserving national security. However, the parliamentary memoranda failed to clarify which measures were considered 'less intrusive', while being considered as protecting national security equally. The government argued that the principle of subsidiarity demanded that, when possible, the application of the criminal justice system had to be given priority to imposing the administrative measures. ${ }^{488}$ Hence, when there was adequate reason/cause to initiate a criminal investigation, that was deemed preferable to merely imposing liberty-restricting measures, such as included in the Bill.

It appears as if the government applies the principle of subsidiarity reversely. When it concerns the prevention of terrorism, the most far-reaching measure in terms of respect for fundamental rights, must if possible, be applied, instead of the less sweeping measures. In this respect, it may be questioned what 'less intrusive' means. Can personal disturbance, or even consistent observation pursuant to Article 126zd of the DCCP, be considered as 'less intrusive' measures? That would imply that interferences with the right to privacy are considered inferior to interferences with the right to freedom of movement. In that case, almost any criminal law based measure - aside from actual deprivation of liberty - would be deemed less disturbing.

Finally, the necessity principle demanded that the administrative measures be appropriate and effective to factually protect national security. ${ }^{489}$ It remains to be seen how, if at all, the effectiveness of such measures was to be examined and measured. Even more, how exactly was national security to be protected by means

\footnotetext{
488 Kamerstukken II 2005-2006, 30 566, nr. 3, pp. 16-19.

489 See Article 10 of the Bill, which obliged the Minister of the Interior to send a report to Parliament concerning the effectiveness of the Bill, three years after its entering into force.
} 
of subjecting a person to one or more of the administrative measures? This will further be discussed in the next section.

To clarify the notion of 'national security', the government referred to case law of the ECtHR. However, Strasbourg case law does not provide an unequivocal explanation of this notion. ${ }^{490}$ The government considered terrorism to automatically pose a threat to national security. This would have partly undermined the importance of the prerequisite that the administrative measures had to be necessary to protect national security. The terrorist threat posed to the Netherlands is not likely to disappear, which means that national security will continue to be threatened. ${ }^{491}$ Consequently, imposing administrative measures would have remained, in part, automatically necessary.

\section{ThE ADMINISTRATIVE MEASURES, STATUTORY REMEDIES AND FURTHER DETAILS}

Article 2 of the Bill would have authorised the Minister of Interior to impose liberty-restricting measures on a person who may be connected, on the basis of his conduct, with terrorist activities or the support thereof. ${ }^{492}$ The following measures could have been imposed either separately or cumulatively:

1. An injunction forbidding them being in the vicinity of certain objects or in certain parts of the Netherlands (area injunction), ${ }^{493}$

2. An injunction forbidding them being in the vicinity of certain persons (person injunction), ${ }^{494}$

3. An obligation to report periodically to the police (duty to report). ${ }^{495,496}$

490 Compare with Article 8, section 2 of the ECHR.

491 See www.nctb.nl/.

492 Kamersukken II 2005-2006, 30 566, nr. 3, p. 6.

493 Article 2, section 2 under a of the Bill. The explanatory memorandum prescribed that the area injunction must be proportionate to the interest of safeguarding national security. Therefore, the injunction could not - save exceptions - concern the house or work of the person concerned, or the place where he practised his religion. Furthermore, the scope of the injunction was said to be broad, and had to be seen as 'a sliding scale' in the sense that if necessary, the area might be enlarged. For instance, a measure could, to begin with, concern a parliamentary building, then be extended to the city of the Hague, and finally regard the Province of South Holland.

494 Article 2, section 2 under b of the Bill.

495 Article 2, section 2, under $\mathrm{c}$ of the Bill. A person that would have been subject to a duty to report would have been obliged to report to the local police station once a day, every other day, or once a week, depending on the necessity.

496 The Bill also made it possible for the competent authorities to decline administrative applications, to withdraw an application, or to attach specific conditions to an application: (1) when the person concerned could be connected with terrorist activities on the basis of his behaviour, and (2) if there was a serious risk that he would use the application to support those 
The administrative measures were temporary measures, and could, initially, be imposed for three months. ${ }^{497}$ After the expiration of this initial period, the extension of the measures was allowed for up to a maximum of two years. The Minister of Interior was obliged to account for the length of (the extension of) these measures. Also, he would have been obliged to explicate: (1) in what way the person concerned posed a threat to national security, (2) on the basis of which behaviour he was supposed to be connected with terrorist activities, and (3) the nature of his connection with those activities.

Pursuant to Article 4 of the Bill, a person subject to the measures had the right to lodge an appeal with the administrative judge of the Hague District Court. The administrative judge then was obliged to handle the notice of objection with considerable swiftness. Appeal to a higher court could be lodged with the administrative department of the Council of State. ${ }^{498}$

The Minister of Interior was authorised to change the content, the number, or sort, of the administrative measure(s), or to withdraw them if changed circumstances required so. Article 3, section 5 of the Bill explicitly prescribed that the measures were to be revoked if they were no longer necessary to protect national security. If the circumstances that originally led to the imposition of a measure changed to such an extent that they actually encompassed a new situation, which, however, also demanded the imposition of administrative measures, the Minister of Interior was to withdraw the 'old' measures and had to impose 'new' ones. The 'new' measures could then, again, be imposed for an initial three months, with the possibility of extending them for up to a maximum of two years. This would have brought with it the risk of subjecting persons to administrative measures for a considerably longer period than the maximum of two years.

The last important aspect of the Bill was that non-compliance with the administrative measures would have constituted a criminal offence, and could have led to a prison sentence of one year pursuant to Article 7 of the Bill. In addition, Article 67 of the DCCP was to be amended, due to which, detention on remand would have been allowed in the case of a person disobeying the administrative measures imposed on him. ${ }^{499}$

terrorist activities. See Articles 5 and 6 of the Bill. These provisions will not further be discussed in this work.

497 See Article 3, section 1 of the Bill.

498 Section 7:1 of the AWB did not apply to proceedings regarding the imposition of the administrative measures comprised in the Bill. See Article 4, section 1 of the Bill.

$499 \quad$ Articles 7 and 8 of the Bill. 


\section{THE EXPECTED EFFECTS}

The question is how the Bill was, factually, to contribute to the prevention of terrorism. The explanatory memoranda gave several examples of the expected effects of the administrative measures. For instance, a duty to report periodically to the police would keep a person from going abroad to join, for example, an Islamic training camp, without the Dutch authorities being aware of it. There is, however, a whole lot to be said against this line of reasoning.

It is doubtful that a duty to report to the police once a week would in fact contribute to protecting national security by withholding a person from preparing an alleged terrorist attack. In addition, it appears unlikely that radicalised persons who aspire to commit a terrorist offence, even at the cost of their own life, would be inclined to live up to such a duty.

If a person did not comply with the administrative measures imposed, he would have been criminally liable pursuant to Article 7 of the Bill. It is unclear if, and how, the responsible authorities were going to enforce that provision. ${ }^{500}$ It is all but hypothetical that by the time the police would discover such a person's disappearance, it would be too late to arrest him on account of Article 7 of the Bill.

The parliamentary memoranda also argued that persons who were to be subjected to administrative measures would become useless in a terrorist organisation/group. The fact that a person had been spotted by the government would automatically make him a risk factor for participating in joint terrorist activities. This issue has already been discussed with respect to personal disturbance. ${ }^{501}$ Comparable questions arise in respect of the administrative measures.

Firstly, not every terrorist offence is jointly committed. For instance, Mohammed B. planned, prepared and committed the terrorist murder of Theo van Gogh alone. Thus, only if terrorist activities take place jointly, might the government's line of reasoning hold true. However, it is still questionable whether the administrative measures would always have made a person completely useless within a 'terrorist group'. With respect to personal disturbance, that might be the case, but the administrative measures would not have authorised the police to actively tail the person concerned. Aside from, for instance, the moment the person had to report to the police, he would have been free to go where he pleased.

\section{EXISTING ADMINISTRATIVE LAW MEASURES}

It is important to note that there are several existing administrative law measures that may be used to prevent terrorism. Firstly, there is the act ${ }^{502}$ concerning special

\footnotetext{
500 Compare with Article 7 of the Bill.

501 See Chapter III.

502 Staatsblad 1996, 367.
} 
powers civil authority [Wet buitengewone bevoegdheden burgerlijk gezag, the Act], which includes powers to limit, and even deprive, persons of their liberty, in the interest of safeguarding national security. Article 9 of the Act authorises the Minister of Interior and the provincial governor to impose a restraining order on a person suspected of endangering public order and/or security. In the case of a threat to the existence of the state [volksbestaan], Article 18 of the Act empowers the Minister of Interior and the provincial governor to intern people.

The application of state powers comprised in the Act has some limitations. Firstly, the powers comprised in Articles 9 and 19 of the Act can only be applied in special circumstances, such as a declared state of emergency. Secondly, there must be a suspicion that the person concerned poses a threat to national security. When it concerns the prevention of current terrorism, the government deems these limitations too demanding. The Bill did not include these limitations, and would accordingly have filled in the alleged legislative gap.

Article 56 of the Aliens Act [Vreemdelingenwet, AA] ${ }^{503}$ authorises the Minister of Immigration and Integration to deprive aliens of their liberty in the interest of national security and/or public order. Also, Article 54 of the AA empowers the Minister to oblige an alien to report periodically to the superintendent. This latter provision is comparable to the administrative measure included in Article 2, section 2 under $\mathrm{c}$ of the Bill. Neither Article 54 of the AA, nor Article 2 of the Bill, require a form of suspicion as defined in the DCCP, or any additional requirement besides the fact that the application of these powers must be in the interest of national order/ security. Obviously, the AA can only be applied to specific groups of people. That makes the AA only in part applicable to prevent terrorism.

Article 172 of the Municipality Act [Gemeentewet] ${ }^{504}$ empowers the Mayor to, among others, impose a restraining order [gebiedsvebod] on persons in the case of impending public disturbances. Such an order prohibits person(s) from entering a certain area. An individualised suspicion is not required. So far, this provision has, foremost, been used to deal with, for instance, groups of notorious hooligans, but the provision does not exclude the possibility of using it on specific persons. Article 172 of the Municipality Act provides a legal basis for imposing measures as comprised in Article 2, section 2 under a of the Bill. Pursuant to Articles 154a and 176a of the Municipality Act, the Mayor is, furthermore, authorised to deprive persons, who may cause serious public disorder/irregularities, of their liberty to safeguard public order. Such an order is valid for a period of 12 hours. No specific suspicion of a criminal offence is required.

503 Staatsblad 2000, 495 and Staatsblad 2000, 497.
504 Staatsblad 1992, 96. 
The government deemed these existing administrative law measures inadequate to effectively prevent terrorism, even if considered in light of the already existing powers, such as personal disturbance and the special investigation techniques available within the DCCP. Further, the government underlined that the Bill was to be used in addition to the whole set of existing criminal and administrative law based measures to guarantee public security as much as possible. ${ }^{505}$ Whether, and if so, to what extent, this co-existence of overlapping anti-terrorism legislation influenced the alleged necessity of the Bill, is discussed below.

\section{CRITICISM AND RECOMMENDATIONS FROM EXPERTS}

The Bill has been the subject of quite some criticism. ${ }^{506}$ As the Bill did not enter into force, it is interesting to briefly discuss the recommendations of several specialised organisations given during the parliamentary discussions. ${ }^{507}$ Two remarks appear in every recommendation. Firstly, all of them endorsed the government's view that adequate measures should be taken to prevent terrorism. Secondly, most of these organisations argued that the criteria for the application of the administrative measures were too broad, and could potentially lead to the arbitrary enforcement of the Bill.

For instance, the Dutch Association for the Administration of Justice [Nederlands Vereniging voor de Rechtspraak, the Association] and the Council for the Administration of Justice ${ }^{508}$ [Raad voor de Rechtspraak, the Council] considered the notion of 'terrorist activities' and the notion of 'behaviour' to be too broad. ${ }^{509}$ The government used these broad concepts on purpose to provide the administrative authorities with sufficient discretionary power. Also, it was argued that these notions were difficult to define more concisely. The prevention of terrorism demands

Kamerstukken II 2005-2006, 30 566, nr. 3, pp. 4-5.

See M. Kuijer, Van Lawless naar een rechtmatige bestrijding van terrorisme, Wolf Legal Publishers, Amsterdam 2005, pp. 15-17; T. Hammarberg, Report by the Commissioner for Human Rights on his visit to the Netherlands, 2008 (CommDH (2009) 2); A.E.M. van den Berg \& P.C.M. Heinen, 'Wet Bibob en wetsvoorstel Bestuurlijke maatregelen nationale veiligheid: te kort door de Straatsburgse bocht?', in Gemeentestem 2007, 7285, pp. 611-621; C.L.G.F.H. Albers en R.J.N. Schlösels, 'Terrorismebestrijding: het bestuursrecht aan zet, de rechtsstaat in gevaar?', in NJB 2006, p. 2522-2530.

The following institutes provided recommendations: Vereniging van Nederlandse Gemeenten $(V N G)$, Interprovinciaal Overleg (IPO), College van Procureurs-Generaal (College), Nederlandse Vereniging voor Rechtspraak (NVvR), Raad voor de Rechtspraak (RvdR), Nederlandse Orde van Advocaten (NOvA), Raad van Hoofdcommissarissen (RHC).

Find the recommendation at: www.rechtspraak.nl/NR/rdonlyres/E20B9E65-DA65-4030B1D5-2F8010410DD0/0/6889defadviesbestmaatrnationaleveiligheid1.pdf.

Strikingly, the NOvA endorsed the government's view that these notions cannot be defined with more precision when it concerns the prevention of terrorism. See www.advocatenorde.nl/ wetenregelgeving/adviezen.asp. 
broad criteria for the application of state powers. This line of reasoning has been used repeatedly, also to justify the DTA and the DPTA. 510

The Board of Prosecutors General [College van Procureurs-Generaal, the Board] ${ }^{511}$ questioned the necessity of the Bill, when considered in light of other (antiterrorism) legislation in the field of criminal - and public order law. ${ }^{512}$ Quite clearly, the government deemed these latter measures inadequate to prevent terrorism. ${ }^{513}$ It is very doubtful if that is the case, particularly since the entering into force the DTA and DPTA, which provide for far-reaching investigative powers to investigate broadly defined terrorist offences early in the pro-active phase. ${ }^{514}$

The government has argued that the administrative measures would serve an additional purpose compared to the other anti-terrorism legislation. Theoretically, these measures - like personal disturbance - served to keep an eye on non-suspected persons whom the government believed to be connected with, or involved in, terrorist activities. The criminal justice system aims to investigate a yet to be committed terrorist offence. It is questionable whether that discernment is still tenable, in light of the current broad criminal liability on account of terrorist offences.

The Board also highlighted the risk that the administrative measures could thwart criminal investigations into terrorist offences. According to the government, the application of the administrative measures would precede criminal investigations or would follow an acquittal. If, by chance, these measures were, nevertheless, applied during a criminal investigation, that did not have to result in the investigation being thwarted. The Minister of Interior was obliged to attune the application of the administrative measures to criminal investigations. ${ }^{515}$ Also, pursuant to Article 3 of the Bill, the necessity of the measures in specific cases had to be reviewed

510 See Part II for a discussion of broadly defined criminal behaviour and the principle of legality.

511 Find the College's recommendation at: www.om.nl/over_het_om/wetgevingsadvisering/ formeel_strafrecht/.

512 The Commissie Suyver equally questioned the necessity of the Bill. See J.J.H. Suyver, M.J. Borgers, C.P.M. Cleiren and P.J. van Zunderd (Commissie Suyver), Rapport van de Commissie evaluatie antiterrorismebeleid, Naar een integrale evaluatie van antiterrorismemaatregelen, mei 2009, pp. 34-38, 47-51 and 90.

513 See Chapters III, V, VI, VII for a discussion of the anti-terrorism legislation in the field of public order law, criminal law and criminal procedure.

514 Compare with the criminalisation of the conspiracy of various serious terrorist offences, pursuant to Article 96 of the DCC.

515 See Article 1, section 2 of the Bill. The College recommended that not only should the Minister of Justice be consulted if the Minister of Interior intended to apply one or more of the administrative measures, but also the public prosecution office, in order to prevent ongoing criminal international or national investigations being thwarted due to application of the administrative measures. 
periodically. ${ }^{516}$ These periodic reviews would include the question of whether a criminal investigation had been, or was going to be, initiated.

Whether the safeguards mentioned by the government would have sufficed to prevent the foiling of criminal investigations into terrorism is unclear. That would, to a large extent, been dependent on: (1) the level of communication between the Ministry of the Interior and the Ministry of Justice, and (2) on the question of whether activities within the administrative law system and the criminal law system would adequately be geared to one another.

\section{Recommendations of the Council of State}

The recommendations of the Council of State will be discussed separately in this section. ${ }^{517}$ The Council of State, primarily, questioned the necessity of the Bill. To substantiate this claim, the Council referred: (1) to the restrictions that the ECtHR may set on the use of the administrative measures, (2) to the expected lack of effectiveness of the measures, and (3) to the difficulty of enforcing the Bill.

The area injunction and the person injunction would have infringed upon the right to freedom of movement. In order to justify these infringements, the measures had to be absolutely indispensable to prevent terrorism pursuant to Article 2, section 2 of the Protocol. If the measures could not be assessed as such, they had to be rejected beforehand. The Council of State therefore required the government to provide a detailed overview of the situations in which the criminal justice system or the secret intelligence services were to be considered inadequate to effectively counter terrorism, while there was, at the same time, an urgent need for preventive measures.

In response to the Council of State's requests, the government argued that there was a gap in countering terrorism when it came to preventing it. In the government's view, there were no effective procedural powers to prevent terrorism in between arresting a suspect on the basis of a reasonable suspicion for one thing and tailing $a$ person who allegedly formed a threat against national security on the basis of the secret intelligence services' powers. That gap needed to be filled in by the Bill.

As mentioned above, these considerations were completely superseded by the entering into force of the DPTA in 2007. The DPTA enabled the investigative authorities to use state powers on the basis of 'indications', instead of 'a reasonable

\footnotetext{
516 See Article 3, section 4, in conjunction with Article 1, section 2 of the Bill.

517 See, regarding the Council of State's specific role of advising the government, Articles 14-19 of the Act on the Council of State [Wet op de Raad van State] and Article 38 of the Dutch Constitution.
} 
suspicion'. Furthermore, the threshold for coming to a reasonable suspicion is not as high as the government insinuated. ${ }^{518}$

In light of the ECHR, the Council of State held that the notion of 'terrorist activities' was too broad. It should be aligned with terrorist offences as defined in Articles 83 and $83 \mathrm{a}$ of the DCC, rather than extending the scope of (administrative) terrorist activities beyond the criminal justice system. It was doubtful whether the vaguely edited Article 2 of the Bill would comply with Strasbourg's qualitative requirements for legislation regarding the required foreseeability. The government simply referred to the explanatory memoranda, without further reacting to the Council of State's recommendations.

Finally, there was the question of the enforcement, and consequently, the effectiveness of the Bill. Who would monitor compliance with imposed administrative measures, and how would it be done? Neither the administrative authorities, nor the police - acting under the authority of the Mayor - are allowed to tail a person. ${ }^{519}$ The secret intelligence services are authorised to constantly monitor a person who poses a threat against national security, but only for the purpose of gathering information. Thus, lawfully speaking, the secret intelligence services cannot tail someone to effectively enforce an administrative or criminal law provision.

According to the government, good cooperation between the Minister of the Interior and his staff on the one hand, and the competent decentralised authorities, on the other, would suffice to guarantee adequate and effective enforcement of the Bill. Also, the simultaneous imposition of different administrative measures would contribute to the effectiveness and the enforcement of the Bill. ${ }^{520}$ For instance, it was presumed that an area injunction, combined with a duty to report, would assure that a person would not be able to commit a terrorist attack on the Queen during Koninginnedag. ${ }^{521}$

In sum, the Bill came under fierce criticism - criticism that the government did not refute convincingly. The alleged lack of effectiveness, the questionable necessity, and the excessively broadly defined basis for the application of the administrative measures have all also been discussed in light of the Strasbourg right to freedom of movement, for example, by the Council of Europe's Commissioner for Human Rights. It is to the discussion of this right that this work now turns. Would the ECtHR be as critical of the Bill as the Council of State and the above-mentioned expert organisations had been?

518 See Chapter VI for an elaborate discussion of the DPTA.

519 If there was a reasonable suspicion against the person concerned, special investigation techniques could be applied.

520 Kamerstukken I 2007-2008, 30 566, C, pp. 2-3.

521 Handelingen II 2006-2007, 2826, pp. 47-2853 and further. 


\section{THE RIGHT TO FREEDOM OF MOVEMENT}

\subsection{Introduction}

Pursuant to Article 2 of the $4^{\text {th }}$ Protocol with the ECHR ('the Protocol'), everyone who resides lawfully within the territory of a state has, within that territory, the right to liberty of movement and the freedom to choose his residence. ${ }^{522}$ Restrictions to this right are allowed, provided that these are in accordance with the law and necessary in a democratic society. ${ }^{523}$ The goal of the following sections is to examine the scope of the right to freedom of movement in light of the administrative measures comprised in the Bill. Would Article 2 of the Protocol - if the Bill had entered into force - have raised the same issues as regards to these measures as the ones raised by the Council of State and the other expert organisations?

Firstly, the difference between merely restricting a person's liberty and depriving a person of his liberty will be discussed. ${ }^{524}$ Then, two important judgements are analysed regarding the right to liberty of movement. Thirdly, the restriction clause comprised in section 3 of Article 2 of the Protocol is examined, particularly with regard to the necessity requirement.

\subsection{Restrictions on liberty of movement versus deprivation of liberty}

Merely restricting someone from freely exercising his right to liberty of movement should be distinguished from actually depriving a person of his liberty. The first situation falls under the scope of Article 2 of the Protocol, whereas the second situation falls under the scope of Article 5 of the ECHR. ${ }^{525}$ This section analyses what distinguishes these two situations from one another in light of Strasbourg case law. The government argued that the administrative measures would only interfere with the right to freedom of movement. The question is whether that point of view is endorsed by the ECtHR's case law.

\footnotetext{
522 In this work, only the right to liberty of movement will be examined.

523 See Piemont v. France, appl. nos. 15773/89 and 15774/89, 27 April 1995, §40-42; Fedorov and Fedorova v. Russia, appl. no. 31008/02, 13 October 2005, §36. These criteria were interpreted similarly as the restriction clause comprised in Article 8 of the ECHR. In Landvreugd v. the Netherlands, the ECtHR argued that the notion of 'in accordance with the law' not only requires that the impugned measure should have some basis in domestic law, but also referred to the quality of the law in question, requiring that it should be accessible to the person concerned and foreseeable as to its effects. See Landvreugd $v$. the Netherlands, appl. no. 37331/97, 4 September 2002, §54-68. See, also, H.M. v. Switzerland, appl. no. 39187/98, 26 May 2002. See Chapters VI and VII for a discussion of the Strasbourg right to liberty.

525 See, also, Assanidze v. Georgia, appl. no. 71503/01, 8 April 2005; Bozano v. France, appl. no. 9120/80, 18 December 1986.
} 


\section{GuZZARDI v. ITALY}

Guzzardi v. Italy is one of the leading judgements concerning the difference between restrictions to the right to freedom of movement and the deprivation of liberty. ${ }^{526}$ The applicant in this case, Guzzardi, was accused of belonging to the Mafia. Detention on remand on account of such a charge was allowed for a maximum period of two years. This proved to be inadequate for the prosecuting authorities to effectively prepare the prosecution of Guzzardi. Therefore, the authorities placed him under 'special supervision' on an island near Sardinia, directly after the time spent in detention on remand. The area reserved for persons in this sort of 'compulsory residence' - as the government defined it - was a fraction of not more than $2.5 \mathrm{sq}$. km. The area was bordered by the sea, roads and a cemetery. There was no fence to mark out the perimeter. About nine tenths of the island was occupied by a prison. ${ }^{527}$ Guzzardi had to stay indoors between 10 p.m. and 7 a.m., unless there was an emergency, in which case he had to ask permission to leave. Opportunities to work were very limited, and he had to give prior notice to the police in the case of receiving or outgoing phone calls. ${ }^{528}$ Disobedience of any of these obligations was punished by arrest. The special supervision lasted three years. Guzzardi claimed that these measures interfered with his right to freedom of movement and his right to liberty. The Italian government denied that the measures interfered with Article 5 of the ECHR, and argued that the Mafia and political terrorism seriously threatened public order. 529

The ECtHR ${ }^{530}$ first underlined that to determine whether someone has been deprived of his liberty, the starting point must be the concrete situation. Account must be taken of a whole range of criteria, such as the type, duration, effects, and manner of implementation of the measure in question. ${ }^{531}$ The difference between deprivation of, and a restriction upon, liberty is merely one of degree or intensity, and not one of nature or substance. In that light, the process of classification into

526 Guzzardi v. Italy, appl. no. 7367/76, 6 November 1980. In this case the question of whether it concerned the deprivation of liberty or merely a restriction of the right to freedom of movement was particularly important, as Italy had not ratified the $4^{\text {th }}$ Protocol.

527 Guzzardi v. Italy, appl. no. 7367/76, 6 November 1980, §22 and §53. Guzzardi also claimed violations of Articles 3, 8 and 9 of the ECHR. Only his claims under Article 2 of the $4^{\text {th }}$ Protocol will be discussed.

528 See, for a complete overview of the measures imposed on Guzzardi, Guzzardi v. Italy, appl. no. 7367/76, 6 November $1980 \S 22-43$.

529 Guzzardi v. Italy, appl. no. 7367/76, 6 November $1980, \S 12$ and further and $\S 88$.

530 The Commission was of the view that Guzzardi suffered a deprivation of liberty within the meaning of Article 5 of the ECHR. It attached particular significance to the extremely small size of the area where Guzzardi was confined, the almost permanent supervision to which he was subjected, the all but complete possibility for him to make social contacts and the length of his enforced stay on the Island. Guzzardi v. Italy, appl. no. 7367/76, 6 November 1980, $\$ 90$.

531 Decision regarding the admissibility in Van Den Dungen v. the Netherlands, appl. no. 22838/93, 22 February 1995. 
one or the other category sometimes is no easy task and, may in borderline cases, be a matter of pure opinion. ${ }^{532}$ It is definitely so that deprivation of liberty may take numerous other forms than actual detention on remand or imprisonment. ${ }^{53}$ According to the ECtHR, that was exactly the case with respect to Guzzardi. It was not possible to speak of actual 'deprivation of liberty' on the strength of any one of the measures imposed on Guzzardi taken separately. However, cumulatively, they certainly did raise an issue under Article 5 of the ECHR, rather than just under Article 2 of the Protocol. ${ }^{534}$ The measures, hence, clearly exceeded a restriction of Guzzardi's right to liberty of movement only. ${ }^{535}$

\section{Engel AND Others v. The Netherlands}

Also in Engel and Others v. the Netherlands, attention focused on the difference in scope between Article 2 of the Protocol and Article 5 of the ECHR. The applicants, members of the Dutch military, were subjected to 'light arrest', 'aggravated arrest' and 'strict arrest', respectively. ${ }^{536}$ Light arrest and aggravated arrest still enabled the person(s) concerned to proceed with their work. Therefore, the ECtHR considered these forms of arrest not to constitute a deprivation of liberty but, rather, a restriction of the right to liberty of movement. Conversely, strict arrest, even if imposed for only a few days, amounted to actual deprivation of liberty, because it had to be served day and night in a locked cell. Strict arrest made it impossible to perform normal duties. 537

In sum, when a person's daily routine is, to a large extent, determined by state authorities, that may be considered a deprivation of liberty. ${ }^{538}$ Also, the application of several measures simultaneously, which all restrict a person's liberty of movement, may raise an issue under Article 5 of the ECHR. All of this depends on the measures' duration, ${ }^{539}$ the severity of the effects, and the manner of implementation. Obviously, the circumstances of the case play an important role. Although the dividing line between deprivation of liberty and mere interferences with the right to liberty of movement is not clear-cut, the administrative measures

532 Guzzardi v. Italy, appl. no. 7367/76, 6 November 1980, $\$ 93$ and 94. See, also, H.M. v. Switzerland, appl. no. 39187/98, 26 May 2002, §42; Ashingdane v. the United Kingdom, appl. no. 8225/78, 28 May $1985, \S 41$.

534 Guzzardi v. Italy, appl. no. 7367/76, 6 November 1980, §95. See, also, Raimondo v. Italy, appl. no. 12954/87, 22 February 1994.

535 Guzzardi v. Italy, appl. no. 7367/76, 6 November 1980 §95. Compare with Labita v. Italy, appl. no. 26772/95, 6 April 2000, §63.

536 Engel and others $v$. the Netherlands, appl. no. 5100/71, 8 June 1976. See, for a broad explanation of the differences between the various forms of arrest, §15-22.

537 Engel and others $v$. the Netherlands, appl. no. 5100/71, 8 June 1976, $§ 63$.

538 See, also, Gillan and Quinton v. the United Kingdom, appl. no. 4158/05, 12 January 2010, \$56-57.

539 Ivanov v. Ukraine, appl. no. 15007/02, 7 December 2006, §90-97. 
of the Bill would have raised an issue under Article 2 of the Protocol rather than under Article 5 of the ECHR. Even though these measures might have been applied for a considerable time, they would most likely not have determined a person's daily routine, as in the above-discussed cases. Person subjected to the administrative measures would have remained empowered to determine part of their daily routine and would only, in part, have been limited in their whereabouts. Furthermore, they would not have been restricted in frequenting their acquaintances or family, nor would they have been obliged to stay within a certain demarcated area. Hence, the administrative measures only need to be examined on compatibility with Article 2 of the Protocol. ${ }^{540}$ It is that provision which the following section will turn to.

\subsection{The scope of the right to liberty of movement}

The right to liberty of movement guarantees the right to move, without restrictions, within a state's territory. Article 2 of the Protocol also includes the right to freely leave the territory without being unnecessarily hindered by the government. ${ }^{541}$ For instance, in Baumann v. France, the ECtHR considered that a measure by means of which an individual is dispossessed of an identity document undoubtedly constitutes an interference with his right to liberty of movement. The person concerned was then denied the use of an identity document which, had he wished, would have permitted him to leave the country and to go to any other country. ${ }^{542}$

Even though the Bill did not include powers to confiscate someone's passport, obliging a person to report periodically - even every day - to the police does limit that person's right to leave the state considerably. For a person on whom such a measure would have been imposed, it could have become, factually speaking, impossible to leave the country without risking criminal prosecution pursuant to Article 7 of the Bill.

Prohibiting a person to leave the place of his residence without permission also constitutes an interference with someone's right to liberty of movement - though of minimal intrusiveness. This measure, a form of house arrest, is primarily applied to accused persons to guarantee their presence at trial. That restriction on the right to liberty of movement is, depending on the duration, allowed under Article 2 of the Protocol. 543

540 Compare with Tatishvili v. Russia, appl. no. 1509/02, 22 February 2007, §44-45; Denizci and Others v. Cyprus, appl. nos. 25316-25321/94 and 27207/95, 23 May 2005, §346-347 and 403404; Bolat v. Russia, appl. no. 14139/03, 5 October 2006, $\$ 65$.

541 Baumann v. France, appl. no. 33592/96, 22 August 2001, §60; Riener v. Bulgaria, appl. no. 46343/99, 23 May 2006, §109.

542 Baumann v. France, appl. no. 33592/96, 22 August 2001, §62-63. See, as well, Napijalo v. Croatia, appl. no. 66485/01, 13 November 2003, §68 and 69.

543 Fedorov and Fedorova v. Russia, appl. no. 31008/02, 13 October 2005, §7-21. 
Strasbourg case law demonstrates that the question of whether a person is involved in criminal proceedings at the time his right to liberty of movement is restricted, plays a role in assessing the lawfulness of such restrictions. The administrative measures comprised in the Bill were to be imposed when the criminal justice system could not yet, or could no longer, be applied. It remains to be seen under which circumstances measures that restrict the right to liberty of movement, beyond criminal proceedings, are admissible in light of the principles of proportionality and subsidiarity.

Furthermore an injunction to enter a certain area, restricts the right to liberty of movement as well.544 In Landvreugd v. the Netherlands and Olivieira v. the Netherlands, the Mayor of Amsterdam, relying on Articles 172 and 175 of the Municipality Act, imposed an injunction on the applicants to the effect that the latter would not be allowed, for a period of 14 days, to enter a particular area, i.e. the Ganzenhoef area. ${ }^{545}$ This area was designated as an emergency area by the Mayor. ${ }^{546}$ However, the applicants in these cases continued to use hard drugs in that area, which disturbed public order.

The ECtHR considered this injunction to interfere with the right to liberty of movement. Subjecting someone to an area injunction in compliance with Article 2, section 2 sub a of the Bill would doubtlessly fall within the scope of Article 2 of the Protocol.

\subsection{Lawful restrictions on the right to liberty of movement}

Restrictions to the right to liberty of movement are allowed provided that: (1) they are in accordance with the law, (2) they serve a legitimate aim, and (3) they are necessary in a democratic society. These prerequisites apply in the same way as the corresponding restriction clauses of Articles 8 and 10 of the ECHR. Generally, the first and second prerequisites do not lead to major problems in terms of the right to freedom of movement. However, non-compliance with the necessity requirement has often led to a violation of Article 2 of the Protocol. The following sections will therefore primarily discuss the scope of the necessity requirement.

The ECtHR has repeatedly held the necessity requirement to include 'showing that the action taken was in pursuit of the legitimate aim, and that the interference

544 Landvreugd v. the Netherlands, appl. no. 37331/97, 4 September 2002, §46.

545 Landvreugd v. the Netherlands, appl. no. 37331/97, 4 September 2002; Olivieira v. the Netherlands, appl. no. 33129/96, 4 June 2002.

546 Landvreugd $v$. the Netherlands, appl. no. 37331/97, 4 September 2002, $\$ 10$ and 47. The Landvreugd area was an area in which public disorder was systematically caused due to the excessive drug use of drug addicts. The applicant, who was a drug addict himself, had already been given six consecutive eight-hour prohibition orders for openly using hard drugs in the Landvreugd area. In addition, the police had given him warnings - both orally and in writing of the likely consequences. 
with the rights protected was no greater than was necessary to achieve it'. This requirement - considered to include the principle of proportionality - demands that restrictive measures should be appropriate to achieve their protective function. ${ }^{547}$ The necessity requirement, as interpreted under Article 2 of the Protocol, includes the following aspects.

\subsubsection{Criminal proceedings?}

The question of whether a person is accused, or otherwise involved in criminal proceedings, plays a role in deciding if liberty-restricting measures are necessary. When a state imposes measures that restrict a person's liberty of movement during criminal proceedings, the necessity of these measures may be demonstrated by the importance of a proper course of such proceedings. On the other hand, when criminal proceedings lead to an acquittal, the necessity of such measures diminishes.

In Fedorov and Fedorova v. Russia, the ECtHR attached substantial weight to the fact that the applicants' liberty of movement was restricted during criminal proceedings in order to make sure that they appeared in court. ${ }^{548}$ The ECtHR considered that when it concerns accused persons, a state can apply preventive measures restricting their liberty in order to ensure the efficient conduct of a criminal prosecution. 549

Hence, the applicants' prosecution and the importance of the proper course of criminal proceedings sustained the necessity of preventive measures that restricted their liberty of movement. It may even be argued that such measures comply more with the principles of proportionality and subsidiarity than actual deprivation of liberty i.e., police custody and detention on remand. ${ }^{550}$

In Raimondo v. Italy ${ }^{551}$, the applicant (Raimondo) was suspected of belonging to a 'mafia-type organisation', on account of which criminal proceedings were lodged against him. ${ }^{552}$ During the proceedings, Raimondo was placed in detention on remand. However, after a while that was replaced by a measure of special police supervision, which became effective when he was acquitted of all charges. ${ }^{553}$ Police supervision consisted of several aspects. Raimondo was required to lodge a security

\footnotetext{
547 Bartik v. Russia, appl. no. 55565/00, 21 December 2006, §46.

548 Fedorov and Fedorova v. Russia, appl. no. 31008/02, 13 October 2005, §41; Antonenkov and Others $v$. the Ukraine, appl. no. 14183/02, 22 February 2005, §61.

549 Antonenkov and Others v. the Ukraine, appl. no. 14183/02, 22 February, §59-67; Bolat v. Russia, appl. no. 14139/03, 5 October 2006, §67-70.

550 See Chapters VI and VII for a discussion of Article 5 of the ECHR.

551 Raimondo v. Italy, appl. no. 12954/87, 22 February 1994.

552 Raimondo v. Italy, appl. no. 12954/87, 22 February 1994, §7.

553 Raimondo v. Italy, appl. no. 12954/87, 22 February 1994, §9.
} 
sum of 2,000,000 lire as a guarantee to ensure that he complied with the constraints attached to the measure. Also, he was not to leave his home without informing the police, and he had to report to the police on the days indicated to that effect. Lastly, Raimondo had to return to his house by 9 p.m. and not leave it before 7 a.m., unless he had valid reasons for doing so and had first informed the relevant authorities of his intention. ${ }^{554}$

The Italian state authorities did not comply with the national procedure for imposing special supervision which led the Court of Appeal to annul the special supervision measure and to order the restitution of the security and the property seized and confiscated. There had been a delay of nearly five months in drafting the grounds for the decision ordering the supervision, which was, nevertheless, immediately enforced. Also, Raimondo was not informed of a revocation for 18 days of the supervision. ${ }^{555}$

In general, the ECtHR underlined that in view of the threat posed by the Mafia to 'democratic society', the measure was necessary 'for the maintenance of ordre public' and 'for the prevention of crime. ${ }^{556}$ It was, in particular, proportionate to the aim pursued, up to the moment at which the Court of Appeal decided to revoke it. However, due to the above-mentioned procedural shortcomings, the ECtHR considered that the measure was not in accordance with the law or necessary in a democratic society for a short period after the Court of Appeal's judgement. The ECtHR therefore concluded that Article 2 of the Protocol had been violated. ${ }^{557}$

When comparing police supervision - as imposed in Raimondo v. Italy - with the application of administrative measures comprised in the Bill, three issues must be noted. Firstly, the interference with the right to freedom of movement in Raimondo v. Italy was obviously more intrusive than the interference would have been in the case of the application of the administrative measures. Even in the case of a person subjected to all three of the administrative measures concurrently and with considerable frequency, for two years, that person would still be free to at least leave his house when he wanted to without informing the police. Hence, the following two considerations only apply, to a certain extent, in case the administrative measures were imposed concurrently, with a considerable frequency, and possibly combined with other measures that interfere with fundamental rights.

The second issue is that the Italian police supervision was ordered by a District Court, whereas the administrative measures were to be imposed by the Minister of Interior. The District Court, as judicial authority, moreover, has to provide a well-

554 Raimondo v. Italy, appl. no. 12954/87, 22 February 1994, §13.

555 Raimondo v. Italy, appl. no. 12954/87, 22 February 1994, §14-15.

556 Compare with Ivanov v. Ukraine, appl. no. 15007/02, 7 December 2006, $\$ 96$ where the ECtHR considered that ' $(. .$.$) the lengthy interference occurred in the context of prosecuting a medium$ grave offence (...)'.

557 Raimondo v. Italy, appl. no. 12954/87, 22 February 1994, §39-40. See, also, Timishev v. Russia, appl. nos. 55762/00 and 55974/00, 13 December 2005, §45-50. 
motivated written decision including the grounds leading to the application of the police supervision.

Thirdly, the required level of suspicion for police supervision is considerably more demanding than that for the application of the administrative measures. Police supervision is exclusively justified when based on the objective establishment and assessment of facts that reveal the behaviour and lifestyle of the person concerned as member of a Mafia-type organisation. A mere suspicion is insufficient, as are alleged connections with terrorist/Mafia activities. ${ }^{558}$ The requirements for lawfully subjecting a person to police supervision are important safeguards against arbitrariness.

\subsubsection{Level of suspicion and evidence}

In Labita v. Italy ${ }^{559}$, the applicant (Labita) was arrested on suspicion of being a member of a Mafia-type organisation and of running a financial company on behalf of the leader of that organisation. During the criminal proceedings against Labita, and after his acquittal, he was subjected to preventive police supervision. ${ }^{560}$ The supervision included that: (1) he was not to leave his home without informing the authorities responsible for his supervision, (2) he had to live an 'honest life' and not to arouse suspicion, (3) he was prohibited from associating with persons who had a criminal record or who were subject to preventive or security measures, (4) he was not to return home later than 8 p.m. or to leave home before 6 a.m., unless due cause could be shown, and in all cases only after informing the authority responsible for supervising him, (5) he was not to keep or carry weapons, (6) he was not to go to bars or to attend public meetings, (7) he was obliged to have on him at all times the card setting out his precise obligations under the preventive measures and a copy of the court order, and lastly (8) he had to report to the police station on Sundays between 9 a.m. and 12 noon. ${ }^{561}$

The ECtHR first considered, in general, that 'it is legitimate for preventive measures, including special supervision, to be taken against persons suspected of being members of the Mafia, even prior to conviction, as they are intended to prevent crimes being committed. Furthermore, an acquittal does not necessarily deprive

558 Raimondo v. Italy, appl. no. 12954/87, 22 February 1994, §16-21.

559 Labita v. Italy, appl. no. 26772/95, 6 April 2000.

560 Labita v. Italy, appl. no. 26772/95, 6 April 2000, \$103-104. In Raimondo v. Italy, the preventive measures could exclusively be applied when there was sufficient factual evidence to consider someone as a threat against society, security or public order. Furthermore, the preventive measure of special police supervision was only to be imposed by a court. That court had to give a reasoned decision, after hearing the representative of the public prosecutor's office and the person on whom it was proposed to impose the preventive measure. The person concerned had the right to lodge memorials and to be represented by a lawyer.

561 Labita v. Italy, appl. no. 26772/95, 6 April 2000, §63. See for the considerations of the Italian government, $§ 72$. 
such measures of all foundation, as concrete evidence gathered at trial, though insufficient to secure a conviction, may nonetheless justify reasonable fears that the person concerned may in the future commit criminal offences.' 562

Hence, comparable to the reasoning in Raimondo v. Italy, the ECtHR did not, as such, consider preventive measures like police supervision inadmissible under Article 2 of the Protocol. However, the ECtHR required: (1) there to be a considerable suspicion of actual membership of a Mafia organisation, and (2) evidence to factually sustain that suspicion.

These two prerequisites were examined in Labita $v$. Italy. The ECtHR explicitly analysed the information that led to special police supervision being imposed on Labita. It considered that it failed to see how the mere fact that Labita's wife was the sister of a Mafia boss - who was since deceased - could justify such severe measures being taken against Labita. There was no further concrete evidence to sustain a real risk that Labita would offend. Furthermore, the ECtHR took into account that Labita had no criminal record. Also, the acquittal of the charge that he was a member of the Mafia due to lack of evidence played a role of importance. These considerations led the ECtHR to conclude that the restrictions on Labita's liberty of movement were not necessary in a democratic society, and violated Article 2 of the Protocol.

Several aspects of this judgement are important while examining the necessity of the Bill. Firstly, the question of whether a person has a criminal record or not plays a role in deciding on the necessity of preventive measures. When a person has no criminal record, and the evidence to justify preventive measures is not convincing, such measures will most likely be disproportionate, and consequently, not necessary in a democratic society. The administrative measures were to be used when the criminal law system could not (yet) be applied. Most persons that would have been subjected to such measures would therefore not have had a criminal record. In addition, the level of suspicion required for the application of the administrative measures was all but demanding.

This makes it very questionable whether the required information to justify application of the administrative measures was as factual, objective and convincing as demanded by the ECtHR. For instance, the fact that Labita's brother-in-law was the head of a Mafia clan did not automatically imply that Labita himself was involved in a Mafia organisation. The fact that Labita worked in a company that was allegedly involved in Mafia activities also did not convince the ECtHR of Labita's supposed inclination to commit offences that would endanger public order or even national security.

Hence, there are criteria for the amount, the kind, and the reliability, of information used to justify measures that infringe upon the right to liberty of 
movement. It is doubtful whether the ECtHR would consider having contact with people adhering to an extreme interpretation of Islam, or even the existence of family ties with supposed terrorists, as sufficient information to have justified the application of the administrative measures in light of Article 2, section 3 of the Protocol.

Nevertheless, the administrative measures comprised in the Bill would, undeniably, have restricted the right to liberty of movement to a lesser extent than the Italian special police supervision did. The question is whether information to justify measures that limit the right to liberty of movement may be less convincing when the measures are less intrusive. In other words, how may the necessity of the administrative measures be influenced by the relationship between the intrusiveness of the measures and the quality and amount of information used to justify such measures?

The answer to this question is, to a large extent, dependent on the specific circumstances of the case. Questions like how many administrative measures would have been imposed on a person, for how long, and how these measures were practically implemented (i.e. a duty to report once a week or every day), are of importance. It is also important to underline that although the Italian police supervision was more intrusive than the administrative measures would have been, a judicial authority instead of the Minister of the Interior was the competent authority. This is particularly significant with respect to the necessity requirement, because the ECtHR considers a judicial authority as an important counterbalancing safeguard against arbitrariness. The Minister of the Interior is no judicial authority, and is not as independent and impartial as such an authority. In light of these considerations, the Minister of Interior may not have been the appropriate authority to balance the alleged need to apply the administrative measures against the consequent infringement on the right to liberty of movement.

\subsubsection{Automatic continuation and prior warning}

A measure that restricts a person's liberty of movement may initially be lawful, but may become disproportionate when the measure is automatically continued - i.e., without proper periodical assessment of the circumstances/facts. ${ }^{563}$ The ECtHR attaches considerable weight to the question of whether a person subject to such measures has had the opportunity to rebut the necessity thereof, preferably before a court. ${ }^{564}$ Basically, there is a duty for the competent authorities to take appropriate care that any interference with the right to liberty of movement is justified and

563 Gochev v. Bulgaria, appl. no. 34383/03, 26 November 2009, §51-57.

564 Fedorov and Fedorova v. Russia, appl. no. 31008/02, 13 October 2005, §42; Antonenkov and Others v. the Ukraine, appl. no. 14183/02, 22 February, §62; Riener v. Bulgaria, appl. no. 46343/99, 23 May 2006, §121. In this latter judgement, the ECtHR considered that 'Even where a restriction on the individual's freedom of movement was initially warranted, maintaining 
proportionate throughout its whole duration. This implies that the authorities must take into account (changed) individual circumstances of the case. Generally, the necessity of measures that restrict a person's freedom of movement will diminish with the passage of time. ${ }^{565}$

Article 3 of the Bill would have established a system of regular control on the necessity of continued application of one or more of the administrative measures. However, this control was not to be executed by a court, but by the same authority that initially imposed the measure, namely, the Minister of the Interior. The National Coordinator for the Combating of Terrorism [Nationaal Coördinator Terrorismebestrijding, $\mathrm{NCTb}$ ] was to assist the Minister in regularly examining the necessity of the administrative measures in specific cases. Continued application of administrative measures was, nevertheless, going to be ordered, without a judicial monitoring authority. This meant that a person subject to such measures could only rebut the necessity thereof when he lodged an appeal.

In the above-mentioned case of Landvreugd v. the Netherlands and in Olivieira $v$. the Netherlands, the applicants were repeatedly warned prior to being subject to an area injunction. The Mayor informed them that if they dealt or used hard drugs again in the designated emergency area, a 14-day area injunction would be imposed. Also, the applicants had already been issued with several eight-hour area injunctions, but had, nevertheless, returned each time to the emergency area to use hard drugs. The applicants did not live or work in the emergency area, and did not have a post office box there. The measure was, furthermore, limited in time, and did not prevent them from meeting their friends elsewhere. In the ECtHR's view, it could not, therefore be said that the restriction to the applicants' freedom of movement was disproportionate to the aims of preventing crime and maintaining public order. ${ }^{566}$

There is a clear difference between the area injunction imposed in Landvreugd $v$. the Netherlands pursuant to the Municipality Act, and the one that would have been imposed pursuant to Article 2 of the Bill. In Landvreugd v. The Netherlands, the applicant had already repeatedly used hard drugs prior to the imposition of the injunction. Furthermore, the injunction was based on, and justified by, these criminal offences. Persons who could have been subjected to the administrative measures would frequently not have committed any criminal offence, while they could be submitted to more far-reaching (up to two years) injunctions than an area

it automatically over a lengthy period of time may become a disproportionate measure violating the individual's rights.'

Luordo v. Italy, appl. no. 32190/96, 17 July 2003, §92-97; Forte c. Italie, requête no. 77986/01, 10 novembre 2005, §30-32; Antonenkov and Others v. the Ukraine, appl. no. 14183/02, 22 February, §59-67; Bartik v. Russia, appl. no. 55565/00, 21 December 2006, §51. 
injunction for 14 days. This would undeniably have diminished the proportionality of the administrative measures considerably.

\subsection{In sum}

There is no Strasbourg case law on interferences with the right to freedom of movement caused by state powers comparable to the administrative measures comprised in the Bill. The practical scope of these administrative measures remains, furthermore, unclear due to the fact that the Bill has not entered into force. However, on the basis of the above discussion, there are three issues that must be underlined when assessing the powers comprised in the Bill on compatibility with Article 2 of the Protocol.

First and foremost, it must be underlined that Article 2 of the Bill was broadly defined and created a large discretionary power for the Minister of the Interior. The notions of 'terrorist activities', 'connected with', and 'certain conduct', were vague, even despite the attempted clarifications in the parliamentary memoranda. That generated a risk of arbitrariness, and might very well have created legal uncertainty in the implementation of the Bill. It is questionable whether this large discretionary power was sufficiently counterbalanced by procedural guarantees.

In this respect, it is important to note, secondly, that the Minister of Interior is no judicial authority, and would therefore have been less suited, in Strasbourg terms: (1) to decide whether administrative measures were to be applied to begin with, and (2) to monitor and examine the necessity of continued application. Whether or not judicial control would have been exerted on the imposition and/or continuation of these measures was dependent on the question of whether the person subjected to such measures lodged an appeal with the Hague District Court pursuant to Article 4 of the Bill. Hence, no automatic judicial review would take place either prior to, or after, the imposition of these measures.

The scope of these proceedings was, furthermore, unclear. It might very well have been that the administrative judge would not have been given access to all the relevant information. Such information would frequently have stemmed from the secret intelligence services, and consequently might not - with reference to national security concerns - have been disclosed to the judge or to the person concerned. ${ }^{567}$ That might have come to undermine the quality of such judicial review.

Thirdly, after the entering into force of the DPTA and of Articles 134a and 83b of the DCC, it became doubtful whether the administrative measures were necessary in a democratic society. When considered in light of the scope of the DTA and the DPTA, the Bill appeared to be redundant. The behaviour on the basis of which the administrative measures were to be applied, leads to criminal liability under the

567 See, in this respect, Articles 8:27, 8:28, 8:29, 8:31 and 8:45 of the AWB. 
DCCP. This implies that the investigative authorities have, at their disposal, several (special) investigation techniques that may contribute to the prevention of terrorism, possibly even more effectively. In light of the findings in Chapter II, it is unclear what 'pattern of conduct' used to demonstrate a person's alleged connections with (the support of) terrorism, and which seriously endangers national security, will not lead to criminal liability pursuant to the DCC.

The intrusiveness of the measures would obviously have been dependent on the specific circumstances of the case. Applying all of the three administrative measures cumulatively for a longer period obviously would have increased the intrusiveness, especially when taking into account that a (reasonable) suspicion was not required to impose these measures. Secret intelligence information may have sufficed to apply the administrative measures for up to a period of two years. Such interferences with the right to freedom of movement, which would, moreover, have been based on paper-thin evidence and on a broadly defined legal basis, may easily be deemed disproportionate in light of Article 2, section 2 of the Protocol.

A last issue that needs attention relates to the possibility of imposing the administrative measures after an acquittal. ${ }^{568}$ Even though the ECtHR does not seem to have too many problems with such state action, when it serves to prevent serious organised crime, and provided that there are sufficient procedural safeguards and judicial control, it may be questioned whether that also goes for future and potential criminal conduct committed by one person.

568 The explanatory memoranda of the Bill explicitly stated that the administrative measures would not serve a punitive goal. 


\section{Chapter V \\ Indications of a Terrorist Offence}

\section{INTRODUCTION}

Since the terrorist attacks on The United States, Madrid and London, the Dutch government has adopted a firm anti-terrorism policy. This policy consists of numerous juridical, quasi-juridical and non-juridical measures, which have, however, one common goal: the prevention of terrorism. The criminal justice system has been chosen as the primary juridical means to attain this goal. The preceding chapters demonstrated, however, that administrative law and public order law may also be used to avert terrorism.

The amendments to the DCC brought about by the DTA have led to broad criminal liability for terrorist offences. ${ }^{569}$ In order to adequately enforce the DTA, investigative powers had to be extended significantly in respect of terrorism; in the government's view: 'terrorism cannot be countered by means of the classical (common) criminal procedure. ${ }^{570}$ To that effect, the preventive function of criminal procedure in the case of terrorism had to be reinforced considerably.

To meet these demands, the Dutch procedural anti-terrorism act ('DPTA') [Wet tot Wijziging van het Wetboek van Strafvordering, het Wetboek van Strafrecht en enige andere wetten ter verruiming van de mogelijkheden tot opsporing en vervolging van terroristische misdrijven] entered into force in 2006. ${ }^{571}$ This Act brought about five considerable amendments to the Dutch code of criminal procedure ('DCCP') [Wetboek van strafvordering] in the field of investigations into terrorist offences:

1. Extended powers to gather (public and private) information during an exploratory inquiry into terrorist offences;

2. Broadened powers to frisk persons and investigate means of transport and objects in security risk areas, without a reasonable suspicion concerning a specific (terrorist) offence;

569 See Chapter 2 regarding the DTA.

570 See College van procureurs-generaal, Advies wetsvoorstel bijzondere bevoegdheden tot opsporing van terroristische misdrijven, 21 December 2004.

571 Staatsblad 2006, 580; Staatsblad 2006, 730; Staatsblad 2006, 731. The Dutch government announced its intent to amend the DCCP in order to better prevent and investigate terrorist offences on 10 September 2004. Kamerstukken II 2003-2004, 29 754, no. 1. 
3. Extended powers to use special investigation techniques ${ }^{572}$ in the case of investigations into terrorist offences;

4. The ability to remand suspects in custody for 20 days on the basis of a reasonable suspicion in the case of a terrorist offence;

5. A power for the public prosecutor to postpone access to the case file for the defence and the trial judge in the case of investigations into terrorism.

This chapter discusses the first three amendments. All of these three amendments relate to the introduction of a new suspicion criterion into the DCCP, brought forth by the DPTA, that of 'indications of a terrorist offence.' Firstly, this new suspicion criterion will be considered together with the powers available to the investigative authorities, in the case of such indications. ${ }^{573}$

Secondly, this chapter elaborates on the Strasbourg right to privacy concerning comparable state powers. Case law of the ECtHR in the field of investigative powers will be discussed with a focus on the question of what consequences that case law may have on the practical enforcement of the above-mentioned amendments.

Amendments 4 and 5 are scrutinised in the following chapters as they concern other, more demanding, suspicion criteria.

In section 2, the notion of 'indications of a terrorist offence' will be clarified. This notion forms the main criterion for the application of various far-reaching procedural powers during investigations into terrorism. What sort and how much information is needed to substantiate indications of a terrorist offence? From which authorities, organisations or persons may the investigative authorities request or receive information in that respect? And to what extent can this new suspicion criterion be distinguished from the reasonable suspicion criterion that generally forms the main prerequisite for applying procedural powers? Lastly, in connection with Article 8 of the ECHR, the notion of indications of a terrorist offence is to be considered in light of the principles of legality and legal (un)certainty.

572 The notion of special investigation techniques is defined as follows by the Council of Europe: 'Techniques for gathering information systematically in such a way as not to alert the target person(s), applied by law enforcement officials for the purpose of detecting and investigating crimes and suspects.' (see Council of Europe Publishing, Terrorism: special investigative techniques, Strasbourg 2005, p. 13).

573 The special investigation techniques available in the case of indications of a terrorist offence are comprised in Title VB, $1^{\text {st }}$ to $3^{\text {rd }}$ division of the DCCP. The powers to preventively search persons, objects and means of transport in certain (temporary or permanent) risk areas are codified in Title VB, $4^{\text {th }}$ division of the DCCP. Title VB corresponds to Title IVA and V concerning special powers of investigation (common criminal offences) and special investigation techniques in connection with the planning or committing of serious organised crime, respectively. The DPTA has also introduced a new Title VC into the DCCP: assistance by civilians in criminal investigations into terrorist offences. This Title corresponds to Title VA: assistance by civilians in criminal investigations into the planning or committing of serious organised crime. 
Then, in sections 3 to 7, the powers that may be applied on the basis of indications of a terrorist offence are considered. These powers can be divided into 3 categories: (1) the exploratory inquiry into terrorist offences, (2) special investigation techniques and (3) investigative powers in security risk areas. These powers will be discussed extensively, with particular focus on the safeguards provided for in the relevant provisions.

The powers that may be used upon indications of a terrorist offence interfere with the right to privacy as interpreted by the ECtHR. ${ }^{574}$ The application of these powers primarily raises issues concerning: (1) the quality of the law, as examined under the requirement that interferences with the private life must be in accordance with the law, and (2) concerning the necessity requirement. These two requirements also involve the prerequisite that domestic law must provide effective and adequate safeguards to prevent arbitrary interferences with the right to privacy.

Section 8 will elaborate extensively on the ECtHR's case law concerning the application of comparable powers in investigations into terrorist crimes and common crimes. How clear do criminal law provisions need to be to make interferences with privacy lawful? Does the fact that powers serve to prevent terrorism make the ECtHR more lenient in its examination under Article 8 of the ECHR? May broadly edited provisions be compensated by extra safeguards and, if so, how? How does the ECtHR examine the necessity requirement in cases concerning application of procedural powers within criminal investigations? When is such an application considered really necessary, and hence, in compliance with the proportionality principle? And what role does compliance with the requirement that there must be adequate and effective safeguards play in that respect? When are safeguards considered effective and adequate, and under which circumstances does the ECtHR deem compliance with such safeguards of particular importance?

\section{INDICATIONS OF A TERRORIST OFFENCE}

\section{INTRODUCTION}

The DPTA introduced a new suspicion criterion into the DCCP for procedural powers which are applied during investigations into terrorist offences: indications of a terrorist offence. Such indications must be based on 'information holding facts or circumstances that indicate that (a) terrorist offence(s) will be committed or has/ have been committed. ${ }^{575}$ This suspicion criterion is less demanding than the regular

$574 \quad$ See Chapter 1.

575 Kamerstukken II 2004-2005, 30 164, no. 3, p. 9. The terrorist offences that will be committed, or are being, or have been committed, can also be preparatory acts, conspiracy to commit a terrorist offence, an attempt to commit a terrorist offence, or any participatory behaviour that is liable to punishment. 
suspicion criterion in the DCCP, that of a 'reasonable suspicion' pursuant to Article 27 of the DCCP. Indications presuppose that there is insufficient information to come to a reasonable suspicion. ${ }^{576}$ Formally, indications of a terrorist offence form the main prerequisite (1) for the initiation of an exploratory inquiry into terrorist offences, (2) for the application of special investigation techniques during investigations into terrorist offences and (3) to order the application of preventive investigative powers within security risk areas.

Before the coming into force of the DPTA, special investigation techniques like systematically observing a person or tapping their phone, could only be used in the case of a 'reasonable suspicion' that a concrete offence had been committed, ${ }^{577}$ or in the case that there were facts or information leading to a reasonable suspicion that severe offences ${ }^{578}$ were being plotted or committed in an organised context. ${ }^{579}$ Either way, a reasonable suspicion formed a clear prerequisite for employment of special investigation techniques. At present there is a dichotomy in applying special investigation techniques: the application of such techniques to investigate common crimes still requires a reasonable suspicion, whereas the application of these techniques to investigate terrorist crimes is possible upon indications of a terrorist offence.

As such, the criterion of indications of a terrorist offence has thus led to the establishment of a special division within the DCCP that exclusively comprises rules with respect to investigations into one category of specific offences, that of terrorist offences. Practice shows that, so far, indications of a terrorist offence have primarily concerned the following terrorist offences: participation in a terrorist organisation (Article 140a of the DCC) and/or conspiracy to or preparation of an explosion or murder (Articles 96, section 2; 83(a); 157, section 3; and 289 of the DCC). ${ }^{580}$

576 Compare with Title IV $1^{\text {st }}$ and $2^{\text {nd }}$ division and Title IVA of the DCCP. The connection between these respective suspicion criteria will be discussed further below. At this point it is important to note that these two suspicion criteria, along with the other (common) suspicion criteria in the criminal justice system can be placed on a rising sliding scale starting with: (1) 'indications of a terrorist offence' (Title VB en VC DCCP), followed by (2) facts or circumstances which result in a reasonable suspicion that severe offences are being plotted or committed in an organised context (V) followed by (3) a reasonable suspicion that an offence has been committed (Title IVA and the general Article 27 DCCP), followed by (4) serious objections (Title IV DCCP), and finally (5) the legal conviction that the suspect has indeed committed an offence (Article 350 DCCP). 


\section{INFORMATION}

What kind and how much information is needed to substantiate indications of a terrorist offence? The parliamentary memoranda discuss four situations in which the information available to the investigative authorities is adequate to demonstrate such indications. ${ }^{581}$ Firstly, rumours that are, with regard to their content, difficult to verify but which nevertheless point to, for instance, the preparation of a terrorist offence, suffice. These rumours may even come from a source that cannot, or not sufficiently, be determined, like an anonymous tip-off. Despite the fact that the content and the source of the information cannot be verified, such 'soft' information may, nevertheless, lead to indications of a terrorist offence. ${ }^{582}$ In actual practice, the application of special investigation techniques on the basis of such thinly substantiated information primarily serves to: (1) assess information at the earliest moment possible, and (2) to exclude any risks. ${ }^{583}$

Secondly, it is also possible that the content and the origin of the information used to substantiate indications is amply verifiable, while the information does not sufficiently indicate which specific terrorist offence it concerns. This may be the case when bona fide (secret) informants working for the Criminal Secret Intelligence Unit of the police [Criminele Inlichtingen Eenheid, CSIU], each separately notice the special interest of a number of persons in the construction details of a governmental building. ${ }^{584}$ If these details appear, moreover, to be of importance for the perpetration of a terrorist attack, that information is adequate to assume indications of a terrorist offence. So, even though such information does not clarify which specific terrorist offence is allegedly being prepared or conspired to, it is adequate to corroborate indications.

Thirdly, (CSIU) information that is unverifiable in respect of its content, its source, and the specific terrorist offence it allegedly regards, is also adequate to demonstrate indications. For instance, when a person anonymously reports to the police that one of his acquaintances has told him that he is planning, with a number of other persons, to cause 'major damage in the city centre in order to teach that pernicious Western world a lesson', that is sufficient to substantiate indications. Hence, even

\footnotetext{
581 Kamerstukken II 2004-2005, 30 164, no. 3, pp. 7-16.

582 The application of such techniques must additionally serve the interest of the investigation. This second requirement will be discussed below.

583 C.J. de Poot, R.J. Bokhorst, W.H. Smeenk, R.F. Kouwenberg, De Opsporing verruimd? De Wet opsporing terroristische misdrijven een jaar in werking, WODC, Cahier 2008-9, p. 3 and 43-44.

584 See, also, B. van Gestel, C.J. de Poot, R.J. Bokhorst, R.F. Kouwenberg, Signalen van terrorisme en de opsporingspraktijk. De Wet opsporing terroristische misdrijven twee jaar in werking, WODC Cahier 2009-2010, p. 10-12.
} 
such unverifiable and unequivocal information may lawfully lead to assuming indications of a terrorist offence.

Fourthly, general threat analysis drawn up by the secret intelligence services may also lead to assuming indications of a terrorist offence. ${ }^{585}$ According to the government, criminal investigations into terrorism primarily serve to prevent terrorist attacks rather than to substantiate a reasonable suspicion. Therefore, the investigative authorities must be empowered to use, for instance, special investigation techniques, even if that is done on the basis of secret intelligence information or on the basis of unverifiable rumours. When the application of a state power may reasonably be expected to contribute to the prevention of a terrorist attack, that power should be applied even if there is no sufficiently substantiated suspicion. ${ }^{586}$ Application of such powers on the basis of such soft information is justified, as long as it serves the interest of the investigation. The question of whether application of a special investigation technique is in the interest of the investigation depends on the seriousness of the alleged intended terrorist offence and the probability that the threat will actually occur. ${ }^{587}$

In sum, during criminal investigations into terrorism, the general content of information has become more important than the reliability, the accuracy, or the source of such information. The question of whether there may be a terrorist threat is decisive, rather than the question of whether the information underlying that assumption is accurate and reliable. The course of a criminal investigation into terrorism on the basis of indications is, accordingly, primarily depend on: (1) the content of the information, and (2) the moment when the information is provided to the police. ${ }^{588}$

585 See, also, B. van Gestel, C.J. de Poot, R.J. Bokhorst, R.F. Kouwenberg, Signalen van terrorisme en de opsporingspraktijk. De Wet opsporing terroristische misdrijven twee jaar in werking, WODC Cahier 2009-2010, p. 10.

586 Kamerstukken II 2004-2005, 30 164, no. 3, p. 11.

587 C.J. de Poot, R.J. Bokhorst, W.H. Smeenk, R.F. Kouwenberg, De Opsporing verruimd? De Wet opsporing terroristische misdrijven een jaar in werking, WODC, Cahier 2008-9, p. 16.

588 See also B. van Gestel, C.J. de Poot, R.J. Bokhorst, R.F. Kouwenberg, Signalen van terrorisme en de opsporingspraktijk. De Wet opsporing terroristische misdrijven twee jaar in werking, WODC Cahier 2009-2010, p. 10-11. 


\section{CONTENT OF INFORMATION}

The Dutch scientific research and documentation centre [Wetenschappelijk Onderzoek- en Documentatiecentrum, WODC] published three monitoring reports regarding the application of procedural powers to investigate terrorist offences in the periods 2007-2008, 2008-2009, and 2009-2010. ${ }^{589}$ These WODC reports demonstrate that indications of terrorist offences are primarily assumed on the basis of: (1) information relating to possible contacts of a person with alleged terrorist organisations, and (2) information concerning a person's alleged preparatory behaviour. It appears that alleged preparatory behaviour is, in practice, assumed on the basis of information relating to attempts to acquire explosive substances. Such behaviour is also assumed on the basis of alleged recruiting-activities that take place in a Mosque. The sources of such information are the secret intelligence services and, in one case, the report of someone who felt threatened. ${ }^{590}$

The circle of persons that may be subjected to investigative powers on the basis of indications of a terrorist offence is considerable. For instance, acquaintances of a person who is supposed to have contacts with an (inter)national terrorist organisation may very well be subjected to special investigation techniques, such as wiretapping or systematic observation. Criminal investigations, accordingly, serve primarily to ascertain who is, for instance, connected to a presumed terrorist organisation. Inevitably, such a working method that strives to exclude any risks will lead to many common citizens being subjected to various investigation techniques. This example also demonstrates the difference between a reasonable suspicion pursuant to Article 27 of the DCCP, and indications of a terrorist offence. The person allegedly connected to the (inter)national terrorist organisation may be considered a suspect, whereas his acquaintances are not suspects, but they may, nevertheless, be subjected to various powers, because it concerns a situation of indications of a terrorist offence. ${ }^{591}$

Let me give some other examples of situations in which the investigative authorities assumed indications of a terrorist offence on rather scant information. In one case, the telephone number of a Dutch man, which had been found in the possession of

589 C.J. de Poot, R.J. Bokhorst, W.H. Smeenk, R.F. Kouwenberg, De Opsporing verruimd? De Wet opsporing terroristische misdrijven een jaar in werking, WODC, Cahier 2008-9; B. van Gestel, C.J. de Poot, R.J. Bokhorst, R.F. Kouwenberg, Signalen van terrorisme en de opsporingspraktijk. De Wet opsporing terroristische misdrijven twee jaar in werking, WODC Cahier 2009-2010; B. van Gestel, C.J. de Poot and R.F. Kouwenberg, De Wet opsporing terroristische misdrijven drie jaar in werking, WODC, Cahier 2010-3. These reports are further discussed in section 7.

590 Gestel, B., van; Poot, C.J., de; Bokhorst, R.J.; Kouwenberg, R.F., Signalen van terrorisme en de opsporingspraktijk. De Wet opsporing terroristische misdrijven twee jaar in werking, WODC Cahier 2009-2010, p. 20-21; see, also, pp. 36 and 39 for two other examples.

591 Gestel, B., van; Poot, C.J., de; Bokhorst, R.J.; Kouwenberg, R.F., Signalen van terrorisme en de opsporingspraktijk. De Wet opsporing terroristische misdrijven twee jaar in werking, WODC Cahier 2009-2010, p. 19-20. 
persons that were arrested abroad in respect of potential involvement in the preparation of terrorist attacks, sufficed to corroborate indications of a terrorist offence. Another case concerned a perpetrator of a violent offence, who was presumed to have possible connections with a terrorist organisation. To discover if these respective persons indeed had connections with a terrorist organisation, special investigation techniques were applied in both cases. ${ }^{592}$

\section{COlLeCtives IN 'RISKY Situations'}

The above considerations demonstrate that 'indications of a terrorist offence' as a suspicion criterion, will often concern a collective situation, rather than an individual who is suspected of a specific offence. Indications do not necessarily need to relate to specific 'suspicious' persons or a specified terrorist offence to justify the application of special investigation techniques or other powers. The interest of the investigation and the expected effectiveness of the application of state powers in preventing terrorism increasingly determines if such powers must be applied, and on whom, rather than the level of suspicion. That decreases the factual value and the protective function, in terms of fundamental rights, of the required suspicion criterion.

The question of whether a person appears in, for instance, a specific social environment basically determines if he may become subject to the powers available to the investigative authorities upon indications of a terrorist offence. ${ }^{593}$ Actual involvement in the plotting of, preparation of, or conspiracy to commit, terrorist offences is no longer a prerequisite for the lawful application of various state powers. ${ }^{594}$ Often, only after such powers have been applied is it possible to ascertain who may and who may not be connected to terrorist offences.

The criterion of indications of a terrorist offence accordingly serves as means to sort possible terrorist suspects from non-suspects. This 'shifting-process' is employed on large groups of people, and based on thinly substantiated information. Consequently, criminal investigations into terrorism serve to exclude risks or to

592 Gestel, B., van; Poot, C.J., de; Bokhorst, R.J.; Kouwenberg, R.F., Signalen van terrorisme en de opsporingspraktijk. De Wet opsporing terroristische misdrijven twee jaar in werking, WODC Cahier 2009-2010, p. 20.

593 See, also, C.J. de Poot, R.J. Bokhorst, W.H. Smeenk, R.F. Kouwenberg, De Opsporing verruimd? De Wet opsporing terroristische misdrijven een jaar in werking, WODC, Cahier 2008-9, pp. $48-50$.

594 See Nederlandse orde van advocaten, adviescommissie strafrecht, Advies wetsvoorstel bijzondere bevoegdheden tot opsporing van terroristische misdrijven, $23^{\text {th }}$ December 2004, at: www.advocatenorde.nl/wetenregelgeving/adviezen.asp; also, P.H.P.H.M.C. van Kempen, 'Het conceptwetsvoorstel voorkoming, opsporing en vervolging van terroristische misdrijven: terrorisme bestrijding door marginalisering van strafvorderlijke waarborgen', in NJB 2005, nr. 8, p. 397-400; see for the full version of this article, www.portill.nl/articles/vankempen/ VanKempen_1.PDF. 
detect criminal behaviour early in the pro-active phase, rather than to take decisions to enforce criminal law, as defined in Article 132a of the DCCP. ${ }^{595}$ This issue will further be discussed in the next section.

\section{INDICATIONS AS ‘NEW’ SUSPICION CRITERION}

The explanatory memorandum argues that 'indications' as a suspicion criterion is not unfamiliar in Dutch criminal procedure. Articles 51-52 of the Weapons and Ammunition Act [Wet wapens en munitie, WAA] also include this suspicion criterion. These provisions empower the public prosecutor to order investigative officers to preventively search persons and to investigate vehicles in so-called security risk areas. Secondly, within the framework of the Act on economical offences [Wet op de economische delicten, AEO], the prerequisite of 'in the interest of the investigation' is interpreted comparably to the interpretation of indications. ${ }^{596}$

However, when it comes to the WAA, 'indications' is not the only prerequisite for the application of powers to search persons and to investigate vehicles. Furthermore, this is a separate special Act limited to investigations into weapons and ammunition, like the AEO, which makes a comparison with the criterion of indications of a terrorist offence in the DCCP not completely self-evident. In addition, the WAA and the AEO provide for less far-reaching powers than the DPTA. This issue will further be elaborated on in the following sections.

\section{POWERS ON THE BASIS OF INDICATIONS OF A TERRORIST OFFENCE}

The following sections will provide an overview of the three (sets of) powers that the investigative authorities have at their disposal in the case of indications of a terrorist offence. Firstly, there is the power to initiate an exploratory inquiry into terrorist offences on the basis of indications pursuant to Articles 126hh and 126ii of the DCCP. That inquiry is examined in the upcoming section 4. Secondly, special investigation techniques, like systematic observation or infiltration, can be

595 B. van Gestel, C.J. de Poot, R.J. Bokhorst, R.F. Kouwenberg, Signalen van terrorisme en de opsporingspraktijk. De Wet opsporing terroristische misdrijven twee jaar in werking, WODC Cahier 2009-2010, p. 19.

596 The explanatory memorandum enumerates Articles 51 and 52 of the WAA [Wet Wapens en Munitie] and the AEO [Wet Economische Delicten]. The WAA includes a power to preventively search vehicles and persons on indications of the presence of weapons or ammunition in an area that has been denoted a risk area. However, the WAA additionally requires the public prosecutor to specify the facts or circumstances on the basis of which investigative officers are authorised to apply these powers. The AEO includes several powers that may be used when application thereof is 'in the interest of the investigation'. According to the government, the interpretation of the notion of 'in the interest of the investigation' is comparable to the one of 'indications'. See Supreme Court 9 March, 1993, NJ 1993, 633; Supreme Court 30 October 1984, NJ 1985, 275. 
mobilised in accordance with Articles 126za to 126zq of the DCCP. In section 5 these techniques are discussed. Thirdly, the DCCP empowers the investigative authorities to preventively search persons and/or investigate objects and means of transport in (permanent) security risk areas on the basis of indications of a terrorist offence. ${ }^{597}$ These preventive investigative powers are detailed in Articles 126zq to $126 \mathrm{zs}$ of the DCCP. Section 6 will elaborate on these powers.

\section{ThE EXPLORATORY INQUIRY INTO TERRORIST OFFENCES}

\section{INTRODUCTION}

This section discusses the exploratory inquiry into terrorist offences pursuant to Articles $126 \mathrm{hh}$ and $126 \mathrm{ii}$ of the DCCP. ${ }^{598}$ An exploratory inquiry precedes a criminal investigation and serves to prepare such an investigation by gathering, comparing and processing information. ${ }^{599}$ Information gathered and processed within the context of an exploratory inquiry may also lead to the application of special investigation techniques, to an arrest, and may serve as evidence during criminal proceedings. Technically, an exploratory inquiry does not belong to the preliminary investigation, and consequently, the fundamental principles of criminal law do not apply. To lawfully initiate an exploratory inquiry into terrorist offences, indications, based on facts or information, that terrorist offences are being potentially jointly plotted or committed suffice. ${ }^{600} \mathrm{~A}$ risk analysis from the secret intelligence services or an anonymous tip-off is adequate to adduce such facts or information.

The exploratory inquiry primarily serves to ascertain in what way certain forms of serious criminality have installed themselves within certain parts of society, and which persons are involved in this. It enables the prosecuting authorities to acquire

597 The special investigation techniques available in the case of indications of a terrorist offence are listed in Title VB, $1^{\text {st }}$ to the $3^{\text {rd }}$ division of the DCCP. The powers to preventively search persons, objects and means of transport, in certain (temporary or permanent) risk areas, listed in Title $\mathrm{VB}, 4^{\text {th }}$ division of the DCCP.

Staatsblad 2006, no. 580. See, also, Kamerstukken II 2003-2004, 29 754, no. 1.

C.P.M. Cleiren, J.F. Nijboer, Tekst \& Commentaar Strafvordering, Kluwer Deventer 2001, $4^{\text {de }}$ druk, pp. 453-461. An exploratory inquiry is considered to fall under the heading of 'preservation of the legal order' as defined in Article 13 of the PA [Politiewet].

600 The notion of 'plotting' is defined as conduct connected to the perpetration of a criminal offence, which precedes the actual perpetration of that offence. Kamerstukken II 1996-1997, 25 403, no. 3, p. 26 and p. 50; C.P.M. Cleiren, J.F. Nijboer, Tekst \& Commentaar Strafvordering, Kluwer Deventer 2001, 4de druk, p. 453. The exploratory inquiry must result in information which relates to specific persons who belong to the suspected collective of persons that plots or commits offences. See Supreme Court 8 April 2003, NJ 2003/420, paragraph 3.2; H.H. Kielman and W.I. Koelewijn, 'Minder registers, meer gegevens: Over gegevensverwerking betreffende zware criminaliteit', in Ars Aequi 2005/54, no. 6, pp. 451-457. 
a better information position at the beginning of a criminal investigation. As a rule, non-suspected common civilians may, just as well as persons involved in terrorist activities, become subject to such an inquiry. That makes the exploratory inquiry into terrorism a far-reaching measure in terms of respect for fundamental rights such as the right to privacy.

The following sections will focus on the question of what information may be gathered throughout an exploratory inquiry, and the way in which the investigative authorities process it. What information may be collected under what circumstances and from whom? And may the competent authorities store information yielded by the processing, or are they obliged to destroy it once it is not used? Furthermore, the question of whether there are safeguards provided, and if so, what are they, is also discussed.

First however, Article 126gg of the DCCP (1999), which provides for the exploratory inquiry into common offences, is briefly discussed. This is particularly important in light of the alleged necessity of Articles $126 \mathrm{hh}$ and $126 \mathrm{ii}$ of the DCCP in terms of compliance with Article 8 of the ECHR.

\subsection{Exploratory inquiry into common offences: Article 126gg of the DCCP}

Next to an exploratory inquiry into terrorist offences, Article 126gg of the DCCP provides for an exploratory inquiry into common offences. The latter provision has been in force since $1999 .{ }^{601}$ The question arises as to why the government deemed it necessary to enact Article 126h next to Article 126gg of the DCCP? To answer that question, this section will briefly discuss the scope of an exploratory inquiry into common offences. ${ }^{602}$

Like an exploratory inquiry into terrorist offences, an exploratory inquiry into common offences serves to prepare a criminal investigation and to examine if such an investigation would be opportune. The explanatory memorandum clarifies that an exploratory inquiry is to 'ascertain if and in what way criminal offences are potentially being plotted/prepared within certain sectors of society. ${ }^{603}$ For instance, an exploratory inquiry pursuant to Article 126gg of the DCCP, may be initiated on the basis of 'indications' that within the transport sector, serious offences are being plotted.

\footnotetext{
601 Staatsblad 1999, 245.

602 See, for an elaborate discussion on the scope of an exploratory inquiry into common offences C.P.M. Cleiren and J.F. Nijboer, Tekst \& Commentaar Strafvordering, 8ste druk, Kluwer Deventer 2009, pp. 645-652; see Kamerstukken II 1998-1999, 26 269, no. 4-5; Kamerstukken II 1998-1999, 25 403, no. 3.

603 Kamerstukken II 1998-1999, 25 403, no. 3, p. 49-52.
} 
The scope of Article 126gg of the DCCP is more confined than Article 126hh of the DCCP. To start with, an exploratory inquiry into common offences is limited to the offences listed in Article 67, section 1 of the DCCP. ${ }^{604}$ In addition, the joint plotting or the perpetration of these offences must severely infringe the legal order. This requirement constitutes a separate prerequisite, whereas it does not with respect to terrorist offences. Thirdly, Article 126gg of the DCCP only allows for the gathering of: (1) information which was already available to the investigative authorities, (2) information stemming from public sources, or (3) information coming from public or private organisations that voluntarily provided the information to the investigative authorities.

So, the kind of sources that the investigative authorities have access to is very limited. They are not allowed to request information from private sources. ${ }^{605}$ When it regards the prevention of terrorism, the government deems this restriction to stand in the way of conducting an effective exploratory inquiry. Powers to collect and process information have therefore been considerably broadened in case an inquiry serves to prepare a criminal investigation into terrorist offences. ${ }^{606}$ We will now turn to discussing the precise scope of an exploratory inquiry into terrorist offences in accordance with Articles 126hh and 126ii of the DCCP.

\subsection{Exploratory inquiry into terrorist offences: Articles 126hh and 126ii of the DCCP}

\section{ARTicle 126hH OF THE DCCP}

Articles $126 \mathrm{hh}$ and $126 \mathrm{ii}$ of the DCCP lay down rules for the exploratory inquiry into terrorist offences. The first provision allows the public prosecutor, after prior authorisation of an investigative judge, to request and process data files from public and/or private parties. The second provision empowers the public prosecutor to request and process so-called identifying information from public and private parties. In this section, Article $126 \mathrm{hh}$ of the DCCP is examined; discussion of Article 126ii of the DCCP follows in the upcoming section.

Criminal offences as enumerated in Article 67 of the DCCP, are - but for some exceptions offences with a penalty of at least four years imprisonment, for which remanding in custody and detention on remand are allowed.

606 See, D.V.A. Brouwer, 'Het verkennend onderzoek in strafzaken en de wetgevingsspiraal', in NJB 2000 , no. 12 , pp. $637-640$. Brouwer had already predicted in 2000 , that following the entering into force of Article 126gg of the DCCP, the scope of the exploratory inquiry would be broadened. He sustained this claim by referring to the fact that many (special investigative) powers intended to exclusively counter a limitative amount of specific offences (e.g. economic offences), also became applicable to investigate common criminal offences. Brouwer advised against a broadened scope of the exploratory inquiry. 
The distinguishing characteristic of Article 126hh, compared to Article 126gg of the DCCP, is that it includes a broadened power to collect and process data files from public, and from private, companies, which are not yet available to the investigative authorities. In the government's view, the investigative authorities need far-reaching powers to collect all the information necessary to prepare criminal investigations into terrorist offences, and therewith, to adequately prevent terrorism. Articles $126 \mathrm{hh}$ and $126 \mathrm{ii}$ of the DCCP meet those demands.

Two cumulative criteria must be fulfilled to initiate an exploratory inquiry into terrorist offences pursuant to Article $126 \mathrm{hh}$ of the DCCP. ${ }^{607}$ Firstly, there must be 'indications', on the basis of facts or information, that terrorist offences may be plotted or committed 'within a loosely structured compilation of persons.' The explanatory memorandum argues that such facts or information may be demonstrated by other exploratory inquiries, by a criminal investigation, by secret intelligence information, or by non-specific, though suspicious, information available to the police. ${ }^{608}$ For instance, a public prosecutor may receive (secret intelligence) information that a group of persons has facilities, (financial) services or means, that may serve to commit or prepare terrorist offences, from an un-identified organisation which is located in a certain block of buildings. The prosecutor is then authorised to request information - i.e. databases - from companies residing in (one of) these buildings. That will enable him to search for information to demonstrate the alleged connection between the 'compilation of persons' and the organisation(s) that facilitate the supposed terrorist activities. The indications do not need to concern a specific terrorist offence or a specific person. Nevertheless, mere assumptions or presumptions are insufficient. Secondly, collecting and processing data files and (identifying) information must be in the interest of the investigation. This requirement will, however, be easily fulfilled when it concerns terrorism, and is, as such, of little value.

Article $126 \mathrm{hh}$ of the DCCP prescribes that when the public prosecutor wants to request and process data files, he must acquire the prior authorisation of an investigative judge. Thus, he may initiate an exploring inquiry when the two abovediscussed requirements have been fulfilled, but to apply the broadened powers the

607 The requirements prescribed in Article 126gg of the DCCP equally apply. Hence, the exploratory inquiry must concern terrorist offences that severely infringe upon the legal order. That requirement is considered to be automatically fulfilled in the case of terrorist offences. These requirements also apply in the case of Article 126ii of the DCCP. Kamerstukken II 2004-2005, 30164 , no. 3 , pp. $18-19$.

608 With respect to Article 126gg of the DCCP, the government argues that such indications may stem from (1) information concerning offences yet committed, combined with (2) information concerning alleged future offences, and (3) from certain scholarly research which demonstrates that certain professional groups are (proportionally) more involved in criminal activities. See, also, the law concerning police records [Wet Politieregisters] and Kamerstukken II 1998-1999, 25 403, no. 3, p. 49. 
public prosecutor needs prior approval of an investigative judge. This ex ante judicial review serves to counterbalance the public prosecutor's far-reaching discretionary power to request and process data files when it concerns an exploratory inquiry into terrorist offences. It is important to note that in the case of Article 126ii of the DCCP, concerning identifying information, the public prosecutor does not need to acquire any prior judicial authorisation. The parliamentary memoranda do not elaborate on this distinction. Most likely, identifying information is considered to be less 'sensitive', in terms of respect for the right to privacy, than data files.

The public prosecutor processes the data files that he has requested from public or private organisations. Processing data files means that several aspects of different data files are connected and then compared, which yields new information. ${ }^{609}$ This is mostly done electronically. Although the new information is general, that information is valued and examined on compatibility with 'terrorist profiles'. Processing data files allows the public prosecutor, accordingly, to discover patterns and to see if a person/persons act(s) concurrently in different situations that are all relevant to the inquiry. This is also denoted as 'combined data-processing'. Data is analysed in such a way that profiles can be compiled. These profiles then serve to search other files for a person's potential involvement in terrorist activities. As a result, hidden suspicious patterns become detectible, and persons can be examined on compliance with a certain 'terrorist' profile.

This profiling technique is currently also used to compile common offender profiles, to draft risk analysis of certain districts or victims and to map out patterns of criminal modus operandi. Profiling brings forth a considerable error rate: information obtained by combined data-processing easily leads to wrongly considering a person as a 'terrorist suspect'. ${ }^{610}$ This issue will further be elaborated on in Section 8 of this chapter and in Chapter 8.

609 Processing is considered to include various operations such as gathering, recording, organising, conserving, adapting or amending, consulting or extracting, disseminating, deleting, destructing, and the like. See Terrorism: special investigative techniques, Council of Europe Publishing, April 2005, p. 19.

610 NRC Handelsblad 6 June 2009, 'Verdachten terreur zelden veroordeeld'. See, also, B. van Gestel, C.J. de Poot, R.J. Bokhorst, R.F. Kouwenberg, Signalen van terrorisme en de opsporingspraktijk. De Wet opsporing terroristische misdrijven twee jaar in werking, WODC Cahier 2009-2010, p. 11 and further; C.J. de Poot, R.J. Bokhorst, W.H. Smeenk and R.F. Kouwenberg, De opsporing verruimd? De Wet opsporing terroristische misdrijven een jaar in werking, WODC Cahier 2008-2009; B. van Gestel, C.J. de Poot en R.F. Kouwenberg, De wet opsporing terroristische misdrijven drie jaar in werking, WODC, Memorandum 2010-3. The WODC-reports during the period 2007-2009 demonstrate that none of the 37 criminal investigations into terrorist offences led to criminal prosecution in respect of the commission or the plotting of a terrorist offence. All of these investigations were halted due to a lack of adequate evidence. Often, the public prosecutor passed the collected information on to the secret intelligence services who 'continued the investigation'. See, for further discussion of this issue, Chapter IX, Section 2.1. 
The government does not deny the fact that persons who are not involved in terrorism will also form part of an exploratory inquiry pursuant to Article $126 \mathrm{hh}$ of the DCCP. People, unrelated to terrorist activities, let alone terrorist offences, will inevitably be screened when they, for instance, happen to be within a 'suspicious compilation of persons.' That makes an exploratory inquiry a considerably farreaching investigative method, particularly when one takes into account the sweeping powers to request information during such an inquiry. To counterbalance these powers and to prevent violations of the right to privacy, five safeguards are provided for. 611

Firstly, a public prosecutor may only request and process data files pursuant to Article $126 \mathrm{hh}$ of the DCCP, after prior approval of an investigative judge. The investigative judge examines whether the data files that the public prosecutor wants to request and process are necessary for an effective proceeding of the exploratory inquiry. ${ }^{612}$ Secondly, the public prosecutor is obliged to specify how, and which, information is to be processed, on the basis of which criteria or profiles. The actual data-processing and its results, moreover, need to be laid down in an official report. 613

Thirdly, the data-processing must be carried out in such way that the right to privacy of the persons under investigation is respected as much as possible. ${ }^{614}$ This means that an exploratory inquiry is preferably performed completely computerised. Data files can then be processed and examined on the compatibility with certain profiles without anyone viewing the content of the obtained data files. The error rate, however, remains considerable with a $100 \%$ computerised system. The investigative authorities remain, furthermore, authorised to inspect the content of data files when such a file matches with a 'terrorist profile', and might, hence, be of use in an ensuing criminal investigation.

Fourthly, sections 4 to 7 of Article $126 \mathrm{hh}$ of the DCCP include specific procedural rules, which serve to further curtail the public prosecutor's significant discretionary power. These sections prescribe that data files may be used for further criminal investigations and which information has to be destroyed after the data-processing. These regulations serve to guarantee that only information concerning persons who are actually relevant to further criminal investigations is saved. In theory, privacy sensitive information that is not relevant to an ensuing criminal investigation, thus cannot be saved or further processed.

\footnotetext{
611 Kamerstukken II 2004-2005, 30 164, no. 3, pp. 21-23; Kamerstukken I 2006-2007, 30164 , no. G. pp. 3-5.

612 Article 126hh, section 1 of the DCCP; Kamerstukken II 2004-2005, 30 164, nr. 3, p. 21.

613 Article 126hh, section 4 of the DCCP; Kamerstukken II 2004-2005, 30 164, nr. 3, p. 22.

614 Article 126hh, section 3 of the DCCP; Kamerstukken II 2004-2005, 30 164, nr. 3, p. 22.
} 
Fifthly, the Board of Procurers-General [College Procureurs-Generaal, the Board) set up a specific procedure for how exploratory inquiries are to be initiated and carried out. ${ }^{615}$ This procedure prescribes that: (1) the public prosecutor has to submit a request for an exploratory inquiry to the head-prosecutor of his district, who (2) subsequently forwards the request for final approval to the national public prosecutor. If the exploratory inquiry will have implications for society, or has a national or interregional character, the public prosecutor must, moreover, obtain the approval of the Board. An exploratory inquiry into terrorist activities will, most likely, have implications for society and it will have an interregional character, which makes the approval of the Board practically mandatory. This means that a public prosecutor has to submit a well-argued request to the Board to get approval prior to initiating an exploratory inquiry into terrorist offences. He has to state the facts and circumstances underlying the request for the initiation of an exploratory inquiry. Also, he is obliged to inform the Board of the central question of the inquiry. Lastly, the public prosecutor has to define, as precisely as possible, the group of persons that needs to be subject to the exploratory inquiry.

\section{Article 126II OF THE DCCP}

Article 126ii of the DCCP authorises the public prosecutor to request identifying information from private or public persons/(telecommunication) companies during an exploratory inquiry into terrorist offences. ${ }^{616}$ Identifying information concerns a person's name, address, place of residence, date of birth, sex, phone number(s), and/ or administrative characteristics. Administrative characteristics may include customer numbers, bank account numbers, or a membership number available to the relevant person or organisations and to telecommunication providers. ${ }^{617}$ The requested information must, of course, be relevant to further gain insight into the terrorist offences that are potentially being jointly plotted or committed. Unlike Article $126 \mathrm{hh}$ of the DCCP, the public prosecutor does not need the prior approval of an investigative judge to request identifying information.

It is important to note that, again, the identifying information pursuant to Article 126ii of the DCCP, is not yet available to the investigative authorities, or publicly accessible. The information is used to discover the identity of the persons subject to the exploratory inquiry, to map out the connections among these persons, and to connect them to certain situations. So, Article 126ii of the DCCP serves to clarify the object of the exploratory inquiry into terrorist offences. It sounds paradoxical, that when an exploratory inquiry is initiated, the public prosecutor does not need to know precisely who will be the subject of the inquiry.

615 Staatscourant 2000, 25 and Staatscourant 2004, 227.

616 See, also, Article 126zk of the DCCP which includes a power to request identifying information during a criminal investigation with respect to a specific terrorist offence.

617 See, Article 126ii, section 1 and 2 of the DCCP. 
The explanatory memorandum asserts that requesting identifying information constitutes a minor interference with the right to privacy. Also, the government has argued that the prevention of terrorism currently demands that this information, which is said to be very useful, should be accessible to the investigative authorities during an exploratory inquiry. ${ }^{618}$ Why the prior approval of an investigative judge, as with respect to Article $126 \mathrm{hh}$ of the DCCP, is not required when it concerns identifying information, remains unclear. As indicated above, this is most likely inspired by the fact that identifying information is considered to be less 'sensitive' in terms of respect for the right to privacy. ${ }^{619}$ Also, indentifying information is a more confined category of information than the data files, as mentioned in Article $126 \mathrm{hh}$ of the DCCP.

\section{SPECIAL INVESTIGATION TEChNiQUeS}

\section{INTRODUCTION}

Articles 126za to 126zq of the DCCP (Title VB) comprise the special investigation techniques to investigate terrorist offences. These techniques correspond, as regards content and scope, to the special investigation techniques used to investigate common offences, pursuant to Articles $126 \mathrm{~g}$ to $126 \mathrm{z}$ of the DCCP. ${ }^{620}$ This implies that the DCCP currently contains two sets of exactly the same special investigation techniques, one to investigate terrorist offences, and one to investigate common (severe) offences. The only difference is, as discussed in section 2 , the suspicion criterion. Investigations into terrorist offences require indications of a terrorist offence, whereas investigations into common offences still demand a reasonable suspicion.

To get a comprehensive picture of the scope of the available special investigation techniques to investigate terrorist offences, this section discusses Articles 126za to 126zq of the DCCP (Title VB). ${ }^{621}$ Each of the coming Sections scrutinises one

618 Kamerstukken II 2004-2005, 30 164, no. 3, p. 19.

619 Rapport van de Commissie Strafvorderlijke gegevensvergaring in de informatiemaatschappij, Gegevensvergaring in strafvordering: nieuwe bevoegdheden tot het vorderen van gegevens ten behoeve van strafvorderlijk onderzoek, mei 2001, pp. 85-86.

620 Titles IVA and V of the DCCP entail one provision for each respective special investigative technique. This way of incorporation produces a Title full of repetitions and references because many criteria for application are the same for each technique. In Title VB and VC however, the government has chosen a different method of incorporation. First, there are three provisions (126za, 126zb and 126zc of the DCCP) comprising general provisions applicable to Title VB. Then there is one provision that includes special investigation techniques which are all conditioned by the same criteria for application. The remaining provisions include other powers that are governed by (slightly) different criteria for application.

621 Title VC - regarding assistance by civilians to criminal investigations into terrorism - will not be discussed. 
division of Title VB. Firstly, the general provisions applicable to all of the special investigation techniques are briefly described in Section 5.1. Then, the following special investigation techniques will be discussed in Section 5.2: systematic observation, pseudo-purchase or -services, systematic gathering of information, powers to enter enclosed places, and infiltration. Section 5.3 then continues with the power to record confidential (tele)communications with a technical device. ${ }^{622}$ Lastly, Section 5.4 considers the power to request data during an investigation into terrorist offences.

\subsection{General provisions}

The first three provisions of Title VB, Articles 126za, 126zb and 126zc of the DCCP, comprise general rules that apply to all of the investigation techniques and powers comprised in Titles VB and VC, respectively. ${ }^{623}$ Additional specific criteria for application are enacted in the provisions that enclose the various special investigation techniques and powers.

Articles 126za and $126 \mathrm{zb}$ of the DCCP include regulations concerning orders of the public prosecutor and regarding authorisations of the investigative judge. These regulations are, with regard to content, comparable to the formal requirements comprised in the provisions of Titles IVA and V of the DCCP. The basic principle, as set out in Articles 126za and 126zb of the DCCP is that an order for the application of a special investigation technique and an authorisation from the investigative judge, if necessary, must be put in writing. Any modification, filling up, extension or withdrawal ${ }^{624}$ of such an order/authorisation has to be put in writing as well. Nevertheless, a verbal order that is, forthwith, put in writing, is equal to a written order and is thus, also adequate. ${ }^{625}$ One exception to these rules regards the application of preventive investigative powers comprised in division 4 of Title VB: the public prosecutor's order to preventively search persons and investigate objects or means of transport may be given verbally, and needs only to be laid down in a procès-verbal afterwards. ${ }^{626}$

622 The powers comprised in division 4 of Title VB will be discussed separately because these powers may only be applied within (temporary or permanent) security risk areas. The scope of the notion of security risk areas needs extra clarification. Furthermore, these powers are relatively new in the DCCP, whereas the powers comprised in divisions 1, 2 and 3 and Title VC correspond to the powers in Titles IVA and V of the DCCP.

See losbladige Melai \& Groenhuijsen e.a., Wetboek van strafvordering, titels IVA-VC Bijzondere bevoegdheden tot opsporing.

624 See Article 126za, section 5 of the DCCP which prescribes that any order for the application of special investigation techniques relating to criminal investigations into terrorist offences may be modified, supplemented, extended or withdrawn.

625 Articles 126za and 126zb, section 1 of the DCCP.

626 Article 126za, section 1 and 3 of the DCCP in conjunction with Article 126zk, section 3 of the DCCP. Article 152 of the DCCP prescribes that recording in a procès-verbal must take place at the earliest convenience. Furthermore, such a procès-verbal may include - if possible - 
Generally, an order for the application of a special investigation technique includes: (1) the terrorist offence, and (2) the facts and/or circumstances demonstrating that the criteria for application have been fulfilled. Furthermore, the order may state the way in which the special investigation technique is to be enforced. ${ }^{627}$ Further rules regarding the information that is to be comprised in a verbal or written order are to be enacted in a ministerial decree. ${ }^{628}$

Article $126 \mathrm{zc}$ of the DCCP prescribes that, by royal decree, persons in the public service of a foreign state may be placed on the same footing as Dutch investigative officers for the application of Articles 126zd, $1^{\text {st }}$ section under a, b and $\mathrm{c}$ and Article 126ze of the DCCP. Persons in the public service of a foreign state accordingly acquire the same status as Dutch investigative officers. This serves to investigate cross-border terrorist activities. At this point I will not go into further detail of Article 126zc of the DCCP.

\subsection{Systematic surveillance, pseudo purchases and the provision of services, undercover systematic gathering of information, powers to enter enclosed places, and infiltration}

The second division of Title VB consists of two Articles: 126zd and 126ze of the DCCP. Firstly, Article 126zd of the DCCP codifies four special investigation techniques: (a) systematic surveillance, (b) pseudo purchases and the provision of services, (c) undercover systematic gathering of information, and (d) powers to enter enclosed places. The principal criteria for the application are the same for the four techniques - i.e. there must be indications of a terrorist offence and the application of the techniques must serve the interest of the investigation. Quite contrary to Title $\mathrm{IV}$, the legislature has listed these techniques all in one provision, instead of drafting, for each technique, a separate provision. Then secondly, Article 126ze of the DCCP provides a legal basis for infiltration.

With respect to all of the special investigation techniques in Articles 126zd and 126ze of the DCCP, the public prosecutor is the competent authority to authorise criminal investigators to apply such techniques. An order for the application of these techniques is valid for a period not exceeding three months and may be extended, on each occasion, for a further three months. ${ }^{629}$

information concerning de way in which the relevant investigation techniques have been applied, the moment at which the verbal order was given and the period of validity. See, on this issue, A.A. Franken, 'Regels voor het strafdossier', in Delikt en Delinkwent 2010, 24.

629 See Article 126zd, section 5 of the DCCP. 


\section{Systematic SURVEILLANCE}

Article 126zd, section 1(a) of the DCCP includes a power to follow a person or to observe his presence or behaviour on a systematic basis. ${ }^{630}$ Systematic surveillance serves to get a more or less complete picture of (a) certain aspect(s) of a person's life, like his pattern of spending or his connections with criminals. ${ }^{631}$ Surveillance in accordance with Article 126zd of the DCCP, is to contribute to mapping out the involvement of person(s) in the plotting or actual committing of alleged terrorist offences. For instance, when the public prosecutor receives 'indications' about the potential 'awakening' of a 'sleeping terrorist cell', meaning that preparations may be about to be taken to commit a terrorist attack, he is allowed to order systematic surveillance.

Persons who, on the basis of the aforesaid indications, might be connected to this terrorist cell, can be put under surveillance at the earliest stage possible. ${ }^{632}$ Thus, Article 126zd, section 1(a) of the DCCD authorises investigating officers to observe the behaviour of every potential member of this 'awakening terrorist cell', acquaintances of such alleged members, or other persons important to the investigation, provided that it is in the interest of the investigation. Accordingly, the main goal of systematic surveillance is to discover who may be, and who is not, connected to the perpetration (in the broad sense of the word) of potential terrorist offences.

\section{PSEUdO PURCHASES AND THE PROVISION OF SERVICES}

Article 126zd, section 1(b) of the DCCP contains a power to: (1) buy goods from, or to provide services to, a person; or (2) to purchase information that has been computerised stored, processed or transferred through a public telecommunication network from a person. ${ }^{633}$ The explanatory memorandum gives two examples of how this special investigation technique is to contribute to investigations into terrorist offences. Firstly, services may be provided to persons active in the field of

630 Compare with Article 126g and Article 126o of the DCCP. See Kamerstukken II 1996-1997, 25 403 , no. 3, pp. 26-28 and 70-73. See, also, Chapter 4 regarding personal disturbance and the comparison of personal disturbance with systematic surveillance pursuant to Article $126 \mathrm{~g}$ and Article 1260 of the DCCP. See, also, Melai \& Groenhuijsen e.a., Wetboek van strafvordering, titels IVA-VC Bijzondere bevoegdheden tot opsporing, artikel 126g (bewerkt door Prof. mr. Y. Buruma), no. 3 and 5.

631 See Y. Buruma, 'Stelselmatig - een sleutelbegrip in de Wet Bijzondere Opsporingsmethoden', in NJCM-Bulletin 2000, pp. 649-658.

632 Kamerstukken II 2004-2005, 30 164, no. 3, p. 38.

633 Compare with Article 126i and Article 126q of the DCCP. Note that these two provisions relate to 'a suspect' instead of to 'a person' as is the case with respect to Article 126zd of the DCCP. See, Kamerstukken II 1996-1997, 25 403, no. 3, pp. 33, 66-77, 119-120. See, also, Melai \& Groenhuijsen e.a., Wetboek van strafvordering, titels IVA-VC Bijzondere bevoegdheden tot opsporing, artikel 126i (Bewerkt door Prof. Mr. Y. Buruma and mr. L.J. Verborg), no. 2, 3, 6, 7 , 8,9 . 
weapons and ammunition trafficking, or weapons may be purchased from such persons. This serves to enable the investigative authorities to trace persons who might be involved in the planning or the preparation of a terrorist attack. Secondly, the investigative authorities are also allowed to provide services to a group of persons allegedly involved in the plotting of a terrorist attack, like offering them a language teacher or an accommodation for rent.

\section{UNDERCOVER SYSTEMATIC GATHERING OF INFORMATION}

Pursuant to Article 126zd, section 1(c) of the DCCP, systematically gathering information on a person without it being known that he is acting in the capacity of investigating officer is allowed. ${ }^{634}$ For instance, an investigative officer is allowed to mingle with a person who may be involved in terrorist activities, or who is acquainted with someone who is involved in such activities. To that end, the officer must actively try to get as close as possible to the person(s) concerned to acquire information about that person(s) and/or his/their surroundings.

This may imply that investigative officers participate in internet chat-rooms that are visited by persons who support radical Islamic ideas. Also, participating in the same political or religious organisation or frequenting the same restaurants or cafés as persons allegedly involved in the plotting of terrorist offences, is possible under Article 126zd, section 1(c) of the DCCP. ${ }^{635}$

\section{POWERS TO ENTER ENCLOSED PLACES}

Article 126zd, section 1 under d of the DCCP lists a power to enter an enclosed place, ${ }^{636}$ not being a dwelling, or to use a technical device to observe such a place, without the permission of the title holder, in order to:

(1) examine the place in question;

(2) secure evidence found there; or

(3) place a technical device (like a transmitter) with a view to establishing the presence or transport of a particular object. ${ }^{637}$

634 Compare with Article 126j and Article 126qa of the DCCP. See, Kamerstukken II 1996-1997, 25 40, no. 3, pp. 22, 29, 34-35, 77-78, 119-120. See, also, Melai \& Groenhuijsen e.a., Wetboek van strafvordering, titels IVA-VC Bijzondere bevoegdheden tot opsporing, artikel 126j (Bewerkt door Prof. Mr. Y. Buruma and mr. L.J. Verborg), no. 3, 4, 5, 8.

635 Compare with Article 126k and Article 126r of the DCCP. See, Kamerstukken II 2004-2005, 30 164 , no. 3 , p. 38 .

636 To enter an enclosed place, the investigative authorities need prior authorisation of the public prosecutor, see Article 126zd, section 3 of the DCCP. A dwelling may never be entered without permission of the rightful claimant.

637 See Kamerstukken II 1996-1997, 25 403, no. 3, pp. 23, 40-44, 77-78, 112-113. 
Places that may be entered are, for instance, sheds, hangars, or company premises. They must always be places of which it is 'by no means illusory that they might be used to plot or prepare terrorist offences'. ${ }^{638}$ This special investigation technique enables the authorities to ascertain whether objects that might point at the plotting or preparation of a terrorist offence, are present in certain places. It may concern objects of which the possession is prohibited, like explosives, weapons or ammunition, but it may also concern quite 'innocent' objects like diving equipment or a private plane.

It is important to see that these four special investigation techniques can be applied to any person who is considered to be potentially linked to the indications of a terrorist offence. The interest of the investigation determines, primarily, who should be subject to these techniques, rather than the indications that are merely the cause for applying the techniques. Hence, persons on whom these techniques can be applied must just, one way or another, be linkable to the 'indications', otherwise it cannot be considered in the interest of the investigation to apply the material investigation technique.

The broadness of the notion of 'indications of a terrorist offence', extends the scope of application of the special investigation techniques considerably. While most $^{639}$ of the equivalent powers in Title IVA and V of the DCCP can still only be applied to persons directly suspected of involvement in the plotting or committing of criminal offences (in an organised context), that limitation does not apply to any of the investigation techniques within the framework of Title VB of the DCCP. Even if powers comprised in Title IVA or V are not limited to application of suspects, there still needs to be a reasonable suspicion of a specific (severe) criminal offence, instead of merely indications of a terrorist offence.

\section{INFILTRATION}

In accordance with Article 126ze of the DCCP the public prosecutor may, if this is urgently required in the interests of the investigation, order an investigative officer $^{640}$ to join or assist a group of persons, in respect of which there are

See Article 126zd, section 4 of the DCCP, which further prescribes that the technical equipment may not be used to record private communication or be attached on a person without that person's approval.

639 Articles 126g, 1261, 126m, 126n, 126na, 126nc, 126nd, 126nf, 126ni, 126o, 126t, 126u, 126ua, 126uc, 126ud, 126ue, 126uf, 126ug, 126uh, 126ui of the DCCP are not limited to application on a suspect. However, most of these provisions provide for powers to demand information from (telecommunication) organisations, so the powers are not directed at potential suspects. discern between different sorts of criminal investigators. Any criminal investigator pursuant to Articles 140 and 141 of the DCCP is empowered to infiltrate pursuant to Article 126ze of the DCCP. 
indications that within that group a terrorist offence is being plotted or committed. ${ }^{641}$ The plotting or perpetration of one terrorist offence is sufficient for an infiltration order.

Infiltration is enclosed in a separate provision because of its (partly) distinguishing prerequisites. First of all, the provision does not entail a statutory maximum period of validity. ${ }^{642}$ Secondly, Article $126 z$ of the DCCP contains more demanding criteria of application than the ones listed in Article 126zd of the DCCP. ${ }^{643}$ The public prosecutor must, for instance, demonstrate that the infiltration order is urgently required in the interest of the investigation. ${ }^{644}$ This prerequisite obliges the public prosecutor to strictly comply with the principles of subsidiarity and proportionality. Theoretically, these principles oblige the prosecutor to ascertain that there is no other, less intruding, investigation technique available to reach the same goal. However, in practice, the severity of the criminal offence is more decisive. Also, case law shows that the Judiciary pays more attention to the proportionality principle than to the subsidiarity principle. ${ }^{645}$

An infiltration order must pursuant to Article 126ze, section 2 of the DCCP, include three aspects. ${ }^{646}$ Firstly, a description of the group of persons into which the investigative officer is to infiltrate. Secondly, the facts or circumstances demonstrating that the conditions set out in section 1 have been fulfilled. ${ }^{647}$ Thirdly, the way in which the order is to be executed including any activities that constitute an offence, in so far as this is possible to foresee at the time the order is issued. And fourthly, the order must include the period for which the infiltration order is valid.

With respect to the first requirement (a description of the group of persons) it is important to note that the notion of 'group' does not presuppose that the prerequisites pursuant to Articles 140 and 140a of the DCC, need to be complied with. A group of persons, as referred to in Article 126ze of the DCCP, includes not only wellstructured terrorist organisations, but also mere fluid webs, which, with regard to their compilation and structure, do not have any continuity.

\footnotetext{
641 See Melai \& Groenhuijsen e.a., Wetboek van strafvordering, titels IVA-VC Bijzondere bevoegdheden tot opsporing, artikel 126h (bewerkt door Prof. mr. Y. Buruma), no. 3 and 4.

642 The fact that an order for infiltration does not need to indicate the duration thereof explains why this special investigative technique is laid down in a separate provision, instead of it being included in Article 126zd of the DCCP, which lists investigative techniques that are bound by a three-month limit.

643 Kamerstukken II 2004-2005, 30 164, no. 3, p. 40; Kamerstukken II 1996-1997, 25 403, no. 3, pp. 21-23, 28-33, 73-76 and 119 .

644 Article 126ze, section 1 of the DCCP.

645 Melai \& Groenhuijsen e.a., Wetboek van strafvordering, titels IVA-VC Bijzondere bevoegdheden tot opsporing, artikel 126g-126gg (Bewerkt door Prof. Mr. Y. Buruma), no. 12.

646 Article 126ze, section 3 of the DCCP.

647 Article $126 \mathrm{za}$ of the DCCP.
} 
The investigative officer who actually infiltrates a 'terrorist group', acts under alias. He participates in the activities of the group and lends assistance (from outside) to the group. This working method implies that an infiltration order automatically includes an order for pseudo purchase and/or the provision of services. ${ }^{648}$ An infiltration order must, furthermore, indicate as far as possible, which offences the investigative officer will most likely have to commit in order to gain credit within the terrorist group. ${ }^{649}$ In this respect, section 2 of Article 126ze of the DCCP must be underlined, which comprises of a prohibition of entrapment. ${ }^{650}$ This prohibition also applies in the case of the special investigation techniques, as listed in Article $126 z d$ of the DCCP. ${ }^{651}$

\subsection{Recording of confidential communication}

Division 3 of Title VB of the DCCP includes provisions regarding the recording of confidential (tele)communications. The special investigation techniques comprised in Articles 126zf to 126zj of the DCCP differ from the above-discussed techniques in that the public prosecutor needs prior authorisation from an investigative judge to apply these techniques - with the exception of Articles 126zh and 126zj of the DCCP. As interception of private communication leads to considerable interferences with the right to privacy, judicial control effected by a higher authority than a public prosecutor, is required.

Division 3 consists of 6 provisions that basically provide for three special investigation techniques. Firstly, Articles 126zf, 126zg and $126 \mathrm{ga}^{652}$ of the DCCP include powers to record private communication and telecommunication, ${ }^{653}$ respectively by means of technical devices. Secondly, Articles 126zh and 126zi of the DCCP entail a power for the public prosecutor to demand identifying information or the disclosure of information regarding all traffic of a telecom user via telecommunications infrastructure or via the telecommunications installation that provides a service to the public. Thirdly and last, Article 126zj of the DCCP includes a power to take identifying information off the ether through scan equipment.

648

649

This is also the case with respect to Article $126 \mathrm{~h}$ of the DCCP.

Kamerstukken II 2004-2005, 30 164, no. 3, p. 41.

Melai \& Groenhuijsen e.a., Wetboek van strafvordering, titels IVA-VC Bijzondere bevoegdheden tot opsporing, artikel 126h (Bewerkt door Prof. Mr. Y. Buruma), no. 9.

Article 126zd, section 2 of the DCCP.

Compare with Articles 1261, 126m, 126ma, 126s, 126t and 126ta of the DCCP. Kamerstukken II 1996-1997, 25 403, no. 3, pp. 22-24, 35-39, 51, 63, 71, 78-80, 93-94, 109 and 120.

See, for a definition of 'telecommunication', Article $126 \mathrm{~m}$, section 2 of the DCCP: 'telecommunication' means communication not intended for the public which takes place via the telecommunications infrastructure or via a telecommunications installation which provides a service to the public. 
Article 126zf of the DCCP contains a power to record private communications involving any person, by means of a technical device, ${ }^{654}$ provided that the interest of the investigation urgently demands so. As mentioned above, the public prosecutor must obtain prior authorisation from the investigative judge. ${ }^{655}$ To adequately prevent terrorist offences, the government deems it necessary that when there is any information relating to the plotting or preparation of a terrorist offence, the investigative authorities should be able to record it. ${ }^{656}$ Basically anyone's private communication may be recorded as long as the interest of the investigation urgently demands so. Again, the interest of the investigation, rather than the indications, determines whose private communication is to be recorded. The order for the recording of private telecommunication must include ${ }^{657}$ :

(1) the name of at least one of the persons taking part in the communication, or, if the order relates to communication taking place in an enclosed place or vehicle, the name of one of the persons taking part in the communication or as accurate as possible a description of the place or the vehicle; ${ }^{658}$

(2) the place to be entered (if section 2 is applied);

(3) the period for which the order is valid. ${ }^{659}$

In accordance with Article 126zf, section 2 of the DCCP, the public prosecutor may decide that an enclosed place, not being a dwelling, shall be entered, without the permission of the title-holder, in order to carry out the order. It must be in the interest of the investigation, and the public prosecutor can even order a dwelling to be entered, without the permission of the title-holder, if the investigation urgently so requires. However, to enter a dwelling the public prosecutor needs to obtain prior explicit authorisation from an investigative judge.

Article 126zg of the DCCP includes a power to record telecommunication by means of a technical device. As with respect to Article 126zf of the DCCP, the order must be urgently required in the interest of the investigation and the public prosecutor must obtain prior authorisation from an investigative judge. ${ }^{660}$ If the order relates to

654 These devices may be bugs, microphones and suchlike equipment.

655 The notion of 'recording' in these two provisions includes a power for the investigative authorities to concurrently listen in on the intercepted (tele-)communication when this is, technically speaking, feasible.

656 Kamerstukken II 2004-2005, 30 164, no. 3, p. 41.

657 The order must also include the aspects mentioned in Article 126za of the DCCP (general considerations).

658 Article 126zf, section 3 of the DCCP.

659 Article 126zf, section, 2 and 3 of the DCCP.

660 Article 126zg, section, 1 and 5 in conjunction with Article 126m, section 5 of the DCCP. 
telecommunication taking place through public telecommunication services, the public prosecutor will request the provider to render assistance. ${ }^{661}$

An order to record telecommunication must include:

(1) the number or another indication by means of which the individual user of the communication service is identified;

(2) if known, the name and address of the user of the communication service;

(3) an indication of the nature of the technical device used to record telecommunication. 662

The order for application of each of these two special investigation techniques may be given for a period not exceeding four weeks and may be extended, on each occasion, for a further four weeks. ${ }^{663}$ Furthermore, with respect to both powers, a procès-verbal must be drawn up within three days after having recorded the private (tele)communication. ${ }^{664}$

Article 126zf of the DCCP is considered as more far-reaching measure than Article 126zg of the DCCP. Article 126zg of the DCCP makes it possible to record any form of private communication, while Article 126zf of the DCCP merely allows for recording of telecommunication. Therefore, and in light of the principles of proportionality and subsidiarity, the investigative authorities are obliged to make use of the latter Article, as far as possible, before applying the first.

Demanding information Relating to telecommunication, Articles 126zh and 126zi of the DCCP

Article 126zh of the $\mathrm{DCCP}^{665}$ allows the public prosecutor to demand disclosure of information concerning a user of telecommunication services ${ }^{666}$ and all traffic via the telecommunications infrastructure or via a telecommunications installation that provides a service to the public, relating to that user. It may only concern information that has been appointed beforehand by a royal decree. Furthermore, the prosecutor may demand information that has been processed at the time the order is lodged, or

661 Article 126zg, section 3 of the DCCP.

662 Article 126zg, section, 2 of the DCCP.

663 Article 126zf, section 4 of the DCCP and Article 126zg, section 5 of the DCCP.

664 Article 126zf, section 4 and 5 of the DCCP and Article 126zg, section 5 of the DCCP in conjunction with Article 126m, section 4 of the DCCP and Article 1261, section 8 of the DCCP.

665 Compare with Article 126n, Article 126na and Article 126nb of the DCCP. See in this respect also Staatsblad 2004, 105

666 A 'user of telecommunication' is denoted in Article 126n, section 2 of the DCCP, as a person or company who enters into agreement with a telecommunication-provider relating to the usage of a public telecommunication-web or the supply of public telecommunication services as well as the person or company that actually uses a public communication-web or a public communication-service. 
information that will be processed afterwards. ${ }^{667}$ An order pursuant to Article 126zh of the DCCP, can be given for a period not exceeding three months and may be extended, on each occasion, for a further three months. ${ }^{668}$ The order must be recorded in a procès-verbal that states:

(1) the terrorist offence and, if known, the names, or otherwise as specific possible an indication, of the user(s) of the telecommunication services;

(2) facts or circumstances demonstrating that the conditions set out in the first section have been fulfilled;

(3) the information that has been demanded. ${ }^{669}$

Article 126zi of the DCCP empowers investigative officers to demand the personal details of users of telecommunication services, such as their name, address, post-box number, place of residence, telephone number and the kind of telecommunication service that is used ${ }^{670}$ In case this information is not available to the telecommunication provider, while it is needed for the application of Article 126zf or Article 126zg of the DCCP, the public prosecutor may order the provider to retrieve the impugned information and to supply it to the investigative authorities. ${ }^{671}$ The way in which the provider is to retrieve the requested information is determined by a royal decree. ${ }^{672}$

TAKING IDENTIFYING INFORMATION OFF THE ETHER ${ }^{673}$

Article 126zj of the DCCP empowers the public prosecutor to order the deployment of scanning equipment in order to take identifying information ${ }^{674}$ off the ether. This special investigation technique serves to retrieve the (telephone) number by means of which the user of a telecommunication service can then be identified. On the basis of that information, the prosecutor is able to apply Articles 126zg and/or 126zh of the DCCP. Even more, Article 126zj of the DCCP may only be used to enable the prosecutor to use the special investigation techniques, pursuant to Articles 126zg and/ or 126zh of the DCCP. The order is valid for a period of one week and it must include:

(1) The facts or circumstances demonstrating that the criteria for the application of Articles 126zg and 126zh of the DCCP have been complied with;

\footnotetext{
667 See Article 126zh, section 1 under a and b of the DCCP.

668 See Article 126zi, section 2 of the DCCP, in conjunction with, Article 126n, section 4 of the DCCP.

669 See Article 126zh, section 2 of the DCCP and Article 126n, section 2 to 6 of the DCCP. These prerequisites also apply to an order pursuant to Article 126zi of the DCCP.

670 Article 126zi, section 1 of the DCCP.

671 Article 126zi, section 2 of the DCCP.

672 Article 126zi, section 2 of the DCCP.

673 Compare with Article 126nb and Article 126ub of the DCCP.

674 'Identifying information' within this context means the phone number with which the user of telecommunication can be identified. See Article 126nb, section 1 of the DCCP.
} 
(2) As accurate as possible a description of the person(s) who use(s) the telecommunication service, i.e. the person(s) whose telephone number is to be obtained. ${ }^{675}$

Lastly, Article 126zja ${ }^{676}$ of the DCCP includes a power for the public prosecutor to order a telecommunication provider to save, and keep available, certain automated and specified data for a period of 90 days, provided that the interest of the investigation urgently demands so. The order can exclusively concern well-specified data that is already available to the telecommunication provider at the moment that the prosecutor files the order. This so-called 'freezing of data' serves to prevent that data that might contribute to criminal investigations is no longer available because it has become irrelevant for the operational management of the telecommunication provider. The order is valid for 90 days and may be extended once for another 90 days. It must include:

(1) as accurate as possible a description of the data that must be kept available;

(2) the time at which the order is filed;

(3) the title of the order;

(4) the period during which the data must be kept available. ${ }^{677}$

\subsection{Requisition of data 678}

Division 3A of Title VB includes powers for the investigative officers and the public prosecutor to demand data from private and public organisations/companies/ persons. It may concern four types of information: (1) identifying information (Article 126zk of the DCCP), (2) other information (Article 126zl of the DCCP), (3) future information (Article 126zm of the DCCP) or (4) sensitive information (Article $126 \mathrm{zn}$ of the DCCP). In addition, this division authorises the public prosecutor to demand that data which has been encrypted, is 'de-encrypted' pursuant to Article 126zp of the DCCP.

675 Article 126zj of the DCCP and Article 126nb, section 3 of the DCCP.

676 See, also, Article 126ni and Article 126ui of the DCCP.

677 Article 126ni, section 3 of the DCCP. Article 126ni, section 4 of the DCCP prescribes which information must be comprised in the procès-verbal that includes the order.

678 The parliamentary memoranda do not elaborate broadly on the question of what the notion of information/data [gegevens] stands for. The explanatory memorandum only states that information/data includes information that has been recorded or stored on a data carrier, in writing or electronically. See also Melai \& Groenhuijsen e.a., Wetboek van strafvordering, titels IVA-VC Bijzondere bevoegdheden tot opsporing, artikel 126nc (Bewerkt door mr. E.C. Mac Gillavry), no. 5. 
Pursuant to Article $126 \mathrm{zk}^{679}$ of the DCCP investigative officers are authorised to demand, from someone who processes information for other purposes than his own, ${ }^{680}$ certain indentifying information about a person that has been stored or recorded ${ }^{681}$ Identifying information includes as person's name, address, place of residence, date of birth, sex, and administrative characteristics. ${ }^{62}$ The investigative officer is not allowed to demand information regarding a person's religion, philosophy of life, race, political persuasion, health, sexual orientation, or membership of a labour union. ${ }^{683}$

This power enables the investigative officer to discover the identity of persons who are subject of a criminal investigation into terrorist offences. Also, the connection between that person and the party who provides the identifying information can be ascertained. The order to request identifying information includes:

(1) an indication of the person whose identifying information is demanded;

(2) the identifying information that is requested;

(3) the term for providing the requested information;

(4) the title for the order. ${ }^{684}$

The procès-verbal following the order must, furthermore, state, in addition to the above four aspects, what information has been provided, the offence it concerns, and the facts and circumstances demonstrating that the conditions, as included in the first section, have been fulfilled. ${ }^{685}$

679 Compare with Article 126nc and Article 126uc of the DCCP. See, Melai \& Groenhuijsen e.a., Wetboek van strafvordering, titels IVA-VC Bijzondere bevoegdheden tot opsporing, artikel 126nc (Bewerkt door mr. E.C. Mac Gillavry), no. 2-27.

680 Kamerstukken II 2003-2004, 29 441, no. 3, p 7-8.

681 The information - as far as it concerns other information than the information that can be requested pursuant to Article 126zh and 126zi of the DCCP - can also be requested from a communication provider as defined in Article 126la of the DCCP. See Article 126zo of the DCCP.

682 Article 126zk, section 2 and Article 126nc, section 2 of the DCCP. Kamerstukken II 2003-2004, 29 441, no. 3, p. 7.

683 Article 126zk, section 2 and Article 126nc, section 3 of the DCCP.

684 Article 126zk, section 2 and Article 126nc, section 4 of the DCCP.

685 Article 126zk, section 2 and Article 126nc, section 6 of the DCCP. 


\section{REQUISITION OF OTHER INFORMATION}

Article $126 \mathrm{zl}^{686}$ of the DCCP comprises a power for the public prosecutor ${ }^{687}$ to demand certain information that has been stored or recorded from someone who supposedly has access to such information. Hence, information may also be requested from parties who process information for their own purpose. This provision includes a power to demand other information than identifying information. It may concern information regarding services that have been provided like the duration, the dates, the place and the nature of the services as well as account- and payment information. ${ }^{688}$ Again, it is not permitted to demand information regarding a person's religion, philosophy of life, race, political persuasion, health, sexual orientation, or membership of a labour union. ${ }^{689}$ Formal criteria for the order are the same as the ones applicable regarding Article 126zk of the DCCP. ${ }^{690}$ The procès-verbal contains one additional requirement, however: the public prosecutor must state why he considers the information that he demands to be in the interest of the investigation. ${ }^{691}$

\section{REQUISITION OF FUTURE INFORMATION}

Article $126 \mathrm{zm}^{692}$ of the DCCP authorises the public prosecutor to determine that the order made pursuant to Article 126zl of the DCCP may concern information that is only processed after the order has been filed (future information). Processed in this context means any action that has been performed on the information after the creation of the information, like receiving it, storing it, recording it, destroying it, processing it or distributing it. The order may be directed at a party who processes information in respect of a certain function or in the execution of one's professional duties, like governmental institutions, societies, professional service providers and institutions that provide services relating to culture, sports etc. ${ }^{693}$ on a commercial

686 Compare with Article 126nd and Article 126ud of the DCCP. See, Melai \& Groenhuijsen e.a., Wetboek van strafvordering, titels IVA-VC Bijzondere bevoegdheden tot opsporing, artikel 126nd (Bewerkt door mr. E.C. Mac Gillavry), no. 2-13.

687 Compare to Article 126zk of the DCCP, this provision contains a power that infringes, to a more far-reaching extent, on the right to privacy. That explains why the public prosecutor is the competent authority.

See, Kamerstukken II 2003-2004, 29 441, no. 3, pp. 8-9.

689 Article 126zl, section 2 and Article 126nd, section 2 of the DCCP.

690 Article 126zl, section 2 and Article 126nd, section 3 of the DCCP.

691 Article 126zl, section 2 and Article 126nd, section 5 under e of the DCCP.

692 Compare with Article 126ne and Article 126ue of the DCCP. See Melai \& Groenhuijsen e.a., Wetboek van strafvordering, titels IVA-VC Bijzondere bevoegdheden tot opsporing, artikel 126ne (Bewerkt door mr. E.C. Mac Gillavry), no. 2-12. In Melai it is argued that this power primarily serves to make it unnecessary for the public prosecutor to repeatedly lodge an order for the requisition of future information.

693 The information - as far as it concerns other information than the information that can be requested pursuant to Article 126zh and 126zi - can also be requested from a communication provider as defined in Article 126la of the DCCP. See Article 126zo of the DCCP. 
or non-profit basis. This special investigation technique is, for instance, used to monitor money transfers. The order is valid for four weeks and may be extended, on each occasion, with four weeks. If the public prosecutor wants to receive the information immediately after it has been processed, he needs prior authorisation from an investigative judge. ${ }^{694}$ The formal requirements relating to the order and the procès-verbal are the same as the ones applicable in case of an order pursuant to Article $126 \mathrm{zl}$ of the DCCP. ${ }^{695}$

\section{REQUISITION OF SENSITIVE INFORMATION}

The public prosecutor may, furthermore, demand so-called 'sensitive information' about a person if the interest of the investigation urgently demands so pursuant to Article $126 \mathrm{zn}^{696}$ of the DCCP. Sensitive information means information concerning a person's religion, philosophy of life, race, political persuasion, health, sexual orientation, or membership of a trades union. ${ }^{697}$ The prosecutor demands this information from any third party who can reasonably be suspected to have access to such information. Due to the nature of the information that can be requested and the far-reaching interference it induces on the right to privacy, the public prosecutor needs a written prior authorisation from an investigative judge. ${ }^{698}$ The formal requirements concerning the procès-verbal and the order are the same as the one prescribed in Article 126zl of the DCCP.

\section{DE-ENCRYPTING INFORMATION}

If the information that has been requested pursuant to Articles 126zl, 126zm or $126 \mathrm{zn}$ of the DCCP, is encrypted, the public prosecutor is authorised to order a third party to assist in the de-encrypting of the relevant information pursuant to Article $126 \mathrm{zp}^{699}$ of the DCCP. Anyone - except for the person on whom information is gathered - who can reasonably be suspected to have knowledge of how to de-encrypt of the relevant information may be ordered to lend assistance. That assistance may imply that the third party is to de-encrypt the information or that the relevant knowledge is to be put at the public prosecutor's disposal.

\footnotetext{
694 Article $126 \mathrm{zm}$, section 3 of the DCCP.

695 Articless 126zm, section 1 and 126nd sections 3 and 5 of the DCCP.

696 Compare with Article 126nf and Article 126uf of the DCCP. See Melai \& Groenhuijsen e.a., Wetboek van strafvordering, titels IVA-VC Bijzondere bevoegdheden tot opsporing, artikel 126nf (Bewerkt door mr. E.C. Mac Gillavry), no. 2-10.

697 See Article 16 of the Act on the Protection of Personal Details [Wet bescherming persoonsgegevens].

698 See Article 126zn, section 2 of the DCCP in conjunction with Article 126nf, section 3 of the DCCP.

699 Compare with Article 126nh and Article 126uh of the DCCP. See Melai \& Groenhuijsen e.a., Wetboek van strafvordering, titels IVA-VC Bijzondere bevoegdheden tot opsporing, artikel 126nh (Bewerkt door mr. E.C. Mac Gillavry), no. 2-4.
} 


\section{INVESTIGATIVE POWERS IN SECURITY RISK AREAS}

\section{INTRODUCTION}

The fourth division of Title VB consisting of Articles 126zq, 126zr and 126zs of the DCCP, includes a power to order so-called security risk areas [veiligheidsrisicogebied], and a power for investigative officers to search persons and to investigate means of transport and objects within so-called (permanent or temporary) security risk areas. These investigative powers have a different character than the above-discussed special investigation techniques.

To start with, investigative officers are only authorised to enforce these investigative powers in security risk areas which have been appointed as such on the basis of indications of a terrorist offence by the public prosecutor, or by a royal decree. ${ }^{700}$ Special investigation techniques are obviously not limited to application within a predetermined area. Furthermore, the investigative powers are enforced in public, while the special investigation techniques are applied secretly. Lastly, the investigative powers can basically be applied without a connection between the persons, means of transport or objects that are searched and investigated, respectively, and the indications of a terrorist offence. The security risk areas are appointed on the basis of indications of a terrorist offence, but the application of the investigative powers in specific cases can be done without such indications. Hence, investigative officers are allowed to search anyone and to investigate any means of transport and any object present in a security risk area, without having indications of a terrorist offence concerning that individual, the means of transport or the object. Because of this different interpretation of the notion of 'indications of a terrorist offence' in the case of investigative powers, the following section will elaborate a bit more on this issue.

Prior to the enactment of the DPTA, comparable investigative powers could only be applied in the case of actual or impeding disturbance of the public order due to the presence of weapons or ammunition. ${ }^{701}$ Articles 126zq, 126zr and 126zs of the

700 As will further be set out in the following section, an area may be denoted as permanent security risk area on the basis of a royal decree or as a temporary security risk area by a public prosecutor for a period of a maximum of 12 hours (repeatedly extendible by periods of 12 hours).

701 Compare with Article 50, section 3, Article 51, section 3 and Article 52, section 3 of the WAA, in conjunction with Article $151 \mathrm{~b}$ of the Municipality Act. When the Mayor has designated a certain area as security risk area, due to actual or impending disturbance of public order due to the presence of weapons or ammunition pursuant to Article 151b of the Municipality Act, the prosecutor is subsequently authorised to order that everyone who enters that area, and any means of transport present in that area, may be searched for weapons or ammunition. This order is valid for a maximum of 12 hours. Article 50, section 3, Article 51, section 3 and Article 52, section 3 of the WAA, however, oblige the prosecutor additionally, to define the facts or information, on the basis of which, searching someone or searching a means of transport in the security risk area, may be deemed necessary. 
DCCP are, in part, comparable to the investigative powers as listed in Article 50, 51 and 52 of the WAA and Article 21 and 23 of the AEO. However, as will be elaborated on below, the WAA and the AEO do require some form of an individualised 'suspicion' against the person who is frisked or in relation to the means of transport or object that is searched.

\subsection{Indications of a terrorist offence and security risk areas}

TEMPORARY AND PERMANENT SECURITY RISK AREAS

Pursuant to Articles 126zq, 126zr and 126zs of the DCCP, a specific area may be denoted as temporary or as permanent security risk area. ${ }^{702}$ This may be done in two ways. Firstly, the public prosecutor is allowed to designate an area as temporary security risk area, on the basis of indications of a terrorist offence, for a period of 12 hours, which may, on each occasion, be extended by 12 hours. ${ }^{703}$ Secondly, an area may be designated as permanent security risk area by means of a royal decree. ${ }^{704}$ With respect to a permanent security risk area, there is hence, no need for an additional order of the public prosecutor. The Binnenhof, the railway stations of Amsterdam, Rotterdam, Utrecht and The Hague, all airports and their surroundings, the nuclear power station at Borssele and the mediapark in Hilversum, are all designated as permanent security risk areas by royal decree..$^{705}$

It is important to note that the indications of a terrorist offence do not, hence, concern the persons, means of transport or object that are to be frisked and searched, but they exclusively relate to the area which allegedly forms the intended target of a terrorist offence.

Within a temporary or permanent security risk area, investigative officers are free to search any person and to investigate any means of transport and any object present within that area. They do not have to demonstrate that the indications of a terrorist offence relate to the person, means of transport or object that are searched and investigated. In this respect, there is a clear difference with Articles 50, 51 and 52 of the WAA. These provisions demand that the order, on the basis of which a certain area is designated as a security risk, area must also prescribe which facts or circumstances may lead an investigative officer to search a person, a means of

702 The DCCP does not mention the notion of permanent and temporary security risk areas, but this distinction makes it easier to understand the two paths by means of which investigative officers are allowed to use preventive searching powers within a certain area. The DCCP simply discerns between (1) the order given by the public prosecutor to the investigative officers to use the respective powers within a certain area and (2) a security risk area designated by royal decree.

703 Article 126zk, section 3 of the DCCP.

704 Article 126zk, section 4 of the DCCP.

705 Staatsblad 2006, 730 and Bijlage bij het besluit opsporing terroristische misdrijven, pp. 10-14. 
transport or an object. ${ }^{706}$ Hence, the investigative officers do not have complete carte blanche in deciding who or what to search. The public prosecutor must provide some guidelines in that respect.

Conversely, Articles 126zq, 126zr and 126zs of the DCCP prescribe as only criterion for deciding whether or not to apply investigative powers in a specific case, the question of whether the application of such powers serves the interest of the investigation. The investigative officers are not obliged to give a detailed account of what power they have applied to which person and for what reasons. This leaves the investigative officers with a large discretionary power. Basically, the application of the investigative powers is then completely dependent on investigative interests that are valued, in concrete cases, by the enforcing investigative officer. For instance, if an investigative officer sees a person in 'traditional attire' with a van, on the main runway from which an El Al aeroplane is about to take off, it is most likely that this person will be frisked, and that his car will be inspected..$^{707}$

The decision of an investigative officer to search and investigate a person, a means of transport, or object, is, to a considerable extent, dependent on the character of the security risk area and on the experience and function of the investigative officer. For instance, frisking a large group of persons at a railway station is more obvious, and hence, more likely to be considered in the interest of the investigation, than frisking persons in a rural, sparesely populated area, in which there is a nuclear power station. In the latter scenario it would be more obvious to search means of transport or objects, than to frisk persons. However, the expertise, experience, professionalism, but also the personal characteristics of the investigative officer decide to a large extent who or what is searched and investigated. ${ }^{708}$

\section{INFORMATION}

The public prosecutor will generally designate an area as a temporary security risk area on the basis of (inter)national risk analysis or secret intelligence information that demonstrate an acute terrorist threat within the area. Permanent security risk areas may be designated following secret intelligence information demonstrating a constant terrorist threat within that area. ${ }^{709}$ This underlines, once again, that secret intelligence information is adequate and often used to demonstrate indications of a terrorist offence.

A secret intelligence memo mentioning that explosives imported by sea are going to be used for a terrorist attack is adequate information for a public prosecutor

Article 50, Article 51 and Article 52, section 3 of the WAA.

B. van Gestel, C.J. de Poot, R.J. Bokhorst, R.F. Kouwenberg, Signalen van terrorisme en de opsporingspraktijk. De Wet opsporing terroristische misdrijven twee jaar in werking, WODC Cahier 2009-2010, p. 17.

Staatsblad 2006, 730, p. 6.

Staatsblad 2006, 730, p. 5. 
to designate an area - the Rotterdam port, for instance - as a temporary security risk area. Also, information that 'explorations will be undertaken' in the vicinity of certain government buildings by (still) unidentified persons, is sufficient information for a public prosecutor to order that any person present in that area must show an identification card and will be searched if necessary.

\subsection{Powers of investigation}

\section{INVESTIGATING OBJECTS}

Article 126zq of the DCCP authorises investigative officers to investigate any object present within a permanent or temporary security risk area. The notion of 'objects' is broad and includes suitcases, handbags, briefcases, bags, (film)cameras, and, generally, any object that has been left behind. In sum, 'objects' are everything present in a security risk area, aside from means of transport and persons. 'Investigating objects' includes a power to take photographs, to measure or to weigh objects or to confiscate those objects for a short period. ${ }^{710}$ Furthermore, the packaging of objects may be opened if necessary. As to the practical enforcement of Article 126zq of the DCCP, the basic principle is that the investigative officer first asks the owner of an object to open, for instance, his bag or suitcase himself. In the case of a refusal, the investigative officer is authorised to open the object himself, hence, against the owner's will.

\section{INVESTIGATING MEANS OF TRANSPORT}

In accordance with Article 126zr of the DCCP, investigative officers are entitled: (1) to investigate the load of any means of transport (also when there is no driver in the vehicle), ${ }^{711}$ (2) to demand inspection of car registration documents ${ }^{712}$ and (3) to demand any person to stop his means of transport and to move it to a location determined by the investigative officer, within permanent or temporary security risk areas. ${ }^{713}$ The notion of 'means of transport' includes cars, trucks, trains, bicycles, private planes, ships or boats, and even wheelchairs.

Means of transport may be investigated, irrespective of whether the driver is present. For instance, when a car is parked in front of a government building within a permanent or temporary security risk area, the investigative officers are allowed to check that car, for instance, for the presence of explosives, without prior authorisation from the owner of the car.

710 Criminal investigators are however not competent to seize such objects under Article 126zk of the DCCP.

711 Article 126zl, section 2 under a of the DCCP.

712 Article 126zl, section 2 under b of the DCCP.

713 Article 126zl, section 2 under c of the DCCP. See furthermore Article 126zl, section 3 of the DCCP which declares Article 126zk, section 3 and 4 of the DCCP of analogous application. 


\section{FRISKING PERSONS}

Lastly, investigative officers are entitled to frisk any person within a permanent or temporary security risk area pursuant to Article 126zs of the DCCP. ${ }^{714}$ Frisking comprises a power to touch persons' clothes and, if necessary, a power to investigate specific garments. ${ }^{715}$ To that end, persons may be forced to take off certain garments. In that light, Article 126zs of the DCCP is not limited to mere superficial security-searches, as, for instance, comprised in the general rules of engagement of the police and the Royal Military Police. The explanatory memorandum with the DPTA argues that this is justified because Article 126zs of the DCCP serves to investigate indications of a terrorist offence, instead of 'merely' safeguarding the police's security while investigating common offences. ${ }^{716}$

Practically speaking, investigative officers are entitled to use detective devises, other (technical) devices and dogs capable of tracing explosives. Article 126zs of the DCCP does not yet entail a power to employ body scans. Furthermore, frisking a person must, as far as possible, be done by an investigative officer that is the same sex as the person that is frisked. Also, the frisk must, as far as possible, be carried out in the presence of a second investigative officer. Lastly, if the investigative officer or the person that is to be frisked demand so, the frisking should take place in a secluded room. ${ }^{717}$ Further rules concerning the practical enforcement of this power are to be comprised in a royal decree. ${ }^{718}$

\section{FormaLITIES}

In the case of a written order of the public prosecutor, the investigative officer who applies the powers comprised in Articles 126zq, 126zr and 126zs of the DCCP is obliged to record the following information in a procès-verbal:

(1) the moment at which the order was given, the name of the public prosecutor who gave the order, the period of validity of the order, and a description of the area in which the order applies;

(2) how many times the power(s) has/have been used;

(3) the way in which the power has been enforced. ${ }^{719}$

Article 126zm, section 3 of the DCCP declares Article 126zk, section 3 and 4 of the DCCP of analogous application.

Compare with Article 37h, section 1 under a and b of the Aircraft Statute.

Kamerstukken II 2004-2005, 30 164, no. 3, p. 46.

Staatsblad 2006, 730, Article 5.

Article 126zs, section 4 of the DCCP.

Staatsblad 2006, 730, Article 2. When it concerns a permanent security risk area, the investigative officer only needs to include, in the procès-verbal, how many times he used the respective powers, and the way in which he enforced the powers. The latter aspect is not so 
A person who is subjected to the investigative powers must be provided with a written document that comprises information regarding the investigative powers that have been applied. That information must furthermore include:

(1) the official number of the investigative officer;

(2) a specification of the moment and place at/where the powers were applied;

(3) the power(s) that has/have been applied;

(4) information on where the person subjected to the powers can lodge a complaint. ${ }^{720}$

\section{Practical application of the powers}

As mentioned above, the WODC ${ }^{721}$ published three monitoring reports regarding the application of the above-discussed powers regarding the periods 2007-2008, 2008-2009, 2009-2010.722 To map out the scope of the practical application of the powers comprised in the DPTA, the authors of these reports interviewed employees of the public prosecution office, police officers, employees of the secret intelligence services and military policemen. ${ }^{723}$ Also, the authors had access to case files regarding criminal investigations into terrorism. This means that the authors of the WODC reports had access to information that is normally not publicly available to other (non-governmental) research centres/researches.

Case law regarding the practical application of these powers is lacking. This is due to the fact that so far, criminal investigations during which these powers were used have not led to criminal proceedings, through which the lawfulness of application of the powers is contested. Therefore the WODC reports are the principal source to examine the questions of: (1) on what scale, and (2) how the abovediscussed powers are, in fact, used.

demanding. If the way in which the powers are enforced is recorded with too many details, that might damage the effectiveness of the powers. See Article 3, section 2 under a and b and p. 6 .

720 Staatsblad 2006, 730, Article 3, section 3 and 4.

721 The WODC is a research institute, forming part of the Ministry of Security and Justice, which conducts research in the area of 'the administration of justice and security'. See www.wodc.nl/ organisatie/.

722 C.J. de Poot, R.J. Bokhorst, W.H. Smeenk, R.F. Kouwenberg, De Opsporing verruimd? De Wet opsporing terroristische misdrijven een jaar in werking, WODC, Cahier 2008-9; B. van Gestel, C.J. de Poot, R.J. Bokhorst, R.F. Kouwenberg, Signalen van terrorisme en de opsporingspraktijk. De Wet opsporing terroristische misdrijven twee jaar in werking, WODC Cahier 2009-2010.

723 These reports only concern the application of the powers as comprised in the DPTA, hence, powers that serve to investigate terrorist offences. In general, special investigation techniques to investigate common offences are used on a large-scale, see, for further details on the scope of application of some of these techniques, Y. Buruma, 'De rechtsstaat in de knel tussen populisme en absolutisme', in Delikt en Delinkwent 2009, 73. 
The first report covers the period from February 2007 until February 2008. ${ }^{724}$ Throughout that period, special investigation techniques on the basis of indications were applied during 8 criminal investigations. In most of these cases, the investigative authorities applied one or more special investigation techniques for relatively short periods. Only in one of these investigations, were several techniques applied on a number of persons for a longer period of time. ${ }^{725}$ The authorities did not use the powers available pursuant to Articles $126 \mathrm{hh}$ and 126ii of the DCCP (exploratory inquiry), or the investigative powers in accordance with Articles 126zq to $126 \mathrm{zs}$ of the DCCP. ${ }^{726}$

From February 2008 until February 2009, there were 29 criminal investigations into terrorism..$^{727} 15$ of these investigations involved the use of special investigation techniques. However, during only 3 of these 15 investigations did the competent authorities apply the special investigation techniques on the basis of indications of a terrorist offence. ${ }^{728}$ Each time, multiple (a maximum of four) special investigation techniques were concurrently applied. It concerned, for instance, the recording of telecommunication, combined with the requisition of telecommunication traffic information and/or the systematic observation of persons.

None of these 29 criminal investigations into terrorist offences led to criminal prosecution in respect of the commission or the plotting of a terrorist offence. All of these investigations were halted due to a lack of adequate evidence. Often, the public prosecutor passed the collected information on to the secret intelligence services who, 'continued the investigation' 729

724 C.J. de Poot, R.J. Bokhorst, W.H. Smeenk, R.F. Kouwenberg, De Opsporing verruimd? De Wet opsporing terroristische misdrijven een jaar in werking, WODC, Cahier 2008-9.

725 C.J. de Poot, R.J. Bokhorst, W.H. Smeenk, R.F. Kouwenberg, De Opsporing verruimd? De Wet opsporing terroristische misdrijven een jaar in werking, WODC, Cahier 2008-9, pp. 41-42.

726 C.J. de Poot, R.J. Bokhorst, W.H. Smeenk, R.F. Kouwenberg, De Opsporing verruimd? De Wet opsporing terroristische misdrijven een jaar in werking, WODC, Cahier 2008-9, p. 2.

727 Fifteen of these investigations were conducted under the authority of the national public prosecutor's office [landelijk parket], and 14 investigations under the authority of district public prosecutor's office. B. van Gestel, C.J. de Poot, R.J. Bokhorst, R.F. Kouwenberg, Signalen van terrorisme en de opsporingspraktijk. De Wet opsporing terroristische misdrijven twee jaar in werking, WODC Cahier 2009-2010, p. 14.

728 Two of these investigations were led by the national public prosecutor's office, and one, by a district public prosecutor's office. These statistics only relate to criminal investigations that were finished at the time the WODC report was written. This means that, most likely, there will have been more investigations into terrorist offences during which special investigative techniques on the basis of indications were applied, than the ones discussed in the WODC report. B. van Gestel, C.J. de Poot, R.J. Bokhorst, R.F. Kouwenberg, Signalen van terrorisme en de opsporingspraktijk. De Wet opsporing terroristische misdrijven twee jaar in werking, WODC Cahier 2009-2010, p. 15.

729 B. van Gestel, C.J. de Poot, R.J. Bokhorst, R.F. Kouwenberg, Signalen van terrorisme en de opsporingspraktijk. De Wet opsporing terroristische misdrijven twee jaar in werking, WODC Cahier 2009-2010, p. 26-28. 
Throughout this period, the investigative authorities did not initiate any exploratory inquiry into terrorist offences. The investigative powers pursuant to Articles 126zq until 126zs of the DCCP, had only been used within the permanent security risk area of Schiphol and its surroundings. The application of the investigative powers did not yield any information relating to terrorism/terrorist offences. Furthermore, a team of special investigative officers was set up during this period in order to guard and secure Schiphol and its surroundings. ${ }^{730}$

From February 2009 until February 2010 there were 31 criminal investigations into terrorism. During four of these investigations, the investigative authorities used powers comprised in the DPTA. ${ }^{731}$ In three cases the investigative authorities applied special investigation techniques on the basis of indications of a terrorist offence. One of these cases was initiated on the basis of information regarding preparatory behaviour. It concerned information on the manufacturing of explosives in combination with significant money transfers. Eventually, it emerged that these circumstances were not related to a terrorist offence. In the two other cases, the investigative authorities assumed indications in order to investigative the potential connections of various persons with someone arrested on suspicion of a terrorist offence. These investigations, hence, served to ascertain whether the other persons were also involved in the preparation of a terrorist offence. In both cases the persons subjected to the special investigation techniques did not have anything to do with terrorism. . $^{732}$

The investigative powers pursuant to Articles 126zq, 126zr, 126zs of the DCCP, were only used in the permanent security risk area of Schiphol and its surroundings. No new security risk areas were appointed during this period, and no exploratory inquiries were initiated.

\section{The Right to PRIVACY}

\section{INTRODUCTION}

This section discusses the issues that may arise in terms of respect for the right to privacy in case of: (1) an exploratory inquiry into terrorist offences, (2) the application of special investigation techniques on the basis of indications, and (3) the application of investigative powers within security risk areas. Which specific

\footnotetext{
730 B. van Gestel, C.J. de Poot, R.J. Bokhorst, R.F. Kouwenberg, Signalen van terrorisme en de opsporingspraktijk. De Wet opsporing terroristische misdrijven twee jaar in werking, WODC Cahier 2009-2010, p. 16-17.

731 B. van Gestel, C.J. de Poot and R.F. Kouwenberg, De Wet opsporing terroristische misdrijven drie jaar in werking, WODC, Cahier 2010-3, p. 7-8.

732 B. van Gestel, C.J. de Poot and R.F. Kouwenberg, De Wet opsporing terroristische misdrijven drie jaar in werking, WODC, Cahier 2010-3, p. 9.
} 
problems will come up, in terms of the limitation clause of Article 8, section 2 of the ECHR, when the competent authorities apply these powers? What judgements has the ECtHR passed in comparable cases? More specifically, under what circumstances does the ECtHR consider the application of comparable powers to be in accordance with the law and to be necessary in a democratic society? ${ }^{733}$

The scope of those two main requirements, as applied in comparable cases, will be discussed in the coming sections. First of all, the requirement that legal provisions have to be sufficiently foreseeable is examined in light of the notion of indications of a terrorist offence as a prerequisite for the application of the above-discussed powers. This requirement also includes the question of what safeguards and what kind of judicial control there must be to act in compliance with Article 8 of the ECHR. ${ }^{734}$ Thirdly, the necessity requirement is scrutinised: how do the principles of proportionality and subsidiarity limit state powers during criminal investigations? Can the need to prevent terrorism contribute to demonstrating that there is a pressing social need for applying far-reaching investigative powers during the proactive phase on the basis of broad legal bases?

\subsection{In accordance with the law? ${ }^{735}$}

\subsubsection{Qualitative requirements for legal provisions}

The central goal of this section is to discuss the scope of the Strasbourg requirement that interferences with privacy must be in accordance with the law, specifically in

733 The fact that application of the broadened investigative techniques interferes with citizens' privacy is evident. I will therefore not elaborate further on this issue. Concerning the investigative powers comprised in Article 126zq, Article 126zr and Article 126zs of the DCCP, it can further be presumed that application of these powers does not solely interfere with citizens' private sphere, but also, more specifically, with their physical integrity. The ECtHR has repeatedly held that Article 8 of the ECHR includes a right to the enjoyment of physical integrity without state interference. See, Glass v. the United Kingdom, appl. no. 61827/00, 9 March 2004, §70; X and Y v. The Netherlands, appl. no. 8978/80, 26 March 1985, §22; Pretty v. the United Kingdom, appl. no. 2346/02, 29 April 2002, §61 and 63; Y.F. v. Turkey, appl. no. 24209/94, 22 July 2003, §33.

734 Although in this chapter the question of the existence of sufficient procedural safeguards is examined as part of the first requirement ('in accordance with the law'), it is important to note that the ECtHR in some cases, also deals with that issue while examining the third requirement (necessity). See Kruslin v. France, appl. no. 11801/85, 24 April 1990, §30-37; Huvig v. France, appl. no. 11105/84, 24 April 1990, §29-36; Herczegfalvy v. Austria, appl. no. 10533/83, 24 September 1992, §89-93 vis-à-vis Niemietz v. Germany, appl. no. 13710/88, 16 December 1992, §37-39; Crémieux v. France, appl. no. 11471/85, 25 February 1993, §38-42.

735 While discussing this first requirement, it should, however, be kept in mind that the ECtHR allocates a rather broad margin of appreciation to Member States to examine a given national restrictive measure on compatibility with the ECHR. The ECtHR considers that: ' (...) the logic of the system of safeguards established by the Convention sets limits upon scope of the power of review exercisable by the ECtHR in this respect. It is in the first place for the national authorities, notably the courts, to interpret and apply the domestic law: the national authorities are, in the 
the field of state powers applied during criminal investigations. This issue is examined in light of Title VB of the DCCP and the two main criteria for the application of the powers comprised in this title (indications and investigative interests). What criteria must be fulfilled for domestic legislation comprising powers that interfere with the private life to satisfy the requirement that interferences must be in accordance with the law?

It is important to note that the concept of 'indications of a terrorist offence' involves an ambiguity, which is twofold: first, there is the broad notion of 'indications' and second, there is the broad scope of 'terrorist offence' as defined in the DCC. ${ }^{736}$ There is no case law on the notion of indications of a terrorist offence to further clarify the scope of that notion, and if there were, the information that led the investigative authorities to assume indications of a terrorist offence may very well not be disclosed.

The above-discussed WODC reports demonstrate that criminal investigations relating to terrorism, in which special investigation techniques have been used, do generally not lead to criminal proceedings. ${ }^{737}$ This implies that the way in which the powers comprised in Title VB are applied, among which the question of on what information, is not examined by the Judiciary, and consequently, not made public. Even the investigative authorities themselves are still exploring the scope of the notion of indications of a terrorist offence and its relation to other suspicion criteria, like the reasonable suspicion criterion. ${ }^{738}$ In light of the importance of adequately safeguarding legal protection, they, moreover, argue that the material powers should be used as little as possible on the basis of indications. ${ }^{739}$ The parliamentary memoranda do not provide for extensive clarifications either.

The Strasbourg requirement of 'lawful interferences with the right to privacy' primarily concerns qualitative requisites for legislation. Legislation must be accessible, ${ }^{740}$ foreseeable, and hence, compatible with the rule of law, to protect

nature of things, particularly qualified to settle the issues arising in this connection (...)'. See Barthold v. Germany, appl. no. 8734/79, 25 March 1983, §52; Amann v. Switzerland, appl. no. 27798/95, 16 February 2000, §52.

736 See Part 2 for further elaborations on the definition of terrorist offence pursuant to Articles 83 and $83 \mathrm{a}$ of the DCC.

737 B. van Gestel, C.J. de Poot, R.J. Bokhorst, R.F. Kouwenberg, Signalen van terrorisme en de opsporingspraktijk. De Wet opsporing terroristische misdrijven twee jaar in werking, WODC Cahier 2009-2010, p. 3.

738 See, for discussion of the reasonable suspicion criterion, Chapter VI. It is important to note that during criminal investigations into common crime, special investigation techniques can only be applied on the basis of a reasonable suspicion.

739 C.J. de Poot, R.J. Bokhorst, W.H. Smeenk, R.F. Kouwenberg, De Opsporing verruimd? De Wet opsporing terroristische misdrijven een jaar in werking, WODC, Cahier 2008-9, p. 49.

740 I will not, at this point, elaborate further on the requirement that the law must be accessible. See, on this issue, Malone v. the United Kingdom, appl. no. 8691/79, 2 August 1984, §66; Sunday Times v. the United Kingdom, appl. no. 6538/74, 26 April, 1979, §49. 
citizens against arbitrariness. ${ }^{741}$ First of all, it needs to be kept in mind that the foreseeable requirement does not demand absolute certainty; experience shows this to be unattainable. Even though certainty is highly desirable, the ECtHR has repeatedly underlined that it may bring with it excessive rigidity, and the law must be able to keep pace with changing circumstances. Accordingly, many laws are inevitably couched in terms which, to a greater or lesser extent, are vague, and whose interpretation and application are questions of practice. ${ }^{742}$

Generally, a legal provision is foreseeable when it is worded sufficiently precisely to enable an individual to adapt his or her behaviour, without implying that a person should be capable of foreseeing when exactly the authorities will, for example, monitor his telephone conversations. ${ }^{743}$ The ECtHR has frequently underlined that the foreseeability requirement is not to be interpreted equally in all cases and under all circumstances. ${ }^{744}$ The level of precision required of domestic legislation - which, hence, cannot, in any case, provide for every eventuality - depends, to a considerable degree, on the content of the instrument in question, the field it is designed to cover, and the number and status of those to whom it is addressed..$^{745}$

For instance, the ECtHR has held, on several occasions, that the reference to 'foreseeability' in the context of interception of communications cannot be the same as in many other fields. ${ }^{746}$

A whole range of ECtHR judgements discusses the requirement of legal foreseeability in the special context of secret measures of surveillance ${ }^{747}$ such as

741 Kvasnica v. Slovakia, appl. no. 72094/01, 9 June 2009, §78; Davydov and Others v. the Ukraine, appl. nos. 17674/02 and 39081/02, 1 July 2010, §326; Liberty and Others v. the United Kingdom, appl. no. 58243/00, 1 July 2008, §59; Wingrove v. the United Kingdom, appl. no. 17419/90, 25 November 1996, $\$ 40$.

742 Sunday Times $v$. the United Kingdom, appl. no. 6538/74, 26 April, 1979, \$49.

743 See Terrorism: special investigative techniques, Council of Europe Publishing, Council of Europe, April 2005, p. 27.

744 Leander v. Sweden, appl. no. 9248/81, 26 March 1987, §51. See, as well, Malone v. the United Kingdom, appl. no 8691/79, 2 August 1984, §68; A ̆gaoğlu c. Turquie, requête no 27310/95, 6 décembre, \$52-56.

745 S. And Marper v. the United Kingdom, appl. nos. 30562/04 and 30566/04, 4 December 2008, §96.

746 Decision as to the admissibility in Weber and Saravia v. Germany, appl. no. 54934/00, 29 June 2006, §93 and further; Kennedy v. the United Kingdom, appl. no. 26839/05, 18 May 2010, §152.

747 Secret measures of surveillance include telephone tapping, recordings made in public places by directional microphones, and in private places by the installation of bugging devices or a microphone carried by an infiltrated officer, but also secretly collecting and storing (personal) information. See Terrorism: special investigative techniques, Council of Europe Publishing, Council of Europe, April 2005, p. 28. See, further, S. and Marper v. the United Kingdom, appl. nos. 30562/04 and 30566/04, 4 December 2008, $\$ 99$, regarding the power for the investigative authorities to retain samples and fingerprints: 'The ECtHR agrees with the applicants that at least the first of these purposes [prevention or detection of crime] is worded in rather general terms and may give rise to extensive interpretation. It reiterates that it is as essential, in this context, as in telephone tapping, secret surveillance and covert intelligence-gathering, to have 
the interception of communications. This requirement cannot mean that an individual should be able to foresee when the authorities are likely to intercept his communications so that he can adapt his conduct accordingly. ${ }^{748}$ However, the domestic law must be sufficiently clear, in its terms, to give individuals an adequate indication as to the circumstances in which, and the conditions on which, public authorities are empowered to resort to any such measures. ${ }^{749}$ This means that phone tapping and other forms of interception of (telephone) conversations or communications, especially during pro-active investigations, must be based on a 'law' that is particularly precise. ${ }^{750}$ The intrusiveness of such techniques, and consequently, the serious interference with private life and correspondence, demand unequivocal legal provisions. Furthermore, according to the ECtHR, it is essential to have clear, detailed rules on the subject, as the technology available for use is continually becoming more sophisticated. ${ }^{751}$ The more intruding a power is and the further into the pro-active phase it is applied, the more precise the laws that grant such powers must be.

In the field of secret measures of surveillance, ECHR case law furthermore focuses on the scope of the discretionary power attributed to the investigative authorities. Since, in practice, the implementation of measures of secret surveillance of communications is not open to scrutiny by the individuals concerned or the public at large, it is considered contrary to the rule of law for the legal discretion granted to the Executive or to a judge to be expressed in terms of an unfettered power. ${ }^{752}$ However, the ECtHR does recognise that 'it may be difficult to frame laws with absolute precision (KV) and that a certain degree of flexibility may even be desirable to enable the national courts to develop the law in the light of their assessment of what measures are necessary in the interest of justice.' That flexibility must, however, be counterbalanced. The law must indicate the scope of any discretion conferred on the competent authorities and the manner of its exercise with sufficient clarity, having regard to the legitimate aim of the measure in

clear, detailed rules governing the scope and application of measures, as well as minimum safeguards concerning, inter alia, duration, storage, usage, access of third parties, procedures for preserving the integrity and confidentiality of data and procedures for its destruction, thus providing sufficient guarantees against the risk of abuse and arbitrariness.'

748 Liberty and Others v. the United Kingdom, appl. no. 58243/00, 1 July 2008, §62; Kennedy v. the United Kingdom, appl. no. 26839/05, 18 May 2010, $\$ 152$; the decision as to the admissibility in; Weber and Saravia v. Germany, appl. no. 54934/00, 29 June 2006, §93; Malone v. the United Kingdom, 8691/79, 2 August 1984, §67.

749 Kvasnica v. Slovakia, appl. no. 72094/01, 9 June 2009, §79.

750 See, also, Terrorism: special investigative techniques, Council of Europe Publishing, Council of Europe, April 2005, p. 20; Kruslin v. France, appl. no. 11801/85, 24 April 1990, §30-37; Huvig v. France, appl. no. 11105/84, 24 April 1990, §29-36.

751 Kruslin v. France, appl. no. 11801/85, 24 April 1990, §30-37; Huvig v. France, appl. no. 11105/84, 24 April 1990, §29-36.

752 Decision as to the admissibility in Weber and Saravia v. Germany, appl. no. 54934/00, 29 June 2006, §94; Segerstedt-Wiberg and Others v. Sweden, appl. no. 62332/00, 6 June 2006, §76. 
question. ${ }^{753}$ This serves to give the individual adequate protection against arbitrary interferences with his privacy. ${ }^{75}$ In addition, adequate and effective safeguards including judicial control must be provided for to counterbalance large discretionary powers. ${ }^{755}$ This last-mentioned key aspect will be discussed separately below (8.1.3).

In its case law on secret measures of surveillance, the ECtHR has developed the following minimum safeguards that should be set out in statute law in order to avoid abuses of power: (1) the nature of the offences which may give rise to an interception order, (2) a definition of the categories of people liable to have their telephones tapped ${ }^{756}$ (3) a limit on the duration of telephone tapping, (4) the procedure to be followed for examining, using and storing the data obtained, (5) the precautions to be taken when communicating the data to other parties, and (6) the circumstances in which recordings may or must be erased or the tapes destroyed. ${ }^{757}$ Laws that provide for secret measures of surveillance will be considered legitimate if they meet these conditions. ${ }^{758}$

The requirement that the effects of the 'law' be foreseeable means, hence, primarily, in the sphere of monitoring (telephone) communications, that the guarantees stating the extent of the authorities' discretion and the manner in which it is to be exercised, must be set out in detail in domestic law so that it has a binding force, which consequently circumscribes the public prosecutors' or judges'

753 See, Silver and Others $v$. the United Kingdom, appl. nos. 5947/72; 6205/73; 7052/75; 7061/75; $7107 / 75 ; 7113 / 75 ; 7136 / 75,25$ March 1983, §85-91; Leander v. Sweden, appl. no. 9248/81, 26 March 1987, §50-51; Liberty and Others v. the United Kingdom, appl. no. 58243/00, 1 July 2008, §62; S. and Marper v. the United Kingdom, appl. nos. 30562/04 and 30566/04, 4 December 2008, §99; Bykov v. Russia, appl. no. 4378/02, 10 March 2009, §78.

754 S. and Marper v. the United Kingdom, appl. nos. 30562/04 and 30566/04, 4 December 2008, §95; Liberty and Others v. the United Kingdom, appl. no. 58243/00, 1 July 2008, §62; Goodwin v. the United Kingdom, appl. no. 28957/95, 11 July 2002, §92-93; Demokratischer Soldaten Österreichs and Gubi v. Austria, appl. no. 15153/89, 19 December 1994, §38-41.

755 Kvasnica v. Slovakia, appl. no. 72094/01, 9 June 2009, \$79.

756 Telephone tapping includes placing a directional microphone or the installation of bugging devices.

757 The Association for european integration and human rights and Ekimdzhiev v. Bulgaria, appl. no. 62540/00, 28 June 2007, §75-77; Kennedy v. the United Kingdom, appl. no. 26839/05, 18 May 2010, \$152 and 158-170; decision as to the admissibility in Weber and Saravia, appl. no. 54934/00, 29 June 2006, §95; Malone v. the United Kingdom, appl. no. 8691/79, 2 august 1984, §67-68; Amann v. Switzerland, appl. no. 27798/95, 16 February 2000, §55-62; Valenzuela Contreras v. Spain, appl. no. 58/1997/842/1048, 30 July 1998, §46-62; Prado Bugallo c. Espagne, requête no 58496/00, 18 février 2003, §28-34; Kruslin v. France, appl. no. 11801/85, 24 April 1990, §30-37; Huvig v. France, appl. no. 11105/84, 24 April 1990, §32.

758 See, in this respect, also P.J.A. de Hert, 'Balancing security and liberty within the European human rights framework', in A.M. Hol \& J.A.E. Vervaele (eds.), Security and Civil Liberties: The Case of Terrorism, Yearbook Utrecht Law Review 2005, Intersentia, p. 52. 
discretion in the application and examination of such measures. ${ }^{759}$ The question of whether these safeguards have been adequately complied with in a specific case, is considered under the necessity requirement. This means that even if all of the above safeguards have been included in domestic law (formal), the ECtHR may still find a violation of Article 8 of the ECHR if the manner of enforcement of the relevant powers (substantive), in practice, did not comply with the statutory safeguards. This latter issue is discussed in Section 8.2 regarding the scope of the necessity requirement.

Let me now give some examples of judgements in which the ECtHR scrutinised the lawfulness, among which formal compliance with the above discussed safeguards, in cases regarding secret measures of surveillance.

\section{Huvig and Kruslin v. France}

In Huvig v. France the ECtHR argued that the categories of people liable to have their telephones tapped by judicial order, and the nature of the offences that may give rise to such an order, were nowhere defined in legislation or case law. So even though the order to place a telephone tap was given by an investigating judge, as the independent judicial authority, who supervised senior police officers and was himself supervised by the Indictment Division (chambre d'accusation) of the Court of Appeal, by trial courts and courts of appeal and by the Court of Cassation, the ECtHR nevertheless judged that 'Mr and Mrs Huvig did not enjoy the minimum degree of protection to which citizens are entitled under the rule of law in a democratic society' simply because French law did not sufficiently specify whose private communications could be intercepted. ${ }^{760}$

\section{Kennedy v. The United Kingdom}

In Kennedy v. the United Kingdom, the ECtHR systematically examined the United Kingdom (UK) legislation regarding the interception of communications on its compatibility with all of the above-mentioned six prerequisites. ${ }^{761}$ Under UK law, communications may be intercepted on three grounds: (1) in the interests of national

759 Valenzuela Contreras v. Spain, appl. no. 58/1997/842/1048, 30 July 1998, §60; Malone v. the United Kingdom, appl. no. 8691/79, 2 august 1984, §79.

760 Huvig v. France, appl. no. 11105/84, 24 April 1990, §33-35; Kruslin v. France, appl. no. 11801/85, 24 April 1990, §34-36; Vetter c. France, requête no 59842/00, 31 mai 2005, §25-28; Wisse c. France, requête no $71611 / 01,20$ décembre 2005, §32-35.

761 See, also, decision as to the admissibility in Weber and Saravia, appl. no. 54934/00, 29 June 2006, §93-102, in which the ECtHR systematically examined German legislation in the field of interception of communications on compatibility with these conditions. 
security, ${ }^{762}$ (2) for the purpose of preventing or detecting serious crime, ${ }^{763}$ or (3) for the purpose of safeguarding the economic well-being of the UK. The applicant primarily asserted that the notions of 'national security' and 'serious crime' were insufficiently foreseeable.

First of all, the ECtHR argued that states are not required to set out exhaustively by name, the specific offences which may give rise to interception. However, sufficient detail should be provided as to the nature of the offences in question. ${ }^{764}$ With regard to the notion of 'national security', the ECtHR made a comparison with decisions to deport individuals, and argued that states are not obliged to enact legal provisions listing in detail all conduct that may prompt a decision to deport an individual on 'national security' grounds. The ECtHR asserted that by the nature of things, threats to national security may vary in character and may be unanticipated or difficult to define in advance. ${ }^{765}$ Similar considerations apply to the use of the term in the context of secret surveillance. According to the ECtHR, the reference to serious crime and national security, together with the interpretative clarifications in the Act at issue and the clarifications provided for by the Commissioner, ${ }^{766}$ give citizens an adequate indication as to the circumstances in which and the conditions

762 The term 'national security' is not defined in the legislation concerned. However, it has been clarified by the Interception of Communications Commissioner who, stated (in a report) that he had adopted the following definition: '[activities] which threaten the safety or well-being of the State, and which are intended to undermine or overthrow Parliamentary democracy by political, industrial or violent means.' See, Kennedy v. The United Kingdom, appl. no. 26839/05, 18 May $2010, \S 32-34$.

763 The notion of 'serious crime' is defined as a crime which satisfies one of the following criteria: (a) that the offence or one of the offences that is or would be constituted by the conduct is an offence for which a person who has attained the age of twenty-one and has no previous convictions could reasonably be expected to be sentenced to imprisonment for a term of three years or more, or (b) that the conduct involves the use of violence, results in substantial financial gain or is conduct by a large number of persons in pursuit of a common purpose. See, Kennedy v. the United Kingdom, appl. no. 26839/05, 18 May 2010, §34.

764 Kennedy v. the United Kingdom, appl. no. 26839/05, 18 May 2010, §159.

765 Al-Nashif v. Bulgaria, appl. no. 50963/99, 20 June 2002, §121.

766 Section 57 of the RIPA (The Regulation of Investigatory Powers Act 2000) provides that the Prime Minister shall appoint an Interception of Communications Commissioner ("the Commissioner'). He must be a person who holds or has held high judicial office. To date, there have been two Commissioners appointed under the RIPA. Both are former judges of the Court of Appeal. The Commissioner's functions include: (1) to keep under review the exercise and performance by the Secretary of State of powers and duties in relation to interception conferred or imposed on him by the RIPA, (2) the exercise and performance of powers and duties in relation to interception by the persons on whom such powers or duties are conferred or imposed, and (3) the adequacy of the arrangements by virtue of which the duty which is imposed on the Secretary of State by section 15 is sought to be discharged. Kennedy v. the United Kingdom, appl. no. 26839/05, 18 May 2010, §57-58. This issue will be elaborated on further in Section 8.2, regarding judicial control and procedural safeguards. 
on which public authorities are empowered to resort to secret surveillance measures. ${ }^{767}$

As to the second condition, it is possible for the communications of any person in the UK to be intercepted. In this respect, the ECtHR observed that there is an overlap between the condition that the categories of persons be specified and the condition that the nature of the offences be clearly defined. The relevant circumstances that can give rise to interception give guidance as to the categories of persons who are likely, in practice, to have their communications intercepted. ${ }^{768}$

Furthermore, the ECtHR underlined that the warrant for interception must clearly specify, either by name or by description, one person as the interception subject or a single set of premises as the premises in respect of which the warrant is ordered. Names, addresses, telephone numbers and other relevant information must be specified in the schedule to the warrant. Indiscriminate capturing of vast amounts of communications is, hence, not permitted. The ECtHR considered that, in the circumstances, no further clarification in the legislation of the categories of persons liable to have their communications intercepted could reasonably be required. ${ }^{769}$

In respect of the duration of any telephone tapping warrant, UK law clearly stipulates, first, the period after which an interception warrant will expire and, second, the conditions under which a warrant can be renewed. The ECtHR held the opinion that the overall duration of any interception measures will depend on the complexity and duration of the investigation in question and, provided that adequate safeguards exist, it is not unreasonable to leave this matter to the discretion of the relevant domestic authorities. ${ }^{770}$

The fourth condition was met as well, according to the ECtHR. An intercepting agency can, in principle, listen to all of the intercepted material. As an order relates to one person or one set of premises only, the scope of the authorities' discretion to intercept and listen to private communications is, accordingly, limited. Moreover, any intercepted data which are not necessary for any of the authorised purposes, must be destroyed. ${ }^{771}$

As to the fifth condition, the ECtHR argued that UK law imposes a duty on the Secretary of State to ensure that arrangements are in place to secure any data obtained from interception and contains specific provisions on the communication, storing, copying and accessing of intercept material. The ECtHR was satisfied that the provisions on processing and communication of intercepted material provide

\footnotetext{
767 Kennedy v. the United Kingdom, appl. no. 26839/05, 18 May 2010, §159.

768 Kennedy v. the United Kingdom, appl. no. 26839/05, 18 May 2010, §160.

769 Kennedy v. the United Kingdom, appl. no. 26839/05, 18 May 2010, §160.

770 Kennedy v. the United Kingdom, appl. no. 26839/05, 18 May 2010, §161.

771 Kennedy v. the United Kingdom, appl. no. 26839/05, 18 May 2010, §162.
} 
adequate safeguards for the protection of data obtained. ${ }^{772}$ Furthermore, as far as the destruction of intercepted material is concerned, UK law requires that the material and any related communications data, as well as any copies made of the material or data, must be destroyed as soon as there are no longer any grounds for retaining them as necessary. ${ }^{773}$

In sum, the ECtHR ruled that UK law on interception of internal communications together with the clarifications brought by the publication of the Code, indicate, with sufficient clarity, the procedures for the authorisation and processing of interception warrants as well as the processing, communicating and destruction of intercepted material collected. There is no evidence of any significant shortcomings in the application and operation of the surveillance regime. Having regard to the safeguards against abuse in the procedures, as well as the more general safeguards offered by the supervision of the Commissioner and the review of the IPT, ${ }^{774}$ the impugned surveillance measures were considered to be justified. ${ }^{775}$

\section{LiBerTy AND Others v. THE United Kingdom}

The case of Liberty and Others $v$. the United Kingdom concerned, like the case of Kennedy v. the United Kingdom, the interception of telephone, facsimile, e-mail and data communications. The main difference between these two judgements is that the first related to interception of 'external' communications, whereas the second case concerns interception of 'internal' communications. ${ }^{776}$

The relevant UK law allows the Executive an extremely broad discretion in respect of the interception of communications between the UK and an external receiver, namely, to intercept 'such external communications as are described in the warrant.' 777 There is no limit to the type of external communications that can be included in a warrant. Warrants cover very broad classes of communications, for

Kennedy v. the United Kingdom, appl. no. 26839/05, 18 May 2010, §163.

Kennedy v. the United Kingdom, appl. no. 26839/05, 18 May 2010, §164.

IPT stands for the Investigatory Powers Tribunal. The IPT was established to hear allegations by citizens of wrongful interference with their communications as a result of conduct covered by the RIPA. Members of the tribunal must hold, or have held, high judicial office or be a qualified lawyer of at least ten years' standing. Any person may bring a claim before the IPT and, save for vexatious or frivolous applications, the IPT must determine all claims brought before it. It has jurisdiction to investigate any complaint that a person's communications have been intercepted and, where interception has occurred, to examine the authority for such interception. The IPT has the power to award compensation and to make such other orders as it thinks fit, including orders quashing or cancelling any interception warrant and orders requiring the destruction of any records obtained under such a warrant. Kennedy v. the United Kingdom, appl. no. 26839/05, 18 May 2010, §75-80. This issue will be elaborated on further in Section 8.2, regarding judicial control and procedural safeguards.

Kennedy v. the United Kingdom, appl. no. 26839/05, 18 May 2010, §169.

Liberty and Others $v$. the United Kingdom, appl. no. 58243/00, 1 July 2008, §22-27.

Liberty and Others $v$. the United Kingdom, appl. no. 58243/00, 1 July 2008, §64. 
example, 'all commercial submarine cables having one terminal in the UK and carrying external commercial communications to Europe'. All communications falling within the specified category would be physically intercepted. ${ }^{778}$ In principle, any person who sends or receives any form of telecommunication outside the British Islands during the period in question (1990-1997779) could have had his communication intercepted. The legal discretion granted to the Executive for the physical capture of external communications was, therefore, virtually unfettered. ${ }^{780}$

First of all the ECtHR noted that there is no ground to apply different principles regarding the accessibility and clarity of the rules governing the interception of individual communications, on the one hand, and more general programmes of surveillance, on the other. ${ }^{781}$ Secondly, the ECtHR did not consider that the domestic law at the relevant time indicated with sufficient clarity, so as to provide adequate protection against abuse of power, the scope or manner of exercise of the very wide discretion conferred on the state to intercept and examine external communications. In particular, it did not set out, in a form accessible to the public any indication of the procedure to be followed for selecting for examination, sharing, storing and destroying intercepted material. In this connection the ECtHR recalled that the procedures to be followed for examining, using and storing intercepted material, inter alia, should be set out in a form which is open to public scrutiny and knowledge. Since that had not been done, the interference with the applicants' rights under Article 8 of the ECHR, was considered to be not 'in accordance with the law'.782

\section{Amann v. Switzerland}

In Amann v. Switzerland, the ECtHR rules that Swiss legislation regarding the recording of telephone communications did not regulate, in detail, the case of persons who had been monitored 'fortuitously' as 'necessary participants' in a telephone conversation recorded by the authorities. In particular, that law did not specify the precautions that should be taken with regard to those persons. The primary object of the law was the surveillance of persons suspected or accused of a crime or major offence, or even third parties presumed to be receiving information from or sending it to such persons. The applicant in this case had not been the subject of the impugned measure - interception of telephone communications either as a suspect or an accused, or as a third party presumed to be receiving information or sending it to a suspect or an accused, but had been involved 'fortuitously' in a telephone conversation recorded in the course of surveillance

\footnotetext{
778 Liberty and Others $v$. the United Kingdom, appl. no. 58243/00, 1 July 2008, $\$ 43$ and 64.

779 Liberty and Others $v$. the United Kingdom, appl. no. 58243/00, 1 July 2008, §42.

780 Liberty and Others $v$. the United Kingdom, appl. no. 58243/00, 1 July 2008, §64.

781 Liberty and Others $v$. the United Kingdom, appl. no. 58243/00, 1 July 2008, \$63.

782 Liberty and Others $v$. the United Kingdom, appl. no. 58243/00, 1 July 2008, §67 and 69.
} 
measures taken against a particular member of staff of the former Soviet embassy in Berne.

Swiss law did not indicate with sufficient clarity the scope and conditions of exercise of the authorities' discretionary power in the area of fortuitously monitored persons. ${ }^{783}$ In light of these considerations, the ECtHR concluded that the interference on the applicant's privacy could not, therefore, be considered to have been 'in accordance with the law'.

\section{Segerstedt-Wiberg and Others v. Sweden}

The case of Segersteds-Wiberg and Others $v$. Sweden concerned the registration of personal information in registers of the Security Police. Under Swedish law, the Security Police are allowed to gather personal information only if: (1) the person concerned by the information is suspected of having engaged in, or of intending to engage in, criminal activity that entails a threat to national security or a terrorist offence; (2) the person concerned has undergone a security check under the Security Protection Act; or (3) considering the purpose for which the register is kept, there are other special reasons. The applicants complained that this last criterion of 'other special reasons' comprised an unfettered power for the competent authorities. ${ }^{784}$

The ECtHR argued that the preparatory work concerning the relevant Swedish legislation gave several specific and clear examples of the notion of 'other special reasons', including: a person who is connected with another person who has been registered, a person who may be the target of a threat, a person who may be the object of recruitment by a foreign intelligence service, or a person in contact with someone suspected of a crime.

Even though the ECtHR considered the Security Police to enjoy a certain discretion in assessing who and what information should be registered and also in examining if there are 'other special reasons', that discretion is not unfettered. First of all, no entry regarding a citizen may be made in a public register exclusively on the basis of that person's political opinion without his consent. Secondly, the purpose of the register must be borne in mind where registration is made for 'other special reasons': the purpose of storing information of the Security Police register must be to facilitate investigations undertaken to prevent and uncover crimes against national security or to combat terrorism. Further limitations follow from the prescribed manner of recording data in the Security Police register.

In light of these considerations, the ECtHR concluded that the scope of the discretion conferred on the competent authorities, and the manner of its exercise, was indicated with sufficient clarity, having regard to the legitimate aim of the 
measure in question, to give the individual adequate protection against arbitrary interference. ${ }^{785}$

IN SUM

These judgements demonstrate that the ECtHR has set up a rather detailed set of requirements and conditions for domestic legislation to be in accordance with the law pursuant to Article 8, section 2 of the ECHR. Even though the ECtHR refers primarily to measures of secret surveillance (of communications), case law shows that this set of requirements also applies in the case of the power to retain samples and fingerprints and in the case of secret gathering of information or other surveillance activities. The ECtHR fails to specify what procedural powers are not governed by the rule that 'laws' comprising powers that interfere with the right to privacy must be particularly precise (when applied during the pro-active phase). With respect to procedural powers to counter terrorism, it is also important to keep in mind the Guidelines on human rights and the fight against terrorism which, in general, prohibit arbitrariness (Guideline $\mathrm{II}^{786}$ ) and underline the importance of lawful anti-terrorism measures (Guideline III $^{787}$ ).

The six conditions mentioned above must be comprised in statutory law, but the practical interpretation may, in part, be deduced from case law or other secondary law sources. That may diminish the effectiveness of these conditions in grading up the quality of national legislation that interferes with citizens' privacy. Nevertheless, some careful 'guidelines' can be deduced from the above-discussed case law, which are of importance with respect to the powers comprised in Title VB of the DCCP.

First of all, the larger the scope of a power is, the more precisely the discretionary power for the Executive must be specified in statutory law. The law must indicate the scope of any discretion conferred on the competent authorities, and the manner of its exercise, with sufficient clarity, having regard to the legitimate aim of the measure in question. Powers for the Executive may never be unfettered. Secondly, powers that also interfere with non-suspected citizens' private life must provide for particular rules in that respect. Thirdly, the application of powers that interfere with the private life must (preferably) be ordered by a judicial authority and be monitored and examined afterwards also by a judicial authority. Fourthly, the more intrusive a power is, and the further into the pro-active phase it is applied, the more precise the laws that grant such powers must be. In this respect, it is important to note that the

785 Segerstedt-Wiberg and Others v. Sweden, appl. no. 62332/00, 6 June 2006, §79-80.

786 Guideline II reads: 'All measures taken by states to fight terrorism must respect human rights and the principle of the rule of law, while excluding any form of arbitrariness as well as any discriminatory or racist treatment and must be subject to appropriate supervision.'

787 Guideline III reads: '(1) All measures taken by States to combat terrorism must be lawful and (2) When a measure restricts human rights, restrictions must be defined as precisely as possible and be necessary and proportionate to the aim pursued.' 
ECtHR has discerned an overlap between the condition that the categories of persons be specified and the condition that the nature of the offences be clearly defined. The more specifically the law prescribes the nature of the offences, the less specifically the category of persons must be specified. Fifthly, it must be kept in mind that the above-discussed Strasbourg case law primarily regards application of powers on persons suspected of a crime or powers applied to an accused during criminal proceedings. There is no explicit case law available regarding powers applied during the pro-active phase to persons who cannot be considered as suspects yet. That makes it difficult to unequivocally answer the question of whether the provisions comprised in Title VB are of adequate quality to comply with Strasbourg requirements.

\subsubsection{Investigative powers within security risk areas and the law}

In case of investigative powers within security risk areas, primarily the temporary areas, several more specific problems arise. Are the limits to the use of these powers sufficient to answer a challenge that the right to privacy of the person who is searched is being violated because its use is unforeseeable and may therefore be arbitrary? Does the law adequately define who or what may be investigated, on the basis of which facts or information? The only requirement that Articles 126zq, $126 \mathrm{zr}$ and 126zs of the DCCP provide is that application of the investigative powers must be in the interest of the investigation. The decision of whether a search is in the interest of the investigation is left to the discretion of the investigative officers.

The first indication for members of the public that they are liable to be stopped and searched is when the order to stop is given. Those who are well-informed may get some indication as to what is afoot when they see the police with bundles of forms in their hands looking in their direction. But for most people, the order to stop will come as a surprise. In this respect, one needs to discern between temporary security risk areas and permanent security risk areas. By royal decree, the permanent security risk areas are made public. Security risk areas ordered by the public prosecutor are not, however, made public.

In Gillan and Quinton v. the United Kingdom, the ECtHR passed judgement on the police power to stop and search at random, where expedient, to prevent acts of terrorism. ${ }^{788}$ The relevant legislation empowers senior police officers to authorise any constable in uniform to stop a vehicle in an area or at a place specified in the authorisation, and to search the vehicle, the driver of the vehicle, a passenger in the vehicle, or anything in or on the vehicle or carried by the driver or a passenger, without a reasonable suspicion. Secondly, such an authorisation may empower any

788 Gillan and Quinton v. the United Kingdom, appl. no. 4158/05, 12 January 2010. In the United Kingdom, the powers examined in this judgement are often described as the power of random search or intuitive stops, requiring for its exercise no reasonable suspicion of wrongdoing. See $\S 23$. 
constable in uniform to stop a pedestrian in an area or at a place specified in the authorisation, and to search the pedestrian and anything carried by him, without a reasonable suspicion. ${ }^{789}$

This legislation, hence, dispensed with the condition of a reasonable suspicion, and therewith departs from the normal rule applicable, where a constable exercises a power to stop and search. The UK alleged that it serves to ensure that a constable is not deterred from stopping and searching a person whom he does suspect as a potential terrorist, by the fear that he could not show reasonable grounds for his suspicion. ${ }^{790}$ A Code of Practice was issued by the Secretary of State to guide police officers and constables in the exercise of all statutory powers of stop and search. It is required to be readily available at all police stations for consultation by police officers and constables and is a public document. The Code requires, inter alia, that the powers be 'used fairly, responsibly, with respect to people being searched'. It requires also that the power 'must not be used to stop and search for reasons unconnected with terrorism' and that the power should be used 'to search only for articles which could be used for terrorist purposes' ${ }^{9}{ }^{71}$ Searches take place in public, ${ }^{792}$ and failure to submit to them amounts to an offence punishable by imprisonment, a fine, or both.

The legislation is said to provide for several safeguards. A senior officer may only give an authorisation if that is considered to be expedient 'for the prevention of acts of terrorism'. The authorisation must be directed to that objective. The authorisation may be given only by a very senior police officer. Also, the authorisation cannot extend beyond the boundary of a police force area, and need not extend so far, and is limited to a period of 28 days. Furthermore, the authorisation must be reported to the Secretary of State forthwith and the authorisation lapses after 48 hours, if not confirmed by the Secretary of State. Additionally, the Secretary of State may abbreviate the term of an authorisation, or cancel it with effect from a specified time. A subsequent renewed authorisation is subject to the same confirmation procedure. A further safeguard is that the powers conferred on a constable by an authorisation may only be exercised to search for articles of a kind which could be used in connection with terrorism. These powers may, however, be exercised whether or not the constable had grounds for suspecting the presence of articles of that kind. Parliament made provision for reports on the working of the Act to be made to it at least once a year, which has, in the event, been made. Lastly, any

\footnotetext{
789 Gillan and Quinton v. the United Kingdom, appl. no. 4158/05, 12 January 2010, §30-35.

790 Gillan and Quinton v. the United Kingdom, appl. no. 4158/05, 12 January 2010, §16 and 21.

791 Gillan and Quinton v. the United Kingdom, appl. no. 4158/05, 12 January 2010, §35-37.

792 Gillan and Quinton v. the United Kingdom, appl. no. 4158/05, 12 January 2010, §63. The ECtHR underlined, in this respect, that the public nature of the search may, in certain cases, compound the seriousness of the interference, because of an element of humiliation and embarrassment. Items such as bags, wallets, notebooks and diaries may, moreover, contain personal information, which the owner may feel uncomfortable about having exposed to the view of his companions or the wider public.
} 
misuse of the power to authorise or confirm or search will expose the authorising officer, the Secretary of State or the constable, as the case may be, to corrective legal action. ${ }^{793}$

This case concerned two applicants who had both been subjected to these preventive searching powers during a Defence Systems and Equipment International Exhibition ('the arms fair'). The first applicant was stopped and searched by two police officers who told him he was being searched for articles which could be used in connection with terrorism. He was handed a notice to that effect. He was apparently stopped because a lot of protesters were about and the police were concerned that they would cause trouble. Nothing incriminating was found (although computer printouts giving information about the demonstration were seized by the officers), and the first applicant was allowed to go on his way. He was detained for roughly 20 minutes. ${ }^{794}$

The second applicant, wearing a photographer's jacket, carrying a small bag and holding a camera in her hand, was stopped close to the arms fair. She had apparently emerged from some bushes. She was a journalist present in the area to film the protests. She was searched by a police officer, notwithstanding that she showed her press cards to show who she was. She was told to stop filming. Nothing incriminating was found and she was allowed to go on her way after 30 minutes. ${ }^{795}$

The applicants' complaints were focused on the general compatibility of the stop and search powers with Articles 5, 8, 10 and 11 of the ECHR. They did not, hence, seek to challenge whether the authorisation which applied to them was justified in view of the intelligence available to the Metropolitan Police Commissioner and the Secretary of State, nor whether the constables stopped them 'for the purpose of searching for articles of a kind which could be used in connection with terrorism'. 796 Taking into account the resemblance of the UK stop and search powers with the Dutch system of investigative powers in security risk areas, the ECtHR's considerations are important, and need to be discussed thoroughly.

To start with, in the ECtHR's view, the above-mentioned safeguards, provided for by UK law, have not been demonstrated to constitute a real curb on the wide powers afforded to the Executive so as to offer the individual adequate protection against arbitrary interference. The relevant legislation confers a wide discretion on the police, both in terms of the authorisation of the power to stop and search and its application in practice. ${ }^{797}$

\footnotetext{
793 Gillan and Quinton v. the United Kingdom, appl. no. 4158/05, 12 January 2010, §16. See, for further rules regarding the application of the powers, $\$ 35-37$.

794 Gillan and Quinton v. the United Kingdom, appl. no. 4158/05, 12 January 2010, §8.

795 Gillan and Quinton v. the United Kingdom, appl. no. 4158/05, 12 January 2010, §9.

796 Gillan and Quinton v. the United Kingdom, appl. no. 4158/05, 12 January 2010, §51 and 52.

797 Gillan and Quinton v. the United Kingdom, appl. no. 4158/05, 12 January 2010, §79.
} 
Secondly, the ECtHR underlined that the senior police officer is empowered to authorise any constable in uniform to stop and search a pedestrian in any area specified by him, within his jurisdiction, if he 'considers it expedient for the prevention of acts of terrorism'. 'Expedient' means no more than 'advantageous' or 'helpful' in this context. There is, hence, no requirement at the authorisation stage that the stop and search power be considered 'necessary' and therefore no requirement of any assessment of the proportionality of the measure. Even though the authorisation is subject to confirmation by the Secretary of State within 48 hours, he is not allowed to alter the geographical coverage of an authorisation and although he can refuse confirmation or substitute an earlier time of expiry, it appears that in practice this has never been done. In sum, although the exercise of the powers of authorisation, and confirmation is subject to judicial review, the width of the statutory powers is such that applicants face formidable obstacles in showing that any authorisation and confirmation are beyond the authorities' power or an abuse of power. ${ }^{798}$

Furthermore, the fact that an authorisation for the Metropolitan Police District has been continuously renewed on a 'rolling programme basis' since the powers were first granted, demonstrates the failure of the statutory temporal and geographical restrictions to act as any real check on the issuing of authorisations by the Executive. ${ }^{799}$

In the ECtHR's view, of still further concern is the breadth of the discretion conferred on the individual police officer/constable. The officer/constable is obliged, in carrying out the search, to comply with the terms of the Code of practice. However, the Code of practice essentially governs the mode in which the stop and search is carried out, rather than providing any restriction on the officer's decision to stop and search. That decision is one based exclusively on the 'hunch' or 'professional intuition' of the officer/constable concerned. Not only is it unnecessary for him to demonstrate the existence of any reasonable suspicion, he is not required even subjectively to suspect anything about the person stopped and searched. The sole proviso is that the search must be for the purpose of looking for articles that could be used in connection with terrorism, a very wide category which could cover many articles commonly carried by people in the streets. Provided the person concerned is stopped for the purpose of searching for such articles, the police officer/constable does not even have to have grounds for suspecting the presence of such articles. 800

In relation to this, the ECtHR was struck by the statistical and other evidence showing the extent to which by police officers/constables had resorted to the powers of stop and search under section 44 of the Act. The Ministry of Justice recorded a

798 Gillan and Quinton v. the United Kingdom, appl. no. 4158/05, 12 January 2010, §80.

799 Gillan and Quinton v. the United Kingdom, appl. no. 4158/05, 12 January 2010, §81.

800 Gillan and Quinton v. the United Kingdom, appl. no. 4158/05, 12 January 2010, §83. 
total of 33.177 searches in 2004/5, 44.545 in 2005/6, 37.000 in 2006/7 and 117.278 in $2007 / 8$. None of the many thousands of searches had ever related to a terrorism offence. Examples of poor and unnecessary use of the stop and search powers were abound, there being evidence of cases where the person stopped was so obviously far from any known terrorism profile that, realistically, there was not the slightest possibility of him being a terrorist, or having any other feature to justify the stop. ${ }^{801}$

These considerations led the ECtHR to conclude that there is a clear risk of arbitrariness in the grant of such a broad discretion to the police officer/constable. In addition, the risk of the discriminatory use of the powers is a very real consideration. The available statistics show that black and Asian persons have been disproportionately affected by the powers. There has also been a practice of stopping and searching white people purely to produce greater racial balance in the statistics. There is, furthermore, a risk that such a widely framed power could be misused against demonstrators and protestors. In particular, in the absence of any obligation on the part of the officer/constable to show a reasonable suspicion, it is likely to be difficult, if not impossible, to prove that the power was improperly exercised. In conclusion, the ECtHR held that the powers of authorisation and confirmation, as well as those of stop and search, are neither sufficiently circumscribed, nor subject to adequate legal safeguards against abuse. They are not, therefore, 'in accordance with the law'. 802

IN SUM

This judgement demonstrates again that the ECtHR attaches particular importance to: (1) the question of whether powers that interfere with citizens' privacy are adequately specified in domestic legislation, and (2) the question of whether there are sufficient safeguards to prevent arbitrariness in the application of such powers. The essence of the judgement is the relationship between these two aspects: the connection between clearly defined legal provisions and effective counterbalancing safeguards, including judicial control on the enforcement of such provisions. The wider the powers are, the more difficult it will be for the Judiciary to examine whether the powers have been applied lawfully. Hence, the effectiveness of judicial control diminishes progressively in the case of broad legal provisions while such provisions particularly demand extra judicial control. In this case, due to the broadly defined power: (1) for the senior police officer to give an authorisation and (2) for a constable to use his stop and search power, adequate examination by the Judiciary was impossible. 
So, despite the safeguards provided for under UK law, the factual power of a senior officer to give an authorisation and the power of police officers/constables to use their stop and search powers, were not sufficiently restricted by law. If these respective powers had been restricted by law, Strasbourg conform control would have been feasible, both during the authorisation stage and during the stop and search stage. In this respect, it is interesting to note that the ECtHR explicitly underlined that the general requirement of having a reasonable suspicion (against the person who is searched) is a key safeguard to prevent arbitrariness.

It goes without saying that the UK stop and search powers are comparable to the investigative powers within security risk areas pursuant to Articles 126zq, 126r and $126 \mathrm{~s}$ of the DCCP. Both in terms of the power to appoint an area as a security risk area and the power to use the stop and search/investigative powers, the similarities are striking. Most important is that in both systems the police officers are empowered to apply the stop and search/investigative powers without a reasonable suspicion.

The difference between the UK system and the Dutch system is primarily textual and regards (1) the length of an authorisation (28 days in the UK, and 12 hours and permanently, in the Netherlands); (2) the competent authority (senior police officer and the Secretary of State in the UK, and the public prosecutor or a royal decree, in the Netherlands); (3) the basis for an authorisation (expedient 'for the prevention of acts of terrorism' in the UK, and indications of a terrorist offence, in the Netherlands); (4) the basis for a stop and search (to search for articles of a kind which could be used in connection with terrorism in the UK, and the interest of the investigation, in the Netherlands).

However, the two main issues which led the ECtHR to finding a violation of Article 8 of the ECHR in Gillan and Quinton v. the United Kingdom are very much the same in UK law and Dutch law: both law systems include wide discretionary powers for the Executive to decide: (1) if an authorisation should be given, and (2) if the stop and search powers should be used. In addition, both systems comprise a limited possibility for the Judiciary to control the lawfulness of the Executive's use of these discretionary powers.

\subsubsection{The exploratory inquiry and the law}

The exploratory inquiry into terrorist offences primarily raises problems due to the broad scope of the notion 'data files' pursuant to Article 126h of the DCCP. This provision does not specify what kind of data files may be gathered during an exploratory inquiry into terrorism. Considerations regarding the broad notion of 'indications of a terrorist offence', as described above, equally apply. Strasbourg case law regarding the collection and gathering of information by the investigative authorities to prepare a criminal investigation does not exist. Therefore, the 
following cases can only, in part, provide an answer to the question of whether Article $126 \mathrm{hh}$ complies with Strasbourg conditions regarding qualitative requirements for legislation.

Amann v. Switzerland

In Amann v. Switzerland (see further above Section 8.1.1) the ECtHR underlined the importance of specifying (in law) what kind of information may be gathered and stored. In this case, the Swiss Public Prosecutor's Office drew up a card on the applicant, for its national security card index, on the basis of particulars provided by the police. In the applicant's case, the card had been created following the interception of a telephone call he had received from a person at the former Soviet embassy in Berne.

When the public learned of the existence of the card index being kept by the Public Prosecutor's Office, many people, including the applicant, asked to consult their card. The special officer in charge of the Confederation's national security documents sent the applicant, at his request, a photocopy of his card. ${ }^{803}$ Some passages, had, however, been blacked-out.

The ECtHR considered that the legal basis for creating the card only included some general principles, for example that 'there must be a legal basis for the processing of personal data' or that 'personal data may be processed only for very specific purposes'. However, the relevant provisions did not contain any appropriate indication as to the scope and conditions of exercise of the power conferred on the Public Prosecutor's Office to gather, record and store information. The legislation did not specify the conditions under which cards could be created, the procedures that had to be followed, and the information that could be stored or comments that were forbidden. ${ }^{804}$ The ECtHR concluded that Swiss law did not indicate with sufficient clarity the scope and conditions of exercise of the authorities' discretionary power.

Therefore, both the creation of the card by the Public Prosecutor's Office and the storing of it in the Confederation's card index amounted to interference with the applicant's private life that could not be considered to be 'in accordance with the law'.

Rotaru v. ROMANIA

The case of Rotaru v. Romania concerned a retired lawyer who had been sentenced in 1948 (during the Communist regime) to one-year imprisonment on account of 
insulting behaviour. ${ }^{805}$ After the Communist regime had been overthrown, the new government issued a decree that granted certain rights to those who had been prosecuted by the Communist regime and who had not, moreover, engaged in any fascist activities. On the basis of that decree, Rotaru lodged proceedings to have the prison sentence that had been imposed on him taken into account in the calculation of his length of service at work. Also, he sought payment of the corresponding retirement entitlements. During these proceedings, the Ministry of the Interior used information from the Romanian Intelligence Service (RIS). ${ }^{806}$

That (damaging) information was false according to Rotaru, and besides, the RIS should never have possessed it, passed it on to the Ministry of the Interior, which, in turn, should never have made it public by introducing it as evidence during his trial. ${ }^{807}$ During the proceedings it appeared that the RIS had made a 'regrettable mistake', and that the incriminating information was, indeed, false and concerned someone else. ${ }^{808}$

Rotaru complained before the ECtHR that the RIS still held the incriminating information and could use it at any time, even if some of it was false and defamatory. He therefore alleged a violation of Article 8 of the ECHR.

Although, as the ECtHR considered, Romanian law did indeed provide a clearly accessible legal basis for storing private information and subsequently passing it on

805 Rotaru v. Romania, 4 May 2000, appl. no. 28341/95, §7-9. In 1948 Rotaru was refused permission by the prefect of the county he lived in to publish two pamphlets, 'Student Soul' and 'Protests', on the ground that they expressed anti-government sentiments. Dissatisfied with that refusal, the applicant wrote two letters to the prefect in which he protested against the abolition of freedom of expression by the new people's regime. Thereupon he was arrested and sentenced to one year imprisonment.

806 Rotaru v. Romania, 4 May 2000, appl. no. 28341/95, §7-25. It is important to see that this judgement concerns data collection and processing by the secret intelligence services, instead of by the investigative authorities. This difference will further be elaborated on below.

807 Rotaru v. Romania, 4 May 2000, appl. no. 28341/95, §10-15. The information consisted of several claims: (1) during his studies in the Faculty of Sciences, Rotaru was a member of the Christian Students' Association, (2) in 1946 he applied for permission to publish two pamphlets enTitled 'Student Soul' and 'Protests' but his request was turned down because of the antigovernment sentiments expressed in them, (3) he belonged to the youth section of the National Peasant Party, as appears from a statement he made in 1948, (4) he has no criminal record and, contrary to what he maintains, was not imprisoned during the period he mentions and (5) in 1946-48 he was summoned by the security services on several occasions because of his ideas and questioned about his views.

808 The contention that Rotaru had been a legionnaire was false, in that they probably related to someone else with the same name. Rotaru v. Romania, 4 May 2000, appl. no. 28341/95, $\$ 24$. The ECtHR considered in Bensaid v. the United Kingdom that not every act or measure that adversely affects moral or physical integrity interferes with the right to privacy guaranteed by Article 8 of the ECHR. However, the ECtHR's case law does not exclude that treatment which does not reach the threshold of severity required under Article 3 of the ECHR, may, nonetheless, breach Article 8 of the ECHR in its private life aspect where there are sufficiently adverse effects on physical and moral integrity. See, Bensaid v. the United Kingdom, appl. no. 44599/98, 6 February $2001, \S 46$. 
to the Ministry of Interior, this legislation was not, however, sufficiently foreseeable as to its effects.

First of all, the legislation did not define the kind of information that could be recorded, the categories of people against whom surveillance measures, such as gathering and keeping information could be taken, the circumstances under which such measures could be taken, or the procedure to be followed. Secondly, the law did not lay down limits on the age of information held, or the length of time for which it could be kept. Lastly, the ECtHR noted that the legislation lacked any explicit, detailed provision concerning the persons authorised to consult the files.

In sum, Romanian law was insufficiently precise as to the nature of the files that could be collected, the procedure to be followed, and the use that could be made of the information accordingly obtained. That being so, the ECtHR concluded that Romanian legislation did not indicate with reasonable clarity the scope and manner of exercise of the relevant discretion conferred on the public authorities. Consequently, the interference with Rotaru's private life was not 'in accordance with the law'. 809

\section{LEANDER V. SWEDEN}

The applicant in Leander v. Sweden ${ }^{810}$ (Leander) was a Swedish citizen who started to work as a temporary replacement as museum technician at a Naval Museum. The museum was adjacent to a Naval Base, which is a restricted military security zone. After two weeks work Leander was told to leave his work pending the outcome of a personnel control that had to be carried out on him by the National Police Board. This Board had the power: (1) to collect and store, in registers not accessible to the public, information on persons, and (2) to use this information when assessing the suitability of candidates for employment in posts of importance to national security. As Leander needed access to the restricted military security zone and obtained insight into secret activities, this personnel control was compulsory for his work. The outcome of the personnel control was that it appeared that Leander posed a threat to national security, and he therefore lost his job at the Museum. He was not allowed access to the secret information leading to his being considered a threat to national security. ${ }^{811}$ Leander complained to the ECtHR that he had been prevented

809 Rotaru v. Romania, 4 May 2000, appl. no. 28341/95, §60-63.

810 Leander v. Sweden, appl. no. 9248/81, 26 March 1987.

811 Leander v. Sweden, appl. no. 9248/81, 26 March 1987, §9-18. Leander himself declared, however, that at the relevant time, he had not belonged to any political party for three years. He had previously been a member of the Swedish Communist Party. He had been a member of an association publishing a radical review. During his military service, 8 years earlier, he had been active in the soldiers' union and a representative at the soldiers' union conference, which, according to him, had been infiltrated by the security police. His only criminal conviction stemmed from his time in military service and consisted of a fine of 10 Swedish Crowns for having been late for a military parade. He had also been active in the Swedish Building Workers' 
from obtaining employment on account of secret information. This amounted to an attack on his reputation and he ought to have had an opportunity to defend himself properly before a tribunal. ${ }^{812}$

In this case, the ECtHR concluded that Swedish law did provide an adequate legislative basis for the personal control. The legislation prescribed a detailed procedure which gave citizens a sufficient indication as to the scope and the manner of exercise of the discretion conferred on the responsible authorities to collect, record and release information under the personnel control system. The National Police Board had a wide discretion as to what information could be entered in their police-registers. Nevertheless, this rather wide discretion was subsequently limited by a ruling that "no entry is allowed merely for the reason that a person, by belonging to an organisation or by other means, has expressed a political opinion'. In addition, the Board's discretion, in this connection, was circumscribed by instructions issued by the government. Furthermore, the entering of information to the secret police register was also subject to the requirements that the information be necessary for the special police service, and be intended to serve the purpose of preventing or detecting 'offences against national security'. Lastly, the legislation contained explicit and detailed provisions as to what information could be handed out, the authorities to which information could be communicated, the circumstances under which such communication could take place and the procedure to be followed by the National Police Board when taking decisions to release information. ${ }^{813}$

\section{IN SUM}

Even though the legislation that is discussed in these judgements is not completely comparable to Articles 126h and 126ii of the DCCP, these judgements demonstrate that the ECtHR does attach importance to the question of whether legislation adequately prescribes what kind of information the Executive may demand. Article 126ii of the DCCP does explicitly prescribe that investigative officers are allowed to request identifying information, the notion of which is further clarified in the parliamentary memoranda. Both Article 126hh and 126ii of the DCCP prescribe, in detail, the procedure that the public prosecutor must follow to lawfully open an exploratory inquiry and to demand data files. However, Article 126hh of the DCCP fails to specify (in part) the scope and conditions of the exercise of the power, and specifically the information that can be demanded from third parties. The notion of data files is broad and is only specified by the requirement that demanding data files must be in the interest of the investigation. Furthermore, the

Association and he had travelled a couple of times in Eastern Europe. According to unanimous statements by responsible officials, none of the above-mentioned circumstances should have been the cause for the unfavourable outcome of the personnel control.

812 Leander v. Sweden, appl. no. 9248/81, 26 March 1987, §45.

813 Leander v. Sweden, appl. no. 9248/81, 26 March 1987, §53-59. 
purpose of demanding such files is wide as well, i.e. the preparation of criminal investigation into terrorist offences. In practice, the public prosecutor is allowed to request any data file that may (potentially) contribute to the preparation of a criminal investigation into terrorist offences. Results of the processing of such data files may be used for ensuing criminal investigations. ${ }^{814}$

\subsubsection{Effective and adequate safeguards}

In several judgements, the ECtHR has emphasised that part of a state's duty to act 'in accordance with the law' is the duty to provide for adequate and effective safeguards against abuse. ${ }^{815}$ Especially in the context of secret measures of surveillance by public authorities, because of the lack of public scrutiny and the risk of abuse of power, the domestic law must provide protection against arbitrary interference with Article 8 of the ECHR ${ }^{816}$ These safeguards must be established by law and enable the monitoring of the competent services' activities. ${ }^{817}$ Supervision procedures must:

'(...) follow the values of a democratic society as faithfully as possible, in particular the rule of law, which is expressly referred to in the Preamble to the Convention. The rule of law implies, inter alia, that interferences by the Executive authorities with an individual's rights should be subject to effective supervision, which should normally be carried out by the Judiciary, at least in the last resort, since judicial control affords the best guarantees of independence, impartiality and a proper procedure. ${ }^{, 818}$

814 See Article $126 \mathrm{hh}$, sections 5 and 6 of the DCCP.

815 The issue of whether there are adequate effective safeguards against abuse and sufficient judicial control is, in some cases, also examined under the requirement that interferences with the right to privacy must be necessary in a democratic society (the proportionality principle). See, for example, Camenzind v. Switzerland, appl. no. 136/1996/755/954, 16 December 1997, §45; the ECtHR considered, with respect to the proportionality principle, that it ' (...) must firstly ensure that the relevant legislation and practice afford individuals 'adequate and effective safeguards against abuse' (ibid.); 'notwithstanding the margin of appreciation which the ECtHR recognises the Contracting States have in this sphere, it must be particularly vigilant where, as in the present case, the authorities are empowered under national law to order and effect searches without a judicial warrant. If individuals are to be protected from arbitrary interference by the authorities with the rights guaranteed under Article 8, a legal framework and very strict limits on such powers are called for (...)'. In this book, the issue of sufficient adequate safeguards will, however, be discussed as part of a state's duty to act in accordance with the law.

816 The Association for European Integration and Human Rights and Ekimdzhiev v. Bulgaria, appl. no. 62540/00, 28 June 2007, §76. See, also, Klass and Others v. Germany, appl. no. 5029/71, 6 September 1978, §54-56; Leander v. Sweden, appl. no. 9248/81, 26 March 1987, §25-27; decision as to the admissibility in Weber and Saravia v. Germany, appl. no. 54934/00, 29 June 2006, $\$ 94$.

817 Halford v. the United Kingdom, appl. no. 20605/92, 25 June 1997, §48-52. See, also, Antunes Rocha c. Portugal, requête $\mathrm{n}^{\circ}$ 64330/01, 31 mai 2005, §71-81.

818 Rotaru v. Romania, 4 May 2000, appl. no. 28341/95, §59. And, see, Klass and Others v. Germany, appl. no. 5092/71, 6 September 1978, §55-56, where the ECtHR argued that ' $(. .$.$) in a field where$ 
To verify if there are adequate and effective safeguards, all circumstances are taken into account, such as: (1) the nature, scope and duration of the material measures, ${ }^{819}$ (2) the grounds required for ordering them, ${ }^{820}$ (3) the authorities competent to permit, carry out and supervise them, and (4) the kind of remedy provided for by domestic law. ${ }^{821}$ In addition, the six conditions discussed in the previous section (8.1.1) should be complied with in order to minimise the risk of arbitrary application of measures of secret surveillance. As the obligation to provide adequate and effective safeguards forms part of the concept of lawful interferences, this issue has partly been discussed already. ${ }^{822}$ This section will therefore only elaborate on three more judgements in which the ECtHR extensively discussed the safeguards that should be provided in order to act in accordance with the law.

At the end of this section some more remarks will be made regarding the interaction between broadly defined legal provisions and the need for adequate and effective guarantees against abuse. Can such safeguards counterbalance potential legal uncertainty caused by broadly defined state powers?

abuse is potentially so easy in individual cases and could have such harmful consequences for democratic society as a whole, it is in principle desirable to entrust supervisory control to a judge.'

819 See, for example, Uzun v. Germany, appl. no. 35623/05, 2 September 2010, §66, in which the ECtHR considered that: ' $(. .$.$) these rather strict standards, set up and applied in the specific$ context of surveillance of telecommunications are not applicable as such to cases such as the present one, concerning surveillance via GPS of movements in public places and thus a measure which must be considered to interfere less with the private life of the person concerned than the interception of his or her telephone conversations. It will therefore apply the more general principles on adequate protection against arbitrary interference with Article 8 rights as summarised above.'

820 C.G. v. Bulgaria, appl. no. 1365/07, 24 April 2008, \$46-50; Iordachi and Others v. Moldova, appl. no. 25198/02, 10 February 2009, §44, in which the ECtHR considered: '(...) Still, the nature of the offences which may give rise to the issue of an interception warrant is not, in the ECtHR's opinion, sufficiently clearly defined in the impugned legislation. In particular, the ECtHR notes that more than one half of the offences provided for in the Criminal Code fall within the category of offences eligible for interception warrants. Moreover, the ECtHR is concerned by the fact that the impugned legislation does not appear to define sufficiently clearly the categories of persons liable to have their telephones tapped. It notes that Article $156 \S 1$ of the Criminal Code uses very general language when referring to such persons and states that the measure of interception may be used in respect of a suspect, defendant or other person involved in a criminal offence. No explanation has been given as to who exactly falls within the category of 'other person involved in a criminal offence'.

821 The Association for European Integration and Human Rights and Ekimdzhiev v. Bulgaria, appl. no. 62540/00, 28 June 2007, §76. See, also, Uzun v. Germany, appl. no. 35623/05, 2 September 2010, §63; Vetter c. France, requête no 59842/00, 31 mai 2005, §25-28.

822 See Section 8.1.1, for a discussion of Kennedy v. the United Kingdom, appl. no. 26839/05, 18 May 2010. 
The Association for European Integration and Human Rights and Ekimdzhiev v. Bulgaria

In The Association for European Integration and Human Rights and Ekimdzhiev v. Bulgaria, the ECtHR elaborated extensively on the question of whether Bulgarian law regarding measures of secret surveillance contains adequate guarantees to prevent abuse. ${ }^{823}$ Under Bulgarian law, measures of secret surveillance may be used to prevent or uncover serious offences or to protect national security. They may only be used if there are grounds to suspect that a serious offence is being planned, or is being, or has been, committed. However, these latter requirements apply only with regard to combating criminal conduct, not in the case of protecting national security.

Surveillance is allowed only pursuant to a written application giving reasons, which may be made solely by the heads of certain state services. The application must identify the persons or objects to be placed under surveillance. It must also set out the grounds for suspecting these persons of planning, or committing, or having committed, an offence. Finally, the application must specify the duration of the proposed surveillance and the methods to be used, as well as all previous investigative steps.

The warrant authorising the surveillance can be issued only under the hand of the President or the Vice-President of a regional court, a military regional court, or a court of appeal. This judicial authorisation must, in principle, ${ }^{824}$ be given before the surveillance has taken place. It must also, as a rule, be followed by an order of the Minister of Internal Affairs or a specifically designated deputy. Surveillance may be authorised for a maximum of two months. This time limit may be extended, up to six months, only pursuant to a fresh application and warrant. ${ }^{825}$

The applicants did not claim that surveillance measures had, in fact, been ordered or implemented against them, or that they had been indirectly involved in a surveillance measure directed against other persons. They primarily conceded that even though there is domestic legislation regarding measures of secret surveillance, that legislation is inadequate to justify interferences with the private life, in

823 The Association for European Integration and Human Rights and Ekimdzhiev v. Bulgaria, appl. no. $62540 / 00,28$ June 2007.

824 Exceptions from the procedure outlined above are only possible in urgent cases: the authorisation is then given by the Minister of Internal Affairs or by a specifically designated deputy. However, a judicial warrant must be issued not more than 24 hours after that. This exception is to be used sparingly, and only in duly justified cases. The Association for European Integration and Human Rights and Ekimdzhiev v. Bulgaria, appl. no. 62540/00, 28 June 2007, §16 and 82.

825 The Association for European Integration and Human Rights and Ekimdzhiev v. Bulgaria, appl. no. 62540/00, 28 June 2007, $\$ 7$ and further and 79-84. 
accordance with the law. ${ }^{826}$ In their opinion, there are inadequate effective statutory safeguards and there is insufficient judicial control.

The ECtHR first of all underlined that the Bulgarian system provides substantial safeguards against arbitrary or indiscriminate surveillance during the initial stage of a criminal investigation, when surveillance is being authorised. But only provided that the system is strictly adhered to - in particular, if care is taken not to stretch the concept of 'national security' beyond its natural meaning. ${ }^{827}$ However, the ECtHR then proceeded to examine if such safeguards also exist during the later stages, when the surveillance is actually carried out or has already ended. In that respect, the ECtHR noted several shortcomings.

Firstly, Bulgarian legislation does not provide for any review of the implementation of secret surveillance measures by a body or official that is either external to the services deploying the means of surveillance, or at least required to have certain qualifications ensuring his independence and adherence to the rule of law. On the contrary, all these activities are carried out solely by officers of the Ministry of Internal Affairs. The legislation makes no provision for acquainting the judge who authorised the application of measures of secret surveillance with the results of the surveillance, and does not command him to review whether the requirements of the law have been complied with. ${ }^{828}$

Secondly, there is a lack of regulations specifying, with an appropriate degree of precision, the manner of screening of the intelligence obtained through surveillance, or the procedures for preserving its integrity and confidentiality and the procedures for its destruction.

Thirdly, the ECtHR underlined that the overall control over the system of secret surveillance is entrusted solely to the Minister of Internal Affairs, who not only is a political appointee and a member of the Executive, but is directly involved in the commissioning of special means of surveillance. Control of the system of secret surveillance should be preferably entrusted to independent bodies, such as a special board elected by the Parliament and an independent commission, as was the case in Klass and Others v. Germany. ${ }^{82}$ The manner in which the Minister effects this control is not set out in the law. There is no statute that lays down a procedure governing the Minister's actions in this respect, and the Minister did not issue any

826 The Association for European Integration and Human Rights and Ekimdzhiev v. Bulgaria, appl. no. $62540 / 00,28$ June 2007, $\$ 6$ and 65. See, for information regarding the material legislation, $\S 7$ and further.

827 The Association for European Integration and Human Rights and Ekimdzhiev v. Bulgaria, appl. no. 62540/00, 28 June 2007, §84.

828 The Association for European Integration and Human Rights and Ekimdzhiev v. Bulgaria, appl. no. 62540/00, 28 June 2007, §85.

829 The Association for European Integration and Human Rights and Ekimdzhiev v. Bulgaria, appl. no. 62540/00, 28 June 2007, §86 and 87; Klass and Others v. Germany, appl. no. 5092/71, 6 September 1978, §21, 53 and 56. 
publicly available regulations or instructions on the subject. Moreover, neither the Minister, nor any other official, is required to regularly report to an independent body or to the general public on the overall operation of the system, or on the measures applied in individual cases.

Fourthly, if the intelligence gathered falls outside the scope of the application for the use of special means of surveillance, it is the Minister of Internal Affairs who decides, discretionarily and without any independent control, what is to be done with it.

Fifthly, the ECtHR noted that under Bulgarian law the persons subjected to measures of secret surveillance are not notified of this fact at any point in time and under any circumstances. The fact that persons concerned by such measures are not apprised of them while the surveillance is in progress or even after it has ceased, cannot, by itself, warrant the conclusion that the interference was not justified under the terms of Article 8, section 2 of the ECHR, as it is the very unawareness of the surveillance which ensures its efficacy. However, as soon as notification can be made without jeopardising the purpose of the surveillance after its termination, information should be provided to the persons concerned. ${ }^{830}$

Finally, the ECtHR verified, in so far as the available information permits, whether the shortcomings have an impact on the actual operation of the system of secret surveillance. Here, the ECtHR noted that the Bulgarian Supreme Cassation Prosecutor's Office apparently found, in a report of January 2001, that numerous abuses had taken place. According to this report, more than 10.000 warrants were issued over a period of some 24 months, from 1 January 1999 to 1 January 2001, and that number does not even include the tapping of mobile telephones (for a population of less than 8.000.000). Out of these, only 267 or 269 had subsequently been used in criminal proceedings. A significant number of breaches of the law had been observed. Additionally, in an interview published on 26 January 2001 the then Minster of Internal Affairs conceded that he had signed 4.000 orders for the deployment of means of secret surveillance during his 13 months in office. By contrast, in Malone v. the United Kingdom, the number of the warrants issued was considered relatively low (400 telephone tapping warrants and less than 100 postal warrants annually during the period $1969-79$, for more than 26.428 .000 telephone lines nationwide). ${ }^{831}$

According to the ECtHR, these numbers are telling, even if allowance is made for the development of the means of communication and the rise in terrorist activities in recent years. They also show that the system of secret surveillance in Bulgaria is,

\footnotetext{
830 The Association for European Integration and Human Rights and Ekimdzhiev v. Bulgaria, appl. no. 62540/00, 28 June 2007, §89 and 90.

831 Malone v. the United Kingdom, appl. no. 8691/79, 2 August 1984, §53 and 79.
} 
to say the least, overused, which may in part be due to the inadequate safeguards that the law provides. ${ }^{832}$ In light of these considerations, the ECtHR concludes that Bulgarian law does not provide sufficient guarantees against the risk of abuse. The interference with Article 8 of the ECHR was not, therefore, 'in accordance with the law'.

\section{IORDACHI AND OTHERS v. MOLDOVA}

The case of Iordachi and Others v. Moldava is very much the same as the case of The Association for European Integration and Human Rights and Ekimdzhiev v. Bulgaria. ${ }^{833}$ Also in this case, the ECtHR found a violation of Article 8 of the ECHR, due to the lack of adequate and effective safeguards against abuse. ${ }^{834}$ After a brief discussion of the facts, the most important considerations of the ECtHR will be considered.

The applicants were members of 'Lawyers for Human Rights', a non-governmental organisation specialised in the representation of applicants before the ECtHR. According to the applicants, after the coming to power of the Communist Party, the number of violations of human rights increased considerably. In that context their organisation was created, whose sole purpose was the protection of human rights by assisting persons who sought to introduce applications to the ECtHR. As a result, the applicants considered that they had caused the government serious harm in terms of damage to the government's image and financial loss as a result of the findings of violation in cases they had helped to bring before the ECtHR. They maintained that they ran a serious risk of having their telephones tapped as a result of their activity, due to the state of the legislation in force. ${ }^{835}$ They did not claim to have been victims of any specific interception of their communications, whether by telephone or post, and they had not instituted any domestic proceedings in that respect. ${ }^{836}$

832 The Association for European Integration and Human Rights and Ekimdzhiev v. Bulgaria, appl. no. 62540/00, 28 June 2007, §92. See, also, Iordachi and Others v. Moldova, appl. no. 25198/02, 10 February 2009, $\$ 52$.

833 Iordachi and Others v. Moldova, appl. no. 25198/02, 10 February 2009.

834 Iordachi and Others v. Moldova, appl. no. 25198/02, 10 February 2009, §53-54.

835 They had asked the President of the Supreme Court of Justice for statistical information concerning, inter alia, the number of applications lodged by the investigating bodies with courts for the interception of telephone conversations and the number of successful (granted requests) and unsuccessful (refused requests) applications. The Head of the President's Office of the Supreme Court of Justice replied that in 2005 of a total of 2,609 applications for interception lodged, $98.81 \%$ had been successful; in 2006 of the 1,931 applications lodged, $97.93 \%$ had been successful; and in 2007 of the 2,372 applications lodged, $99.24 \%$ had been successful. Iordachi and Others v. Moldova, appl. no. 25198/02, 10 February 2009, §11-13.

836 Iordachi and Others v. Moldova, appl. no. 25198/02, 10 February 2009, §7-10. 
They submitted that neither legislative regime for the interception of communications satisfied the requirement of foreseeability as neither provided sufficient safeguards against arbitrary interception and abuse.

Firstly, the ECtHR stated that legislation in Moldova prior to 2003 lacked both clarity and detail and did not satisfy the minimum safeguards contained in the relevant Strasbourg case law. There was no judicial control over the grant and application of a measure of interception and, as regards the persons capable of being caught by its provisions, the legislation was very open-ended in its reach. The circumstances in which a warrant of interception could be issued lacked precision. Some major improvements were, however, carried out after $2003 .{ }^{837}$

Regarding the initial stage of the procedure of interception (authorising the surveillance), the ECtHR noted that after 2003 the Moldovan legislation appears to be clearer in respect of the interception of communications of persons suspected of criminal offences. It is made explicit that someone suspected of a serious, very serious, or exceptionally serious, offence, risks, in certain circumstances having the measure applied to him. Moreover, the amended legislation now provides that interception warrants are to be issued by a judge. ${ }^{838}$

As to the second stage of the procedure of interception of telephone communications (the actual carrying out of the surveillance), the ECtHR underlined that the investigating judge plays a very limited role. The law makes no provision for acquainting the investigating judge with the results of the surveillance, and does not require him or her to review whether the requirements of the law have been complied with. ${ }^{839}$

The ECtHR further noted that overall control of the system of secret surveillance is entrusted to the Parliament, which exercises it through a specialised body. However, the manner in which the Parliament effects its control is not set out in the law, nor is there a procedure in place which governs the Parliament's activity in this area.

However, the nature of the offences that may give rise to the issue of an interception warrant is not, in the ECtHR's opinion, sufficiently clearly defined in the impugned legislation. In particular, more than one half of the offences provided for in the Moldovan Criminal Code fall within the category of offences eligible for interception warrants. Moreover, the impugned legislation does not appear to define sufficiently clearly the categories of persons liable to have their telephones tapped. The legislation at issue uses very general language when referring to such persons, and states that the measure of interception may be used in respect of 'a suspect, defendant or other person involved in a criminal offence'. No explanation has been given as to who exactly falls within the category of 'other person involved in a

\footnotetext{
837 Iordachi and Others v. Moldova, appl. no. 25198/02, 10 February 2009, §41.

838 Iordachi and Others v. Moldova, appl. no. 25198/02, 10 February 2009, §43.

839 Iordachi and Others v. Moldova, appl. no. 25198/02, 10 February 2009, §47.
} 
criminal offence'. ${ }^{840}$ Also, it is unclear under the impugned legislation who - and under what circumstances - risks having the measure applied to him. ${ }^{841}$

Furthermore, the legislation in question does not provide for a clear limitation in time of a measure authorising interception of telephone communications. While the Criminal Code imposes a limitation of six months, there are no provisions that would prevent the prosecution authorities from seeking and obtaining a new interception warrant after the expiry of the statutory six-month period. ${ }^{842}$

Lastly, and most important, the ECtHR drew attention to the fact that in 2007 the Moldovan courts authorised virtually all the requests for interception made by the prosecuting authorities. In that light, the ECtHR stressed that telephone tapping is a very serious interference with a person's rights and that only very serious reasons based on a reasonable suspicion that the person is involved in serious criminal activity should be taken as a basis for authorising it. Moldovan legislation does not elaborate on the degree of reasonableness of the suspicion against a person for the purpose of authorising an interception. Nor does it contain safeguards other than requiring that interception should take place only when it is otherwise impossible to achieve the aims. This is a matter of concern to the ECtHR when looked at against the very high percentage of authorisations issued by investigating judges. This could reasonably be taken to indicate that the investigating judges do not address themselves to the existence of compelling justification for authorising measures of secret surveillance. ${ }^{843}$

\section{UZUn V. GERMANY}

The case of Uzun v. Germany concerned an applicant (Uzun) who had been subjected to several secret measures of surveillance, among which, was surveillance by GPS. ${ }^{844} \mathrm{He}$ claimed before the ECtHR that the legal basis for this GPS surveillance did not comply with the qualitative conditions for domestic legislation. The ECtHR elaborated considerably on the question of whether there are sufficient and effective safeguards included in the relevant provisions.

Firstly, the ECtHR underlined that in its nature conducting surveillance of a person by installing a GPS receiver into the car he uses, coupled with visual surveillance of that person, permits the authorities to track that person's movements in public places when he is travelling in that car. Under German legislation, there was no fixed

\footnotetext{
840 Iordachi and Others v. Moldova, appl. no. 25198/02, 10 February 2009, $\$ 44$.

841 Iordachi and Others v. Moldova, appl. no. 25198/02, 10 February 2009, $\$ 46$.

842 Iordachi and Others v. Moldova, appl. no. 25198/02, 10 February 2009, $\S 45$.

843 Iordachi and Others v. Moldova, appl. no. 25198/02, 10 February 2009, §51.

844 Uzun v. Germany, appl. no. 35623/05, 2 September 2010. See, for a more elaborate discussion of the facts of this case, Section 8.2 on the necessity requirement.
} 
statutory limit on the duration of such monitoring. ${ }^{845}$ However, the ECtHR was satisfied that the duration of such a surveillance measure was examined on its proportionality, in the circumstances, by the prosecution and by the domestic courts. On that account, German law therefore provided sufficient guarantees against abuse. ${ }^{846}$

With regard to the grounds required for ordering a person's surveillance through GPS under German law, such surveillance could only be ordered against a person suspected of a criminal offence of considerable gravity or, in very limited circumstances, against a third person suspected of being in contact with the accused, and if other means of detecting the whereabouts of the accused had less prospect of success or were more difficult. The ECtHR considered that in this respect, there were quite strict standards for authorising surveillance through GPS. ${ }^{847}$

As to the judicial control provided for, the prosecution was able to order a suspect's surveillance through GPS, which was carried out by the police. Even though control by an investigative judge is preferable, the ECtHR noted that under the provisions in force at the relevant time, surveillance via GPS had not been removed from judicial control. In subsequent criminal proceedings against the person concerned, the criminal courts could review the legality of such a measure of surveillance and, in the event that the measure was found to be unlawful, had discretion to exclude the evidence thereby obtained from use at the trial. ${ }^{848}$ Such (post facto) judicial review and the possibility of excluding evidence obtained from an illegal GPS surveillance constituted an important safeguard, as it discouraged the investigating authorities from collecting evidence by unlawful means.

The ECtHR considered this to offer sufficient protection against arbitrariness. This consideration must, however, be seen in light of the fact that GPS surveillance is considered to interfere less with a person's private life than, for instance, telephone tapping. Moreover, a further safeguard against abuse is that the person concerned must be informed of the surveillance measure he has been subjected to under certain circumstances. ${ }^{849}$

Lastly, the ECtHR asserted that sufficient safeguards against abuse require, in particular, that uncoordinated investigation measures taken by different authorities

845 A fixed time limit had only subsequently been enacted in so far as under a new provision of the Code of Criminal Procedure, the systematic surveillance of a suspect ordered by a Public Prosecutor could not exceed one month, and any further extension could only be ordered by a judge. Uzun v. Germany, appl. no. 35623/05, 2 September 2010, §69. 
must be prevented and that, therefore, the prosecution, prior to ordering a suspect's surveillance via GPS, had to make sure that it was aware of further surveillance measures already in place. At the relevant time the safeguards in place to prevent a person's total surveillance, including the principle of proportionality, were sufficient to prevent abuse. 850

In light of these considerations, the ECtHR concluded that all of these safeguards were sufficiently effective and adequate to prevent arbitrariness during the application of surveillance by GPS.

IN SUM

These judgements demonstrate, again, that the ECtHR has set up a considerable system of mandatory safeguards that must be complied with for measures of secret surveillance to be in accordance with the law. The more detailed and demanding domestic procedural rules concerning such measures are, the more likely it is that the ECtHR will consider the enforcement thereof to be in accordance with Article 8 of the ECHR. ${ }^{851}$ This implies, for example, that domestic legislation needs to indicate, with an appropriate degree of precision, the manner of screening of the intelligence obtained through surveillance, the procedures for preserving its integrity and confidentiality, and the procedures for its destruction. It also means that uncoordinated application of various investigative measures by different authorities should be prevented. Another general consideration is that the ECtHR attaches considerable value to the question of whether the principle of proportionality has been adequately safeguarded, both in statutory law and in practice. This means, for instance, that the intrusiveness of the measure of secret surveillance must bear a proper proportion to the seriousness of the offence.

Furthermore, to be adequate in Strasbourg terms, safeguards must apply during the initial stages of ordering the application of measures of secret surveillance, and during the further enforcement of these measures. Safeguards must be particularly vigilant where the authorities are empowered to order and effect such techniques without a judicial warrant. ${ }^{852}$ Generally, measures of secret surveillance should preferably be made dependent on a judicial warrant. ${ }^{853}$ The more intruding measures of secret surveillance are on persons' privacy, the more adequate and effective the safeguards must be. Both the ordering and the monitoring must be done by a different independent (judicial) authority. ${ }^{854}$ This means that the (judicial) authority

850 Uzun v. Germany, appl. no. 35623/05, 2 September 2010, $\$ 73$.

851 These remarks primarily concern the ordering and factual implementation of the special investigation techniques in Titles VB and VC of the DCCP and, to a lesser extent, the searching powers comprised in Title VB.

852 Camenzind v. Switzerland, appl. no. 136/1996/755/954, 16 December 1997, §45.

853 Uzun v. Germany, appl. no. 35623/05, 2 September 2010, §71.

854 Iordachi and Others v. Moldova, appl. no. 25198/02, 10 February 2009, §42. 
that reviews the implementation of measures of secret surveillance must be done by a body or official that is either external to the services deploying the means of surveillance, or at least, required to have certain qualifications ensuring his independence and adherence to the rule of law. Also, that body or official must be acquainted with the results of the measure of secret surveillance that have been applied and that body or official must review whether the requirements of the law have been complied with. ${ }^{855}$ Generally speaking, prior control of measures of secret surveillance should - among others according to the Council of Europe - preferably be the responsibility of a body independent of the individuals implementing or carrying out the operation to prevent arbitrariness. ${ }^{856}$ Overall control of the system should be attributed to a judge or, in any case, to an authority independent of the authority who ordered the measures of secret surveillance.

With respect to Title VB of the DCCP two main problems may arise in the field of effective and adequate guarantees. First and foremost, it is to be kept in mind that large discretionary powers for the Executive limit the effectiveness of statutory safeguards, and foremost, of judicial control. This is at odds with the fact that the potential intrusiveness of the powers comprised in Title VB call for an increased level of effective safeguards under Strasbourg case law. It remains, therefore, to be seen if, for instance, judicial control on the ordering and also on the enforcement is adequately provided for in Title VB. ${ }^{857}$ Even though, with respect to the Dutch system of tapping telephone conversations during criminal investigations into common crimes, the ECtHR judged the system to comprise adequate and effective safeguards against abuse in the admissibility decisions in Aalmoes and Others $v$. The Netherlands, ${ }^{858}$ Peters c. Les Pays-Bas, ${ }^{859}$ Van Pelt v. The Netherlands, ${ }^{860}$ and

855 Iordachi and Others v. Moldova, appl. no. 25198/02, 10 February 2009, §47.

856 See Guideline II of the Guidelines on human rights and the fight against terrorism and Kopp $v$. Switzerland, appl. no. 23224/94, 25 March 1998, \$72. The ECtHR considered that '(...) it by no means seeks to minimise the value of some of the safeguards built into the law, such as the requirement at the relevant stage of the proceedings that the prosecuting authorities' telephonetapping order must be approved by the President of the Indictment Division, who is an independent judge, or the fact that the applicant was officially informed that his telephone calls had been intercepted'.

Rotaru v. Romania, appl. no. 28341/95, 4 May 2000, §59, in which the ECtHR considered: '(...) that interference by the Executive authorities with an individual's rights should be subject to effective supervision, which should normally be carried out by the Judiciary, at least in the last resort, since judicial control affords the best guarantees of independence, impartiality and a proper procedure'. It is, furthermore, noteworthy that in this case the ECtHR did not discuss the lack of judicial control and/or supervision in respect of the necessity requirement, but as part of the lawfulness requirement. Decision as to the admissibility in Aalmoes and Others v. the Netherlands, appl. no. 16269/02, 25 November 2004. 
K.D. c. Pays-Bas, ${ }^{861}$ the ECtHR may very well judge otherwise in case of investigations into terrorist offences.

In this respect, special attention should be paid to the above-discussed case of Iordachi and Others v. Moldova, in which the ECtHR underlined the importance of a reasonable suspicion for the ordering of the tapping of telephone conversations. There must be a reasonable suspicion - strong justifications - for infringements on the right to privacy to be considered justified in the case of application of secret measures of surveillance.

Secondly, the ordering of secret measures of surveillance pursuant to Title VB is with respect to most measures - attributed to the public prosecutor. Even though, the ECtHR does not require per se a judge as ordering authority, it remains to be seen if a public prosecutor is sufficiently independent to prevent arbitrary application of the powers comprised in Title VB. In this respect, it is important to keep in mind the 3 kinds of control that can - and should - be exercised in case of secret measures of surveillance: (1) control through prior authorisation, e.g. are there sufficient reasons or suspicions to apply powers which intrude on persons' private life?; (2) by means of supervision during the enforcement of secret measures of surveillance; or (3) through ex post facto control. ${ }^{862}$ The ECtHR has underlined time and again that these three ways of control should, preferably, be exercised cumulatively. How and to what extent are these various ways of control reflected in Title VB of the DCCP?

All of the powers comprised in title VB are 'controlled' through prior authorisation by the public prosecutor and, in some cases, by an investigative judge. ${ }^{863}$ With regard to control by means of supervision during the implementation of measures of secret surveillance as comprised in Title VB, there are no specific provisions that prescribe such monitoring. Article 126za, section 2 DCCP merely contains a possibility for public prosecutors to state in which way the criminal investigators have to implement the order for a specific special investigation techniques, but this is by no means mandatory. Generally speaking, public prosecutors are in charge of a criminal investigation. That task brings with it a power to monitor the course of that investigation. In this respect, it is, however, important to note that the ECtHR requires the monitoring of secret measures of surveillance to be exercises by a body independent of the authority that enforces the measure. Lastly, there is the ex post facto control. ${ }^{864}$ This way of control has limited effects with respect to the powers

861 Décision as to the admissibility in K.D. c. Pays-Bas, requête no. 21207/93, 30 Novembre 1994.

862 See Terrorism: special investigative techniques, Council of Europe Publishing, Council of Europe, April 2005, pp. 23-25.

863 Generally speaking, a prior order - verbal respectively written - from a public prosecutor is required with the exception of the interception of private telecommunication (order of an investigative judge is required) and the application of searching powers in permanent risk areas (no prior order required at all).

864 See, in this respect also, Guideline VI of the Guidelines on human rights and the fight against terrorism. 
comprised in Title VB. The above-discussed WODC reports demonstrate that application of these powers has in no case led to criminal proceedings in respect of a terrorist offence. Therefore, in many cases it will be dependent on the person(s) who has/have actually been subjected to such powers, provided that they are, in fact, acquainted with the powers applied, whether ex post facto control takes place.

\subsection{Necessary in a democratic society}

The last requirement for ECHR conform application of secret measures of surveillance and other state powers in the field of criminal investigations regards the necessity. ${ }^{865}$ How does the ECtHR interpret and apply the necessity requirement with respect to such measures and powers? ECtHR case law concerning these issues is not abundant. ${ }^{866} \mathrm{In}$ answering the question whether an interference was 'necessary in a democratic society' for achieving the legitimate aims, the ECtHR has acknowledged that the Contracting States enjoy a certain margin of appreciation in assessing the existence and extent of such necessity. ${ }^{867}$ This margin of appreciation considerably limits the scope of the necessity requirement, as applied and examined by the ECtHR. Also, frequently when the ECtHR has already concluded that an interference was not in accordance with the law, the necessity requirement is not examined. ${ }^{868}$ In deciding on the necessity requirement, the ECtHR relies heavily upon the principle of proportionality. ${ }^{869}$ Theoretically, this would enable the ECtHR to balance all the relevant interests and factual circumstances, and also to take into account the intensity of the infringement as well as the question of whether the essence of the right to private life has been infringed. The more far-reaching the infringement or the more essential the aspect of the right to privacy that has been interfered with, the more substantial or compelling the legitimate aims pursued should be..$^{870}$

865 See, also, Chapter 4, Section 3.3. on the necessity of personal disturbance.

866 See, in this respect also, P.J.A. de Hert, 'Balancing security and liberty within the European human rights framework', in A.M. Hol \& J.A.E. Vervaele (eds.), Security and Civil Liberties: The Case of Terrorism, Yearbook Utrecht Law Review 2005, Intersentia, pp. 53-54 and 62-76.

867 Kvasnica v. Slovakia, appl. no. 72094/01, 9 June 2009, §80. And see, in general, on the margin of appreciation which the ECtHR allocates to Member States within the context of the 'necessity requirement', J. Schokkenbroeck, 'De margin of appreciation-doctrine in de jurisprudentie van het Europese Hof', in Veertig jaar EVRM, NJCM-Special 1990, pp 41-58; Brannigan \& McBride v. the United Kingdom, appl. nos. 14553/89 and 14554/89, 26 May 1993, §43.

868 Kopp v. Switzerland, appl. no. 23224/94, 25 March 1998, §55-77; Valenzuela Contreras v. Spain, appl. no. 58/1997/842/1048, 30 July 1998, §62; N.F. v. Italy, appl. no. 37119/97, 2 August 2010, §33. See P.J.A. de Hert, 'Balancing security and liberty within the European human rights framework', in A.M. Hol \& J.A.E. Vervaele (eds.), Security and Civil Liberties: The Case of Terrorism, Yearbook Utrecht Law Review 2005, Intersentia, pp.70-72.

870 P. van Dijk, F van Hoof, A. van Rijn and L. Zwaak (eds.), Theory and Practice of the European Convention on Human Rights, $4^{\text {th }}$ Edition 2006, Intersentia Antwerpen-Oxford, pp. 747-748. 
The notion of 'necessary in a democratic society', as used by the ECtHR, is the same in all cases in which the ECtHR refers to it, nevertheless, the intensity of the control does differ and is dependent upon many circumstances, including the seriousness of the interference and the position of the person who claims a violation of his right to privacy. ${ }^{871}$ What is proportionate depends on the circumstances. Delmas-Marty argues that, in determining proportionality the ECtHR takes particularly into account: (1) the nature of the measures taken (its reach, whether it is general or absolute, its adverse consequences and the scope for abuse of the measures), (2) whether the state concerned could have taken other measures or implemented them in a less drastic way, (3) any status of the persons involved which legitimately renders their rights subject to greater limitation (e.g. prisoners), and (4) whether there are any safeguards which can compensate for the infringement of rights which a measure can create. ${ }^{872}$ This latter aspect has been mentioned above in Section 8.1.1 and primarily concerns the question of whether statutory safeguards, as comprised in domestic legislation, have been complied with in a specific case.

Specifically, with respect to special investigation techniques during investigations into terrorism, the Council of Europe has explicitly subdivided the necessity requirement in three sub-conditions. Firstly, the sub-condition of subsidiarity prescribes that special investigation techniques may be applied only if no other, less intrusive investigation method enables the offence to be detected or prevented. Secondly, the sub-condition of proportionality requires that these techniques may be used, only if the interest of safeguarding public order overrides the interest of protecting the private life. Thirdly, the sub-condition of specificity prescribes that the information gathered in the course of pro-active investigations may be used, only in support of the charges which led to their being conducted. ${ }^{873}$ In the ECtHR's case law, the second sub-condition is primarily applied. The sub-conditions of subsidiarity ${ }^{874}$ and specificity are rarely used in Strasbourg case law. ${ }^{875}$

871 P. van Dijk, F van Hoof, A. van Rijn and L. Zwaak (eds.), Theory and Practice of the European Convention on Human Rights, $4^{\text {th }}$ Edition 2006, Intersentia Antwerpen-Oxford, p. 750.

872 M. Delmas-Marty, The European Convention for the Protection of Human Rights, Dordrecht, 1992. Quoted by P.J.A. de Hert, 'Balancing security and liberty within the European human rights framework', in A.M. Hol \& J.A.E. Vervaele (eds.), Security and Civil Liberties: The Case of Terrorism, Yearbook Utrecht Law Review 2005, Intersentia, p. 54. See, also, S. Van Drooghenbroeck, La proportionalité dans le droit de la convention europpeénne des droits de l'homme. Prendre l'idée simple au sérieux, Bruxelles, Bruylant/Publications des FUSL, 2002.

873 Terrorism: special investigative techniques, Council of Europe Publishing, Council of Europe, April 2005, p. 20-23.

874 If the ECtHR mentions the subsidiarity principle it refers to its own ultimate supervisory jurisdiction in relation to the jurisdiction of national states. It is for the national authorities to make the initial assessment of the reality of the pressing social need implied by the notion of 'necessity'. See, Raban v. Romania, appl. no. 25437/08, 26 October 2010, §29; Akdivar and Others v. Turkey, appl. no. 21893/93, 16 September 1996, §6-7.

875 Kvasnica v. Slovakia, appl. no. 72094/01, 9 June 2009, §86, where the ECtHR mentioned the sub-conditions of subsidiarity and specificity as part of the necessity requirement. 
I will now turn to discussing three judgements in which the ECtHR explicitly examined application of secret measures of surveillance/state powers during criminal investigations on compliance with the necessity requirement.

\section{Kvasnica v. SLovakia}

Kvasnica v. Slovakia illustrates the increasingly procedural function that the necessity requirement has. This requirement serves, among others, to verify if the national authorities, in enforcing secret measures of surveillance, have complied with domestic procedural rules that comprise safeguards against abuse (see Section 8.1.4) ${ }^{876}$ This implies that sometimes - as in this case - the ECtHR discusses the question of the lawfulness of an interference together with the necessity requirement, as these requirements both relate to the question of whether there are adequate and effective safeguards to prevent arbitrariness. ${ }^{877}$ Under the notion of 'in accordance with the law', the ECtHR examines whether, in law, such safeguards are provided for. Pursuant to the necessity requirement, the ECtHR considers whether these safeguards have, in the particular circumstances of the case, been complied with.

This case concerns the tapping of telephone conversations of the applicant (Kvasnica). He asserted that there are insufficient safeguards against abuse under domestic law, and that the safeguards that are enacted in law had not been complied with.

The ECtHR argued, without much deliberation, that the statutory conditions had not, in their entirety, been complied with. For example, it had not been shown that the guarantees were met relating to the duration of the interference, whether there had been judicial control of the interception on a continuous basis, whether the reasons for the use of the devices remained valid, whether, in practice, measures were taken to prevent the interception of telephone calls between Kvasnica as a lawyer and criminal defendants as his clients. Similarly, it had not been shown that the interference restricted the inviolability of Kvasnica's home, the privacy of his correspondence and the privacy of information communicated, only to an extent that was indispensable, and that the information thus obtained was used exclusively for attaining the aim set out in domestic legislation. ${ }^{878}$

In addition, statements by several police officers and the judge involved were indicative of a number of other shortcomings as regards compliance with the relevant law. In particular, the director of the special division of the financial and criminal police had concluded that the interference in issue had not been based on any specific suspicion against Kvasnica, and no specific purpose had been indicated

\footnotetext{
876 See, also, Matheron c. France, requête n ${ }^{0}$ 57752/00, 29 mars 2005, §33-46.

877 Kvasnica v. Slovakia, appl. no. 72094/01, 9 June 2009, $\$ 84$.

878 Kvasnica v. Slovakia, appl. no. 72094/01, 9 June 2009, §86.
} 
in the relevant request. In his written statement, the Regional Court judge, who had authorised the interception, remarked that similar requests were made in writing, but were submitted by the police investigators in person. The officer submitting the request presented the case orally and the oral presentation was usually more comprehensive than the written request. As requests for authorisation had to be handled with the utmost urgency, judges had no practical opportunity to examine the case file or to verify that the request for authorisation corresponded to the contents of the case file. Depositions of the four members of the financial police investigative team involved in the case included, inter alia, the information that the request for authorisation of the interception of the applicant's telephone had been drafted without a prior consultation of the case file.

The ECtHR concluded that domestic procedures for ordering and supervising the implementation of the interception of the Kvasnica's telephone were shown not to have fully complied with the requirements of the relevant law. Those procedures were therefore inadequate to have kept the interference with the Kvasnica's right to respect for his private life and correspondence to what was 'necessary in a democratic society'. 879

\section{Uzun v. Germany}

In Uzun v. Germany, the ECtHR explicitly examined the necessity of secret measures of surveillance primarily in light of: (1) other measures that had already been applied, (2) the seriousness of the offence, and (3) the intrusiveness of the measure at issue. ${ }^{880}$

The applicant (Uzun) was suspected of participation in offences committed by the so-called Anti-Imperialist Cell (Antiimperialistische Zelle), an organisation pursuing the armed combat abandoned since 1992 by the Red Army Fraction (Rote Armee Fraktion), a left-wing extremist terrorist movement. In 1993 the North Rhine-Westphalia Department for the Protection of the Constitution (Verfassungsschutz) began a long-term observation of Uzun. As a consequence, he was occasionally kept under visual surveillance and the entrances to his flats were filmed by video cameras. The Department also intercepted the telephones in his house and in a telephone box situated nearby. Moreover, post addressed to him was opened and checked. Likewise, S., a presumed accomplice of Uzun, was subjected to surveillance measures from 1993 onwards. The authorities intercepted his telecommunications and his post. He was, furthermore, occasionally observed. ${ }^{881}$

\footnotetext{
879 Kvasnica v. Slovakia, appl. no. 72094/01, 9 June 2009, $\$ 87$ and 88.

880 Uzun v. Germany, appl. no. 35623/05, 2 September 2010. See, for a discussion of the question of whether domestic law provided adequate and effective safeguards to prevent arbitrariness (including some notes on the proportionality of the measures at issue), Section 8.1.3. 
In 1995 the Federal Public Prosecutor General instituted investigatory proceedings against Uzun and S. for participation in bomb attacks for which the Anti-Imperialist Cell had claimed responsibility. Following this, the authorities continued to apply various secret measures of surveillance including (video)observation, telephone tapping, surveillance and the installation of transmitters. However, Uzun and S. detected and destroyed the transmitters and as they suspected that their telecommunications were being intercepted and that they were being observed, they never spoke to each other on the phone, and succeeded, on many occasions, in evading visual surveillance by the investigative authorities.

In view of this, the Federal Office for Criminal Investigation built a Global Positioning System (GPS) ${ }^{882}$ receiver into S.'s car in December 1995, by order of the Federal Public Prosecutor General. Thereby it could determine the location and the speed of the car once per minute. However, the data were only recovered every other day in order to prevent detection of the receiver. This observation lasted until the Uzun's and S.'s arrest on 25 February 1996 (hence for two to three months). ${ }^{883}$

Uzun complained before the ECtHR that the surveillance via GPS and the application of several further measures of surveillance, as well as the use of the data obtained thereby in the criminal proceedings against him, had violated his right to respect for his private life. Uzun did not contest the lawfulness of any of the additional surveillance measures other than the GPS surveillance.

According to the German Code of Criminal Procedure, surveillance via GPS does not have to be ordered by a judge, as opposed to measures interfering more profoundly with the right to self-determination in the sphere of information (Recht auf informationelle Selbstbestimmung). Whether or not a surveillance measure can be ordered in addition to measures already in place, is a question of proportionality of the additional measure in question.

First of all, it is important to note that the ECtHR considered the rather strict standards, set up and applied in the specific context of measures of secret surveillance regarding the foreseeability requirement, not to apply, as such, to cases such as the present one, concerning surveillance via GPS of movements in public places. Surveillance via GPS, as such, is considered to interfere less with the private life of the person concerned than the interception of his or her telephone conversations. Therefore the ECtHR, at first sight, applied the more general

882 GPS is a radio navigation system that works with the help of satellites. It shows the continuous location, without lapse of time, of objects equipped with a GPS receiver anywhere on earth, with a maximum tolerance of 50 metres at the time. It does not comprise any visual or acoustical surveillance. As opposed to transmitters, its use does not necessitate the knowledge of where approximately the person to be located can be found. Uzun v. Germany, appl. no. 35623/05, 2 September 2010, $\$ 13$.

883 Uzun v. Germany, appl. no. 35623/05, 2 September 2010, §6-14. 
principles on adequate protection against arbitrary interference with Article 8 of the ECHR. 884

Then, specifically with regard to the necessity of the GPS surveillance, the ECtHR considered the notion of necessity to imply that the interference corresponds to a pressing social need and, in particular, that it is proportionate to the legitimate aim pursued. In examining whether, in the light of the case as a whole, the measure taken was proportionate to the legitimate aims pursued, the ECtHR underlined that Uzun's surveillance via GPS was not ordered from the outset. The authorities had first attempted to determine whether he was involved in the bomb attacks at issue through measures that interfered less with his right to respect for his private life, i.e. by means of transmitters and surveillance. It was clear that other methods of investigation, which were less intrusive than Uzun's surveillance by GPS, had proved to be less effective. ${ }^{885}$

In the ECtHR's view, surveillance via GPS had led to a quite extensive observation of Uzun's conduct by two different State authorities. In particular, the fact that he had been subjected to the same surveillance measures by different authorities had led to a more serious interference with his private life, in that the number of persons to whom information regarding his conduct had become known had been increased. Against this background, the interference through Uzun's additional surveillance via GPS thus necessitated more compelling reasons if it was to be justified. However, the GPS surveillance was carried out for a relatively short period of time (some three months), and, as with the visual surveillance by state agents, affected Uzun essentially only at weekends and when he was travelling in S.'s car. Therefore, he could not be said to have been subjected to total and comprehensive surveillance.

Moreover, the investigation for which the surveillance was put in place concerned very serious crimes, namely, several attempted murders of politicians and civil servants by bomb attacks. As shown above, the investigation into these offences, and notably the prevention of further similar acts by the use of less intrusive methods of surveillance, had previously not proved successful. In light of these considerations, the ECtHR concluded that Uzun's surveillance via GPS, as carried out in the circumstances of the present case, was proportionate to the legitimate aims pursued, and thus 'necessary in a democratic society' within the meaning of Article 8, section 2 of the ECHR. ${ }^{886}$

884 Uzun v. Germany, appl. no. 35623/05, 2 September 2010, §63.

885 Uzun v. Germany, appl. no. 35623/05, 2 September 2010, §78-79.

886 Uzun v. Germany, appl. no. 35623/05, 2 September 2010, $\S 80$. 


\section{LEANDER V. SWEDEN}

The case of Leander v. Sweden has already been discussed partly in Section 8.1.3. ${ }^{887}$ Leander was subjected to a personnel control, carried out on him by the National Police Board, to see whether he could be allowed access to a restricted military zone. ${ }^{888}$ The ECtHR did consider the interference with Leander's private life to be in accordance with the law, but was that interference also necessary in a democratic society? Was the interference proportionate to the legitimate aim pursued, i.e. the protection of national security, taking into account that Leander was not allowed to inspect (and rebut) the information himself $?^{889}$

First of all, the ECtHR underlined that the interference with Leander's private life was rather mild. Secondly, there had indeed been a pressing social need for the Swedish authorities to check certain aspects of Leander's private life, taking into account that he needed to have access to restricted military zones for his work. The fact that the information released to the military authorities was not communicated to Leander, could not, as such lead to the finding that the interference was not 'necessary in a democratic society in the interests of national security'. The effectiveness of the personnel control required the absence of such communication.

Leander claimed, furthermore, before the ECtHR, that effective safeguards were lacking because he did not have any possibility of challenging or refuting the secret information that caused him to be labelled as threat to national security. ${ }^{890}$ The ECtHR however did not agree with that allegation. Under Swedish law, the use of the relevant information in areas outside personnel control, were limited to cases of public prosecution and cases concerning the obtaining of Swedish citizenship. Furthermore, the presence of parliamentarians on the National Police Board, ${ }^{891}$ and the supervision effected by the Chancellor of Justice ${ }^{892}$ and the Parliamentary Ombudsman, as well as the Parliamentary Committee on Justice provided for an

Leander v. Sweden, appl. no. 9248/81, 26 March 1987.

See, for further details regarding the circumstances of the case, Section 8.1.3.

Leander v. Sweden, appl. no. 9248/81, 26 March 1987, §58; Gillow v. the United Kingdom, appl. no. 9063/80, 24 November 1984, $\$ 48$ and further.

Leander v. Sweden, appl. no. 9248/81, 26 March 1987, §61.

The parliamentary members of the Board, including members of the Opposition participate in all decisions regarding whether or not information should be released to the requesting authority. In particular, each of them is vested with a right of veto, the exercise of which automatically prevents the Board from releasing the information. In such a case, a decision to release can be taken only by the government itself, and then only if the matter has been referred to them by the National Police Commissioner or at the request of one of the parliamentarians. The ECtHR considered this direct and regular control over the most important aspect of the register - the release of information - as a major safeguard against abuse. Leander $v$. Sweden, appl. no. 9248/81, 26 March 1987, $§ 65$.

As far as the Chancellor of Justice is concerned, it may be that in some matters he is the highest legal adviser of the government. However, it is the Swedish Parliament that has given him his mandate to supervise, amongst other things, the functioning of the personnel control system. In 
important safeguard against abuse. Hence, the safeguards provided for by the Swedish system, which had, moreover, been complied with, were considered adequate and effective. In light of these considerations, the ECtHR concluded that the interference with Leander's private life had been proportionate and therefore necessary in a democratic society. 893

\section{IN SUM}

Even though case law on the necessity requirement in the field of criminal procedure is far from abundant, these three judgements provide for some guidelines on the issue that may be relevant with respect to the powers comprised in Title VB. First of all, it is striking to see that Strasbourg case law only concerns the application of state powers during criminal investigations/proceedings on suspects or on accused. Within the legal systems of, for instance, Germany and France secret measures of surveillance by the investigative authorities can only be applied to the accused or (minimum) suspects. A reasonable suspicion as a requirement for the application of special measures of secret surveillance serves as extra justification for interferences with the private life, and, accordingly, as a safeguard against arbitrariness. Suspicion criteria comparable to the Dutch 'indications of a terrorist offence' do not appear in Strasbourg case law. Especially with respect to 'innocent persons' who form part of a compilation of persons, as defined in Article 126hh DCCP, it is to be seen whether interferences with their right to privacy are necessary in a democratic society, and proportional and subsidiary to the goals pursued.

Another important issue is that several foreign legislative systems regarding secret measures of surveillance explicitly refer to the principles of proportionality and subsidiarity in the relevant provisions. Within Title VB, these principles are considered to be included in the general requirement that the application of a measure must be in the interest of the investigation or urgently demanded by the investigation.

A last important feature with respect to foreign legislation on secret measures of surveillance is that less intrusive measures of surveillance can initially be ordered by a public prosecutor, but if these are applied for longer than one month, authorisation of an investigating judge is required. There is, hence, a multi-stage system of competent authorities for the ordering of such measures, depending on the intrusiveness of these measures, in combination with the period during which they are applied. Such a system reflects the ECtHR's rule that the more far-reaching interferences are, the more mandatory safeguards there must be and the more precisely the ECtHR will examine compliance with such safeguards in practice.

doing so, he acts in much the same way as the Ombudsman and is, at least in practice, independent of the government. Leander v. Sweden, appl. no. 9248/81, 26 March 1987, §65. 
Furthermore, the two above-discussed judgements demonstrate the intertwinement between the requirement that interferences with the private life must be in accordance with the law, and the necessity requirement. Procedures, both formal as well as substantive, regarding the imposition of secret measures of surveillance, are inadequate where they are unable to keep interferences with the right to respect private life to what is 'necessary in a democratic society'. This consideration is interesting with regard to the investigative powers within security risk areas. The intrusiveness of these powers is considerable while the safeguards, both formal and substantive, are not abundant. For instance, the proportionality requirement concerning the application of investigative powers in security risk areas only relates to the decision of an investigative officers to investigate means of transport/objects or to frisk a person.

The proportionality, and hence necessity, of a measure of secret surveillance decreases when other measures are/have been applied concurrently/successively. Concurrent or successive application of relatively harmless (regarding intrusiveness) state powers may very well lead to far-reaching interferences with the private life that require solid justifications in terms of necessity. The question of how many different authorities concurrently investigate the same suspect (person) and, hence, criminal offence, or have access to information on the investigation, raises the intrusiveness of the interference and calls for extra safeguards to prevent abuse. This also raises questions of subsidiarity: what is the least intrusive measure available with the most effective and adequate safeguards?

The seriousness of the crime that is investigated and the effectiveness of other investigative measures also determines the necessity of the interferences with the right to privacy. The more serious a crime is, the more necessary it may be to apply secret measures of surveillance. This applies, particularly, where other (less intrusive) measures have not proved to be effective. The ECtHR has used these considerations only with respect to suspects and accused on whom such measures had been applied for a relatively short period and under supervision of a judge.

Another issue that needs to be mentioned at this point regards the number of times that secret measures of surveillance are used in practice. The above-discussed cases against Moldova, Bulgaria and the United Kingdom demonstrate that the ECtHR also takes into account the question of the scope of the practical use of state powers that interfere with the private life. An 'overuse' of a system of secret surveillance or a high number of authorised requests for the application of specific powers of secret surveillance may be indicative of a lack of effective and adequate safeguards to prevent arbitrariness.

The above-discussed WODC reports (Section 7) show that investigative officers expect the practical value of Title VB to be limited. This expectation is primarily inspired by the low requirements for coming to a reasonable suspicion when it 
concerns a criminal investigation into terrorism. ${ }^{894}$ The investigative authorities assert that the scope of the reasonable suspicion criterion is considerably extended when it concerns terrorism which brings the authorities 'to actively explore and use the lower limits of the reasonable suspicion criterion, certainly when it regards an imminent terrorist threat'. ${ }^{895}$ They argue, moreover, that application of special investigation techniques on the basis of indications is often not effective as, due to the thin basis on which such investigations are initiated, most of these investigations will not yield useful incriminating information. ${ }^{896}$ When it concerns an imminent terrorist threat, the authorities would rather take a person(s) in police custody on the basis of a reasonable suspicion than using special investigation techniques.

Consequently, according to the investigative authorities' estimate, the application of special investigation techniques is only necessary for a very small number of cases, and will primarily serve: (1) to exclude risks, and (2) to see whether there is an imminent terrorist threat. The WODC reports demonstrate that the investigative authorities cooperate extensively with the secret intelligence service in this respect.

A related issue that the ECtHR considers of importance is the scope of application of secret measures of surveillance. The more criminal offences may be investigated by means of such measures, the less likely it is that the ECtHR will consider such application necessary in a democratic society. Within the DCC and DCCP there are over 43 terrorist offences that may be investigated by means of the powers comprised in Title VB. This amount is even considerably higher when multiplied with punishable complicity in, participation in, participation as accessory, in such offences, as well as with punishable preparation of such offences, attempts to commit a terrorist offence, provocation to commit such an offence, or conspiracy to commit a terrorist offence. In addition, in the case of a suspicion of common criminal offences, special investigation techniques may be used. To what extent are the powers and measures comprised in Title VB really necessary when considered in light of: (1) the non-criminal law based anti-terrorism measures as discussed in the previous chapters, (2) the powers comprised in Titles IVA and V of the DCCP, and (3) the powers of the secret intelligence services, combined with the information exchange between the investigative authorities and the secret intelligence services? ${ }^{897}$

894 C.J. de Poot, R.J. Bokhorst, W.H. Smeenk, R.F. Kouwenberg, De Opsporing verruimd? De Wet opsporing terroristische misdrijven een jaar in werking, WODC, Cahier 2008-9, p. 53; B. van Gestel, C.J. de Poot, R.J. Bokhorst, R.F. Kouwenberg, Signalen van terrorisme en de opsporingspraktijk. De Wet opsporing terroristische misdrijven twee jaar in werking, WODC Cahier 2009-2010, p. 31.

895 C.J. de Poot, R.J. Bokhorst, W.H. Smeenk, R.F. Kouwenberg, De Opsporing verruimd? De Wet opsporing terroristische misdrijven een jaar in werking, WODC, Cahier 2008-9, p. 53-54.

896 C.J. de Poot, R.J. Bokhorst, W.H. Smeenk, R.F. Kouwenberg, De Opsporing verruimd? De Wet opsporing terroristische misdrijven een jaar in werking, WODC, Cahier 2008-9, p. 54.

897 These questions will further be elaborated on in Chapter 9. 
A further remark concerns the above-mentioned sub-condition of specificity - even though the Council of Europe interprets this part of the necessity requirement with flexibility. ${ }^{898}$ Within the Dutch criminal justice system it is a commonly accepted phenomenon that information as result of lawfully applied investigative powers may be used to substantiate another charge than the one for which these investigate techniques were originally applied. This is the so-called continued application of powers [voortgezette toepassing], and makes it possible for the investigative authorities to charge and subsequently prosecute someone for drug smuggling pursuant to the WAA on the basis of evidence gathered during a car search.

During criminal investigations into terrorist offences, the authorities generally also discover other criminal offences. Committing or preparing terrorist offences often go hand-in-hand with common crimes. To prepare a terrorist attack, the perpetrator needs weapons or ammunition, which he will most likely not obtain through lawful means. Consequently, even if criminal investigators use the powers comprised in Title VB completely in good faith, they will undeniably and inevitably also detect common crimes, like the possession of illegal weapons. In this respect it is important to underline again that the criteria for the application of the procedural powers of Title VB are less demanding than comparable powers comprised in Title IVA or V, and in the WAA.

In examining whether national security reasons may be used to demonstrate the necessity of interferences with the right to privacy, two main aspects play a role: (1) how nearby and actual the threat against national security is, and (2) how severe the infringement on the privacy is. ${ }^{899}$ These criteria are, for instance, important with respect to the exploratory inquiry into terrorist offences. How severely is a person's

898 Or to put it in other words: information obtained during the pro-active phase can exclusively be used for the purpose for which it has been gathered initially.

899 See, also, S. and Marper v. the United Kingdom, appl. nos. 30562/04 and 30566/04, 4 December $2008, \S 101-104$. The ECtHR argued that where a particularly important facet of an individual's existence or identity is at stake, the margin of appreciation allowed to the state will be restricted. Where, however, there is no consensus within the Member States of the Council of Europe, either as to the relative importance of the interest at stake, or as to how best to protect it, the margin will be wider. The ECtHR deems the protection of personal data to be of fundamental importance to a person's enjoyment of his or her right to respect for private and family life, as guaranteed by Article 8 of the ECHR. The domestic law must afford appropriate safeguards to prevent any such use of personal data, as may be inconsistent with the guarantees of this Article. The need for such safeguards is all the greater where the protection of personal data undergoing automatic processing is concerned, not least when such data are used for police purposes. The domestic law should notably ensure that such data are relevant and not excessive in relation to the purposes for which they are stored; and preserved in a form which permits the identification of the data subjects for no longer than is required for the purpose for which those data are stored (see Article 5 of the Data Protection Convention and the preamble thereto and Principle 7 of Recommendation R(87) 15 of the Committee of Ministers regulating the use of personal data in the police sector). The domestic law must also afford adequate guarantees that retained personal data is efficiently protected from misuse and abuse (see notably Article 7 of the Data Protection Convention). 
private life interfered with when he is subjected to an exploratory inquiry pursuant to Articles 126hh and 126ii of the DCCP? The prosecution may retrieve a person's phone number, credit card number, bank account number, shopping preferences, expenses and the persons one meets or knows. This identifying information is considered to be less 'sensitive'. In the context of a criminal investigation, it is generally considered that the recording of identity related data does not constitute a disproportionate interference, given the aims of preventing crime or maintaining public order. ${ }^{900}$

However, data files may concern more or less any type of information, including rather 'sensitive' information on a person's private life. Requesting data files may, hence, lead to a considerable interference with the right to privacy. There must, consequently, be compelling reasons to justify such an inquiry. When there is solid evidence that a terrorist offence is indeed plotted by a group of persons, that may be the case. But the broader the compilation of persons is, and the more vague the allegations are, the larger the group of ordinary citizens whose privacy is interfered with. Such interferences cannot easily be considered necessary in a democratic society. This is all the more true when one keeps in mind that the ECtHR generally assumes that secret measures of surveillance are exclusively applied to suspects or accused.

900 See Terrorism: special investigative techniques, Council of Europe Publishing, April 2005, p. 30 . 



\section{Chapter VI \\ A Reasonable Suspicion}

\section{INTRODUCTION}

This chapter discusses three issues. Firstly, the reasonable suspicion criterion pursuant to Article 27 of the DCCP. Secondly, the powers available to the investigative authorities in the case of a reasonable suspicion of a (terrorist) offence, and thirdly, the fundamental rights that are at stake when investigative authorities apply powers that interfere with the right to liberty and security of person. The application of coercive powers, like an arrest, can only be lawful when there is a reasonable suspicion prior to subjecting a person to such powers: A person must legitimately be considered as a suspect to subject him to coercive powers. This prerequisite primarily serves to protect civilians against arbitrary state interferences with their liberty rights.

The first question that arises is when can a person lawfully be considered as a suspect? Article 27, section 1 of the DCCP defines a suspect - prior to the initiation of legal proceedings - as a person in respect of whom, on the basis of facts or circumstances, there is a reasonable suspicion of guilt concerning a criminal offence. ${ }^{901}$ What does the notion of facts or circumstances mean? What type of information can be considered as fact and/or as circumstance? From whom and/or from what authorities does the relevant information come and how does that influence the reliability of the information? Are sources different in the case of criminal investigations into terrorist offences? When, furthermore, is a suspicion reasonable? All of the above questions will first be discussed in light of the DCCP (Section 2) and then in light of Strasbourg case law on Article 5, Section 1 under c of the ECHR (Section 10).

A further important question is if, and if so to what extent, the reasonable suspicion criterion is gradually losing ground to other suspicion criteria, such as the ones that have been discussed in the foregoing chapters, during investigations into terrorist offences. In this respect it is important to note that the government refers to a light reasonable suspicion when it concerns the application of coercive powers to investigate terrorist offences. ${ }^{902}$

At the same time, it can be questioned whether or not the reasonable suspicion criterion has gained importance when it concerns deprivation of liberty of terrorist

\footnotetext{
901 Article 27, section 2 of the DCCP regards the suspect against whom criminal proceedings have been lodged, the accused, and section 3 applies to suspects in a financial criminal investigation. This chapter exclusively discusses the scope of Article 27, section 1 of the DCCP.

Kamerstukken II 2004-2005, 30 164, nr. 3, p. 26.
} 
suspects. A (light) reasonable suspicion is currently the only firm prerequisite for police custody and remand in custody. A terrorist suspect may be kept deprived of his liberty for 20 days and 15 hours on the basis of a (light) reasonable suspicion, whereas for common offences there must additionally be serious objections against suspects. ${ }^{903}$ The importance of answering the above questions has gained importance since the entering into force of DPTA.

During the whole pre-trial phase, and especially during the first stages thereof, suspects are considered as subject to a criminal investigation rather than as (equal) party to a criminal investigation. In the case of a reasonable suspicion of a (terrorist) offence, the competent authorities are entitled to stop the suspect, ${ }^{904}$ frisk him to discover his identity, ${ }^{905}$ arrest him, ${ }^{906}$ take him into police arrest [ophouden voor verhoor $]^{907}$, into police custody [inverzekeringstelling] ${ }^{908}$ and remand him in custody [bewaring], ${ }^{909}$ and subject him to various investigative measures. ${ }^{910}$ Nevertheless, being considered as a suspect also brings with it certain rights to counterbalance the investigative authorities' powers, including the right to remain silent during interrogations, ${ }^{911}$ the right to be assisted by a lawyer of one's choice,,${ }^{912}$ and the right to have access to one's case file. ${ }^{913}$

It is of crucial importance to determine at what moment exactly a person may lawfully be considered as a suspect of an (terrorist) offence. That moment is a turning point, both for the suspect and for the investigative authorities, within the context of criminal investigations and proceedings. On the one hand, the suspicion criterion forms the gateway for state authorities to apply all kinds of coercive powers on civilians. On the other hand, from that moment on, the authorities are obliged to effectively guarantee various fundamental rights of the suspect.

In terms of the ECHR, this chapter will focus on Article 5, section 1 under $\mathrm{c}$ and section 3. This Article guarantees everyone the right to liberty and security. Limitations to that right are only allowed under the circumstances described in

903 Article 67 and $67 \mathrm{a}$ of the DCCP.

904 Article 52 of the DCCP.

905 Article 55b of the DCCP. Searching a suspect's clothes pursuant to Article 55b of the DCCP, exclusively serves to discover a suspect's identity. If the investigative authorities want to search a suspect for other purposes, there must be 'serious objections' against the suspect pursuant to Article 56 of the DCCP. See, for a discussion of the notion 'serious objections' Chapter 7. 
section 1 under a to f. For deprivation of liberty in the context of criminal investigations/proceedings, section 1 under $\mathrm{c}$ is of importance: a person may be deprived of his liberty in the case of a lawful arrest or detention effected for the purpose of bringing him before the competent legal authority on reasonable suspicion of having committed an offence, or when it is reasonably considered necessary to prevent his committing an offence or fleeing after having done so.

Section 3, furthermore, prescribes that everyone arrested or detained in accordance with the provisions of section 1 under $\mathrm{c}$, shall be brought promptly before a judge or other officer authorised by law to exercise judicial power and shall be entitled to trial within a reasonable time or to release pending trial.

The key question is under what circumstances limitations to the right to liberty and security are considered lawful in the ECtHR's opinion. Is there a different framework for terrorist suspects in this respect? How does Strasbourg interpret the notion of a reasonable suspicion, and how does that criterion relate to other requirements for lawful deprivation of liberty during the pre-trial phase? It is important to note that there will be an overlap with the following chapter in this respect. Part of the examination of Article 5, section 3 of the ECHR in Section 11 will also play a role of importance with respect to remand detention [gevangenhouding], as discussed in Chapter VII.

In the upcoming sections, the following subjects will be examined. Firstly, Section 2 will elaborate on the scope of Article 27, section 1 of the DCCP. Then, Sections 3 to 7 go into the coercive powers available to the investigative authorities in the case of a reasonable suspicion. Coercive powers that imply deprivation of liberty are discussed more elaborately and with specific regard to terrorist suspects. Thirdly, the practical application of these latter coercive measures is scrutinised in Section 8 and 9. Lastly, Sections 10 and 11 elaborate on the Strasbourg framework for lawful interferences with the right to liberty and security of person during the pre-trial phase.

\section{ReAsONABLE SUSPICION}

This section elaborates on the reasonable suspicion criterion pursuant to Article 27, section 1 of the DCCP. To clarify this criterion, it will be divided into 3 sub-criteria: (1) facts or circumstances, (2) the reasonableness, and (3) guilty of a criminal offence. Each of these sub-criteria will primarily be exemplified in view of case law.

\subsection{Facts or circumstances}

The phrase 'facts or circumstances' in Article 27, section 1 of the DCCP refers to the kind of information that may lead to assuming reasonable suspicion. It also 
concerns the question of that information's source. Who, or what organisation or actor, may provide information for a suspicion? May, for example, an anonymous tip-off or secret intelligence information be considered as 'fact', and if so, is such information sufficient to reasonably regard a person as a suspect? Can other information, such as a person's police record or his notorious reputation in terms of criminal conduct, lawfully contribute to being considered a suspect?

As will be demonstrated below, there is no unequivocal answer to these questions. This is primarily due to the fact that what may be considered as relevant facts or circumstances is, to a considerable extent, dependant on: (1) the circumstances of a specific situation, and (2) on the criminal offence of which a person is suspected. Criminal law provisions do not exclusively define the limits of criminal liability, but indirectly those provisions also reflect which specific facts or circumstances can contribute to coming to a reasonable suspicion of that specific offence. It is therefore important to consider the criminal law provision defining the crime of which a person is suspected when examining whether there are sufficient facts or circumstances to substantiate a reasonable suspicion. For example, the fact that someone goes to a Mosque that is known for its radical Islamic legacy 5 times a day, while at the same time openly distributing pamphlets regarding hatred of the Western world and information on who to contact to get cheap flights to Afghanistan, is inadequate to assume suspicion on account of robbery. However that information may be sufficient to demonstrate suspicion on account of Article 205 of the DCC recruitment for armed conflict. In sum, to justly consider a person as a suspect there must a priori be sufficient and causal facts or circumstances that are, moreover, directly connected to the elements of the criminal law provision with regard to which the suspicion has arisen. Facts or circumstances on which a reasonable suspicion is based must be open to objectification. This means that a suspicion must be based on objective, concrete information. ${ }^{914}$

Although Article 27, section 1 of the DCCP refers to facts or circumstances, one fact or one circumstance containing an indication of sufficient power may very well suffice to establish a reasonable suspicion, especially when the investigative authorities catch someone red-handed. Furthermore, the law does not prescribe any specific conditions as to the source or the nature of the facts or circumstances. ${ }^{915}$ Generally speaking, it is presumed that a reasonable suspicion can be based on the same sources and carry the same nature, as evidence during actual criminal proceedings, including observations by police officers pursuant to Article 2 of the

914 See Chapter II for a discussion of the facts and circumstances that (may) lead to a reasonable suspicion on account of a terrorist offence.

915 Lensing J.A.W., Wetboek van Strafvordering - Suppl. 108 (1998), artikel 27, aantekening 3 en 3a, 56-60, in Melai A.L. \& Groenhuijsen M.S. e.a., Het Wetboek van Strafvordering, voortgezet onder redactie van Groenhuijsen M.S. (head-editor), de Roos Th.A., Swart A.H.J. and Kristen F.G.H., Kluwer, Deventer, losbladig. 
PA, statements of the alleged suspect, statements of witness(es), reporting of a criminal offence by a victim, and written documents and facts of general knowledge. ${ }^{916}$ Opinions, speculations, conclusions, or police officers' intuition, do not suffice to assume a reasonable suspicion. ${ }^{917}$

The experience of criminal investigators can, unlike their intuition or speculations, play a role in valuing other, more objective, facts or circumstances. For example, police officers who have been working for several years in a neighbourhood that is known for its drug trafficking activities, are considered more capable to assess if a person can reasonably be considered a suspect concerning a violation of the Opium Act (Opiumwet, OA). However, a police officer who just starts to work in the same neighbourhood is less competent in that respect. ${ }^{918}$ It is, however, difficult to clearly distinguish experience and expertise of criminal investigators from, for example, investigators' prejudices.

Outward appearances cannot, as such, lead to a reasonable suspicion. However, they can justly contribute to coming to a reasonable suspicion. If a criminal investigator receives, for example, a tip-off from a witness that a robbery has just been committed by a person of colour, the police may legitimately consider persons of colour in the neighbourhood of the crime scene as potential suspects for this robbery. In such a situation, outward appearances can, hence, count as objective 'fact', instead of as a prejudice, and can, consequently, contribute to the establishment of a reasonable suspicion. ${ }^{919}$ Practically speaking, it will not however - just as with respect to experience vis-à-vis prejudice - always be possible to judge post facto whether a suspect's outward appearance played a role as prejudice or as fact.

\section{CASE LAW: AN INTRODUCTION}

One of the best-known judgements regarding the interpretation of Article 27, section 1 of the DCCP is the Hollende Kleurling. ${ }^{920}$ The case concerned an alleged reasonable suspicion in respect of an opium related offence. The facts were as follows. During night surveillance, two police officers saw a man of colour running from the direction of a bar known for its drug trafficking and use. In addition, this person kept his left hand stiffly in his pocket. The investigative officers stopped

\footnotetext{
916 Compare with Articles 339, 341, 342 and 344 of the DCCP.

917 See, in this respect, Koppelaar L., Winkel F.W. and Van Der Steen J.C., 'Psychologische kanttekeningen bij artikel 27 Sv: een experiment rond etnische origine, ritmisch gedrag en verdacht zijn', in Delikt en Delinkwent 16, 1986, afl. 1, pp. 25-28. Supreme Court 6 December 1983, NJ 1984/442; Supreme Court 14 January 1975, NJ 1975/207.

919 'Contribute' because, most likely, there will have to be additional objective information to sufficiently sustain a reasonable suspicion.

920 Amsterdam Court of Appeal 3 June 1977, NJ 1978/601.
} 
him ${ }^{921}$ and subsequently searched his clothes. ${ }^{922}$ However, the alleged suspect resisted, and during the struggle that followed, he took his hand out of his pocket and tried to throw away a paper filled with some - as appeared later - heroine. To lawfully stop and arrest a person, there must be a reasonable suspicion, and to officially frisk a suspect, there need, moreover, to be serious objections against the suspect. ${ }^{923,} 924$ The Amsterdam Court of Appeal considered that a man of colour who comes running from the direction of a bar, even if that bar is known for its drug trafficking activities, combined with the fact that this man kept his left hand stiffly in his pocket, did not amount to sufficient objective facts and/or circumstances to generate a reasonable suspicion. ${ }^{925}$

Another case concerned a person who was stopped during the night in respect of a presumed traffic offence. ${ }^{926}$ The alleged suspect came by car from the direction of a neighbourhood where one or more drug dealers lived. After two investigative officers stopped him, they received information from the police information centre that this person had appeared in the police administration for violation of the WAA and two violations of the OA. The police information centre considered that 'further investigation' seemed desirable. On the basis of this information, the investigative officers decided to frisk the alleged suspect and to take him to the police station for further investigation.

The Rotterdam District Court considered that despite the fact that the alleged suspect refused to tell the officers where or from whom he came, he could not reasonably be denoted as suspect of any drugs or weapons related criminal offence on the basis of the above-mentioned facts and circumstances.

In both of these two judgements, the investigative officers based their suspicion, to a considerable degree, on knowledge about the criminal activities taking place in a neighbourhood and in a bar, respectively. However, such knowledge does not suffice to establish reasonable suspicion. There must always be additional facts or circumstances, which are, moreover, open to objectification.

\section{CASe law: Police Record And CRiminal investigation}

Can the fact that someone has a police record or is known to the police for criminal activities contribute to the establishment of a reasonable suspicion? In the Plastic Boodschappentasje judgement, two investigative officers saw a person (P.) who,

\footnotetext{
921 Article 52 of the DCCP.

922 Articles 55b and Article 56, section 4 of the DCCP.

923 See Chapter VII for a discussion of the notion 'serious objections'.

924 See, for a comparable case, Rotterdam regional court 28 August 1980, NJ 1980/639.

925 Consequently, the suspect was acquitted due to a lack of evidence. See Article 359a of the DCCP.

926 Rotterdam District Court 28 August 1980, NJ 1980/639.
} 
they knew had a police record for drug related criminal offences and theft. ${ }^{927} \mathrm{P}$. carried with him a plastic bag. The investigative officers ask him what he was carrying in the bag, to which $\mathrm{P}$. answered that there were 4 books in the bag. Subsequently, the investigative officers inquired where he bought the books. ${ }^{928} \mathrm{P}$. answered that he had just stolen the books. The officers thereupon arrested P.

At what moment - before the questions, in between the first and the second question, or rather after the two questions - were there sufficient facts and/or circumstances to consider $\mathrm{P}$. as a suspect? Could the fact that the investigative officers knew P. as 'an old friend of the police' contribute to demonstrating a reasonable suspicion? The Supreme Court argued that the above-described facts and circumstances were insufficient to regard P., prior to asking him the questions concerning the plastic bag which he carried with him, as a suspect. So the fact that P. had a considerable police record did not weigh heavily in considering him as a suspect of a new criminal offence.

Hence, the mere fact that a person has a police record does not, as such, form sufficient reason to assume a reasonable suspicion. ${ }^{929}$ The well-known adage 'once a thief always a thief' is therefore not of any considerable value in establishing a reasonable suspicion. At all times, there must be objective facts or circumstances, in addition to a police record. An ongoing criminal investigation relating to the alleged suspect's criminal activities may yield such objective facts or circumstances. In HR 16 November 1982,930 for instance, the police investigated a network of drug traffickers in The Hague, of which the presumed suspect formed part. According to other persons belonging to that network, the alleged suspect trafficked drugs and used them as well. The police had received, from various sources, the same incriminating information about the person concerned. When the police saw him in the city centre, they asked him whether he was carrying any drugs with him.

The Supreme Court decided that there was ample objective information to consider the person concerned as a suspect, even prior to the police asking him whether he had any drugs on him. The fact that the suspect already formed the object of an ongoing criminal investigation regarding drug trafficking activities,

927 Supreme Court 29 September 1981, NJ 1982/258.

928 'Questioning' a person who cannot be deemed to be a suspect is normally based on Article 2 of the PA [Politiewet]. See Supreme Court 2 October 1979, NJ 1980/243; Supreme Court 29 September 1981, NJ 1982/258; Supreme Court 6 January 1981, NJ 1981/500.

929 See, also, the Hague District Court 26 November 1981, NJ 1982/441. In this case, the Hague District Court concluded that a police record, as such, is insufficient to come to a reasonable suspicion. See, also, Supreme Court 8 December, NJ 1982/533; Supreme Court 1 May 1984, NJ 1984/687; Supreme Court 14 October 1986, NJ 1987/564 (Schaduwen I); Supreme Court 14 October 1986, NJ 1988/511 (Schaduwen II). Two cases in which the fact that a person was known to the police and had a police record only played a marginal role in coming to a reasonable suspicion are, furthermore, Supreme Court 1 November 1980, NJ 1981/125; Supreme Court 21 May 1991, NJ 1991/731; Supreme Court 23 November 1999, NJ 2000/127.

Supreme Court 16 November 1982, NJ 1983/283. 
and his role in those activities, was sufficient information for a reasonable suspicion.

\section{Case law: Notorious areas}

The notoriety of the area where a person lives, is arrested or commits a criminal offence, is an aspect that often plays a role in sustaining a reasonable suspicion. The more notorious a neighbourhood is, the more inclined investigative officers are to consider persons present in that area as suspects. In the Stormsteeg judgement, ${ }^{931}$ the Supreme Court attached considerable importance to the notorious reputation of the area in which the 'suspect' was arrested.

In this case, two investigative officers literally ran into a man in a street where drugs were frequently trafficked and used. The man had his right hand deep in his pocket and quickened his pace upon seeing the investigative officers. On the basis of these circumstances, the investigative officers assumed a reasonable suspicion, and stopped and frisked the person concerned. They discovered an amount of heroine in the suspect's pocket. ${ }^{932}$

The Supreme Court argued that these circumstances were sufficient to establish a reasonable suspicion. ${ }^{933}$ Even though the Supreme Court did not explicitly examine whether the notoriety of the neighbourhood formed a crucial circumstance in coming to a reasonable suspicion, it is highly unlikely that the same conclusion would have been reached if the suspect had been stopped in an area not known as 'drug neighbourhood'.

In the Damrak judgement, ${ }^{934}$ the notoriety of the area where the alleged suspects were apprehended unequivocally played a role of importance in sustaining a reasonable suspicion. The facts of this case took place in the vicinity of the Damrak in Amsterdam, an area that was, at the time, a well-known drugs-trafficking spot. Among experienced members of the police, it was, furthermore, common knowledge that interactions between foreign white skin-coloured persons and Dutch coloured persons in the surroundings of the Damrak were more or less always an indication of ongoing drugs-related activities. The alleged suspects were two Germans - white skin-coloured - and several Dutch coloured persons. They were arrested on suspicion of trafficking in drugs.

The Supreme Court considered that the notorious reputation of the area where the alleged suspects were arrested, in combination with the nationality/skin colour of these persons, who moreover, tried to ran off upon seeing the investigative

\footnotetext{
931 Supreme Court 2 February 1988, NJ 1988/820.

932 For the search, 'serious objections' were required. See Article 27 of the DCCP and Article 9 of the OA.

933 These circumstances were also adequate to sustain serious objections pursuant to Article 9 of the OA and Article 56, section 4 of the DCCP.

934 Supreme Court 6 December 1983, NJ 1984/442 (Damrak-arrest).
} 
officers, was sufficient to demonstrate a reasonable suspicion. The fact that the investigative officers had considerable experience in the area concerned also contributed to this conclusion.

A last important judgement in which the notorious reputation of an area played a role is the Ruimte judgement. ${ }^{935}$ This case primarily concerned the question of whether there was sufficient information to demonstrate serious objections against the alleged suspect, but that automatically answered the question of whether there were adequate facts or circumstances to assume a reasonable suspicion. The youth centre, Ruimte, in Rotterdam was a well-known spot among the local police because of the drug trafficking and drug using activities that took place there on a broad scale. One night, a number of investigative officers went to this youth centre and observed that several, not further identified, persons were trafficking and using drugs. On the basis of that information, the police raided the centre and stopped and searched a number of persons in respect of drugs offences.

The District Court, the Court of Appeal and the Supreme Court all concluded that because it was known to the police that drug trafficking was taking place in the centre on a broad scale, which was moreover ascertained on the night concerned, prior to raiding the centre, the investigative authorities had sufficient facts and circumstances to assume a reasonable suspicion on account of the OA.

In sum, if an area or a specific spot or building has a notorious reputation among the investigative authorities for its criminal activities, that knowledge may very well contribute to denoting persons present in such an area or spot as a suspect. The more 'suspiciously' persons behave in a notorious area/spot, and the more notorious and well outlined that area or spot is, the more easily investigative authorities may assume a reasonable suspicion.

\section{CASE LAW: ANONYMOUS TIP-OFFS AND OTHER ANONYMOUS OR SECRET INFORMATION}

Anonymous or secret information is often used to sustain a reasonable suspicion, particularly during criminal investigations into terrorist offences. ${ }^{936}$ The investigative authorities increasingly use such information to come to a reasonable suspicion, to sustain serious objections, to justify police custody and remand in custody and even as evidence during trial. ${ }^{937}$ Even though such information is hence basically used during the whole course of the criminal process, I will only examine what role anonymous or secret information may lawfully play in generating a reasonable suspicion during the pre-trial phase.

\footnotetext{
935 Supreme Court 14 January 1975, NJ 1975/207.

936 See, in this respect B. van Gestel, C.J. de Poot and R.F. Kouwenberg, De Wet opsporing terroristische misdrijven drie jaar in werking, WODC, Cahier 2010-3, p. 12.

937 Staatsblad 2006, 460.
} 
There are several kinds of anonymous or secret information. To start with, the anonymous tip-off: the police receive a phone call, ${ }^{938}$ an e-mail or a note from an unknown source concerning (ongoing) criminal activities. Such anonymous tip-offs are often used to sustain a reasonable suspicion, in part depending on the nature of the alleged criminal offence. ${ }^{939}$ The more serious the alleged criminal activities are, the more justified it is considered to use anonymous information to generate a reasonable suspicion. Using difficultly verifiable anonymous tip-offs to sustain a reasonable suspicion concerning terrorist crimes and serious drug related crimes is considered more justified than when it would regard petty crimes. ${ }^{940}$ This is provided that the incriminating information is sufficiently concrete ${ }^{941}$ and up-todate: the information must concern criminal activities that are ongoing or have just taken place. ${ }^{942}$ This type of anonymous information is the most unverifiable one with regard to content as well as reliability. That lack of verifiability should arouse caution with the investigative authorities when using such information as the (only) basis to assume a reasonable suspicion. ${ }^{943}$

As early as 1980, the Supreme Court was asked to judge on the use of anonymous tip-offs to sustain a reasonable suspicion. ${ }^{944}$ In one case, the police received an anonymous phone call from a person who stated that someone living in Amsterdam had just entered his house with a plastic bag that (allegedly) contained drugs. Can

938 Through the so-called kliklijn/Meld Misdaad Anoniew-lijn (snitch line). This is a phone number anyone can call to report information concerning criminal activities without being obliged to reveal their identity to the investigative authorities. The legal basis for such 'investigative methods' is Article 2 of the PA [Politiewet]. See Amsterdam Court of Appeal 7 February 2005, LJN: AS5816.

939 Haarlem District Court 19 February 2004, LJN: AO4855. The Haarlem District Court took into account that the suspicion concerned serious criminal offences (violation of the OA).

940 Supreme Court 25 September 2001, LJN: ZD1858, NJ 2002, 97; Supreme Court 11 March 2008, NbStr. 2008, 144.

941 Compare with Supreme Court 8 December 1982, NJ 1982/533. In this case police officers received further information from the police information centre regarding two persons that the police officers were observing. One of the alleged suspects (W.) was known to the police as a presumed drug trafficker. In addition, the police-info-centre informed the police officers of the fact that W. was (potentially) trafficking in, transporting, or possessing, drugs. This information was, according to the Supreme Court, insufficiently concrete and precise to legitimately generate a reasonable suspicion - pursuant to Article 27, section 1 of the DCCP as well as pursuant to Article 9, section 1 sub a of the OA. See, also, 's-Hertogenbosch Court of Appeal 4 February 2009, LJN: BH2038, 20-001853-08.

942 Amsterdam Court of Appeal 7 February 2005, LJN: AS5816, NJ 2005/147; Supreme Court 13 June 2006, LJN: AV4179, NJ 2006/346. However, in Supreme Court 13 June 2006, LJN: AV6195, the time span between the receiving of incriminating information and the actual establishment of a reasonable suspicion and ensuing application of coercive measures (house search and arrest) was six months.

943 See in this respect also Van Der Kruijs P.W., 'Het vereiste van redelijk vermoeden op basis van anonieme informatie in het bijzonder bij terroristische misdrijven', in Strafblad, afl. 4, 2004 jrg. 2, pp. 255-270.

944 Supreme Court 18 November 1980, NJ 1981/125. 
such an anonymous tip-off play a role, as fact or circumstance, to demonstrate a reasonable suspicion? The Supreme Court answered this question unequivocally in the affirmative, and has repeatedly judged alike in various comparable cases. Besides the tip-off, the Supreme Court also took into account that the alleged suspect was known to the police due to several earlier convictions for drug related offences. That formed, next to the rather unverifiable tip-off, a more objective fact to demonstrate a reasonable suspicion. ${ }^{945}$ In this case, the Supreme Court did not, however, conclude that an anonymous tip-off as such - and hence without additional (objectively verifiable) information - is adequate to establish a reasonable suspicion.

What would the Supreme Court have decided if the suspect had not had such an abundant police record? A judgement from the Hague District Court concerned a case in which the police received an anonymous phone call through the so-called Meldlijn M (Meld Misdaad Anoniem). ${ }^{946}$ The anonymous caller stated that he had seen/heard that a person, named Y., of Dutch nationality and of about 30 years of age, and living in $\mathrm{X}$ or $\mathrm{X} 2$, had threatened to throw a bomb into the Mosque on $Z$-street. The police checked this information - foremost the personal details of the alleged suspect - on their registration system and performed two house searches in one of the addresses mentioned by the anonymous caller. They found a jerry can that smelled of fuel and two weapons.

Even though the Hague District Court considered the phone call to be a fact pursuant to Article 27, section 1 of the DCCP, it did not consider that fact sufficient to demonstrate a reasonable suspicion. The fact that the alleged suspect was registered on the police data system concerning other criminal offences ${ }^{947}$ was inadequate to further demonstrate a reasonable suspicion. Concluding, it can be said that at this point it seems as if anonymous tip-offs may very well count as fact or circumstance and contribute to the establishment of a reasonable suspicion, but there must be some extra information that is open to objectification to generate a reasonable suspicion. ${ }^{948}$

In another case, the Supreme Court explicitly argued that an anonymous tip-off, without any additional information, is insufficient to generate a reasonable

945 Remarkably, the Advocate-General in this case unambiguously underlined that anonymous tipoffs are indispensable for investigative officers to perform their task and have, moreover, always formed an accepted cause for police investigations.

946 The Hague District Court 3 December 2004, LJN: AR 7038.

947 The police had not specified for which precise criminal offences the alleged suspect appeared on the police registration system. The Court might have come to a different conclusion if the alleged suspect had a police record with several convictions for the same criminal offences as the one he was suspected of this time.

948 Compare, also, with Haarlem District Court 19 February 2004, LJN: AO4855; Amsterdam District Court 29 June 2005, LJN: AT846 and Supreme Court 13 June 2006, LJN: AV 4179. 
suspicion. ${ }^{949}$ It concerned a considerably detailed tip-off regarding illegal hemp cultivation in the basement of a house. The tip-off provided the investigative authorities with specific information regarding the place where the hemp was cultivated, the people involved in it, and the quantity of hemp. The investigative authorities thereupon raided the house and found 1000 hemp plants.

The Court of Appeal considered that, if possible, it is desirable that the authorities collect additional information themselves besides from the anonymous tip-off, but that it is not per se prohibited to use an anonymous tip-off as the only basis for a reasonable suspicion. The Supreme Court, hence, did not agree with this line of reasoning and argued that an anonymous tip-off is insufficient to sustain a reasonable suspicion. ${ }^{950}$

\section{CASE LaW: CIE-INFormation}

Every region in The Netherlands has a Regional Criminal Information division (RCIE) that collects relevant information [Criminele Inlichtingen Eenheid, CIE information] for investigative purposes. These investigative activities are generally based on Article 2 of the PA. ${ }^{951}$ In several judgements, the Supreme Court has held this Article to provide an adequate legal basis for the application of several, not too far-reaching, investigative techniques such as ordering certain persons to leave a place and/or to take certain objects with them, occasionally tailing persons or observing persons in public and photographing persons in public. ${ }^{952}$ Important to underline in this respect is that these investigative methods pursuant to Article 2 of the PA, are applied to persons who are not yet considered as suspects. ${ }^{953}$

CIE information does not always need to be secret with regard to its source. Regularly, such information is simply information stemming from certain teams of police officers who conduct so-called tactical investigations into certain kinds of criminal activities.954 This information is often used to start a criminal investigation ${ }^{955}$ but also to establish a reasonable suspicion, as a basis for serious

Supreme Court 13 July 2010, LJN: BM2492, 08/03674. See, also, Supreme Court 11 March 2008, NJ 2008, 328 and NJ 2008, 329.

Supreme Court 13 July 2010, LJN: BM2492, 08/03674, paragraph 2.6. The Supreme Court concluded in the above-discussed way even despite the fact that the raid was urgent as the hemp was being cut which meant that all people involved in the hemp cultivation were present. Amsterdam Court of Appeal 7 February 2005, LJN: AS5816.

952 Supreme Court 19 December 1995, NJ 1996/249. See, furthermore, Chapter III for a more elaborate discussed of Article 2 of the PA.

953 See Chapter $\mathrm{V}$ for a discussion of the exploratory inquiry into terrorist offences.

954 Such as a tactical team regarding terrorism, criminal organisations, drugs or weapons.

955 Rotterdam District Court 19 December 2006, LJN: AZ8683; Supreme Court 11 June 2002, LJN: AE0045; Supreme Court 18 November 2003, LJN: AJ0517; Supreme Court 9 March 2004, NJ 2004/263; Rotterdam District Court 1 December 2006, LJN: AZ3589 (Piranha case). 
A Reasonable Suspicion

objections and even to legitimise the application of special investigation techniques. ${ }^{956}$

Besides CIE information from tactical investigations, such information may also contain statements of criminals - informants - concerning the criminal activities, plans and whereabouts of co-offenders. Because these informants are often afraid of reprisals from their (former) colleagues, they normally want to remain anonymous and only transmit the incriminating information through the CIE. ${ }^{957}$ Therefore their statements are comprised in a procès-verbal without mentioning their name. ${ }^{958}$ Subsequently, the head of a RCIE is allowed to transmit the procès-verbal to the criminal investigation department, which, in its turn, takes over the criminal investigation. ${ }^{959}$ At this point the crucial question is whether this kind of information may contribute to or even establish as such a reasonable suspicion?

Non-anonymous and anonymous CIE information may, comparable to anonymous tip-offs, ${ }^{960}$ depending on: (1) the concreteness (as to person and place), and (2) on the preciseness (alleged criminal activities/offence(s)) of the information,

956 Supreme Court 14 February 2006, NJ 2006/167. In this case the RCIE (Regionale Criminele Inlichtingen Eenheid) had been observing three persons for a considerable time. The RCIE discovered that the three men possessed several weapons and quantities of ammunition. On the basis of that information, the police assumed a reasonable suspicion, as well as serious objections, against two of the three men. The Supreme Court approved this method of investigation and judged the information to be sufficient for a reasonable suspicion. See, also, 's-Hertogenbosch Court of Appeal 29 April 2003, LJN: AO9041 in which the Court of Appeal repeatedly stated that CIE information may, as such, very well generate a reasonable suspicion without any additional facts or circumstances. And see Haarlem District Court 27 November 2006, LJN: AZ3147, in which judgement the District Court states that CIE-information can be sufficient for an investigative judge to order a private phone to be tapped. The CIE-information was considered to be consistent and rather concrete in nature, considerable as to amount and the information had moreover been gathered during a large period of time (4 years). See also Maastricht District Court 22 December 2003, LJN: AO0739 in which judgement CIEinformation was used as basis for application of the special investigative techniques comprised in Articles $126 \mathrm{~m}$ and $126 \mathrm{n}$ of the DCCP.

957 The Utrecht District Court (Utrecht District Court 10 March 2005, LJN: AS 9913) considered that CIE-information from criminal/civilian informants is not anonymous, because the investigative authorities do know the informant's identity (which is, moreover, registered with the investigative authorities). Nevertheless, the defence counsel and the suspect do not know the informant's identity. I will therefore denote this information as anonymous. See, in this respect also, Staatscourant. 2006, 25: Aanwijzing opsporingsbevoegdheden, see foremost Article 3.5.2.

958 Such information is not the same as anonymous information pursuant to Article $126 \mathrm{v}$ of the DCCP. Information from the RCIE which comprises statements of anonymous criminal informants does, therefore, have a rather peculiar position in the criminal process primarily in terms of respect for defence rights.

959 See Staatscourant. 2000, 25: Aanwijzing opsporingsbevoegdheden, foremost Article 3.5.2. This provision obliges the RCIE to provide information to the police in writing. See, also, Supreme Court 9 December 2003, NJ 2004/132.

960 The difference between anonymous tip-offs, on the one hand, and anonymous CIE informants, on the other, is that the latter persons are known as their identity is known to, and registered with, the CIE. See Staatscourant 2006, 25: Aanwijzing opsporingsbevoegdheden, see foremost Article 3.5.2. 
very well establish or contribute to a reasonable suspicion. ${ }^{961}$ Foremost, when it concerns information regarding a severe criminal offence, like a terrorist offence, the Judiciary considers CIE information as such as adequate basis for a reasonable suspicion. ${ }^{962}$

In practice, there will often be additional facts or circumstances to sustain the (anonymous) CIE information. For instance, when the police receives information from the RCIE that Mr. X will arrive around 12.30 by plane from Isla Margariha in Schipol Airport with a considerable quantity of cocaine and the police actually see $\mathrm{Mr}$. X at 12.30 with a large bag, that latter observation by the police is an additional (objective) circumstance which sustains the alleged reasonable suspicion flowing from the CIE information. ${ }^{963}$

It should, however, be kept in mind that even if the anonymous CIE information is insufficient to generate a reasonable suspicion, for example, because the informant appears to be unreliable, investigative officers may use that information to apply special investigation techniques pursuant to Title VB. Hence, CIE information can also be sufficient to generate indications of a terrorist offence. ${ }^{964}$

\section{CASE LAW: SeCret intelligenCe information}

At present, secret intelligence information is often used to establish a reasonable suspicion, particularly in the case of terrorist offences. ${ }^{965}$ Such information may be rather concrete, concerning specific persons and specified suspicious behaviour. However, it may just as well concern rather general information about 'trends which threaten our democratic society', risk analysis or general information stemming from foreign intelligence information. One aspect applies, however, to all types of information stemming from the secret intelligence services: the source remains, generally speaking, secret for the investigative authorities, the alleged suspect and the Judiciary. 966

961 Haarlem District Court 10 October 2006, LJN: AZ1026; Utrecht District Court 10 March 2005, LJN: AS 9913 and 's-Hertogenbosch Court of Appeal 29 April 2003, LJN: AO9041.

962 Utrecht District Court 10 March 2005, LJN: AS9913.

963 Haarlem District Court 10 October 2006, LJN: AZ1026.

964 See Chapter V on indications of a terrorist offence.

965 Though the Dutch secret intelligence services do not exclusively consist of the AIVD - but also of the MIVD - I will solely refer to AIVD-information (see Articles 6 and 7 of the Act on the secret intelligence services (Wet op de Inlichtingen - en veiligheidsdiensten 2002). So far, I have not found any judgements/instances in which the MIVD has passed information to the investigative authorities which then led to fulfilment of the reasonable suspicion criterion, as comprised in Article 27, section 1 of the DCCP. See, in this respect also, Reijntjes J.M., 'Terreurbestrijding en het delen van geheimen', in Strafblad, afl. 4, jrg. 2, 16 December 2004, pp. 271-279.

966 Article 85 and further of the Act on the secret intelligence services and see the Hague Court of Appeal 21 June 2004, NJ 2004/432. 
The secret intelligence services are allowed to and even - under certain circumstances - obliged to, pass information concerning criminal activities to the investigative authorities and several other authorities. ${ }^{967}$ This information exchange often serves to attain a specific (practical) aim. For instance, the secret intelligence services have incriminating information about a presumed terrorist organisation and they deem it necessary for the investigative authorities to perform a house search. As the secret intelligence services are not allowed to apply such investigative powers, they will pass the necessary information on to the investigative authorities. ${ }^{968}$ If the secret intelligence services have information that may be of importance for the investigation of, or the prosecution of, terrorist offences, they pass it on to the National Public Prosecutor Terrorism who - after evaluation of the information - forwards the information to a regular public prosecutor who will be responsible for the actual criminal investigation.

The judgements that will now be discussed all concern cases in which the investigative authorities came to a reasonable suspicion regarding (terrorist) offences on the basis of secret intelligence information. ${ }^{969}$

The first judgement ${ }^{970}$ concerns several persons suspected of belonging to a criminal (terrorist) organisation, which, among other offences, forged travelling documents. ${ }^{971}$ The suspicion against these persons was exclusively generated by secret intelligence information. Allegedly, an infiltrator of the secret intelligence services mapped out the structure of a (international as well as national, according to the prosecution) criminal organisation to which the suspects belonged. The secret intelligence services passed that information on to a public prosecutor who initiated the prosecution against 13 suspects. The prosecutor, furthermore, ordered a (house) search and the suspects' arrest. Hence, the 'reasonable suspicion' against the

967 Article 36 and Article 38 of the Act on the secret intelligence services. See, also, Kamerstukken II 2002-2003, 28845 , no. 2, p. 23 and no. 5, p. 4.

968 Article 6 and Article 6, section 1 of the Act on the secret intelligence services. See, also, Kamerstukken II 1997-1998, 25 877, no. 3, p. 55 and further.

969 Rotterdam District Court and the Hague Court of Appeal 18 December 2002 and 21 June 2004, respectively, and 31 December 2002 and 17 January 2003, LJN: AF2141, AP3601, AF2579, AP2058 and AF 3039 (Rotterdamse zaken).

970 Rotterdam District Court 18 December 2002, LJN: AF2141 and 10/150080/01.

971 They were charged with the following offences: participation in forgery of passports, driving licences, and other travel- and identity documents; participation in and possession of, issuing of and handling, the above-mentioned documents; participation in an international and national criminal organisation. Rotterdam District Court 18 December 2002, LJN: AF2141 and $10 / 150080 / 01$. In the appeal judgement the suspects were denoted as having the purpose to commit terrorist attacks/offences, even though such a purpose had not yet been transformed into practical criminal activities - see the Hague Court of Appeal 21 June 2004, LJN: AP3601 and 2200071203 , paragraphs $10.1 .1,10.1 .2,10.1 .3$. and 10.3 . 
suspects, the house(search $)^{972}$ and the arrests ${ }^{973}$ were all based on the same secret intelligence information without there being any additional information gathered by the investigative authorities.

The Rotterdam District Court argued that secret intelligence information may very well have led to the opening of a criminal investigation, but that secret information in itself is insufficient to yield facts or circumstances pursuant to Article 27, section 1 of the DCCP. ${ }^{974}$ The investigative authorities are obliged to gather additional information themselves to fulfil the requirements of Article 27, section 1 of the DCCP. In light of these considerations, the Court deemed the reasonable suspicion against the suspects, the house(search) and the arrest all illegal due to a lack of sufficient grounds.

The Hague Court of Appeal ${ }^{975}$ did not share the Rotterdam District Court's opinion, and judged in the complete opposite direction. ${ }^{976}$ In the Hague Court of Appeal's opinion, the secret intelligence services were allowed to supply the police with information which might be of importance for a police investigation. ${ }^{977}$ Even more, the secret intelligence services and the investigative authorities may very well each run their own investigations into the same persons at the same time (parallel). During such parallel investigations, the secret intelligence services remain entitled to provide the police with relevant information concerning the case. Only when the police unambiguously use the secret intelligence services exclusively to gather information for (ongoing) criminal investigations, is this parallel manner of investigating forbidden. In line with these considerations, the Hague Court of Appeal concluded that secret intelligence information, as such, is sufficient to demonstrate a reasonable suspicion. ${ }^{978}$

972 Article 96 of the DCCP. For a house search the prosecutor needs a warrant from an investigative judge pursuant to Article 110 of the DCCP.

973 Article 54 of the DCCP.

974 See, in this respect also, Kamerstukken II 2002-2003, 28 845, no. 1-2, pp. 25.30.

975 The Hague Court of Appeal 21 June, 2004, LJN: AP3601, 2200071203.

976 On appeal, the Hague Court of Appeal nevertheless did confirm the Rotterdam District Court's view that the secret intelligence services on the one hand, and the investigative authorities, on the other, should remain strictly divided in their working sphere. The judgement underlines explicitly that the secret intelligence services are not allowed to employ specific criminal law based procedural powers (paragraph 4.3.7 and see Article 9, sections 1 and 2 of the Act on the secret intelligence services.

Article 38 of the Act on the secret intelligence services. A National Prosecutor for TerrorismCases [Landelijk (terreur)officier van justitie] has been appointed to pass the information in the form of an official report from the secret intelligence services to the investigative authorities.

978 The Hague Court of Appeal 21 June 2004, LJN: AP3601, 2200071203, paragraphs 4.3.8 and 4.3.10. 
The second important judgement concerning the use of secret intelligence information to demonstrate a reasonable suspicion followed the Hague Court of Appeal's line of reasoning. 979

In this case the reasonable suspicion was based on: (1) secret intelligence information, and (2) on incriminating information that had been found during a house search in the house of the suspect's friend. It is interesting to see that the Rotterdam District Court explicitly argued that secret intelligence information, certainly when it concerns 'terrorist suspects', may very well be used for investigative purposes throughout criminal proceedings, and such information may therefore also be used to generate a reasonable suspicion and to justify the application of coercive powers. Three aspects led the Rotterdam District Court to conclude that the secret intelligence information was adequate to generate that reasonable suspicion, to perform the house search, and to arrest and detain the suspect.

Firstly, the fact that the National prosecutor for terrorism related offences examined if the information was acquired by lawful means contributed to the trustworthiness of the information. Second, having regard to the detailed content of the information, it was considered to be based on more than merely on an incidental tip-off. Thirdly, the Rotterdam District Court underlined that for the past few years criteria to come to a reasonable suspicion have dropped considerably, especially when it concerns suspicions regarding organised crime. As a result, the only limitation to apply investigative/coercive powers is the interest of the investigation. So, the interest of the investigation is more decisive for the lawful application of such powers than the question of whether there is a reasonable suspicion.

In addition, the Rotterdam District Court argued that the application of procedural/ coercive powers is no longer connected to a certain suspect, but more and more to persons who are allegedly involved in crimes committed in an organised context. ${ }^{980}$ This implies that suspicion criteria increasingly refer to a suspicious situation, rather than to a suspicious person. When the police detect the alleged plotting or committing of serious criminal offences in an organised context and they suspect someone of being involved in that organised context, in that situation, hence, that person may lawfully be deemed as a suspect. Also, the Rotterdam District Court argued that case law and literature demonstrate that anonymous tip-offs, information received through application of control orders, and official documents from foreign

979 Rotterdam District Court 31 December 2002, LJN: AF2579, 10/000109-02. The secret intelligence services in this case had passed information to the National public prosecutor responsible for combating terrorism who, in turn, examined - marginal - the information's content and passed it to another (common) public prosecutor, who actually prosecuted the case. The suspect was allegedly occupied with 'terrorist offences', or at least with the preparation thereof. On the basis of the secret intelligence information, his house was searched and he was arrested.

980 Compare also with the preceding Chapter V concerning application of special investigative techniques in investigations into terrorist crimes. 
services may generate a reasonable suspicion. In light of these considerations, the Rotterdam District Court saw no reason to refuse secret intelligence information as the basis for a reasonable suspicion. Secret intelligence information may, hence, without limitations be used to sustain a reasonable suspicion. This latter line of reasoning does not, however, completely coincide with case law. In various judgements anonymous tip-offs, as well as information from the police information centre have, as has been discussed above, been deemed inadequate as the basis for such a reasonable suspicion.

On appeal, the Hague Court of Appeal agreed with the District Court. The judgement of the Court of Appeal comprised three important remarks regarding the issue of using secret intelligence information as the basis for a reasonable suspicion. Firstly, secret intelligence information that the investigative authorities use to sustain a reasonable suspicion must always contain sufficiently objective facts. This is a clear reference to the normal standards concerning a reasonable suspicion. Secondly, the seriousness/gravity of the crimes allegedly committed - terrorist crimes - plays a role of importance in deciding whether secret information may lead to a reasonable suspicion. ${ }^{981}$ Thirdly, the Hague Court of Appeal underlined that secret intelligence information must be examined on its trustworthiness. If there are well-founded indications to believe that the secret intelligence services grossly violated fundamental rights of the suspect during their informationgathering, the judge sitting in the case has an obligation to investigate the manner in which the information has been gathered by the secret intelligence services. ${ }^{982}$ However, so far, this exceptional circumstance has never occurred.

Finally, the Supreme Court confirmed the Hague Court of Appeal's judgement. ${ }^{983}$ Secret intelligence information may be considered as facts or circumstances to fill up the reasonable suspicion criterion. Furthermore, as the Supreme Court considered, secret intelligence information can also form the basis for starting criminal investigations, and it can be used as evidence during trial, provided that defence rights are not tampered with to such extent that a fair trial can no longer be guaranteed.

Concluding, secret intelligence information can generate a reasonable suspicion, especially when it concerns investigations into terrorism. ${ }^{984}$ This is, in the

\footnotetext{
981 The Hague Court of Appeal 21 June 2006, LJN: AP2058 and 2200071403, paragraph 2.

982 The Hague Court of Appeal 21 June 2006, LJN: AP2058 and 2200071403, paragraph 4.3.9.

983 Supreme Court 5 September 2006, RVDW 2006/803 and Supreme Court 5 September, RVDW 2006/808

984 See, also, for a more general context; Lensing J.A.W., Wetboek van Strafvordering - Suppl. 108 (1998), artikel 27, aantekening 3k, 97-102 in Melai A.L. \& Groenhuijsen M.S. e.a., Het Wetboek van Strafvordering, voortgezet onder redactie van Groenhuijsen M.S. (editor), de Roos Th.A., Swart A.H.J. and Kristen F.G.H., Kluwer, Deventer, losbladig.
} 
Judiciary's opinion, justified because it regards crimes that severely threaten our democratic society. ${ }^{985}$ The only limitation is that the information must comprise objective 'facts or circumstances' as required by Article 27, section 1 of the DCCP.

\subsection{Reasonable}

To lawfully consider someone as a suspect, Article 27, section 1 of the DCCP requires the suspicion to be reasonable. Generally speaking, this Article therefore includes two presumptions. Firstly, the presumption that a criminal offence has taken place, ${ }^{986}$ and secondly, the presumption that a certain person - the suspect committed the presumed criminal offence. Both presumptions must be 'reasonable' in light of the available facts and/or circumstances. ${ }^{987}$ The more reliable and objective facts or circumstances there are, the more reasonable a suspicion will be. Therefore, the reasonableness of a suspicion is primarily dependent on the amount, the reliability and the kind of source(s) of the information used to demonstrate a suspicion.

The reasonableness of a suspicion also regards the question of what the normal situation on site would be, or how another person would have behaved in a comparable situation. ${ }^{988}$ Is it normal to run away upon seeing two investigative officers during the night in an area known for ongoing criminal activities? Is it usual for a convicted burglar to drive a minivan to a construction site at $3 \mathrm{am}$ ? Is it normal for a group of minors to buy large quantities of inflammable substances at the local drugstore for personal use?

The point is, hence, that everything that more or less deviates from the 'normal' can contribute to generating a reasonable suspicion. However, the issue whether there is indeed such 'deviant' behaviour should not be considered as an exclusive or decisive element in determining whether there is, or is not, a reasonable suspicion. This is to a high extent a subjective and personal question. Nevertheless, the

985 See, also, Rotterdam District Court 1 December 2006, LJN: AZ3589 (Piranha case) in this judgement the District Court, without much consideration, accepted that secret intelligence information had been used for the start of a criminal investigation as well as for the organisation of the investigation itself. Furthermore, certain evidence gathered by the secret intelligence services, such as telephone conversations which had been tapped, was used as evidence during the trial.

986 Including criminal offences that have not yet been committed but that are being plotted. See the relevant titles of the DCCP regarding special investigation techniques.

987 Supreme Court 3 December 1991, NJ 1992/324; the Hague Court of Appeal 28 February 1991, NJ 1991/699; Supreme Court 23 November 1999, NJ 2000/127; Maastricht District Court 26 March 2002, Nieuwsbrief Strafrecht 2002, 136; Amsterdam Court of Appeal 5 November 2002, Nieuwsbrief Strafrecht 2003, 64; Rotterdam District Court 1 May 2000, Nieuwsbrief Strafrecht 2000, 216; Rotterdam District Court 23 May 2000, Nieuwsbrief Strafrecht 2000, 215; Amsterdam Court of Appeal 28 August 2002, Nieuwsbrief Strafrecht 2003, 65.

988 Supreme Court 14 January 1975, NJ 1975/207; Supreme Court 6 December 1983, NJ 1984/442. 
investigative authorities are undeniably more capable of somehow objectively determining which situations indeed diverge from the normal. ${ }^{989}$

Also, the investigative authorities do have a discretionary power to fill in legal notions such as the reasonable suspicion criterion. Reasonable does not mean that there cannot be drawn any other conclusion than the investigative officers' conclusion that a person is deemed a suspect. ${ }^{990}$ Facts or circumstances used to demonstrate a suspicion may make one investigator conclude that someone should indeed be considered as suspect, whereas another investigator might decide that there is insufficient information to come to a reasonable suspicion. Judges tend to respect the investigative authorities' discretionary power in this respect. ${ }^{991}$ Judicial review of compliance with Article 27, section 1 of the DCCP is consequently marginal.

The requirement that a suspicion must be reasonable has several functions. Primarily, it serves to objectify a suspicion: pure subjective intuition or speculations are inadequate to generate a reasonable suspicion, though they may very well generate a 'normal' suspicion. A suspicion as it is, must thus be reasonable, instead of exclusively being reasonable in the eyes of the investigative authorities. ${ }^{992}$ It must be open to objectification, which presupposes concrete information concerning content and source. In light of these considerations, the mere possibility that a person committed a criminal offence is insufficient to come to a reasonable suspicion. On the other hand, the requirement of reasonableness does not go as far as to oblige the investigative authorities to demonstrate that there is no other option possible than the alleged suspect having committed the offence. This also depends on the seriousness of the allegedly committed offence and on the intrusiveness of the power that is to be applied. ${ }^{993}$

989 Supreme Court 24 February 1981, NJ 1981/366; Rotterdam District Court 28 March 1984, NJ 1984/508; Supreme Court 20 March 1984, NJ 1984/549; Supreme Court 2 February 1988, NJ 1988/820; Supreme Court 18 October 1988, NJ 1989/430; Supreme Court 3 December 1991, NJ 1992/324.

990 Lensing J.A.W., Wetboek van Strafvordering - Suppl. 108 (1998), artikel 27, aantekening 3c, 62-66 in Melai A.L. \& Groenhuijsen M.S. e.a., Het Wetboek van Strafvordering, voortgezet onder redactie van Groenhuijsen M.S. (editor), de Roos Th.A., Swart A.H.J. and Kristen F.G.H., Kluwer, Deventer, losbladig. See, also, Duk W., 'Beoordelingsvrijheid en beleidsvrijheid', in Rechtskundig Maandblad Themis 1988, pp. 156-169; Cleiren C.P.M., Beginselen van een goede procesorde - een analyse van rechtspraak in strafzaken, Arnhem 1989, pp 50-51. Supreme Court 3 December 1991, NJ 1992/324.

992 Handelingen II 1913-1914, 286, no. 2 and 3.

993 See, in this respect also, C.J. de Poot, R.J. Bokhorst, W.H. Smeenk, R.F. Kouwenberg, De Opsporing verruimd? De Wet opsporing terroristische misdrijven een jaar in werking, WODC, Cahier 2008-9, pp. 16, 44-46 and 53-55. 


\subsection{Guilty of a criminal offence}

The DCC and the DCCP comprise the notion of 'guilty' in various contexts, each time with a different connotation. Firstly, this notion stands for the general prerequisite that to be held criminally liable, there must be some degree of guilt or at least reproachableness [verwijtbaarheid] in a person's behaviour. This is an implicit requirement in every criminal law provision. Secondly, 'guilty' serves as explicit prerequisite in various criminal law provisions. ${ }^{994}$ In such provisions guilt implies carelessness, recklessness or lack of caution. ${ }^{995}$

Thirdly, 'guilty' is used to distinguish between intentional criminal behaviour and criminal behaviour caused by guilt [schuldvormen]. Lastly, the notion of 'guilty' may imply that a person is, in fact, guilty of the criminal offence he has been accused of.996

This last-mentioned meaning attached to the notion of 'guilty' applies in the case of Article 27, section 1 of the DCCP: to lawfully consider a person as a suspect, the investigative authorities must have a reasonable suspicion that the person concerned has actually committed an offence i.e. that he fulfilled all of the elements comprised in a criminal law provision. ${ }^{997}$ However, during the initial stages of a criminal investigation not all of the elements need to be equally substantiated by facts or circumstances. It suffices when, on the basis of the available information, it can reasonably be concluded that a criminal offence is being committed or has been committed. That presupposes that the suspicion concerns the core of the material criminal offence - i.e. the essential parts thereof. ${ }^{998}$ In this respect, it is of importance to note that the suspicion does not need to be as clear as to unequivocally demonstrate which precise criminal offence it concerns. It is sufficient when the relevant behaviour is, at the very, least punishable on the basis of a criminal law provision. .99

\footnotetext{
994 See, for instance, Title XXI of the DCC.

995 See Articles 98b, 158. 161ter, 161quinquies, 163, 165, 307, 308 of the DCC.

996 See Articles 225, 261, 262, 310, 321, 340 of the DCC.

997 Lensing J.A.W., Wetboek van Strafvordering - Suppl. 108 (1998), artikel 27, aantekening 2, 37-42 in Melai A.L. \& Groenhuijsen M.S. e.a., Het Wetboek van Strafvordering, voortgezet onder redactie van Groenhuijsen M.S. (head-editor), de Roos Th.A., Swart A.H.J. and Kristen F.G.H., Kluwer, Deventer, losbladig.

998 Case law regarding Article 27, section 1 of the DCCP demonstrates that in this respect there is a difference between a reasonable suspicion regarding drug or weapon related offences for one thing, and a reasonable suspicion concerning common criminal offences, for another. See, for example, Rotterdam District Court 28 March 1984, NJ 1984/508.

999 Lensing J.A.W., Wetboek van Strafvordering - Suppl. 108 (1998), artikel 27, aantekening 2b, 44-48 in Melai A.L. \& Groenhuijsen M.S. e.a., Het Wetboek van Strafvordering, voortgezet onder redactie van Groenhuijsen M.S. (head-editor), de Roos Th.A., Swart A.H.J. and Kristen F.G.H., Kluwer, Deventer, losbladig.
} 


\section{Powers on the basis OF A ReASONABLE SUSPICION}

The DCCP includes various coercive powers that can be used on the basis of a reasonable suspicion, including powers to frisk and arrest suspects or the power to place a suspect in police custody. These powers can be divided into two categories: (1) powers that lead to deprivation of liberty, and (2) powers that do not imply a deprivation of liberty, but merely interfere with, for instance, a person's privacy or personal integrity, or imply a restriction on the right to liberty of movement.

With respect to persons suspected of a terrorist offence, primarily the first category of powers is important within the context of this book. Following enactment of the DPTA, the investigative authorities are currently allowed to remand terrorist suspects in custody on the mere basis of a reasonable suspicion. In the case of persons suspected of common offences a more demanding suspicion criterion applies, i.e. that of serious objections. Conversely, criteria for the application of the powers in the second category have not been amended. So those criteria are - in law - the same for persons suspected of common offences and of terrorist offences.

The following sections will discuss the powers as included in Articles 52-67a of the DCCP, starting with a brief overview of the second category of powers. The system of police custody and remand in custody will be discussed more elaborately, as it is exactly in this area that a different mechanism applies in the case of persons suspected of terrorist offences.

\section{STOPPING SUSPECTS ${ }^{1000}$}

The first coercive measure available to the investigative authorities ${ }^{1001}$ in the case of a reasonable suspicion is the power to stop a suspect. ${ }^{1002}$ The authorities are then allowed to ask the suspect's (first and family) name(s), date of birth, place of birth, place of residence (conform entry in a local register or the suspect's factual place of residence ${ }^{1003}$ ) and national insurance number. ${ }^{1004}$ On stopping a suspect, authorities

1000 This provision was last amended on 24 March 1993, Staatsblad 1993, 182. The amendment broadened the list of personal details which the investigative authorities may ask a suspect to provide, pursuant to Article 52 of the DCCP (date of birth and place of birth).

1001 See, for an enumeration of the competent investigative authorities, Articles 141 and 142 of the DCCP. 'Investigative authorities' in this context include police officers, assistant public prosecutors and public prosecutors.

1002 The Supreme Court has stated that witnesses may be stopped pursuant to Article 52 of the DCCP as well. Supreme Court 11 November 1947, NJ 1948/126.

1003 Staatsblad 1994, 565

1004 Article 55b, section 1 of the DCCP. 
are only allowed to ask for these personal details. ${ }^{1005}$ Asking for a suspect's personal details pursuant to Article 52 of the DCCP, is not considered an interrogation in accordance with Article 29 of the DCCP. ${ }^{1006}$

Factually speaking, Article 52 of the DCCP allocates the investigative authorities the power to literally stop suspects and ask them for the above-mentioned personal details. When a suspect refuses to provide the details, the competent authorities are allowed to search a suspect's clothes and/or any objects he carries with him, provided that it is necessary to discover the information asked for (Article 55b, section 2 of the DCCP). In addition, the competent authorities are authorised to use minor proportional forms of force, like grabbing the suspect and asking him again for his personal details, in case the suspect refuses to provide the information. ${ }^{1007}$

The importance of Article 52 of the DCCP has diminished considerably since the enactment of a statute that obliges everyone to carry identification papers [Wet uitgebreide identificatieplicht, 2005]. Pursuant to that statute, the investigative authorities ${ }^{1008}$ are empowered to ask any person over 14 years of age to show their identification papers, provided it is in the interest of the police's general task to safeguard public order. ${ }^{1009}$ This power may be applied without having a reasonable suspicion concerning the commission of a criminal offence. Refusal to comply with a request pursuant to Article 2 of the statute, constitutes a criminal offence in accordance with Article 447e of the DCC. ${ }^{1010}$

\section{Arrest AND POlice ARrest for interrogative PURPoSeS}

The second coercive measure that the investigative authorities can exert on a suspect is arrest and police arrest [ophouden voor onderzoek], pursuant to Articles 53, 54 and 61 of the DCCP.1011 This means that a suspect is, if need be with the use of proportional violence, brought to a place of interrogation, i.e. a police station, where

\footnotetext{
1005 Supreme Court 24 February 2004, NJ 2004/226. In this case, police officers knew the suspect's personal details because he was known to the police for prior criminal offences he had committed.

1006 Supreme Court 18 September 1989, NJ 1990/531; Supreme Court 6 January 1981, NJ 1981/500; Supreme Court 2 October 1979, NJ 1980/243; Supreme Court 7 October 1980, NJ 1981/61; Supreme Court 28 June 1977, NJ 1978/115.

1007 Supreme Court 17 December 2002, NJ 2003/178.

1008 Article $8 \mathrm{a}$ of the PA.

1009 Article 2 of the Wet op de identificatieplicht, in conjunction with Article 8a of the PA.

1010 The penalty for this offence amounts to a fine of the second category i.e. 3350 Euros (see Article 23, section 4 of the DCC). As will be set out below, the police are entitled to arrest a person who refuses to show his/her ID papers upon request, see Article 447e of the DCC and Article 53, section 1 of the DCCP.

1011 This law has lastly been amended in November 1963, see Staatsblad 1963, 565.
} 
he may be kept for a maximum period of six hours. ${ }^{1012}$ Suspects must obey a lawfully performed arrest. If a suspect (attempts to) run away or uses violence to resist a lawfully performed arrest, he is criminally liable pursuant to Article 180 of the DCC. ${ }^{1013}$ Anyone is allowed to arrest a suspect when caught red-handed pursuant to Article 53 of the DCCP. Article 54 of the DCCP appoints the investigative authorities to perform an arrest in case the suspect has not been arrested when caught red-handed. ${ }^{1014}$

Investigative officers have to pass a suspect who has been arrested, as soon as possible, over to a(n) (assistant) public prosecutor. ${ }^{1015}$ Accordingly, the arrest will, at the earliest moment possible, be examined on its lawfulness by a higher authority - i.e. a(n) (assistant) public prosecutor. ${ }^{1016}$

In addition to the arrest, Articles 55b and 95 of the DCCP empower the (assistant) public prosecutor and criminal investigators to frisk the suspect and to seize any object(s) he carries with him. ${ }^{1017}$ In practice, this power is always applied following an arrest, and, in any, case prior to taking a suspect into police arrest. It serves to discover and confiscate illegal objects like drugs or weapons, and to safeguard a suspect's and the warders' safety during police arrest.

After the arrest, the suspect is brought in before a(n) (assistant) public prosecutor who examines whether the arrest was lawful. ${ }^{1018}$ The (assistant) public prosecutor, furthermore, decides what has to be done next: to release the suspect or keep him in

1012 A.J. Blok and L. Ch. Besier, Het Nederlandsch strafproces, deel I, Haarlem, 1925, p. 184 and G.J.M. Corstens, Het Nederlands Strafprocesrecht, 5de druk, Kluwer 2005, p. 361. See also Supreme Court 19 October 1976, NJ 1978/53; Leeuwarden Court of Appeal 26 January 2007, LJN: AZ7193; Supreme Court 1 October 1991, NJ 1992/60; Supreme Court 1 October 1991, NJ 1992/60.

1013 The penalty comprised in Article 180 of the DCC is a maximum of one year imprisonment or a fine of the third category (6700 Euros, see Article 23, section 4 of the DCC). See, in this respect, Supreme Court 26 November 1957, NJ 1958/356. This does not apply in the case of an arrest performed by a civilian pursuant to Article 53, section 4 of the DCCP.

1014 It goes beyond the scope of this chapter to examine in detail when a suspect is considered to be caught red-handed pursuant to Article 128 of the DCCP, but see, for more information in this respect; G.J.M. Corstens, Het Nederlands Strafprocesrecht, 5de druk, Kluwer 2005, p. 365 and further; Bijl. Handelingen II 1913-1914, 286, no. 3, ad Art. 131; Melai A.L. \& Groenhuijsen M.S. e.a., Het wetboek van strafvordering, voortgezet onder redactie van M.S. Groenhuijsen (head editor), Th. A. de Roos, A.H.J. Swart and F.G.H. Kristen, Kluwer, Deventer, losbladig, aant. 2 ad art. 128, suppl. 7; Naeyé J., Heterdaad: Politiebevoegdheden bij ontdekking op heterdaad in theorie en praktijk, 1990; Supreme Court 17 February 1987, NJ 1987/963; Arnhem Court of Appeal 30 March 1976, NJ 1976/515; Supreme Court 17 May 1949, NJ 1949/553; Supreme Court 5 February 1957, NJ 1957/455.

1015 Article 53, section 3 of the DCCP. Criminal investigators have some extra time to pass a suspect over to a(n) (assistant) public prosecutor than a civilian who performs an arrest on the basis of Article 53, section 4 of the DCCP. See Supreme Court 14 October 1986, NJ 1988/511.

1016 See, in this respect also, National Ombudsman 9 November 1987, Administratiefrechtelijke beslissing 1988/365.

1017 Article 55b and Article 95 of the DCCP.

1018 See, for an example of an unlawful arrest, 's-Hertogenbosch Court of Appeal 11 October 2006, LJN: AZ0086. 
police arrest for (further) questioning pursuant to Article 61 of the DCCP. ${ }^{1019}$ During police arrest, a suspect may be subject to various general investigative measures: he may be interrogated, ${ }^{1020}$ searched (clothes and objects he carries with him) and/or confronted with witnesses, all as far as necessary in the interest of the investigation or to glean a suspect's identity. ${ }^{1021}$ The suspect must also be informed of the reasons for his arrest during the so-called verification interrogation, which is basically the first police interrogation after a suspect has been arrested. Even though there is no provision in the DCCP that explicitly compels the investigative authorities to provide the suspect with such information, this prescription is based on Article 5, section 2 ECHR, and on common decency. ${ }^{1022}$

During the police arrest, the suspect is obviously deprived of his liberty. This is justified by the reasonable suspicion against the person concerned and by investigative purposes. Before a law amendment dating from 2002, a suspect could be kept in police arrest exclusively in order to be questioned - hence for interrogative purposes. Since 2002, police arrest is justified by the reasonable suspicion and by investigative interests, thus, in general. Ergo the current Article 61 of the DCCP is 'stopping a suspect for investigation' [ophouden voor onderzoek], instead of the former 'stopping a suspect for interrogations' [ophouden voor verhoor]. ${ }^{1023}$ The scope of police arrest has accordingly been expanded.

Police arrest can be justified by a general need to apply investigative measures during the first phase of a criminal investigation. ${ }^{1024}$ The investigative authorities may apply the following investigative measures pursuant to Article 61a of the $\mathrm{DCCP}^{1025}$ : performing a witness confrontation, ${ }^{1026}$ applying measures to retrieve a

1019 See Melai A.L. \& Groenhuijsen M.S. e.a., Het wetboek van strafvordering, voortgezet onder redactie van M.S. Groenhuijsen (head editor), Th. A. de Roos, A.H.J. Swart and F.G.H. Kristen, Kluwer, Deventer, losbladig, aant. 4 ad art. 53, suppl. 13. This provision was amended in 2001, see Staatsblad 2001, 532.

1020 Interrogations may, however, also have taken place prior to a suspect being brought before a(n) (assistant) public prosecutor. See Supreme Court 2 April 1985, NJ 1985/796. An earlier interrogation may not, however, lead to a substantial delay in bringing the suspect before the (assistant) public prosecutor, see Supreme Court 22 November 1983, NJ 1984/805.

1021 Articles 55a, 55b and 56 of the DCCP. See also G.J.M. Corstens, Het Nederlands Strafprocesrecht, 5de druk, Kluwer 2005, p. 364-365.

1022 See G.J.M. Corstens, Het Nederlands Strafprocesrecht, 5 de druk, Kluwer 2005, p. 367.

1023 Police arrest pursuant to Article 61 of the DCCP used to be allowed only for interrogative purposes, however in 2001 a legislative amendment broadened the scope of this article to all investigative purposes. See Staatsblad 2001, 532, which entered into force on 1 March 2002.

1024 Section 3 furthermore states that police arrest may also be justified by the need to issue a suspect certain judicial announcements in person.

1025 This is no exhaustive list, the parliamentary history demonstrates that other measures which have not been explicitly codified in Article 61a of the DCCP may also be applied, as long as they serve the interest of the investigation. See Kamerstukken II 1999-2000, 26 983, no. 3, p. 26.

1026 Article 61a, section 1 under c of the DCCP. This measure may solely be employed against a suspect when that suspect is in police arrest on suspicion of a criminal offence for which police custody (Article 57 of the DCCP) is allowed, see Article 61a, section 2 of the DCCP. 
suspect's identity, ${ }^{1027}$ interrogating the suspect, taking pictures or video-recording the suspect, ${ }^{1028}$ measuring a suspect's body (parts), ${ }^{1029}$ taking a suspect's fingerprints, ${ }^{1030}$ carrying out a scent-identification test, ${ }^{1031}$ forcing a suspect to change his (facial) hair style, ${ }^{1032}$ forcing a suspect to wear certain specific clothes during a confrontation, ${ }^{1033}$ placing a suspect in an observation-cell, ${ }^{1034}$ and lastly, a suspect may be investigated for shot-rests on his body or clothes. ${ }^{1035}$

Basically, these measures all serve to dispel or sustain the initial reasonable suspicion. ${ }^{1036}$ It is furthermore important to note that a suspect has no right to assistance by a defence counsel during the phase of police arrest. ${ }^{1037}$ However, the suspect does have the right to see a counsel of his own choosing after the police arrest. 1038

Police arrest pursuant to Article 61 of the DCCP may be imposed for a maximum period of six hours from the moment when the (assistant) public prosecutor decides that it is in the interest of the investigation to keep the suspect in police arrest. ${ }^{1039}$ If

1027

\section{Article $55 \mathrm{~b}$ of the DCCP.}

Article 61a, section 1 under a of the DCCP. This measure may be applied to discover a suspect's identity, see Article 61a, section 2 of the DCCP.

Article 61a, section 1 under a of the DCCP.

Article 61a, section 1 under b of the DCCP. This measure may be applied to discover a suspect's identity, see Article 61a, section 2 of the DCCP.

Article 61a, section 1 under d of the DCCP. This measure may solely be employed against a suspect when that suspect is in police arrest on suspicion of a criminal offence for which police custody (Article 57 of the DCCP) is allowed, see Article 61a, section 2 of the DCCP.

Article 61a, section 1 under e of the DCCP. This measure may solely be employed against a suspect when that suspect is in police arrest on suspicion of a criminal offence for which police custody (Article 57 of the DCCP) is allowed, see Article 61a, section 2 of the DCCP.

Article 61a, section 1 under $\mathrm{f}$ of the DCCP. This measure may solely be employed against a suspect when that suspect is in police arrest on suspicion of a criminal offence for which police custody (Article 57 of the DCCP) is allowed, see Article 61a, section 2 of the DCCP.

Article 61a, section 1 under $g$ of the DCCP. This measure may solely be employed against a suspect when that suspect is in police arrest on suspicion of a criminal offence for which police custody (Article 57 of the DCCP) is allowed, see Article 61a, section 2 of the DCCP. See in this respect, also Supreme Court 19 March 1996, NJ 1997/86; Kamerstukken II 1999-2000, 26 983, no. 3 , p. 26 .

Article 61a, section 1 under $\mathrm{h}$ of the DCCP. This measure may solely be employed against a suspect when that suspect is in police arrest on suspicion of a criminal offence for which police custody (Article 57 of the DCCP) is allowed, see Article 61a, section 2 of the DCCP.

See Besluit toepassing maatregelen in het belang van het onderzoek, KB 22 January 2002, Staatsblad 2002, 46, which entered into force on 1 March 2002.

Supreme Court 22 November 1983, NJ 1984/805.

Article 57, section 2 of the DCCP.

Supreme Court 31 August 2004, NJ 2004/590. Thus, the time between an arrest and the arrival at, for example, the police station, does not count towards the six-hour period under Article 61 of the DCCP. Supreme Court 24 May 1988, NJ 1988/918. The time between midnight and 9a.m. does not count. See Article 61, section 4 of the DCCP. Therefore, the total maximal period of police arrest pursuant to Article 61, section 1 of the DCCP is 15 hours and 21 hours in the case of 
however, at the end of those six hours the suspect's identity has not been discovered and he is suspected of a criminal offence for which remand in custody is not allowed, the suspect may be kept in police arrest for an additional six hours in accordance with Article 61, section 2 of the DCCP. ${ }^{1040}$

\section{Police custody}

\subsection{Introduction}

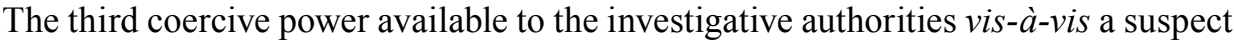
is police custody [inverzekeringstelling]. Generally, police custody follows police arrest. Comparable to police arrest, this power interferes with a suspect's right to liberty as defined in Article 5 of the ECHR. ${ }^{1041}$ The legislative history reveals that vivid discussions regarding suspects' rights and freedoms and investigative interests preceded the coming into force of the current system of police custody. ${ }^{1042}$

At the end of the 1980s the Dutch police custody system was amended following the ECtHR's judgement in Brogan and Others v. The United Kingdom. ${ }^{1043}$ Prior to this amendment, suspects could be kept in police custody without any mandatory judicial control for four days. ${ }^{1044}$ In light of the above-mentioned ECtHR judgement,

Article 61, section 2 of the DCCP. See, also, Kamerstukken II 1989-1990, 19 757, no. 8, p. 35; Supreme Court 2 February 1988, NJ 1988/971; Supreme Court 24 May 1988, NJ 1988/918.

1040 When a person is suspected of a criminal offence for which remand in custody is allowed, the public prosecutor is compelled to order the suspect's police custody or to release the suspect after expiration of the six-hour term in accordance with Article 57 of the DCCP.

1041 At this point the main focus will be on Article 5 of the ECHR. In the Dutch legal system, (inter) national legislation cannot be examined on compatibility with the Dutch Constitution (see Article 120 of the Dutch Constitution), therefore it is argued that the rights and liberties, as comprised in the Constitution, are of minor practical importance when examining legislation on compliance with fundamental rights.

1042 See kamerstukken II 1988-1989, 1990-1991, 1992-1993, 21 225, nos. 1 up to and including 15.

1043 Brogan and Others $v$. the United Kingdom, appl. nos. 11209/84; 11234/84; 11266/84; 11386/85, 29 November 1988. In this case, the ECtHR concluded that Article 5 of the ECHR had been violated. The United Kingdom had held several terrorist suspects in police custody for periods of between 4 days and 6 hours up to 6 days and 16.5 hours, without any judge or other judicial authority having been called to judge the lawfulness of that deprivation of liberty, while Article 5, section 1 under c, in conjunction with section 3 of the ECHR, clearly requires Member States to provide for such a controlling mechanism whenever suspects' right to liberty is interfered with. See, also, Kamerstukken II 1988-1989, 21 225, no. 3, p. 3. There were, however, also two judgements from the former European Commission which partly caused the amendments to the Dutch system of police custody, see T. v. The Netherlands, appl. no. 18090/91, 4 July 1991; J.C. v. The Netherlands, appl. no. 19139/91, 30 March 1992.

1044 See Kamerstukken II 1988-1989, 21 225, no. 4, p. 31. See for an examination of the notion of judicial control, Schiesser v. Switserland, appl. no. 7710/76, 4 December 1979, NJ 1980/547; De Jong, Baljet and Van Den Brink v. The Netherlands, appl. no. 8805/79, 22 May 1984; Nikolova v. Bulgaria, appl. no. 31195/96, 25 March 1999. See below Section 12, for a further elaboration on this issue. 
that system was held to be in violation of Article 5 of the ECHR. Therefore, mandatory judicial control of the lawfulness of police custody after three days and 15 hours, from the moment of arrest, was introduced into the DCCP.

\subsection{Rules and formalities ${ }^{1045}$}

Police custody may be ordered, provided: (1) that there is a reasonable suspicion, (2) that it serves the interest of the investigation, and (3) that it concerns a criminal offence with respect to which remand in custody is allowed. ${ }^{1046}$ These criteria for application apply in the case of suspects of common crimes and in the case of terrorist suspects

It is important to note that police custody partly serves to enable the public prosecutor to decide whether or not it is necessary to file an order for remand in custody after the expiration of police custody. The competent authority to order the first three days of police custody is the assistant public prosecutor and the public prosecutor before whom the suspect has been brought. ${ }^{1047}$ If it happens to be an assistant public prosecutor who orders police custody, he is obliged to immediately inform the public prosecutor of that order. ${ }^{1048}$ Pursuant to Article 57 of the DCCP, the (assistant) public prosecutor must interrogate the suspect before he orders police custody. In practice, this interrogation is generally conducted by an investigative officer.

When a suspect is taken in police custody, he has the right to an assigned defence counsel. The defence counsel has free access to the suspect, as long as this right is not used to obstruct the process of establishing the truth. ${ }^{1049}$ A suspect is, furthermore, allowed to lodge a request to have his defence counsel be present during (police) interrogations. ${ }^{1050}$

1045 The following issues will not be discussed: the obligation to draft a procès-verbal of every interrogation of the suspect during police arrest and police custody, the content of and formal substantive requisites for an order for police custody, a public prosecutor's power to lodge an appeal against the investigative judge's decision to release the suspect from police custody.

1046 Article 58, section 1 of the DCCP. See, for the list of criminal offences with respect to which remand in custody may be imposed, Article 67 and $67 \mathrm{a}$ of the DCCP.

1047 Article 57, section 1 of the DCCP. In practice, it is almost always the assistant public prosecutor who orders the suspect's police custody.

1048 Article 57, section 4 of the DCCP.

1049 Article 50, section 1 of the DCCP.

1050 Article 57, section 2 of the DCCP. See, as well, Kamerstukken II 1972-1973, p. 1787, right column, and Supreme Court 22 November 1983, NJ 1984/805. See, also, L. Stevens, W.J. Verhoeven, Raadsman bij politieverhoor. Invloed van voorafgaande consultatie en aanwezigheid van raadslieden op organisatie en wijze van verhoren en proceshouding van verdachten, WODC-report, Boom Juridische uitgevers, Den Haag 2010. 


\subsection{Terms regarding police custody}

Pursuant to Article 58, section 2 of the DCCP, the (assistant)public prosecutor is allowed to order police custody for a period of three days. After expiration of the three days and 15 hours, ${ }^{1051}$ the public prosecutor may: (1) release the suspect immediately, if the interest of the investigation permits so, ${ }^{1052}$ (2) extend the order for police custody once, for three days, when that is urgently necessary in the interest of the investigation, ${ }^{1053}$ or (3) lodge an order for remand in custody with the investigative judge when the criteria comprised in Articles 67 and 67a DCCP have been complied with. ${ }^{1054}$ In practice, the second possibility is not often used. Mostly, suspects are either released or placed in remand in custody. The fact that the second possibility - that of extending police custody by three days - is rarely used, finds its rationale in several aspects. ${ }^{1055}$

First and foremost, police custody is served at the police station, whereas remand in custody is served in a house of detention, i.e. in an actual prison. ${ }^{1056}$ Cells in police stations are considerably less well-equipped than a cell in a house of detention. Furthermore, police stations offer fewer possibilities for detainees to get fresh air, and there are less sport facilities or other recreational or work resources. In light of these considerations, suspects are kept at police stations, preferably, for as short a time as possible. ${ }^{1057}$

Secondly, the extension of police custody is considered to negatively affect the general rule that more intrusive state powers have to be ordered by a higher (judicial) authority. Police custody (and extension thereof) is ordered by a(n) (assistant) public prosecutor, remand in custody is ordered by an investigative

1051 Tree days police custody and 15 hours police arrest. The period of three days and 15 hours starts from the moment of the actual arrest, and not from the moment at which a suspect arrives at the police station. This serves to underline unequivocally the importance of bringing a suspect as soon as possible to the police station or another place of interrogation after his arrest. See College of Attorneys General, Beleidsregel aanwijzing inverzekeringstelling, entering into force 15 March 2000, Staatscourant 2000, 43 and 2004, 246.

Article 58 , section 2 of the DCCP.

Article 63 of the DCCP.

See, also, College of Attorneys General, Beleidsregel aanwijzing inverzekeringstelling, entering into force 15 March 2000, Staatscourant 2000, 43 and 2004, 246.

1056 Article 59, section 6 of the DCCP. A public prosecutor is, however, empowered to decide - under special circumstances - that a suspect will serve his police custody in a house of detention, instead of at a police station. Such special circumstances may, for example, be found in the suspect's personality, which appears to be unfit to serve police custody at a police station. See Kamerstukken II 1992-1993, 21 225, no. 12, p. 6. See, further, also, Article 62 of the DCCP, comprising further rules concerning the regime of police custody. Article 76 of the DCCP declares these rules also applicable for the period of remand in custody.

1057 Article 6, section 2 of the ECHR. 
judge, ${ }^{1058}$ and remand detention is ordered by the full bench of a District Court. ${ }^{1059}$ Salient detail, in this respect, is that during the early stages of the drafting process (1988-1989) of the current Articles 57 DCCP to 62a DCCP, one version of the bill attributed the power to renew an order for police custody to the investigative judge, rather than to the public prosecutor. ${ }^{1060}$ However, due to reasons of effectiveness and efficiency, the government finally abandoned that idea.

Thirdly, there is a difference between police custody and remand in custody, as regards its purpose: police custody serves the interest of the investigation, whereas remand in custody has a more 'controlling' purpose, i.e. to keep a suspect in custody because there is, for example, a risk that he will commit another criminal offence. Also, remand in custody serves to discover the truth regarding the commission of an offence through other paths than by interrogating the suspect. Police custody is to be used to investigate criminal offences, mainly by means of the suspect (i.e. interrogations, witness confrontation etc.). The 'investigative purpose' of police custody is to be interpreted broadly, and includes not only the need to interrogate the suspect, but also to create a possibility for the public prosecutor to prepare the next potential procedural steps in the criminal process, such as the question of whether he should file a request for remand in custody with an investigative judge pursuant to Article 60 and 63 of the DCCP. ${ }^{1061}$ Furthermore, the interest of the investigation may also comprise the need to hand out to the suspect certain judicial decisions in person, ${ }^{1062}$ or a necessity to confront witnesses with the suspect, to trace co-suspects without the suspect being able to tip them off, or to verify a suspect's identity. ${ }^{1063}$ Extending the term of police custody for other purposes than such investigative purposes, while there are, moreover, adequate grounds available to request remand in custody, may lead to arbitrariness. ${ }^{1064}$

Lastly, there is a practical aspect that stands in the way of extending an order for police custody rather than lodging a request for remand in custody. Pursuant to Article 59a, section 1 of the DCCP, a suspect in police arrest and police custody must be brought before the investigative judge after three days and 15 hours. During that hearing, the investigative judge has to rule on the lawfulness of the arrest, the police arrest and the police custody, and he has to decide whether there are sufficient justifications to remand the suspect in custody. If however, the public prosecutor

\footnotetext{
1058 Article 63 of the DCCP.

1059 Article 65 of the DCCP and Article 59a, section 1 of the DCCP.

1060 Kamerstukken II 1988-1989, 21 225, no. 4, pp. 43 and 44; Kamerstukken II 1990-1991, 21225 , no. 5, pp.5-6.

1061 Supreme Court 31 October 2000, NJ 2001/239. See, as well, Bijlagen Handelingen II 1913/1914, 286, no. 2, ad art. 58 en 59; Reijntjes J.M., Voorarrest, W.E.J. Tjeenk Willink, Zwolle 1994, pp. $87-88$.

1062 Article 57, section 1 of the DCCP; Kmerstukken II 2004-2005, 29 805, no. 3, p.9.

1063 Supreme Court 29 May 1990, NJ 1990/754.

1064 Kamerstukken II 1988-1989, 21 225, no. 4, p. 45.
} 
extends the order for police custody, instead of immediately requesting remand in custody, the suspect has to be brought before the investigative judge twice: once after three days and 15 hours to rule on the lawfulness of the arrest, the police arrest and police custody, and then after six days and 15 hours again to judge on the request for remand in custody. Extension of police custody would then increase investigative judges' workload, which is considered to be quite contrary to one of the primary aims of the new system of police custody: an effective and efficient criminal process. ${ }^{1065}$

Though extension of police custody is thus more exception than rule, the legal history demonstrates that in some cases it may be deemed urgently necessary, and thus legitimate for a public prosecutor to extend a suspect's police custody. Extension may be justified when transporting the suspect from one place to another has taken considerable time, or when the investigation has not yet yielded sufficient information - for example, due to the complexity or the magnitude of the case - for the public prosecutor to decide whether he will lodge a request for remand in custody pursuant to Article 63 DCCP. ${ }^{1066}$ It is important to note that such circumstances often occur during criminal investigations into terrorist offences.

\subsection{Supportive coercive measures}

Both (assistant) public prosecutors and investigative judges ${ }^{1067}$ are authorised to impose various supportive coercive measures on a suspect during police custody, among which are the measures of Article 61a of the DCCP. ${ }^{1068}$ Article 62, section 1 of the DCCP prescribes, furthermore, that a suspect is not to be subjected to any restrictions other than the ones which are strictly necessary in the interest of the investigation, or to preserve order.

Article 62, section 2 of the DCCP enumerates two specific sets of powers that can be imposed on suspects in police custody. Firstly, suspects may be restricted in receiving visits, phone calls, letters, papers, readings, or other data carriers. More generally, the imposition of any (other) restrictive measure relating to a suspect's stay in police custody, is allowed.

1065 Kamerstukken II 1992-1993, 21 225, no. 12, p. 5.

1066 Kamerstukken II 1992-1993, 21 225, no. 12, p. 5.

1067 If a judicial inquiry [gerechtelijk vooronderzoek] has been opened, the investigative judge is the competent authority to order the imposition of restrictive measures during police custody. Otherwise, the public prosecutor remains authorised to order such restrictive measures or, if the appearance of a public prosecutor cannot be awaited, the assistant public prosecutor. See Article 62a, section 1 and 2 of the DCCP and Article 181 of the DCCP.

1068 Article 61a and Article 62, section 2 of the DCCP. See, for an overview of the coercive measures as comprised in Article 61a of the DCCP the preceding section. It should be noted that imposing such measures may not hamper the suspect's right to freedom of communication with his defence counsel. That communication can only be restricted pursuant to Article 50 of the DCCP. 
Secondly, Article 62, section 2 of the DCCP stipulates that suspects may be brought to a hospital during their stay in police custody, or to any other institution in which medical supervision is guaranteed. In that respect, a suspect can also be placed in a special cell, suitable for medical supervision. ${ }^{1069}$

Additional powers, besides the ones comprised in Articles 61a and 62, section 2 of the DCCP, may be imposed, provided that these are in the interest of the investigation or in the interest of preserving order. ${ }^{1070}$

\subsection{Police custody and judicial control}

While the (assistant) public prosecutor orders police custody, the investigative judge examines whether the prosecutor's order and the arrest were lawful and legitimate. This post facto control mechanism has three functions according to the relevant parliamentary memoranda: (1) the correction function, (2) the legitimising function and (3) the preventive function. ${ }^{1071}$

The correction function implies that there must be mandatory judicial control to 'correct' an unlawful arrest or police custody. ${ }^{1072}$ If the investigative judge decides that the criteria for application of arrest or police custody have not been (sufficiently) complied with, he is accordingly authorised to order a suspect's immediate release. The legitimising function means that judicial control by an investigative judge increases the legitimacy of police custody. The preventive function presupposes that public prosecutors will take into account prerequisites for lawful police custody, as set by investigative judges. Unlawful deprivation of liberty during the initial stages of criminal proceedings would, accordingly, be prevented.

An investigative judge is compelled to weigh the interests of the suspect against the investigative interests as independent authority without giving a priori preference to an efficient and effective course of the criminal investigation. The examination of the lawfulness of arrest and police custody by an investigative judge is, therefore, quite extensive, and includes: examination of the lawfulness of the initial deprivation of liberty (i.e. the arrest) scrutinising the well-foundedness and legitimacy of the reasonable suspicion which led to the suspect's arrest and police arrest, evaluating

1069 These coercive measures will, foremost, be imposed on suspects of drug related offences. Kamerstukken II 1999-2000, 26 983, no. 3, p. 27.

1070 This appears from the words 'among others' in Article 62, section 1 of the DCCP.

1071 See Kamerstukken II 1992-1993, 21 225, no. 13, p. 5.

1072 Article 59a, section 5 of the DCCP. If the investigative judge decides that police custody is unlawful in a certain case and orders thereupon the immediate release of the suspect, the public prosecutor is entitled to lodge an appeal against the investigative judge's order with the District Court pursuant to Article 59c, section 1 of the DCCP. See, for example, Utrecht District Court 10 March 2005, LJN: AS9913. 
whether the interest of the investigation really demands police custody, checking whether the criminal offence presumably committed by the suspect is an offence for which remand in custody is allowed, viewing a suspect's personal interests and obligations, examination of the investigative authorities' behaviour during the arrest, police arrest and police custody and lastly whether the formal rules concerning police custody, have been complied with. ${ }^{1073}$

Parliamentary memoranda also prescribe that the investigative judge should examine police custody on compatibility with unwritten legal principles such as the equality principle, the principle of legitimate expectations, the proportionality principle and the prohibition of détournement de pouvoir or arbitrariness. ${ }^{1074}$

\section{REMAND IN CUSTODY}

\subsection{Introduction}

This section discusses the system of remand in custody of terrorist suspects pursuant to Articles 63, 64, 67, section 4 and 67a of the DCCP. When the term for police custody expires, a suspect is either released or placed under remand in custody pursuant to Articles 67 and 67a of the DCCP. The DPTA changed the system of remand in custody for persons suspected of a terrorist offence considerably. Prerequisites for lawful remand in custody of terrorist suspects have been lowered in quantity as well as in quality. An investigative judge is allowed to put a person suspected of a common crime under remand in custody when: (1) there are 'serious objections' [ernstige bezwaren] against the suspect, and (2) when one or more of the grounds enumerated in Article 67a of the DCCP has/have been complied with. The DPTA added a new section 4 to Article 67 of the DCCP, which prescribes that whenever someone is suspected of a terrorist offence, there need not to be such 'serious objections' against the suspect to put him under remand in custody. This means that a reasonable suspicion, as required level of suspicion, is sufficient for the remanding in custody of terrorist suspects.

In this respect, it should be kept in mind that a 'light' reasonable suspicion is ample when it regards terrorist offences. ${ }^{1075}$ The investigative authorities argue, in this respect, that the difference between a 'light' reasonable suspicion and indications of a terrorist offence is very limited when it concerns a criminal investigation into terrorist offences. ${ }^{1076}$ Hence, only a very limited amount of

1073 Kamerstukken II 1989-1999, 21 225, no. 4, p. 42.

1074 Kamerstukken II 1990-1991, 21 225, no. 5, p. 9. See, also, 's-Hertogenbosch District Court 7 November 1994, NJ 1995/109.

1075 Kamerstukken II 2004-2005, 30 164, no. 3, p. 26. And see, C.J. de Poot, R.J. Bokhorst, W.H. Smeenk, R.F. Kouwenberg, De Opsporing verruimd? De Wet opsporing terroristische misdrijven een jaar in werking, WODC, Cahier 2008-9, pp. 44-48.

1076 C.J. de Poot, R.J. Bokhorst, W.H. Smeenk, R.F. Kouwenberg, De Opsporing verruimd? De Wet opsporing terroristische misdrijven een jaar in werking, WODC, Cahier 2008-9, pp. 53-54. 
information is required to come to a reasonable suspicion in the case of terrorist offences. The above-mentioned WODC reports speak of 'stretching the reasonable suspicion criterion or of actively investigating the boundaries of that criterion in case of a terrorist threat' ${ }^{1077}$

The notion of serious objections will be discussed in the next chapter. However, to understand the scope of the amendment to the system of remand in custody for terrorist suspects, some preliminary remarks must be made at this point. Basically, the concept of serious objections refers to the level of suspicion present against a suspect. It presupposes that it is very likely that the suspect committed the criminal offence of which he is suspected. Serious objections as a suspicion criterion, hence, clearly exceeds the reasonable suspicion criterion. This more demanding level of suspicion serves to justify the more intrusive interference with the right to liberty of a suspect, due to his being kept under remand in custody.

\subsection{Rules and formalities}

The public prosecutor is the competent authority to lodge a request for remand in custody with the investigative judge pursuant to Article 63 of the DCCP. Generally speaking, police custody precedes remand in custody. This is not, however, compulsory - remand in custody may also be ordered immediately after an arrest. ${ }^{1078}$ Prior to deciding on the public prosecutor's request, the investigative judge is obliged to interrogate the suspect. ${ }^{1079}$ During this interrogation, the suspect is represented by a lawyer pursuant to Article 63, section 4 of the DCCP. Remand in custody is allowed for all terrorist offences.

The investigative judge orders remand in custody when: (1) there is a reasonable suspicion, and (2) when one or more of the grounds enumerated in Article 67a of the DCCP has/have been complied with. Article 67a, section 1 under a and $b$ of the DCCP includes the following grounds for a lawful order for remand in custody: (1) a serious danger that the suspect will abscond, an alleged danger is based on the suspect's conduct or on other personal circumstances, ${ }^{1080}$ or (2) a significant reason

1077 C.J. de Poot, R.J. Bokhorst, W.H. Smeenk, R.F. Kouwenberg, De Opsporing verruimd? De Wet opsporing terroristische misdrijven een jaar in werking, WODC, Cahier 2008-9, pp. 53-54.

1078 J.M. Reijntjes, Artikel 67, in A.L. Melai and M.S. Groenhuijsen e.a., Het Wetboek van Strafvordering, voortgezet onder redactie van M.S. Groenhuijsen, Th.A. de Roos, A.H.J. Swart en F.G.H. Kristen, Kluwer, Deventer, losbladig.

1079 Article 63, section 3 of the DCCP. In practice, this interrogation takes place during the hearing pursuant to Article 59a of the DCCP.

1080 Danger of absconding is interpreted as hiding from trial or as hiding from the enforcement of a judgement. For such a danger to be assumed, it is not necessary that a suspect actually leaves the country. J.M. Reijntjes, Artikel 67a, in A.L. Melai and M.S. Groenhuijsen e.a., Het Wetboek van Strafvordering, voortgezet onder redactie van M.S. Groenhuijsen, Th.A. de Roos, A.H.J. Swart en F.G.H. Kristen, Kluwer, Deventer, losbladig, 67a-7. 
concerning public safety, based on certain circumstances, that requires the suspect's immediate deprivation of liberty. ${ }^{1081}$ The meaning of 'a significant reason concerning public safety' is further specified in Article 67a, section 2 of the DCCP, and may exist in four instances:

- If the offence for which pre-trial detention is ordered carries a statutory sentence of at least 12 years imprisonment, and ${ }^{1082}$ provided that the legal order has been seriously shocked by the offence (Article 67a, section 2 under 1 of the DCCP);

- If there is a serious risk that the suspect will commit a crime, that carries a statutory sentence of not less than six years imprisonment, or an offence which may jeopardise the safety of the state or the health or safety of persons, or create a general danger to property (Article 67a, section 2 under 2 of the DCCP);

- If there is a serious suspicion that the suspect has committed a property offence and will re-offend, while less than five years have passed since a punishment comprising deprivation or restriction of liberty or community services has been imposed (Article 67a, section 2 under 3 of the DCCP); or

- If it is necessary to detain the suspect in order to establish the truth by other methods than through the suspect's own statements (Article 67a, section 2 under 4 of the DCCP). ${ }^{1083}$

The Judiciary considers the first instance to include two cumulative practical prerequisites: (1) there has to be a danger that releasing the suspect will factually lead to public disorder, this in light of the specific seriousness of the concrete criminal offence and the public reaction thereto, and (2) public disorder presupposes that it is judged to be incomprehensible and unacceptable by society if a suspect were to be allowed to await his trial in freedom. ${ }^{1084}$

1081 Article 67a of the DCCP applies to remand in custody, as well as to remand detention. The system of remand detention will be discussed in Chapter VII.

1082 It is important to note that these two requirements are cumulative: the suspect must be suspected of a criminal offence with a penalty clause of at least 12 years imprisonment, and the criminal offence must have severely shocked the legal order. Not every criminal offence with a penalty clause of 12 years imprisonment will necessarily shock the legal order, and consequently justify remand in custody or detention on remand.

1083 Article 67a, section 3 of the DCCP prescribes, furthermore, that pre-trial deprivation of liberty cannot be continued if it is unlikely that a punishment of unconditional imprisonment will be imposed. Besides that, a suspect must be released if it is likely that the actual term of imprisonment (taking into consideration the provisions of early release) will be shorter than the period spent in pre-trial detention. On the basis of this provision many suspects serve their sentences in pre-trial detention, hence, prior to a conviction by a court. See A.H. Klip, 'Slappe rechters', in Delikt en Delinkwent 2010, 79.

1084 Leeuwarden District Court 9 May 2007, LJN: BA 4744; Amsterdam Court of Appeal 16 May 2007, LJN: BA6642; Haarlem District Court 5 August 2005, LJN: AU0581; Haarlem District Court 13 April 2007, LJN: BA2938. 
In the case of suspicion of a terrorist offence, compliance with these prerequisites will not cause an impediment to placing a suspect under remand in custody. Terrorist offences are considered to be the most serious offences comprised in the DCC. These offences will, by their nature, shock the public and legal order - taking into account the potential amount of damage and human suffering caused, and the reactions terrorist offences produce, within society.

Furthermore, the media coverage of cases concerning terrorist offences is abundant, and the actual release of a terrorist suspect from remand in custody will undoubtedly lead to factual public disorder. Satisfying the above-mentioned criteria in the case of a suspect of a terrorist offence may, also taking into account the contemporary public attitude towards terrorism, not be too difficult.

With regard to the second instance, i.e. danger of recidivism, ${ }^{1085}$ it can be argued that the required penalty clause of six years will easily be fulfilled: most terrorist offences within the DCC have a penalty clause exceeding six years imprisonment. Furthermore, remand in custody on this second instance is deemed justified when the suspect belongs to a certain 'notorious' group of perpetrators, such as drug addicts or the homeless. ${ }^{1086}$ Such a differentiation can easily be developed for alleged terrorists.

The last instance - the necessity to detain a suspect in order to establish the truth clearly demonstrates the difference in rationale between police custody and remand in custody. Remand in custody may never be imposed with the primary aim of interrogating the suspect. Article 67a, section 2 under 4 of the DCCP therefore explicitly prescribes that a suspect can be placed under remand in custody to establish the truth by other means than through the suspect's statement(s). This means that there must, for instance, be a need to question witnesses without a suspect's interference, or to use the suspect in a witness confrontation.

This last instance therefore primarily serves to thwart the danger of collusion. According to the government, the danger of collusion is all but illusory during investigations into terrorist offences. Just as with respect to criminal investigations into other serious criminal activities, influencing or even threatening witnesses,

1085 Almelo District Court 18 August 2005, LJN: AU1198.

1086 See J.M. Reijntjes, Artikel 67a, in A.L. Melai and M.S. Groenhuijsen e.a., Het Wetboek van Strafvordering, voortgezet onder redactie van M.S. Groenhuijsen, Th.A. de Roos, A.H.J. Swart en F.G.H. Kristen, Kluwer, Deventer, losbladig, 67a-26-30. Dworkin asserts, in this respect, that it seems wrong to imprison a man awaiting trial on the basis of a prediction that he might commit further crimes if released. For 'any such prediction, if it is sound, must be based on the view that an individual is a member of a class having particular features, which class is more likely than others to commit crime (...). But it is unjust to put someone in jail on the basis of a judgement about a class, however accurate, because that denies his claim to equal respect as an individual'. See, R. Dworkin, Taking rights seriously, London: Duckworth 1978, p. 13. 
rebutting of evidence, or otherwise tampering with evidence, is no hypothetical danger. ${ }^{1087}$

\subsection{Terms regarding remand in custody}

An order for remand in custody is valid for a period not exceeding 14 days. ${ }^{1088}$ This means that a suspect of a terrorist offence may be kept deprived of his liberty for a total period of 20 days and 15 hours on the basis of a 'light' reasonable suspicion. ${ }^{1089}$

\section{Practical application of the powers}

The WODC reports regarding the practical application of the investigative powers that the DPTA introduced into the DCCP demonstrate that remand in custody of terrorist suspects, on the basis of Article 67, section 4 of the DCCP, has been used to a limited extent.

During the period 2007-2008, Article 67, section 4 of the DCCP was applied in three criminal investigations into terrorism. ${ }^{1090}$ The investigative authorities state that remand in custody pursuant to Article 67, section 4 of the DCCP, is foremost used to avert alleged threats. ${ }^{1091}$ Placing someone under remand in custody is basically the most effective way to prevent a terrorist attack. In that light, the seriousness of the threat determines whether a person is to be deprived of his liberty, rather than if there is a reasonable suspicion or whether the grounds enumerated in Article 67a of the DCCP have been complied with. Such a working method currently even leads to situations where a person is arrested and placed under remand in custody on the basis of indications of a terrorist offence. ${ }^{1092}$

The second WODC report, covering the period 2008-2009, reveals the same trend. It shows that Article 67, section 4 of the DCCP has only been used in one criminal

1087 See, for example, the 'Hofstadgroep' judgement in which an important witness was influenced by several suspects, and subsequently withdrew her statements. Rotterdam District Court 10 March 2006, LJN: AV5108. Chapter II discusses this judgement. Article 64, section 1 of the DCCP.

1089 Usually, an order for remand in custody is preceded by police custody for a maximum of six days pursuant to Article 57 of the DCCP. That results in a period of 20 days and 15 hours (15 hours of police arrest pursuant to Article 61 of the DCCP) of pre-trial deprivation of liberty.

1090 C.J. de Poot, R.J. Bokhorst, W.H. Smeenk, R.F. Kouwenberg, De Opsporing verruimd? De Wet opsporing terroristische misdrijven een jaar in werking, WODC, Cahier 2008-9, p. 41.

1091 C.J. de Poot, R.J. Bokhorst, W.H. Smeenk, R.F. Kouwenberg, De Opsporing verruimd? De Wet opsporing terroristische misdrijven een jaar in werking, WODC, Cahier 2008-9, p. 44.

1092 C.J. de Poot, R.J. Bokhorst, W.H. Smeenk, R.F. Kouwenberg, De Opsporing verruimd? De Wet opsporing terroristische misdrijven een jaar in werking, WODC, Cahier 2008-9, pp. 44-45. 
investigation. ${ }^{1093}$ The relevant investigative authorities unequivocally stated that the suspect had been placed under remand in custody exclusively to avert the terrorist threat that he allegedly posed to society. Again, this report demonstrates that the nature and seriousness of the threat is more decisive than the level of suspicion when it comes to the deprivation of liberty of terrorist suspects. ${ }^{1094}$ It seems as if prevention of political responsibility for terrorist offences is more important than strict compliance with clearly drafted legal provisions. In this respect, it is interesting to note that the investigative authorities themselves underline that the reasonable suspicion criterion pursuant to Article 27 of the DCCP, has been expanded to such an extent, and covers so many situations, that, for instance, the need for the criterion of 'indications of a terrorist offence' is basically redundant. ${ }^{1095}$ Furthermore, several persons were arrested on suspicion of a terrorist offence. These criminal investigations have not led to prosecution of the suspects in respect of terrorist offences. ${ }^{1096}$ In all of these investigations, the information underlying the reasonable suspicion was considered adequate to arrest a person or to perform a house search. However, each time after an arrest and further investigation, it appeared to be false alarm, (boyish) prank, persons acting the tough guy, or it concerned psychological problems with the alleged suspect/reporter of the relevant information. 1097

During the period 2009-2010 the national office of the public prosecutor requested an investigative judge in one case to remand several terrorist suspects in custody pursuant to Article 67, section 4 of the DCCP. ${ }^{1098}$ The investigation was initiated on the basis of a memo of the secret intelligence services regarding alleged participation of several persons in a Jihadist training camp abroad. These persons were therefore

1093 See B. van Gestel, C.J. de Poot, R.J. Bokhorst, R.F. Kouwenberg, Signalen van terrorisme en de opsporingspraktijk. De Wet opsporing terroristische misdrijven twee jaar in werking, WODC Cahier 2009-2010, p. 2.

1094 See B. van Gestel, C.J. de Poot, R.J. Bokhorst, R.F. Kouwenberg, Signalen van terrorisme en de opsporingspraktijk. De Wet opsporing terroristische misdrijven twee jaar in werking, WODC Cahier 2009-2010, pp. 10-11.

1095 See B. van Gestel, C.J. de Poot, R.J. Bokhorst, R.F. Kouwenberg, Signalen van terrorisme en de opsporingspraktijk. De Wet opsporing terroristische misdrijven twee jaar in werking, WODC Cahier 2009-2010, p. 31.

1096 See B. van Gestel, C.J. de Poot, R.J. Bokhorst, R.F. Kouwenberg, Signalen van terrorisme en de opsporingspraktijk. De Wet opsporing terroristische misdrijven twee jaar in werking, WODC Cahier 2009-2010, pp. 25-26.

1097 See B. van Gestel, C.J. de Poot, R.J. Bokhorst, R.F. Kouwenberg, Signalen van terrorisme en de opsporingspraktijk. De Wet opsporing terroristische misdrijven twee jaar in werking, WODC Cahier 2009-2010, p. 30.

1098 B. van Gestel, C.J. de Poot en R.F. Kouwenberg, De wet opsporing terroristische misdrijven drie jaar in werking, WODC, Memorandum 2010-3, p. 7. 
remanded in custody in respect of a terrorist offence that was (also) committed abroad. 1099

In sum, these reports sustain the presumption that, when it concerns criminal investigations into terrorism, investigative interests, the prevention of terrorism and, more generally, risk management, have become more decisive as criteria for the application of coercive measures than the level of suspicion.

\section{SUSPICIONS, TERRORISM AND TERRORIST SUSPECTS}

Why is it important to discuss the general suspicion criterion pursuant to Article 27 of the DCCP while this dissertation exclusively focuses on terrorism? This question needs to be considered in light of the suspicion criteria that have been discussed in the preceding chapters. In what way do these suspicion criteria affect the reasonable suspicion criterion of Article 27, section 1 of the DCCP?

First of all, the suspicion criteria discussed in the preceding chapters, and the broadened state powers to prevent and investigate terrorism attached to these criteria, decrease the importance of Article 27, section 1 DCCP as a pivotal point in the criminal process. Investigative authorities no longer need to have a reasonable suspicion to apply various far-reaching investigative powers that infringe upon fundamental rights. Alleged involvement in supposed terrorist activities suffices for personal disturbance. Indications of a terrorist offence suffice for the application of special investigative techniques and for the investigative powers in security risk areas. ${ }^{1100}$

Article 27, section 1 of the DCCP has accordingly become less important as a justification for applying state powers when it concerns terrorism. Nevertheless, if state authorities intrude on persons' physical integrity and/or factual liberty, such as in the case of police arrest, police custody and remand in custody, they still need a reasonable suspicion, even if it concerns a terrorist offence. Considered from that point of view, the importance of the reasonable suspicion criterion with respect to terrorism has not lost its value. One may even argue that Article 27 of the DCCP has gained importance when it comes to terrorist suspects, because it has become the only prerequisite - in terms of suspicion criteria - for remand in custody.

Demonstrating a reasonable suspicion has, however, become less difficult, especially with respect to terrorist offences. This also has to do with the influence of the above-enumerated suspicion criteria on the fulfilment of the reasonable suspicion criterion. As result of: (1) the broadened powers for state authorities, (2) the less demanding suspicion criteria, and (3) the expanded criminal liability in and beyond

\footnotetext{
1099 B. van Gestel, C.J. de Poot en R.F. Kouwenberg, De wet opsporing terroristische misdrijven drie jaar in werking, WODC, Memorandum 2010-3, p. 12.

1100 See Chapters III, IV and V.
} 
the criminal law system, there is increasingly less need for the investigative authorities to investigate the commission of terrorist offences themselves.

In addition, the secret intelligence services will pass information regarding alleged (groups of) terrorists on to Mayors and public prosecutors. The Mayor may provide the public prosecutor with information concerning presumed 'terrorists' following, for example, the application of personal disturbance powers. Information will, furthermore, easily be gathered by means of exploring inquiries, the application of special investigative techniques and the employment of investigative powers in security risk areas. The CT-Infobox plays an important role in this respect.

Also, more general investigative techniques are employed to gather information that may be relevant to come to a reasonable suspicion of a terrorist offence, like largescale DNA-investigations, camera surveillance in public as well as private spaces, computer investigations, the employment of the obligation for all civilians to show their ID papers upon request, linking all sorts of (computer) databases, and exchanging secret intelligence information with foreign (secret) services. ${ }^{1101} \mathrm{Such}$ information is used to substantiate a reasonable suspicion against alleged terrorist suspects. Considered from this point of view, the factual value of Article 27 of the DCCP in terms of safeguarding legal protection and of curtailment of the application of state powers has diminished.

All of this implies that, in addition to the light reasonable suspicion applicable in the case of terrorism, the need for investigative authorities to demonstrate such a suspicion themselves has diminished considerably.

\section{A reasonable Suspicion and the ECtHR}

\subsection{Introduction}

To lawfully deprive a person of his liberty there must be a reasonable suspicion that he committed an offence, pursuant to Article 5, section 1 under c of the ECHR. ${ }^{1102}$ Strasbourg case law regarding the scope of the right to liberty and security is abundant, but only a small part explicitly relates to the interpretation of the notion of a reasonable suspicion. There are four key judgements concerning persons suspected of terrorist offences, in which the ECtHR explicitly elaborated on the scope of a reasonable suspicion: Fox, Campbell and Hartley v. the UK, Margaret Murray v. the UK, O'Hara v. the UK, and Brogan and Others v. the UK.

The ECtHR requires, just as the Dutch Judiciary, that a reasonable suspicion must be based on facts or circumstances that are open to objectification. But when exactly

\footnotetext{
1101 See, Rathenau Instituut, Van Privacyparadijs tot controlestaat? Misdaad en terreurbestrijding In Nederland aan het begin van de 21ste eeuw, February 2007, the Hague.

1102 McKay v. the United Kingdom, appl. no. 543/03, 3 October 2006, §40.
} 
does the ECtHR consider there to be sufficiently objective facts or circumstances to generate a reasonable suspicion? What information and from whom may contribute to coming to a reasonable suspicion? Furthermore, the question of whether the serious nature of certain criminal offences, such as terrorist offences, may lower the threshold for coming to such a suspicion will be elaborated on.

\subsection{The 'UK cases'}

Fox, Campbell and Hartley V. The UK

The case of Fox, Campbell and Hartley v. the $U K^{1103}$ regards complaints about lack of a reasonable suspicion in case of an arrest and police custody. In this case, the ECtHR delineated the scope of a reasonable suspicion unequivocally. In all subsequent judgements regarding the notion of a reasonable suspicion, this case has been referred to.

At the time of the judgement, UK anti-terrorism legislation allowed for arrest of alleged 'terrorists' by any officer who had an honest suspicion. No official warrant was required for the arrest. ${ }^{1104}$ The suspicion was, hence, dependent on the police's subjective opinion, rather than on objective facts or circumstances. The applicants in this case were stopped and brought to a police station, where a full search of the vehicle in which they were travelling, was carried out. Twenty-five minutes after their arrival at the police station they were formally arrested on suspicion of 'being terrorists'. ${ }^{105}$ According to the government, the information underlying the suspicion against the applicants was already available to the police when they stopped their car, so prior to searching the car and arresting them. ${ }^{1106}$

The ECtHR took well into account the difficulties a state faces in countering terrorism, but, at the same time, it set a firm minimum standard for satisfying the requirements of Article 5, section 1 under $\mathrm{c}$ of the ECHR. ${ }^{1107}$ According to the ECtHR, the 'reasonableness' of the suspicion on which an arrest must be based forms an essential part of the safeguards against arbitrary arrest, the core element of Article 5 of the ECHR, and detention. ${ }^{1108}$ Precisely for that reason, extensive elaboration was dedicated to the question of when such 'reasonableness' is considered to be justified. ${ }^{1109}$ First of all, the ECtHR underlined that Article 5 of the

\footnotetext{
1103 Fox, Campbell and Hartley v. the United Kingdom, appl. no. 12244/86, 30 August 1990.

1104 Fox, Campbell and Hartley v. the United Kingdom, appl. no. 12244/86, 30 August 1990, §19.

1105 Fox, Campbell and Hartley v. the United Kingdom, appl. no. 12244/86, 30 August 1990, $\$ 9$.

1106 Fox, Campbell and Hartley v. the United Kingdom, appl. no. 12244/86, 30 August 1990, \$10.

1107 Çetinkaya and Çağlayan v. Turkey, appl. nos. 3921/02, 35003/02 and 17261/03, 23 April 2007, $\S 38$.

1108 Tuncer and Durmuş v. Turkey, appl. no. 30494/96, 2 November 2004, §47; Shannon v. Latvia, appl. no. 32214/03, 24 November 2009, §45.

1109 Fox, Campbell and Hartley v. the United Kingdom, appl. no. 12244/86, 30 August 1990, \$32.
} 
ECHR speaks of a 'reasonable suspicion' rather than of a genuine and bona fide suspicion. ${ }^{1110} \mathrm{~A}$ genuine and bona fide suspicion during the early stages of criminal investigations is, foremost, not required because the very purpose of an arrest and subsequent deprivation of liberty is to dispel or sustain the initial suspicion. ${ }^{1111}$ The ECtHR explicitly specified which minimum circumstances may lead to a reasonable suspicion:

'Having a reasonable suspicion presupposes the existence of facts or information which would satisfy an objective observer that the person concerned may have committed the offence. What may be regarded as reasonable will however depend upon all the circumstances.'1112

This consideration resembles the Dutch interpretation of a reasonable suspicion: a suspicion must be based on facts, circumstances or information that must, moreover, be open to objectification in order to be deemed reasonable. In this respect, it is important to note that even though the ECtHR acknowledged that terrorism falls into a special category, ${ }^{1113}$ the exigencies of dealing with terrorism cannot justify stretching the notion of 'reasonableness' to the point where the 'essence of the safeguard secured by Article 5, section 1 under c of the ECHR is impaired'. 1114 Accordingly, the ECtHR puts a ban on using terrorism as 'excuse' to restrict the

1110 Fox, Campbell and Hartley v. the United Kingdom, appl. no., 12244/86, 30 August 1990, §31 and 32.

1111 Cebotari v. Moldova, appl. no. 35615/06, 13 November 2007, $\S 48$ and further.

1112 Fox, Campbell and Hartley v. the United Kingdom, appl. no. 12244/86, 30 August 1990, §62. See, also, Özçelik v. Turkey, appl. no. 56497/00, 20 February 2007, §17; Tuncer and Durmuş v. Turkey, appl. no. 30494/96, 2 November 2004, §47; Leva v. Moldova, appl. no. 12444/05, 15 December 2009, §50; Makhmudov v. Russia, appl. no. 35082/04, 26 July 2007, §80 and further. In this latter case the ECtHR considered that: '(...) The submissions by the respondent Government to the Court contained no facts or information relating to the offence of disobedience, which had allegedly been the basis for the applicant's arrest. Furthermore, if the police had indeed harboured a suspicion of the applicant's involvement in the commission of an offence, it was incumbent on them to carry out an investigation with a view to confirming or dispelling the concrete suspicion grounding the applicant's arrest. However, no such investigation was carried out and the police made no attempt to collect evidence capable of proving or disproving any suspicion against the applicant which they might have had. In these circumstances, the Court does not discern any facts or information which could satisfy an objective observer that the applicant might have committed the offence of disobedience which was invoked as the basis for his arrest.'

1113 The attendant risk of loss of life and human suffering obliges the police to act with the utmost urgency in following up all information, including information from secret sources. Fox, Campbell and Hartley v. the United Kingdom, appl. no., 12244/86, 30 August 1990, §59.

1114 The United Kingdom government held another opinion and argued that because the case involved suspects of terrorist crimes, different criteria for coming to a reasonable suspicion applied. Fox, Campbell and Hartley v. the United Kingdom, appl. no. 12244/86, 30 August 1990, §33. See, also, Brogan and Others v. The United Kingdom, appl. no. 10/1987/133/184-187, 29 November 1988, §59; Adirbelli and Others v. Turkey, appl. no. 20775/03, 2 December 2008, $\S 27$. 
requirements of Article 5 of the ECHR without making use of a derogation under Article 15 of the ECHR. ${ }^{1115}$ States have to furnish at least some facts or information capable of satisfying the ECtHR that the arrested person was reasonably suspected of having committed an offence. ${ }^{116}$ This is all the more necessary where, as in Fox, Campbell and Hartley $v$. the $U K$, the domestic law does not require a reasonable suspicion, but sets a lower threshold by merely requiring an honest suspicion.

However, the ECtHR also underlined that Article 5 of the ECHR should not be applied in such a manner as to put disproportionate difficulties in the way of the police authorities in taking effective measures to counter terrorism. ${ }^{117}$ This means, for instance, that states cannot be asked to establish the reasonableness of the suspicion grounding the arrest of a suspected terrorist by disclosing the confidential sources of supporting information, or even facts which would be susceptible of indicating such sources or their identity. ${ }^{1118}$

With regard to this last consideration, three aspects must be underlined. Firstly, the fact that the ECtHR spoke of 'supporting' information. Does that mean that 'secret' information, as such, cannot justify a 'reasonable suspicion'? That would imply that secret intelligence information, without any additional information, is insufficient to generate a reasonable suspicion.

1115 See, in this respect also, the ECtHR's considerations regarding Article 5 of the ECHR in $A$. and others v. The United Kingdom, appl. no. 3455/05, 19 February 2009, §171-172. See, also, J.P. Loof, Mensenrechten en staatsveiligheid: verenigbare grootheden? Opschorting en beperking van mensenrechtenbescherming tijdens noodtoestanden en andere situaties die de staatsveiligheid bedreigen (dissertation, Leiden) Nijmegen, Wolf Legal Publishers, 2005.

1116 Furnishing a suspicion without providing any indication as to the basis for that suspicion beyond reference to sensitive material, available to the police, connecting the suspect to the offence, is insufficient to establish a reasonable suspicion according to the ECtHR. Fox, Campbell and Hartley v. the United Kingdom, appl. no. 12244/86, 30 August 1990, §8-14. See, also, Adirbelli and Others v. Turkey, appl. no. 20775/03, 2 December 2008, \$27, in which the ECtHR considered that: 'In that context terrorist crime poses particular problems, as the police may be called upon, in the interests of public safety, to arrest a suspected terrorist on the basis of information which is reliable but which cannot be disclosed to the suspect or produced in court without jeopardising the informant. However, although Contracting States cannot be required to establish the reasonableness of the suspicion grounding the arrest of a suspected terrorist by disclosing confidential sources of information, the Court has held that the exigencies of dealing with terrorist crime cannot justify stretching the notion of 'reasonableness' to the point where the safeguard secured by Article $5 \S 1$ (c) is impaired. Even in those circumstances, the respondent Government have to furnish at least some facts or information capable of satisfying the Court that the arrested persons were reasonably suspected of having committed the alleged offence.'

1117 Klass and Others v. Germany, appl. no. 5029/71, 6 September 1978, $\S 48$.

1118 Fox, Campbell and Hartley v. the United Kingdom, appl. no. 12244/86, 30 August 1990, \$32-34. See, also, Brogan and Others v. the United Kingdom, appl. nos. 11209/84, 11234/84, 11266/84, 11386/85, 29 November 1988, §53; Adirbelli and Others v. Turkey, appl. no. 20775/03, 2 December 2008, $\$ 27$. 
Secondly, the ECtHR referred to 'sources'. Is one (secret) source grounding a reasonable suspicion inadequate? Some Strasbourg judgements indeed seem to sustain that one source is insufficient to demonstrate a reasonable suspicion..$^{1119}$

Thirdly, it is important to note that the phrase of 'disproportionate difficulties' does not refer to the level of suspicion, but rather to the investigative authorities' duty to reveal the information underlying the reasonable suspicion. So, in this respect Strasbourg case law does not appear to justify the conclusion that lower suspicion criteria apply in the case of serious criminal offences. ${ }^{1120}$

How did the ECtHR judge the circumstances of the case in Fox, Campbell and Hartley v. the UK? Fox, Campbell and Hartley had previously been detained for terrorist acts. This justified their being considered as terrorists to some extent. However, in the end, their former involvement in terrorism could not, as such, justify the arrest and detention. ${ }^{121}$ Furthermore, the ECtHR underlined that the interrogations of Fox, Hartley and Campbell - during which questions were posed regarding specific terrorist acts - do no more than confirm that the arresting officers had a genuine suspicion that the applicants had been involved in those acts. Though, that could not convince an objective observer that Fox, Hartley and Campbell might have committed these acts. So, specific, objectively verifiable facts that connect a concrete criminal offence to a person are required to adequately demonstrate a reasonable suspicion. ${ }^{1122}$

Margaret Murray v. THe UK

In Margaret Murray v. the UK, the ECtHR examined the question of whether the facts or information used to sustain a reasonable suspicion were objectively perceptible for everyone. The applicant ('Murray') was arrested, placed in police custody for three hours, and subsequently released without charge. She was 'reasonably suspected' of involvement in the collection of money for the purchase of arms for the Provisional Irish Republican Army ('Provisional IRA') in the

1119 O'Hara v. the United Kingdom, appl. no. 37555/97, 16 October 2001. This judgement will be discussed below. See, also, Ipek and Others v. Turkey, appl. nos. 17019/02 and 30070/02, 3 February 2009, §30-31 in which the ECtHR considered that: '(...) As regards the other applicants, however, it appears that they were arrested merely because they were at the second applicant's house at the time of the search. Against this background and in the absence of any information or documents demonstrating the contrary, the Court considers that, at the time of their arrest, these applicants were not detained on reasonable suspicion of having committed an offence, or to prevent their committing an offence, within the meaning of Article $5 \S 1$ (c) of the Convention. There has accordingly been a violation of this provision in respect of $\mathrm{Mr}$ İpek and Mr Demirel (...)'.

1120 See, for example, Leva v. Moldova, appl. no. 12444/05, 15 December 2009, §50.

1121 Fox, Campbell and Hartley v. the United Kingdom, appl. no. 12244/86, 30 August 1990, §35.

1122 Gusinskiy v. Russia, appl. no. 70276/01, 19 May 2004, §53. 
USA. ${ }^{1123}$ The suspicion was based on a briefing that the arresting officer had received. ${ }^{1124}$ Interrogations during police custody, however, concerned the question of whether Murray was still in contact with her brothers who were convicted in the USA of weapon related offences connected with the purchase of weapons for the Provisional IRA. ${ }^{1125}$ Margaret Murray had recently visited the USA and kept in contact with her brothers there. ${ }^{1126}$ Furthermore, it was known that the offences for which her brothers were convicted were ones that implied collaboration with 'trustworthy' persons residing in Northern Ireland. ${ }^{1127}$

The key question in this case was whether the detention of Murray's brothers for offences relating to the Provisional IRA and her contacts with them - which were objectively perceptible - could justify the reasonable suspicion that she, herself, was connected to such offences as well.

Given: (1) the level of factual justification of a suspicion required at the initial stage of criminal proceedings, (2) the special exigencies of investigating terrorist crime, ${ }^{1128}$ and (3) the specific circumstances of the case, the ECtHR concluded that there were, indeed, sufficient facts or information to sustain a reasonable suspicion. In the ECtHR's view, there was an adequate plausible and objective basis for a suspicion that Murray may have committed the offence of involvement in the collection of funds for the provisional IRA. ${ }^{129}$

In this respect, it is important to note that Murray had been kept in police custody for only three hours. That may have played a role in the ECtHR concluding that there were sufficient facts/circumstances, that were, moreover, objectively perceptible, to demonstrate a reasonable suspicion. Taking into account the limited infringement on Murray's right to liberty of person, a conviction of family members in the USA for IRA related offences in which reference was made to contact with

1123 Murray v. the United Kingdom, appl. no. 14310/88, 28 October 1994, §11.

1124 Murray v. the United Kingdom, appl. no. 14310/88, 28 October 1994, §20.

1125 Murray v. the United Kingdom, appl. no. 14310/88, 28 October 1994, §10.

1126 Murray v. the United Kingdom, appl. no. 14310/88, 28 October 1994, §62.

1127 According to the United Kingdom government this was sufficiently indicative of Murray’s involvement in financing the Provisional IRA. Murray v. the United Kingdom, appl. no. 14310/88, 28 October 1994, $\$ 52$.

1128 The ECtHR explicitly mentioned terrorism as a justified cause for states to take recourse to various procedural powers that interfere with liberty rights. The ECtHR also acknowledged the need to use secret intelligence information in countering terrorism: '(...) The Court would firstly reiterate its recognition that the use of confidential information is essential in combating terrorist violence and the threat that organised terrorism poses to the lives of citizens and to democratic society as a whole (...)'. See, Murray v. the United Kingdom, appl. no. 14310/88, 28 October 1994, §58. Again, the phrase 'special exigencies of investigating terrorist crime' referred to the kind of information underlying a reasonable suspicion, rather than to the level of suspicion. 
'trustworthy' persons in Ireland, combined with Murray's recent visit to the USA, it was hence considered sufficient to demonstrate a reasonable suspicion. ${ }^{1130}$

\section{O’HARA v. THE UK}

In O'Hara $v$. the UK, the ECtHR considered four independently provided secret intelligence sources adequate to satisfy the standard for a reasonable suspicion. ${ }^{1131}$ The suspicion was primarily based on this secret information, which had been passed on to the police by informers who identified the applicant (O'Hara) as one of a number of persons suspected of involvement in a specific terrorist murder. ${ }^{1132}$ Also, two incriminating statements of 'terrorist-colleagues', who had, moreover, previously proved reliable, and whose information concerning the alleged offence was consistent, also contributed to the reasonableness of the suspicion. ${ }^{1133}$

The ECtHR's firstly underlined that O'Hara's arrest was a pre-planned operation, more akin to the arrest in the case of Murray, and was based on slightly more specific details than in the case of Fox, Campbell and Hartley. ${ }^{1134}$ Secondly, the ECtHR emphasised that it understood governments using secret intelligence information without revealing the source to the arrested person. However, it also limited that practice by requiring that this may never lead to violating the core of Article 5 of the ECHR: prevention of arbitrary and unlawful deprivation of liberty. ${ }^{1135}$

Furthermore, the ECtHR argued that former convictions for similar offences can reinforce a suspicion deriving from other material. But, a former conviction for a similar offence cannot justify, as such, suspicions concerning a newly committed offence, in which case additional 'objective reasons' are required. ${ }^{1136}$ It appears thus, to be essential that a suspicion is linked to a person's present conduct.

Interrogations during which questions concerning specific terrorist offences are posed, can contribute to a (subjective) honest suspicion, but cannot justify to an objective observer that the person in question is 'reasonably suspected' of having

1130 Most probably the very limited length of police custody played an important role more than that the contact with her brothers served as sufficiently objective information. Murray v. the United Kingdom, appl. no. 14310/88, 28 October 1994, §56: 'The length of the deprivation of liberty at risk may also be material to the level of suspicion required. The period of detention permitted under the provision by virtue of which Mrs Murray was arrested, namely section 14 of the 1978 Act, was limited to a maximum of four hours'.

1131 O'Hara v. the United Kingdom, appl. no. 37555/97, 16 October 2001, §38-44. Compare with Shannon v. Latvia, appl. no. 32214/03, 24 November 2009, §45-50.

1132 O'Hara v. the United Kingdom, appl. no. 37555/97, 16 October 2001, §40.

1133 Talat Tepe v. Turkey, appl. no. 31247/96, 21 December 2004, §59.

1134 O'Hara v. the United Kingdom, appl. no. 37555/97, 16 October 2001, $\$ 42$.

1135 O'Hara v. the United Kingdom, appl. no. 37555/97, 16 October 2001, §35.

1136 Fox, Campbell and Hartley v. the United Kingdom, appl. no. 12244/86, 30 August 1990, §35. 
committed the offence. ${ }^{1137}$ In this reasoning the ECtHR clearly established its two constituents for coming to a reasonable suspicion: 1) the subjective aspect, i.e. the bona fides of the arresting officer, and 2) the objective aspect, i.e. facts or information that are objectively perceptible.

In this respect it is important to note that the UK had just amended its legislation. During the cases of Fox, Campbell and Hartley v. the UK and Murray v. the UK, the 'old' UK anti-terrorism legislation, merely requiring an honest suspicion, was valid. The ECtHR declared such a suspicion not to be in consonance with Article 5 of the ECHR. At the time of the O'Hara v. the UK judgement, UK anti-terrorism legislation required an honest suspicion on reasonable grounds. This new criterion was, theoretically, considered in compliance with ECHR-standards. A striking detail in this judgement is that the ECtHR explicitly assessed UK legislation in general on (non-)compliance with Article 5, section 1 under $\mathrm{c}$ of the ECHR. ${ }^{1138}$

The last important aspect concerns the fact that O'Hara only raised a limited amount of complaints during domestic proceedings. During the proceedings before the ECtHR, O'Hara argued that that he was arrested as part of an arbitrary police policy, which targeted him as a prominent member of Sinn Fein. ${ }^{1139}$ The ECtHR, however, dismissed this complaint by recalling that O'Hara had not challenged the good faith of any of the officers involved in the arrest or detention during the domestic proceedings. ${ }^{1140}$ That may have contributed to the ECtHR's conclusion that the suspicion against O'Hara was sufficient to justify his arrest and initial police custody.

\subsection{Case law based on the UK judgements}

Almost all of the judgements regarding an alleged lack of reasonable suspicion for arrest/police custody refer to the above-discussed key judgements. The case of $\ddot{O}_{z c ̧ e l i k}$ v. Turkey ${ }^{1141}$ concerned an applicant who was the Deputy Chairman of the pro-Kurdish HADEP (People's Democracy Party). The applicant was arrested during the course of a police operation carried out against the PKK. Subsequently, he was taken into custody by police officers from the anti-terror branch. According to the arrest protocol, signed by four police officers and the applicant, a search

1137 Fox, Campbell and Hartley v. the United Kingdom, appl. no. 12244/86, 30 August 1990, \$36.

1138 See, in this respect, Vlemminx F.M.C., 'Hirst en Broniowski: De tandem waarmee het EHRM de nationale wetgever in de wielen rijdt?', in NJB, nr. 6, 2007, pp. 322-329.

1139 O'Hara v. the United Kingdom, appl. no. 37555/97, 16 October 2001, \$23-25 and 39.

1140 O'Hara v. the United Kingdom, appl. no. 37555/97, 16 October 2001, §40 and 43.

1141 Özçelik v. Turkey, appl. no. 56497/00, 20 February 2007. See, also, the decision as to the admissibility in Turgay Elğay v. Turkey, appl. no. 18992/03, 11 September 2007; Varga c. Roumanie, requête no 73957/01, 1 avril 2008. 
warrant had been issued in respect of the applicant. ${ }^{1142}$ When the officers saw the applicant, they asked him to show his identity card. The applicant, however, attempted to escape. ${ }^{1143}$

The ECtHR considered that these circumstances were sufficient to support the conclusion that there was 'reasonable suspicion' for the applicant's arrest. In addition, the ECtHR argued that the fact that the criminal proceedings against the applicant were suspended did not, of itself, call into question the existence of a reasonable suspicion. ${ }^{1144}$

The case of Adirbelli and Others v. Turkey ${ }^{1145}$ concerns, again, members of the HADEP. The applicants, in this case, allege that they had been arrested only because of their membership of HADEP. During the investigation, the applicants were not questioned about their membership of the political party. In that light, the ECtHR did not consider it necessary to speculate as to whether the applicants' membership of HADEP was the ground for their arrest. ${ }^{1146}$ Nevertheless, the ECtHR observed that, 'although requested twice, the Government did not submit the documents concerning the evaluation made by the anti-terrorist branch which led to the applicants' arrest. Nor does the decision of the Court authorising the security forces to conduct a search of the applicants' houses contain any information regarding the reasons established by the security forces and the public prosecutor for suspecting the applicants of having participated in the armed attack. ${ }^{1147}$

Moreover, even though no evidence was found during the house searches at the applicants' homes linking them to the armed attack they were suspected of, they were still arrested and placed in police custody. In the absence of a satisfactory explanation on the part of the government for the applicants' arrest and detention, the ECtHR did not discern any facts or information that could satisfy an objective observer that the applicants might have taken part in the armed attack in question. It therefore held that the applicants were not detained on reasonable suspicion of having committed an offence. ${ }^{1148}$

1142 Compare with Tanrikulu and Others v. Turkey, appl. nos. 29918/96, 29919/96 and 30169/96, 6 October 2005, $\$ 30$.

1143 Özçelik v. Turkey, appl. no. 56497/00, 20 February 2007, §4-5.

1144 Özçelik v. Turkey, appl. no. 56497/00, 20 February 2007, §17-21. See, in this respect also, Cebotari v. Moldova, appl. no. 35615/06, 13 November 2007, §48; Aşan and Others v. Turkey, appl. no. 56003/00, 31 July 2007. See, also, the decision as to the admissibility in Turgay Elgay v. Turkey, appl. no. 18992/03, 11 September 2007; Varga c. Roumanie, requête no 73957/01, 1 avril 2008; Gusinskiy v. Russia, appl. no. 70276/01, 19 May 2004, §53.

1145 Adirbelli and Others v. Turkey, appl. no. 20775/03, 2 December 2008. See, also, the decision as to the admissibility in Turgay Elğay v. Turkey, appl. no. 18992/03, 11 September 2007; Varga c. Roumanie, requête no 73957/01, 1 Avril 2008.

1146 Adirbelli and Others v. Turkey, appl. no. 20775/03, 2 December 2008, §28.

1147 Adirbelli and Others v. Turkey, appl. no. 20775/03, 2 December 2008, \$29.

1148 Adirbelli and Others v. Turkey, appl. no. 20775/03, 2 December 2008, §29-30. See, for a comparable reasoning, Tuncer and Durmuş v. Turkey, appl. no. 30494/96, 2 November 2004, $\S 47-52$. 
A last example is the case of Shannon v. Latvia. In that case, the ECtHR first of all reiterated that a reasonable suspicion does not mean that the suspected person's guilt must, at the time of the arrest, be established. ${ }^{1149}$ Article 5, section 1 under c of the ECHR does not even presuppose that the police should have obtained sufficient evidence to bring charges, either at the point of arrest or while the applicant is in custody. ${ }^{1150}$ Nor does the arresting police officer have to know the precise nature of the offence. ${ }^{1151}$ The applicant, in this case, was suspected of having sexually assaulted juveniles. The initial suspicion was based on statements from four victims and the testimony from an unnamed eyewitness. Such evidence was sufficient to have created a reasonable suspicion against the applicant, according to the ECtHR. ${ }^{1152}$

\subsection{In sum}

First of all, it is important to note that Strasbourg case law with respect to Article 5 of the ECHR is, to a considerable extent, dependent on the specific circumstances of the case, certainly with respect to the question of the reasonableness of the suspicion. That makes it almost impossible to provide more than just some guidelines in respect of the question of when a person can reasonably be considered as a suspect in Strasbourg terms.

Firstly, in examining whether there is a reasonable suspicion, the ECtHR discerns between: (1) the subjective side of a suspicion, i.e. the bona fides of the investigative authorities, and (2) the objective side of a suspicion, i.e. objective, concrete and relevant facts or circumstances to sustain the suspicion. Only if both aspects have been fulfilled, will a suspicion be reasonable. ${ }^{1153}$ The facts or information that underlie a suspicion must objectively connect the alleged suspect with the supposed crime. There will, therefore, have to be evidence of actions directly implicating the suspect on the basis of, for example, documents, testimonial evidence, forensic evidence, or, under certain circumstances, secret evidence. ${ }^{1154}$ Suspicions based on feelings, instincts, mere associations or prejudice are inadequate to sustain a reasonable suspicion, no matter how reliable these may be considered by the investigative authorities as an indicator of someone's involvement in the commission

\footnotetext{
1149 O’Hara v. the United Kingdom, appl. no. 73555/97, 16 October 2001, §36.

1150 Shannon v. Latvia, appl. no. 32214/03, 24 November 2009, §45; Erdagöz v. Turkey, 22 October 1997, appl. no. 21890/93, §51; Gusinskiy v. Russia, appl. no. 70276/01, 19 May 2004, §53; Tanrikulu and Others v. Turkey, appl. nos. 29918/96, 29919/96 and 30169/96, 6 October 2005, $\S 28$; Emil Hristov v. Bulgaria, appl. no. 52389/99, 20 October 2005, §38.

1151 See, also, Ipek and Others v. Turkey, appl. nos. 17019/02 and 30070/02, 3 February 2009, §2629; Özçelik v. Turkey, appl. no. 56497/00, 20 February 2007, §17.

1152 Shannon v. Latvia, appl. no. 32214/03, 24 November 2009, §46.

1153 Cebotari v. Moldova, appl. no. 35615/06, 13 November 2007, §48-53.

1154 Pavlik v. Slovakia, appl. no. 74827/01, 30 January 2007, §92 and further.
} 
of an offence. The more detailed and precise the information used to demonstrate the suspicion is, the more likely it is that the ECtHR will assess the suspicion as reasonable. ${ }^{1155}$

The question of whether there was precise (incriminating) information prior to an arrest can, for example, appear from the way in which an arrest is planned: the more detailed the planning of the arrest, the more likely it becomes that the suspicion is considered reasonable. ${ }^{1156}$

The ECtHR does not seem to object to using secret intelligence information to come to a reasonable suspicion. However, the above-discussed judgements demonstrate that there normally needs to be additional information to demonstrate a reasonable suspicion. If secret intelligence information is used, that information must at least comprise some facts or information capable of satisfying a court that the arrested person was justly suspected of having committed an offence(s). The ECtHR attaches special importance to the question of whether the relevant facts or information could have led an objective bystander, under the same circumstances, to consider a person as a suspect as well.

Furthermore, a person's police record may reinforce the reasonableness of a suspicion, but it cannot as such justify a reasonable suspicion. The investigative authorities remain, at all times, obliged to come up with objectively perceptible facts or information concerning the current criminal offence of which a person is suspected.

Another aspect that plays a role is the kind, nature and seriousness of the interference with a suspect's right to liberty. In Murray v. the UK, the ECtHR connected the level of suspicion directly with the seriousness of the interference: the less serious the interference is, the less strictly requirements for a reasonable suspicion are interpreted. The more serious interferences are, such as in the case of police custody or remand in custody, or the more serious in character they are, the requirements for a reasonable suspicion will be interpreted equally strictly. ${ }^{1157}$ This issue will further be elaborated on in the next section.

1155 Talat Tepe v. Turkey, appl. no. 31247/96, 21 December 2004, §11-14 and 58. In this case the applicant was arrested on suspicion of abetting the PKK. His arrest and the required reasonable suspicion were grounded on two incriminating statements given by two members of the PKK. However, these statements dated back some three years. The applicant claimed that reasonable suspicion for his arrest and consequent detention on remand were lacking. The ECtHR however, accepted the statements as sufficiently objective and concrete to satisfy the standards for reasonable suspicion and concluded that Article 5, section 1 under $\mathrm{c}$ of the ECHR, had not been violated.

1156 Compare with case law regarding Article 2 of the ECHR, in which the ECtHR asserts that the better an arrest is prepared and planned, the less likely it is that Article 2 of the ECHR is violated when a suspect dies during arrest.

1157 Khudoyorov v, Russia, appl. no. 6847/02, 8 November 2005, §174-189; Boicenco v. Moldova, appl. no. 41088/05, 11 July 2006, §141-146. 
Case law demonstrates, furthermore, that the ECtHR employs one criterion for establishing a reasonable suspicion, which, moreover, applies to all criminal offences. Even though the ECtHR understands a state's difficulties in countering terrorism, it does not allow for the creation of different suspicion criteria which depend on the type of crime that a person is suspected of having committed. States remain obliged to take measures to preserve the safeguards against arbitrary arrest and detention, also and maybe even more so when it concerns terrorist suspects. ${ }^{158}$ This reasoning makes the Dutch government's consideration that when it concerns alleged terrorists, suspicion criteria should be less demanding, questionable.

A last important aspect concerns the role of judicial review vis-à-vis a reasonable suspicion. A procedural safeguard to prevent arbitrary arrest is adequate domestic judicial review of the reasons for arrest. In O'Hara $v$. the $U K$, the applicant's arrest was examined by three levels of domestic courts. In those proceedings, evidence was given by the arresting officer concerning the circumstances of the arrest, and the applicant was given the opportunity to cross-examine. Effective proceedings presuppose the disclosure of specific facts furnishing at least some information capable of satisfying the Judiciary that the arrested person was arrested on reasonable suspicion of having committed an offence. The Judiciary must, hence, be granted access to the (objective) facts or circumstances that led to the arrest/ deprivation of liberty to perform an effective post facto control on the lawfulness of the interference with a person's right to liberty. ${ }^{1159}$

\section{The RIGHT TO LIBERTY AND SECURITY OF PERSON}

\subsection{Introduction}

This section discusses the scope of Article 5, section 1 under c and section 3 of the ECHR, basically comprising the Strasbourg judicial framework for lawful pre-trial deprivation of liberty in the context of criminal proceedings. Article 5, section 1, under $\mathrm{c}$ of the ECHR has partially been discussed above, and the remainder of that section will now be examined. Article 5, section 3 of the ECHR is structurally concerned with two separate matters: the early stages following an arrest when an individual is taken into the power of the authorities (arrest period), and the period pending eventual trial before a criminal court, during which the suspect may be detained or released with or without conditions (pre-trial/remand period). In McKay v. the United Kingdom, the ECtHR underlined that these two limbs confer distinct

1158 Imakayeva v. Russia, appl. no. 7615/02, 9 November 2006, §175.

1159 Compare with Mooren v. Germany [GC], appl. no. 11364/03, 9 July 2009, §79: ‘(...) Furthermore, in the context of sub-paragraph (c) of Article $5 \$ 1$, the reasoning of the decision ordering detention is a relevant factor in determining whether a person's detention must be considered as arbitrary (...)'. And, see, Vrenčev v. Serbia, appl. no. 2361/05, 23 September 2008, §65. 
rights, and are not, on their face, logically or temporally linked. ${ }^{1160}$ In this respect it is also important to note that section 1 under $\mathrm{c}$ and section 3 of Article 5 of the ECHR complement and overlap each other. ${ }^{1161}$

ECtHR case law with regard to Article 5 of the ECHR is obviously important to examine whether Article 67, section 4 of the DCCP is Strasbourg conforming. During the parliamentary discussions regarding the DPTA, many questions mainly within the Upper House - were posed concerning the compatibility of the amended system of pre-trial detention for terrorist suspects with Article 5 of the ECHR. ${ }^{1162}$ Members of the Upper House alleged that remanding in custody without 'serious objections' would be in contravention to the right to liberty of person, as interpreted by the ECtHR.

Which effects, in terms of positive and negative obligations, does Article 5, section 1 and 3 of the ECHR have on the Dutch system of pre-trial detention? How can states deprive suspects of their liberty without infringing the ECHR? Does the lawfulness of arrest and initial deprivation of liberty depend on the seriousness of the offence? Is it permitted to place a suspect of a terrorist offence in police custody on less well-substantiated grounds, than when it concerns a suspect of a common criminal offence? In this respect it is important to differentiate between initial deprivation of liberty and continued deprivation of liberty. How does continued pretrial detention affect the prerequisites for lawful, Strasbourg conforming, deprivation of liberty? How, and to what extent, does the type of criminal offence a person is suspected of influence these prerequisites?

In the following sections, I will first briefly discuss the scope of the concept of 'liberty and security of person', as interpreted by the ECtHR. Then, the requirements for lawful deprivation of liberty during (1) the arrest period and (2) the pre-trial/ remand period are discussed.

\subsection{The concept of 'Liberty and security of Person'}

The fundamental principle of Article 5 of the ECHR is that everyone should benefit from his liberty and security and that a person can only be deprived of that asset in exceptional circumstances. ${ }^{1163}$ The importance of this right is shown by the strict requirements that have to be adhered to in the case of deprivation of liberty. These requirements are, moreover, defined in a very detailed way, leaving hardly any

1160 McKay v. the United Kingdom, appl. no. 543/03, 3 October 2006, §31; Bujac c. Romanie, requête no. 37217/03, 2 novembre 2010, $\$ 66$.

1161 Jiga c. Roumanie, requête no. 14352/04, 16 mars 2010, §73.

1162 Kamerstukken I 2006-2007, 30 164, no. C, pp. 8-9.

1163 Macovei, M., A Guide to the implementation of article 5 of the European Convention on Human Rights, Human rights handbooks, no. 5, Council of Europe Publishing; Strasbourg 2002, p. 8. 
margin of appreciation to Member States. In that respect, Article 5 of the ECHR unequivocally differs from other rights such as the right to privacy.

Infringements of a person's liberty are only allowed in the case of an exhaustively listed ${ }^{1164}$ set of scenarios specified in Article 5, section 1 of the ECHR. The ECtHR interpretation of section a until $\mathrm{f}$ is very strict. In K.-F.v Germany, the ECtHR underlined that the list of exceptions to the right to liberty is an exhaustive one, and only narrow interpretation of these exceptions is consistent with the aim of that provision, namely, to ensure that no one is arbitrarily deprived of his or her liberty. ${ }^{165}$

Article 5 of the ECHR refers to the right to liberty and the right to security of person. With regard to substance, Strasbourg case law primarily concerns infringements of the right to liberty. What role does the notion of 'security' play in Article 5 of the ECHR? Generally, the right to liberty and the right to security are bracketed together and discussed together in case law and in literature. Literally taken, these two notions do not automatically and necessarily imply the same. In Bozano v. France, the ECtHR distinguished between the two and considered the right to security a separate right, hence in addition to the right to liberty of person, by underlining that:

'(...) What is at stake here is not only the 'right to liberty' but also the 'right to security'. 1166

The right to security of person is specifically mentioned in this case to indicate that restrictions on the right to security may never - just as with respect to the right to liberty of person - be imposed arbitrarily. ${ }^{1167}$ In Öcalan $v$. Turkey, both the applicant and the ECtHR explicitly referred to the notion of 'security' pursuant to Article 5 of the ECHR. ${ }^{1168}$ Öcalan had been arrested in Kenya for terrorism related crimes that he had allegedly committed in Turkey. He argued that his right to liberty and his right to security had been violated when he was arrested. The ECtHR considered that an arrest made by the authorities of one state in the territory of another state, without the consent of the latter, affects the person's individual rights to security under Article 5, section 1 of the ECHR. ${ }^{1169}$

\footnotetext{
1164 Ciulla v. Italy, appl. no. 11152/84, 22 February 1989, §41: '(...) certainly the Court does not underestimate the importance of Italy's struggle against organised crime, but it observes that the exhaustive list of permissible exceptions in paragraph 1 of article 5 (art. 5-1) of the Convention must be interpreted strictly.'

1165 K.-F. v. Germany, appl. no. 25629/94, 27 November 1997, §70.

1166 Bozano v. France, appl. no. 5/1985/91/138, 18 December 1986, §54.

1167 Bozano v. France, appl. no. 5/1985/91/138, 18 December 1986, §60.

1168 Öcalan v. Turkey, appl. no. 46221/99, 12 March 2003.

1169 Öcalan v. Turkey, appl. no. 46221/99, 12 March 2003, §88.
} 
In Giorgi Nikolaishvili v. Georgia, the ECtHR elaborated a bit more on the scope of the right to security. ${ }^{1170}$ First of all, the ECtHR argued that the expression 'liberty and security of person' must be read as a single right and that, consequently, 'security' should be understood in the context of 'liberty'. The protection of 'security' is concerned with guaranteeing an individual's personal liberty against arbitrary interference by a public authority. ${ }^{1171}$ This means that the 'security' clause reminds the national authorities of the mandatory obligation 'to follow the rule-oflaw safeguards and other rudimentary forms of legal protection when the deprivation of a person's liberty is at stake'.1172

The ECtHR then contended that the 'right to security of person' was understood by the authors of the ECHR to imply more than just an obligation to give legal protection to a person's physical liberty. What is at stake is both the physical liberty of individuals, as well as their personal security. The notion of 'security' then refers to the fact that national authorities are normally expected to act in good faith when depriving a person of his liberty. ${ }^{1173}$ This implies also that a person that has been deprived of his liberty should be able to resort to the available and legitimate remedies aimed at opposing the authorities' actions and preserving his liberty. ${ }^{1174}$

Lastly, the ECtHR connected the principle of legal certainty to 'the right to security' and reasoned that 'when a person's liberty is at stake, it is particularly important that the general principle of legal certainty is satisfied. It is essential that the statutory criminal law, as well as the authorities' formal decisions and actions, are accessible and unequivocal to such an extent that the person - if need be, with appropriate advice - is able to foresee, to a degree that is reasonable in the circumstances, the consequences which a given action may entail'. ${ }^{1175}$ Accordingly, an arrest under circumstances that undermine the principles of legal certainty can, in principle, lead to a breach of the right to security of person. ${ }^{1176}$

In this context, the right to security refers rather to the circumstances surrounding a person's deprivation of liberty, more precisely, circumstances that may imply arbitrariness on the authorities' part. In Giorgi Nikolaishvili v. Georgia, the

1170 Giorgi Nikolaishvili v. Georgia, appl. no. 37048/04, 13 January 2009.

1171 Kemal Güven v. Turkey, appl. no. 31847/96, 30 May 2000. See, also, Moskovets v. Russia, appl. no. 14370/03, 23 April 2009, §53; Kaboulov v. the Ukraine, appl. no. 41015/04, 19 November 2009, §130-132.

1172 Giorgi Nikolaishvili v. Georgia, appl. no. 37048/04, 13 January 2009, §52.

1173 Čonka v. Belgium, appl. no. 51564/99, 5 February 2002, §41 and 42; Bozano v. France, appl. no. 9990/82, 18 December 1986, §55.

1174 Bozano v. France, appl. no. 9990/82, 18 December 1986, §59-60; Shamayev and Others v. Georgia and Russia, appl. no. 36378/02, 12 April 2005, \$380.

1175 Gusinskiy v. Russia, appl. no. 70276/01, 19 May 2004, §62 and 68; Ladent v. Poland, appl. no. 11036/03, 18 March 2008, §53 and 56; Kawka v. Poland, appl. no. 25874/94, 9 January 2001, $\S 49$; Lukanov v. Bulgaria, appl. no. 21915/93, 20 March 1997, §44; Moskovets v. Russia, appl. no. 14370/03, 23 April 2009, §54.

1176 Öcalan v. Turkey [GC], appl. no. 46221/99, 12 May 2005, §85. 
applicant appeared voluntarily before the authorities to be interviewed as a witness in a murder case in which his brother was implicated. During the interrogation he was arrested and placed in police custody allegedly on account of his presumed involvement in firearms offences. This latter, however, only served as a formal basis for the detention. Neither the prosecution nor the judicial authorities denied the fact that, by detaining the applicant, their aim was to ensure the proper investigation of his brother's criminal case. So, whilst maintaining that the applicant's cooperation as a witness was necessary for the investigation into the unrelated murder case, the authorities were apparently misleading the applicant about their real interest in him.

The ECtHR considered that 'such opaque methods may not only undermine legal certainty and, consequently, as the present case suggests, instil a feeling of personal insecurity in individuals summoned as witnesses, but they may also generally risk undermining public respect for and confidence in the prosecution authorities'.1177

In such circumstances, as the ECtHR concluded, the applicant's arrest, even if formally consistent with the domestic law, was, nevertheless, contrary to Article 5, section 1 of the ECHR. The authorities' misleading methods (the prospect of detention being used to exert moral pressure) reveal that the deprivation of the applicant's liberty fell short of the main purpose of Article 5, section 1 of the ECHR, that is, to protect the individual from arbitrariness. The protection against arbitrariness hence necessarily entails states' obligation to safeguard persons from undue threats to their liberty and to their security.

This judgement was the first case in respect of which the ECtHR discussed the scope of the right to security in such detail. One may conclude that the right to security enlarges a suspect's rights during arrest and pre-trial detention. The ECtHR basically underlined the importance of legal certainty, and therewith, the prevention of arbitrariness within the framework of Article 5 of the ECHR. The right to security factually adds a positive obligation for states regarding the right to liberty, in the sense that states must actively protect people against attacks on their personal security while being arrested and detained. That obligation presupposes bona fide deprivation of liberty in strict conformity with domestic legislation. ${ }^{1178}$ Accordingly, if the real purpose for interferences with the right to liberty does not coincide with the legal provision on that which interference is based, Article 5 of the ECHR will be violated in respect of arbitrary infringement of the right to liberty, and especially, of the right to security. ${ }^{1179}$

1177 Giorgi Nikolaishvili v. Georgia, appl. no. 37048/04, 13 January 2009, §55 and further.

1178 Moskovets v. Russia, appl. no. 14370/03, 23 April 2009, §59-62.

1179 Engel and others v. The Netherlands, appl. no. 5100/71, 8 June 1976, §58: 'In proclaiming the 'right to liberty', paragraph 1 of Article 5 is contemplating individual liberty in its classic sense, that is to say the physical liberty of the person. Its aim is to ensure that no one should be dispossessed of this liberty in an arbitrary fashion'. 
In literature, positive obligations regarding the right to security are also considered to include an obligation for states to give guarantees against other encroachments on the physical security of persons and groups. For instance, states may be obliged to protect persons/groups against unnecessary threats to the physical integrity of spectators during police action or against incitement to action against a particular group of persons. ${ }^{1180}$

\subsection{Arrest period}

Article 5, section 1 under $\mathrm{c}$ of the ECHR prescribes that a person may lawfully be deprived of his liberty in the case of a lawful arrest or detention effected for the purpose of bringing him before the competent legal authority on reasonable suspicion of having committed an offence, or when it is reasonably considered necessary to prevent his committing an offence or fleeing after having done so. Case law demonstrates that several prerequisites must be fulfilled in order for a state to lawfully restrict a person's right to liberty within the context of criminal proceedings.

First and foremost, there must be an appropriate legal basis within the domestic legal system, which, moreover, complies with several qualitative requirements. This is even prescribed in the exordium of Article 5 of the ECHR, and it applies to all forms of deprivation of liberty mentioned in that Article.

Secondly, there must be a reasonable suspicion that the person in question has either committed a criminal offence, is in the middle of committing an offence, or is about to commit the offence. This requirement has been discussed in the preceding section and will therefore no further be elaborated on.

Thirdly, the purpose of an arrest and subsequent deprivation of liberty must be (1) to bring the suspect before the competent judicial authority, and/or (2) to prevent a suspect from committing (further) criminal offences, or (3) to prevent him from fleeing after having committed an offence.

As the ECtHR considers the right to liberty as one of the cornerstones of a democratic society, these requirements are narrowly interpreted and applied. ${ }^{1181}$ Case law on Article 5 of the ECHR is abundant. The following sections will go into the scope of the above-enumerated three requirements, starting with the scope of Article 5, section 1 under $\mathrm{c}$ of the ECHR and the reasons for deprivation of liberty under that Article.

1180 P. van Dijk, F. van Hoof, A. van Rijn and L. Zwaak (eds.), Theory and Practice of the European Convention on Human Rights, fourth edition, Intersentia Antwerpen-Oxford 2006, p. 457.

1181 See Ladent v. Poland, appl. no. 11036/03, 18 March 2008, §45. 


\subsubsection{The scope of and the reasons for deprivation of liberty}

\section{INTRODUCTION}

The scope of article 5, section 1 under c ECHR runs from the moment of arrest and comes to an end when the suspect, in pre-trial detention, is convicted or acquitted by a court of first instance. ${ }^{182}$ In order for deprivation of liberty to fall within the scope of Article 5, section 1 under $\mathrm{c}$ of the ECHR, the conduct giving rise to the deprivation of liberty must be alleged to fall within the scope of an offence already established by law. ${ }^{183}$

Article 5, section 1 under c of the ECHR comprises three alternative reasons, ${ }^{1184}$ in respect of which, someone may lawfully be arrested and detained prior to a conviction: (1) when there is 'a reasonable suspicion that a criminal offence has been committed or is in the middle of being committed', (2) when 'it is reasonably considered necessary to prevent his [the suspect] committing an offence', or (3) to prevent a suspect 'of fleeing after having done so [committing an offence]'. The purpose of arrest and consequent pre-trial detention must always be - for all of the above-mentioned reasons - to bring the suspect before the competent legal authority. Actual compliance with this mandatory purpose should be seen independently of its achievement in practice

\section{ARREST AND DETENTION BASED ON A REASONABLE SUSPICION}

To lawfully deprive a suspect of his liberty pursuant to Article 5, section 1 under c and section 3 of the ECHR there must be a reasonable suspicion that the suspect has committed an offence, is in the middle of committing an offence, or is about to commit an offence. ${ }^{185}$ The arresting officer does not need to know for sure whether

1182 The wording of Article 5, section 1 under $\mathrm{c}$ of the ECHR clearly indicates that this subsection only applies in the context of criminal proceedings. Wloch v. Poland, appl. no. 27785/95, 19 October 2000, §109: 'Article 5, paragraph 1.c, requires that the facts invoked can be reasonably considered as falling under one of the sections describing criminal behaviour in the criminal code. Thus, there could clearly not be a reasonable suspicion if the acts invoked against the detained person did not constitute a crime at time when they occurred.'

1183 Decision as to the admissibility in Lukanov v. Bulgaria, appl. no. 21915/93, 20 March 1997. Note that the ECtHR attaches an autonomous meaning to the notion of 'criminal charge' and hence to what behaviour falls within the sphere of criminal law and what conduct does not. Öztürk $v$. Germany, appl. no. 8544/79, 21 February 1984, §50 and further.

1184 P. van Dijk, F. van Hoof, A. van Rijn and L. Zwaak (eds.), Theory and Practice of the European Convention on Human Rights, fourth edition, Intersentia Antwerpen-Oxford 2006, p. 471.

1185 See, also, Guideline 7 of the Guidelines of the Committee of Ministers of the Council of Europe on Human Rights and the Fight against Terrorism (2002) regarding arrest and police custody. This Guideline explicitly prescribes that a person suspected of terrorist activities may only be arrested if there are reasonable suspicions. 
the suspect has indeed committed the offence, ${ }^{186}$ neither does he have to know the precise nature of the offence. However, to sustain a 'reasonable suspicion', domestic authorities are obliged to prove a link between the suspect, a (terrorist) offence, and objective facts or information leading to the suspicion. How the ECtHR interprets the concept of 'reasonable suspicion' has been discussed extensively in the previous section, this issue will therefore not be discussed further at this point.

\section{ARREST AND DETENTION TO PREVENT A SUSPECT FROM COMMITTING AN OFFENCE}

The second reason for arrest and detention is to prevent a suspect from committing an offence. Basically, this comes down to forms of administrative or preventive detention. The travaux préparatoires to the ECHR state that 'it may (...) be necessary in certain circumstances to arrest an individual in order to prevent his committing a crime, even if the facts which show his intention to commit the crime do not of themselves constitute a criminal offence'. ${ }^{1187}$ When exactly does the ECtHR consider it necessary and justified to prevent a suspect from committing a crime?

First of all, it is important to note that there must be a suspect. Hence, internment without a reasonable suspicion to prevent terrorism is per se prohibited pursuant to Article 5 of the ECHR. In Ciulla v. Italy, ${ }^{1188}$ the applicant was prosecuted for alleged involvement in Mafia related criminal offences. He was subjected to 'special supervision', including a prohibition to reside in certain areas. ${ }^{1189}$ During criminal proceedings, he was forced to stay in one specific place of residence for 16 days. ${ }^{1190}$ As the applicant did not appear for trial, the public prosecutor filed a request for compulsory residence, and eventually also a request for detention on remand until the judgement became final. ${ }^{1191}$

1186 O'Hara v. the United Kingdom, appl. no. 73555/97, 16 October 2001, $\$ 36$.

1187 P. van Dijk, F. van Hoof, A. van Rijn and L. Zwaak (eds.), Theory and Practice of the European Convention on Human Rights, fourth edition, Intersentia Antwerpen-Oxford 2006, p. 471; Council of Europe, Collected Edition of the 'Traveaux Préparatoires' of the European Convention on Human Rights, Vol. IV, Strasbourg, 1977, p. 260.

1188 Ciulla v. Italy, appl. no. 11152/84, 22 February 1989.

1189 Ciulla v. Italy, appl. no. 11152/84, 22 February 1989, §15-18. Special supervision is based on a law that provides for preventive measures against 'persons presenting a danger to safety and public morals'. If the application for such a measure is for an order for compulsory residence in a specified locality, the presiding judge during the procedure may, where there are 'particular serious grounds', make a reasoned order that a person be held in prison until the preventive measure becomes final. At the same time as it makes the order for compulsory residence in a specified locality, the court orders that the person concerned be taken by the police from the prison in which he is being held to the place of compulsory residence, and handed over to the local police authorities. These provisions are drafted primarily in order to effectively counter Mafia type associations.

1190 Ciulla v. Italy, appl. no. 11152/84, 22 February 1989, §10-18.

1191 In the Italian government's view, the detention complained of was justified under Article 5, section 1 under $\mathrm{c}$ of the ECHR as there had been a 'reasonable suspicion' that the applicant had 
The ECtHR considered these preventive measures to be in violation of Article 5 of the ECHR. This was primarily due to the fact that neither the prosecution nor the Judiciary mentioned any concrete and specific offences that the applicant had to be prevented from committing. The domestic authorities relied on the past 'serious offences' that had led to a 'heavy sentence' passed on him by the Milan District Court and on 'circumstances' that indicated that he was a 'danger to society'.1192

So, to lawfully detain a suspect to prevent him from committing a crime, the authorities need to indicate which specific criminal offence the suspect is allegedly about to commit on the basis of new and specific information. The fact that a suspect is considered to pose a danger to society is insufficient to justify preventive deprivation of liberty pursuant to Article 5, section 1 under c of the ECHR. ${ }^{1193}$ Past offences, as severe as they may be, cannot, as such, lead to lawful preventive detention in the ECtHR's view.

In Eriksen v. Norway ${ }^{1194}$ the ECtHR came to a different conclusion regarding the lawfulness of 'preventive detention'. The applicant was convicted for threatening behaviour and inflicting bodily harm, and he was therefore sentenced to five years imprisonment. In an expert psychiatric opinion obtained at that time, he was declared mentally ill and he spent the period of five years in mental hospitals. ${ }^{195}$ Upon his release, he assaulted his father, for which he was placed under 'judicial observation'. This measure was imposed on the basis of an expert psychiatric opinion obtained at that time, which concluded that he was not mentally ill, but had an underdeveloped and permanently impaired mental capacity. Furthermore, this psychiatric opinion stated that there was a clear risk of his committing further criminal offences. ${ }^{1196}$ Until the moment the complaint was filed in Strasbourg, the applicant continued to be deprived of his liberty and switched from mental hospitals, to detention on remand, to supervised living at his parents' house.

'committed an offence', and it had also been 'reasonably considered necessary to prevent his committing one'. Thus, the fact that Mr. Ciulla supposedly belonged to a Mafia organisation was, in the government's opinion, sufficient to demonstrate a reasonable suspicion of the risk of recidivism. Ciulla v. Italy, appl. no. 11152/84, 22 February 1989, §37.

1192 Ciulla v. Italy, appl. no. 11152/84, 22 February 1989, §40.

1193 Guzzardi v. Italy, appl. no. 7367/76, 6 November 1980. This case makes - as in Ciulla v. Italy clear that preventive detention as part of a campaign to combat organised crime cannot be justified under Article 5, section 1 under $\mathrm{c}$ of the ECHR. In $\$ 102$, the ECtHR declared: 'In any event, the phrase under examination is not adapted to a policy of general prevention directed against an individual or a category of individuals who, like Mafiosi, present a danger on account of their continuing propensity to crime; it does no more than afford the Contracting States a means of preventing a concrete and specific offence. This can be seen both from the use of the singular ('an offence', 'celle-ci' in the French text) and from the object of Article 5, namely to ensure that no one should be dispossessed of his liberty in an arbitrary fashion'.

1194 Eriksen v. Norway, appl. no. 102/1995/608/696, 27 May 1997.

1195 Eriksen v. Norway, appl. no. 102/1995/608/696, 27 May 1997, §7.

1196 Eriksen v. Norway, appl. no. 102/1995/608/696, 27 May 1997, §9-10. 
The applicant's complaint concerned a period of preventive detention in which, as he alleged, he had been unlawfully detained with the only purpose for the authorities to gain time to collect the necessary documents for a request to extend the detention in a psychiatric hospital. ${ }^{1197}$ The government referred to Article 5, section 1 under a and under $\mathrm{c}$ of the ECHR to justify the 'bridging detention' between the soon-toexpire security detention ${ }^{1198}$ and the to- be-prolonged security detention. The ECtHR agreed with the government and considered this 'bridging detention' to be lawful. ${ }^{1199}$

With respect to Article 5, section 1 under c of the ECHR, the ECtHR concluded this to be exceptionally ${ }^{1200}$ applicable too, because there were substantial grounds for believing that the applicant would commit similar offences in the future. So, in the case of a reasonable suspicion that a yet convicted suspect might commit a further similar offence as the one for which he is convicted, deprivation of liberty on the basis of Article 5, section 1 under c of the ECHR, is allowed. The ECtHR contended that 'In a situation such as that in the present case, the authorities were entitled, having regard to the applicant's impaired mental state and history as well as to his established and foreseeable propensity for violence, to detain the applicant (...) Such a 'bridging' detention was of a short duration, was imposed in order to bring the applicant before a judicial authority and was made necessary by the need to obtain updated medical reports on the applicant's mental health as well as by the serious difficulties facing the authorities in arranging preventive supervision outside prison due to the applicant's aggressive conduct and his objection to close supervision.' 1201

In this case there was considerably more information used to justify the preventive detention than in Ciulla v. Italy. The information used for the security detention included a specific expert opinion substantiating the risk of recidivism upon release. That opinion stated, moreover, which specific offence the suspect would most probably commit. In M. v. Germany, the ECtHR underlined, in this respect, that Article 5, section 1 under $\mathrm{c}$ of the ECHR does no more than afford a means of preventing a concrete and specific offence. This can be seen both from the use of the singular ('an offence'), and from the object of Article 5 of the ECHR, namely, to ensure that no one should be dispossessed of his liberty in an arbitrary fashion. ${ }^{1202}$

Eriksen v. Norway, appl. no. 102/1995/608/696, 27 May 1997, §35-40.

Eriksen v. Norway, appl. no. 102/1995/608/696, 27 May 1997, §53 and 77.

Eriksen v. Norway, appl. no. 102/1995/608/696, 27 May 1997, §85.

Eriksen v. Norway, appl. no. 102/1995/608/696, 27 May 1997, §86. The ECtHR explicitly emphasised the exceptional character of the case, so the implications of this judgement should not be overrated.

Eriksen v. Norway, appl. no. 102/1995/608/696, 27 May 1997, §86-87.

M. v. Germany, appl. no. 19359/04, 17 December 2009, $\S 89$ and 102. In this judgement, the ECtHR concluded that the applicant's preventive detention could not be based on Article 5, section 1 under c of the ECHR because ' (...) the potential further offences are not, however, sufficiently concrete and specific, as required by the Court's case law as regards, in particular, 
In the case of Lawless $v$. Ireland, the applicant did not have any previous convictions for (terrorist) offences prior to his preventive detention in a military camp. ${ }^{1203}$ The applicant did, however, admit that he had belonged to the IRA, but he claimed to be no longer a member at the time of arrest. ${ }^{1204}$ The government, nevertheless, detained the applicant in a military camp for 16 days - on suspicion of being engaged in activities prejudicial to the preservation of public peace and order or to the security of the state -and subsequently released him without charge. ${ }^{1205}$

The ECtHR considered the applicant's detention, even though it was based on domestic legislation, to be contrary to the provisions of Article 5, section 1 under $\mathrm{c}$ and section 3 of the ECHR. ${ }^{1206}$ However, Ireland had declared a state of emergency pursuant to Article 15 of the ECHR, therewith derogating from Article 5 of the ECHR. The ECtHR therefore refrained from providing, in general, rules on lawful preventive detention, and primarily went into the question of whether Ireland had lawfully declared a state of emergency. The ECtHR did, however, underline that Ireland had provided for sufficient safeguards to prevent the arbitrary deprivation of liberty: detention commissions periodically reviewed the preventive detention, parliamentary supervision controlled the detention, and the act providing for the preventive detention could be annulled at any time by Parliament. Lastly, administratively detained suspects were set free when they announced they would refrain from behaviour contrary to the act or normal laws. In light of these safeguards, the ECtHR concluded that the detention without trial was a measure strictly required by the exigencies of the situation, within the meaning of Article 15 of the ECHR. ${ }^{1207}$ Hence, only because Ireland had declared a state of emergency pursuant to Article 15 of the ECHR, was preventive detention considered justified.

After having decided that the regime in abstracto was in compliance with the ECHR, the application in the specific case of the applicant follows. Basically, the ECtHR examined whether there was a justified suspicion of the applicant being

the place and time of their commission and their victims (...)'. See, Haidn v. Germany, appl. no. 6587/04, 13 January 2011, §76 and 90; Schummer v. Germany, appl. nos. 27360/04 and 42225/07, 13 January 2011, §56; decision as to the admissibility in Loncaric v. Slovenia, appl. no. 30887/96, 4 September 1996. Another issue that played a role in the aforementioned two German judgements is that pursuant to Article 5, section 3 of the ECHR everyone detained in accordance with the provisions of section 1 under $\mathrm{c}$ of that Article must be brought promptly before a judge and tried within a reasonable time, or released pending trial. The applicants' detention for preventive purposes in these two judgements was not, however, decided in order for them to be brought promptly before a judge and tried for offences - potential ones - and was, thus, not pre-trial detention, as permitted by that provision. See in this respect also, the decision as to the admissibility in Nicol and Selvanayagam v. the United Kingdom, appl. no. 32213/96, 11 January 2001.

1203 Lawless v. Ireland, appl. no. 332/57, 1 July 1961.

1204 Lawless v. Ireland, appl. no. 332/57, 1 July 1961, §4.

1205 Lawless v. Ireland, appl. no. 332/57, 1 July 1961, §9.

1206 Lawless v. Ireland, appl. no. 332/57, 1 July 1961, \$15.

1207 Lawless v. Ireland, appl. no. 332/57, 1 July 1961, §38. 
involved in IRA related offences. This suspicion was based on his association with persons known to be active members of the IRA, his conviction for carrying incriminating documents and 'other circumstances'. ${ }^{1208}$ After the applicant had given a verbal undertaking before the Detention Commission not to 'take part in any activities that are illegal under the Offences against the State Acts 1939 and 1940', he was immediately set free. The ECtHR deemed these specific circumstances sufficient, and concluded that no breach of Article 5 of the ECHR had taken place.

In sum, preventive detention to keep a suspect from committing future offences requires a clear law on which such detention can be based. ${ }^{1209}$ Secondly, the competent state authorities must specify which offences the suspect will allegedly commit upon release. This assumption must, thirdly, be based on 'substantial grounds'. It must be underlined that there will only be very few cases falling within the category of 'detention being reasonably considered necessary to prevent a suspect from committing an offence'. General preventive detention is not allowed. In M. v. Germany, the ECtHR argued that 'that ground of detention is not adapted to a policy of general prevention directed against an individual or a category of individuals who present a danger on account of their continuing propensity to crime. ${ }^{1210}$ Evidence of intention on the part of the suspect to commit a concrete (future) offence must be demonstrated. However, in most European countries, acts preparatory to the actual commission of a (terrorist) crime are themselves categorised as criminal offences. Such evidence would therefore usually be sufficient to lawfully arrest and detain a suspect within the first category of Article 5, section 1 under $\mathrm{c}$ of the ECHR: 'arrest and detention upon reasonable suspicion of having committed an offence'. Similarly, any arrest or pre-trial detention falling within the third reason, 'to prevent the detainee fleeing after having committed an offence', will also fall within the first alternative of Article 5, section 1 under $\mathrm{c}$ of the ECHR. Strasbourg case law justifies this assumption: almost all judgements regarding Article 5, section 1 under $\mathrm{c}$ of the ECHR concern arrest and detention upon a reasonable suspicion of having committed an offence.

Therefore, I will at this point elaborate no further on this third reason for arrest and detention. In the next section, regarding justifications for continued deprivation of liberty, flight risk as a basis for pre-trial detention, will be discussed.

\footnotetext{
1208 Lawless v. Ireland, appl. no. 332/57, 1 July 1961, §38.

1209 Qualitative requirements for domestic legislation have to be adhered to. This will often be difficult in provisions making free way for preventive/administrative detention.

1210 M. v. Germany, appl. no. 19359/04, 17 December 2009, §89; Haidn v. Germany, appl. no. 6587/04, 13 January 2011, §76; Schummer v. Germany, appl. nos. 27360/04 and 42225/07, 13 January 2011, §56.
} 
Article 5, section 1 under c of the ECHR explicitly prescribes that arrest and deprivation of liberty under this section must be effected for the purpose of bringing the arrested person before the competent legal authority. ${ }^{1211}$ This means that all of the above-discussed reasons for arrest and detention are covered by this mandatory purpose. The notion of 'competent legal authority' means a judge or other officer authorised by law to exercise judicial power. ${ }^{1212}$ The scope of this notion will further be discussed in section 12, as it also (primarily) plays a role of importance with respect to Article 5, section 3 of the ECHR. In this respect, it must be underlined again that Article 5, section 1 under $\mathrm{c}$ of the ECHR has to be read in conjunction with section 3 of the same Article.

The fact that a suspect is not promptly brought before the competent legal authority after arrest and deprivation of liberty does not necessarily make the arrest and detention unlawful. In K.-F. v. Germany, the applicant and his wife had been apprehended on suspicion of fraud and had been detained for about one day. ${ }^{1213}$ They were not brought before a judicial authority and they were released without charge. ${ }^{1214}$

After having established that the government had supplied sufficient facts and information to furnish a reasonable suspicion, ${ }^{1215}$ the ECtHR argued that '(...) the fact that the applicant was neither charged nor brought before a court does not necessarily mean that the purpose of his detention was not in accordance with Article 5(1c). The existence of such a purpose must be considered independently of its achievement (...)'. ${ }^{1216}$

Hence, the purpose of an arrest that is based on an initial reasonable suspicion, must be to bring that suspect before a legal authority. However, during the ensuing

1211 Lawless v. Ireland, appl. no. 332/57, 1 July 1961, \$9.

1212 Ireland v. the United Kingdom, appl. no. 5310/71, 18 January 1978, §199; Lawless v. the United Kingdom, appl. no. 332/57, 1 July 1961, §14; Schiesser v. Switzerland, appl. no. 7710/76, 4 December 1979, $\$ 30$.

1213 K.-F. v. Germany, appl. no. 25629/94, 27 November 1997, §13-17.

1214 K.-F. v. Germany, appl. no. 25629/94, 27 November 1997, §20.

1215 In the present case Mrs S., the landlady, had informed the police that Mr and Mrs K.-F. had rented her flat without intending to perform their obligations as tenants, and were about to make off without paying what they owed. After initial inquiries had revealed that Mr and Mrs K.-F.'s address was merely a Post Office box and that Mr K.-F. had previously been under investigation for fraud, the police arrested the couple and took them to the police station so that their identities could be checked. In a report, the police stated that they strongly suspected Mr and Mrs K.-F. of rent fraud, and that there was a risk that they would abscond. Having regard to those circumstances, the ECtHR considered the reasoning of the Koblenz Court of Appeal, which, in its judgement, held that the police officers' suspicions of rent fraud and the danger that Mr K.-F. would abscond, were justified. K.-F. v. Germany, appl. no. 25629/94, 27 November 1997, §58-60.

1216 K.-F. v. Germany, appl. no. 25629/94, 27 November 1997, §61. 
deprivation of liberty, interrogations and the use of other means of investigation can lead to the conclusion that the evidence gathered is insufficient to sustain a formal charge. ${ }^{1217}$ Under such circumstances, bringing a suspect before a judicial authority becomes futile.

In K.-F. v. Germany, there was nothing to suggest that the police inquiries were not conducted in good faith or that the applicant's arrest and detention, which were decided after consultation of the public prosecutor's office, were effected for a purpose other than to complete the inquiries by checking the identity of the applicants and investigating the allegations made against them. To that end, the applicants were questioned. Accordingly, the ECtHR concluded that: '(...) it may legitimately be supposed that, had it been possible to confirm the suspicions of rent fraud, the applicant would have been brought before the relevant judicial authority.' 1218

Arrest and initial deprivation of liberty is intended to further a criminal investigation by way of confirming or dispelling the concrete suspicions. If an initial suspicion is dispelled directly after the arrest, there is, hence, no need to bring the suspect before the competent legal authority. However, when the investigation confirms the preliminary suspicion against a suspect, he must be brought before a legal authority.

In Brogan and others v. the UK, the ECtHR also argued that the fact that the applicants were neither charged nor brought before a judicial authority did not necessarily imply that the purpose of their deprivation of liberty was not in accordance with Article 5, section 1 under c of the ECHR. The central question in these matters is whether the police would have brought the suspect before the competent legal authority, had it been possible, in view of the evidence. ${ }^{1219}$ As long as - at the time of arrest and detention - the investigative authorities' intention was to bring the suspect before the competent legal authority, it is immaterial whether or not, in the event, the suspect is actually brought before such a authority or even charged.

All of this does not change states' obligation to bring everyone arrested or detained promptly before a judge or other officer authorised by law to exercise judicial power, i.e. within a maximum period of four days. This issue will further be discussed below.

In sum, there is a close connection between the required reasonableness of the suspicion leading to an arrest and compliance with the requirement that arrest must serve to bring a suspect before the competent legal authority. When there is a reasonable suspicion, it is generally assumed that arrest and deprivation of liberty

1217 See, also, O'Hara v. the UK, appl. no. 73555/97, 16 October 2001, $\$ 36$.

1218 K.-F. v. Germany, appl. no. 25629/94, 27 November 1997, §62.

1219 Brogan and Others v. the United Kingdom, appl. no. 10/1987/133/184-187, 29 November 1988, $\S 53$. 
served to bring the suspect before the competent legal authority - provided that the investigative authorities acted in good faith. This has, in part, to do with the indissoluble link between sections 1c and 3 of Article 5 of the ECHR; the former authorising deprivation of liberty, but the latter requiring that, where this ground is used for such action, the person concerned must be brought 'before a judge or other officer authorised by law to exercise judicial power and shall be entitled to trial within a reasonable time or to release pending trial'.

\subsubsection{A procedure prescribed by law and lawful: A tripartite structure}

Pursuant to the exordium of Article 5 of the ECHR, deprivation of liberty must take place 'in accordance with a procedure prescribed by law'. This prerequisite is generally considered together with the precept that any infringement on a suspect's liberty must be 'lawful', as prescribed in Article 5, section 1 under c of the ECHR. ${ }^{1220}$ These two obligations are interpreted and applied together, and lead to a tripartite structure to examine whether deprivation of liberty has been imposed lawful, in the broad sense of the word. ${ }^{1221}$ This structure will now be discussed.

Firstly, any deprivation of liberty must obviously be imposed in conformity with the substantive and procedural domestic law system. ${ }^{122}$ Whether domestic law has been complied with may be a matter of determining if an essential procedure has been followed, or of assessing whether there is, in fact, a legal provision covering the action taken at all. The latter may be a matter of construing the scope of a particular provision, but it may also be a question of establishing that the sort of factual situation to which such a provision applied actually existed. Even though the ECtHR does examine whether the national authorities acted in conformity with domestic law, it normally refrains from extensively interpreting the domestic

1220 Every one of the exhaustively enumerated instances in the case of which deprivation of liberty is allowed, pursuant to Article 5, section 1 of the ECHR, speaks of lawful deprivation of liberty. This is a requirement which comes in addition to the prerequisite that interferences with persons' liberty must, at all times, be in accordance with a procedure prescribed by law. See, in this respect also, the Guidelines of the Committee of Ministers of the Council of Europe on Human Rights and the Fight against Terrorism 2002. Guideline 3 obliges all Member States to only take measures to combat terrorism that are lawful.

1221 In cases concerning Article 5, section 1 under $\mathrm{c}$ of the ECHR, the ECtHR refers both to 'a procedure prescribed by law' and to the requirement that deprivation of liberty must be 'lawful'. Moskovets v. Russia, appl. no. 14370/03, 23 April 2009, §53; Ladent v. Poland, appl. no. 11036/03, 18 March 2008, §47-48.

1222 Although accepting that it is primarily for the state authorities - and especially the domestic courts - to interpret and apply domestic law, the ECtHR reserves the power to review whether that law has, in fact, been complied with. In some instances it has reached a different conclusion from that arrived at by those authorities. See, for example, Kruslin v. France, appl. no. 7/1989/167/223, 24 April 1990, §29. 
legislation itself. ${ }^{1223}$ Examination is, though, very strict in the sense that even minor deviations of domestic procedural rules can lead to a violation of Article 5 of the ECHR. ${ }^{1224}$

Specifically with respect to detention orders, the ECtHR has clarified, particularly in its more recent case law, that not every fault discovered in a detention order renders the underlying detention, as such, unlawful. ${ }^{1225}$ A period of detention will, in principle, be lawful if carried out pursuant to a court order. A subsequent finding that the domestic court erred under domestic law in making the order, will not necessarily, retrospectively affect the validity of the intervening period of detention. For the assessment of compliance with Article 5, section 1 under $\mathrm{c}$ of the ECHR in this matter, the ECtHR distinguishes between ex facie invalid detention orders - for example, given by a court in excess of jurisdiction, or where the interested party did not have proper notice of the hearing - and detention orders that are prima facie valid and effective, unless and until they have been overturned by a higher court (due to errors of fact or law). ${ }^{1226}$

In light of these considerations, the ECtHR considered, for instance in Khudoyorov v. Russia, that certain flaws in the procedure on appeal do not, in themselves, mean that the detention was unlawful. ${ }^{1227}$ In issuing the material detention order, the competent domestic (district) court did not act in bad faith and did not neglect to attempt to apply the relevant legislation correctly. ${ }^{1228}$ However, in Lloyd v. the

1223 Bouamar v. Belgium, appl. no. 9106/80, 29 February 1988, §49; Wloch v. Poland, appl. no. $27785 / 95,19$ October $2000, \S 110$.

1224 Wassink v. The Netherlands, appl. no. 12535/86, 27 September 1990, \$27, where the ECtHR argued that 'On the other hand, the fact that no registrar was present at the hearing infringed Article 72 of Regulation I made in pursuance of the Judiciary (Organisation) Act and this was also the opinion of the Attorney General. Consequently, there was in this respect a failure to comply with a 'procedure prescribed by law', which amounted to a breach of Article $5 \S 1$ of the Convention'.

1225 Mooren v. Germany [GC], appl. no. 11364/03, 9 July 2009, §74. See, also, Douiyeb v. the Netherlands, appl. no. 31464/96, 4t August 1999, §45; Minjat v. Switzerland, appl. no. 38223/97, 28 October 2003, §41; Hadi v. Croatia, appl. no. 42998/08, 1 July 2010, §24.

1226 Khudoyorov v. Russia, appl. no. 6847/02, 8 November 2005, §128-129. See, also, Benham v. the United Kingdom, appl. no. 19380/92, 10 June 1996, §42-48; Lloyd and Others v. the United Kingdom, appl. nos. 29798/96, 30395/96, 34327/96, 34341/96, 35445/97 36267/97, 36367/97, 37551/97, 37706/97, 38261/97, 39378/98, 41590/98, 41593/98, 42040/98, 42097/98, 45420/99, 45844/99, 46326/99, 47144/99, 53062/99, 53111/99, 54969/00, 54973/00, 54997/00, 55046/00, $55068 / 00,55071 / 00,56109 / 00,56231 / 00,56232 / 00,56233 / 00,56429 / 00,56441 / 00,2460 / 03$, 2482/03, 2483/03, 2484/03 and 2490/03, 1 March 2005, §108, 113 and 116; decision as to the admissibility in Gaidjurgis v. Lithuania, appl. no. 49098/00, 16 January 2001; Jéčius v. Lithuania, appl. no. 34578/97, 31 July 2000, §56, 65-70.

1227 See, also, decision as to the admissibility in Gaidjurgis v. Lithuania, appl. no. 49098/00, 16 January 2001; decision as to the admissibility in Kamantauskas v. Lithuania, appl. no. 45012/98, 29 February 2000.

1228 Khudoyorov v. Russia, appl. no. 6847/02, 8 November 2005, §131-132. 
United Kingdom, the ECtHR found a violation of Article 5, section 1 under c of the ECHR due to the fact that the competent state authorities failed to ensure that an applicant had proper notice of a hearing. This necessarily prevented that applicant from making any representations at, or in respect of, the hearing, including on why the warrant should not be issued, whether in his absence or otherwise, and any change in circumstances since the initial hearing. ${ }^{1229}$

In Mooren v. Germany, the ECtHR specified that a detention order must be considered as ex facie invalid if the flaw in the order amounted to a 'gross and obvious irregularity' in the exceptional sense. ${ }^{1230}$ Accordingly, unless they constitute a gross and obvious irregularity, defects in a detention order may be remedied by the domestic appeal courts in the course of judicial review proceedings. ${ }^{1231}$

In this case, the Düsseldorf Court of Appeal found that the detention order issued by the competent District Court failed to comply with the formal requirements of domestic law, as it did not describe in sufficient detail the facts and evidence establishing the grounds for the strong suspicion that the applicant was guilty of tax evasion, or for the arrest. The detention order thus suffered from a formal defect. Did the ECtHR consider the flaw in the order against the applicant to amount to a 'gross and obvious irregularity' so as to render the underlying period of his detention unlawful? In answering this question, the ECtHR considered all of the circumstances of the case, including, in particular, the assessment made by the domestic courts. ${ }^{1232}$

The ECtHR considered that 'even though the detention order should have been based on more detailed facts according to the provisions of domestic law, the District Court still specified the charges against the applicant. In doing so, it listed the names of the firms that had paid the commission which the applicant had allegedly failed to declare to the tax authorities. It was moreover, clear that the suspicions against the applicant were based on the business records which had been seized at the applicant's home.' In light of these considerations, Article 5, section 1 under $\mathrm{c}$ of the ECHR had not been violated on this account.

1229 Lloyd and Others $v$. the United Kingdom, appl. nos. 29798/96, 30395/96, 34327/96, 34341/96, 35445/97 36267/97, 36367/97, 37551/97, 37706/97, 38261/97, 39378/98, 41590/98, 41593/98, 42040/98, 42097/98, 45420/99, 45844/99, 46326/99, 47144/99, 53062/99, 53111/99, 54969/00, $54973 / 00,54997 / 00,55046 / 00,55068 / 00,55071 / 00,56109 / 00,56231 / 00,56232 / 00,56233 / 00$, 56429/00, 56441/00, 2460/03, 2482/03, 2483/03, 2484/03 and 2490/03, 1 March 2005, §116-120.

1230 Mooren v. Germany [GC], appl. no. 11364/03, 9 July 2009, §75; Garabayev v. Russia, appl. no. 38411/02, 7 June 2007, §89; Liu v. Russia, appl. no. 42086/05, 6 December 2007, §81; Marturana v. Italy, appl. no. 63154/00, 4 March 2008, §78-79; Hadi v. Croatia, appl. no. 42998/08, 1 July $2010, \S 28$.

1231 Mooren v. Germany [GC], appl. no. 11364/03, 9 July 2009, §73-76.

1232 See, also, Hadi v. Croatia, appl. no. 42998/08, 1 July 2010, §29. 
With respect to compliance with substantive rules, the ECtHR deems itself empowered to examine claims as well. ${ }^{1233}$ For example, in Steel and Others $v$. the United Kingdom ${ }^{1234}$, the ECtHR scrutinised compliance with the substantive legal basis for a temporary deprivation of liberty. Several applicants in this case had been arrested and detained on remand for 'breach of the peace' due to a protest during which they handed out leaflets and were holding up banners saying 'Work for peace and not war'. ${ }^{1235}$ After approximately seven hours of detention, they were released without being charged. The question in this case was whether the conduct of the aforementioned applicants could be labelled as 'offence' i.e. as 'breach of the peace'. Despite the fact that the ECtHR underlined that it is, in the first place, for the national authorities, notably the courts, to interpret and apply domestic law, it considers itself obliged (and authorised) to exercise a power of review in this matter. ${ }^{1236}$

This is important as it implies that the ECtHR does not always refrain from interpreting national substantive legislation as such and testing its scope in various ways on compliance with the ECHR, even under Article 5 of the ECHR. It is, hence, all but hypothetical that Article 83a of the DCC will be examined, concerning its substantive merits, on compatibility with Article 5 of the ECHR as such, if confronted with deprivation of liberty on suspicion of a terrorist offence.

To scrutinise whether, in the above-mentioned case, the applicants indeed committed a criminal offence pursuant to the United Kingdom's legislation, the ECtHR examined: (1) the circumstances which led the authorities to arrest the applicants for 'breach of the peace', and (2) whether these specific circumstances could have led the police to consider the substantive requirements for this offence to be fulfilled.

The ECtHR reached a different conclusion than the United Kingdom government in this respect: it saw no reason - on the basis of the circumstances of the case - to regard the applicants' protest as other than entirely peaceful. There was no indication in the evidence adduced by the government that the applicants 'significantly obstructed or attempted to obstruct those attending the conference, or took any other action likely to provoke these others to violence'. Therefore, there was nothing in their behaviour that could have justified the police in fearing that a breach of the peace was likely to be caused. This led the ECtHR to conclude that Article 5, section 1 under $\mathrm{c}$ of the ECHR had been violated. ${ }^{1237}$

\footnotetext{
1233 Ladent v. Poland, appl. no. 11036/03, 18 March 2008, §47.

1234 Steel and Others $v$. the United Kingdom, appl. no. 67/1997/851/1058, 23 September 1998.

1235 Steel and Others $v$. the United Kingdom, appl. no. 67/1997/851/1058, 23 September 1998, \$22-26.

1236 Steel and Others v. the United Kingdom, appl. no. 67/1997/851/1058, 23 September 1998, \$56.

1237 Steel and Others $v$. the United Kingdom, appl. no. 67/1997/851/1058, 23 September 1998, §64 and 65.
} 
The second step of the tripartite structure concerns an examination of domestic legislation on compliance with qualitative requirements, pursuant to the general obligation of adhering to the rule of law. ${ }^{1238}$ Domestic legislation regarding pre-trial detention must be particularly clear, precise, foreseeable and accessible. ${ }^{1239}$ Failure to satisfy these prerequisites may be seen as an order from the ECtHR to (re)shape domestic legislation in such a way as to limit the scope for arbitrary deprivation of liberty as far as possible. ${ }^{1240}$

For instance, the accessibility requirement is not met if a deprivation of liberty is based on a legal provision that was secret or unpublished. This requirement will also apply to subsidiary rules adopted in the practical enforcement of a law. If such subsidiary rules are not widely available, the ECtHR might find a violation of Article 5 of the ECHR. ${ }^{1241}$

In this respect, it is interesting to note the overlap that the lawfulness requirement has with Article 7 of the ECHR, guaranteeing the principle of legality. ${ }^{1242}$ Vague language in criminal procedural and substantive law provisions can result in a violation of Article 7 of the ECHR, as well as in a violation of Article 5 of the ECHR. In Jecius v. Lithuania, the ECtHR concluded that any provision which is as vague as to cause confusion amongst the competent authorities with regard to its interpretation must be per se incompatible with the requirements of lawfulness. ${ }^{1243}$

1238 Dougoz v. Greece, appl. no. 40907/98, 6 March 2001, §55. See, also, Huvig v. France, appl. no. 11105/84, 24 April 1990, §34; Mooren v. Germany [GC], appl. no. 11364/03, 9 July 2009, §72 and 76.

1239 Malone v. the United Kingdom, appl. no. 8691/79, 2 August 1984, §66, where the ECtHR underlined that 'Firstly, the law must be adequately accessible: the citizen must be able to have an indication that is adequate in the circumstances of the legal rules applicable to a given case. Secondly, a norm cannot be regarded as 'law' unless it is formulated with sufficient precision to enable the citizen to regulate his conduct: he must be able - if need be with appropriate advice to foresee to a degree that is reasonable in the circumstances, the consequences which a given action may entail'. See, also, Laumont v. France, appl. no. 43626/98, 8 November 2001, §45; Kawka v. Poland, appl. no. 25874/94, 9 January 2001, $\$ 48$ and 49, where the ECtHR stressed '(...) that where deprivation of liberty is concerned, it is particularly important that the general principle of legal certainty is satisfied. It is therefore essential that the conditions for deprivation of liberty under domestic law should be clearly defined, and that the law itself be foreseeable in its application, so that it meets the standard of 'lawfulness' set by the Convention, a standard which requires that all law should be sufficiently precise to allow the person - if needed, to obtain the appropriate advice - to foresee, to a degree that is reasonable in the circumstances, the consequences which a given action may entail.'

1240 Baranowski v. Poland, appl. no. 28358/95, 28 March 2000.

1241 Amuur v. France, appl. no. 17/1995/523/609, 25 June 1996, §53-54. The ECtHR considers an unpublished circular - the only text that dealt specifically with the practice of holding aliens in the transit zone - too brief and lacking in appropriate guarantees required to have the quality of law. It was immaterial therefore, to this finding, that the circular was actually unpublished and thus inaccessible. However, undoubtedly there will be other cases where this would be the key consideration.

1242 See Chapter II which discusses the principle of legality.

1243 Jecius v. Lithuania, appl. no. 34578/97, 31 July 2000, §56 and 59. 
However, imprecise notions within the criminal justice system can still be considered in compliance with Article 5 of the ECHR if they have been clarified by, for example, practice. In Steel and Others v. the United Kingdom, the notion of 'breach of the peace' had been clarified through two decades of domestic judicial decisions..$^{244}$ The effect of this development was thus to turn a fairly imprecise notion into one that was regulated with sufficient guidance and appropriate precision to satisfy the requirement of Article 5 of the ECHR as far as the 'lawfulness' was concerned. However, until domestic case law clarifies the scope of such vague legal concepts, deprivation of liberty may very well be considered in violation of Article 5 of the ECHR, due to a legal basis of inadequate quality, and possibly in violation of Article 7 of the ECHR. ${ }^{1245}$

The third aspect of the lawfulness requirement is that legislation providing for pretrial detention must always be in compliance with the ECHR as such, and the principles implied or expressed therein. ${ }^{1246}$ Deprivation of liberty presupposes compliance with the purpose of Article 5 of the ECHR, namely, to protect individuals from arbitrariness. ${ }^{1247}$ This means that pre-trial detention can thus very well be in violation of Article 5 of the ECHR, even if the deprivation of liberty was in conformity with the applicable domestic procedure.

For example, when deprivation of liberty is legally justified at national level by other grounds than those exhaustively listed in Article 5, section 1 under a-f of the ECHR, conformity of that domestic legislation with the ECHR and its principles will be lacking. A breach due to lack of 'lawfulness' will be the result. Such deprivation of liberty, though legal at domestic level, runs contrary to the rationale of Article 5 of the ECHR, as well as to the ECHR and its implied principles.

1244 Steel and Others v. the United Kingdom, appl. no. 67/1997/851/1058, 23 September 1998, §55.

1245 See, in this respect, Mooren v. Germany [GC], appl. no. 11364/03, 9 July 2009, §72 and 76 in which the ECtHR argued that: '(...) The Court must further ascertain in this connection whether domestic law itself is in conformity with the Convention, including the general principles expressed or implied therein, notably the principle of legal certainty'. And in $\$ 93$ the ECtHR considered that: ' $(. .$.$) in general, the principle of legal certainty may be compromised if domestic$ courts introduce exceptions in their case law which run counter to the wording of the applicable statutory provisions. Such interpretations should thus be kept to a minimum (...)'.

1246 Butkevičius v. Lithuania, appl. no. 48297/99, 26 March 2002, §36.

1247 Wassink v. The Netherlands, appl. no. 12535/86, 27 September 1990, §24. In this case it concerned a request for extension of a psychiatric confinement filed by the State Prosecutor. The president of the competent court did extend the confinement, but without the attendance of a registrar, as required by law. The President of the competent court asserted that the court was understaffed and therefore unable to comply with this procedural requirement in every extension-case. The ECtHR, however, concluded that there was, in this respect, a failure to comply with the requirement of 'a procedure prescribed by law', which amounted to a breach of Article 5, section 1 of the ECHR. See, also, Benham v. the United Kingdom, appl. no. 19380/92, 10 June 1996, §40; Quinn v. France, appl. no. 18580/91, 22 March 1995, §47; Ladent v. Poland, appl. no. 11036/03, 18 March 2008, §47-56. In this latter case, the ECtHR argued that arbitrary interferences with Article 5 of the ECHR may also be caused by a disproportional deprivation of liberty in light of the goals pursued $(\$ 56)$. 
Basically, this third and last touchstone for examining whether deprivation of liberty is based on a 'procedure prescribed by law' and is, moreover, 'lawful', is formed by the overall regulative impact that Article 5 ECHR has on domestic procedures, and according practice, that lead to deprivation of liberty. So, domestic procedures regarding pre-trial detention should not merely be in compliance with the qualitative formal requirements set by Article 5 of the ECHR, but any measure depriving a person of his liberty should, in addition, be in conformity with the ECHR in general and with 'the spirit' of the right to liberty: protecting people from arbitrary state interference with their right to liberty. ${ }^{1248}$ The ECtHR considers, therefore, as fundamental principle that no detention which is arbitrary can be compatible with Article 5, section 1 of the ECHR and the notion of 'arbitrariness'. ${ }^{1249}$

The notion of 'arbitrary' has been mentioned several times, but what does 'arbitrary' actually mean within the context of Article 5 of the ECHR? First of all, it is important to note that this notion varies, to a certain extent depending on the type of detention involved. ${ }^{1250}$ One general principle established in case law is that detention will be arbitrary where, despite complying with the letter of national law, there has been an element of bad faith or deception on the part of the authorities. ${ }^{1251}$ The condition that there be no arbitrariness further demands that both the order to detain, and the execution of the detention, must genuinely conform with the purpose of the restrictions permitted by the relevant sub-paragraph of Article 5, section 1 of the ECHR. ${ }^{1252}$ There must, in addition, be some relationship between the ground of permitted deprivation of liberty relied on, and the place and conditions of detention. ${ }^{1253}$ Also, detention will be considered arbitrary when the domestic authorities neglected to attempt to apply the relevant legislation correctly. ${ }^{1254}$ Furthermore, the reasoning of the decision ordering detention is a relevant factor in determining whether a person's detention must be considered as arbitrary. The ECtHR has considered the absence of any grounds given by the judicial authorities

1248 Butkevičius v. Lithuania, appl. no. 48297/99, 26 March 2002, §36; X v. the United Kingdom, appl. no. 7215/75, 5 November 1981, §43.

1249 Saadi v. the United Kingdom, appl. no. 13229/03, 29 January 2008, §67; Mooren v. Germany [GC], appl. no. 11364/03, 9 July 2009, §72 and 77-82; Vrenčev v. Serbia, appl. no. 2361/05, 23 September 2008, §59.

1250 Saadi v. the United Kingdom, appl. no. 13229/03, 29 January 2008, §68.

1251 Bozano v. France, appl. no. 9990/82, 18 December 1986; Quinn v. France, appl. no. 18580/91, 22 March 1995, §47. With respect to other grounds for deprivation of liberty, the ECtHR has formulated additional criteria that must be complied with for detention to be considered not arbitrary. See, for example, Witold Litwa v. Poland, appl. no. 26629/95, 4 April 2000.

1252 Winterwerp v. The Netherlands, appl. no. 6301/73, 24 October 1979, §39; Bouamar v. Belgium, appl. no. 9106/80, 29 February 1988, §50; O'Hara v. the United Kingdom, appl. no. 37555/97, 16 October 2001, §34; Mooren v. Germany [GC], appl. no. 11364/03, 9 July 2009, §78.

1253 Bouamar v. Belgium, appl. no. 9106/80, 29 February 1988, §50; Aerts v. Belgium, appl. no 25357/94, 30 July 1998, §46; Enhorn v. Sweden, appl. no. 56529/00, 25 January 2005, §42.

1254 Benham v. the United Kingdom, appl. no. 19380/92, 10 June 1996, §47; Liu v. Russia, appl. no. 42086/05, 6 December 2007, §82; Marturana v. Italy, appl. no. 63154/00, 4 March 2008, $\S 80$. 
in their decisions authorising detention for a prolonged period of time to be incompatible with the principle of the protection from arbitrariness, as enshrined in Article 5, section 1 of the ECHR. ${ }^{1255}$ Detention is not arbitrary if the domestic court gave certain grounds justifying the continued detention on remand, unless the reasons given are extremely laconic and without reference to any legal provision which would have permitted a person's detention. ${ }^{1256}$

In case of pre-trial deprivation of liberty pursuant to Article 5, section 1 under $\mathrm{c}$ of the ECHR, there is one additional aspect of the lawfulness requirement that needs to be discussed. For continued pre-trial detention to be lawful, the deprivation of liberty has to be legitimate and necessary based on the circumstances of the case. Flight risk of a suspect, the danger of a suspect intimidating witnesses or tampering with evidence, the suspect causing public disorder upon release or a risk of recidivism are the only four grounds that, according to the ECtHR, may justify continued pre-trial detention of a non-convicted person. These four grounds and the circumstances that can lead to fulfilment thereof will be discussed in the next Section (11.4).

\subsubsection{Judicial control during the arrest period}

This last section briefly examines the scope of the required judicial control on the lawfulness of arrest and pre-trial detention during the arrest period, pursuant to Article 5, section 3 of the ECHR. The main purpose of Article 5, section 3 of the ECHR is to afford to individuals deprived of their liberty within the criminal law context, a procedure of a judicial nature designed to ensure that no one is arbitrarily deprived of his liberty. Secondly, it is intended to ensure that any arrest or detention will be kept as short as possible. ${ }^{1257}$ Indirectly, accordingly, Article 5, section 3 of the ECHR contributes to the prevention of torture or other forms of ill-treatment of people who are being kept in police detention. ${ }^{1258}$

Article 5, section 3 of the ECHR concerns two separate matters: the early stages following an arrest when an individual is taken into the power of the authorities (arrest period), and the period pending eventual trial before a criminal court during which the suspect may be detained or released with or without conditions (pre-trial period). During both periods, states are obliged to provide for judicial control of the

1255 Mooren v. Germany [GC], appl. no. 11364/03, 9 July 2009, §79; Imakayeva v. Russia, appl. no. 7615/02, 9 November 2006, §171-179; Stašaitis v. Lithuania, appl. no. 47679/99, 21 March 2002, §67; Nakhmanovich v. Russia, appl. no. 55669/00, 2 March 2006, §70; Belevitskiy v. Russia, appl. no. 72967/01, 1 March 2007, \$91.

1256 Mooren v. Germany [GC], appl. no. 11364/03, 9 July 2009, §80; Khudoyorov v. Russia, appl. no. $6847 / 02,8$ November $2005, \S 131$ and $157-158$.

1257 P. van Dijk, F. van Hoof, A. van Rijn and L. Zwaak (eds.), Theory and Practice of the European Convention on Human Rights, fourth edition, Intersentia Antwerpen-Oxford 2006, p. 487.

1258 Altay v. Turkey, appl. no. 22279/93, 22 May 2001, §64 and 65. 
lawfulness of the deprivation of liberty. However, the scope of the judicial control during those periods is not the same. This section discusses judicial control during the arrest period, and in the next section, judicial control during the pre-trial period is elaborated on.

Article 5, section 3 of the ECHR provides that the accused should be brought promptly before a 'judge or other officer authorised by law to exercise judicial power'. In the cases of Schiesser v. Switzerland ${ }^{1259}$ and De Jong, Baljet and Van Den Brink v. The Netherlands, ${ }^{1260}$ the ECtHR delineated this phrase. Three cumulative requirements must be complied with for an authority to be considered as 'judge or other officer authorised by law to exercise judicial power'. Firstly, the authority that examines the lawfulness of arrest and pre-trial detention must be independent both from the Executive and from the parties involved. This does not, however, mean that the authority may not be, to some extent, subordinate to other judges or officers as long as they themselves enjoy similar independence. ${ }^{1261}$

Secondly, there is a 'procedural requirement' obliging the judicial authority to hear himself the suspect brought in before him. This condition can naturally be compared with general criteria concerning the right to profit from adversarial proceedings as facet of the right to fair trial pursuant to Article 6 of the ECHR.

Lastly, there is a 'substantive requirement' that obliges the judicial authority to review all the circumstances militating for or against pre-trial detention - with reference to legal criteria - when deciding whether there are sufficient reasons to justify detention and of ordering release if there are no such reasons. ${ }^{1262}$ The mandatory independence of any judicial authority from the Executive and the parties involved is clearly reflected in this substantive criterion. ${ }^{1263}$

With respect to the first requirement, criteria are comparable to the ones comprised in Article 6, section 1 of the ECHR. Potential doubts as to the independence and impartiality of 'the other officer authorised by law to exercise judicial power' must be objectively justified. The requirements for the functioning of a 'judge' and for an 'other officer authorised by law to exercise judicial power' are, to a certain extent, equally high. In Nikolova v. Bulgaria, the ECtHR emphasises the importance of objective appearance at the time when decisions on pre-trial detention are taken. The ECtHR considered that '(...) the 'officer' must be independent of the Executive and of the parties. In this respect, objective appearances at the time of the decision on detention are material: if it appears at that time that the 'officer' may later

1259 Schiesser v. Switzerland, appl. no. 7710/76, 4 December 1979.

1260 De Jong, Baljet and Van Den Brink v. The Netherlands, appl. no. 8805/79, 22 May 1984.

1261 Schiesser v. Switzerland, appl. no. 7710/76, 4 December 1979, §31.

1262 Schiesser v. Switserland, appl. no. 7710/76, 4 December 1979, \$31.

1263 These three requirements also apply in the case of judicial control during the pre-trial period. See, for a discussion of the scope of judicial control during the pre-trial period, the following section. 
intervene in subsequent criminal proceedings on behalf of the prosecuting authority, his independence and impartiality are capable of appearing open to doubt. ${ }^{, 1264}$

Judicial control during the arrest period must comply with three requirements. First of all, the judicial control on the first appearance of an arrested individual must be prompt, to allow detection of any ill-treatment, and to keep to a minimum any unjustified interference with individual liberty. The strict time constraint (a maximum of 4 days) imposed by this requirement leaves little flexibility in interpretation, otherwise there would be a serious weakening of a procedural guarantee to the detriment of the individual and the risk of impairing the very essence of the right protected by this provision. ${ }^{1265}$

Secondly, judicial review during the arrest period must be automatic and cannot depend on the application of the detained person. In this respect, it must be distinguished from Article 5, section 4 of the ECHR, which gives a detained person the right to apply for release. ${ }^{1266}$

And thirdly, the judge or judicial officer must offer the requisite guarantees of independence from the Executive and the parties involved. He must, furthermore, have the power to order release, after hearing the individual and reviewing the lawfulness of, and justification for, the arrest and detention. As regards the scope of that review, the above-discussed remarks regarding substantive and procedural requirements apply: the judge or judicial officer is obliged to consider the merits of the detention. ${ }^{1267}$ This means that the initial automatic review of arrest and detention must be capable of examining lawfulness issues, and whether or not there is a reasonable suspicion that the arrested person has committed an offence, in other words, that detention falls within the permitted exception set out in Article 5, section 1 under $\mathrm{c}$ of the ECHR. ${ }^{1268}$

\subsection{Pre-trial/remand period}

\subsubsection{Introduction}

Article 5, section 3 of the ECHR prescribes that a suspect must either be tried within a reasonable time or released pending trial - which release may be conditioned by guarantees to appear for trial, such as the setting of bail. In the

1264 Nikolova v. Bulgaria, appl. no. 31195/96, 25 March 1999, §49.

1265 McKay v. the United Kingdom, appl. no. 543/03, 3 October 2006, §33; Brogan and Others v. the United Kingdom, appl. nos. 11209/84, 11234/84, 11266/84, 11386/85, 29 November 1988, §62. In this latter judgement, the ECtHR judged periods of more than four days in detention without appearance before a judge to be in violation of Article 5, section 3 of the ECHR, even in the special context of terrorist investigations.

1266 McKay v. the United Kingdom, appl. no. 543/03, 3 October 2006, §34.

1267 McKay v. the United Kingdom, appl. no. 543/03, 3 October 2006, §35.

1268 McKay v. the United Kingdom, appl. no. 543/03, 3 October 2006, §40. 
ECtHR's opinion, Article 5, section 3 of the ECHR does not give judicial authorities a choice between either bringing a suspect/an accused to trial within a reasonable time, or granting him provisional release pending trial. Until his conviction, the suspect/accused must be presumed innocent, and the purpose of the aforementioned provision is essentially to require him to be released provisionally once his continuing detention ceases to be reasonable. ${ }^{1269}$ The ECtHR considers continued pre-trial detention, hence, as an exceptional measure that must be strictly necessary and - more generally - not contrary to the core of Article 5 of the ECHR. ${ }^{1270}$ In principle, the Strasbourg starting point is that a suspect must be released pending trial. $^{1271}$

This section discusses the question of when continued pre-trial detention - as exceptional measure hence ${ }^{1272}$ - is justified in the ECtHR's view. The persistence of a reasonable suspicion that a person has committed an offence is a conditio sine qua non for the lawfulness of the arrest within the meaning of Article 5, section 1 under c of the ECHR, but this may be insufficient for a judicial decision extending detention. ${ }^{1273}$ For continued deprivation of liberty to be lawful, the ECtHR requires a more solid basis to show not only that there is genuinely a reasonable suspicion but also that there are other serious elements of public interest, which, notwithstanding the presumption of innocence, outweigh the right to liberty. ${ }^{1274}$ In its case law on Article 5, section 3 of the ECHR, the ECtHR therefore requires 'relevant' and 'sufficient' grounds to justify continued pre-trial detention. ${ }^{1275}$ The

1269 Aleksandr Makarov v. Russia, appl. no. 15217/07, 12 March 2009, §117; Lyubimenko v. Russia, appl. no. 6270/06, 19 March 2009, §67; Moskovets v. Russia, appl. no. 14370/03, 23 April 2009, $\S 75$.

1270 Knebl c. République Tchèque, requête no 20157/05, 28 octobre 2010, §62.

1271 Polonskiy v. Russia, appl. no. 30033/05, 19 March 2009, §139; Moskovets v. Russia, appl. no. 14370/03, 23 April 2009, §75; Bordikov v. Russia, appl. no. 921/03, 8 October 2009, §87; Castravet v. Moldova, appl. no. 23393/05, 13 March 2007, §30 and 32; McKay v. the United Kingdom, appl. no. 543/03, 3 October 2006, §41; Jabłoński v. Poland, appl. no. 33492/96, 21 December 2000, §83; Neumeister v. Austria, appl. no. 1936/63, 27 June 1968, §4; Lind v. Russia, appl. no. 25664/05, 6 December 2007, §72. See, also, T.M. Schalken, 'Vrijheidsbeneming volgens het EVRM en de Nederlandse praktijk inzake voorarrest', in: Via Straatsburg Liber Amicorum Egbert Myjer, Wolf Legal Publishers 2004, pp. 257-268.

1272 See, in this respect, A.H. Klip, 'Slappe rechters', in Delikt en Delinkwent 2010, 79.

1273 Patsuria v. Georgia, appl. no. 30779/04, 6 November 2007, §65. See, also, Kalashnikov v. Russia, appl. no. 47095/99, 15 July 2002, §114, where the ECtHR underlined that '(...) the existence of a strong suspicion of the involvement of a person in serious offences, while constituting a relevant factor, cannot alone justify a long period of pre-trial detention (...)' Aleksandr Makarov v. Russia, appl. no. 15217/07, 12 March 2009, §116.

1275 Stögmüller v. Austria, appl. no. 1602/62, 10 November 1969, 4-16; B. v. Austria, appl. no. 11968/86, 28 March 1990, §42 and further; Tomasi v. France, appl. no. 12850/87, 27 August 1992, §85-100; W. v. Switzerland, appl. no. 14379/88, 26 January 1993, §30-39; K.-F. v. Germany, appl. no. 144/1996/765/962, 27 November 1997, §63; Clooth v. Belgium, appl. no. 12718/87, 12 December 1991, §36; Letellier v. France, appl. no. 29/1990/220/282, 26 June 
scope of the Strasbourg grounds for continued pre-trial detention will be elaborated on in the coming sections.

The subject of continued pre-trial detention is discussed at this point, because the Strasbourg grounds for continued detention correspond to the grounds of Article $67 \mathrm{a}$ of the DCCP. It is, however, important to note that this section will primarily play a role of importance in the next Chapter regarding serious objections.

In the decision of Hendriks v. the Netherlands, the ECtHR ruled that the question of when exactly detention on remand is no longer justified, purely on the basis of a reasonable suspicion, cannot be answered in the abstract. ${ }^{1276}$ Consequently, the question of when a state needs to adduce relevant and sufficient grounds to justify continued pre-trial detention remains unclear. Most cases regarding continued pretrial detention on the basis of such grounds concern long periods of deprivation of liberty, of at least several months. However, in McKay v. the United Kingdom, the ECtHR considered that 'there must exist the opportunity for judicial consideration of release pending trial as even at this stage [the very early stage of pre-trial detention] there will be cases where the nature of the offence or the personal circumstances of the suspected offender are such as to render detention unreasonable, or unsupported by relevant or sufficient grounds' ${ }^{1277}$ This line of reasoning presupposes that even during the early stages of pre-trial detention - after 4 days - there must be grounds to justify detention.

In addition, the fact that the ECtHR explicitly distinguishes between the arrest period (reasonable suspicion) and the pre-trial period (reasonable suspicion and relevant and sufficient grounds) pursuant to Article 5, section 3 of the ECHR, justifies the careful conclusion that a mere reasonable suspicion is adequate for the first few days of arrest and police custody, whereas after the lapse of that period, states are obliged to demonstrate extra grounds for the continued deprivation of liberty. It is, furthermore, important to note, in this respect, that the ECtHR has repeatedly emphasised that Article 5, section 3 of the ECHR cannot be seen as unconditionally authorising detention, provided that it lasts no longer than a certain period. Justification for any period of detention, no matter how short, must be convincingly demonstrated by the authorities. ${ }^{1278}$

1991, §35; decision as to the admissibility in Ramishvili and Kokhreidze v. Georgia, appl. no. 1704/06, 27 June 2007.

1276 Decision as to the admissibility in Hendriks v. the Netherlands, appl. no. 43701/04, 5 July 2007. See, also, decision as to the admissibility in Kanzi v. the Netherlands, appl. no. 28831/04, 5 July 2007.

1278 Polonskiy v. Russia, appl. no. 30033/05, 19 March 2009, §139; Shishkov v. Bulgaria, appl. no. 38822/97, 9 January 2003, §66; Lyubimenko v. Russia, appl. no. 6270/06, 19 March 2009, $\S 66$; Tarău c. Romanie, requête no 3584/02, 24 février 2009, §45; Moskovets v. Russia, appl. no. 14370/03, 23 April 2009, §75; Patsuria v. Georgia, appl. no. 30779/04, 6 November 2007, $\S 66$; Lind v. Russia, appl. no. 25664/05, 6 December 2007, §84. 
In its case law, the ECtHR has developed four grounds that may justify continued pre-trial detention ${ }^{1279}$ :

- Danger of absconding;

- The risk of an interference with the course of justice (risk of collusion);

- The need to prevent crime (danger of recidivism);

- The need to preserve public order.

The longer a suspect is kept in pre-trial detention, the stronger the justification for that detention must become and the more urgent the question becomes whether the suspect can be released - possibly with guarantees. If the competent domestic authorities consider release to be no option, they are obliged to prove the continuous presence of relevant and sufficient justifications for this interference with the suspect's liberty. The ECtHR has repeatedly underlined that shifting the burden of proof to the detained person in such matters is tantamount to overturning the rule of Article 5 of the ECHR. ${ }^{1280}$ The national judicial authorities must examine all the facts arguing for or against the existence of a genuine requirement of public interest justifying, with due regard to the principle of the presumption of innocence, a departure from the rule of respect for individual liberty, and must set them out in their decisions dismissing the applications for release. ${ }^{1281}$ In Tarău c. Romanie, the ECtHR underlined in this respect that 'ce n'est qu'en fournissant les motifs sur lesquels une décision se fonde que l'on peut permettre un contrôle public de l'administration de la justice'. ${ }^{1282}$ It is essentially on the basis of the reasons given in the domestic courts' decisions and of the true facts mentioned by an applicant in his appeals that the ECtHR decides whether or not there has been a violation of Article 5, section 3 of the ECHR. ${ }^{1283}$

1279 These four Strasbourg reasons for (continued) pre-trial detention have been summarised and surveyed in the leading case of Smirnova v. Russia, appl. no. 46133/99, 24 July 2003. See, also, Kemmache v. France, appl. no. 12325/86 and 14992/89, 27 November 1991, §45-57; Jiga c. Roumanie, requête no 14352/04, 16 mars 2010, §75. See, in this respect also, E. Myjer, 'De te lang gehechte identieke tweelingzusjes', in NJCM-Bulletin 2004/3, p. 379; T.M. Schalken, 'Vrijheidsbeneming volgens het EVRM en de Nederlandse praktijk inzake voorarrest', in Via Straatsburg Liber Amicorum Egbert Myjer, Wolf Legal Publishers 2004, pp. 257-268.

1280 Bordikov v. Russia, appl. no. 921/03, 8t October 2009, §88; Rokhlina v. Russia, appl. no. 54071/00, 7 April 2005, §67; decision as to the admissibility in Ramishvili and Kokhreidze v. Georgia, appl. no. 1704/06, 27 June 2007; Ilijkov v. Bulgaria, appl. no. 33977/96, 26 July 2001, §84-85.

1281 Czarnecki v. Poland, appl. no. 75112/01, 28 July 2005, §37; Polonskiy v. Russia, appl. no. 30033/05, 19 March 2009, §140; Popov and Vorobyev v. Russia, appl. no. 1606/02, 23 April $2009, \S 77$.

1282 Tarău c. Romanie, requête no 3584/02, 24 février 2009, §45; Suominen c. Finlande, requête no 37801/97, 1 juillet 2003, $\$ 37$.

1283 Bordikov v. Russia, appl. no. 921/03, 8 October 2009, §88; Korchuganova v. Russia, appl. no. 75039/01, 8 June 2006, §72; Jiga c. Roumanie, requête no 14352/04, 16 mars 2010, §78; Goroshchenya v. Russia, appl. no. 38711/03, 22 April 2010, §78; Knebl c. République Tchèque, requête no 20157/05, 28 octobre 2010, §62; Bouchet c. France, requête no 33591/96, 20 mars 
It goes without saying that a reasonable suspicion remains a condition sine qua non for continued pre-trial detention. ${ }^{1284}$ Hence, to examine the lawfulness of continued pre-trial detention, the ECtHR scrutinises, in terms of substance, whether (1) there still is a reasonable suspicion and (2) whether the justifications brought forth by the government to justify the deprivation of liberty, were relevant and sufficient. ${ }^{1285}$ In addition, there is also a procedural touchstone comprised in Article 5, section 3 of the ECHR. Domestic prosecuting authorities are obliged to conduct the proceedings with special diligence when a suspect is kept in pre-trial detention. ${ }^{1286}$ This aspect will be discussed in the following chapter.

Let us now turn to discussing the above-mentioned four Strasbourg grounds for continued pre-trial detention. It is important to keep in mind that, again, that the specific circumstances of the case are decisive for the ECtHR in examining complaints under Article 5, section 3 of the ECHR. ${ }^{1287}$

\subsubsection{Danger of absconding ${ }^{1288}$}

The vast amount of judgements regarding the danger of absconding demonstrates that states frequently allege flight risk to justify continued pre-trial detention,

2001, §39; Lelièvre c. Belgique, requête no 11287/03, 8 novembre 2007, §89; Ilijkov, appl. no. 33977/96, 26 July 2001, §86; Labita v. Italy, appl. no. 26772/95, 6 April 2000, §152.

1284 Popov and Vorobyev v. Russia, appl. no. 1606/02, 23 April 2009, §75; Moskovets v. Russia, appl. no. 14370/03, 23 April 2009, §74; Bordikov v. Russia, appl. no. 921/03, 8 October 2009, §86; Jiga c. Roumanie, requête no 14352/04, 16 mars 2010, §74; Goroshchenya v. Russia, appl. no. 38711/03, 22 April 2010, §80; Knebl c. République Tchèque, requête no 20157/05, 28 octobre $2010, \S 63$.

1285 Popov and Vorobyev v. Russia, appl. no. 1606/02, 23 April 2009, §76; Czarnecki v. Poland, appl. no. 75112/01, 28 July 2005, §39; Jablonski v. Poland, appl. no. 33492/96, 21 December 2000, $\S 80$; Patsuria v. Georgia, appl. no. 30779/04, 6 November 2007, §62; Lind v. Russia, appl. no. 25664/05, 6 December 2007, §71.

1286 Aleksandr Makarov v. Russia, appl. no. 15217/07, 12 March 2009, §120; Labita v. Italy, appl. no. 26772/95, 6 April 2000, §153; Polonskiy v. Russia, appl. no. 30033/05, 19 March 2009, §138; Popov and Vorobyev v. Russia, appl. no. 1606/02, 23 April 2009, §75; Knebl c. République Tchèque, requête no 20157/05, 28 octobre 2010, $\$ 63$.

1287 See Wemhoff v. the Federal Republic of Germany, appl. no. 2122/64, 27 June 1968, §10, where the ECtHR considered that: ' $(. .$.$) The reasonableness of an accused person's continued detention$ must be assessed in each case according to its special features. The factors which may be taken into consideration are extremely diverse. Hence, the possibility of wide differences in opinion in the assessment of the reasonableness of a given detention (...)'. See, also, Moskovets v. Russia, appl. no. 14370/03, 23 April 2009, §76.

1288 Compare with Article 67a, section 1 under a of the DCCP. With the enactment of the European Union Council Framework Decision 2002/584/JHA of 13 June 2002 on the European arrest warrant and the surrender procedures between Member States (OJ L 190, 1-17, 18.7.2002) and the European Union Council Framework Decision 2009/829 of 23 October 2009 on the application, between Member States of the European Union, of the principle of mutual recognition to decisions on supervision measures as an alternative to provisional detention (OJ L 
certainly when law enforcement officers have experienced difficulties in apprehending the suspect. The ECtHR does not, however, so easily accept a government's assertion of there being a genuine risk of the suspect absconding during the criminal investigation. There are several aspects that play a role in deciding whether or not there is a justified danger of absconding in a specific case.

Firstly, there is the question of whether a suspect may flee, despite the possible consequences for his trial and/or the hazards attached to the flight. In this respect, the case of Stögmuller v. Austria ${ }^{1289}$ is important. The ECtHR argued that the risk of absconding does not arise necessarily and per se from it being solely feasible or simple for a suspect to cross the border. In Letellier v. France ${ }^{1290}$, the ECtHR considered that the nature and severity of the penalty that could be imposed on the suspect if convicted of the alleged offence, might substantiate an alleged danger of absconding initially, but the fact that a severe sentence can be anticipated is not in itself sufficient to justify a continuation of pre-trial detention. ${ }^{1291}$ In this respect, the case of Patsuria v. Georgia must be mentioned as well. The ECtHR considered in this case that 'a practice of automatic remands in custody for three months solely on a statutory presumption based on the gravity of the charges because of a hypothetical danger of absconding, re-offending or collusion, is incompatible with Article 5, section 3 of the ECHR'. ${ }^{1292}$

In B. v. Austria ${ }^{1293}$ the government raised additional circumstances, next to the severity of the sentence, to demonstrate a danger of flight, including the suspect's lack of social integration and his contacts abroad. Furthermore, the government referred to the fact that the suspect had already been convicted for similar activities

294, 20-40, 11.11.2009), the risk of absconding must be considered to have diminished considerably.

1289 Stögmüller v. Austria, appl. no. 1602/62, 10 November 1969, §15: '(...) there must be a whole set of circumstances, particularly, the heavy sentence to be expected or the accused's particular distaste of detention, or the lack of well-established ties in the country, which give reason to suppose that the consequences and hazards of flight will seem to him to be a lesser evil than continued imprisonment (...)'.

1290 Letellier v. France, appl. no. 29/1990/220/282, 26 June 1991.

1291 Letellier v. France, appl. no. 29/1990/220/282, 26 June 1991, §50 and further. See, also, Goral v. Poland, appl. no. 38654/97, 30 October 2003, §68 where the ECtHR argued 'However, this ground of detention, which goes to the notion of gravity of the offence, cannot constitute a 'relevant and sufficient' ground for holding the applicant in detention for almost eighteen months'. See, also, Aleksandr Makarov v. Russia, appl. no. 15217/07, 12 March 2009, §124; Lyubimenko v. Russia, appl. no. 6270/06, 19 March 2009, §72; Popov and Vorobyev v. Russia, appl. no. 1606/02, 23 April 2009, §81; Panchenko v. Russia, appl. no. 45100/98, 8 February 2005, $\S 102$; Goral v. Poland, appl. no. 38654/97, 30 October 2003, §68; Moskovets v. Russia, appl. no. 14370/03, 23 April 2009, §82-83; Goroshchenya v. Russia, appl. no. 38711/03, 22 April 2010, §83; Lind v. Russia, appl. no. 25664/05, 6 December 2007, §75-77.

1292 Patsuria v. Georgia, appl. no. 30779/04, 6 November 2007, §67.

1293 B. v. Austria, appl. no. 8/1989/168/224, 28 March 1990, §44. 
and had committed new offences following prior release. Hence, there was additionally a substantial danger of repetition. According to the ECtHR, these additional specific circumstances, among which the danger of recidivism, justified the continued pre-trial detention - even if the nature of the sentence played a significant part in ordering the suspect's pre-trial detention.

In K.-Fv. Germany, the suspects were deprived of their liberty on the basis of an alleged danger of flight and because their identity could not be checked at the time of arrest. ${ }^{1294}$ Also, the investigative authorities wanted to examine whether there were outstanding arrest warrants for the suspects. These circumstances were considered adequate to justify the suspects' continued pre-trial detention. ${ }^{1295}$

In Goroshchenya v. Russia, the ECtHR argued that the mere lack of a fixed abode does not give rise to a danger of absconding or reoffending. ${ }^{1296}$ However, a suspect's placement on the wanted persons' list is a relevant factor in assessing the risk of absconding. It is, however, necessary that the danger be a plausible one and the measure appropriate, in the light of the circumstances of the case and in particular the past history and the personality of the person concerned. ${ }^{1297}$

Danger of flight can further be demonstrated by referring to previous instances when a suspect has fled after being charged or where extradition has been required in order for the proceedings to be pursued. ${ }^{1298}$ Also, a suspect's clear distaste for detention or his links with another country that might make fleeing easier, and/or the absence of links with the country in which the proceedings are being brought, can play a role. ${ }^{1299}$ Specific plans of a suspect for an attempted escape can justify continued pre-trial detention as well. ${ }^{1300}$ The domestic authorities are, furthermore, obliged to take into account the suspect's character, the danger he poses to society, his financial resources, the connection he has with the state that prosecutes him and his contacts abroad. ${ }^{1301}$

1294 K.-F. v. Germany, appl. no. 25629/94, 27 November 1997, §54.

1295 K.-F. v. Germany, appl. no. 25629/94, 27 November 1997, §68 and 71-73 where the ECtHR considered that 'It has been established, however, that the police continued to make inquiries throughout the night and up until the applicant's release, partly in order to check whether an arrest warrant had been issued against him. Having regard to those circumstances, the Court concludes that the applicant's detention from 9.45 p.m. on 4 July to 9.45 a.m. the following day was justifiable'.

1296 Goroshchenya v. Russia, appl. no. 38711/03, 22 April 2010, §86; Pshevecherskiy v. Russia, appl. no. 28957/02, 24 May 2007, §68; Lind v. Russia, appl. no. 25664/05, 6 December 2007, §75-77.

1297 Goroshchenya v. Russia, appl. no. 38711/03, 22 April 2010, §87.

1298 Punzelt v. the Czech Republic, appl. no. 31315/96, 25 April 2000, §76; Bordikov v. Russia, appl. no. 921/03, 8 October 2009, §91.

1299 Stögmuller v. Austria, appl. no. 1602/62, 10 November 1969; W. v, Switzerland, appl. no. 14379/88, 26 January 1993, §31-34.

1300 Matznetter v. Austria, appl. no. 2178/64, 10 November 1969.

1301 Knebl c. République Tchèque, requête no 20157/05, 28 octobre 2010, §65; Czarnecki v. Poland, appl. no. $75112 / 01,28$ July $2005, \S 37$. 
The ECtHR's case-to-case approach, and the decisive role that the specific circumstances of the case play, make it almost impossible to determine in abstracto when there is a genuine danger of the suspect absconding. ${ }^{1302}$ However, three general guidelines can be inferred from Strasbourg case law.

Firstly, broadly formulated considerations to demonstrate danger of flight, such as the high penalty attached to a certain criminal offence, do not suffice. The ECtHR requires states to furnish an alleged danger of flight with specific information that is, moreover, directly linked to the suspect's behaviour and personal circumstances. Secondly, the reasons provided for an alleged flight risk have to be linked specifically to genuine possibilities of flight geared to the suspects (personal) ${ }^{1303}$ situation, supported by evidentiary findings. ${ }^{1304}$ And thirdly, the ECtHR generally accepts an alleged danger of absconding as justification for a short period, for example, to provide the prosecution authorities with time to verify the available incriminating information and to adduce evidence in support. However, with the passage of time this is insufficient, as such, to justify continued pre-trial detention. ${ }^{1305}$

\subsubsection{The risk of an interference with the course of justice ${ }^{1306}$}

The second ground to justify continued pre-trial detention is the risk of a suspect making use of the occasion of his release to undermine the preparation of a case against him, by, for example, putting pressure on witnesses not to testify. Another way of interfering with the course of justice concerns suspects who, upon release, tip off co-offenders or collude with these 'colleagues' as to how they will behave during interrogations. Destroying evidence, or in some other form, disrupting the criminal investigation, are further examples of potential justifications for continued pre-trial detention under this heading. ${ }^{1307}$

1302 Wemhoff v. the Federal Republic of Germany, appl. no. 2122/64, 27 June 1968, §10.

1303 Letellier v. France, appl. no. 29/1990/220/282, 26 June 1991. In this judgement, the ECtHR took into account the fact that the applicant was the mother of eight minor children. This personal circumstance made the danger of absconding minimal.

1304 Stögmüller v. Austria, appl. no. 1602/62, 10 November 1969. The fact that the applicant had a flying licence was insufficient to demonstrate a danger of absconding. See, also, Aleksandr Makarov v. Russia, appl. no. 15217/07, 12 March 2009, §127; Musuc v. Moldova, appl. no. 42440/06, 6 November 2007, §45.

1305 Aleksandr Makarov v. Russia, appl. no. 15217/07, 12 March 2009, §126.

1306 Compare with Article 67a, section 2 under 4 of the DCCP.

1307 W. v. Switzerland, appl. no. 14379/88, 26 January 1993, §36, where the ECtHR had regard 'not only to W.'s personality and antecedents, but also primarily to the circumstance that, according to the case file, W. had in the context of other proceedings had exonerating evidence manufactured, documents antedated and witnesses manipulated'. 
This second ground primarily plays a role during the initial stages of a criminal investigation. ${ }^{1308}$ After the evidence has been collected, this ground becomes insufficient to justify the detention. ${ }^{1309}$ For example, in Letellier v. France, the ECtHR argued that there might have been a risk of the suspect influencing witnesses initially, but that risk diminished during the suspect's continued pre-trial detention and eventually disappeared completely. ${ }^{1310}$

Strasbourg case law demonstrates, hence, that the further a criminal investigation has proceeded, the less likely it gets that a suspect will (be able to) interfere with the course of the criminal investigation and the criminal proceedings. Obviously, the prosecuting authorities need to get an opportunity to prepare the case well, but when the criminal investigation has been (more or less) concluded, other grounds are required to justify the suspect's continued deprivation of liberty. In Clooth v. Belgium, the ECtHR underlined that a very complicated case combined with a suspect who impedes and delays the criminal investigation, may justify continued pre-trial detention, at least at the outset. In the long term, however, the requirements of the investigation do not suffice to justify the detention of a suspect. 1311

A general reference to the risk of a suspect obstructing the investigation, without bringing forth (new) information or circumstances to sustain that alleged risk, is insufficient. Domestic authorities are obliged to provide for specific and individualised reasons that, moreover, regard the suspect's conduct. ${ }^{1312}$ There must be a direct link between the particular circumstances of the case, the character of the suspect and the deprivation of liberty. In that respect, the ECtHR attaches considerable importance to the question of how exactly the competent domestic authorities have measured the persistence of the alleged risk of obstruction of justice. The following aspects may play a role in this respect: the advancement of the investigation or judicial proceedings, the suspect's personality, his behaviour before and after the arrest, and any other specific indications justifying the fear that

1308 Aleksandr Makarov v. Russia, appl. no. 15217/07, 12 March 2009, §129.

1309 Mamedova v. Russia, appl. no. 7064/05, 1 June 2006, §79.

1310 Letellier v. France, appl. no. 29/1990/220/282, 26 June 1991, §39; Czarnecki v. Poland, appl. no. 75112/01, 28 July 2005, §41.

1311 Clooth v. Belgium, appl. no. 12718/87, 12 December 1991, §43.

1312 Clooth v. Belgium, appl. no. 12718/87, 12 December 1991, §41. According to the government, $\mathrm{Mr}$ Clooth contributed considerably to rendering the facts more complicated by the number and changing nature of his statements. By repeatedly obliging the investigators to undertake new inquiries, he bore a large part of the responsibility for the length of the investigation. The atrociousness of the crimes in question [murder of a young girl] led them to leave no avenue unexplored, as was shown by the voluminous criminal file, which contained more than 350 reports and notes. Furthermore, it was necessary to pre-empt any attempt at collusion or intimidation of witnesses. See, also, decision as to the admissibility in Ramishvili and Kokhreidze v. Georgia, appl. no. 1704/06, 27 June 2007; Patsuria v. Georgia, appl. no. 30779/04, 6 November $2007, \S 71$. 
the suspect might abuse his regained liberty by carrying out acts aimed at falsification or destruction of evidence or manipulation of witnesses. ${ }^{1313}$

In Lyubimenko v. Russia, the ECtHR has, furthermore argued that in cases concerning organised crime, the risk that a suspect, if released, might put pressure on witnesses or might otherwise obstruct the proceedings, is often particularly high. That can justify a relatively longer period of pre-trial detention. However, it does not give the authorities unlimited power to extend the detention. ${ }^{1314}$ In Popov and Vorobyev v. Russia, the ECtHR followed the same line of reasoning with respect to criminal conspiracy. ${ }^{1315}$ However, in that case there was, besides from the seriousness of the criminal offence, no indication that the applicants had made any attempts to intimidate witnesses or to obstruct the course of the proceedings in any other way. In such circumstances, the ECtHR did not accept the allegation that there was a risk of interference with the administration of justice, even if the suspect was charged with criminal conspiracy. ${ }^{1316}$

\subsubsection{The need to prevent crime $e^{1317}$}

Continued pre-trial detention may, thirdly, also be justified by the need to keep a suspect from committing further criminal offences. In Assenov v. Bulgaria, the applicant was charged with sixteen or more burglaries and robberies, the latter involving some violence. Although he had been questioned in connection to this series of thefts prior to his arrest, a number of the offences with which he was charged were committed after these preliminary interrogations; the last robbery having taken place just three days before his arrest. ${ }^{1318}$ Also, it was not the first time that he was in trouble with the police. ${ }^{1319}$

The ECtHR argued that the national authorities were not unreasonable in fearing that the applicant might reoffend if released. The fact that the suspect had already committed several criminal offences of the same serious and moreover violent nature, even after previous contacts with law enforcement agencies concerning these offences, therefore justified the government's assumption that there was a risk of recidivism. ${ }^{1320}$

\footnotetext{
1313 Aleksandr Makarov v. Russia, appl. no. 15217/07, 12 March 2009, §130.

1314 Lyubimenko v. Russia, appl. no. 6270/06, 19 March 2009, §73. See, also, Osuch v. Poland, appl. no. 31246/02, 14 November 2006, §26; Celejewski v. Poland, appl. no. 17584/04, 4 May 2006, §37-38; Popov and Vorobyev v. Russia, appl. no. 1606/02, 23 April 2009, §82.

1315 Popov and Vorobyev v. Russia, appl. no. 1606/02, 23 April 2009, §82.

1316 Popov and Vorobyev v. Russia, appl. no. 1606/02, 23 April 2009, §82.

1317 Compare with Article 67a, sections 2 under 2 and 3 of the DCCP.

1318 Assenov v. Bulgaria, appl. no. 90/1997/874/1086, 28 October 1998, §32-50.

1319 Assenov v. Bulgaria, appl. no. 90/1997/874/1086, 28 October 1998, $\S \S 151$.

1320 Compare with Knebl c. République Tchèque, requête no 20157/05, 28 octobre 2010, §66.
} 
In Muller v. France, the applicant had been kept in pre-trial detention for four years, on suspicion of armed robbery. The government primarily justified the detention with reference to several antecedents regarding the suspect's behaviour. The ECtHR underlined that as far as the danger of reoffending is concerned, a mere reference to a person's antecedents cannot suffice on itself to justify a refusal to release a suspect while he awaits his trial. ${ }^{1321}$ There must be specific and substantiated evidence to adequately demonstrate a danger of reoffending. ${ }^{1322}$ Again, general references such as to the serious nature of a criminal offence, do not suffice in this respect. ${ }^{1323}$

Furthermore, the ECtHR attaches considerable weight to the factual course of the domestic proceedings leading to a suspect's deprivation of liberty. More specifically, the ECtHR examines how the pros and cons have been weighted against each other, and how the facts have been valued at domestic level, without however, doubting those facts as such. The ECtHR has underlined time and again that it has no individual fact finding task in these matters. Its working scope is limited to examining facts brought forth by an applicant and a respondent government in light of the rights and freedoms comprised in the ECHR. ${ }^{1324}$ This clarifies, in part, why the ECtHR demands that justifications for continued pre-trial detention be substantiated with clear, precise and individualised arguments and circumstances, which moreover, explicitly concern a suspect's personality, circumstances and (criminal) history. ${ }^{1325}$

\subsubsection{The need to preserve public order ${ }^{1326}$}

The case of Letellier v. France $e^{1327}$ is one of the leading judgements regarding the question of whether the need to protect public order can justify a suspect's continued

1321 Muller v. France, appl. no. 21802/93, 17 March 1997, §43 and 44. See, also, Lyubimenko v. Russia, appl. no. 6270/06, 19 March 2009, §74.

1322 Muller v. France, appl. no. 21802/93, 17 March 1997, §43: '(...) the Court notes that it is not apparent from the decisions not to release the applicant that there was a real risk of his absconding. Although such a danger may exist where the sentence faced is a long term of imprisonment, the Court points out that the risk of absconding cannot be gauged solely on the basis of the severity of the sentence faced'.

1323 Lind v. Russia, appl. no. 25664/05, 6 December 2007, §75-77.

1324 Czarnecki v. Poland, appl. no. 75112/01, 28 July 2005, §38.

1325 Erkalo v. the Netherlands, appl. no. 89/1997/873/1085, 2 August 1998, §35 and 55.

1326 Compare with Article 67a, section 1 under b of the DCCP.

1327 Letellier v. France, appl. no. 29/1990/220/282, 26 June 1991. In X. v. the United Kingdom, appl. no. 7215/75, 5 November 1981, the ECtHR clearly afforded Member States a certain margin of appreciation in respect of applying the principle of 'lawfulness' entailed in Article 5, section 1 under c ECHR. In $\S 41$ the ECtHR asserts that: 'The object and purpose of Article 5 par. 1 is precisely to ensure that no one should be deprived of his liberty in an arbitrary fashion; consequently, quite apart from conformity with domestic law, 'no detention that is arbitrary can ever be regarded a 'lawful'. Whilst the Court undoubtedly has the jurisdiction to verify the fulfillment of these conditions in a given case, the logic of the system of safeguard established 
pre-trial detention. The applicant in this case, who was suspected of having hired two persons to kill her ex-husband, had been kept in pre-trial detention for two years and nine months. ${ }^{1328}$ The investigative authorities justified this with reference to: (1) a risk of her absconding, and (2) the fact that public order would be gravely disturbed upon the applicant's release. This assumption was primarily based on the gravity of the criminal offence - murder. ${ }^{1329}$

The former Commission interpreted the concept of 'public order' similarly to the notion of 'public opinion', and argued that 'the danger of such a disturbance, which it understood to mean disturbance of public opinion, following the release of a suspect, cannot derive solely from the gravity of a crime or the charges pending against the person concerned.' In order to determine whether there is a danger of disturbing public opinion/order, it is necessary to take account of other factors, such as the possible attitude and conduct of the accused/suspect once released. ${ }^{1330}$

Both the former Commission and the ECtHR contend that the gravity of the offence is insufficient to demonstrate that public order will be disturbed when a suspect is released. There needs to be an additional element relating to the person of the suspect, and more specifically, to his potential conduct after release. However, the ECtHR does acknowledge that 'by reason of their particular gravity and public reaction to them, certain offences may give rise to a social disturbance capable of justifying pre-trial detention, at least for a time.' So, in exceptional circumstances the gravity of an offence may, temporarily, therefore be taken into account for the purposes of the ECHR, provided that (1) domestic law recognises the notion of disturbance to public order caused by an offence, and (2) it is based on facts capable of showing that the suspect's release would actually disturb public order. ${ }^{1331}$ Furthermore, pre-trial detention will continue to be legitimate only if public order remains actually disturbed. Continued pre-trial detention cannot, hence, be used to anticipate a custodial sentence. ${ }^{1332}$

Summarising, states may place a suspect of an exceptionally grave offence - such as a terrorist offence - in pre-trial detention with reference to an expected disturbance of public order, but only when the investigative authorities can

by the Convention places limits on the scope of this control; since the national authorities are better placed to evaluate the evidence adduced before them, they are to be recognised as having a certain discretion in the matter and the Court's task is limited to reviewing under the Convention the decisions they have taken'.

1328 Letellier v. France, appl. no. 29/1990/220/282, 26 June 1991, §8-10.

1329 Letellier v. France, appl. no. 29/1990/220/282, 26 June 1991, §48.

1330 Letellier v. France, appl. no. 29/1990/220/282, 26 June 1991, §49.

1331 Letellier v. France, appl. no. 29/1990/220/282, 26 June 1991, §51. And see Aleksandr Makarov v. Russia, appl. no. 15217/07, 12 March 2009, §136-137; Jiga c. Roumanie, requête no 14352/04, 16 mars 2010, §76; decision as to the admissibility in Hendriks $v$. the Netherlands, appl. no. 43701/04, 5 July 2007.

1332 Letellier v. France, appl. no. 29/1990/220/282, 26 June 1991, §51. 
demonstrate that the suspect's release will actually disturb public order due to the nature of the offence and the person of the suspect. With respect to the latter aspect, the investigative authorities will have to predict, to a certain extent, the suspect's conduct upon release. Any claim that a suspect's release will cause public disorder must therefore be backed up with relevant and sufficiently individualised facts and circumstances. ${ }^{1333}$ It is, furthermore, important to note that the need to preserve public order will diminish once the initial shock caused by a grave criminal offence, has disappeared. The longer a suspect of such an offence is kept in pre-trial detention, the more difficult it will get for domestic authorities to use an impending disturbance of the public order as justification for that detention. Additional justifications for a suspect's deprivation of liberty will then have to be adduced.

In Letellier v. France, family members of the victim had declared not to be against the release of the applicant. The murder with which the applicant was charged was, as such, furthermore insufficient to justify pre-trial detention. Anticipating a custodial sentence is not permitted as justification. In light of these considerations, and due to lack of a further sufficient and relevant justification for the applicant's deprivation of liberty, the ECtHR concluded that Article 5 of the ECHR had been violated.

In the decision of Kanzi v. the Netherlands and in the decision of Hendriks v. the Netherlands, the ECtHR underlined that the extent to which the commission of an offence has attracted or been given publicity can play a role, though no decisive role, in the domestic determination of the possible 'disturbance to public order'. The passage of time will, however, generally weaken the justification of pre-trial detention based on such considerations. ${ }^{1334}$

If one compares these two decisions with the case of Letellier v. France, it may be assumed that the length of the pre-trial detention considerably influences the question of the extent to which the grounds invoked to justify the detention, may legitimise the detention. The longer pre-trial detention lasts, the more convincing the grounds used to justify that detention must become, also when it concerns severe criminal offences.

\footnotetext{
1333 See, also, Tarău c. Romanie, requête no 3584/02, 24 février 2009, §47-52.
}

1334 Decision as to the admissibility in Kanzi v. the Netherlands, appl. no. 28831/04, 5 July 2007; decision as to the admissibility in Hendriks $v$. the Netherlands, appl. no. 43701/04, 5 July 2007. In both cases, the ECtHR declared the complaints inadmissible. Most likely, this ass in part due to the fact that the length of the pre-trial detention was relatively limited ( 3 months and 7 days and 5 months and thirty days, respectively). Furthermore with respect to the decision of Kanzi $v$. the Netherlands, the diligence with which the criminal proceedings had been conducted, the fact that it concerned drug trafficking and the serious objections against the applicant, may have played a role. 


\subsubsection{Alternative measures}

In its case law, the ECtHR has repeatedly emphasised that domestic authorities, when deciding whether a suspect should be released or detained, have an obligation under Article 5, section 3 of the ECHR, to consider alternative measures of ensuring a suspect's appearance at the trial. ${ }^{1335}$ This obligation reflects the Strasbourg point of view that release pending trial is the rule, and pre-trial detention the exception. Non-compliance with this obligation, or insufficient deliberation by the domestic authorities on the reasons why alternative measures would not be effective in the specific circumstances of a case, may considerably contribute to finding a violation of Article 5, section 3 of the ECHR. ${ }^{1336}$ By obliging domestic authorities to consider such alternatives instead of automatically depriving suspects of their liberty, the ECtHR forces Member States to examine intended pre-trial detention on compatibility with the principles of proportionality and subsidiarity. ${ }^{1337}$

In Wemhoff v. the Federal Republic of Germany, the ECtHR argued, in this respect, that it 'wishes however, to emphasise that the concluding words of Article 5 (3) of the Convention show that, when the only remaining reasons for continued detention is the fear that the accused will abscond and thereby subsequently avoid appearing for trial, his release pending trial must be ordered if it is possible to obtain from him guarantees that will ensure such appearance. ${ }^{1338}$

Alternative measures may, for instance, be a written undertaking, bail, a duty to report periodically to the police headquarters, or an obligation to wear an electronic tag. ${ }^{1339}$ In this respect, it is important to note that these measures may only be imposed, as long as reasons justifying detention prevail. When such reasons do

1335 Aleksandr Makarov v. Russia, appl. no. 15217/07, 12 March 2009, §138; Popov and Vorobyev v. Russia, appl. no. 1606/02, 23 April 2009, §85; Jiga c. Roumanie, requête no 14352/04, 16 mars 2010, §79; Jabłoński c. Pologne, requête no 33492/96, 21 décembre 2000, §83-84; Goroshchenya v. Russia, appl. no. 38711/03, 22 April 2010, §89; Knebl c. République Tchèque, requête no 20157/05, 28 octobre 2010, §67; Czarnecki v. Poland, appl. no. 75112/01, 28 July 2005, §42; Patsuria v. Georgia, appl. no. 30779/04, 6 November 2007, §75-77; Lind v. Russia, appl. no. 25664/05, 6 December 2007, §82-84.

1336 Tarău c. Romanie, requête no 3584/02, 24 février 2009, §47 and 50-51. And, see, Popov and Vorobyev v. Russia, appl. no. 1606/02, 23 April 2009, §87, where the ECtHR considered that: '(...) the Court considers that by failing to address specific facts or consider alternative 'preventive measures' and by relying essentially on the gravity of the charges, the authorities extended the applicants' detention on grounds which, although 'relevant', cannot be regarded as 'sufficient' to justify its duration (...)'. See, also, Moskovets v. Russia, appl. no. 14370/03, 23 April 2009, §87; Jiga c. Roumanie, requête no 14352/04, 16 mars 2010, §79; Goroshchenya $v$. Russia, appl. no. 38711/03, 22 April 2010, §91; Patsuria v. Georgia, appl. no. 30779/04, 6 November 2007, §77; Lind v. Russia, appl. no. 25664/05, 6 December 2007, §84-86. See, in this respect, W. v. Switzerland, appl. no. 14379/88, 26 January 1993, §33.

Wemhoff v. the Federal Republic of Germany, appl. no. 2122/64, 27 June 1968, §15.

Compare with Article 80 of the DCCP which empowers courts to set bail instead of placing a suspect in pre-trial detention. In practice, the possibility of setting bail pursuant to Article 80 of the DCCP is never used. 
prevail, the scope of the measures must be assessed principally in relation to the person concerned and his assets. ${ }^{1340}$

In Mangouras v. Spain, the ECtHR considered that 'its [bail, KV] amount must therefore be assessed principally by reference to the accused, his assets and his relationship with the persons who are to provide the security, in other words to the degree of confidence that is possible that the prospect of loss of the security or of action against the guarantors in case of his non-appearance at the trial will act as a sufficient deterrent to dispel any wish on his part to abscond'. ${ }^{1341}$ The domestic authorities must take as much care in fixing appropriate bail as in deciding whether or not the suspect's continued detention is indispensable. ${ }^{1342}$

The obligation for domestic authorities to consider alternative measures for pre-trial detention should be considered in light of the above-discussed grounds. In Bordikov v. Russia, the ECtHR considered that 'in the particular circumstances of the case, a substantial risk of the applicant's absconding persisted throughout his detention and [the ECtHR therefore] accepts the domestic courts' finding that no other measures to secure his presence would have been appropriate'. ${ }^{1343}$ In this case, the investigation had been suspended for almost three years when the applicant failed to appear for questioning and the authorities could not establish his whereabouts. Under such specific circumstances, alternative measures will not be effective.

\subsection{In sum}

Even though the ECtHR's interpretation of the grounds capable of justifying continued pre-trial detention depends on the specific circumstances of the case, there are a number of guidelines that apply to all of the above-discussed grounds.

Firstly, the ECtHR has emphasised time and again, that suspects must, if possible, be released pending trial. Pre-trial detention, if considered necessary, must comply with the principles of proportionality and subsidiarity. That implies that alternative measures should be considered prior to holding a suspect in pre-trial detention. In this respect, it is also important to stress the fact that any system of mandatory detention pending trial is incompatible per se with Article 5, section 3 of

\footnotetext{
1340 Aleksandr Makarov v. Russia, appl. no. 15217/07, 12 March 2009, §139.

1341 Mangouras v. Spain, appl. no. 12050/04, 28 September 2010, §78-93. In this case the ECtHR concluded that ' $(. .$.$) the domestic courts, in fixing the amount of bail, took sufficient account of$ the applicant's personal situation, and in particular his status as an employee of the ship's owner, his professional relationship with the persons who were to provide the security, his nationality and place of permanent residence and also his lack of ties in Spain and his age. In view of the particular context of the case and the disastrous environmental and economic consequences of the oil spill, the courts were justified in taking into account the seriousness of the offences in question and the amount of the loss imputed to the applicant (...)'.

1342 Mangouras v. Spain, appl. no. 12050/04, 28 September 2010, §79.

1343 Bordikov v. Russia, appl. no. 921/03, 8 October 2009, §92-93.
} 
the ECHR. Domestic authorities must establish and demonstrate the existence of concrete facts outweighing the rule of respect for individual liberty. ${ }^{1344}$

Secondly, domestic authorities need to demonstrate specific and individualised circumstances regarding a suspect, his conduct and personality, when deciding whether or not to keep him in pre-trial detention. This means that the investigative authorities must explicitly take into account a suspect's private life and personal circumstances as well. ${ }^{1345}$ General, abstract or declaratory considerations that are not clearly sustained by the specific circumstances of a case, cannot serve as adequate justification in this respect. ${ }^{1346}$ This also implies that the (serious) nature of the criminal offence of which a person is suspected or the severe sentence that may be imposed, is insufficient to justify continued pre-trial detention. ${ }^{1347}$

Thirdly, the longer pre-trial detention lasts, the more relevant and sufficient the grounds used to legitimise the detention must become - in substance as well as in number. In most cases, reference to, for example, a risk of the suspect interfering with the course of justice may be accepted during the first stages of pre-trial detention, but ceases to be relevant as detention continues. States are then obliged to either release the suspect or demonstrate additional grounds.

Fourthly, all of the four above-discussed grounds presuppose a close and, moreover, demonstrable, link between: (1) the specific personal circumstances of a case and a suspect, (2) domestic law, and (3) the factual circumstances that the competent authorities use to justify the deprivation of liberty.

1344 Moskovets v. Russia, appl. no. 14370/03, 23 April 2009, §83; Belevitskiy v. Russia, appl. no. 72967/01, 1 March 2007, §102.

1345 Lyubimenko v. Russia, appl. no. 6270/06, 19 March 2009, §76.

1346 Aleksandr Makarov v. Russia, appl. no. 15217/07, 12 March 2009, §119; Tarău c. Romanie, requête no 3584/02, 24 février 2009, §45; decision as to the admissibility in Ramishvili and Kokhreidze v. Georgia, appl. no. 1704/06, 27 June 2007; Nikolov v. Bulgaria, appl. no. 38884/97, 30 January 2003, §73.

1347 See, in this respect, specifically Aleksandr Makarov v. Russia, appl. no. 15217/07, 12 March 2009, §122; Polonskiy v. Russia, appl. no. 30033/05, 19 March 2009, §155-156, where the ECtHR underlined the fact ' $(. .$.$) that it has frequently found a violation of Article 5 \S 3$ of the Convention in Russian cases where the domestic courts extended an applicant's detention relying essentially on the gravity of the charges and using stereotyped formulae without addressing specific facts or considering alternative preventive measures (...)'. See, also, Moskovets v. Russia, appl. no. 14370/03, 23 April 2009, §86; Belevitskiy v. Russia, appl. no. 72967/01, 1 March 2007, §99 and further; Khudobin v. Russia, appl. no. 59696/00, 26 October 2006, §103 and further; Mamedova v. Russia, appl. no. 7064/05, 1 June $2006 \$ 72$ and further; Dolgova v. Russia, appl. no. 11886/05, 2 March 2006, 338 and further; Khudoyorov v. Russia, appl. no. 6847/02, 8 November 2005, §172 and further; Rokhlina v. Russia, appl. no. 54071/00, 7 April 2005, §63 and further; Panchenko v. Russia, appl. no. 45100/98, 8 February 2005, §91 and further; Smirnova v. Russia, appl. nos. 46133/99 and 48183/99, 24 July 2003, §56 and further. 
The above-discussed obviously implies that judicial control during the pre-trial period has a broader scope than judicial control during the arrest period. In McKay v. the United Kingdom, the ECtHR underlined that domestic courts are under an obligation to review the continued detention of persons pending trial, with a view to ensuring release when circumstances no longer justify continued deprivation of liberty. ${ }^{1348}$ This judicial control not only encompasses an examination of the reasonable suspicion, but also of the grounds used to justify the deprivation of liberty. ${ }^{1349}$ The longer pre-trial detention lasts, the more justifications there must be, and the broader the scope of judicial review must consequently be. 


\section{Chapter VII Serious ObJections}

\section{INTRODUCTION}

This chapter discusses the most demanding suspicion criterion during the pre-trial phase, that of 'serious objections'. Contrary to the reasonable suspicion criterion, the notion of serious objections is not, as such, defined in the DCCP, but it occurs in various provisions as one of the prerequisites for the application of coercive/ investigative powers. For example, serious objections are required to frisk a suspect, to force a suspect to hand over DNA samples or to place a suspect under remand in custody.

With respect to pre-trial deprivation of liberty of a terrorist suspect, serious objections only start to play a role in the case of detention on remand [gevangenhouding/gevangenneming], the last phase of pre-trial detention. This is due to the fact that, as discussed in the previous chapter, the system of pre-trial detention is different for terrorist suspects when it comes to the prerequisites for remand in custody: To place a 'common suspect' under remand in custody, serious objections are required, but in the case of a terrorist suspect, this requirement has been dropped by enactment of Article 67, section 4 of the DCCP. Hence, when it comes to terrorist suspects, detention on remand is the only coercive measure, implying deprivation of liberty, for which the investigative authorities need to demonstrate serious objections.

The DPTA amended Article 66, section 3 of the DCCP. At present, terrorist suspects may be detained on remand for two years and 90 days, instead of for 90 days as in the case of 'common suspects'. The question arises of whether such an extended term of detention on remand can still be considered compatible with Article 5, section 3 of the ECHR. This Article prescribes that everyone detained pursuant to section 1 under $\mathrm{c}$ is entitled to trial within a reasonable time. The key question discussed in this Chapter is how the ECtHR interprets the notion of reasonable, and what role the so-called 'special diligence requirement' plays in this respect? What circumstances determine whether or not the investigative authorities conducted a criminal investigation with the required special diligence? Does the fact that it concerns a suspicion of a terrorist offence offer more leeway when it comes to this requirement, and consequently to the reasonableness of the length of pre-trial deprivation of liberty?

As result of the extended term of detention on remand for terrorist suspects, potential restrictions on such suspects' rights during the pre-trial phase apply for an equally longer period. One of the restrictions that may be imposed is that of 
temporarily denying the suspect access to part of the case file pursuant to Article 30, section 2 of the DCCP. Access to the whole case file is of crucial importance when a suspect wants to lodge proceedings by which the lawfulness of his pre-trial detention is examined in accordance with Article 69 or Article 71 of the DCCP.

The question that will be examined below is how the extended term during which terrorist suspects may be denied access to part of the case file affects their right to lodge proceedings by which the lawfulness of the pre-trial detention is decided on. Article 5, section 4 of the ECHR obliges states to provide an effective system of such habeas corpus proceedings. In order to effectively enforce the right to lodge a habeas corpus complaint, the suspect and the competent court need to know on the basis of which information the suspect is held in pre-trial detention. What requirements does the ECtHR set for habeas corpus proceedings under Article 5, section 4 of the ECHR, and what role does Article 6 of the ECHR play during these proceedings? Does the ECtHR place proceedings under Article 5, section 4 of the ECHR on the same footing as proceedings under Article 6 of the ECHR? To what extent do habeas corpus proceedings need to be adversarial and in compliance with the principle of equality of arms, including the right to have access to one's case file? Does a suspect need to have full access to the case file in order for proceedings under Article 5, section 4 of the ECHR to be Strasbourg conforming? And what role - if any - does the fact that it regards investigations into terrorist offences, play in that respect? Can defence rights of terrorist suspects to a more farreaching extent be interfered with during habeas corpus proceedings than when it would regard a common suspect?

In order to answer all of these questions, the following issues will be analysed in this chapter. Firstly, Section 2 elaborates on the notion of serious objections as a precondition for the application of various coercive/investigative powers during the pre-trial phase. Then, the system of detention on remand for terrorist suspects is examined in Section 3. Next, the extended period during which terrorist suspect's can be denied access to the case file compared to 'common suspects' is scrutinised in Section 4.

Subsequently, Sections 5 and 6 concern the Strasbourg perspective. Firstly, the scope of Article 5, section 3 of the ECHR is discussed as regards to the reasonableness of the length of pre-trial detention in light of the special diligence requirement. Secondly, Section 6 examines the scope of the right for suspects in pre-trial detention to lodge a habeas corpus complaint. In this respect, the focus will primarily be on the importance for a suspect to have access to the case file when lodging a habeas corpus complaint. 


\section{Serious OBJECtions}

\section{INTRODUCTION}

During criminal proceedings, the most demanding suspicion criterion within the DCCP is that of 'serious objections'. Basically, the notion of serious objections implies a heightened level of suspicion against a person compared to other suspicion criteria, such as the one comprised in Article 27 of the DCCP. ${ }^{1350}$ Some authors contend that the criterion of serious objections requires that it must be probable that the suspect committed the offence. ${ }^{1351}$ Others refer to the criterion as a more solid form of a suspicion than a mere reasonable suspicion. ${ }^{1352}$ Reijntjes considers serious objections foremost as an 'instructing standard' that serves to keep the public prosecutor from requiring, and the investigative judge from ordering, too easily a suspect's remand in custody. ${ }^{1353}$

Irrespective of how one interprets the criterion of serious objections, this criterion and the powers attached to it clearly reflect the correlation between: (1) the far-reachingness of coercive/investigative powers, (2) the scope of the criteria of application for such powers, and (3) the competent authority for ordering/applying the powers. Generally, the more intrusive a coercive/investigative power is and/or the longer it is applied, the higher the competent authority is, and the more solid the justifications must be to legitimise the application of such powers. ${ }^{1354}$

Reijntjes argues that in the case of serious crimes and crimes that are difficult to prove, serious objections may, more easily, on the basis of less information, be assumed than in the case of simple, frequently recurring criminal offences. ${ }^{1355}$ This

1350 Supreme Court 8 February 2011, LJN: BO9823, 09/01078; Supreme Court 15 June 1982, LJN: AC4196, 73928.

1351 C.P.M. Cleiren, J.F. Nijboer, Tekst \& Commentaar Strafvordering, Kluwer, Deventer 2009, achtste druk, p. 281. See, Middelburg District Court 24 December 2010, LJN: BP1091, 12/715499-10; Maastricht District Court 14 September 2010, LJN: BN8121, 03/700459-10; Leeuwarden District Court 2 May 2007, LJN: BA4744, 17/880141-07; Amsterdam District Court 21 July 2009, LJN: BJ4828, 13/410256-09.

1352 J.M. Reijntjes, Artikel 67, in A.L. Melai and M.S. Groenhuijsen e.a., Het Wetboek van Strafvordering, voortgezet onder redactie van M.S. Groenhuijsen, Th.A. de Roos, A.H.J. Swart en F.G.H. Kristen, Kluwer, Deventer, losbladig.

1353 J.M. Reijntjes, Artikel 67, in A.L. Melai and M.S. Groenhuijsen e.a., Het Wetboek van Strafvordering, voortgezet onder redactie van M.S. Groenhuijsen, Th.A. de Roos, A.H.J. Swart en F.G.H. Kristen, Kluwer, Deventer, losbladig.

1354 Leeuwarden District Court 3 January 2007, LJN: AZ5681, 17/880370-06 RDK; Leeuwarden District Court 20 March 2000, LJN: AA5299, 17/080242-99.

1355 Compare with NJ 1997/441, Supreme Court 18 February 1997 in which judgement the AttorneyGeneral reasoned that the notion of serious objections does not only refer to the degree of suspicion against a suspect, but also relates to the seriousness of the criminal offence. Thus, if a person is suspected of a weapons related offence (as was the case in this judgement) or a terrorist offence, serious objections will easier be established than in case of a simple burglary. 
would imply that in the case of a suspicion of a 'hard-to-prove-crime', the investigative authorities may, for example, deprive a suspect more easily of his liberty than in the case of an 'easy-to-prove-crime'. One may wonder whether that should not be the other way around? The harder a criminal offence can be proven, the less easily coercive measures should be open for application. ${ }^{1356}$

Reijntjes also contends that the requirement of serious objections in the case of less intrusive coercive measures, such as a body search pursuant to Article 56 of the DCCP, ${ }^{1357}$ is more easily fulfilled than in the case of more intrusive coercive measures, such as remand in custody/detention on remand. That would mean that within the concept of serious objections there are several possible interpretations, depending on the intrusiveness of the coercive measure that has been applied. In various judgements, the Judiciary has underlined that the notion of serious objections has one meaning, even if it forms a statutory requirement for different coercive measures. ${ }^{1358}$ In the upcoming sections I will consider serious objections as one concept, with one meaning, irrespective of the powers it aspires to legitimise.

Reijntjes summarises his remarks on the notion of serious objections as follows: (1) the greater the public interest in the investigation is, the less well-substantiated serious objections may be, and (2) the more important the interest of the suspect is, the graver the serious objections against the suspect must be. This reasoning appears self-contradictory: investigations into, for example, alleged terrorist offences will always be of the highest (public) interest. This would then justify the application of coercive/investigative powers on the basis of less well-substantiated serious objections against the suspect. However, the interest of a terrorist suspect in keeping his liberty or in not being subjected to body searches is considerably high, particularly if he has already been placed under remand in custody or subjected to a search on the mere basis of a 'light' reasonable suspicion.

\section{CASE LAW ON SERIOUS OBJECTIONS: AN INTRODUCTION}

Case law demonstrates that 'serious objections' are established on the basis of the same kind of facts and/or circumstances as a 'reasonable suspicion'. There is hence only a difference in degree between these two suspicion criteria. Just as with respect to the reasonable suspicion criterion, whether or not there are serious objections depends on the specific circumstances of the case, which makes the concept casuistic in nature. Case law does not always succeed in clarifying under which circumstances there are serious objections. First of all, this is due to the fact that the decisions of investigative judges regarding requests for remand in custody are not

\footnotetext{
1356 Leeuwarden District Court 3 January 2007, LJN: AZ5681, 17/880370-06 RDK.

1357 Reijntjes also mentions DNA-investigations pursuant to Article 195d of the DCCP.

1358 Rotterdam District Court 15 March 2001, LJN: AB0563; Haarlem District Court 1 August 2006, LJN: AY5781; Supreme Court 17 February 2004, NJ 2004/332.
} 
published. ${ }^{1359}$ If remand in custody is rejected due to a lack of serious objections against the suspect, the reasons for that decision will only become public if the public prosecutor decides to file an appeal against the investigative judge's decision. ${ }^{1360}$ And even then, these reasons are often not examined extensively. Judgements of District Courts/Courts of Appeal deciding on the lawfulness of detention on remand or on complaints about allegedly unlawfully applied coercive powers, do not always provide clarification as to the question of why there were (no) serious objections against the suspect. ${ }^{1361}$

Serious objections is a criterion for the application of various coercive/investigative powers, like a body search or the taking of DNA samples against the suspect's will. It is, furthermore, a precondition for remand in custody (only regarding common offences) and for detention on remand. Most case law that explicitly goes into the scope of serious objections regarding the application of the first-mentioned coercive measures. The case law that will be discussed below therefore regards, primarily, judgements on alleged unlawful body searches and DNA investigation. When an investigative judge rejects an order for remand in custody, this is frequently rather caused by a lack of sufficient and relevant grounds for remand in custody - as required by Article 67a of the DCCP - than by lack of information to demonstrate serious objections. ${ }^{1362}$

1359 Generally, the investigative judge examines the following aspects while deciding on a request for remand in custody: (1) all of the available incriminating evidence on a suspect's account against the evidence which points in the direction of the suspect's innocence, (2) the suspect's personal interests, (3) the question whether it is likely that more incriminating evidence will arise during the suspect's continued deprivation of liberty, and (4) the grounds for remand in custody as enumerated in Article 67a of the DCCP. See, Utrecht District Court 15 May 2007, LJN: BA5177, 16/600491-07; Hague District Court 21 November 2007, LJN: BB8481, 09/750006-06; Leeuwarden District Court 8 August 2007, LJN: BB1908, 17/880180-07; the Hague District Court 7 December 2007, LJN: BC0029, 297765.

1360 See Article 64, section 3 DCCP. Middelburg District Court 24 December 2010, LJN: BP1091, 12/715499-10.

1361 See Utrecht District Court 19 November 2009, LJN: BK5248, 16/6000905-08; the Hague District Court 7 December 2007, LJN: BC0113, 298645; Haarlem District Court, 28 March 2008, LJN: BC9324, 15/751650-06; Maastricht District Court, 8 December 2003, LJN: AO1048, 03/005799-03 and Utrecht District Court 25 November 2009, LJN: BK5244, 16/711031-08; Supreme Court 24 April 2007, LJN: AZ8411, 02141/05; Rotterdam District Court 31 December 2002, LJN: AF2579, 10/000109-02; Amsterdam District Court 17 November 2009, LJN: BK4842, 13/421052-09; Amsterdam Court of Appeal 2 July 2008, LJN: BE8345; Almelo District Court 9 August 2000, LJN: AA6740, 08/000120-00.

1362 See, for example, Utrecht District Court 4 December 2006, LJN: AZ4177; Supreme Court 16 November 2004, LJN: AR3264; Amsterdam District Court 23 June 2004, LJN: AP3499. See the previous chapter for a discussion of the grounds required for remand in custody/detention on remand. 
As discussed in the previous chapter, a reasonable suspicion pursuant to Article 27 of the DCCP, may be based on one anonymous tip-off, certainly when it concerns alleged terrorist offences. ${ }^{1363}$ To generate serious objections, that tip-off must be supplemented with additional information like a bona fide witness statement, factual incriminating circumstances, such as the possession of weapons or drugs or a confession from the suspect. ${ }^{1364}$ Such additional information must be of considerable importance. ${ }^{1365}$ For example, RCIE information that cannot be examined on its reliability, combined with the fact that a suspect of multiple armed robberies kept in close contact with another suspect of those armed robberies, is insufficient to demonstrate serious objections. ${ }^{1366}$ A considerably detailed anonymous tip-off that could not, however, be examined on its reliability, combined with the fact that the person concerned was present in a building in which drug addicts and dealers lived, was not sufficient to generate serious objections. ${ }^{1367}$

There are several judgements concerning (alleged lack of) serious objections regarding the tracking down of drug runners at Schiphol Airport. The investigative authorities regularly use sniffer-dogs to that end. When a sniffer-dog reveals an alleged drug runner, the Judiciary considers this fact as adequate basis for denoting this person as a suspect pursuant to Article 27 of the DCCP. However, to demonstrate serious objections against the suspect, there must be additional incriminating circumstances or information. For example, the fact that the suspect has a peculiar thickening in his trousers, which appears to be an often used hiding place for drugs, may contribute to generate serious objections. ${ }^{1368}$

In a comparable case, although not regarding drug runners, an investigative judge followed the same line of reasoning. The mere fact that a person attended a dance event that was known for its drug related activities, in combination with the fact that that person reached in his pocket upon seeing the police, was insufficient to demonstrate serious objections. The investigative judge considered that a

1363 This is dependent on the content (concreteness) of the information and the possibility verifying the reliability of the information, see Supreme Court 11 March 2008, LJN: BB7662, 02752/06, m.nt. M.J. Borgers. See, also, P.W. van der Kruijs, 'Het vereiste van een redelijk vermoeden op basis van anonieme informatie in het bijzonder bij terroristische misdrijven', in Strafblad, SDU uitgevers 2004, afl. 4, pp. 255-271.

1364 G.J.M. Corstens, Het Nederlands strafprocesrecht, 5de druk, Kluwer, p. 386. See, also, Leeuwarden District Court 9 May 2007, LJN: BA 4744; Supreme Court 14 February 2006, LJN: AU8064, 00333/05; Rotterdam District Court 31 December 2002, LJN: AF2579, 10/000109-02.

1365 Amsterdam Court of Appeal 23 February 2009, LJN: BH3912, 23-006605-07; Amsterdam District Court 23 October 2003, LJN: AM2870, 13/077060-03; Maastricht District Court 11 August 2010, LJN: BN4821, 03/700032-10.

1366 Utrecht District Court 13 December 2006, LJN: AZ4257, 16/715077-05.

1367 Maastricht District Court 2 September 2009, LJN: BJ6752, 03-700053-09.

1368 Haarlem District Court 1 August 2006, LJN: AY5781; Supreme Court 24 January 2006, LJN: AU6787; Supreme Court 24 January 2006, LJN: AU6787, 00839/05. 
'collective suspicion' as held with respect to dance events, is not compatible with the individualised suspicion as, incorporated within the Dutch criminal justice system. ${ }^{1369}$ The Arnhem District Court argued that the above-mentioned circumstances were sufficient to generate a reasonable suspicion. Only after the suspect was ordered to hand over the 'thing he put into his pocket', which appeared to be a sachet containing drugs, were there serious objections against the suspect on account of illegal drug possession. ${ }^{1370}$

Police officers' experience regarding ongoing criminal activities in specific areas may contribute to generate serious objections. ${ }^{1371}$ In a case regarding an alleged drug dealer, the Supreme Court ruled the following circumstances sufficient to demonstrate serious objections: (1) it concerned a person known to the police as drug dealer, (2) who was present in a neighbourhood known for its drug trafficking activities, (3) who was in the company of several drug addicts who had money in their hands, and (4) who motioned the drug addicts to leave when he saw two police officers. Next, when the police officers addressed the alleged suspect, they saw him making strange 'tongue-movements' which suggested that he had little balls filled with hard-drugs in his mouth. He tried to swallow these balls upon which the police officers grabbed his throat to prevent this. The alleged suspect resisted heavily. The Supreme Court considered these circumstances to be sufficient to sustain serious objections against the suspect. ${ }^{1372}$

In this respect, it is important to note that the fact that a person is a known drug dealer and drug user or has, for example, been convicted several times for theft or other criminal offences, is insufficient, as such, to demonstrate serious objections. ${ }^{1373}$ There must be additional factual evidence to sustain serious objections, even if the information regarding a person's (former) involvement in, or conviction on account of, drug dealing activities stems from official computerised police systems. ${ }^{1374}$

The prosecution often uses a well-known modus operandi to sustain serious objections. ${ }^{1375}$ For example, among police officers it is known that in Amsterdam drug dealers often deliver drugs to drug addicts' homes. The drugs dealers use bicycles, which they leave unlocked in front of the drug addicts' home. If a person

\footnotetext{
1369 Arnhem District Court 9 December 2004, LJN: AT6878, 05/095205-04.

1370 Compare with Amsterdam District Court 1 December 1976, LJN: AB6907; the Hague District Court 26 November 1981, LJN: AC7417.

1371 's-Hertogenbosch Court of Appeal 14 September 2006, LJN: AY8234, 20-010436-05.

1372 Supreme Court 17 February 2004, LJN: AO1712, 01118/03; Supreme Court 19 January 1999, LJN: ZD1307, 109110; Supreme Court 25 May 2004, LJN: AO6422, 02023/03.

1373 Arnhem Court of Appeal 10 august 2009, LJN: BJ4913, 24-002842-07.

1374 Leeuwarden Court of Appeal 26 October 2010, LJN: BO1912, 24-002166-09.

1375 Zwolle District Court 28 January 2010, LJN: BL3211, 07/400266-09; Zutphen District Court 7 March 2007, LJN: BA0137, 06/460609-06; Supreme Court 28 May 1985, LJN: AC8904, 77947.
} 
informs the police that he regularly sees a man of colour allegedly delivering drugs by bike to address $\mathrm{X}$, and the police actually see a man matching the witness testimony information, that is sufficient to generate serious objections. ${ }^{1376}$

A judgement of the Maastricht District Court demonstrates that investigative authorities are authorised to stop a car with a French number plate driving towards the Belgian border in the middle of the night. This is allowed in light of the fact that it is common knowledge that in Maastricht French 'drug tourists' often violate the OA. In this case, there had, moreover, been complaints by local residents that drug runners were driving it high speed to and from Belgium during the night. Upon stopping one of these cars, the police officers saw two men who looked like drug users, and a woman who held her hand in her crotch. It is common knowledge among the police that women often hide drugs in their crotch. These circumstances considered together could generate serious objections on account of illegal drug use and/or drug trafficking. ${ }^{1377}$

Other circumstances that may contribute to demonstrating serious objections are the notorious nature of a neighbourhood in which a suspect is present, ${ }^{1378}$ the fact that the suspect is in the company of one or more known perpetrators of, for example, drug related offences, suspicious behaviour of a suspect such as running away upon seeing the police, ${ }^{1379}$ or providing the police with a false name, ${ }^{1380}$ the criminal record of a suspect, ${ }^{1381}$ and the suspect's attitude vis-à-vis the investigative authorities during interrogations or at any other moment during the investigation. ${ }^{1382}$

As mentioned before, these circumstances are similar to the facts or circumstances used to demonstrate a reasonable suspicion pursuant to Article 27 of the DCCP. The difference between a reasonable suspicion and serious objections does not, hence, lie in the nature of the information leading to the fulfilment of the respective suspicion criteria, but rather in the amount of, coherence between, such

1376 Amsterdam District Court 21 July 2009, LJN: BJ4828, 13/410256-09. Compare with 's-Hertogenbosch Court of Appeal 14 September 2006, LJN: AY8231, 20-010437-05.

1377 Maastricht District Court 26 August 2008, LJN: BH1170, 03/702958-08.

1378 The fact that a person is present in a neighbourhood where many weapons related offences have been/are committed is, as such, insufficient to demonstrate serious objections against a person present in that neighbourhood after 20.00, see Rotterdam District Court 4 January 2000, LJN: AA4046, 10/101498-99; Supreme Court 28 May 1985, LJN: AC8904, 77947. Zwolle District Court 28 January 2010, LJN: BL3211, 07/400266-09.

1380 Middelburg District Court 9 March 2001, LJN: AB0464, 12/0151179-00.

1381 The Hague District Court 4 November 2010, LJN: BO2992, 09/925777-10; Rotterdam District Court 25 April 2008, LJN: BD0621, 10/710036-08.

1382 See, for example, NJ 2004/332, Supreme Court 17 February 2004. Alleged involvement of a suspect in other, similar, criminal offences cannot substantiate serious objections, see Nederlandse Antillen District Court 30 March 2010, LJN: BM0334, 400.00056/10; the Hague District Court 21 August 2002, LJN: AE6832, 09/757046-02; Amsterdam District Court 23 February 2000, LJN: AA4906, 13/057828-99; Zwolle District Court 28 January 2010, LJN: BL3211, 07/400266-09; Amsterdam Court of Appeal 30 July 2009, LJN: BJ4235, 21-003141-08. 
facts and/or circumstances, and the concreteness of the information. ${ }^{1383}$ In that latter respect, case law shows that there needs to be a clear connection between the suspect, his factual (illegal) conduct and the specific offence(s) he allegedly committed. ${ }^{1384}$ For example, general information that in the past, weapons related offences took place in the vicinity of a casino, combined with the fact that some porters of that casino allegedly possess a weapon, is insufficient to demonstrate serious objections against one of the porters. ${ }^{1385}$ There is no clear connection between that specific porter and the available information.

In sum, even though the notion of serious objections remains, as to its scope and its connection to the reasonable suspicion criterion, to a large extent dependent on the specific circumstances of the case, it does appear to form an extra obstacle for the investigative authorities to apply various (far-reaching) coercive/investigative powers.

There is no case law on how the notion of serious objections is interpreted in the case of terrorist suspects. It is, however, important to take into account that, when it comes to pre-trial deprivation of liberty of terrorist suspects, the investigative authorities have almost 21 days to sustain serious objections. In the case of common suspects that term is considerably shorter, namely six days and 15 hours. Furthermore, when it regards criminal investigations into terrorist offences, the investigative authorities are often provided with secret intelligence information that may be used to demonstrate serious objections. These considerations, combined with the broad criminal liability for terrorist offences, make it unlikely that the investigative authorities will have difficulty in proving serious objections.

\section{DETENTION ON REMAND}

When the order for remand in custody ${ }^{1386}$ expires, the public prosecutor may request the court of first instance, by means of a hearing in chambers [raadkamer], to hold or take the suspect into detention on remand [gevangenhouding/gevangenneming] pursuant to Article 65 of the DCCP. ${ }^{1387}$ With respect to common offences, detention

1383 See, for example, the Hague District Court 13 September 2007, LJN: BB3482, 09.750006-06; the Hague Court of Appeal 3 October 2007, LJN: BB4662, 0975000606; Zwolle District Court 30 June 2009, LJN: BJ2242, 99-000006-36; 's-Hertogenbosch District Court 2 July 2007, LJN: BA8799, 01/885004-07; Amsterdam District Court 23 June 2004, LJN: AP3499, 0000230604; Arnhem Court of Appeal 20 March 2006, LJN: BC7862, 21-007549-04.

1384 Amsterdam Court of Appeal 10 June 2010, LJN: BN7254, 13-650667-10; Zwolle District Court 22 July 2010, LJN: BN2270, 07/653098-10.

1385 Arnhem Court of Appeal 25 May 2009, LJN: BI7259, 21-004106-08.

1386 See Chapter VI for a discussion of the system of remand in custody.

1387 The DCCP distinguishes between detention on remand following remand in custody [gevangenhouding] and detention on remand of a suspect who is not being kept deprived of his liberty yet [gevangenneming]. See Articles 64 to 66 of the DCCP. The order for detention on remand is given by means of a hearing in full chambers [raadkamer], while the extension of such an order is decided on by one judge, except in the case of a complicated case. See Article 21, 
on remand does not differ from remand in custody as to the criteria of application. Both forms of pre-trial detention require serious objections, a suspicion of an offence as enumerated in Article 67 of the DCCP, one or more of the grounds as enumerated in Article 67a of the DCCP ${ }^{1388}$ and compliance with Article 67a, section 3 of the DCCP. ${ }^{1389}$ However, in the case of terrorist suspects, remand in custody does differ from detention on remand regarding the required criteria of application. A public prosecutor must, contrary to remand in custody, sustain serious objections when he requests detention on remand of a terrorist suspect. ${ }^{1390}$ As discussed in Chapter VI, this distinction is a consequence of Article 67, section 4 of the DCCP, which section the DPTA introduced into the DCCP in 2006.

Detention on remand of suspects of common offences is limited to a period of 90 days pursuant to Article 66, section 1 of the DCCP. ${ }^{1391}$ After the lapse of that period, the prosecution is statutorily obliged to issue a summons to the suspect or to issue a notification of further prosecution. However, with the enactment of the DPTA, this period has been extended by two years when it concerns a terrorist suspect. To that effect, the following two sentences have been added to Article 66, section 3 of the DCCP.

'In case a suspicion regards a terrorist offence, the duration of the order for detention on remand may, after lapse of 90 days, be extended with an additional 2 years, each time with periods of 90 days maximum. The proceedings, during which a request for extension of detention on remand is heard, have to take place in public.'

This means that a terrorist suspect may be kept in pre-trial detention for a total period of two years, 110 days and 15 hours, after which, the case must be presented to a court of first instance. ${ }^{1392}$ Hence, the potential period of pre-trial detention is

section 1 of the DCCP. See, also, P.W. van der Kruijs, 'De voorlopige hechtenis in theorie en praktijk', in C.P.M. Cleiren, Th. A. De Roos, M.A.H. van der Woude (eds.), Jurisprudentie Strafrecht Select, Sdu Uitgevers, Den Haag, 2006, pp. 27-49.

1388 See Chapter VI for a discussion of the grounds for remand in custody and detention on remand pursuant to Article 67a of the DCCP.

1389 Amsterdam District Court 18 October 2010, LJN: BO8912, 13/529088-07; Utrecht District Court 4 December 2006, LJN: AZ4177, 16/715077-05; Gemeenschappelijk Hof van Justitie van de Nederlandse Antillen en Aruba 8 October 2008, LJN: BL2938, 123/2008; Amsterdam Court of Appeal 3 January 2003, LJN: AF2675, 6561-16; 's-Hertogenbosch 1 November 2002, LJN: AE9778, 11587; Rotterdam District Court 8 October 1979, LJN: AC0524; Supreme Court 16 November 2004, LJN: AR3264, 00731/04B, m.nt. J.M. Reijntjes.

1390 See, Kamerstukken II 2004-2005, 30 164, nr. 3, p.4.

1391 See, for further details on the system of detention on remand for suspects of common offences, Melai \& Groenhuijsen e.a., Wetboek van Strafvordering, artikel 66 Strafvordering, aantekening 5.

139215 hours police arrest, six days police custody, fourteen days remand in custody and two years and 90 days detention on remand. This does not mean that after that period the case must be dealt with as to content. Through pro forma hearings, actual criminal proceedings may be postponed repeatedly. 
considerably longer for terrorist suspects than for suspects of common offences. One consequence of the extended pre-trial period is that the case file may be kept (in part) from the terrorist suspect for equally as long - when investigative interests demand so. In the parliamentary memoranda, the government presents this latter consequence as the object of the amendment to Article 66, Section 3 of the DCCP. ${ }^{1393}$ The right for a public prosecutor to withhold (part of) the case file from a terrorist suspect for an additional two years is, accordingly, effected through a 'detour'. For, factually speaking, the last two sentences of Article 66, Section 3 of the DCCP extend the period of detention on remand. The moment at which the prosecution is statutorily obliged to issue summons to the suspect or to issue a notification of further prosecution is deferred. This issue will further be discussed in the next section, but it is important to keep in mind that the possibility of prolonged detention on remand of terrorist suspects is directly connected to the power to withhold part of the case file from the suspect.

It is, furthermore, important to note that after the lapse of the potentially 27-month period of detention on remand, the trial does not yet need to start as to content. Often, the actual start of the criminal trial is adjourned by means of pro forma hearings by three-month periods. ${ }^{1394}$ The prosecution may repeatedly request such a suspension. ${ }^{1395}$ This means that detention on remand can be repetitively extended beyond the above-mentioned period, which implies that the factual start of a trial regarding terrorist offences may take considerably longer than 27 months.

Suspects in detention on remand have the right to request the District Court to lift the order for detention on remand pursuant to Article 69 of the DCCP. In principle, the suspect is allowed to file such a request as often as he wants. ${ }^{1396}$ In deciding on such a request, the District Court examines whether all of the requirements enumerated in Article 67a of the DCCP are still complied with. In addition, the court verifies the opportunity of continued deprivation of liberty. ${ }^{1397}$ The extended

1393 Kamerstukken II 2004-2005, 30 164, nr. 3, pp. 27-31.

1394 Article 282, sections 2 and 4, in conjunction with Article 66 of the DCCP. Kamerstukken II 2009-2010, 32 468, nr. 3, p. 24 and R.H. Hermans, 'Kennisneming van processtukken in het voorbereidend onderzoek in strafzaken', in Delikt en Delinkwent 2009, 39. Hermans refers to 's-Hertogenbosch District Court 9 december 2004, LJN AS6603, NbSr 2005, 78; the Hague District Court 16 november 2005, NbSr 2005, 512; Rotterdam District Court 3 april 2006, LJN AW4868; Amsterdam District Court 17 april 2007, LJN BA3539, NbSr 2007, 232; Amsterdam District Court 9 mei 2007, LJN BA5058; Maastricht District Court 27 mei 2007, LJN BB0831; Groningen District Court 9 augustus 2007, LJN BB5991, NbSr 2007, 381.

1395 The sole limitation in this respect is that suspects have a right to trial within a reasonable time in accordance with article 6 of the ECHR. See, also, Kamerstukken II 2004-2005, 30 164, nr. 3, p. 28.

1396 Melai \& Groenhuijsen e.a., Wetboek van Strafvordering, artikel 69 strafvordering, aantekening 4 (Reijntjes).

1397 Melai \& Groenhuijsen e.a., Wetboek van Strafvordering, artikel 69 strafvordering, aantekening 3 (Reijntjes). 
term of detention on remand of terrorist suspects has increased the importance of the right to lodge a habeas corpus complaint considerably for these suspects. ${ }^{1398}$

When the suspect files a request for release for the first time he must be heard, or at least summoned, pursuant to Article 69, section 2 of the DCCP. With respect to subsequent requests, such a hearing is optional. ${ }^{1399}$ If the competent court rejects the suspect's request, the suspect can lodge an appeal with the Court of Appeal within three days of the rejection in accordance with Article 87, section 2 of the DCCP. ${ }^{1400}$

Pursuant to Article 71 of the DCCP, the suspect may, furthermore, lodge an appeal against the court's decision to place him under detention on remand or against an order to prolong the detention on remand. An appeal against an order to prolong the detention on remand can only be lodged once, and provided that the accused did not lodge an appeal against the decision to place him under detention on remand. ${ }^{1401}$ The Court of Appeal must decide as soon as possible on appeals lodged against the decision to place a suspect under detention on remand or against an order to prolong the detention on remand. In practice, this means within a month. ${ }^{1402}$

It is important to note that the proceedings regarding the lawfulness of detention on remand do not imply full disclosure of the case file. ${ }^{1403}$ In practice, this also implies that judges cannot effectively verify whether all of the documents that are of importance to decide on the lawfulness of (the extension of) detention on remand, have been disclosed to the suspect, his lawyer, and to the judges themselves. This is odd, considering that the judges have to: (1) monitor the progress of the investigation, and (2) decide on the lawfulness of a suspect's continued detention on remand. It

1398 See, in this respect, Kamerstukken II 2004-2005, 30 164, nr. 5, p. 5. As set out above, the decision to extend the period of detention on remand is imposed for a maximum of three months. Hence, every three months there will have to be a court ruling on the lawfulness of the extension. This court hearing must take place in public by a Chamber consisting of three judges. See also Article 21, section 5 of the DCCP.

1399 Melai \& Groenhuijsen e.a., Wetboek van Strafvordering, artikel 69 strafvordering, aantekening 6 (Reijntjes)

1400 See for more details on the scope of the possibilities of appeal Melai \& Groenhuijsen e.a., Wetboek van Strafvordering, artikel 69 strafvordering, aantekening 8 (Reijntjes).

1401 Article 71, section 2 of the DCCP. Melai \& Groenhuijsen e.a., Wetboek van Strafvordering, artikel 71 strafvordering, aantekening 4 (Reijntjes).

1402 Article 71, section 4 of the DCCP. Melai \& Groenhuijsen e.a., Wetboek van Strafvordering, artikel 71 strafvordering, aantekening 7 (Reijntjes). Reijntjes refers to 's-Hertogenbosch Court of Appeal 18 January 1996, NJ 1996/339 (26 days falls within the scope of 'as soon as possible'); Leeuwarden Court of Appeal 29 september 1992, NJ 1993/67 (one month does not fall within the scope of 'as soon as possible'). See, also, H. Anker, 'Zo spoedig mogelijk', in Nieuwsbrief Strafrecht 2004 pp. 1013-1017.

1403 Melai \& Groenhuijsen e.a., Wetboek van Strafvordering, artikel 23 Strafvordering aantekening 7, supplement 113, januari 2000 (W.E.C.A. Valkenburg). 
appears hardly possible to adequately perform these tasks if judges are not allowed access to the whole case file. Judges may, accordingly, be faced with unnecessarily difficult decisions regarding requests for extension of a terrorist suspect's detention on remand and regarding suspects' request for release. ${ }^{1404}$ If they are not informed of all the available information regarding the suspect, a moral dilemma may arise when they have to decide on such a request: either they set the alleged terrorist suspect free due to lack of convincing evidence, ${ }^{1405}$ while potentially risking the occurrence of a terrorist offence, or they keep the suspect in detention, despite a lack of sufficient evidence on account of the fact that the suspect is a terrorist suspect.

During the parliamentary discussions on the DPTA, the Council of State underlined, in this respect, that the case file presented to the suspect and the competent court during proceedings regarding an extension of the period of detention on remand, should at least comprise sufficient information to adequately value counterarguments brought forth by the suspect. ${ }^{1406}$

\section{Non-disclosure OF THE CASE FILE}

Every decision taken or order given during criminal proceedings, which affects (the legal status) of a suspect, is based on the case file. The decision to place a suspect in custody or to hold him in detention on remand, or the decision to search a suspect's house, are all founded on the case file. For a suspect to effectively challenge the lawfulness of one of these decisions and to adequately prepare his defence, it is of the utmost importance that he is allowed access to all of the information comprised in the case file. Access to the case file is, therefore, a condition sine qua non to safeguard the proper conduct of pre-trial/criminal proceedings.

In principle, a suspect and his lawyer ${ }^{1407}$ have the right to access and inspect all relevant information available within the case file during the pre-trial phase pursuant to Article 30, section 1 of the DCCP. ${ }^{1408}$ This goes for suspects who are kept detained, as well as for suspects who await their trial in freedom.

1404 See also Kamerstukken II 2005-2006, 30 164, nr. 6, p. 19.

1405 Lack of convincing evidence might make a judge conclude that there is insufficient information to demonstrate 'serious objections' against the suspect pursuant to Article 67, section 3 of the DCCP. A judge is, however, also obliged to set the suspect free if it is to be expected that the suspect will not be sentenced to a higher penalty than the time spend in detention on remand (see Article 67a, section 3 of the DCCP).

1406 Kamerstukken II 2005-2006, 30 164, nr. 6, p 19.

1407 See Article 51 of the DCCP which gives defence lawyers the same rights as their clients (the suspect) have pursuant to Articles 30 until 33 of the DCCP. From here on I will refer to suspect implying therewith also his lawyer.

1408 See G.J.M. Corstens, Het Nederlandse Strafprocesrecht, Deventer, Kluwer 2008, 6de druk, p. 240. See Article 30 of the DCCP. See, also, Supreme Court 7 May 1996, NJ 1997/687 m.nt. Sch; Melai \& Groenhuijsen e.a., Wetboek van Strafvordering, artikel 30 Strafvordering, 
In theory, a case file consists of all incriminating and exempting information that may reasonably be relevant. ${ }^{1409}$ This includes documents that are necessary to demonstrate the (un)reliability of certain evidence or to answer one or more of the questions, as comprised in Articles 348 and 350 of the DCCP. ${ }^{1410}$ Information in the case file includes, for example, witness statements, expert opinions, procès-verbal drafted by the investigative judge, the public prosecutor or the police, statements of the suspect, as well as pictures that have been taken at the crime scene. ${ }^{1411}$ It is the public prosecutor who composes the case file and who consequently decides which information is important for all parties concerned. ${ }^{1412}$ The public prosecutor may leave irrelevant information from the case file. ${ }^{1413}$ Practice shows that the prosecution is often reluctant to disclose all the information available. ${ }^{1414}$ Often public prosecutors only provide the suspect and his lawyer with the information that is strictly necessary. Sometimes information is simply kept out of the case file, which implies that theoretically, the prosecutor does not withhold the suspect information as included in the case file. ${ }^{1415}$ This practice is maintained due to the fact that there is no strict conformity as regards the interpretation and scope of the notions of: (1) record [ processtuk], and (2) case file. That leaves the public prosecutor with a large discretionary power to decide what is, and what is not, to be included in the case file. Moreover, it appears to be no exception that a suspect and his lawyer are only given access to (relevant) information just before the beginning of trial proceedings.

aantekening 2 and 6 (S.V. Pelsser). Note that the DCCP does not provide for an explicit definition of the word 'record' [processtuk]. Everything that is added to the case file by the investigative authorities is however considered to be such a record.

1409 Melai \& Groenhuijsen e.a., Wetboek van Strafvordering, artikel 30 Strafvordering, aantekening 6 (S.V. Pelsser) and G.J.M. Corstens, Het Nederlandse strafprocesrecht, Deventer, Kluwer 2008, 6de druk; Supreme Court 7 May 1996, NJ 1996/687, m.nt. Schalken; Supreme Court 21 January 1997, NJ 1997/321.

1410 See Article 33 of the DCCP and C.P.M. Cleiren, J.F. Nijboer, Strafvordering Tekst \& Commentaar, Kluwer Deventer 2003, $5^{\text {de }}$ druk pp. 92-93; NJ 1996/343, Rotterdam District Court 13 September 1995; NJ 1998/61, Breda District Court 16 December 1997; Amsterdam District Court 8 February 2008, NJ 2008/131.

1411 NJ 1983/6, Breda District Court 15 February 1982; NJ 1998/856, Supreme Court 3 March 1998; Supreme Court 20 June 2000, NJ 2000/502; Supreme Court 4 January 2000, NJ 2000/537 m.nt. Sch.

1412 See Articles 30, section 1, 126aa, 155, 156 and 157 of the DCCP. Some authors propose that the investigating judge should be involved in compiling the case file. See D. Emmelkamp and G. Meijer, 'De nuances tussen zwart en wit', in NJB, 2010/319. This proposal fits well into the Bill regarding the reinforcement of the role of the investigative judge during criminal proceedings [Wet versterking positie rechter-commissaris], see Kamerstukken II 2003-2008, 29 271, nr. 1-7.

1413 D. Emmelkamp and G. Meijer, 'De nuances tussen zwart en wit', in NJB, 2010/319; A.A. Franken, 'Regels voor het strafdossier, in Delikt en Delinkwent 2010, 24.

1414 Kamerstukken II 2009-2010, 32 468, nr. 3, 19.

1415 However, D. Emmelkamp and G. Meijer argue that if information has not been included in the case file while it should have been, that information is still regarded as record. D. Emmelkamp and G. Meijer, 'De nuances tussen zwart en wit', in NJB, 2010/319. See, also, Rotterdam District Court 13 September 1995, NJ 1996/343; Breda District Court 16 December 1997, NJ 1998/61. 
These deficits as regards to the vague notions of record and case file, the question of which information is to be included in the case file and the large discretionary power for the public prosecutor are to be clarified and remedied by means of a bill regarding amendments to the rules on records in criminal cases (2009-2010). ${ }^{1416}$ However, this bill also expands powers for the public prosecutor to withhold information from a suspect included in the case file. ${ }^{1417}$

The DCCP does not grant suspects an absolute right to unrestricted access to the whole case file during the pre-trial phase. ${ }^{1418}$ Article 30, section 2 of the DCCP authorises the investigative judge and the public prosecutor to temporarily withhold from the suspect certain parts of ${ }^{1419}$ the case file when the interest of the investigation demands so. ${ }^{1420}$ Basically, 'the interest of the investigation' refers to the interest of discovering the true facts of the matter. Withholding from the suspect certain information will be considered in the interest of the investigation only when the investigative authorities have a justified fear that the suspect will obstruct the fact-finding process if he has access to the complete case file. ${ }^{1421}$ However, the

1416 Kamerstukken II 2009-2010, 32 468, nr. 2 and nr. 3, p. 16-31. This bill proposes to insert a new Article 149a, section 2 into the DCCP, which defines record as 'all items that may reasonably be of importance for the judges in taking the decisions that need to be taken in court' [Tot de processtukken behoren alle stukken die voor de ter terechtzitting door de rechter te nemen beslissingen redelijkerwijs van belang kunnen zijn].

1417 See, for recommendations from the Council of State, the advisory bodies of the Judiciary, the prosecution service, the police association and the Bar association Kamerstukken II 2009-2010, bijlage bij kamerstuk 32 468, nr. 3.

1418 See, in this respect, the bill regarding amendment to the rules regarding records in criminal law cases [Wijziging van het Wetboek van Strafvordering in verband met de herziening van de regels inzake processtukken, de verslaglegging door de opsporingsambtenaar en enkele andere onderwerpen (herziening regels betreffende de processtukken in strafzaken], Kamerstukken 2010-2011, 32 468, nr. 1-8. This bill seeks to reinforce the role of the investigating judge during the pre-trial phase as regards the right of the suspect to inspect the whole case file by attributing to the investigating judge the power to judge on a complaint pursuant to Article 32 of the DCCP.

1419 Article 30 of the DCCP presupposes that certain documents from the case file are kept from the suspect in their entirety, but it is also possible that only part of a document is not disclosed to the suspect. See NJ 1996/249, Supreme Court 19 December 1995. Complete non-disclosure of the case file is considered to be prohibited within the Dutch criminal law system. See C.P.M. Cleiren, J.F. Nijboer, Strafvordering Tekst \& Commentaar, Kluwer Deventer 2003, $5^{\text {de }}$ druk, p. 88 .

1420 Amsterdam District Court 8 February 2008, LJN: BG1806; Amsterdam District Court 7 October 2008, NbSr 2008, 426 (39.5); Leeuwarden District Court 13 June 2006, LJN: AX881; the Hague District Court 16 November 2005, NbSr 2005, 512; Amsterdam District Court 20 September 2001, LJN AL6505, NbSr 2002, 25; Alkmaar District Court 5 July 2004, LJN AR2598, NbSr 2004, 340; Groningen District Court 9 August 2007, LJN BB5991, NbSr 2007, 381; 's-Hertogenbosch District Court 4 February 2004, LJN AO4972, NbSr 2004, 108; Amsterdam District Court 26 June 2008; Amsterdam District Court 27 February 2003, LJN: AL6804, NbSr 2003, 144.

1421 For example, by intimidating future witnesses. See Melai \& Groenhuijsen e.a., Wetboek van Strafvordering, artikel 30 Strafvordering, aantekening 9 (S.V. Pelsser). And see T. Spronken, 
explanatory memorandum of the DPTA demonstrates that even though the interest of the investigation remains the exclusive touchstone for public prosecutors to withhold from a terrorist suspect part of the case file, that touchstone is to be interpreted broadly. ${ }^{1422}$ Interests related to safeguarding national security may very well serve to keep certain evidence from persons suspected of a terrorist offence. Throughout investigations into terrorism, national security will always and automatically play a role. This means that the sole prerequisite for withholding from a terrorist suspect the case file, will, without problems, be fulfilled because it concerns terrorism.

With respect to information regarding the application of special investigation techniques, Article 126aa, section 1 and 3 of the DCCP are of importance. Generally speaking, the public prosecutor is obliged to add the information brought forth by application of such techniques to the case file when the interest of the investigation permits so. ${ }^{1423}$

When a preliminary investigation ends or is closed, when a writ or a notification of further prosecution is served on the suspect or when a punitive order is issued, the suspect must, theoretically, be given access to the whole case file pursuant to Article 33 of the DCCP. ${ }^{1424}$ This means that in the case of common criminal offences, the investigative authorities are allowed to withhold from the suspect information for a maximum period of 110 days and 15 hours, provided that nondisclosure remains in the interest of the investigation during that period. When it concerns a terrorist suspect, the investigative authorities may withhold from the suspect information for 2 years, 110 days and 15 hours. It is, however, important to note that if, after lapse of this period, the trial does not start, but instead a pro forma

Tekst en Commentaar Strafvordering 2009, art. 30, aant. 6, p. 98-99; P.A.M. Mevis, 'Enige opmerkingen over het recht op kennisneming van processtukken in het licht van de artikelen 5 en 6 van het EVRM', in Delikt en Delinkwent 1991, p. 29; Amsterdam District Court 12 September 1997, Nieuwsbrief Strafrecht 1997, 20; Amsterdam District Court 20 September 2001, Nieuwsbrief Strafrecht 2002, 25; Amsterdam Court of Appeal 18 July 2002, Nieuwsbrief Strafrecht 2003, 67; 's-Hertogenbosch District Court 4 February 2004, Nieuwsbrief Strafrecht 2004, 108; Amsterdam District Court 26 August 2008, Nieuwsbrief Strafrecht 2008, 319; Amsterdam District Court 25 April 2008, Nieuwsbrief Strafrecht 2008, 253.

1422 Kamerstukken II 2005-2006, 30164 nr. 7, p. 3.

1423 See, furthermore, Article 187d and Articles 226a until 226s of the DCCP. These Articles include possibilities to withhold the suspect and his lawyer information with reference to security interests regarding a witness, the interest of the investigation or state security reasons. However, these provisions do not concern temporarily non-disclosure of information, but permanent nondisclosure of information during the criminal (trial) proceedings. The scope of these Articles has not changed by the amended Article 66, section 3 of the ECHR and will therefore not further be discussed in this writing.

1424 Melai \& Groenhuijsen e.a., Wetboek van Strafvordering, artikel 30 Strafvordering, aantekening 6 and 8 (S.V. Pelsser) and Melai \& Groenhuijsen e.a., Wetboek van Strafvordering, artikel 33 Strafvordering, aantekening 3 (S.V. Pelsser). 
session takes place, non-disclosure of the case file may continue. ${ }^{1425}$ Factually, this practice is not based on the relevant statutory provisions, and may therefore be considered to be contra legem..$^{1426}$

Pursuant to Article 31 of the DCCP, there are three kinds of documents a suspect must always be allowed access to: (1) the procès-verbal of his interrogations, (2) the procès-verbal of interrogations or deeds of investigation, with respect to which the suspect or his lawyer had a right to be present - unless such a procès-verbal reveals a circumstance of which the suspect must remain temporarily ignorant and regarding which an order pursuant to Article 50, section 2 of the DCCP, has been given, and (3) the procès-verbal of interrogations, of which the suspect has already been (verbally) informed completely as to its content. The rationale for giving the suspect unrestricted access to these three categories of information is that suspects should not be hindered in having access to documents of which they already know, or might know, the content anyway.

In the parliamentary memoranda regarding the DPTA, the government asserts that records comprised in the case file which are of importance to decide on the lawfulness of detention on remand, may not be withheld from the suspect or from the judges who have to decide on the lawfulness of pre-trial deprivation of liberty. Whether, and if so, how, the suspect and the competent judges can verify if all those records - the incriminating but foremost the exonerating records - have been presented to them remains unclear. At that stage of the proceedings, it may even not always be clear-cut which precise records are important to judge on the lawfulness of a suspect's detention on remand. ${ }^{1427}$

When a public prosecutor or an investigative judge decide to withhold the suspect information, they are obliged to inform the suspect that the case file is incomplete, provided that the information forms part of the case file. This applies as far as the suspect explicitly requests to have access to the case file. ${ }^{1428}$ The investigative authorities are not obliged to inform the suspect which precise documents are not

1425 Kamerstukken II 2009-2010, 32 468, nr. 3, p. 24; Kamerstukken II 2009-2010, bijlage bij Kamerstuk 32 468, nr. 3 (recommendations of the prosecution services), p. 13; T.J. Kelder, 'Onthouding van processtukken bij pro-forma zittingen. Een lapje uit de lappendeken gelicht', in Strafblad 2008, pp. 523-533. See, also, Almelo District Court 25 July 2000, LJN: AA6608, $25 / 00$.

1426 R.H. Hermans, 'Kennisneming van processtukken in het voorbereidend onderzoek in strafzaken', in Delikt en Delinkwent 2009, 39. Hermans refers to the following judgements to demonstrate this practice: 's-Hertogenbosch District Court 9 December 2004, LJN AS6603, NbSr 2005, 78; the Hague District Court 16 November 2005, NbSr 2005, 512; Rotterdam District Court 3 April 2006, LJN AW4868; Amsterdam District Court 17 April 2007, LJN BA3539, NbSr 2007, 232; Amsterdam District Court 9 May 2007, LJN BA5058; Maastricht District Court 27 May 2007, LJN BB0831; Groningen District Court 9 August 2007, LJN BB5991, NbSr 2007, 381.

1427 Kamerstukken II 2005-2006, 30 164, nr. 6, p. 19.

1428 See Melai \& Groenhuijsen e.a., Wetboek van Strafvordering, artikel 30 Strafvordering, aantekening 9 (S.V. Pelsser). 
disclosed. ${ }^{1429}$ Pursuant to Article 32 of the DCCP, the suspect has the right to lodge a complaint with the District Court against the investigative authorities' decision to withhold information. ${ }^{1430}$ Jebbink argues that this right concerns both case fileinformation that is temporarily not disclosed, as well as information that the public prosecutor does not deem relevant and has therefore never been included in the case file. ${ }^{1431}$ To lodge such a complaint, it is not required that the public prosecutor or the investigative judge explicitly informed the suspect of the fact that the case file was incomplete. Even if the suspect merely thinks that the case file has not been disclosed in whole to him, or if the suspect is, for example, otherwise unofficially informed of certain information that is being kept from him, he has the right to lodge a complaint with the competent court to require full disclosure of the case file.

Judges deciding on a complaint pursuant to Article 32 of the $\mathrm{DCCP}^{1432}$ examine 2 issues: (1) whether the public prosecutor - or the investigative judge in the case of a preliminary investigation - has rightfully withheld from the suspect the information, and (2) whether that was justly considered as in the interest of the investigation, as required by Article 30, section 2 of the DCCP. These two issues oblige the judges to examine the well-foundedness and the severity of the reasons which the public prosecutor adduced to legitimise the non-disclosure of information. ${ }^{1433}$ However, it is important to note that the judges deciding on a complaint do not have access to the non-disclosed information either. Hence, just as the suspect, the judges cannot, with regard to substance, examine which specific information is being kept from the suspect. This undermines the effectiveness of the remedy pursuant to Article 32 of the DCCP, even in the government's view. ${ }^{1434}$

1429 See Melai \& Groenhuijsen e.a., Wetboek van Strafvordering, artikel 30 Strafvordering, aantekening 9 (S.V. Pelsser).

1430 The term for lodging an appeal against the prosecutor's/investigative judge's decision to keep certain documents from the suspect pursuant to Article 32 of the DCCP, is 14 days. However, if the suspect's lawyer fails to lodge an appeal within time, he may request the prosecutor/ investigative judge to renew his decision, which results in a new term of 14 days for the lawyer to lodge an appeal. Zutphen District Court 29 October 1987, NJ 1988/576. See Melai \& Groenhuijsen e.a., Wetboek van Strafvordering, artikel 32 Strafvordering, aantekening 4 (S.V. Pelsser).

1431 W.H. Jebbink, 'Rechter-commissaris niet in alle opzichten de geschikte verantwoordelijke voor de volledigheid van het strafdossier', in NJB, 2010/1332. See, also, D. Emmelkamp and G. Meijer, 'De nuances tussen zwart en wit', in NJB, 2010/319; D. Emmelkamp and G. Meijer, 'Naschrift', in $N J B, 2010 / 1333$.

1432 During a hearing in chambers, see Article 21 of the DCCP.

1433 Kamerstukken II 2009-2010, 32 468, nr. 3, p. 25.

1434 Kamerstukken II 2009-2010, 32468 , nr. 3, p. 8 and 19. The bill regarding amendment to the rules regarding records in criminal law cases [Wijziging van het Wetboek van Strafvordering in verband met de herziening van de regels inzake processtukken, de verslaglegging door de opsporingsambtenaar en enkele andere onderwerpen (herziening regels betreffende de processtukken in strafzaken] serves to reinforce a suspect's right to get access to the case file (during the pre-trial phase by means of a more important role for the investigating judge). 
During parliamentary discussions on the DPTA, the Minister of Justice argued, in this respect, that the longer information is not disclosed to the suspect, the more convincing and substantial the arguments to do so must become. ${ }^{1435}$ Theoretically, this would mean that the public prosecutor cannot adduce the same reasons for nondisclosure of certain information during the whole period of 27 months of detention on remand of a terrorist suspect. ${ }^{1436}$

Since the entering into force of the DPTA, Article 32 of the DCCP currently prescribes that a suspect has the right to lodge a complaint against the withholding of information every 90 days. ${ }^{1437}$ Before this amendment, there was no statutory time limit/maximum in this respect. ${ }^{1438}$ The first complaint must be lodged within two weeks of the public prosecutor informing the suspect that the case file is incomplete. The suspect is authorised to repeatedly lodge a complaint, however only at 90 -day intervals.

The WODC reports regarding the monitoring of the DPTA demonstrate that the investigative authorities have not yet made use of the prolonged possibilities to withhold from a terrorist suspect information included in the case file. ${ }^{1439}$ This also means that there is no case law on the application of the amended Article 66, section 3 of the DCCP, in conjunction with Article 30, section 2 of the DCCP.

\section{The REASONABLENESS OF PRE-TRIAL DETENTION AND SPECIAL DILIGENCE}

\subsection{Introduction}

Article 5, section 3 of the ECHR prescribes that everyone arrested or detained in accordance with the provisions of Article 5, section 1 under $\mathrm{c}$ of the ECHR shall be entitled to trial within a reasonable time or to release pending trial. This issue has, in part, been discussed in the preceding chapter, but specifically with respect to the

1435 See, in this respect, G. Mols, 'Informatiestop', in Nieuwsbrief Strafrecht 2004, afl. 9, pp 714-715.

1436 Kamerstukken I 2006-2007, 30 164, D, p. 20

1437 Kamerstukken II 2005-2006, 30 164, nr. 17.

1438 See in this respect T. Kooijmans \& J.B.H.M. Simmelink, 'Het recht op kennisneming van de processtukken in het Wetsvoorstel tot verruiming van de mogelijkheden tot opsporing en vervolging van terroristische misdrijven', in Delikt en Delinkwent 2006, afl. 10/79, pp. 11071126; R.H. Hermans, 'Kennisneming van processtukken in het voorbereidend onderzoek in strafzaken', in Delikt en Delinkwent 2009, 39; Kamerstukken I 2006-2007, 30 164, D, pp. 7 and 20 .

1439 C.J. de Poot, R.J. Bokhorst, W.H. Smeenk, R.F. Kouwenberg, De Opsporing verruimd? De Wet opsporing terroristische misdrijven een jaar in werking, WODC, Cahier 2008-9, p. 2; B. van Gestel, C.J. de Poot, R.J. Bokhorst, R.F. Kouwenberg, Signalen van terrorisme en de opsporingspraktijk. De Wet opsporing terroristische misdrijven twee jaar in werking, WODC Cahier 2009-2010, p. 10; B. van Gestel, C.J. de Poot en R.F. Kouwenberg, De wet opsporing terroristische misdrijven drie jaar in werking, WODC, Memorandum 2010-3, p. 7 and 13. 
amended Article 66, section 3 of the DCCP there is one more aspect that needs to be elaborated on: For pre-trial detention to be lawful and for the length of pre-trial detention to be reasonable, state authorities are obliged to conduct criminal proceedings of persons who are kept in pre-trial detention pending trial with 'special diligence' and drive. The special diligence requirement relates directly to the concept of reasonable in Article 5, section 3 of the ECHR, and consequently to the length of pre-trial detention.

As explained above the period from arrest to the moment of the first official trial hearing may amount to two years, 110 days and 15 hours when it regards investigations into terrorist offences. After the lapse of that period, the public prosecutor may request an adjournment of the trial pursuant to Article 282, section 4 DCCP. ${ }^{1440}$ Pre-trial detention of terrorist suspects may be considerably longer than that when it concerns common criminal offences. This does not only affect the right to be tried within a reasonable time pursuant to Article 6 of the ECHR, but it may also affect compliance with the mandatory obligation for states to ensure detained suspects a trial within a reasonable time and compliance with the special diligence requirement. ${ }^{1441}$

This section discusses the scope of this special diligence-requirement. How does the ECtHR interpret this requirement, and after how long does the length of pretrial detention cease to be reasonable? What aspects/circumstances determine the reasonableness of pre-trial detention when it comes to this requirement? Does the fact that it concerns a suspicion of terrorist offences influence the reasonableness of the length of pre-trial detention? These questions are examined in light of the fact that terrorist suspects may be held in detention on remand for an additional two years, compared to suspects of common criminal offences.

The preceding chapter discussed the prerequisite that pre-trial detention has to remain 'lawful and reasonable' at all times. The special diligence requirement forms the last element of the general prerequisite that all pre-trial deprivation of liberty must be lawful and in accordance with a procedure prescribed by law. ${ }^{1442}$ Case law

1440 The government explicitly acknowledges the possibility of having one or more pro forma hearings, even after the term of two years, 110 days and 15 hours of pre-trial detention has lapsed. Kamerstukken II 2005-2006, 30164 nr. 7, p. 36.

1441 Some members of Parliament submitted an Amendment to drop the (at that time) proposed new Article 66 , section 3 of the DCCP, with reference to the fact that criminal investigations into terrorism will not be conducted with the required special diligence if the investigative authorities are allowed to wait another two years before the case is referred to trial. See, Kamerstukken II 2005-2006, 30 164, nr. 9. The amendment has not been adopted.

1442 Nikolov v. Bulgaria, appl. no. 38884/97, 30 January 2003, §67; Labita v. Italy, appl. no. 26772/95, 6 April 2000, §153; Kudla v. Poland, appl. no. 30210/96, 26 October 2000, §111; McKay v. the United Kingdom, appl. no. 543/03, 3 October 2006, §44; Bykov v. Russia, appl. no. 4378/02, 10 March 2009, §64; Matznetter v. Austria, appl. no. 2178/64, 10 November 1969, §12; Assenov and Others v. Bulgaria, appl. no. 90/1997/874/1086, 28 October 1998, §155; Kalashnikov v. Russia, appl. no. 47095/99, 15 July 2002, §114; Mamedova v. Russia, appl. no. 7064/05, 1 June 2006, §73; Vayiç v. Turkey, appl. no. 18078/02, 20 June 2006, §33; Chraidi v. Germany, appl. 
on Article 5, section 1 under $\mathrm{c}$ and section 3 of the ECHR demonstrates that the ECtHR firstly examines whether there were relevant and sufficient reasons to keep a suspect in pre-trial detention ${ }^{1443}$ and secondly, if there were such reasons, the ECtHR scrutinises whether the investigation and criminal proceedings were conducted with the required special diligence. ${ }^{1444}$ This working method explains why a considerable amount of violations of Article 5, section 3 of the ECHR does not elaborate on the special diligence requirement.

Articles 5 and 6 of the ECHR include various time-related requirements that must be complied with during criminal proceedings. Besides the question of how the ECtHR interprets these timeframes as to their scope, it is important to clearly discern between the timeframes in terms of applicability. ${ }^{145}$ For a better understanding of the following sections, it is, therefore, important to briefly enumerate the four timeframes comprised in Articles 5 and 6 of the ECHR. It is, furthermore, important to keep in mind that these timeframes function separately. ${ }^{1446}$

Firstly, Article 5, section 3 of the ECHR prescribes that everyone who is arrested or detained shall be brought promptly before a judge or other officer authorised by law to exercise judicial power. The notion of promptly refers to the period between an arrest and the first time a suspect is brought before a judge or other officer authorised by law to exercise judicial power. In this respect, four days is not deemed sufficiently prompt, but three days does satisfy the 'promptly' requirement. ${ }^{1447}$

Secondly, anyone who has been lawfully arrested and detained is entitled to trial within a reasonable time. This regards the period between the moment of arrest and that of the judgement of a court of first instance, in accordance with Article 5, section 3 of the ECHR. ${ }^{1448}$ This timeframe will be discussed in this section. ${ }^{1449}$

Thirdly, Article 5, section 4 of the ECHR gives everyone who is deprived of his liberty by arrest and subsequent detention, the right to take proceedings by which the lawfulness of his detention is decided speedily. The notion of speedily refers to the time between the lodging of a habeas corpus complaint pursuant to Article 5,

no. 65655/01, 26 October 2006, §36; Bak v. Poland, appl. no. 7870/04, 16 January 2007, §53; Klyakhin v. Russia, appl. no. 46082/99, 30 November 2004, §61.

See Chapter VI for a discussion of this requirement.

Castravet v. Moldova, appl. no. 23393/05, 13 March 2007, §35; Panchenko v. Russia, appl. no. 45100/98, 8 February 2005, §108-109; Khudoyorov v. Russia, appl. no. 6847/02, 8 November 2005, §188; Iovchev v. Bulgaria, appl. no. 41211/98, 2 February 2006, §104-110.

Wemhoff v. Germany, appl. no. 2122/64, 27 June 1968, \$9; Matznetter v. Austria, appl. no. 2178/64, 10 November $1969, \S 12$.

Matznetter v. Austria, appl. no. 2178/64, 10 November 1969, $\$ 12$.

See the preceding two chapters for a discussion of Article 5, section 1c and 3 of the ECHR.

Wemhoff v. Germany, appl. no. 2122/64, 27 June 1968, §7-9, of the ECtHR's considerations; Klyakhin v. Russia, appl. no. 46082/99, 30 November 2004, §57.

Wemhoff v. Germany, appl. no. 2122/64, 27 June 1968, §7-10, of the ECtHR's considerations. 
section 4 of the ECHR and the decision on such a complaint. This timeframe will be discussed in the next section (6).

Fourthly, Article 6 of the ECHR prescribes that in the determination of any criminal charge against him, everyone is entitled to a fair and public hearing within a reasonable time. This refers to the whole period of criminal proceedings from the moment of arrest until the moment when a judicial decision becomes irrevocable.

Article 6, section 1 of the ECHR poses questions of interpretation similar to those raised by Article 5, section 3 of the ECHR. However, the question whether the time was reasonable for the purposes of Article 5, section 3 of the ECHR, for one thing, and for the purpose of Article 6 of the ECHR, for another, must be judged differently. The former, being intended to safeguard the physical freedom of the individual during the pre-trial phase, which requires stricter application than the latter, the object of which is to protect the individual against abnormally long judicial proceedings - irrespective of the question of the actual detention. ${ }^{1450}$ This latter timeframe will not be discussed in this writing.

It is, furthermore, important to distinguish between a suspect who is held in detention on remand while awaiting his trial and a suspect who awaits his trial in freedom. The first situation is conditioned by Article 5, section 3 of the ECHR, the second by Article 6, section 1 of the ECHR. Terrorist suspects are generally not released pending trial. Therefore, in this writing, the focus will be on suspects who are kept in pre-trial detention and who, consequently, have the right to be tried within a reasonable time in accordance with Article 5, section 3 of the ECHR.

With respect to the following section, it must, furthermore, be kept in mind that the ECtHR does not provide for unambiguous criteria regarding the reasonableness of the length of pre-trial detention in light of the special diligence requirement. ${ }^{1451}$ The specific circumstances of the case determine, to a considerable extent, whether Article 5, section 3 of the ECHR has been violated. In several judgements, the ECtHR even explicitly held that a maximum term with respect to the length of pretrial detention cannot be given, even though case law demonstrates that five years appears to be a maximum. ${ }^{1452}$ Features, facts and circumstances that decide whether or not the length of pre-trial detention is reasonable, are extremely diverse. That

1450 Wemhoff v. Germany, appl. no. 2122/64, 27 June 1968, §6 of the former Commission's considerations.

1451 McKay v. the United Kingdom, appl. no. 543/03, 3 October 2006, §45, the ECtHR explicitly argued that ' $(. .$.$) as the question whether or not a period of detention is reasonable cannot be$ assessed in the abstract but must be assessed in each case according to its special features, there is no fixed time frame applicable to each case'.

1452 W. v. Switzerland, appl. no. 14379/88, 26 February 1993, §30, where the ECtHR considered that '(...) the Commission's opinion was based on the idea that Article 5 para. 3 implies a maximum length of pre-trial detention. The Court cannot subscribe to this opinion, which moreover finds no support in its case law (...)'. 
explains the possibility of wide differences in opinion throughout the assessment of the reasonableness of a given detention. We will now turn to discussing the most important aspects to determine the reasonableness of the length of pre-trial detention in light of the special diligence requirement.

\subsection{Criteria to determine compliance with the special diligence requirement}

The special diligence requirement essentially implies a balancing between: (1) the right of a detained suspect to have his case examined with reasonable speed, and (2) the duty of judicial officers to carry out their tasks with the desired care, which tasks should not be unnecessarily hindered. ${ }^{1453}$

In Wemhoff v. Germany, ${ }^{1454}$ the former Commission drafted a scheme consisting of seven elements, which served to examine the question of whether the length of pre-trial detention was reasonable. Basically, the former Commission's system provided for an overview of various aspects and circumstances that could play a role in deciding on complaints under Article 5, section 3 of the ECHR on account of the special diligence requirement. These seven elements included:

1. The actual length of the pre-trial detention;

2. The length of the pre-trial detention in relation to the nature of the offence, the penalty prescribed and to be expected in the case of conviction and any legal provisions making allowance for such a period of detention in the execution of the penalty which may be imposed;

3. Material, moral or other effects on the detained person;

4. The conduct of the accused:
a. Did he contribute to the delay or expedition of the investigation or trial?
b. Was the procedure delayed as a result of applications for release pending trial, appeals or other remedies resorted to by him?
c. Did he request release on bail or offer other guarantees to appear for trial?

5. Difficulties encountered during the criminal investigation of the case (its complexity in respect of facts or number of witnesses or co-accused, need to obtain evidence abroad, etc.);

6. The manner in which the investigation was conducted:
a. the system of investigation applicable
b. the conduct displayed by the authorities of the investigation (the diligence shown by them in dealing with the case and the manner in which they organised the investigation);

7. The conduct of the judicial authorities concerned:

a. in dealing with the applications for release pending trial

\footnotetext{
1453 Erdem v. Germany, appl. no. 38321/97, 5 July 2001, §46; Matznetter v. Austria, appl. no. 2178/64, 10 November 1969, §12; Van Der Tang v. Spain, appl. no. 19382/92, 13 July 1995, §72.

1454 Wemhoff v. Germany, appl. no. 2122/64, 27 June 1968.
} 


\section{b. in completing the trial. ${ }^{1455}$}

Although this scheme provided for a well-balanced system to decide on the reasonableness of the length of pre-trial detention, while taking into account the interests of all parties involved, the former Commission itself put the scheme in perspective by recognising that 'any particular case will be the outcome of an overall evaluation of all of the elements'. That overall evaluation is, not surprisingly, to a large extent depending on the specific circumstances of the case. Even if examination of some of the criteria may lead to the conclusion that the length of the pre-trial detention is (un)reasonable, the application of other criteria may lead to a contrary conclusion. The final and determining conclusion will therefore depend on the relative weight and importance of the respective criteria, but this in no way precludes one single criterion from having decisive importance in some cases. ${ }^{1456}$

However as will be demonstrated below, the ECtHR (indirectly) scrutinises all of the above-mentioned aspects when examining whether the competent authorities acted with the required special diligence during criminal investigations and proceedings. ${ }^{1457}$ The ECtHR scrutinises these aspects within the framework of: (1) the complexity of the case, (2) the attitude of the suspect, and (3) the attitude of the investigative authorities, including (4) the (necessity of the) applied investigative measures. These four aspects are comparable to the criteria used to examine whether criminal proceedings as a whole, have taken place within a reasonable time pursuant to Article 6 of the ECHR. However, the criteria are applied in a different way.

As to the facts of Wemhoff v. Germany, the ECtHR held that the exceptional length of the investigation and of the trial, were justified by the exceptional complexity of the case, and by further unavoidable reasons for delay. The investigation concerned 13 persons. It was conducted by a member of the Public Prosecutor's Office, and

1455 Wemhoff v. Germany, appl. no. 2122/64, 27 June 1968, §2, of the former Commission's considerations.

1456 Wemhoff v. Germany, appl. no. 2122/64, 27 June 1968, §3.

1457 This is despite the fact that the ECtHR did not consider itself obliged to examine cases on the basis of such a elaborate scheme. Wemhoff v. Germany, appl. no. 2122/64, 27 June 1968, §12, where the ECtHR considered that it: '(...) does not feel able to adopt this method. Before being referred to the organs set up under the Convention to ensure the observance of the engagements undertaken therein by the High Contracting Parties, cases of alleged violation of Article 5 (3) must have been the subject of domestic remedies and therefore of reasoned decisions by national judicial authorities. It is for them to mention the circumstances which led them, in the general interest, to consider it necessary to detain a person suspected of an offence but not convicted. Likewise, such a person must, when exercising his remedies, have invoked the reasons which tend to refute the conclusions drawn by the authorities from the facts established by them, as well as other circumstances which told in favour of his release. It is in the light of these pointers that the Court must judge whether the reasons given by the national authorities to justify continued detention are relevant and sufficient to show that detention was not unreasonably prolonged and contrary to Article 5 (3) of the Convention'. 
lasted two years and three months without significant interruptions. Wemhoff was interrogated on about 40 occasions. The ECtHR further underlined that several dozen witnesses were questioned, both in the Federal Republic and abroad. In addition some 15 expert opinions were obtained from a number of auditing firms and accountants and from a retired President of the Deutsche Bundesbank. The number of workdays amounted to 6,000. The reports of the financial experts alone comprised 1,500 pages. By the time the charge was complete, the domestic court's records comprised 45 volumes containing some 10,000 pages. ${ }^{1458}$

These facts led the ECtHR to conclude that: 'while an accused person in detention is entitled to have his case given priority and conducted with particular expedition, this must not stand in the way of the efforts of the judges to clarify fully the facts in issue, to give both the defence and the prosecution all facilities for putting forward their evidence and stating their cases and to pronounce judgement only after careful reflection on whether the offences were in fact committed and on the sentence'. ${ }^{1459}$

\subsection{Special diligence: The type of criminal behaviour}

In the case of Contrada $v$. Italy, ${ }^{1460}$ the applicant had been kept in pre-trial detention for a total period of two years, seven months and seven days, of which approximately 14 months during the criminal investigation and the remainder during trial. The applicant complained that the length of his pre-trial detention was not reasonable and consequently in violation of Article 5, section 3 of the ECHR.

According to the ECtHR, the alleged lack of 'special diligence' during the proceedings was possibly due to the fact that the applicant was suspected of Mafia related crimes. ${ }^{1461}$ A suspicion of involvement in the Mafia, led the investigation to encompass a number of highly complex required measures, including checking statements of pentiti, ${ }^{1462}$ obtaining many items of evidence, hearing witnesses and obtaining international judicial assistance. During the investigative proceedings, the applicant had, moreover, been implicated by other pentiti, which led to additional investigative measures being taken.

The ECtHR took due notice of the difficulties the Italian authorities encounter when investigating Mafia type crimes, and especially when the suspect is a member of the law-enforcement authorities - as was the case here. With respect to the

\footnotetext{
1458 Wemhoff v. Germany, appl. no. 2122/64, 27 June 1968, §8.

1459 Wemhoff v. Germany, appl. no. 2122/64, 27 June 1968, $\$ 17$ of the Court's considerations.

1460 Contrada v. Italy, appl. no. 27143/95, 24 august 1998.

1461 Contrada v. Italy, appl. no. 27143/95, 24 august 1998, §6-12. The applicant was suspected of involvement in a mafia type organisation (concorso in associazione de stampo Mafioso) on the basis of statements of several pentiti during questioning in the course of various investigations into Mafia offences. He was a member of several law-enforcement authorities himself prior to his arrest and detention.

1462 These are former members of the Mafia who have decided to cooperate with the authorities.
} 
employed investigative powers, the ECtHR examined whether the measures applied were really necessary to further the investigation, and whether they were moreover used in a way consistent with the requirement of displaying 'special diligence' throughout criminal investigations. The ECtHR considered that:

'(...) although investigative measures such as the hearing of witnesses and confrontations are quite unexceptional in criminal cases, it should not be forgotten that trials of presumed members of the Mafia, or, as in the present case, of persons suspected of supporting that organisation from within State institutions, are particularly sensitive and complicated. With its rigid hierarchical structure and very strict rules and its substantial power of intimidation based on the rule of silence and the difficulty in identifying its followers, the Mafia represents a sort of criminal opposition force capable of influencing public life directly or indirectly and of infiltrating the institutions. It is for that reason - to enable the 'organisation' to be undermined through information supplied by former 'members' - that detailed inquiries are necessary'. ${ }^{1463}$

Since the applied investigative measures were deemed necessary in this specific case due to the type of crimes, and as the measures had, moreover, been applied in a way that was deemed compatible with the special diligence requirement, the applicant's pre-trial detention was not judged to be unreasonably long. Article 5, section 3 of the ECHR had not been violated, even though the suspect had been kept deprived of his liberty for a considerable time.

In Chraidi v. Germany, the ECtHR argued that the specific nature of terrorist offences and, in particular, the difficulties intrinsic to the investigation of offences committed by criminal associations acting on a global scale, call for special consideration. The ECtHR explicitly kept this context in mind when assessing the reasonableness of the length of the applicant's continued detention, which lasted five years and almost six months, in particular the grounds for his detention and the conduct of the proceedings in the light of the complexity of the case. ${ }^{1464}$

The applicant's case involved a particularly complex investigation and trial concerning serious offences of international terrorism that caused the death of three victims and serious suffering to more than a hundred. Following his extradition from Lebanon, the sole reason for the applicant's presence in Germany was to stand trial for these offences. The case concerned serious charges against the applicant and four co-defendants, and it necessitated the hearing of 169 witnesses. The case had a terrorist and international background and, moreover, involved 106 joint

1463 Contrada v. Italy, appl. no. 27143/95, 24 august 1998, §67.

1464 Chraidi v. Germany, appl. no. 65655/01, 26 October 2006, §33-37. The period to be taken into consideration started with the applicant's transfer to Germany on 24 May 1996 and ended on 13 November 2001 with his conviction by the Berlin Regional Court. 
plaintiffs. ${ }^{1465}$ As to the conduct of the proceedings, no delay in the proceedings had been attributable to the German courts and authorities, which had displayed the necessary diligence throughout the proceedings, according to the ECtHR. The applicant's trial began seven months after the indictment. Hearings took place on 281 separate days with on average of two hearings per week until the Regional Court's decision after 3.5 years after the beginning of the trial.

In light of these facts, the ECtHR concluded that 'having regard to the difficulties intrinsic to the prosecution of offences committed in the context of international terrorism, the competent judicial authorities cannot be said to have displayed a lack of special diligence in handling the applicant's case. (...) The competent national court acted with the necessary special diligence in conducting the proceedings in the applicant's case'. ${ }^{1466}$

It must, however, be underlined that the ECtHR considered the circumstances of this case to be exceptional, which justified the long period of pre-trial detention. ${ }^{1467}$ In general, detention on remand exceeding five years constitutes a violation of Article 5, section 3 of the ECHR, even if it concerns a complex case. ${ }^{1468}$ Pre-trial detention for four years and four months is also considered as an inordinate length and states have to put forward very weighty reasons to justify keeping a suspect in

1465 Chraidi v. Germany, appl. no. 65655/01, 26 October 2006, §43. Compare with Sulaoja v. Estonia, appl. no. 55939/00, 15 February 2005, §65-68. In the latter case, the applicant had been kept in pre-trial detention for one year, six months and 22 days on account of a five counts burglary and inducement of minors to commit criminal offences. The ECtHR considered these charges not so complex and voluminous as to justify the length of the pre-trial investigation. This consideration was further sustained by the fact that the judgement by which the applicant was initially convicted, extended to two pages. Furthermore, only five witnesses were heard during the preliminary investigation and at the hearing. See, also, Calleja v. Malta, appl. no. 75274/01, 7 April 2005, §111.

1466 Chraidi v. Germany, appl. no. 65655/01, 26 October 2006, §44-45. See, also, Bak v. Poland, appl. no. 7870/04, 16 January 2007, §64.

1467 Chraidi v. Germany, appl. no. 65655/01, 26 October 2006, §48.

1468 Polonskiy v. Russia, appl. no. 30033/05, 19 March 2009, §156; Lyubimenko v. Russia, appl. no. 6270/06, 19 March 2009, §80 and compare with Starokadomskiy v. Russia, appl. no. 42239/02, 31 July 2008, §74. It is striking to see that, for example, international criminal tribunals appear to have a different opinion as regards to the reasonableness of the length of pre-trial detention. See, for example, the judgement of the International Criminal Tribunal for Rwanda in the case of The Prosecutor v. Casimir Bizimungu, Justin Mugenzi, Jérome-Clément Bicamumpaka, Prosper Mugiranez, Case No. ICTR-99-50-T, decision on Prosper Mugiraneza's second motion to dismiss for deprivation of his right to trial without undue delay, in A.H. Klip and G. Sluiter (eds.), Annotated Leading Cases of International Criminal Tribunals, The International Criminal Tribunal for Rwanda 2006-2007, pp. 419-427. The suspect in this judgement had been kept in pre-trial detention for 11 years. This was considered reasonable in light of the complexity of the case and the absence of any wrongdoing on the part of the Prosecution or the relevant authorities. 
pre-trial detention for such lengthy periods without violating Article 5, section 3 of the ECHR. ${ }^{1469}$

It is important to see that the specific criminal and terrorist offences of which the applicant was suspected led to a very complex criminal investigation and trial which, in turn, could justify the lengthy pre-trial detention. This implies that it is rather the complexity of the case, even though that is caused by the nature of the offences, which justifies the length of the pre-trial detention rather than the nature of the offences as such. The investigative authorities had, furthermore, conducted the proceedings with the required special diligence.

\subsection{Special diligence: Inactivity of domestic authorities}

Inactivity during a criminal investigation while the suspect is kept in pre-trial detention often leads to a violation of Article 5, section 3 of the ECHR, particularly when the domestic authorities fail to provide for a convincing explanation. ${ }^{1470}$

In Assenov and Others v. Bulgaria, the investigative authorities virtually took no action in connection with the investigation for a period of one year, no new evidence was collected and the applicant was questioned only once during that period. Furthermore, the applicant's many appeals for release should not have been allowed to have the effect of suspending the investigation and thus delaying his trial, according to the ECtHR. In light of these considerations, the ECtHR considered a period of two years pre-trial detention too long, and concluded that the applicant had been denied a trial within a reasonable time. ${ }^{1471}$

1469 Moskovets v. Russia, appl. no. 14370/03, 23 April 2009, §81.

1470 See, specifically, Vasilev v. Bulgaria, appl. no. 59913/00, 2 February 2006, §71-75; Calleja v. Malta, appl. no. 75274/01, 7 April 2005, §111.

1471 Assenov and Others v. Bulgaria, appl. no. 90/1997/874/1086, 28 October 1998, §157. See, also, Vayiç v. Turkey, appl. no. 18078/02, 20 June 2006, §38, where the ECtHR considered that five years and one month pre-trial detention, during which period there was a lack of special diligence on the part of the authorities in the conduct of the criminal proceedings was not reasonable. The government did not explain why it had taken the public prosecutor almost six months to lodge an indictment against the applicant, or why it had taken nearly three years for the Istanbul Assize Court to reply to the State Security Court's inquiry regarding the case against police officers. As a result of this latter element, hearings were regularly adjourned to another date. The ECtHR further noted that the State Security Court waited more than four years and seven months before giving its final decision. See, also, Matwiejczuk v. Poland, appl. no. 37641/07, 2 December 2003, §79; Čevizović v. Germany, appl. no. 499746/99, 29 July 2004, §43-57; Dzelili v. Germany, appl. no. 65745/01, 10 November 2005, §75-81; Toth v. Austria, appl. no. 11894/85, 12 December 1991, §74-79; Trzaska v. Poland, appl. no. 25792/94, 11 July 2000, §67-69; Pavletić v. Slovakia, appl. no. 39359/98, 22 June 2004, §87; Latasiewicz v. Poland, appl. no. 44722/98, 23 June 2005, §62; Sardinas Albo v. Italy, appl. no. 56271/00, 17 February 2005, $\S 96$. In this latter case, the ECtHR considered that '(...) while accepting that the issue of determining the competent jurisdiction could have been of some complexity and might have required to establish facts and to clarify legal points, the Court considers that a delay of more than seven months to solve a question of competence ratione loci is excessive. It follows that during an overall period of more than one year and four months, there was either a total stay of 
In Mitev v. Bulgaria, the ECtHR considered Article 5, section 3 of the ECHR to be violated because more than two years of the period spent by the applicant in pretrial detention (total of three years and eight months) were taken up by repeated referrals of the case back to the investigation stage, owing to discrepancies in the indictment and the material prepared by the investigators and the prosecutor. Many months elapsed after each referral, and the discrepancies were not remedied expeditiously. In addition, the domestic authorities did not express any concern about the fact that the investigators' and prosecutors' omissions resulted in the applicant's lengthy pre-trial detention. ${ }^{1472}$

Also, in Khudoyorov $v$. Russia the delays were completely attributable to the domestic authorities. The trial court was unable to begin the examination of the case for 11 months because the prosecution persistently failed to arrange for a translation of the bill of indictment into Tajik, the language spoken by seven of the defendants. After that defect had been rectified, the domestic courts were unable to agree whether other procedural shortcomings had irreparably impaired the defence rights, and this led to a further delay of seven months. Furthermore, on each occasion the file was returned to the competent District Court, it took a considerable amount of time - ranging from one and a half to four months - merely to fix the hearing date. In sum, the ECtHR considered that the domestic authorities failed to display special diligence in the conduct of the proceedings. ${ }^{1473}$

In Tomasi v. France the applicant had been kept in pre-trial detention for a total period of five years and seven months, on suspicion of murder, attempted murder and the carrying of weapons and ammunition. ${ }^{1474}$ The applicant argued that the length of his pre-trial detention was not attributable to his own conduct during the criminal investigation, or to the alleged complexity of the case, but to the fact that the judicial authorities had made numerous errors and omissions. He claimed, for example, that in these five years he had been interrogated only once.

the proceedings, or a suspension of the examination of the merits of the case awaiting a ruling on a preliminary issue'. Inactivity of the domestic authorities due to the busy schedule of a court cannot justify lengthy periods of pre-trial detention, see E.M.K. v. Bulgaria, appl. no. 43231/98, 18 January 2005, $\$ 124$.

1472 Mitev v. Bulgaria, appl. no. 40063/98, 22 December 2004, §107-111.

1473 Khudoyorov v. Russia, appl. no. 6847/02, 8 November 2005, §188-189; Kaszczyniec v. Poland, appl. no. 59526/00, 22 May 2007, §60-61; Kuibishev v. Bulgaria, appl. no. 39271/98, 30 September 2004, §70-71; Shenoyev v. Russia, appl. no. 2563/06, 10 June 2010, §56; Czarnecki v. Poland, appl. no. 75112/01, 28 July 2005, §44, in this latter case the ECtHR considered that '(...) it took the trial court almost a year to hold the first hearing. The Government failed to provide any explanation as to this period during which the trial court apparently remained inactive. That delay should be considered significant and it cannot therefore be said that the authorities displayed 'special diligence' in the conduct of the criminal proceedings against the applicant'.

1474 Tomasi v. France, appl. no. 12850/87, 27 august 1992, §6-9. 
After having scrutinised compliance with the first three requirements for lawful pre-trial detention ${ }^{1475}$, the ECtHR examined the French investigative authorities' attitude throughout the course of the criminal investigation. The ECtHR concluded that the evidence showed that in this case the French courts did not act with the necessary promptness. The length of the contested detention could not essentially be attributed either to the complexity of the case or to the applicant's conduct. ${ }^{1476}$ Even the principal public prosecutor at the Court of Cassation acknowledged this in his opinion before the Compensation Board: the investigation 'could have been considerably shortened without the various delays noted'. Article 5, section 3 of the ECHR had thus been violated. The ECtHR based this conclusion exclusively on the fact that the investigative authorities did not display special diligence during the criminal proceedings. None of the causes adduced by the government to account for the length of pre-trial detention could justify such a long period of deprivation of liberty prior to a judgement before the court of first instance. ${ }^{1477}$

\subsection{Special diligence: The complexity of the case and investigative measures}

In many cases regarding an alleged violation of Article 5, section 3 of the ECHR, the ECtHR balanced the complexity of the case against the suspect's interest of being released. In Matznetter $v$. Austria the applicant had been detained for two years and two months. According to the ECtHR, the unusual length of the investigation (two years) could be justified by the exceptional complexity of the case. ${ }^{1478}$ The intervals of several months between different interrogations of Matznetter, and the fact that he was scarcely heard within the period of fifteen months after his arrest on the part he himself had taken in the alleged dishonest operations could be justified by: (1) the extent and the number of the alleged dishonest dealings (fraud), (2) the skills of the applicant, (3) the skills of and number of participants in the group of accused, (4) the almost inextricable confusion of the links connecting the various undertakings of the group of accused to which the applicant belonged, and (5) the great complexity of the criminal law problems to be solved.

The ECtHR further underlined that the competent authorities ordered certain charges to be split up and the investigative judge was relieved from his duty to take

1475 The ECtHR could not adequately judge the reasonableness of the detention (length) only on the basis of the grounds on which the detention was based, provided for by the government. The ECtHR reasoned that 'in conclusion, some of the reasons for dismissing Mr Tomasi's applications [for release pending trial] were both relevant and sufficient, but with the passing of time they became much less so, and it is thus necessary to consider the conduct of the proceedings'. Tomasi v. France, appl. no. 12850/87, 27 august 1992, §99.

1476 Tomasi v. France, appl. no. 12850/87, 27 august 1992, $\$ 102$.

1477 Compare with Sevgin and Ince v. Turkey, appl. no. 46262/99, 20 September 2005, §65-69.

1478 Compare with the Tariq v. Czech Republic, appl. no. 75455/01, 18 April 2006, §96. In this case the ECtHR judged 3.5 years between the moment of arrest and the indictment to be unreasonably long, even though the case was complex. 
on new cases, thus showing their anxiety to avoid any delay in the course of the proceedings. In this respect, the ECtHR underlined that while an accused person held in custody is entitled to have his case given priority and conducted with special diligence this must not stand in the way of the proper administration of justice. ${ }^{1479}$

In Tariq v. the Czech Republic, the complexity of the case could not justify pre-trial detention for four years and a total period of six years for pre-trial proceedings. ${ }^{1480}$ The ECtHR considered that, although the case may have been factually complex, involving a considerable number of accused persons, requiring the hearing of a large number of witnesses and the administration of other evidence, the considerable delays in submitting the official indictments against the applicant were significant (two years). The authorities accordingly failed to display special diligence in the conduct of the criminal proceedings against the applicant. ${ }^{1481}$

In Scott v. Spain, the applicant had been held in pre-trial detention for four years and 16 days on account of rape charges. ${ }^{1482}$ The government ascribed this lengthy pre-trial period to the alleged complexity of the case and to the various difficulties associated with the implementation of an international letter of judicial cooperation (translation of documents, transmission by diplomatic channels, repeated summons of the complainant).

The ECtHR considered that the case was not particularly complex. It was apparent from the case file that, after the investigation had been terminated, the evidence against the applicant only included two statements by the complainant, two statements by the accused and four medical certificates. Furthermore, there was nothing to suggest that the length of the proceedings could be attributable in whole or in part to the applicant's conduct. Those considerations led the ECtHR to conclude that Article 5, section 3 of the ECHR had been violated. ${ }^{1483}$

Case law demonstrates that the more complex a criminal investigation is, the more likely it is that prolonged periods of pre-trial detention - even up to four years - still remain in compliance with Article 5, section 3 of the ECHR. However, it should be remembered that such periods cover the moment of arrest, up to and including the judgement before a court of first instance. Criminal investigations into organised crime may justify such (prolonged) periods of pre-trial detention. By nature, this type of criminal behaviour presents more difficulties for the investigative authorities,

1479 Matznetter v. Austria, appl. no. 2178/64, 10 November 1969, §5 and 12. See, also, Scott v. Spain, appl. no. 21335/93, 18 December 1996, §74; Klamecki v. Poland, appl. no. 25415/94, 28 March 2002, §76; Rażniak v. Poland, appl. no. 6767/03, 7 October 2008, §33. Tariq v. Czech Republic, appl. no. 75455/01, 18 April 2006, §80-96.

1481 Tariq v. Czech Republic, appl. no. 75455/01, 18 April 2006, §96.

1482 Scott v. Spain, appl. no. 21335/93, 18 December 1996, §75. The pre-trial detention was ordered first on account of alleged rape (2 years) and then for extradition purposes.

1483 Scott v. Spain, appl. no. 21335/93, 18 December 1996, $§ 83$. 
and later for the courts, in determining the facts and the degree of responsibility of each member of the group. Therefore, the ECtHR does take into account, in assessing the conduct of the investigative authorities, the special circumstances deriving from the fact that it concerns specific kinds of (serious) organised criminal behaviour, such as being a member of a criminal gang. ${ }^{1484}$ However, generally the complexity of the case, the number or the conduct of the defendants cannot justify more than five years detention pending investigation and trial. ${ }^{1485}$ It remains unclear what the maximum length of a criminal investigation is according to the ECtHR. In the above-discussed case of Matznetter v. Austria, the ECtHR considered a criminal investigation that lasts two years, during which period the suspect remained in pretrial detention, to be unusually long. That deprivation of liberty could only be justified by the exceptional complexity of the case. Again it must be underlined that in these matters the complexity of the case is decisive, rather than the nature of the criminal/terrorist offences a suspect is accused of.

With respect to the investigative measures applied, the ECtHR examines which investigative measures have been applied throughout the investigation, whether these measures were necessary - taking into account the nature of the criminal offence and the complexity of the case - and whether the way in which they have been applied complies with the special diligence requirement. Circumstances that appear to be important for the ECtHR while assessing whether the investigative authorities acted with the required diligence in this respect are: the nature of the suspected criminal offence, the (non)complex nature of the investigative measures which have been applied, and the question of whether these measures are extraordinary, in the sense that they are regularly not employed within criminal investigations. In this respect, the ECtHR will most likely show understanding for prolonged periods of pre-trial detention, as long as the necessary and timeconsuming investigative measures have been applied with the required special diligence. Cases that require the use of investigative measures that, by their nature, demand considerable time, can therefore justify prolonged periods of pre-trial detention. Those measures must, however, be demonstrably needed in order to adequately solve a case. ${ }^{1486}$

1484 Bak v. Poland, appl. no. 7870/04, 16 January 2007, §56-57; Van Der Tang v. Spain, appl. no. 19382/92, 13 July 1995, §75; Sardinas Albo v. Italy, appl. no. 56271/00, 17 February 2005, §95; Nevmerzhitsky v. Ukraine, appl. no. 54825/00, 5 April 2005, §132. Polonskiy v. Russia, appl. no. 30033/05, 19 March 2009, §156.

1486 Matznetter v. Austria, appl. no. 2178/64, 10 November 1969, §12; Kalashnikov v. Russia, appl. no. 47095/99, 15 July 2002, §114; Laszkiewicz v. Poland, appl. no. 28481/03, 15 January 2008, $\S 61$. 


\subsection{Special diligence: The suspect's attitude}

The attitude of the suspect during the criminal investigation or his individual circumstances, ${ }^{1487}$ also play a role in deciding whether the length of the pre-trial detention is reasonable. In Mamedova v. Russia, the ECtHR considered that even though the applicant's refusal to testify may have slowed the proceedings down and generated delays, the applicant was not obliged to co-operate with the authorities and she could not be blamed for having taken full advantage of her right to silence. In such circumstances, it is incumbent on the investigative authorities to collect evidence and conduct the investigation in such a way that ensures trial within a reasonable time. ${ }^{1488}$

However, in W. v. Switzerland, the ECtHR underlined that if a suspect decides to remain silent, even if he was not obliged to co-operate with the authorities, he must bear the consequences that his attitude may cause for the progress of the investigation. Nevertheless, in this case the ECtHR also referred to the exceptional complexity of the case to account for the considerable length of the pre-trial detention (four years and three days). ${ }^{1489}$

\subsection{In sum}

The above-discussed judgements demonstrate that the ECtHR has developed some benchmarks to examine whether a criminal investigation and criminal proceedings regarding a suspect kept in pre-trial detention are conducted with the required special diligence and drive. The most important aspect is that inactivity on the part of the competent authorities during a criminal investigation is basically always unacceptable. In case of alleged non-compliance with the special diligence requirement, the ECtHR always explicitly scrutinises whether there were periods of inactivity on the part of the investigative authorities. If the circumstances of a case reveal such inactivity, foremost during protracted periods, that will automatically lead to a violation of Article 5, section 3 of the ECHR. In case the length of a period spent in pre-trial detention does not appear to be attributable either to the complexity of the case, or to the applicant's conduct and the authorities did not act with the necessary promptness, Article 5, section 3 of the ECHR is also violated.

To examine the complexity of the case, the ECtHR quite factually examines the scope of the case, including the amount of interrogations, expert opinions, pages of

\footnotetext{
1487 See, specifically, Gulub Atanasov v. Bulgaria, appl. no. 73281/01, 6 November 2008, $§ 53$.

1488 Mamedova v. Russia, appl. no. 7064/05, 1 June 2006, \$70-84. See, for an opposite line of reasoning, Kevin O'Dowd v. the United Kingdom, appl. no. 7390/07, 21 September 2010, §71-78.

1489 W. v. Switzerland, appl. no. 14379/88, 26 January 1993, \$39-43. Compare with Pecheur c. Luxembourg, requête $\mathrm{n}^{\circ}$ 16308/02, 11 décembre 2007, \$62 (four years, two months and 19 days pre-trial detention); Knebl c. République Tchèque, requête $\mathrm{n}^{\circ}$ 20157/05, 28 Octobre 2010, §69-70 (two years and seven months).
} 
the case file, working days and the complexity and necessity of the applied investigative measures. This means, for example, that the more encompassing the case file is, and the more witnesses have to be interrogated, the longer pre-trial detention may endure - even up to 4.5 years - provided that there are no periods of inactivity on the government's side. In this respect it must, however, be underlined that the ECtHR considers such periods of pre-trial detention to be exceptional and requiring solid justifications. Also it needs to be kept in mind that pre-trial proceedings run from the moment of arrest until a judgement by a court of first instance.

The nature of a criminal offence also influences the reasonableness of the length of pre-trial detention, though to a limited extent. Complex criminal offences, such as offences connected to international criminal or terrorist organisations or Mafiarelated crimes influence the complexity of the case, and consequently, the accepted length of pre-trial detention. However case law demonstrates that even if it regards complex criminal offences and there have not been periods of inactivity on the investigative authorities' side, the ECtHR may, nevertheless, conclude to a violation of Article 5, section 3 of the ECHR.

The amended Article 66, section 3 of the DCCP raises several issues under Article 5, section 3 of the ECHR. Placing a suspect under detention on remand for such lengthy periods increases the ECtHR's examination of compliance with the special diligence requirement. It is questionable whether 27 months for a criminal investigation, during which period the suspect is deprived of his liberty, is reconcilable with the above-discussed Strasbourg case law, all the more since that period does not yet include the criminal proceedings.

In addition, many investigative powers are applied prior to a suspect's arrest and deprivation of liberty. The case law discussed in Chapter II shows that timeconsuming powers, such as special investigative techniques are not deployed during the suspect's pre-trial detention. This means that the competent authorities cannot refer to the complexity and time-consuming nature of the necessary investigative measures applied to justify interferences with Article 5, section 3 of the ECHR.

Another important issue is that criminal proceedings regarding terrorist offences within the Netherlands, so far, do not bear an extreme or exceptional complex character. These cases did not concern involvement in an international terrorist organisation, neither were there many witness testimonies to be heard, nor was there any need for extensive international judicial cooperation. The cases did raise complex issues of law, which may contribute to justifying longer periods of pre-trial detention.

The criminal investigations/proceedings discussed in Chapter II demonstrate that these investigations primarily regard the processing and/or assessing of (written) evidence found and confiscated at the suspects' houses. Documents 
comprising inciting texts, texts regarding extreme interpretations of Islam and other threatening texts had to be (partly) translated and interpreted. That took quite some time, but the normal period of 90 days of detention on remand, possibly supplemented with pro-forma hearings, sufficed. The suspects in the Hofstadgroep case, the Piranha I case, and the Piranha II case, were kept in pre-trial detention for 16 months, 12 months and six weeks, and 29 months and two weeks, respectively (including the criminal investigation and criminal proceedings).

It is questionable to what extent the nature of terrorist offences may contribute, as such, to justifying lengthy periods of pre-trial detention. Even though the ECtHR may take into account the specific nature of terrorist offences when deciding on complaints under Article 5, section 3 of the ECHR, it is primarily the potential difficulty intrinsic to the investigation of such offences, which are committed in an organised context, that influences the reasonableness of the length of continued pretrial detention, rather than the nature of terrorism as such.

\section{Habeas CORPUS PROCEEDINGS}

Article 5, section 4 of the ECHR prescribes that 'everyone who is deprived of his liberty by arrest or detention shall be entitled to take proceedings by which the lawfulness of his detention shall be decided speedily by a court and his release ordered if the detention is not lawful'. ${ }^{1490}$ This section provides suspects in pre-trial detention the right to lodge habeas corpus proceedings. ${ }^{1491}$ Deciding on a habeas corpus complaint must be done speedily which requirement includes: (1) the opportunity for legal review to be provided soon after the person is taken into detention and, if necessary, at reasonable intervals thereafter, ${ }^{1492}$ and (2) an obligation for the domestic authorities to conduct review proceedings with due diligence. $^{1493}$

1490 The right to lodge a habeas corpus complaint is incorporated in Article 69 of the DCCP. See Section 3 above for a discussion of this provision.

1491 The proceedings under Article 5, section 4 of the ECHR are generally referred to as habeas corpus proceedings (originating from English law), see P. van Dijk, F. van Hoof, A. van Rijn and L. Zwaak (eds.), Theory and Practice of the European Convention on Human Rights, Intersentia Antwerpen-Oxford 2006, p. 498 and S. Trechsel, Human Rights in Criminal Proceedings, Oxford University Press 2005, p. 462. Note that the right for persons deprived of their liberty to lodge habeas corpus proceedings in accordance with Article 5, section 4 of the ECHR, is considered as lex specialis of the general right to an effective remedy as guaranteed under Article 13 of the ECHR. See, among others, De Jong, Baljet and van den Brink v. The Netherlands, appl. no. 8805/79, 22 May 1984, §60; Chahal v. the United Kingdom, appl. no. 22414/93, 15 November 1996, §127; Spasov v. Bulgaria, appl. no. 51796/99, 16 November 2006, §60. I will not further elaborate on Article 13 of the ECHR.

1492 Jurjevs c. Lettonie, requête $\mathrm{n}^{\circ} 70923 / 01,15$ juin 2006, $§ 63$.

1493 Sergey Volosyuk v. Ukraine, appl. no. 1291/03, 12 March 2009, §48; Khudobin v. Russia, appl. no. 59696/00, 26 October 2006, $\S 115$. 
Obviously, Article 5, section 4 of the ECHR gains importance when the (statutory) period of pre-trial detention is prolonged, as has been done within the Dutch criminal justice system through the amendment of Article 66, section 3 of the DCCP. The longer pre-trial detention lasts, the more justifications there must be and the more important the right to lodge habeas corpus proceedings accordingly becomes. Taking into account the potentially lengthy period of pre-trial detention in case of terrorist suspects, it is necessary to discuss the scope of habeas corpus proceedings pursuant to Article 5, section 4 of the ECHR. In this respect, fair trial principles as comprised in Article 6 of the ECHR, (in)directly play a role as well. Firstly, defence rights must (partly) be complied with throughout habeas corpus proceedings, and secondly, interferences with a suspect's defence rights during the pre-trial phase may lead to a violation of Article 6 of the ECHR if the ensuing trial can no longer be deemed fair due to these interferences.

The following sections will therefore: (1) examine the procedural and substantive scope of habeas corpus proceedings, and (2) the extent to which fair trial principles must be complied with during these proceedings, particularly with respect to the right to access the case file.

Article 6, section 3 under a and b of the ECHR comprises a so-called 'right to information' for suspects during criminal proceedings. ${ }^{1494}$ To what extent is nondisclosure of the case file during habeas corpus proceedings compatible with Article 5, section 4 and Article 6, section 3 under a and b of the ECHR? And what role does the fact that it regards terrorism play in this respect? The Dutch government argues, in this respect, that a terrorist suspect's right to have access to his case file during such proceedings may be restricted more easily than when it regards suspicion of a common criminal offence. This would mean that the nature of terrorist offences, and the danger which the commission of such offences poses to national security, is used to restrict defence rights throughout habeas corpus proceedings. Does the ECtHR endorse such a differentiation based on the nature of the offence regarding compliance with fair trial principles during proceedings under Article 5, section 4 of the ECHR?

As discussed above, both the judges and the suspect may be denied access to part of the case file pursuant to Article 30, section 2 of the DCCP. How and to what extent does that influence the nature and quality of habeas corpus proceedings? What rules can be derived from Strasbourg case law regarding the effects of nondisclosure of part of the case file on the thoroughness of the review under Article 5, section 4 of the ECHR? 


\subsection{The right to lodge a habeas corpus complaint}

Strasbourg case law regarding Article 5, section 4 of the ECHR, reflects a synthesis of all of the principles covered by the right to liberty of person. Faced with a complaint under this section, the ECtHR examines whether all of the requirements for lawful deprivation of liberty, as comprised in section 1 under $\mathrm{c}$ and section 3 , are reviewed by domestic courts during habeas corpus proceedings. This also means that domestic courts must examine whether a suspect's pre-trial detention is not contrary to the core of Article 5 of the ECHR: the prevention of arbitrary deprivation of liberty. ${ }^{1495}$ In Varbanov v. Bulgaria the ECtHR considered that:

'(...) everyone who is deprived of his liberty is entitled to a supervision of the detention's lawfulness by a court. The Convention requirement that an act of deprivation of liberty be amenable to independent judicial scrutiny is of fundamental importance in the context of the underlying purpose of Article 5 of the Convention to provide safeguards against arbitrariness. What is at stake is both the protection of the physical liberty of individuals and their personal security'. ${ }^{1496}$

Even though there is a close coherence between the various sections of Article 5 of the ECHR, which becomes visible in section 4, one should nevertheless distinguish between the sections on a number of procedural issues. To start with, there is a clear distinction between the judicial supervision guaranteed by section 3 and that guaranteed by section 4 . Section 3 refers to 'a judge or other officer authorised by law to exercise judicial power', whereas section 4 appoints a 'court' as competent authority to decide on the lawfulness of pre-trial detention. In addition, the scope of judicial review under section 3 and section 4 differs considerably as will further be demonstrated below.

Another procedural difference is that a person who is being kept deprived of his liberty profits automatically and promptly, without intervention from his side, from the judicial supervision under section 3 , whereas section 4 refers to a right 'for everyone who is deprived of his liberty by arrest or detention to take proceedings'. The factual enforcement of Article 5, section 4 ECHR is, hence, completely dependent on the suspect's desire to have the lawfulness of his (prolonged) pre-trial detention examined by a court.

Due to altered circumstances, the assessment of the lawfulness of pre-trial detention may change in time, resulting in different judicial review under the respective sections. Initial compliance with sections $1 \mathrm{c}$ and 3 does not preclude a breach of section 4 later on. ${ }^{1497}$ The longer a suspect is kept in pre-trial detention, the more

1495 Koendjbiharie v. the Netherlands, appl. no. 11487/85, 25 October 1990, §27.

1496 Varbanov v. Bulgaria, appl. no. 31365/96, 5 October 2000, $\$ 58$.

1497 Kolompar v. Belgium, appl. no. 11613/85, 24 September 1992, §45. See, also, Bouamar v. Belgium, appl. no. 9106/80, 29 February 1988, §55. The latter case concerned the reverse 
likely it becomes that the interference with his right to liberty is unlawful, and thus, in violation of Article 5 of the ECHR. Section 4 enshrines a procedural safeguard against continuation of detention which, albeit initially lawfully ordered, may have later become unlawful and unjustified. In particular, the rationale underlying the requirements of speediness and periodic judicial review at reasonable intervals, within the meaning of Article 5, section 4 of the ECHR, is that a suspect should not run the risk of remaining in detention long after the moment when his deprivation of liberty has become unjustified. ${ }^{1498}$

A last procedural difference between sections $1 \mathrm{c} / 3$ and section 4 is that the proceedings under the latter carry a mandatory adversarial character comparable to Article 6 of the ECHR, whereas proceedings pursuant to section $1 \mathrm{c} / 3 \mathrm{do}$, to a lesser extent, need to be organised in compliance with principles of fair trial. This will further be discussed in the next section.

In sum, habeas corpus proceedings differ from proceedings pursuant to Article 5, section 3 of the ECHR, as regards: the applicability, the competent authority, the nature of the proceedings, the rights/responsibilities of the suspect during habeas corpus proceedings, and the timeframe for deciding on a habeas corpus complaint. These aspects will now be further elaborated on.

\subsection{Applicability of Article 5, section 4 of the ECHR}

The right to lodge habeas corpus proceedings applies to all of the categories of deprivation of liberty, as enumerated in Article 5, section 1 of the ECHR. ${ }^{1499}$ In Van Droogenbroeck $v$. Belgium the ECtHR argued that 'the scope of the obligation undertaken by the Contracting States under paragraph 4 of Article 5 will not necessarily be the same in all circumstances and as regards every category of deprivation of liberty'. ${ }^{1500}$ This implies that the right to lodge habeas corpus proceedings for a person convicted by a competent court to a prison sentence, does not necessarily have the same scope as for a suspect in pre-trial detention. ${ }^{1501}$ The following sections will only elaborate on the right for suspects in pre-trial detention

situation: section 1 had been violated and the ECtHR subsequently asserted that: "Although the Court has found that there was a breach of paragraph 1 of Article 5 in the instant case, that finding does not dispense it from proceeding to inquire whether there was a failure to comply with paragraph 4 , as the two provisions are distinct'.

1498 Shishkov v. Bulgaria, appl. no. 38822/97, 9 January 2003, $§ 88$.

1499 De Wilde, Ooms and Versyp ("Vagrance”) v. Belgium, appl. nos. 2832/66; 2835/66; 2899/66, 18 June 1971, §73; Asenov c. Bulgarie, requête $\mathrm{n}^{\circ}$ 42026/98, 15 juillet 2005, §77; Hristova c. Bulgarie, requête $n^{\circ}$ 60859/00, 7 décembre 2006, §122; König v. Slovakia, appl. no. 39753/98, 20 January 2004, $\$ 19$.

1500 Droogenbroeck v. Belgium, appl. no. 7906/77, 24 June 1982, §47.

1501 Bouamar v. Belgium, appl. no. 9106/80, 29 February 1988, §60; Chahal v. the United Kingdom, appl. no. 22414/93, 15 November 1996, §127. 
to lodge a habeas corpus complaint pursuant to Article 5, section 1 under $\mathrm{c}$ of the ECHR.

The right to apply for judicial control on the lawfulness of pre-trial detention arises immediately after a suspect's arrest and/or detention, and persists to apply throughout the whole period of pre-trial detention. ${ }^{1502}$ There can be no justification for delays in this respect. ${ }^{1503}$ However, in De Jong, Baljet and van den Brink v. The Netherlands ${ }^{1504}$ the ECtHR expressed that, if the procedure pursuant to Article 5, section 3 of the ECHR, has been carried out according to the requirements set in section 4, this might have a 'certain incidence on compliance with the latter'. For example, where a procedure culminates in a decision by a 'court' ordering or confirming deprivation of the person's liberty, the judicial control of lawfulness required by section 4 is incorporated in this initial decision.

Nevertheless, finally the two procedural guarantees for judicial review comprised in Article 5 of the ECHR should both remain open for a suspect in pre-trial detention. The guarantee assured by section 4 is of a different order from, and additional to, that provided by section 3.1505 After an initial examination of the lawfulness of arrest and pre-trial detention pursuant to Article 5, section 3 of the ECHR - even if it has been effected by a court - section 4 gives the detained suspect the continued right to repeatedly and at reasonable intervals, have the lawfulness of his deprivation of liberty directly examined by a court. ${ }^{1506}$

The right guaranteed pursuant to Article 5, section 4 of the ECHR is only applicable to persons deprived of their liberty. It has no application for the purposes of

1502 Chitayev and Chitayev v. Russia, appl. no. 59334/00, 18 January 2007, §177. Article 5, section 4 of the ECHR guarantees no right, as such, to appeal against decisions ordering or extending detention, as the provision speaks of 'proceedings' and not of 'appeal'. The intervention of one organ satisfies Article 5, section 4 of the ECHR on condition that the procedure followed has a judicial character, and gives to the individual concerned, guarantees appropriate to the kind of deprivation of liberty in question. Nevertheless, a state which sets up a second level of jurisdiction for the examination of applications for release from detention must, in principle, accord to the detainee the same guarantees on appeal as at first instance. Toth v. Austria, 12 December 1991, §84; Lanz v. Austria, appl. no. 24430/94, 31 January 2002, §42.

1503 Sakik and Others v. Turkey, appl. no. 87/1996/706/898-903, 26 November 1997, §51-54; İğdeli v. Turkey, appl. no. 29296/95, 20 June 2002, §34-36; İkincisoy v. Turkey, appl. no. 26144/95, 27 July 2004, §109; Abdülsamet Yaman v. Turkey, appl. no. 32446/96, 2 November 2004, §80-81; Fatma Tunç v. Turkey, appl. no. 16608/02, 20 October 2005, §26-28; Taş v. Turkey, appl. no. 24396/94, 14 November 2000, §86-87.

1504 De Jong, Baljet and van den Brink v. The Netherlands, appl. no. 8805/79, 22 May 1984.

1505 De Jong, Baljet and van den Brink v. The Netherlands, appl. no. 8805/79, 22 May 1984, §57; Herczegfalvy v. Austria, appl. no. 10533/83, 24 September 1992, §74-78.

1506 Lebedev v. Russia, appl. no. 4493/04, 25 October 2007, §79; Reinprecht v. Austria, appl. no. 67175/01, 15 November 2005, §31-34. Hearings reviewing the lawfulness of pre-trial detention must be held at short intervals ( 1 or 2 months maximum). In general, hearings on the lawfulness of pre-trial detention do not have to be public. However, the ECtHR does not exclude the possibility that a public hearing may be required in particular circumstances. 
obtaining, after release, a declaration that a previous detention or arrest was unlawful. Consequently, Article 5, section 4 of the ECHR cannot be invoked by a person who is lawfully released, or released on bail. ${ }^{1507}$ Furthermore Article 5, section 4 of the ECHR does not establish a right to an order of unconditional release.

\subsection{The competent authority}

Under Article 5, section 4 of the ECHR the responsibility to judge on the lawfulness of pre-trial detention is explicitly attributed to a court. How does the ECtHR interpret the notion of court? Does a court, within the context of section 4 need to comply with the same qualitative requirements as a tribunal pursuant to Article 6, section 1 of the ECHR?

When judging on complaints regarding alleged violations of Article 5, section 4 of the ECHR, the ECtHR has underlined, time and again, that the ECHR uses the word 'court' (French 'tribunal') in several of its Articles, including Article 5, section 4 of the ECHR Articles 2, section 1, Article 5, section 1, under a and b, and Article 6, section 1 of the ECHR. This serves to mark out one of the constitutive elements of the guarantee afforded to the individual by the provision in question. In all these different cases it concerns bodies which exhibit common fundamental features, of which the most important is independence of the Executive and of the parties to the case. Accordingly, the ECtHR aligns the notion of court as comprised in Article 5, section 4 of the ECHR, with the concept of tribunal pursuant to Article 6, section 1 of the ECHR as regards to independence.

In D.N. v. Switzerland, the ECtHR extended the alignment between the judicial authorities mentioned in Article 5, section 4 and Article 6 of the ECHR with the impartiality of the court respectively tribunal. The ECtHR argued that both independence and impartiality are the most important constitutive elements of the notion of a 'court'. 1508

The ECtHR has two criteria to examine whether a domestic court deciding on a habeas corpus complaint is impartial: (1) a subjective test which refers to the personal conviction of a particular judge in a given case, and (2) an objective test to ascertain whether a particular judge offered sufficient guarantees to exclude any legitimate doubt as to his impartiality. ${ }^{1509}$

1507 Decision as to the admissibility in Guliyev v. Azerbaijan, appl. no. 35584/02, 27 May 2005; Stephens v. Malta (no. 1), appl. no. 11956/07, 21 April 2009, §102. Note, however, that the ECtHR does consider house arrest to constitute deprivation of liberty within the meaning of Article 5 , section 4 of the ECHR. N.C. v. Italy, appl. no. 24952/94, 11 January 2001, §33 and Nikolova v. Bulgaria (No. 2), appl. no. 40896/98, 30 September 2004, §74.

1508 D.N. v. Switzerland, appl. no. 27154/95, 29 March 2001, §42.

1509 D.N. v. Switzerland, appl. no. 27154/95, 29 March 2001, §44. 
In general, Strasbourg case law demonstrates that the personal (subjective) impartiality of a judge must be presumed until there is proof to the contrary. The objective impartiality is determined irrespective of the judge's personal conduct. If there are ascertainable facts that may raise doubts as to his impartiality, for example, caused by the internal organisation of the Judiciary, these doubts may be judged legitimate. In this respect even appearances may be of importance. ${ }^{1510}$

In the ECtHR's opinion, the confidence which the courts in a democratic society, must inspire in the public is at stake, which renders the objective impartiality naturally of great importance. ${ }^{1511}$ Accordingly, any judge with respect to whom there is legitimate reason to fear a lack of impartiality, must withdraw. In deciding whether there is indeed a legitimate reason to fear that a particular judge lacks impartiality, the ECtHR has repeatedly underlined that 'the standpoint of the parties concerned is important though not decisive'.

What is decisive is whether this fear can be held to be objectively justified, which is, in turn dependent on the specific circumstances of the case. ${ }^{1512}$ For example, a prosecutor cannot be regarded as a court. However, the ECtHR does consider an investigating judge deciding on the lawfulness of pre-trial detention pursuant to Article 59a of the DCCP, to constitute a court in accordance with Article 5, section 4 of the ECHR. ${ }^{1513}$ The President of a District Court can be considered as a court as long as the procedure followed has a judicial character. ${ }^{1514}$ This issue will further be elaborated on in the next section.

The case of Hauschildt $v$. Denmark ${ }^{1515}$ demonstrates that judges who have already dealt with a case in an earlier stage of the proceedings may be considered partial, especially when the judge decided on questions closely related to issues of substantive domestic law. ${ }^{1516}$ This may be the case when a judge already decided on the question of whether there was a reasonable suspicion sufficiently strong to lawfully detain a suspect. In this respect, it is important to note that in Varbanov $v$.

1510 Compare with the requirements set for judicial authorities pursuant to Article 5, section 3 of the ECHR in which appearances play a role as well.

1511 Hauschildt v. Denmark, appl. no. 10486/83, 24 May 1989, §48.

1512 Hauschildt v. Denmark, appl. no. 10486/83, 24 May 1989, §48. See, also, Bülbül v. Turkey, appl. no. 47297/99, 22 May 2007, §26-28; Ramishvili and Kokhreidze v. Georgia, appl. no. 1704/06, 27 January 2009, §133-136. See, also, S. Trechsel, Human Rights in Criminal Proceedings, Oxford University Press 2005, p. 479-481.

1513 Douiyeb v. the Netherlands, appl. no. 31464/96, 4 August 1999, §57-59.

1514 Wassink v. the Netherlands, appl. no. 12535/86, 27 September 1990, §30; Keus v. the Netherlands, appl. no. 12228/86, §28; Bouamar v. Belgium, appl. no. 9106/80, 29 February 1988, §57; Droogenbroeck v. Belgium, appl. no. 7906/77, 24 June 1982, §54.

1515 Hauschildt v. Denmark, appl. no. 10486/83, 24 May 1989.

1516 Hauschildt v. Denmark, appl. no. 10486/83, 24 May 1989, §49-53. Compare with Lavents c. Lettonie, requête $\mathrm{n}^{\mathrm{o}} 58442 / 00,28$ novembre 2002, $\$ 80-84$; Jurjevs c. Lettonie, requête $\mathrm{n}^{\circ}$ $70923 / 01,15$ juin 2006, $\$ 55$. 
Bulgaria the ECtHR underlined that if the authority that initially ordered ${ }^{1517}$ a suspect's detention, does not comply with the procedural guarantees implied in Article 5, section 4 of the ECHR, the suspect must be provided 'effective recourse to a second authority which does provide all the guarantees of judicial procedure'. 1518

A third qualitative requirement relating to the notion of court within the context of Article 5, section 4 of the ECHR, is that a court must not merely have advisory functions, ${ }^{1519}$ but it must have the competence to factually decide on the lawfulness of the pre-trial detention and to order release if pre-trial detention is considered unlawful. Specialised bodies, such as a Parole Board, are not precluded, as long as they have sufficient authority to actually decide on the lawfulness of pre-trial detention. ${ }^{1520}$

An important question, in this respect, is to what extent judges can in fact decide on the lawfulness of pre-trial detention in case they do not have access to the complete case file. The power of a court to factually examine whether a suspect's pre-trial detention is in compliance with Article 5 of the ECHR is considerably restricted when the public prosecutor withholds the suspect and the court part of the case file. That may undermine the competent court's power to effectively examine whether pre-trial detention is (un)lawful. This issue will further be discussed below in Section 6.5.

In sum, Strasbourg requires a court pursuant to Article 5, section 4 of the ECHR, to be composed of judges who are sufficiently independent ${ }^{1521}$ and impartial in accordance with Article 6, section 1 of the ECHR. This court does not necessarily have to be a court of law of the classic kind, integrated within the standard judicial machinery of the country. However, a court within the context of Article 5, section 4 of the ECHR must: (1) possess sufficient power to factually decide on the lawfulness of pre-trial detention during judicial proceedings, and (2) be empowered to order the suspect's release if the pre-trial detention is considered unlawful. ${ }^{1522}$

1517 The ECtHR noted that the applicant's detention was ordered by a district prosecutor, who subsequently became a party to proceedings against the applicant, seeking his psychiatric internment.

1518 Varbanov v. Bulgaria, appl. no. 31365/96, 5 October 2000, §58.

1519 Violations of Article 5, section 4 of the ECHR have been concluded to regarding so-called 'specialised bodies' for review of the lawfulness of pre-trial detention. Such specialised bodies in fact only had an advisory function. See, Ireland v. the United Kingdom, appl. no. 5310/71, 18 January 1978, §200: 'advisory committee'. Van Droogenbroeck v. Belgium, appl. no. 7906/77, 24 June 1982, §50: 'recidivists board'.

1520 Weeks $v$. the United Kingdom, appl. no. 9787/82, 2 May 1987, §61.

1521 Varbanov v. Bulgaria, appl. no. 31365/96, 5 October 2000, §58: 'In some cases the judicial supervision may be incorporated in the decision ordering detention if it is taken by a body which constitutes a 'court' within the meaning of Article $5 \S 4$ of the Convention. In order to constitute such a 'court', an authority must be independent from the Executive and from the parties'.

1522 Gavril Yosifov v. Bulgaria, appl. no. 74012/01, 6 November 2008, §56. 


\subsection{The nature of habeas corpus proceedings}

For habeas corpus proceedings to be Strasbourg conforming, they must have a judicial character and give to the individual concerned guarantees appropriate to the kind of deprivation of liberty in question. Domestic courts deciding on habeas corpus complaints must warrant respect for the fundamental guarantees of judicial procedure and habeas corpus proceedings must meet, to the largest extent possible, the basic requirements of a fair trial. ${ }^{1523}$ This section discusses which fundamental guarantees of judicial procedure it concerns, and to what extent fair trial principles pursuant to Article 6 of the ECHR must be complied with. ${ }^{1524}$

In Bouamar v. Belgium, the ECtHR formulated 4 benchmarks to examine whether habeas corpus proceedings are sufficiently judicial in nature: (1) the question of whether an accused is allowed to be present during the court-hearing, (2) whether he has access to a counsel, (3) whether that counsel has access to the whole case file, and (4) the question of whether the accused is accompanied by his counsel during the hearings. In this case, the ECtHR concluded that Article 5, section 4 of the ECHR had been violated, because Mr. Bouamar's lawyer was denied access to the court-hearings. ${ }^{1525}$

It is important to note that the ECtHR considers the question of whether a suspect and his lawyer have been granted access to the whole case file (3) as criterion for examining the nature of habeas corpus proceedings. As will further be elaborated on, the ECtHR has underlined that all parties involved in habeas corpus proceedings should, in principle, have access to the whole case file. Withholding (part of) the case file from the suspect and/or his lawyer may undermine the quality of the habeas corpus proceedings, and may render them insufficiently judicial in nature. It goes without saying that this consideration is of the utmost importance with respect to the potential scope of Article 66, section 3 in conjunction with Article 30, section 2 of the DCCP.

1523 Svipsta v. Latvia, appl. no. 66820/01, 9 March 2006, §129; Reinprecht v. Austria, appl. no. 67175/01, 15 November 2005, §39; D.N. v. Switzerland, appl. no. 27154/95, 29 March 2001, $\S 41$; Megyeri v. Germany, appl. no. 13770/88, 12 May 1992, §22; Lietzow v. Germany, appl. no. 24479/94, 13 February, §44; Schöps v. Germany, 25116/94, 13 February 2001, §44.

1524 Schöps v. Germany, appl. no. 25116/95, 13 February 2001, §44. See for an extensive examination of the applicability of fair trial principles as comprised in Article 6 of the ECHR during habeas corpus proceedings pursuant to Article 5, section 4 of the ECHR: S. Trechsel, Human Rights in criminal proceedings, Oxford University Press 2005, pp. 478-491.

1525 Bouamar v. Belgium, appl. no. 9106/80, 29 February 1988, §59-62. The ECtHR also ruled that the lapse of time between the filing of the complaint and the decision exceeded the reasonable time-period mentioned in Article 5, section 4 of the ECHR. Furthermore, the appellate court did not really 'decide' the 'lawfulness' of the placement measures which were challenged before it by Mr. Bouamar. 
In Schöps v. Germany, the applicant complained that the review proceedings that he lodged against his pre-trial detention were not truly adversarial. He and his counsel were not given sufficient access to the case file and could consequently not properly question the lawfulness of the continued pre-trial detention. ${ }^{1526}$ The German Government however, argued that the proceedings under Article 5, section 4 of the ECHR, are not governed by the same procedural standards as Article 6 of the ECHR. ${ }^{1527}$

The ECtHR explicitly went into the nature of habeas corpus proceedings, and recalled 'that arrested or detained persons are entitled to a review bearing upon the procedural and substantive conditions which are essential for the 'lawfulness', in the sense of the Convention, of their deprivation of liberty. This means that the competent court has to examine not only compliance with the procedural requirements set out in domestic law but also the reasonableness of the suspicion grounding the arrest and the legitimacy of the purpose pursued by the arrest and the ensuing detention'. ${ }^{1528}$

This presupposes that the scope of habeas corpus proceedings 'must be adversarial and must always ensure 'equality of arms' between the parties, the prosecutor and the detained person. Equality of arms is not ensured if the counsel is denied access to those documents in the investigation file which are essential in order effectively to challenge the lawfulness of his client's detention. In the case of a person whose detention falls within the ambit of Article 5(1c), a hearing is required (...). 1529

These two quotes demonstrate that the ECtHR distinguishes between: (1) the required substantive scope of habeas corpus proceedings, i.e. on the basis of what aspects do domestic courts need to examine the lawfulness of pre-trial detention, and (2) the required procedural scope of such proceedings, i.e. what (domestic) procedural guarantees must be complied with in order for habeas corpus proceedings to be sufficiently judicial. This section discusses the required procedural scope of habeas corpus proceedings. Section 6.5 scrutinises the required substantive scope of such proceedings.

In terms of procedure, habeas corpus proceedings must be of an adversarial character $^{1530}$, the principle of equality of arms must be guaranteed, and there must

\footnotetext{
1526 Schöps v. Germany, appl. no. 25116/95, 13 February 2001, §41.

1527 Schöps v. Germany, appl. no. 25116/95, 13 February 2001, §42.

1528 Schöps v. Germany, appl. no. 25116/95, 13 February 2001, §44. See, also, Garcia Alva v. Germany, appl. no. 23541/94, 13 February 2001, §39; Staykov v. Bulgaria, appl. no. 49438/99, 12 October 2006, §96; Bochev v. Bulgaria, appl. no. 73481/01, 13 November 2008, §64; Nikolova v. Bulgaria, appl. no. 31195/96, 25 March 1999, §58-59; Ramishvili and Kokhreidze v. Georgia, appl. no. 1704/06, 27 January 2009, §124.

1529 Schöps v. Germany, appl. no. 25116/95, 13 February 2001, $\$ 44$.

1530 Krejčiŕr c. République Tchèque, requêtes n ${ }^{\text {os }} 39298 / 04$ et 8723/05, 26 mars 2009, §116.
} 
be a fair hearing. ${ }^{1531}$ Both the prosecution and the defence must be given the opportunity to have knowledge of and comment on the observations filed and the evidence adduced by the other party. This implies that, in light of the principle of equality of arms, the suspect must be granted access to all of the information within the case file that is of importance to question the lawfulness of the pre-trial detention. Accordingly, the suspect will have the opportunity to effectively challenge the statements or views that the prosecution bases on these documents. ${ }^{1532}$

However, the ECtHR does not consider all of the prerequisites comprised in Article 6 of the ECHR to be automatically and without restrictions, applicable during habeas corpus proceedings. Fair trial principles must be met to the largest extent possible. The question is whether the ECtHR employs a mandatory minimum level of compliance with fair trial principles to be complied with during habeas corpus proceedings? And what circumstances may justify restrictions on compliance with fair trial principles during habeas corpus proceedings? In the following sections, the focus will be on restrictions on the right to have access to the case file. The most important Strasbourg judgements in that respect will now be discussed.

1531 This implies that, in principle, suspects as well or at least their lawyer must be granted the right to be present during habeas corpus proceedings. See, Migon v. Poland, appl. no. 24244/94, 25 June 2002, $\S 68$ and 70-72. In Svipsta v. Latvia the ECtHR considers that in the case of a person whose detention falls within the ambit of Article 5, section 1 under $\mathrm{c}$ of the ECHR, Article 5, section 4 of the ECHR requires that a hearing be held. The hearing must be adversarial; this normally involves legal representation and, where appropriate, the possibility of calling and questioning witnesses'. Svipsta v. Latvia, appl. no. 66820/01, 9 March 2006, §129. See, also, Hussain v. the United Kingdom, appl. no. 21928/93, 21 February 1996, §60; Singh v. the United Kingdom, appl. no. 23389/94, 21 February 1996, §68; Kampanis v. Greece, appl. no. 17977/91, 13 July 1995, §47; Włoch v. Poland, appl. no. 27785/95, 19 October 2000, §126; Yunus Aktaş et Autres c. Turquie, requête $\mathrm{n}^{\circ}$ 24744/03, 20 octobre 2009, §36; Öcalan v. Turkey [GC], appl. no. 46221/99, 12 May 2005, §66-73; Molodorych v. Ukraine, appl. no. 2161/02, 28 October 2010, §98; Krejčír c. République Tchèque, requêtes $\mathrm{n}^{\text {os }}$ 39298/04 et 8723/05, 26 mars 2009, §116; G.K. v. Poland, appl. no. 38816/97, 20 January 2004, §91; Kawka v. Poland, appl. no. 25874/94, 9 January 2001, §57; Vrenčev v. Serbia, appl. no. 2361/05, 23 September 2008, §81-84; Belevitskiy v. Russia, appl. no. 72967/01, 1 March 2007, §110. In the latter judgement, the ECtHR explicitly considered that 'the possibility for a detainee to be heard either in person or through some form of representation features among the fundamental guarantees of procedure applied in matters of deprivation of liberty'. See, also, Sergey Volosyuk v. Ukraine, appl. no. 1291/03, 12 March 2009, §54-55. In this latter judgement, the ECtHR argued, regarding the absence of the applicant and his lawyer during habeas corpus proceedings, that ' $(. .$.$) the guarantee of$ equality of arms in the course of that hearing was not respected since the applicant had no opportunity to comment on the arguments or contest the reasons invoked by the prosecuting authorities to justify his detention'.

1532 Svipsta v. Latvia, appl. no. 66820/01, 9 March 2006, §129. 


\section{LAMY v. BELGIUM}

The case of Lamy v. Belgium is a key judgement regarding the scope of suspects' right to access the case file during the pre-trial phase. ${ }^{1533}$ The applicant had lodged a habeas corpus complaint with the court of first instance, the Court of Appeal and the Belgian Supreme Court. All three courts judged the applicant's pre-trial detention to be lawful. ${ }^{1534}$

The applicant complained before the ECtHR that review of the lawfulness of his detention should have taken place through adversarial proceedings. As he claimed, these could not be considered to have taken place due to a major flaw in the proceedings: the investigative judge and prosecution had had an opportunity to make their submissions in full knowledge of the contents of a substantial case file, while the applicant could only argue his case on the vague charges made in the arrest warrant he was given shortly after his arrest. ${ }^{1535}$ Secondly, during the first 30 days of pre-trial detention, the applicant was not allowed access to the case file. Subsequently, his lawyer - but not he himself - had access to it but only during the forty-eight hours preceding each appearance before the respective courts. Thirdly, the applicant claimed that the court of first instance as well as the Court of Appeal had taken no account of his submissions. ${ }^{1536}$

The ECtHR held that 'access to these documents [the case file] was essential for the applicant at this crucial stage in the proceedings, when the court [of first instance] had to decide whether to remand him [the applicant] in custody or to release him. Such access would, in particular, have enabled counsel for Mr Lamy to address the court on the matter of the co-defendants' statements and attitude'.

Having access to the whole case file was considered a precondition for effectively challenging the lawfulness of the arrest warrant. ${ }^{1537}$ Because the prosecution had the whole case file at its disposal, whereas the applicant did not, habeas corpus proceedings did not afford the applicant an effective opportunity of challenging appropriately the reasons relied upon to justify his pre-trial detention. Since it therefore failed to ensure equality of arms, the procedure was not truly adversarial and therefore violated Belgium's obligations pursuant to Article 5, section 4 of the ECHR. ${ }^{1538}$

In this respect it is important to note that the ECtHR, generally, deems the appraisal of the need for remand in custody and the subsequent assessment of guilt to be 'too closely linked for access to documents to be refused in the former case

\footnotetext{
1533 Lamy v. Belgium, appl. no. 10444/83, 30 March 1989.

1534 Lamy v. Belgium, appl. no. 10444/83, 30 March 1989, §9-17.

1535 See, also, Migon v. Poland, appl. no. 24244/94, 25 June 2002, §16 and 18.

1536 Lamy v. Belgium, appl. no. 10444/83, 30 March 1989, §27.

1537 Lamy v. Belgium, appl. no. 10444/83, 30 March 1989, §29.

1538 See, also, Nikolov v. Bulgaria, appl. no. 38884/97, 30 January 2003, §59 and 96-99.
} 
when the law requires it in the latter case'. ${ }^{1539}$ While it is left to the discretion of the national authorities to decide on how to satisfy this requirement, whatever method is chosen should ensure that the defence will be aware that observations have been filed and will have a real opportunity to comment thereon. ${ }^{1540}$

In Bochev v. Bulgaria the ECtHR reiterated this line of reasoning and considers that habeas corpus proceedings are not truly adversarial and do not ensure equality of arms between the parties when the prosecution authorities have the privilege of addressing the judges with arguments that cannot be countered by the suspect in pre-trial detention. ${ }^{1541}$

\section{SCHÖPS v. GeRMANY}

In Schöps v. Germany, the ECtHR considered that the case file should have been send to the applicant and his lawyer because it consisted of the evidence on which the suspicion was based. When the public prosecutor requested the prolongation of the applicant's detention on remand, he based the suspicion against the applicant on the contents of the case file. The documents comprised in the case file appeared to be essential to the issue of the applicant's continued detention and should therefore have been disclosed to him and his lawyer. Even though the applicant was initially informed about the charges against him by the detaining authority - in general terms and through the arrest warrant - the information provided in this way was only an account of the facts as construed by the District Court. That account was construed on the basis of all the information made available to it by the public prosecutor. ${ }^{1542}$

The ECtHR reiterated that it is hardly possible for a suspect to challenge properly the reliability of such an account without being made aware of the underlying evidence. The suspect should be given sufficient opportunity to have knowledge of statements and other pieces of evidence underlying them, such as the results of the police and other investigations, irrespective of whether the suspect is able to provide any indication as to the relevance for his defence of the pieces of evidence to which he seeks to be given access. This is even more so in the case of complex investigations and when there is a large quantity of material on which the suspicion against a suspect is grounded. ${ }^{1543}$ In the ECtHR's opinion, it was therefore essential for the applicant, as well as for his lawyer, to have access to the whole case file.

\footnotetext{
1539 Lamy v. Belgium, appl. no. 10444/83, 30 March 1989, §29, Svipsta v. Latvia, appl. no. 66820/01, 9 March 2006, §129; Lexa v. Slovakia (no. 2), appl. no. 34761/03, 5 January 2010, §69.

1540 Svipsta v. Latvia, appl. no. 66820/01, 9 March 2006, §129.

1541 Bochev v. Bulgaria, appl. no. 73481/01, 13 November 2008, §69.

1542 Schöps v. Germany, appl. no. 25116/94, 13 February 2001, §7-37.

1543 Schöps v. Germany, appl. no. 25116/94, 13 February 2001, §50-53.
} 
These considerations demonstrate that the ECtHR acknowledges that, in principle, there indeed exists a right for suspects to have access to the complete case file during pre-trial proceedings under Article 5, section 4 ECHR. This even applies when the suspect has not filed an official request to view the records comprised in the case file. Information regarding the facts leading to the reasonable suspicion and the pre-trial detention must be provided to the suspect, especially when it concerns a complex case with a large case file. ${ }^{1544}$ It remains to be seen whether, and if so to what extent, the ECtHR allows for restrictions on the right to access the whole case file.

\section{SHISHKOV v. Bulgaria}

In Shishkov v. Bulgaria, the ECtHR balanced investigative (public) interests against defence rights during habeas corpus proceedings. The applicant stated that, contrary to Article 5, section 4 of the ECHR, the usual practice was for lawyers and accused persons in Bulgaria is to be refused access to the case file during the preliminary investigation, allegedly to ensure that information obtained in the investigation remained confidential. ${ }^{1545}$

The ECtHR explicitly acknowledged the need for criminal investigations to be conducted efficiently, which may imply that part of the information collected during such investigations is to be kept secret, in order to prevent suspects from tampering with evidence and undermining the course of justice. However, the interest of effective criminal investigations cannot be pursued at the expense of substantial restrictions on the rights of the defence. This implies that information that is essential for the assessment of the lawfulness of a detention, should be made available in an appropriate manner to the suspect and his lawyer. ${ }^{1546}$

Interferences with a suspect's right to access the case file cannot be justified with reference to investigative interests if the information is indispensable to judge on the lawfulness of pre-trail detention. Needless to say, it may concern both exempting as well as incriminating information. ${ }^{1547}$ Vice versa, this reasoning however also implies that when the information that is not disclosed to the suspect, is irrelevant with respect to the habeas corpus proceedings, the information may be kept from a suspect when investigative interests require so. It is, however, questionable what

1544 Schöps v. Germany, appl. no. 25116/94, 13 February 2001, §49-52.

1545 Shishkov v. Bulgaria, appl. no. 38822/97, 9 January 2003, §69.

1546 Shishkov v. Bulgaria, appl. no. 38822/97, 9 January 2003, §77. Compare with Kehayov v. Bulgaria appl. no. 41035/98, 18 January 2005, §84-88.

1547 According to the ECtHR, public prosecutors are not allowed to retain exempting evidence from the suspect and/or his defence lawyer. See, Edwards v. the United Kingdom, appl. no. 13071/87, 16 December 1992; Schöps v. Germany, appl. no. 25116, 13 February 2001; Lietzow v. Germany, appl. no. 24479/94, 13 February 2001; Garcia Alva v. Germany, appl. no. 23541/94, 13 February 2001; Fitt v. the United Kingdom, appl. no. 29777/96, 16 February 2000. 
information within the case file will not be of importance to decide on the lawfulness of pre-trial detention.

As the ECtHR held in Schöps v. Germany, all information that underlies the suspicion against an accused and the information used to further justify pre-trial detention is important while deciding on the lawfulness of pre-trial detention. This also demonstrates the close connection between the substantive scope and the procedural scope of habeas corpus proceedings pursuant to Article 5, section 4 of the ECHR: in order to adequately examine all substantive prerequisites for lawful pre-trial detention (i.e. reasonable suspicion, relevant and sufficient grounds, special diligence), all parties involved in habeas corpus proceedings must have access to the documents which sustain or contradict the alleged fulfilment of these prerequisites.

Lastly, it is important to note that information may be kept from the suspect during the initial period of pre-trial detention. This is, however, only allowed when the investigation is still in an early and uncertain stage, and the detained suspect has moreover not (yet) lodged a habeas corpus complaint. Once the suspect decides to lodge proceedings pursuant to Article 5, section 4 ECHR, defence rights relating to the principle of equality of arms - such as the right to access one's case file - prevail over investigative interests.

\section{Garcia Alva v. Germany}

In Garcia Alva v. Germany ${ }^{1548}$, the public prosecutor had dismissed the applicant's lawyer's request for consultation of the case files on the ground that consultation of these documents would endanger the purpose of the investigation. The lawyer requested, in particular, access to files concerning a crucial incriminating witness testimony. That testimony had been used to order the suspect's prolonged pre-trial detention. In his opinion, the applicant did therefore not have an opportunity to adequately challenge the evidence for - and consequently the lawfulness of - his continued pre-trial detention. ${ }^{1549}$

Not surprisingly, the ECtHR argued that because the detention was primarily based on evidence to which the applicant had not been given access - though that evidence was clearly essential in respect of the assessment of the lawfulness of the detention - the standards flowing from the principle of equality of arms had not been complied with during the habeas corpus proceedings. Therefore, Article 5, section 4 of the ECHR had been violated. ${ }^{1550}$

\footnotetext{
1548 Garcia Alva v. Germany, appl. no. 23541/94, 13 February 2001.

1549 Garcia Alva v. Germany, appl. no. 23541/94, 13 February 2001, §40-42.

1550 Garcia Alva v. Germany, appl. no. 23541/94, 13 February 2001, §42-44.
} 
This line of reasoning emphasises again that as regards to access to the case file during habeas corpus proceedings, interests of the investigation - however pressing they may allegedly be - have to bend for defence rights as guaranteed in Article 6 of the ECHR to guarantee adversarial proceedings during which the principle of equality of arms is lived up to. This is especially the case when the information that is being kept from a suspect and his lawyer, is explicitly used to justify his continued pre-trial detention. ${ }^{1551}$

\section{Migon v. Poland}

In Migon v. Poland ${ }^{1552}$, the applicant had not been allowed access to the case file for a period of more than eight months. The government contented that this was necessary to prevent the suspect from tampering with the evidence. Furthermore, neither the applicant nor his lawyer, were allowed to be present during the habeas corpus proceedings. Therefore, the applicant was basically held in pre-trial detention without being able to inspect or effectively challenge the evidence used to justify his pre-trial detention - besides from the charges comprised in the arrest warrant.

The ECtHR elaborated extensively on the suspects' right to inspect the (whole) case file during the pre-trial phase. ${ }^{1553}$ During habeas corpus proceedings, the suspect must be allowed access to the case file, if only to such an extent as to afford him an opportunity of effectively challenging evidence on which his detention was based. ${ }^{1554}$ Without access to one's case file, the right to lodge habeas corpus proceedings becomes practically meaningless. Respect for defence rights during habeas corpus proceedings serves to make (the right to lodge) such proceedings effective. Again, it turns out that defence rights outweigh interests of the investigation within the scope of Article 5, section 4 of the ECHR. ${ }^{1555}$

However, at the same time, the ECtHR has also repeatedly underlined that there are exceptional circumstances under which a suspect's right to inspect the whole case file may be restricted. Four aspects determine whether or not certain documents

1551 Svipsta v. Latvia, appl. no. 66820/01, 9 March 2006, §137. In this case, the applicant had been kept in pre-trial detention for 6 months without being allowed access to the whole case file. The ECtHR considered this to constitute a violation of Article 5, section 4 of the ECHR. See, also, Krejčír c. République Tchèque, requêtes $\mathrm{n}^{\text {os }} 39298 / 04$ et 8723/05, 26 mars 2009, §116. In the latter case, the ECtHR argued that '(...) il n'y a pas égalité des armes lorsqu'un avocat se voit refuser l'accès aux documents du dossier d'instruction dont l'examen est indispensable pour contester efficacement la légalité de la détention de son client. (...) des informations essentielles pour apprécier la légalité de la détention d'une personne doivent toujours être mises à la disposition de son avocat d'une manière adaptée à la situation'. 
may be kept from a suspect. Even though this must be assessed in light of the particular circumstances of the case, each of these four aspects played a role of importance in the above-discussed judgements.

Firstly, there is the nature of the documents that are being kept from the suspect. The more documents are used to fulfill the substantive requirements for lawful pretrial detention, the less justifications there will be to withhold them from the suspect.

The second aspect is the number of documents that the suspect is not allowed to inspect. The more documents that are not disclosed to the suspect, the more likely it is that Article 5, section 4 of the ECHR is not complied with.

Thirdly, the importance of the documents with respect to the assessment of the lawfulness of the detention plays a role. The more important documents are to effectively challenge and/or decide on the lawfulness of the detention, the more reason there is to disclose them to the suspect and the court.

The fourth aspect is the period during which the suspect is not allowed access to the case file. ${ }^{1556}$ Investigative interests may justify withholding the suspect certain documents during the initial stages of a criminal investigation, but as pre-trial detention wears on and/or when the suspect lodges a habeas corpus complaint, there will increasingly be less reason for such a restriction on a suspect's defence rights. 1557

In applying these aspects to the present case, the ECtHR concluded that Article 5, section 4 of the ECHR had been violated. Firstly, the investigative authorities and the domestic courts relied on various documents and evidence to which the suspect did not have access. Secondly, new evidence had been coming to light gradually during the criminal investigation, revealing new aspects of the case of which the suspect was uninformed. Thirdly, the documents that had been made available to the suspect - through the arrest warrant - did not provide an adequate basis on which to address the arguments relied on both by the prosecution and by the domestic courts in support of the decisions to prolong the suspect's detention. ${ }^{1558}$

In sum, any effective possibility for the defence throughout the detention proceedings was lacking. In the ECtHR's view this was all the more true 'when taking into account the progress of the investigation, in which new evidence was gradually coming to light which was moreover used to justify the suspect's continued pre-trial detention'.

\footnotetext{
1556 Migon v. Poland, appl. no. 24244/94, 25 June $2002 \S 81$.

1557 In Shamayez and Others v. Georgia and Russia the ECtHR considered Article 5, section 4 of the ECHR to be violated because the applicants were not allowed to inspect their case files in order to prepare for habeas corpus proceedings. See, Shamayev and Others v. Georgia and Russia, appl. no. 36378/02, 12 April 2005, §431-432.

1558 Migon v. Poland, appl. no. 24244/94, 25 June $2002 \S 82-86$.
} 


\section{Mooren v. Germany}

The case of Mooren v. Germany concerned an applicant suspected of tax evasion. ${ }^{1559}$ The domestic courts reached their conclusion that there was a strong suspicion of the applicant having committed tax evasion, with reference to the contents of voluminous case files. These files included business records seized at the applicant's home, but also witness statements made by the proprietors of firms the applicant had been working for, as well as contracts of employment and wage slips and commission statements. Hence, the suspicion against the applicant was grounded on a large quantity of material, which was only referred to in general terms in the detention orders. The content of the case file appeared to have played a key role in the courts' decisions to prolong the applicant's pre-trial detention. While the Public Prosecutor's Office and the courts were familiar with the case file, their precise content was not initially brought to the knowledge of the applicant's counsel. The Public Prosecutor's Office repeatedly dismissed the counsel's request for access to the case file on the ground 'that consultation of these documents would endanger the purpose of the investigations'.

It was only after a decision of the Court of Appeal ${ }^{1560}$ that the applicant's counsel was provided with copies of four pages of the voluminous case file containing an overview on the amount of the applicant's income and the taxes he was suspected of having evaded. However, these documents only gave an account of the facts as construed by the prosecution authorities on the basis of all the information available to them. In the ECtHR view 'it is virtually impossible for an accused, even if assisted by counsel, properly to challenge the reliability of such an account without being aware of the evidence on which it is based'. Even in a case such as the present one in which the detention order was partly based on evidence seized at the defendant's home which, in principle, he would have been familiar with, his defence counsel should have been given sufficient opportunity to acquaint himself personally with the underlying statements and other pieces of evidence. For the same reasons, the ECtHR deemed the proposal by the prosecution, which was

1559 Mooren v. Germany, appl. no. 11364/03, 13 December 2007; Mooren v. Germany [GC], appl. no. 11364/03, 9 July 2009, §124-125. The Grand Chamber fully endorsed the reasoning of the Chamber and found that the procedure by which the applicant sought to challenge the lawfulness of his pre-trial detention violated the fairness requirements of Article 5, section 4 of the ECHR.

1560 The Court of Appeal quashed the decisions taken by the District Court and the Regional Court in the proceedings for judicial review of the detention order. It found that the detention order was defective because the facts and evidence on which the suspicion that an offence had been committed and the reasons for the applicant's detention were based were not described in such detail as to enable him to comment and defend himself effectively. According to the Court of Appeal, these defects amounted to a denial of the right of the accused to be heard in view of the fact that counsel for the defence had been refused access to the case files under section $147 \S 2$ of the Code of Criminal Procedure. Mooren v. Germany, appl. no. 11364/03, 13 December 2007, $\S 97$. 
endorsed by the courts, 'to give the applicant's counsel merely an oral account of the facts and evidence in the case files' insufficient. ${ }^{1561}$

Even though the ECtHR did not lose sight of the fact that the refusal to grant the applicant's lawyer's access to the case files was based on a risk of compromising the success of the ongoing investigations, that goal could not be pursued at the expense of substantial restrictions on the rights of the defence. The applicant/lawyer should have been given access to those parts of the case files on which the suspicion against the applicant was essentially based. ${ }^{1562}$ It follows that the applicant and his lawyer did not have an opportunity to adequately challenge the findings referred to by the Public Prosecutor or the courts, as required by the principle of equality of arms. ${ }^{1563}$

The fact that the applicant's lawyer was granted access to the case files after the applicant's conditional release from prison could not remedy in an effective manner the procedural shortcomings in the earlier stages of the proceedings. These considerations led the ECtHR to conclude that Article 5, section 4 of the ECHR had been violated. ${ }^{1564}$

IN SUM

Habeas corpus proceedings pursuant to Article 5, section 4 of the ECHR must, to a considerable extent, comply with fair trial principles as comprised in Article 6 of the ECHR. ${ }^{1565}$ The longer pre-trial detention lasts, the more likely it is that Article 5, section 4 of the ECHR substantially stands for the same fair trial guarantees as Article 6, section 1 of the ECHR in its criminal aspect. ${ }^{1566}$ Basically, for habeas corpus proceedings to comply with the ECtHR's procedural requirements, those proceedings must be sufficiently certain and effective ${ }^{1567}$, the proceedings must be

1561 Mooren v. Germany, appl. no. 11364/03, 13 December 2007, §95-96.

1562 See, also, Lexa v. Slovakia (no. 2), appl. no. 34761/03, 5 January 2010, §73. In this judgement, the ECtHR underlined that the accused is to be given 'a sufficient opportunity to take cognisance of statements and other pieces of evidence underlying them, such as the results of police and other investigations, irrespective of whether the accused is able to provide any indication as to the relevance for his defence of the pieces of evidence which he seeks to be given access to'.

1563 Mooren v. Germany, appl. no. 11364/03, 13 December 2007, §96.

1564 Mooren v. Germany, appl. no. 11364/03, 13 December 2007, §93-99. Compare with Easzkiewicz v. Poland, appl. no. 28481/03, 15 January 2008, §79-86.

1565 Ilijkov v. Bulgaria, appl. no. 33977/96, 26 July 2001, §103; Shiskov v. Bulgaria, appl. no. 38822/97, 9 January 2003, $\$ 77$.

1566 A. and Others $v$. the United Kingdom, appl. no. 3455/05, 19 February 2009, §217.

1567 Svipsta v. Latvia, appl. no. 66820/01, 9 March 2006, §130-135. Effective judicial review pursuant to Article 5, section 4 of the ECHR, implies that there will be an effective examination of the parties' observations. Orders extending pre-trial detention based on a pro forma model, prepared in advance, which undergo minor alterations each time before being printed out and signed in summary fashion at the end of each hearing, are, in most cases, in violation of Article 5, section 4 of the ECHR. Secondly, effective judicial review implies that the existence of the remedy required by Article 5, section 4 of the ECHR must be sufficiently certain, not only in theory but 
of an adversarial nature, must respect the principle of equality of arms, and provide, within that context, for a fair oral hearing before the competent court. Furthermore, the detained suspect and/or at least his lawyer have a right to be present during habeas corpus proceedings, they should be granted sufficient time and facilities to prepare their claims, and the suspect should be admitted to consult a lawyer in private. ${ }^{1568}$ Since the persistence of a reasonable suspicion that the accused person has committed an offence is a condition sine qua non for the lawfulness of the continued detention, the detainee must be given an opportunity effectively to challenge the basis of the allegations against him. ${ }^{1569}$ This implies that a suspect must, in principle, be allowed access to the whole case file and he must be granted the right to question witnesses. ${ }^{1570}$

The ECtHR's case law demonstrates that equality of arms is not ensured if the suspect is denied access to those documents in the case file that are essential in order to challenge effectively the lawfulness of the pre-trial detention and to

also in practice, failing which, it will lack the accessibility and effectiveness required for the purposes of that provision. The accessibility of a remedy means that the circumstances voluntarily created by the authorities must be such as to afford applicants a realistic possibility of using the remedy. See, also, Soumare v. France, appl. no. 48/1997/832/1038, 24 August 1998, $\S 43$; Kadem v. Malta, appl. no. 55263/00, 9 January 2003, §41; Shchebet v. Russia, appl. no. 16074/07, 12 June 2008, §75; Ryabikin v. Russia, appl. no. 8320/04, 19 June 2008, §137-138; Soldatenko v. Ukraine, appl. no. 2440/07, 23 October 2008, §125; Khodzhayev v. Russia, appl. no. 52466/08, 12 May 2010, §121-126; Ismoilov and Others v. Russia, appl. no. 2947/06, 24 April 2008, §145; R.M.D. v. Switzerland, appl. no. 81/1996/700/892, 26 September 1997, §52; Fodale v. Italy, appl. no. 70148/01, 1 June 2006, §43; Ramishvili and Kokhreidze v. Georgia, appl. no. 1704/06, 27 January 2009, §129-131; Talat Tepe v. Turkey, appl. no. 31247/96, 21 December $2004, \S 72$.

1568 Kampanis v. Greece, appl. no. 17977/91, 13 July 1995, $\$ 47$ and 58. In this judgement, the ECtHR underlined again that the principle of equality of arms is one of the main safeguards inherent in judicial proceedings conducted in conformity with the ECHR. To ensure compliance with this principle, the ECtHR considered it, in general, necessary to give a detained suspect the opportunity to appear at the same time as the prosecutor before the court deciding on the lawfulness of his detention so that he can reply to his arguments. Kawka v. Poland, appl. no. 25874/94, 9 January 2001, §57-61; M.B. v. Poland, appl. no. 34091/96, 27 April 2004, §6567; Frommelt v. Liechtenstein, appl. no. 49158/99, 24 June 2004, §36; Kotsaridis c. Grèce, requête $\mathrm{n}^{0}$ 71498/01, 23 septembre 2004, §29-32; E.M.K. v. Bulgaria, appl. no. 43231/98, 18 January 2005, §130-134; Bilen c. Turquie, requête no 34482/97, 21 février 2006, §51-52; Nešták v. Slovakia, appl. no. 65559/01, 27 February 2007, §81-83. A suspect in pre-trial detention has a right to effective legal assistance by a lawyer, see Istratii and Others v. Moldova, appl. nos. 8721/05, 8705/05 and 8742/05, 27 March 2007, §86-102; Tarău c. Roumanie, requête $\mathrm{n}^{\circ}$ 3584/02, 24 février 2009, §60-63; Boloş c. Roumanie, requête no 33078/03, 12 janvier 2010, §29-39; Erkan Inan c. Turquie, requête $n^{\circ}$ 13176/05, 23 février 2010, §31-33. This issue will not further be elaborated on.

1569 Becciev v. Moldova, appl. no. 9190/03, 4 October 2005, §68-72.

1570 Hussain v. the United Kingdom, appl. no. 21928/93, 21 February 1996; Sanchez-Reisse v. Switzerland, appl. no. 9862/82, 21 October 1986, §51; Megyeri v. Germany, appl. no. 13770/88, 12 May 1992. 
effectively prepare/lodge a habeas corpus complaint. ${ }^{1571}$ Therefore, in general detained suspects have a right to access the case file, at least from the moment when they lodge a habeas corpus complaint. ${ }^{1572}$ Public prosecutors are obliged to disclose the case file to a suspect, regardless of whether the suspect has lodged a formal request to inspect the case file. The suspect does not, therefore, even need to know which precise records the case file contains, and which of those he wants to inspect. Having access to the case file normally outweighs interests of the investigation.

This predominance of respect for the principle of equality of arms during habeas corpus proceedings finds its rationale primarily in the fundamental nature of the right to liberty of person. During the initial stages of a criminal investigation the right to access the case file is less absolute, and may more easily be interfered with - if interests of the investigation require so - than when the investigation proceeds.

Complex criminal investigations during which a large case file is composed, call for complete access to the case file for the suspect and his lawyer. Criminal investigations into terrorism are frequently complex and result in an extensive case file. This may imply that especially when a person is suspected of terrorist offences, he should be granted access to the complete case file when he lodges a habeas corpus complaint, or at least to all information that is used to justify the pre-trial detention. This assumption is even more justified when taking into account that terrorist suspects may be kept in pre-trial detention for prolonged periods. We will now turn to examining the question of whether the ECtHR accepts state security reasons to justify non-disclosure of the case file during habeas corpus proceedings. The judgements discussed so far only refer to the interest of the investigation which does not include state security reasons.

\subsection{Habeas corpus proceedings in case of terrorism: Exceptions?}

As discussed above, the Dutch government deems national security interests as justified reasons to deny a terrorist suspect access to information comprised in the case file. The question that is examined in this section is whether more far-reaching limitations to the right to access the case file during habeas corpus proceedings are allowed in case of a terrorist suspect. What if the case file contains sensitive information which, once made public, could jeopardise national security? How does the ECtHR balance the (state) interest of keeping certain parts of the case file secret to safeguard national security against a suspect's interest of having access to the whole case file in order to adequately enforce his right under Article 5, section 4 of

1571 Frommelt v. Liechtenstein, appl. no. 49158/99, 24 June 2004, §33; Włoch v. Poland, appl. no. 27785/95, 19 October 2000, §127; Nikolova v. Bulgaria, appl. no. 31195/96, 25 March 1999 §58; Lamy v. Belgium, appl. no. 10444/83, 30 March 1989, §29; Fodale v. Italy, appl. no. 70148/01, 1 June 2006, §41; Kehayov v. Bulgaria appl. no. 41035/98, 18 January 2005, §84-88.

1572 Lanz v. Austria, appl. no. 24430/94, 31 January 2000, §41-44; Brandstetter v. Austria, appl. no. 28 August 1991, §67. 
the ECHR? Merely referring to investigative interests cannot justify withholding a suspect who lodges habeas corpus proceedings the case file, but what if such investigative interests also concern national security?

The following judgements primarily regard habeas corpus proceedings within the context of deprivation of liberty pursuant to Article 5, section 4 under $\mathrm{f}$ of the ECHR. However, the ECtHR has repeatedly underlined that such proceedings, when initiated to challenge continued pre-trial detention pursuant to Article 5, section 1 under $\mathrm{c}$ of the ECHR, must import substantially the same fair trial guarantees as Article 6, section 1 of the ECHR in its criminal aspect. ${ }^{1573}$ This means that procedural guarantees during habeas corpus proceedings are certainly not less demanding in the case of deprivation of liberty under section 1 under $\mathrm{c}$ than in the case of deprivation of liberty under section 1 under $\mathrm{f}$ of the ECHR.

\section{Chahal v. the United Kingdom and Al-Nashif v. Bulgaria}

In Chahal v. the United Kingdom the ECtHR balanced legitimate security concerns about the nature and sources of secret intelligence information against the importance of providing persons deprived of their liberty a substantial measure of procedural justice. ${ }^{1574}$ The applicant complained that during judicial review proceedings regarding his detention pursuant to Article 5, section 1 under $\mathrm{f}$ of the ECHR, he was not entitled to legal representation, and he was merely given an outline of the grounds for the notice of intention to deport.

The ECtHR acknowledged that the use of confidential material may be unavoidable where national security is at stake, but that does not mean that the national (investigative) authorities can be free from effective control by the domestic courts whenever they choose to assert that national security and terrorism are involved. ${ }^{1575}$ This is the same line of reasoning as the ECtHR has adopted with respect to claims under Article 5, section 1 under c and section 3. ${ }^{1576}$ Regarding non-disclosure of information from the case file to a person deprived of his liberty during habeas corpus proceedings, the ECtHR referred to the system as applied in Canada. Canada introduced legislation making provision for the appointment of a 'special counsel' who - with respect to cases involving national security - cross-examines the witnesses who have to remain secret during an in camera hearing. The special counsel generally assists the court to test the strength of the state's case. A summary

\section{instead of under section 1 under $\mathrm{c}$ of that Article.}

See Chapter VI for a discussion of this subject.

A. and Others v. the United Kingdom, appl. no. 3455/05, 19 February 2009, §217.

Chahal v. the United Kingdom, appl. no. 22414/93, 15 November 1996, §112-113. Chahal was, just as in Al-Nashif, deprived of his liberty pursuant to Article 5, section 1 under $\mathrm{f}$ of the ECHR See, Chahal v. the United Kingdom, appl. no. 22414/93, 15 November 1996, §131. 
of the evidence obtained by this procedure, with necessary deletions, is then given to the person concerned. 1577

This procedure demonstrates that there are techniques to balance legitimate security concerns about the nature and sources of secret intelligence information against measures of procedural justice. There must be a form of effective judicial control by domestic courts on the lawfulness of deprivation of liberty, even if the case involves national security concerns.

In this case, the full material on which the decisions to deprive the applicant of his liberty were based, was not made available to the courts or to the applicant. According to the ECtHR, this meant that the domestic courts were not, therefore, in a position to review whether the decisions to detain Mr Chahal and to keep him in detention were justified on national security grounds. Although there was the safeguard of an advisory panel, chaired by a Court of Appeal judge, which had full sight of the national security evidence, that panel could not be considered a 'court' within the meaning of Article 5, section 4 of the ECHR because the applicant was not entitled to legal representation before it, and was given only an outline of the national security case against him. The panel had, moreover, no power of decision and its advice to the Home Secretary was not binding and was not disclosed. In light of these considerations, the ECtHR concluded that the domestic habeas corpus proceedings were in violation of the United Kingdom's obligations under Article 5, section 4 of the ECHR. ${ }^{1578}$

Since this judgement, the United Kingdom has introduced legislation making provision for the appointment of the above-described special counsel in certain cases involving national security. This procedure applies during habeas corpus proceedings as well as during criminal proceedings pursuant to Article 6 of the ECHR. ${ }^{1579}$

In Al-Nashif v. Bulgaria, domestic legislation did not provide for judicial appeal against detention pending deportation in cases where the deportation order was

1577 Chahal v. the United Kingdom, appl. no. 22414/93, 15 November 1996, §131 and 144. Under the Canadian Immigration Act 1976, a Federal Court judge holds an in camera hearing of all the evidence, at which the applicant is provided with a statement summarising, as far as possible, the case against him or her and has the right to be represented and to call evidence. The confidentiality of security material is maintained by requiring such evidence to be examined in the absence of both the applicant and his or her representative. However, in these circumstances, their place is taken by a security-cleared counsel instructed by the court, who cross-examines the witnesses and generally assists the court to test the strength of the state's case. A summary of the evidence obtained by this procedure, with necessary deletions, is given to the applicant. Chahal v. the United Kingdom, appl. no. 22414/93, 15 November 1996, §121 and 130-132.

1579 Jasper v. the United Kingdom, appl. no. 27052/95, 16 February 2000, §51-53; Botmeh and Alami v. the United Kingdom, appl. no. 15187/03, 7 June 2007, §37; Edwards and Lewis v. the United Kingdom, appl. nos. 39647/98 and 40461/98, 27 October 2004, §46-48. 
issued on grounds of national security. ${ }^{1580}$ The applicant was detained pursuant to Article 5, section 1 under $\mathrm{f}$ of the ECHR, on suspicion of terrorism-related crimes. He tried, in vain, to challenge the lawfulness of his detention but he was not allowed to consult a lawyer in order to prepare his case, the case file was not disclosed to him and even in the detention order no reasons for his arrest and detention where comprised. He was kept in incommunicado detention ${ }^{1581}$ and he was, on the whole, deprived of any possibility to have access to a court pursuant to Article 5, section 4 of the ECHR.

The ECtHR deemed such a situation to be incompatible with Article 5, section 4 of the ECHR and its underlying rationale, the protection of individuals against arbitrariness. It reiterated that 'national authorities cannot do away with effective control of lawfulness of detention by the domestic courts whenever they choose to assert that national security and terrorism are involved'. 1582

Even though this judgement regards deprivation of liberty under Article 5, section 1 under $f$ of the ECHR instead of under $\mathrm{c}$, the ECtHR formulated its considerations with respect to depriving civilians of an effective right to lodge habeas corpus proceedings in such general terms, that it may very well be that this also goes for pre-trial deprivation of liberty. ${ }^{1583}$ The ECtHR argued in general terms, that 'the right to have the lawfulness of one's detention reviewed, aims at preventing arbitrariness in restricting persons' right to liberty of person'.

\section{A. And Others v. The United Kingdom}

The case of $A$. and Others $v$. the United Kingdom is of key importance with respect to the issue of balancing national security interests against procedural fairness during habeas corpus proceedings. The applicants of this case were detained under the United Kingdom Anti-terrorism, Crime and Security Act 2001. This Act authorises the Secretary of State to issue a certificate indicating his belief that a person's presence in the United Kingdom is a risk to national security, and that he suspects the person of being an international terrorist. On the basis of this certificate, the person concerned is arrested and detained. The certificate is subject to an appeal to the Special Immigration Appeals Commission ('SIAC'), which has power to cancel it if it considers that the certificate should not have been issued. There is an appeal on a point of law from a ruling by the SIAC. In addition, the certificate is reviewed by SIAC at regular intervals. The SIAC is also able to grant bail, where

\footnotetext{
1580 Al-Nashif v. Bulgaria, appl. no. 50963/99, 20 June 2002, §35-47.

1581 This would rather be in contravention to Article 3 of the ECHR (inhuman or degrading treatment) than that it would cause a violation of Article 5 of the ECHR.

1582 Al-Nashif v. Bulgaria, appl. no. 50963/99, 20 June 2002, §94.

1583 Note, however, that the ECtHR has repeatedly ruled that the scope of obligations under Article 5, section 4 of the ECHR is not identical for every kind of deprivation of liberty, see Chahal v. the United Kingdom, appl. no. 22414/93, 15 November 1996, §127.
} 
appropriate, subject to conditions. It is open to a detainee to end his detention at any time by agreeing to leave the United Kingdom. ${ }^{1584}$

During proceedings before the SIAC, the United Kingdom authorities used special advocates to counterbalance procedural unfairness caused by lack of full disclosure of the evidence. ${ }^{1585}$ This meant that although the judges sitting as SIAC were able to consider both the 'open' and 'closed' information, however neither the applicants nor their legal advisers could see the closed material. Instead, the closed material was disclosed to one or more 'special advocates', appointed by the Solicitor General to act on behalf of each applicant. During the closed sessions before the SIAC, the special advocate could make submissions on behalf of the applicant, both as regards procedural matters, such as the need for further disclosure, and as to the substance of the case. However, from the point at which the special advocate first had sight of the closed material, he was not permitted to have any further contact with the applicant and his representatives, save with the permission of the SIAC. In respect of each appeal against certification, the SIAC issued both an open and a closed judgement. 1586

To the extent that the exercise of the extended powers under the aforementioned Act would be inconsistent with the United Kingdom's obligations under Article 5, 1 under f of the ECHR, the government decided to avail itself of the right of derogation pursuant to Article 15, section 1 of the ECHR. This is an important consideration, as it influences the balancing of interests pursuant to Article 5, section 4 of the ECHR. The House of Lords, as well as the ECtHR, however, judged the declared state of emergency to be unlawful and judged detention under the Act to be incompatible with Articles 5, section 1 and 14 of the ECHR, insofar as it was disproportionate and permitted discriminatory detention of suspected international terrorists. ${ }^{1587}$ However, the declaration of incompatibility made by the House of Lords was not binding on the parties to the litigation, and the applicant's detention therefore remained lawful until legislative change was effected by Parliament. ${ }^{1588}$

The government withdrew the notice of derogation on 16 March 2005. Those applicants who remained in detention were released in March 2005, and immediately made subject to control orders under the Prevention of Terrorism Act 2005, which came into effect on 11 March 2005. 1589

1584 A. and Others v. the United Kingdom, appl. no. 3455/05, 19 February 2009, $\$ 11$.

1585 A. and Others $v$. the United Kingdom, appl. no. 3455/05, 19 February 2009, \$96-98 and 209-210.

1586 A. and Others $v$. the United Kingdom, appl. no. 3455/05, 19 February 2009, $\$ 215$.

1587 A. and Others v. the United Kingdom, appl. no. 3455/05, 19 February 2009, §14-23 and 173-191.

1588 A. and Others $v$. the United Kingdom, appl. no. 3455/05, 19 February 2009, $\$ 194$.

1589 A. and Others $v$. the United Kingdom, appl. no. 3455/05, 19 February 2009, §82-87. 
All of the applicants in this case were deprived of their liberty on the basis of the aforementioned Act. ${ }^{1590}$ Firstly, the applicants complained that they did not have access to a court to have the lawfulness of their detention reviewed. Secondly, they contended that the procedure before the SIAC, and in particular the lack of disclosure of material evidence except to special advocates with whom the detained person was not permitted to consult, violated Article 5, section 4 of the ECHR. They argued that 'in certain circumstances it might be permissible for a court to sanction non-disclosure of relevant evidence to an individual on grounds of national security, but it could never be permissible for a court assessing the lawfulness of detention to rely on such material where it bore decisively on the case the detained person had to meet and where it had not been disclosed, even in gist or summary form, sufficiently to enable the individual to know the case against him and to respond'. In all of the applicants' appeals, except that of the tenth applicant, the SIAC relied on closed material and recognised that the applicants were thereby put at a disadvantage. ${ }^{1591}$

In deciding on the merits of the case, the ECtHR took as its starting point that, as the national courts found, during the period of the applicants' detention the activities and aims of the Al-Qaida network had given rise to a 'public emergency threatening the life of the nation'. Hence, at the relevant time there was considered to be an urgent need to protect the population of the United Kingdom from terrorist attacks and, although the United Kingdom did not derogate from Article 5, section 4 of the ECHR, a strong public interest in obtaining information about Al-Qaida and its associates and in maintaining the secrecy of the sources of such information. ${ }^{1592}$

However, balanced against these important public interests, was the applicants' right under Article 5, section 4 of the ECHR to procedural fairness. Although the ECtHR found that, with the exception of the second and fourth applicants, the applicants' detention did not fall within any of the categories listed in subparagraphs a to f of Article 5, section 1 of the ECHR, it considered that 'the case law relating to judicial control over detention on remand is relevant, since in such cases also the reasonableness of the suspicion against the detained person is a condition sine qua non'. Moreover, in the circumstances of the present case and in view of the dramatic impact of the lengthy, and what appeared at that time to be indefinite, deprivation of liberty on the applicants' fundamental rights, Article 5, section 4 of the ECHR was

1590 A. and Others $v$. the United Kingdom, appl. no. 3455/05, 19 February 2009, $\$ 13$ and $\$ 26-70$.

1591 A. and Others $v$. the United Kingdom, appl. no. 3455/05, 19 February 2009, §195 and 196. The government submitted that there were valid public interest grounds for withholding the closed material. Moreover, the right to disclosure of evidence, pursuant to Article 6 and Article 5, section 4 of the ECHR, was not absolute. The government argued that Strasbourg case law from the case of Chahal $v$. the United Kingdom onwards had indicated some support for a special advocate procedure in particularly sensitive fields. Furthermore, according to the government in each applicant's case, the open material gave sufficient notice of the allegations against him to enable him to mount an effective defence.

1592 A. and Others v. the United Kingdom, appl. no. 3455/05, 19 February 2009, §216. 
considered to import substantially the same fair trial guarantees as Article 6, section 1 of the ECHR in its criminal aspect. ${ }^{1593}$ Therefore, it was deemed essential that as much information about the allegations and evidence against each applicant was disclosed as was possible, without compromising national security or the safety of others. Where full disclosure was not possible, Article 5, section 4 of the ECHR requires that the difficulties this causes are counterbalanced in such a way that each applicant still has the possibility effectively to challenge the allegations against him. ${ }^{1594}$ As discussed above, in Chahal v. the United Kingdom, the ECtHR made reference to the special advocate procedure, but without expressing any opinion as to whether such a procedure would be in conformity with Article 5, section 4 of the ECHR. In this case, the ECtHR did examine this procedure on compliance with Strasbourg requirements regarding habeas corpus proceedings.

First of all, the ECtHR considered that the SIAC, which was a fully independent court and which could examine all the relevant evidence, both closed and open, was best placed to ensure that no material was unnecessarily withheld from the detainee. In this connection, the special advocate could provide an important, additional safeguard, through questioning the state's witnesses on the need for secrecy and through making submissions to the judge regarding the case for additional disclosure. The ECtHR did not consider that excessive and unjustified secrecy was employed in respect of any of the applicants' appeals or that there were not compelling reasons for the lack of disclosure in each case. ${ }^{1595}$

Even though generally the ECtHR considered that the special advocate could perform an important role in counterbalancing the lack of full disclosure and the lack of a full, open, adversarial hearing by testing the evidence and putting arguments on behalf of the detainee during the closed hearing, that special advocate could not perform this function in any useful way unless the detainee was provided with sufficient information about the allegations against him to enable him to give effective instructions to the special advocate. To assess whether the applicants could, in fact, still effectively challenge the allegations against them, the ECtHR distinguished between three different scenarios - even though this question must be decided on a case-by-case basis.

The first scenario is where the evidence was, to a large extent, disclosed, and the open material played the predominant role in the determination of the lawfulness of

1593 A. and Others v. the United Kingdom, appl. no. 3455/05, 19 February 2009, §205-210 and 217. See, with respect balancing public interests against respect for defence right within the context of Article 6, section 1 of the ECHR, Doorson v. the Netherlands, appl. no. 20524/92, 26 March 1996, §70; Van Mechelen and Others v. the Netherlands, appl. nos. 21363/93, 21364/93, 21427/93 and 22056/93, 23 April 1997, §58; Jasper v. the United Kingdom, appl. no. 27052/95, 16 February 2000, §51-53; S.N. v. Sweden, appl. no. 34209/96, 2 July 2002, §47; Botmeh and Alami v. the United Kingdom, appl. no. 15187/03, 7 June 2007, §37.

1594 A. and Others v. the United Kingdom, appl. no. 3455/05, 19 February 2009, §216-218.

1595 A. and Others $v$. the United Kingdom, appl. no. 3455/05, 19 February 2009, §219. 
the detention. In such a situation, it cannot be said that the applicant was denied an opportunity effectively to challenge the reasonableness of the Secretary of State's belief and suspicions about him. This was the case with respect to 5 applicants. The open evidence included detailed allegations about, for example, the purchase of specific telecommunications equipment, possession of specific documents linked to named terrorist suspects, and meetings with named terrorist suspects with specific dates and places. These allegations were sufficiently detailed to permit the applicants effectively to challenge them. ${ }^{1596}$

The second scenario is where all or most of the underlying evidence remained undisclosed. If, nevertheless, the allegations contained in the open material were sufficiently specific, it was deemed possible for the applicant to provide his representatives and the special advocate with information with which to refute them, if such information existed, without his having to know the detail or sources of the evidence which formed the basis of the allegations. An example would be the allegation made against several of the applicants that they had attended a terrorist training camp at a stated location between stated dates. Given the precise nature of the allegation, it would have been possible for the applicant to provide the special advocate with exonerating evidence, for example, of an alibi or of an alternative explanation for his presence there, sufficient to permit the advocate effectively to challenge the allegation.

The third scenario is where the open material consisted purely of general assertions. In these cases, the SIAC's decision to uphold the certification and maintain the detention was based solely or to a decisive degree on closed material. Under such circumstances, the procedural requirements of Article 5, section 4 of the ECHR would not be satisfied in the ECtHR's opinion. ${ }^{1597}$ This was the case with respect to 4 applicants. The principal allegations against two of them were that they had been involved in fund-raising for terrorist groups linked to Al'Qaeda. There was open evidence of large sums of money moving through one of the applicant's bank account, and there was open evidence that another applicant had been involved in raising money through fraud. However, in each case the evidence that allegedly provided the link between the money raised and terrorism was not disclosed to either applicant. In these circumstances, the ECtHR did not consider that these applicants were in a position effectively to challenge the allegations against them. 1598

Lastly, against two other applicants there were open and general allegations principally implying that they were members of named extremist Islamist groups linked to Al'Qaeda. Even the SIAC observed in its judgements dismissing each of these applicants' appeals that the open evidence was insubstantial and that the

1596 A. and Others $v$. the United Kingdom, appl. no. 3455/05, 19 February 2009, §222.

1597 A. and Others $v$. the United Kingdom, appl. no. 3455/05, 19 February 2009, §220.

1598 A. and Others $v$. the United Kingdom, appl. no. 3455/05, 19 February 2009, §223. 
evidence on which it relied against them was largely to be found in the closed material. Also, with respect to these two applicants, the ECtHR did not consider that they were in a position effectively to challenge the allegations against them. ${ }^{1599}$

IN SUM

In sum, case law demonstrates that national security concerns and/or terrorism cannot, as such, justify far-reaching infringements on suspects' defence rights during habeas corpus proceedings as regards to the withholding of information. The Executive is not free from effective control by the domestic courts with respect to non-disclosure of information during such proceedings whenever they choose to assert that national security and terrorism are involved. ${ }^{1600}$

Infringements on defence rights during habeas corpus proceedings must be adequately counterbalanced, for instance, by the above-described special advocate procedure. Even within the context of such a system suspects must basically always be able to effectively challenge the lawfulness of their detention before a court, also if it concerns terrorism. This implies that they must some way or the other be enabled to rebut the state's allegations of suspicion of terrorism. Therefore, a suspect must be kept informed and permitted to make submissions and participate in the decision-making process during habeas corpus proceedings as far as possible without disclosing the material that the prosecution wants to keep secret. Information that is of decisive importance to the outcome of a suspect's appeal for release and is issue of fact which forms part of the prosecution case must be released to the suspect, even if it concerns terrorism. If domestic courts decide on the lawfulness of pre-trial detention, solely or to a decisive extent, on the basis of essential evidence that was not disclosed to the suspect, Article 5, section 4 of the ECHR will be violated.

What, hence, seems the decisive element for the ECtHR in these matters is whether a (terrorist) suspect has been given an adequate and proper opportunity to challenge the allegation against him, either when made or at a later stage. That implies that he must be informed of the allegations against him and of the most important evidence underlying these allegations to be able to rebut these - possibly by means of a special counsel.

\subsection{Lawfulness of pre-trial detention}

While discussing the case of Schöps v. Germany, it has been underlined that Article 5, section 4 of the ECHR not only encompasses procedural requirements for

1599 A. and Others $v$. the United Kingdom, appl. no. 3455/05, 19 February 2009, $\$ 224$.

1600 A. and Others $v$. the United Kingdom, appl. no. 3455/05, 19 February 2009, \$210. 
habeas corpus proceedings, but also substantive requirements. ${ }^{1601}$ So far, primarily the procedural requirements have been discussed, this section elaborates on the question of how the lawfulness of pre-trial detention must be assessed by domestic courts during habeas corpus proceedings as to substance.

Does 'lawfulness', as interpreted under Article 5, section 1 under c and section 3 of the ECHR ${ }^{1602}$, suffice regarding substance to adequately examine habeas corpus complaints? That is what has been assumed so far in this chapter. That would mean that during habeas corpus proceedings, domestic courts must examine: (1) compliance with domestic procedural and substantive law, (2) whether there is a reasonable suspicion against the detained person, (3) whether there are relevant and sufficient grounds to justify pre-trial detention, (4) whether the national authorities acted with special diligence and (5) whether the detention is in accordance with general principles of law as enshrined in the ECHR. Is examination of pre-trial detention on the basis of these substantive requirements adequate to comply with Article 5, section 4 of the ECHR?

In Brogan and Others v. the United Kingdom, the ECtHR argued that the elements of the lawfulness-requirement are the same for section 1c in conjunction with section 3 and for section 4. So, the two proceedings for judicial review of the lawfulness of pre-trial detention as comprised in Article 5 of the ECHR, are equal in terms of substance. ${ }^{1603}$ This means that compliance with the complete array of prerequisites, as comprised in section 1 under $\mathrm{c}$ and 3, must be reviewed throughout proceedings under section $4 .{ }^{1604}$ However, the scope of examination of pre-trial detention under Article 5, section 4 of the ECHR must be more thoroughly.

Domestic courts are obliged to review compliance with these prerequisites in detail during habeas corpus proceedings, even if the same matter has already been examined when the arrest and detention were first imposed on the suspect. ${ }^{1605}$ This appears obvious, as what would otherwise be the purpose of a right to have the lawfulness of your arrest and (prolonged) pre-detention examined during habeas

1601 Svipsta v. Latvia, appl. no. 66820/01, 9 March 2006, §129; Kadem v. Malta, appl. no. 55263/00, 9 January 2003, §41.

1602 See chapter VI for a discussion of the lawfulness requirement.

1603 Brogan and Others v. the United Kingdom, appl. no. 11209/84, 29 November 1988, §65. See, also, Chahal v. the United Kingdom, appl. no. 22414/93, 15 November 1996, §127. In the latter case, the ECtHR considered that ' $(. .$.$) the notion of 'lawfulness' under paragraph 4$ of Article 5 has the same meaning as in paragraph 1 , so that the detained person is entitled to a review of his detention in the light not only of the requirements of domestic law but also of the text of the Convention, the general principles embodied therein and the aim of the restrictions permitted by Article 5 para. 1'. See, also, Ilijkov v. Bulgaria, appl. no. 33977/96, 26 July 2001, §94; A. and Others v. the United Kingdom, appl. no. 3455/05, 19 February 2009, §202.

1604 Stašaitis v. Lithuania, appl. no 47679/99, 21 March 2002, §90. See, also, Belevitskiy v. Russia, appl. no. 72967/01, 1 March 2007, §108; Sergey Volosyuk v. Ukraine, appl. no. 1291/03, 12 March 2009, §47; A. and Others v. the United Kingdom, appl. no. 3455/05, 19 February 2009, §202; Kostadinov v. Bulgaria, appl. no. 55712/00, 7 February 2008, §84-87. 
corpus proceedings in addition to the possibility of judicial review guaranteed under Article 5, section 3 of the ECHR?

In its case law on Article 5, section 3 and 4 of the ECHR, the ECtHR refers often back to the underlying 'spirit' of that provision: the prevention of arbitrary deprivation of liberty and respect for the rule of law. Habeas corpus proceedings are considered as 'final procedural watchdog' to guarantee respect for all direct and indirect substantive requirements attached to the right to liberty of person. This calls for a broad examination of the lawfulness of pre-trial detention, as is demonstrated by the case of Klyakhin v. Russia. The applicant complained that the domestic courts had failed to indicate the reasons for his continued pre-trial detention. During the habeas corpus proceedings he had provided for an extensively detailed claim that he brought before the competent court. He claimed his pre-trial detention to be completely unlawful in light of Article 5 of the ECHR. The domestic court failed to address the specific arguments advanced by the applicant regarding the lack of reasons for his prolonged detention. Other complaints remained unanswered as well.

The question was whether, despite such negligence of the substantive claims filed by the applicant, the habeas corpus proceedings could still be considered in compliance with the requirements as comprised in Article 5, section 4 of the ECHR? The ECtHR considered in this respect, that 'whilst Article $5 \S 4$ of the Convention does not impose an obligation to address every argument contained in the detainee's submissions, the judge examining remand appeals must take into account concrete facts which are referred to by the detainee and capable of casting doubt on the existence of those conditions essential for the 'lawfulness', for Convention purposes, of the deprivation of liberty'. ${ }^{1606}$

Thus, the facts which a suspect brings forth during habeas corpus proceedings must be sufficiently concrete, not appear implausible or frivolous, they must be explicitly brought up by the applicant, and these facts must be able to cast doubt on the existence of crucial circumstances required to fulfil the lawfulness-requirement. ${ }^{1607}$ Upon fulfilment of these aspects, the domestic court deciding on a habeas corpus complaint is obliged to extensively address every facet of a suspect's claim. ${ }^{1608}$

1606 Klyakhin v. Russia, appl. no. 46082/99, 30 November 2004, §76.

1607 Klyakhin v. Russia, appl. no. 46082/99, 30 November 2004, §77. See, also, Grauslys v. Lithuania, appl. no. 36743/97, 10 October 2000, \$54. In the latter judgement, the domestic court deciding on the lawfulness of the pre-trial detention refused to examine the applicant's complaints concerning breaches of domestic law. Subsequently, the applicant was released from detention, which could, in the ECtHR's opinion, be understood as an acknowledgement of the unlawfulness of the pre-trial detention. However, the ECtHR did not consider that release in compliance with the rights of the arrested person pursuant to Article 5, section 4 of the ECHR and found a breach of that section.

1608 Klyakhin v. Russia, appl. no. 46082/99, 30 November 2004, §78 and 79. Note however, that the ECtHR has repeatedly ruled that Article 5, section 4 of the ECHR does not guarantee a right to 
Domestic courts are also required to hear witnesses whose testimony appears prima facie to have a material bearing on the continuing lawfulness of the detention. ${ }^{1609}$

In practice, to fulfil these obligation, courts must obviously - just as suspects be allowed access to the complete case file. Equally, suspects cannot explicitly bring forth sufficiently concrete facts, which can, moreover, cast doubt on the lawfulness of their pre-trial detention, if they are not familiar with the information that led to their arrest and pre-trial detention. In order to make such explicit and relevant claims, suspects hence need access to the complete case file, especially when they are kept in prolonged detention on remand. ${ }^{1610}$ The result of withholding the case file from the suspect and the court, is that neither of these two parties will be able to live up the requirement under Article 5, section 4 of the ECHR to challenge and thoroughly examine all substantive prerequisites for lawful deprivation of liberty.

In case domestic courts do not address crucial issues directly relating to the lawfulness of pre-trial detention, the ECtHR considers that there is 'thus no adequate judicial response to the applicant's complaints' as explicitly required by section 4' which automatically leads to a violation of Article 5 of the ECHR. ${ }^{1611}$

In Danov v. Bulgaria, the competent authorities used secret intelligence information from the police to justify the applicant's continued deprivation of liberty. The applicant and his lawyer were never informed of the source of the intelligence information obtained by the police. Moreover, none of the parties to the proceedings, including the courts and Prosecutor's Office, were ever provided with this information. Nevertheless, the domestic courts dismissed the applicant's appeals for release by partly relying on the contents of the intelligence data against the applicant to justify their conclusion that there was a risk that he might abscond or,

judicial review of such breadth as to empower domestic courts, on all aspects of the case including questions of pure expediency - to substitute its own discretion for that of the decisionmaking authority. The review should, however, be wide enough to bear on those conditions that are essential for the 'lawful' detention of a person according to Article 5, section 1 of the ECHR. See, Chahal v. the United Kingdom, appl. no. 22414/93, 15 November 1996, §127; Sergey Volosyuk v. Ukraine, appl. no. 1291/03, 12 March 2009, §50; Molodorych v. Ukraine, app1. no. 2161/02, 28 October 2010, §108; Svershov v. Ukraine, appl. no. 35231/02, 27 November 2008, §70-72; Khudoyorov v. Russia, appl. no. 6847/02, 8 November 2005, §205-207.

1609 Becciev v. Moldova, appl. no. 9190/03, 4 October 2005, §72-76; Turcan and Turcan v. Moldova, appl. no. 39835/05, 23 October 2007, §67-70.

1610 Svipsta v. Latvia, appl. no. 66820/01, 9 March 2006, §129; Nikolova v. Bulgaria, appl. no. 31195/96, 25 March 1999, §61; Grauslys v. Lithuania, appl. no. 36743/97, 10 October 2000, $\S 54$.

1611 Butkevičius v. Lithuania, appl. no. 48297/99, 26 March 2002, §46; Belevitskiy v. Russia, appl. no. 72967/01, 1 March 2007, §111-112; I.I. v. Bulgaria, appl. no. 44082/98, 9 June 2005, §102107. In the latter case, the domestic court deciding on the lawfulness of the pre-trial detention did not inquire into issues relating to the sufficiency of the evidence against the suspect. Neither did the court give specific reasons why it considered that the suspect presented a risk of re-offending, impeding the investigation or fleeing. This led the ECtHR to conclude that 'the domestic court did not provide judicial control over the applicant's detention on remand of the scope required by Article 5, section 4 of the ECHR'. 
subsequently, by simply stating that there were no new circumstances warranting a re-evaluation of the imposed restriction. Before the ECtHR, the applicant claimed to have been denied the opportunity to effectively challenge the credibility of the secret intelligence information.

The ECtHR considered that by relying on secret intelligence information to which source none of the parties involved had full access, the applicant was incapable of effectively challenging the lawfulness of his deprivation of liberty. Therefore, he was denied access to a judicial procedure, satisfying the requirements of Article 5, section 4 of the ECHR. 1612

In Yankov v. Bulgaria, the ECtHR found a violation of Article 5, section 4 of the ECHR, as the domestic court deciding on the lawfulness of pre-trial detention devoted no consideration to any of the arguments brought forth by the applicant. The domestic court apparently treated these arguments as irrelevant to the question of the lawfulness of his pre-trial detention. The applicant had referred to concrete facts, for example, that all the evidence had been collected during the first few months of the investigation, which minimised any danger of him obstructing the course of justice, that he had no criminal record and that there was no danger of his absconding in view of his age, family ties, state of health and way of life. The applicant had also asserted that the evidence against him was weak and that the charges had been based on erroneous interpretation of the relevant law. ${ }^{1613}$

The ECtHR considered the applicant's submissions to contain concrete facts that did not appear implausible or frivolous. Those submissions, were, moreover capable of putting in doubt the existence of the conditions essential for the 'lawfulness' of the deprivation of liberty. By not taking them into account, the domestic courts failed to provide a judicial review of the scope and nature required by Article 5, section 4 of the ECHR. ${ }^{1614}$

So even though judicial control pursuant to Article 5, section 3 of the ECHR and judicial control during habeas corpus proceedings under section 4 , are, in terms of substantive aspects equal, the latter form of judicial control is more thorough than the former. The ECtHR requires domestic courts to examine in-depth whether all of the procedural and substantive requirements for lawful arrest and pre-trial detention have been complied with and, in general, whether the interference with the suspect's right to liberty has not been imposed arbitrarily. ${ }^{1615}$ Habeas corpus proceedings are primarily used to examine prolonged pre-trial deprivation of liberty. ${ }^{1616}$ The longer

1612 Danov v. Bulgaria, appl. no. 56796/00, 26 October 2006, §82 and 91-93.

1613 Yankov v. Bulgaria, appl. no. 39084/97, 11 December 2003, §182-183.

1614 Yankov v. Bulgaria, appl. no. 39084/97, 11 December 2003, \$184-187. Compare with Hamanov v. Bulgaria, appl. no. 44062/98, 8 April 2004, §79-86.

1615 Belevitskiy v. Russia, appl. no. 72967/01, 1 March 2007, §108; Svetoslav Dimitrov v. Bulgaria, appl. no. 55861/00, 7 February 2008, §65.

1616 Svetoslav Dimitrov v. Bulgaria, appl. no. 55861/00, 7 February 2008, §67. 
a suspect is deprived of his liberty, the more justifications a state must adduce to legitimise the interference with Article 5 of the ECHR. This means that automatically, judicial control under Article 5, section 4 of the ECHR will be more encompassing than judicial control under section 3. This also implies that initial compliance with section 1 under $\mathrm{c}$ in conjunction with section 3 does not preclude breaches of section 4 for continued interferences with a suspect's right to liberty. ${ }^{1617}$

\subsection{Deciding speedily}

The right to lodge habeas corpus proceedings must not merely be theoretical and illusory, but practical and effective. Therefore, Article 5, section 4 of the ECHR requires domestic courts to decide speedily on a complaint regarding the lawfulness of pre-trial detention. Strict compliance with the 'speedily-requirement' is called for. ${ }^{1618}$ There are two aspects to this requirement: (1) the opportunity for legal review of pre-trial detention must be provided soon after the person is taken into detention and, if necessary, at reasonable intervals thereafter, and (2) the review proceedings must be conducted with due diligence. ${ }^{1619}$ The first aspect has been discussed in the preceding sections. This section primarily elaborates on the second aspect. The question that will be discussed in this section is which precise timelimits the notion of speedily imposes on states with respect to deciding on a habeas corpus complaint.

Again, it is interesting to draw a comparison between the judicial control pursuant to Article 5, section 3 of the ECHR which must be prompt, and habeas corpus proceedings that must be decided on speedily. Clearly, more leeway in terms of time to decide on complaints regarding pre-trial detention is provided for under section 4. This relatively wider timeframe is, however, in part also dependent on the question of whether prior to a habeas corpus procedure, judicial review of the detention has already taken place pursuant to Article 5, section 3 of the ECHR. When pre-trial detention has not been examined promptly by a judicial authority pursuant to Article 5, section 3 of the ECHR, a period of, for example 6 days pretrial detention without having a right to lodge habeas corpus proceedings is automatically considered as a violation of Article 5, section 4 of the ECHR. Under these circumstances the ECtHR considers such a lapse of time not to comply with

1617 As discussed in Chapter VI, the longer the detention wears on the stronger the justifications must be to justify the deprivation of liberty.

1618 Mayzit v. Russia, appl. no. 63378/00, 20 January 2005, §48-50.

1619 Sergey Volosyuk v. Ukraine, appl. no. 1291/03, 12 March 2009, §48; Knebl c. République Tchèque, requête no 20157/05, 28 Octobre 2010, §85; Silva Rocha v. Portugal, appl. no. 18165/91, 15 November 1996, §28-32. 
the speedily requirement. ${ }^{1620}$ This explicitly also applies in case of pre-trial detention of terrorist suspects. ${ }^{1621}$ Nevertheless, if judicial review pursuant to Article 5, section 3 of the ECHR has taken place promptly from the outset of pretrial detention, and the suspect additionally initiates habeas corpus proceedings, the speedily-requirement is less strict.

For the purpose of Article 5, section 4 of the ECHR, the time begins to run when the proceedings challenging the lawfulness of the detention are instituted, and ends when the final decision regarding the habeas corpus-complaint has been passed. ${ }^{1622}$

In Bezicheri v. Italy, the applicant had been arrested and detained on suspicion of being accessory to an aggravated murder. ${ }^{1623}$ His detention on remand had been judicially reviewed once, but he filed an additional complaint to have the lawfulness of his detention on remand examined, one month after the first judicial review. The domestic court considered it not 'reasonable' that the applicant lodged his second application scarcely one month after the dismissal of the first and declared his complaint inadmissible. ${ }^{1624}$ The applicant claimed that his right pursuant to Article 5, section 4 of the ECHR had been violated. ${ }^{1625}$

The ECtHR, deciding in the applicant's favour, considered that 'the nature of detention on remand calls for short intervals; there is an assumption in the Convention that detention on remand is to be of strictly limited duration, because its raison d'être is essentially related to the requirements of an investigation which is to be conducted with expedition. In the present case an interval of one month is not unreasonable'. ${ }^{1626}$ This consideration, hence, primarily regards the question of at what intervals a suspect should be allowed to lodge a habeas corpus complaint.

In addition, the ECtHR found a violation of Article 5, section 4 of the ECHR on account of the fact that it took the domestic court approximately five and a half months to decide on the habeas corpus complaint. The delays in the proceedings were not attributable to the applicant, even though he also sought investigative measures besides from requests to examine the lawfulness of the detention. ${ }^{1627}$ In

1620 In De Jong, Baljet and van den Brink v. the Netherlands, appl. no. 8805/79, 22 May 1984, the applicants were for seven, eleven and six days, respectively, kept deprived of their liberty without any legal remedy at all, this amounted to a violation of Article 5, section 4 of the ECHR, according to the ECtHR. See, also, Iğdeli v. Turkey, appl. no. 29296/95, 20 June 2002, §32-37.

1621 Sakik and Others v. Turkey, appl. no. 87/1996/706/898-903, 26 November 1997, §51-54. See, also, İ̆gdeli v. Turkey, appl. no. 29296/95, 20 June 2002, §34-36; Ikincisoy v. Turkey, appl. no. 26144/95, 27 July 2004, §109; Abdülsamet Yaman v. Turkey, appl. no. 32446/96, 2 November 2004, §80-81; Fatma Tunç v. Turkey, appl. no. 16608/02, 20 October 2005, §26-28.

1622 Singh v. the Czech Republic, appl. no. 60538/00, 25 January 2005, §75.

1623 Bezicheri v. Italy, appl. no. 11400/85, 25 October 1989, §9.

1624 Bezicheri v. Italy, appl. no. 11400/85, 25 October 1989, §10-11 and 21.

1625 Bezicheri v. Italy, appl. no. 11400/85, 25 October 1989, §18 and 20.

1626 Bezicheri v. Italy, appl. no. 11400/85, 25 October 1989, §21.

1627 Bezicheri v. Italy, appl. no. 11400/85, 25 October 1989, §24-25. The government contended that the heavy workload of the courts obstructed the proceedings to be conducted with more 
this respect it is important to note that even if a detained suspect has made several applications for release, Article 5, section 4 of the ECHR does not give the authorities a 'margin of discretion', or a choice in respect of which of them should be handled more expeditiously and which at a slower pace. All such proceedings are to run speedily. ${ }^{1628}$

Case law demonstrates that the suspect may sometimes be also responsible for delays in deciding on a habeas corpus complaint. In Navarra v. France, the applicant waited until 28 May before filing an appeal on points of law against a decision taken on 23 April. ${ }^{1629}$ The ECtHR took into account the fact that it was because of the applicant's 'late reaction' that the overall length of the proceedings might have been a bit too long. ${ }^{1630}$ However, the applicant anyway retained the right to submit further applications for release at any time during the proceedings - which right he did not invoke. ${ }^{1631}$ This latter aspect seems to be of importance for the ECtHR in judging on complaints regarding delays in deciding on a habeas corpus complaint. ${ }^{1632}$ In light of these considerations Article 5, section 4 of the ECHR had not been violated.

This line of reasoning is comparable to the one regarding complaints under Article 6 of the ECHR on account of unreasonably long criminal proceedings.

expedition. The ECtHR however held the view that 'the Convention requires the Contracting States to organise their legal systems so as to enable the courts to comply with its various requirements'. Compare with Marturana c. Italie, requête $\mathrm{n}^{0}$ 63154/00, 4 mars 2008, §111; Kučera v. Slovakia, appl. no. 48666/99, 17 July 2007, §108-112 (two months and seven days, two months and 25 days, two months and 17 days, one month and 22 days and 16 days); Trzaska $v$. Poland, appl. no. 25792/94, 11 July 2000, \$77 (two years and ten months); Koendjbiharie v. The Netherlands, appl. no. 11487/85, 25 October 1990, §29-31; Mayzit v. Russia, appl. no. 63378/00, 20 January 2005, §49-50 and 52; Rehbock v. Slovenia, appl. no. 29462/95, 28 November 2000, $\S 84-88$; Sulaoja v. Estonia, appl. no. 55939/00, 15 February 2005, §74. In the latter judgement, the ECtHR found a violation of Article 5, section 4 of the ECHR in case of delays of 23 days and of two months and 24 days, in deciding on a habeas corpus complaint. Compare with Marturana c. Italie, requête $\mathrm{n}^{\circ} 63154 / 00,4$ mars 2008, §111; Wloch v. Poland, appl. no. 27785/95, 19 October $2000, \S 133-136$.

1628 Itowiecki v. Poland, appl. no. 27504/95, 4 October 2001, §78.

1629 Navarra v. France, appl. no. 13190/87, 23 November 1993, §11.

1630 Navarra v. France, appl. no. 13190/87, 23 November 1993, §11-12. The forwarding of the applicant's file to the Court of Cassation and subsequently to the Montpellier Indictment Division, following the remittal of the case to that court, took some time 28 May - 19 June 1986 and 13 September - 1 October 1986.

1631 Navarra v. France, appl. no. 13190/87, 23 November 1993, §28 and 29.

1632 Letellier v. France, appl. no. 12369/86, 26 June 1991, §56. In this case, the ECtHR had certain doubts about the overall length of the examination of the second application for release, in particular, before the indictments divisions called upon to rule after a previous decision had been quashed in the Court of Cassation. However, the applicant retained the right to submit a further application at any time. The applicant lodged six other applications within seven months, which were all dealt with in periods of from eight to twenty days. In light of these considerations, the ECtHR concluded that Article 5, section 4 of the ECHR had not been violated on account of the speediness requirement. 
When the suspect/accused is (partly) responsible for delays in (pre-trial or trial) proceedings, overstepping the speedily-requirement respectively non-compliance with the reasonable time-standard, does not lead to a violation of the relevant articles. ${ }^{1633}$ The complexity of the case, the exigencies of internal domestic procedure, and the prosecutor's attitude may, just as within the context of Article 6 of the ECHR, also justify delays in deciding on habeas corpus complaints. ${ }^{1634}$

In Jablonski v. Poland, the ECtHR considered a period of 43 days between the lodging of a complaint and the decision by the Polish Supreme Court, excessive. ${ }^{1635}$ In this respect, it is important to note that the ECtHR does, however, acknowledge that in certain instances the complexity of medical - or other - issues involved in a determination of whether a person should be detained or released can be a factor which may be taken into account when assessing compliance with Article 5, section 4 of the ECHR. That does not mean, however, that the complexity of a given dossier - even exceptional - absolves the national authorities from complying with the speedy-requirement. ${ }^{1636}$ In Baranowski v. Poland the ECtHR underlined in this respect that the overall length of habeas corpus proceedings 'has to remain consistent with the special diligence required in the conduct of the proceedings'. ${ }^{1637}$

In Jablonski v. Poland, neither the complexity of the case nor medical issues had been cited as reasons ${ }^{1638}$ for the period of 43 days to conduct the habeas corpus proceedings. In these circumstances the ECtHR assessed that lapse of time to be inconsistent with Article 5, section 4 of the ECHR. ${ }^{1639}$

In Moiseyev v. Russia, the ECtHR explicitly underlined the connection between the presumption of innocence and the requirement that domestic courts must decide speedily on habeas corpus complaints. ${ }^{1640}$ As Article 5, section 4 of the ECHR concerns issues of liberty, these proceedings require particular expedition: there is a special need for a swift decision determining the lawfulness of detention in cases

1633 Shannon v. Latvia, appl. no. 32214/03, 24 November 2009, §69.

1634 Hutchison Reid v. the United Kingdom, appl. no. 50272/99, 20 February 2003, §79; Nikolov v. Bulgaria, appl. no. 38884/97, 30 January 2003, §94-95; Mayzit v. Russia, appl. no. 63378/00, 20 January 2005, §48-50; Z.N.S. v. Turkey, appl. no. 21896/08, 19 January 2010, §62; Veliyev v. Russia, appl. no. 24202/05, 24 June 2010, §167; Žrovnický v. the Czech Republic, appl. no. 23661/03, 30 September 2010, $\S 84$.

Jablonski v. Poland, appl. no. 33492/96, 21 December 2000, §88. See, also, Nikolov v. Bulgaria, appl. no. 38884/97, 30 January 2003, §93-95.

1636 Jablonski v. Poland, appl. no. 33492/96, 21 December 2000, §92. See, in this respect, also, Musial v. Poland, appl. no. 24557/94, 25 March 1999, §47.

1637 Baranowski v. Poland, appl. no. 28358/95, 28 March 2000, §70-73.

1638 The Government did refer to the excessive workload of the domestic courts.

1639 Baranowski v. Poland, appl. no. 28358/95, 28 March 2000, §94.

1640 Compare with Lebedev v. Russia, appl. no. 4493/04, 25 October 2007, §95-98; Frasik v. Poland, appl. no. 22933/02, 5 January 2010, §63; Itowiecki v. Poland, appl. no. 27504/95, 4 October 2001, $\$ 76$ (deciding on an habeas corpus complaint took the domestic courts three weeks to about two months. These periods were deemed not sufficiently speedy). 
where a trial is pending because the defendant should benefit fully from the principle of the presumption of innocence. ${ }^{1641}$

In this case, the applicant's three appeals against his pre-trial detention were examined 71, 63, and approximately 50 days later, respectively. Their entire duration appears to have been attributable to the authorities. Nothing suggests that the applicant, having lodged the appeals, caused any delays in their examination. In light of these considerations, the ECtHR considered that these three periods were excessively long and fell short of the 'speediness' requirement of Article 5, section 4 of the ECHR. 1642

In Sabeur Ben Ali v. Malta, the ECtHR explicitly stated that a period of approximately eight weeks from the lodging of an application for habeas corpus proceedings to judgement appears prima facie difficult to reconcile with the 'speediness' requirement. ${ }^{1643}$ In Kadem v. Malta, even a period of 17 days was deemed insufficiently speedily for the purpose of Article 5, section 4 of the ECHR. ${ }^{1644}$ In Rehbock v. Slovenia, the ECtHR found delays of 23 days for one level of jurisdiction, and 43 days or 32 days for two levels of jurisdiction, to be incompatible with Article 5, section 4 of the ECHR. ${ }^{1645}$

So, even though the ECtHR refuses to set concrete, generally to be applied, criteria with respect to the speediness requirement, ${ }^{1646}$ one can assume as maximum guideline a period not exceeding some weeks to comply with this requirement. ${ }^{1647}$

1641 Moiseyev v. Russia, appl. no. 62936/00, 9 October 2008, §160; Iłowiecki v. Poland, appl. no. 27504/95, 4 October 2001, §76; Hutchison Reid v. the United Kingdom, appl. no. 50272/99, 20 February 2003, $\$ 79$.

1642 Moiseyev v. Russia, appl. no. 62936/00, 9 October 2008, §164-165. Compare with Mamedova v. Russia, appl. no. 7064/05, 1 June 2006, §96. In the latter case, the ECtHR considered habeas corpus proceedings which lasted from 29 to 36 days not sufficiently speedy.

1643 Sabeur Ben Ali v. Malta, appl. no. 35892/97, 29 June 2000, §38. Compare with Frasik v. Poland, appl. no. 22933/02, 5 January 2010, $\$ 66$ (46 days for deciding on a habeas corpus complaint).

1644 Kadem v. Malta, appl. no. 55263/00, 9 January 2003, §45 (17 days constituted a violation). See, also, Rehbock v. Slovenia, appl. no. 29462/95, 28 November 2000, §82-86, in which judgement the ECtHR considered a delay of 23 days in deciding on the applicant's claims for immediate release to be excessive. See, also Sarban v. Moldova, appl. no. 3456/05, 4 October 2005, §118124 (21 days excessive); Lebedev v. Russia, appl. no. 4493/04, 25 October 2007, §102, in which judgement periods of respectively 27 days, 1 month and 17 days and 50 days were deemed insufficiently speedy.

1645 Rehbock v. Slovenia, appl. no. 29462/95, 28 November 2000, §82-88.

1646 Sanchez-Reiss v. Switzerland, appl. no. 9862/82, 21 October 1986, §55, where the ECtHR underlined that ' this concept cannot be defined in the abstract; the matter must - as with the 'reasonable time' stipulation in Article 5 para. 3 and Article 6 para. 1 - be determined in the light of the circumstances of each case'.

1647 In Şevk v. Turkey a period of 41 days for the domestic court to convey its decision to the suspect was considered in violation of the speedily requirement pursuant to Article 5, section 4 of the ECHR. See, Şevk v. Turkey, appl. no. 4528/02, 11 April 2008, §38-41. See, also, Singh v. the Czech Republic, appl. no. 60538/00, 25 ${ }^{\text {th }}$ January 2005, §76; Khudobin v. Russia, appl. 
It is, furthermore, of importance to emphasise that a detained suspect must be given the right to repeatedly, at short intervals, lodge a habeas corpus-complaint, even if only 1 month has passed since the last judicial control on the lawfulness of the deprivation of liberty.

\subsection{In sum}

The right to have access to the case file is, in the ECtHR's view, an essential feature of the principle of equality of arms, which should be complied with during habeas corpus proceedings. That principle is not lived up to if the suspect is denied access to those documents in the case file which are essential in order to effectively challenge the lawfulness of pre-trial detention.

Taking into account the above-discussed Strasbourg case law, it may be unclear what information available within the case file will not be of importance to decide on the lawfulness of prolonged pre-trial detention. Having regard to the extensive scope of substantive requirements for lawful pre-trial detention, which must be examined during habeas corpus proceedings, there will not be much information in the case file that is irrelevant.

In practice, the answer to this question is, within the Dutch criminal justice system, dependent on the public prosecutor's judgement. No effective control is exerted on the way in which the public prosecutor balances investigative interests against the interest of the (terrorist) suspect to have access to his whole case file, and the competent court's interest in examining a habeas corpus complaint with full knowledge of all the evidence available - both incriminating as well as exempting.

no. 59696/00, 26 October 2006, §117-122 (delays of three months, one month and 21 days and one month and 24 days); Mitev v. Bulgaria, appl. no. 40063/98, 22 December 2004, §124-125 (44 days for habeas corpus proceedings was considered not sufficiently speedy); Luberti v. Italy, appl. no. 9019/80, 23 February 1984, §31-37; Svipsta v. Latvia, appl. no. 66820/01, 9 March 2006, §129; Koendjbiharie v. the Netherlands, appl. no. 11487/85, 25 October 1990, §29-30; Kolev v. Bulgaria, appl. no. 50326/99, 28 April 2005, §80. See, also, G.B. v. Switzerland, appl. no. 27426/95, 30 November 2000, \$34-39 (21 days for deciding on a habeas corpus complaint was not sufficiently speedily); M.B. v. Switzerland, appl. no. 28256/95, 30 November 2000, §2944 (34 days for deciding on a habeas corpus complaint was not sufficiently speedily). On the other hand, in Rokhlina v. Russia, appl. no. 54071/00, 7 April 2005, §79 where the global duration of the proceedings was 41 days for two levels of jurisdiction, the ECtHR found no violation of Article 5, section 4 of the ECHR. In that case the ECtHR noted, in particular, that the applicant had requested leave to appear in person at the appeal court, and that because of it the court had to adjourn the proceedings for one week. In Mamedova v. Russia, appl. no. 7064/05, 1 June 2006, $\$ 96$ the ECtHR found delays of 36, 29 and 26 days to be incompatible with Article 5, section 4 of the ECHR, stressing that the entire duration of the appeal proceedings was attributable to the authorities. Lastly, in Kostadinov v. Bulgaria, appl. no. 55712/00, 7 February 2008, §87-90, the ECtHR deemed a period of 26 days for the domestic court to decide on a habeas corpus complaint to be insufficiently speedy. 
As to the legal position of the (terrorist) suspects, it should, furthermore, be kept in mind that with enactment of the DPTA possibilities to lodge a complaint against the public prosecutor's decision to withhold evidence have diminished pursuant to the amended Article 32 of the DCCP. Suspects can only lodge a complaint under Article 32 of the DCCP once every 90 days. Whether such an interval can be considered adequate in the case of suspects who initiate habeas corpus proceedings, remains to be seen. Complaining about a denial to access one's case file, may, moreover, prove to be a rather ineffective, taking into account that the court deciding on such a complaint does not, just as the suspect, have access to the whole case file.

The longer pre-trial detention lasts, the more encompassing habeas corpus proceedings will have to be, and the more information there will need to be disclosed to the suspect and the competent court. Also, as the criminal investigation progresses, the need for non-disclosure of evidence on the basis of the interest of the investigation will considerably diminish. The tenability of the government's general reasoning that the nature of investigations into terrorism justifies more farreaching restrictions on suspects' rights during the pre-trial phase is questionable in light of the above-discussed Strasbourg case law.

Important to underline, in this respect, is that the ECtHR attaches special significance to the question of whether there are sufficient procedural safeguards and/or guarantees to counterbalance infringements on a suspect's defence rights during habeas corpus proceedings. The amended Article 66, section 3 of the DCCP has not been provided with safeguards to counterbalance the potentially more farreaching limitations on a terrorist suspect's rights under Article 5, section 4 of the ECHR. ${ }^{1648}$ The government just refers to the fact that habeas corpus proceedings pursuant to Article 69, in conjunction with Article 66, section 3 of the DCCP, have to take place in public. However, the ECtHR does not consider the public nature of habeas corpus proceedings as counterbalancing safeguard.

The DPTA has, statutorily at least, not changed the interval or the scope for terrorist suspects to lodge habeas corpus complaints, but factually habeas corpus proceedings may be different as to substance in case the prosecutor decides to make use of the amended Article 66, section 3, in conjunction with Article 30, section 2 of the DCCP. Article 66, section 3 of the DCCP first of all prolongs the period of detention on remand for terrorist suspects. Terrorist suspects should, accordingly, profit from broadened possibilities of judicial control in terms of substance. This presupposes full knowledge of all the information on which the prosecutor bases the reasons and justifications for the pre-trial detention.

1648 See, in this respect, F. Vanneste, 'Het Europese Hof voor de Rechten van de Mens en de overheden die terrorisme bestrijden: brothers in arms?', in Rechtskundig Weekblad 2003-2004, nr. 41, pp. $1665-1677$. 
Repercussions for the court deciding on a habeas corpus complaint pursuant to Article 69 or 71 of the DCCP, should not be neglected either: the court may, just as the suspect, not be granted access to information comprised in the case file. That may hamper the court in effectively judging on the lawfulness of pre-trial detention of terrorist suspects. ${ }^{1649}$ Strasbourg case law on Article 5, section 4 of the ECHR primarily deals with situations where the competent court and the prosecution did have access to the whole case file, whereas the suspect and/or his lawyer did not. How the ECtHR will decide on cases where neither the court nor the suspect had access to the case file, remains to be seen. This may bring about problems in terms of the required effectiveness of judicial control under Article 5, section 4 of the ECHR.

1649 See in this respect, Antiterrorismemaatregelen in Nederland in het eerste decennium van de 21e eeuw. Overtotstandkoming, toepassing, beoordeling en aanpassing van antiterrorismemaatregelen in Nederland 2001-2010, January 2011, Nationaal Coördinator Terrorismebestrijding, bijlage H: P.H.P.H.M.C. van Kempen, J. van de Voort, Nederlandse antiterrorism-regelgeving getoetst aan fundamentele rechten. Een analyse met meer bijzonder aandacht voor het EVRM, Radboud Universiteit Nijmegen 1 December 2010, pp. 60-63; P.H.P.H.M.C. van Kempen, 'Het conceptvoorstel voorkoming, opsporing en vervolging van terroristische misdrijven: terrorismebestrijding door marginalisering strafvorderlijke waarborgen', in NJB 2005/8. 



\section{Chapter VIII Blacklisted as Terrorist}

\section{InTRODUCTION}

In addition to the above discussed police, administrative and criminal law measures to counter terrorism, there is one more legal instrument that needs to be discussed: blacklisting and the imposition of fund-freezing measures. As stated in Chapter I, the European Union's system of blacklisting terrorists does not rely on suspicion criteria, and can therefore not be arranged within the continuum approach as applied in the preceding chapters. Discussing the European Union's blacklisting system at this point is therefore primarily inspired by the intrusive character of this system, specifically in terms of compliance with fundamental legal rights and principles of law as incorporated in the Charter of Fundamental Rights of the European Union ('the Charter') and in the ECHR.

Since the early 1990 s, the international community, under the aegis of the UN, has started to draw up publicly accessible lists of states, groups, entities and individuals, who have allegedly been involved in terrorism. Blacklisted parties may subsequently be the subjects of various 'targeted sanctions', including arms embargos, travel bans and fund-freezing measures. Initially, the blacklists consisted primarily of states or organisations which were considered to have certain links with acts of terrorism, such as Libya, Sudan, Iraq and the Taliban - and later, Al-Qaida. ${ }^{1650}$ However, after the 9/11 attacks in the USA, the UN called upon the international community to prevent and suppress (the financing of) terrorism, in general hence, by all means, which included blacklisting and the imposition of fund-freezing measures. To implement this firm UN anti-terrorism policy adequately, the Union established a blacklisting system of its own, which also incorporates the UN blacklists. This chapter discusses the Union blacklisting system.

As a rule, once a party is included on the Union blacklist, all its assets are frozen, including, among other things, insurance, insurance related services, bank credits, travellers' cheques, bank cheques, money orders, shares, securities, bonds, drafts, and letters of credit. The freezing of assets implies that a blacklisted person cannot work, travel, provide for himself, have medical insurance etc. Basically, he no longer has access to all the necessary means to lead a 'normal life'. The blacklisted

1650 The UN also imposes comparable targeted sanctions on states, organisations or individuals in respect of, for example, serious human rights violations. Examples that may be mentioned are the targeted sanctions imposed on Somalia, Congo, Sierra Leone, Angola and Liberia. As these sanctions do not specifically relate to the combating of terrorism, I will not elaborate on this issue. 
party is not, moreover, informed of the intended imposition of fund-freezing measures and only discovers this when his assets have already been frozen.

Whereas the actual listing, as well as the imposition of the fund-freezing measures, is quite simple, delisting has proven to be almost impossible. Theoretically, available legal remedies turn out to be factually useless, because of the lack of compliance with essential (defence) rights and procedural requirements. Unsurprisingly, the blacklisting system has generated quite some criticism in recent years. Even though some improvements have been made in the legal status of blacklisted parties, it remains to be seen whether the system is in consonance with fundamental rights and principles as enshrined in various international treaties.

The main goals of this chapter are: (1) to map out the course of the Union's listing and delisting proceedings, (2) to discuss the criteria for being listed, (3) to scrutinise the factual (current) legal status of blacklisted parties during these proceedings, and (4) to examine the Union Judiciary's case law with regard to compliance with fundamental (defence) rights during the proceedings. Various sub-questions arise. For example, how and by whom are the blacklists drawn up, following what (amount and kind of) information, and on the basis of what justifications? Once a party is indeed blacklisted, what possibilities are there for being delisted? With regard to the safeguarding of fundamental (defence) rights it is also important to establish the nature of fund-freezing measures: are they based on criminal law or merely administrative in nature? The answer to this latter question determines whether or not the Union is, legally at least, obliged to comply fully with fair trial principles throughout (de)-listing proceedings as comprised in, for example, the Charter and the ECHR. In this respect, the notion of freezing assets needs clarifying. Does the freezing of assets simply amount to confiscating a party's possessions for a limited time? Should such measures be characterised as sanctions?

In the following sections, I will first discuss the Union blacklisting system, its origin, and the main legislative documents. Then the question of how these measures affect fundamental rights and principles is examined on the basis of Union case law. In that respect, firstly procedural rights, such as defence rights, the right to effective judicial review, and the right to be presumed innocence, are discussed. Secondly, I consider alleged interferences with substantive rights and fundamental principles, such as the right to property, the right to privacy, and the principles of proportionality and subsidiarity. The question of how the Union balances the competing interests of preventing terrorism by means of the blacklisting system on the one hand, and safeguarding fundamental rights, on the other, is crucial in this respect. 


\section{Origin of the European Union blacklisting system: The United Nations BLACKLISTING}

On 28 September 2001, the United Nations Security Council (UNSC) adopted Resolution 1373 (2001), laying down strategies to combat terrorism and, in particular, the financing thereof. ${ }^{1651}$ The Security Council acted under Chapter VII of the United Nations Charter entitled 'Action with respect to threats to the peace, breaches of the peace and acts of aggression'. Article 1, section c of this Resolution stipulates, among other things, that 'all States must freeze, without delay, funds and other financial assets or economic resources of persons who commit, or attempt to commit, terrorist acts or participate in or facilitate the commission of terrorist acts (...)'. Entities owned or controlled by such persons must also be subjected to such measures. Prior to this Resolution, which has a more general scope, the UNSC adopted Resolution 1267 (1999). ${ }^{1652}$ By means of this latter Resolution, the UNSC established a sanctions regime specifically to cover individuals and entities associated with Osama Bin Laden and/or the Taliban and/or Al Qaida. Article 4, section b obliges States 'to freeze funds and other financial resources, including funds derived or generated from property owned or controlled directly or indirectly by the Taliban (...).'. ${ }^{1653}$

The UN targeted sanctions, freezing of assets, travel bans and arms embargos, currently apply to individuals and entities associated with Al-Qaida, Osama bin Laden and/or the Taliban, wherever they may be located. Names of these individuals and entities are placed on the so-called 'Consolidated List'. ${ }^{1654}$ Only narrative summaries of reasons for listing are included on this list, if at all available. ${ }^{1655}$ It is, furthermore, unclear who is authorised to submit listing requests and, moreover, what type and amount of information needs to be provided with such requests. Hardly any notification is provided to individuals or entities upon listing and little guidance is provided on what constitutes 'acceptable humanitarian exemptions'. ${ }^{656}$

1651 UNSC Resolution 1373 (2001) On Threats to international peace and security caused by terrorist acts adopted by the Security Council at its $4385^{\text {th }}$ meeting, on 28 September 2001 (S/RES/1373 (2001)).

1652 UNSC Resolution 1267 (1999) Establishing the Al-Qaida and Taliban Sanctions Committee adopted by the Security Council at its $4051^{\text {st }}$ meeting on 15 October 1999 (S/RES/1267 (1999)).

1653 The Sanctions Regime established by this Resolution has been modified and strengthened by subsequent Resolutions, including Resolutions 1333 (2000), 1390 (2002), 1455 (2003), 1526 (2004), 1617 (2005), 1735 (2006) and 1822 (2008).

1654 See www.un.org/sc/committees/1267/pdf/consolidatedlist.pdf (last updated on 22 October 2009).

1655 See www.un.org/sc/committees/1267/individuals_associated_with_the taliban.shtml. See also www.un.org/sc/committees/1267/individuals_associated_with_Al-Qaida.shtml. And see www.un.org/sc/committees/1267/entities_other_groups_undertakings_associated_with_ Al-Qaida.shtml.

1656 Compare with Article 6 of Common Position 931/2001/CFSP. 
Hence, the 'obligatory' notification does not necessarily include the exact reasons why the respective parties were listed - assuming that they even received notification of the listing.

Listed parties are not, in addition, allowed to communicate directly with the Sanctions Committee, as a state intermediary is required. Even though some improvements have been made in the (de-)listing procedures, they remain largely incompatible with the standards of the UN, which is said to uphold the rule of law as a fundamental principle. ${ }^{1657}$ There is, moreover, still the prospect that individuals might be listed based upon mistaken identity. This chapter primarily deals with the Union blacklists; I will therefore not elaborate further the UN system. However, it is important to note that the aforementioned UNSC Resolutions led the Union to drafting legislation for fund-freezing measures. ${ }^{1658}$

\section{The European Union blaCkListing System}

The Union did not retreat in the fight against (the financing of) terrorism. On 27 December 2001, the Council adopted Common Position 2001/930/CFSP (CP 930) on combating terrorism and Common Position 2001/931/CFSP (CP 931) on the application of specific measures to combat terrorism. ${ }^{1659}$ To implement the measures

1657 See, for example, Report of the Eminent Jurists Panel on Terrorism, Counter-terrorism and Human Rights: Assessing Damage, Urging Action, an initiative of the International Commission of Jurists 2009; I. Cameron, The European Convention on Human Rights, Due Process and United Nations Security Council Counter-Terrorism Sanctions, Council of Europe Publishing 2006; G. A. Lopez, D. Cortright, A. Milar and L. Gerber-Stellingwerf, Overdue Process. Protecting Human Rights while sanctioning Alleged Terrorists. A report to Cordaid from the Fourth Freedom Forum and Kroc Institute for International Peace Studies at the University of Notre Dame April 2009; T. Biersteker and S. Eckert, Addressing challenges to Targeted Sanctions. An Update of the "Watson Report", 2009.

1658 For more information on the UN blacklists and its relation to the European lists see, I. Tappeiner, 'The fight against terrorism. The lists and the gaps', in Utrecht Law Review, Volume 1, Issue 1 (September) 2005, pp. 97-125. At: www.utrechtlawreview.org/publish/articles/000006/article. pdf; P.J.A. De Hert and K.A.P.G. Weis, 'Geglobaliseerde terrorismebestrijding en lokale rechtsbescherming. Europese rechters stappen niet mee in het scenario van de jumping of scales', in Panopticon. Tijdschrift voor strafrecht, criminologie en forensisch welzijnswerk, afl. 2009-1, pp. 1-9.

1659 Adopted under Article 29 of the Treaty on the Functioning of the European Union (TFEU) (15 of the TEU), Article 31 of the TFEU ( 23 of the TEU) and Article 34 of the TEU (repealed). The current provisions of Title VI of the TEU, on police and judicial cooperation in criminal matters, are replaced by the provisions of Chapters 1 and 5 of Title IV of Part Three of the TFEU. See furthermore the Preamble of Common Position 2001/930/CFSP which refers explicitly to UNSC Resolution 1373(2001). The Preamble also underlines the Union's and its Member States' determination to play their full part, in a coordinated manner, in the global coalition against terrorism, under the aegis of the United Nations and in close cooperation with the United States. See also the Preamble of Common Position 2001/931/CFSP which refers to the need for the Union to take additional measures in order to implement UNSC Resolution 1373(2001). 
comprised in these Common Positions, the Council furthermore adopted Council Regulation (EC) No. 2580/2001 (the Regulation) on specific restrictive measures directed against certain persons and entities with a view to combating terrorism. ${ }^{1660}$ These two Common Positions and the Regulation serve to implement UNSC Resolution 1373, and accordingly enable the Council to maintain its own 'Union blacklist' - in addition to the UNSC blacklist. It is important to bear in mind that this latter Resolution does not provide for a blacklist, unlike UNSC Resolution 1267. ${ }^{1661}$ The blacklist comprised in Resolution 1267 has been literally copied and incorporated in Council Regulation (EC) No 467/2001. ${ }^{1662}$ This means that the Union blacklist consists of: (1) parties listed on the Union's own initiative, and (2) those already on the UN blacklist.

The three core legislative documents on combating the financing of terrorism within the Union are, hence, CP 930, CP 931 and the Regulation. These three instruments form the legal basis for the Union's own blacklisting system. ${ }^{1663}$ In the following pages, these three documents are discussed.

\subsection{Council Common Position 930/2001/CFSP}

The first founding document for blacklisting proceedings - CP 930 - is a rather general document in which all Union Member States declare their united will to cooperate in the fight against (the financing of) terrorism and strengthen their joint (practical) efforts in that respect. In the Preamble, the Council reaffirms its determination to play a full part in the global coalition against terrorism, under the aegis of the United Nations and in close cooperation with the United States. Furthermore, the Preamble specifically underlines the importance of increased cooperation between the operational services responsible for combating terrorism within the Union: Europol, Eurojust, the national intelligence services, police forces and judicial authorities. ${ }^{1664}$

1660 Pursuant to Article 75 of the TFEU (Article 60 of the TEC), Article 215 of the TFEU (Article 301 of the TEC) and Article 352 of the TFEU (Article 308 of the TEC).

1661 See, in this respect, also Article 15 of Common Position 2001/931/CFSP, which prescribes that Member States have to increase cooperation and fully implement the relevant international conventions and protocols relating to terrorism and UNSC Resolutions 1269 (1999) and 1368 (2001).

1662 See Common Position 2001/154/CFSP and Council Regulation (EC) No 881/2002.

1663 See the Preamble of Common Position 2001/931/CFSP, which underlines that the Council adopted Common Position 2001/154/CFSP pursuant to UNSC Resolution 1333 (2000) which provides for the freezing of funds of Osama bin Laden and individuals and entities associated with him. Consequently, those persons, groups and entities are not covered by Common Position 2001/931/CFSP.

1664 Council Common Position of 27 December 2001 on combating terrorism (2001/930/CFSP), section (4) of the Preamble. 
With regard to content, CP 930 prescribes that Member States, first of all, are to criminalise the financing of terrorism and all related offences (Articles 1-3). Second, states have to take measures to suppress any form of support - active or passive - to entities or persons involved in terrorist acts and, more generally, to prevent terrorist acts (Articles 4-5). Safe havens to those who finance, plan, support or commit terrorist acts should be denied, and states have to bring perpetrators of terrorist acts to justice and assist one another throughout criminal investigations/ proceedings (Articles 6-9). Fourth, states must ensure effective border controls and controls on the issuing of identity papers and travel documents, and take the required measures to prevent counterfeiting, forgery or the fraudulent use of identity papers and travel documents (Articles 10 and 11). The exchange of operational information should, furthermore, be accelerated, as well as cooperation in administrative and judicial matters (Article 12). The last important obligation arises from Article 14: all Member States must, as soon as possible, become party to the relevant international conventions relating to terrorism.

In sum, CP 930 is a general framework for the prevention and combating of (the financing of) terrorism which comprises substantive as well as procedural (criminal) law elements. It obliges Member States to criminalise the financing of terrorism and other related terrorist offences. Additionally, Member States must increase cooperation in their joint fight against terrorism pursuant to CP 930.

\subsection{Council Common Position 931/2001/CFSP}

The second legislative document, $\mathrm{CP}$ 931, prescribes who, when, for how long, and fulfilling which substantive and procedural requirements, may be blacklisted and/or subjected to fund-freezing measures. It contains, first of all, definitions of: 'terrorist act', 1665 'persons, groups and entities involved in terrorist acts', 1666 'terrorist group' and 'structured group'. ${ }^{167}$ These definitions are exactly the same as those comprised in the 2002 Framework Decision on Combating Terrorism. ${ }^{1668}$ CP 931 applies to 'persons, groups and entities involved in terrorist acts' ${ }^{1669}$ Being involved in terrorist acts is further specified in Article 1, section 2 as: 'persons who commit, or attempt to commit, terrorist acts or who participate in, or facilitate, the commission of terrorist acts and/or groups and entities owned or controlled directly or indirectly by such persons, and persons, groups and entities acting on behalf of, or under the direction of, such persons, groups and entities, including funds derived or generated from property owned or controlled directly or indirectly by such persons and

\footnotetext{
1665 Article 1, section 3 of CP 931.

1666 Article 1, section 2 of CP 931.

1667 Article 1, section 3 of CP 931.

1668 See Part II for a discussion of the 2002 EU Framework Decision on Combating Terrorism and on the definition of terrorist act.

1669 Article 1, section 1of CP 931.
} 
associated persons, groups and entities. ${ }^{1670}$ In theory, this phrase may be considered as the suspicion criterion that needs to be fulfilled at domestic level. However, as will appear in Section 6, this criterion is of little value to the Council's blacklisting decision.

The Council of the Union drafts the blacklist on the basis of "precise information or material' that indicates that a decision has been taken by a 'competent authority' in respect of the persons, groups and entities concerned. Such a decision, taken at domestic level, may concern the instigation of investigations or prosecution for a terrorist act, an attempt to perpetrate, participate in, or facilitate, such an act based on serious and credible evidence or clues, or condemnation for such deeds. ${ }^{1671}$ Theoretically speaking, these prerequisites must be fulfilled in order to include a party on the blacklist and/or to impose fund-freezing measures lawfully.

However, it is important to note that the Council and the Court of First Instance (CFI) and the European Court of Justice (ECJ) in fact only verify whether a 'decision' has indeed been taken at the national level. The underlying 'evidence' for that decision is not examined. So, the factual conduct that led the national authorities to label a person/entity/organisation as 'terrorist' does not play a role in the blacklisting proceedings. The blacklisting system is regarded as introducing a specific form of cooperation between the Council and the Member States in the context of combating terrorism, which obliges the Council to defer, as far as possible, to the assessment conducted by the competent national authority, at least where it is a judicial authority, in particular in respect of the existence of 'serious and credible evidence' on which the national decision is based. ${ }^{1672}$ Furthermore, mutual trust between the Union and the Member States results in a marginal

1670 Article 1, section 3 of CP 931. See for an interpretation of this provision the judgement of the General Court (Seventh Chamber) of 9 September 2010 in the case of Stichting Al-Aqsa v. the Council of the European Union (Case T-348/07), paragraphs 55-62 in which the General Court considers that: 'The 'persons' referred to in the first indent of Article 1(2) of Common Position 2001/931 may therefore be both natural and legal persons, whereas the 'groups and entities' referred to in the second indent of Article 1(2) of Common Position 2001/931 may be any other types of social organisations which although they do not have legal personality none the less exist in a more or less structured form.'

1671 Article 1, section 4 of CP 931.

1672 Judgement of the Court of First Instance (Seventh Chamber) of 23 October 2008 in the case of People's Mojahedin Organisation of Iran v. the Council of the European Union (Case T-256/07) (PMOI I), paragraph 133; judgement of the Court of First Instance (Seventh Chamber) of 4 December 2008 in the case of People's Mojahedin Organisation of Iran v. the Council of the European Union (Case T-284/08) (PMOI II), paragraph 53; judgement of the Court of First Instance (Second Chamber) 12 December 2006 in the case of Organisation des Modjahedines du people d'Iran (France) v. the Council of the European Union (Case T-228/02) (OMPI), paragraph 124; judgement of the Court of First Instance (Seventh Chamber) of 30 September 2009 in the case of Jose Maria Sison v. the Council of the European Union (Case T-341/07), paragraph 95; judgement of the General Court (Seventh Chamber) of 9 September 2010 in the case of Stichting Al-Aqsa v. the Council of the European Union (Case T-348/07), paragraph 80. 
examination of the factual justification for considering a person/entity/organisation as terrorist. 1673 This issue will further be elaborated on below.

A 'competent authority' means a judicial authority, or, where judicial authorities have no competence in the area covered, an equivalent competent authority in that area. ${ }^{1674}$ This means that a decision of another (administrative) competent national authority also suffices. ${ }^{1675}$ Precise information or material may furthermore come from banks, other financial institutions, insurance companies and other bodies and persons. Such information is only to be used for the purposes for which it was provided or received. Any information directly received by the Commission of the Union has to be made available to the competent authorities of the Member States concerned and to the Council.1676

When the above-mentioned criteria are fulfilled, a person, group or entity is included on the blacklist. Subsequently, the Council orders the freezing of his/its funds and other financial assets or economic resources. ${ }^{1677}$ Additionally, no funds, financial assets or economic resources, or financial or other related services are to be made available, directly or indirectly, for the benefit of those persons, groups and/or entities. ${ }^{1678}$

Article 4 of CP 931 obliges Member States to afford each other the widest possible assistance in preventing and combating terrorist acts, by means of police and judicial cooperation in criminal matters. In that respect, they have to exert, with respect to enquiries and proceedings conducted by their authorities regarding any of the blacklisted parties, upon request their full existing powers in accordance with

1673 Judgement of the Court of First Instance (Seventh Chamber) of 23 October 2008 in the case of People's Mojahedin Organisation of Iran v. the Council of the European Union (Case T-256/07) (PMOI I), paragraph 132; judgement of the Court of First Instance (Seventh Chamber) of 4 December 2008 in the case of People's Mojahedin Organisation of Iran v. the Council of the European Union (Case T-284/08) (PMOI II), paragraph 52; judgement of the Court of First Instance (Second Chamber) 12 December 2006 in the case of Organisation des Modjahedines du people d'Iran (France) v. the Council of the European Union (Case 228/02) (OMPI), paragraph 123; judgement of the Court of First Instance (Seventh Chamber) of 30 September 2009 in the case of Jose Maria Sison v. the Council of the European Union (Case T-341/07), paragraph 94; judgement of the General Court (Seventh Chamber) of 9 September 2010 in the case of Stichting Al-Aqsa v. the Council of the European Union (Case T-348/07), paragraph 79.

1674 Article 1, section 5 of CP 931.

1675 Judgement of the Court of First Instance (Seventh Chamber) of 23 October 2008 in the case of People's Mojahedin Organisation of Iran v. the Council of the European Union (Case T-256/07) (PMOI I), paragraph 144; judgement of the General Court (Seventh Chamber) of 9 September 2010 in the case of Stichting Al-Aqsa v. the Council of the European Union (Case T-348/07), paragraph 88 .

1676 Article 4 of Council Regulation No 2580 of 27 December 2001 on specific restrictive measures directed against certain persons and entities with a view to combating terrorism (EC/2580/2001).

1677 Article 2 of CP 931.

1678 Article 3 of CP 931. 
acts of the Union and other international agreements, arrangements and conversations which are binding upon Member States. ${ }^{1679}$

The names of the blacklisted parties in the Annex to CP 931 are to be reviewed at regular intervals, and at least once every six months, so as to ensure that there are (legitimate) grounds for them remaining on the list. ${ }^{1680}$

Theoretically, CP 931 may comprise sufficient guarantees to ensure compliance with the rule of law throughout blacklisting proceedings. Nevertheless, it remains to be seen if and how the Union interprets and applies these guarantees, and ultimately whether blacklisting and the imposition of fund-freezing measures, as performed by the Union, in fact respect the rule of law.

It is important to note that the CP 931 blacklist consists of two categories of presumed terrorists. First, there are the so-called internal terrorists (or European terrorists). ${ }^{1681}$ These can only be subjected to the measures prescribed in the abovementioned Article 4 of CP 931. This means that the Council includes these persons/groups/entities on the blacklist, but may then only subject them to judicial and police cooperation among Member States. Thus, fund-freezing measures, as prescribed in the Regulation, are not imposed on them. The Union regards several Basque organisations and splinter factions of the IRA as internal terrorists.

The second category consists of external terrorists (or non-European terrorists). They are blacklisted and subjected to both the fund-freezing measures comprised in the Regulation, as well as to the measures specified in Article 4 of CP 931. I will elaborate further on the legal consequences of this categorisation in section 5 specifically in terms of the scope of effective legal remedies available to internal terrorists. ${ }^{1682}$

\subsection{Council Regulation (EC) No 2580/2001}

The third, and last, legislative core document - the Regulation - enumerates the specific fund-freezing measures that may be imposed on blacklisted parties. Article 1 of the Regulation defines 'funds, other financial assets and economic resources' as 'assets of every kind, whether tangible or intangible, movable or immovable, however acquired, and legal documents or instruments in any form, including electronic or digital, evidencing title to, or interest in, such assets, including, but not limited to, bank credits, travellers' cheques, bank cheques, money

1679 Article 4 of CP 930.

1680 Article 1, section 6 and Article 6 of CP 930.

1681 These internal terrorists are indicated with an "*" on the blacklist.

1682 See for more information on this issue: P.J.A. De Hert and K.A.P.G. Weis, 'Terrorismelijsten en de paradox van de rechtsbescherming' in Tijdschrift voor Europees en economisch recht, aflevering 2009-9. 
orders, shares, securities, bonds, drafts and letters of credit.' ${ }^{\prime 683}$ Freezing is then defined as 'preventing any move, transfer, alteration, use of or dealing with funds in any way that would result in any change in their volume, amount, location, ownership, possession character, destination or other change that would enable the funds to be used, including portfolio management.' 1684 In accordance with these definitions, the Regulation prescribes that all funds, other financial assets and economic resources belonging to, or owned or held by, a blacklisted party, are to be frozen and none is to be made available to the party concerned. ${ }^{1685}$

Article 5 of the Regulation provides for one possible exception to the allencompassing nature of these measures: Member States are authorised to grant special authorisation for exemptions from, among other things, essential human needs and the payment of taxes. Such an authorisation for exemption is, however, an exception to the general freezing of all assets, funds and resources. ${ }^{1686}$ The Council, acting unanimously, establishes, reviews and amends the list of persons, groups and entities to which the Regulation applies, in accordance with the provisions of Articles 1, section 4, 5 and 6 of CP 931 - on the basis of information supplied by Member States.

In sum, the Regulation prescribes which specific restrictive fund-freezing measures may be imposed on blacklisted persons, groups and entities and when special authorisation for exemptions from such measures can be granted.

\section{SAFEgUARDing FUNDAMENTAL RIGHTS AND FREEDOMS THROUGHOUT BLACKLISTING PROCEEDINGS}

Blacklisting and the imposition of fund-freezing measures infringe upon a large number of fundamental human rights and principles, as guaranteed by the ECHR, the ICCPR, the ICESCR and the Charter. Simply being listed can damage a person's reputation by insinuating that he is associated with terrorists, or is even a direct participant in terrorism. Furthermore, the freezing of assets itself infringes upon substantive rights, such as the right to property, privacy and the right to freedom of assembly, association and expression.

Additionally, the blacklisting proceedings contravene various procedural rights and fair trial principles, such as the right to effective judicial review, the right to be presumed innocent until proven guilty and the right to be informed of the charges. In the following sections, I discuss to what extent the CFI and the ECJ consider interferences with listed persons' rights - procedural and substantive - to amount to actual violations. 
Initially, case law regarding blacklisting and the imposition of fund-freezing measures primarily concerned aspects of procedural law, such as the lack of effective judicial review and the lack of a fair hearing prior to, and during, the blacklisting proceedings. Claims about alleged violations of substantive rights only came to play a significant role from 2008 onwards, starting with the ECJ Kadi judgement. For example, the 2007 CFI Sison judgement only dealt with presumed infringements of procedural rights, even though Sison also claimed violations of substantive rights such as the infringements on his right to property. Allegations regarding infringements of substantive rights, such as the right to property and privacy and non-compliance with evidentiary standards - in accordance with the Regulation and CP 931 - were all dismissed or not even thoroughly examined. In 2008, the ECJ concluded - for the first time - in the Kadi, Yusuf and Al Barakaat judgements that substantive rights - in these cases the right to property - had been violated due to the imposition of fund-freezing measures.

When elaborating on case law regarding the Union blacklists, it is important to bear in mind that there are three categories of listed persons/groups/entities. The first category consists of parties listed following UNSC Resolution 1267, i.e. blacklisting of members or associates of Al-Qaida, Osama Bin Laden and/or the Taliban. ${ }^{1687}$ Illustrative of this category are the Kadi, Yusuf, Hassan and Ayadi judgements of the CFI and the ECJ. ${ }^{168}$

Second, there are persons/groups/entities who have been listed and subjected to fund-freezing measures on the Union's own initiative, in line with UNSC Resolution 1373, such as in the PMOI I, PMOI II, and the OMPI judgements, and such as the members of the Hofstadgroep - the external terrorists. ${ }^{1689}$

The third category consists of the above-discussed internal terrorists. Examples of this category are Segi and Gestoras Pro Amnistia. ${ }^{1690}$ This differentiation needs

1687 See www.un.org/sc/committees/1267/.

1688 Judgement of the Court of First Instance (Second Chamber, Extended Composition) of 21 September 2005 in the case of Yassin Abdullah Kadi (Saudi Arabia) v. the Council of the European Union and the Commission of the European Communities (T - 315/01); Judgement of the Court of First Instance (Second Chamber, Extended Composition) of 21 September 2005 in the case of Ahmed Ali Yusuf and the Al Barakaat International Foundation v. The Council of the European Union and the Commission of the European Communities (Case T - 306/01).

1689 For example, judgement of the Court of First Instance (Second Chamber) of 2 September 2009 in the case of Mohammed El Morabit v. The Council of the European Union (Joined Cases T-37/07 and T-323/07).

1690 See Article 4 of CP 931, which reads: 'Member States shall, through police and judicial cooperation in criminal matters within the framework of Title VI of the Treaty on European Union, afford each other the widest possible assistance in preventing and combating terrorist acts. To that end they shall, with respect to enquiries and proceedings conducted by their authorities in respect of any of the persons, groups and entities listed in the Annex, fully exploit, upon request, their existing powers in accordance with acts of the European Union and other international agreements, arrangements and conventions which are binding upon Member States.' 
to be kept in mind to fully understand the reasoning and approach of the CFI and the ECJ while judging on a complaint.

In the following, I first discuss the procedural complaints that listed persons have raised before the Union Judiciary. All cases deal with, more or less, identical complaints regarding procedural law. Blacklisted parties claim: (1) an alleged lack of competence of the Union - both Council and Judiciary - in including them on the blacklist and in imposing fund-freezing measures; (2) alleged interferences with defence rights, such as the right to a fair hearing, the right to be informed of the reasons for being blacklisting, and the right to an effective legal remedy; (3) noncompliance with the right to an effective judicial review, and lastly (4) complete disregard for the right to be presumed innocent.

With regard to the latter aspect, the question of whether blacklisting and the imposition of fund-freezing measures should be considered as a criminal charge, in accordance with Article 6 of the ECHR, is also elaborated on. This provision guarantees anyone charged with a criminal offence various fair trial principles, such as the right to a fair and public hearing within a reasonable time, the right to be presumed innocent, the right to be informed promptly, in a language which one understands and in detail, of the nature and cause of the accusation against one, and the right to have adequate time and facilities for the preparation of one's defence. The question of whether blacklisting and the imposition of fund-freezing measures belong to the criminal or to the administrative law sphere is therefore of considerable importance. The Judiciary of the Union does not (to date, at least) regard fundfreezing measures as criminal sanctions, but merely administrative, precautionary and temporary measures. Consequently, fair trial principles do not need to be complied with throughout blacklisting proceedings. An interesting question is obviously whether the ECtHR would agree, if confronted with this issue. This question will be examined in the following sections.

Subsequently, substantive complaints will be elaborated on in section 6 . The amount of case law on substantive complaints is considerably smaller than on procedural complaints. First of all, I will examine alleged infringements on Article 2 of the Regulation and/or on Article 1 of CP 931 - i.e. the question of whether all legal (substantive) prerequisites for inclusion on the list have been met. Secondly, I will elaborate on presumed infringements on the principles of subsidiarity, proportionality and legal certainty. Then, interferences with the right to property are examined. Lastly, I will discuss alleged infringements on the right to assembly, association, expression and privacy. 


\section{Procedural violations}

\subsection{Competence of the Union regarding blacklisting}

All listed persons/groups/entities, irrespective of which category they belong to, have claimed, before the Judiciary of the Union, that the Council misused/ overstepped their powers in drawing up the blacklists and in the subsequent freezing of their funds. More precisely, they have contended that the Council misused its powers acting in Union matters with disregard for the Community's competences, in order to deprive it of all forms of judicial protection. ${ }^{1691}$

The CFI and the ECJ have concluded, in all cases, that neither the Council nor the Commission overstepped or misused their powers in drafting and implementing the contested Common Positions, Decisions and Regulation. ${ }^{1692}$

1691 Judgement of the Court of First Instance (Second Chamber) 12 December 2006 in the case of Organisation des Modjahedines du people d'Iran (France) v. the Council of the European Union (Case 228/02) (OMPI judgement); judgement of the Court of First Instance (Seventh Chamber) of 23 October 2008 in the case of People's Mojahedin Organisation of Iran v. the Council of the European Union (Case T-256/07) (PMOI I judgement); judgement of the Court of First Instance of 3 April 2008 in the case of Osman Ocalan on behalf of the Kurdistan Workers' Party (PKK) $v$. The Council of the European Union (Case T-229/02); judgement of the Court of Justice (Grand Chamber) of 27 February 2007 (Appeal) in the case of Segi, Araitz Zubimendi Izaga and Aritza Galarraga v. The Council of the European Union (Case C-355/04 P); judgement of the Court of First Instance (Second Chamber) of 11 July 2007 in the case of Jose Maria Sison v. the Council of the European Union (Case T-47/03); judgement of the Court of First Instance (Second Chamber) of 11 July 2007 in the case of Stichting Al-Aqsa v. the Council of the European Union (Case T-327/03); order of The Court of First Instance (Second Chamber) of 18 November in the case of Abdelghani Selmani v. The Council of the European Union and the Commission of the European Communities (Case T-299/04); judgement of the Court of First Instance (Second Chamber, Extended Composition) of 21 September 2005 in the case of Ahmed Ali Yusuf and the Al Barakaat International Foundation v. The Council of the European Union and the Commission of the European Communities (Case T - 306/01); judgement of the Court of First Instance (Second Chamber) of 12 July 2006 in the case of Faraj Hassan v. The Council of the European Union and the Commission of the European Communities (Case T-49/04).

1692 See, among others, judgement of the Court of First Instance (Second Chamber) 12 December 2006 in the case of Organisation des Modjahedines du people d'Iran (France) v. the Council of the European Union (Case 228/02), paragraphs 55-56. The CFI reasoned that the Council, acting in Union matters, far from infringing upon the Community's competences, on the contrary, relied on them in order to implement the contested Common Position. First, it was argued that the Council, having made use of the relevant Community powers, in particular those laid down in Article 75 of the TFEU (Article 60 of the TEC) and Article 215 of the TFEU (Article 301 of the TEC), could not be criticised for having been unaware of them. Second, it was highlighted that the provisions themselves provide for the prior adoption of a Common Position or a joint action in order to be applicable. It follows, it was asserted, that the prior adoption of a Common Position before the implementation of the Community competences demonstrates compliance with those competences and not breach thereof. Moreover, even if the use of a Common Position on the basis of the (former) EU Treaty meant that the persons affected are denied a direct remedy before the Community Courts, namely the possibility of challenging directly the lawfulness of 
In several judgements, the CFI has underlined that, at present, states can no longer be regarded as the only source of threats to international peace and security. Like the international community, the Union is not to be prevented from responding to these new threats by imposing economic and financial sanctions not only on third countries, but also on associated persons, groups, undertakings or entities engaged in international terrorist activity or in any other way constituting a threat to international peace and security. ${ }^{1693}$ Such an interpretation is justified both by considerations of effectiveness and by humanitarian concerns. ${ }^{1694}$ In the $2008 \mathrm{Kadi}$ judgement on appeal, the ECJ upheld the CFI's line of reasoning on this matter, and declared the joint Articles 75, 215 and 352 of the TFEU to be an appropriate and sufficient legal basis for the imposition of fund-freezing measures. ${ }^{1695}$

Specifically with regard to the first category of blacklisted persons, ${ }^{1696}$ another issue should be mentioned. The inclusion of terrorists, named on the UN list, on the Union blacklist is, as mentioned above, directly based on their inclusion on the UN list. In the 2006 Kadi judgement, the CFI underlined the supremacy of international law, and Member States' obligation to implement international law fully, compared with Union Law. The CFI considered it mandatory for the Union to incorporate the UN-blacklist, without amendments, into the Union list. Kadi and Yusuf were, hence, with the consent of the CFI, included on the Union list simply on the basis of their being on the UN blacklist. ${ }^{169}$ Complaints regarding the Union's lack of

the contested Common Position, such a result does not constitute as such a disregard of the Community's competences. See, also, the judgement of the Court of First Instance (Second Chamber) of 11 July 2007 in the case of Jose Maria Sison v. the Council of the European Union (Case T-47/03), paragraphs 98-104.

1693 Judgement of the Court of First Instance (Second Chamber, Extended Composition) of 21 September 2005 in the case of Yassin Abdullah Kadi (Saudi Arabia) v. the Council of the European Union and the Commission of the European Communities (T - 315/01) and judgement of the Court of First Instance (Second Chamber) of 12 July 2006 in the case of Faraj Hassan v. The Council of the European Union and the Commission of the European Communities (Case T-49/04).

1694 See, for further elaboration on this point, judgement of the Court of First Instance (Second Chamber, Extended Composition) of 21 September 2005 in the case of Ahmed Ali Yusuf and the Al Barakaat International Foundation v. The Council of the European Union and the Commission of the European Communities (Case T - 306/01), paragraphs 124-172; judgement of the Court of First Instance (Second Chamber) of 12 July 2006 in the case of Faraj Hassan $v$. The Council of the European Union and the Commission of the European Communities (Case T-49/04); judgement of the Court of First Instance (Second Chamber) of 12 July 2006 in the case of Chafiq Ayadi v. The Council of the European Union (Case T-253/02).

1695 Judgement of the Court (Grand Chamber) of 3 September 2008 (Appeals) in the cases of Yassin Abdullah Kadi and Al Barakaat International Foundation v. The Council of the European Union (Joint Cases C-402/05 P and C-415/05 P), paragraphs 116-117; judgement of the Court of First Instance (Second Chamber) of 12 July 2006 in the case of Faraj Hassan v. The Council of the European Union and the Commission of the European Communities (Case T-49/04).

1696 See Council Regulation No 881/2002/EC.

1697 The CFI reasons in this respect that Resolutions of the Security Council fall, in principle, outside the ambit of the CFI's judicial review and the CFI has no authority to call in question, even 
competence in drafting the blacklists and in subsequently imposing fund-freezing measures were therewith dismissed.

Eventually, in 2008 the ECJ overruled this line of reasoning on appeal in the Kadi, Hassan and Ayadi judgements. The ECJ judged the Judiciary of the Union to be fully competent to review the lawfulness of the contested Decisions, the Regulation and the Common Positions within the Union's own legal system, and accordingly to judge on the Union's competence in blacklisting UN terrorists. ${ }^{1698}$ Nevertheless, the ECJ did not judge the working method of literally incorporating the UN list into Union law, as such, to be unlawful. So, even though following the Kadi judgement on appeal, the Judiciary of the Union is now authorised - and even obliged - to hear and judge the claims of UN terrorists within the Union's own legal order, the automatic inclusion of the UNSC Resolution 1267 list on the Union list remains a fact. I will further elaborate on this issue in the following section.

In sum, quite irrespective of which 'group' a listed person/group/entity belongs to, the CFI and the ECJ deem the Union authorised to draft blacklists, and consequently, to impose fund-freezing measures.

\subsection{Defence rights}

In the 2007 Sison judgement, the CFI contended that because the identification of the persons/groups/entities considered in UNSC Resolution 1373 (2001) and the adoption of the ensuing measure to freeze funds involve the exercise of the Union's own powers, entailing a discretionary assessment for the Union, the Council is, as a rule, bound to observe the defence rights of blacklisted parties. Thus, theoretically, the Union is obliged to safeguard defence rights in the context of blacklisting proceedings. ${ }^{1699}$ To what extent this obligation is implemented in practice during blacklisting proceedings is discussed in this section.

The Union Judiciary considers the general notion of defence rights to consist of three rights: (1) the right to a fair hearing, (2) the right for blacklisted parties to be

indirectly, their lawfulness in the light of Union law. On the contrary, the CFI is bound, so far as possible, to interpret and apply that law in a manner compatible with the obligations of the Member States under the Charter of the United Nations. See judgement of the Court of First Instance (Second Chamber, Extended Composition) of 21 September 2005 in the case of Yassin Abdullah Kadi (Saudi Arabia) v. the Council of the European Union and the Commission of the European Communities (T - 315/01) paragraphs 213-215, 221-223, 225-226.

1698 Judgement of the Court (Grand Chamber) of 3 September 2008 (Appeals) in the cases of Yassin Abdullah Kadi and Al Barakaat International Foundation v. The Council of the European Union (Joint Cases C-402/05 P and C-415/05 P) and judgement of the Court of Justice (Second Chamber) of 3 December 2009 in the cases of Faraj Hassan and Chafiq Ayadi v. The Council of the European Union and the European Commission (Joint Cases C-399/06 P and C-403/06 P).

1699 Judgement of the Court of First Instance (Second Chamber) of 11 July 2007 in the case of Jose Maria Sison v. the Council of the European Union (Case T-47/03), paragraphs 140-142 and $154-155$. 
informed of the reasons for their inclusion on the blacklist and (3) the right to an effective legal remedy. ${ }^{1700}$ Therefore, these three procedural interrelated rights are jointly discussed in this section. When reading the following sections, it is important to keep in mind that defence rights are closely related, in the sense that interferences with one of the three rights will inevitably affect the safeguarding of the other two. How far, exactly, this interdependence goes will be discussed below.

\subsubsection{The right to a fair hearing}

In the CFI's view, the right to a fair hearing throughout fund-freezing proceedings has a relatively limited scope. In the case of an initial decision to freeze funds, the CFI requires, in principle, first, that a blacklisted party be informed by the Council of the specific information or material in the file which indicates that a decision meeting the definition given in Article 1(4) of CP 931 has been taken in respect of it by a competent authority of a Member State - and also, where applicable, of any new material. Second, the blacklisted party must be placed in a position in which it can effectively make its view known on the information or material in the file. The first aspect basically encompasses the Council's obligation to state reasons whereas the second aspect specifically refers to a party's right to a fair hearing.

In the case of a subsequent decision to freeze funds, observance of the right to a fair hearing similarly requires, first, that the party concerned be informed of the information or material in the file which, in the view of the Council, justifies keeping it on the disputed lists, and also, where applicable, of any new material. Second, the party concerned must be afforded the opportunity to effectively make known its view on the matter. ${ }^{1701}$

First of all, the practical effects of the right to a fair hearing are very limited, due to the Council's marginal examination of the national decision pursuant to Article 1(4) of CP 931. Factually speaking, the Council only examines if such a decision has been taken without thoroughly scrutinising the information used at the national level to consider a person/entity/organisation as being connected with the financing of terrorism. Hence, the information or material in the file does not, generally speaking, include factual incriminating evidence. The Council, with reference to the mutual thrust between Member States and the Union, is satisfied once it is clear

1700 Principally the right to a fair hearing and the right for blacklisted parties to be informed of the reasons for inclusion on the blacklist are discussed in case law. The right to an effective legal remedy is considered to form part of the notion of defence rights. See, further, Article 48, section 2 of the Charter of Fundamental Rights of the European Union which ensures respect for defence rights of anyone who has been charged. Obviously, the problem is that for fund-freezing measures to be lawfully imposed, the party concerned does not need to be charged with a criminal offence.

1701 Judgement of the Court of First Instance (Second Chamber) 12 December 2006 in the case of Organisation des Modjahedines du people d'Iran (France) v. the Council of the European Union (Case 228/02), paragraph 126. 
that a national decision has, in fact, been taken, irrespective of the factual justifications. This makes the practical scope of the right to a fair hearing very limited.

Secondly, the CFI allows for certain restrictions on the right to a fair hearing in circumstances such as those of the OMPI and PMOI I\&II judgements. ${ }^{1702}$ Notification of the information adduced, and a hearing of the parties concerned, prior to the adoption of the initial decision to freeze funds, would be liable to jeopardise the effectiveness of the sanctions, and would thus be incompatible with the public interest objective pursued by the Union under UNSC Resolution 1373 (2001).

An initial measure freezing funds must, in the CFI's view, be able to benefit from a surprise effect, and to be applied with immediate effect. Such a measure cannot, therefore, be the subject matter of notification and a hearing before it is implemented. With regard to subsequent decisions to freeze funds adopted by the Council in connection with the re-examination of the justification for keeping parties on the blacklist, the CFI holds that the preceding considerations are not relevant. At that stage, the funds are already frozen, and it is, accordingly no longer necessary to ensure a surprise effect in order to guarantee the effectiveness of the sanctions. Any subsequent decision to freeze funds must therefore be preceded by the possibility of a further hearing and, where appropriate, notification of any new information.

However, these restrictions may even be extended further under the so-called 'escape clause'. In the OMPI, PMOI I \& II judgements, the CFI held that overriding considerations concerning the security of the Union and its Member States, or the

1702 The Organisation des Modjahedines du peuple d'Iran (People's Mujahidin of Iran, Mujahedin-e Khalq in Farsi), was founded in 1965, and set itself the objective of replacing the regime of the Shah of Iran, then the mullahs' regime, with a democracy. In 1981 it took part in the foundation of the National Council of Resistance of Iran (NCRI), a body defining itself as the 'parliament in exile of the Iranian resistance'. At the time of the facts giving rise to the dispute, it was composed of five separate organisations and an independent section, making up an armed branch operating inside Iran. According to the Organisation's representative, however, the Organisation and all its members expressly renounced all military activity from June 2001, and it therefore no longer had an armed structure. The Organisation was placed on the Union blacklist on the Union's own initiative (following general UNSC Resolution No. 1373). The Organisation claimed before the CFI that the Council imposed sanctions on it and caused it considerable harm, without its having being able to express its views either before the adoption of the act, or even afterwards. It submitted that, given that its offices and managers are known, its representatives ought to have been summoned and heard before it was included on the disputed list. At the oral hearing, the Organisation insisted that it was not even aware of the identity of the national authority that took the decision in respect of it for the purposes of Article CP 931 and Article 2(3) of the Regulation, or of the evidence and/or information on the basis of which such a decision was taken. According to the Organisation, it was included on the disputed list 'apparently solely only on the basis of documents produced by the Tehran regime'. 
conduct of their international relations, may preclude the communication to blacklisted parties of certain information adduced against them. The CFI underlined that what is at issue is a temporary protective measure restricting the availability of the property of certain persons, groups and entities in connection with combating terrorism. That, it was argued, justifies further restrictions on the right to a fair hearing of blacklisted parties.

It follows from the foregoing that the general principle of observance of the right to a fair hearing requires - unless precluded by the above mentioned overriding considerations - that the information adduced against the party concerned, should be notified to it, in so far as possible, either concomitantly with, or as soon as possible after, the adoption of an initial decision to freeze funds. However, that information only needs to demonstrate the fact that a national decision pursuant to Article 1(4) of CP 931, has been taken. Further (incriminating) information to justify that decision, let alone 'evidence' as used throughout criminal proceedings, is not required.

Subject to the same reservations, any subsequent decision to freeze funds must, in principle, be preceded by the notification of any new information adduced and a hearing. However, observance of the right to a fair hearing does not require either that the information adduced against the party concerned be notified to it prior to the adoption of an initial measure to freeze funds, or that that party automatically be heard after the event in such a context. ${ }^{1703}$

\subsubsection{The right to be informed of the reasons for inclusion on the blacklist}

The above-discussed considerations with regard to the right to a fair hearing apply, mutatis mutandis, to the right to be informed of the reasons for inclusion on the blacklist. This right implies an obligation for the Union to state the reasons for a blacklisting decision. ${ }^{1704}$ The purpose of the obligation to state the reasons for an act adversely affecting a person is: (1) to provide the person concerned with sufficient information to make it possible to determine whether the act is well founded or whether it is vitiated by an error which may permit its validity to be contested before the Union Judiciary, and (2) to enable the Union Judiciary to review the lawfulness of the decision. The obligation to state reasons, in accordance with Article 296 of the TFEU, applies in all cases where the Union adopts an act that directly affects the party concerned. Article 296 of the TFEU is thereby not

1703 Judgement of the Court of First Instance (Second Chamber) 12 December 2006 in the case of Organisation des Modjahedines du people d'Iran (France) v. the Council of the European Union (Case 228/02), paragraphs 127-138.

1704 See Case T-218/02 Napoli Buzzanca v Commission [2005] ECR II-0000, paragraph 57; Case C-199/99 P Corus UK v. Commission [2003] ECR I-11177, paragraph 145; Joined Cases C-189/02 P, C-202/02 P, C-205/02 P to C-208/02 P; C-213/02 P Dansk Rørindustri and Others v. Commission [2005] ECR I-5425, paragraph 462. 
exclusively important for blacklisting and the imposition of fund-freezing measures, but also for other fields of law, such as competition law. Generally, the obligation to state reasons constitutes an essential principle of Union law that may be derogated from only for compelling reasons.

If the blacklisted party is not afforded the opportunity to be heard before the adoption of an initial decision to freeze funds, compliance with the obligation to state reasons is all the more important, because it consequently constitutes the sole safeguard enabling the party, especially after the adoption of that decision, to make effective use of the legal remedies available to it to challenge the lawfulness of the blacklisting decision. In principle, the statement of reasons for a fund-freezing measure must therefore refer not only to the statutory conditions of application of the Regulation and CP 931, but also to the reasons why the Council considers, in the exercise of its discretion, that such a measure must be adopted. ${ }^{1705}$ However, the Council is not obliged to specify all the relevant matters of fact and law. The question of whether the statement of reasons meets the requirements of Article 296 of the TFEU must be assessed with regard, not only to its wording, but also to its context and to all the legal rules governing the matter in question.

With respect to the obligation to state reasons, restrictions are allowed for in the case of the above-mentioned 'overriding considerations', the escape clause. These restrictions apply, above all, to 'the serious and credible evidence or clues' on which a national decision to instigate an investigation or prosecution is based, in so far as they may have been brought to the attention of the Council. According to the CFI, it is conceivable that the restrictions on access to information may concern the specific content or the particular grounds for a blacklisting decision, or even the identity of the authority that took it. It is even possible that, in certain, very specific circumstances, the identification of the Member State or third country in which a competent authority has taken a decision in respect of a blacklisted party, may be liable to jeopardise public security by providing the party concerned with sensitive information.

In sum, the statement of reasons for an initial decision to freeze funds must at least make actual and specific reference to each of the aspects referred to in Article 1, section 4 to 6 of CP 931. Furthermore, the Council is obliged to state the reasons why it considers, in the exercise of its discretion, that fund-freezing measures must be taken in respect of the party concerned. In practice, the latter aspect is very limited as will further be discussed in Section 6. The statement of reasons for a subsequent decision to freeze funds must state the actual and specific reasons why

\footnotetext{
1705 Judgement of the Court of First Instance (Second Chamber) 12 December 2006 in the case of Organisation des Modjahedines du people d'Iran (France) v. the Council of the European Union (Case 228/02), paragraphs 138-146.
} 
the Council considers, following re-examination, that the freezing of the funds of the party concerned remains justified. ${ }^{1706}$ As with respect to the right to a fair hearing, these guarantees can be restricted considerably when the above-discussed 'escape clause' applies. Case law demonstrates that the information that is provided to blacklisted parties regarding the reasons for their inclusion on the blacklist is often very limited.

\subsubsection{The right to an effective legal remedy}

In applying the above-recited considerations, the CFI concluded in the OMPI judgement that even though the Organisation des Modjahedines du people d'Iran ('the Organisation') had learned that it was soon to be included on the disputed list, and despite the fact that it consequently took the initiative to contact the Council in an attempt to prevent the adoption of fund-freezing measures, it had not been apprised of the specific information adduced against it. Consequently, the Organisation had not been in a position to effectively make known its views on the matter. In the absence of any statement setting out the actual and specific grounds justifying the blacklisting decision, the Organisation had not been placed in a position to avail itself of its right to an effective legal remedy.

These considerations demonstrate the links between safeguarding the right to a fair hearing, the right to be informed of the reasons for inclusion on the blacklist, and the right to an effective legal remedy. When the Council does not provide the blacklisted party with a statement of reasons and denies the party the right to a fair hearing, that party's right to an effective legal remedy is consequently infringed. Blacklisted parties are not provided with an effective legal remedy when they are not sufficiently informed of the reasons for their inclusion on the blacklist, and, moreover when they have not been adequately heard. In this respect, the Union Judiciary has repeatedly underlined that the possibility of regularising the total absence of a statement of reasons after an action has been started, would prejudice the right to a fair hearing and the right to an effective legal remedy.

In conclusion, the CFI found, in the OMPI judgement, that the blacklisting decision did not contain a sufficient statement of reasons and was hence adopted in the course of a procedure during which the Organisation's right to a fair hearing and its right to an effective legal remedy were not observed. ${ }^{1707}$

1706 Judgement of the Court of First Instance (Second Chamber) 12 December 2006 in the case of Organisation des Modjahedines du people d'Iran (France) v. the Council of the European Union (Case 228/02), paragraph 151.

1707 Judgement of the Court of First Instance (Second Chamber) 12 December 2006 in the case of Organisation des Modjahedines du people d'Iran (France) v. the Council of the European Union (Case 228/02), paragraphs 160-175. 


\subsubsection{The interdependence of defence rights}

The Union Judiciary considers the three above-discussed defence rights to be closely interrelated and interdependent. Non-compliance with one of the three inevitably affects conformity with the remaining two. This section serves to further demonstrate how far, exactly, this interdependence extends. The practical scope of defence rights for blacklisted parties will also be discussed in more detail.

Case law shows that until the 2009 Sison judgement, the obligation to state reasons was quite easily fulfilled. In the PMOI I judgement, ${ }^{1708}$ for example, the CFI was satisfied when the Council referred to a series of acts, allegedly performed by the Organisation, which it considered to fall within the scope of terrorist act as defined in Article 1 of CP 931. Having stated that the grounds for including the Organisation on the blacklist were still valid, the Council informed the Organisation of its decision to continue to subject it to fund-freezing measures. In addition, the Council sent the Organisation a letter containing a statement explaining the reasons that, in its opinion, justified the Organisation's continued inclusion on the list at issue. That statement contained specific examples of acts of terrorism as referred to in the relevant provisions of CP 931, for which the Organisation was said to be responsible. It also declared that, in light of those acts, a decision had been taken by a competent authority of the United Kingdom (1) to proscribe the Organisation as an organisation concerned in acts of terrorism, (2) that that decision was subject to review under the applicable United Kingdom legislation and (3) that it was still in force. Lastly, the Council communicated to the Organisation a number - not all - of the documents from the file.

The CFI contended that the Council accordingly placed the Organisation in a position to make its case properly regarding the information incriminating it. The Organisation's right to an effective legal remedy was therefore not violated. As set out above, an oral hearing is not, furthermore, an absolute requirement. With respect to the Organisation's allegation that the statement of reasons for the contested decision was exactly the same as the one of the former blacklisting decision, the CFI held that in itself, that only means that the Council maintained its point of view. Such similarity of texts does not, according to the CFI, establish that the Council failed, when assessing the case, to afford proper consideration to the arguments put forward by the blacklisted party in arguing its case.

In sum, the CFI concluded, in the PMOI I judgement, that the Council had sufficiently complied with its obligation to state reasons. ${ }^{1709}$ In light of that

\footnotetext{
1708 Judgement of the Court of First Instance (Seventh Chamber) of 23 October 2008 in the case of People's Mojahedin Organisation of Iran v. the Council of the European Union (Case T-256/07).

1709 Judgement of the Court of First Instance (Seventh Chamber) of 23 October 2008 in the case of People's Mojahedin Organisation of Iran v. the Council of the European Union (Case T-256/07), paragraphs $83-87$.
} 
conclusion, the right to an effective legal remedy had also been complied with. No further reference was made to the factual substance of the information leading the Council to the blacklisting decision. As will be discussed below, such further elaboration and examination of the substance of the information was made for the first time in the 2009 Sison judgement.

Following a subsequent action before the CFI, the Organisation was, however, finally proved right. By that time, the United Kingdom's Proscribed Organisations Appeal Commission ('the POAC') ${ }^{1710}$ decided that the Organisation's inclusion on the terrorism list was no longer justified. The POAC even described as 'perverse', the Home Secretary's decision refusing to lift the Organisation's proscription as a terrorist organisation. Even though the Council was aware of the POAC's decision, the Organisation remained on the blacklist. In addition, the Council and the French authorities refused to communicate, even to the CFI alone, all the information underlying the Organisation's inclusion on the list.

Thereupon, the CFI underlined that 'judicial review of the lawfulness of a decision to freeze funds extends to the assessment of the facts and circumstances relied on as justifying it, and to the information on which that assessment is based.' ${ }^{1711}$ Due to the lack of such information, the CFI deemed itself unable to review the lawfulness of the blacklisting decision. As a result, the CFI, as well as the Organisation, were unable to verify if the contested decision was adopted in compliance with CP 931 and the Regulation. In sum, the CFI concluded that due to the lack of an adequate statement of reasons, the Organisation's right to an effective legal remedy was infringed. ${ }^{1712}$ This implies that the Council is not entitled to base its fund-freezing decisions on information or material in the file communicated by a Member State, if the said Member State is not willing to authorise its communication to the Community judicature 'whose task is to review the lawfulness of that decision.' 1713

1710 This is a specialist body set up by the Parliament of the United Kingdom to hear and determine appeals brought against decisions proscribing, or refusing to lift the proscription of, organisations regarded as terrorist by the Home Secretary.

1711 Judgement of the Court of First Instance (Seventh Chamber) of 4 December 2008 in the case of People's Mojahedin Organisation of Iran v. the Council of the European Union (Case T-284/08), paragraph 74.

1712 Judgement of the Court of First Instance (Seventh Chamber) of 4 December 2008 in the case of People's Mojahedin Organisation of Iran v. the Council of the European Union (Case T-284/08), paragraphs 59-79. France brought an application for appeal before the Court of Justice against the judgement of the Court of First Instance, in which it asked the Court of Justice to set aside the judgement of the Court of First Instance of 4 December 2008 in case T-284/08 People's Mojahedin Organisation of Iran v. The Council of the European Union. See application for appeal brought on 21 January 2009 by the French Republic against the judgement delivered on 4 December 2008 by the Court of First Instance (Seventh Chamber) in case T-284/08 People's Mojahedin Organisation of Iran v. The Council of the European Union (case C-27/09 P).

1713 Judgement of the Court of First Instance (Seventh Chamber) of 4 December 2008 in the case of People's Mojahedin Organisation of Iran v. the Council of the European Union (Case T-284/08), paragraph 73 . 
In the 2008 PKK judgement ${ }^{1714}$ the CFI came to a similar conclusion. The blacklisting decision regarding the PKK did no more than state that it was 'desirable', or that it had been 'decided', to adopt an up-to-date list of the persons, groups and entities to which the Regulation applied. The Union Judiciary regarded such a general and formulaic wording as practically the same as a total failure to state reasons. No reference was made to the question of why the Council considered that a decision satisfying the definition given in Article 1(4) of CP 931 had been taken by a competent authority of a Member State regarding the PKK. Nor did the Council indicate why it took the view - in the exercise of its discretion - that the PKK had to be the subject of fund-freezing measures. ${ }^{1715}$ As mentioned above, there is no possibility to remedy the total absence of a statement of reasons after an action has been brought. That would prejudice respect for defence rights. Moreover, the principle of equality of the parties before the Union judicature would accordingly be adversely affected.

The CFI concluded that, as a result of the absence of any statement of reasons, Ocalan was not placed in a position in which he was able to understand, clearly and unequivocally, the reasoning by which the Council considered that the conditions laid down in CP 931/CFSP and in the Regulation had been satisfied. ${ }^{1716}$

When it comes to subsequent fund-freezing decisions, the Council must, hence, equally indicate the main reasons why - after re-examination - it considers that there are still valid grounds to keep a party's funds frozen. ${ }^{1717}$ In the 2007 Sison judgement, the CFI added that when the Council does not provide the blacklisted party with any statement of reasons, the party concerned is not only unable to make its views known to the Council effectively, but also to make use of its right to an

1714 Judgement of the Court of First Instance of 3 April 2008 in the case of Osman Ocalan on behalf of the Kurdistan Workers' Party (PKK) v. The Council of the European Union (Case T-229/02). This judgement has been brought after referral of the ECJ. See, also,judgement of the Court of First Instance (Second Chamber) of 11 July 2007 in the case of Jose Maria Sison v. the Council of the European Union (Case T-47/03).

1715 Judgement of the Court of First Instance of 3 April 2008 in the case of Osman Ocalan on behalf of the Kurdistan Workers' Party (PKK) v. The Council of the European Union (Case T-229/02), paragraph 65 .

1716 Judgement of the Court of First Instance of 3 April 2008 in the case of Osman Ocalan on behalf of the Kurdistan Workers' Party (PKK) v. The Council of the European Union (Case T-229/02), paragraphs $65-71$.

1717 Judgement of the Court of First Instance (Second Chamber) of 11 July 2007 in the case of Jose Maria Sison v. the Council of the European Union (Case T-47/03), paragraphs 207-218. It is noticeable that the CFI only mentioned blacklisted parties belonging to Category 2, instead of also referring to the UN terrorists who belong to Category 1. In that respect, it is important to note that in the 2006 Kadi judgement (Category 1), the CFI did not consider Kadi's defence rights to be violated whereas in the 2006 OMPI judgement (Category 2) the CFI did find a violation of defence rights. The circumstances of these cases - regarding defence rights - were almost the same, the mere difference was the list on which the respective parties were placed: Kadi on the 1267 blacklist and subsequently on the Union list, and the Organisation only on the Union blacklist. 
effective legal remedy. This conclusion is not surprising, given the links between the guarantees of the rights of the defence, of the obligation to state reasons, and of the right to an effective legal remedy.

In the first $A l$-Aqsa judgement, ${ }^{1718}$ in which the applicant was an entity, the CFI added an important specification to the above-discussed set of rules: when the grounds of a subsequent decision to freeze funds are, in essence, the same as those already relied on when a previous decision was adopted, a mere statement to that effect may suffice, particularly when the person concerned is a group or entity. ${ }^{1719}$ This means that the CFI distinguishes between blacklisted persons on the one hand, and blacklisted entities and groups on the other, when it comes to the right to be informed of the reasons for inclusion on the blacklist.

The CFI formulated this specification even though it eventually decided that the Council did not provide Al-Aqsa with an adequate statement of reasons. That statement merely referred to information that Al-Aqsa had made transfers of funds to organisations supporting terrorism in the Middle East. ${ }^{1720}$ The Council failed to disclose in a clear and unequivocal fashion, the reasoning followed while adopting the fund-freezing measures in such a way as to enable Al-Aqsa to ascertain the reasons for the measures. Consequently, Al-Aqsa had not been put in a position in which it was able to understand, clearly and unequivocally, why it had been included on the blacklist and on the basis of what precise information. ${ }^{1721}$ As a result, the right to an effective legal remedy was violated, and the CFI considered itself, moreover, unable to exercise its power of judicial review. This line of reasoning demonstrates, once again, the close connection between the obligation to state reasons and the right to an effective legal remedy.

However, despite the CFI's judgement, Al-Aqsa remained on the blacklist. The Council informed Al-Aqsa that, in its view, the reasons for including it on the blacklist originally were still valid, and that it therefore intended to continue to include Al-Aqsa on the blacklist. Enclosed with that letter was the Council's

1718 Judgement of the Court of First Instance (Second Chamber) of 11 July 2007 in the case of Stichting Al-Aqsa v. the Council of the European Union (Case T-327/03). Al-Aqsa is a foundation that describes itself as an Islamic social welfare institution. According to its constitution, its objectives include social welfare and improvement of the living conditions of Palestinians living in the Netherlands, and also the provision of assistance to Palestinians living in the territories occupied by Israel.

1719 Judgement of the Court of First Instance (Second Chamber) of 11 July 2007 in the case of Stichting Al-Aqsa v. the Council of the European Union (Case T-327/03), paragraph 54. See, also, judgement of the Court of First Instance (Seventh Chamber) of 23 October 2008 in the case of People's Mojahedin Organisation of Iran v. the Council of the European Union (Case T-256/07), paragraph 82.

1720 The contested decision merely referred to confidential information.

1721 The Hague district court 13 May 2003, LJN: AF8506, KG 03/514 (Al-Aqsa I); the Hague district court 3 June 2003, LJN: AF9389, KG 03/514 (Al Aqsa II). 
statement of reasons which read as follows: 'The [applicant] was constituted in the Netherlands in 1993 as a foundation governed by Netherlands law. It raised funds for certain organisations belonging to the Palestinian movement Hamas, which appears on the list of groups involved in terrorist acts within the meaning of Article 1(2) of Council Common Position 2001/931/CFSP (...) on the application of specific measures to combat terrorism. Some of those organisations make funds available for the commission, or for facilitation in the commission, of terrorist acts. Such acts are those which fall within Article 1(3)(k) of Common Position 2001/931 and are committed with the aims set out in Article 1(3)(i) and (iii) of that Common Position. The [applicant] therefore falls within Article 2(3)(ii) of Regulation... No 2580/2001.'1722

The Council based its decision to continue to include Al-Aqsa on the blacklist on two domestic decisions: (1) on the Dutch Minister for Foreign Affairs and for Finance's decision, by Ministerial Regulation ${ }^{1723}$ (the 'Sanctieregeling Terrorisme') to freeze all assets belonging to Al-Aqsa and (2) the order delivered by the President of the Civil Law Section of the Hague district court hearing the application for interim measures, which stated that Al-Aqsa must be regarded as an organisation supporting Hamas and enabling the latter to commit or facilitate terrorist activities. ${ }^{1724}$

Al-Aqsa lodged an action against its continued inclusion on the blacklist in September 2007.1725 Even though the General Court explicitly considered the information used by the domestic authorities to justify, with regard to content, the above-recited Ministerial Regulation and Order, and deemed that information sufficient for the initial decision to include Al-Aqsa on the blacklist, ${ }^{1726}$ the Council failed to adequately review whether it was appropriate to continue to include Al-Aqsa on the blacklist.

The Sanctieregeling terrorisme was repealed on 3 August 2003, almost immediately after the entry into force, on 28 June 2003, of the initial decision freezing Al-Aqsa's funds, and ceased to have any legal effect as a result of its repeal. The Council claimed the contested decisions were based not on the Sanctieregeling terrorisme itself, but merely on the order of the Hague district court hearing the application for interim measures. However, the General Court considered it impossible in this case to take into consideration the order of the Hague district

\footnotetext{
1722 Judgement of the General Court (Seventh Chamber) of 9 September 2010 in the case of Stichting Al-Aqsa v. the Council of the European Union (Case T-348/07), paragraph 4.

1723 DJZ/BR/219-03 of 3 April 2003. The Sanctieregeling was published in the Staatscourant on 7 April 2003.

1724 The Hague district court 3 June 2003, LJN: AF9389, KG 03/514; the Hague district court 13 May 2003, LJN: AF8506, KG 03/514.

1725 Action brought on 12 September 2007 in the case of Al-Aqsa v. the Council of the European Union (Case T-348/07).

1726 Judgement of the General Court (Seventh Chamber) of 9 September 2010 in the case of Stichting Al-Aqsa v. the Council of the European Union (Case T-348/07), paragraphs 119-133.
} 
court hearing the application for interim measures in isolation, without having regard, at the same time, for the Sanctieregeling terrorisme.

Therefore, since the repeal of the Sanctieregeling terrorisme within the Durch legal order, the order of the Hague district court hearing the application for interim measures, which, hence, formed an inseparable whole with the Sanctieregeling terrorisme, could no longer provide a valid basis for the contested decisions. In sum, the General Court considered that the Council overstepped the bounds of its discretion by continuing to include Al-Aqsa indefinitely on the blacklist, when periodically reviewing the latter's situation, while the Sanctieregeling terrorisme had, in the meantime, been repealed by the body which issued it. ${ }^{1727}$

Lastly, in the 2008/2009 Kadi, Yusuf, Al Barakaat, Hassan and Ayadi judgements on appeal, ${ }^{1728}$ the ECJ concluded that defence rights also hold for blacklisted persons belonging to Category 1. In these cases, the Council had neither communicated to the persons concerned the information used against them to justify the fund-freezing measures, nor afforded them the right to be informed of that information within a reasonable period after those measures were enacted. As a result, those persons had not had the opportunity to make their point of view in that respect known to - among others - the Union Judiciary. ${ }^{1729}$ The ECJ asserted

1727 Judgement of the General Court (Seventh Chamber) of 9 September 2010 in the case of Stichting Al-Aqsa v. the Council of the European Union (Case T-348/07), paragraphs, 159-181.

1728 Conversely, the CFI considered, on this point, that Kadi's (and Yusuf, the Al Barakaat, Hassan and Ayadi) right to be heard was not violated. Since both the substance of the measures in question and the mechanisms for re-examination fell wholly within the purview of the Security Council and its Sanctions Committee, the Union institutions had no power of investigation, no opportunity to check the matters taken to be facts by the Security Council and the Sanctions Committee, no discretion with regard to those matters and no discretion either as to whether it was appropriate to adopt sanctions vis-à-vis Kadi. According to the CFI, the principle of Union law relating to the right to be heard could not apply in such circumstances, where to hear the person concerned could not, in any case, lead the institution to review its position. The CFI further contended that: 'Such a restriction of the right to be heard, directly and in person, by the competent authority is not, however, to be deemed improper in the light of the mandatory prescriptions of the public international order. On the contrary, with regard to the challenge to the validity of decisions ordering the freezing of funds belonging to individuals or entities suspected of contributing to the financing of international terrorism, adopted by the Security Council through its Sanctions Committee under Chapter VII of the Charter of the United Nations on the basis of information communicated by the States and regional organisations, it is normal that the right of the persons involved to be heard should be adapted to an administrative procedure on several levels, in which the national authorities referred to in Annex II of the contested regulation play an indispensable part.' Therefore, the Council was not obliged to hear Kadi on the subject of his inclusion on the blacklist. Non-compliance with the right to be heard is not, hence, regarded as an actual infringement on Kadi's rights. Judgement of the Court of First Instance (Second Chamber, Extended Composition) of 21 September 2005 in the case of Yassin Abdullah Kadi (Saudi Arabia) v. the Council of the European Union and the Commission of the European Communities (T - 315/01), paragraph 190.

1729 As mentioned above, all these judgements concerned applicants that had been included on the Union blacklist following UNSC Resolution 1267. This means that the Council has simply 
therefore that 'given the failure to inform Kadi, Yusuf and the Al Barakaat of the evidence adduced against them, and having regard to the inter-dependence of the defence rights, they were unable to defend their rights with regard to that evidence in satisfactory conditions before the Union Judiciary.'

Non-compliance with the obligation to state reasons and with the right to a fair hearing also led the ECJ to conclude that consequently the right to an effective legal remedy was infringed. Furthermore, the ECJ underlined that the Council had not remedied these infringements in the course of the actions. In addition, the Council had provided the Union Judiciary with no evidence of any kind regarding the blacklisted parties' alleged involvement in terrorist acts. For that reason, the ECJ considered itself unable to review the lawfulness of the blacklisting and the imposition of the fund-freezing measures. In sum, the ECJ found violations of the right to be heard, the right to be provided with a statement of reasons, and the right to an effective legal remedy. ${ }^{1730}$

\subsection{Effective judicial review and essential procedural requirements}

As we have seen, effective judicial review ${ }^{1731}$ forms part of the notion of defence rights to a certain extent, but it should, nevertheless, also be considered and discussed as a separate category, together with other essential procedural requirements. The Union Judiciary deals with the question of whether: (1) it was able to exert effective judicial review, and (2) of whether essential procedural requirements were complied with after having examined claims regarding compliance with defence rights. In this section, the question of how 'effective'

'copied' the UN list without itself conducting any further investigation. Therefore, the applicants had not been provided with an adequate statement of reasons, nor were they heard by the Council. However, with reference to the Union's obligation to implement UNSC Resolutions, the CFI did not judge this working method to be in violation of the applicants' defence rights. Judgement of the Court of First Instance (Second Chamber, Extended Composition) of 21 September 2005 in the case of Yassin Abdullah Kadi (Saudi Arabia) v. the Council of the European Union and the Commission of the European Communities (T - 315/01), paragraphs 153, 181-212.

1730 Judgement of the Court (Grand Chamber) of 3 September 2008 (Appeals) in the cases of Yassin Abdullah Kadi and Al Barakaat International Foundation v. The Council of the European Union (Joint Cases C-402/05 P and C-415/05 P), paragraph 348-354. See, for further important considerations, judgement of the Court (Grand Chamber) of 3 September 2008 (Appeals) in the cases of Yassin Abdullah Kadi and Al Barakaat International Foundation v. The Council of the European Union (Joint Cases C-402/05 P and C-415/05 P), paragraph 348; judgement of the Court of Justice (Second Chamber) of 3 December 2009 in the cases of Faraj Hassan and Chafiq Ayadi v. The Council of the European Union and the European Commission (Joint Cases C-399/06 P and C-403/06 P), paragraph 83 and 84.

1731 See, also, Article 47 of the Charter of Fundamental Rights of the European Union (2000/c 364/01). 
judicial review by the Union Judiciary is when it comes to claims of blacklisted parties, will be discussed.

The safeguarding of essential procedural requirements determines the potential effectiveness of review proceedings, and will, from that perspective, also be elaborated on. ${ }^{1732}$ It goes without saying that these questions are closely related to the question of whether defence rights are sufficiently guaranteed, both prior to lodging an action to be delisted, as well as during the delisting proceedings. If a blacklisted party is not provided with a statement of reasons and/or is not heard to make known its views, it will be unable to effectively challenge the Council's order and the Union Judiciary will consequently be incapable of performing an effective judicial review. ${ }^{1733}$ In sum, effective judicial review will be lacking when defence rights and essential procedural requirements are not complied with. Due to this close connection between safeguarding defence rights, on the one hand, and guaranteeing effective judicial review on the other, some overlap between this section and the previous one is inevitable.

\subsubsection{The scope of judicial review}

In theory, judicial review of the lawfulness of a blacklisting decision extends to the assessment of all the facts and circumstances relied on as justifying such a decision, as well as to all the information on which that assessment was based. ${ }^{1734}$ This means that, in theory, the Union Judiciary has to examine both compliance with procedural, as well as with substantive, prerequisites. Such an all-encompassing review is all the more imperative because it constitutes the only procedural safeguard capable of examining if a fair balance is struck between the need to effectively prevent and combat terrorism on the one hand, and the protection of fundamental rights of blacklisted parties, on the other.

The above-discussed restrictions on defence rights should be counterbalanced by a full and effective judicial review. Ideally, the Union Judiciary ought to carry out a judicial review without it being possible for the Council or a Member State to

1732 The CFI considers defence rights (a statement of reasons, a fair hearing and access to an effective legal remedy) and the right to an effective judicial review as two separate aspects. Judgement of the Court of First Instance (Second Chamber) of 11 July 2007 in the case of Jose Maria Sison v. the Council of the European Union (Case T-47/03), paragraph 142. The CFI reasoned, in this case, that 'the safeguarding of the rights of the defence in the context of the administrative procedure itself is to be distinguished from the safeguarding of the right to an effective judicial remedy against the act having adverse effects which may be adopted at the end of that procedure.'

1733 Judgement of the Court of First Instance (Second Chamber) of 11 July 2007 in the case of Stichting Al-Aqsa v. the Council of the European Union (Case T-327/03), paragraph 64.

1734 Judgement of the Court of First Instance (Second Chamber) of 11 July 2007 in the case of Jose Maria Sison v. the Council of the European Union (Case T-47/03), paragraph 199. 
raise objections that the information underlying a blacklisting decision is secret or confidential. ${ }^{1735}$

In case law, the CFI has underlined, time and again, that the Council enjoys a broad discretion in its assessment of the matters to be taken into consideration for the purpose of adopting fund-freezing measures - quite consistent with a common position adopted on the basis of the CFSP. Furthermore, the Union Judiciary may not substitute its assessment of the information, facts and circumstances justifying the adoption of such measures for that of the Council. Basically, judicial review carried out by the CFI of the lawfulness of blacklisting decisions must be restricted to: (1) checking that the rules governing procedure and the statement of reasons have been complied with, (2) that the facts are materially accurate, and (3) that there has been no manifest error of assessment of the facts or misuse of power. Limited review applies, especially, to the assessment of the considerations of appropriateness on which a blacklisting decision is based. ${ }^{1736}$

Both the Member States vis-à-vis the Council, and the Council vis-à-vis the Union Judiciary, enjoy a broad discretion in deciding on these matters that, hence, limits the effectiveness of the judicial review of the Union Judiciary. That does though not mean that the Union Judiciary is not to review the interpretation made by the Council of the relevant facts. Theoretically, it must not only establish whether the 'evidence' relied on is factually accurate, reliable and consistent, but it must also ascertain whether that 'evidence' contains all the relevant information to be taken into account in order to assess the situation and whether it is capable of substantiating the conclusions drawn from it. In practice however, as will appear henceforth, 'evidence' as referred to above, primarily concerns the question of whether the Council based its blacklisting decision on "precise information or material indicating that a decision has been taken by a competent authority in respect of the persons, groups and entities concerned.'1737 The notion of 'evidence' does not, hence, concern incriminating evidence used to sustain the alleged involvement of the person/group/entity in terrorist activities, in the common sense of the word.

1735 Judgement of the Court of First Instance (Second Chamber) of 11 July 2007 in the case of Jose Maria Sison v. the Council of the European Union (Case T-47/03), paragraph 202.

1736 See Judgement of the Court of First Instance (Second Chamber) of 11 July 2007 in the case of Jose Maria Sison v. the Council of the European Union (Case T-47/03), paragraph 206; judgement of the General Court (Seventh Chamber) of 9 September 2010 in the case of Stichting Al-Aqsa v. the Council of the European Union (Case T-348/07), paragraphs 82-83.

1737 Judgement of the General Court (Seventh Chamber) of 9 September 2010 in the case of Stichting Al-Aqsa v. the Council of the European Union (Case T-348/07), paragraphs 76-107. The considerations of the General Court in this judgement clearly demonstrate the General Court's broad interpretation of Article 1, section 4 of CP 931, which extends the discretion of the Council and Members States in respect of the blacklisting and the imposition of fund-freezing measures. 
In sum, one may conclude that at first sight it seems as if judicial review regarding claims of listed persons/entities is quite all-encompassing, but that broad review is considerably limited by the large margin of appreciation/discretion that is granted to the Council and to the Member States.

\subsubsection{Judicial review for Category 1 terrorists}

Parties blacklisted following UNSC Resolution 1267 had, prior to the ECJ 2008 Kadi judgement, factually no effective legal remedy at their disposal, and effective judicial review consequently also was lacking. The CFI, in the 2006 Kadi judgement, did not consider itself authorised to verify whether there had been an error of assessment of the facts and evidence relied on by the Security Council in support of the fund-freezing measures, or to check indirectly (ius cogens), the appropriateness and proportionality of those measures. In the CFI's view, it was impossible to carry out such a check without trespassing on the Security Council's prerogatives under Chapter VII of the Charter of the United Nations in relation to determining, first, whether there existed a threat to international peace and security, and, second, the appropriate measures for confronting or settling such a threat. ${ }^{1738}$

In addition, the CFI underlined that the Security Council had not established an independent international court responsible for ruling, in law and on the facts, in actions brought against individual decisions taken by the Sanctions Committee. In light of these considerations, the CFI concluded that there was no judicial remedy available to Kadi. Such lacuna in the judicial protection available to Kadi was not, however, considered to be, in itself, contrary to jus cogens. Here the CFI referred to the fact that the right of access to the courts - a principle recognised by both Article 8 of the Universal Declaration of Human Rights and article 14 of the International Covenant on Civil and Political Rights - is not absolute. ${ }^{1739}$ Concluding, the CFI accordingly held that in the circumstances of Kadi's case, Kadi's interest in having a court hear his case on its merits was not enough to outweigh the essential public interest in the maintenance of international peace and

1738 Judgement of the Court of First Instance (Second Chamber, Extended Composition) of 21 September 2005 in the case of Yassin Abdullah Kadi (Saudi Arabia) v. the Council of the European Union and the Commission of the European Communities ( $\mathrm{T}$ - 315/01), paragraphs 209-234 and 277-292.

1739 At a time of public emergency which threatens the life of the nation, measures may be taken derogating from that right, as provided for under certain conditions by Article 4, section 1 of th ICCPR. With respect to Kadi, the CFI considered that the limitation of his right of access to a court - as a result of the immunity from jurisdiction enjoyed, as a rule, in the domestic legal order of the Member States of the United Nations, by resolutions of the Security Council adopted under Chapter VII of the Charter of the United Nations - to be in accordance with the relevant principles of international law and inherent in that right as guaranteed by ius cogens. 


\section{Blacklisted as Terrorist}

security in the face of a threat clearly identified by the Security Council in accordance with the Charter of the United Nations. ${ }^{1740}$

Quite contrary to the CFI, the ECJ has opined that an international agreement (in this case UNSC Resolution 1267) cannot affect the autonomy of the Union legal system. ${ }^{1741}$ Fundamental rights form an integral part of the general principles of law, whose observance the ECJ ensures. For that purpose, the ECJ draws inspiration from the constitutional traditions common to the Member States and from international instruments for the protection of human rights. In that regard, the ECHR obviously, has special significance. Obligations imposed by an international agreement, such as UNSC Resolution 1267, cannot moreover, have the effect of prejudicing the constitutional principles of the TFEU, which include the principle that all Union acts must respect fundamental rights. Respect for those principles constitutes a condition for the lawfulness of Union acts.

Consequently, the question of the scope of judicial review with regard to Category 1 terrorists arises in the context of the internal and autonomous legal order of the Union. Therefore, as the ECJ has reasoned, it falls within the ECJ's ambit to review the validity of all Union acts on compliance with fundamental rights that form an integral part of the general principles of Union law. As a result, judicial review of fund-freezing measures must be ensured, even if the imposition of such measures is based on UNSC Resolutions under Chapter VII of the Charter of the United Nations. ${ }^{1742}$

Thus, the factual scope of judicial review for Category 1 terrorists is currently the same as for the above discussed Category 2 terrorists. In light of this conclusion, it is hardly surprising that the ECJ considered that no effective judicial review could be performed regarding the blacklisting of Kadi, Yusuf and the Al Barakaat, for the Council did not provide them - or the ECJ - with the information used against them

1740 Judgement of the Court of First Instance (Second Chamber, Extended Composition) of 21 September 2005 in the case of Yassin Abdullah Kadi (Saudi Arabia) v. the Council of the European Union and the Commission of the European Communities (T - 315/01), paragraph 190; judgement of the Court of First Instance (Second Chamber, Extended Composition) of 21 September 2005 in the case of Ahmed Ali Yusuf and the Al Barakaat International Foundation v. The Council of the European Union and the Commission of the European Communities (Case $\mathrm{T}-306 / 01$ ); judgement of the Court of First Instance (Second Chamber) of 12 July 2006 in the case of Faraj Hassan v. The Council of the European Union and the Commission of the European Communities (Case T-49/04); judgement of the Court of First Instance (Second Chamber) of 12 July 2006 in the case of Chafiq Ayadiv. The Council of the European Union (Case T-253/02).

1741 Judgement of the Court (Grand Chamber) of 3 September 2008 (Appeals) in the cases of Yassin Abdullah Kadi and Al Barakaat International Foundation v. The Council of the European Union (Joint Cases C-402/05 P and C-415/05 P), paragraph 282.

1742 Judgement of the Court (Grand Chamber) of 3 September 2008 (Appeals) in the cases of Yassin Abdullah Kadi and Al Barakaat International Foundation v. The Council of the European Union (Joint Cases C-402/05 P and C-415/05 P), paragraph 283. 
to justify the fund-freezing measures, nor afforded them the right to be informed of that information within a reasonable period after those measures were enacted. ${ }^{1743}$

After the 2008 judgements of the ECJ in Kadi, Yusuf and Al Barakaat, the CFI pursued the same line of reasoning and came to a similar decision in the Othman judgement. ${ }^{1744}$ The circumstances in the Othman case were comparable to those in the above-mentioned judgements. This brought the CFI to the conclusion that fundfreezing measures were imposed on Othman without him having been provided with the inculpatory information and without a proper hearing. In light of these procedural deficiencies and the clear disregard for his defence rights, his right to effective judicial protection had been infringed. ${ }^{1745}$

\subsubsection{Judicial review for Category 3 terrorists}

For internal terrorists, such as Segi and Gestoras Pro Amnistía, effective judicial review is lacking. As internal terrorists are exclusively blacklisted and merely subjected to Article 4 of CP 931, the CFI and the ECJ have considered the former Article 34 EU [repealed by the TFEU] as the only relevant legal basis of the measures from which the alleged damage may arise. It follows from Article 52 of the TFEU, that, in the context of Title VI of the former EU Treaty (police and judicial cooperation in criminal matters), the only judicial remedies envisaged are the reference for a preliminary ruling, the action for annulment and the procedure for settling disputes between Member States. ${ }^{1746}$ This implies that no judicial remedy for compensation is available for internal terrorists. Therefore, the Union Judiciary does not consider itself authorised to judge over actions for damages in so

1743 Judgement of the Court (Grand Chamber) of 3 September 2008 (Appeals) in the cases of Yassin Abdullah Kadi and Al Barakaat International Foundation v. The Council of the European Union (Joint Cases C-402/05 P and C-415/05 P), paragraph 338-344 and 348-354; judgement of the Court of First Instance (Seventh Chamber) of 11 June 2009 in the case of Omar Mohammed Othman v. The Council of the European Union and the Commission of the European Communities (Case T-318/01); judgement of the Court of Justice (Second Chamber) of 3 December 2009 in the cases of Faraj Hassan and Chafiq Ayadi v. The Council of the European Union and the European Commission (Joint Cases C-399/06 P and C-403/06 P), paragraph 89.

1744 Judgement of the Court of First Instance (Seventh Chamber) of 11 June 2009 in the case of Omar Mohammed Othman v. The Council of the European Union and the Commission of the European Communities (Case T-318/01).

1745 Judgement of the Court of First Instance (Seventh Chamber) of 11 June 2009 in the case of Omar Mohammed Othman v. The Council of the European Union and the Commission of the European Communities (Case T-318/01), paragraph 82-99.

1746 Order of the Court of First Instance (Second Chamber) on 7 June 2004 in case of Segi Araitz Zubimendi Izaga and Aritza Galarraga v. Council of the European Union (Case T - 338/02), paragraphs 33-37; order delivered on 7 June 2004 by the Second Chamber of the Court of First Instance of the European Communities in Case T-333/02 between Gestoras Pro Amnistía, J.M. Olano Olano, J. Zelarain Errasti and the Council of the European Union (Case C-354/04 P). 
far as they seek compensation for any damage which may have been caused by the inclusion of Segi and Gerstoras Pro Amnistía on the blacklist. ${ }^{1747}$

\subsubsection{The burden of proof in (de)-listing procedures}

After having examined the scope of judicial review, it is now important to shortly discuss the burden of proof, as divided between the parties involved in (de)-listing proceedings. In the $O M P I$ and the $P M O I$ judgements, the CFI elaborated extensively on the question of who is to carry what part of the burden of proof.

First, it is important to note that the blacklisting procedure takes place at two levels, at a national level and a Union level, and consists of two phases. In the first phase, a competent national authority - in principle, judicial - must take a decision meeting the requirements as comprised in CP 931. Verifying that there is indeed such a decision is an essential precondition for the adoption, by the Council, of an initial decision to freeze funds, whereas verification of the consequences of that decision at the national level is imperative in the context of the adoption of a subsequent decision to freeze funds. ${ }^{1748}$ In the second phase, the Council - acting by unanimity - decides to include the person/group/entity concerned on the blacklist, on the basis of precise information or material in the relevant file that indicates that a judicial decision at domestic level has been taken. After the initial blacklisting decision, the Council must, at regular intervals, and at least once every

1747 Segi and Gestoras Pro Amnistía exclusively claimed damages in respect of the loss caused by the inclusion of their association on the list of persons, groups or entities drawn up under the legislation on the fight against terrorism. With regard to the existence of "a loss", Gestoras Pro Amnistía's representatives hold that the inclusion of their association in the disputed list causes particularly serious harm to its reputation and to its freedom of expression in that it implies that the association is accused of being a terrorist organisation. In the same way, its inclusion on the list harms the reputation, the freedom of expression, the freedom of association and the private lives of the representatives themselves, who are spokesmen for the association. With regard to the required causal link between the Council's behaviour and the loss suffered, the representatives hold that the repercussions on their reputation are an inescapable and immediate consequence of the inclusion in the list. Judgement of the Court of Justice (Grand Chamber) of 27 February 2007 (Appeal) in the case of Gestoras Pro Amnistia, Juan Mari Olano Olano and Julen Zelarain Errasti v. the Council of the European Union (Case C-354/04 P), paragraphs 48-58; judgement of the Court of Justice (Grand Chamber) of 27 February 2007 (Appeal) in the case of Segi, Araitz Zubimendi Izaga and Aritza Galarraga v. The Council of the European Union (Case C-355/04 P), paragraphs 48-57. See, also, Segi's application before the ECtHR: By decision of 23 May 2002, the ECtHR dismissed as inadmissible the action brought by the applicants against the 15 Member States, concerning CP 931, on the ground that the situation complained of did not entitle them to be regarded as victims of an infringement of the ECHR pursuant to Article 34 of the ECHR.

1748 Judgement of the General Court (Seventh Chamber) of 9 September 2010 in the case of Stichting Al-Aqsa v. the Council of the European Union (Case T-348/07), paragraph 78. 
six months, be satisfied that there are still valid grounds to keep the person/group/ entity on the blacklist. ${ }^{1749}$

Although theoretically it is indeed for the Council to prove that the imposition of fund-freezing measures is legally justified, the burden of proof for the Council to include someone on the blacklist has, factually, a relatively limited scope, as was explicitly acknowledged in the 2010 Al-Aqsa judgement. ${ }^{1750}$ Generally, according to the CFI, the Council should defer, as far as possible, to the assessment conducted by the competent national authority. Second, the Union Judiciary has underlined the fact that Member States and the Union institutions cooperate in good faith, an assumption that also applies in the case of blacklisting proceedings in general. In the case of an initial decision to freeze funds, the burden of proof essentially relates to the existence of precise information or material in the relevant file that indicates that the aforementioned national decision has been taken with regard to the person concerned. Furthermore, in the case of a subsequent decision to freeze funds, after review, the burden of proof essentially relates to the question of whether the freezing of funds is still justified, having regard to all the relevant circumstances of the case and, most particularly, to the action taken upon the decision of the competent national authority. The prime consideration for the Council, in this respect, must be its perception or evaluation of the danger that funds might be used to fund or prepare acts of terrorism. Assessment of the considerations of appropriateness, on which fund-freezing decisions are based, is left to the discretion of the Council. ${ }^{1751}$ The factual gathering of information and the important question of whether indeed a person ought to be blacklisted to begin with, is completely left to the discretion of Member States.

With the 2009 Sison judgement, the CFI however took the first step in attributing more responsibility to the Council in proving the lawfulness of blacklisting and the consequent imposition of fund-freezing measures. I will further elaborate on this issue in Section 6.

\footnotetext{
1749 Judgement of the General Court (Seventh Chamber) of 9 September 2010 in the case of Stichting Al-Aqsa v. the Council of the European Union (Case T-348/07), paragraphs 76-78; judgement of the Court of First Instance (Seventh Chamber) of 23 October 2008 in the case of People's Mojahedin Organisation of Iran v. the Council of the European Union (Case T-256/07), paragraphs 129-150.

1750 Judgement of the General Court (Seventh Chamber) of 9 September 2010 in the case of Stichting Al-Aqsa v. the Council of the European Union (Case T-348/07), paragraph 81.

1751 Judgement of the Court of First Instance (Seventh Chamber) of 23 October 2008 in the case of People's Mojahedin Organisation of Iran v. the Council of the European Union (Case T-256/07), paragraph 134.
} 


\subsubsection{Safeguarding essential procedural requirements and the nature of fund- freezing measures}

Important in the discussion regarding the safeguarding of procedural requirements in (de)-listing proceedings is the question of whether fund-freezing measures are administrative or criminal in nature. If blacklisting and the imposition of fundfreezing measures are considered as having a criminal law character, all fair trial principles and procedural requirements enclosed in Articles 47 and 48, section 2 of the Charter, and Article 6 of the ECHR, should be complied with throughout (de)listing procedures. Conversely, when they are considered administrative in nature, these principles do not, automatically, at least, apply - aside from the civil rights and obligations.

The ECJ and the CFI both consider the blacklisting procedures and the imposition of fund-freezing measures as administrative in nature. In the 2007 Sison judgement, ${ }^{1752}$ the CFI repeatedly referred to 'administrative proceedings' rather than criminal proceedings, even though it cited the imposed measures as 'penalty' and as 'a measure adversely affecting Sison.' ${ }^{1753}$ Furthermore, the CFI justified restrictions on defence rights throughout blacklisting procedures, with reference to justified interferences with fair trial principles in the context of criminal proceedings concerning terrorism under the ECtHR's case law. ${ }^{1754}$ Despite these references to, and comparisons with, upholding human rights throughout criminal law proceedings, the CFI concluded that fund-freezing measures are of a mere administrative nature, because the assets of the persons concerned are not confiscated as the proceeds of crime, but rather frozen as a precautionary measure. Therefore, those measures do not constitute criminal sanctions, and do not, moreover, imply any accusation of a criminal nature.

So, inclusion on the Union blacklist and the consequent imposition of fund-freezing measures are not to be considered as a criminal charge and a criminal sanction, respectively, which means that Articles 47 and 48, section 2 of the Charter and Article 6 of the ECHR, do not automatically fully apply throughout (de)-listing proceedings. ${ }^{1755}$ However, the CFI has argued at the same time, that observance of defence rights is - as in all proceedings initiated against a person that is liable to

1752 Judgement of the Court of First Instance (Second Chamber) of 11 July 2007 in the case of Jose Maria Sison v. the Council of the European Union (Case T-47/03). In various other judgements, the Union Judiciary referred to fund-freezing measures as administrative precautionary measures instead of to penal law measures/sanctions.

1753 Judgement of the Court of First Instance (Second Chamber) of 11 July 2007 in the case of Jose Maria Sison v. the Council of the European Union (Case T-47/03), paragraph 139.

1754 Judgement of the Court of First Instance (Second Chamber) of 11 July 2007 in the case of Jose Maria Sison v. the Council of the European Union (Case T-47/03), paragraph 182.

1755 Judgement of the Court of First Instance (Second Chamber) of 11 July 2007 in the case of Jose Maria Sison v. the Council of the European Union (Case T-47/03), paragraph 101. 
culminate in a measure adversely affecting that person - a fundamental principle of Union law which must be guaranteed, even in the absence of any rules governing the procedure in question.

In the Morabit judgement, ${ }^{1756}$ the CFI reiterated that blacklisting and the imposition of fund-freezing measures have an administrative character. Additionally, the CFI formulated three criteria to assess whether administrative fund-freezing measures have been imposed lawfully. ${ }^{1757}$

First, the material measure should be provided for by law. In the case of Morabit, the fund-freezing measures were based on Article 1, section 4 in conjunction with Article 2 of CP 931, and hence, sufficiently provided for by law. Second, the measure has to be imposed by the competent authority. The Council imposed the measures, as prescribed by Article 1, section 6 of CP 931. Third, the material measure must be of a temporary nature. ${ }^{1758}$ In this respect, the CFI underlined that the blacklists are reviewed every six months to ascertain whether the measures are still justified. Lastly, the CFI held that imposing fund-freezing measures is permitted as long as these measures do not anticipate of the (judicial) decision regarding a person's guilt/ innocence. This latter issue mainly concerns the scope of the presumption of innocence throughout fund-freezing proceedings. I will elaborate further on the presumption of innocence below.

In sum, the CFI concluded that the Council's decision to include Morabit on the terrorism list was a 'confiscation measure' ${ }^{1759}$ imposed throughout an administrative

1756 Judgement of the Court of First Instance (Second Chamber) of 2 September 2009 in the case of Mohammed El Morabit v. The Council of the European Union (Joined Cases T-37/07 and T-323/07). See in this respect also Action brought on 12 March 2007 by Ahmed Hamdi v. the Council of the European Union (Case T-75/07); action brought on 14 September 2007 by Hamdi $v$ the Council (Case T-363/07); action brought on 14 September 2007 by El Fatmi v. The Council (Case T-362/07); action brought on 12 March 2007 in the case of El Fatmi v. The Council of the European Union (Case T-76/07); action brought on 24 September 2008 in the case of El Fatmi v. The Council of the European Union (Case T-409/08).

In the Netherlands, the Rotterdam district court found Mohamed El M. guilty of membership of a terrorist organisation, and sentenced him to two years imprisonment (10 March 2006). On 21 December 2006, the Council included him on the Union blacklist. Subsequently, Mohamed El M. lodged an action for the annulment of the Council decision. He submitted that although he had been found guilty by a court of participating in a criminal organisation with a terrorist aim, he had appealed against the judgement. In his opinion, there was a real chance that he would be acquitted on appeal. The Council's decision was therefore premature, in Mohamed El. M.'s opinion. After Mohamed's inclusion on the blacklist, the Hague court of appeal indeed acquitted him of all charges on 23 January 2008. The Council thereupon delisted Mohamed. See Rotterdam district court 10 March 2006, LJN: AV 5180, 10/000322-04; 10/000328-04; $10 / 000396-04 ; 10 / 000393-04 ; 10 / 000325-04 ; 10 / 000323-04 ; 10 / 000395-04$ and the Hague Court of Appeal 23 January 2008, LJN: BC 4177, 2200186406.

Judgement of the Court of First Instance (Second Chamber) of 2 September 2009 in the case of Mohammed El Morabit v. The Council of the European Union (Joined Cases T-37/07 and T-323/07), paragraph 40.

1759 The applicant's assets are seized, and not the proceeds of criminal/terrorist acts. 
procedure, with the sole goal of the effective prevention of the financing of terrorism. Such measures are, in the CFI's opinion, not criminal sanctions, and do not imply a criminal charge, which implies that fair trial principles and procedural requirements, as included in Article 6 of the ECHR, do not apply. ${ }^{1760}$

At this point I will not elaborate further on this issue, but some remarks should, however, be made. First of all, it is noticeable that CP 931 uses exactly the same definition of 'terrorist act' as the Framework Decision on Combating Terrorism, while the first instrument uses merely administrative measures, and the second, criminal law measures of the most severe nature. ${ }^{1761}$

Second, even though the Union Judiciary deems blacklisting and the imposition of fund-freezing measures formally as administrative in nature, the language used - 'sanctions', 'severe crime' and 'penalties' - is, at the very least, confusing, and leaves ample room for debate on this point. Third, one of the criteria for the lawful imposition of fund-freezing measures included in the Morabit judgement is that these measures must be limited in time. Even though, in theory, the blacklists are reviewed every six months, practice shows that persons can easily remain on the blacklist for 8 years without a proper basis. Blacklisted persons have even be known to remain on the blacklist, when at national level, they have already been delisted.

Fourth, the third criterion included in the Morabit judgement prescribes that fund-freezing measures must not anticipate the (judicial) decision regarding a person's guilt/innocence. Taking into account the criterion comprised in CP 931 (involvement in terrorist acts) for the required national decision, one may wonder how the fulfilment of such a standard - resulting in the total freezing of all of a person's assets for lengthy periods - does not amount to an anticipation of the decision of whether someone is guilty or not.

Lastly, it remains to be seen how the severity, the all-encompassing nature, and the length of fund-freezing measures influences the character of these measures. It is to this issue that we will now turn.

\subsection{Infringement on the right to be presumed innocent}

Several blacklisted persons have alleged a violation of their right to be presumed innocent. ${ }^{1762}$ Article 48, section 1 of the Charter ensures that anyone who has been

1760 See, also, judgement of the Court of First Instance of 11 July 2007 in the case of Sison v. The Council of the European Union (Case T-47/03). paragraph 101.

1761 See, for further remarks on this issue, the next section.

1762 See judgement of the Court of First Instance (Second Chamber) of 2 September 2009 in the case of Mohammed El Morabit v. The Council of the European Union (Joined Cases T-37/07 and T-323/07); judgement of the Court of First Instance (Second Chamber) of 11 July 2007 in the case of Jose Maria Sison v. the Council of the European Union (Case T-47/03); judgement of the Court of First Instance (Second Chamber) 12 December 2006 in the case of Organisation des Modjahedines du people d'Iran (France) v. the Council of the European Union (Case 228/02); 
charged is to be presumed innocent until proven guilty according to law. ${ }^{1763}$ This means that in such a case, no measure may be taken, and no restriction may be imposed, which could imply the guilt of the person concerned. Further, declarations that a charged person is guilty of an offence are forbidden. However, as discussed above, being charged is no prerequisite for the lawful imposition of fund-freezing measures in accordance with CP 931. Article 1, section 4 of CP 931 prescribes, as the sole requirement in that respect, 'a decision taken by a competent authority in respect of the persons, groups and entities concerned, irrespective of whether it concerns the instigation of investigations or prosecution for a terrorist act, an attempt to perpetrate, participate in or facilitate such an act based on serious and credible evidence or clues, or condemnation for such deeds.'

Case law shows that substantive requirements for fulfilling this criterion are not as demanding as the literal wording suggests. For example, mere past alleged involvement in terrorist acts - without that being lawfully proven in (a criminal) court - may very well contribute to the blacklisting decision. Also, the Union Judiciary has tolerated alleged involvement in criminal, not terrorist, offences as an adequate substantive basis for eight years of fund-freezing measures. The substantive scope of Article 1, section 4 of CP 931 will further be elaborated on in the following section (6). At this point, it is, however, essential to realise that in order to be blacklisted and subjected to fund-freezing measures, a criminal charge, pursuant to Article 48, section 2 of the Charter and Article 6 of the ECHR, is not required.

In the Morabit judgement, Mohamed El M. maintained that his right to be presumed innocent was violated due to his being subjected to fund-freezing measures prior to the Hague Court of Appeal judging on his appeal. ${ }^{1764}$ In his opinion, the notion of 'conviction' in Article 1, section 4 of CP 931 should be interpreted as 'irrevocable judgement' in the sense that no legal remedy is no longer available. ${ }^{1765}$ To interpret the notion otherwise, would erode the presumption of innocence.

The CFI argued first that respect for the presumption of innocence presupposes that anyone subjected to a criminal investigation/proceedings should be considered

judgement of the Court of First Instance (Seventh Chamber) of 23 October 2008 in the case of People's Mojahedin Organisation of Iran v. the Council of the European Union (Case T-256/07).

See, also, Article 6, section 2 of the ECHR. See for an elaborate discussion on the presumption of innocence in light of the ECHR: S. Trechsel, Human Rights in Criminal Proceedings, Oxford University Press 2005, pp. 153-192; E. Van Sliedregt, Ten to one. A contemporary reflection on the presumption of innocence, Boom Juridische Uitgevers 2009, Inaugural Lecture.

1764 Judgement of the Court of First Instance (Second Chamber) of 2 September 2009 in the case of Mohammed El Morabit v. The Council of the European Union (Joined Cases T-37/07 and T-323/07) (only French and Dutch available). See further notes on the circumstances of the case above under the heading 'Procedural safeguards and the nature of fund-freezing measures'.

1765 Judgement of the Court of First Instance (Second Chamber) of 2 September 2009 in the case of Mohammed El Morabit v. The Council of the European Union (Joined Cases T-37/07 and T-323/07), paragraph 28. 
innocent until proven guilty. This principle does not, however, prevent the competent (inter)national authorities from seizing goods/assets as an administrative measure, instead of as a criminal sanction. Not surprisingly, the CFI decided, therefore, that the presumption of innocence was not interfered with, simply because it does not apply with respect to fund-freezing measures.

In addition, the CFI argued that the Council was not obliged to await the Hague Court of Appeal's judgement prior to subjecting the applicant to the restrictive measures, in light of the presumption of innocence. Such a working method would hinder the effective prevention of (the financing of) terrorism. ${ }^{1766}$ In that respect, the CFI referred to the fact that the Council immediately delisted Mohamed El M. once the Hague Court of Appeal acquitted him of participation in a terrorist organisation.

The Morabit judgement, is the only judgement in which the Union Judiciary unequivocally dealt (in substance) with a complaint regarding an alleged violation of the right to be presumed innocent. With respect to earlier complaints, the Union Judiciary either judged the presumption not to be applicable due to the administrative nature of fund-freezing measures or exclusively dealt with procedural law issues. ${ }^{1767}$ Even though the Union considers blacklisting and the imposition of fund-freezing measures as administrative in nature, and consequently deems these measures not to infringe upon the presumption of innocence, some objections may be raised regarding the rationale behind the Union's line of reasoning.

First and foremost, it is striking that suspected involvement in terrorist act - a serious criminal offence - is merely reacted to by means of administrative measures, rather than with criminal law based sanctions. Terrorist offences constitute, according to the Union, 'a real challenge to the world and to Europe' and the fight against terrorism is considered as 'a top priority within the Union.' ${ }^{1768}$ In 2009, the Council stressed again that the threat from terrorists remains significant, and is

1766 Judgement of the Court of First Instance (Second Chamber) of 2 September 2009 in the case of Mohammed El Morabit v. The Council of the European Union (Joined Cases T-37/07 and T-323/07), paragraphs 51-57.

1767 Also, the ECtHR has refrained, sometimes, from dealing with complaints regarding alleged violations of the presumption of innocence. When applicants claim a violation both of their right to a fair trial and of their right to be presumed innocent, the ECtHR will often begin by determining whether there has been a violation of Article 6, section 1 of the ECHR. If the ECtHR finds a violation of Article 6, section 1 of the ECHR, it will generally not consider the complaint under Article 6, section 2 of the ECHR. The ECtHR then argues that the latter claim is absorbed by the earlier findings under Article 6, section 1 of the ECHR. See Deweer $v$. Belgium, 27 February 1980, appl. no. 6903/75, §56; Bönisch v. Austria, 6 May 1985, appl. no. 8658/79, §37; Delta v. France, 19 December 1990, appl. no. 11444/85, §37.

1768 These statements were issued after the 9/11 attacks. Nevertheless, the Union's attitude towards countering terrorism has not considerably changed since. See for example Council of the European Union, The Stockholm Programme - An open and secure Europe serving and protecting the citizens of 2 December 2009, 16484/1/09 REV 1 JAI 866 + ADD 1. 
constantly evolving in response to both the international community's attempts to combat it, and to new opportunities that present themselves. In that respect, the Council has underlined that the Union and its Member States must not lower their guard against 'these heinous criminals.' 1769

Also at domestic level within the Member States' legal systems, terrorist offences are considered as very serious criminal offences that are primarily dealt with, and reacted to, using the criminal justice system. If terrorism is countered by means of other measures within domestic legal systems, such as in the Netherlands by personal disturbance and the formerly proposed administrative measures comprised in the Bill, the underlying factual conduct is different and the measures are not as far-reaching as fund-freezing measures. ${ }^{1770}$

Furthermore, in Article 83 of the TFEU, situated in Title V regarding the Area of Freedom, Security and Justice, terrorism is considered as a particularly serious crime that requires a common policy among Member States regarding the definition of criminal offences and sanctions. This point of view is, furthermore, reflected in the obligations that the FD 2002 creates for Member States. ${ }^{1771}$ The preamble of the FD 2002 refers to terrorism as constituting one of the most serious violations of principles of democracy and the rule of law, and as a threat to democracy, to the free exercise of human rights, and to economic and social development. ${ }^{1772}$ The FD 2002 refers exclusively to penalties and sanctions that reflect the seriousness of terrorist offences.

Further, the definition of terrorist offence in the FD 2002 is exactly the same as the one used in CP 931 for terrorist act. So, with regard to content, terrorism is defined in precisely the same way in both documents, only the label attached to it differs, 'offence' vis-à-vis 'act', is different. Where the FD 2002 obliges states to act fiercely against terrorist offences by means of high penalties, CP 931 provides for the imposition of administrative measures to prevent terrorist acts. Despite this difference in label, the factual conduct to which the Union reacts/prevents is, thus, exactly the same.

In sum, a person committing a terrorist offence in accordance with the FD 2002, and a person involved in terrorist acts, pursuant to the CP 931, contravene the same

1769 See Council of the European Union, The Stockholm Programme - An open and secure Europe serving and protecting the citizens of 2 December 2009, 16484/1/09 REV 1 JAI 866 + ADD 1, p. 50 .

1770 See Chapter III on personal disturbance, and Chapter IV on the administrative measures to prevent terrorism as comprised in the Bill.

1771 See Chapter II in which the 2002 Framework Decision and its repercussion on the Dutch criminal justice system are discussed. See, also, Council of the European Union Proposal for a Council Framework Decision amending Framework Decision 2002/475/JHA on combating terrorism of 13 November 2007.

1772 Council Framework Decision of 13 June 2002 on combating Terrorism (2002/457/JHA), paragraphs 1-2. See also Council Framework Decision 2008/919/JHA of 28 November 2008 amending Framework Decision 2002/475/JHA on combating terrorism. 
substantive norm, and are both denoted as terrorists at a national and Union level but, completely different measures are imposed on them with far-reaching consequences in the field of guaranteeing fair trial principles. In light of these considerations, it may - at the very least - be called inconsistent that the Union characterises fund-freezing measures as mere administrative measures.

Even though the Union Judiciary does not consider blacklisting proceedings as criminal proceedings, and consequently, fund-freezing measures not as criminal sanctions, it is not unlikely that the ECtHR will conclude otherwise.

First of all, terrorist acts are classified as criminal offences within all domestic systems, as well as within the Union. Even though this first criterion is not that important in determining the nature of proceedings/measures, it cannot be left unmentioned that terrorist acts indisputably belong to the domestic criminal law sphere. In this respect it must also be underlined that even though the ECtHR normally interprets a criminal charge as 'the official notification given to an individual by the competent authority of an allegation that he has committed a criminal offence', such a formal notification is not always required. ${ }^{1773}$ The ECtHR has deemed other measures equally indicative for a criminal charge, such as the search of a person's home and/or the seizure of certain goods, the request that a person's immunity be lifted, and the confirmation by a court of the sealing of a building. ${ }^{1774}$ In Corigliano v. Italy, the ECtHR considered that 'Whilst 'charge', for the purpose of Article 6, para 1 of the ECHR, may in general be defined as the official notification given to an individual by the competent authority of an allegation that he has committed a criminal offence, it may in some instances take the form of other measures which carry the implication of such an allegation and which likewise substantially affect the situation of the suspect.'1775

Secondly, the norm at issue is addressed to anyone, and not to a restricted group of persons, or to persons as members of a particular group. Anyone, any group, and any entity, may potentially be considered as terrorist/terrorist group/terrorist entity in accordance with CP 931. These measures are imposed following a set of rules, which not only covers everyone in their capacity as citizens, but whose purpose is, moreover, both deterrent and - it cannot be denied - punitive. ${ }^{1776}$ The purpose of

1773 See, among others, Deweer v. Belgium, appl. no. 6903/75, 27 February 1980, §46. See, also, P. Van Dijk, F. van Hoof, A. van Rijn and L. Zwaak (eds), Theory and Practice of the European Convention on Human Rights, Intersentia 2006, $4^{\text {th }}$ edition, p. 540.

1774 P. Van Dijk, F. van Hoof, A. van Rijn and L. Zwaak (eds), Theory and Practice of the European Convention on Human Rights, Intersentia 2006, $4^{\text {th }}$ edition, p. 540, the authors refer, in this respect, to Eckle v. Germany, appl. no. 8130/78, 15 July 1982, §12 and 74.

1775 Corigliano v. Italy, appl. no. 8304/78, 10 December 1982, §34, where the ECtHR moreover refers to Eckle v. Germany.

1776 Özturk v. Germany, 21 February 1984, appl. no. 8544/79; Bendenoun v. France, 24 February 1994, appl. no. 12547/86 and the case of Engel and Others v. the Netherlands, appl. nos. 5100/71; 5101/71; 5102/71; 5354/72; 5370/72, 8 June 1976, §80-86. 
the imposition of fund-freezing measures is, according to the Union, the prevention of (the financing of) terrorism. Nevertheless, these measures, in addition, have a punitive (side-)effect, taking into account the fact that punitive elements of a criminal sanction may also have the aim of compelling respect for the law in a preventive way in respect of the future. This is all the more valid when one takes into account that the purpose of the penalty - as sub-criterion of the second criterion in determining a criminal charge - primarily serves to distinguish criminal sanctions from purely reparatory or compensatory sanctions. ${ }^{1777}$

Lastly, there is the criterion of the nature and degree of severity of the measures incurred. This criterion has, in certain cases, been the ultimately decisive criterion in ascertaining whether or not Article 6 of the ECHR is applicable. As discussed earlier, Article 6, section 2 of the ECHR applies to all those proceedings which may result in the imposition of a punitive measure which, with regard to its nature and/ or consequences, is so similar to criminal sanctions that there is no justification for excluding fair trial principles - even though the underlying conduct is characterised as administrative in nature within the domestic legal system. Such measures may also include restrictions on economic or professional freedom of a punitive character, which, moreover, could affect civil rights and obligations. ${ }^{1778}$ In this respect, it is important to note that measures of a repetitive character, or of such a long duration that the reparatory character will be overshadowed by the punitive side-effects, may also be covered by this third criterion. ${ }^{1779}$ This also implies that even if the purpose of a measure - discussed under the second criterion - does not make the second criterion applicable, the nature and the severity of the measure may still bring the procedure under Article 6 of the ECHR. ${ }^{1780}$

Fund-freezing measures lead to a situation in which the blacklisted party becomes incapable of normal functioning in society: no work, no insurance, no bank account, no credit, no health support, and foremost, no adequate means of alleviating, let alone lifting, these measures. ${ }^{1781}$ The question of whether measures imposed on a person influence his everyday life has been proven to be important for the ECtHR in determining whether that measure may be deemed to be a sanction. ${ }^{1782}$ In Corigliano v. Italy, the ECtHR, in addition, underlined that measures which carry the 'implication' of an allegation and which substantially affect the situation of the

1777 E.L., R.L. and J.O.-L. v. Switzerland, 29 August 1997, appl. no. 20919/92, \$42 and 46; A.P., M.P. and T.P. v. Switzerland, 29 August 1997, appl. no. 19958/92, §42.

1778 See P. Van Dijk, F. van Hoof, A. van Rijn and L. Zwaak (eds), Theory and Practice of the European Convention on Human Rights, Intersentia 2006, $4^{\text {th }}$ edition, p. 556-557.

1779 See P. Van Dijk, F. van Hoof, A. van Rijn and L. Zwaak (eds), Theory and Practice of the European Convention on Human Rights, Intersentia 2006, $4^{\text {th }}$ edition, p. 547; Pierre-Bloch $v$. France, appl. no. 120/1996/732/938, 21 October 1997, §57-58.

1780 Engel and Others $v$. the Netherlands, appl. nos. 5100/71; 5101/71; 5102/71; 5354/72; 5370/72, 8 June $1976, \S 85$.

1781 See, for a complete overview of all the fund-freezing measures, the Regulation.

1782 Malige v. France, appl. no. 68/1997/852/1059, 23 September 1998, §39. 
'suspect' may fall under the scope of Article 6 of the ECHR. ${ }^{1783}$ The length of the applicability of fund-freezing measures - easily nine years - may therefore increase the severity of the consequences accordingly. Listed persons become completely dependent on the generosity of others, and on the - scarcely allowed - possibility of granting specific authorisations. ${ }^{1784}$ Despite the fact that the severity of the sanction, as such, does not automatically imply that the measure has a punitive character, it has been acknowledged - as asserted above - that measures of a repetitive character, or of such a long duration that the reparatory character is overshadowed by the punitive side effects, may be considered as punitive in character, nevertheless. Fund-freezing measures cannot even be considered as having a reparatory character, because no damage has yet occurred. Also, fund-freezing measures do not merely concern part of a person's financial assets - as with respect to confiscation, for example - but all assets, regardless of the question of whether, in fact, these assets may be, have been, can be, or will be, used to finance acts of terrorism. Lastly, when comparing fund-freezing measures with a confiscation/seizure - as the CFI does - it should be remembered that confiscation normally occurs following a court order in light of a criminal offence, which is clearly not the case regarding fundfreezing measures. ${ }^{1785}$

In light of all these considerations, fund-freezing measures may be considered to at the very least - resemble criminal sanctions to a high degree. The nature, ${ }^{1786}$ severity and consequences of fund-freezing measures demand these measures to be labelled as criminal sanctions, instead of as mere administrative measures. This would mean that all fair trial principles, including the presumption of innocence, should be complied with during (de)-listing procedures. It goes almost without saying that blacklisted persons' right to be presumed innocent is violated on a large scale. First and foremost, because the measures are imposed without the person concerned being found guilty by law following a judgement of a competent court. Secondly, throughout blacklisting procedures, it is, factually speaking, for the listed person to prove his innocence, instead of for the Council to actually prove his 'guilt'.

Furthermore, following the ECtHR judgement in Allenet de Ribemont judgement, ${ }^{1787}$ it may also be concluded that the presumption of innocence is

1783 Corigliano v. Italy, appl. no. 8304/78, 10 December 1982, $§ 34$.

1784 See Article 6 of the Regulation.

1785 Compare with Raimondo v. Italy, 22 February 1994, appl. no. 12954/87; Phillips v. the United Kingdom, 5 July 2001, appl. no. 41087/98.

1786 Trechsel, moreover, argues that the character (nature) of the offence (as second criterion) is the central point in determining whether Article 6 of the ECHR applies. He contends that this character is not only manifested by the nature of the misbehaviour and the norms that are infringed, but also in the type of sanctions which are incurred. In evaluating these elements, the ECtHR uses, as a guideline, the practice followed in the Member States. See S. Trechsel, Human Rights in Criminal Proceedings, Oxford University Press 2005, p. 30.

1787 Allenet de Ribemont v. France, 10 February 1995, appl. no. 15175/89. 
violated, due to the fact that the blacklists are made public. Blacklisted persons are publicly denoted as being involved in (the financing of) terrorist acts by the Council, without any prior judgement being pronounced by a competent court. The public inclusion of someone on the blacklist undeniably implies an expression of guilt on account of involvement in (the financing of) terrorism, even though the person has not been formally convicted. Further, even if it could be concluded that fundfreezing measures are not penalties, but, rather, seizing measures ( in the criminal law context) the presumption of innocence can nevertheless be violated, due to the excessive length of time that blacklisted persons are subjected to these measures. ${ }^{1788}$

\section{Substantive violations}

Due to blacklisting and the subsequent imposition of fund-freezing measures, several substantive rights and/or principles may be infringed. First of all, there are obvious claims of alleged infringement of the right to property, the right to freedom of assembly, association and/or expression, and the right to privacy. Some listed persons, furthermore, have alleged a violation of the prohibition of torture and/or inhuman or degrading treatment and/or punishment. ${ }^{1789}$ Then there are various blacklisted parties who, moreover, have asserted that the principle of nondiscrimination, the principles of proportionality and subsidiarity, ${ }^{1790}$ and the principle of legal certainty, have been devalued due to their being listed and subjected to fund-freezing measures. The Union Judiciary only started to factually acknowledge claims regarding alleged substantive violations starting with the 2008 Kadi judgement on appeal. This means that case law with respect to substantive violations is relatively scarce.

This section serves to answer the question of how the Union Judiciary deals with claims of alleged infringements on substantive rights during the blacklisting procedures. As infringements on substantive rights have only been recognised recently, this chapter exclusively elaborates on judgements passed since the 2008 Kadi judgement on appeal. ${ }^{1791}$

First of all, alleged infringements on Article 2 of the Regulation, and/or Article 1 of CP 931, are discussed. This concerns the question of whether all legal

1788 Raimondo v. Italy, 22 February 1994, appl. no. 12954/87.

1789 Action brought on 6 February 2003 by Jose Maria Sison against the Council of the European Union and the Commission of the European Communities (Case T-47/03, 2003/C101/75).

1790 Action brought on 12 September 2007 by Al-Aqsa v. Council of the European Union (Case T-348/07); action brought on 7 July 2004 by Abdelghani Selmani against the Council of the European Union and the Commission of the European Communities (Case T-299/04).

1791 In the 2005 Kadi judgement, the CFI also examined (partly) substantive claims, but exclusively under ius cogens. As this judgement has been superseded by the ECJ judgement, I will not discuss it. 
(substantive) prerequisites for inclusion on the list have been met. Secondly, I will elaborate on presumed infringement on the principles of subsidiarity, proportionality and legal certainty. Thirdly, interferences with the right to property are examined. Lastly, alleged infringements on the right to assembly, association, expression and privacy are briefly considered.

\subsection{Non-compliance with substantive prerequisites of the Regulation and CP 931}

Blacklisted parties often contend that substantive prerequisites for inclusion on the blacklist - as prescribed by the Regulation and CP 931 - have not been complied with. They claim, for example, that their inclusion was not based on a 'decision taken by a competent authority' or they allege that other substantive requirements, as comprised in Article 1 of CP 931, were not fulfilled. This latter claim is obviously closely connected to the above-discussed notion of 'statement of reasons': with regard to content, the statement of reasons is the required substantive suspicion criterion for application of fund-freezing measures. The Council is obliged to send a blacklisted party a statement of reasons in order for it to understand why, exactly, and on what grounds, it is included on the blacklist. What substantive requirements does the Union Judiciary set for such a statement of reasons? What and how much information/proof is required for assets to be lawfully frozen? Another related issue, in this respect, is the question of whether past terrorist activities may contribute to the Council's decision to include a person/entity on the list - even if those activities have been stopped. This question will also be examined in this section.

Before going into these questions, some preliminary remarks should be made. To begin with, one has to keep in mind that the questions relating to compliance with substantive (suspicion) requirements are difficult to answer fully, as not all the information is made known to the Council/Judiciary and the blacklisted party, let alone that that the information is made public in case law. Furthermore, it is essential to bear in mind that the Union Judiciary considers Member States and the Council to have a large discretionary power in deciding whether or not to freeze a party's assets on the basis of which, what, and how much (incriminating) information. ${ }^{1792}$ In practice, the Judiciary is basically satisfied once a national decision has been made. Lastly, with respect to the relationship between Member States and the Council, it is to be kept in mind that in the case of fund-freezing measures, the CFI reasons that in light of reciprocal duties to cooperate in good faith, the Council has to defer, as far as possible, to the assessment conducted by the competent national authority. This limitation on the Council's power applies to: (1) the issue of whether there are 'serious and credible evidence or clues' on which the national decision is based, and (2) on the recognition of potential restrictions to

\footnotetext{
1792 See the foregoing section.
} 
access to that 'evidence' or those clues, legally justified under national law for overriding reasons of public policy, public security or the maintenance of international relations. ${ }^{1793}$

\section{THE 2009 Sison JUdGemEnT}

Until the 2009 Sison judgement, the Union Judiciary did find, in various cases, procedural violations of Article 2, section 3 of the Regulation and Article 1, section 4 of CP 931, i.e. a complete lack of any statement of reasons, but it never concluded to any purely substantive violation. ${ }^{1794}$ This section will therefore exclusively deal with this landmark judgement.

A 'purely substantive violation' is the finding that the substantive grounds that the Council uses to blacklist someone are insufficient to fulfil the 'suspicion criterion' as comprised in Article 1, section 4 of CP 931. It goes without saying that such a finding can only be reached if the Council at all provides the listed person, and hence, also the Judiciary, with a statement of reasons. Once the Union Judiciary started to oblige the Council to provide an adequate statement of reasons, in the 2006 OMPI judgement, it became possible to examine whether the substantive grounds adduced by the Member State and indirectly, by the Council, were indeed adequate.

Sison contended, in all his actions before the CFI and the ECJ, that there was no evidence to sustain his alleged involvement in terrorist acts. ${ }^{1795}$ Sison's inclusion on

1793 Judgement of the Court of First Instance (Second Chamber) of 11 July 2007 in the case of Jose Maria Sison v. the Council of the European Union (Case T-47/03), paragraph 170-171. The CFI added however, to the above-recited considerations, that these are valid only in so far as the evidence or clues in question have, in fact, been assessed by the competent national authority. If, on the other hand, in the course of the procedure before it, the Council bases its initial decision or a subsequent decision to freeze funds on information or evidence communicated to it by representatives of the Member States, without having been assessed by the competent national authority, that information must be considered to be fresh incriminating evidence, which must, as a rule, be the subject of notification and of a hearing at Community level, by reason of its not having already been so at national level (paragraph 172).

1794 Judgement of the Court of First Instance (Seventh Chamber) of 4 December 2008 in the case of People's Mojahedin Organisation of Iran v. the Council of the European Union (Case T-284/08) (PMOI II), paragraphs 50-80.

1795 Judgement of the Court of First Instance (Seventh Chamber) of 30 September 2009 in the case of Jose Maria Sison v. the Council of the European Union (Case T-341/07), paragraphs 72 and 73. At this point I will only discuss the most recent judgements regarding allegations of substantive violations. Prior to the 2009 Sison judgement, neither the CFI nor the ECJ acknowledged allegations of non-compliance with substantive prerequisites for being listed in accordance with Article 2 of the Regulation and CP 931. With respect to blacklisted parties in accordance with UNSC Resolution 1267, the CFI considered, for example, in the Kadi judgement that it 'does not fall to the Union Judiciary to verify that there has been no error of assessment of the facts and evidence relied on by the Security Council in support of the measures it has taken'. Judgement of the Court of First Instance (Second Chamber, Extended Composition) of 21 September 2005 
the blacklist 1796 was based on: (1) two judgements of the Council of State of 1992/1995, ${ }^{1797}$ and (2) a 1997 decision of the District Court, ${ }^{1798}$ and (3) the

in Yassin Abdullah Kadi (Saudi Arabia) v. the Council of the European Union and the Commission of the European Communities (T - 315/01), paragraphs 279-291. As stated before, the Union simply copied the UNSC Resolution 1267-list without verifying whether the underlying information was sufficient to satisfy prerequisites as comprised in Regulation 2580/2001 and Common Position 931/2001. In the OMPI judgement, the CFI did not even get a chance to review whether substantive prerequisites had been fulfilled, as the Organisation did not at all receive a statement of reasons notifying it of the reasons for its inclusion on the blacklist. Judgement of the Court of First Instance (Second Chamber) 12 December 2006 in the case of Organisation des Modjahedines du people d'Iran (France) v. the Council of the European Union (Case 228/02), paragraphs 160-175. This goes for all the following judgements in which a violation of the obligation to state reasons was found, such as the 2007 Sison judgement (paragraphs 185-199), the 2007 Al-Aqsa judgement (paragraphs 53-68) and the 2008 KongraGel judgement (paragraphs 95-105).

1796 Sison filed several actions before the CFI and the ECJ. The document/judgement/decision on which his inclusion on the terrorism list was based changes throughout the various proceedings. However, the judgements of the Council of State of 1992/1995, the 1997 decision of the district court, the Sanctieregeling and the American decision are mentioned throughout all proceedings. It is furthermore important to keep in mind that Sison was not always aware of the fact that these judgements/decisions served as (substantive) basis for the blacklisting and the freezing of his funds. See for example Judgement of the Court of Justice (First Chamber) of 1 February 2007 in the case of Jose Maria Sison v. The Council of the European Union (Case C-266/05 P), paragraph 221.

1797 In the 1992 judgement, the Council of State concluded that the State Secretary for Justice did not sufficiently sustain - with evidence - its decision (1990) in which it rejected Sison's request to be admitted as a refugee and to be granted a permit for residence. Therefore, the Council of State nullified the aforesaid decision of the State Secretary of Justice. In a subsequent decision taken in 1993, the State Secretary of Justice - deciding on Sison's request for reconsideration of the decision to reject his request for refugee status - again rejected this. This rejection was mainly based on secret intelligence information accusing Sison of involvement in acts of terror. Against this Decision, Sison made an appeal on the basis of the Aliens Law. In the 1995 judgement, the Council of State decided that Article 1(A) of the Treaty of Geneva concerning the states of refugees of 28 July 1951, as amended by the Protocol of New York of 31 January 1967 (the Treaty), was applicable to Sison, whereas Article 1(F) did not apply to him. This meant that the Council of State does considered Sison as refugee in the sense of Article 1(A), section 2 of the Treaty, and underlined that it is contrary 'to the generally justice-conscious principle of proper administration that a decision must be based on and for the concerned recognisable justifications.' See, for the relevant decisions, www.josemariasison.org/.

1798 In 1997, the REK (Rechtseenheidkamer) decided that Sison was not to be expelled because Article 1(A) of the Treaty applied to him, but the REK, nevertheless, relying on secret intelligence information, considered Sison to be in touch with 'terrorists'. Hence, he was not expelled, but neither was he granted the asylum status. 
Sanctieregeling, ${ }^{1799}$ and/or (4) on the American decision. ${ }^{1800,} 1801$ None of these documents however could, according to Sison, be considered as a 'decision taken by a competent authority' able moreover to fulfil the further substantive requirements for involvement in terrorist activities as required by CP 931. ${ }^{1802}$

In accordance with the above discussed OMPI judgement and the 2007 Sison judgement, both the statement of reasons for an initial decision to freeze funds and the statement of reasons for subsequent decisions must, in principle, with regard to substantive prerequisites, refer not only to the legal conditions of application - in particular the existence of a national decision taken by a competent authority - but also to the actual and specific reasons why the Council considers, in the exercise of its discretion, that the person concerned must be made the subject of fund-freezing measures. The CFI does not, hence, accept the position advocated by the Council that the statement of reasons may consist merely of a general, stereotypical formulation, modelled on the drafting of Article 1(4) or (6) of CP 931. ${ }^{1803}$

In the 2009 Sison judgement, the CFI, furthermore, underlined the importance of distinguishing between, the obligation to state reasons as an essential procedural requirement on the one hand, and the issue of the validity of the reasoning, on another, the latter falling within the ambit of the substantive lawfulness of a blacklisting decision. Thus, a challenge to the merits of that reasoning may not be examined at the stage of verifying whether the procedural obligation, laid down by Article 294 of the TFEU, has been performed.

In light of these considerations, the CFI reasoned that even though the Council complied with its procedural obligation to provide Sison with a statement of

1799 Ministerial Decree No DJZ/BR/749-02 of 13 August 2002 of the Netherlands Ministers for Foreign Affairs and for Finance.

1800 The decision of the United States Government designating the applicant as a 'Specially Designated Global Terrorist' in accordance with Executive Order No 13224, signed by President George W. Bush on 23 September 2001.

1801 However, for the purposes of these proceedings the Council asserted that it relied on the judgement of the Raad van State of 1995 and the decision of the Rechtbank alone to base the contested Decisions on. The Council took the Sanctieregeling and the US Decision into consideration, in exercising its discretion, only as facts intended to bear out the findings made in the two decisions in question, concerning Sison's continuing involvement in the CPP and the NPA. Judgement of the Court of First Instance (Seventh Chamber) of 30 September 2009 in the case of Jose Maria Sison v. the Council of the European Union (Case T-341/07), paragraphs 101 and 102 .

1802 Judgement of the Court of First Instance (Seventh Chamber) of 30 September 2009 in the case of Jose Maria Sison v. the Council of the European Union (Case T-341/07), paragraphs 73-81.

1803 Judgement of the Court of First Instance (Seventh Chamber) of 30 September 2009 in the case of Jose Maria Sison v. the Council of the European Union (Case T-341/07), paragraph 60. See, also, judgement of the Court of First Instance (Second Chamber) 12 December 2006 in the case of Organisation des Modjahedines du people d'Iran (France) v. the Council of the European Union (Case 228/02), paragraphs 138-151 and judgement of the Court of First Instance (Second Chamber) of 11 July 2007 in the case of Jose Maria Sison v. the Council of the European Union (Case T-47/03), paragraphs 185-198. 
reasons, it may still be that substantive requirements concerning the merits of the case have not been complied with, due to an insufficiently valid reasoning. And that was, for the first time in 'the blacklisting case law history', the case with respect to Sison.

The CFI held that, first of all, neither the 1995 judgement of the Council of State, nor the 1997 decision of the District Court constituted 'a decision taken by a competent authority' within the meaning of Article 1(4) of CP 931. ${ }^{1804}$ This was primarily due to the fact that the judgement, respectively decision, did not contain any evidence at all of any 'condemnation' [sic] of Sison, within the meaning of those provisions. Nor did the judgements or that decision constitute decisions for the 'instigation of investigations or prosecution for a terrorist act' etc., within the meaning of those provisions.' The judgements and decision on which Sison's inclusion on the blacklist was based, dealt with the question of whether Sison could be granted asylum and a refugee status under Dutch Alien Law. However, the CFI requires that a decision to 'instigat[e] ... investigations or prosecut[e]' must form part of national proceedings seeking, directly and chiefly, the imposition on the person concerned of measures of a preventive or punitive nature, in connection with the combating of terrorism and by reason of that person's involvement in terrorism. That requirement is not satisfied with a decision of a national judicial authority ruling only incidentally and indirectly on the possible involvement of the person concerned in such activity, in relation to a dispute concerning rights and duties of a civil nature. ${ }^{1805}$

Sison thus correctly emphasised that the procedures before the Council of State and the District Court were in no way directed at punishing his possible participation in past acts of terrorism, but were solely concerned with the review of the lawfulness of the decision of the Secretary of State for Justice refusing to grant him refugee status and a residence permit in the Netherlands. Even though the Council of State and the District Court studied the secret intelligence file relating to Sison's alleged involvement in certain terrorist activities in the Philippines, they did not decide for that reason to open an investigation into those facts, still less to instigate a prosecution against Sison. ${ }^{1806}$

In sum, the CFI considered that the aforementioned judgements and decision could not be considered to satisfy the substantive requirements as comprised in $\mathrm{CP}$ 931.

1804 Judgement of the Court of First Instance (Seventh Chamber) of 30 September 2009 in the case of Jose Maria Sison v. the Council of the European Union (Case T-341/07), paragraph 107.

1805 Judgement of the Court of First Instance (Seventh Chamber) of 30 September 2009 in the case of Jose Maria Sison v. the Council of the European Union (Case T-341/07), paragraph 111.

1806 Judgement of the Court of First Instance (Seventh Chamber) of 30 September 2009 in the case of Jose Maria Sison v. the Council of the European Union (Case T-341/07), paragraphs 111-115 and 117. 
To further sustain this conclusion, the CFI examined yet another issue. In 2002 enquiries were made to ascertain whether there was sufficient evidence to warrant the opening of a criminal investigation against Sison. That was not the case. Three weeks before Sison was first included on the blacklist, the prosecuting authority stated by the Kingdom of the Netherlands at the hearing to be an independent judicial authority - considered that the secret intelligence file regarding Sison did not contain information sufficiently serious to warrant the opening of criminal investigations into, or prosecutions of, Sison in the Netherlands, in respect of an act of terrorism relating to his alleged involvement in the activities of the CPP and/or the NPA. ${ }^{1807}$

Sison also requested the CFI to annul several other blacklisting decisions, and one Regulation, ${ }^{1808}$ which were taken following the opening of a criminal investigation regarding Sison's alleged involvement in two common (not terrorist) murders committed in the Philippines. At the beginning of the criminal investigation, Sison was put in detention on remand. The Hague District Court and the Hague Court of Appeal however, ordered the immediate release of Sison, and in the end the prosecuting authorities abandoned prosecution due to lack of evidence. ${ }^{1809}$ Despite the fact that the Netherlands' prosecuting authority considered that there was no evidence justifying the criminal investigation relating to Sison, the Council kept Sison on the blacklist. ${ }^{1810}$

First of all, the CFI's considered that it would be improper for the same acts to be the subject of a criminal investigation in the Netherlands and in the Philippines. Most important, however, was the fact that the criminal proceedings relating to Sison, like the decision of the Supreme Court of the Philippines, disclosed no serious and credible information or indication of his participation in any terrorist activity whatsoever, but quite the contrary. The Council also failed to take into consideration the decision of the examining judge of 21 November 2007, closing the preliminary criminal investigation for want of serious evidence. Moreover, the alleged acts, referred to in the context of the criminal proceedings in the Netherlands, were not terrorist acts within the meaning of CP 931. Therefore, the CFI held that it had not been established - or even alleged - that those murders or

\footnotetext{
1807 Judgement of the Court of First Instance (Seventh Chamber) of 30 September 2009 in the case of Jose Maria Sison v. the Council of the European Union (Case T-341/07), paragraphs 119-124.

1808 Decisions 2008/343, 2008/583 and 2009/62 and Regulation No 501/2009.

1809 See the Hague District Court 13 September 2007, LJN: BB3484, 09.750006-06; the Hague Court of Appeal 3 October 2007, LJN: BB4662, 0975000606.

1810 Judgement of the Court of First Instance (Seventh Chamber) of 30 September 2009 in the case of Jose Maria Sison v. the Council of the European Union (Case T-341/07), paragraph 118. In addition, even before Decision 2008/343 - one of the contested blacklisting decisions - had been adopted, the charges in question had already been dismissed in the procedure conducted in the Philippines dealing with the substance, as being 'politically motivated', by judgement of the Supreme Court of the Philippines of 2 July 2007.
} 
attempted murders, even if they could be ascribed to Sison, could have been regarded as acts of terrorism.

In light of these considerations, the CFI reasoned, more generally, that when the Council contemplates adopting or maintaining, after review, a fund-freezing measure, it may not disregard subsequent developments arising out of investigations or prosecution. Domestic police or security enquiries may very well be closed without giving rise to any judicial consequences, because it proved impossible to gather sufficient evidence, or that measures of investigation ordered by the investigating judge did not lead to further proceedings for the same reasons. Similarly, a decision to prosecute may end in the abandoning of the prosecution, or in acquittal in the criminal proceedings. The Council is obliged to take account of such matters, as these form part of the body of information that has to be taken into account in order to assess the situation. To decide otherwise would be as good as giving the Council and the Member States the excessive power to freeze a person's funds indefinitely, beyond review by any court, and whatever the result of any judicial proceedings taken. ${ }^{1811}$ Not surprisingly, the CFI judged the above decisions to be substantially insufficient to warrant Sison's continued inclusion on the blacklist. ${ }^{1812}$

\section{PAST TeRrorist ACTIVITIES AS JUSTIFICATION FOR BLACKLISTING}

A last issue is the question of whether past terrorist activities may contribute to fulfilment of the substantive criteria for blacklisting and the imposition of fundfreezing measures. Can a party be blacklisted, despite the fact that it has stopped its terrorist activities and committed no recent terrorist acts?

In the PMOI I judgement, ${ }^{1813}$ the Organisation claimed that its inclusion on the blacklist was not based on current, or at least recent, terrorist activity, but merely on a review based on historical acts. The CFI however, considered that the Organisation's interpretation of the relevant provisions of CP 931 (primarily Article 1, section 4) was unduly restrictive, and that nothing in those provisions precluded the imposition of fund-freezing measures on parties that have, in the past,

\footnotetext{
1811 Judgement of the Court of First Instance (Seventh Chamber) of 30 September 2009 in the case of Jose Maria Sison v. the Council of the European Union (Case T-341/07), paragraph 116.

1812 Judgement of the Court of First Instance (Seventh Chamber) of 30 September 2009 in the case of Jose Maria Sison v. the Council of the European Union (Case T-341/07), paragraphs 124-138.

1813 Judgement of the Court of First Instance (Seventh Chamber) of 23 October 2008 in the case of People's Mojahedin Organisation of Iran v. the Council of the European Union (Case T-256/07). See, for further notes on this judgement, the preceding sections - primarily regarding procedural violations.
} 
committed acts of terrorism, despite the lack of evidence to show that they are, at present, committing or participating in such acts. ${ }^{1814}$

So, continued inclusion on the blacklist of parties not having committed any fresh act of terrorism during the six-month period or periods before the review, is allowed for, provided that continued inclusion is still justified in the light of all relevant circumstances. What the notion of 'all relevant circumstances' means is not further discussed or clarified. In the CFI's view, fund-freezing measures, being intended essentially to prevent the perpetration of terrorist acts or their repetition, are based more on the appraisal of a present or future threat than on the evaluation of past conduct. This implies that the already broad discretion enjoyed by the Council extends to the evaluation of the threat that may be represented by an organisation having, in the past, committed acts of terrorism, notwithstanding the suspension of its terrorist activities for a more or less long period, or even their apparent cessation. 1815 The CFI upheld this line of reasoning once again in the 2009 Sison judgement and in the 2010 Al-Aqsa judgement. Past terrorist activity may thus very well contribute, within the appraisal of a presumed present or future threat, to the Council's decision to include a party on the blacklist. 1816

\subsection{Infringement on the right to property}

Article 17 of the Charter, and Article 1 of Protocol No. 1 to the ECHR, guarantee everyone the right to own, use, dispose of, and bequeath, his lawfully acquired possessions. ${ }^{1817}$ Nevertheless, restrictions are permitted in the public interest, and in the cases and under the conditions provided for by law, subject to fair compensation being paid in good time for their loss. It goes without saying that fund-freezing measures interfere with the right to property: blacklisted parties no longer have free disposal of their (financial) possessions. Even though restrictions

1814 Judgement of the Court of First Instance (Seventh Chamber) of 23 October 2008 in the case of People's Mojahedin Organisation of Iran v. the Council of the European Union (Case T-256/07), paragraphs $107-109$.

1815 Judgement of the Court of First Instance (Seventh Chamber) of 23 October 2008 in the case of People's Mojahedin Organisation of Iran v. the Council of the European Union (Case T-256/07), paragraph 112 .

1816 See, for a full account, judgement of the Court of First Instance (Seventh Chamber) of 30 September 2009 in the case of Jose Maria Sison v. the Council of the European Union (Case T-341/07), paragraphs 59-72; judgement of the General Court (Seventh Chamber) of 9 September 2010 in the case of Stichting Al-Aqsa v. the Council of the European Union (Case T-348/07), paragraphs $142-147$.

1817 For more information on the right to property P. Van Dijk, F. van Hoof, A. van Rijn and L. Zwaak (eds.), Theory and Practice of the European Convention on Human Rights, Intersentia 2006, $4^{\text {th }}$ edition, pp. 363-895; A. Grgić, Z. Mataga, M. Longar, A. Vilfan, The right to property under the European Convention on Human Rights. A guide to the implementation of the European Convention on Human Rights and its protocols, Council of Europe Human rights handbooks, No. 10, 2007 and www.europarl.europa.eu/comparl/libe/elsj/charter/art17/default_ en.htm. 
on the free exercise of the right to property are allowed for, both under the Charter and under the ECHR, it remains to be seen whether the interferences caused by fund-freezing measures remain within the scope of the limitation clauses, and can hence be considered lawful. This section will exclusively elaborate on the Union Judiciary's case law in this respect.

In the Kadi judgement on appeal, ${ }^{1818}$ the ECJ discussed the question of whether fund-freezing measures amount to disproportionate and intolerable interferences with the right to respect for property. ${ }^{1819}$ First and foremost, the ECJ emphasised that these measures constitute temporary precautionary measures which are not supposed to actually deprive those persons of their property. ${ }^{1820}$ Nevertheless, the ECJ did judge the measures to undeniably amount to a restriction on the exercise of Kadi's right to property. Moreover, the restriction was classified as considerable, having regard to: (1) the general application of the freezing measure, and (2) the fact that it had been applied to him for a period of seven years.

The next question was then obviously whether there were any justifications for the restriction on Kadi's right to property?

1818 At this point I will not elaborate further on the Kadi judgement of the Court of First Instance regarding the alleged violations of substantive rights. As discussed in the previous paragraph, the CFI exclusively examined these alleged violations on compliance with international norms of jus cogens. The CFI did not find any violations of the substantive rights that Kadi brought forward. Judgement of the Court of First Instance (Second Chamber, Extended Composition) of 21 September 2005 in the case of Yassin Abdullah Kadi (Saudi Arabia) v. the Council of the European Union and the Commission of the European Communities (T - 315/01). See, also, judgement of the Court of First Instance (Second Chamber, Extended Composition) of 21 September 2005 in the case of Ahmed Ali Yusuf and the Al Barakaat International Foundation v. The Council of the European Union and the Commission of the European Communities (Case $\mathrm{T}-306 / 01$ ), paragraphs 332-348; judgement of the Court of First Instance (Second Chamber) of 12 July 2006 in the case of Faraj Hassan v. The Council of the European Union and the Commission of the European Communities (Case T-49/04), 105-129; judgement of the Court of First Instance (Second Chamber) of 12 July 2006 in the case of Chafiq Ayadi v. The Council of the European Union (Case T-253/02). The ECJ did not agree with this point of view as discussed above, see judgement of the Court (Grand Chamber) of 3 September 2008 (Appeals) in the cases of Yassin Abdullah Kadi and Al Barakaat International Foundation v. The Council of the European Union (Joint Cases C-402/05 P and C-415/05 P), paragraph 282.

1819 Judgement of the Court (Grand Chamber) of 3 September 2008 (Appeals) in the cases of Yassin Abdullah Kadi and Al Barakaat International Foundation v. The Council of the European Union (Joint Cases C-402/05 P and C-415/05 P); judgement of the Court of Justice (Second Chamber) of 3 December 2009 in the cases of Faraj Hassan and Chafiq Ayadi v. The Council of the European Union and the European Commission (Joint Cases C-399/06 P and C-403/06 P).

1820 In this respect it is interesting to note, that under the ECHR, even a mere interference on the peaceful enjoyment of property may amount to a violation of the right to property. See, for example, decision as to the admissibility in Wiggins v. The United Kingdom, 8 February 1978, appl. no. 7456/76, §46-47; Sporrong and Lönnroth v. Sweden, 23 September 1982, appl. no. $7151 / 75$ and $7152 / 75, \S 103$. 
In the ECJ's view, with explicit reference to the threats to international peace and security posed by acts of terrorism, fund-freezing measures imposed on persons identified by the UNSC or by the Sanctions Committee as being associated with Osama bin Laden, members of the Al-Qaeda organisation, and the Taliban, cannot per se be regarded as inappropriate or disproportionate. In this respect, the ECJ took into account that Articles 5 and 6 of the Regulation provide for specific authorisations to unfreeze funds necessary to cover basic expenses, including payments for food, rent, medicines and medical treatment, taxes or public utility charges- unless the Sanctions Committee expressly objects. ${ }^{1821}$ In addition, funds necessary for any 'extraordinary expense' may be unfrozen, on the express authorisation of the Sanctions Committee. The ECJ, furthermore, referred to the periodic re-examination of fund-freezing measures. Lastly, the possibility of lodging a request to be delisted was underlined - both to the Sanctions Committee and to the Union Judiciary. 1822

In light of these considerations, the ECJ concluded that so far the fund-freezing measures constitute merely a restriction on the right to property, which may, in principle be justified. Nevertheless, the de-listing procedures must also afford a blacklisted party reasonable opportunity of putting its case to the competent authorities. In order to ascertain whether this condition has been satisfied, the ECJ took an 'all-inclusive view' of the de-listing procedures. As discussed above, de-listing procedure for Category 1 terrorists was - prior to this judgement without any procedural guarantees enabling the blacklisted parties to put their case to the competent authorities. In addition, the ECJ considered the restriction on Kadi's right to property as significant, having regard to the general application and actual continuation of the fund-freezing measures. In light of those two aspects, the imposition of the measures constituted an unjustified restriction on his right to property. ${ }^{1823}$

\footnotetext{
1821 See Articles 5 and 6 of the Regulation.

1822 See www.un.org/sc/committees/1267/fact_sheet_delisting.shtml.

1823 Judgement of the Court (Grand Chamber) of 3 September 2008 (Appeals) in the cases of Yassin Abdullah Kadi and Al Barakaat International Foundation v. The Council of the European Union (Joint Cases C-402/05 P and C-415/05 P), paragraphs 354-377 and judgement of the Court of Justice (Second Chamber) of 3 December 2009 in the cases of Faraj Hassan and Chafiq Ayadi v. The Council of the European Union and the European Commission (Joint Cases C-399/06 P and C-403/06 P), paragraphs 91-95. The ECJ reaches the same conclusion - i.e. infringement on the right to property - as in the Kadi, Yusuf and Al Barakaat judgements. In the Othman judgement, the CFI adopted the same line of reasoning as the ECJ. The CFI judged the Regulation to be adopted without furnishing any guarantee enabling Othman to put his case to the competent authorities, in a situation in which the restriction of his property rights was significant, having regard to the general application and actual continuation of the restrictive measures affecting him. In that light, the CFI deemed the imposition of the fund-freezing measures laid down by the contested Regulation to constitute an unjustified restriction on Othman's right to property. Judgement of the Court of First Instance (Seventh Chamber) of 11 June 2009 in the case of Omar
} 
So, the Union Judiciary only began to acknowledge actual violations of the right to property from 2008 with the Kadi judgement on appeal. When fund-freezing measures have been imposed for a considerable time (several years), and additionally, apply to all assets of a blacklisted party, the Union Judiciary will, most likely, conclude there has been a violation of the right to property. The fact that (de)-listing procedures are not furnished with the required essential procedural guarantees contributes to that conclusion.

\subsection{Infringement on the principles of subsidiarity, proportionality and legal certainty}

The fundamental principles of proportionality, subsidiarity and legal certainty form part of any legal system, and are, therefore, unsurprisingly codified in the Charter. ${ }^{1824}$ The first two principles play a role with respect to all complaints regarding alleged violations of substantive rights. In addition, blacklisted parties have, generally claimed that fund-freezing measures as such interfere with these principles. Additionally, due to the vague definition of 'involvement in terrorist acts', various parties have argue that the principle of legal certainty is seriously devalued.

So far, the Union Judiciary has only dealt with alleged interferences with these principles under the heading of alleged violations of substantive rights, such as the right to property, instead of examining whether fund-freezing measures, as such, devalue these fundamental principles.

In the 2005 Kadi, Yusuf and Al Barakaat judgements, ${ }^{1825}$ the CFI characterises fund-freezing measures as temporary precautionary measures merely restricting the availability of the property of the blacklisted parties, and then concluded that the right to property was accordingly not interfered with (under ius cogens). ${ }^{1826}$

Mohammed Othman v. The Council of the European Union and the Commission of the European Communities (Case T-318/01), paragraph 85-95.

1824 See Articles 49, 51, 52 and the preamble of the Charter.

1825 Judgement of the Court of First Instance (Second Chamber, Extended Composition) of 21 September 2005 in the case of Yassin Abdullah Kadi (Saudi Arabia) v. the Council of the European Union and the Commission of the European Communities (T - 315/01), paragraph 190; judgement of the Court of First Instance (Second Chamber) of 12 July 2006 in the case of Faraj Hassan v. The Council of the European Union and the Commission of the European Communities (Case T-49/04), paragraphs 105-129; judgement of the Court of First Instance (Second Chamber) of 12 July 2006 in the case of Chafiq Ayadi v. The Council of the European Union (Case T-253/02), paragraphs 104-117.

1826 Judgement of the Court of First Instance (Second Chamber, Extended Composition) of 21 September 2005 in the case of Yassin Abdullah Kadi (Saudi Arabia) v. the Council of the European Union and the Commission of the European Communities (T - 315/01), paragraph 274; judgement of the Court of First Instance (Second Chamber, Extended Composition) of 21 September 2005 in the case of Ahmed Ali Yusuf and the Al Barakaat International Foundation 
Other judgements, passed before the 2008 Kadi judgement on appeal, did not elaborate in great detail on substantive claims. The only, more or less general, consideration which is repeatedly provided is that threats to international peace and security, caused by terrorist acts, easily outweigh interferences with substantive rights of blacklisted parties, and therefore comply with the principles of subsidiarity and proportionality. ${ }^{1827}$

In the 2007 Sison judgement, the ECJ emphasised that the Union legislature must be allowed a broad discretion in areas which involve political, economic and social choices, and in which it is called upon to undertake complex assessments. The ECJ concluded therefore, that the legality of a measure adopted in these fields can be affected only if the measure is manifestly inappropriate, having regard to the objective which the competent institution is seeking to pursue. ${ }^{1828}$ What the notion of 'manifestly inappropriate' implies was not further explained.

In the 2009 Morabit judgement, the CFI considered the principles of proportionality and subsidiarity not to be violated with regard to Morabit's complaint of an alleged violation of his right to property. Again, safeguarding peace and security, and hence, the effective prevention of (the financing of) terrorism, was considered to outweigh restrictions on these principles. In that respect, the CFI explicitly referred to the possibility of granting specific authorisations for exemptions in accordance with Articles 5 and 6 of the Regulation. In light of these considerations, the CFI concluded that fund-freezing measures do not interfere with, or violate, the principle of proportionality or subsidiarity. ${ }^{1829}$ In this specific case, the fact that Morabit had already been found guilty of membership of a terrorist organisation in The Netherlands may have played a role of importance for the CFI in coming to this conclusion.

v. The Council of the European Union and the Commission of the European Communities (Case $\mathrm{T}-306 / 01)$, paragraph 320 .

1827 See for example judgement of the Court of First Instance (Second Chamber) of 12 July 2006 in the case of Faraj Hassan v. The Council of the European Union and the Commission of the European Communities (Case T-49/04), paragraphs 105-129; judgement of the Court of First Instance (Second Chamber, Extended Composition) of 21 September 2005 in the case of Yassin Abdullah Kadi (Saudi Arabia) v. the Council of the European Union and the Commission of the European Communities (T - 315/01), paragraph 190; judgement of the Court of First Instance (Second Chamber) of 12 July 2006 in the case of Chafiq Ayadi v. The Council of the European Union (Case T-253/02), paragraphs 87-93.

1828 Judgement of the Court of Justice (First Chamber) of 1 February 2007 in the case of Jose Maria Sison v. The Council of the European Union (Case C-266/05 P), paragraph 33.

1829 Judgement of the Court of First Instance (Second Chamber) of 2 September 2009 in the case of Mohammed El Morabit v. The Council of the European Union (Joined Cases T-37/07 and T-323/07), paragraphs 59-65. 
Even though the Union Judiciary does not, hence, unequivocally acknowledge that fund-freezing measures are disproportional, as such, in relation to the ends pursued, i.e. prevention of terrorism, or that the Union could have found other (less intrusive) means, the Union Judiciary has found violations of the right to property starting from the Kadi judgement on appeal, which hence relate to these principles.

So, one may conclude that the Union Judiciary started to acknowledge, even though indirectly, interferences with the principles of proportionality and subsidiarity with the 2008 Kadi judgement on appeal, but only within the framework of complaints regarding alleged interferences on the right to property.

\subsection{Infringement on the right to assembly, association, expression and privacy}

The right to freedom of assembly, association and expression and the right to privacy are comprised in Articles 10, 11, and Article 8 of the Charter, respectively. ${ }^{1830}$ Blacklisted groups and entities, in particular, such as Gestoras Pro Amnistía, Segi and OMPI, have complained about alleged violations of the first three rights. Allegations regarding interferences with the right to privacy are obviously also brought forth by blacklisted persons. However, so far, all claims regarding interferences with the right to privacy have been rejected. ${ }^{1831}$ None of these rights have an absolute character, so interferences are theoretically allowed, as long as they remain within the scope of the relevant limitation clause.

In the PMOI I judgement, the Organisation claimed a serious interference with the right to freedom of expression and the right to freedom of assembly and association. Therefore, fund-freezing measures ought to comply with the relevant limitation clauses. In other words: the Council had to prove that the imposition of the fundfreezing measures was prescribed by law, pursued a legitimate aim, and was necessary in a democratic society. ${ }^{1832}$

The CFI first argued that fund-freezing measures are prescribed by law, namely (indirectly), by UNSC Resolution 1373, and (directly) by the Regulation. Second, the measures serve the legitimate purpose of combating terrorism, as is apparent from the preambles to those acts. With respect to the third criterion, the CFI referred to the preamble of UNSC Resolution 1373, in which the Security Council reaffirmed

\footnotetext{
1830 See, further, Articles 8, 10 and 11 of the ECHR. For more information on these rights see, also, P. Van Dijk, F. van Hoof, A. van Rijn and L. Zwaak (eds), Theory and Practice of the European Convention on Human Rights, Intersentia 2006, $4^{\text {th }}$ edition, pp. 663-751, 773-817 and 817-841.

1831 See, for an example, judgement of the Court of First Instance (Second Chamber) of 12 July 2006 in the case of Faraj Hassan v. The Council of the European Union and the Commission of the European Communities (Case T-49/04), paragraphs 126-128.

1832 Judgement of the Court of First Instance (Seventh Chamber) of 23 October 2008 in the case of People's Mojahedin Organisation of Iran v. the Council of the European Union (Case T-256/07), paragraphs 116-129.
} 
the need to combat threats to international peace and security caused by terrorist acts by all means. In light of these considerations, the CFI concluded that States are even obliged to complement international cooperation by taking additional measures to prevent and suppress the financing and preparation of any acts of terrorism. Hence, fund-freezing measures are deemed necessary in order to effectively prevent terrorism, which implies that the Organisation's rights were lawfully interfered with. ${ }^{1833}$

\section{IN SUM}

Prevention of terrorism remains a top priority for the Union. Blacklisting and the imposition of fund-freezing measures are considered as indispensable means to that effect. Despite the fact that the Union Judiciary has repeatedly judged several parts of the blacklisting system to be in violation of fundamental (mainly procedural) rights, the Council has called for a reinforcement of the prevention strand in its counter-terrorism policy. ${ }^{1834}$ Moreover, the Union intends to continue playing an active role in the fight against terrorism in different multilateral forums, and, in particular, in the United Nations, where it is to work towards 'enhancing the design, implementation and effectiveness of sanctions by the UN Security Council with a view to safeguarding fundamental rights and ensuring fair and clear procedures. ${ }^{\text {'1835 }}$ The Union has underlined, time and again, that measures in the fight against terrorism must be undertaken within the framework of full respect for fundamental rights so that they do not give rise to challenge. It is, however, highly doubtful that the Union will succeed in complying with fundamental rights while keeping in force the current blacklisting system.

Assuming that the blacklisting proceedings do fall under the scope of Articles 47 and 48, section 2 of the Charter, and Article 6 of the ECHR, various fundamental rights ought to be complied with, such as: the right to a fair and public hearing within a reasonable time, the right to be presumed innocent until proven guilty, the right to be informed promptly, in detail, of the nature and cause of the accusation against one, and the right to have adequate time and facilities for the preparation of

1833 Judgement of the Court of First Instance (Seventh Chamber) of 23 October 2008 in the case of People's Mojahedin Organisation of Iran v. the Council of the European Union (Case T-256/07), paragraph 143. See, also, judgement of the Court of Justice (Grand Chamber) of 27 February 2007 (Appeal) in the case of Gestoras Pro Amnistía, Juan Mari Olano Olano and Julen Zelarain Errasti v. the Council of the European Union (Case C-354/04 P).

1834 See Council of the European Union, The Stockholm Programme - An open and secure Europe serving and protecting the citizens of 2 December 2009, 16484/1/09 REV 1 JAI 866 + ADD 1, p. 50 .

1835 See Council of the European Union, The Stockholm Programme - An open and secure Europe serving and protecting the citizens of 2 December 2009, 16484/1/09 REV 1 JAI 866 + ADD 1, p. 51 . 
one's defence. ${ }^{1836}$ For the past few years, NGOs, academics and other organisations have furthermore developed lists of essential guarantees (primarily procedural) which must be observed in order for the blacklisting system to remain in conformity with fundamental rights and principles. ${ }^{1837}$ If one combines all these criteria, the following minimum list may be used to assess the Union blacklisting system:

1. Substantive criteria for inclusion on the blacklist should be clear;

2. There must be sufficient notification to the blacklisted parties regarding decisions taken and the grounds on which these have been taken, preferably prior to the actual implementation of these decisions;

3. The listings must be strictly time-limited and subject to effective renewal;

4. In order to profit from the right to an effective legal remedy, blacklisted parties must be allowed access to all relevant information and be given a fair hearing;

5. Effective judicial review must be assured by an independent and impartial court which moreover has the power to factually annul or modify the blacklistingdecision;

6. Compensation ought to be given to unlawfully blacklisted parties.

If one considers compliance with these conditions and principles as a precondition for (de)-listing proceedings to be in accordance with fundamental rights, the following issues arise.

Firstly, the substantive 'suspicion criterion' of involvement in terrorist acts as comprised in CP 931, is broad, and leads to a considerable discretionary power for the Member States and the Council. Until 2009, the Union Judiciary did not scrutinise compliance with this criterion. Broad discretionary powers for the Member States and the Council accordingly limit the possibilities for the Union Judiciary to examine the lawfulness of blacklisting decisions. Also, the periodic review of blacklisting decisions loses effectiveness when the criteria for inclusion on the blacklist are broad.

Secondly, no type of hearing is held, and no statement of reasons needs to be provided to the party concerned, prior to, or after, the blacklisting and the imposition of fund-freezing measures. If a hearing is held after the imposition of these

\footnotetext{
1836 See also Articles 48 to 51 of the Charter.

1837 See, in this respect also, Article 52 of the Charter, which prescribes that any limitation on the exercise of the rights and freedoms recognised by the Charter must be provided for by law and respect the essence of those rights and freedoms. Limitations may - subject to the principle of proportionality - only be made if they are necessary and genuinely meet objectives of general interest recognised by the Union or the need to protect the rights and freedoms of others. Furthermore, this article prescribes that rights which correspond to rights guaranteed by the ECHR must be interpreted, as to meaning and scope, in the same way as those laid down by the ECHR.
} 
measures, that hearing only serves to inform the party concerned of the measures imposed and of the national decision underlying the Council's decision. In addition, information underlying the blacklisting decision does not fully need to be disclosed to the party concerned, certainly not when national security is at stake. As a result, blacklisted parties are not, generally speaking, (fully) informed of the reasons for being considered as involved in terrorist acts. It goes without saying that respect for the right to an effective legal remedy and the right to effective judicial review is difficult to realise in such circumstances.

Regarding the Council's obligation to state reasons, it is furthermore important to keep in mind that, with regard to substance, fulfilling this obligation is not always fully possible. First of all, the Union Judiciary has repeatedly argued that Member States are allowed to keep certain information confidential when national security demands so. Secondly, Member States are attributed a rather large discretion in deciding which party is to be included on the list, which consequently limits the Council's powers in that respect. Furthermore, Member States and the Council are obliged to cooperate in good faith and mutual trust, which further limits the Council's power throughout the listing proceedings. This implies that the Council not easily refuses a blacklisting initiative of a Member State, even if the underlying information is not as convincing as it ought to be. Once the Council has verified that a national decision pursuant to article 1(4) of CP 931, has been taken, a person/ entity/organisation is included on the blacklist and subjected to fund-freezing measures. Thus, even though the Council is theoretically the competent authority to blacklist a party, factually speaking the Member States decide who is to be included on the Union blacklist.

Thirdly, parties are - theoretically at least - listed for six months, after which time the Council examines whether continued inclusion on the blacklist is still justified. This implies that the Council should perform a full (new) review of the reasons for, and hence, the lawfulness of, a party's inclusion on the blacklist. The actual practice is different: so far, only Morabit was delisted on the Council's own motion. Other blacklisted parties, such as the PMOI, remained on the list despite the fact that they had already been delisted at national level. Sison stayed on the list, notwithstanding the fact there was insufficient substantive evidence for his alleged involvement in terrorist acts. And even when the Union Judiciary finally ordered the Council to delist Sison, his assets remained frozen.

Even though the Council is obliged to provide a blacklisted party with a new statement of reasons following the periodic review, often the Council confines itself to a literal copy of the preceding statement of reasons. The Union Judiciary tolerates this practice, and even underlines that two identical statement of reasons - one for the initial blacklisting decision and one for a subsequent decision - only reaffirms the fact that the reasons for a party's inclusion on the blacklist are still valid. This means that the prescribed periodic review, in real terms, comes down to a simple 
six-month extension of the blacklisting decision without the required full review of the initial reasons for inclusion on the list. In this respect, it is, furthermore, of importance to note that periodic review of the blacklisting decisions is performed by the executive authority itself, who, moreover, initially imposed the measures, instead of by a court.

Fourthly, despite the fact that in theory there is a remedy available for blacklisted parties belonging to Category 1 and 2, the above-discussed procedural deficiencies, the broadly edited substantive provisions, and the fact that fair trial principles are only in part applicable, undermine the right to an effective legal remedy. The Union Judiciary interprets the right to an effective legal remedy as having factual access to a remedy. Such access is adequately guaranteed, as long as blacklisted parties are provided with an adequate statement of reasons and when they are heard. Hence, the Judiciary's interpretation comes down to the questions of: (1) whether the Council has complied with its obligation to state reasons, and (2) of whether the blacklisted party has been heard. This means that the right to an effective legal remedy is made completely dependent on compliance with the other two defence rights and is, as such, of little value.

Fifthly, the above-discussed case law shows that the scope of judicial review before the Union Judiciary is limited. Both the Council and the requesting Member State are allowed to withhold information from the Union Judiciary and the blacklisted party if national security is at stake. The Council is, moreover, to cooperate in good faith with the Member States, which allows full play for the requesting Member State when it comes to blacklisting. Also, the Council and the Member States have a large margin of appreciation/discretion in deciding who is to be included on the blacklist.

In general, when it comes to Category 1 terrorists, one can wonder how effective judicial review is at all, taking into account the fact that the Union will most likely not supersede the UN Sanctions Committee. Effective judicial review regarding claims of blacklisted parties belonging to Category 3 are clearly insufficient. So far, the Union Judiciary has declared actions parties belonging to Category 3 inadmissible.

Even though full respect for fair trial principles is still far from being realised for blacklisted parties within the Union, some improvements have been made since 2006. As result of the 2006 OMPI and PMOI judgements and the 2008 Kadi judgement, the Council is currently obliged to comply - to a certain extent at least - with defence rights during the (de)-listing procedures, and to assure blacklisted parties access to an effective legal remedy. The most unequivocal procedural improvement is undoubtedly the fact that blacklisted parties must at some point be provided with a statement of reasons. If the Council fails to comply with this essential procedural requirement, the Union Judiciary automatically annuls the 
blacklisting decision. The right to a fair hearing, the right to an effective legal remedy, and the right to effective judicial review, cannot be guaranteed without a statement of reasons.

However, the 2009 Sison judgement also demonstrates that compliance with the obligation to state reasons may, in terms of procedural requirements, be fulfilled, while in terms of substance, it is still completely unclear why, in fact, a party has been included on the list. If the Council provides a blacklisted party with a letter containing an enumeration of terrorist acts that fall under CP 931, it therewith complies with the procedural side of the obligation to state reasons. However, that does not automatically imply that substantive requirements have also been met. The 2009 Sison judgement is the only judgement in which the Union Judiciary examined this latter issue and ordered the Council to delist Sison because there was insufficient evidence to assume that he was involved in terrorist acts. With hindsight, this means that Sison had been included on the blacklist and had had his assets frozen for eight years without there being any convincing evidence of his alleged involvement in terrorist acts. 


\section{Chapter IX Conclusions and Recommendations}

\section{INTRODUCTION}

Dutch anti-terrorism legislation aims at preventing terrorism rather than at responding to it. This goes for all of the powers discussed in this dissertation, irrespective of the applicable field of law. To that effect, criminal liability has been expanded, the criteria for application of state powers have been decreased, and the scope of these powers consequently increased. This has led, and continues to lead, to interferences with civilians' fundamental rights and it undermines fundamental principles of (criminal) law.

The difference between the powers discussed in the previous chapters regards the required criteria for application, the nature, and the scope of the powers. Every level of 'suspicion' provides state authorities with one or more powers or measures to counter terrorism. The pursuit of such a 'broad approach' implies that there should be no gaps in the arsenal of state powers to counter terrorism, even when it is highly questionable whether there is indeed a situation involving terrorism. At present it has become highly unlikely that there will be a situation where state authorities are not allowed to use one or more of the powers or measures discussed above. The Somali case, as referred to in the introduction, and the National Anti-Terrorism Coordinator's comments regarding that case, are important proof of the accuracy of this presupposition.

This last chapter elaborates on three issues. Firstly, the general characteristics of Dutch anti-terrorism legislation will be discussed, to begin with substantive antiterrorism legislation and then procedural anti-terrorism legislation. Implementing anti-terrorism legislation into the Dutch common criminal justice system has created a dichotomy within that system: Common offences and corresponding state powers, as opposed to terrorist offences and their corresponding state powers. Hence, despite the fact that terrorism is considered as a separate category of specific criminal behaviour requiring a different approach, it has been vested within the common criminal justice system. That is important to keep in mind with respect to the following sections.

Secondly, the scope of the repercussions of anti-terrorism legislation for fundamental rights and principles of law is scrutinised. Can the powers and measures to prevent terrorism discussed above be considered in compliance with these rights and principles, specifically when considered in light of the lowered criteria for application? 
Thirdly, in the last section I will provide several possible solutions to counterbalance the interferences that the current anti-terrorism powers and measures have on the right to liberty, the right to privacy, the right to freedom of movement and on defence rights. These recommendations may contribute to adequately countering terrorism without overstepping the Dutch treaty obligations in the field of international fundamental rights and principles of law.

\section{Characteristics of DUtCh anti-Terrorism legislation}

\subsection{Substantive anti-terrorism legislation}

Characteristics of substantive anti-terrorism legislation are primarily found in the amendments to the DCC brought about by the DTA. As mentioned above, these amendments have produced, within the DCC, a dichotomy: the DCC currently consists of terrorist offences and of common offences. This is striking, taking into account that, for example, offences regarding illegal weapons and ammunition and offences relating to drugs have been codified in separate acts.

Articles $83,83 \mathrm{a}$ and $83 \mathrm{~b}$ of the DCC are broadly defined, both to comply with the FD 2002/475 and FD 2008/919, and to encompass Dutch legislative initiatives. Practice shows that these provisions have significantly broadened criminal liability, in respect of both terrorist offences, and the common offences to prepare or facilitate terrorist offences. The extended criminal liability is foremost visible in offences committed during the pro-active phase. ${ }^{1838}$

Conspiracy to commit a terrorist offence, preparatory behaviour pursuant to Article 96, section 2 of the DCCP and pursuant to Article 46 of the DCCP, and participation in a terrorist organisation, are the most prominent examples. The ambiguity of these provisions and the weak linkage between terrorist intent and the factual behaviour required for criminal liability, as well as the rather low requirements for such behaviour, not only undermine the principle of legality, but also create legal uncertainty. The risk of holding people criminally liable for terrorist offences primarily on the basis of intentions rather than on the basis of the factual danger, which they, through their conduct, pose or may come to pose to society, its legal values, and persons' lives or goods, has increased considerably with the entering into force of the DTA.

Before enactment of the DTA, the Dutch criminal justice system already gave plenty of room to prosecute terrorist crimes, without, however, the label 'terrorist' attached to the behaviour liable to punishment. What the DTA actually does is to broaden criminal liability for inchoate offences and, indirectly, to broaden the scope of application of investigate powers during the pro-active phase. As a consequence,

1838 See, explicitly, B. van Gestel, C.J. de Poot en R.F. Kouwenberg, De wet opsporing terroristische misdrijven drie jaar in werking, WODC, Memorandum 2010-3, p. 12. 
the preparatory investigation has become more inquisitorial regarding investigations into terrorism.

\section{TERRORIST INTENT}

The introduction of 'intent' on such a large scale as a constitutive element in criminal law provisions within the DCC, is revolutionary. As will be demonstrated below, 'intent' as a constitutive element of criminal law provisions brings about a considerable subjectivism within the DCC. Notwithstanding the case law on Article $83 \mathrm{a}$ of the DCC, which defines terrorist intent, the precise scope of this concept remains uncertain. The case law discussed in Chapter II demonstrates that whether or not a suspect acted with terrorist intent, depends on the specific circumstances of the case. The way in which the offence has been committed (factual circumstances), oral or written statements/documents (on the internet) belonging to or read by the suspect, objects found at the suspect's home, the factual consequences which the offence induced within society, and the (destabilising) effects which the offence brought about in society, are all aspects that play a role in this respect. However, in all judgements regarding alleged terrorist offences, the political religious conviction of the suspect contributed, considerably, to proving terrorist intent. ${ }^{1839}$

Terrorist intent refers to the aims of a suspect rather than to his factual success in materialising his intentions. For example, theoretically, it is irrelevant whether (part of) a population was indeed frightened by his actions, as long as he intended to frighten them. The Judiciary does not always follow this line of reasoning. Up to now, in some of the judgements the Judiciary exclusively examined whether (part of) the population could be considered as being frightened by an alleged terrorist offence, whereas in other judgements, the Judiciary also explicitly took into account the suspect's actual intentions. This latter situation is most clearly demonstrated in the case of two members of the Hofstadgroep. Even though people must have been frightened after two suspects threw hand grenades at policemen, it could not be proven that this was the suspects' intention before they actually threw the hand grenades - i.e. when they possessed the hand grenades. But in other cases, the Judiciary has underlined the fact that (part of) the population must be considered frightened by a suspect's behaviour, even though that was not necessarily the suspect's intention.

Such dissimilarities in the interpretation of terrorist intent are almost intrinsic to the introduction of intent as a constitutive element of many forms of common criminal behaviour, specifically in the case of inchoate terrorist offences. This is due to the fact that terrorist intent refers to a certain state of mind. It is impossible to determine with absolute certainty, from the outward manifestation of a criminal offence, what its actual aim was. One needs the suspect's statements, documents 
and/or witness testimonies to clarify his intent. In practice, terrorist intent is primarily established by means of objects and documents owned by the suspect, demonstrating adherence to the extreme Islam, rather than by the suspect's direct statements or factual conduct. Often the accused of a terrorist offence remain silent during criminal proceedings.

In this respect, it is important to distinguish between 'complete' offences, such as terrorist murder, kidnapping or assault, and inchoate offences, such as conspiracy to commit a terrorist murder. The further one criminalises behaviour in the proactive phase, the more one has to prove, and therefore to substantiate with evidence the suspect's ideas, plans, ideals or intentions, and, more particularly, the suspect's intent with, for example, conspiring to commit or preparing, an intended crime. This implies that objective circumstances, such as what specific objects or documents a suspect possesses, become of importance, primarily when they are considered in the light of the suspect's presumed intentions. Naturally, discovering someone's intentions is a difficult task. This is certainly the case when no objectively incriminating and, moreover, dangerous factual behaviour has (yet) been exhibited by the suspect.

For example, the illegal possession of a loaded weapon is a crime in itself, but is insufficient proof off the intent to commit a terrorist offence with that weapon, even if the suspect forms part of a terrorist organisation. The possession of the weapon in itself might be an individual decision of the suspect, even against the wishes of the organisation. On the other hand, to shoot a well-known person in broad daylight, and leaving a threatening letter pinned on his chest, addressed to all unbelievers, can undoubtedly be considered as a terrorist murder.

Hence, terrorist intent, combined with the illegal possession of ammunition or arms, does not automatically turn a common WAA crime into a terrorist offence, or into a WAA crime that serves to prepare a terrorist offence. To prosecute a suspect caught while illegally possessing weapons for a terrorist WAA offence, the prosecution must prove: (1) what the suspect's intent was with the arms he possessed, and (2) what he aspired to accomplish with the intended crime. Case law shows that the difficulty lies not in proving the suspect's intentions, but in linking, beyond reasonable doubt, these intentions to the terrorist offence still to be committed.

In theory, terrorist intent, as such, is insufficient for a conviction. It must be linked to the factual conduct the suspect displayed. There must be a clear and, preferably objectively, verifiable connection between a suspect, his intentions and the specific offence/behaviour he committed/displayed. The mere simultaneity of terrorist intent and (illegal) factual conduct does not justify the automatic conclusion that (illegal) conduct was committed with terrorist intent. ${ }^{1840}$ 
It is, however, important to note that this factual conduct does not need to pose a direct threat to the legal order, to persons or goods. In addition, the requirement of factual conduct in terrorist cases appears to be not as demanding as in cases of common criminal offences, especially when it regards inchoate offences. Case law shows, furthermore, that the harm that would have occurred when the suspect would not have been arrested for an inchoate terrorist offence is often not particularly clear. That does not, however, stand in the way of holding a person criminally liable on account of a terrorist offence or an offence that serves to prepare or facilitate a terrorism offence. The scope of terrorist intent and the required connection between this intent and the factual conduct in the case of the aforementioned three inchoate terrorist offences will now be further elaborated upon.

\section{TERRORIST INTENT AND PREPARATORY BEHAVIOUR}

The DPTA amended Article 46 of the DCC. Objects which serve to prepare a (terrorist) offence no longer need to serve evidently [kennelijk], to prepare such an offence. The subjective purpose of the objects is considered sufficient to constitute criminal liability. ${ }^{1841}$ Consequently, even more weight is attached to the suspect's intention itself, than to objectively verifiable facts and circumstances. The amendment to Article 46 of the DCC not only applies in the case of terrorist offences, but also in the case of common offences. This means that the broadened criminal liability in this respect goes beyond that of terrorist offences. Even to possess objects that are, in themselves, completely harmless, may be construed as incriminating evidence for the preparation of a (terrorist) offence or the intention to commit such an offence. The question of whether such objects found in the suspect's possession, separately or collectively, by their outward manifestation at the time of the material conduct, could have been suitable for the criminal purpose that the suspect had in using them, has become more important than the question of whether these objects could have served to factually prepare a terrorist/criminal offence.

From the judgements discussed in Chapter II it appears that these intentions are, again, primarily deduced from documents on radical Islam, threatening documents confiscated at the suspect's house, witness statements, online chat conversations on the violent Jihad, and evidence from taped telephone conversations. ${ }^{1842}$ These kinds of information are used: (1) to demonstrate a suspect's terrorist intentions, and (2) to prove the suspect's factual conduct, for example, for the purposes of Article 46/ Article 96, section 2, and Article 131, 132, 137d of the DCC.

1841 Kamerstukken II 2004-2005, 30 164, no. 3, p. 49. See, in this respect, S.L.J. Janssen, 'De strafbare intentie is bijna een feit', in NJB 2006/0757.

1842 See Chapter II, Section 5.2. 
It is of crucial importance at which moment objects found in a suspect's possession are evaluated, and in light of what presumed intentions. The criminal proceedings against Samir A. on account of preparatory behaviour demonstrate that the Dutch Supreme Court tends to evaluate such objects ex ante instead of ex post. In that case, the intended use of the unfit explosives was crucial and the Judiciary abstracted from the fact that the means to materialise the presumed intentions were unfit. ${ }^{1843}$ This means that subjective intentions, that become clear from documents and other objects demonstrating a suspect's adherence to a violent form of Islam are considered decisive in inferring criminal liability pursuant to Article 46 of the DCC. Sympathy for radical Islam in the past may also play a role. The question of whether the suspect actually poses, or is going to pose, an objective verifiable danger to society due to his preparatory acts, is irrelevant. ${ }^{1844}$

The assertion that ideas, beliefs and intentions are not punishable within the Dutch criminal justice system becomes questionable when the requirements for factual behaviour on account of Article 46 of the DCC are decreased to such an extent. Both a suspect's factual behaviour, which does not need to threaten the legal order/ values, and, for example, the objects he possesses, which, in themselves, may be completely harmless, are valued in light of his presumed (terrorist) intentions. Objects found in a suspect's possession which are used to constitute criminal liability under Article 46 and Article 96, section 2 of the DCC in themselves do not need to threaten the legal order, they merely need to be potentially useful to prepare a terrorist offence. This implies that determining the suspect's intentions is needed in order to ascertain whether objects in the suspect's possession may serve to prepare a terrorist offence. The suspect's intention to commit a terrorist offence, combined with his intended use of the preparatory object(s) is then decisive in answering the question of whether that suspect can be convicted on account of preparatory behaviour. Accordingly, the direct connection between the offence and the preparatory object(s) becomes less obvious and less important while the suspect's intentions increase in importance.

\section{TERRORIST INTENT AND PARTICIPATION IN A TERRORIST ORGANISATION}

In Chapter II the criminal proceedings against the Hofstadgroep and the Piranha groep were discussed. The judgements in these cases demonstrate that in the case of prosecution on account of Article 140a of the DCC, the mental and/or political

1843 Note that Samir A. was not prosecuted on account of terrorist offences. The DTA had not yet entered into force at the moment when he committed the offences. Rotterdam District Court, 6 April 2005, LJN: AT3315, 10/030075-04; the Hague Court of Appeal 18 November 2005, LJN: AU6181, 10-00075-04, NJ 2006/96, Supreme Court 20 February 2007, LJN: AZ0213, 00447/06; the Amsterdam Court of Appeal, 17 September 2007, LJN: BB3756, 23-001907-07.

1844 The fact that Samir A. choose to remain silent during trial, and his failure to explain the objects found, was also taken into account. 
religious legacy of suspects plays a crucial role in: (1) deciding on the question of whether the suspects formed an organisation and (2) in ascertaining whether that organisation aspired to commit terrorist offences. During the proceedings against the Hofstadgroep and the Piranha groep all the courts asked to rule on these issues came to a different conclusion on the basis of different considerations.

With the situation as it stands, a group is considered to be an organisation when the members of the group can be considered to feel tied to one another due to their common extreme violent, political, and religious beliefs. This may be assumed when all members are more or less systematically taught those beliefs, and when structured activities are organised to further convince one another of those beliefs and 'to mature their spirits' for participation in the violent Jihad. Also, the fact that all members possess the same inciting/threatening documents is used as evidence of the structured nature of a group. This means that the commonly shared and practiced interest in extreme beliefs/ideologies is sufficient to demonstrate that several suspects cooperate in a structured and enduring manner. The fact that the suspects differ regarding: (1) the extent to which they accept and are involved in shared political religious beliefs/ideologies, and (2) the intensity of the contacts they maintain with other group members, does not matter in this respect.

As to the second requirement for criminal liability under Article 140a of the DCC, that the organisation's jointly shared purpose must be the perpetration of terrorist offences in the near future, it is striking to see that in this respect also, the political and religious beliefs/ideologies of the suspects play an important role.

Adherence of suspects to a religiously based ideology that preaches the use of violence against non-believers is not sufficient to prove the organisation's intent of committing violent terrorist offences. To that effect, it must be proven that the organisation has started realising these beliefs by means of practical (illegal) activities, such as the possession of weaponry and/or by actively gathering information, such as addresses of prominent politicians. But adherence of suspects to such religiously based ideologies, while possessing inciting and threatening documents that are meant to be distributed beyond the organisation, is adequate to demonstrate the organisation's purpose of the common and terrorist offences pursuant to Articles 131, 132, 137d and 285 of the DCC. Uttering threatening words and distributing threatening texts directed at certain prominent politicians is insufficient proof of the potential committing of a terrorist murder in the near future, but is considered sufficient to prove that an organisation was aiming to threaten these politicians with terrorist offences, even though the threats were not directly, and in person, expressed against them. When suspects distribute threatening documents outside the organisation and incite others to distribute these documents further, it may prove the group's purpose of inciting others to join the violent Jihad, but, for example, again is insufficient to prove preparation of a terrorist attack. 
All in all, case law makes clear that illegal or legal 'action' and a shared radical ideology which justifies the use of violence is sufficient to assume that a terrorist organisation has a joint purpose, namely, the perpetration of (violent) terrorist offences. Concrete action, like possession by group members of documents on radical Islam, or documents that incite to commit (terrorist) offences, together with the group's beliefs, justify, then, the conclusion that the organisation aimed at committing common and terrorist offences. This implies that an organisation's (criminal) activities are evaluated in light of the organisation's (violent) ideological and/or religious beliefs, rather than the other way around.

Participation in a terrorist organisation is only liable to punishment when the participatory behaviour is considered to contribute to the realisation of the joint purpose - the commission of terrorist offences. That presupposes a clear connection between the knowledge/intent of the organisation's member, that organisation's goal, and the factual behaviour of this organisation's member. Merely forming part of the organisation, without factually contributing to the realisation of the organisation's purpose, is, theoretically, not liable to punishment. Vice versa, if a person commits a terrorist offence, but does not really belong to the organisation, this person cannot be convicted pursuant to Article 140a of the DCC either. However, the factual significance of the requirement of actual participatory behaviour is limited in the case of Article 140a of the DCC.

Criminal liability in respect of participation in a terrorist organisation presupposes compliance with two requirements: (1) 'the subjective aspect' implying that it has been proven, that, for example, the suspect adheres to beliefs in which the use of (deadly) violence is justified. This then enables the Judiciary to determine whether or not the suspect acted with terrorist intent as comprised in Article 83a of the DCC; and (2) 'the objective aspect' which requires that these beliefs must have been (partly) manifested by means of practical (preparatory) behaviour, such as the possession or distribution of inciting documents. Requirements for the objective aspect are all but demanding.

In the Hofstadgroep case, the District Court and the Hague Court of Appeal judged reading, listening to, or possessing, inciting and threatening texts, without the intention to distribute them, as non-participatory behaviour, and hence, not as leading to criminal liability. Possessing large quantities of documents on the violent Jihad and manufacturing guides for bombs was allowed, with reference to Articles 9 and 10 of the ECHR. The Hague Court of Appeal underlined that the freedom of religion pursuant to Article 9 of the ECHR, also comprises the right to convince, for example, neighbours or friends to change religion by means of such written documents. However, once these documents are used to insult or threaten others or to incite others to join, for example, the violent Jihad, such behaviour no longer falls under the protective sphere of the right to freedom of opinion and the freedom of religion. 
The Amsterdam Court of Appeal went one step further - after the Dutch Supreme Court's judgement - and concluded that: (1) receiving and keeping documents that incite the use of violence or that contain threatening texts combined with (2) attendance at meetings of the organisation, is sufficient to be held liable on account of Article 140a of the DCC. How such behaviour directly contributes to the commission of terrorist offences remains unclear. ${ }^{1845}$

In the Hofstadgroep case, the Piranha I and the Piranha II cases, all suspects were charged with participation in a criminal and in a terrorist organisation. The question was then, of course, whether members must have known about the criminal and terrorist offences in order to be convicted on account of both Article 140 and Article 140a of the DCC. The District Court and the Hague Court of Appeal concluded that for criminal liability in respect of participation in a criminal and terrorist organisation, it is sufficient when the group member knew, in general, about the organisation's intent of committing criminal offences [onvoorwaardelijk opzet $]$ and about the chance that the group might shift towards committing terrorist offences, as well [voorwaardelijk opzet].

The Amsterdam Court of Appeal held an even broader interpretation: the suspect must, in general, know about the organisation's intent of committing offences. The suspect does not, however, need to have intent on the organisation's offences, nor does he have to participate in the perpetration of an offence or know of any concrete criminal or terrorist offence. In addition, criminal liability does not require the suspect to have cooperated with or known all of the group members. It goes without saying that such an interpretation of Articles 140 and 140a of the DCC quite easily broadens criminal liability. The added value of the requirement, that for criminal liability under Article 140/140a of the DCC, one needs to actually participate in the organisation, accordingly becomes minimal. The knowledge of the organisation's member about the organisation's intentions has become more important than the question of whether he factually contributed to the realisation of the organisation's purpose. ${ }^{1846}$

In this respect, it is also important to note that Articles 140 and 140a of the DCC do not presuppose that the terrorist offence(s) which the organisation intents to commit, has/have already been committed. Thus, if it can be proven that the (terrorist) organisation aimed at committing such offences and the members generally knew about these intentions, the members may already be liable to punishment. Due to the penalty attached to Article 140a of the DCC (maximum of 15 years imprisonment), Article 46 of the DCC may, moreover, be used to determine the purpose of the organisation. Vice versa also, theoretically speaking at least, prosecution on account of preparation of participation in a terrorist organisation is possible. Such a combination comes down to the criminalisation of behaviour that takes place long

1845 See Chapter II, Section 6.3.1.

1846 See Chapter II, Section 6.3.1. 
before the 'complete' terrorist offence of Article 140a of the DCC takes place. Compared to Article 140 of the DCC (maximum of 6 years imprisonment) this obviously implies a broadened criminal liability. This may lead to the criminalisation of behaviour that takes place largely before the factual perpetration of any 'common criminal behaviour'. ${ }^{1847}$

\section{CONSPIRACY AND TERRORIST INTENT}

The DTA considerably extended the scope of conspiracy pursuant to Article 96 of the DCC: there are almost 30 'terrorist conspiracy offences' at present. Article 96 of the DCC includes the most far-reaching form of criminal liability in respect of terrorist offences. It is beyond doubt that the conduct that Article 96, sections 1 and 2 of the DCC criminalises is primarily connected to a person's intentions, rather than to their clear, objective, and factual, conduct. In Article 96, section 2, subsections 1 to 5 of the DCC, criminal liability is constituted, irrespective of the consequences or results. The mere intention of preparing or facilitating the commission of limitative enumerated terrorist offences, and 'some concrete steps' towards the realisation of that intention, are sufficient for criminal liability. A direct relationship between what a person strives to realise, for one thing, and any form of behaviour that directly threatens or may come to threaten the legal order/values, for another, is not required.

Intentions, on account of Article 96, section 2 of the DCC, may very well be sustained by the suspect's adherence to some extreme political religious law that justifies the use of violence against non-adherence. The required 'concrete steps' are shown by means of more practical evidence - however limited - like an attempt to acquire a weapon with the intent to prepare an offence, or with the intent of inciting another person to provide means that contribute to the preparation of an offence. Theoretically, a person who exclusively adheres to extreme interpretations of, for example, Islam cannot be convicted under Article 96, section 2 of the DCC, but the factual conduct required, pursuant to this provision, is so minimal that, at the very least, intentions are predominant in inferring criminal liability under this provision.

The criminalisation of conspiracy to commit a terrorist offence implies a double uncertainty. The act of conspiracy comes down to a declaration of intent and a terrorist offence includes terrorist intent. ${ }^{1848}$ Conspiracy to commit a terrorist

1847 See, in this respect, Anti-terrorismemaatregelen in Nederland in het eerste decennium van de 2le eeuw. Over totstandkoming, toepassing, beoordeling en aanpassing van antiterrorismemaatregelen in Nederland 2001-2010, January 2011, Nationaal Coördinator Terrorismebestrijding, bijlage H: P.H.P.H.M.C. van Kempen, J. van de Voort, Nederlandse antiterrorism-regelgeving getoetst aan fundamentele rechten. Een analyse met meer bijzonder aandacht voor het EVRM, Radboud Universiteit Nijmegen 1 December 2010, pp. 32, 34 and 39.

1848 The same line of reasoning applies to the preparation of a terrorist offence pursuant to Article 46 of the DCC (possessing objects that are intended to prepare an offence with terrorist intent), and 
offence therefore leans heavily on presumptions regarding the potential realisation of intentions, intentions that might just as well have changed, or even disappeared. The government has argued that the prosecution can be trusted to apply criminal law in a proper and just way, also when it comes to the prosecution - read prevention - of terrorist offences. I wonder whether that trust is justified.

Firstly, one should keep in mind that the prosecution is under very heavy pressure to prevent all acts of potential terrorism. ${ }^{1849}$ Secondly, terrorism might not be, but Islamic terrorism certainly is, a relatively new phenomenon in the Netherlands. Thirdly, terrorist offences and the accompanying procedural powers based on lower suspicion criteria to investigate such crimes are new within the DCC and the DCCP, respectively. ${ }^{1850}$ Fourthly, many terrorist offences take place during the pro-active phase. ${ }^{1851}$ This creates a considerable amount of uncertainty and a strong reliance on information provided by the secret intelligence services, which, by their character, tends to be kept secret, at least with regard to the sources.

As will further be discussed below, suspicions are certainly less clear and unambiguous than they should be in order to justify the application of far-reaching procedural powers that interfere with persons' rights. So much uncertainty throughout criminal proceedings paves the way for legal errors. ${ }^{1852}$ Recent examples corroborate the accuracy of this presumption. ${ }^{1853}$ Besides the consequent violations of persons' fundamental rights at the moment of application of procedural powers, this may also lead to defamation of character.

In addition, one sees that in the view of many, some communities, as a whole, become suspect, merely because persons belonging to that community were

participation in a terrorist organisation pursuant to Article 140a of the DCC (an organisation which intends to commit offences with terrorist intent).

1849 The terrorist threat is assumed to persist. Many authors have criticised this unsubstantiated claim. See, for example, Naar een integrale evaluatie van anti-terrorismemaatregelen. Rapport van de Commissie evaluatie anti-terrorismebeleid, May 2009, at: www.nctb.nl/Images/Rapport_ Suyver_tcm91-203904.pdf.

1850 See C.J. de Poot, R.J. Bokhorst, W.H. Smeenk, R.F. Kouwenberg, De Opsporing verruimd? De Wet opsporing terroristische misdrijven een jaar in werking, WODC, Cahier 2008-9; B. van Gestel, C.J. de Poot, R.J. Bokhorst, R.F. Kouwenberg, Signalen van terrorisme en de opsporingspraktijk. De Wet opsporing terroristische misdrijven twee jaar in werking, WODC Cahier 2009-2010; B. van Gestel, C.J. de Poot en R.F. Kouwenberg, De wet opsporing terroristische misdrijven drie jaar in werking, WODC, Memorandum 2010-3.

1851 For the prosecution of terrorist offences committed beyond the pro-active phase anti-terrorism legislation is not necessary. A terrorist murder can just as well be prosecuted on the basis of Article 289 of the DCC.

1852 See NRC Handelsblad 13 March 2009, 'Zeven personen vast na bedreiging A'dam. Terrorisme Huiszoekingen in Amsterdam; geen explosieven gevonden; winkels weer open'.

1853 See NRC Handelsblad 21 March 2009, 'Mo is nog elke dag bang voor Guanánamo. Terrorisme advocaten en ombudsman willen meer excuses en vergoeding van overheid voor inbreuk op leven na onterechte arrestaties'. See, also, NRC Handelsblad 17 March 2007, 'Cohen: belster wist geen details' and NRC Handelsblad 16 March 2009, 'Een 'serieuze dreiging' die binnen 24 uur verdampte'. 
suspected of being terrorists without any proper reason. ${ }^{1854}$ In turn, this labelling paves the way for social/cultural friction, envy and even hatred, between immigrants and natives, with all the possibility of public disorder. ${ }^{1855}$ The vicious circle this might create might well form a hotbed for future terrorism. There is, accordingly, an undeniable connection between an excessively broadly defined criminal liability, far-reaching procedural and investigative powers into terrorism, and the violation of fundamental rights and general principles of law. This certainly, by itself, does not necessarily make society more stable or more secure, whatever the claims to the contrary.

To criminalise behaviour that takes place during the early stages of the pro-active phase, like conspiracy to commit a terrorist offence, undermines the protective function of the principles of proportionality, subsidiarity and legality. That makes it quite incomprehensible that the Dutch government did not deem it necessary to consult the Council of State, or the advisory bodies of the Judiciary, the prosecution service, the police and the Bar Association, as is customary, regarding the amendments to Article 96 and 205 of the DCC. Taking into account the broadened criminal liability and the fact that Articles 96 and 205 of the DCC are not a requested implementation of the FD 2002, the recommendations by the Council of State would have been all the more important.

\section{CRiminal LiabiLity ASSURED}

The three examples discussed above - preparation of a terrorist offence, belonging to a terrorist organisation and conspiracy to commit a terrorist offence - are no random choice. These three terrorist offences complement each other and guarantee full criminal liability for terrorism during the pro-active phase. When there is insufficient information to sustain a person's alleged participation in a terrorist organisation, the available information may be sufficient to substantiate a suspicion on account of the (joint) preparation of a terrorist offence, or even of conspiracy to commit a terrorist offence. Finally, there is the possibility of criminal liability on account of the intent to prepare or facilitate a limitative enumerated set of terrorist offences pursuant to Article 96, section 2 of the DCC.

1854 See, in this respect, M.A.H. van der Woude, 'Brede benadering terrorismebestrijding', in Openbaar bestuur, November 2009, pp. 2-5.

1855 See NRC Handelsblad 10 July 2009, 'Moslims nemen moord in rechtszaal hoog op. Duitse moslimraad signaleert discriminatie'. See, also, NRC Handelsblad 3 February 2009, 'Baardige Arabier meestal onschuldig'; NRC Handelsblad 27 July 2009, 'Verdachte van terreurmelding Ikea vrijgelaten'; W.H. Press, 'Strong profiling is not mathematically optimal for discovering rare malfeasors', in PNAS (Proceedings of the National Academy of Sciences), 10 February 2009, vol. 106, no. 6, pp. 1716-1719. 
The DTA unequivocally aims at preventing terrorism by means of the criminal justice system. Therefore, the government: (1) enacted broadly drafted criminal law provisions regarding terrorist offences, and (2) expanded the scope of existing common criminal law provisions during the pro-active phase. Persons adhering to extreme interpretations of, for instance, Islam, but who have hardly taken any steps to materialise these beliefs - let alone factually endangered society, other persons or goods - become liable to punishment. The Minister of Justice even argued that preparation of conspiracy to commit a terrorist offence is - theoretically speaking, at least - liable to punishment. ${ }^{1856}$ It is questionable whether such behaviour may, in light of the system of the DCC, be considered a criminal offence, taking into account that conspiracy is considered as specialis of preparation, and preparation of preparation is not liable to punishment within the Dutch criminal justice system.

Furthermore, in the explanatory memorandum of the DTA, the Minister of Justice argued that conspiracy regards intentions and readiness, as well as willingness to commit a terrorist offence. ${ }^{1857}$ Apparently, in the Minister of Justice's opinion, no factual criminal conduct in the common sense is required to convict a person for such a crime. As has been demonstrated above, case law shows that for criminal liability pursuant to Articles 96, 46 or 140/140a of the DCC, some factual conduct is still required, even though that conduct does not need to be criminal in nature. However, requirements for a conviction under the aforementioned provisions with regard to the required factual behaviour have become all but demanding.

The broad definition of terrorist offences makes the application of investigative powers possible early in the pro-active phase. Often, 'terrorist suspects' are arrested and deprived of their liberty on the basis of a 'light suspicion' of an inchoate offence. Throughout pre-trial detention, the investigative authorities often release the suspect due to lack of evidence or, when it does come to criminal proceedings, the suspect is acquitted. ${ }^{1858}$ Accordingly, the substantive criminal justice system is at risk of being robbed of its substance, and merely being used to facilitate the application of procedural powers in order to prevent presumed terrorist suspects from realising

\footnotetext{
1856 Kamerstukken II 2003/04, 28 463, nr. 10, p. 19.

1857 Handelingen II 2003/04, nr. 33, p. 2350; Kamerstukken I 2003/04, 28 463, nr. C, p. 10.

1858 NRC Handelsblad 6 June 2009, 'Verdachten terreur zelden veroordeeld'. See, also, B. van Gestel, C.J. de Poot, R.J. Bokhorst, R.F. Kouwenberg, Signalen van terrorisme en de opsporingspraktijk. De Wet opsporing terroristische misdrijven twee jaar in werking, WODC Cahier 2009-2010, p. 11 and further; C.J. de Poot, R.J. Bokhorst, W.H. Smeenk and R.F. Kouwenberg, De opsporing verruimd? De Wet opsporing terroristische misdrijven een jaar in werking, WODC Cahier 2008-2009; B. van Gestel, C.J. de Poot en R.F. Kouwenberg, De wet opsporing terroristische misdrijven drie jaar in werking, WODC, Memorandum 2010-3. The WODC reports during the period 2007-2009 demonstrate that none of the 37 criminal investigations into terrorist offences led to criminal prosecution on account of the commission or the plotting of a terrorist offence. All of these investigations were halted due to a lack of adequate evidence. Often, the public prosecutor passed the collected information on to the secret intelligence services who 'continued the investigation'.
} 
their alleged intentions. ${ }^{1859}$ Procedural powers - which interfere with persons' fundamental rights - can be used without proper cause and without the required justifications, because the substantive criminal justice system currently creates an almost unlimited criminal liability regarding terrorist offences.

Even though the government argues, for example, that the preparation of or an attempt to, commit conspiracy to commit a terrorist offence are hard to prove, it is important to see that such behaviour is currently considered as a terrorist offence. This means that despite the fact that such behaviour might be difficult to prove in court, it may lead to application of far-reaching (special) investigative powers during the pre-trial phase. The question is whether such behaviour, which in fact does not threaten any legal values, is sufficient justification for the application of (special) investigative powers that interfere with fundamental rights and principles of law. This question will be examined below in Section 2.2 and 3.

So far, the Judiciary has not had the chance to examine this 'improper use' of the criminal justice system on the compatibility with fundamental principles of law, such as the principle of legality, because these cases do not generally end up before a court. After the initial phases of the criminal investigation - i.e. arrest and police custody - suspects are often released and no further criminal proceedings take place. The Judiciary has, to date, never been never asked to rule on the question of whether the definition of terrorist offence, as defined in Articles 83 and 83a of the DCC, is indeed too broad and may undermine the principle of legality, and, more precisely, undercut legal certainty. No examination takes place, paradoxically, because the material criminal law provisions are too broad and leave the Executive with too large a margin of appreciation and with too many discretionary powers. Powers which they may moreover use, without legally exceeding their authority, in order to prevent alleged intended terrorist offences, instead of to react to a yet committed (complete) crime. Broadened criminal liability for terrorist offences, combined with light suspicion criteria, and the interest of the investigation as the leading criterion for the application of investigative powers throughout criminal investigations into terrorism, makes the authorities' power to apply investigative powers unlimited in such investigations. This is further demonstrated in the following section.

Case law discussed in Chapter II demonstrates that among the Judiciary there is no consistency in terms of the scope of terrorist offences as defined in Article 83 and

1859 See, in this respect, C.J. de Poot, R.J. Bokhorst, W.H. Smeenk and R.F. Kouwenberg, De opsporing verruimd? De Wet opsporing terroristische misdrijven een jaar in werking, WODC Cahier 2008-2009, primarily p. 44 and further. The investigative authorities unequivocally contend that, for example, remand in custody is often used in the case of suspicions of which the underlying information is not verifiable. Basically, a person is then deprived of his liberty to check the reliability of the information on which the light suspicion is based and to thwart any potential terrorist threat. 
83a of the DCC. The District Court, Court of Appeal and the Dutch Supreme Court contradict each other and the Dutch Supreme Court unfortunately refrains from clearly interpreting the scope of specific terrorist offences. The lack of certainty regarding the scope of criminal liability for terrorist offences within Dutch case law is not caused by incompetence within the Judiciary, but by excessively broadly defined criminal law provisions that equip the Executive with an excessive large discretionary power, and, hence, considerably restrict the Judiciary's powers.

In sum, broadly edited criminal law provisions regarding terrorism and the farreaching state powers available to investigate such crimes tend to increasingly undermine fundamental principles of law, and especially the principle of legal certainty and legality. Articles 83 and $83 \mathrm{a}$ of the DCC have significantly broadened criminal liability, chiefly during the pro-active phase. ${ }^{1860}$ Especially inchoate terrorist offences such as pursuant to Article 96 of the DCC, do not primarily serve to guarantee criminal liability but they are used as a means to prevent risks from materialising. The main goal of anti-terrorism legislation is then to discover who may be, and who is not, connected to the perpetration (in the broad sense of the word) of potential terrorist offences. In that respect, substantive law regarding terrorist offences has become an instrument to contribute to risk management and an instrument to control, rather than an instrument to ensure criminal liability on account of yet committed criminal or terrorist offences. This also implies that the relationship between substantive law and procedural law has changed considerably when it comes to terrorism: substantive law has been made subservient to procedural law. It is to this key importance of criminal procedure in Dutch anti-terrorism policy that we will now turn.

\subsection{Procedural anti-terrorism legislation}

Following the enactment of the DPTA and the DTA, the scope of procedural (investigative or coercive) powers during the pre-trial phase has increased in the case of criminal investigations into terrorism. ${ }^{1861}$ First of all, increased penalties for terrorist offences have led to an enlarged scope of application of investigative powers. In addition, the legal prerequisites for applying such powers have been

1860 See, in this respect, H.G. van der Wilt, Het terroristisch oogmerk, in Terrorisme, Europa en strafrecht, onder redactie van M.M. Dolman, Cahiers van Hamel, Vossiuspers UvA, 2003, p. 76. Van der Wilt predicted in 2003 that terrorist intent would primarily take effect on inchoate offences, 'on the periphery of criminal liability'. He also predicted that the state would aim at bringing as much as factual conduct within the scope of terrorist intent. On both accounts, van der Wilt's presumptions proved to be right.

1861 See E. Prakken, 'Voorzichtig met Europese strafrechtelijke terrorismebestrijding', in NJB 2001/1879. In 2001 Prakken aleady drew attention to the fact that substantive criminal law provisions regarding terrorism sooner or later always lead to exception rules in the field of criminal procedure. 
decreased by the DPTA. What distinguishes the powers discussed in the preceding chapters from comparable powers to investigate common offences are the reduced criteria for application, primarily in terms of the required level of suspicion. In the case of criminal investigations into common offences, investigative authorities are obliged to demonstrate objectively visible, convincing and relevant facts or circumstances which sustain a reasonable suspicion concerning the commission of a criminal offence to lawfully exert certain powers upon civilians. In the case of terrorism, three main things have changed in this respect: (1) with regard to some powers, statutory suspicion criteria have been lowered for terrorist offences only, (2) requirements to come to a reasonable suspicion in the case of terrorism have been (informally) lowered, and (3) the interest of the investigation has become the key criterion in deciding whether or not to apply procedural powers. These three aspects will now jointly be further elaborated upon.

\section{THE INTEREST OF THE INVESTIGATION AND SUSPICION CRITERIA}

Throughout parliamentary memoranda on the DPTA, the government argued that when it comes to investigations into alleged terrorism not as much the required level of suspicion, but the interest of the investigation, is to be the decisive criterion. So, the question of whether the application of, for example, special investigation techniques may contribute to the investigation of terrorist offences is more decisive than the question of whether there is sufficient information to come to indications of a terrorist offence. In practice, the question of whether the application of special investigation techniques is in the interest of the investigation depends on the seriousness of the allegedly intended terrorist offence and the probability that the threat will actually occur. ${ }^{1862}$ These criteria provide public prosecutors with large discretionary powers that, moreover, are not restricted by a demanding suspicion criterion. Consequently, special investigation techniques are applied on the basis of very thinly substantiated information, which, moreover, cannot be verified as to its source and reliability. Under these circumstances, the application of such techniques then primarily serves to: (1) assess information at the earliest moment possible, and (2) to exclude any risks.

This predominance of the interest of the investigation and the broad interpretation of such investigative interests, while deciding whether or not to apply procedural (investigative) powers, represents a clean break from the common criminal justice system, where the level of suspicion is primarily the decisive criterion. To thwart an alleged terrorist threat, the criminal justice system is, accordingly, more and more used as means to control the behaviour of large groups of potential suspects rather than to investigative criminal or terrorist behaviour.

1862 C.J. de Poot, R.J. Bokhorst, W.H. Smeenk, R.F. Kouwenberg, De Opsporing verruimd? De Wet opsporing terroristische misdrijven een jaar in werking, WODC, Cahier 2008-9, p. 16. 
Large discretionary powers for the Executive regarding the application of procedural powers or measures in and beyond the criminal justice system, lead to lack of clarity and certainty in various respects and affect all parties involved: the Executive that enforces legislation, the persons who may be subjected to such powers or measures, and the Judiciary that is asked to consider, with hindsight, the lawfulness of the application of such powers or measures. How does the broad scope of procedural powers and measures in the case of terrorism affect these three parties?

For the Executive it means that the sky is the limit: all alleged (involvement in/ support of) terrorist activity justifies the application of state powers or measures as comprised in the anti-terrorism legislation discussed above. The authorities are not obliged to substantiate an individualised suspicion, let alone a reasonable suspicion, prior to the application of these powers or measures. It suffices to show that there is a situation involving the possibility of a terrorist offence taking place, or of involvement in, or connections with, terrorist activities or with alleged terrorists. Justifications are found in the nature of the crime and the interest of the investigation, which is to thwart any potential terrorist threat. The problem is that during the proactive phase, and, even more, prior to that phase, the Executive normally does not yet know whether it indeed concerns terrorist activities or a terrorist crime, specifically in the case of inchoate terrorist offences.

For example, terrorist intent can only be detected by applying one or more special investigation technique, or on the basis of secret intelligence information. The application of the powers comprised in Titles VB and VC of the DCCP, based on general risk analysis, secret intelligence information and/or ill-substantiated rumours, may therefore boil down to 'fishing expeditions'. Such a practice is, even in cases concerning terrorism, prohibited by the ECtHR, and is, furthermore, quite contrary to the structure of the Dutch criminal justice system. Normally application of procedural powers should be preceded by an (individualised) reasonable suspicion concerning a specific offence(s). That is no longer the case. The application of procedural powers in terrorist cases, is rather, connected to an alleged threatening situation than to a suspicion against the persons who are subjected to the procedural powers. This is very clearly demonstrated in the above-discussed WODC reports, where the investigative authorities themselves argue that procedural powers implying the deprivation of liberty, such as police custody, are often used to thwart terrorist threats rather than to further a criminal investigation on the basis of a 'full' reasonable suspicion.

The broad scope of the above-discussed powers and measures clearly works to the detriment of those persons who may be subject to these powers or measures. Almost anyone may, intended or not, get implicated in 'indications of a terrorist offence', or be considered as involved in, or connected to, terrorist activities: people living or working in a security risk area, persons who strictly adhere to a religion like Islam, persons who have acquaintances in Islamic circles, persons who travel a lot to 
Islamic countries for their work, people who give private flying lessons, persons who teach or study foreign languages, people working in/studying chemistry, etc. So the group of persons, suspected or not, subjected to powers or measures that infringe their fundamental rights has increased considerably since the anti-terrorism powers and measures started to take effect.

Lastly, it remains to be seen whether the Judiciary will be able to clarify the scope of anti-terrorism powers and measures. Firstly, it is very doubtful that the Judiciary will at all be asked to rule on the lawfulness of the application of such powers and measures. As demonstrated above, cases throughout which these powers and measures are applied, have not, so far, ended up before a court. Secondly, if the Judiciary was, however, asked to rule on the application of the anti-terrorism powers and measures discussed above, it would only have a marginal framework for judicial review. The large discretionary powers of the Executive in matters concerning alleged terrorism considerably limit the Judiciary's power to review the lawfulness of the Executive's conduct. Furthermore, the Judiciary will not always be provided with all the relevant information needed to administer justice.

\section{SLIDING SUSPICIONS}

In theory, the facts/circumstances on which a reasonable suspicion is founded must be objective, relevant, indicative and convincing, not merely to the authority who exerts procedural powers, but also to other persons who would, hypothetically, be confronted with the same situation. When it comes to preventing terrorism by means of the criminal justice system, the scope of a reasonable suspicion has changed considerably. More generally, the relevance of suspicion criteria as justification for, and as criteria for the application of, state powers or measures, has significantly diminished. A suspicion as prerequisite for the lawful application of procedural powers or measures serves two aims: first, it constitutes a limiting barrier and it serves as prior, though initial, justification for interferences with civilians' rights. Second, it enables the Judiciary post facto to examine the foundation and rightness of the suspicion and the ensuing interferences. It goes without saying that decreasing the value of suspicion criteria as a precondition for the lawful application of procedural powers or measures equally undermines the protective function, in terms of respect for the fundamental rights and principles of law, of these suspicion criteria. How exactly has the value of suspicion criteria changed, and what consequences does that have in terms of respect for these rights and principles? The first question will be answered in this section, and the second question is discussed in the following one.

First of all, over the past few years the sources and types of information that may lead to a (reasonable) suspicion have changed considerably. Currently, the Executive increasingly gathers information from other, private, organisations or actors. Until 
some years ago, these organisations or actors were not directly and per se involved in delivering (fundamental) incriminating information during the early stages of a criminal investigation. At present, they are, progressively, more requested to lend their services or information to criminal investigations into terrorism. Examples of such organisations are: telecom companies, insurance companies, (foreign) aviation companies, (international) banks, ${ }^{1863}$ (international) secret services, schools, municipalities, ordinary (non-suspected and/or anonymous) civilians, and international organisations. In the case of investigations into alleged terrorism, the sources of the information that leads to a suspicion and to the application of procedural powers or measures are, hence, more diverse, less direct and often anonymous or secret. In part, this is inherent to investigating terrorist offences. The secret intelligence services are also participating more and more in criminal investigations into terrorism. They provide the investigative authorities with relevant information regarding alleged terrorists or terrorist groups/organisations. The investigative authorities consequently use that information to generate a reasonable suspicion, to apply coercive and investigative powers and the prosecution uses it as evidence during trial. ${ }^{1864}$ Also, Mayors are provided with secret intelligence information that is used to justify the application of personal disturbance powers or which could have been used if the above discussed Bill on administrative powers had not been withdrawn.

The increased cooperation between the secret intelligence services and the Executive is almost inevitable, as terrorist offences may take place before the Executive is allowed to act. However, with the enactment of the DPTA, the Dutch government made it clear that the investigative authorities also need to be enabled to detect and prevent terrorist threats during the early stages of the pro-active phase. To that effect, they have been equipped with special investigation techniques, comparable to the secret services' powers, which may be applied in the case of indications of a terrorist offence. As a result of the entering into force of the DTA and the DPTA, the secret intelligence services and the investigative authorities are progressively more similar with regard to their working scope and the available powers when it comes to terrorism. That development may, in time, either decrease the Executive's dependence on the secret intelligence services when it comes to countering terrorism, and/or result in a situation of increased cooperation on an

1863 Banks, for example, play a considerable role within the blacklisting system.

1864 See, also, C.J. de Poot, R.J. Bokhorst, W.H. Smeenk and R.F. Kouwenberg, De opsporing verruimd? De Wet opsporing terroristische misdrijven een jaar in werking, WODC Cahier 2008-2009, p. 54 and further. The investigative authorities often take a person into police custody/remand in custody on the basis of merely 1 memorandum of the secret intelligence services. Also, house searches are often performed following secret intelligence information. This is called 'upside down-investigating' [opsporing op zijn kop], which means that investigative authorities deprive a person of his liberty (for example) and then start to investigate whether there is incriminating information on account of the perpetration of (terrorist) offences, instead of the other way around. This working method is performed in the case of an imminent terrorist threat (based on the secret intelligence's assessment). 
equal footing between these two organisations. One way or the other, the secret intelligence services and the Executive progressively more and more share one and the same substantive working area, that of thwarting (potential) threats against national security. In such a situation, the general principles of criminal procedure, which do not apply to the work of the secret intelligence services, can easily be undermined.

The types of information used to corroborate a suspicion have expanded. Ordinary kinds of information which used to underpin a suspicion, such as police officers' own observations, direct witness statements, or reports by victims, are increasingly replaced by indirect and not always verifiable types of information, such as video tapes of cameras present in public and private places, biometric information, information stemming from data mining and profiling processes, secret intelligence information in the form of concise memos, which remain secret as to their source, anonymous witness testimonies, telephone tapping, hacking, bank account information, information from the immigration services, and so on. The CT-infobox plays a role of importance in this respect. The information available within the CT-infobox may be used to corroborate a suspicion and consequently to justify the application of one or more of the powers or measures.

Civilians, even anonymously through Meld Misdaad Anoniem, and all kinds of financial organisations come up either voluntarily or compulsorily with such information as well. ${ }^{1865}$ Even though all these kinds of information have not been gathered by the Executive and can therefore not always be equally examined on reliability, they can, nevertheless lawfully be used to come to a suspicion of a terrorist offence. It is inevitable that due to the indirect and unverifiable nature of some of these types of information, a suspicion may be less objectively verifiable and consequently less reliable.

The course of recent investigations into terrorist crimes demonstrates that the rate of error in such investigations is considerable, certainly when suspicions and consequently the application of, for example, special investigation techniques are based on anonymous information. ${ }^{1866}$ The prevention of terrorism - a crime that is

1865 See, in this respect, Y. Buruma, 'De rechtsstaat in de knel tussen populisme en absolutism', in Delikt en Delinkwent 2009, 73. In his article, Buruma underlines the considerable contribution of civilians to criminal investigations. See, also, S. Brinkhoff, 'Anoniem melden startinformatie voor een strafrechtelijk onderzoek', in NJB 2008, pp. 1224-1228.

1866 See NRC Handelsblad, 'Verdachten terreur zelden veroordeeld. Tweederde snel weer vrijgelaten', 6 June 2009. It appears that not even $25 \%$ of the persons arrested on suspicion of a terrorist offence are convicted on account of such an offence. This percentage differs considerably from the one regarding investigations into common crimes: $50 \%$ of the cases end up for trial and $90 \%$ are convicted. In the period 2004-2008 (since the entering into force of the DTA), the public prosecutor's office has prosecuted 113 terrorist suspects, of which only 27 have been convicted of a terrorist offence. These percentages do not include persons who have been arrested and released shortly afterwards, nor do these percentages include the application of other coercive 
highly dependent on persons' intentions - inevitably carries a high risk of 'catching the wrong guy'. However, in addition, the above-discussed WODC reports show that procedural coercive powers, such as police custody and remand in custody, are often applied to thwart an alleged terrorist threat, rather than to take decisions regarding criminal procedure [strafvorderlijke beslissingen]. Prevention of terrorist offences does not fall within the limited listed grounds pursuant to Article 67a of the DCC. Using procedural powers, comprised in the DCCP, to prevent alleged terrorism, instead of taking decisions regarding criminal procedure, as prescribed in Article 132a of the DCCP, may very well be deemed unlawful and may lead to arbitrariness. This issue is further discussed in the next section.

In addition, practice shows that suspicions are more easily fulfilled in the case of terrorist offences than in case of common offences. This means that a reasonable suspicion on account of a terrorist offence demands less information than in the case of a common offence. The difference between a reasonable suspicion and indications of a terrorist offence is, therefore, hardly visible in practice, also to the investigative authorities themselves.

Hence, besides the creation of new suspicion criteria and an informal differentiation created within the reasonable suspicion criterion itself, procedural coercive measures are applied for other purposes than for those the powers are actually intended. Corroborating a suspicion by means of the above-mentioned new sources/types of information and the government's emphasis on preventing terrorism further reinforces these aspects.

\section{CHARACTERISING SUSPICIONS}

The perspective and object of a suspicion have changed as well. While a suspicion used to refer to an individual who had allegedly committed a more or less welldefined criminal offence, at present suspicions increasingly concern groups of still unidentified individuals who presumably prepare, plot, plan or commit vaguely defined (terrorist) offences or are involved in or connected to (the support of) terrorist activities.

Suspicions also increasingly concerns situations rather than specific persons. 'Suspicious' situations, instead of concrete human behaviour, have become the

\footnotetext{
measures in the case of suspicion of a terrorist offence or merely a suspicion of a terrorist offence without the application of any coercive measures. Also, the percentage does not cover persons who have been acquitted on appeal after a conviction by the courts of first instances. In sum, two thirds of the persons arrested on account of terrorist crime(s) have been released without further prosecution. See, also, the course of the investigations into terrorism discussed in C.J. de Poot, R.J. Bokhorst, W.H. Smeenk, R.F. Kouwenberg, De Opsporing verruimd? De Wet opsporing terroristische misdrijven een jaar in werking, WODC, Cahier 2008-9; B. van Gestel, C.J. de Poot, R.J. Bokhorst, R.F. Kouwenberg, Signalen van terrorisme en de opsporingspraktijk. De Wet opsporing terroristische misdrijven twee jaar in werking, WODC Cahier 2009-2010; B. van Gestel, C.J. de Poot and R.F. Kouwenberg, De Wet opsporing terroristische misdrijven drie jaar in werking, WODC, Cahier 2010-3.
} 
starting point and basis for (later) individualised suspicions. Persons who may be linked to 'a situation possibly involving terrorism or terrorist activities' are considered as 'suspect', rather than these persons being considered as suspect on the basis of their own individual criminal conduct. This changed perspective and object of a suspicion can further be clarified by means of the following key words: collectivism, vagueness, and prevention and/or pro-activity.

(1) Collectivism refers to the fact that suspicions increasingly concern a 'suspicious situation' to which a person can be linked, rather than an individual who exhibits specific suspicious behaviour. Suspicions also refer gradually more and more to groups of persons who all possess one or more common characteristic, such as a religion, a way of living, a state of mind or a hobby. Belonging to such a group, being acquainted with an alleged member of such a group, or being in a suspicious situation may accordingly furnish a suspicion and consequently justify the application of procedural powers or measures.

Football hooligans, common rioters, members of an alleged 'terrorist group' and the Hells Angels are all examples of these collective suspicions. Football hooligans are groups of, sometimes still unidentified, persons who commit various criminal offences that are divergent in nature, and range from disturbances of the public order to serious forms of assault, insult or vandalism. The same goes for common rioters, who simply travel, as individuals or in groups, to places where a riot, for whatever reason, is expected, in order to participate in that riot, purely out of recreational motives. Members of alleged terrorist groups or members of the Hells Angels are also often still not convincingly 'suspicious', while the collective suspicion of the group has already been presumed and investigative or coercive powers have been applied. So, the circle of persons that may be subjected to procedural powers or measures, especially when it concerns alleged terrorism, has become larger. Such a working method that strives to exclude any risks, will inevitably lead to subjecting many common citizens to various state powers that infringe on fundamental rights and undermine respect for fundamental principles of law. This latter issue is further discussed in Section 3

(2) Applying procedural powers or measures to individuals on the basis of a collective suspicion is possible due to the broadened criminal liability on account of inchoate terrorist offences, in combination with the extented scope of procedural powers and measures. The consequent vagueness and uncertainty further characterises the interpretation of a suspicion. Due to broadly edited criminal law provisions, especially during the pro-active phase, it becomes increasingly unclear what behaviour may not lead to the application of procedural powers and measures.

Not only have terrorist offences been broadly defined, but criminal law provisions are edited and adapted to other provisions in such a way that there may, sometimes, even be overlap between provisions, only to ensure criminal liability throughout the whole pro-active phase. For example, the combination of 
participation in a terrorist organisation, preparation of a terrorist offence (pursuant to Article 46 and 96, section 2 of the DCC), conspiracy to commit a terrorist offence, and training for terrorism, aim at guaranteeing criminal liability in respect of terrorism as far as possible. The distinguishing elements between the behaviour criminalised in these provisions is gradual. Obviously, guaranteeing criminal liability for every potential form of terrorist activity is inspired by the emphasis on prevention of terrorism in the Dutch crime control policy. The uncertainty that such broad criminal liability produces is doubled by the low, and ambiguously defined, suspicion criteria attached to the various procedural powers and measures to prevent terrorism.

(3) Prevention and pro-activity are notions which are unequivocally connected to suspicion criteria, particularly when it regards terrorism. Broadened criminal liability in respect of inchoate terrorist crimes paves the way to unsubstantiated suspicions, and consequently, to unlawful application of procedural powers and measures. During criminal investigations into terrorism, the general content of information has become more important than the reliability, the accuracy, or the source of such information. The question of whether there may be a terrorist threat is decisive, rather than the question of whether the information underlying that assumption is accurate and reliable.

The prevention of terrorism by means of the criminal justice system may, therefore, easily become a breeding ground for an increased rate of error, for unlawful interferences with civilians' fundamental rights and freedoms, for legal uncertainty, and in the end, it bars an effective implementation of the substantive criminal justice system. That latter aspect may very well lead, once again, to a progressively more visible crisis of confidence between the state and its citizens, or as the case may be, subjects, when it comes to safeguarding security.

The foregoing comments justify the question of whether the interpretation of the notion of 'reasonable suspicion' is still reasonable, particularly regarding suspicion of terrorist offences. Presumptions, and in some instances, even prejudices, progressively play a bigger role in coming to suspicions when it concerns terrorist offences. With regard to terrorism, the substantive criminal justice system has criminalised many kinds of behaviour to such far-reaching extents that it is hardly possible to acquire an objectively verifiable suspicion concerning the commission of such offences. The more a suspicion is based on presumptions and speculations the less reasonable grounds suspicion will have. In light of the ECHR, it is of utmost importance that a suspicion is based on objective facts or circumstances, also when it regards terrorism. This issue is further discussed in the next section.

In sum, all of the above discussed suspicion criteria, in and beyond the criminal justice system, gradually concern, more and more, groups of persons rather than individuals in the case of terrorism. Individuals primarily become suspected when 
they form part of, or may be connected to, a suspicious collective. This is especially visible in the case of indications of a terrorist offence, a notion which, in practice, refers to a situation. On the basis of a situation allegedly implying a terrorist threat, the investigative authorities start to look for persons who may be connected to that situation. In that sense, indications of a terrorist offence differs considerably from the common reasonable suspicion criterion. Again, this changed scope of suspicion criteria is partly caused by factual shifts in the substantive (criminal) law system and the aim of preventing terrorism, but it also finds its origin in a rather practical feature of certain forms of criminal behaviour: the structured/organised context in which these crimes occur. Crimes such as terrorism are especially often, though not always, plotted, conspired to, prepared, and eventually committed, within a group of persons/suspects. The government aims at tracking down all persons connected to such terrorist activities, irrespective of the question to what extent they factually contributed to materialisation of the terrorist offence. Therefore, suspicion criteria do not concern one person, but the whole group/the whole network from which the alleged terrorist behaviour or threat originates.

The above demonstrates that there is a link between the nature/seriousness of an offence and compliance with suspicion criteria: the more severe the criminal offence is, the less difficult it is to comply with suspicion criteria. ${ }^{1867}$ Obviously, this is the case, particularly for terrorist offences. This connection, however, also applies to other forms of criminal behaviour. For example, state powers to investigate drug related offences or weapon related offences, such as house searches and frisks, may, in practice, be applied on the basis of less demanding information than in case of common criminal offences.

In theory, the application of such procedural powers regarding these types of offences requires the fulfilment of the same statutory suspicion criteria as in the case of other less severe criminal offences, but in practice, these criteria are more easily fulfilled. The legal history of the WAA and the OA reveals that due to the severity of drug or weapons related crimes, less or other sorts of facts or circumstances may be adduced to substantiate a suspicion, and to justify the application of procedural powers. Apparently, these offences are deemed so blameworthy and threatening that investigative interests tend to prevail over a convincing fulfilment of the statutory suspicion criteria. ${ }^{1868}$

This approach can, at the very least, be called paradoxical. To investigate the most severe crimes, the Executive may use the most far-reaching procedural powers

1867 See, C.J. de Poot, R.J. Bokhorst, W.H. Smeenk and R.F. Kouwenberg, De opsporing verruimd? De Wet opsporing terroristische misdrijven een jaar in werking, WODC Cahier 2008-2009, primarily p. 44. The investigative authorities state unambiguously that the seriousness of terrorist offences and the threat attached to such offences diminish requirements for coming to a reasonable suspicion.

1868 It goes without saying that his approach contrasts sharply with the factual implementation of the OA regarding soft drugs. 
and measures on the basis of the lowest suspicion criteria available within the Dutch criminal justice system. Taking into account the penalty clauses attached to terrorist offences and the explanatory memorandum with the DTA in this respect, all terrorist offences are considered as severe criminal offences. This affects, either implicitly or explicitly, the practical fulfilment of suspicion criteria when it concerns terrorist offences.

\section{Purged of TERRoRist SUSPICION?}

Personal disturbance, the formerly proposed administrative measures comprised in the Bill, blacklisting and the imposition of fund-freezing measures have in common that these instruments are often used when the criminal justice system cannot (yet or anymore) be mobilised. When there is insufficient information to come to indications or to a reasonable suspicion of a terrorist offence, or when someone is acquitted of terrorist charges, the government may still take its recourse to other legal instruments than the ones available within the criminal justice system.

The fact that such a 'safety net' is created, despite the expanded scope of procedural powers and the broadened criminal liability for terrorist offences, is striking. All potential legal means are deployed to exert powers on persons allegedly involved in, or connected with, terrorist activities or terrorist offences, also when a person has been acquitted of terrorist charges by the Judiciary. It appears to be rather difficult to be purged of a suspicion when it comes to terrorism.

\section{ANTI-TERRORISM LEGISLATION AND FUNDAMENTAL RIGHTS AND PRINCIPLES OF LAW}

\subsection{The principle of legality and the DTA}

Broad criminal liability in respect of terrorist offences, as such, will most likely not yield any problems in terms of Article 7 of the ECHR. The notion of terrorist offence and terrorist intent as defined in Article 83 and 83a of the DCC specifies the conduct that leads to criminal liability and the sentence attached to such behaviour. Even though particularly inchoate terrorist offences and inchoate offences to prepare or facilitate a terrorist offence induce a large criminal liability, the law does set out the factual conduct required to constitute such a liability. Moreover, the factual conduct of a terrorist offence is, with the exception of some provisions such as Article 205 of the DCC, not new. Murder and terrorist murder, kidnapping and terrorist kidnapping, assault and terrorist assault are the same in respect of the required factual conduct. The difference lies in the terrorist intent.

Case law shows that the scope of terrorist intent still has to take shape, but that will not lead to violations of the principle of legality, as enshrined in Article 7 of the 
ECHR. Strasbourg case law on Article 7 of the ECHR emphasises that judges should be left free to interpret and develop criminal law provisions according to changing societal circumstances. Offences that are too clearly defined may obstruct that.

When it comes to serious criminal offences, among which are undoubtedly, severe terrorist offences, the ECtHR deems the punishing of perpetrators of such offences, even if not obviously falling within the scope of a criminal law provision, more important than the strict application of the principle of legality. Even a completely different (broader) interpretation of a yet existing criminal law provision regarding a serious offence, hence without gradual preceding development, does not necessarily imply a violation of Article 7 of the ECHR. Simply stated: very severe offences cannot be left unpunished simply because there is no clear provision in criminal law.

The fact that the nature of the offence, as such, influences the question of whether fundamental principles of law have been violated is, within the ECtHR's case law, quite extraordinary. Even though the ECtHR considers the nature of the offence indirectly within the framework of the complexity of the case while examining complaints under Article 5 of the ECHR, the nature of the offence, as such, does not make the ECtHR more lenient in its examination. This issue is further discussed in the next section.

Even though broadly edited criminal law provisions will not unequivocally lead to a violation of the Strasbourg principle of legality, such broad provisions may lead to violations of the right to privacy, the right to liberty of movement, and the right to liberty due to non-compliance with the requirement that interferences with these rights must be in accordance with the law. The ECtHR appears to carry out a more in-depth examination of compliance of domestic legislation with the foreseeability prerequisite pursuant to Articles 5 and 8 of the ECHR and Article 2 of the Protocol, than of compliance with Article 7 of the ECHR.

Domestic case law shows that also in the Dutch criminal justice system, qualitative criteria for criminal law provisions are not especially demanding. The lex certa prerequisite primarily requires criminal law provisions to be sufficiently clear in order for citizens to behave in accordance with norms and standards underlying these provisions. Paradoxically, the broad criminal liability in respect of terrorist offences makes it very unlikely that the principle of legality will be violated. There is hardly any alleged 'terrorist conduct' that cannot be categorised as a(n) (inchoate) terrorist offence under the DCC.

However, the constitutional dimension of the principle of legality, as developed by Kelk (implying that this principle attributes power to the State and authority to the Executive, to be used without overstepping the balance of powers [trias politica], all in order to implement/apply criminal law) is clearly further undermined by the DTA and the DPTA. Broadly defining terrorist offences implies that the Executive 
gains power at the cost of the Judiciary and, to a lesser extent, at the cost of the legislature. This is reinforced by the fact that criteria for application of procedural powers and measures have been decreased. So both in determining whether 'conduct' is to be considered as terrorist offence, and in determining whether procedural powers or measures can be applied, the Executive is given a larger discretionary power in the case of terrorist offences than in the case of common offences. In the following section it will further be discussed how this affects the power of the Judiciary to examine the lawfulness of applied procedural powers during the pre-trial phase.

\subsection{The right to privacy and Dutch anti-terrorism legislation}

Most of the powers comprised in the anti-terrorism legislation discussed above interfere with the right to privacy, though not all in the same way and to the same extent. Generally speaking, the more severe an infringement on Article 8 of the ECHR is, the more compelling the state's reasons for applying the intrusive measures must be and the more importance is attached to the existence of sufficient procedural safeguards against abuse.

For interferences with the right to privacy to be justified pursuant to Article 8, section 2 of the ECHR, they must be: (1) in accordance with the law and (2) necessary in a democratic society. ${ }^{1869}$ In its case law the ECtHR often discusses these two requirements jointly. This is partly caused by the fact that both requirements relate to the question of whether there are adequate and effective safeguards to prevent arbitrariness. Under the notion of 'in accordance with the law', the ECtHR examines whether domestic law provides such safeguards. Pursuant to the necessity requirement, the ECtHR considers whether these safeguards have, in the particular circumstances of the case, been complied with. It goes without saying that the question of whether there are adequate counterbalancing safeguards is of key importance when assessing the anti-terrorism legislation discussed above on compatibility with Article 8 of the ECHR.

This section discusses to what extent the powers and measures to prevent terrorism, as discussed in Chapters III and V, are compatible with Article 8 of the ECHR, specifically in light of the fact that it concerns powers and measures to counter terrorism. Firstly, I will elaborate on the problems that arise under the notion of 'in accordance with the law'. Secondly, issues arising under the necessity requirement are discussed.

1869 See Chapter III, Section 5 and Chapter V, Section 8. 


\subsection{1 'In accordance with the law' for the sake of preventing terrorism?}

Generally speaking, the ECtHR's case law demonstrates that the requirement referred to as 'in accordance with the law' requires that powers that interfere with the right to privacy should have some basis in domestic law. Domestic law must comply with certain qualitative prerequisites: Legislation must be accessible and foreseeable as to its effects. This also implies that there must be adequate legal protection, provided for in domestic law, against arbitrary interferences by public authorities with the right to privacy. ${ }^{1870}$

Case law on Article 8 of the ECHR shows a certain flexibility with regard to the foreseeability requirement. Even though certainty is highly desirable, the ECtHR has repeatedly underlined that it may bring with it excessive rigidity. The law must be able to keep pace with changing circumstances. Therefore, it is commonly accepted that laws are couched in terms which, to a greater or lesser extent, are vague and whose interpretation and application are questions of practice. This line of reasoning is comparable to the one developed under Article 7 of the ECHR. However, case law under Article 8 of the ECHR also demonstrates that the more intrusive state powers are and the further into the pro-active phase such powers are applied, the more precise the laws that grant these powers must be. First of all, this implies that large discretionary powers for the Executive in applying procedural powers must be counterbalanced. Secondly, this implies that the law must indicate, with sufficient clarity, the scope of any discretion conferred on the competent authorities and the manner of its exercise, while having regard to the legitimate aim of the measure in question.

\section{Personal Disturbance}

In terms of the requirement that all interferences with the right to privacy must be in accordance with the law, personal disturbance causes the largest problems. Personal disturbance powers, as applied in their most far-reaching form during the period 2004-2007, lacked a Strasbourg-conforming basis in domestic law. ${ }^{1871}$ In

1870 In Uçar v. Turkey, the ECtHR considered the protection of individuals against arbitrary interferences by public authorities with their right to privacy as essential object of Article 8 of the ECHR. See, Uçar v. Turkey, appl. no. 52392/99, 11 April 2006, §133.

1871 See, in this respect, Anti-terrorismemaatregelen in Nederland in het eerste decennium van de 2le eeuw. Over totstandkoming, toepassing, beoordeling en aanpassing van antiterrorismemaatregelen in Nederland 2001-2010, January 2011, Nationaal Coördinator Terrorismebestrijding, bijlage H: P.H.P.H.M.C. van Kempen, J. van de Voort, Nederlandse antiterrorism-regelgeving getoetst aan fundamentele rechten. Een analyse met meer bijzonder aandacht voor het EVRM, Radboud Universiteit Nijmegen 1 December 2010, p. 141. The authors consider there to be a 'considerable risk that the ECtHR will deem the provisions on which personal disturbance is based insufficiently foreseeable pursuant to Article 8, section 2 of the ECHR'. 
addition, it must be emphasised that the ECtHR attaches considerable importance to the question of whether powers that interfere with fundamental rights, are imposed throughout proceedings which are furnished with adequate guarantees to prevent arbitrary application. There were no safeguards to prevent the arbitrary application of personal disturbance. Persons have been subjected to personal disturbance powers while the original reasons for denoting them as 'terrorist threat due to involvement in terrorist activities' had ceased to exist.

The application of the most intrusive form of personal disturbance on the basis of Articles 2 and 12 of the Police Act was in clear violation of Article 8 of the ECHR. In that respect it should also be kept in mind that Article 2 of the Police Act has, in the past, also been used as the legal basis for camera surveillance. After considerable criticism regarding unjustified interferences with the right to privacy, the government provided for an explicit legal basis (Article 151c of the Municipality Act) for camera surveillance. The application of far-reaching personal disturbance powers may interfere with the right to privacy to a larger extent than camera surveillance. In that light, there is all the more reason for the government to provide for an explicit legal basis for personal disturbance powers, if such powers were to be used currently.

\section{THE EXPLORATORY INQUIRY}

The introduction of the suspicion criterion 'serious objections of a terrorist offence' as a precondition for: (1) initiating an exploratory inquiry into terrorist offences, and (2) for the application of special investigation techniques and investigative powers in security risk areas also raises problems under the first requirement of Article 8, section 2 of the ECHR. In general, Strasbourg case law on Article 8 of the ECHR refers to suspects or accused. There is no explicit case law on interferences with Article 8 of the ECHR within the context of criminal investigations in which less demanding suspicion criteria are admitted as adequate justification for such interferences.

Let us begin with the exploratory inquiry pursuant to Article $126 \mathrm{hh}$ and 126ii of the DCCP. First of all, what is striking in Article 126hh of the DCCP is that this provision, quite contrary to other provisions within the DCCP, does not prescribe, in detail, the powers that may be applied during an exploratory inquiry into terrorism. The broad scope of the notion of 'data files' gives no indication whatsoever of what it is that public prosecutors may, in fact, demand during an exploratory inquiry. Therefore, rather than to the text of this provision, one needs to turn to the parliamentary memoranda. And even these memoranda do not specify the scope of the notion of data files as comprised in Article 126hh of the DCCP. Case law on this provision is not available. The above-discussed WODC reports, furthermore, indicate that Articles 126hh and 126ii of the DCCP have so far not been used. This implies that it remains unclear what information the public 
prosecutor is allowed to demand from third parties within the framework of an exploratory inquiry.

Article 126hh of the DCCP provides for an important procedural safeguard: the prosecutor needs prior approval for data collection and data processing from an investigative judge. The ECtHR considers (prior) effective judicial control on state powers that interfere with the right to privacy to be of the utmost importance. However, due to the public prosecutor's wide powers pursuant to Article 126hh of the DCCP, it will be difficult for the investigative judge to examine ex ante whether requesting data files is necessary. ${ }^{1872}$ The effectiveness of judicial control diminishes progressively in the case of broadly defined legal provisions, while such provisions particularly demand extra judicial control. As to the issue of judicial review, it is, furthermore, important to note that exploratory inquiries do not automatically lead to a criminal investigation and are not, hence, often examined post facto by the Judiciary. This means that the lawfulness of powers applied during such inquiries is generally not post facto reviewed by a judicial authority. The lack of effective judicial review, combined with a broad discretionary power for the Executive easily leads to violations of Article 8 of the ECHR. In this respect, it should be emphasised that data collection and data processing during exploratory inquiries is not only applied on the basis of, and justified by, scarce information, but these powers are moreover applied to large groups of yet unidentified and non suspected civilians. This heavily undermines the requirement that interferences on Article 8 of the ECHR must be justified, also when it regards the prevention of terrorism. As these two aspects primarily regard the necessity of Article 126hh and Article 126ii of the DCCP, this will further be discussed in the next section.

Strasbourg case law on data collection and data processing is scarce. In addition, that case law primarily refers to interferences with the right to privacy that take place during criminal investigations/proceedings. In the Council of Europe Guidelines on Human rights and the Fight against Terrorism, the collection and processing of personal data are explicitly mentioned as measures that interfere with respect for private life. ${ }^{1873}$ The ECtHR has even argued that an individual may, under certain conditions, claim to be a victim of a violation of Article 8 of the ECHR occasioned by the mere existence of secret measures or of legislation permitting secret measures, without having to allege that such measures were, in fact, applied to him. Obviously, this consideration broadens the scope of Article 8 of the ECHR significantly, also in case of data collection and data processing.

1872 See, in general on the limited possibilities to exert effective judicial control in the case of wide discretionary powers for the Executive, J. Oranje, 'Schuldig tot het tegendeel is bewezen', in NRC Handelsblad 12 February 2005.

1873 Guideline of the Council of Europe, Guidelines on human rights and the fight against terrorism, adopted by the Committee of Ministers on July 2002 at the $804^{\text {th }}$ meeting of the Ministers' Deputies. 
Legislation, as such, even if it is not applied (yet), may be brought before the ECtHR to be examined on its compatibility with the ECHR.

In practice, the question of whether Articles $126 \mathrm{hh}$, and, to a lesser extent Article 126ii of the DCCP will be considered as adequate legal basis to justify interferences on Article 8 of the ECHR, depends on the scope of judicial review exerted by the investigative judge. It is highly doubtful whether ex ante judicial control by the investigative judge is sufficient to counterbalance the very large discretionary power attributed to the public prosecutor during exploratory inquiries into terrorism. This issue will further be elaborated on in Section 3.2.2 and in Section 4.

\section{SPeCial InVESTigation teChNiqueS}

The power to apply special investigation techniques on the basis of 'indications of a terrorist offence', instead of on the basis of a reasonable suspicion, raises two main issues in terms of the requirement that interferences on the right to privacy must be in accordance with the law. First of all, the criteria for application of special investigation techniques are so broad that these provisions may fail to comply with Strasbourg qualitative requirements attached to criminal (procedural) law. 1874 Secondly, there are insufficient procedural safeguards to prevent arbitrary application of these techniques.

It is crucial to see that even the investigative authorities are not certain about the scope of the suspicion criterion of 'indications of a terrorist offence' as a statutory requirement for the application of special investigation techniques. The difference with the normally required reasonable suspicion is unclear as well, particularly since that latter criterion is stretched to its very limits in the case of investigations into alleged terrorism. This means that even the professional authorities invested with the power of proper and lawful application of far-reaching special investigation techniques are ill-informed regarding the scope of the criteria for the application of such techniques. Such uncertainty is doubled by the fact that the scope of terrorist offences, as such, is also still uncertain. Especially when it regards indications of inchoate terrorist offences it will therefore be very difficult to ascertain whether or not that criterion has been fulfilled.

1874 See, in this respect, Anti-terrorismemaatregelen in Nederland in het eerste decennium van de 2le eeuw. Over totstandkoming, toepassing, beoordeling en aanpassing van antiterrorismemaatregelen in Nederland 2001-2010, January 2011, Nationaal Coördinator Terrorismebestrijding, bijlage H: P.H.P.H.M.C. van Kempen, J. van de Voort, Nederlandse antiterrorism-regelgeving getoetst aan fundamentele rechten. Een analyse met meer bijzonder aandacht voor het EVRM, Radboud Universiteit Nijmegen 1 December 2010, pp. 68-72. The authors do not consider the DPTA, as regards the special investigation techniques to conflict, in and of itself, with Article 8 of the ECHR. 
Despite this vagueness, the WODC reports discussed above demonstrate that special investigation techniques are indeed applied simply on the basis of indications of a terrorist offence. These reports indicate that the purpose is then: (1) to exclude risks, and (2) to see whether there is an imminent terrorist threat. The purpose of applying special investigation techniques seems to have become decisive, rather than the statutory criteria for application. Hence, whether to apply special investigation techniques on the basis of indications of a terrorist offence or on the basis of a reasonable suspicion of a terrorist offence is, to a large extent, determined by the purpose of applying such techniques. This implies that the law appears to become less directive and influential in applying procedural powers when it regards terrorism. In terms of the required legal certainty pursuant to Article 8, section 2 of the ECHR, this is a dubious trend.

While examining complaints under Article 8 of the ECHR caused by the application of special investigation techniques, the ECtHR takes into account, among other things, the question of whether a person is subjected to the same surveillance measures by different authorities. If so, that leads to a more serious interference with the private life, because the number of persons to whom information on a person's conduct has become known consequently increases. When persons, prior to being subjected to a special investigation technique, have also been 'watched' by the secret intelligence services and have been subjected to other special investigation techniques, it increases the severity of the interference with Article 8 of the ECHR. More severe interferences demand more solid justifications and more procedural guarantees, instead of less justifications and guarantees.

The nature of the offences which may give rise to the issue of, for example, an interception warrant, must be sufficiently clearly defined in domestic legislation for interferences with the right to privacy to be in accordance with the law. Moreover, such legislation must define sufficiently clearly the categories of persons liable to have, for example, their telephones tapped. Using very general language when referring to such persons, and stating, for instance, that a measure of interception may be used in respect of 'a suspect, defendant or other person involved in a criminal offence', without specifying the scope of 'other person involved in a criminal offence' does not suffice in terms of Article 8, section 2 of the ECHR. ${ }^{1875}$

The special investigation techniques comprised in Title VB and VC of the DCCP may be applied in the case of all terrorist offences and the categories of persons liable to be subjected to such techniques are not explicitly defined in law with respect to most of these techniques. Hence, the potential categories of persons that may be subjected to special investigation techniques pursuant to Titles VB and VC of the DCCP, is determined by the information giving rise to indications of a terrorist offence in a specific situation, rather than statutorily by the law. In addition, 
these titles do not indicate (with sufficient clarity) the scope and conditions of the exercise of the authorities' discretionary power in the area of fortuitously monitored persons, an issue of importance to the ECtHR. These considerations seriously undermine the required foreseeability under Article 8, section 2 of the ECHR. ${ }^{1876}$

Large discretionary powers for the Executive inevitably limit the effectiveness of statutory safeguards, and foremost, of judicial control. This is at odds with the fact that the potential intrusiveness of the powers comprised in Title VB, calls for an increased level of effective safeguards under Strasbourg case law.

The ordering of the application of special investigation techniques pursuant to Title VB, is - with respect to most techniques - attributed to the public prosecutor. Even though the ECtHR does not require per se a judge as ordering authority, the ECtHR does attach importance to the question of how judicial control is exerted in the decision to apply such techniques. In the ECtHR's view there are three potential kinds of control in the case of special investigation techniques: (1) control through prior authorisation, e.g. are there sufficient reasons or suspicions to apply powers which intrude on a person's private life?; (2) by means of supervision during the enforcement of such techniques; or (3) through ex post facto control. ${ }^{1877}$

The ECtHR has underlined time and again that these three ways of control should, preferably, be exercised cumulatively. In the case of application of the powers comprised in Title VB of the DCCP, all three kinds of control are either limited or lacking.

Control through prior authorisation is undeniably very limited due to the low and very broadly defined statutory level of suspicion. This is reinforced by the fact that the techniques, as comprised in Title VB, are applied rather to determine whether there are potential terrorist risks, than to act on a suspicion. Hence, the practical value of the statutory criteria for the application of these techniques is limited.

With regard to control by means of supervision during the implementation of special investigation techniques as comprised in Title VB, generally speaking, public prosecutors are in charge of a criminal investigation. That task brings with it a power to monitor the course of that investigation. In this respect, it is, however, important to note that the ECtHR requires the monitoring of secret measures of surveillance, preferably to be exercises by a body independent of the authority that enforces the measure.

Lastly, there is the ex post facto control. ${ }^{1878}$ This way of control has limited effects with respect to the powers comprised in Titles VB and VC. Ex post facto

1876 See, in this respect, L. Stevens, B.J. Koops, P. Wiemans, 'Een strafvorderlijke gegevensvergaring nieuwe stijl', in $N J B, 2004$, afl 32, pp. 1680-1686.

1877 See, Terrorism: special investigative techniques, Council of Europe Publishing, Council of Europe, April 2005, pp. 23-25.

1878 See, in this respect also Guideline VI of the Council of Europe Guidelines on human rights and the fight against terrorism. 
control of the application of special investigation techniques, on the basis of indication of a terrorist offence, does not, generally speaking, take place as persons subjected to these techniques are not, in most cases, prosecuted, as is shown by the WODC reports. Hence, it will be dependent on the person(s) who has/have actually been subjected to such techniques, provided that they are, in fact, acquainted with the powers applied on them, whether ex post facto control takes place.

\section{INVESTIGATIVE POWERS}

Investigative powers applied within security risk areas pursuant to Articles 126zq, $126 z r, 126 z s$ of the DCCP, raise several more specific problems in terms of the requirement that interferences with the right to privacy must be in accordance with the law. Following the ECtHR's judgement in Gillan and Quinton v. the United Kingdom, it is very doubtful whether these provisions are compatible with Article 8 of the ECHR. This judgement underlined once again, that civilians must be afforded adequate protection against arbitrary interference with their right to privacy, even when it concerns the prevention of terrorism. It has been demonstrated in Chapter $\mathrm{V}$ that both the power to denote an area as security risk area, and the power for police officers to apply the investigative powers in such areas, are wide powers afforded to the Executive.

In Gillan and Quinton v. the United Kingdom, the ECtHR was very concerned about the breadth of the discretion conferred on the individual police officer to decide whether or not to search persons, objects or means of transport. Under the UK system of stop and search powers, the police officer is not obliged to demonstrate the existence of a reasonable suspicion, he is not required even subjectively to suspect anything about the person stopped and searched. A reasonable suspicion as mandatory criterion for the application of powers that interfere with the right to privacy is explicitly mentioned by the ECtHR as a key safeguard to prevent arbitrariness in the execution of such powers.

The similarity of the UK system of stop and search powers to the Dutch system of applying investigative powers in security risk areas, is striking. The power for the public prosecutor to order the application of investigative powers in a certain area, and the power for police officers to actually apply investigative powers, should be sufficiently circumscribed and subject to adequate legal safeguards against abuse. Otherwise they will most likely not be considered 'in accordance with the law' due to the clear risk of arbitrariness in the grant of such a broad discretion to the public prosecutor and the police officer.

The most apparent difference between the UK and the Dutch system is the extent to which police officers resort to their powers of stop and search, and the investigative powers, respectively. While in the UK these powers are used on an extremely large scale, the WODC reports demonstrate that the investigative powers pursuant to Articles 126zq, 126zr, 126zs of the DCCP, have only been used in the 
permanent security risk area of Schiphol airport and its surroundings. This raises the question of whether there is a difference between the application of investigative powers in permanent security risk areas and the application of these powers in temporary security risk areas. Permanent security risk areas are made public by means of an ordinance, whereas temporary security risk areas are not made public at all. This implies that in terms of Article 8 of the ECHR, the application of investigative powers in permanent security risk areas most probably will be considerably more foreseeable than in temporary security risk areas, as regards to the authorisation stage. However, the wide discretion conferred upon police officers to decide whether or not to actually apply the investigative powers in a specific case is the same for both types of security risk areas.

\subsubsection{Necessary for the sake of preventing terrorism?}

To be considered lawful, the application of state powers that interfere with fundamental rights must be necessary in a democratic society. ${ }^{1879}$ Chapters III and $\mathrm{V}$ elaborate extensively on the Strasbourg necessity requirement.

The Council of Europe has subdivided the necessity requirement in three subconditions, specifically as regards to application of special investigation techniques during investigations into terrorism: the sub-condition of subsidiarity, the subcondition of proportionality, and the sub-condition of specificity. ${ }^{1880}$ In the ECtHR's case law the necessity requirement, as included in Article 8, section 2 of the ECHR, primarily regards the sub-condition of proportionality. The sub-conditions of subsidiarity and specificity are, as such, rarely applied in Strasbourg case law. Therefore, the anti-terrorism legislation discussed above will primarily be examined on compatibility with the proportionality principle and, to a lesser extent, with the subsidiarity principle.

In the parliamentary memoranda regarding the DPTA, the government waved away criticism regarding the impact of anti-terrorism legislation on fundamental rights and principles of law with unsubstantiated arguments. The government argued that 'the ECtHR feels strongly about terrorism' which would make actual violations of the right to privacy less likely. The government failed to adequately corroborate this statement with Strasbourg case law. ${ }^{1881}$ Also, when the government was asked to

1879 See in this respect M. Kuijer, Van Lawless naar een rechtmatige bestrijding van terrorisme, Wolf Legal Publishers 2005, pp. 9-10 where Kuijer underlines the importance of the obligation for states to account for and justify the necessity of powers or measures to counter terrorism which interfere with fundamental rights.

1880 Terrorism: special investigative techniques, Council of Europe Publishing, Council of Europe, April 2005, p. 20-23.

1881 See, E. Kalse and J. Verlaan, 'Ik moet primair terreur bestrijden. Donner over kritiek rechters', in NRC Handelsblad 18 February 2005; 'Donner: aanpak terreur conform Europese regels', in NRC Handelsblad 12 February 2005; Kamerstukken II 2003-2004, 30 164, no. 3, p. 32. 
give real life examples of situations where existing powers were inadequate, it replied that it was not necessary to demonstrate for each intended broadening of investigation powers why, on the basis of empirical evidence, the powers were to be applied on the basis of less information in the case of investigations into terrorism.

Basically, the government refused to demonstrate why exactly the existing powers within the DCCP would be inadequate to counter terrorism. The question of the necessity of powers comprised in the DPTA that interfere with the right to privacy and of personal disturbance powers has, therefore, not sufficiently been established. The doubtful necessity of the above discussed anti-terrorism legislation increases when this legislation is examined as a whole, instead of its separate items. In this respect, it is important to note that the DPTA and personal disturbance are no mandatory implementation of Union legislation. All of these measures originate from the Dutch government's own initiative.

\section{Personal disturbance}

The necessity of personal disturbance has been completely superseded since the entering into force of the DPTA. The information required to corroborate indications of a terrorist offence is so marginal and the investigation techniques that may then be applied so far-reaching, that personal disturbance cannot be considered necessary in a democratic society, particularly in light of the inadequate legal basis for personal disturbance. The special investigation techniques comprised in Titles IVA, $\mathrm{V}, \mathrm{VA}, \mathrm{VB}$ and $\mathrm{VC}$ of the DCCP provide for comparable powers but are provided with a better legal basis and with better procedural safeguards.

\section{EXPLORATORY INQUIRY INTO TERRORIST OFFENCES}

Is an exploratory inquiry into terrorist offences really necessary to prepare criminal investigations into terrorism, specifically when considered in light of: (1) Article $126 \mathrm{gg}$ of the DCCP, (2) the role of the secret intelligence services when it comes to terrorism, and (3) the special investigation techniques available in the case of indications of a terrorist offence?

During an exploratory inquiry into terrorist offences, the authorities collect information on 'a compilation of persons' without precisely knowing what information they are looking for on which particular persons. Therefore, exploratory inquiries interfere with the right to privacy of many civilians without solid justifications. That may easily lead to 'fishing expeditions' for large quantities of unspecified information on large groups of still unidentified persons. ${ }^{1882}$ Procedural safeguards normally applicable during criminal investigations do not, moreover,

1882 The Council of Europe sticks to the basic principle that 'fishing expeditions remain prohibited even in countering terrorism'. The Council further asserts that the use of special investigation techniques must be linked to the existence of sufficient reason to believe that an offence has been committed, prepared or planned by one or more particular persons or an as-yet-unidentified 
apply because the exploratory inquiry does not belong to the preliminary investigation.

It is important to underline that the ECtHR deems the protection of personal data of fundamental importance to a person's enjoyment of his right to respect for private and family life, as guaranteed by Article 8 of the ECHR. In that light, domestic legislation must afford appropriate safeguards to prevent any such use of personal data as may be inconsistent with the guarantees of Article 8 of the ECHR. The need for such safeguards is all the greater where the protection of personal data undergoing automatic processing is concerned, not least when such data are used for police purposes. Therefore, domestic legislation should notably ensure that such data are relevant and not excessive in relation to the purposes for which they are stored, and they must be preserved in a form that permits the identification of the data subjects for no longer than is required for the purpose for which those data are stored. ${ }^{1883}$

The broader the compilation of persons is and the more vague the allegations are, the larger the group of common citizens whose privacy is interfered with will be, and the more far-reaching those interferences will be. Such interferences cannot easily be considered necessary in a democratic society. This is all the more true when one keeps in mind that the ECtHR generally assumes that secret measures of surveillance are exclusively applied to suspects or accused. It is unlikely that prior authorisation of an investigative judge as required by Article 126hh of the DCCP, or the College's specific procedure on how exploratory inquiries are to be initiated and carried out, will adequately counterbalance this lack of necessity in specific cases.

Factually, an exploratory inquiry may very well be compared to the work of the secret intelligence services. The secret intelligence services contribute considerably to criminal investigations into terrorism, particularly in fulfilling criteria for the application of special investigation techniques, in coming to a reasonable suspicion and in providing for incriminating evidence during criminal proceedings. The WODC reports demonstrate that the investigative authorities cooperate extensively with the secret intelligence service when it concerns terrorism. In that light, it is unclear if and how an exploratory inquiry will further contribute to the prevention of terrorism.

In addition, the substantive criteria for the application of state powers during an exploratory inquiry - facts or information that terrorist offences may be plotted or committed within a loosely structured compilation of persons - also justifies the application of several special investigation techniques. Articles 126zk until 126zp of the DCCP include the same powers for the public prosecutor/police officer as the

group of individuals. See, Council of Europe Publishing, Terrorism: special investigative techniques, Strasbourg 2005, p. 21.

1883 See Article 5 of the Data Protection Convention and the preamble thereto and Principle 7 of Recommendation $\mathrm{R}(87) 15$ of the Committee of Ministers regulating the use of personal data in the police sector. 
powers available to the public prosecutor during an exploratory inquiry. That makes the necessity of an exploratory inquiry questionable.

All of this may very well render the application of, specifically, Article $126 \mathrm{hh}$ and, to a lesser extent, Article 126ii of the DCCP, disproportionate to the aim pursued, i.e. the need to prepare a criminal investigation into joint terrorist offences. That purpose is the only aspect that may distinguish an exploratory inquiry from the secret intelligence services' work and from the application of special investigation techniques.

It is, furthermore, questionable whether the possibility of preparing a criminal investigation into joint terrorist offences is at all necessary in practice. So far, Articles $126 \mathrm{hh}$ and $126 \mathrm{ii}$ of the DCCP have not yet been used. Generally, when it regards the prevention of terrorism within the criminal law context, special investigation techniques are applied or alleged suspects are deprived of their liberty. Will there be need and, moreover, time to prepare a criminal investigation into terrorist offences in the case of indications of a terrorist offence? In this respect, it is important to emphasise that in practice, even Article $126 \mathrm{gg}$ of the DCCP is hardly used.

When examining whether national security reasons may be used to demonstrate the necessity of interferences with the right to privacy, two main aspects play a role: (1) how nearby and actual the threat against national security is, and (2) how severe the infringement on the privacy is. These two aspects are important with respect to the exploratory inquiry into terrorist offence. How severe is a person's private life interfered with when he is subjected to an exploratory inquiry pursuant to Articles $126 \mathrm{hh}$ and 126ii of the DCCP? The prosecution may retrieve a person's phone number, credit card number, bank account number, shopping preferences, expenses and the persons one meets or knows. This identifying information is considered to be less 'sensitive'. In the context of a criminal investigation, it is generally considered that the recording of identity related data does not constitute a disproportionate interference given the aims of preventing crime or maintaining public order. ${ }^{1884}$

However data files pursuant to Article $126 \mathrm{hh}$ of the DCCP may concern more or less any type of information, also rather 'sensitive' information on a person's private life. Requesting data files may, hence, lead to a considerable interference with the right to privacy. There must, consequently, be compelling reasons to justify such an inquiry. In this respect, it is important to emphasise that an exploratory inquiry does not serve to prevent an actual and near terrorist threat from materialising, but it serves to prepare future criminal investigations into jointly committed terrorist offences.

1884 See, Terrorism: special investigative techniques, Council of Europe Publishing, April 2005, p. 30 . 
Let us now turn to the presumed necessity of Titles VB and VC of the DCCP. The government does not bring up any solid reasons, aside from the general terrorist threat, as alleged in almost all parliamentary memoranda regarding the DPTA, to demonstrate the necessity of these two new titles. That makes it almost impossible to fully examine the proportionality and subsidiarity of Titles VB and VC. One side of the assessment is lacking: we do know that the application of special investigation techniques on the basis of indications of a terrorist offence and the application of investigative powers within security risk areas interfere, to far-reaching extents, with persons' privacy, but we do not know how actual and near the presumed terrorist threat is.

First of all, it is important to emphasise again that exactly the same special investigation techniques already existed prior to the entering into force of the DPTA. The difference is that when it concerns terrorism, a less demanding suspicion criterion applies. However, the WODC reports demonstrate that the reasonable suspicion criterion is no longer as demanding when it concerns terrorism. A reasonable suspicion may be based on an anonymous tip-off or on the basis of secret intelligence information. That, as such, already undermines the necessity of the special investigations techniques on the basis of indications of a terrorist offence.

The ECtHR considers special investigation techniques, such as telephone tapping, to constitute a very serious interference with a person's rights that must be based on very serious reasons based on a reasonable suspicion that the person is involved in serious criminal activity. Also, according to the Council of Europe, such pro-active techniques may exclusively be employed when there is a reasonable suspicion that an offence will be committed. ${ }^{1885}$

A reasonable suspicion, as a requirement for the application of special measures of secret surveillance, is considered to serve as extra justification for interferences with the private life, and accordingly, as an important safeguard against arbitrariness. Especially when there is a very high amount of authorisations issued by investigative judges to apply such special investigation techniques, this becomes a matter of concern to the ECtHR. In some cases the ECtHR concluded that such a high percentage of authorisations could reasonably be taken to indicate that the investigative judges do not address themselves to the existence of compelling justification for authorising measures of secret surveillance.

1885 See, Terrorism: special investigative techniques, Council of Europe Publishing, Council of Europe, April 2005, p. 21. 
With regard to the required scope of procedural safeguards, and specifically judicial control of the application of special investigation techniques, the ECtHR attaches special value to the question of on whom and under what circumstances the investigative authorities are statutorily allowed to apply such techniques. Also, the severity of the crime is of importance: more severe criminal offences may more easily justify the application of special investigation techniques, provided that such application strictly complies with the principles of proportionality and subsidiarity in statutory law and in practice. The ECtHR has used these considerations only with respect to suspects and accused to whom special investigation techniques had been applied for a relatively short period, and under the supervision of a judge. In this respect the ECtHR, moreover, underlines that less intrusive powers should be applied before taking recourse to more intrusive measures. This would imply that the application of the special investigation techniques comprised in Title VB and $\mathrm{VC}$, should be considered as ultimum remedium, instead of as an automatic means to investigate alleged terrorist offences.

Ex post facto judicial control of the application of special investigation techniques also plays a role of importance. When criminal courts review, during criminal proceedings against the person to whom such techniques have been applied, the legality of such a measure of surveillance that is considered an important procedural guarantee, provided that in the event that the measure is found to be unlawful, the courts have discretion to exclude the evidence obtained thereby from use at the trial. Such (ex post facto) judicial review and the possibility of excluding illegally obtained evidence constitutes an important safeguard, as it discouraged the investigating authorities from collecting evidence by unlawful means. As has been underlined repeatedly, ex post facto judicial control of the application of special investigation techniques does generally not take place when it regards criminal investigations into terrorism, as these investigations do often not lead to prosecution on account of terrorist or common offences.

The proportionality, and hence necessity, of special investigation techniques decreases when other measures are/have been applied concurrently/successively. Concurrent or successive application of relatively harmless (regarding intrusiveness) state powers may very well lead to far-reaching interferences with the private life that require solid justifications in terms of necessity. The question of how many different authorities concurrently investigate the same suspect (person) and hence, alleged criminal or terrorist offence/conduct, or have access to information on the investigation, increases the intrusiveness of the interference, and calls for extra safeguards to prevent abuse.

This means that when multiple special investigation techniques are applied concurrently, the person concerned is being watched by the secret intelligence services and at local level under the supervisions of the Mayor, and the person is 'discussed' within the framework of the CT-Infobox, the interference with his right 
to privacy is very far-reaching. In that light, the application of special investigation techniques on the basis of indications of a terrorist offence, and without adequate judicial supervision and review, may very well be deemed disproportionate in terms of Article 8, section 2 of the ECHR.

Another issue that needs to be mentioned is that the WODC reports demonstrate that the application of special investigation techniques on the basis of indications is often not effective. Due to the very low level of suspicion on which investigations into alleged terrorism are initiated, most of these investigations do not yield useful incriminating information. ${ }^{1886}$ And when it concerns an imminent terrorist threat, the authorities would rather take a person(s) in police custody on the basis of a light reasonable suspicion, than use special investigation techniques on the basis of indications of a terrorist offence. Consequently, according to the investigative authorities' estimate, the application of special investigation techniques is only necessary for a very small number of cases, and will primarily serve: (1) to exclude risks, and (2) to see whether there is, in fact, an imminent terrorist threat.

In deciding on the necessity of applying special investigation techniques, the ECtHR considers of importance the scope of application of such techniques: the more criminal offences may be investigated by means of special investigation techniques, the less likely it is that application of such techniques will be deemed necessary in a democratic society. This contrasts sharply with the broad statutory possibilities for the investigative authorities to use special investigation techniques pursuant to Titles VB and VC: all terrorist offences may be investigated by means of the powers comprised in these titles. Especially when the special investigation techniques comprised in Titles VB and VC are considered in light of: (1) the non- criminal law based anti-terrorism measures, as discussed in the previous chapters, (2) the powers comprised in Titles IVA, V and VA of the DCCP, and (3) the powers of the secret intelligence services combined with the information exchange between the investigative authorities and the secret intelligence services, the necessity of these titles is difficult to adequately substantiate. ${ }^{1887}$

\section{INVESTIGATIVE POWERS}

The application of investigative powers in security risk areas, pursuant to Articles 126zq, 126zr and 126zs of the DCCP demand no suspicion regarding the person searched or the objects or the means of transport that are investigated. The interest of the investigation is the only criterion that needs to be complied with for

\footnotetext{
1886 C.J. de Poot, R.J. Bokhorst, W.H. Smeenk, R.F. Kouwenberg, De Opsporing verruimd? De Wet opsporing terroristische misdrijven een jaar in werking, WODC, Cahier 2008-9, p. 54.

1887 G. Corstens argues in this respect that the 'common' special investigation techniques as comprised in Titles IVA, V and VA have not yet been completely exploited. J. Oranje, 'Schuldig tot het tegendeel is bewezen', in NRC Handelsblad 12 February 2005.
} 
police officers to make use of the investigative powers. As to the authorisation, the public prosecutor needs indications of a terrorist offence. These indications do not, however, directly need to relate to the application of these powers in specific cases, and do not therefore, restrict the police officers in using the investigative powers. There is hence, no requirement at the authorisation stage that the application of investigative powers is considered 'necessary' and therefore no requirement of any assessment of the proportionality of the investigative powers. This is most striking with respect to the temporary security risk areas.

Furthermore, whether or not and to what extent investigative powers will be used, is completely dependent on the expertise, experience, professionalism, but also personal characteristics, of the police officers. The application of investigative powers must be in the interest of the investigation, but that will hardly restrict the considerable discretionary power of the police officers. The abovementioned provisions, or any other publicly accessible legislative document or code of practice, provide for guidelines as to the question of what may, in practice, justify the application of these powers. Such broad powers may pave the way for discriminatory and arbitrary application of preventive searching powers, as is shown in Gillan and Quinton v. the United Kingdom.

Factually speaking, the government creates a different legal system within security risk areas. Interferences with fundamental rights do not need to be justified by the normally required criteria for the application such as a reasonable suspicion or serious objections. ${ }^{1888}$ Rogier compares this with invoking a restricted (tied to a certain area) state of emergency as provided for pursuant to Article 15 of the ECHR (of which the Secretary-General of the Council of Europe is to be informed). Within security risk areas, interferences with human rights are allowed, whereas outside of these areas such interferences would amount to violations of such rights. That would call for increased counterbalancing procedural safeguards. However, such safeguards are lacking. The competent authority is (again) the Executive rather than the Judiciary, and there is no review of the lawfulness of these measures by an independent (monitoring) authority.

In light of Gillan and Quinton v. the United Kingdom, the investigative powers in security risk areas considerably infringe on the right to privacy, especially in light of the almost unfettered powers for the Executive in this respect. The effectiveness of applying these investigative powers is doubtful. In the UK, the UK Ministry of Justice recorded a total of 33.177 searches in 2004/5, 44.545 in 2005/6, 37.000 in $2006 / 7$ and 117.278 in 2007/8. None of the many thousands of searches ever related to a terrorism offence. Within the Netherlands, the investigative powers have, so far, only been applied in permanent security risk areas. Like in the UK, none of the searches pursuant to Article 126zq, 126zr, 126zs of the DCCP related to terrorism. 
Even though in the UK investigative powers are applied on a considerably larger scale, which tends to contribute to finding a violation of Article 8 of the ECHR, the ECtHR has also judged legislation as such to violate Article 8 of the ECHR where such legislation does not provide for adequate safeguards in the case of far-reaching interferences with the right to privacy. In light of the above considerations, the necessity, primarily in terms of the proportionality, of applying investigative powers in (foremost) temporary security risk areas is therefore very doubtful, especially in light of the very questionable effectiveness, the lack of adequate substantive justifications, and the lack of procedural safeguards to counterbalance the large discretionary power of the Executive. This means that Articles 126zq, 126zr, 126zs of the DCCP may very well, both with regard to procedural and substantive prerequisites, be deemed inadequate, as they are unable to keep interferences with the right to respect private life to what is 'necessary in a democratic society'.

\subsubsection{The error rate and the risks of Rasterfahndung}

A last issue that influences both requirements for lawful interferences with the right to privacy is the high error rate and the inherent dangers of so-called 'rasterfahndung' attached to preventing terrorism. The notion of 'rasterfahndung', developed in the 1970s when the 'Rote Armee Fraktion' (RAF) committed terrorist offences in Germany. ${ }^{1889}$ Certain distinguishing characteristics of RAF members were collated and recorded in a checklist - the profile. Subsequently, the investigative authorities collected data and searched it for matches with these terrorist profiles. For instance, RAF members were said to pay their housing and energy costs in cash, instead of by money transfer. The investigative authorities started to search public as well as private databases, making use of such specific features concerning the modus operandi of RAF members.

Especially during exploratory inquiries into terrorist offences, but also in the case of personal disturbance, the investigative authorities will make use of profiles. Most likely, persons who adhere to, or know people how adhere to, extreme forms of Islam easily become the subject of an exploratory inquiry into terrorist offences. Data files may be processed on the basis of one or more of the following characteristics: male; involved in the Islamic mental legacy; lawful residence in the Netherlands; no children; student; multilingual; no criminal record; travelling regularly; application for visas; financially independent. Islamic people will be screened disproportionately on a purely discriminatory basis, while terrorist offences may also be plotted or committed within groups of persons who adhere to extreme right or left-wing ideas.

1889 See, in this respect, A. Oehmichen, Terrorism and Anti-Terror Legislation: The Terrorrised Legislator? A Comparison of Counter-Terror Legislation and Its Implications on Human Rights in the Legal Systems of the United Kingdom, Spain, Germany and France, dissertation, Intersentia 2009, Leiden, pp. 71, 76, 108-111, 113, 121-123, 126, 237-289. 
The error rate attached to using data collection and processing as method of investigation, and special investigation techniques on the basis of indications of a terrorist offence as method of investigation, is considerable. This has repeatedly been demonstrated by several unjustified arrests, house searches and cases of deprivation of liberty, and by the WODC reports discussed in Chapter V. ${ }^{1890}$

To give an example: the fact that a retired chemistry teacher starts collecting information about 'hard water' - which is a required ingredient for manufacturing explosives - does not make that teacher necessarily involved in terrorism. ${ }^{1891}$ The fact that terrorists apparently frequent a Mosque five times a day does not imply that everyone who visits a Mosque five times a day is necessarily a 'terrorist'. The fact that some terrorists have received their 'Jihad-education' in training camps in Afghanistan does not automatically mean that every Western Muslim who wears a robe, has a long beard, and travels to Afghanistan, is a 'terrorist'. However, on the basis of data processing and profiling techniques, and, in general, following the application of special investigation techniques pursuant to Titles VB and VC, such persons will be screened extensively. ${ }^{1892}$

While using the powers and measures comprised in Titles VB and VC of the DCCP, the investigative authorities have to be constantly aware of this error rate and the consequent risk of unjustifiably denoting persons as 'terrorists'. This is all the more important, as persons who form the object of an exploring inquiry or are subjected to special investigation techniques do not have any opportunity to rebut 'suspicions' raised due to their behaviour, their way of living, their adherence to a religion or mental legacy, simply because they often do not yet know that they are being 'screened'.

\subsection{The right to liberty and Dutch anti-terrorism legislation}

Police arrest, police custody, remand in custody and detention on remand of (terrorist) suspects interfere with the right to liberty pursuant to Article 5 of the ECHR, and with the right to a fair trial under Article 6 of the ECHR. These two provisions do not include absolute rights and therefore allow state authorities to

1890 See, for example, NRC Handelsblad 11 \& 12 June 2005, 'U kent deze man' and NRC Handelsblad 8 July 2006, 'Of ze konden komen praten over massavernietigingswapens. Het verhaal van een scheikundeleraar over de infiltratie van de geheime dienst in zijn leven'; R. Suskind, The one percent doctrine: Deep inside America's pursuit of its enemies since 9/11, Simon \& Schuster 2006.

1891 See NRC Handelsblad 8 July 2006, 'Of ze konden komen praten over massavernietigingswapens. Het verhaal van een scheikundeleraar over de infiltratie van de geheime dienst in zijn leven'. This retired chemistry teacher appeared to be making the final examination paper for chemistry under the authority of the CITO.

1892 See, in this respect, J. Oranje, 'Schuldig tot het tegendeel is bewezen', in NRC Handelsblad 12 February 2005, where F. Bauduin (judge) discusses potential consequences of the broad powers of data collection and data processing. 
impose restrictions on the right to liberty and the right to a fair trial. The key question in this section is whether the expanded interferences with these two fundamental rights, as a result of the entering into force of the DPTA, may be deemed lawful. First, the system of police arrest, police custody and remand in custody (the arrest period) regarding terrorist suspects will be considered in light of Article 5 of the ECHR. Secondly, remand in custody will be examined on compatibility with Article 5 and 6 of the ECHR.

\subsubsection{The arrest period and Article 5 of the ECHR}

The 'reasonableness' of the suspicion on which an arrest and subsequent deprivation of liberty must be based forms an essential part of the required safeguards against arbitrary arrest and pre-trial detention under Article 5 of the ECHR. The kind, nature and seriousness of the interference with a suspect's right to liberty influences the question of whether Article 5 of the ECHR has been violated: the less serious the interference is, the less strictly requirements for a reasonable suspicion are interpreted. The more serious interferences are, or the more serious in character they are, equally strict the requirements for a reasonable suspicion will be interpreted. The more objectively perceptible and visible the facts or circumstances underlying the suspicion, the sooner that suspicion will be denoted as reasonable. Also, the more detailed the information leading to the suspicion is, the more objective and reasonable the suspicion will be.

The ECtHR has argued repeatedly that the 'reasonableness' of a suspicion cannot be stretched beyond the point where the essence of the safeguard, secured by Article 5, section 1 under $\mathrm{c}$ of the ECHR, is impaired, even though the ECtHR acknowledges that terrorist offences fall under 'a special category'. Throughout its case law, the ECtHR holds on to the principle that a reasonable suspicion presupposes the existence of facts or information that would satisfy an objective observer that the person concerned may have committed an offence. That viewpoint leaves no scope for attributing a major role to the severity/nature of an offence in coming to a (reasonable) suspicion. ${ }^{1893}$

Guideline 7 of the Guidelines of the Committee of Ministers of the Council of Europe on Human Rights and the Fight against Terrorism (2002) explicitly prescribes that a person suspected of terrorist activities may only be arrested if there are reasonable suspicions. Even though the ECtHR understands a state's difficulties in countering terrorism, it does not allow for the creation of different suspicion criteria that depend on the type of crime that a person is suspected of having committed. ${ }^{1894}$ States remain obliged to take measures to preserve the

1893 See Chapter VI, Section 10.

1894 In that respect, I do not fully agree with the conclusions that Aksu draws in this respect. See M. Aksu, Straatsburgse kaders voor terrorismebestrijding. EVRM, strafrecht en terrorisme, Wolf Legal Publishers 2007, pp. 71-80, 108-109. 
safeguards against arbitrary arrest and detention, also when it concerns terrorist suspects. ${ }^{1895}$ Strasbourg case law does not include indications that a reasonable suspicion, in the case of terrorism, does not need to be based on objective facts or information, even though the ECtHR does understand that information regarding national security may not always be disclosed to the suspect. This also depends on the stage of the criminal investigation, and is hence connected to length of the deprivation of liberty. The case of A. and Others v. the United Kingdom unequivocally corroborates this presumption and also shows what consequences should be attached to deprivation of liberty, without the required objective facts or information. ${ }^{1896}$

Among the investigative authorities it is unclear how the notion of a reasonable suspicion relates to the notion of 'serious objections'. The government, furthermore refers to a 'light reasonable suspicion' in the case of terrorist offences. In light of that latter consideration, the reasonable suspicion criterion is, without statutory amendments, stretched to its very boundaries in the case of terrorist offences. The ECtHR has held repeatedly that the exigencies of dealing with terrorist crime cannot justify stretching the notion of 'reasonableness' to the point where the safeguard secured by Article 5, section 1 under c of the ECHR is impaired. Even in those circumstances, the respondent government 'have to furnish at least some facts or information capable of satisfying the ECtHR that the arrested person was reasonably suspected of having committed the alleged offence'. ${ }^{1897}$

It is undeniable that the introduction of terrorist offences into the common criminal justice system has caused confusion among the investigative authorities, not only as to the interpretation of terrorist offences but also regarding the interpretation of criteria for the application of existing procedural powers when these serve to investigate terrorist offences. Accordingly, the criminalisation of terrorism within substantive criminal law produces legal uncertainty, and possibly arbitrariness, throughout criminal procedure. The ECtHR deems any provision that is as vague as to cause confusion amongst the competent authorities as to its interpretation per se incompatible with the requirements of lawfulness, pursuant to Article 5 of the ECHR. ${ }^{1898}$ This does not come as a surprise when considering that large discretionary powers of the Executive very easily undermine the protective function of the lawfulness requirement, especially in the case of terrorism.

The WODC reports demonstrate that terrorist suspects are often arrested and placed under police arrest and police custody to thwart a supposed terrorist threat rather

\footnotetext{
1895 See Chapter VI, Section 10.

1896 See Chapter VII, Section 6.5.

1897 See, in this respect, M. Alink, 'AIVD-informatie als bewijs in het strafproces, Een Straatsburgs perpectief', in Via Straatsburg. Liber Amicorum Egbert Myjer, Wolf Legal Publishers 2004, pp. $155-181$.

1898 Jéčius v. Lithuania, appl. no. 34578/97, 31 July 2000, §56 and 59.
} 
than to prosecute the suspect. Such a practice is questionable,both in light of the DCCP, and in light of the ECHR. First of all, the ECtHR does not approve of a policy of general prevention directed against an individual or a category of individuals who, like Mafiosi, present a danger on account of their continuing propensity to commit crime. Article 5, section 1 under $\mathrm{c}$ of the ECHR does no more than afford the Contracting States a means of preventing a concrete and specific offence. This means that for pre-trial detention to be used to prevent offences the competent authorities must indicate these offences sufficiently concretely and specifically, in particular, the place and time of their commission and their victims.

Secondly, pursuant to Article 5, section 3 of the ECHR, everyone detained in accordance with the provisions of section 1 under $\mathrm{c}$ of that provision must be brought promptly before a judge and tried within a reasonable time, or released pending trial. Detention for preventive purposes beyond serving to bring the suspects promptly before a judge and trying for offences is not permitted by Article 5, section 1 under $\mathrm{c}$ of the ECHR. An arrest under circumstances that undermine the principle of legal certainty can, in principle, lead to a breach of the right to liberty of person. So, also on that account, even though domestic legislation may, theoretically, be complied with, deprivation of liberty under such circumstances may very well be considered arbitrary in light of the core of Article 5 of the ECHR.

Even though it does not unequivocally follow from Strasbourg case law that remand in custody on the basis of a mere light reasonable suspicion is incompatible with the explicit and moreover formal requirements for pre-trial deprivation of liberty under Article 5 of the ECHR, ${ }^{1899}$ that case law does comprise indications to sustain the proposition that remand in custody without serious objections for terrorist suspects is incompatible with the required safeguards to secure respect for the core and rationale of the right to liberty of person. This is further reinforced by the fact that practice shows that the not legally defined purpose of deprivation of liberty has become more important than compliance with statutory criteria for application in the case of deprivation of liberty of terrorist suspects. Important to note is that the Netherlands already have a system of pre-trial detention (pre-trial detention, unless...), which goes flatly against Strasbourg basic principles in that respect (awaiting trial in freedom, unless...). ${ }^{1900}$ So, even quite apart from the key question

1899 See, in this respect, Anti-terrorismemaatregelen in Nederland in het eerste decennium van de 2le eeuw. Over totstandkoming, toepassing, beoordeling en aanpassing van antiterrorismemaatregelen in Nederland 2001-2010, January 2011, Nationaal Coördinator Terrorismebestrijding, bijlage H: P.H.P.H.M.C. van Kempen, J. van de Voort, Nederlandse antiterrorism-regelgeving getoetst aan fundamentele rechten. Een analyse met meer bijzonder aandacht voor het EVRM, Radboud Universiteit Nijmegen 1 December 2010, pp. 55-60. The authors conclude that Article 67, section 4 of the DCCP is not incompatible with Article 5, section 1 under $\mathrm{c}$ of the ECHR.

1900 See, in this respect, T.M. Schalken, 'Vrijheidsbeneming volgens het EVRM en de Nederlandse praktijk inzake voorarrest', in Via Straatsburg. Liber Amicorum Egbert Myjer, Wolf Legal Publishers 2004, pp. 257-268; A.H. Klip, 'Slappe rechters', in Delikt en Delinkwent 2010, 79. 
of whether Article 67, section 4 of the DCCP is, in fact, incompatible with Strasbourg standards, the very narrow practical implementation of the prerequisites of Article 5 of the ECHR is a deplorable development. This is all the more true when one takes into account that the ECHR, as such, provides for minimum standards. Every human rights respecting country will make sure to offer its civilians more than that minimum, even in the case of persons suspected of terrorist offences. By providing for a separate system of remand in custody for suspects of terrorist offences with lower statutory requirements and a less demanding practical interpretation of the existing statutory criteria for application, the Netherlands has distanced itself even more from the ECtHR's rules on pre-trial detention.

The ECtHR attaches particular importance to the question of whether there are adequate procedural safeguards to prevent arbitrary deprivation of liberty. This means that domestic proceedings must reveal specific objective facts furnishing at least some information capable of satisfying the ECtHR that a suspect has been arrested on reasonable suspicion of having committed a terrorist offence. ${ }^{1901}$ Secret intelligence information of which the content is not revealed to the suspect cannot serve as justification for the deprivation of liberty. Under such circumstances, judicial control is useless. Even though a suspect does not need to be informed of the sources of such information, he must be informed of the content of that information, the reasons for his arrest and detention. If not, judicial control is not effective and will fail to comply with Article 5 of the ECHR. Arrest and deprivation of liberty based on secret information may, accordingly, erode legal protection and effective safeguarding of the principles of subsidiarity and proportionality and equality before the law, especially when it regards the deprivation of liberty of terrorist suspects.

There is, aside from the new Article 67, section 4 of the DCCP, also a more general feature relating to the Dutch system of judicial control on remand in custody that reinforces the above-described shortcomings. The investigative judge has a twofold function within the Dutch system of pre-trial detention: (1) he has to judge on the lawfulness of the arrest and the police custody, and (2) he has to decide on the public prosecutor's request for remand in custody. ${ }^{1902}$ Generally speaking, the investigative judge decides on these two issues during one and the same interrogation, namely, after the maximum period of three days and 15 hours of police custody. Article 59a

Klip underlines, that within the Netherlands, many suspects have already served their sentence during the pre-trial period, hence, prior to being convicted by a court. See, also, Y. Buruma, 'De rechtsstaat in de knel tussen populisme en absolutism', in Delikt en Delinkwent 2009, 73. Buruma emphasises that in 2007 there were more suspects/accused in pre-trial detention than convicted offenders serving a sentence in prison. In light of that finding, Buruma justly argues that it is questionable whether the basic principle that deprivation of liberty must, in principle, be based on a conviction, is still really adhered to. 
of the DCCP prescribes that besides the suspect and his lawyer, the public prosecutor will also be present during this interrogation with the investigative judge. The fact that all parties involved may (and should) be present during this interrogation serves to safeguard principles of equality of arms: the suspect and his lawyer may pose questions to the public prosecutor regarding the need for remand in custody, and vice versa, all in the presence of the investigative judge who eventually has to pass judgement.

The factual implementation of Article 59a of the DCCP is, however, quite different. To start with, public prosecutors are rarely present during the interrogation with the investigative judge regarding remand in custody. This means that the suspect and his lawyer are not enabled to question the public prosecutor on either the lawfulness of the arrest and police custody, or on the justifiability of the request for remand in custody. ${ }^{1903}$ Furthermore, the suspect and his lawyer often have insufficient time to adequately prepare for the interrogation with the investigative judge. The precise charge(s) frequently only become known to the suspect when he is brought before the investigative judge.

When it concerns a suspicion of a terrorist offence, specifying which precise terrorist offence the suspect is charged with may even be more difficult, taking into account the broadened criminal liability for terrorist offence. Furthermore, not only do the suspect and his lawyer often have insufficient time to prepare for the interrogation with the investigative judge, but the investigative judge himself has inadequate time as well. Often he has about 15 minutes, or even less, to plough through a dossier. That does not ameliorate the quality of judicial control either. Lastly, the grounds brought forth by public prosecutors to demonstrate the need for remand in custody pursuant to Article 67a of the DCCP, are often based on standardised phrased investigative interests, such as the need to interrogate witnesses. These grounds are mostly, without any further investigation, accepted by investigative judges when it regards serious offences, whereas Strasbourg requires that if such grounds form a statutory prerequisite for the deprivation of liberty, the competent authority must examine compliance with these grounds while having regard to the peculiarities of the case.

The fact that investigative judges more or less automatically accept the existence of the required grounds for remand in custody in the case of severe criminal offences, combined with dropping the requirement of serious objections if it concerns the pre-trial detention of terrorist suspects, undeniably diminishes the effectiveness of judicial control of police custody and remand in custody. Furthermore, a reasonable suspicion will not be hard to sustain for public prosecutors in the case of terrorism. In practice, this means that the investigative judge's examination of the lawfulness of arrest and police arrest will not, as to content, differ from the examination of the

1903 See in this respect also P.W. van der Kruijs, 'Het vereiste van redelijk vermoeden op basis van anonieme informatie in het bijzonder bij terroristische misdrijven', in Strafblad 2004, jrg. 2, afl. 4, pp. 255-270. 
request for remand in custody. Quite contrary to this practice, the ECtHR demands that the Judiciary must examine the (objective) facts or circumstances which led to the arrest/deprivation of liberty to perform an effective post facto control on the lawfulness of the interference with a person's right to liberty and an effective ex ante control on the lawfulness of the coming deprivation of liberty.

In sum, the factual judicial control on initial pre-trial detention of terrorist suspects may very well raise questions in Strasbourg regarding the qualitative adequacy of this control due to: (1) the lowering of the substantive requirements for initial deprivation of liberty, and due to (2) the practical shortcomings in the procedure with the investigative judge.

Even though the developments described above, individually considered, may not seem so alarming, the cumulative effect of these developments does give rise to doubts in terms of compliance with Article 5 of the ECHR regarding the initial deprivation of liberty of terrorist suspects. Coming to a reasonable suspicion regarding the commission of terrorist offences has become less difficult. Broad legal definitions of terrorist offences, which, moreover, criminalise behaviour occurring far into the pro-active phase, facilitates smooth fulfilment of suspicion criteria even more. Information underlying suspicion criteria concerning terrorist offences is not, moreover, often gathered by the investigative authorities themselves, and remains (in part) secret regarding the sources. In light of these developments and the practical implementation of the system of initial pre-trial deprivation of liberty, it cannot be denied that the core element of Article 5 of the ECHR is heavily undermined. The deprivation of liberty in the case of terrorism may very well take place beyond the legally defined criteria for application. This consideration is not exclusively important regarding criminal investigations into terrorist offences, but also regarding (severe) common criminal offences. Investigations into terrorist activities often lead, additionally, to suspicions, prosecution and conviction on account of common criminal offences, such as illegal weapons possession or international trade in drugs, but also on account of social security-fraud. Moreover, when the prosecution does not succeed in proving the required terrorist intent, it may always switch to the common equivalent. Hence, investigating common criminal offences also becomes easier due to (statutory) amendments in the criteria for application of state powers to investigate terrorist offences.

\subsubsection{The remand period and Article 5 of the ECHR}

The ECtHR considers the deprivation of liberty to be an exceptional measure. Suspects must, if possible, be released pending trial. If pre-trial deprivation of liberty is, nevertheless, deemed necessary, domestic authorities need to take into account specific and individualised personal circumstances regarding a suspect, his conduct, personality and private life, when deciding whether or not to keep him in pre-trial detention. General, abstract or declaratory considerations that are not 
clearly sustained by the specific circumstances of a case, cannot serve as adequate justification in this respect.

The (serious) nature of the criminal offence of which a person is suspected, or the severe sentence that may be imposed, is, as such, insufficient to justify continued pre-trial detention. The longer pre-trial detention lasts, the more relevant and sufficient the grounds used to legitimise the detention must become - in substance as well as in number. Furthermore, the grounds used to show the necessity of deprivation of liberty presuppose a close, and moreover, demonstrable link between: (1) the specific personal circumstances of a case and a suspect, (2) domestic law, and (3) the factual circumstances that the competent authorities use to justify the deprivation of liberty.

In the case of terrorist suspects, the grounds required for lawful remand in custody and detention on remand pursuant to Article 67a of the DCCP, will hardly serve as extra substantive justification for pre-trial deprivation of liberty - next to the reasonable suspicion requirement. One or more of the statutorily defined grounds for remand in custody will always be complied with, certainly in view of the relatively light examination of compliance with these grounds on domestic level.

The longer pre-trial detention lasts, the more justifications there must be and the broader the scope of judicial review must, consequently, be. Domestic courts must, moreover, review continued detention of persons pending trial with a view to ensuring release when circumstances no longer justify the continued deprivation of liberty. Such judicial control includes an examination of the reasonable suspicion, but also of the grounds used to justify the deprivation of liberty. The existence of a strong suspicion of the involvement of a person in serious offences, while constituting a relevant factor, cannot, alone justify a long period of pre-trial detention.

Due to the amendment of Article 66, section 3 of the DCCP, terrorist suspects may be kept deprived of their liberty for an additional two years, and they may be denied access to the case file for an equally longer period, without requiring compliance with more demanding criteria for application. The government argues that criminal investigations into terrorist offences often (in part) take place abroad, and, moreover, frequently depend on the information of foreign secret services that would justify longer periods of pre-trial detention. Is that consideration tenable in light of the case law discussed in Chapter II?

First and foremost, that case law demonstrates that even though criminal proceedings regarding terrorist offences raise complex issues of law, and even though criminal investigations into terrorist offences generally take quite some time, the normal period of 90 days of detention on remand, supplemented with hearings pro-forma, suffices. The accused in the Hofstadgroep case, the Piranha I case, and the Piranha II case, were kept in pre-trial detention for 16 months, 12 
months and 6 weeks, 29 months and 2 weeks, respectively, which included the criminal investigation and criminal proceedings. None of these judgements corroborate the government's assumption that the possibility of an additional two years of detention on remand was necessary because it concerned terrorism.

In addition, the WODC reports demonstrate that the amended Article 66, section 3 of the DCCP has not yet been used. Hence, for four years, during which various criminal investigations into terrorist offences have taken place, it has not proven necessary to extend the pre-trial phase, or to withhold the suspect and the competent court information comprised in the case file beyond the system of detention of remand for common offences.

None of the criminal proceedings discussed in Chapter II concern prosecution on account of participation in an international terrorist organisation. Either the accused formed part of a national terrorist organisation or they acted as individual perpetrator. During criminal investigations into alleged terrorism, the investigative authorities are, moreover, considerably 'assisted' in furthering the investigation by, for example, the secret intelligence services, by means of information stemming from the CT-Infobox and by information from the aliens registration office. Also, the investigative authorities have, at their disposal, as set out in the previous chapters, a considerable set of broadened investigative powers and measures throughout investigations into terrorism. It appears highly unlikely that, in light of these aspects, all criminal investigations into terrorist offences are thornier, and will take more time to conclude than investigations into common criminal offences. It remains, therefore, unclear why it is deemed necessary to also prolong the period of pre-trial detention by an extra two years. All of the amendments to the procedural criminal justice system should, in fact, have made it easier for the investigative authorities to swiftly conduct criminal investigations into terrorism. The necessity of the new amended Article 66, section 3 of the DCCP is all but obvious in this respect.

All of this implies that the government failed to adequately corroborate the alleged necessity of the amendment to Article 66, section 3 of the DCCP. This has consequences in terms of compliance with Articled 5 and 6 of the ECHR. First of all, the potential extension of detention on remand by two years in criminal investigations into terrorism, may take away all incentives for the investigative authorities to conduct such investigations with the required due diligence. This is especially the case as Article 66, section 3 of the ECHR does not include additional or increased criteria for application regarding extended detention on remand in the case of terrorist suspects. Hence, there is no statutorily prescribed obligation for the public prosecutor to examine the necessity, and thus, the proportionality, of such an extension.

To conduct criminal investigations with due diligence is a mandatory obligation under Article 5 of the ECHR. When a suspect is kept in pre-trial detention, his case 
must be conducted with extra speed - i.e. due diligence - in order to limit the deprivation of liberty without conviction by a competent court, to the utmost extent possible. In addition, lengthy periods of pre-trial detention increase the ECtHR's examination of compliance with the special diligence requirement.

Furthermore, the nature of a criminal offence can only indirectly, and to a limited extent, influence the reasonableness of the length of pre-trial detention. Complex criminal offences, such as offences connected to international criminal or terrorist organisations, or Mafia related crimes, influence the complexity of the case, and consequently, the accepted length of pre-trial detention and compliance with the special diligence requirement. So even though the ECtHR may take into account the specific nature of terrorist offences when deciding on complaints under Article 5, section 3 of the ECHR, it is primarily the potential difficulty intrinsic to the investigation of such offences, which may be committed in an organised context, that influences the reasonableness of the length of continued pre-trial detention, rather than the nature of terrorism as such. In that light, extending the period of detention on remand with wto years because it regards a terrorist offence appears to be irreconcilable with Strasbourg case law on the special diligence requirement.

It can be argued that there is an explicit need to conduct criminal investigations into terrorist offences with extra diligence when one takes into account the heightened error rate in such investigations. The combination of broad criminal liability for (inchoate) terrorist offences, the lowered suspicion criteria for the application of procedural powers and measures, and the possibility of using secret intelligence information and other 'soft evidence' during the investigation and during trial, makes the likelihood of 'having the wrong guy' considerably less illusory. That likelihood is increased even more when one takes into account the burden placed on the investigative authorities to prevent terrorism at all costs. If the error rate regarding criminal investigations into terrorism, proves to be, indeed, considerably higher than in the case of common criminal investigations, it is all the more important to oblige public prosecutors to present their case to a court as soon as possible in order to judge on the legitimacy of the charges and the lawfulness of the pre-trial detention, instead of giving public prosecutors two extra years to present the case to court. In general, it goes without saying that the amended Article 66, section 3 of the DCCP goes flatly against all of the above Strasbourg basic principles under Article 5 of the ECHR. Especially when a suspect is kept in detention on remand on account of inchoate terrorist offences based on 'soft evidence' it is, moreover, essential that these suspects are given access to the complete case file to adequately challenge the accusations. It is to this important issue that we will now turn. 


\subsubsection{Non-disclosure of part of the case file, habeas corpus proceedings and Articles 5 and 6 of the ECHR}

The nature of habeas corpus proceedings must be judicial, just as the proceedings pursuant to Article 6 of the ECHR. This implies that habeas corpus proceedings must have an adversarial character, ensure respect for the principle of equality of arms, warrant respect for defence rights, and guarantee a fair hearing before the competent court. In light of these requirements, both the prosecution and the suspect must be given the opportunity to have knowledge of, and comment on, the observations filed, and the evidence adduced, by the other party. Fair trial principles are not, however, absolute, and may, hence, be limited, depending on the specific circumstances of the case. The right to have access to the case file is, in the ECtHR's view, an essential feature of the principle of equality of arms, which should be complied with during habeas corpus proceedings pursuant to Article 5, section 4 of the ECHR. That principle is not lived up to if the suspect is denied access to those documents in the case file which are essential in order to effectively challenge the lawfulness of pre-trial detention. Having regard to the extensive scope of substantive requirements for lawful pre-trial detention, which must be examined during habeas corpus proceedings, there will not be much information in the case file that is irrelevant. During the initial stages of an investigation, the case file may partly be kept from a suspect, provided that investigative interests demand so, but as the investigation proceeds, defence rights and a rightful course of habeas corpus proceedings prevail.

Guideline IX of the Guidelines on human rights and the fight against terrorism explicitly prescribes that restrictions on defence rights must be strictly proportionate to their purpose. If such restrictions are considered to be proportionate, states are, moreover, obliged to provide for compensatory measures to protect the interests of the accused so as to maintain the fairness of the proceedings and to ensure that procedural rights are not drained of their substance. It is important to note that no compensatory measures have been provided for with the enactment of the amended Article 66, section 3 of the DCCP.

The ECtHR has repeatedly judged that 'national authorities cannot do away with effective control of lawfulness of detention by the domestic courts whenever they choose to assert that national security and terrorism are involved'. ${ }^{1904}$ A suspect's right to effectively challenge the lawfulness of his detention before a court implies that he must, in one way or another, be enabled to rebut the state's allegations. Therefore, a suspect must be kept informed and permitted to make submissions and participate in the decision-making process during habeas corpus proceedings as far as possible without disclosing the material the prosecution may want to keep secret. Information that is of decisive importance to the outcome of a suspect's appeal for 
release and is an issue of fact that forms part of the prosecution case, must be released to the suspect, even if it concerns terrorism.

Within the Dutch criminal justice system, the question of which information in the case file is relevant during habeas corpus proceedings completely depends on the public prosecutor's judgement. In addition, no effective control is exerted on the way in which the public prosecutor balances investigative interests against the interest of the (terrorist) suspect to have access to his whole case file and the competent court's interest in examining a habeas corpus complaint with full knowledge of all the evidence available - both incriminating as well as exempting. Since the enactment of the DPTA, suspects can only lodge a complaint against the non-disclosure of information comprised in the case file once every 90 days under Article 32 of the DCCP. Complaining about a denial to access one's case file, may, moreover, prove to be rather ineffective, taking into account that the court deciding on such a complaint does not, just as the suspect, have access to the whole case file. It goes without saying that these restrictions may considerably hinder a suspect in making full use of his right to lodge a habeas corpus complaint pursuant to Article 5, section 4 of the ECHR.

The explanatory memorandum of the DPTA argues that information included in the case file, which is essential for the Judiciary to decide on a request for the extension of detention on remand, may not be kept from the suspect or from the competent court during the pre-trial-phase. ${ }^{1905}$ Hence, in theory, the competent court and the suspect must be presented with all of the information available within the case file that is of importance to adequately judge on the lawfulness of detention on remand. This obligation is not, however, statutorily laid down in the DCCP, nor is there an independent monitoring authority to inspect whether that obligation is, in fact, lived up to. As discussed in Chapter VII, practice shows that even during criminal investigations into common offences, the suspect and the competent court are not able to examine whether the public prosecutor disclosed all of the information important to decide on the lawfulness of the pre-trial deprivation of liberty. This means that both the suspect and the competent court are completely dependent on the goodwill of the investigative authorities.

In addition, it must be kept in mind that 'the interest of the investigation', as included in Article 30, section 2 of the DCCP, is the exclusive touchstone for public prosecutors to withhold the suspect information. ${ }^{1906}$ In the case of terrorism, that touchstone is to be interpreted broadly. According to the Minister of Justice, the interest of the investigation during criminal investigations into terrorism also relates to safeguarding national security interests. During such investigations, national security will automatically play a role. Therefore, information will easily and

1905 Kamerstukken II 2004-2005, 30 164, nr. 3, p. 4.

1906 Kamerstukken II 2005-2006, 30 164, nr. 7, p. 3. 
without much difficulty be kept from terrorist suspects with mere reference to national security interests.

In the case of restrictions on defence rights during the pre-trial phase, the ECtHR attaches particular importance to the question of whether these restrictions have been adequately counterbalanced, for example, by means of judicial control. The fact that no one, except for the public prosecutor, has access to the complete case file for protracted periods, heavily undermines the Judiciary's power to: (1) monitor the progress of the investigation, and to (2) effectively decide on the lawfulness of a suspect's continued detention on remand. How can the Judiciary perform these tasks if it is not allowed access to the whole case file? If a court is unaware of all the available information, a moral dilemma may, moreover, arise when deciding on a habeas corpus complaint: either they set the alleged terrorist suspect free due to lack of convincing evidence with the risk of not preventing a terrorist offence, or they keep the suspect in detention despite the lack of evidence, solely because this suspect is a terrorist suspect. ${ }^{1907}$ The latter scenario, practically the most conceivable, implies that a person is kept deprived of his liberty without proper cause because it concerns alleged terrorism. A better option would then be to provide at least the court with access to the whole case file. I will further elaborate on this in Section 4.

The longer pre-trial detention lasts, the more encompassing habeas corpus proceedings will have to be, and the more information there will need to be disclosed to the suspect and to the competent court. Also, as the criminal investigation progresses the investigative authorities can increasingly less rely on the interest of the investigation to justify non-disclosure of information comprised in the case file and to justify continued pre-trial detention. This implies that as pretrial detention continues, the suspect must be enabled to repeat applications for release at short intervals.

The DPTA has not, statutorily at least, changed the interval for terrorist suspects to lodge habeas corpus complaints, but factually, the scope of habeas corpus proceedings will be different in case the prosecutor decides to make use of the amended Article 66, section 3, in conjunction with Article 30, section 2 of the DCCP. As the potential period of detention on remand for terrorist suspects is prolonged, terrorist suspects should profit from broadened possibilities of judicial control on the lawfulness of the deprivation of liberty. This is not the case. The fact

1907 See, in this respect, also the $R v d R$-report p. 5 in which the $R v d R$ explicitly states that the amended Article 66, section 3 of the DCCP places judges in a thorny dilemma. Judges must now judge on the lawfulness of detention on remand, as well as on the withholding of the case file on the basis of scanty evidence which, is not, moreover, verifiable. The $R v d R$ concludingly asserts that this new system insufficiently equips judges to deal with this dilemma in a socially acceptable way. And, see, J. Oranje, 'Schuldig tot het tegendeel is bewezen', in NRC Handelsblad 12 February 2005. 
that the court deciding on a habeas corpus complaint pursuant to Article 69 or 71 of the DCCP, may, just as the suspect, not be granted access to all of the information comprised in the case file, may considerably hamper the competent court in effectively judging on the lawfulness of pre-trial detention of terrorist suspects. In this respect, it is, moreover, of importance that the complexity of the criminal investigation influences the scope of habeas corpus proceedings and the scope of the suspect's right to access the case file: the more complex an investigation is, the more reason there is to give the suspect and the competent court access to the case file to prepare for and examine a habeas corpus complaint. That line of reasoning has not been statutorily incorporated into the Dutch criminal justice system, especially not when it comes to terrorist suspects who lodge a habeas corpuscomplaint.

It is, furthermore, important to keep in mind that Strasbourg case law on Article 5, section 4 of the ECHR primarily deals with situations where the competent court and the prosecution did have access to the whole case file, whereas the suspect and/ or his lawyer did not. How the ECtHR will decide in cases where the court nor the suspect had access to the case file, remains to be seen. Most likely, this will bring forth considerable problems in terms of the required effectiveness of judicial control under Article 5, section 4 of the ECHR. A court cannot adequately and effectively examine the lawfulness of pre-trial detention as required by the ECtHR, when it does not have access to the all of the information by means of which the public prosecutor justifies the suspect's pre-trial detention. This is all the more true when one takes into account that the longer pre-trial detention lasts, the more encompassing the scope of habeas corpus proceedings has to be, and the more information there will need to be disclosed to the suspect and the competent court.

There are several general principles which must be taken into account while limiting a suspect's fair trial rights: the limitation must comply with the principle of proportionality, counterbalancing measures must be provided for, and there must be judicial control on such limitations. These three principles are hardly complied with. The proportionality of the broadened scope of the power for public prosecutors to withhold a suspect has not been showed to be necessary. The broadened scope of the public prosecutor's power to withhold terrorist suspects part of the case file and the amendment to Article 32 of the DCCP have not been compensated. ${ }^{1908}$ Judicial control on the public prosecutor's powers under Article 30, section 2 in conjunction with Article 66, section 3 of the DCCP, proves to be hardly effective, as the court has no access to the non-disclosed information either. The government's general reasoning that the nature of investigations into terrorism justify, as such, more far-

1908 See in this respect F. Vanneste, 'Het Europese Hof voor de Rechten van de Mens en de overheden die terrorisme bestrijden: brothers in arms?', in Rechtskundig Weekblad 2003-2004, nr. 41, pp. 1665-1677. 
reaching restrictions on suspects' rights during the pre-trial phase, is not corroborated by the case law discussed in Chapter VII.

To examine the necessity, including the proportionality, of Article 66, section 3 in conjunction with Article 30, section 2 of the DCCP, these provisions should furthermore be considered in light of the other amendments that the DPTA brought about. Extension of the term during which information may be kept from a suspect serves to further facilitate the course of criminal investigations into terrorism. In the government's view, the investigative authorities should not be hindered in any way while conducting such investigations. An obligation for the prosecution to disclose the whole case file to a terrorist suspect after nine months detention on remand, would, in that respect, be an unnecessary hindrance. In this respect, it should not, however, be left unmentioned that in practice, the period of nine months can be extended, and consequently also the full disclosure of the case file by means of pro forma hearings.

A last question that should be discussed at this point is whether far-reaching interferences with a terrorist suspect's defence rights during habeas corpus proceedings can be justified with reference to national security concerns and/or a terrorist threat? The ECtHR recognises that there may be circumstances in which it is unavoidable to keep certain information from the suspect. However, the importance of this consideration is greatly diminished by the following limitations. To start with, investigative authorities are never exempt from the obligation to ensure that the domestic courts are, in fact, able to exercise free, full and effective control on the lawfulness of a suspect's pre-trial detention. This consideration limits the amount of, nature of, and time during which, information may be kept from a suspect and the competent court. That certainly goes for complex cases, with a large investigative file. Strasbourg case law mainly refers to secret intelligence information, instead of to information gathered by the investigative authorities. Therefore, it is highly questionable if the latter kind of information may be kept secret at all. Taking into account that the ECtHR even obliges states to disclose secret intelligence information to the suspect if necessary, it may be argued that information stemming from common investigative authorities will always have to be revealed to the suspect and the competent court - even if it regards criminal investigations into terrorism.

Complying with Articles 5 and 6 of the ECHR during habeas corpus proceedings in the case of terrorist suspects, may very well prove to be difficult in light of the above-discussed shortcomings. How these shortcomings can be adequately counterbalanced will be discussed in Section 4. 


\subsection{The right to freedom of movement and Dutch anti-terrorism legislation}

If the Bill comprising the administrative measures, as discussed in Chapter IV, had entered into force, infringements on the right to freedom of movement pursuant to Article 2 of the Protocol, would have been all but hypothetical. Fierce criticism has been voiced of the Bill, concerning the alleged lack of effectiveness, the questionable necessity, and the excessively broadly defined criteria for the application of the administrative measures. Like with respect to the DPTA, the government was not able to convincingly refute this criticism.

Drawing watertight conclusions with regard to the compliance of the measures comprised in the Bill with the Strasbourg right to liberty of movement is difficult. First of all, because there is no Strasbourg case law on interferences with the right to freedom of movement caused by state powers comparable to the administrative measures comprised in the Bill. The case law discussed in Chapter IV relates to interferences with the right to freedom of movement prior to, during, or after, criminal proceedings. Secondly, the Bill was withdrawn in June 2011, which means that there is no practical experience with these administrative measures whatsoever.

The intrusiveness of the administrative measures in terms of the right to freedom of movement, would have depended on the specific circumstances of the case. Would the person 'suspected' of connections with the (support of) terrorist activities have been obliged to report to the police headquarters three times a day or three times a week? And would he, in addition, have been subjected to an area injunction? How would these measures have been implemented practically? The more administrative measures the Minister of Interior would have imposed during protracted periods, the more far-reaching the interference with the right to freedom of movement would have been. Despite these uncertainties regarding the practical scope of the administrative measures included in the Bill, there are, at least, three key aspects that unequivocally lend support to the withdrawal of the Bill.

Firstly, the very broadly defined criteria for the application of the administrative measures would have created an equally large discretionary power for the Minister of the Interior. As repeatedly emphasised by the ECtHR with respect to all fundamental rights that allow for restrictions, large discretionary powers pave the way to arbitrariness and legal uncertainty. Whether the application of the administrative measures would have been considered in accordance with the law is, therefore, doubtful. Moreover, large discretionary powers must be counterbalanced with procedural guarantees, such as adequate judicial control.

The Minister of the Interior is obviously no judicial authority, and was therefore less suited, in Strasbourg terms: (1) to decide whether administrative measures were to be applied to begin with, and (2) to monitor and examine the necessity of continued application of such measures. Mandatory ex ante or ex post facto judicial 
control was not provided for. Whether or not a court would have been asked to examine the lawfulness of imposed administrative measures depended on the question of whether the person subjected to such measures lodged an appeal with the Hague District Court pursuant to Article 4 of the Bill. The scope of these proceedings, as to substance, remains, furthermore, unclear. In order for a court to effectively review the lawfulness of restrictions on fundamental rights, judges should have been given access to the information used to justify the application of the administrative measures. Taking into account the very broad 'suspicion criterion' that would have been attached to the application of the administrative powers, which, moreover, referred to behaviour that could take place even prior to the pro-active phase, makes it very likely that secret intelligence information would have come to play the chief role in fulfilling the criteria for application. ${ }^{1909}$ It goes without saying that when such information is not disclosed to a person that would have been subjected to the measures and/or to the competent court, it may undermine the quality of such judicial review. In addition, the scope of such judicial control would have been limited, given the large discretionary power attributed to the Minister of Interior.

Secondly, according to the government there were no effective procedural powers to prevent terrorism in between arresting a suspect on the basis of a reasonable suspicion for one thing, and tailing a person who allegedly formed a threat against national security on the basis of the secret intelligence services' powers, for another. That gap needed to be filled in by the Bill. However, in light of the (special) investigation techniques and procedural powers applicable on the basis of 'a light reasonable suspicion' or on the basis of indications of a terrorist offence, and since the entering into force of Article 134a and $83 \mathrm{~b}$ of the DCC, there is no longer a gap in the state arsenal regarding the prevention of terrorism. That makes it very doubtful that the administrative measures would have been considered necessary in a democratic society as required under Article 2 of the Protocol. The administrative measures comprised in the Bill were basically rather redundant. In light of the findings in Chapter II it is, moreover, unclear what 'pattern of conduct' used to demonstrate a person's alleged connections with (the support of) terrorism, that seriously endangers national security, will not lead to criminal liability pursuant to the DCC. Behaviour on the basis of which the administrative measures would have been applied, currently leads to criminal liability under the DCCP on account of one or more of the many inchoate terrorist offences. In sum, it appears as if the investigative authorities have, at their disposal, adequate (special) investigation techniques and procedural powers that may contribute to the prevention of terrorism, possibly even more effectively.

That last aspect brings us to the third aspect: the very doubtful effectiveness of the administrative measures comprised in the Bill. This issue has been discussed in 
Section 8 of Chapter IV. ${ }^{1910}$ Rather than preventing terrorism, the administrative measures would have been more likely to further polarise different communities, which in turn might very well have led to radicalisation.

So, (1) the broad discretionary power for the Minister of Interior caused by the vague criteria for application of the administrative powers, (2) the lack of adequate mandatory judicial control on the lawfulness of the interferences with the right to freedom of movement caused by these measures, and (3) the very doubtful necessity and effectiveness of the Bill would, most likely, have led the ECtHR to conclude that these measures were disproportional and, consequently, not necessary, as required by Article 2, section 2 of the Protocol.

In his letter regarding the withdrawal of the Bill, the Minister of Justice asserted that the Bill was withdrawn because of the new anti-terrorism measures and powers introduced in the criminal justice system. ${ }^{1911}$ Hence, the administrative measures had indeed become redundant, in particular, after enactment of the DPTA.

\subsection{Blacklisting and fundamental rights and principles of law}

The last set of anti-terrorism measures that needs to be discussed in light of fundamental rights and principles of law is the European Union's blacklisting system. On top of all the anti-terrorism legislation discussed above, blacklisting and the imposition of fund-freezing measures constitute a form of ostracism: parties that are allegedly related to (the financing of) terrorism are cut off from all the basic means of functioning normally within society, without proven guilt. Just as for the Netherlands, also for the Union and for the UN, the prevention of terrorism is, and will remain, a top priority. Blacklisting and the imposition of fund-freezing measures are considered an indispensable means to effectively prevent (the financing of) terrorism. Despite the fact that the Union Judiciary repeatedly judged several parts of the blacklisting system to be in violation of fundamental rights, the Union does not at all intend to fundamentally change the blacklisting system, let alone rescind it. On the contrary, the Union calls for a reinforcement of the prevention strand in its counter-terrorism policy. ${ }^{1912}$

Even though the Union continues to underline that measures in the fight against terrorism must be undertaken within the framework of full respect for fundamental rights so that they do not give rise to challenge, practice shows that the blacklisting system does not comply with fundamental rights and principles of law, comprising

1910 See, also, M. Kuijer, Van Lawless naar een rechtmatige bestrijding van terrorisme, Wolf Legal Publishers 2005, pp. 16-17, where Kuijer underlines the very doubtful effectiveness of the administrative measures comprised in the Bill.

1911 Kamerstukken I 2010-2011, 30 566, E.

1912 See, Council of the European Union, The Stockholm Programme - An open and secure Europe serving and protecting the citizens of 2 December 2009, 16484/1/09 REV 1 JAI 866 + ADD 1, p. 50 . 
defence rights, the right to property, and the principles of proportionality, subsidiarity and legal certainty.

As discussed in Chapter VIII, blacklisting and the imposition of fund-freezing measures should be considered to fall within the scope of 'criminal charge' pursuant to Article 6 of the ECHR. Fund-freezing measures are of such a repetitive character, so all-encompassing, and are imposed for such long duration, that these must be considered to amount to criminal sanctions. The nature and severity in terms of the consequences of (subjecting parties to) fund-freezing measures further uphold this assumption. ${ }^{1913}$ Additionally, the Union's choice of words regarding terrorism and anti-terrorism measures is unmistakable: terrorism constitutes a serious criminal offence that must be effectively countered by means of the criminal justice system. The FD 2002, which calls upon states to criminalise terrorist offences and to punish terrorists with penalties reflecting the seriousness of the offence, is a clear demonstration of this criminal law inspired attitude.

The problems, in terms of compliance with fundamental rights and principles of law, that arise with respect to the domestic anti-terrorism legislation discussed above, also occur with respect to the blacklisting system.

Case law demonstrates that even though the Council is, theoretically, the competent authority to blacklist a party, factually speaking the Member States decide who is included on the Union blacklist. The prescribed periodic review, in real terms, comes down to a simple six-month extension of the blacklisting decision, without the required full review of the initial reasons for inclusion on the list. That extension is performed by the Executive authority itself, who, moreover, initially imposed the measures, instead of by a court.

Generally, the longer a party is subjected to measures adversely affecting it (throughout criminal proceedings), the more justifications - among which in terms of suspicion - there must be to justify interferences with fundamental rights and principles of law. For example: to justify continued pre-trial detention, there must be an equally rising level of suspicion and there must be relevant and sufficient substantiated justifications. Far-reaching restrictive measures/sanctions imposed for extensive periods, without there being any effective periodic judicial review, and hence, without any examination of the validity of the reasons used to justify the initial imposition of such measures, heavily undermines the right to respect for defence rights, and it erodes fundamental principles of law such as the principle of proportionality. ${ }^{1914}$

Despite the fact that, in theory, there is a remedy available for blacklisted parties belonging to category 1 and 2, the procedural deficiencies attached to judicial 
proceedings, during which the lawfulness of fund-freezing measures is examined, have made that remedy factually meaningless as far as it concerns delisting. The right to an effective legal remedy is made completely dependent on compliance with the right to be heard and the right to be provided with a statement of reasons. Hence, the Union Judiciary interprets the right to an effective legal remedy merely as having factual access to a remedy. Generally, the statement of reasons is provided to the blacklisted party and the party is heard after the implementation of the blacklisting decision. If there were be a possibility for the blacklisted party to effectively rebut the substantive information that led to the national decision, and consequently, to the Council's decision to freeze his funds, that would be acceptable. However, that is clearly not the case. ${ }^{1915}$

The substantive 'suspicion criterion' of involvement in (the financing of) terrorism pursuant to CP 931, is very broad, and has, in practice, hardly any relevance in deciding whether or not to include a party on the blacklist. Factually, the Member States and the Council have an unlimited discretionary power in this respect. The formalistic interpretation of the criteria for the application of fund-freezing measures leads to a factual situation where blacklisted parties are kept from questioning in front of the union Judiciary the well-foundedness of the substantive basis of these measures. Respect for the right to an effective legal remedy and the right to effective judicial review of decisions adversely affecting civilians cannot be adequately guaranteed when blacklisted parties are not (fully) informed of the reasons, as to substance, for being considered as involved in (the financing of) terrorism. This makes judicial review before the Union Judiciary very limited.

At first sight it seems as if judicial review, following an action to be delisted, is all-encompassing, but in practice, that is not the case. The scope of judicial review is limited due to the fact that: (1) the Council has to cooperate in good faith with the Member States, which allows, in practice, full play for the requesting Member State when it comes to blacklisting, and (2) the Council and the Member States have a large discretionary power in deciding who is to be included on the blacklist vis-àvis the Union Judiciary.

In addition, it is important to keep in mind that the Union Judiciary repeatedly argued that Member States are allowed to keep certain evidence confidential when national security demands so. That not only limits the Council's obligation to provide a blacklisted party with a full statement of reasons, but it also considerably restricts the Judiciary in deciding on the lawfulness of these measures, especially as regards substance.

Practice demonstrates, furthermore, that even if the Union Judiciary orders a party to be delisted, the Council simply repairs the procedural deficiencies and takes a new blacklisting decision. The mere difference for these parties is that the Council is obliged to provide them with a statement of reasons, assure them a fair 
hearing at some point, and offer them access to a legal remedy. Once these requirement have, in terms of procedure, been met the Union Judiciary is satisfied, even though the parties claim that substantive requirements as comprised in CP 931, have still not been complied with.

This means that judgements of the Union Judiciary become, in part, meaningless for the parties affected. These judgements do not necessarily change the blacklisted party's legal status. The factual situation of blacklisted parties remains therefore unchanged: Kadi, Yusuf, Othman, Al Barakaat and Al-Aqsa remain(ed) on the blacklist, and their assets continue(d) to be frozen, despite the fact that the Judiciary concluded that fundamental rights had been violated. Sison was removed from the blacklist but his assets are still frozen - the legal basis of which is unclear.

Even though the Union blacklisting system has been improved in terms of procedural fairness in recent years, among which the obligation to provide blacklisted parties at some point with a statement of reasons, a lot still needs to be done to make these proceedings comply with fundamental rights and principles of law. The right to a fair hearing, the right to an effective legal remedy, and the right to effective judicial review, cannot be guaranteed without giving the blacklisted party access to (some of) the information which led the national authority to denote the party as being involved in (the financing of) terrorism. In this respect, it is important to note that the 2009 Sison judgement demonstrates that compliance with the obligation to state reasons may, in terms of procedural requirements, be fulfilled, while in terms of substance it is still completely unclear why in fact a party has been included on the list. This means that compliance with the procedural requirements attached to the obligation to state reasons does not suffice to ensure an effective legal remedy and effective judicial review.

A last issue regards the necessity of blacklisting and the imposition of fund-freezing measures. Will the freezing of assets of parties presumably involved in (the financing of) terrorism in fact contribute to the prevention of terrorism? Are blacklisting and the imposition of fund-freezing measures a proportional means to prevent terrorism in light of the limited (review on) substantive prerequisites to impose such measures and the restricted procedural guarantees throughout blacklisting proceedings?

To adequately answer these questions it needs, for example, to be ascertained if the perpetration of terrorist offences in fact requires extensive funds. Case law, as discussed in Chapter II, demonstrates that terrorist offences, as committed within the Netherlands, for example, do not appear to require extensive funds, but primarily require technical knowledge. However, even if the perpetration of terrorist offences would turn out to be expensive, it is questionable how fund-freezing measures will effectively prevent alleged terrorists from gathering funds through other (illegal) means. In this respect, it would be interesting to know what amount of money the Union (and the UN) has frozen in order to prevent terrorism. 
These questions are crucial while examining the blacklisting proceedings on compatibility with fundamental rights and the principles of law, primarily those relating to the necessity of fund-freezing measures. This is all the more important, given that the alleged effectiveness of fund-freezing measures is used as justification for blacklisting presumed terrorists. The Union justifies interferences with, and even violations of, defence rights and other fundamental rights with reference to the importance of effectively preventing terrorism and safeguarding security. If subjecting parties to fund-freezing measures appears to be not as effective as alleged, the most important justification for these measures loses its value.

\section{COUNTERBALANCING INTERFERENCES WITH FUNDAMENTAL RIGHTS AND PRINCIPLES OF LAW}

After the large scale 9/11 terrorist attacks in the USA and the terrorist attacks in, for example, Madrid (2004), London (2005) and Moscow (2008), life today without a firm preventive anti-terrorism policy is impossible to imagine. Taking into account the large number of victims and the fear that such attacks induce in society, the prevention of terrorism is a legitimate goal that may, moreover, be attained in full compliance with fundamental rights and principles of law. ${ }^{1916}$ The preamble of the Guidelines of the Council of Europe on Human Rights and the Fight against Terrorism reaffirms the imperative duty of states to protect their populations against possible terrorist acts. Pursuant to Article 1 of these Guidelines, states are under the obligation to take the measures needed to protect the fundamental rights of everyone within their jurisdiction against terrorist acts, especially the right to life. This positive obligation fully justifies states' fight against terrorism, as long as that fight remains in accordance with the other provisions comprised in the Guidelines.

However, the present overuse of the (criminal) justice system in preventing terrorism, primarily by a strong emphasis on broad criminal liability for inchoate (terrorist) offences and corresponding broadly defined state powers, can lead to violations of fundamental rights and principles of law. To broaden criminal liability far into the pro-active phase, while concurrently expanding the scope of application of procedural powers without providing for the required counterbalancing safeguards, shall inevitably raise issues before the ECtHR. Anti-terrorism legislation creates a two-fold legal uncertainty that makes it almost impossible to ascertain under which circumstances what powers may be applied to investigate which kind of criminal behaviour.

The joint effects of the anti-terrorism legislation discussed above, and in that light, the insufficiently corroborated necessity of these measures, are striking.

1916 In that respect, I agree with the conclusion Aksu has drawn in her dissertation. See M. Aksu, Straatsburgse kaders voor terrorismebestrijding. EVRM, strafrecht en terrorisme, Wolf Legal Publishers, 2007, pp. 201-202. 
Basically, an entirely new criminal justice system is developing, however without being furnished with adequate counterbalancing procedural (judicial) guarantees. This last section therefore aims at giving an initial impetus to develop ways to prevent terrorism by means of the powers and measures discussed above, without violating fundamental rights and principles of law.

\subsection{Terrorist offences}

The combination of terrorist intent with complete offences is less problematic in terms of fundamental rights and principles of criminal law, such as the principle of legality and proportionality, than when terrorist intent is linked to inchoate offences. Rescinding the amendments brought about by the DTA is very unlikely given the fact that the DTA is an implementation of the FD 2002. Theoretically, the amendments that exceed the implementation of the FD 2002, such as conspiracy and recruitment for the armed struggle, could be rescinded. Taking into account the current political trend within the Netherlands, it is improbable that there will be sufficient political support to do so. ${ }^{1917}$ In addition, the fact that substantive criminal law as regards terrorist offences also serves to broaden the scope of application of criminal procedure, makes it very unlikely that the broad category of terrorist offences will be narrowed down to the most severe offences. This implies that the principles of legality and legal certainty, as applicable within substantive law, will, foremost, have to be guarded by means of amendments to criminal procedure, rather than by directly amending substantive criminal law as regards to terrorist offences.

Primarily, the Judiciary should guard against unlimited criminal liability in respect of terrorist offences. The fundamental principle that (terrorist) intentions are not liable to punishment should be preserved. Case law shows that the Judiciary is still exploring the scope of the notion of terrorist intent. In that respect, an elaborate judgement of the Dutch Supreme Court on this notion should be very welcome. In general, using the criminal justice system to prevent terrorism, without violating fundamental rights, and foremost, without undermining the principle of legality and legal certainty, presupposes that the notion of terrorist intent should be specified and narrowly interpreted by the Judiciary and applied by the Executive. Prerequisites for factual conduct should, furthermore, remain the same as those for common offences.

1917 See, in this respect, A.H. Klip, 'Totaalstrafrecht', in Delikt en Delinkwent 2010, 34, pp. 583-592; R. Schoof and M. de Waard, 'Het denken wordt strafbaar. Jurist André Klip over tereurbestrijding in de rechtsstaat', in NRC Handelsblad, 8 January 2005. 


\subsection{Special investigation techniques}

First of all, the broad scope of the suspicion criterion of 'indications of a terrorist offence' should be supplemented with a factual statutory benchmark in order to enable the investigative authorities and the judicial ones to effectively balance and examine whether the special investigation techniques comprised in Title VB can be applied lawfully in a specific case. To that effect, a general provision could be added to the first division of Title VB - General Provisions - entailing a clear substantive description of the suspicion criterion for the application of the special investigation techniques and the investigative powers in security risk areas. Such a provision would take away part of the current ambiguity for the Executive and the Judiciary in judging whether or not certain information may be considered sufficient to lead to 'indications of a terrorist offence'. Also, such a provision should clarify the difference between application of special investigation techniques pursuant to Titles IVA/VA on the basis of a reasonable suspicion, and Title VB on the basis of indications of a terrorist offence. That suspicion criterion should, furthermore, be 'reinstated' as the main criterion for the application of these techniques, instead of the interest of the investigation. The application of special investigation techniques on the basis of indications of a terrorist offence merely to exclude risks, as happens now, goes beyond the statutory scope of application of these techniques. ${ }^{1918}$

The very broad scope of special investigation techniques on the basis of indications of a terrorist offence can, furthermore, be counterbalanced in various ways. One possibility is to include an explicit statutory obligation for the competent authorities to examine the necessity, and hence the proportionality, of applying such techniques on the basis of indications of a terrorist offence, rather than on the basis of a reasonable suspicion. To that effect, an extra criterion for the application of these techniques can be included in the provisions of Titles VB and VC: the application of the techniques comprised in these titles is only possible when the application of the same techniques pursuant to Titles IVA, V, VA, proved to be ineffective, while the application of these techniques is urgently demanded by the interest of the investigation.

Another possibility is to oblige the competent authority to first apply less intrusive techniques prior to having recourse to the most severe techniques or to concurrent application of several special investigation techniques. German legislation in the field of measures of secret surveillance demonstrates that a multi-stage system as regards to the competent authority is an option as well. ${ }^{1919}$ This would mean that less intrusive special investigation techniques can initially be ordered by a public prosecutor but if these are applied for longer than one month, the authorisation of an

1918 See Chapter V, Section 7.
1919 See Chapter V, Section 8.2. 
investigative judge is required. A differentiation on account of the terrorist offence that is investigated is also possible: the application of special investigation techniques in the case of inchoate terrorist offences requires prior authorisation of an investigative judge, whereas 'complete' terrorist offences do not require such an authorisation; or inchoate terrorist offences have to be investigated on the basis of a reasonable suspicion (Titles IVA, V and VA), whereas complete terrorist offences may be investigated on the basis of Title VB.

Whatever combination of possible amendments one chooses, there should be a multi-stage system of competent, authorising and monitoring judicial authorities for the techniques comprised in Title VB, depending on the intrusiveness of the special investigation techniques, the terrorist offence in respect of which these techniques are applied, and the period during which they are applied. Such a system would better reflect the ECtHR's general rule that the more far-reaching interferences with fundamental rights are, the more demanding the justifications must be, and the more mandatory procedural safeguards must exist, to prevent arbitrariness.

The ECtHR considers the monitoring of the application of special investigation techniques, particularly relevant in the case of interferences with Article 8 of the ECHR. ${ }^{1920}$ Besides the public prosecutor's task of generally supervising the course of a criminal investigation, the DCCP does not provide for a statutorily prescribed supervision by an independent authority. Within the Dutch criminal justice system, such supervision is all the more important due to the fact that most criminal investigations during which special investigation techniques on the basis of indications of a terrorist offence are used, do not lead to criminal proceedings and do not include an obligation for the Executive to request prior authorisation from an investigative judge. Monitoring the implementation of special investigation techniques pursuant to Title VB, should be attributed to a judge, or, in any case, to an authority independent of the Executive.

In sum, the most important goal of the possibilities described above is to counterbalance the extensive discretionary power of the investigative authorities and the legal uncertainty this creates. Strasbourg case law shows that the less wellsubstantiated a suspicion is, as a legal prerequisite for the application of procedural powers, the greater the need for compensation in the form of independent judicial control (preferably by a court). Therefore, despite the fact that also for an investigative judge or court it will be difficult to examine whether the broad criteria for the application of the techniques and powers have been complied with, that option is preferable to attributing the large discretionary power to a public prosecutor only. Such a prosecutor is inevitably less independent and obviously more inspired by prosecutorial motives, especially when it concerns a political sensitive issue such as terrorism. 


\subsection{Investigative powers in security risk areas}

In line with the ECtHR's judgement in Gillan and Quinton v. the United Kingdom the principles of proportionality and subsidiarity should be explicitly comprised within the system of Articles 126zr, 126zs and 126zq of the DCCP and must be complied with regarding: (1) the order from the public prosecutor/the ordinance, and (2) regarding the application of the investigative powers in specific cases. This forms an important safeguard against arbitrary interferences with the right to privacy. In that respect, the application of investigative powers in security risk areas can, first of all, be better aligned to the system of security risk areas, as comprised in Article 50, section 3, Article 51, section 3, and Article 52, section 3 of the WAA. This means that the public prosecutor should be statutorily obliged to indicate in the order to apply the investigative powers, the facts and circumstances that make such application necessary. However, the criteria for application comprised in the abovementioned WAA provisions create a considerably more limited power than Articles 126zr, 126zs and 126zq of the DCCP. Investigative powers within security risk areas pursuant to the WAA and the Municipality Act, may only be used to search for weapons and ammunition, whereas investigative powers within security risk areas pursuant to Article 126zr, 126zs and 126zq of the DCCP, are not limited as to what the police officers may look for. This almost unfettered power is, in terms of compliance with Article 8 of the ECHR, a huge shortcoming. Moreover, this power is not at all counterbalanced by adequate safeguards, such as ex ante or ex post facto mandatory authorisation, supervision, or control by a court.

To further counterbalance the large discretionary power of the public prosecutor to order the application of investigative powers and of the police officers to use these powers, it would be better to restrict the category of terrorist offences in the case of which the application of the investigative powers may be ordered and used, to the most severe ones, and to demand prior authorisation from an independent judicial authority or court. In light of Article 8 of the ECHR, the doubtful effectiveness of applying investigative powers to prevent terrorism can only justify the application of such powers in a limited category of severe terrorist offences - those that directly threaten lives or goods. ${ }^{1921}$

1921 See, in this respect, P.H.P.H.M.C. van Kempen, 'Het conceptvoorstel voorkoming, opsporing en vervolging van terroristische misdrijven: terrorismebestrijding door marginalisering strafvorderlijke waarborgen', in $N J B$ 2005/8, p. 397 and further, paragraph 8. Van Kempen proposes to limit the application of the powers/measures comprised in the DPTA to terrorist offences with a penalty clause of life imprisonment. 
Chapter IX

\subsection{Exploratory inquiry}

As demonstrated above, the power for the public prosecutor to demand data files during an exploratory inquiry into terrorist offences is extremely broad. Demanding data files from large groups of non-suspected civilians without a reasonable suspicion of a specific offence, requires considerable safeguards against arbitrary interferences with the right to privacy. Unlike the other powers and measures to prevent terrorism, Article $126 \mathrm{hh}$ of the DCCP has been provided with a counterbalancing safeguard: the public prosecutor is obliged to get prior authorisation from an investigative judge to demand data files. He also has to submit a well-argued request to the Board Procurers General to get approval prior to initiating an exploratory inquiry into terrorist offences. Due to the broad scope of exploratory inquiries, such prior authorisation should also apply in the case of Article 126ii of the DCCP, even if that provision concerns less privacy-sensitive information.

In practice, whether or not these provisions are compatible with Article 8 of the ECHR is dependent on the extent to which the investigative judge and the Board Procurers-General are able to effectively examine the justifications for, and the necessity of, demanding data files in specific cases.

\subsection{Deprivation of liberty}

Even though remand in custody on the basis of a reasonable suspicion instead of on the basis of serious objections is as such not incompatible with Article 5 of the ECHR, there are several aspects which do require increased judicial control of pretrial deprivation of liberty of terrorist suspects.

First of all, remand in custody on the basis of a light reasonable suspicion applies to suspects of all terrorist offences. No differentiation has been made between offences that pose an imminent and acute threat to life or goods and offences that may eventually in the future lead to such a threat. The first category of terrorist offences may justify remand in custody on a (light) reasonable suspicion, the second category cannot, as such, be considered necessary. In this respect, it should be kept in mind that the Dutch system of pre-trial detention is already at odds with Strasbourg criteria on lawful deprivation of liberty. ${ }^{1922}$ Lastly, police custody and remand in custody of terrorist suspects is currently used to thwart alleged terrorist threats, instead of being justified on one of the statutorily defined criteria mentioned in Article 67a of the DCCP. Strictly speaking, this is unlawful.

Pre-trial detention of terrorist suspects demands extra automatic judicial control by a court. Currently a terrorist suspect is mostly only interrogated once by the investigative judge during the term of police custody and remand in custody. In

See Section 3.4. 
case the term of police custody is extended once by three days, the suspect will be interrogated twice. Irrespective of whether police custody has been extended, one extra arraignment before the investigative judge during these first three weeks of pre-trial detention will provide for an extra safeguard against arbitrary interferences with the right to liberty of person in the case of a terrorist suspect. This is all the more important as there is no legal remedy against the investigative judge's decision to place a suspect under remand in custody. Extra judicial control of police custody and remand in custody will, furthermore, only be effective if the arraignment before the investigative judge includes a serious examination of compliance with the substantive criteria for the application of these coercive powers.

With regard to the possibility of prolonged detention on remand of terrorist suspects, it would be preferable to comprise an explicit and mandatory element of proportionality in Article 66, section 3 of the DCCP. Generally, to adjourn trial for three months pursuant to Article 282 of the DCCP, the public prosecutor must demonstrate 'weighty reasons' [klemmende redenen] to do so. However, extension of the period of detention on remand by two years pursuant to Article 66, section 3 of the DCCP, regarding terrorist offences, does not require the fulfilment of such an extra prerequisite. It would be advisable to include the requirement of demonstrating weighty reasons also in Article 66, section 3 of the DCCP. That would oblige the public prosecutor, while requesting the extension of detention on remand, to demonstrate the necessity thereof, and the competent court, while examining such a request, to explicitly examine the same.

During the prolonged period of detention on remand for terrorist suspects, the right to lodge a habeas corpus complaint pursuant to Article 69 of the DCCP, should enable the suspect to repeatedly, within short intervals (one month), lodge habeas corpus proceedings. The effectiveness of this remedy depends to a large extent on how much information the public prosecutor is willing to disclose to the suspect and the competent court. It is to this issue that we will now turn.

\subsection{Non-disclosure of information comprised in the case file}

To counterbalance the potentially far-reaching interferences with Articles 5 and 6 of the ECHR, the amendment to Article 66, section 3 of the DCCP and its impact on the scope of Article 30, section 2 of the DCCP should have been provided with counterbalancing safeguards. As stated above, prolonged pre-trial detention must go hand in hand with periodic judicial review during which all substantive requirements for lawful, and hence, Strasbourg conforming, detention on remand, can sufficiently be challenged and examined. In this respect, it is important to keep in mind that the longer pre-trial detention lasts, the more habeas corpus proceedings are considered to import substantially the same fair trial guarantees as Article 6, section 1 of the ECHR in its criminal aspect. If it is deemed necessary to prolong 
the period of pre-trial detention for persons suspected of a terrorist offence, at least the court deciding on the lawfulness of the pre-trial detention should have access to all the information that makes the deprivation of liberty, in the prosecution's opinion, lawful, necessary, proportional and non-arbitrary.

To compensate for the considerable interference with terrorist suspects' right to access the case file, reference should be made to the UK disclosure procedure, as discussed in A. and Others $v$. the United Kingdom. ${ }^{1923}$ The special advocate procedure will serve as an adequate safeguard against unjustified interferences with fair trial rights during habeas corpus proceedings, provided that the special advocate is allowed: (1) to actually inspect the evidence, (2) to put arguments on behalf of the detainee during the closed hearing, and (3) to make submissions to the judge regarding the case for additional disclosure. The suspect must be provided with sufficient information about the allegations against him to enable him to give effective instructions to the special advocate.

As mentioned above, introducing the UK disclosure-procedure into the DCCP is only effective when the court deciding on the lawfulness of the pre-trial detention has access to all the information in the case file. Only then will the competent court be able to fully examine whether the non-disclosure of certain records is strictly necessary in the interest of the investigation and state security, without losing sight of the importance the ECtHR attaches to defence rights, and proportional to the aim pursued. ${ }^{1924}$ The competent court should ensure that information that is of importance to examine the lawfulness of pre-trial detention is never kept from a (terrorist) suspect. Related to this, a suspect should be granted adequate access to the case file in order to decide whether or not he wants to make use of his rights under Article 5, section 4 of the ECHR. Hence, the court should not merely guard a suspect's right to access to the required documents during habeas corpus proceedings, but also prior to such proceedings. Otherwise, a suspect's right under Article 5, section 4 ECHR may become ineffective, unenforceable and consequently illusory.

The ECtHR regards the UK disclosure procedure as an effective measure to both accommodate investigative interests, and concurrently guarantee respect for important defence rights, also in cases regarding terrorism. Hence, if Article 66, section 3 of the DCCP, in conjunction with Article 30, section 2 of the DCCP remains in force, it should be an independent court deciding on the question of whether a terrorist suspect may be denied access to part of the case file, and not a public prosecutor that forms part of the Executive. In this respect, the amendment to Article 32 of the DCCP should be revoked. The scope of the right to lodge complaints against non-disclosure of information from the case file should not be

1923 See Chapter VII, Section 6.5.

1924 See, in this respect, also, T. Kooijmans \& J.B.H.M. Simmelink, 'Het recht op kennisneming van de processtukken in het Wetsvoorstel tot verruiming van de mogelijkheden tot opsporing en vervolging van terroristische misdrijven', in Delikt en Delinkwent 2006, 10/79, pp. 1107-1126. 
statutorily limited, particularly not because the enforcement of that right directly influences the effectiveness of the right to lodge a habeas corpus complaint.

The importance of allowing judges access to the complete case file is considerable when it regards terrorism. In practice, this may prove to be in the interest of all parties involved. Investigations into terrorism bring about a considerable rate of error. As has been repeatedly stated in this dissertation, there is a substantial chance of getting 'the wrong guy' when investigating alleged terrorist offences. Several aspects cause this: The broad criminal responsibility when it concerns terrorist offences, the fact that procedural powers may be applied far into the pro-active phase, the role of the secret intelligence services in tracing alleged terrorist suspects, the pressure on the investigative authorities to prevent terrorist offences, and the application of measures implying deprivation of liberty to thwart an alleged terrorist threat. These features - non-limitative - make it all but illusory that a public prosecutor would deem an innocent person to be a terrorist suspect. This risk is not to be sneezed at, because it implies a chance of depriving an innocent person of his liberty for a considerable time. The materialisation of such a risk during investigations into terrorism may be prevented by granting at least the court deciding on pre-trial deprivation of liberty, but preferably also the suspect, full access to all the information which led the investigative authorities to considering the person concerned as suspect of a terrorist offence. Also, if the competent court were allowed access to the whole case file, judges would not be faced with unnecessarily difficult decisions regarding requests for extension of a terrorist suspect's detention on remand. ${ }^{1925}$

\subsection{Blacklisting}

To make blacklisting proceedings compliant with fundamental rights and principles of law, these proceedings have to be amended considerably. I will discuss three of the most essential amendments.

Firstly, the substantive 'suspicion criterion' of involvement in terrorist acts as comprised in CP 931, should, in practice, become the main criterion for the application of the Council's blacklisting decision and for the imposition of fundfreezing measures, rather than the formalistic question of whether there is a 'national decision'. This criterion should, furthermore, be phrased more precisely and restrictively to preserve legal certainty, to limit the large discretionary powers of the Member States and of the Council of the European Union, and to increase the power of judicial control for the Union Judiciary. The accordingly enhanced scope of the substantive prerequisites for blacklisting will reinforce, with regard to substance, the Council's obligation to state reasons. That will considerably contribute to safeguarding respect for the right to an effective legal remedy, to the

1925 See Kamerstukken II 2005-2006, 30 164, nr. 6, p. 19. 
right to a fair and effective hearing and consequently, to effective judicial review on the lawfulness of blacklisting and the imposition of fund-freezing measures.

And finally, the mandatory periodic review of blacklisting decisions will gain weight and effectiveness as to its substance when criteria for inclusion on the blacklist are restricted and phrased with more precision. The obligation to provide the blacklisted party with a new statement of reasons after the periodic review will in fact have an actual purport, instead of being a literal copy of an earlier statement of reasons.

Secondly, affected parties should be heard as soon as possible after the blacklisting decision, and, in any case, immediately after the freezing of their funds. In terms of substance, the Council should inform the affected parties with precise and detailed information regarding the reasons for their inclusion on the blacklist. During this first hearing, the blacklisted parties must particularly be enabled to factually raise objections against the allegation of being involved in (the financing of) terrorism before a judicial authority. Parties that have been wrongly blacklisted, and/or on the basis of false information, should be delisted immediately. To furthermore make such a hearing effective, specific authorisation should be granted to blacklisted parties to pay for legal assistance throughout delisting proceedings.

Thirdly, effective judicial review of blacklisting decisions should be guaranteed. In order for the Union Judiciary to examine the lawfulness of a blacklisting decision, regarding both procedural and substantive aspects, it must have all the information which led the Council and the Member State to include the party on the blacklist and to impose fund-freezing measures. Withholding information from the Judiciary and from the blacklisted party makes delisting proceedings more or less meaningless. Case law of the Union Judiciary tends to give some leeway for a construction where the Judiciary is allowed access to all the information, whereas the blacklisted party is not. In terms of guaranteeing full and effective judicial review that is not, however, the most preferable situation. Given the far-reaching interferences with a blacklisted party's rights, that party should be allowed access to the information that led to the blacklisting decisions as far as possible. In this respect, it is, furthermore, important that the annulment of a blacklisting decision will, in practice, lead to delisting. Hence, the Union Judiciary's judgements regarding blacklisted parties must factually be implemented. This also implies that funds of delisted persons should not remain frozen despite an annulment of the blacklisting decision.

\section{Concluding Remarks}

The state powers and measures to prevent terrorism available within the Dutch legal system, unmistakably infringe upon, and in some cases, may violate, fundamental legal rights and principles of law, as enshrined in treaties to which the Netherlands 
are bound. Indeed, treaties such as the ECHR are higher law in a way the Dutch Constitution is not. Strange as this may sound, Dutch laws cannot be examined on compatibility with the Dutch Constitution. Unlike in, e.g., Germany and the United States, the Dutch Judiciary is even expressly forbidden to do so. However, Dutch laws can be examined on compatibility with the ECHR. In the case of conflict, the ECHR prevails. The ECtHR has made its stance on these matters abundantly clear, by judging part of the UK anti-terrorism legislation in contravention of British treaty obligations under the ECHR.

In attempting to answer the key research question as defined in Chapter I of this dissertation, I have entered into partly unchartered territory. There are three reasons for this. Firstly, domestic case law on the scope of criminal liability for terrorist offences is still scarce, and so far only to a very limited extent, clarifies the notion itself of terrorist offences, and more specifically, of terrorist intent. The consequent legal uncertainty concerns both substantive law and criminal procedure. Secondly, there is no domestic case law regarding the scope of the application of pre-trial state powers and measures that serve to prevent terrorism. The extensive statutory discretionary powers available to the Executive are therefore in no way specified, let alone limited. And thirdly, there is hardly any Strasbourg case law on the compatibility of anti-terrorism powers and/or measures such as the ones available within the Netherlands, with fundamental legal rights and principles of law as enshrined in the ECHR.

So far, the application of powers and measures to prevent terrorism under the statutorily defined criteria discussed in the preceding chapters is a field of law without proper and effective judicial review or control. ${ }^{1926}$ Not so much the Judiciary, as the Executive itself, controls the application of such powers and measures. This is at odds with the fact that various aspects of the anti-terrorism legislation discussed above may lead to violations of the ECHR. The extremely broad scope of criminal liability for terrorist offences, particularly during the proactive phase, and the wide discretionary powers of the Executive in this field, create the danger for consistent arbitrary and/or improper use of the (criminal) justice system, and therefore demand increased judicial control of the application of the powers and measures discussed in the preceding chapters. The Somali-case discussed in the introduction is a striking example of such arbitrary and improper use of the criminal justice system.

Prosecuting actual terrorist offences, and hence, literally applying and implementing the substantive (criminal) justice system, has been made subservient to the goal of

\footnotetext{
1926 This fits well into a trend of growing state powers and concurrently decreased judicial control of the application of such powers. See, Y. Buruma, 'De rechtsstaat in de knel tussen populisme en absolutism', in Delikt en Delinkwent 2009, 73.
} 
thwarting any potential terrorist activities by means of procedural law. To that effect, terrorist threats are assumed upon fulfillment of low and collectively applied suspicion criteria that are based on secret, anonymous, and often non-verifiable, information regarding persons' intentions, rather than regarding factual conduct that would lead to criminal liability. Consequently, large indefinite groups of people are controlled and screened by means of far-reaching (investigative) powers and measures, rather than specific suspected individuals forming the object of a criminal investigation into a specific terrorist offence.

Where it concerns terrorism, the objective of preventing alleged terrorism is considered more important than the question of whether the statutory means made available to that effect are really necessary, effective and, in general, whether these means are in compliance with fundamental rights and principles of law as defined in treaties the Netherlands subscribed to. In the previous section I have demonstrated that, in terms of the law, the justified aim of preventing acts of terrorism can be pursued without unnecessarily infringing on these rights and principles. What might be lacking is the unequivocal political will to do so. 


\section{BiBLIOGRAPHY}

Abels, P.H.A.M. and Willemse, R, 'Veiligheidsdienst in verandering; de BVD/AIVD sinds het einde van de Koude Oorlog', in Justitielle verkenningen, 30/3 2004.

Abspoel, J.J., 'Requisitoir bezetting Indonesisch consulaat', in Delikt en Delinkwent 1976.

Aden, S.H. and Whitehead, J.W, 'Forfeiting enduring freedom for homeland security: A constitutional Analysis of the USA Patriot Act and the justice department's antiterrorism initiatives', in The American University Law Review 2002.

Aksu, M., Straatsburgse kaders voor terrorismebestrijding. EVRM, strafrecht en terrorisme, dissertatie Wolf Legal Publishers 2007.

Albers, C.L.G.F.H. and Schlössels, R.J.N., 'Terrorismebestrijding: het bestuursrecht aan zet, de rechtsstaat in gevaar?', in NJB/44, 2006.

Alberts, J., 'Of ze konden komen praten over massavernietigingswapens. Het verhaal van een scheikundeleraar over de infiltratie van de geheime dienst in zijn leven', in NRC Handelsblad 8 July 2006.

Aldrich, R.J., 'Transatlantic intelligence and security cooperation', in International Affairs 80/4 2004.

Alink, M., 'AIVD-informatie als bewijs in het strafproces, Een Straatsburgs perpectief', in Via Straatsburg. Liber Amicorum Egbert Myjer, Wolf Legal Publishers 2004.

Anker, H., 'Zo spoedig mogelijk', in Nieuwsbrief Strafrecht 2004.

ANP, 'Meer Somaliërs opgepakt door OM dan AIVD wilde', in Volkskrant, 28 December 2010.

Asbeck, F.D. van and Jongeneel-van Amerongen, M., 'Uitgangspunten van het Wetsvoorstel bijzondere opsporingsbevoegdheden', in Tak P.J.P., (red.), Bespiegelingen omtrent de Wet Bijzondere Opsporingsbevoegdheden, Gouda Quint, Deventer 1998.

Bakkers, R.W.A., 'Risk-based AML-wetgeving roept om een robuust AML-raamwerk', in TvCo nr. 4, juli/augustus 2007.

Bal, P.L., 'De USA Patriot Act 1 en 2: Ongekendde uitbreiding van bevoegdheden in de strijd tegen het terrorisme', in Strafblad, 2/4 2004, 279-289.

Bassiouni, M.C., 'Legal Control of International Terrorism: A policy Oriented Assessment', in Harvard International Law Journal, 43/1 2002.

Berg, A.E.M. van den, \& Heinen, P.C.M., 'Wet Bibob en wetsvoorstel Bestuurlijke maatregelen nationale veiligheid: te kort door de Straatsburgse bocht?', in Gemeentestem 2007, 7285.

Biersteker, T. and Eckert, S., Addressing Challenges to Targeted Sanctions: An Update of the "Watson Report", October 2009.

Bijer, A., Brokhorst, R.J., Boone, M., Brants, C.H., Lindeman, J.M.W., De Wet bijzondere opsporingsmethoden - eindevaluatie, WODC 2004 Boom Juridische Uitgevers, Meppel.

Blekxtoon, R, 'Europees arrestatiebevel', in NJB/22, 2002.

Blok, A.J., and Besier, L. Ch., Het Nederlandsch strafproces, deel I, Haarlem, 1925. 
Boeles, P., 'Het gevaar van veiligheid', in MR. 6/7, 2006.

Borgers, M.J., 'De grenzen van het Rijk in Europa en de grenzen van interpretatievrijheid van de strafrechter', in Delikt en Delinkwent 2004, afl. 6/44.

Borgers, M.J., 'Strafbaarstellingen in de strijd tegen het terrorisme; Werving ten behoeve van de gewapende strijd en samenspanning tot terroristische misdrijven', in A.H.E.C. Jordaans, P.A.M. Mevis, \& J. Wöretshofer (eds.), Praktisch strafrecht. Liber Amicorum J.M. Reijntjes, Wolf Legal Publishers, Nijmegen.

Borgers, M.J., De vlucht naar voren, Boom Juridische Uitgevers, Den Haag, 2007.

Brinkhoff, S., 'Anoniem melden startinformatie voor een strafrechtelijk onderzoek', in NJB, 2008.

Broek, H. van den, 'ETA of de logica van escalerend geweld', in Proces: Tijdschrift voor berechting en reclassering, 82/2 2003.

Brokhorst, R.J., Kogel, C. de, Meij, C. van der, Evaluatie van de wet BOB: Fase 1, de eerste praktijkervaring met de Wet bijzondere opsporingsbevoegdheden, WODC 2002 Boom Juridische Uitgevers.

Brouns, P.J.H.M., Opzet in het Wetboek van Strafrecht, dissertatie RUG, Gouda Quint, Arnhem, 1988.

Brouwer, D.V.A., 'Het verkennend onderzoek in strafzaken en de wetgevingsspiraal', in $N J B / 12,2000$.

Brouwer, J.G., Van nachtbrakers tot terroristen, over persoonsgericht verstoren, inaugural lecture delivered at 13 June 2006, Groningen.

Buijs, F.J., Harchaoui, S., 'Islamitisch radicalisme en rekrutering in Nederland', in Proces:Tijdschrift voor berechting en reclassering, 82/2 2003.

Buijs, J., 'Tussen 11 september en de aanval op Irak', in Proces: Tijdschrift voor berechting en reclassering, 82/2 2003.

Bulterman, M, 'De financiële strijd tegen het terrorisme en de mensenrechten', in NJCMBulletin, 27/7 2002.

Burke-White, W.W., 'Human Rights and National Security: The Strategic Correlation', in Harvard Human Rights Journal, 172004.

Buruma, Y., 'Gewetensvolle rechters versus publieke opinie', in Delikt en Delinkwent, 33/2 2003.

Buruma, Y., 'Terrorisme en de weerbare rechtsstaat', in Delikt en Delinkwent, 31/10 2001.

Buruma, Y., and Muller, E.R, 'Wet Terroristische Misdrijven in perspectief', in $N J B / 41$, 2003.

Buruma, Y., 'De rechtsstaat in de knel tussen populisme en absolutisme', in Delikt en Delinkwent 2009, 73.

Buruma, Y., 'Grenzen aan de strafrechtelijke aansprakelijkheid', in Groenhuijsen, M.S. \& Simmelink, J.B.H.M. (red.), Glijdende Schalen. Liber Amicorum J. De Hullu, Wolf Legal Publishers, Nijmegen 2003.

Buruma, Y., 'Stelselmatig - een sleutelbegrip in de Wet Bijzondere Opsporingsmethoden', in NJCM-Bulletin 2000.

Buruma, Y., 'Terrorisme en de weerbare rechtsstaat', in Delikt en Delinkwent 2001.

Buruma, Y., 'Toekomstvoorspellingen en repressieve maatregelen', in NJB/10, 2006. 
Bibliography

Buuren van, J. and Schans van der, W., 'Europol actiever na 11 september: Controle en discussie lopen achter', EU-Forum/3 (2002).

Cameron, I., The European Convention on Human Rights, Due Process and United Nations Security Council Counter-Terrorism Sanctions, Council of Europe Publishing 2006.

Cameron, J., (ed.), Trial of Heinz Eck et al. (the Peleus Trial), London 1948.

Carstens, J.H., 'Gewelddadigheid en terrorisme', in Delikt en Delinkwent 1976.

Cassese, A., International Criminal Law, Oxford University Press 2003.

Claes, E., Legaliteit en rechtsvinding in het strafrecht. Een grondslagentheoretische benadering, Universitaire Pers Leuven, 2003.

Cleiren, C.P.M., Beginselen van een goede procesorde - een analyse van rechtspraak in strafzaken, Arnhem 1989.

Cleiren, C.P.M., 'Het legaliteitsbeginsel', in Cleiren, C.P.M., Roos, Th. A. de, Woude, M.A.H. van der, Jurisprudentie Strafrecht Select, Sdu Uitgevers, Den Haag 2006.

Cleiren, C.P.M., Nijboer, J.F., Tekst \& Commentaar Strafvordering, 4de druk, Kluwer, Deventer 2001.

Cleiren, C.P.M., Nijboer, J.F., Tekst \& Commentaar Strafvordering, 5de druk, Kluwer, Deventer 2003.

Cleiren, C.P.M., Nijboer, J.F., Tekst \& Commentaar Strafvordering, 8ste druk, Kluwer, Deventer 2009.

Cleiren, C.P.M., Nijboer, J.F., Tekst \& Commentaar Strafrecht, 7de druk, Kluwer, Deventer 2008.

College van procureurs-generaal, Advies wetsvoorstel bijzondere bevoegdheden tot opsporing van terroristische misdrijven, 21 December 2004.

Corstens, G.J.M., Het Nederlandse Strafprocesrecht, 5de druk, Kluwer, Deventer 2008.

Corstens, G.J.M., Het Nederlandse Strafprocesrecht, 6de druk, Kluwer, Deventer 2008.

Council of Europe Publishing, Terrorism: special investigative techniques, Council of Europe, April 2005.

Delmas-Marty, M., The European Convention for the Protection of Human Rights, Dordrecht, 1992.

Derix, S, and Thie, M., 'Een 'serieuze dreiging' die binnen 24 uur verdampte', in NRC Handelsblad 16 March 2009.

Derix, S, and Thie, M., 'Mo is nog elke dag bang voor Guanánamo. Terrorisme advocaten en ombudsman willen meer excuses en vergoeding van overheid voor inbreuk op leven na onterecht arrestaties', in NRC Handelsblad 21 March 2009.

Derix, S, and Thie, M., 'Verdachten terreur zelden veroordeeld. Tweederde snel weer vrijgelaten', in NRC Handelsblad 6 June 2009.

Dijk, P. van, Hoof, F van, Rijn, A. van, and Zwaak L. (eds.), Theory and Practice of the European Convention on Human Rights, $4^{\text {th }}$ edition 2006, Intersentia AntwerpenOxford.

Dijk, P. van and Hoof, G.J.H van, Theory and Practice of the European Convention on Human Rights, $3^{\text {rd }}$ edition, Kluwer Law International 1998.

Dolman, M.M. (red.), Terrorisme, Europa en Strafrecht, Vossiuspers UvA, Amsterdam 2003. 
Bibliography

Donner, J.P.H. and Remkes, J.W., 'Kritiek op persoonsgerichte aanpak onjuist', in Binnenlands Bestuur 21 July 2006.

Donner, J.P.H., 'Beter tien schuldigen vrijgesproken dan één onschuldige veroordeeld?', in Rechtsgeleerd magazijn Themis 2004-1.

Droesen, H.W.J., 'Pleitaantekeningen bezetting Indonesisch Consulaat', in Delikt en Delinkwent 1976.

Drooghenbroeck, S. Van, La proportionalité dans le droit de la convention europpeénne des droits de l'homme. Prendre l'idée simple au sérieux, Bruylant/Publications des FUSL, Bruxelles, 2002.

Duk, W., 'Beoordelingsvrijheid en beleidsvrijheid', in Rechtskundig Maandblad Themis 1988.

Dworkin, R., Taking rights seriously, London: Duckworth 1978.

Dworkin, R., 'Terror and the attack on Civil Liberties', in The New York Review of Books, 17, 2003.

Dworkin, R., 'The threat to patriotism', in The New York Review of Books, 49/3, 2002.

Dworkin, R., 'What the Court really said', in The New York Review of Books, 51/13, 2004.

Emmelkamp, D. and Meijer, G., 'De nuances tussen zwart en wit', in NJB, 2010/319.

Emmelkamp, D. and Meijer, G., 'Naschrift', in NJB, 2010/1333.

Eskes, J.A.O, 'Effecten nieuw verbodsregime organisaties nu al merkbaar', in NJB/28, 2007.

Fijnaut, C., 'De aanslagen van 11 september 2001 en de reactie van de Europese Unie', in Justitiële verkenningen, 28/5, 2002.

Fijnaut, C., 'Inlichtingendiensten in Europa en Amerika; de heroriëntatie na de val van de Muur en 11 september 2001', in Justitiële verkenningen, 30/3, 2004.

Fletcher, G.P., Basic Concepts of Criminal Law, New York Oxford University Press 1998.

Fokkens, J.W., 'Strafrecht en terrorisme', in NJB/27, 2004.

Foqué, R. and Hart, A.C. 't, Instrumentaliteit en rechtsbescherming, Gouda Quint, 1990.

Franken, A.A., 'Casuïstiek en legaliteit in het materieel strafrecht', in Delikt en Delinkwent 2006, 67.

Franken, A.A., 'Regels voor het strafdossier', in Delikt en Delinkwent 2010, 24.

Franken, A.A., 'Strafrechtwetenschappen en terrorismebestrijding', in Delikt en Delinkwent 2006.

Frielink, P.M., 'Terreurbestrijding en strafwetgeving', in Strafblad, 2/4, 2004.

Gasser, H.P., International Humanitarian Law, The prohibition of terrorist acts and the fight against terrorism, Yearbook of International Humanitarian Law, 4, 2001.

Gerards, J.H., Loof, J.P. and Senden, H.C.K, 'Kroniek van de grondrechten', in NJB/34, 2008.

Gestel, B. van, Poot, C.J. de and Kouwenberg, R.F., De Wet opsporing terroristische misdrijven drie jaar in werking, WODC, Cahier 2010-3.

Gestel, B. van., Poot, C.J. de, Bokhorst, R.J. and Kouwenberg, R.F., Signalen van terrorisme en de opsporingspraktijk. De Wet opsporing terroristische misdrijven twee jaar in werking, WODC Cahier 2009-2010.

Graaf, B. de and Schinkel, W., 'Het recht op veiligheid schept een permanente noodtoestand', in NRC Handelsblad 31 December 2010. 
Graaff, B. de, 'Wie wint 'the war on terrorism'?', in Justitiële verkenningen, 30/3 2004.

Gritter, E. and Sikkema, E., 'Van kennelijke bestemming naar daadwerkelijke voorbereiding: subjectivering van het Nederlandse strafrecht?', in NJB/2, 2008.

Gritter, E. and Sikkema, E., 'Bestemming onbekend. Strafbare voorbereiding (artikel $46 \mathrm{Sr}$ ) en wetsvoorstel 30 164', in Delikt en Delinkwent 2006, afl. 3.

Groenhuijsen, M.S., 'De crisis in de opsporing en het wetsontwerp bijzondere opsporingsbevoegdheden. Enkele inleidende aantekeningen', in Delikt en Delinkwent 1997.

Groenhuijsen, M.S., 'Mariënburcht, annotatie bij Hoge Raad 16 oktober 1990', in Ars Aequi XL 1991.

Guillaume, G., 'Terrorism and International Law', in International and Comparative Law Quarterly, 53, 2004.

Gutwirth, S. and Hert, P de., 'Een theoretische onderbouw voor een legitiem strafproces', in Delikt en Delinkwent, 31/10, 2001.

Hammarberg, T., Report by the Commissioner for Human Rights on his visit to the Netherlands, 2008 (CommDH (2009) 2).

Hart, A.C. 't, Strafrecht en beleid, Essays, Acco, Leuven 1984.

Hermans, R.H., 'Kennisneming van processtukken in het voorbereidend onderzoek in strafzaken', in Delikt en Delinkwent 2009.

Hert, P. de, and Zwenne, G.J., 'Over passagiersgegevens en preventieve misdaadbestrijding binnen de Europese Unie', in NJB/27, 2007.

Hert, P. de, Huisman, W. and Vis, T., 'Intelligence led policing ontleed', in Tijdschrift voor Criminologie, afl. 47/4, 2005.

Hert, P.J.A. de and Weis, K.A.P.G., 'Geglobaliseerde terrorismebestrijding en lokale rechtsbescherming. Europese rechters stappen niet mee in het scenario van de jumping of scales', in Panopticom. Tijdschrift voor strafrecht, criminologie en forensisch welzijnswerk, afl. 2009-1.

Hert, P.J.A. de and Weis, K.A.P.G., 'Terrorismelijsten en de paradox van de rechtsbescherming', in Tijdschrift voor Europees en economisch recht, aflevering 2009-9.

Hert, P.J.A. de, 'Balancing security and liberty within the European human rights framework', in Hol, A.M. \& Vervaele J.A.E., (eds.), Security and Civil Liberties: The Case of Terrorism Yearbook Utrecht Law Review 2005, Intersentia Antwerpen Oxford.

Hinke, B., 'In de belwinkel is iedereen verbaasd', in NRC Handelsblad 27 December 2010.

Hoffman, G.A., 'Litigating Terrorism: The new FISA regime, the Wall and the Fourth Amendment', in American Criminal Law Review, 40/4, 2003.

Hoogenboom, A.B., Schaduwen over Van Traa, Koninklijke Vermande 2000.

Hoogenboom, B, 'Inlichtingenwerk en ethiek; een wildernis van spiegels', in Justitiële verkenningen, 30/3, 2004.

Hullu, J. de, Materieel strafrecht. Over algemene leerstukken van strafrechtelijke aansprakelijkheid naar Nederlands recht, 2de druk, Kluwer, Deventer 2003. 
Bibliography

Hullu, J. de, Materieel Strafrecht: Over algemene leerstukken van strafrechtelijke aansprakelijkheid naar Nederlands recht, 4de druk, Kluwer, Deventer 2009.

Hutchings, R.L., X+9/11: Everything I needed to know about fighting terrorism I learned from George F. Kennan, Foreign Policy 2004.

Janssen, S.L.J., 'De strafbare intentie is bijna een feit', in NJB 2006/0757.

Jebbink, W.H., 'Rechter-commissaris niet in alle opzichten de geschikte verantwoordelijke voor de volledigheid van het strafdossier', in NJB 2010/1332.

Joyner, C.C., 'The United Nations and Terrorism: Rethinking Legal Tensions between National Security, Human Rights and Civil Liberties', in International Studies Perspectives, $5 / 3$ (2004).

Kalmthout van, A. and Fillet, H., 'Uit Franco's nalatenschap', in Ars Aequi, 15/3 (1976).

Kalse, E. and Verlaan, J., 'Ik moet primair terreur bestrijden. Donner over kritiek rechters', in NRC Handelsblad 18 February 2005.

Keijzer, N., Het Europees Vedrag tot Bestrijding van Terrorisme, Amsterdam: Kluwer, Deventer 1979.

Kelder, T.J., 'Onthouding van processtukken bij pro-forma zittingen. Een lapje uit de lappendeken gelicht', in Strafblad 2008.

Kelk, C., Studieboek Materieel Strafrecht, Kluwer, Deventer 2005, 3de druk.

Kempen, H. van, P.H.P.H.M.C. and Voort, J. van de, 'Nederlandse anti-terrorism-regelgeving getoetst aan fundamentele rechten. Een analyse met meer bijzonder aandacht voor het EVRM', Radboud Universiteit Nijmegen 1 December 2010, in Antiterrorismemaatregelen in Nederland in het eerste decennium van de 2le eeuw. Over totstandkoming, toepassing, beoordeling en aanpassing van antiterrorismemaatregelen in Nederland 2001-2010, January 2011, Nationaal Coördinator Terrorismebestrijding, bijlage.

Kempen, P.H.P.H.M.C. van, 'Het conceptwetsvoorstel voorkoming, opsporing en vervolging van terroristische misdrijven: terrorisme bestrijding door marginalisering van strafvorderlijke waarborgen', in $N J B / 8,2005$.

Keulen, B.F., 'Over voetbal, voorbereiding en samenspanning', in NJB 2009/1481.

Kielman, H.H. and Koelewijn, W.I., 'Minder registers, meer gegevens: Over gegevensverwerking betreffende zware criminaliteit', in Ars Aequi 2005/54, no. 6 .

Klerks, P., Terreurbestrijding in Nederland 1970-1988, Ravijn Uitgever, Amsterdam 1989.

Klink, B.M.J. van and Lembecke, O., 'Can terrorism be fought within the boundaries of the rule of law? A review of recent literature in Political Philosophy', in $R \& R$ nr. 2, 2007.

Klink, B.M.J. van, 'Recht is een keuze. Over nut en noodzaak van de uitgebreide identificatieplicht', in $P \& I$ nr. 3, juni 2007.

Klip, A.H. and Sluiter, G. (eds.), Annotated Leading Cases of International Criminal Tribunals, The International Criminal Tribunal for Rwanda 2006-2007.

Klip, A.H. and Swart, A.H.J., 'International Criminal Law in the Netherlands', in Beiträge und Materialien aus dem Max-Planck-Institut für internationales und ausländisches Strafrecht, Band S 66, Freiburg im Breisgau 1997.

Klip, A.H., 'Slappe rechters', in Delikt en Delinkwent 2010, 79.

Klip, A.H., 'Totaalstrafrecht', in Delikt en Delinkwent 2010, 34. 
Bibliography

Klip, A.H., European Criminal Law, an integrative approach, Intersentia AntwerpenOxford 2009.

Kooijmans, T. and Simmelink, J.B.H.M., 'Het recht op kennisneming van de processtukken in het Wetsvoorstel tot verruiming van de mogelijkheden tot opsporing en vervolging van terroristische misdrijven', in Delikt en Delinkwent nr. 10, december 2006.

Koppelaar, L., Winkel, F.W. and Van Der Steen, J.C., 'Psychologische kanttekeningen bij artikel $27 \mathrm{~Sv}$ : een experiment rond etnische origine, ritmisch gedrag en verdacht zijn', in Delikt en Delinkwent 16, 1986, afl. 1.

Kruijs, P.W. van der, 'Het vereiste van redelijk vermoeden op basis van anonieme informatie in het bijzonder bij terroristische misdrijven', in Strafblad, afl. 4, 2004 jrg. 2, SDU uitgevers.

Kruijs, P.W. van der, 'De voorlopige hechtenis in theorie en praktijk', in Cleiren, C.P.M., Roos, Th. A. de, and Woude, M.A.H. van der, (eds.), Jurisprudentie Strafrecht Select, Sdu Uitgevers, Den Haag, 2006.

Kruijs, P.W. van der, 'Kanttekeningen bij een requisitoir', in Delikt en Delinkwent 1976.

Kuijer, M., Van Lawless naar een rechtmatige bestrijding van terrorisme, Wolf Legal Publishers, Amsterdam 2005.

Kuin, F., 'U kent deze man, Canadees staatsburger werd naar emartelkaner van Syrie gebracht', in NRC Handelsblad 11 \& 12 June 2005.

Leeuwen, van, M., 'Religieus terrorisme als 'nieuwe dreiging': Motieven, middelen, milieu', in Internationale Spectator/11 1999.

Leijendekker, M., 'Snel arresteren is ook andere landen strategie', in NRC Handelsblad 28 December 2010.

Leijendekker, M., 'Somalische terreurverdachten Elf verdachten zijn alweer vrij. De arrestaties passen in een europese trend', in NRC Handelsblad 28 December 2010.

Levi, M. and Wall, D.S., 'Technologies, Security, and Privacy in the Post-9/11 European Information Society', in Journal of Law and Society, 31/2 2004.

Lewis, A., 'Making torture legal', in The New York Review of Books, 51/12 2004.

Lintz, J., 'Samenspanning in de Wet terroristische misdrijven', in Delikt en Delinkwent 2005.

Lintz, J.M., De plaats van de Wet terroristische misdrijven in het materiele strafrecht. Een onderzoek naar de wederzijdse beïnloeding door de Wet terroristische misdrijven en het Wetboek van Strafrecht en enkele bijzondere wetten, dissertatie EUR, Wolf Legal Publishers, Nijmegen, 2007.

Loof, J.P., 'Mensenrechten, migratie en staatsveiligheid: verenigbare grootheden?', in $M R$. nr. 6/7, 2006.

Loof, J.P., 'Politie-inmeninging in de persoonlijke levenssfeer zonder wettelijke basis: terrorismebestrijding en constitutioneelrechtelijk experimenteergedrag', in Rechtsgeleerd Magazijn Themis 2007-3.

Loof, J.P., 'Hoe Osama Bin Laden het Verenigd Koninkrijk een noodtoestand bezorgde: Enkele aspecten van het spanningsveld tussen terrorismebestrijding en mensenrechtenbescherming', in NJCM-Bulletin, 30/1 (2005). 
Bibliography

Loof, J.P., Mensenrechten en staatsveiligheid: verenigbare grootheden? Opschorting en beperking van mensenrechtenbescherming tijdens noodtoestanden en andere situaties die de staatsveiligheid bedreigen (dissertation, Leiden), Wolf Legal Publishers, Nijmegen 2005.

Lopez, G. A., Cortright, D., Milar, A. and Gerber-Stellingwerf, L., Overdue Process. Protecting Human Rights while sanctioning Alleged Terrorists. A report to Cordaid from the Fourth Freedom Forum and Kroc Institute for International Peace Studies at the University of Notre Dame April 2009.

Macovei, M., 'A Guide to the implementation of article 5 of the European Convention on Human Rights', in Human rights handbooks, No. 5, Council of Europe Publishing.

Mat, J., 'Nog veel onduidelijk na arrestaties', in NRC Handelsblad 27 December 2010.

Melai, A.L. \& Groenhuijsen, M.S. e.a., Wetboek van Strafrecht, artikel 1 Strafrecht, supplement 121, supplement 143.

Melai, A.L. \& Groenhuijsen, M.S. e.a., Wetboek van Strafvordering, artikel 30 Strafvordering, aantekening 2,6,8 and 9 (S.V. Pelsser).

Melai, A.L. \& Groenhuijsen, M.S. e.a., Wetboek van Strafvordering, artikel 32 Strafvordering, aantekening 4 (S.V. Pelsser).

Melai, A.L. \& Groenhuijsen, M.S. e.a., Wetboek van Strafvordering, artikel 33 Strafvordering.

Melai, A.L. \& Groenhuijsen, M.S. e.a., Wetboek van Strafvordering, artikel 23 Strafvordering, aantekening 7, supplement 113, (W.E.C.A. Valkenburg).

Melai, A.L. \& Groenhuijsen, M.S. e.a., Het Wetboek van Strafvordering, artikel 27 Strafvordering, aantekening 2, 2b, 3, 3a, 3c en 3k (J.A.W. Lensing).

Melai, A.L. \& Groenhuijsen, M.S. e.a., Het wetboek van Strafvordering, artikel 128 Strafvordering, aant. 2, suppl. 7.

Melai, A.L. \& Groenhuijsen, M.S. e.a., Het wetboek van Strafvordering, artikel 53 Strafvordering, aant. 4, suppl. 13.

Melai, A.L. \& Groenhuijsen, M.S. e.a., Wetboek van Strafvordering, artikel 67 en 67a Strafvordering (J.M. Reijntjes).

Melai, A.L. \& Groenhuijsen, M.S. e.a., Wetboek van Strafvordering, artikel 69 Strafvordering, aantekening 3,4,6,8 (J.M. Reijntjes).

Melai, A.L. \& Groenhuijsen, M.S. e.a., Wetboek van Strafvordering, artikel 71 Strafvordering, aantekening 4,7 (J.M. Reijntjes).

Melai, A.L. \& Groenhuijsen, M.S. e.a., Wetboek van Strafvordering, artikel $126 \mathrm{~g}$ Strafvordering (Y. Buruma), no. 3 and 5.

Melai, A.L. \& Groenhuijsen, M.S. e.a., Wetboek van Strafvordering, artikel 126i Strafvordering (Y. Buruma en L.J. Verborg), nr. 2, 3, 6, 7, 8, 9.

Melai, A.L. \& Groenhuijsen, M.S. e.a., Wetboek van Strafvordering, artikel 126j Strafvordering (Y. Buruma en L.J. Verborg), nr. 3, 4, 5, 8.

Melai, A.L. \& Groenhuijsen, M.S. e.a., Wetboek van Strafvordering, artikel 126nc Strafvordering (E.C. Mac Gillavry), nr. 2-27.

Melai, A.L. \& Groenhuijsen, M.S. e.a., Wetboek van Strafvordering, artikel 126nd Strafvordering (E.C. Mac Gillavry), nr. 2-13. 
Melai, A.L. \& Groenhuijsen, M.S. e.a., Wetboek van Strafvordering, artikel 126ne Strafvordering (Mac Gillavry), nr. 2-12.

Melai, A.L. \& Groenhuijsen, M.S. e.a., Wetboek van Strafvordering, artikel 126nf Strafvordering (E.C. Mac Gillavry), nr. 2-10.

Melai, A.L. \& Groenhuijsen, M.S. e.a., Wetboek van Strafvordering, artikel 126nh Strafvordering (Mac Gillavry), nr. 2-4.

Melai, A.L. \& Groenhuijsen, M.S. e.a., Wetboek van Strafvordering, artikel 126g-126gg Strafvordering (Y. Buruma), nr. 12.

Melai, A.L. \& Groenhuijsen, M.S. e.a., Wetboek van Strafvordering, artikel 126h Strafvordering (Y. Buruma), nr. 3, 4, 9.

Melai, A.L. \& Groenhuijsen, M.S. e.a., Wetboek van Strafvordering, artikel 126nc Strafvordering (Mac Gillavry), nr. 5.

Melai, A.L. \& Groenhuijsen, M.S. e.a., Wetboek van Strafvordering, titels IVA-VC Bijzondere bevoegdheden tot opsporing.

Merari, A., 'Terrorism as a Strategy of Insurgency', in Terrorism and Political Violence, 5/4 1993

Mertens, T., 'Rechtspraak of geschiedschrijving? Geen schending van Artikel 7', in NJCMBulletin, jrg. 35, 2010, nr. 8.

Mevis, P., Lange, R. de and Dolman, M.M., Annotation: 'Actus regit locum? Over legaliteit, rechtsmacht en 'prospectieve overruling", in Delikt en Delinkwent, 2004, afl. 2/15.

Mevis, P.A.M. and Wöretshofer, J. (red.), Praktisch strafrecht. Liber Amicorum J.M. Reijntjes, Wolf Legal Publishers, Nijmegen 2005.

Mevis, P.A.M., 'Enige opmerkingen over het recht op kennisneming van processtukken in het licht van de artikelen 5 en 6 van het EVRM', in Delikt en Delinkwent 1991.

Meyer, F., 'EU Terrorism Lists in the Eye of the Rule of Law', in The European Criminal Law Associations' Forum, 1-2/2008.

Mols, 'Informatiestop', in Nieuwsbrief Strafrecht 2004, afl. 9.

Mols, G.P.M.F., 'Annotation with affaire Sud Fondi srl et autres contre Italie', in EHRC 2009, no. 48.

Mols, G.P.M.F. and Roos, TH.A., 'Naar een algemene strafbaarheid van de voorbereidingshandeling: Een keerpunt in de vaderlandse strafrechtsgeschiedenis', in NJB/7, 1992.

Mols, G.P.M.F., Strafbare samenspanning: Een rechtshistorisch en rechtsvergelijkend onderzoek, Gouda Quint bv, Arnhem 1982.

Muller, E.R., 'De geschiedenis van terrorisme in Nederland', in Muller, E.R., Rosenthal, U., Wijk, R. de (eds.), Terrorisme. Studies over terrorisme en terrorismebestrijding, Kluwer, Deventer 2008.

Muller, E.R., Gijzelingen, aanslagen en ontvoeringen in Nederland. Terrorisme en politieke verantwoordelijkheid, Gouda Quint, Leiden 1994.

Muller, E.R., Rogier, L.J.J., Kummeling, H.R.B.M., Bron, R.P., Woltjer A.J. Th., and Kalkhoven, V.C., Bestuur, recht en veiligheid. Bestuursrechtelijke bevoegdheden voor openbare ordehandhaving en terrorismebestrijding, COT Instituut voor Veiligheids en Crisismanagment, Erasmus Universiteit Rotterdam en Universiteit Utrecht, 1 October 2007. 
Bibliography

Myjer, E., 'Minder vrijheid voor meer veiligheid: over voorgestelde maatregelen tot een doeltreffender terrorismebestrijding', in Nieuwsbrief Strafrecht/10 2004.

Myjer, E., 'De te lang gehechte identieke tweelingzusjes', in NJCM-Bulletin 2004/3.

Myjer, E., 'Rechten van de mens en bestrijding van terrorisme; enige opmerkingen over de Europese aanpak en over de rol van de Officier van Justitie', in TREMA/8 2003.

Naert, F. and Wouters, J., 'Of arrest warrents, terrorist offences and extradition deals: An appraisal of the EU's main criminal law measures againts terrorism after "11 September", in Common Market Law Review, 41/4 2004.

Naeyé, J., Heterdaad: Politiebevoegdheden bij ontdekking op heterdaad in theorie en praktijk, Gouda Quint, Arnhem 1990.

Nederlandse orde van advocaten, adviescommissie strafrecht, Advies wetsvoorstel bijzondere bevoegdheden tot opsporing van terroristische misdrijven, 23 December 2004.

Nehmlmann, R., 'License to kill? Over de rechtmatigheid van een extreme antiterreurmaatregel', in NJCM-Bulletin nr. 7, november 2007.

Noyon/Langemeijer/Remmelink Strafrecht, artikel 134a Wetboek van Strafrecht, aantekening 1 tot en met 5 (prof. mr. Fokkens J.W.).

Noyon/Langemeijer/Remmelink, artikel 96 Wetboek van Strafrecht, aantekeningen 1- 8 (Prof. mr. Fokkens, J. W.).

NRC Handelsblad 12 February 2005 'Donner: aanpak terreur conform Europese regels'.

NRC Handelsblad 13 March 2009, 'Zeven personen vast na bedreiging A'dam. Terrorisme Huiszoekingen in Amsterdam; geen explosieven gevonden; winkels weer open'.

NRC Handelsblad 17 March 2009, 'Cohen: belster wist geen details'.

NRC Handelsblad 27 July 2009, 'Verdachte van terreurmelding Ikea vrijgelaten'.

NRC Handelsblad 3 February 2009, 'Baardige Arabier meestal onschuldig'.

Oehmichen, A., Terrorism and Anti-Terror Legislation: The Terrorrised Legislator? A Comparison of Counter-Terror Legislation and Its Implications on Human Rights in the Legal Systems of the United Kingdom, Spain, Germany and France, dissertation, Intersentia Antwerpen-Oxford 2009, Leiden.

Oranje, J., 'Schuldig tot het tegendeel is bewezen', in NRC Handelsblad 12 February 2005.

Orie, A.A.M. and Verburg, J.J.I., 'De Koningin bedreigd', in Delikt en Delinkwent 1975.

Orucu, E., 'Waar wet en cultuur elkaar ontmoeten: Cultureel pluralisme, juridisch pluralisme en pragmatisme', in Justitiële verkenningen, 28/5 2002.

Ouchan, S. and Talsma, L., 'Persoonsgericht verstoren: een disproportionele maatregel in de strijd tegen terrorisme', in NJCM-Bulletin nr. 7, november 2007.

Pelser, C.M., 'Preparation to commit a crime. The Dutch approach to inchoate offences', in Utrecht Law Review, volume 4, issue 3, 2008.

Pelser, C.M., 'Samenspanning: over overt act en uiterlijke verschijningsvorm', in M. Boone e.a. (red.), Discretie in het strafrecht, Boom Juridische uitgevers, Den Haag 2004.

Pelsser, S.V. and Corstens, G.J.M., Het Nederlandse strafprocesrecht, 6de druk, Kluwer, Deventer 2008.

Pelsser, S.V. and Spronken, T., Tekst en Commentaar Strafvordering 2009, art. 30, aant. 6. 
Bibliography

Peters, A.A.G., Het rechtskarakter van het strafrecht, inaugurele rede Utrecht, Kluwer, Deventer 1972.

Poot, C.J. de, Bokhorst, R.J., Smeenk W.H., and Kouwenberg, R.F., De opsporing verruimd? De Wet opsporing terroristische misdrijven een jaar in werking, WODC Cahier 20082009.

Prakken, E., 'Legitieme strafvordering', in Delikt en Delinkwent/10, 2001.

Prakken, E., 'Regelgeving en rechtspraak: terrorisme en het strafproces', in Strafblad, 2/4 2004.

Prakken, E., 'Voorzichtig met Europese strafrechtelijke terrorismebestrijding', in $N J B / 39$, 2001.

Prakken, E., 'Wilders: verbieden of toestaan', in NJB 2009.

Press, W.H., 'Strong profiling is not mathematically optimal for discovering rare malfeasors', in PNAS (Proceedings of the National Academy of Sciences), February 10 2009, vol. 106, no. 6 .

Rapport van de Werkgroep gegevensverstrekking - burgemeesters, Vaste verbindingen: Een advies aan de Minister van Binnenlandse Zaken en Koninkrijksrelaties over de verstrekking van gegevens op het terrein van veiligheid door landelijke diensten aan burgemeesters, november 2005 .

Rapport van de Commissie Strafvorderlijke gegevensvergaring in de informatiemaatschappij, Gegevensvergaring in strafvordering: nieuwe bevoegdheden tot het vorderen van gegevens ten behoeve van strafvorderlijk onderzoek, mei 2001.

Rathenau Instituut, Van Privacyparadijs tot controlestaat? Misdaad en terreurbestrijding In Nederland aan het begin van de 21ste eeuw, February 2007, the Hague.

Redactioneel NJCM-Bulletin, 'Mensenrechten delven het onderspit in uitvoering frontlijnfilosofie', in NJCM-Bulletin, jrg. 33, nr. 1, 2008.

Reijntjes, J.M., 'Terreurbestrijding en het delen van geheimen', in Strafblad, afl. 4, jrg. 2, $16 / 122004$.

Reijntjes, J.M., Voorarrest, W.E.J. Tjeenk Willink, Zwolle 1994.

Reijntjes, J.M., 'Europees aanhoudingsbevel', in NJB/14, 2002.

Reijntjes, J.M., 'Terreurbestrijding en het delen van geheimen', in Strafblad 2/4, 2004.

Remmelink, J., 'Actuele stromingen in het Nederlands strafrecht', in V.H. Davelaar-van Tongeren e.a. (red.), Strafrecht in perspectief, Gouda Quint, Arnhem 1980.

Report of the Eminent Jurists Panel on Terrorism, Counter-terrorism and Human Rights: 'Assessing Damage, Urging Action', an initiative of the International Commission of Jurists 2009.

Rijlaarsdam, B., 'Het moest heel snel. En je kunt niet een beetje ingrijpen', in $N R C$ Handelsblad 29 December 2010.

Ritter von Feuerbach, Paul Johan Anselm, Lehrbuch des gemeinen in Deutschland gültigen peinliches Rechts, 1801.

Rogier, L.J.J., Jong, M.A.D.W. de, Bitter, C.M. and Bleichrodt, F.W., Bestuursrechtelijke aanpak van criminaliteit en terrorisme. Preadviezen Vereniging voor Bestuursrecht, Boom Juridische Uitgevers, Den Haag, 2007. 
Roos, Th. A. de, 'Strafrechtelijke terrorismebesttijding: een vraagteken bij een vraagteken', in Rechtsgeleerd magazijn Themis 2004-1.

Roos, Th. A. de, 'Kroniek van het straf(proces)recht', in NJB/31, 2006.

Röttgering, A.E.M. and Backx, L.M.J., 'Terrorismebestrijding: strafrecht tegen jihad?', in Strafblad 2004.

Röttgering, A.E.M., 'The $7^{\text {th }}$ transnational crime conference in Dublin: over de rechtsstaat onder druk', in Strafblad 2/4, 2004.

Rozemond, K., 'De algemene strafbaarstelling van voorbereidingshandelingen in het licht van de pogingsjurisprudentie van de Hoge Raad', in Delikt en Delinkwent, 24/7 1994.

Rozemond, N., 'De subjectivering van het Nederlandse Strafrecht', in NJB/36, 2007.

Sackers, H.J.B., 'De Terroristenafdeling, voer voor haviken', in Sancties 2, 2007.

Schalken, T.M., 'Vrijheidsbeneming volgens het EVRM en de Nederlandse praktijk inzake voorarrest', in Via. Straatsburg. Liber Amicorum Egbert Myjer, Wolf Legal Publishers 2004.

Schmid, A.P., de Graaf, J.F.A., Bovenkerk, F., Bovenkerk-Teerink, L.M. and Bunt, L., Zuidmoluks terrorisme, de media en de publieke opinie. Twee studies van het Centrum voor Onderzoek van Maarschappelijke Tegenstellingen (Rijksuniversiteit Leiden), Uitgeverij Intermediair Amsterdam 1982.

Schokkenbroeck, J., 'De margin of appreciation-doctrine in de jurisprudentie van het Europese Hof', in Veertig jaar EVRM, NJCM-Special 1990.

Schoof, R., and Waard, M. de, 'Het denken wordt strafbaar. Jurist André Klip over tereurbestrijding in de rechtsstaat', in NRC Handelsblad, 8 January 2005.

Sennef, A., 'Nieuwe wet kan patstelling in "AIVD-zaken" niet doorbreken. Rotterdamse terrorismezaken en Wet afgeschermde getuigen', in Advocatenblad 3, 2007.

Shahabuddeen, M., 'Does the Principle of Legality Stand in the Way of Progressive Development of Law', in Journal of International Criminal Justice 22004 Oxford University Press.

Shattuck, J, 'Religion, Rights and Terrorism', in Harvard Human Rights Journal, 16.

Sliedregt, E. Van, Ten to one. A contemporary reflection on the presumption of innocence, Boom Juridische Uitgevers 2009.

Soeteman, A., 'Worden we beschermd tegen onze beschermers?', in NJB/29, 2006.

Spaaij, R., 'De financiering van terrorisme', in Proces: Tijdschrift voor berechting en reclassering, 82/2 2003.

Spronken, T., 'De communicatieve strafrechter', in NJB 2011/1128.

Spronken, T., 'De politierechtbank of: waar blijft de rechter?', in NJB 2011/1126.

Spronken, T., 'Kroniek van het Straf(proces)recht', in NJB/13, 2007.

Spronken, T., 'Kroniek van het Straf(proces)recht', in $N J B / 16,2008$.

Stangeland, P., 'Openbare veiligheid in Spanje sinds 11 maart 2004', in Justitiële verkenningen, 7/4 2004.

Stevens, L., Koops, B.J. and Wiemans, P., 'Een strafvorderlijke gegevensvergaring nieuwe stijl', in $N J B / 32,2004$. 
Bibliography

Stevens, L. and Verhoeven, W.J., Raadsman bij politieverhoor. Invloed van voorafgaande consultatie en aanwezigheid van raadslieden op organisatie en wijze van verhoren en proceshouding van verdachten, WODC-report, Boom Juridische uitgevers, Den Haag 2010.

Stolwijk, S.A.M., 'Over revolutionairen, strafrecht en terrorisme', in Delikt en Delinkwent, 33/1 2003.

Strijards, G.A.M., Strafbare voorbereidingshandelingen, Zwolle 1995.

Suskind, R., The one percent doctrine: Deep inside America's pursuit of its enemies since 9/11, Simon \& Schuster 2006.

Suyver, J.J.H., Borgers, M.J., Cleiren C.P.M., and Zunderd, P.J. van, (Commissie Suyver), Rapport van de Commissie evaluatie antiterrorismebeleid, Naar een integrale evaluatie van antiterrorismemaatregelen, mei 2009.

Tahir, N., 'Ook ik had een martelaar voor Allah kunnen worden', in NRC Handelsblad 26 and 27 August 2006.

Tappeiner, I., 'The fight against terrorism. The lists and the gaps', in Utrecht Law Review, Volume 1, Issue 1, September 2005.

Thackrah, J.R., Dictionary of Terrorism, $2^{\text {nd }}$ edition, Routledge, Taylor \& Francis Group, London, 2004.

Thie, M., 'Justitie: AIVD zinspeelde op acute dreiging', in NRC Handelsblad, 27 December 2010.

Trechsel, S., Human Rights in Criminal Proceedings, Oxford University Press 2005.

Vaart, J. van der, 'Moslims nemen moord in rechtszaal hoog op. Duitse moslimraad signaleert discriminatie', in NRC Handelsblad 10 July 2009.

Vanneste, F., 'Het Europese Hof voor de Rechten van de Mens en de overheden die terrorisme bestrijden: Brothers in arms?', in Rechtskundig Weekblad 2003-2004, nr. 41.

Vedder, A.H. and Wees, J.G.L. van der, 'Hoe veilig is de privacy van de doorsnee burger sinds 9/11?', in $P \& I$ nr. 1, februari 2007.

Vlemminx, F.M.C., 'Hirst en Broniowski: De tandem waarmee het EHRM de nationale wetgever in de wielen rijdt?', in NJB/6, 2007.

Voermans, W.J.M., Borgers, M.J. and Sieburgh, C.H., Controverses rondom legaliteit en legitimatie, jaarvergadering van de Nederlandse Juristen-Vereniging (NJV) 10 juni 2011.

Volkskrant 25 December 2010, 'Somaliërs opgepakt wegens terrorismedreiging'.

Vries-Leemans, M.J.H.J. de, Art. 140 Wetboek van Strafrecht, Gouda Quint, Arnhem 1995.

Wedzinga, W., 'Bijzondere opsporingsbevoegdheden in wetsontwerp 25 403', in Delikt en Delinkwent 1999, afl. 4.

Wiarda, J.J., 'De wetgeving inzake goedkeuring en uitvoering van het verdrag inzake bestrijding van terroristische bomaanslagen en het Internationaal Verdrag ter bestrijding van de financiering van terrorisme', in Ars Aequi, 51/10 (2002).

Wiebes, C., 'De problemen rond de internationale intelligence liaison', in Justitiële Verkenningen, 30/3 2004. 
Wifferen, F. van, 'Het gebruik van AIVD-informatie in het strafproces', in Justitiële Verkenningen, 30/3 2004.

Wijk, R. de, 'Het gevaar van succes in de strijd tegen terrorisme; portret van de nieuwe vijand', in Justitiële Verkenningen, 30/3 2004.

Wijngaarden, M., 'De invloed van de AIVD op het bestuursrecht', in MR nr. 6/7 2006.

Wilt, H.G. van der, 'Strafrecht en terreur', in Proces: Tijdschrift voor berechting en reclassering, 82/2 2003.

Wilt, H.G. van der, 'Het terroristisch oogmerk', in M. M. Dolman (red.), Terrorisme, Europa en Strafrecht, Vossiuspers UvA, Amsterdam 2003.

Wilt, H.G. van der, 'Ontwikkeling van nieuwe deelnemingsvormen. Ben ik mijn broeders hoeder?', in Delikt en Delinkwent 2007, 10.

Winter, R.E. de, 'Terreur?', in Strafblad, 2/4 2004.

Woude, M.A.H. van der, 'Brede benadering terrorismebestrijding', in Openbaar bestuur, November 2009.

Zwaan, T., 'Het nieuwe transnationale terrorisme. De aanslag in Amerika en Japanse kamikaze', in Proces: Tijdschrift voor berechting en reclassering, 82/2 2003.

\section{EUROPEAN UNION DOCUMENTS}

\section{Common Positions}

Council Common Position of 27 December 2001 (2001/930/CFSP) on combating terrorism.

Council Common Position of 27 December 2001 (2001/931/CFSP) on the application of specific measures to combat terrorism.

Council Common Position of 2 May 2002 (2002/340/CFSP) updating Common Position 2001/931/CFSP on the application of specific measures to combat terrorism.

Council Common Position of 17 June 2002 (2002/462/CFSP) updating Common Position 2001/931/CFSP on the application of specific measures to combat terrorism and repealing Common Position 2002/340/CFSP.

Council Common Position of 28 October 2002 (2002/847/CFSP) updating Common Position 2001/931/CFSP on the application of specific measures to combat terrorism and repealing Common Position 2002/462/CFSP.

Council Common Position of 12 December 2002 (2002/976/CFSP) updating Common Position 2001/931/CFSP on the application of specific measures to combat terrorism and repealing Common Position 2002/847/CFSP.

Council Common Position of 5 June 2003 (2003/402/CFSP) updating Common Position 2001/931/CFSP on the application of specific measures to combat terrorism and repealing Common Position 2002/976/CFSP.

Council Common Position of 27 June 2003 2003/482/CFSP updating Common Position 2001/931/CFSP on the application of specific measures to combat terrorism and repealing Common Position 2003/402/CFSP. 
Council Common Position of 12 December 2003 (2003/651/CFSP) updating Common Position 2001/931/CFSP on the application of specific measures to combat terrorism and repealing Common Position 2003/482/CFSP.

Council Common Position of 22 December 2003 (2003/906/CFSP) updating Common Position 2001/931/CFSP on the application of specific measures to combat terrorism and repealing Common Position 2003/651/CFSP.

Council Common Position of 2 April 2004 (2004/309/CFSP) updating Common Position 2001/931/CFSP on the application of specific measures to combat terrorism and repealing Common Position 2003/906/CFSP.

Council Common Position of 17 May 2004 (2004/500/CFSP) updating Common Position 2001/931/CFSP on the application of specific measures to combat terrorism and repealing Common Position 2004/309/CFSP.

Council Common Position of March 2005 (2005/220/CFSP) updating Common Position 2001/931/CFSP on the application of specific measures to combat terrorism and repealing Common Position 2004/500/CFSP.

Council Common Position of 6 June 2005 (2005/427/CFSP) updating Common Position 2001/931/CFSP on the application of specific measures to combat terrorism and repealing Common Position 2005/220/CFSP.

Council Common Position of 17 October 2005 (2005/725/CFSP) updating Common Position 2001/931/CFSP on the application of specific measures to combat terrorism and repealing Common Position 2005/427/CFSP.

Council Common Position of 21 December 2005 (2005/936/CFSP) updating Common Position 2001/931/CFSP on the application of specific measures to combat terrorism and repealing Common Position 2005/847/CFSP.

Council Common Position of 20 March 2006 (2006/231/CFSP) updating Common Position 2001/931/CFSP on the application of specific measures to combat terrorism and repealing Common Position 2005/936/CFSP.

Council Common Position of 29 May 2006 (2006/380/CFSP) updating Common Position 2001/931/CFSP on the application of specific measures to combat terrorism and repealing Common Position 2006/231/CFSP.

Council Common Position of 21 December 2006 (2006/1011/CFSP) updating Common Position 2006/380/CFSP on the application of specific measures to combat terrorism and repealing Common Position 2006/380/CFSP.

Council Common Position of 28 June 2007 (2007/448/CFSP) updating Common Position 2001/931/CFSP on the application of specific measures to combat terrorism and repealing Common Positions 2006/380/CFSP and 2006/1011/CFSP.

Council Common Position of 20 December 2007 (2007/871/CFSP) updating Common Position 2001/931/CFSP on the application of specific measures to combat terrorism and repealing Common Position 2007/448/CFSP.

Council Common Position of 20 December 2007 (2007/871/CFSP) updating Common Position 2001/931/CFSP on the application of specific measures to combat terrorism and repealing Common Position 2007/448/CFSP. 
Bibliography

Council Common Position of 29 April 2008 (2008/346/CFSP) amending Common Position 2007/871/CFSP updating Common Position 2001/931/CFSP on the application of specific measures to combat terrorism.

Council Common Position of 29 April 2008 (2008/347/CFSP) amending Common Position 2007/871/CFSP updating Common Position 2001/931/CFSP on the application of specific measures to combat terrorism.

Council Common Position of 15 July 2008 (2008/586/CFSP) updating Common Position 2001/931/CFSP on the application of specific measures to combat terrorism and repealing Common Position 2007/871/CFSP.

Council Common Position of 16 December 2008 (2008/959/CFSP) amending Common Position 2008/586/CFSP updating Common Position 2001/931/CFSP on the application of specific measures to combat terrorism.

Council Common Position of 26 January 2009 (2009/67/CFSP) updating Common Position 2001/931/CFSP on the application of specific measures to combat terrorism and repealing Common Position 2008/586/CFSP.

Council Common Position of 15 June 2009 (2009/468/CFSP) updating Common Position 2001/931/CFSP on the application of specific measures to combat terrorism and repealing Common Position 2009/67/CFSP.

\section{Decisions}

Council Decision of 2 May 2002 implementing article 2(3) of Regulation (EC) No 2580/2001 (2002/334/EC) on specific restrictive measures directed against certain persons and entities with a view to combating terrorism and repealing Decision 2001/927/EC.

Council Decision of 17 June 2002 implementing article 2(3) of Regulation (EC) No 2580/2001 (2002/460/EC) on specific restrictive measures directed against certain persons and entities with a view to combating terrorism and repealing Decision 2002/334/EC.

Council Decision of 28 October 2002 implementing article 2(3) of Regulation (EC) No $2580 / 2001(2002 / 848 / \mathrm{EC})$ on specific restrictive measures directed against certain persons and entities with a view to combating terrorism and repealing Decision 2002/460/EC.

Council Decision of 12 December 2002 implementing article 2(3) of Regulation (EC) No $2580 / 2001(2002 / 974 / E C)$ on specific restrictive measures directed against certain persons and entities with a view to combating terrorism and repealing Decision 2002/848/EC.

Council Decision of 27 June 2003 implementing article 2(3) of Regulation (EC) No $2580 / 2001(2003 / 480 / E C)$ on specific restrictive measures directed against certain persons and entities with a view to combating terrorism and repealing Decision 2002/974/EC.

Council Decision of 12 September 2003 implementing article 2(3) of Regulation (EC) No $2580 / 2001(2003 / 646 / E C)$ on specific restrictive measures directed against certain 
persons and entities with a view to combating terrorism and repealing Decision 2003/480/EC.

Council Decision of 22 December 2003 implementing article 2(3) of Regulation (EC) No $2580 / 2001(2003 / 902 / E C)$ on specific restrictive measures directed against certain persons and entities with a view to combating terrorism and repealing Decision 2003/646/EC.

Council Decision of 2 April 2004 implementing article 2(3) of Regulation (EC) No $2580 / 2001(2004 / 306 / E C)$ on specific restrictive measures directed against certain persons and entities with a view to combating terrorism and repealing Decision 2003/902/EC.

Council Decision of 14 March 2005 implementing article 2(3) of Regulation (EC) No 2580/2001 (2005/221/CFSP) on specific restrictive measures directed against certain persons and entities with a view to combating terrorism and repealing Decision 2004/306/EC.

Council Decision of 6 June 2005 implementing article 2(3) of Regulation (EC) No 2580/2001 (005/428/CFSP) on specific restrictive measures directed against certain persons and entities with a view to combating terrorism and repealing Decision 2005/221/CFSP.

Council Decision of 17 October 2005 implementing article 2(3) of Regulation (EC) No $2580 / 2001(2005 / 722 / E C)$ on specific restrictive measures directed against certain persons and entities with a view to combating terrorism and repealing Decision 2005/428/CFSP.

Council Decision of 29 November 2005 implementing article 2(3) of Regulation (EC) No $2580 / 2001(2005 / 848 / \mathrm{EC})$ on specific restrictive measures directed against certain persons and entities with a view to combating terrorism and repealing Decision 2005/722/EC.

Council Decision of 21 December 2005 implementing article 2(3) of Regulation (EC) No $2580 / 2001(2005 / 930 / E C)$ on specific restrictive measures directed against certain persons and entities with a view to combating terrorism and repealing Decision 2005/848/EC.

Council Decision of 29 May 2006 implementing article 2(3) of Regulation (EC) No $2580 / 2001(2006 / 379 / \mathrm{EC})$ on specific restrictive measures directed against certain persons and entities with a view to combating terrorism and repealing Decision 2005/930/EC.

Council Decision of 21 December 2006 implementing article 2(3) of Regulation (EC) No $2580 / 2001(2006 / 1008 / E C)$ on specific restrictive measures directed against certain persons and entities with a view to combating terrorism and amending Decision 2005/379/EC.

Council Decision of 28 June 2007 implementing article 2(3) of Regulation (EC) No $2580 / 2001(2007 / 445 / E C)$ on specific restrictive measures directed against certain persons and entities with a view to combating terrorism and repealing Decisions 2006/379/EC and 2006/1008/EC.

Council Decision of 20 December 2007 implementing article 2(3) of Regulation (EC) no $2580 / 2001(2007 / 868 / \mathrm{EC})$ on specific restrictive measures directed against certain 
Bibliography

persons and entities with a view to combating terrorism and repealing Decision 2007/445/EC.

Council Decision of 15 July 2008 implementing article 2(3) of Regulation (EC) No $2580 / 2001$ (2008/583/EC) on specific restrictive measures directed against certain persons and entities with a view to combating terrorism and repealing Decision 2007/868/EC.

Council Decision of 26 January 2009 implementing article 2(3) of Regulation (EC) No $2580 / 2001$ (2009/62/EC) on specific restrictive measures directed against certain persons and entities with a view to combating terrorism and repealing Decision 2008/583/EC.

\section{Regulations}

Regulation of 27 December 2001 (2001/2580/EC) on specific restrictive measures directed against certain persons and entities with a view to combating terrorism.

Regulation of April 2003 amending Council Regulation No 2580/2001 (EC) (No 745/2003) on specific restrictive measures directed against certain persons and entities with a view to combating terrorism.

Regulation of 27 July 2005 amending Council regulation No 2580/2001 (EC) (No $1207 / 2005)$ on specific restrictive measures directed against certain persons and entities with a view to combating terrorism.

Regulation of 29 November 2005 amending Council Regulation No 2580/2001 (EC) (No $1957 / 2005)$ on specific restrictive measures directed against certain persons and entities with a view to combating terrorism.

Regulation of September 2006 amending Council Regulation (EC) No 2580/2001 (No 1461/2006) on specific restrictive measures directed against certain persons and entities with a view to combating terrorism.

Regulation of 15 June 2009 implementing article 2(3) of Regulation No 2580/2001 (EC) (No $501 / 2009)$ on specific restrictive measures directed against certain persons and entities with a view to combating terrorism and repealing Decision 2009/62/EC.

\section{Framework Decisions}

Framework Decision of 13 June 2002 on combating terrorism (2002/475/JHA).

Framework Decision of 13 June 2003 on the European arrest warrant and the surrender procedures between Member States (2002/584/JHA).

Framework Decision of 28 November 2008 amending Framework Decision 2002/475/JHA on combating terrorism (2008/919/JHA). 
Bibliography

\section{United Nations documents}

UN Security Council Resolution 1267 (1999) adopted by the Security Council at its $4051^{\text {st }}$ meeting on 15 October 1999 (S/RES/1267 (1999)).

UN Security Council Resolution 1333 (2000) adopted by the Security Council at its $4251^{\text {st }}$ meeting, on 19 December 2000 (S/RES/1333 (2000)).

UN Security Council Resolution 1373 (2001) adopted by the Security Council at its $4385^{\text {th }}$ meeting, on 28 September 2001 (S/RES/1373 (2001)).

UN Security Council Resolution 1390 (2002) adopted by the Security Council at its $4452^{\text {nd }}$ meeting, on 16 January 2002 (S/RES/1390 (2002)).

UN Security Council Resolution 1455 (2003) adopted by the Security Council at its $4686^{\text {th }}$ meeting, on 17 January 2003 (S/RES/1455 (2003)).

UN Security Council Resolution 1526 (2004) adopted by the Security Council at its $4908^{\text {th }}$ meeting, on 30 January 2004 (S/RES/1526 (2004)).

UN Security Council Resolution 1617 (2005) adopted by the Security Council at its $5244^{\text {th }}$ meeting, on 29 July 2005, (S/RES/1617 (2005)).

UN Security Council Resolution 1735 (2006) adopted by the Security Council at its $5609^{\text {th }}$ meeting, on 22 December 2006 (S/RES/1735 (2006)).

UN Security Council Resolution 1822 (2008) adopted by the Security Council at its $5928^{\text {th }}$ meeting, on 30 June 2008 (S/RES/1822 (2008)).

\section{European Union case law}

- Abdelghani Selmani against the Council of the European Union and the Commission of the European Communities, action brought on 7 July 2004 (Case T-299/04).

- Abdelghani Selmani v. The Council of the European Union and the Commission of the European Communities, order of the Court of First Instance (Second Chamber) of 18 November 2005 (Case T-299/04).

- Ahmed Ali Yusuf and the Al Barakaat International Foundation v. The Council of the European Union and the Commission of the European Communities, judgement of the Court of First Instance (Second Chamber, Extended Composition) of 21 September 2005 (Case T-306/01).

- Ahmed Hamdi v. the Council of the European Union, action brought on 12 March 2007 (Case T-75/07).

- Al-Aqsa v. Council of the European Union, action brought on 12 September 2007 (Case $\mathrm{T}-348 / 07)$.

- Chafiq Ayadi v. The Council of the European Union, judgement of the Court of First Instance (Second Chamber) of 12 July 2006 (Case T-253/02).

- Congrès National du Kurdistan against the Council of the European Union, action brought on 2 July 2002 (Case T-206/02).

- El Fatmi v. The Council of the European Union, action brought on 12 March 2007 (Case $\mathrm{T}-76 / 07)$. 
Bibliography

- El Fatmi v. The Council of the European Union, action brought on 24 September 2008 (Case T-409/08).

- El Fatmi v. the Council, action brought on 14 September 2007 (Case T-362/07).

- El Morabit v. the Council of the European Union, action brought on 30 August 2007 (Case T-323/07).

- Fahas v. the Council of the European Union, action brought on 20 February 2007 (Case T-49/07).

- Faraj Hassan and Chafiq Ayadi v. The Council of the European Union and the European Commission, judgment of the Court of Justice (Second Chamber) of 3 December 2009 (Joint Cases C-399/06 P and C-403/06 P).

- Faraj Hassan v. The Council of the European Union and the Commission of the European Communities, judgement of the Court of First Instance (Second Chamber) of 12 July 2006 (Case T-49/04).

- Gestoras Pro Amnistía association, Juan Mari Olano Olano and Julen Zelarain Errasti against the Council of the European Union, action brought on 31 October 2002 (Case T-333/02).

- Gestoras Pro Amnistía, J.M. Olano Olano, J. Zelarain Errasti and the Council of the European Union, appeal brought on 17 August 2004 by Pro Amnistía, J.M. Olano Olano, J. Zelarain Errasti against the order delivered on 7 June 2004 by the Second Chamber of the Court of First Instance of the European Communities in Case T-333/02 (Case C-354/04 P).

- Gestoras Pro Amnistía, Juan Mari Olano Olano and Julen Zelarain Errasti v. the Council of the European Union, judgment of the Court of Justice (GC) of 27 February 2007 (Case C-354/04 P).

- Gestoras Pro-Amnistía and Others v. Council of The European Union, order of the Court of First Instance, 7 June 2004 (T-333/02).

- Hamdi $v$ the Council, action brought on 14 September 2007 (Case T-363/07).

- Hamdi v. the Council of the European Union, order of the Court of First Instance of 2 September 2008 (Joined Cases T-75/07 and T-363/07).

- Jose Maria Sison against the Council of the European Union and the Commission of the European Communities, action brought on 6 February 2003 (Case T-47/03, 2003/ $\mathrm{C} 101 / 75)$.

- Jose Maria Sison v. Council of the European Union, order of the President of the Court of First Instance, 15 May 2003 (case T-47/03 R).

- Jose Maria Sison v. The Council of the European Union, judgement of the Court of Justice (First Chamber) of 1 February 2007 (Case C-266/05 P).

- Jose Maria Sison v. the Council of the European Union, judgment of the Court of First Instance (Second Chamber) of 11 July 2007 (Case T-47/03).

- Jose Maria Sison v. the Council of the European Union, judgment of the Court of First Instance (Seventh Chamber) of 30 September 2009 (Case T-341/07).

- Kongra-Gel v. The Council of the European Union, judgment of the Court of First Instance of 3 April 2008 (case T-253/04). 
- Kurdische Arbeiterpartei (PKK) and Kurdischer Nationalkongress (KNK) v. the Council of the European Union, opinion of Advocate General Kokott delivered on 27 September 2006 (Case C-229/05 P).

- Melli Bank plc v. The Council of the European Union, judgment of the Court of First Instance (Second Chamber) of 9 July 2009 (Joined Cases Y-246/08 and T-332/08).

- Mohamed El Morabit v. the Council of the European Union, action brought on 16 February 2007 (Case T-37/07).

- Mohammed El Morabit v. The Council of the European Union, judgment of the Court of First Instance (Second Chamber) of 2 September 2009 (Joined Cases T-37/07 and T-323/07).

- Omar Mohammed Othman v. The Council of the European Union and the Commission of the European Communities, judgment of the Court of First Instance (Seventh Chamber) of 11 June 2009 (Case T-318/01).

- Organisation des Modjahedines du people d'Iran (France) v. the Council of the European Union, judgment of the Court of First Instance (Second Chamber) 12 December 2006 (Case 228/02) (OMPI).

- Organisation des Modjahedines du Peuple d'Iran (OMPI) against the Council of the European Union, action brought on 26 July 2002 (Case T-228/02).

- Osman Ocalan on behalf of Kurdistan Workers Party (PKK) and Serif Vanly on behalf of Kurdistan National Congress (KNK) against the Council of the European Union, action brought on 31 July 2002 (Case T-229/02).

- Osman Ocalan on behalf of the Kurdistan Workers' Party (PKK) v. The Council of the European Union, judgment of the Court of First Instance of 3 April 2008 (Case $\mathrm{T}-229 / 02)$.

- Osman Ocalan on behalf of the PKK and Serif Vanly on behalf of the KNK v. the Council of the European Union, judgment of the Court of Justice (First Chamber) of 18 January 2007 (Case C-229/05 P).

- People's Mojahedin of Iran v. the Council of the European Union, action brought on 21 July 2008 (Case T-284/08).

- People's Mojahedin Organisation of Iran v. The Council of the European Union, application for Appeal brought on 21 January 2009 by the French Republic against the judgment delivered on 4 December 2008 by the Court of First Instance (Seventh Chamber) in Case T-284/08 (case C-27/09 P).

- People's Mojahedin Organisation of Iran v. Council of the European Union, application for Appeal brought on 23 December 2008 by People's Mojahedin Organisation of Iran against the judgment of the Court of First Instance (Seventh Chamber) delivered on 23 October 2008 in Case T-256/07 (Case C-576/08 P).

- People's Mojahedin Organisation of Iran v. Council, action brought on 16 July 2007 (Case T-256/07).

- People's Mojahedin Organisation of Iran v. the Council of the European Union, action brought on 9 May 2007 (Case T-157/07). 
Bibliography

- People's Mojahedin Organisation of Iran v. the Council of the European Union, judgment of the Court of First Instance (Seventh Chamber) of 23 October 2008 (Case T-256/07) (PMOI I).

- People's Mojahedin Organisation of Iran v. the Council of the European Union, judgment of the Court of First Instance (Seventh Chamber) of 4 December 2008 (Case T-284/08) (PMOI II).

- PKK and the KNK (Belgium) v. the Council of the European Union, order of the Court of First Instance (Second Chamber) of 15 February 2005 (Case T-229/02).

- Segi and Gestoras Pro-Amnistía v. Germany and Others, appl. no. 6422/02 and 9916/02, 23 May 2002.

- Segi Araitz Zubimendi Izaga and Aritza Galarraga v. Council of the European Union, order of the Court of First Instance (Second Chamber) on 7 June 2004 (Case T-338/02).

- Segi Association, Araitz Zubimendi Izaga and Aritza Galarraga against the Council of the European Union, action brought on 13 November 2002 (Case T-338/02).

- Segi, Araitz Zubimendi Izaga and Aritza Galarraga v. The Council of the European Union, judgment of the Court of Justice (GC) of 27 February 2007 (Case C-355/04 P).

- Segi, Araitz Zubimendi Izaga, Aritza Galarraga v. the Council of the European Union, opinion of Advocate General Mengozzi delivered on 26 October 2006 (Case C-355/04 P) (Appeal).

- Silvio Berlusconi, Sergio Adelchi and Marcello Dell'Utri and Others; judgements of the Court (GC) of 3 May 2005 (Joined Cases C-387/02, C-391/02 and C-403/02).

- Sison v. the Council, action brought on 10 September 2007 (Case T-341/07).

- Stiching Al-Aqsa against the Council of the European Union and Commission of the European Communities, action brought on 19 September 2003 (Case T-327/03).

- Stichting Al-Aqsa v. Council of the European Union supported by Kingdom of the Netherlands, judgment of the Court of First Instance (Second Chamber), 11 July 2007, case T-327/03.

- Stichting Al-Aqsa v. the Council of the European Union, judgment of the Court of First Instance (Second Chamber) of 11 July 2007 (Case T-327/03).

- Stichting Al-Aqsa v. the Council of the European Union, judgement of the General Court (Seventh Chamber) of 9 September 2010 (Case T-348/07).

- Yassin Abdullah Kadi and Al Barakaat International Foundation v. The Council of the European Union, judgment of the Court (GC) of 3 September 2008 (Joint Cases C-402/05 P and C-415/05 P).

- Yassin Abdullah Kadi (Saudi Arabia) v. the Council of the European Union and the Commission of the European Communities, judgement of the Court of First Instance (Second Chamber, Extended Composition) of 21 September 2005 (Case T-315/01).

\section{Strasbourg case law}

- A. and Others v. the United Kingdom, appl. no. 3455/05, 19 February 2009.

- Aalmoes and Others v. the Netherlands, decision as to the admissibility, appl. no. 16269/02, 25 November 2004. 
- Abdülsamet Yaman v. Turkey, appl. no. 32446/96, 2 November 2004.

- Achour v. France, appl. no. 67335/01, 29 March 2006.

- Adirbelli and Others v. Turkey, appl. no. 20775/03, 2 December 2008.

- Aerts v. Belgium, appl. no 25357/94, 30 July 1998.

- Ağaoğlu c. Turquie, requête no 27310/95, 6 décembre.

- Akdivar and Others v. Turkey, appl. no. 21893/93, 16 September 1996.

- Aleksandr Makarov v. Russia, appl. no. 15217/07, 12 March 2009.

- Al-Nashif v. Bulgaria, appl. no. 50963/99, 20 June 2002.

- Altay v. Turkey, appl. no. 22279/93, 22 May 2001.

- Amann v. Switzerland, appl. no. 27798/95, 16 February 2000.

- Amuur v. France, appl. no. 17/1995/523/609, 25 June 1996.

- Antonenkov and Others v. the Ukraine, appl. no. 14183/02, 22 February 2005.

- Antunes Rocha c. Portugal, requête no 64330/01, 31 mai 2005.

- Aşan and Others v. Turkey, appl. no. 56003/00, 31 July 2007.

- Asenov c. Bulgarie, requête $\mathrm{n}^{\circ}$ 42026/98, 15 juillet 2005.

- Ashingdane v. the United Kingdom, appl. no. 8225/78, 28 May 1985.

- Assanidze v. Georgia, appl. no. 71503/01, 8 April 2005.

- Assenov and Others v. Bulgaria, appl. no. 90/1997/874/1086, 28 October 1998.

- B. v. Austria, appl. no. 11968/86, 28 March 1990.

- Bak v. Poland, appl. no. 7870/04, 16 January 2007.

- Baranowski v. Poland, appl. no. 28358/95, 28 March 2000.

- Barthold v. Germany, appl. no. 8734/79, 25 March 1983.

- Bartik v. Russia, appl. no. 55565/00, 21 December 2006.

- Başkaya and Okçuoğlu v. Turkey, appl. nos. 23536/94 and 24408/94, 8 July 1999.

- Baumann v. France, appl. no. 33592/96, 22 August 2001.

- Becciev v. Moldova, appl. no. 9190/03, 4 October 2005.

- Belevitskiy v. Russia, appl. no. 72967/01, 1 March 2007.

- Benham v. the United Kingdom, appl. no. 19380/92, 10 June 1996.

- Bensaid v. the United Kingdom, appl. no. 44599/98, 6 February 2001.

- Bezicheri v. Italy, appl. no. 11400/85, 25 October 1989.

- Bilen c. Turquie, requête no 34482/97, 21 février 2006.

- Bochev v. Bulgaria, appl. no. 73481/01, 13 November 2008.

- Boicenco v. Moldova, appl. no. 41088/05, 11 July 2006.

- Bolat v. Russia, appl. no. 14139/03, 5 October 2006.

- Boloş c. Roumanie, requête no 33078/03, 12 janvier 2010.

- Bordikov v. Russia, appl. no. 921/03, 8 October 2009.

- Botmeh and Alami v. the United Kingdom, appl. no. 15187/03, 7 June 2007.

- Bouamar v. Belgium, appl. no. 9106/80, 29 February 1988.

- Bouchet c. France, requête no 33591/96, 20 mars 2001.

- Bozano v. France, appl. no. 9990/82, 18 December 1986.

- Brandstetter v. Austria, appl. no. 28 August 1991.

- Brannigan \& McBride v. the United Kingdom, appl. nos. 14553/89 and 14554/89, 26 May 1993. 
Bibliography

- Brogan and Others v. the United Kingdom, appl. nos. 11209/84, 11234/84, 11266/84, 11386/85, 29 November 1988.

- Bujac c. Romanie, requête no 37217/03, 2 novembre 2010.

- Bülbül v. Turkey, appl. no. 47297/99, 22 May 2007.

- Butkevičius v. Lithuania, appl. no. 48297/99, 26 March 2002.

- Bykov v. Russia, appl. no. 4378/02, 10 March 2009.

- C.G. v. Bulgaria, appl. no. 1365/07, 24 April 2008.

- C.R. v. the United Kingdom, appl. no. 20190/92, 22 November 1995.

- Calleja v. Malta, appl. no. 75274/01, 7 April 2005.

- Camenzind v. Switzerland, appl. no. 136/1996/755/954, 16 December 1997.

- Cantoni v. France, appl. no. 17862/91, 15 November 1996.

- Castravet v. Moldova, appl. no. 23393/05, 13 March 2007.

- Cebotari v. Moldova, appl. no. 35615/06, 13 November 2007.

- Celejewski v. Poland, appl. no. 17584/04, 4 May 2006.

- Çetinkaya and Çağlayan v. Turkey, appl. nos. 3921/02, 35003/02 and 17261/03, 23 April 2007.

- Čevizović v. Germany, appl. no. 499746/99, 29 July 2004.

- Chahal v. the United Kingdom, appl. no. 22414/93, 15 November 1996.

- Chitayev and Chitayev v. Russia, appl. no. 59334/00, 18 January 2007.

- Chraidi v. Germany, appl. no. 65655/01, 26 October 2006.

- Ciulla v. Italy, appl. no. 11152/84, 22 February 1989.

- Clooth v. Belgium, appl. no. 12718/87, 12 December 1991.

- Coëme et Autres c. Belgique, appl. nos. 32492/96, 32547/96, 32548/96, 33209/96 et 33210/96, 22 juin 2002.

- Čonka v. Belgium, appl. no. 51564/99, 5 February 2002.

- Contrada v. Italy, appl. no. 27143/95, 24 August 1998.

- Crémieux v. France, appl. no. 11471/85, 25 February 1993.

- Custers, Deveaux and Turk v. Danmark, appl. no. 11843/03, 11847/03 and 11849/03, 3 May 2007.

- Czarnecki v. Poland, appl. no. 75112/01, 28 July 2005.

- D.N. v. Switzerland, appl. no. 27154/95, 29 March 2001.

- Danov v. Bulgaria, appl. no. 56796/00, 26 October 2006.

- Davydov and Others v. the Ukraine, appl. nos. 17674/02 and 39081/02, 1 July 2010.

- De Jong, Baljet and Van Den Brink v. The Netherlands, appl. no. 8805/79, 22 May 1984.

- De Wilde, Ooms and Versyp ("Vagrance") v. Belgium, appl. nos. 2832/66; 2835/66; 2899/66, 18 June 1971.

- Demokratischer Soldaten Österreichs and Gubi v. Austria, appl. no. 15153/89, 19 December 1994.

- Denizci and Others v. Cyprus, appl. nos. 25316-25321/94 and 27207/95, 23 May 2005.

- Dolgova v. Russia, appl. no. 11886/05, 2 March 2006.

- Doorson v. the Netherlands, ECHR, appl. no. 20524/92, 26 March 1996.

- Dougoz v. Greece, appl. no. 40907/98, 6 March 2001.

- Douiyeb v. the Netherlands, appl. no. 31464/96, 4 August 1999. 
- Dragotoniu et Militaru-Pidhorni c. Roumanie, requête no. 77193/01 et 77196/01, 24 mai 2007.

- Droogenbroeck v. Belgium, appl. no. 7906/77, 24 June 1982.

- Drozdowski v. Poland, appl. no. 20841/02, 6 March 2006.

- Dzelili v. Germany, appl. no. 65745/01, 10 November 2005.

- E.K. c. Turquie, requête $\mathrm{n}^{\circ}$ 28496/95, 7 février 2002.

- E.M.K. v. Bulgaria, appl. no. 43231/98, 18 January 2005.

- Edwards and Lewis v. the United Kingdom, appl. nos. 39647/98 and 40461/98, 27 October 2004.

- Edwards v. the United Kingdom, appl. no. 13071/87, 16 December 1992.

- El Boujaïdi v. France, appl. no. 123/1996/742/941, 26 September 1997.

- Emil Hristov v. Bulgaria, appl. no. 52389/99, 20 October 2005.

- Engel and others v. the Netherlands, appl. no. 5100/71, 8 June 1976.

- Enhorn v. Sweden, appl. no. 56529/00, 25 January 2005.

- Erdagöz v. Turkey, 22 October 1997, appl. no. 21890/93.

- Erdem v. Germany, appl. no. 38321/97, 5 July 2001.

- Eriksen v. Norway, appl. no. 102/1995/608/696, 27 May 1997.

- Erkalo v. the Netherlands, appl. no. 89/1997/873/1085, 2 August 1998.

- Erkan Inan c. Turquie, requête no 13176/05, 23 février 2010.

- Fatma Tunç v. Turkey, appl. no. 16608/02, 20 October 2005.

- Fedorov and Fedorova v. Russia, appl. no. 31008/02, 13 October 2005.

- Fitt v. the United Kingdom, appl. no. 29777/96, 16 February 2000.

- Fodale v. Italy, appl. no. 70148/01, 1 June 2006.

- Forte c. Italie, requête no. 77986/01, 10 novembre 2005.

- Fox, Campbell and Hartley v. the United Kingdom, appl. no., 12244/86, 30 August 1990.

- Frasikv. Poland, appl. no. 22933/02, 5 January 2010.

- Frommelt v. Liechtenstein, appl. no. 49158/99, 24 June 2004.

- G. v. France, appl. no. 15312/89, 27 September 1995.

- G. V. France, appl. no. 29/1994/476/557, 31 August 1995.

- G.B. v. Switzerland, appl. no. 27426/95, 30 November 2000.

- G.K. v. Poland, appl. no. 38816/97, 20 January 2004.

- Gabarri Moreno c. Espagne, appl. no. 68066/01, 22 juillet 2003.

- Gaidjurgis v. Lithuania, decision as to the admissibility, appl. no. 49098/00, 16 January 2001.

- Garabayev v. Russia, appl. no. 38411/02, 7 June 2007.

- Garcia Alva v. Germany, appl. no. 23541/94, 13 February 2001.

- Gavril Yosifov v. Bulgaria, appl. no. 74012/01, 6 November 2008.

- Gillan and Quinton v. the United Kingdom, appl. no. 4158/05, 12 January 2010.

- Gillow v. the United Kingdom, appl. no. 9063/80, 24 November 1986.

- Giorgi Nikolaishvili v. Georgia, appl. no. 37048/04, 13 January 2009.

- Glass v. the United Kingdom, appl. no. 61827/00, 9 March 2004.

- Gochev v. Bulgaria, appl. no. 34383/03, 26 November 2009. 
Bibliography

- Goodwin v. the United Kingdom, appl. no. 28957/95, 11 July 2002.

- Goral v. Poland, appl. no. 38654/97, 30 October 2003.

- Görgülü v. Germany, appl. no. 74969/01, 26 May 2004.

- Goroshchenya v. Russia, appl. no. 38711/03, 22 April 2010.

- Grauslys v. Lithuania, appl. no. 36743/97, 10 October 2000.

- Grigoriadus v. Greece, appl. no. 121/1996/740/939, 25 November 1997.

- Guliyev v. Azerbaijan, Decision as to the admissibility appl. no. 35584/02, 27 May 2005.

- Gulub Atanasov v. Bulgaria, appl. no. 73281/01, 6 November 2008.

- Gurguchiani c. Espagne, requête n 16012/06, 15 décembre 2009.

- Gusinskiy v. Russia, appl. no. 70276/01, 19 May 2004.

- Guzzardi v. Italy, appl. no. 7367/76, 6 November 1980.

- H.M. v. Switzerland, appl. no. 39187/98, 26 May 2002.

- Haase v. Germany, appl. no. 11057/02, 8 July 2004.

- Hadi v. Croatia, appl. no. 42998/08, 1 July 2010.

- Haidn v. Germany, appl. no. 6587/04, 13 January 2011.

- Halford v. the United Kingdom, appl. no. 20605/92, 25 June 1997.

- Hamanov v. Bulgaria, appl. no. 44062/98, 8 April 2004.

- Hauschildt v. Denmark, appl. no. 10486/83, 24 May 1989.

- Hendriks v. the Netherlands, decision as to the admissibility, appl. no. 43701/04, 5 July 2007.

- Herczegfalvy v. Austria, appl. no. 10533/83, 24 September 1992.

- Hoffmann v. Germany, appl. no. 34045/96, 11 October 2001.

- Hristova c. Bulgarie, requête $\mathrm{n}^{\circ}$ 60859/00, 7 décembre 2006.

- Hussain v. the United Kingdom, appl. no. 21928/93, 21 February 1996.

- Hutchison Reid v. the United Kingdom, appl. no. 50272/99, 20 February 2003.

- Huvig v. France, appl. no. 11105/84, 24 April 1990.

- I.I. v. Bulgaria, appl. no. 44082/98, 9 June 2005.

- İ̆delív. Turkey, appl. no. 29296/95, 20 June 2002.

- Ikincisoy v. Turkey, appl. no. 26144/95, 27 July 2004.

- Ilijkov v. Bulgaria, appl. no. 33977/96, 26 July 2001.

- Itowiecki v. Poland, appl. no. 27504/95, 4 October 2001.

- Imakayeva v. Russia, appl. no. 7615/02, 9 November 2006.

- Imbrioscia v. Switzerland, appl. no. 13972/88, 24 November 1993.

- Iordachi and Others v. Moldova, appl. no. 25198/02, 10 February 2009.

- Iovchev v. Bulgaria, appl. no. 41211/98, 2 February 2006.

- Ipek and Others v. Turkey, appl. nos. 17019/02 and 30070/02, 3 February 2009.

- Ireland v. the United Kingdom, appl. no. 5310/71, 18 January 1978.

- Ismoilov and Others v. Russia, appl. no. 2947/06, 24 April 2008.

- Istratii and Others v. Moldova, appl. nos. 8721/05, 8705/05 and 8742/05, 27 March 2007.

- Ivanov v. Ukraine, appl. no. 15007/02, 7 December 2006.

- J.C. v. The Netherlands, appl. no. 19139/91, 30 March 1992.

- Jablonski v. Poland, appl. no. 33492/96, 21 December 2000.

- Jamil v. France, appl. no. 15917/89, 8 June 1995. 
- Jasper v. the United Kingdom, appl. no. 27052/95, 16 February 2000.

- Jéčius v. Lithuania, appl. no. 34578/97, 31 July 2000.

- Jiga c. Roumanie, requête no 14352/04, 16 mars 2010.

- Jorgic v. Germany, appl. no. 74613/01, 12 July 2007.

- Jurjevs c. Lettonie, requête $\mathrm{n}^{0} 70923 / 01,15$ juin 2006.

- K.A. et A.D. c. Belgique, appl. nos. 42758/98 et 45558/99, 17 February 2005.

- K.D. c. Pays-Bas Décision as to the admissibility, requête no. 21207/93, 30 Novembre 1994.

- $\quad$ K.-F. v. Germany, appl. no. 25629/94, 27 November 1997.

- K.-H.W. v. Germany, appl. no. 37201/97, 22 March 2001.

- Kaboulov v. the Ukraine, appl. no. 41015/04, 19 November 2009.

- Kadem v. Malta, appl. no. 55263/00, 9 January 2003.

- Kafkaris v. Cyprus, appl. no. 21906/04, 12 February 2008.

- Kalashnikov v. Russia, appl. no. 47095/99, 15 July 2002.

- Kalin c. Turquie, appl. no. 31236/96, 10 November 2004.

- Kamantauskas v. Lithuania, decision as to the admissibility, appl. no. 45012/98, 29 February 2000.

- Kampanis v. Greece, appl. no. 17977/91, 13 July 1995.

- Kanzi v. the Netherlands, decision as to the admissibility, appl. no. 28831/04, 5 July 2007.

- Kaszczyniec v. Poland, appl. no. 59526/00, 22 May 2007.

- Kawka v. Poland, appl. no. 25874/94, 9 January 2001.

- Keegan v. the United Kingdom, appl. no. 28867/03, 18 July 2006.

- Kehayov v. Bulgaria appl. no. 41035/98, 18 January 2005.

- Kemal Güven v. Turkey, appl. no. 31847/96, 30 May 2000.

- Kemmache v. France, appl. no. 12325/86 and 14992/89, 27 November 1991.

- Kemmache v. France, appl. no. 17621/91, 24 November 1994.

- Kennedy v. the United Kingdom, appl. no. 26839/05, 18 May 2010.

- Keus v. the Netherlands, appl. no. 12228/86.

- Kevin O'Dowd v. the United Kingdom, appl. no. 7390/07, 21 September 2010.

- Khodzhayev v. Russia, appl. no. 52466/08, 12 May 2010.

- Khudobin v. Russia, appl. no. 59696/00, 26 October 2006.

- Khudoyorov v. Russia, appl. no. 6847/02, 8 November 2005.

- Klamecki v. Poland, appl. no. 25415/94, 28 March 2002.

- Klass and Others v. Germany, appl. no. 5092/71, 6 September 1978.

- Klyakhin v. Russia, appl. no. 46082/99, 30 November 2004.

- Knebl c. République Tchèque, requête $\mathrm{n}^{\circ}$ 20157/05, 28 octobre 2010.

- Koendjbiharie v. The Netherlands, appl. no. 11487/85, 25 October 1990.

- Kokkinakis v. Greece, appl. no. 14307/88, 25 May 1993.

- Kolev v. Bulgaria, appl. no. 50326/99, 28 April 2005.

- Kolompar v. Belgium, appl. no. 11613/85, 24September 1992.

- König v. Slovakia, appl. no. 39753/98, 20 January 2004.

- Kononov v. Latvia (GC), appl. no. 36376/04, 17 May 2010. 
Bibliography

- Kononov v. Latvia, appl. no. 36376/04, 24 July 2008.

- Kopp v. Switzerland, appl. no. 23224/94, 25 March 1998.

- Korbely v. Hungary (GC), appl. no. 9174/02, 19 September 2008.

- Korchuganova v. Russia, appl. no. 75039/01, 8 June 2006.

- Kostadinov v. Bulgaria, appl. no. 55712/00, 7 February 2008.

- Kotsaridis c. Grèce, requête no 71498/01, 23 septembre 2004.

- Krejcír c. République Tchèque, requêtes nos 39298/04 et 8723/05, 26 mars 2009.

- Kruslin v. France, appl. no. 11801/85, 24 April 1990.

- Kučera v. Slovakia, appl. no. 48666/99, 17 July 2007.

- Kudla v. Poland, appl. no. 30210/96, 26 October 2000.

- Kuibishev v. Bulgaria, appl. no. 39271/98, 30 September 2004.

- Kuznetsov v. the Ukraine, appl. no. 39042/97, 29 April 2003.

- Kvasnica v. Slovakia, appl. no. 72094/01, 9 June 2009.

- Labita v. Italy, appl. no. 26772/95, 6 April 2000.

- Ladent v. Poland, appl. no. 11036/03, 18 March 2008.

- Lamy v. Belgium, appl. no. 10444/83, 30 March 1989.

- Landvreugd v. the Netherlands, appl. no. 37331/97, 4 September 2002.

- Lanz v. Austria, appl. no. 24430/94, 31 January 2000.

- Laszkiewicz v. Poland, appl. no. 28481/03, 15 January 2008.

- Latasiewicz v. Poland, appl. no. 44722/98, 23 June 2005.

- Laumont v. France, appl. no. 43626/98, 8 November 2001.

- Lawless v. Ireland, appl. no. 332/57, 1 July 1961.

- Lavents c. Lettonie, requête no 58442/00, 28 novembre 2002.

- Lawless v. the United Kingdom, appl. no. 332/57, 1 July 1961.

- Leander v. Sweden, appl. no. 9248/81, 26 March 1987.

- Lebedev v. Russia, appl. no. 4493/04, 25 October 2007.

- Lelièvre c. Belgique, requête no 11287/03, 8 novembre 2007.

- Letellier v. France, appl. no. 12369/86, 26 June 1991.

- Leva v. Moldova, appl. no. 12444/05, 15 December 2009.

- Lexa v. Slovakia (no. 2), appl. no. 34761/03, 5 January 2010.

- Liberty and Others v. the United Kingdom, appl. no. 58243/00, 1 July 2008.

- Lietzow v. Germany, appl. no. 24479/94, 13 February 2001.

- Liivik v. Estonia, appl. no. 12157/05, 25 June 2009.

- Lind v. Russia, appl. no. 25664/05, 6 December 2007.

- Lloyd and Others v. the United Kingdom, appl. nos. 29798/96, 30395/96, 34327/96, $34341 / 96$, 35445/97 36267/97, 36367/97, 37551/97, 37706/97, 38261/97, 39378/98, 41590/98，41593/98，42040/98，42097/98，45420/99，45844/99，46326/99，47144/99, $53062 / 99,53111 / 99,54969 / 00,54973 / 00,54997 / 00,55046 / 00,55068 / 00,55071 / 00$, $56109 / 00,56231 / 00,56232 / 00,56233 / 00,56429 / 00,56441 / 00,2460 / 03,2482 / 03,2483 / 03$, 2484/03 and 2490/03, 1 March 2005.

- Loncaric v. Slovenia, decision as to the admissibility, appl. no. 30887/96, 4 September 1996.

- Luberti v. Italy, appl. no. 9019/80, 23 February 1984. 
- Lukanov v. Bulgaria, appl. no. 21915/93, 20 March 1997.

- Lukanov v. Bulgaria, decision as to the admissibility appl. no. 21915/93, 20 March 1997.

- Luordo v. Italy, appl. no. 32190/96, 17 July 2003.

- Lupsa v. Romania, appl. no. 10337/04, 8 June 2006.

- Lyubimenko v. Russia, appl. no. 6270/06, 19 March 2009.

- M. v. Germany, appl. no. 19359/04, 17 December 2009.

- M.B. v. Poland, appl. no. 34091/96, 27 April 2004.

- M.B. v. Switzerland, appl. no. 28256/95, 30 November $2000 \mathrm{ev}$.

- Makhmudov v. Russia, appl. no. 35082/04, 26 July 2007.

- Malone v. the United Kingdom, appl. no. 8691/79, 2 august 1984.

- Mamedova v. Russia, appl. no. 7064/05, 1 June 2006.

- Mangouras v. Spain, appl. no. 12050/04, 28 September 2010.

- Marturana v. Italy, appl. no. 63154/00, 4 March 2008.

- Matheron c. France, requête no 57752/00, 29 mars 2005.

- Matwiejczuk v. Poland, appl. no. 37641/07, 2 December 2003.

- Matznetter v. Austria, appl. no. 2178/64, 10 November 1969.

- Mayzit v. Russia, appl. no. 63378/00, 20 January 2005.

- McKay v. the United Kingdom, appl. no. 543/03, 3 October 2006.

- McLeod v. the United Kingdom, appl. no. 24755/94, 23 September 1998.

- Megyeri v. Germany, appl. no. 13770/88, 12 May 1992.

- Migon v. Poland, appl. no. 24244/94, 25 June 2002.

- Minjat v. Switzerland, appl. no. 38223/97, 28 October 2003.

- Mitev v. Bulgaria, appl. no. 40063/98, 22 December 2004.

- Moiseyev v. Russia, appl. no. 62936/00, 9 October 2008.

- Molodorych v. Ukraine, appl. no. 2161/02, 28 October 2010.

- Mooren v. Germany [GC], appl. no. 11364/03, 9 July 2009.

- Mooren v. Germany, appl. no. 11364/03, 13 December 2007.

- Moskovets v. Russia, appl. no. 14370/03, 23 April 2009.

- Moustaquim v. Belgium, appl. no. 12313/86, 18 February 1991.

- Muller v. France, appl. no. 21802/93, 17 March 1997.

- Murray v. the United Kingdom, appl. no. 14310/88, 28 October 1994.

- Musial v. Poland, appl. no. 24557/94, 25 March 1999.

- Musuc v. Moldova, appl. no. 42440/06, 6 November 2007.

- N.C. v. Italy, appl. no. 24952/94, 11 January 2001.

- N.F. v. Italy, appl. no. 37119/97, 2 August 2010.

- Nakhmanovich v. Russia, appl. no. 55669/00, 2 March 2006.

- Napijalo v. Croatia, appl. no. 66485/01, 13 November 2003.

- Narinen v. Finland, appl. no. 45027/98, 1 June 2004.

- Navarra v. France, appl. no. 13190/87, 23 November 1993.

- Nešták v. Slovakia, appl. no. 65559/01, 27 February 2007.

- Neumeister v. Austria, appl. no. 1936/63, 27 June 1968.

- Nevmerzhitsky v. Ukraine, appl. no. 54825/00, 5 April 2005. 
Bibliography

- Nicol and Selvanayagam v. the United Kingdom, decision as to the admissibility, appl. no. 32213/96, 11 January 2001.

- Niemietz v. Germany, appl. no. 13710/88, 16 December 1992.

- Niemietz v. Switzerland, appl. no. 13710/88, 16 December 1992.

- Nikolov v. Bulgaria, appl. no. 38884/97, 30 January 2003.

- Nikolova v. Bulgaria (No. 2), appl. no. 40896/98, 30 September 2004.

- Nikolova v. Bulgaria, appl. no. 31195/96, 25 March 1999.

- O'Hara v. the United Kingdom, appl. no. 37555/97, 16 October 2001.

- Öcalan v. Turkey, appl. no. 46221/99, 12 March 2003.

- Öcalan v. Turkey, appl. [GC] no. 46221/99, 12 May 2005.

- Olivieira v. the Netherlands, appl. no. 33129/96, 4 June 2002.

- Osuch v. Poland, appl. no. 31246/02, 14 November 2006.

- Özçelik v. Turkey, appl. no. 56497/00, 20 February 2007.

- Öztürk v. Germany, appl. no. 8544/79, 21 February 1984.

- P.G. and J.H. v. the United Kingdom, appl. no. 44787/98, 25 September 2001.

- Panchenko v. Russia, appl. no. 45100/98, 8 February 2005.

- Papon v. France, appl. no. 54210/00, 25 July 2002.

- Patsuria v. Georgia, appl. no. 30779/04, 6 November 2007.

- Pavletić v. Slovakia, appl. no. 39359/98, 22 June 2004.

- Pavlík v. Slovakia, appl. no. 74827/01,30 January 2007.

- Pecheur c. Luxembourg, requête $n^{\circ}$ 16308/02, 11 décembre 2007.

- Pessino v. France, appl. no. 40403/02, 10 October 2006.

- Peters c. Les Pays-Bas, Décision as to the admissibility, requête no. 21132/93, 6 avril 1994.

- Piemont v. France, appl. nos. 15773/89 and 15774/89, 27 April 1995.

- Pisk-Piskowski v. Poland, appl. no. 29/03, 14 June 2005.

- Ploski v. Poland, appl. no. 26761/95, 12 November 2002.

- Polonskiy v. Russia, appl. no. 30033/05, 19 March 2009'.

- Poltorastskiy v. the Ukraine, appl. no. 38812/97, 29 April 2003.

- Popov and Vorobyev v. Russia, appl. no. 1606/02, 23 April 2009.

- Prado Bugallo c. Espagne, requête no 58496/00, 18 février 2003.

- Pretty v. the United Kingdom, appl. no. 2346/02, 29 April 2002.

- Protopapa v. Turkey, appl. no. 16084/90, 24 February 2009.

- Pshevecherskiy v. Russia, appl. no. 28957/02, 24 May 2007.

- Puhk v. Estonia, appl. no. 55103/00, 10 February 2004.

- Punzelt v. the Czech Republic, appl. no. 31315/96, 25 April 2000.

- Quinn v. France, appl. no. 18580/91, 22 March 1995.

- R.M.D. v. Switzerland, appl. no. 81/1996/700/892, 26 September 1997.

- Raban v. Romania, appl. no. 25437/08, 26 October 2010.

- Radaj v. Poland, appl. nos. 29537/95 and 35453/97, 28 November 2002.

- Radovanovic v. Russia, appl. no. 42703/98, 22th July 2004.

- Raimondo v. Italy, appl. no. 12954/87, 22 February 1994.

- Ramishvili and Kokhreidze v. Georgia, appl. no. 1704/06, 27 January 2009. 
- Ramishvili and Kokhreidze v. Georgia, decision as to the admissibility, appl. no. 1704/06, 27 June 2007.

- Rażniak v. Poland, appl. no. 6767/03, 7 October 2008.

- Rehbockv. Slovenia, appl. no. 29462/95, 28 November 2000.

- Reinprecht v. Austria, appl. no. 67175/01, 15 November 2005.

- Riener v. Bulgaria, appl. no. 46343/99, 23 May 2006.

- Rokhlina v. Russia, appl. no. 54071/00, 7 April 2005.

- Rotaru v. Romania, appl. no. 28341/95, 4 May 2000.

- Ryabikin v. Russia, appl. no. 8320/04, 19 June 2008.

- S. and Marper v. the United Kingdom, appl. nos. 30562/04 and 30566/04, 4 December 2008.

- S.N. v. Sweden, appl. no. 34209/96, 2 July 2002.

- S.W. v. the United Kingdom, appl. no. 20166/92, 22 November 1995.

- Saadi v. the United Kingdom, appl. no. 13229/03, 29 January 2008.

- Sabeur Ben Ali v. Malta, appl. no. 35892/97, 29 June 2000.

- Sakik and Others v. Turkey, appl. no. 87/1996/706/898-903, 26 November 1997.

- Sanchez-Reisse v. Switzerland, appl. no. 9862/82, 21 October 1986.

- Sarban v. Moldova, appl. no. 3456/05, 4 October 2005.

- Sardinas Albo v. Italy, appl. no. 56271/00, 17 February 2005.

- Schiesser v. Switserland, appl. no. 7710/76, 4 December 1979, NJ 1980/547.

- Schöps v. Germany, appl. no. 25116/94, 13 February 2001.

- Schummer v. Germany, appl. nos. 27360/04 and 42225/07, 13 January 2011.

- Scoppola v. Italy (No. 2) (GC), appl. no. 10249/03, 17 September 2009.

- Scott v. Spain, appl. no. 21335/93, 18 December 1996.

- Segerstedt-Wiberg and Others v. Sweden, appl. no. 62332/00, 6 June 2006.

- Sergey Volosyuk v. Ukraine, appl. no. 1291/03, 12 March 2009.

- Sevgin and Ince v. Turkey, appl. no. 46262/99, 20 September 2005.

- Şevk v. Turkey, appl. no. 4528/02, 11 April 2008.

- Shamayev and Others v. Georgia and Russia, appl. no. 36378/02, 12 April 2005.

- Shannon v. Latvia, appl. no. 32214/03, 24 November 2009.

- Shchebet v. Russia, appl. no. 16074/07, 12 June 2008.

- Shenoyev v. Russia, appl. no. 2563/06, 10 June 2010.

- Shiskov v. Bulgaria, appl. no. 38822/97, 9 January 2003.

- Silva Rocha v. Portugal, appl. no. 18165/91, 15 November 1996.

- Silver and Others $v$. the United Kingdom, appl. nos. 5947/72; 6205/73; 7052/75; 7061/75; 7107/75; 7113/75; 7136/75, 25 March 1983.

- Singh v. the Czech Republic, appl. no. 60538/00, 25 January 2005.

- Singh v. the United Kingdom, appl. no. 23389/94, 21 February 1996.

- Smirnova v. Russia, appl. nos. 46133/99 and 48183/99, 24 July 2003.

- Soini and Others v. Finland, appl. no. 36404/97, 17 January 2006.

- Soldatenko v. Ukraine, appl. no. 2440/07, 23 October 2008.

- Soumare v. France, appl. no. 48/1997/832/1038, 24 August 1998.

- Spasovv. Bulgaria, appl. no. 51796/99, 16 November 2006. 
Bibliography

- Sporrong and Lönnroth v. Sweden, 23 September 1982, appl. no. 7151/75 and 7152/75.

- Starokadomskiy v. Russia, appl. no. 42239/02, 31 July 2008.

- Stašaitis v. Lithuania, appl. no 47679/99, 21 March 2002.

- Staykov v. Bulgaria, appl. no. 49438/99, 12 October 2006.

- Steel and Others v. the United Kingdom, appl. no. 67/1997/851/1058, 23 September 1998.

- Stephens v. Malta (no. 1), appl. no. 11956/07, 21 April 2009.

- Stögmüller v. Austria, appl. no. 1602/62, 10 November 1969.

- Streletz, Kessler and Krenz v. Germany, appl. no. 34044/96, 35532/97 and 44801/98, 22 March 2001.

- Sud Fondi srl et autres contre Italie, appl. no. 75909/01, 20 January 2009.

- Sulaoja v. Estonia, appl. no. 55939/00, 15 February 2005.

- Sunday Times v. the United Kingdom, appl. no. 6538/74, 26 April 1979.

- Suominen c. Finlande, requête no 37801/97, 1 juillet 2003.

- Svershov v. Ukraine, appl. no. 35231/02, 27 November 2008.

- Svetoslav Dimitrov v. Bulgaria, appl. no. 55861/00, 7 February 2008.

- Svipsta v. Latvia, appl. no. 66820/01, 9 March 2006.

- T. v. The Netherlands, appl. no. 18090/91, 4 July 1991.

- Talat Tepe v. Turkey, appl. no. 31247/96, 21 December 2004.

- Tanrikulu and Others v. Turkey, appl. nos. 29918/96, 29919/96 and 30169/96, 6 October 2005.

- Tarău c. Roumanie, requête no 3584/02, 24 février 2009.

- Tariq v. Czech Republic, appl. no. 75455/01, 18 April 2006.

- Taş v. Turkey, appl. no. 24396/94, 14 November 2000.

- Tatishvili v. Russia, appl. no. 1509/02, 22 February 2007.

- Taylor-Sabori v. the United Kingdom, appl. no. 47114/99, 22 October 2003.

- Tess v. Latvia, appl. no. 34854/02, 12 December 2002.

- The Association for European Integration and Human Rights and Ekimdzhiev v. Bulgaria, appl. no. 62540/00, 28 June 2007.

- Timishev v. Russia, appl. nos. 55762/00 and 55974/00, 13 December 2005.

- Tomasi v. France, appl. no. 12850/87, 27 august 1992.

- Toth v. Austria, appl. no. 11894/85, 12 December 1991.

- Trzaska v. Poland, appl. no. 25792/94, 11 July 2000.

- Tuncer and Durmuşv. Turkey, appl. no. 30494/96, 2 November 2004.

- Turcan and Turcan v. Moldova, appl. no. 39835/05, 23 October 2007.

- Turgay Elğay v. Turkey, decision as to the admissibility, appl. no. 18992/03, 11 September 2007.

- Uçar v. Turkey, appl. no. 52392/99, 11 April 2006.

- Ünsal Öztürk v. Turkey, appl. no. 29365/95, 4 October 2005.

- Uzun v. Germany, appl. no. 35623/05, 2 September 2010.

- Valenzuela Contreras v. Spain, appl. no. 58/1997/842/1048, 30 July 1998.

- Van Anraat v. the Netherlands, decision regarding the admissibility, appl. no. 65389/09, 6 July 2010. 
- Van Den Dungen v. the Netherlands, appl. no. 22838/93, 22 February 1995.

- Van Der Tang v. Spain, appl. no. 19382/92, 13 July 1995.

- Van Droogenbroeck v. Belgium, appl. no. 7906/77, 24 June 1982.

- Van Mechelen and Others v. the Netherlands, appl. nos. 21363/93, 21364/93, 21427/93 and 22056/93, 23 April 1997.

- Van Pelt v. the Netherlands, Decision as to the admissibility, appl. no. 20555/92, 6 April 1994.

- Varga c. Roumanie, requête no 73957/01, 1 avril 2008.

- Vasilev v. Bulgaria, appl. no. 59913/00, 2 February 2006.

- Vayiç v. Turkey, appl. no. 18078/02, 20 June 2006.

- Veeber v. Estonia (no. 2), appl. no. 45771/99, 21 January 2003.

- Veliyev v. Russia, appl. no. 24202/05, 24 June 2010.

- Vetter c. France, requête no 59842/00, 31 mai 2005.

- Vrenčev v. Serbia, appl. no. 2361/05, 23 September 2008.

- W. v. Switzerland, appl. no. 14379/88, 26 February 1993.

- Wassink v. the Netherlands, appl. no. 12535/86, 27 September 1990.

- Weber and Saravia v. Germany, Decision as to the admissibility in, appl. no. 54934/00, 29 June 2006.

- Weeks v. the United Kingdom, appl. no. 9787/82, 2 May 1987.

- Wemhoff v. Germany, appl. no. 2122/64, 27 June 1968.

- Wiggins v. The United Kingdom, 8 February 1978, appl. no. 7456/76.

- Wingrove v. the United Kingdom, appl. no. 17419/90, 25 November 1996.

- Winterwerp v. The Netherlands, appl. no. 6301/73, 24 October 1979.

- Wisse c. France, requête n 71611/01, 20 décembre 2005.

- Witold Litwa v. Poland, appl. no. 26629/95, 4 April 2000.

- Wloch v. Poland, appl. no. 27785/95, 19 October 2000.

- $\quad$ and Yv. The Netherlands, appl. no. 8978/80, 26 March 1985.

- $\quad$ X. v. the United Kingdom, appl. no. 7215/75, 5 November 1981.

- Y.F. v. Turkey, appl. no. 24209/94, 22 July 2003.

- Yankov v. Bulgaria, appl. no. 39084/97, 11 December 2003.

- Yaşar Kemal Gökçeli c. Turquie, appl. no. 27215/95 et 36194/97, 4 March 2003.

- Yildiz v. Austria, appl. no. 37295/97, 31 October 2002.

- Yunus Aktaş et Autres c. Turquie, requête no 24744/03, 20 octobre 2009.

- Z.N.S. v. Turkey, appl. no. 21896/08, 19 January 2010.

- Žirovnickýv. the Czech Republic, appl. no. 23661/03, 30 September 2010.

\section{Dutch Parliamentary Memoranda}

- Handelingen II 1913-1914, 286, no. 2 and 3, ad Art. 131.

- Handelingen II 2003-2004, nr. 31.

- Handelingen I 2003-2004, nr. 32, p. 1699-1712.

- Handelingen II 2003-2004, nr. 33.

- Handelingen II 2006-2007, p 2826. 
Bibliography

- Kamerstukken I 2003-2004, 28 463, C and E.

- Kamerstukken I 2006-2007, 30164 C, D and G.

- Kamerstukken I 2007-2008, 30 566, C.

- Kamerstukken I 2010-2011, 30 566, E.

- Kamerstukken II 1972-1973, p. 1787.

- Kamerstukken II 1988-1989, 1990-1991, 1992-1993, 21 225, nrs. 1 t/m 15.

- Kamerstukken II 1988-1989, 21 225, nr. 3, nr. 4.

- Kamerstukken II 1989-1990, 19 757, nr. 8.

- Kamerstukken II 1989-1999, 21 225, nr. 4.

- Kamerstukken II 1990-1991, 21 225, nr. 5.

- Kamerstukken II 1990-1991, 22 268, nr. 3.

- Kamerstukken II 1992-1993, 21 225, nr. 12, nr. 13.

- Kamerstukken II 1996-1997, 25 403, nr. 3, nr. 7.

- Kamerstukken II 1997-1998, 25 877, nr. 3.

- Kamerstukken II 1998-1999, 26 269, nr. 4-5.

- Kamerstukken II 1999-2000, 26 983, nr. 3.

- Kamerstukken II 2001-2002, 27 925, nr. 10.

- Kamerstukken II 2001-2002, 28 463, nr. 3.

- Kamerstukken II 2001-2002, 28 251, nr. 3.

- Kamerstukken II 2001-2002, 28 463, nr. 3.

- Kamerstukken II 2002-2003, 28 463, nr. 5, nr. 6.

- Kamerstukken II 2002-2003, 27 925, nr. 96.

- Kamerstukken II 2002-2003, 28 463, nr. 3, nr. 5, nr. 6, nr. 8.

- Kamerstukken II 2002-2003, 28 649, nr. 3.

- Kamerstukken II 2002-2003, 28 845, nr. 1-2.

- Kamerstukken II 2003-2004, 28 463, nr. 10, nr. 24, nr. 29.

- Kamerstukken II 2003-2004, 29 441, nr. 3.

- Kamerstukken II 2003-2004, 29 754, nr. 1.

- Kamerstukken II 2003-2004, 30 164, nr. 3.

- Kamerstukken II 2003-2008, 29 271, nr. 1-7.

- Kamerstukken II 2004-2005, 27 925, nr. 21.

- Kamerstukken II 2004-2005, 29 754, nr. 13.

- Kamerstukken II 2004-2005, 29 805, nr. 3.

- Kamerstukken II 2004-2005, 30 164, nr. 3.

- Kamerstukken II 2005-2006, 29 754, nr. 60.

- Kamerstukken II 2005-2006, 29 876, nr. 9.

- Kamerstukken II 2005-2006, 30 164, nr. 6, nr. 7, nr. 9, nr. 12, nr. 17.

- Kamerstukken II 2005-2006, 30 566, nr. 3.

- Kamerstukken II 2006/2007, 30 566, nr. 6.

- Kamerstukken II 2006-2007, 29 754, nr. 100.

- Kamerstukken II 2006-2007, 30 977, nr. 104.

- Kamerstukken II 2007-2008, 31 386, nr. 3. 
- Kamerstukken II 2008-2009, 31 386, nr. 8, nr. 12.

- Kamerstukken II 2009-2010, 32 468, nr. 3.

- Kamerstukken II 2009-2010, bijlage bij kamerstuk 32 468, nr. 3.

- Kamerstukken II 2010-2011, 32 468, nr. 1-8.

- Staatsblad 1963, 565.

- Staatsblad 1992, 96.

- Staatsblad 1994, 565.

- Staatsblad 1994, 60.

- Staatsblad 1996, 367.

- Staatsblad 1999, 245.

- Staatsblad 2000, 495.

- Staatsblad 2000, 497.

- Staatsblad 2001, 532.

- Staatsblad 2001, 675.

- Staatsblad 2002, 46.

- Staatsblad 2004290.

- Staatsblad 2004, 105.

- Staatsblad 2004, 290.

- Staatsblad 2006, 460.

- Staatsblad 2006, 461.

- Staatsblad 2006, 580.

- Staatsblad 2006, 730.

- Staatsblad 2006, 731.

- Staatsblad 2009, 245.

- Staatsblad 2010, 139.

- Staatscourant 2000, 25.

- Staatscourant 2003, 68.

- Staatscourant 2003, 146.

- Staatscourant 2004, 227.

- Staatscourant 2006, 25.

\section{Dutch case law}

- $\quad$ Supreme Court 15 November 1843, NJ 1944/186.

- Supreme Court 21 November 1892, W 6282.

- Supreme Court 27 June 1898, W 7146.

- Supreme Court 1 May 1903, W 7919.

- Supreme Court 23 May 1921, NJ 1921/564.

- Supreme Court 23 January 1928, NJ 1928/363.

- Supreme Court 21 January 1929, NJ 1929.

- Supreme Court 28 October 1940, NJ 1940/192. 
Bibliography

- Supreme Court 11 November 1947, NJ 1948/126.

- Supreme Court 17 May 1949, NJ 1949/553.

- Supreme Court 20 July 1950, NJ 1950/646.

- Supreme Court 31 March 1953, NJ 1953/493.

- Supreme Court 22 June 1954, NJ 1954/477.

- Supreme Court 1 March 1955, NJ 1956/2.

- Supreme Court 10 May 1955, VR 1955/69.

- Supreme Court 28 February 1956, NJ 1956/204.

- Supreme Court 5 February 1957, NJ 1957/455.

- Supreme Court 26 November 1957, NJ 1958/356.

- Supreme Court 30 January 1959, NJ 1959/584.

- Supreme Court 19 February 1963, NJ 1963/512.

- Supreme Court 29 November 1966, NJ 1967/116.

- Supreme Court 19 November 1968, NJ 1969/360.

- Supreme Court 18 February 1969, NJ 1970/31.

- $\quad$ Supreme Court 2 February 1971, NJ 1971/385.

- Supreme Court 19 October 1971, NJ 1971/490.

- Supreme Court 16 November 1971, NJ 1972/61.

- Supreme Court 29 February 1972, NJ 1972, 347.

- Supreme Court 14 January 1975, NJ 1975/207.

- Arnhem District Court 8 July 1975, NJ 1975/418.

- Arnhem Court of Appeal 30 March 1976, NJ 1976/515.

- Supreme Court 22 June 1976, NJ 1976/563.

- Supreme Court 19 October 1976, NJ 1978/53.

- Amsterdam District Court 1 December 1976, LJN: AB6907.

- Supreme Court 15 February 1977, NJ 1978/6.

- Amsterdam Court of Appeal 3 June 1977, NJ 1978/601.

- Supreme Court 28 June 1977, NJ 1978/115.

- Supreme Court 28 November 1978, NJ 1979/93.

- Supreme Court 2 October 1979, NJ 1980/243.

- Rotterdam District Court 8 October 1979, LJN: AC0524.

- Rotterdam District Court 28 August 1980, NJ 1980/639.

- Supreme Court 7 October 1980, NJ 1981/61.

- Supreme Court 18 November 1980, NJ 1981/125.

- Supreme Court 6 January 1981, NJ 1981/500.

- Supreme Court 24 February 1981, NJ 1981/366.

- Supreme Court 29 September 1981, NJ 1982/258.

- The Hague District Court 26 November 1981, NJ 1982/441.

- Breda District Court 15 February 1982 NJ 1983/6.

- Supreme Court 15 June 1982, LJN: AC4196, 73928.

- Supreme Court 16 November 1982, NJ 1983/283.

- Supreme Court 8 December 1982, NJ 1982/533.

- Supreme Court 11 October 1983, NJ 1984/111. 
- Arnhem Court of Appeal 27 October 1983, NJ 1984/80.

- Supreme Court 22 November 1983, NJ 1984/805.

- Supreme Court 6 December 1983, NJ 1984/442.

- Supreme Court 7 February 1984, NJ 1984/740.

- Supreme Court 20 March 1984, NJ 1984/549.

- Rotterdam District Court 28 March 1984, NJ 1984/508.

- Supreme Court 1 May 1984, NJ 1984/687.

- Supreme Court 26 June 1984, NJ 1985/92.

- Supreme Court 30 October 1984, NJ 1985, 275.

- $\quad$ Supreme Court 2 April 1985, NJ 1985/796.

- Supreme Court 28 May 1985, LJN: AC8904, 77947.

- Supreme Court 14 October 1986, NJ 1987/564 (Schaduwen I).

- Supreme Court 14 October 1986 NJ 1988/511.

- Supreme Court 17 February 1987, NJ 1987/963.

- Zutphen District Court 29 October 1987, NJ 1988/576.

- Nationale Ombudsman 9 November 1987, Administratiefrechtelijke beslissing 1988/365.

- Supreme Court 2 February 1988, NJ 1988/820.

- Supreme Court 2 February 1988, NJ 1988/971.

- Supreme Court 24 May 1988, NJ 1988/918.

- Supreme Court 18 October 1988, NJ 1989/430.

- Supreme Court 18 September 1989, NJ 1990/531.

- Supreme Court 29 May 1990, NJ 1990/754.

- Supreme Court 16 October 1990 (Mariënburcht), NJ 1991/442.

- Supreme Court 23 October 1990, NJ 1991/542.

- Supreme Court 6 November 1990, NJ 1991/218.

- Supreme Court 29 January 1991, NJB 1991/50.

- Supreme Court 26 February 1991, NJ 1991/499.

- The Hague Court of Appeal 28 February 1991, NJ 1991/699.

- Supreme Court 21 May 1991, NJ 1991/731.

- Supreme Court 1 October 1991, NJ 1992/60.

- Supreme Court 16 October 1991, NJ 1991/442.

- Supreme Court 3 December 1991, NJ 1992/324.

- Leeuwarden Court of Appeal 29 september 1992, NJ 1993/67.

- Supreme Court 13 October 1992, NJ 1993/223.

- Supreme Court 9 March, 1993, NJ 1993, 633.

- 's-Hertogenbosch District Court 7 November 1994, NJ 1995/109.

- Supreme Court 11 November 1994, NJ 1995/400.

- Supreme Court 21 March 1995, NJ 1995/440.

- Supreme Court 12 September 1995, DD 96.009.

- Rotterdam District Court 13 September 1995, NJ 1996/343.

- Supreme Court 28 November 1995, NJ 1996, 383.

- Supreme Court 19 December 1995, NJ 1996/249.

- 's-Hertogenbosch Court of Appeal 18 January 1996, NJ 1996/339. 
Bibliography

- Supreme Court 19 March 1996, NJ 1997/86.

- Supreme Court 19 March 1996, NJ 1997/85.

- Supreme Court 7 May 1996, NJ 1996/585.

- Supreme Court 7 May 1996, NJ 1997/687.

- Supreme Court 1 July 1996, DD 96, 364.

- Supreme Court 3 December 1996, NJ 1997/574.

- Supreme Court 7 January 1997, NJ 1997/361.

- Supreme Court 7 January 1997, NJB 1997/18.

- Supreme Court 21 January 1997, NJ 1997/321.

- Amsterdam District Court 12 September 1997, Nieuwsbrief Strafrecht 1997, 20.

- Supreme Court 18 November 1997, NJ 1998/225.

- Supreme Court 2 December 1997, NJ 1998, 290.

- Breda District Court 16 December 1997, NJ 1998/61.

- Supreme Court 3 March 1998, NJ 1998/856.

- Supreme Court 1 September 1998, NJ 1999/61.

- Supreme Court 20 October 1998, NJ 1998/48.

- Supreme Court 19 January 1999, LJN: ZD1307, 109110.

- Supreme Court 23 November 1999, NJ 2000/127.

- Rotterdam District Court 4 January 2000, LJN: AA4046, 10/101498-99.

- Supreme Court 4 January 2000, NJ 2000/537.

- Supreme Court 25 January 2000, NJ 2000/279.

- Amsterdam District Court 23 February 2000, LJN: AA4906, 13/057828-99.

- District Court 20 March 2000, LJN: AA5299, 17/080242-99.

- Rotterdam District Court 1 May 2000, Nieuwsbrief Strafrecht 2000, 216.

- Rotterdam District Court 23 May 2000, Nieuwsbrief Strafrecht 2000, 215.

- Supreme Court 20 June 2000, NJ 2000/502.

- Almelo District Court 25 July 2000, LJN: AA6608, 25/00.

- Almelo District Court 9 August 2000, LJN: AA6740, 08/000120-00.

- Rotterdam District Court 26 October 2000, LJN: AA8004, 10/433648-99.

- Supreme Court 31 October 2000, NJ 2001/239.

- Supreme Court 31 October 2000, NJ 2001/14.

- Supreme Court 6 February 2001, NJ 2001/498.

- Middelburg District Court 9 March 2001, LJN: AB0464, 12/0151179-00.

- Rotterdam District Court 15 March 2001, LJN: AB0563.

- Supreme Court 5 June 2001, NJ 2001/518.

- Supreme Court 10 July 2001, NJ 2001/ 687.

- Supreme Court 18 September 2001, LJN: AB1471, 00749/01 CW 2323.

- Amsterdam District Court 20 September 2001, LJN AL6505, NbSr 2002, 25.

- Supreme Court 25 September 2001, LJN: ZD1858, NJ 2002, 97.

- Supreme Court 20 November 2001, NJ 2003/632, LJN AB2809.

- Supreme Court 12 February 2002, NJ 2002/301.

- Zwolle District Court, 13 February 2002, LJN: AD9245, 07/40081-01.

- Maastricht District Court 26 March 2002, Nieuwsbrief Strafrecht 2002, 136. 
- Supreme Court 28 May 2002, LJN: AE1490, 01549/01.

- Supreme Court 28 May 2002, LJN: AE1494, 01552/01.

- Supreme Court 28 May 2002, LJN: AE1511, 01569/01.

- Supreme Court 11 June 2002, LJN: AE0045.

- Amsterdam Court of Appeal 18 July 2002, Nieuwsbrief Strafrecht 2003, 67.

- The Hague District Court 21 August 2002, LJN: AE6832, 09/757046-02.

- Amsterdam Court of Appeal 28 August 2002, Nieuwsbrief Strafrecht 2003, 65.

- Supreme Court 8 October 2002, NJ 2003/64.

- 's-Hertogenbosch 1 November 2002, LJN: AE9778, 11587.

- Amsterdam Court of Appeal 5 November 2002, Nieuwsbrief Strafrecht 2003, 64.

- Rotterdam District Court 18 December 2002, LJN: AF2141.

- The Hague Court of Appeal 31 December 2002, LJN: AP2058.

- Rotterdam District Court 18 December 2002, LJN: AF2141, 10/150080/01.

- Rotterdam District Court 31 December 2002, LJN: AF2579, 10/000109-02.

- Amsterdam Court of Appeal 3 January 2003, LJN: AF2675, 6561-16.

- The Hague Court of Appeal 17 January 2003, LJN: AF 3039.

- Amsterdam District Court 27 February 2003, LJN: AL6804, NbSr 2003, 144.

- Supreme Court 8 April 2003, NJ 2003/420.

- 's-Hertogenbosch Court of Appeal 29 April 2003, LJN: AO9041.

- The Hague District Court 13 May 2003, LJN: AF8506, KG 03/514 (Al Aqsa I).

- The Hague District Court 3 June 2003, LJN: AF9389, KG 03/514 (AL Aqsa II).

- Amsterdam District Court 23 October 2003, LJN: AM2870, 13/077060-03.

- Supreme Court 18 November 2003, LJN: AJ0517.

- Maastricht District Court 8 December 2003, LJN: AO1048, 03/005799-03.

- Supreme Court 9 December 2003, NJ 2004/132.

- Supreme Court 17 December 2002, NJ 2003/178.

- Maastricht District Court 22 December 2003, LJN: AO0739.

- 's-Hertogenbosch District Court 4 February 2004, LJN AO4972, NbSr 2004, 108.

- Supreme Court 17 February 2004, NJ 2004/332.

- Supreme Court 17 February 2004, LJN: AO1712, 01118/03.

- The Hague District Court 19 February 2004, Nieuwsbrief Strafrecht 2004/139.

- Haarlem District Court 19 February 2004, LJN: AO4855.

- Supreme Court 24 February 2004, NJ 2004/226.

- Supreme Court 9 March 2004, NJ 2004/263.

- Supreme Court 30 March 2004, NJ 2004/377.

- The Hague District Court 6 May 2004, LJN: AO8977, 09/757708-03.

- Supreme Court 25 May 2004, LJN: AO6422, 02023/03.

- Rotterdam District Court 21 June 2004, LJN: AP3601.

- The Hague Court of Appeal 21 June, 2004, LJN: AP3601, 2200071203.

- The Hague Court of Appeal 21 June, 2004, LJN: AP2058, 2200071403.

- Amsterdam District Court 23 June 2004, LJN: AP3499, 0000230604.

- Alkmaar District Court 5 July 2004, LJN AR2598, NbSr 2004, 340.

- Supreme Court 31 August 2004, NJ 2004/590. 
Bibliography

- Supreme Court 16 November 2004, LJN: AR3264, 00731/04B.

- The Hague District Court 3 December 2004, LJN: AR 7038.

- Arnhem District Court 9 December 2004, LJN: AT6878, 05/095205-04.

- 's-Hertogenbosch District Court 9 December 2004, LJN AS6603, NbSr 2005, 78.

- Supreme Court 18 January 2005, LJN: AR6579, 01142/04 E.

- Supreme Court 18 January 2005, NJ 2006/12.

- Amsterdam Court of Appeal 7 February 2005, LJN: AS5816, NJ 2005/147.

- Middelburg District Court 14 February 2005, LJN: AS5730, 12/000211-04.

- Utrecht District Court 10 March 2005, LJN: AS 991.

- Supreme Court, 29 March 2005, LJN: AS5435, 01289/04 E.

- Rotterdam District Court, 6 April 2005, LJN: AT3315, 10/030075-04.

- Amsterdam District Court 29 June 2005, LJN: AT846 and Supreme Court 13 June 2006, LJN: AV 4179.

- Amsterdam District Court 26 July 2005, LJN: AU0025, 13/129227-04.

- Haarlem District Court 5 August 2005, LJN: AU0581.

- Almelo District Court 18 August 2005, LJN: AU1198.

- Supreme Court 4 October 2005, Nieuwsbrief Strafrecht 2005/412.

- Supreme Court 4 October 2005, LJN: AT3643, 02246/04 E.

- The Hague District Court 14 October 2005, LJN: AU4373, 09/751005-04.

- Rotterdam District Court 19 October 2005, LJN: AU4531, 10/600046-05.

- Amsterdam District Court 7 November 2005, LJN: AU5675, 13/997079-05.

- The Hague District Court 16 November 2005, NbSr 2005, 512.

- The Hague Court of Appeal 18 November 2005, LJN: AU6181, 10-00075-04, NJ 2006/96.

- $\quad$ Supreme Court 29 November 2005, NJ 2006/177.

- Amsterdam District Court, 1 December 2005, LJN: AU7314, 328230/KG 05-2159 AB.

- Supreme Court 24 January 2006, LJN: AU6787, 00839/05.

- Supreme Court 14 February 2006, NJ 2006/167.

- Supreme Court 14 February 2006, LJN: AU8064, 00333/05.

- Rotterdam District Court 14 February 2006, LJN: AV1652, 10-600017-05.

- Amsterdam District Court 9 March 2006, LJN: AV4173, 335612/KG 06-282 SR.

- Rotterdam District Court 10 March 2006, LJN: AV5108, 10/000322-04, 10/000328-04, 10/000396-04, 10/000393-04, 10/000325-04, 10/000323-04, 10/000395-04.

- Arnhem Court of Appeal 20 March 2006, LJN: BC7862, 21-007549-04.

- Supreme Court 28 March 2006, LJN: AV1613, 00903/05.

- Rotterdam District Court 3 April 2006, LJN AW4868.

- Rotterdam District Court 25 April 2006, LJN: AW 5519, 05/2647.

- Supreme Court 13 June 2006, LJN: AV4179, NJ 2006/346.

- Supreme Court 13 June 2006, LJN: AV6195.

- Leeuwarden District Court 13 June 2006, LJN: AX881.

- The Hague Court of Appeal 21 June 2006, LJN: AP2058 and 2200071403, legal grounds 2 and 4.3.9.

- Haarlem District Court 1 August 2006, LJN: AY5781. 
- $\quad$ Supreme Court 5 September 2006, RVDW 2006/803.

- Supreme Court 5 September 2006, RVDW 2006/808.

- Supreme Court 5 September 2006, LJN: AV4122, 01422/05.

- Supreme Court 5 September 2006, LJN: AV4149 and AV4122 and AV4144, 01424/05 and 01422/05 and 01423/05.

- 's-Hertogenbosch Court of Appeal 14 September 2006, LJN: AY8234, 20-010436-05.

- 's-Hertogenbosch Court of Appeal 14 September 2006, LJN: AY8231, 20-010437-05.

- Supreme Court 15 September 2006, LJN: AV7387, C05/120HR.

- Haarlem District Court 10 October 2006, LJN: AZ1026.

- 's-Hertogenbosch Court of Appeal 11 October 2006, LJN: AZ0086.

- The Hague District Court November 2006, LJN: AZ1371.

- Haarlem District Court 27 November 2006, LJN: AZ3147.

- Rotterdam District Court 1 December 2006, LJN: AZ3589, 10/600052-05, 10/60010805, 10/600134-05, 10/600109-05, 10/600122-05, 10/600023-06, 10/600100-06.

- Utrecht District Court 4 December 2006, LJN: AZ4177, 16/715077-05.

- Rotterdam District Court 18 December 2006, LJN: AZ6087, 05/6174.

- Rotterdam District Court 19 December 2006, LJN: AZ8683.

- Leeuwarden District Court 3 January 2007, LJN: AZ5681, 17/880370-06 RDK.

- The Hague District Court 12 January 2007, LJN: AZ6637, 06/36973.

- Arnhem Court of Appeal 23 January 2007, LJN: AZ6688, 21-001331-06.

- Leeuwarden Court of Appeal 26 January 2007, LJN: AZ7193.

- The Hague Court of Appeal 29 January 2007, LJN: AZ4173, 2200613105.

- Supreme Court 20 February 2007, LJN: AZ0213, 00447/06.

- The Hague Court of Appeal 1 March 2007, LJN: AZ9644, 2200754605.

- Zutphen District Court 7 March 2007, LJN: BA0137, 06/460609-06.

- The Hague Court of Appeal 3 April 2007, LJN: BA2127, 2200603405.

- Haarlem District Court 13 April 2007, LJN: BA2938.

- Supreme Court 17 April 2007, LJN: BA1764, 03237/06.

- Amsterdam District Court 17 april 2007, LJN BA3539, NbSr 2007, 232.

- Rotterdam District Court 17 April 2007, LJN: BA3357, 10/640128-06.

- Supreme Court 17 April 2007, LJN: BA1764, 03237/06.

- Supreme Court 24 April 2007, LJN: AZ8411, 02141/05.

- Leeuwarden District Court 2 May 2007, LJN: BA4744, 17/880141-07.

- Amsterdam District Court 9 May 2007, LJN BA5058.

- Leeuwarden District Court 9 May 2007, LJN: BA 4744.

- Utrecht District Court 15 May 2007, LJN: BA5177, 16/600491-07.

- Amsterdam Court of Appeal 16 May 2007, LJN: BA6642.

- Maastricht District Court 27 May 2007, LJN BB0831.

- The Hague District Court 25 June 2007, LJN: BA7877, 09/750001-06.

- 's-Hertogenbosch District Court 2 July 2007, LJN: BA8799, 01/885004-07.

- Leeuwarden District Court 8 August 2007, LJN: BB1908, 17/880180-07.

- Groningen District Court 9 August 2007, LJN BB5991, NbSr 2007, 381.

- The Hague Court of Appeal 13 August 2007, LJN: BB1870, 2200242007. 
Bibliography

- The Hague District Court 13 September 2007, LJN: BB3482, 09-750006-06.

- Amsterdam Court of Appeal 17 September 2007, LJN: BB3756, 23-001907-07.

- The Hague Court of Appeal 3 October 2007, LJN: BB4662, 0975000606.

- Rotterdam District Court 30 October 2007, LJN: BB7174, 10/600045-06.

- Rotterdam District Court 30 October 2007, LJN: BB7203, 10/600130-05.

- The Hague Court of Appeal 8 November 2007, LJN: BB8087, 000299-07.

- The Hague Court of Appeal 8 November 2007, LJN: BB8101, 000300-07.

- The Hague Court of Appeal 8 November 2007, LJN: BB8078, 000298-07.

- The Hague Court of Appeal 8 November 2007, LJN: BB8066, 00029707'.

- Supreme Court 13 November 2007, LJN: BA2553, 01543/06.

- The Hague District Court 21 November 2007, LJN: BB8481, 09/750006-06.

- The Hague District Court 7 December 2007, LJN: BC0029, 297765.

- The Hague District Court 7 December 2007, LJN: BC0113, 298645.

- Utrecht District Court 21 December 2007, LJN: BC0843, 16/600941-07.

- Supreme Court 22 January 2008, LJN: BB7134, 01263/07.

- Supreme Court 22 January 2008, NJ 2008/72.

- The Hague Court of Appeal 22 January 2008, LJN: BB7134.

- The Hague Court of Appeal 23 January 2008, LJN: BC2576, 22001897-06.

- The Hague Court of Appeal 23 January 2008, LJN: BC4129, 22001886-06.

- The Hague Court of Appeal 23 January 2008, LJN: BC4171, 22001871-06.

- The Hague Court of Appeal 23 January 2008, LJN: BC4177, 22001864-06.

- The Hague Court of Appeal 23 January 2008, LJN: BC4178, 22100862-06.

- The Hague Court of Appeal 23 January 2008, LJN: BC4182, 22001863-06.

- The Hague Court of Appeal 23 January 2008, LJN: BC4183, -06. 221866.

- The Hague Court of Appeal 8 February 2008, LJN: BC 3872, 2200454506.

- Amsterdam District Court 8 February 2008, LJN: BG1806.

- Amsterdam District Court 8 February 2008, NJ 2008/131.

- The Hague Court of Appeal 8 February 2008, LJN: BC 3872.

- Utrecht District Court 13 February 2008, LJN: BC4152, 16/436712-07.

- Utrecht District Court 13 February 2008, LJN: BC4155, 16/436713-07.

- Utrecht District Court 13 February 2008, LJN: BC4156, 16/436459-07.

- Utrecht District Court 13 February 2008, LJN: BC4158, 16/436458-07.

- Utrecht District Court 13 February 2008, LJN: BC4161, 16/436624-07.

- Utrecht District Court 13 February 2008, LJN: BC4162, 16/436623-07.

- Utrecht District Court 13 February 2008, LJN: BC4202, 16/436625-07.

- Supreme Court 11 March 2008, NJ 2008, 328 and NJ 2008, 329.

- Supreme Court 11 March 2008, LJN: BB7662, 02752/06.

- Rotterdam District Court 25 March 2008, LJN: BC7531, 10/600111-05.

- Haarlem District Court 28 March 2008, LJN: BC9324, 15/751650-06.

- 's-Hertogenbosch District Court 15 April 2008, LJN: BC 9370, 01/889067-05.

- Amsterdam District Court 25 April 2008, Nieuwsbrief Strafrecht 2008, 253.

- Rotterdam District Court 25 April 2008, LJN: BD0621, 10/710036-08.

- Almelo District Court 29 April 2008, LJN: BD 0835, 08/710423-07. 
- Amsterdam Court of Appeal 2 July 2008, LJN: BE8345.

- Supreme Court 8 July 2008, LJN: BC7418, 07/10063.

- The Hague Court of Appeal 11 July 2008, LJN: BF3925, 22-000473-08 A.

- The Hague Court of Appeal 11 July 2008, LJN: BD7009, 22-000473-08.

- Amsterdam District Court 26 August 2008, Nieuwsbrief Strafrecht 2008, 319.

- Maastricht District Court 26 August 2008, LJN: BH1170, 03/702958-08.

- Arnhem Court of Appeal 1 October 2008, LJN: BF3946, 21-001061-08.

- The Hague Court of Appeal 2 October 2008, LJN: BF 3987, 22007349-06.

- The Hague Court of Appeal 2 October 2008, LJN: BF 5180, 22-007384-06.

- The Hague Court of Appeal 2 October 2008, LJN: BF 5225, 22-007350-06.

- The Hague Court of Appeal 2 October 2008, LJN: BF 4814, 22-007351-06.

- Amsterdam District Court 7 October 2008, NbSr 2008, 426.

- Gemeenschappelijk Hof van Justitie van de Nederlandse Antillen en Aruba 8 October 2008, LJN: BL2938, 123/2008.

- Amsterdam Court of Appeal 21 January 2009, Nieuwsbrief Strafrecht 2009/51.

- Amsterdam Court of Appeal 21 January 2009, LJN: BH0496, K08/0309, K08/0374, K08/0277, K08/0444, K08/0310, K08/0328, K08/0329, K08/0330 and K08/0353.

- 's-Hertogenbosch Court of Appeal 4 February 2009, LJN: BH2038, 20-001853-08.

- Amsterdam Court of Appeal 23 February 2009, LJN: BH3912, 23-006605-07.

- Breda District Court 3 April 2009, LJN: BH9853, 636049-09.

- 's-Hertogenbosch Court of Appeal 12 May 2009, LJN: BI3572, 20-001211-09.

- Arnhem Court of Appeal 25 May 2009, LJN: BI7259, 21-004106-08.

- Supreme Court 30 June 2009, LJN: BG4822, 07/10742 (NJ 2009, 481.

- Zwolle District Court 30 June 2009, LJN: BJ2242, 99-000006-36.

- Amsterdam District Court 21 July 2009, LJN: BJ4828, 13/410256-09.

- Amsterdam Court of Appeal 30 July 2009, LJN: BJ4235, 21-003141-08.

- Arnhem Court of Appeal 10 august 2009, LJN: BJ4913, 24-002842-07.

- Maastricht District Court 2 September 2009, LJN: BJ6752, 03-700053-09.

- Leeuwarden Court of Appeal 10 November 2009, LJN: BK2773, 24-002668-08.

- Amsterdam District Court 17 November 2009, LJN: BK4842, 13/421052-09.

- Utrecht District Court 19 November 2009, LJN: BK5248, 16/6000905-08.

- Utrecht District Court 25 November 2009, LJN: BK5244, 16/711031-08.

- Zwolle District Court 28 January 2010, LJN: BL3211, 07/400266-09.

- Supreme Court 2 February 2010, LJN: K5174/BK5193/BK5189/BK5174/BK5196/ BK5175/BK5182/BK5172, 08/00721, 08/00695, 08/04955, 08/00721, 08/00740, 09/01625, 09/01626, 08/00623.

- Supreme Court 23 February 2010, Nieuwsbrief Strafrecht 2010/101.

- Nederlandse Antillen District Court 30 March 2010, LJN: BM0334, 400.00056/10.

- Amsterdam Court of Appeal 10 June 2010, LJN: BN7254, 13-650667-10.

- Supreme Court 13 July 2010, LJN: BM2492, 08/03674.

- Zwolle District Court 22 July 2010, LJN: BN2270, 07/653098-10.

- Maastricht District Court 11 August 2010, LJN: BN4821, 03/700032-10.

- Maastricht District Court 14 September 2010, LJN: BN8121, 03/700459-10. 
Bibliography

- Amsterdam District Court 18 October 2010, LJN: BO8912, 13/529088-07.

- Leeuwarden Court of Appeal 26 October 2010, LJN: BO1912, 24-002166-09.

- The Hague District Court 4 November 2010, LJN: BO2992, 09/925777-10 and.

- Amsterdam Court of Appeal 17 December 2010, LJN: BO7690, 23-000751-10.

- Amsterdam Court of Appeal 17 December 2010, LJN: BO8032, 23-000747-10.

- Amsterdam Court of Appeal 17 December 2010, LJN: BO9014, 23-000749-10.

- Amsterdam Court of Appeal 17 December 2010, LJN: BO9015, 23-000750-10.

- Amsterdam Court of Appeal 17 December 2010, LJN: BO9016, 23-000745-10.

- Amsterdam Court of Appeal 17 December 2010, LJN: BO9017, 23-000746-10.

- Amsterdam Court of Appeal 17 December 2010, LJN: BO9018, 23-000748-10.

- Middelburg District Court 24 December 2010, LJN: BP1091, 12/715499-10.

- Supreme Court 8 February 2011, LJN: BO9823, 09/0107. 


\section{SUMMARY}

\section{Chapter I Terrorism as Timeless Trend: an Introduction}

Anti-terrorism legislation is a relatively new phenomenon in the Netherlands, even though terrorism is not. Dutch counter terrorism policy in the period 2001-2011 primarily focused on prevention. This dissertation discusses one aspect of that policy: the scope of the prevention oriented anti-terrorism legislation within and without criminal law, and its impact on principles of (criminal) law, and on fundamental legal rights and principles as enshrined in the relevant European treaties, which in case of the Netherlands, is higher law. This has led to the following key research question:

To what extent are the statutory criteria for the application of pre-trial antiterrorism powers and measures and their practical implementation, especially as regards the required level of suspicion, within the criminal justice system, public order law, administrative law and European Union law, in compliance with the relevant fundamental legal rights and principles of law, as enshrined in the applicable European treaties?

To answer this question, several sub-questions are raised and discussed, of which these are the most important three:

I. What constitutes an act of terrorism as the law stands within the Dutch criminal justice system, and how and to what extent has the criminalisation of terrorism affected criminal liability, particularly during the pro-active phase?

II. What level of suspicion is required to apply which powers and/or measures situated in what area of law to prevent terrorism?

III. How does the application of these state powers, particularly in light of their criteria for application, affect which fundamental legal rights and principles of law?

The above research questions have resulted in a tripartite structure in this dissertation. First of all, Chapter II relates to the first sub-question, and examines the scope of criminal liability with regard to terrorist offences in terms of mens rea and actus reus. Chapters III to VIII concern themselves with the second subquestion, and therefore discuss several specific pre-trial measures and powers available to the executive to prevent terrorism within the field of public order law, administrative law, criminal procedure and European Union law. The third subquestion is the leading thread throughout all of the chapters. Chapter IX, in 
particular, discusses the actual scope of the effects of the discussed powers and measures on the relevant fundamental legal rights and principles of law.

\section{Chapter II The Criminalisation of Terrorist Offences}

Chapter II discusses Dutch anti-terrorism legislation in the field of substantive criminal law, and the effects of this legislation on the principle of legality, as enshrined in Article 1 of the DCC and Article 7 of the ECHR. This legislation is based on two main starting points. The first is legislation aimed at preventing terrorism rather than at responding to it. Persons who presumably intend to commit a terrorist offence should be stopped prior to committing it. The second point is that anyone suspected of being involved in, or linked to, 'terrorist activities' in any way should be stopped as well. In order to achieve these two goals, criminal liability has been broadened considerably with regard to terrorism. The risk of holding people criminally liable for terrorist offences, primarily on the basis of intentions rather than on the basis of the factual danger that they, through their conduct, pose or may come to pose to society, its legal values, and persons' lives or goods, has increased with the entering into force of the DTA. Special intent as a constitutive element of criminal law provisions brings with it a considerable subjectivism within the DCC. Notwithstanding the case law on Article 83a of the DCC that defines terrorist intent, the precise scope of this concept remains uncertain. Among the judiciary there is no consistency with regard to the scope of terrorist offences. Even though the specific circumstances of the case are decisive, in all judgements regarding alleged terrorist offences, the political religious conviction of the suspect has contributed considerably to proving terrorist intent. Persons adhering to extreme interpretations of, for instance, Islam, but who have hardly taken any steps to realise these beliefs - let alone actually endangered society, other persons or goods - become liable to punishment.

The ECtHR rarely acknowledges that criminal law provisions as such violate Article 7 of the ECHR due to non-compliance with the lex certa requirement. Criminal law provisions must be applicable in various situations and to all potential (future) perpetrators. This implies that such provisions must be edited in somehow broad terms whereas the principle of legality, theoretically, requires criminal behaviour to be addressed as clearly as possible. There is, consequently, a constant inherent tension in drafting, as clearly as possible, criminal law provisions, which, at the same time, also cover all (future) behaviour that is to be considered criminal in nature. The ECtHR deems an extensive interpretation of criminal law provisions, which is in line with (gradual) changing (societal) circumstances, not to be in violation of the principle of legality as long as the interpretation remains in accordance with the essence of the provision and, to a certain extent, foreseeable. Nevertheless, several judgements show that even a completely different (broader) interpretation of a criminal law provision regarding serious offences - hence without gradual preceding development - does not automatically imply a violation 
of Article 7 of the ECHR. Faced with such a dilemma, the ECtHR deems the punishing of serious criminal behaviour - even if not obviously falling within the scope of a criminal law provision - more important than the strict application of the principle of legality. It seems as if it is only when legal uncertainty of a person is almost total that the ECtHR will conclude that there has been a violation of Article 7 of the ECHR - due to non-compliance with the lex certa requirement.

\section{Chapter III Allegedly Involved in Terrorist Activities}

This chapter discusses the anti-terrorism measure referred to as 'personal disturbance' [persoonlijke verstoring] and the underlying suspicion criterion. During the period 2004-2007 the police acting under authority of the Mayor, used a range of surveillance powers (personal disturbance-powers) on persons allegedly involved in terrorist activities/persons posing a terrorist threat. These surveillance powers included driving noticeably by a person's house and stopping, for several minutes, in front of it with the engine running, during the day, as well as during the night; following that person by (police) car whenever he goes out; stopping visitors and asking for their identity card; calling the person when he is not at home; and observing his house on a regular basis. The government invoked Articles 2 and 12 of the Police Act (PA) and Article 172 of the Municipality Act as a legal basis for personal disturbance. These provisions include the general task description of the Mayor and the police, that of safeguarding public order. None of these provisions include specific criteria for the application of personal disturbance powers, nor do they define the scope of these powers. The criteria of 'persons allegedly involved in terrorist activities' or 'persons who pose a terrorist threat' are not codified, but merely mentioned in parliamentary memoranda.

The judiciary has been asked twice to rule on the lawfulness of specific cases of personal disturbance. In both cases, the application of personal disturbance powers - when based on Article 12 of the PA - was not, as such, explicitly prohibited. The competent court only judged explicitly on the question of whether the personal disturbance powers were proportional to the aims pursued, which was dependent on the specific circumstances of the case. The more incriminating the evidence against a person is, and the less intrusive the personal disturbance powers are, the more inclined the judiciary is to allow such powers to be exerted on the basis of Article 12 of the PA.

This chapter also discusses the Strasbourg right to privacy pursuant to Article 8 of the ECHR, in light of the application of personal disturbance powers. During the period 2004-2006, the most intrusive forms of personal disturbance interfered with the right to privacy. Personal disturbance implies a large discretionary power for the Mayor - a power that is not, moreover, counterbalanced by automatic and effective procedural safeguards like mandatory judicial control. Whether the application of personal disturbance powers is in compliance with Article 8 of the 
ECHR can only partly be examined post facto by summary proceedings lodged by the person subjected to personal disturbance.

\section{Chapter IV Assumed Connections with Terrorism}

In this chapter the bill on the administrative law measures to safeguard national security is discussed [Wet bestuurlijke maatregelen nationale veiligheid, 'the Bill']. In June 2011, this Bill was revoked. At the time it was introduced in Parliament, it was the first proposed legal anti-terrorism measure that was situated in the administrative law system. The principal aim of the Bill was to act when the criminal justice system could not yet, or could no longer, be applied. It was meant to 'complete the set of anti-terrorism measures', also without the criminal justice system. Persons deemed to be connected with terrorist activities or the support thereof could be subjected to a restraining order and/or to a duty to report periodically to the police ('the administrative measures'). A reasonable suspicion of a specific terrorist offence was no prerequisite for the application of the proposed administrative measures. When state authorities would impose one or more of these administrative measures, the person concerned would be restricted in his freedom to choose where to go and who to meet. Applying all three of the administrative measures cumulatively for a longer period, would increase the intrusiveness in terms of the right to freedom of movement pursuant to Article 2 of the $4^{\text {th }}$ Protocol with the ECHR ('the Protocol'), especially when taking into account that a (reasonable) suspicion was not required to impose these measures and that secret intelligence information would have sufficed to apply the administrative measures for up to a period of two years. There is no Strasbourg case law on interferences with the right to freedom of movement caused by state powers comparable to the administrative measures proposed in the Bill. The intended practical scope of the administrative measures has, furthermore, remained unclear due to the fact that the Bill never entered into force. Nevertheless, there are three issues that must be underlined when assessing the powers comprised in the Bill on compatibility with Article 2 of the Protocol.

First and foremost, Article 2 of the Bill, which included the criteria for the application of the administrative measures, was broadly defined and created a large discretionary power for the Minister of Interior, even despite the attempted clarifications in the parliamentary memoranda. That generated a risk of arbitrariness. Secondly, the Bill did not provide for automatic judicial review, either prior to, or after, the imposition of the administrative measures. Whether or not judicial control would be exerted on the imposition and/or continuation of these measures would have been dependent on the question of whether the person subjected to such measures lodged an appeal with the Hague District Court pursuant to Article 4 of the Bill. The scope of these proceedings is, furthermore, unclear. Thirdly, after the entering into force of the DPTA and of Article 134a and 83b of the DCC, the Bill appeared to be redundant. 


\section{Chapter V Indications of a Terrorist Offence}

In order to adequately enforce the DTA, investigative powers had to be expanded significantly when it concerned terrorism. In the Government's view: 'terrorism cannot be countered by means of the classical (common) criminal procedure'. To that effect, the preventive function of criminal procedure in the case of terrorism had to be reinforced. This chapter discusses part of the Dutch procedural antiterrorism act ('DPTA') that entered into force in 2006. This Act brought about considerable amendments to the Dutch code of criminal procedure ('DCCP') in the field of investigations into terrorist offences:

1. Extended powers to gather (public and private) information during an exploratory inquiry into terrorist offences;

2. Broadened powers to frisk persons and investigative means of transport and objects in security risk areas, without a reasonable suspicion concerning a specific (terrorist) offence;

3. Extended powers to apply special investigation techniques in the case of investigations into terrorist offences;

4. Remand in custody for 20 days on the basis of a reasonable suspicion in the case of a terrorist offence;

5. A power for the public prosecutor to postpone access to the case file for the defence and the trial judge in the case of investigations into terrorism.

This chapter discusses the first three amendments. All of these three amendments relate to the introduction of a new suspicion criterion in the DCCP brought about by the DPTA - that of 'indications of a terrorist offence'. The powers that may be used upon indications of a terrorist offence interfere with the right to privacy as interpreted by the ECtHR. Strasbourg case law concerning the application of comparable powers reveals that the larger the scope of a power is, the more intruding it is, and the earlier in the pro-active phase that it is applied, the more precisely the discretionary power of the executive must be specified in statutory law. The law must indicate the scope of any discretion conferred on the competent authorities, and the manner of its exercise with sufficient clarity, having regard to the legitimate aim of the measure in question. Powers of the executive may never be unfettered. The more specific the law prescribes the nature of the offences, the less specific the category of persons needs to be specified. However, powers that also interfere with non-suspected citizens' private life must provide for particular rules in that respect. The application of powers that interfere with the private life must (preferably) be ordered by a judicial authority and must be monitored and examined afterwards, also by a judicial authority. However, the wider the powers are, the more difficult it will be for the judiciary to examine whether the powers have been applied lawfully. The effectiveness of judicial control diminishes, therefore, progressively in the case of broad legal provisions, while such provisions particularly demand extra judicial 
control. The more detailed and demanding domestic procedural rules concerning such measures of secret surveillance are, the more likely it is that the ECtHR will consider the enforcement thereof to be in accordance with Article 8 of the ECHR. Procedural safeguards must, moreover, apply during the initial stages of ordering the application of such measures, and during the further enforcement of these measures. Safeguards must be particularly vigilant where the authorities are empowered to order and effect such measures without a judicial warrant, and/or in the case of intruding measures of secret surveillance.

The proportionality, and hence necessity, of a measure of secret surveillance decreases when other measures are/have been applied concurrently/successively. Furthermore, the more criminal offences that may be investigated by means of such measures, the less likely it is that the ECtHR will consider such an application necessary in a democratic society. In examining whether national security reasons may be used to demonstrate the necessity of interferences with the right to privacy, two main aspects play a role in the ECtHR's view: (1) how close and actual the threat against national security is, and (2) how severe the infringement of the privacy is. The more serious a crime is, the more necessary it may be deemed to apply secret measures of surveillance. This is true particularly when other (less intrusive measures) have proven to be ineffective. The ECtHR has used these considerations, however, only with respect to suspects and accused on whom such measures had been applied for a relatively short period and under supervision of a judge. It is important to note that there is no explicit case law available regarding powers applied during the pro-active phase on persons who cannot yet be considered as suspects.

With respect to the powers discussed in this chapter, two main problems may arise in the field of compliance with Article 8 of the ECHR. First and foremost, large discretionary powers for the executive limit the effectiveness of statutory safeguards, and, primarily of judicial control. This is at odds with the fact that the potential intrusiveness of the powers discussed in this chapter call for an increased level of effective safeguards under Strasbourg case law. Secondly, the ordering of secret measures of surveillance is - with respect to most measures - made by the public prosecutor. Even though the ECtHR does not require a judge as ordering authority per se, it remains to be seen if a public prosecutor is sufficiently independent to prevent arbitrary application of the powers discussed in this chapter. The scope of judicial control on the application of the powers discussed in this chapter appears to be very limited. In this respect, it is striking that most investigations into assumed terrorist offences do not lead to prosecution on account of (terrorist) offences, but are stopped due to lack of evidence. This implies that ex post facto control rarely takes place. 


\section{Summary}

\section{Chapter VI A Reasonable Suspicion}

It is of crucial importance to determine at what moment exactly a person may lawfully be considered as a suspect of an (terrorist) offence. That moment is a turning point, both for the suspect and for the investigative authorities, within the context of criminal investigations and proceedings. On the one hand, the suspicion criterion of Article 27 of the DCCP forms the gateway for state authorities to apply all kinds of coercive powers on civilians. On the other, from that moment on, the authorities are obliged to effectively guarantee various fundamental rights of the suspect.

The coercive powers to investigate terrorist offences that are discussed in this chapter apply in the case of a light reasonable suspicion. This is currently the only firm prerequisite for police custody and remand in custody. Since the entering into force of the DPTA, a terrorist suspect may be kept deprived of his liberty for 20 days and 15 hours on the basis of a (light) reasonable suspicion pursuant to Article 67, section 4 of the DCCP, whereas for suspects of common offences there must additionally be serious objections against suspects. The WODC reports demonstrate that remand in custody of terrorist suspects on the basis of Article 67, section 4 of the DCCP has been used only in five cases during the period 20072011, and primarily to avert alleged threats. These reports sustain the presumption that, when it concerns criminal investigations into terrorism, investigative interests, the prevention of terrorism, and, more generally, risk management, have become more decisive criteria for the application of coercive measures than the statutorily defined level of suspicion.

In terms of the ECHR, Chapter VI focuses on Article 5, section 1 under c and section 3 - the right to liberty and security of person. One precondition for lawful pre-trial deprivation of liberty is that there must be a reasonable suspicion. In examining whether there is a reasonable suspicion, the ECtHR discerns between: (1) the subjective side of a suspicion, i.e. the bona fides of the investigative authorities; and (2) the objective side of a suspicion, i.e. objective, concrete and relevant facts or circumstances to sustain the suspicion. Only if both aspects have been fulfilled, will a suspicion be reasonable. There will have to be evidence of actions directly implicating the suspect. The more detailed and precise the information used to demonstrate the suspicion is, the more likely it is that the ECtHR will assess the suspicion as reasonable. The ECtHR does not seem to object to using secret intelligence information to come to a reasonable suspicion. However, additional information is required to demonstrate a reasonable suspicion. If secret intelligence information is used, that information must at least comprise some facts or information capable of satisfying a court, and, hypothetically, an objective bystander, that the arrested person is justly suspected of having committed an

offence(s). Even though the ECtHR understands a state's difficulties in countering terrorism, it does not allow for the creation of different suspicion criteria that depend on the type of crime that a person is suspected of having committed. This 
reasoning makes the Dutch government's consideration that when it concerns alleged terrorists, suspicion criteria should be less demanding, questionable.

For the ECtHR an important procedural safeguard to prevent arbitrary arrest and deprivation of liberty is adequate domestic judicial review of the reasons for arrest and pre-trial detention. The judiciary must be granted access to the (objective) facts or circumstances that led to the arrest/deprivation of liberty in order to perform an effective post facto control on the lawfulness of the interference with a person's right to liberty. Even though the ECtHR's interpretation of the grounds capable of justifying continued pre-trial detention (danger of absconding, the risk of an interference with justice, the need to prevent crime, the need to preserve public order) depends on the specific circumstances of the case, there are a number of guidelines that apply to all of these grounds. Firstly, suspects must, if possible, be released pending trial. Alternative measures should be considered prior to holding a suspect in pre-trial detention. Secondly, domestic authorities need to demonstrate specific and individualised circumstances regarding a suspect, his conduct and personality, when deciding whether or not to keep him in pre-trial detention. Thirdly, the longer pre-trial detention lasts, the more relevant and sufficient the grounds used to legitimise the detention must become - in substance as well as in number. Fourthly, all of the grounds used to justify arrest and pre-trial detention presuppose a close and, moreover, demonstrable link between: (1) the specific personal circumstances of a case and a suspect, (2) domestic law, and (3) the factual circumstances that the competent authorities use to justify the deprivation of liberty.

\section{Chapter VII Serious Objections}

'Serious objections' is the most demanding suspicion criterion during the pre-trial phase. With respect to pre-trial deprivation of liberty of a terrorist suspect, serious objections only start to play a role in the case of detention on remand [gevangenhouding/gevangenneming] - the last phase of pre-trial detention. This is a consequence of the new Article 67, section 4 of the DCCP. The DPTA amended Article 66, section 3 of the DCCP. Terrorist suspects may be detained on remand for two years and 90 days, instead of for 90 days as in the case of 'common suspects'. This chapter discusses the scope of this amendment and the question of whether such an extended term of detention on remand can still be considered compatible with Article 5, section 3 of the ECHR. Everyone detained pursuant to section 1 under $\mathrm{c}$ is entitled to trial within a reasonable time. The ECtHR has developed some benchmarks to examine whether a criminal investigation and criminal proceedings regarding a suspect kept in pre-trial detention are conducted with the required special diligence and drive. The most important aspect is the question of whether there was any inactivity on the part of the state authorities during the criminal investigation and during the criminal proceedings. Such inactivity is basically always unacceptable. Secondly, the complexity of the case plays a role, as well as 
the attitude of the suspect and the type of criminal behaviour. The nature of a criminal offence only partly influences the reasonableness of the length of pre-trial detention. Complex criminal offences - such as offences connected to international criminal or terrorist organisations - influence the complexity of the case, and consequently, the accepted length of pre-trial detention. Hence, it is primarily the potential difficulty intrinsic to the investigation of such offences that influences the reasonableness of the length of continued pre-trial detention, rather than the nature of terrorism, as such.

As a result of the extended term of detention on remand for terrorist suspects, potential restrictions on such suspects' rights during the pre-trial phase apply for an equally longer period. One of the restrictions that may be imposed is that of temporarily denying the suspect access to part of the case file pursuant to Article 30, section 2 of the DCCP. Access to the whole case file is of crucial importance when a suspect wants to lodge proceedings by which the lawfulness of his pre-trial detention is examined in accordance with Article 71 of the DCCP or pursuant to Article 69 of the DCCP. Article 5, section 4 of the ECHR obliges states to provide for an effective system of such habeas corpus proceedings. In order to effectively enforce the right to lodge a habeas corpus complaint, the suspect and the competent court need to know on the basis of which information the suspect is held in pre-trial detention. National security concerns and/or terrorism cannot, as such, justify farreaching infringements of suspects' defence rights during habeas corpus proceedings as regards to the withholding of information. The right to have access to the case file is, in the ECtHR's view, an essential feature of the principle of equality of arms - a principle that should be complied with during habeas corpus proceedings. That principle is not lived up to if the suspect is denied access to the documents in the case file that are essential in order to effectively challenge the lawfulness of pre-trial detention. In essence, suspects must always be able to effectively challenge the lawfulness of their detention before a court, also if it concerns terrorism. This implies that they must - some way or another - be enabled to rebut the state's allegations of suspicion of terrorism. Therefore, a suspect must be kept informed and permitted to make submissions and participate in the decisionmaking process during habeas corpus proceedings as far as possible, without disclosing the material that the prosecution wants to keep secret. Information that is of decisive importance to the outcome of a suspect's appeal for release, and is an issue of fact which forms part of the prosecution case, must be released to the suspect, even if it concerns terrorism. The longer pre-trial detention lasts, the more encompassing habeas corpus proceedings will have to be and the more information there will need to be disclosed to the suspect and the competent court. Also, as the criminal investigation progresses, the need for non-disclosure of evidence, on the basis of the interest of the investigation, will considerably diminish. The tenability of the government's general reasoning that the nature of investigations into terrorism justifies more far-reaching restrictions on suspects' rights during the pretrial phase is questionable in light of Strasbourg case law. 
The ECtHR attaches special significance to the question of whether there are sufficient procedural safeguards and/or guarantees to counterbalance infringements of a suspect's defence rights during habeas corpus proceedings. The amended Article 66, section 3 of the DCCP has not been provided with safeguards to counterbalance the potentially more far-reaching limitations of a terrorist suspect's rights under Article 5, section 4 of the ECHR. As Article 66, section 3 of the DCCP prolongs the period of detention on remand for terrorist suspects, these suspects should accordingly profit from broadened possibilities of judicial control in terms of substance. This presupposes full knowledge of all the information on which the prosecutor bases the reasons and justifications for the pre-trial detention. The court deciding on the habeas corpus complaint may not, just as the suspect, be granted access to information comprised in the case file. That may hamper the court in effectively judging on the lawfulness of pre-trial detention of terrorist suspects. Strasbourg case law on Article 5, section 4 of the ECHR primarily deals with situations where the competent court and the prosecution had access to the whole case file, whereas the suspect and/or his lawyer did not. Cases where neither the court nor the suspect had access to the case file may bring forth problems in terms of the required effectiveness of judicial control under Article 5, section 4 of the ECHR.

\section{Chapter VIII Blacklisted as Terrorist}

This chapter discusses the Union blacklisting system. As a rule, once a party is included on the Union blacklist, all its assets are frozen, including - among other things - insurance, insurance related services, bank credits, travellers' cheques, bank cheques, money orders, shares, securities, bonds, drafts and letters of credit. The freezing of assets implies that a blacklisted person has no longer access to all the necessary means for leading a 'normal life'. The blacklisted party is not, moreover, informed of the intended imposition of fund freezing measures, and only discovers this when his assets have already been frozen. Whereas the actual listing - as well as the imposition of the fund-freezing measures - is quite simple, delisting has proven to be almost impossible. Theoretically available legal remedies turn out to be factually useless because of the lack of compliance with essential (defence) rights and procedural requirements. Assuming that the blacklisting proceedings do fall under the scope of Articles 47 and 48, section 2 of the Charter and Article 6 of the ECHR, various fundamental rights ought to be complied with. The following minimum list may be used to assess the Union blacklisting system:

1. Substantive criteria for inclusion on the blacklist should be clear;

2. There must be sufficient notification to the blacklisted parties regarding decisions taken, and the grounds on which these have been taken, preferably prior to the actual implementation of these decisions;

3. The listings must be strictly time-limited and subject to effective renewal; 
4. In order to profit from the right to an effective legal remedy, blacklisted parties must be allowed access to all relevant information and be given a fair hearing;

5. Effective judicial review must be assured by an independent and impartial court, which, moreover, has the power to factually annul or modify the blacklisting decision; and

6. Compensation ought to be given to unlawfully blacklisted parties.

If one considers compliance with these conditions and principles as a precondition for (de)-listing proceedings to be in accordance with fundamental rights, the following issues arise. Firstly, the substantive 'suspicion criterion' of involvement in terrorist acts - as comprised in CP 931 - is broad, and leads to a considerable discretionary power for the Member States and the Council, and limits possibilities for the Union judiciary to examine the lawfulness of blacklisting decisions. In addition, the periodic review of blacklisting decisions loses effectiveness when the criteria for inclusion on the blacklist are broad. Secondly, no type of hearing is held, and no statement of reasons needs to be provided to the party concerned, prior to the blacklisting and the imposition of fund-freezing measures. If a hearing is held after the imposition of these measures, that hearing only serves to inform the party concerned of the measures imposed and of the national decision underlying the Council's decision. Blacklisted parties are not, generally speaking, (fully) informed of the reasons for being considered as involved in (the financing of) terrorist acts. In addition, the Council does not easily refuse a blacklisting initiative of a Member State, even if the underlying information is not as convincing as it ought to be. Thirdly, parties are - theoretically at least - listed for six months, after which time the Council examines whether continued inclusion on the blacklist is still justified. The actual practice is different: the prescribed periodic review - in real terms comes down to a simple six-month extension of the blacklisting decision, without the required full review of the initial reasons for inclusion on the list. In this respect, it is, furthermore, of importance to note that periodic review of the blacklisting decisions is performed by the executive authority which itself, moreover, initially imposed the measures, instead of by a court.

Fourthly, despite the fact that, in theory, there is a remedy available for blacklisted parties, the procedural deficiencies, the broadly edited substantive provisions, and the fact that fair trial principles are only in part applicable, undermine the right to an effective legal remedy. In addition, the right to an effective legal remedy is made completely dependent on compliance with the other two defence rights and is, as such, of little value. Fifthly, the above-discussed case law shows that the scope of judicial review before the Union judiciary is limited. Both the Council and the requesting Member State, are allowed to withhold information from the Union judiciary and the blacklisted party if national security is at stake, and they both enjoy a large discretionary power. The Council is, moreover, to cooperate in good faith with the Member States, which allows full play for the requesting Member State when it comes to blacklisting. 


\section{Chapter IX Conclusions and Recommendations}

Chapter IX elaborates on three issues: (1) the general characteristics of Dutch antiterrorism legislation, (2) the scope of the repercussions of anti-terrorism legislation on fundamental rights and principles of law, and (3) several possible solutions to counterbalance the interferences that the current anti-terrorism powers and measures have on these rights and principles.

$I$

The characteristics of substantive anti-terrorism legislation are primarily found in the amendments to the DCC brought about by the DTA. These amendments have produced, in the DCC, a dichotomy: the DCC currently consists of terrorist offences and of common offences. Practice shows that Articles 83 and 83a of the DCC have significantly broadened criminal liability with regard to both terrorist offences, and the common offences to prepare or facilitate terrorist offences - primarily those offences committed during the pro-active phase. Inchoate terrorist offences do not primarily serve to guarantee criminal liability, but they are used as a means to prevent risks from materialising. The main goal of anti-terrorism legislation is, then, to discover who may be, and who is not, connected to the perpetration (in the broad sense of the word) of potential terrorist offences. In that respect, substantive law has become an instrument to contribute to risk management, and an instrument to control rather than an instrument to ensure criminal liability in respect of yet committed criminal or terrorist offences; substantive law has accordingly been made subservient to procedural law.

Following the enactment of the DPTA and the DTA, the scope of procedural powers during the pre-trial phase has increased in the case of terrorism. Three main things have changed: (1) with regard to some powers (statutory), suspicion criteria have been lowered for terrorist offences only; (2) requirements to come to a reasonable suspicion in the case of terrorism have been (informally) lowered; and (3) the interest of the investigation has become the key criterion in deciding whether or not to apply procedural powers. In general, when it comes to preventing terrorism by means of the criminal justice system, the relevance of the suspicion criteria as justification for, and as criteria for the application of, state powers or measures, has significantly diminished. The perspective and object of a suspicion have changed as well. While a suspicion used to refer to an individual who had allegedly committed a more or less well-defined criminal offence, at present, suspicions increasingly concern groups of as yet unidentified individuals who presumably prepare, plot, plan or commit vaguely defined (terrorist) offences or are involved in, or connected to (the support of), terrorist activities. In addition, suspicions increasingly concern situations rather than specific persons. 'Suspicious' situations instead of concrete human behaviour have become the starting point and basis for (later) individualised suspicions. 


\section{Summary}

Even though the scope of terrorist intent/terrorist offences still has to take shape in case law that will not, as such, lead to violations of the principle of legality as enshrined in Article 7 of the ECHR and Article 1 of the DCC. Strasbourg case law on Article 7 of the ECHR emphasises that judges should be left free to interpret and develop criminal law provisions according to changing societal circumstances. Excessively clearly defined offences may obstruct that.

In terms of the requirement that all interferences with the right to privacy must be in accordance with the law, personal disturbance yields the largest problems under Article 8 of the ECHR. Personal disturbance powers, as applied in the most intrusive form during the period 2004-2007, lacked a Strasbourg conforming basis in domestic law. There were, furthermore, no safeguards to prevent the arbitrary application of personal disturbance powers. The application of such powers on the basis of Article 2 and 12 of the Police Act in the most intrusive form was in violation of Article 8 of the ECHR. In addition, the necessity of personal disturbance has been completely superseded since the entering into force of the DPTA.

The introduction of the suspicion criterion of 'serious objections of a terrorist offence' as a precondition for; (1) initiating an exploratory inquiry into terrorist offences, and (2) the application of special investigation techniques, and (3) the application of the investigative powers in security risk areas, raises problems under the first requirement of Article 8, section 2 of the ECHR as well. First of all, the criteria for application - including the suspicion criterion - of these powers are broadly defined. That may raise problems in terms of compliance with Strasbourg qualitative requirements attached to criminal (procedural) law. Secondly, there are insufficient procedural safeguards to prevent arbitrary application of these techniques and powers. Large discretionary powers for the executive inevitably limit the effectiveness of statutory safeguards, and, primarily, of judicial control. This is at odds with the fact that the potential intrusiveness of the powers comprised in Title VB of the DCCP calls for an increased level of effective safeguards under Strasbourg case law. The necessity of the procedural powers comprised in Titles VB and VC of the DCCP is, furthermore, difficult to adequately substantiate when considered in light of: (1) the non-criminal law based anti-terrorism measures, as discussed in the previous chapters; (2) the powers comprised in Titles IVA, V and VA of the DCCP, and (3) the powers of the secret intelligence services, combined with the information exchange between the investigative authorities and the secret intelligence services.

Coming to a (reasonable) suspicion regarding the commission of terrorist offences has become less difficult. Broad legal definitions of terrorist offences, which, moreover, criminalise behaviour occurring early in the pro-active phase, facilitates the smooth fulfilment of suspicion criteria even more. Information underlying 
suspicion criteria concerning terrorist offences is often not, moreover, exclusively gathered by the investigative authorities themselves and remains (in part) secret regarding the sources. In light of these developments and the practical implementation of the system of initial pre-trial deprivation of liberty in the Netherlands, it cannot be denied that the core element of Article 5 of the ECHR is undermined. The deprivation of liberty in the case of terrorism may, moreover, very well take place beyond the legally defined criteria for application. The combination of broad criminal liability for (inchoate) terrorist offences, lowered suspicion criteria for the application of procedural powers and measures, and the possibility of using secret intelligence information and other 'soft evidence' during the investigation and during trial, makes the likelihood of 'having the wrong guy' considerably less illusory. That likelihood is increased even more when one takes into account the burden placed on the investigative authorities to prevent terrorism at all costs. If the error rate regarding criminal investigations into terrorism proves to be indeed considerably higher than in case of common criminal investigations, it is all the more important to oblige public prosecutors to present their case to a court as soon as possible, in order to judge on the legitimacy of the charges and the lawfulness of the pre-trial detention, instead of giving public prosecutors two extra years to present the case to court. In that light, there is an explicit need to conduct criminal investigations into terrorist offences with extra diligence. In that respect, the amended Article 66, section 3 of the DCCP goes flatly against Strasbourg basic principles under Article 5 of the ECHR.

It is, moreover, essential that terrorist suspects in pre-trial detention are given access to the complete case file to adequately challenge the accusations. Strasbourg does not appear to allow for more intrusive interferences with a terrorist suspect's defence rights during habeas corpus proceedings than with a common suspect's rights. The ECtHR does recognise that there may be circumstances where it is unavoidable to keep certain information from the suspect. However, the investigative authorities are never exempt from the obligation to ensure that the domestic courts are, in fact, able to exercise free, full and effective control on the lawfulness of a suspect's pre-trial detention. That certainly goes for complex cases, with a large investigation file. The government's general reasoning that the nature of investigations into terrorism justifies as such more far-reaching restrictions of suspects' rights during the pre-trial phase, is not corroborated by the Strasbourg case law discussed in Chapter VII.

In addition, in case of restrictions to defence rights during the pre-trial phase, the ECtHR attaches particular importance to the question of whether these restrictions have been adequately counterbalanced, for example, by means of judicial control. The fact that no one, except for the public prosecutor, has access to the complete case file for protracted periods undermines the judiciary's power to: (1) monitor the progress of the investigation, and (2) effectively decide on the lawfulness of a suspect's continued detention on remand. 
The necessity of the administrative measures to counter terrorism - as comprised in the proposed Bill - was doubtful when considered in light of the amendments brought about by the DPTA. The broad discretionary power for the Minister of Interior caused by the broadly defined criteria for application of these powers, the lack of adequate and mandatory judicial control on the imposition of these powers, and the very doubtful effectiveness of the administrative measure, might have led to violations of Article 2, section 2 of the Protocol, if the Bill would have entered into force.

Union case law on the blacklisting system demonstrates that even though the Council is, theoretically, the competent authority to blacklist a party, factually speaking, the Member States decide who is included on the Union blacklist. In addition, despite the fact that in theory there is a remedy available for blacklisted parties, the procedural deficiencies attached to judicial proceedings during which the lawfulness of fund-freezing measures is examined have made that remedy factually meaningless as far as it concerns delisting. The Union judiciary interprets the right to an effective legal remedy merely as having factual access to a remedy. Generally, the statement of reasons is provided to the blacklisted party and the party is heard after the implementation of the blacklisting decision. If there were a possibility for the blacklisted party to effectively rebut the substantive information that led to the national decision, and consequently, to the Council's decision to freeze his funds, that would be acceptable. However, that is clearly not the case. The substantive 'suspicion criterion' of involvement in (the financing of) terrorism pursuant to CP 931, is very broad, and has, in practice, hardly any relevance in deciding whether or not to include a party on the blacklist. The formalistic interpretation of the criteria for the application of fund-freezing measures leads to a factual situation where blacklisted parties are kept from questioning in front of the union judiciary the well-foundedness of the substantive basis of these measures. Judgements of the Union judiciary have, in this respect, become partly meaningless for the parties affected. The factual situation of blacklisted parties often remains unchanged, and their assets continue to be frozen, despite the fact that the judiciary has concluded that fundamental rights had been violated.

\section{III}

Primarily the judiciary should guard against unlimited criminal liability on account of terrorist offences. The fundamental principle that (terrorist) intentions are not liable to punishment should be preserved. Using the criminal justice system to prevent terrorism, without violating fundamental rights, and primarily without undermining the principle of legality and legal certainty, presupposes that the notion of terrorist intent should be specified and narrowly interpreted by the judiciary and applied by the executive. 
The large discretionary powers of the investigative authorities pursuant to titles $\mathrm{VB}$ and VC of the DCCP, should be counterbalanced by statutory amendments. It would be best to restrict the category of terrorist offences in the case of which the application of the investigative powers may be ordered and used to the most severe ones, and to demand prior authorisation from an independent judicial authority or court.

Pre-trial detention of terrorist suspects demands extra automatic judicial control by a court. In addition, it would be preferable to include an explicit and mandatory element of proportionality in Article 66, section 3 of the DCCP.

To compensate for the considerable interference with terrorist suspects' right to access the case file, reference should be made to the UK disclosure procedure, as discussed in A. and Others $v$. the United Kingdom. The special advocate procedure may serve as an adequate safeguard against unjustified interferences with fair trial rights during habeas corpus proceedings, provided that the special advocate is allowed: (1) to actually inspect the evidence, (2) to put forward arguments on behalf of the detainee during the closed hearing, and (3) to make submissions to the judge regarding the case for additional disclosure. Introducing the UK disclosureprocedure into the DCCP would only be effective if the court deciding on the lawfulness of the pre-trial detention had access to all the information comprised in the case file. The scope of the right to lodge complaints against non-disclosure of information from the case file should not, furthermore, be statutorily limited, particularly because the enforcement of that right directly influences the effectiveness of the right to lodge a habeas corpus complaint.

To make blacklisting proceedings compliant with fundamental rights and principles of law, the substantive 'suspicion criterion' of involvement in terrorist acts as comprised in CP 931, should, in practice, become the main criterion for the application of the Council's blacklisting decision and for the imposition of fundfreezing measures, rather than the formalistic question of whether there is a 'national decision'. Secondly, affected parties should be heard as soon as possible after the blacklisting decision, and, in any case, immediately after the freezing of their funds. Thirdly, effective judicial review of blacklisting decisions should be guaranteed. Funds of delisted persons should not, furthermore, remain frozen despite an annulment of the blacklisting decision. 


\section{Samenvatting}

\section{Hoofdstuk I. Terrorisme als tijdloze trend: inleiding}

Terrorisme is van alle tijden. Antiterrorismewetgeving is echter een relatief nieuw fenomeen in Nederland. Het Nederlandse antiterreurbeleid in de periode 2001-2011 was in de eerste plaats gericht op de preventie van terroristische misdrijven. Deze dissertatie behandelt één aspect van dit preventiebeleid: de reikwijdte van de antiterrorismewetgeving binnen en buiten het strafrecht en de invloed van deze wetgeving op zowel (straf)rechtsbeginselen als op grondrechten uit verschillende Europese verdragen. Deze verdragen gelden in Nederland als hoger recht dan het nationale. Dit heeft geleid tot de volgende centrale onderzoeksvraag:

In hoeverre zijn de wettelijke criteria voor de toepassing van antiterrorismebevoegdheden en maatregelen en het gebruik ervan in de praktijk, met name met betrekking tot de mate van verdenking, in het straf(proces)recht, het openbare-orderecht, het bestuursrecht en het Europees recht, verenigbaar met de relevante grondrechten en rechtsbeginselen zoals die in de toepasselijke Europese verdragen zijn neergelegd?

Om die vraag te beantwoorden, worden verschillende subvragen gesteld en besproken, waarvan dit de drie belangrijkste zijn:

I. Wat houdt een terroristisch misdrijf in binnen het Nederlandse strafrechtelijke stelsel en op welke manier heeft de strafbaarstelling van terrorisme de strafrechtelijke aansprakelijkheid beïnvloed, met name gedurende de proactieve fase?;

II. Welke bevoegdheden en/of maatregelen zijn er om terrorisme te voorkomen en welke mate van verdenking is vereist om tot toepassing van deze bevoegdheden en/of maatregelen over te gaan?;

III. Hoe beïnvloedt de toepassing van deze bevoegdheden en/of maatregelen fundamentele wettelijke grondrechten en rechtsbeginselen, en dan in het bijzonder bezien in het licht van de toepassingscriteria van die bevoegdheden en/of maatregelen?

De bovengenoemde onderzoeksvragen hebben geleid tot een drieledige structuur in deze dissertatie. Om te beginnen betreft hoofdstuk II de eerste subvraag. Dit hoofdstuk onderzoekt de reikwijdte van de strafrechtelijke aansprakelijkheid voor terroristische misdrijven in termen van mens rea en actus reus. Hoofdstukken III tot en met VIII betreffen de tweede subvraag. Zij behandelen verschillende bevoegdheden en maatregelen die de uitvoerende macht ter beschikking staan 
gedurende de voorfase binnen het openbare-orderecht, het administratief recht, het strafprocesrecht en het Europees recht. De derde subvraag vormt de leidraad voor alle hoofdstukken. Met name hoofdstuk IX gaat in op het bereik van de effecten van de ter discussie staande bevoegdheden en maatregelen op de relevante grondrechten en rechtsbeginselen.

\section{Hoofdstuk II. Strafbaarstelling van terroristische misdrijven}

Dit hoofdstuk bespreekt de Nederlandse antiterrorismewetgeving op het gebied van materieel strafrecht en de effecten van deze wetgeving op het legaliteitsbeginsel, als gecodificeerd in artikel 1 Wetboek van Strafrecht (Sr) en artikel 7 van het Europees Verdrag voor de Rechten van de Mens (EVRM). Deze wetgeving stoelt op twee algemene uitgangspunten. Ten eerste is de wetgeving gericht op het voorkomen van terroristische misdrijven in plaats van op de strafrechtelijke reactie hierop. Personen van wie vermoed wordt dat zij van plan zijn een terroristisch misdrijf te begaan, moeten worden tegengehouden voor die daad een feit is. Het tweede uitgangspunt van de wetgeving is dat eenieder die ervan verdacht wordt betrokken te zijn bij, of banden te hebben met 'terroristische activiteiten', op welke manier ook, eveneens een halt moet worden toegeroepen. Om die twee doelstellingen te bereiken, is met betrekking tot terrorisme de strafrechtelijke verantwoordelijkheid behoorlijk uitgebreid. Echter, het risico van het strafrechtelijk verantwoordelijk houden van mensen voor terroristische misdrijven op basis van vooral intenties, in plaats van op basis van het feitelijke gevaar dat zij door hun gedrag vormen of zouden kunnen vormen voor de maatschappij, is met het van kracht worden van de Wet Terroristische Misdrijven (WTM) toegenomen. Oogmerk als bestanddeel van strafbepalingen brengt subjectiviteit in het strafrechtelijk systeem.

Ondanks een aantal rechterlijke uitspraken met betrekking tot de definitie van het terroristisch oogmerk (art. 83a Sr), blijft de precieze reikwijdte van dit begrip onduidelijk. Er is geen consistentie in de rechtspraak met betrekking tot de grenzen van de strafrechtelijke aansprakelijkheid voor 'terroristische misdrijven' ingevolge de artikelen 83 en 83a Sr. Alhoewel de specifieke omstandigheden van het geval doorslaggevend zijn, draagt de politiek-religieuze overtuiging van de verdachte vaak in aanzienlijke mate bij tot het bewijs voor terroristisch oogmerk. Personen die extreme interpretaties van bijvoorbeeld de islam aanhangen, maar nauwelijks enige stappen hebben ondernomen om hun geloofsopvatting in concrete daden om te zetten, lopen het gevaar strafrechtelijk aansprakelijk gesteld te worden voor een terroristisch misdrijf.

Het Europese Hof voor de Rechten van de Mens (EHRM) concludeert slechts zelden dat strafbepalingen artikel 7 EVRM schenden wegens het niet nakomen van het lex certa-vereiste. Strafbepalingen moeten in verschillende omstandigheden, en op alle mogelijke (toekomstige) daders, toepasbaar kunnen zijn. Dat houdt in dat zulke bepalingen moeten worden vervat in ruime bewoordingen, terwijl het legali- 
teitsbeginsel, theoretisch althans, vereist dat crimineel gedrag zo helder mogelijk wordt gedefinieerd. Als gevolg daarvan is er een voortdurend spanningsveld tussen enerzijds het zo duidelijk mogelijk opstellen van strafbepalingen en anderzijds het (toekomstige) gedrag dekken dat als crimineel dient te worden beschouwd.

Het EHRM vindt dat een brede interpretatie van strafbepalingen - welke spoort met (langzaam) veranderende (maatschappelijke) omstandigheden - niet in strijd is met het legaliteitsbeginsel zolang die interpretatie in overeenstemming blijft met de essentie van de strafbepaling en, tot op zekere hoogte, voorzienbaar is. Desalniettemin laten verschillende uitspraken zien dat zelfs een geheel andere (bredere) interpretatie van een strafbepaling - en dus zonder voorafgaande langzame ontwikkeling - aangaande ernstige misdrijven, niet automatisch een schending inhoudt van artikel 7 EVRM. Geconfronteerd met een dergelijk dilemma acht het EHRM het bestraffen van ernstig misdadig gedrag, zelfs als dat niet duidelijk valt binnen het bereik van een strafbepaling, belangrijker dan de strikte toepassing van het legaliteitsbeginsel. Het lijkt erop dat het EHRM alleen bij grote rechtsonzekerheid tot een schending van het lex certa-vereiste uit artikel 7 EVRM zal concluderen.

\section{Hoofdstuk III. Vermeende betrokkenheid bij terroristische activiteiten}

Dit hoofdstuk gaat in op de antiterreurmaatregel die 'persoonlijke verstoring' wordt genoemd en het onderliggende verdenkingscriterium. Gedurende de periode 20042007 oefende de politie, handelend op en onder gezag van de burgemeester, een scala van observatiebevoegdheden uit op 'personen die beweerdelijk betrokken waren bij terroristische activiteiten'. Deze observatiebevoegdheden omvatten onder andere het merkbaar langs iemands huis rijden en enige minuten voor dat huis stoppen met draaiende motor, zowel overdag als 's nachts, het volgen van die persoon waarheen hij ook gaat, bezoekers staande houden en om hun identiteitsbewijs vragen, de persoon bellen als hij niet thuis is en zijn huis op reguliere basis observeren. De regering beriep zich op de artikelen 2 en 12 Politie Wet (PW) en op artikel 172 van de Gemeentewet als wettelijke basis voor de persoonlijke verstoring. Deze bepalingen omvatten de algemene taakomschrijving van de burgemeester en de politie: handhaving van de openbare orde. Geen van deze bepalingen bevatten specifieke toepassingscriteria voor persoonlijke verstoringsmaatregelen, noch definiëren zij de reikwijdte van de gebruikte observatietechnieken. Het criterium 'personen beweerdelijk betrokken bij terroristische activiteiten' is niet in wetsbepalingen vastgelegd, het wordt alleen vermeld in kamerstukken.

Er zijn twee rechterlijke beslissingen over de rechtmatigheid van specifieke gevallen van persoonlijke verstoring. In beide zaken was de toepassing van verstoringsmaatregelen, indien gebaseerd op artikel $12 \mathrm{PW}$, niet als zodanig uitdrukkelijk verboden. De bevoegde rechtbank sprak zich alleen expliciet uit over de vraag of de persoonlijke verstoringsmaatregelen proportioneel waren tot de beoogde doelen, wat afhing van de specifieke omstandigheden van het geval. Hoe overtuigender het 
bewijs tegen een persoon was, en hoe minder vergaand de verstoringsmaatregelen waren, hoe meer rechters geneigd bleken te zijn dergelijke machtsmiddelen toe te staan op grond van artikel $12 \mathrm{PW}$.

Hoofdstuk III bespreekt ook het Straatsburgse recht op privacy op grond van artikel 8 EVRM. Dit in het licht van de toepassing van persoonlijke verstoringsmaatregelen. Gedurende de periode 2004-2006 maakten de meest vergaande vormen van verstoringsmaatregelen inbreuk op het recht op privacy. De persoonlijke verstoring kent een grote discretionaire bevoegdheid toe aan de burgemeester. Deze bevoegdheid wordt niet in balans gehouden door procedurele waarborgen, zoals verplichte rechterlijke controle. Of de toepassing van persoonlijke verstoringsmaatregelen in overeenstemming is met artikel 8 EVRM, kan alleen deels, en ex post facto, worden vastgesteld door het aanspannen van een kort geding door de persoon die de persoonlijke verstoring heeft ondergaan.

\section{Hoofdstuk IV. Veronderstelde banden met terrorisme}

In dit hoofdstuk komt het wetsvoorstel Bestuurlijke Maatregelen Nationale Veiligheid (het Wetsvoorstel) aan de orde. Inmiddels is dit wetsvoorstel in juni 2011 ingetrokken. Ten tijde van zijn indiening bij het parlement was het de eerste voorgestelde wettelijke antiterreurmaatregel binnen het administratief recht. Het voornaamste doel van het wetsvoorstel was om handelen mogelijk te maken wanneer het strafrecht nog niet of niet meer kon worden toegepast. Het wetsvoorstel diende 'het geheel aan antiterreur-maatregelen te completeren', ook buiten de strafrechtelijke context dus. Personen die, op grond van hun gedragingen, in verband konden worden gebracht met terroristische activiteiten of de ondersteuning daarvan, zouden onderworpen moeten worden aan een gebiedsverbod, een contactverbod en/of een periodieke meldingsplicht bij de politie ('de administratieve maatregelen'). Een redelijke verdenking van een specifiek terroristisch misdrijf was geen voorwaarde voor de toepassing van de beoogde administratieve maatregelen.

Indien de autoriteiten een of meer van deze administratieve maatregelen zouden toepassen, zou de betrokkene beperkt zijn in zijn vrijheid te kiezen waar te gaan en te staan en wie te ontmoeten. Het cumulatief toepassen van deze drie administratieve maatregelen over een langere periode, zou de inbreuk doen toenemen in termen van het recht op vrijheid van beweging als vastgelegd in artikel 2 van het $4 \mathrm{e}$ protocol bij het EVRM (het Protocol) - in het bijzonder wanneer in aanmerking wordt genomen dat een (redelijke) verdenking niet vereist was om deze maatregelen toe te passen en dat informatie van geheime diensten voldoende zou zijn geweest om de administratieve maatregelen toe te passen voor een periode tot twee jaar.

Er is geen Straatsburgse jurisprudentie over inbreuken op het recht op vrijheid van beweging door overheidshandelen dat vergelijkbaar is met de administratieve 
maatregelen zoals die waren voorgesteld in het Wetsvoorstel. De nagestreefde praktische reikwijdte van de administratieve maatregelen is voorts onduidelijk gebleven omdat het wetsvoorstel nooit in werking trad. Desalniettemin zijn er drie kwesties betreffende de vraag of de administratieve maatregelen uit het Wetsvoorstel in overeenstemming zouden zijn geweest met artikel 2 van het Protocol. In de eerste plaats was artikel 2 van het Wetsvoorstel, dat de toepassingscriteria bevatte voor de administratieve maatregelen, breed gedefinieerd en schiep het een grote discretionaire bevoegdheid voor de minister van Binnenlandse Zaken als bevoegde instantie. De breed gedefinieerde toepassingscriteria vergrootten de kans op willekeur. In de tweede plaats voorzag het Wetsvoorstel niet in automatische rechterlijke controle hetzij voorafgaande aan hetzij na het opleggen van de administratieve maatregelen. Of er rechterlijke controle zou worden uitgeoefend bij de oplegging of continuering van deze maatregelen, zou hebben afgehangen van de vraag of de persoon onderworpen aan zulke maatregelen een beroep zou indienen bij de arrondissementsrechtbank in Den Haag, zoals vastgelegd in artikel 4 van het Wetsvoorstel. De reikwijdte van deze procedure was voorts niet duidelijk. Ten derde, na het van kracht worden van de antiterrorismewetgeving binnen het strafprocesrecht en van de artikelen $134 \mathrm{a}$ en $83 \mathrm{~b}$ Sr, leek het Wetsvoorstel overbodig.

\section{Hoofdstuk V. Aanwijzingen van een terroristisch misdrijf}

Om de WTM adequaat te handhaven, dienden de onderzoeksbevoegdheden waar het terrorisme betreft, aanzienlijk te worden uitgebreid. In de visie van de regering: 'terrorisme kan niet worden tegengegaan door middel van de klassieke strafvordering.' Dienaangaande moest de preventieve werking van strafvordering inzake terrorisme krachtiger worden gemaakt. Dit hoofdstuk bespreekt een deel van de Wet Wijziging van het Wetboek van Strafvordering, het Wetboek van Strafrecht en enige andere wetten ter verruiming van de mogelijkheden tot opsporing en vervolging van terroristische misdrijven (WOVTM), die in 2006 van kracht werd. Deze wet bracht vijf aanzienlijke veranderingen aan in het Wetboek van Strafvordering (Sv) op het gebied van opsporing van terroristische misdrijven:

- een verruiming van de mogelijkheden om in een verkennend onderzoek informatie te verzamelen;

- een verruiming van de mogelijkheden om personen, voertuigen en objecten te fouilleren buiten concrete verdenking van een strafbaar feit;

- een verruiming van de toepassingsmogelijkheden van bijzondere opsporingsbevoegdheden zoals stelselmatige observatie en de telefoontap;

- het mogelijk maken van bewaring bij verdenking van een terroristisch misdrijf, ook buiten het geval van ernstige bezwaren;

- een mogelijkheid tot uitstel van volledige inzage van processtukken. 
Dit hoofdstuk gaat in op de eerste drie wetswijzigingen. Deze drie wetswijzigingen betreffen alle drie de invoering van een nieuw verdenkingscriterium in het Wetboek van Strafvordering, namelijk het criterium 'aanwijzingen van een terroristisch misdrijf'. De bevoegdheden die kunnen worden gebruikt in geval van aanwijzingen van een terroristisch misdrijf zijn een inbreuk op het recht op privacy zoals geïnterpreteerd door het EHRM. Straatsburgse jurisprudentie aangaande de toepassing van vergelijkbare bevoegdheden laat zien dat (1) hoe groter de reikwijdte van een bevoegdheid is, (2) hoe vergaander deze is en (3) hoe eerder gedurende de proactieve fase deze kan worden toegepast, hoe preciezer de discretionaire bevoegdheid voor de uitvoerende macht gecodificeerd moet zijn. De wet moet de reikwijdte aangeven van de handelingsbevoegdheid die aan de bevoegde autoriteiten is toegekend. Ook moet de wet voldoende helder zijn over de manier van uitoefening van maatregelen die inbreuk maken op artikel 8 EVRM. Bevoegdheden van de uitvoerende macht mogen nooit ongebonden ('unfettered') zijn. Hoe nauwkeuriger de wet de aard van de misdrijven definieert, hoe minder specifiek de omschrijving van de categorie personen hoeft te zijn waarop de betreffende maatregelen toegepast kunnen worden. Bevoegdheden die ook het privéleven van niet-verdachte personen aantasten, dienen te zijn voorzien van speciale regels in dat opzicht. De toepassing van bevoegdheden die inbreuk maken op de privacy moeten (bij voorkeur) worden bevolen door een rechterlijke autoriteit, gevolgd worden, en achteraf worden onderzocht, ook door een rechterlijke autoriteit. Echter, hoe breder de bevoegdheden, hoe moeilijker het voor de rechterlijke macht is om te beoordelen of de bevoegdheden rechtmatig zijn toegepast. In het geval van brede wettelijke bepalingen vermindert de effectiviteit van rechterlijke controle daarom steeds meer, terwijl zulke bepalingen juist om extra rechterlijke controle vragen.

Hoe gedetailleerder en veeleisender nationale procedurele regels zijn aangaande bijzondere opsporingsbevoegdheden, des te waarschijnlijker is het dat het EHRM de handhaving ervan in overeenstemming zal achten met artikel 8 EVRM. Strafvorderlijke waarborgen moeten daarenboven van kracht zijn tijdens de beginstadia van het uitvaardigen van een bevel tot het toepassen van zulke bevoegdheden, en gedurende de verdere toepassing ervan. Dit soort waarborgen moeten voor extra waakzaamheid zorgen als de autoriteiten bevoegd zijn dit soort bevoegdheden toe te passen, zonder gerechtelijk bevel en/of in het geval van indringende bevoegdheden van bijvoorbeeld heimelijke observatie. De proportionaliteit, en dus de noodzakelijkheid, van bijzondere bevoegdheden tot opsporing vermindert als andere bevoegdheden gelijktijdig of successief zijn of worden toegepast. Voorts, hoe meer misdrijven onderzocht mogen worden met gebruikmaking van heimelijke bevoegdheden tot opsporing, hoe minder snel het EHRM een dergelijke toepassing als noodzakelijk in een democratische samenleving zal beschouwen. Bij het beoordelen van de vraag of redenen van nationale veiligheid gebruikt mogen worden om de noodzakelijkheid aan te tonen van inbreuken op het recht op privacy, spelen in de opvatting van het EHRM twee hoofdaspecten een rol: (1) hoe dichtbij in de tijd en hoe feitelijk is de bedreiging van de nationale veiligheid?; en (2) hoe ernstig is de inbreuk op de 
privacy? Hoe ernstiger een misdrijf is, hoe noodzakelijker het mag worden geacht bijzondere opsporingsbevoegdheden toe te passen. Dat geldt in het bijzonder wanneer andere (minder inbreuk makende) bevoegdheden niet effectief blijken te zijn. Het EHRM heeft deze overwegingen echter alleen gebruikt met betrekking tot verdachten op wie deze bevoegdheden waren toegepast, gedurende een relatief korte tijd, en onder supervisie van een rechter. Het is belangrijk vast te stellen dat er geen expliciete jurisprudentie voorhanden is aangaande bevoegdheden toegepast tijdens de proactieve fase op personen die nog niet als verdachten kunnen worden aangemerkt.

Wat betreft de bevoegdheden die besproken zijn in dit hoofdstuk, kunnen zich twee problemen voordoen ter zake het in overeenstemming zijn met artikel 8 EVRM. Op de allereerste plaats beperken ruime discretionaire bevoegdheden voor de uitvoerende macht de effectiviteit van wettelijke waarborgen, met name die van rechterlijke controle. Dat staat haaks op het feit dat de potentiële inbreuk van de besproken bevoegdheden juist oproept tot uitgebreide effectieve wettelijke procedurele waarborgen gezien de Straatsburgse jurisprudentie. Ten tweede ligt het bevelen van zulke bevoegdheden, bij de meeste ervan, bij het Openbaar Ministerie c.q. de opsporingsinstanties. Hoewel het EHRM niet per se een rechter als bevoegde autoriteit voorschrijft, moet nog worden afgewacht of de opsporingsinstanties voldoende onafhankelijk zijn om willekeurige toepassing van de bevoegdheden, zoals besproken in dit hoofdstuk, te voorkomen. De reikwijdte van rechterlijke controle op de toepassing van deze bevoegdheden blijkt erg beperkt te zijn. In dit opzicht is het meer dan opvallend dat de meeste onderzoeken naar vermeende terroristische misdrijven niet tot vervolging leiden, maar wegens gebrek aan bewijs worden gestaakt. Dat houdt in dat ex post facto controle zelden plaatsvindt.

\section{Hoofdstuk VI. Een redelijk vermoeden van schuld}

Het is van cruciaal belang vast te stellen wanneer iemand aangemerkt kan worden als een verdachte van een (terroristisch) misdrijf. Dat moment is een omslagpunt, zowel voor de verdachte als voor de opsporende autoriteiten binnen het strafrechtelijk onderzoek. Aan de ene kant opent het verdenkingscriterium van artikel $27 \mathrm{~Sv}$ de mogelijkheid voor de opsporende autoriteiten om allerhande dwangmiddelen te gebruiken tegen de verdachte. Aan de andere kant zijn deze autoriteiten vanaf dat moment verplicht verschillende grondrechten van de verdachte effectief te waarborgen. De dwangmiddelen die in dit hoofdstuk worden besproken, worden toegepast bij een lichte redelijke verdenking. Dit is, op het moment, het enige vereiste voor inverzekeringstelling en bewaring van terrorismeverdachten. Sinds de inwerkingtreding van de WOVTM mag een terrorismeverdachte van zijn vrijheid beroofd worden gedurende 20 dagen en 15 uur op grond van een lichte verdenking ingevolge artikel 67, lid 4 Sv, terwijl er in geval van 'gewone verdachten' tevens ernstige bezwaren aangetoond moeten worden. De WODC-rapporten laten zien dat bewa- 
ring zonder ernstige bezwaren op grond van artikel 67, lid $4 \mathrm{~Sv}$ tot nog toe slechts in vijf zaken is toegepast gedurende de periode 2007-2011, en dan met name teneinde vermeende terroristische dreigingen af te wenden. Deze rapporten bevestigen de juistheid van de veronderstelling dat, wanneer het opsporing inzake terrorisme betreft, het belang van het onderzoek, de voorkoming van terrorisme en, meer algemeen, risicomanagement meer doorslaggevend zijn geworden voor toepassing van dwangmiddelen dan het wettelijk vastgelegde verdenkingscriterium.

Op het gebied van het EVRM draait hoofdstuk VI vooral om artikel 5, lid 1, onder c en lid 3 EVRM. Een voorwaarde voor rechtmatige vrijheidsbeneming gedurende de voorfase is dat er sprake moet zijn van een redelijke verdenking. Teneinde vast te stellen of er sprake is van een redelijke verdenking, onderscheidt het EHRM tussen: (1) de subjectieve kant van de verdenking, zijnde de goede trouw van de opsporingsautoriteiten, en (2) de objectieve kant van de verdenking, zijnde objectieve, concrete en relevante feiten of omstandigheden die de verdenking kunnen staven. Een verdenking is uitsluitend redelijk indien aan beide aspecten is voldaan. Er moet bewijs zijn van handelingen waaruit de veronderstelde betrokkenheid van verdachte bij een misdrijf blijkt. Hoe gedetailleerder en preciezer de informatie die de verdenking moet staven is, hoe eerder het EHRM de verdenking als redelijk zal beschouwen. Het EHRM lijkt geen bezwaar te hebben tegen het gebruik van geheime informatie teneinde een verdenking te staven. Maar, aanvullende informatie is dan vereist teneinde een redelijke verdenking aan te kunnen tonen. Als een verdenking (ten dele) gegrond is op geheime informatie, dan dient deze informatie ten minste enkele feiten of informatie te bevatten welke de bevoegde instantie kunnen overtuigen - en theoretisch ook een objectieve derde - dat de gearresteerde persoon terecht verdacht is van het plegen van een misdrijf. Alhoewel het EHRM enig begrip lijkt te hebben voor de moeilijkheden die staten ondervinden bij het bestrijden van terrorisme, laat het niet toe dat er verschillende verdenkingscriteria gecreëerd worden op grond van het type (ernst) van het misdrijf waarvan iemand verdacht wordt. Dit trekt de stelling van de Nederlandse regering in twijfel dat voor terroristische misdrijven een minder veeleisend criterium moet gelden.

Adequate rechterlijke controle van de gronden voor aanhouding en vrijheidsbeneming gedurende de voorfase is voor het EHRM een belangrijke procedurele waarborg teneinde willekeurige aanhouding en vrijheidsbeneming te voorkomen. De rechterlijke macht moet toegang hebben tot de feiten en omstandigheden die tot de aanhouding of vrijheidsbeneming hebben geleid om een effectieve rechtmatigheidstoets ex post facto te kunnen doen. Alhoewel de interpretatie van de Straatsburgse gronden voor voorlopige hechtenis (vluchtgevaar, collusiegevaar, recidivegevaar en verstoring van de openbare orde) afhangt van de omstandigheden van het geval, zijn er enkele richtlijnen te geven die bij alle gronden gelden.

Ten eerste moeten verdachten, voor zover mogelijk, hun proces in vrijheid kunnen afwachten. Vooraleer iemand in hechtenis te nemen, ook gedurende het proces, 


\section{Samenvatting}

dient de mogelijkheid van alternatieve maatregelen overwogen te worden. Ten tweede zijn de bevoegde instanties verplicht specifieke en geïndividualiseerde omstandigheden aangaande het gedrag van de verdachte, en zijn persoonlijkheid, aan te tonen wanneer ze beslissen tot vrijheidsbeneming. Ten derde, hoe langer de vrijheidsbeneming gedurende de voorfase duurt, hoe relevanter en zwaarder de gronden gebruikt teneinde de vrijheidsbeneming te rechtvaardigen, moeten worden - zowel in ernst als in aantal. Ten vierde dienen de gronden die gebruikt zijn om de vrijheidsbeneming te rechtvaardigen een direct verband te leggen tussen: (1) de specifieke en persoonlijke omstandigheden van het geval, (2) nationaal recht, en (3) de feitelijke omstandigheden die de bevoegde instanties gebruikt hebben om de vrijheidsbeneming te rechtvaardigen.

\section{Hoofdstuk VII. Ernstige bezwaren}

Ernstige bezwaren vormt het hoogste verdenkingscriterium gedurende de voorfase. Met betrekking tot vrijheidsbeneming gedurende de voorfase speelt dit verdenkingscriterium pas een rol vanaf de gevangenhouding en -neming. Dit is een gevolg van het nieuwe artikel 67, lid 4 Sv. De WOVTM heeft bovendien artikel 66, lid $3 \mathrm{~Sv}$ gewijzigd. Terrorismeverdachten mogen tot 2 jaar en 90 dagen gevangen worden gehouden, in tegenstelling tot de 90 dagen voor 'gewone verdachten'. Dit hoofdstuk bespreekt het bereik van deze wetswijziging en de vraag of deze verlengde termijn voor gevangenneming en gevangenhouding in overeenstemming kan worden geacht met artikel 5, lid 3 EVRM. Eenieder die van zijn vrijheid is beroofd ingevolge lid 1 onder $\mathrm{c}$, heeft het recht binnen een redelijke termijn berecht te worden. Het EHRM heeft verschillende criteria ontwikkeld om te beoordelen of een strafrechtelijk onderzoek, en het proces, van een persoon die in voorlopige hechtenis zit, met de vereiste nauwkeurigheid en voortvarendheid worden behandeld.

Het belangrijkste criterium betreft de vraag of er sprake is van stilzitten aan de kant van de vervolgende autoriteit gedurende het onderzoek of het proces. Dit stilzitten is eigenlijk altijd onacceptabel. Ten tweede speelt de complexiteit van de zaak een rol, alsmede de houding van de verdachte en het type misdrijf waar het om gaat. De aard van het misdrijf beïnvloedt slechts ten dele de redelijkheid van de lengte van de vrijheidsbeneming gedurende de voorfase. Complexe strafbare feiten, zoals misdrijven inzake internationale criminele of terroristische organisaties, beïnvloeden de complexiteit van een zaak en dientengevolge de toegestane lengte van vrijheidsbeneming gedurende de periode tot aan de uitspraak in eerste instantie. Het is dus meer de potentiële ingewikkeldheid eigen aan onderzoeken met betrekking tot zulke ernstige misdrijven die de redelijkheid van de lengte van de vrijheidsbeneming beïnvloedt, dan de aard van bijvoorbeeld terrorisme als zodanig.

Als gevolg van de verlengde termijn van gevangenhouding en gevangenneming voor terrorismeverdachten gelden potentiële beperkingen op rechten van deze verdachte ook voor een langere termijn. Een mogelijke beperking betreft de bevoegd- 
heid tot tijdelijke onthouding van processtukken uit het procesdossier op grond van artikel 30, lid $2 \mathrm{~Sv}$. Inzage in het gehele procesdossier is onder meer van groot belang indien een verdachte in beroep wil gaan tegen het bevel tot gevangenhouding of gevangenneming via artikel 71 Sv of via artikel 69 Sv. Artikel 5, lid 4 EVRM verplicht staten te voorzien in een effectieve mogelijkheid tot het indienen van een zogenaamd habeas corpus-verzoek. Om het recht op habeas corpus effectief te doen zijn, moeten de verdachte en de bevoegde rechterlijke instantie weten op basis van welke informatie de verdachte van zijn vrijheid is beroofd. De staatsveiligheid en/of het feit dat het terrorisme betreft, kunnen als zodanig geen vergaande inbreuken op verdedigingsrechten betreffende het recht op toegang tot de processtukken gedurende habeas corpus-procedures rechtvaardigen. Het recht op toegang tot het procesdossier is, in de ogen van het EHRM, een essentieel aspect van het beginsel van equality of arms en dat moet zo veel mogelijk nageleefd worden gedurende habeas corpus-procedures. Aan dit beginsel is niet voldaan als de verdachte toegang tot stukken uit het procesdossier wordt ontzegd, terwijl deze stukken essentieel zijn om de rechtmatigheid van de vrijheidsbeneming effectief te kunnen toetsen.

Kortom, verdachten moeten altijd de rechtmatigheid van vrijheidsbeneming gedurende de voorfase effectief kunnen laten toetsen, ook in het geval van terrorisme. Dit veronderstelt dat de verdachte in staat gesteld moet worden de verdenking van terrorisme die de staat heeft, te weerleggen. Een verdachte moet daarom geïnformeerd worden, en blijven, gedurende de besluitvorming tijdens de habeas corpus-procedure. Hij moet in staat gesteld worden op- en aanmerkingen te maken, en deel te nemen aan het besluitvormingsproces, zo veel als mogelijk zonder de stukken die de vervolgende instantie geheim wil houden, te openbaren. Informatie die van doorslaggevend belang is voor de uitkomst van een beroep op invrijheidsstelling, en deel uitmaakt van het dossier van de vervolgende instantie, moet beschikbaar worden gesteld aan de verdachte, zelfs als het terrorisme betreft. Hoe langer de vrijheidsbeneming duurt, hoe omvangrijker habeas corpus-procedures moeten zijn en hoe meer informatie er geopenbaard moet worden aan de verdachte, en aan de bevoegde rechterlijke instantie. Hoe verder het onderzoek vordert, hoe minder aannemelijk het is dat bepaalde informatie geheim mag worden gehouden met een beroep op het belang van het onderzoek. De redenatie van de overheid dat de aard van terroristische misdrijven ingrijpendere beperkingen op de rechten van verdachten rechtvaardigt in dit opzicht, is twijfelachtig in het licht van de Straatsburgse jurisprudentie.

Het EHRM hecht extra waarde aan de vraag of er voldoende procedurele waarborgen en/of garanties zijn die de beperkingen op verdedigingsrechten van verdachten kunnen compenseren tijdens habeas corpus-procedures. Het gewijzigde artikel 66 , lid $3 \mathrm{~Sv}$ is niet voorzien van waarborgen om de potentieel verregaande inbreuken op de verdedigingsrechten van terrorismeverdachten te compenseren onder artikel 5, lid 4 EVRM. Omdat artikel 66, lid $3 \mathrm{~Sv}$ de periode van 
gevangenneming en gevangenhouding verlengt voor terrorismeverdachten, zouden deze verdachten moeten kunnen profiteren van meer rechterlijke controle op de rechtmatigheid van de vrijheidsbeneming. Dit veronderstelt volledige inzage in alle stukken op grond waarvan de vervolgende instantie de vrijheidsbeneming rechtvaardigt en in de stukken die de redenen voor de vrijheidsbeneming bevatten. Op dit moment kan de bevoegde rechterlijke instantie inzake habeas corpusprocedures echter - net als de (terrorisme)verdachte - het recht op volledige inzage in het procesdossier ontzegd worden. Dit bemoeilijkt een effectieve toets op de rechtmatigheid van de vrijheidsbeneming.

Straatsburgse jurisprudentie bij artikel 5, lid 4 EVRM gaat vooral over zaken waar de verdediging geen toegang tot het volledige dossier had, maar de rechter en de vervolgende instantie wel. Gevallen waarbij noch de verdachte, noch de bevoegde rechterlijke instantie inzage in het gehele procesdossier heeft, kunnen in Straatsburg problemen opleveren met name op het gebied van de vereiste effectieve rechterlijke controle op de rechtmatigheid van de vrijheidsbeneming - ingevolge artikel 5, lid 4 van het EVRM.

\section{Hoofdstuk VIII. De terrorismelijsten}

Dit hoofdstuk bespreekt het 'blacklisting-systeem' van de Europese Unie. Wanneer een (rechts)persoon op de terrorismelijst van de Unie terechtkomt, worden al zijn bezittingen bevroren, waaronder verzekeringen, aan verzekering gerelateerde diensten, bankkredieten, reischeques, bankcheques, aandelen, pand- en hypotheekrechten, obligaties en kredietbrieven. Het bevriezen van tegoeden betekent dat een (rechts)persoon ('de betrokkene') die op de terrorismelijst staat, niet langer toegang heeft tot de noodzakelijke middelen voor het leiden van een normaal leven. Deze betrokkene wordt daarenboven niet geïnformeerd over de voorgenomen bevriezing van de tegoeden. Hij ontdekt dit pas wanneer zijn tegoeden reeds bevroren zijn. Terwijl de plaatsing op de lijst, en ook de bevriezing van de tegoeden, relatief simpel is, blijkt verwijdering van de lijst bijna onmogelijk te zijn. De theoretisch beschikbare rechtsmiddelen om van de lijst af te komen, blijken in de praktijk nutteloos vanwege het gebrek aan respect voor verdedigingsrechten en procedurele waarborgen. Aangenomen dat de blacklisting-procedures onder het bereik van artikel 47 en artikel 48, lid 2 van het Charter of Fundamental Rights of the European Union en artikel 6 EVRM vallen, dient er gehandeld te worden in overeenstemming met verschillende grondrechten. De volgende lijst van minimale voorwaarden kan gebruikt worden teneinde de blacklisting-procedures te beoordelen:

1. de materiële voorwaarden voor plaatsing op de lijst moeten duidelijk zijn;

2 . de op de terrorismelijst geplaatste partijen moeten voldoende geïnformeerd worden over de beslissingen en de gronden waarop deze beslissingen worden genomen, bij voorkeur voorafgaand aan de implementatie; 
3. de plaatsing op de lijst moet strikt gebonden zijn aan tijdslimieten en onderworpen zijn aan effectieve periodieke toetsing;

4. de betrokkenen die op de lijst geplaatst zijn, moeten toegang hebben tot alle relevante informatie en moeten gehoord worden, teneinde gebruik te kunnen maken van het recht op een effectief rechtsmiddel;

5. effectief rechterlijk toezicht moet gegarandeerd worden door een onafhankelijk en onpartijdig gerecht, dat daarenboven de bevoegdheid heeft de plaatsing op de lijst te wijzingen of ongedaan te maken;

6. betrokkenen die onrechtmatig op de lijst zijn geplaatst, moeten gecompenseerd worden.

Indien men handelen in overeenstemming met deze voorwaarden en beginselen als voorwaarde ziet teneinde de blacklisting-procedures in overeenstemming met grondrechten te beschouwen, rijzen de volgende zaken.

Ten eerste, het materiële verdenkingscriterium, inhoudende betrokkenheid bij terroristische daden, zoals geformuleerd in Gemeenschappelijk Standpunt 931/2001, is erg breed en leidt tot een behoorlijke discretionaire bevoegdheid voor de lidstaten en de Raad. Daarnaast beperkt dit criterium de mogelijkheden voor de rechterlijke instanties van de Unie om de rechtmatigheid van het plaatsingsbesluit effectief te beoordelen. Periodieke toetsing van de lijsten verliest effectiviteit als de voorwaarden voor plaatsing op de lijst zo ruim geformuleerd zijn. Ten tweede, de betrokkene wordt niet gehoord en er wordt hem geen statement of reasons verstrekt, voorafgaand aan de plaatsing op de lijst en het bevriezen van de tegoeden. Als de betrokkenen gehoord worden na het bevriezen van de tegoeden, dient dat uitsluitend om hen te informeren over de opgelegde maatregelen en over de nationale beslissing die ten grondslag ligt aan de beslissing van de Raad. In het algemeen worden betrokkenen niet geïnformeerd over de redenen waarom ze aangemerkt worden als betrokken bij (het financieren van) terroristische daden. Bovendien weigert de Raad zelden een initiatief van een lidstaat tot plaatsing en bevriezing. Ten derde, betrokkenen worden op de lijst geplaatst voor aanvankelijk een termijn van 6 maanden, na afloop waarvan de Raad beoordeelt of voortdurende plaatsing op de lijst nog altijd gerechtvaardigd is. De praktijk is anders: de voorgeschreven periodieke toetsing komt in werkelijkheid neer op een automatische verlenging van de beslissing met zes maanden, zonder de vereiste volledige toetsing van de redenen voor plaatsing. In dit opzicht is het van belang dat de periodieke toetsing van de beslissingen verricht wordt door het uitvoerend orgaan dat het oorspronkelijke plaatsingsbesluit heeft genomen in plaats van door een rechterlijke instantie.

Ten vierde, de procedurele tekortkomingen, de breed gedefinieerde materiële bepalingen en het feit dat fair trial-beginselen slechts ten dele gelden, ondermijnen het recht op een effectief rechtsmiddel. Daarnaast is het recht op een effectief rechtsmiddel volledig afhankelijk gemaakt van overeenstemming met de andere twee verdedigingsrechten, en heeft als zodanig dus weinig betekenis. Ten vijfde, de jurisprudentie van het Gerecht van Eerste Aanleg en het Hof van Justitie laat zien dat de 
omvang van de rechterlijke toetsing beperkt is. Zowel de Raad als de vragende lidstaat zijn bevoegd om informatie te onthouden aan de bevoegde rechterlijke instantie van de Unie, en aan de betrokkenen, indien nationale veiligheid in het geding is. De Raad en de lidstaten genieten voorts beide een grote discretionaire bevoegdheid inzake de blacklisting-procedures.

\section{Hoofdstuk IX. Conclusies en aanbevelingen}

Hoofdstuk IX bespreekt drie zaken: (1) de algemene kenmerken van de Nederlandse antiterrorismewetgeving, (2) de omvang van de repercussies van deze wetgeving op grondrechten en rechtsbeginselen, en (3) enkele mogelijke oplossingen om de inbreuken die de huidige antiterrorismewetgeving op deze rechten en beginselen maakt, te compenseren.

De kenmerken van de materiële antiterrorismewetgeving zijn voornamelijk te vinden in de wetswijzigingen teweeggebracht door de WTM. Deze wetswijzigingen hebben binnen het Wetboek van Strafrecht geleid tot een tweedeling: het Wetboek van Strafrecht bestaat momenteel uit commune delicten en terroristische misdrijven. De praktijk laat zien dat de artikelen 83 en 83a Sr de strafrechtelijke aansprakelijkheid behoorlijk hebben uitgebreid met betrekking tot de terroristische misdrijven, en de commune delicten ter voorbereiding van terroristische misdrijven of de delicten die deze misdrijven faciliteren - met name de misdrijven begaan tijdens de proactieve fase. Voorbereidende terroristische misdrijven dienen niet in eerste instantie om strafrechtelijke verantwoordelijkheid te vestigen, maar ze zijn bedoeld als middel om de verwezenlijking van risico's te voorkomen. Het belangrijkste doel van antiterrorismewetgeving is dan om te ontdekken wie wellicht wel en wie niet bezig is met (het voorbereiden van) terroristische misdrijven. In dat opzicht is het materiële strafrecht een middel geworden dat bijdraagt aan risicomanagement, en een middel tot controle, meer dan een instrument om tot strafrechtelijke veroordelingen te komen. Het materiële strafrecht is op die manier ondergeschikt gemaakt aan de strafvorderlijke bevoegdheden.

Met de inwerkingtreding van de WTM en de WOVTM is het bereik van procedurele bevoegdheden gedurende het vooronderzoek enorm uitgebreid. Dit betreft met name de volgende zaken: (1) met betrekking tot sommige bevoegdheden zijn (wettelijke) verdenkingscriteria verlaagd voor uitsluitend terroristische misdrijven, (2) voorwaarden om tot een redelijke verdenking te komen inzake terrorisme zijn (informeel) verlaagd, en (3) het belang van het onderzoek is het doorslaggevende criterium geworden om te beslissen of procedurele bevoegdheden toegepast kunnen worden.

In het algemeen is het belang van verdenkingscriteria als rechtvaardiging en voorwaarde voor toepassing van bevoegdheden en maatregelen afgenomen, voor zover 
het de voorkoming van terrorisme met het strafrecht betreft. Het perspectief en het object van verdenkingen zijn ook veranderd. Terwijl een verdenking normaal gesproken verwees naar een individu dat, naar verondersteld werd, een min of meer afgebakend misdrijf zou hebben begaan, betreffen verdenkingen momenteel steeds meer groepen van nog niet geïdentificeerde individuen die vaag omschreven (terroristische) misdrijven zouden voorbereiden, beramen, plannen of begaan, of die betrokken zijn bij of banden hebben met (de ondersteuning van) terroristische activiteiten. Daarnaast betreffen verdenkingen steeds meer situaties in plaats van specifieke personen. Verdachte situaties in plaats van concreet menselijk gedrag zijn het beginpunt geworden voor en de basis van later geïndividualiseerde verdenkingen.

\section{II}

Alhoewel de grenzen van de begrippen 'terroristisch misdrijf' en 'terroristisch oogmerk' nog geen duidelijke vorm hebben aangenomen, zal dit niet als zodanig leiden tot schendingen van het legaliteitsbeginsel ingevolge artikel $1 \mathrm{Sr}$ en artikel 7 EVRM. Straatsburgse jurisprudentie met betrekking tot artikel 7 EVRM benadrukt dat er een rechterlijke vrijheid bestaat in het interpreteren en ontwikkelen van strafbaarstellingen, in lijn met veranderende maatschappelijke omstandigheden.

Met betrekking tot het vereiste dat alle inbreuken op het recht op privacy bij wet voorzien moeten zijn, levert persoonlijke verstoring de grootste problemen op ingevolge artikel 8 EVRM. Persoonlijke verstoring, zoals toegepast in de meest vergaande vorm gedurende de periode 2004-2007, miste een wettelijke basis in overeenstemming met Straatsburgse jurisprudentie. Er waren geen waarborgen teneinde willekeurige toepassing van persoonlijke verstoring te voorkomen. Persoonlijke verstoring in de meest vergaande vorm, wanneer gebaseerd op de artikelen 2 en 12 PW, was daarom in strijd met artikel 8 EVRM. Daarenboven is de noodzakelijkheid van inbreuken op de privacy als gevolg van persoonlijke verstoring opzijgeschoven door de inwerkingtreding van de WOVTM.

De invoering van het verdenkingscriterium van ernstige bezwaren als voorwaarde voor: (1) een verkennend onderzoek naar terroristische misdrijven, (2) de toepassing van bijzondere opsporingsbevoegdheden en (3) preventieve fouillering in veiligheidsrisico-gebieden, zal problemen met zich brengen onder de eerste voorwaarde van artikel 8, lid 2 EVRM. Ten eerste zijn de toepassingscriteria - inclusief het verdenkingscriterium - ruim gedefinieerd. Dit kan leiden tot problemen op het gebied van voldoen aan de kwalitatieve vereisten voor wetgeving van straf(proces) recht. Ten tweede zijn er onvoldoende procedurele waarborgen om willekeurige toepassing van deze technieken en bevoegdheden te voorkomen. Ruime discretionaire bevoegdheden voor de uitvoerende macht beperken onvermijdelijk de effectiviteit van wettelijke waarborgen, en dan met name van rechterlijk toezicht. Dat staat haaks op het feit dat de potentiële inbreuk op het recht op privacy door gebruik van 
de bevoegdheden uit de nieuwe titels VB en VC een verhoogde mate van effectieve waarborgen vereisen ingevolge Straatsburgse jurisprudentie.

De noodzaak van de procedurele bevoegdheden als opgenomen in titels VB en $\mathrm{VC}$ is voorts moeilijk adequaat aan te tonen in het licht van: (1) de antiterrorismebevoegdheden die buiten het strafrechtelijk systeem liggen; (2) de bevoegdheden zoals opgenomen in titels IVA, V en VA inzake commune delicten en (3) de bevoegdheden van de geheime dienst, gecombineerd met de informatie-uitwisseling tussen de opsporingsinstanties en de geheime diensten.

Het is minder moeilijk geworden om tot een (redelijke) verdenking van een (terroristisch) misdrijf te komen. Ruime strafbaarstellingen voor terrorisme, die bovendien gedragingen betreffen in een voorbereidende fase, maken het zelfs nog makkelijker om verdenkingscriteria te vervullen. Daarnaast is informatie die gebruikt wordt om een verdenking te staven meestal niet uitsluitend verzameld door de opsporingsinstanties en blijft deze vaak (deels) geheim. In het licht van deze ontwikkelingen, en in het licht van de praktische implementatie van het systeem van (initiële) vrijheidsberoving gedurende het vooronderzoek in Nederland, kan het niet ontkend worden dat het kernelement van artikel 5 EVRM ondermijnd wordt. Vrijheidsberoving van terrorismeverdachten kan voorts zeer wel plaatsvinden buiten de wettelijk gedefinieerde toepassingscriteria. De combinatie van (1) ruime strafbaarstellingen voor voorbereidende terroristische misdrijven, (2) verlaagde verdenkingscriteria voor de toepassing van procedurele bevoegdheden en maatregelen, en (3) de mogelijkheid om informatie van de geheime dienst te gebruiken en/of ander 'zacht bewijs' gedurende het onderzoek en het proces, kan de foutmarge verhogen. Als de foutmarge bij opsporingsonderzoeken inzake terrorisme inderdaad aanzienlijk hoger blijkt te zijn dan inzake commune opsporingsonderzoeken, dan is het zeker zo belangrijk het Openbaar Ministerie te verplichten een zaak zo spoedig mogelijk voor te leggen aan de rechter teneinde de rechtmatigheid van de aanklacht en de rechtmatigheid van de vrijheidsbeneming te beoordelen. Echter in plaats daarvan krijgt het Openbaar Ministerie twee jaar extra de tijd om de zaak voor te leggen aan het bevoegde gerecht. Het gewijzigde artikel 66, lid $3 \mathrm{~Sv}$ gaat regelrecht in tegen de Straatsburgse beginselen van artikel 5 EVRM.

Het is essentieel dat terrorismeverdachten in voorlopige hechtenis inzage in het hele procesdossier krijgen, teneinde de aanklacht adequaat te kunnen weerleggen. Verdedigingsrechten van terrorismeverdachten mogen, op grond van Straatsburgse jurisprudentie, niet verdergaand beperkt worden dan in geval van verdachten van commune delicten gedurende habeas corpus-procedures. Het EHRM erkent wel dat er omstandigheden denkbaar zijn waarin het onvermijdelijk is om de verdachte bepaalde informatie te onthouden. De opsporingsinstanties dienen te verzekeren dat de nationale gerechten feitelijk in staat blijven om volle en effectieve controle uit te oefenen op de rechtmatigheid van vrijheidsbeneming. Dat geldt zeker in geval van complexe zaken met een uitgebreid onderzoeksdossier. De algemene overweging 
van de Nederlandse regering dat de aard van opsporingsonderzoeken inzake terrorisme, als zodanig, verregaande inbreuken op de rechten van verdachten gedurende de voorfase rechtvaardigt, vindt geen steun in Straatsburgse jurisprudentie zoals besproken in hoofdstuk VII. Daarnaast hecht het EHRM bijzondere waarde aan de vraag of beperkingen op verdedigingsrechten gedurende de voorfase adequaat gecompenseerd zijn door bijvoorbeeld rechterlijke controle. Het feit dat het mogelijk is dat niemand buiten het Openbaar Ministerie inzage heeft in het complete procesdossier voor langere periodes, ondermijnt de bevoegdheid van de rechterlijke macht om: (1) de voortgang van het opsporingsonderzoek in de gaten te houden, en (2) effectief te beslissen over de rechtmatigheid van de voortdurende vrijheidsbeneming van een verdachte.

De noodzaak van de administratieve maatregelen om terrorisme tegen te gaan zoals voorgesteld in het Wetsvoorstel Bestuurlijke Maatregelen Nationale Veiligheid was twijfelachtig in het licht van de wetswijzigingen die de WOVTM en de WTM hadden voortgebracht. De ruime discretionaire bevoegdheid voor de Minister van Binnenlandse Zaken bestaande uit ruim gedefinieerde toepassingscriteria voor de bevoegdheden, het gemis aan adequate en verplichte rechterlijke controle op de oplegging van deze maatregelen en de twijfelachtige effectiviteit van de administratieve maatregelen, zouden hebben kunnen leiden tot schendingen van artikel 2, lid 2 van het Protocol indien het Wetsvoorstel in werking zou zijn getreden.

Jurisprudentie van de gerechten van de Europese Unie betreffende de blacklistingprocedures laat zien dat, hoewel de Raad theoretisch de bevoegde instantie is, feitelijk de lidstaten beslissen wie er opgenomen dient te worden op de terrorismelijst. Hoewel betrokkenen theoretisch beschikken over een rechtsmiddel, is dat rechtsmiddel feitelijk betekenisloos vanwege de procedurele tekortkomingen verbonden aan de procedure gedurende welke de rechtmatigheid van de bevriezingsmaatregelen wordt beoordeeld. De gerechten van de Unie interpreteren het recht op toegang tot een rechtsmiddel slechts als het hebben van feitelijke toegang tot een dergelijk rechtsmiddel. In zijn algemeenheid wordt de betrokkene gehoord en ingelicht over de redenen tot opneming op de lijst, na plaatsing op de lijst en na de bevriezing van de tegoeden. Indien er een effectieve mogelijkheid zou zijn voor de betrokkene om de materiële informatie die geleid heeft tot de nationale beslissing en tot de beslissing van de Raad om de tegoeden te bevriezen, te kunnen ontkrachten, dan zou dat acceptabel zijn. Dat is echter niet het geval. Het materiële 'verdenkingscriterium' van betrokkenheid bij (de financiering van) terrorisme ingevolge Gemeenschappelijk Standpunt 931/2001 is ruim. Het criterium heeft in de praktijk nauwelijks relevantie met betrekking tot de beslissing of de betrokkene wel of niet op de lijst geplaatst moet worden. De formalistische interpretatie van de toepassingscriteria voor bevriezingsmaatregelen leidt tot een feitelijke situatie waarin betrokkenen de mogelijkheid ontzegd wordt om ten overstaan van de Uniegerechten de gegrondheid van de materiële basis voor deze maatregelen te betwisten. Jurisprudentie van de 
Uniegerechten is in dit verband deels zonder betekenis geworden voor de betrokkenen. De feitelijke situatie van de betrokkenen blijft vaak ongewijzigd en hun tegoeden blijven bevroren, ongeacht het feit dat de Uniegerechten hebben geconcludeerd dat grondrechten geschonden waren.

\section{III}

Met name de rechtsprekende macht moet waken tegen oeverloze strafrechtelijke aansprakelijkheid voor terroristische misdrijven. Het fundamentele rechtsbeginsel dat (terroristische) intenties alleen niet strafbaar zijn, moet in ere worden gehouden. Het strafrechtelijk systeem gebruiken zonder schending van grondrechten en rechtsbeginselen, en men name zonder het legaliteitsbeginsel te ondermijnen, veronderstelt dat 'terroristisch oogmerk' duidelijk afgebakend en beperkt geïnterpreteerd moet worden door de rechtsprekende macht. Ook de uitvoerende macht moet dit begrip op eenzelfde terughoudende manier toepassen.

De ruime discretionaire bevoegdheden voor de opsporingsautoriteiten op basis van titel VB en VC zouden gecompenseerd moeten worden door wetswijzigingen. Het verdient aanbeveling de categorie van terroristische misdrijven inzake welke deze bevoegdheden bevolen en toegepast mogen worden, te beperken tot de meest ernstige terroristische misdrijven, en voorafgaande rechterlijke autorisatie te vereisen van een onafhankelijke juridische instantie of een gerecht.

Vrijheidsbeneming van terrorismeverdachten gedurende de voorfase vereist extra en automatische rechtelijke controle door een gerecht. Daarnaast zou het de voorkeur genieten een expliciet verplichte proportionaliteitstoets op te nemen in artikel 66, lid $3 \mathrm{~Sv}$.

Om de vergaande inbreuk op het recht op inzage in het procesdossier te compenseren, is er verwezen naar de zaak $A$. and Others $v$. the United Kingdom. The 'special advocate procedure' besproken in deze zaak, kan dienen als adequate waarborg tegen ongerechtvaardigde inbreuken op fair trial-rechten gedurende habeas corpus-procedures, tenminste indien de special advocate bevoegd is om: (1) het bewijsmateriaal in te zien, (2) het woord te voeren voor de verdachte tijdens de in camera-zitting, en (3) de rechter te vragen om extra inzage in het dossier. Het introduceren van deze procedure zou alleen effectief zijn indien het gerecht dat beslist over de zaak volledige inzage in het dossier heeft. Het bereik van het recht om zich te beklagen over niet-inzage in het dossier zou daarnaast niet wettelijk beperkt mogen zijn, met name omdat de uitoefening van dat recht direct invloed heeft op de effectiviteit van het recht op habeas corpus.

Om plaatsing op de terrorismelijst in overeenstemming te brengen met grondrechten en rechtsbeginselen, zou ten eerste het materiële verdenkingscriterium, inhoudende betrokkenheid bij (de financiering van) terroristische daden ingevolge 
Gemeenschappelijk Standpunt 931/2001, het doorslaggevende toepassingscriterium moeten worden voor het plaatsingsbesluit en de bevriezingsmaatregel, in plaats van de wat formele vraag of er een nationale beslissing is. Ten tweede, betrokkenen moeten zo spoedig mogelijk gehoord worden na het plaatsingsbesluit en in ieder geval na de bevriezing van hun tegoeden. Ten derde, effectieve rechterlijke controle op het plaatsingsbesluit moet gegarandeerd worden. Ten slotte moeten tegoeden van op de terrorismelijst geplaatste betrokkenen niet bevroren blijven als de gerechten van de Unie het plaatsingsbesluit hebben vernietigd. 


\section{Curriculum Vitae of Karin Veegens (25 DECEMber 1979)}

Karin studied Law at Maastricht University from 1998 to 2002. She majored in Law, with a specialisation in Criminal Law and Procedure, in 2002. She completed a work placement at the 'Advocatenpraktijk' in Maastricht in 2002. During her studies, she also worked as a spinning instructor.

In 2002 she studied in Italy for a year (Venice and Padova), where she achieved the European Master's Degree in Human Rights and Democratisation (E.MA) in September 2003. During her studies, she carried out fieldwork in Bosnia, Geneva (UN), and Florence (UNICEF).

In 2004 Karin began her $\mathrm{PhD}$ at Maastricht University under the supervision of André Klip and Peter Bal. In May 2005, she went to Sicily for the Specialisation Course in Criminal Law organized by the International Institute of Higher Studies in Criminal Sciences.

She also lectured undergraduate students in Criminal Law, Criminal Procedure, and Tort Law

Throughout the years that she worked at the University, Karin was actively engaged in the activities of the School of Human Rights Research, both as a representative of all $\mathrm{PhD}$ researchers, and as a member of the Educational Committee. She was also a Board Member of the Maastricht Centre for Human Rights. 



\section{School of Human Rights Research Series}

The School of Human Rights Research is a joint effort by human rights researchers in the Netherlands. Its central research theme is the nature and meaning of international standards in the field of human rights, their application and promotion in the national legal order, their interplay with national standards, and the international supervision of such application. The School of Human Rights Research Series only includes English titles that contribute to a better understanding of the different aspects of human rights.

Editorial Board of the Series:

Prof. dr. J.E. Goldschmidt (Utrecht University), Prof. dr. D.A. Hellema (Utrecht University), Prof. dr. W.J.M. van Genugten (Tilburg University), Prof. dr. M.T. Kamminga (Maastricht University), Prof. dr. P.A.M. Mevis (Erasmus University Rotterdam), Dr. J.-P. Loof (Leiden University) and Dr. O.M. Ribbelink (Asser Institute).

Published titles within the Series:

1. Brigit C.A. Toebes, The Right to Health as a Human Right in International Law ISBN 90-5095-057-4

2. Ineke Boerefijn, The Reporting Procedure under the Covenant on Civil and Political Rights. Practice and Procedures of the Human Rights Committee ISBN 90-5095-074-4

3. Kitty Arambulo, Strengthening the Supervision of the International Covenant on Economic, Social and Cultural Rights. Theoretical and Procedural Aspects ISBN 90-5095-058-2

4. Marlies Glasius, Foreign Policy on Human Rights. Its Influence on Indonesia under Soeharto

ISBN 90-5095-089-2

5. Cornelis D. de Jong, The Freedom of Thought, Conscience and Religion or Belief in the United Nations (1946-1992)

ISBN 90-5095-137-6

6. Heleen Bosma, Freedom of Expression in England and under the ECHR: in Search of a Common Ground. A Foundation for the Application of the Human Rights Act 1998 in English Law

ISBN 90-5095-136-8

7. Mielle Bulterman, Human Rights in the External Relations of the European Union ISBN 90-5095-164-3

8. Esther M. van den Berg, The Influence of Domestic NGOs on Dutch Human Rights Policy. Case Studies on South Africa,Namibia, Indonesia and East Timor ISBN 90-5095-159-7

9. Ian Seiderman, Hierarchy in International Law: the Human Rights Dimension ISBN 90-5095-165-1

10. Anna Meijknecht, Towards International Personality: the Position of Minorities and Indigenous Peoples in International Law

ISBN 90-5095-166-X 
School of Human Rights Research Series

11. Mohamed Eltayeb, A Human Rights Approach to Combating Religious Persecution. Cases from Pakistan, Saudi Arabia and Sudan

ISBN 90-5095-170-8

12. Machteld Boot, Genocide, Crimes Against Humanity, War Crimes: Nullum Crimen Sine Lege and the Subject Matter Jurisdiction of the International Criminal Court ISBN 90-5095-216-X

13. Corinne Packer, Using Human Rights to Change Tradition. Traditional Practices Harmful to Women's Reproductive Health in sub-Saharan Africa

ISBN 90-5095-226-7

14. Theo R.G. van Banning, The Human Right to Property

ISBN 90-5095-203-8

15. Yvonne M. Donders, Towards a Right to Cultural Identity?

ISBN 90-5095-238-0

16. Göran K. Sluiter, International Criminal Adjudication and the Collection of Evidence:

Obligations of States

ISBN 90-5095-227-5

17. Nicola Jägers, Corporate Human Rights Obligations: in Search of Accountability ISBN 90-5095-240-2

18. Magdalena Sepúlveda, The Nature of the Obligations under the International Covenant on Economic, Social and Cultural Rights

ISBN 90-5095-260-7

19. Mitsue Inazumi, Universal Jurisdiction in Modern International Law: Expansion of National Jurisdiction for Prosecuting Serious Crimes under International Law ISBN 90-5095-366-2

20. Anne-Marie L.M. de Brouwer, Supranational Criminal Prosecution of Sexual Violence: The ICC and the Practice of the ICTY and the ICTR

ISBN 90-5095-533-9

21. Jeroen Gutter, Thematic Procedures of the United Nations Commission on Human Rights and International Law: in Search of a Sense of Community

ISBN 90-5095-557-6

22. Hilde Reiding, The Netherlands and the Development of International Human Rights Instruments ISBN 978-90-5095-654-3

23. Ingrid Westendorp, Women and Housing: Gender Makes a Difference ISBN 978-90-5095-669-7

24. Quirine A.M. Eijkman, We Are Here to Serve You! Public Security, Police Reform and Human Rights Implementation in Costa Rica

ISBN 978-90-5095-704-5

25. Antoine Ch. Buyse, Post-conflict Housing Restitution. The European Human Rights Perspective with a case study on Bosnia and Herzegovina ISBN 978-90-5095-770-0

26. Gentian Zyberi, The Humanitarian Face of the International Court of Justice. Its Contribution to Interpreting and Developing International Human Rights and Humanitarian Law Rules and Principles ISBN 978-90-5095-792-2

27. Dragoş Cucereanu, Aspects of Regulating Freedom of Expression on the Internet ISBN 978-90-5095-842-4 
28. Ton Liefaard, Deprivation of Liberty of Children in Light of International Human Rights Law and Standards

ISBN 978-90-5095-838-7

29. Laura van Waas, Nationality Matters. Statelessness under International Law ISBN 978-90-5095-854-7

30. Jeroen Denkers, The World Trade Organization and Import Bans in Response to Violations of Fundamental Labour Rights

ISBN 978-90-5095-855-4

31. Irene Hadiprayitno, Hazard or Right? The Dialectics of Development Practice and the Internationally Declared Right to Development, with Special Reference to Indonesia ISBN 978-90-5095-932-2

32. Michał Gondek, The Reach of Human Rights in a Globalising World: Extraterritorial Application of Human Rights Treaties ISBN 978-90-5095-817-2

33. Jeff Handmaker, Advocating for Accountability: Civic-State Interactions to Protect Refugees in South Africa ISBN 978-90-5095-910-0

34. Anna Oehmichen, Terrorism and Anti-Terror Legislation: The Terrorised Legislator? A Comparison of Counter-Terror Legislation and Its Implications on Human Rights in the Legal Systems of the United Kingdom, Spain, Germany and France ISBN 978-90-5095-956-8

35. Simon Walker, The Future of Human Rights Impact Assessments of Trade Agreements ISBN 978-90-5095-986-5

36. Fleur van Leeuwen, Women's Rights Are Human Rights: The Practice of the United Nations Human Rights Committee and the Committee on Economic, Social and Cultural Rights ISBN 978-90-5095-980-3

37. Eva Rieter, Preventing Irreparable Harm. Provisional Measures in International Human Rights Adjudication ISBN 978-90-5095-931-5

38. Desislava Stoitchkova, Towards Corporate Liability in International Criminal Law ISBN 978-94-000-0024-7

39. Paulien Muller, Scattered Families. Transnational Family Life of Afghan Refugees in the Netherlands in the Light of the Human Rights-Based Protection of the Family ISBN 978-94-000-0021-6

40. Bibi van Ginkel, The Practice of the United Nations in Combating Terrorism from 1946 to 2008. Questions of Legality and Legitimacy

ISBN 978-94-000-0076-6

41. Christophe Paulussen, Male captus bene detentus? Surrendering suspects to the International Criminal Court

ISBN 978-94-000-0100-8

42. Brianne McGonigle Leyh, Procedural Justice? Victim Participation in International Criminal Proceedings

ISBN 978-1-78068-020-0 
School of Human Rights Research Series

43. Maria Ventegodt Liisberg, Disability and Employment. A Contemporary Disability Human Rights Approach Applied to Danish, Swedish and EU Law and Policy ISBN 978-1-78068-028-6

44. Tarlach McGonagle, Minority Rights, Freedom of Expression and of the Media: Dynamics and Dilemmas ISBN 978-94-000-0215-9

45. Marloes van Noorloos, Hate Speech Revisited. A comparative and historical perspective on hate speech law in the Netherlands and England \& Wales ISBN 978-1-78068-032-3

46. Hanneke Senden, Interpretation of Fundamental Rights in a Multilevel Legal System. An analysis of the European Court of Human Rights and the Court of Justice of the European Union ISBN 978-1-78068-027-9

47. Otto Spijkers, The United Nations, the Evolution of Global Values and International Law ISBN 978-1-78068-036-1 